\title{
Transcription and Translation
}

$2 \mathrm{r}^{\mathrm{ol}}$

\author{
עתה בעזרת ה אל גבור ונורא אחל לכ[...] \\ פשטי ספר החומש והאל הנאזר בגור ונוראל לגורה [...]

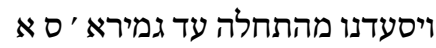

(1)

(2)

(3)

[Genesis 1]

\section{בראשית ברא אלהים את השמים ואת הארץ}

(5) [1] [\{Enk baštan jaratty Tenri osol ol keklerni da

(6) osol oljerni. והארץ [2] Da oljer ediv[eren $]^{2}$

(7) da bos da qarangylyq edi $i^{3}$ jizleri istine ol darjanyn [da $]^{4}$

(8) jeli Tenrinin suvurdaredi jizleri istine ol suvlar [nyn $]^{6}$.

(9) ויאמר [3] Da ajtty Tenri bolsun jaryq da boldu jary [q]7].

(10) [ירא [4 Da kerdi Tenri osol ol jaryqny kijahsydy da

(11) ajyrdy Tenri arasyna ol jaryqnyn da arasyna ol

(12) qarangylyqnyn. ויקרא. [5] Da atady Tenri jaryqqa kin da

(13) qarangyga atady kece da boldu ingir da boldu [tan $]^{8}$

(14) bir kin. [6] Da ajtty Tenri bolsun

(15) raqia' ortasynda ol suvlarnyn da bolsun ajyruvcu

(16) arasyna suvlarnyn suvlarbyla. ויעש [7] Dajaratty ${ }^{9}$ Ten[ri] ${ }^{10}$

(17) osol ol raqia'ny da ajyrdy arasyna ol suvlarnyn $k i$

(18) asajartyn raqia'ġa da arasyna ol suvlarnyn kijoġarraq ${ }^{11}$

(19) da boldu alaj. ויקרא. [8] Da atady Tenri raqiáğa $\langle d a\rangle$

(20) kekler da boldu ingir da boldu tan ekinci kin.

(21) יויאמר [9] Da ajtty Tenri jumulsunlar ol suvlar

$2 \mathrm{~V}^{\mathrm{o}} \quad$ (1) tibinden ol keklernin bir orunga da kerinsin ol

(2) quru da boldu alaj. ויקרא.] Da atady Tenri quruga

(3) jer da jumulmaġyna ol suvlarnyn atady tengizler da

(4) $\langle$ bol〉 kerdi Tenri kijahssydy. ויאמר. [11] Da ajtty

(5) Tenrijasartsyn ol jer jas ot keget urluq etivci

\footnotetext{
${ }^{1}$ Verses Gen 1:1-1:17 of the original manuscript are missing because of damage. These fragments were supplemented by another hand in the 19th century in South-Western Karaim. The folios 2 $\mathrm{r}^{\mathrm{o}}-2 \mathrm{v}^{\mathrm{o}}$ were erroneously sewn in after folio $1 \mathrm{v}^{\mathrm{o}} .{ }^{2} \mathrm{H}$ : veren. | C: viran. | V: heč́. | P: veŕac; a printing error or a scribal error. $\quad{ }^{3}$ TKow.o1: deest. $\quad{ }^{4}$ TKow.o1: $d a$. | H: $d a$. | C: $d a$. | V: $d a$. | P: $d a$. ${ }^{5}$ TKow.o1: šuvuldaredi. $\quad{ }^{6}$ TKow.o1: suvlarnyn. | H: suvlarnyn. | C: suvlarnyy. | V: suvlarnyn. | P: suklarnyn; a printing error or a scribal error. ${ }^{7}$ TKow.o1: jaryq. | H: jaryq. | C: jaryq. | V: jaryh. | P: jaryq. $\quad{ }^{8}$ TKow.o1: tan. | H: tan. | C: ertä. | V: tan. $\quad{ }^{9}$ TKow.o1: qyldy. $\quad{ }^{10}$ TKow.o1: Tenri. | H: Tenri.| C: Tärri.|V: Téńri. ${ }^{11}$ TKow.o1: joġartyn raqiä́ga.
} 
(1) Now, with the help of the mighty and awesome God, I will start to $\quad 2$ r $\mathrm{r}^{\mathrm{o}}$ [write]

(2) my translation of the Chumash. And God, replete with might, [...].

(3) And we will dine from the beginning until completion. First book.

[Genesis 1]

(4) In the beginning, God created the heavens and the earth.

(5) $[1]_{\mathrm{L}}\{$ In the very beginning God created the heaven and

(6) the earth. [2] And the earth was [desolated],

(7) and void, and darkness was over the face of the deep. [And]

(8) the wind of God was hovering over the face [of] the waters.

(9) [3] And God said, 'Let there be light,' and there was light.

(10) [4] And God saw the light, that it was good. And

(11) God separated between the light and the

(12) darkness. [5] And God called the light Day, and

(13) called the darkness Night. And there was evening and there was [morning]:

(14) first ${ }^{2}$ day. [6] And God said, 'Let there be

(15) a firmament in the midst of the waters, and let it divide

(16) water from water.' [7] And God made

(17) the firmament, and separated between the waters which were

(18) under the firmament and the waters which were above:

(19) and it was so. [8] And God called the firmament

(20) Skies. And there was evening and there was morning: a second day.

(21) [9] And God said, 'Let the waters be gathered together

(1) under the heaven into one place, and let the dry land appear.'

(2) And it was so. [10] And God called the dry

(3) land Earth, and the gathering together of the waters he called Seas.

(4) And God saw that it was good. [11] And God said,

(5) 'Let the earth make plants grow, plants yielding seed,

1 The beginning of the original manuscript is missing because of damage. The folios $2 \mathrm{r}^{\mathrm{o}}-2 \mathrm{v}^{\mathrm{o}}$ were erroneously sewn in after folio $1 \mathrm{v}^{\mathbf{o}}$.

2 Lit. 'one'. 
(6) urluqjemis agacy qyluvcu jemis zynsysajyn ki urlugiu

(7) anyn anda ol jer istine da boldu alaj. ותוצא. [12]

(8) Da cygjardy ol jer jas ot ${ }^{1}{ }_{\text {L }}$ urluqlavcu urluq ${ }^{12}$

(9) 3ynsysajyn da agac qyluvcu jemis ki urlugiu anyn

(10) anda zynsysajyn da kerdi Tenri ki jahsydy. ויהי. [13]

(11) Da boldu ingir da boldu tan icinci kin. ויאמר. [14]

(12) Da ajtty Tenri bolsun jaryqlyqlar ${ }^{3}$ raqia'synda ol

(13) keklernin ajyrma arasyna ol kinnin da arasyna

(14) ol kecenin da bolsunlar belgilerge da vagddalarga

(15) da kinlerge da jyllarga. והי [15] Da bolsunlar jaryqlyq-

(16) larǵa raqia'synda ol keklernin jarytma ${ }^{4}$ ol jer

(17) istine da boldu alaj. ויעש. [16] Da jaratty ${ }^{5}$ Tenri osol

(18) eki ol jaryqlyqlarny ol ullularny ${ }^{16}$ osol ol ullu jaryqny ${ }^{7}$

(19) erklenmegine ol kinnin da osol ol kici jaryqlyqny

(20) erklenmegine ol kecenin da osol ol jolduzlarny. ויתן. [17]

(21) Da berdi Tenri alarny raqiassynda ol keklernin jarytma ${ }^{8}$

(22) oljer istine. $\}^{19}$

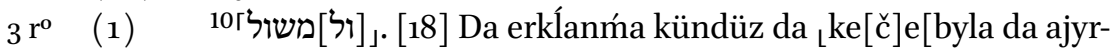

(2) ma $]^{111}$ arasyna ol jaryqnyn da arasyna ol ¿qaran[g்ylyqnyn da] $]^{112}$

(3) kördü Tenri ki jahšyydy. ויהי [19] Da boldu Lin[gir da bol-]

(4) du du $^{113} \tan$ da dörtünčü kün. Da [ajt[ty Tenri]

(5) qozlasynlar ol suvlar qozlamaġyn tiri žannyn da $\_$qu[š učqa-]

(6) lasyn ${ }^{115}$ ol jer üstüńa juvuq raqia'syna ${ }^{16}$ ol kökler[nin $]^{17}$.

(7) יברא [21] Da jaratty Tenri ošol ol [aždahalarny o[l ullular-]

(8) ny ${ }^{118}$ da ošol ol bar tiri žanny ol tebrenedog̉anny _[ki qoz-]

(9) ladylar ${ }^{119}$ ol suvlar క̌ynslary sajyn da ošol bar ol Łqanatl[y qušnu] $]^{120}$

(10) Šynsy sajyn da kördü Tenri ki jahšydy. [22] Da [alğyšla-]

(11) dy ${ }^{21}$ alarny Tenri ajtadoġač jajylyjyz da artyjyz da [toltu-]

\footnotetext{
1'TKow.o1: ot kögöt. $\quad{ }^{2}$ TKow.o1: urluq etüvčü urluq. $\quad{ }^{3}$ TKow.o1: jaryqlar. $\quad{ }^{4}$ TKow.o1: jaryq etḿa. $\quad{ }^{5}$ TKow.o1: qyldy. $\quad{ }^{6}$ TKow.o1: ullu jaryqlyqlarny. $\quad{ }^{7}$ TKow.o1: jaryqlyqny. $\quad{ }^{8}$ TKow.o1: jaryq etḿa. $\quad{ }^{9}$ Insertion by another hand in South-Western Karaim. ${ }^{10}$ Heb. וְלְמְשׁל | | Catchword: ולמשל ${ }^{11}$ TKow.o1: kećabyla da ajyrma. | H: kecede da ajyrma. | C: kečädä da ajyrma. ${ }^{12}$ TKow.o1: qarangylyqnyn da.|H: qaranġylyqnyn da.|C:qarayg்luqnyy da. ${ }^{13}$ TKow.o1: ingir da boldu. | H: ingir da boldu. | C: yyyr da boldy. ${ }^{14}$ TKow.o1:ajtty Tenri.| H:ajtty Tenri.| C: ajtty Tägri. ${ }^{15} \mathrm{H}$ : qus ucqalasyn. | C: quš učsyn. $\quad{ }^{16} \mathrm{~K}$ : raqaia syna; a scribal error; cf. Gen 1:6-8, Gen 1:14-15. | H: raqia synyn; different syntax. | C: tabaqasynyy. | Cf. Heb. רִָ 'firmament'. ${ }^{17}$ TKow.or: kök-

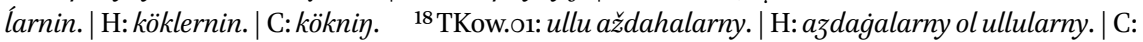
ulu aร̌ydahylarny. ${ }^{19}$ TKow.o1: ki qozladylar. | H: ki qozladylar.| C: ki qozaladylar. ${ }^{20}$ TKow.o1: qanatly qušnu. | H: qanatly qusnu. | C: qanatly qušny. ${ }^{21}$ TKow.o1: alg̈yšlady. | H: alġyslady. | C: alg̈yšlady.
} 
(6) and the fruit tree making fruit, in which is their seed, according to its kind,

(7) on the earth.' And it was so. [12]

(8) And the earth brought forth plants, plants yielding seed

(9) according to their kind, and trees making fruit, in which is their seed,

(10) according to its kind. And God saw that it was good. [13]

(11) And there was evening and there was morning: a third day. [14]

(12) And God said, 'Let there be lights in the firmament of the

(13) skies to distinguish between the day and

(14) the night. And let them be for signs, and for appointed times,

(15) and for days, and for years. [15] And let them be for lights

(16) in the firmament of the skies to give light on the earth.'

(17) And it was so. [16] And God made

(18) two great lights: the great light

(19) to rule the day, and the small light

(20) to rule the night, and the stars. [17]

(21) And God set them in the firmament of the skies to give light

(22) on the earth, $\}^{13}$

(1) [18] And to rule in day time and at night [and to separate]

(2) the light from the [darkness. And]

(3) God saw that it was good. [19] And there was

(4) evening and there was morning and the fourth day. [20] And [God said],

(5) 'Let the waters produce the swarms of living creatures and let [birds

(6) fly] above the earth in the near firmament of the skies.'

(7) [21] And God created [the great] sea creatures

(8) and every living creature that moves [which]

(9) the waters [produced], according to their kinds, and every [winged bird]

(10) according to its kind: and God saw that it was good. [22] And God [blessed]

(11) them, saying, 'Spread, and multiply, and [fill]

3 Inserted by another hand in South-Western Karaim. 
(12) rujuz ${ }^{1}$ ošol ol suvlarny tengizlerd́a da ol quš [art-]

(13) syn ${ }^{2}$ jerd́a. ויהי [23] Da boldu ingir da boldu tan [bešinči]

(14) kün. ויאמר [24] Da ajtty Tenri čyġarsyn ol jer [tiri] ${ }^{4}$

(15) క̌an క̌ynsy sajyn tuvarda qomuzda kijigin jernin „క̌̌yn[sy sajyn] $]^{15}$

(16) da boldu alaj. ויעש [25] Da jaratty Tenri ošol [ki[jigin ol] ${ }^{16}$

(17) jernin క̌ynsy sajyn da ošol ol tuvarny žynsy sajyn da ${ }_{\mathrm{L}} \mathrm{o}[\text { šol bar }]^{17}$

(18) qomuzun ol jernin žynsy sajyn da kördü Tenri ki jahšy [dy $]^{8}$.

(19) . ויאמר (26] Da ajtty Tenri jaratajyq adam susumuz [byla]

(20) uqšašymyzġa köŕa da erklensinlar balyġynda [ [ol ten-]

(21) giznin ${ }^{110}$ da qušunda ol köklernin da tuvarda da bar ${ }_{L}[\mathrm{ol}$

$3 \mathbf{v}^{\mathbf{o}}$ (1) jerd́] $\mathrm{a}^{111}$ da bar ol qomuzda ol tebrenedogan ol jer üstü-

(2) ńa. ויברא [27] Da jaratty Tenri ošol ol adamny susu byla

(3) susu byla malahnyn jaratty any erkekni da tišini jaratty

(4) alarny. ויברד [28 Da alğyšlady alarny Tenri da ajtty alarg̉a

(5) Tenri jajylyjyz da artyjyz da tolturujuz ošol ol jerni

(6) da tutuvlanyjyz anda da er\{r\}klenijiz balyġynda ol tengiznin

(7) da qušunda ol köklernin da bar tiride ol tebrenedoġan

(8) ol jer üstüńa. [29] Da ajtty Tenri muna

(9) berdim sizǵa ošol bar kögötnü urluqlavčunu urluq ki

(10) jüzĺari üstüńa bar ol jernin da ošol bar ol ag̉ačny ki

(11) anda jemiš ag̉ačy urluqlavču urluq sizǵa bolsun jemǵa.

(12) [30] Da bar kijigińa ol jernin da bar qušuna ol köklernin

(13) da bar tebrenedoġanġa ol jer üstüńa ki anda tiri žan

(14) ošol bar ješilligin kögötnün jemǵa da boldu alaj.

(15) וירא (151] Da kördü Tenri ošol barča neki jaratty da

(16) muna jaḩ̌̌ydy astry da boldu ingir da boldu tan ol altyn-

(17) čy kün.

Genesis 2

ויכלו [1] Da tügendilar jaratylmaqlary ol köklernin da ol jernin da bar jyjynlarynyn. ויכל. [2] Da tügelledi

\footnotetext{
${ }^{1}$ TKow.o1: tolturujuz. | H: tolturunuz. | C: toluyuz. | Cf. Gen 1:28. $\quad{ }^{2}$ TKow.o1: artsyn. | H: artsyn. | C: köbäjsin. $\quad{ }^{3}$ TKow.o1: bešinči. | H: besinci. | C: bešinži. $\quad{ }^{4}$ TKow.o1: tiri. | H: tiri.| C: tiri. ${ }^{5}$ TKow.ol: žynsy sajyn. |H: zynsy sajyn. | C: ̌̌insinä. $\quad{ }^{6}$ TKow.or: kijigin ol. | H: kijigin ol. |C: kijigin ol. $\quad{ }^{7}$ TKow.o1: ošol bar. | H: osol ol bar. | C: šol barča. ${ }^{8}$ Cf. Gen. 1:18, 1:21. | TKow.o1: jaḩ̌šydy. | H: jaḩsydy. | C: jaḩ̌̌ydyr. $\quad{ }^{9}$ Cf. Gen. 1:26. | TKow.o1: byla. | H: byla. | C: deest; different syntax. ${ }^{10}$ TKow.o1: ol tengiznin. | H: ol tengiznin. | C: ol teyizniy. ${ }^{11}$ TKow.o1: ol jerd́a. | H: ol jerde. | C: ol jergä.
} 
(12) the waters in the seas and let birds [multiply]

(13) in the earth'. [23] And there was evening and there was morning: the fifth

(14) day. [24] And God said, 'Let the earth bring forth [living]

(15) beings according to their kind, livestock, and creeping animals, and the wild animals of the earth according to their kind.'

(16) And it was so. [25] And God created the [wild animals] of [the]

(17) earth according to their kind and the livestock according to their kinds and every

(18) creeping animal of the earth: and God saw that it was good.

(19) [26] And God said, 'Let us create man [in] our appearance,

(20) after our likeness and let them rule over the fish of [the sea],

(21) and the birds of the skies, and the livestock, and over all [the

(1) earth], and over the creeping animals that move on the earth'

(2) [27] So God created man in his appearance,

(3) in the image of angels he created him: he created them male and female.

(4) [28] And God blessed them and God said to them

(5) 'Spread and multiply and fill the earth,

(6) and subdue it, and rule over the fish of the sea

(7) and over the birds of the skies and over every living thing that moves

(8) on the earth'. [29] And God said, 'Lo,

(9) I have given you every plant bearing seed, which

(10) is on the face of all the earth, and every tree, which

(11) has seeds bearing fruit trees; to you it shall be for food.

(12) [30] And to every wild animal of the earth, and to every bird of the skies,

(13) and to everything that moves on the earth, wherein there is a living being,

(14) I have given| all the green of plants for food.' And it was so.

(15) [31] And God saw everything that he had created, and,

(16) lo, it was very good; and there was evening and there was morning: the sixth

(17) day.

Genesis 2

(17) [1] Thus the creation of the skies

(18) and of the earth and of all their hosts was finished. [2] And 
(19) Tenri ol jedinči künd́a išin özünün ki qyldy da qaldy

(20) ol jedinči künd́a bar išind́an özünün ki qyldy. [3]

(21) Da alg̀yšlady Tenri ošol ol jedinči künnü da aziz etti ${ }^{1}$

$4 \mathrm{r}^{\mathrm{o}} \quad$ (1) $\quad$ [any ki anda $]^{2}$ qaldy bar išindan ${ }_{\mathrm{L}}$ ki jaratty Tenr $[\mathrm{i}]^{13}$.

(2) אלה [4] Bulardylar tuvmušlary ol köklernin da ${ }_{\perp}[\text { ol jernin }]^{14}$

(3) jaratylġanlarynda jaratqan künd́a Adonaj Tenri jerni ${ }_{\text {[ }}$ da kök-]

(4) larni 15 . וכל [5] Da bar teregi ol tüznün Lburun bol[mastan jerde] ${ }^{16}$

(5) da bar kögötü ol jernin burundan bitti ki javdu[rmady $]^{7}$

(6) H Tenri jamġur ol jer üstüńa da adam joġedi [išleme $]^{8}$

(7) ošol ol jerni. ואיד [6] Da myhla kötür\{ü\}lüredi [ [ol jer-]

(8) dan ${ }^{19}$ da sug̉aryredi ošol bar jüzlarin ol jernin. [רייצ' $]^{10}$. [7 [Da [11

(9) jaratty Adonaj Tenri ošol ol adamny topraq ol je[rd́an $]^{12}$

(10) da ürdü burnuna nafstyn tirliknin da boldu ol [adam $]^{13}$

(11) tiri žanġa. ויטע [8] Da burundan ${ }^{14}$ or\{n\}atty Adonaj [Tenri] ${ }^{15}$

(12) bağ bostanda ${ }^{16}$ da qojdu anda ošol ol adamny ki [jaratty $]^{17}$.

(13) ויצמח [9] Da bittirdi Adonaj Tenri ol jerd́an bar ${ }_{L}$ s[uqlan-]

(14) čy ${ }^{118}$ ag̉ačny körümǵa da jahššny jemǵa da ag̉ačyn ol ${ }_{\perp}[$ tir-]

(15) liknin ${ }^{119}$ ortasynda ol bağnyn da ag̉ačyn ol bilmeknin ${ }_{\mathrm{L}}$ [jaḥšy-]

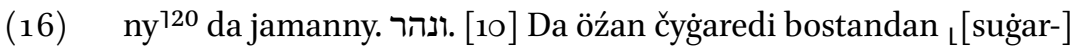

(17) ma ${ }^{121}$ ošol ol bag̉ny da andan ajyrylyredi da boluredi d[ört ${ }^{22}$

(18) bašlarğa. שם. [11] Aty ol birnin Fišon ol edi ol Lqu[ršav-]

(19) ču č ${ }^{123}$ ošol bar jernin Ḥavilanyn ki andady ol altyn. [12]

(20) Da altyny ol jernin jahšydy andady ol inži tübü [da ol $]^{24}$

(21) šoham tašy. ושם [13] Da aty ol ekinči özennin Gi[ḥon] ${ }^{25}$

\footnotetext{
${ }^{1}$ On every folio verso, the last line (or, in some instances, the last two lines) contain one or more catchwords. Catchwords will be omitted from the transcription, but they will be taken into consideration in reconstructing, where applicable, the damaged passages. ${ }^{2}$ Catchword: any. | TKow.o1: any ki anda. | H: any ki anda. | C: any ki anda. $\quad{ }^{3}$ TKow.o1: üzünün ki jaratty Tenri qylma. | H: ki jaratty Tenri qylma. | C: ki jaratty. ${ }^{4}$ TKow.o1: ol jernin. | H: ol jernin. | C: ol jerniy. ${ }^{5}$ TKow.o1: da köklarni. | H: da keklerni.| C: da kökni. $\quad{ }^{6}$ TKow.o1: burundan boldu jerd́a. | H: bolmastan burun jerde. | C: bolmastan burun jerdä. ${ }^{7}$ TKow.o1: javdurmady. | H: javdurmady. | C: jagddyrmajyp edi. $\quad{ }^{8}$ TKow.o1: išlemá. | H: isleme. | C: išlämä. $\quad{ }^{9}$ TKow.o1: ol jerd́an. | H: ol jerden.

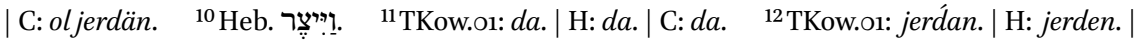
C: jerdän. ${ }^{13}$ TKow.o1: adam. | H: adam qajjam. | C: adam. ${ }^{14} \mathrm{~A}$ mistranslation repeated in a number of manuscripts. | TKow.o1: deest; see, however, the next line. | H: burundan. | C: äväldä. |

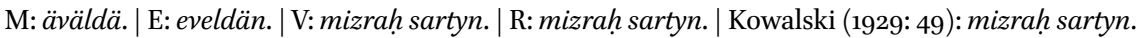

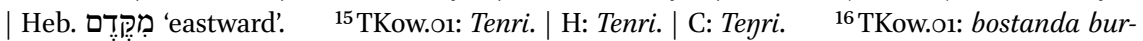
undan. $\quad{ }^{17}$ TKow.o1: jaratty. | H: jaratty. | C: jaratty. ${ }^{18}$ TKow.o1: suqlančy. | H: suqlancy. | C: suqlančly. $\quad{ }^{19}$ TKow.o1: tirliknin. | H: tirliknin. | C: tirliknin. $\quad{ }^{20}$ TKow.o1: jaḩ̌yny. | H: jahsyny. | C: jahšynny. $\quad{ }^{21}$ TKow.o1: suġarma.| H: suvartma. | C: suvarma. $\quad{ }^{22}$ TKow.o1: dört. | H: dert. |C: dört. $\quad{ }^{23}$ TKow.o1: quršavcu. | H: qursavcu. | C: čevirilgän. $\quad{ }^{24}$ TKow.o1: da ol. | H: da ol. | C: da. ${ }^{25}$ TKow.o1: Giḥon. | H: Giḥon. | C: Giḥon.
} 
(19) on the seventh day God ended his own work which he had made and he ceased

(20) |doing $\mid$ on the seventh day all his work that he had made. [3]

(21) And God blessed the seventh day, and sanctified ${ }^{4}$

(1) [it because in it] he ceased from |doing| all his work, which God had $\quad 4 \mathrm{r}^{\mathrm{o}}$ created.

(2) [4] These are the children of the heavens and [of the earth]

(3) when they were created: In the day |when| Lord God |created| the earth [and the heavens],

(4) [5] And every tree of the plain: [before] it was [in the earth],

(5) and every plant of the earth: before it grew, because the LORD God had [not caused]

(6) the rain to rain on the earth, and there was no man [to work]

(7) the ground, [6] But there went up a mist from [the earth]

(8) and watered the whole face of the ground: [7] [And]

(9) the Lord God created man [of] the dust of the [ground]

(10) and breathed into his nose the breath of life, and [man] became a

(11) living being. [8] And earlier 5 the Lord [God] planted

(12) a garden in Eden, and there he put the man whom [he had created].

(13) [9] And the Lord God caused every tree that is comely

(14) to the sight and good for food to grow from the ground, and the tree of [life]

(15) in the midst of the garden, and the tree of knowledge [of good]

(16) and evil. [10] And a river went out of Eden to [water]

(17) the garden, and from there it was parted, and became [four]

(18) heads. [11] The name of one was Pison: it was the one that [encompasses]

(19) the whole land of Havilah, where there is gold. [12]

(20) And the gold of that land is good; there is tpearl bed ${ }^{16}$ [and the]

(21) onyx stone. [13] And the name of the second river was [Gihon]:

4 On every folio verso the last one or two lines contain one or more catchwords. They are omitted from the translation.

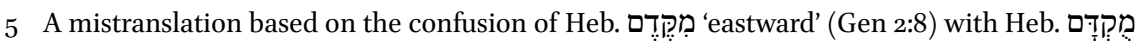
'former, early'. Repeated in a number of Karaim translations, observed already by Henderson (1826: 336). Translated correctly in V, R, and Kowalski (1929: 48).

6 Uncertain translation in inži tübü. 


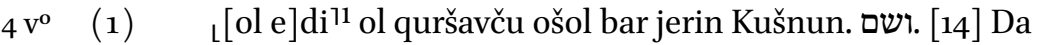

(2) [a]ty² ol üčünčü özennin Ḥidekel ol edi ol baruvču mizrahy-

(3) na Ašurnun da ol dörtünčü öźan oldu Perat. ויקח [15]

(4) Da aldy Adonaj Tenri ošol ol adamny da qojdu any bag̉bostan-

(5) da išlame any da saqlama any. [יצו [16] Da zynharlady

(6) Adonaj Tenri ol adamġa ajtadoġač bar ag̉ačyndan ol bag̉nyn

(7) jemišlarin ašama ašaġyn. ומעץ [17] Vale jemišind́an ag̉a-

(8) čynyn bilmeknin jaḩ̌šny da jamanny ašamağyn andan ki ašag̉an

(9) künüjd́a andan ölüm borčlu bolursen. ויאמר [18] Da ajtty

(10) Adonaj Tenri jaḥ̌y tüvüldü bolma ol adamġa jalġyzg்a qylajym

(11) anar bolušluq qaršysyna köŕa. וייצר [19] Da jaratty

(12) Adonaj Tenri ol jerd́an bar kijigin ol jernin da ošol bar qušun

(13) ol köklernin da keltirdi ol adamġa baqma ne atar

(14) anar da bar tiri žan ki atasajedi anar ol adam at ol edi

(15) aty anyn. ויקרא [20] Da atady ol adam atlar bar ol tuvar-

(16) ġa da qušuna ol köklernin da bar kijigińa ol tüznün

(17) da adam özüńa tapmady bolušluq qaršysyna köŕa.

(18) ויפל (21] Da saldy Adonaj Tenri qaty juqu ol adam üstüńa

(19) da juqlady da aldy birni qaburgalaryndan anyn da bekĺadi et-

(20) byla anyn ornuna. [יבן [22] Da qondardy Adonaj Tenri ošol

(21) ol qaburgany ki aldy ol adamdan bolma qatyn da keltirdi

$5 \mathrm{r}^{\mathrm{r}} \quad$ (1) any ol adamgia. [23] [יאמר [Da ajtty ol ${ }_{\text {L }}$ ada[m bu endi] ${ }^{13}$

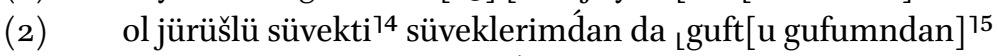

(3) bunar ündelir qatyn ki kišidan alyndy bu. על. [24] [Anyn üčün]

(4) kemišedi kiši atasyn da anasyn da jabušady qatynyna [da ${ }^{7}$

(5) boladylar bir gufqa. ויהיו. [25] Da ediĺar eksila[r]i[da]

(6) jalangačlar ol adam da qatyny anyn da ujalmasedilar.

\section{[Genesis 3]}

(7) (1] Da ol jylan edi ustatraq bar ${ }_{\text {L }}$ kijigin[d́an ol] ${ }^{19}$

(8) tüznün ki jaratty Adonaj Tenri da ajtty ol _qatyn[g்a ham]

\footnotetext{
${ }^{1}$ Cf. Gen. 2:11, 2:14. | TKow.o1: oldu. | H: oldu. | C: oldyr. $\quad{ }^{2}$ TKow.o1: aty. | H: aty. | C: aty. ${ }^{3}$ TKow.o1: adam bundij. | H: adam bundij and adam bu ol keretni. | C: adam bu ol vaht. | V: adam bu ol fornu. | See next footnote. $\quad{ }^{4} \mathrm{H}$ : Two translations provided, probably because of interpretative difficulties: da ajtty ol adam bundij ol jirisli sivekti and da ajtty adam bu ol keretni. In

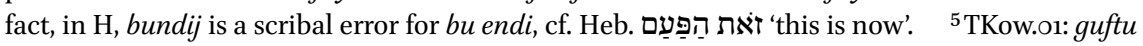
gufumdan. | H: guftu gufumdan. | C: et etimdän. ${ }^{6}$ TKow.o1: anyn ücün. | H: anyn ücün. | C: anyy učun. $\quad{ }^{7}$ TKow.o1: $d a .|\mathrm{H}: d a.| \mathrm{C}: d a . \quad{ }^{8}$ TKow.o1: eksilarida.|H: eksileride.|C: ekisi. ${ }^{9}$ TKow.o1: kijigind́an ol. | H: kijiginden ol. | C: kijigindän.
} 
(1) [it was] the one that encompasses the whole land of Cush. [14] And $4 \mathrm{v}^{\mathrm{o}}$

(2) the name of the third river was Tigris: it was the one that goes toward the east

(3) of Assyria. And the fourth river was Euphrates. [15]

(4) And the Lord God took the man, and put him into the garden of Eden

(5) to work it and to keep it. [16] And the Lord God commanded

(6) the man, saying, 'Of every tree of the garden:

(7) you may surely eat their fruits. [17] But of the fruits

(8) of the knowledge of good and evil: you shall not eat of it, because

(9) in the day that you eat thereof you will have a debt of death'. [18] And the Lord God said,

(10) 'It is not good for the man to be alone; I shall make

(11) him a help corresponding to him.' [19] And

(12) from the ground the Lord God created every wild animal of the earth, and every bird

(13) of the skies, and brought them to the man to see what he would call

(14) them. And whatever the man would call every living being, that was

(15) its name. [20] And the man gave names to all livestock,

(16) and to the bird of the skies, and to all the wild animals of the field.

(17) But for the man: he did not find a help corresponding to him.

(18) [21] And the Lord God sent a deep sleep on the man

(19) and he slept. And he took one of his ribs, and closed up

(20) its place with flesh. [22] And the Lord God built

(21) the rib that he had taken from the man, to be a woman, and he brought

(1) her to the man. [23] And the man said, 'This is now

(2) living bone from my bones, and body [from my body]:

(3) She shall be called "woman", because it was taken from man. [24] [On account of this]

(4) a man leaves his father and his mother and clings to his wife, [and]

(5) they become one flesh. [25] And they were both

(6) naked, the man and his wife, and were not ashamed.

[Genesis 3]

(7) [1] And the serpent was more crafty than any wild animal of [the]

(8) field which the Lord God had created, and he said [to] the woman, 'Has God 
(9) $\mathrm{ki}^{11}$ ajtty Tenri ašamajyz bar jemišind́an ag̉ačynyn ol [bag̉nyn $]^{2}$.

(10) (2] Da ajtty ol qatyn ol jylanġa _jemišin[d́an ag̉a-]

(11) čynyn ${ }^{13}$ ol bağnyn ašajbiz. ומפרי [3] Da jemišind́a[n ol] $]^{14}$

(12) ag̉ačnyn ki ortasynda ol bag̉nyn ajtty Tenri aša[majyz $]^{5}$

(13) andan da tijmejiz anar magat ölersiz. ויאמר. [4] [Da]

(14) ajtty ol jylan ol qatynga ölḿa ölmessiz. [י] [5] [5]

(15) Ki biledi Tenri ki ašaġan künüjüzd́a andan da ačy[lyrlar $]^{8}$

(16) közlerijiz da bolursiz malahlar kibik bilüvčülar [jahšyny ${ }^{9}$

(17) da jamanny. [6] Da kördü ol qatyn ki ja[ḩ̌ysdy $]^{10}$

(18) ol ag̉ač jemǵa da ki küsenčlidi ol közlerǵa ${ }_{\perp}$ [da suq-]

(19) lančydy ${ }^{111}$ ol ag̉ač anlama da aldy jemišind́an da ${ }_{\mathrm{L}}$ aša[dy da] $]^{112}$

(20) berdi daġyn erined́a birgesińa da ašady. [ותפקחנה] [7] [7]

(21) Da ačyldylar közĺari eksilerinind́a da bildilar

$5 \mathrm{v}^{\mathrm{o}} \quad$ (1) gačtyl] $\operatorname{ar}^{114}$ alar da tiktilar japraġyn inžirliknin da qyldylar

(2) özlerińa fartuhlar. [8] Da ešittilar ošol

(3) ünün Adonajnyn Tenrinin jürüjdoġanny bağda jeli vahtynda

(4) ol künnün da jašyndy ol adam da qatyny anyn alnyndan

(5) Adonaj Tenrinin ortasynda ag̉ačynyn ol bag̉nyn. ויקרא. [9]

(6) Da čaġyrdy Adonaj Tenri ol adamġa da ajtty anar

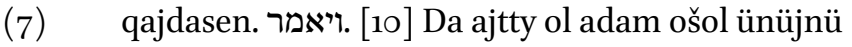

(8) ešittim bağda da qorqtum ki jalanġačtyr men da jašyn-

(9) dym. ויאמר d11 Da ajtty Tenri kim anlatty saja ki

(10) jalanġačtyr sen ol ag̉ačtan mo ašadyj ki zynharladym saja

(11) ašamasqa andan. ויאמר. Da ajtty ol adam ol

(12) qatyn ki berdi $[j]^{15}$ qatymda ol berdi maja jemišind́an ol

(13) aggačnyn da ašadym. ויאמר [13] Da ajtty Adonaj Tenri

(14) qatyngaa ne bu qyldyj da ajtty ol qatyn ol jylan jeldedi

(15) meni da ašadym. ויאמר Da ajtty Adonaj Tenri

(16) jylanġa anyn üčün ki qyldyj bunu qarġyšlyraqtyrsen bar

(17) ol tuvardan da bar kijigind́an ol tüznün qarnyj üstüńa

\footnotetext{
${ }^{1}$ TKow.o1: qatynga ham. | H: qatyng்a ham ki ajtty; ham ki ajtty hem ki ajtty calques Heb. ๆ

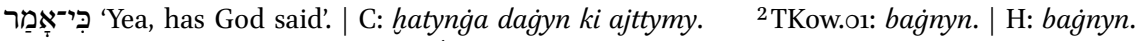
| C: baġnyy. $\quad{ }^{3}$ TKow.o1: jemišindáan. | H: jemisinden ag̉acynyn. | C: jemišindän ag̉ačynyy. ${ }^{4}$ TKow.o1: jemišindáan ol. | H: jemisinden ol. | C: jemišindän ol. $\quad{ }^{5}$ TKow.o1: ašamajyz. | H: asamanyz. | C: ašamayyz. $\quad{ }^{6}$ TKow.o1: $d a .|\mathrm{H}: d a$.$| C: d a . \quad{ }^{7}$ Heb. ${ }^{3} . \quad{ }^{8}$ TKow.o1: ačylyrlar. | H: acylyrlar. | C: ačylyrlar. $\quad{ }^{9}$ TKow.o1: jaḩ̌yny. | H: jaḩsyny. | C: jaȟ̌ynny. $\quad{ }^{10}$ TKow.o1: jahšydy. | H: jahssydy. | C: jaȟ̌ydyr. ${ }^{11}$ TKow.o1: da suqlančydy. | H: da suqlancydy. | C: da suqlančlydyr. ${ }^{12}$ TKow.o1: ašady da. | H: asady da. | C: ašady da. ${ }^{13}$ Heb. jalanġačtylar. | H: ki jalanġactylar. | C: ki jalanġačtyrlar. ${ }^{15} \mathrm{~K}$ : berdi; a scribal error. | TKow.o1: berdij. | H: berdin. | C: berdiy.
} 
(9) said, you shall not eat of all fruits of the trees of the [garden]?'

(10) [2] And the woman said to the serpent, 'Of the fruit of [the]

(11) trees of the garden we may eat. [3] But of the fruit of [the]

(12) tree which is in the midst of the garden, God has said, "You shall not eat

(13) of it, and you shall not touch it, lest you die."' [4] And

(14) the serpent said to the woman, 'You will surely not die. [5]

(15) For God knows that in the day you eat thereof, then

(16) your eyes will be opened, and you will be like angels, knowing good

(17) and evil.' [6] And the woman saw that the tree is good

(18) for food and desirable to the eyes, and that

(19) the tree is desirable ${ }_{L}$ to bring about understanding ${ }^{17}$, and she took of its fruit, and ate, [and]

(20) gave also to her husband with her, and he ate. [7]

(21) And the eyes of them both were opened and they knew [that they were

(1) naked]. And they sewed fig leaves |together|, and made

(2) themselves aprons. [8] And they heard the

(3) voice of the Lord God walking in the garden in the windy time

(4) of the day, and the man and his wife hid themselves from before

(5) the Lord God among the trees of the garden. [9]

(6) And the Lord God called to Adam, and said to him,

(7) 'Where are you?' [10] And the man said, 'I heard your voice

(8) in the garden, and I was afraid, because I was naked, and I hid myself.'

(9) [11] And God said, 'Who explained to you that

(10) you were naked? Have you eaten of the tree of which I commanded you

(11) not to eat?' [12] And the man said, 'The

(12) woman whom you gave to be on my side: she gave me of the fruits of the

(13) tree, and I ate'. [13] And the Lord God said

(14) to the woman, 'What is this that you have done?' And the woman said, "The serpent deceived

(15) me, and I ate.' [14] And the Lord God said

(16) to the serpent, "Because you have done this, you are cursed above all

(17) livestock, and above every wild animal of the field, you will go on your belly,

7 Lit. 'to understand'. 
(18) jürür sen da topraq ašarsen bar tirlik künlerijd́a.

(19) [15] Da dušmanlyq qojarmen araja da arasyna ol qatyn-

(20) nyn da arasyna urlugiujnun da arasyna urlugiunun ol

(21) vatyr seni bašqa da sen tišlerśan any soġančyğyndan. אל. [16]

$6 \mathrm{r}^{\mathrm{o}} \quad$ (1) Ol qatynga ajtty arttyrma arttyrymen qyjynyjny [da $]^{1}$

(2) ḥamilalyg்yjny qyjynbyla törerśan ulanlar da erija özele-

(3) gij da ol erklenir send́a. ולאדם. [17] Da adamġa aj-

(4) tty ki tynladyj sözüńa qatynyjnyn da ašadyj ol ag̉ačnyn

(5) jemišindan ki zynharladym saja ajtadoġač ašamaġyn andan

(6) qarğyšly bolur ol jer senin sibbajdan qyjynbyla ašarsen bitiši[n] $]^{2}$

(7) anyn bar tirlik künlerijda. וקוץ. [18] Da tegenek da

(8) kičitken östürür saja da ašarsen ošol kögötün

(9) ol tüznün. [19] Teribyla burnujnun ašarsen

(10) mek ${ }^{13}$ qajtqanyjadejin ol jerǵa ki andan alyndyj ki topraqty[r]

(11) sen ${ }^{14}$ da topraqqa qajtyrsen. ויקרא. [20] Da atady ol

(12) adam atyn qatynynyn Havva ki ol edi anasy bar tirinin.

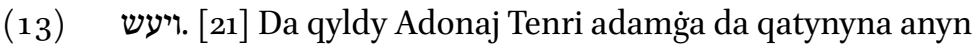

(14) terili kölmeklar da kijdirdi alargaa. ויאמר Da

(15) ajtty Adonaj Tenri muna ol adam boldu bir kibik bizd́an

(16) bilma jaḩ̌yny da jamanny da haligińa mag̉at sunar qolun

(17) da alyr dağyn ag̉ačyndan ol tirliknin da ašar da tiri

(18) bolur dunjaġadejin. וישלחהו. [23] Da sürdü any Adonaj Tenri

(19) bag̉ bostandan išlame ošol ol jerni ki alyndy andan.

(20) Da sürdü ošol ol adamny da toḥtatty

(21) kün tuvušu sartyn bostanġa ošol ol keruvimni da

$6 \mathrm{v}^{\mathrm{o}} \quad$ (1) [o]šol ${ }^{5}$ itisin ol qylyčnyn ol ajlandoġanny saqlama ošol

(2) jolun ag̉ačynyn ol tirliknin.

[Genesis 4]

[1] Da ol adam bildi

(3) ošol Havvany qatynyn da ḥamila boldu da töredi ošol Qajinni

(4) da ajtty bar ettim kiši bujruğundan Adonajnyn. ותסף. [2]

(5) Da arttyrdy töreḿa ošol qaryndašyn anyn ošol

\footnotetext{
${ }^{1}$ TKow.o1: $d a$. | H: da. | C: $d a . \quad{ }^{2}$ TKow.o1: bitišin. | H: bitisin. | C: any. $\quad{ }^{3}$ TKow.o1: ötmek. | H: etmek. | C: ötmäk. $\quad{ }^{4} \mathrm{Cf}$. Gen. 3:14. | TKow.o1: topraqtyrsen.| H: topraq sensen. | C: topraqtyrsen. ${ }^{5}$ TKow.o1: ošol. | H: osol. | C: šol.
} 
(18) and you will eat dust all the days of your life.

(19) [15] And I will put enmity between you and the woman,

(20) and between your seed and her seed. He

(21) will strike your head, and you will bite his heel.' [16]

(1) To the woman He said, 'I will surely multiply your suffering [and]

(2) in suffering you will give birth to children. And your desire [will be] for your husband,

(3) and he will rule over you.' [17] And to the man he said,

(4) 'Because you have listened to the voice of your wife, and have eaten of the fruits of the tree

(5) of which I commanded you, saying, "You shall not eat of it,"

(6) cursed is the ground because of you. You will eat its crops with suffering

(7) all the days of your life. [18] And it will bring forth to you thorns and

(8) nettle, and you will eat the plants

(9) of the field. [19] You will eat bread by the sweat of your nose,

(10) until you return to the ground, because you were taken from it; because

(11) you are dust, and you will return to dust.' [20] And the

(12) man called his wife's name Eve, because she was the mother of all living.

(13) [21] And the Lord God made for the man and for his wife

(14) shirts of skin, and he clothed them. [22] And

(15) the Lord God said, 'Lo, the man has become as one of us,

(16) to know good and evil. And now, lest he put forth his hand,

(17) and take also of the tree of life, and eat, and live

(18) forever': [23] And the Lord God drove him out

(19) from the garden of Eden to work the ground from which he was taken.

(20) [24] And he drove out the man, and he placed

(21) the cherubim at the east of the garden, and

(1) the blade of a revolving sword to guard the

(2) way to the tree of life.

[Genesis 4]

(2) [1] And the man knew

(3) Eve his wife, and she conceived, and bore Cain,

(4) and said, 'I have created a man by the command of the Lord.' [2]

(5) And she went on to give birth to his brother, 
(6) Hevelni da edi Hevel qoj kütüvčü da Qajin edi jer išlev-

(7) čü. [3] Da edi aherind́an zamanlarnyn da keltirdi

(8) Qajin jemišindan ol jernin tirki Adonajg̉a. והבל [4] Da

(9) Hevel keltirdi daġyn olda tungučlaryndan qojunun da jav-

(10) laryndan alarnyn da qajyryldy šeḩina\{sy\} Adonajnyn qabul etḿa

(11) Hevelni da tirkisin anyn. [5] Da Qajinǵa da tir-

(12) kisińa anyn qajyrylmady da ačuv boldu Qajinǵa astry

(13) da tüštülar jüzlari anyn. [6] Da ajtty

(14) Adonaj Qajinǵa nek ačuv boldu saja da nek tüštülar

(15) jüzlarij. הלא. [7] Muna eger tüzetśaj išlarijni

(16) bolalyrsen kötürma jüzlerijni da eger tüzetme-

(17) śaj ešikt́a jazyq jatady da saja özelenḿagi anyn

(18) da sen erklenirsen anda. [8] Da jaman saġyš

(19) etti Qajin Hevel qaryndašy üstüńa da edi bolġanlarynda

(20) tüzd́a da turdu Qajin Hevel qaryndašy üstüńa da

(21) öltürdü any. ויאמר. [9] Da ajtty Adonaj Qajinǵa

$7 \mathrm{r}^{\mathrm{o}}$ (1) qajdady Hevel qaryndašyj da ajtty Qajin bilmejmen ${ }_{L}$ saqlajmen[mo qaryn-

(2) dašymny ${ }^{11}$ men. [10] Da ajtty Tenri ne qyldyj avazy [qanlary-]

(3) nyn ${ }^{2}$ qaryndašyjnyn firjat etedilar maja ol jerd́an. [ועתה] [11]

(4) Da haligińa qarg̉yšlyraq sen sen ol jerdan ki ačty ošol [avzun] ${ }^{4}$

(5) alma ošol qanlaryn qaryndašyjnyn qolujdan. כי [12] Ki i[šlesej] ${ }^{5}$

(6) ošol ol jerni arttyrmasty berma küčün özünün [saja] ${ }^{6}$

(7) bürelüvčü da tünkelüvčü bolursen jerda. ויאמר [13] [Da]

(8) ajtty Qajin Adonajğa ulludu jazyġym bošatmaqtan. הן. [14] M[una ${ }^{8}$

(9) sürdüj meni bügün jüzlari üstünd́an ol jernin da ${ }_{\llcorner}$alny[jdan $]^{19}$

(10) jašynyrmen da bolurmen bürelüvčü da tünkelüvčü jerd́a

(11) da bolg̀aj bar tabuvču meni öltürür meni. [15] [Da] [Dיאמר

(12) ajtty anar Adonaj anyn üčün bar öltürüvčü Qajinni jedi[nči $]^{11}$

(13) dorg̉adejin ${ }^{12}$ öč alynyr da qojdu Adonaj Qajinǵa belgi öltü[r]-

(14) mesḱa ${ }^{13}$ any bar tabuvčusu anyn. ויצא. [16] Da čyqty Q[ajin $]^{14}$

${ }^{1}$ TKow.o1: saqlajmenmo qaryndašymny. | H: saqlajmenmo qaryndasymny. | C: saqlovčymmymen qardašymny. $\quad{ }^{2}$ TKow.o1: qanlarynyn. | H: qanlarynyn. | C: qanlarynyn. $\quad{ }^{3}$ Heb. ${ }^{4}$ TKow.o1: avzun. | H: avzun. | C: aġzyn. $\quad{ }^{5}$ TKow.o1: išlesej. | H: islesen. | C: išläsäy. $\quad{ }^{6}$ TKow.o1: saja. | H: sana. | C: saya. $\quad{ }^{7}$ TKow.o1: $d a$. | H: da. | C: da. $\quad{ }^{8}$ TKow.o1: muna. | H: muna. | C: muna. ${ }^{9}$ TKow.o1: alnyjdan. | H: alnyndan senin.| C: aldygdan. ${ }^{10}$ TKow.o1: $d a .|\mathrm{H}: d a.| \mathrm{C}: d a$. ${ }^{11}$ TKow.o1: jedenči; a scribal error. | H: jedinci. | C: jedinžidä. $\quad{ }^{12} \mathrm{~A}$ mistranslation repeated in a number of manuscripts; cf. Gen 4:24. | TKow.o1: dorǵadejin. | H: dorǵadejin. | C: deest. | M: deest.

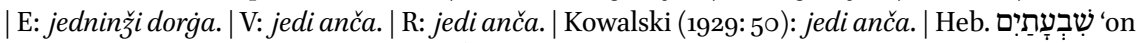
him sevenfold.' ${ }^{13}$ TKow.o1: öltürmeska.| H: vatmasqa.| C: öldürmämäkkä. ${ }^{14}$ TKow.o1: Qajin. | H: Qajin. | C: Qajin. 
(6) Abel. And Abel was a shepherd, and Cain was a worker of the ground.

(7) [3] And in the course of time Cain brought

(8) of the fruit of the ground an offering to the Lord. [4] And

(9) Abel also brought of the firstborn of his sheep and

(10) of their fat. And the divine Presence of the Lord turned to accept

(11) Abel and his offering. [5] But he did not turn to Cain and

(12) to his offering. And Cain became very angry

(13) and his countenance fell. [6] And the Lord said

(14) to Cain, 'Why are you angry, and why has your

(15) countenance fallen? [7] Lo, if you better your deeds,

(16) you will be able to raise your countenance, but if you do not

(17) better |your deeds|, sin lies at the door and its desire is for you.

(18) And you will rule over it.' [8] And Cain

(19) schemed against his brother Abel. And it was, when they were

(20) in the field, Cain rose up against his brother Abel, and

(21) killed him. [9] And the Lord said to Cain,

(2) 'Where is Abel your brother?' And Cain said, 'I do not know. Am I my brother's keeper?' [10] And God said, 'What have you done? The voice

(3) of your brother's [blood] cries to me from the ground. [11]

(4) And now you are cursed from the ground, which has opened its mouth

(5) to take your brother's blood from your hand. [12] When you work

(6) the ground, it will not continue to give its strength to you.

(7) You will be a vagrant and a wanderer on the earth.' [13]

(8) And Cain said to the Lord, 'My sin is greater than can be forgiven. [14] Lo,

(9) you have driven me out today from the face of the ground, and I will be hidden from before you,

(10) and I will be a vagrant and a wanderer in the earth,

(11) and anyone who finds me shall kill me.' [15] And

(12) the Lord said to him, 'Therefore, vengeance shall be taken on him who kills Cain until the ${ }_{L}$ seventh

(13) generation ${ }^{18}$. And the Lord put a mark on Cain,

(14) so that anyone who finds him would not kill him. [16] And Cain went out

8 Probably a mistranslation based on the confusion of Kar. dor 'generation' and Kar. for 'times', cf. Heb. שִשבְעַת 'on him sevenfold'. Repeated in a number of Karaim translations. Translated correctly in V, R, and Kowalski (1929: 50). See also Gen 4:24. 
(15) alnyndan Adonajnyn da olturdu jerind́a Nodnun utrus[una $]^{1}$

(16) bostannyn. וידע. [17] Da bildi Qajin ošol qatynyn da ḥamila

(17) boldu da töŕadi ošol Ḥanohnnu da edi qondaruvču šaha[r $]^{2}$

(18) da atady atyn ol šaharnyn aty kibik uvlunun Ḥanoh.

(19) ויולד [18] Da tuvdu Ḥanohqa ošol Irad da 'Irad tu[v]-

(2o) durdu ${ }^{3}$ ošol Maḥavi'elni da Maḥavi'el tuvdurdu ošol Metuša['elni] ${ }^{4}$

(21) da Metuša'el tuvdurdu ošol Lamehnni. [19] Da aldy [ö-]

$7 \mathrm{~V}^{\mathrm{o}} \quad$ (1) züná ${ }^{5}$ Lemeh eki qatynlar aty ol birisinin 'Ada da aty ol

(2) ekinčisinin Cilla. ותלד] [20] Da töredi 'Ada ošol Javalny ol

(3) edi atasy olturuvčunun čatyrbyla da tuvar kütüvčülernin.

(4) ושם Da aty qaryndašynyn Juval ol edi atasy bar tuvuv-

(5) čunun qobuz da qyžaq. וצלה. [22] Da Cilla töŕadi daġyn olda

(6) ošol Tuval Qajinni jyltratuvčunu bar ustasyn tučnun da te-

(7) mirnin da tuvdug̈u Tuval Qajinnin Na'ama. [23] Da nečik

(8) kördülar qatynlary Lemehnin ki ol tapty ustasyn temir-

(9) nin dunjada da ökündülar anyn üstüńa ajtadog̉ač ki

(10) bunluqbyla artar öltürüšmegi adamlarnyn da ol

(11) క̌urum tag̉ylyr anyn üstüńa ol vaḥtta ajtty Lemeh

(12) qatynlaryna 'Ada da Cilla tynlajyz sözümnü qatynlary Lemeh-

(13) nin qulaq sal[y]jyz ${ }^{6}$ ajtmaġyma ki ol temir savutu tüvül

(14) sibba öltürülmegińa ol adamnyn ki eger kleśam öl-

(15) türḿa kišini ačyq jarambyla öltürürmen any temir

(16) da savutundan bašqa da ulanny öltürürmen bütüvde

(17) jarambyla. כ2 [24] Ki eger Qajin üčün ki özü öltürdü

(18) kišini da öltürüvčüdan any ${ }_{\text { jedinči dorġadejin }}{ }^{17}$ öč alynyr

(19) da jovšem Lemeh üčün ki ančaq tapty ol čerüv savutlarny

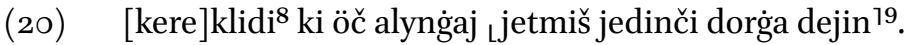

\footnotetext{
${ }^{1}$ TKow.o1: utrusuna. | H: utrusuna. | C: kün dog்ušuna. $\quad{ }^{2}$ TKow.o1: šahar. | H: sahar. | C: šähär. ${ }^{3}$ TKow.o1: tuvdurdu. | H: tuvdurdu. | C: doġurdy. $\quad{ }^{4}$ TKow.o1: Metuša’elni. | H: Metuša’elni. | C: Metuša'elni. $\quad{ }^{5}$ TKow.o1: özüna. | H: özüne. | C: özünä. $\quad{ }^{6} \mathrm{~K}$ : salajyz; a scribal error. | TKow.o1: salyjyz. | H: salynyz.| C: tutuyyz. ${ }^{7}$ A mistranslation; cf. Gen 4:15. | TKow.o1: jedinči dorgadejin. | H: jedi dorġadejin. | C: jedninžidä. | M: jedninžidä. | E: jedninži dävirdä. | V: jedi anča. | R: jedi

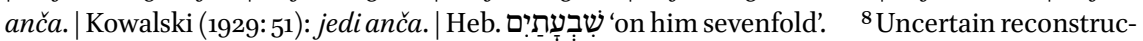
tion. | TKow.or: deest. | H: deest. | C: deest. | V: deest. ${ }^{9}$ A mistranslation; cf. Gen 4:15. | TKow.o1: jetmišjedinči dorgadejin. | H: jetmis jedinci dorǵadejin. | C: jetmišjedidä. | M: jetmišjedidä.| E: jet-

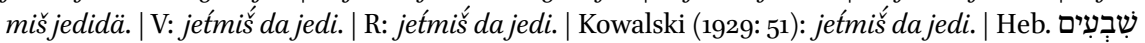

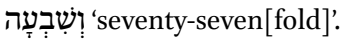


(15) from before the Lord, and dwelt in the land of Nod, against

(16) the garden |of Eden|. [17] And Cain knew his wife, and she conceived,

(17) and bore Enoch, and he was a builder of a city

(18) and called the name of the city like the name of his son, Enoch.

(19) [18] And Irad was born to Enoch, and Irad begat

(20) Mahavi'el, and Mehujael begat Methushael,

(21) and Methushael begat Lamech. [19] And Lamech took

(1) two wives: the name of the one was Adah, and the name

(2) of the second Zillah. [20] And Adah bore Jabal: he

(3) was the father of those who dwell in tents, and of those who have livestock.

(4) [21] And his brother's name was Jubal; he was the father of all

(5) those who play the qobuz ${ }^{9}$ and flute. [22] And Zillah: she also bore

(6) Tubal-Cain; the one who burnishes every ${ }_{L}$ master|piece| of ${ }^{110}$ bronze and iron.

(7) And sister of Tubal-Cain was Naamah. [23] And when

(8) the wives of Lamech saw that ${ }_{\mathrm{L}}$ he had discovered smithery ${ }^{111}$

(9) in the world, they got angry at him, saying that

(10) with $\mid$ all $\mid$ this the mutual killing of people will continue and

(11) punishment will hang over him. Then Lamech said

(12) to his wives, Adah and Zillah, 'Hear my word, you wives of Lamech,

(13) give ear to what I say, |namely| that an iron weapon is not

(14) a reason for a man to be killed, because if I want

(15) to kill a man by an open wound, I will kill him without

(16) iron or weapon, and I will kill a young man even by a

(17) bruise wound. ${ }^{112}$ [24] L Because if for Cain himself, who killed

(18) a man, vengeance shall be taken on the killer ${ }_{L}$ until the seventh generation ${ }^{113}$,

(19) all the more on Lamech, who only discovered the arms,

(20) [it is needed] that a vengeance shall be taken ${ }_{L}$ until the seventyseventh generation ${ }^{114} .^{115}$

$9 \quad$ A kind of string instrument.

10 Uncertain translation in ustasyn.

11 Lit. 'he found the smith in the world'.

12 An interpretative translation of Gen 4:23.

13 A mistranslation, cf. Heb. שִשְׁעָתַת 'on him sevenfold'; cf. Gen 4:15. | Repeated in TKow.o1, and H. Translated correctly in C, M, E, V, R, and Kowalski (1929: 51).

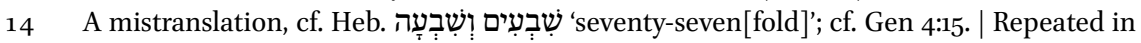
TKow.o1, and H. Translated correctly in C, M, E, V, R, and Kowalski (1929: 51).

15 An interpretative translation of Gen 4:24. 
(21) [ידע] [25] Da bildi Adam dag̉yn ošol qatynyn da töredi $8 \mathrm{r}^{\mathrm{o}} \quad(1) \quad[\mathrm{u}] \mathrm{vul}^{2}$ da atady atyn anyn Šet ajtadog̀ač [ki qojdu maja Tenri $]^{3}$

(2) özǵa urluq Hevel ornuna ki öltürdü any Qajin. [ולשת] . [26]

(3) Da Šetḱa daġyn oldu tuvdu uvul da atady atyn ${ }_{\mathrm{L}} \mathrm{a}\left[\right.$ nyn Enoš ${ }^{15}$

(4) ol vahtta bašlandy ündelḿa aty byla Adonajnyn.

[Genesis 5]

(5) Budur seferi tuvmušlarynyn Adamnyn jaratqan künd́a [Tenri $]^{6}$

(6) adamny uqšašy byla malahnyn jaratty any. זכ. [2] Er[kekni] ${ }^{7}$

(7) da tišini jaratty alarny \{da alġyšlady alarny $\}$ da atady atlaryn alarnyn $\operatorname{ada}[\mathrm{m}]^{8}$

(8) jaratylġan künlerind́a. ויחי [3] Da tiri edi Adam jüz [o-]

(9) tuz ${ }^{9}$ jyl da tuvdurdu uqšašy byla susuna köŕa da a $[\text { tady }]^{10}$

(10) ošol atyn anyn Šet. ויהיו [4] Da edilar künĺari Ada[mnyn]

(11) tuvdurg̉anyndan sortun ošol Šetni segiz jüz jyl da tuv[dur-]

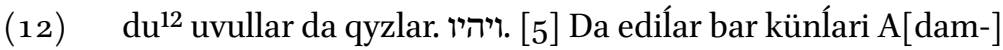

(13) nyn ${ }^{13}$ ki tiri edi tog̉uz jüz jyl da otuz jyl da öldü.

(14) ויחי (6] Da tiri edi Šet jüz da beš jyllar da tuvdurd[u] ${ }^{14}$

(15) ošol Enošnu. ויחי [7] Da tiri edi Šet tuvdurğany[ndan] $]^{15}$

(16) sortun ošol Enošnu segiz jüz jyl da jedi jyllar da tuvdu[rdu ${ }^{16}$

(17) uvullar da qyzlar. ויהיו [8] Da edilar bar künlari Šet[nin]

(18) tog̉uz jüz jyl da on eki jyl da öldü. ויחי [9] Da tiri [edi]

(19) Enoš toqsan jyl da tuvdurdu ošol Qenanny. ויחי [10] Da [tiri] $]^{19}$

(20) edi Enoš tuvdurganyndan sortun ošol Qenanny segiz jüz jy[l] ${ }^{20}$

(21) da on beš jyl da tuvdurdu uvullar da qyzlar. ויהיו [11] [Da]

$8 \mathrm{v}^{\mathrm{o}} \quad$ (1) edilar bar künlari Enošnun tog̉uz jüz jyl da beš jyllar da öldü.

(2) ויחי Da tiri edi Qenan jetmiš jyl da tuvdurdu ošol Mahalal-

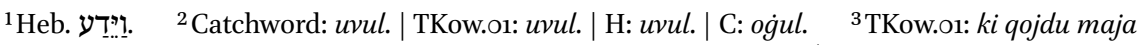
Tenri. | H: ki qojdu mana Tenri. | C: ki qojdu mana Tänri. ${ }^{4}$ Heb. | H: anyn Enoš. | C: Enoš. $\quad{ }^{6}$ TKow.o1: Tenri. | H: Tenri. | C: Täyri. $\quad{ }^{7}$ TKow.o1: erkekni. | H: erkek. | C: erkäk. $\quad{ }^{8}$ TKow.o1: adam. | H: adam. | C: adam. $\quad{ }^{9}$ TKow.o1: otuz. | H: otuz. | C: otuz. ${ }^{10}$ TKow.o1: atady. | H: atady. | C: atady. ${ }^{11}$ TKow.o1: Adamnyn. | H: Adamnyn. | C: Adamnyy. ${ }^{12}$ TKow.o1: tuvdurdu. | H: tuvdurdu. | C: dogurdy. ${ }^{13}$ TKow.o1: Adamnyn. | H: Adamnyn. | C: Adamnyy. $\quad{ }^{14}$ TKow.o1: tuvdurdu. | H: tuvdurdu. | C: doġurdy. $\quad{ }^{15}$ TKow.o1: tuvdurganyndan. | H: tuvdurganyndan. | C: doġurgaanyndan. ${ }^{16}$ TKow.o1: tuvdurdu. | H: tuvdurdu. | C: doġurdy. ${ }^{17}$ TKow.o1: Šetnin. | H: Šetnin. | C: Šetnin. $\quad{ }^{18}$ TKow.o1: edi. | H: edi.| C: deest; different wording. ${ }^{19}$ TKow.o1: tiri.|H: tiri.|C: deest; different wording. $\quad{ }^{20}$ TKow.o1: jyl.|H: jyl.|C: jyl. $\quad{ }^{21}$ TKow.o1: da. $\mid \mathrm{H}: d a$. $\mid \mathrm{C}: d a$.
} 
(21) [25] And Adam knew his wife again, and she bore

(1) a son, and called his name Seth, saying, ['Because God put]

(2) another [offspring for me] in place of Abel, because Cain killed him.' [26]

(3) And a son was born also to Seth, and he called his name Enosh.

(4) Then it was begun to invoke the name of the Lord.

[Genesis 5]

(5) This is the book of the names of the children of Adam. In the day God created

(6) man, he created him in the likeness of angels. [2] He created them male

(7) and female, and blessed them, and called their name Man,

(8) in the day they were created. [3] And Adam lived a hundred

(9) and thirty years, and begat a son in his own likeness, after his image, and called

(10) his name Seth. [4] And the days of Adam

(11) after he had begotten Seth were eight hundred years: and he begat

(12) sons and daughters. [5] And all the days that Adam

(13) lived were nine hundred and thirty years, and he died.

(14) [6] And Seth lived a hundred and five years, and begat

(15) Enosh. [7] And Seth lived after he had begotten

(16) Enosh eight hundred and seven years, and begat

(17) sons and daughters. [8] And all the days of Seth

(18) were nine hundred and twelve year, and he died. [9] And Enosh lived

(19) ninety years, and begat Kenan. [10] And Enosh lived

(20) after he had begotten Kenan eight hundred

(21) and fifteen years, and begat sons and daughters. [11] And

(1) all the days of Enosh were nine hundred and five years, and he died. $8 \mathrm{v}^{\mathrm{o}}$

(2) [12] And Kenan lived seventy years, and begat Mahalalel. 
(3) 'elni. [13] Da tiri edi Qenan tuvdurganyndan sortun ošol

(4) Mahalal'elni segiz jüz jyl da qyrq jyl da tuvdurdu uvullar da

(5) qyzlar. ויהיו [14] Da edilar bar künlari Qenannyn toġuz jüz jyl

(6) da on jyllar da öldü. [15] Da tiri edi Mahalal'el alty-

(7) myš beš jyl da tuvdurdu ošol Jeredni. ויחי [16] Da tiri edi

(8) Mahalal'el tuvdurg̉anyndan sortun ošol Jeredni segiz jüz jyl da

(9) otuz jyl da tuvdurdu uvullar da qyzlar. ויהיו [17] Da edilar

(10) bar künlari Mahalal’elnin segiz jüz jyl da toqsan beš jyl da öldü.

(11) (18] Da tiri edi Jered jüz da altymyš eki jyl da tuvdur-

(12) du ošol Ḥanohnnu. [19] Da tiri edi Jered tuvdurganyndan

(13) sortun ošol Ḥanohnnu segiz jüz jyl da tuvdurdu uvullar da

(14) ויהיו [20] Da edilar bar künĺari Jerednin tog̉uz jüz jyl da

(15) altymyš eki jyl da öldü. ויחי [21] Da tiri edi Ḥanoh

(16) altymyš beš jyl da tuvdurdu ošol Metušelaḥny. [יתהלך. 22]

(17) Da jürüdü Ḥanoh alnynda ol Tenrinin tuvdurgaanyndan sortun

(18) ošol Metušelaḥny [üč ] jüz jyl da tuvdurdu uvullar da qyzlar.

(19) ויחי [23] Da edi bar künlari Ḥanohnnun üč jüz jyl da altymyš

(20) beš jyl. ויתהלך] Da jürüdü Ḥanoh alnynda ol Tenrinin da

(21) joḥtu ki aldy any ol Tenri. ויחי [25] Da tiri edi Metušelaḥ jüz

$1 \mathrm{r}^{03} \quad$ (1) L Lda seksen jedijyl da tuvdurdu osol Lemehni. [26] Da

(2) tiri edi Metušelạ̣ tuvdurğanyndan sortun osol Lemehni

(3) jedi jiz ${ }^{4}$ da seksen ekijyl da tuvdurdu uvullar da qyzlar.

(4) ויהיו [27] Da ediler bar kinleri Metušelahnnyn toġuzjizjyl da

(5) altymys tog்uzjyl da eldi. ויחי [28] Da tiri edi Lemeh jiz ${ }^{5}$ da

(6) seksen ekijyl da tuvdurdu uvul. ויקרא. [29] Da atady osol

(7) atyn anyn Novah ajtadogac bu uvutur ${ }^{6}\langle$ bizni islerimizden da

(8) $\quad$ Lahmetinden qolumuznun isinden ol jernin ${ }^{17}$ ki qargady

(9) any Adonaj. ויח. [30] Da tiri edi Lemeh tuvdurganyndan sortun

(10) osol Novahny bes jiz da toqsan bes jyl da tuvdurdu

(11) uvullar da qyzlar. ${ }^{9}$ [13] Da ediler10 bar kinleri Lemehnin

(12) jedijizjyl da jetmis jedijyllar ${ }^{11}$ da eldi. ויחי [32] Da edi

(13) Novah bes jizjasarlyq $q^{12}$ da tuvdurdu Novah osol Šemni osol

(14) Hamny da osol Jefetni. ויחי

\footnotetext{
${ }^{1}$ TKow.o1: $\ddot{u c} . \mid$ H: $i c . \mid$ C: $\ddot{u} c$. $\quad{ }^{2}$ Catchword: da seksen. $\quad{ }^{3}$ The ending fragment of Gen $5: 25$, the verses of Gen 5:26-6:9, and the beginning of Gen 6:10 of the original manuscript are missing. These fragments were supplemented by another hand in the 19th century in SouthWestern Karaim. The folios $1 \mathrm{r}^{\mathrm{o}}-1 \mathrm{v}^{\mathbf{o}}$ were erroneously sewn in at the beginning of the manuscript. ${ }^{4}$ TKow.o1: jüz jyl. $\quad{ }^{5}$ TKow.o1: jüz jyl. $\quad{ }^{6}$ TKow.o1: juvatyr. $\quad{ }^{7}$ TKow.o1: qyjynyndan qol-

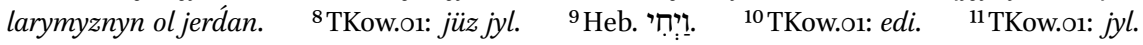
${ }^{12}$ TKow.o1: jašar.
} 
(3) [13] And Kenan lived after he had begotten

(4) Mahalalel eight hundred and forty years, and begat sons and

(5) daughters. [14] And all the days of Kenan were nine hundred

(6) and ten years, and he died. [15] And Mahalalel lived sixty

(7) and five years, and begat Jared. [16] And Mahalalel lived

(8) after he had begotten Jared eight hundred and

(9) thirty years, and begat sons and daughters. [17] And

(10) all the days of Mahalalel were eight hundred ninety and five years, and he died.

(11) [18] And Jared lived a hundred sixty and two years, and he begat

(12) Enoch. [19] And Jared lived after he had begotten

(13) Enoch eight hundred years, and begat sons and

(14) daughters. [20] And all the days of Jared were nine hundred and

(15) sixty and two years, and he died. [21] And Enoch lived

(16) sixty and five years, and begat Methuselah. [22]

(17) And Enoch walked before God after he had begotten

(18) Methuselah [three] hundred years, and begat sons and daughters.

(19) [23] And all the days of Enoch were three hundred sixty

(20) five years. [24] And Enoch walked before God, and

(21) he was not, for God took him. [25] And Methuselah lived a hundred

(1) $\quad$ L and eighty-seven years, and begat Lamech. [26] And

(2) Methuselah lived after he had begotten Lamech

(3) seven hundred and eighty-two years, and begat sons and daughters.

(4) [27] And all the days of Methuselah were nine hundred years and

(5) sixty-nine years, and he died. [28] And Lamech lived a hundred and

(6) eighty-two years, and begat a son. [29] And he called

(7) his name Noah, saying, 'This will console from our labour and

(8) from our hands's toil because of the ground which the Lord has cursed.'

(9) [30] And Lamech lived after he had begotten

(10) Noah five hundred and ninety-five years, and begat

(11) sons and daughters. [31] And all the days of Lamech

(12) were seven hundred years and seventy-seven years, and he died. [32] And

(13) Noah was five hundred years old, and Noah begat Shem,

(14) Ham, and Japheth.

16 The ending fragment of Gen 5:25, the verses of Gen 5:26-6:9, and the beginning of Gen 6:10 of the original manuscript are missing because of damage. The folios $1 \mathrm{r}^{\mathrm{o}}-1 \mathrm{~V}^{\mathrm{o}}$ were erroneously sewn in at the beginning of the manuscript. 
Genesis 6 adam artma jizleri istine ol jernin da qyzlar tuvdular alarġa. ויראו [2] Da kerdiler ulanlary¹ ol terecilernin ${ }^{2}$ osol qyzlaryn ol adamnyn ki ${ }_{1}$ kerkli ediler ${ }^{13}$ alar da aldylar ezlerine qatynlar baryndan ki sajladylar. ויאמר. [3] Da ajtty Adonaj jarg்ulasmasty klegim menim adam icin dunjagadejin anyn icin $k i^{5}$ ol guftu da bolurlar kinleri anyn qajtmaqqa jaman islerinden jiz egirmi jyl ${ }_{\perp}$ da qajtma $[s] s^{6}$ jaman islerinden bu vahtqa uzartma $[\mathrm{m}] \mathrm{men}^{7}$ alarga acuvumnu ki andan sortun keter karanja jaman isleri icin alarnyn ${ }^{18}$. הנפלים. [4] Ol alanqasarlar ediler jerde ol vahtlarda da dag்yn anda [n] ${ }^{9}$ sortun ki kelsejediler ulanlary ol terecilernin ${ }^{10}$ qyzlaryna $[\mathrm{ol}]^{11}$ adamnyn da tererediler alarga alardylar ${ }^{12}$ ol bagatyrlar ki avaldan ol slavaly ${ }^{13}$ el. וירא. [5] Da kerdi Adonaj ki kep ${ }^{14}$ jamanlyg்y ol adamnyn jerde da bar jeceri sag்yslarynyn jireginin tek jamandy har kin. וינחם. [6] Da fasman etti Adonaj ki jaratty ${ }^{15}$ osol adamny ${ }^{16}$ jerde da acyrgandy fikirinde17. ויאמר. [7] Da ajtty Adonaj sirtermen ${ }_{L} o$ [sol] ol118 adamny ki jarattym jizleri istinden ol jernin ba $[\mathrm{r}]^{19}$ adamdan tuvarg்adejin qumuzg்adejin da qusunadejin ol keklernin ki fasman ettim ki qyldym ${ }^{20}$ alarny. וני. [8] Da Novah tapty sirinlik 'enajatlary alnyna ${ }^{121}$ Adonajnyn.

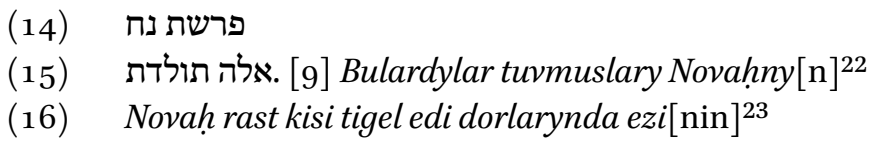

\footnotetext{
${ }^{1}$ TKow.o1: uvullary. $\quad{ }^{2}$ TKow.o1: agalyqlarnyn. $\quad{ }^{3}$ TKow.o1: körklüdülar. $\quad{ }^{4}$ TKow.o1: ne ki. ${ }^{5}$ TKow.o1: ki dagyn. $\quad{ }^{6} \mathrm{~K}$ : qajtmasa; a scribal error. | TKow.o1: deest; different wording. | H: deest; different wording. |C: deest; different wording.|V: deest; different wording. $\quad{ }^{7} \mathrm{~K}$ : uzartmamen; a scribal error. | H: deest; different wording. | C: deest; different wording. | V: deest; different wording. $\quad{ }^{8} \mathrm{~K}$ : Interpretative addition to the standard text. | TKow.o1: da eger bu zaman ašyra tüzetmeselar išlerin keltirirmen alar üstüna ol mabulnu; interpretative addition to the standard text. ${ }^{9}$ TKow.o1: andan. | H: andan. | C: andan. | V: andan. ${ }^{10}$ TKow.o1:agjalyqlarnyn. ${ }^{11}$ TKow.o1: ol. | H: ol. | C: ol.|V:ol. ${ }^{12}$ TKow.o1:alar edilar. ${ }^{13}$ TKow.o1: atly. ${ }^{14}$ TKow.o1: köptü. ${ }^{15}$ TKow.o1: qyldy. $\quad{ }^{16}$ TKow.o1: ol adamny. $\quad{ }^{17}$ TKow.o1: fikirind́an. $\quad{ }^{18}$ TKow.o1: ošol ol. | H: osol ol. | C: šol. ${ }^{19} \mathrm{~K}$ : Uncertain reconstruction. | TKow.o1: deest. | H: deest. | C: deest. | M: deest. | V: deest. | R: deest. $\quad{ }^{20}$ TKow.o1: jarattym. $\quad{ }^{21}$ TKow.o1: enajatlarynda. $\quad{ }^{22}$ TKow.o1: Novahnyn. | H: Novaḥnyn. | C: Novaḥnyy. | V: Novahnnyn. ${ }^{23}$ TKow.o1: özünün. | H: özünin. | C: deest. | V: deest.
} 
Genesis 6

(15) to multiply on the face of the earth, and daughters were born

(16) to them: [2] And the sons of the judges saw the

(17) daughters of men that they were attractive. And they took

(18) them women, from all they chose. [3] And the Lord said,

(19) 'My will shall not strive with man forever,

(20) because he is also flesh; and their days shall be a hundred and twenty years ${ }_{\mathrm{L}}$ to cease

(21) |doing $\mid$ evil deeds, and if they do not cease |doing $\mid$ evil deeds

(22) until that time, I will not prolong my anger at them, because after that

(1) a punishment will come due to their evil deeds.' 117 [4] The

(2) giants were on the earth in those times, and also after that,

(3) when the sons of judges were coming to the daughters

(4) of men, and they were bearing children to them: they are the heroes

(5) which were of old: men of renown. [5] And God saw the great

(6) evil of man was great in the earth, and all the inclination of his thoughts

(7) of his heart was only evil, every day. [6] And the Lord regretted

(8) that he had made man on the earth, and suffered

(9) in his mind. [7] And the Lord said, I will wipe out the

(10) man whom I have created from the face of the earth; from all

(11) the men to animal to creeping thing, and to the birds

(12) of the skies, because I regret that I made them.' [8] But

(13) Noah found favour in the eyes of the Lord.

(14) Parashat Noach

(15) [9] These are the generations of Noah:

(16) Noah was a just man and perfect in his own generations,

17 An interpretative addition to Gen 6:3. 
(17) alnynda ol Tenrinin jiridi Novaḥ. ויולד [10] Da tuvdur[du]

(18) Novah ic $\}^{12}$

$9 \mathrm{r}^{\mathrm{o}} \quad$ (1) [ [uvullar ošol] ${ }^{13}$ Šemni da ošol Hamny da ošol Jefetni.

(2) [ותשחת [1] [11 Da čejpaldy ol jer alnynda ol Tenrinin da ${ }_{\text {L }}$ told[u]

(3) [ol jer avan]lyqtan ${ }^{15}$. וירא [12] Da kördü Tenri ošol ol jerni

(4) [da muna $]^{6}$ čejpaldy ki čejpady bar ten jolun özünün ol jer

(5) [üstüń] [13]. Da ajtty Tenri Novaḥa uču

(6) [ [bar tenni] $\mathrm{n}^{78}$ keldi alnymda ki toldu ol jer avanlyq ${ }_{\mathrm{L}}$ alynlaryn-

(7) [dan alarnyn $]^{19}$ da muna men čejparmen alarny ol jerd́an. עשה. [14]

(8) _[Qylğyn öz] üja ${ }^{110}$ gerep na\{r\}at ag̉ačlaryndan hujalar ${ }^{11}$ qylg̈yn ol

(9) [gerepd́a $]^{12}$ da jaqqyn any ičkertin da tyšqartyn smolabyla

(10) [וזה] [15] Da budur ol qyjas ki qylg̀yn any üč jüz lokot ${ }_{\text {L }}^{13}$ uzunlu-

(11) [g் ol $]^{114}$ gerepnin enli lokot kenligi anyn da otuz lokot

(12) [turušu] anyn. צהר. [16] Terež́a qylg̀yn gerepǵa da lokot

(13) [byla tü]gellegin ${ }^{116}$ any jog̉artyn da ešigin ol gerepnin janynda

(14) [qojğun] ${ }^{17}$ jerǵaler eki qat da üč qat qylğyn any. ואני [17]

(15) $[\mathrm{Da}]^{18}$ muna men keltirirmen ošol suvlaryn ol mabulnun ol

(16) ¿[jer üst] üńa ${ }^{119}$ čejpama bar tenni ki anda nafsty tirlik-

(17) [nin tüb]ünd́an ${ }^{120}$ ol kökĺarnin barča neki jerd́a tynar.

(18) [והקמתי[18] Da qajjam etarmen ošol šertimni birǵaja da

(19) [kelgin ol $]^{22}$ gerepǵa sen da uvullaryj da qatynyj da qatynlary

(20) [uvullaryj]nyn ${ }^{23}$ birǵaja. ומכל. [19] Da bar ol tiridan bar Ltend́a[n]

(21) ekšerini ${ }^{24}$ baryn]dan ${ }^{125}$ keltirgin gerepǵa tiri tutma birǵaja

$9 \mathrm{v}^{\mathrm{o}}$ (1) [e]rkek ${ }^{26}$ da tiši bolsunlar. מהעוף. [20] Ol quštan క̌y[nsy-]

(2) sajyn ${ }^{27}$ da ol tuvardan క̌ynsysajyn bar qomuzundan ol jernin

${ }^{1}$ TKow.o1: tuvdurdu. | H: tuvdurdu. | C: dogiurdy. | V: tuvdurdu. $\quad{ }^{2}$ Insertion by another hand in South-Western Karaim. $\quad{ }^{3}$ Catchword: uvullar. | TKow.o1: uvullar ošol. | H: uvullar. | C: og lanlar šol. $\quad{ }^{4}$ Heb. toldy ol jer avanlyq. $\quad{ }^{6}$ TKow.o1: da muna. | H: da muna. | C: da muna. $\quad{ }^{7}$ TKow.ol: üstüna. | H: istine. | C: üstünä. $\quad{ }^{8}$ TKow.o1: bar tennin. | H: bar tennin. | C: barča tänniฤ. $\quad{ }^{9}$ TKow.o1: alynlaryndan. | H: alynlaryndan. | C: aldlaryndan. ${ }^{10}$ TKow.o1: qylgyn özüje. | H: qylg̀nn ezine. | C: qylġyn özüyä. $\quad{ }^{11}$ Probably a mistranslation. | TKow.o1: hujalar. | H: hujalar. | C: hožralar. | R: ḩužuralar. | Heb. קִִּ̣ 'rooms'. ${ }^{12}$ Cf. Gen 6:16. | TKow.o1: gerepd́a. | H: gerepni. | C: gem-

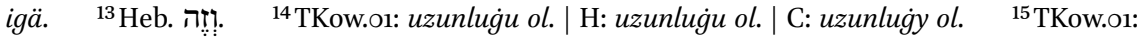
turušu. | H: turusu. | C: bijikligi. ${ }^{16}$ TKow.o1: byla tügállagin. | H: byla tigellegin.| C: bilä tavusqyn. ${ }^{17}$ TKow.o1: qojgun. | H: qojgun. | C: qojgyn. $\quad{ }^{18}$ TKow.o1: da. | H: da. | C: da. $\quad{ }^{19}$ TKow.o1: jer üstüná | H: jer istine. | C: jer üstünä. ${ }^{20}$ TKow.o1: tiri žan tübünd́an. | H: tirliknin istinden. | C: tiri

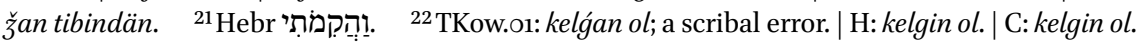
${ }^{23}$ TKow.o1: uvullaryjnyn. | H: uvullarynnyn. | C: og̉lanlaryynyy. $\quad{ }^{24}$ Cf. Gen 7:2. $\quad{ }^{25}$ TKow.o1: tenden ekšerini baryndan. | H: tenden ekseri baryndan. | C: tändän ekišär barčadan. ${ }^{26}$ TKow.o1: erkek. | H: erkek. | C: erkäk. ${ }^{27}$ TKow.o1: క̌ynsysajyn. | H: zynsysajyn. |C: žinsinä. 
(17) and Noah walked before God. [10] And Noah begat

(18) three 118

(1) [sons:] Shem, and Ham, and Japheth.

(2) [11] The earth was broken before God, and the [earth] was filled

(3) with [wickedness]. [12] And God saw the earth,

(4) [and, lo], it was broken, for all flesh had corrupted their own way [on] the earth.

(5) [13] And God said to Noah, 'The end

(6) [of all flesh] has come before me, for the earth is filled with wickedness

(7) through [them], and, lo, I will wipe them out from the earth. [14]

(8) [Make yourself] a ship of pine wood, make nests ${ }^{19}$

(9) [on the ship], and grease it inside and outside with pitch.

(10) [15] And these are the measures |according to| which you shall make it: Three hundred cubits |shall be| [the] length

(11) of the ship, the breadth of it fifty cubits, and thirty cubits

(12) its [height]. [16] Make a window for the ship, and [finish] it [within] a cubit

(13) above, and [set] the door of the ship in its side.

(14) Set storeys: make it a second storey and third storey. [17]

(15) [And], lo, I will bring a flood of waters

(16) [on] the [earth] to destroy all flesh in which is the breath [of] life

(17) [under] the skies. And everything that is in the earth shall die.

(18) [18] But I will strengthen my covenant with you, and

(19) and [you shall come] to the ship, you, and your sons, and your wife,

(20) and your [sons'] wives with you. [19] And of every living thing, of all flesh,

(21) you shall you bring [two of every] one of them to the ship to keep them alive with you.

(1) They shall be male and female: [20] Of the birds

(2) according to their [kinds], and of the livestock according to their kinds, of all creeping animals of the earth

18 Inserted by another hand in South-Western Karaim.

19 Possibly a scribal error (or a mistranslation) instead of the correct hužralar 'rooms', cf. Heb. קָּנִּים 'rooms' (Gen 6:7). 
(3) 3̌ynsysajyn ekš́ari baryndan kelirlar saja tiri tutma.

(4) [21] Da sen alg̀yn özüja bar jemd́an ki ašaldy da

(5) jyštyrg்yn özüja da bolsun saja da alarg̉a jemǵa.

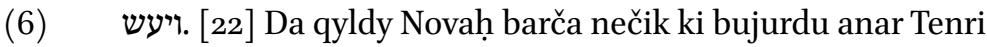

(7) alaj qyldy.

Genesis 7

(8) da bar eli üvüjnün ol gerepǵa ki seni kördüm rastny

(9) alnymda ošpu dorda. מכל. [2] Bar ol tuvardan ol aruv

(10) alg̀yn özüja jediš́arjedišer kišini da qatynyn anyn da ol

(11) tuvardan ki tüvüldü aruv ol ekšerni kišini da qatynyn an[yn]1.

(12) [3ם [3] Dag̉yn qušundan ol köklarnin jedišar jediš́ar er-

(13) kekni da tišini tiri tutma urluq jüzlari üstüńa

(14) bar ol jernin. כ4 Ki hanuz jedi künlerdan men javdurur-

(15) men ol jer üstüńa qyrq kün da qyrq keč́a da sürter-

(16) men ošol bar ol ḥalqny ki jarattym jüzlari üstüńa

(17) bar ol jernin. [5] Da qyldy Novah barča nečik ki bujur-

(18) du anar Adonaj. ונח. [6] Da Novah alty jüz jašar edi da

(19) ol mabul edi suvlar ol jer üstüńa. ויבא [7 Da

(20) keldi Novah da uvullary anyn da qatyny anyn da qatynlary uvul-

(21) larynyn birgesińa ol gerepǵa alnyndan suvlarynyn ol Lmabul

10 $\mathrm{r}^{\mathrm{o}}$ (1) [nun. [8] Ol aruv tuvardan da ol tuvardan ki tüvüldü

(2) aruv da ol quštan d] $\mathrm{a}^{12}$ bar tebrenedoġan ol jer üstüńa.

(3) [ Ekš́ari baryndan keldilar Novahqua ol gerepǵa er-

(4) kek da tiši ki nečik bujurdu Tenri Novaḥqa. ויהי] Da

(5) edi jedi künlerd́an da suvlary ol mabulnun boldular ol jer

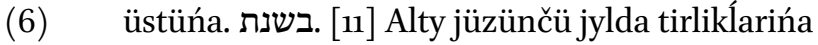

(7) Novaḥnyn ol ekinči janğajda ol jedinči kününd́a janğaj-

(8) nyn ošpu künd́a jarčyqlandylar bar köz suvlary ullu darja[nyn $]^{3}$

(9) da terežaleri ol köklernin ačyldylar. [12] Da e[di] $]^{4}$

(10) ol jamg்ur ol jer üstüńa qyrq kün da qyrq keč́a.

(11) (13] Kensisind́a ošpu künnün keldi Novaḥ da Š[em] $]^{5}$

\footnotetext{
${ }^{1}$ TKow.ol: anyn. | H: anyn. | C: deest. $\quad{ }^{2}$ Catchword (suffix): nun. | TKow.ol: nun. Ol aruv tuvardan da ol tuvardan ki tüvüld aruv da ol quštan ki. | H: mabulnun. מן. Ol tuvardan ol aruv da ol tuvardan ki tivildi aruv da ol qustan da. | C: mabulnyy. מן. Ol aruv tuvardan da ol tuvardan ki aruv dügüldir da ol quštan da. ${ }^{3}$ TKow.o1: darjanyn. | H: darjanyn.| C: derjanyy. $\quad{ }^{4}$ TKow.o1: edi.| H: edi.|C: boldy. $\quad{ }^{5}$ TKow.or: Šem. | H: Šem. | C: Šem.
} 
(3) according to its kind, two of every sort will come to you to keep them alive.

(4) [21] And take with you of all food that is eaten, and

(5) you shall gather it to you, and it shall be for you and for them for food.'

(6) [22] And Noah did everything as God commanded him,

(7) he did so.

Genesis 7

(8) and all your household into the ship, for I have seen you as righteous

(9) before me in this generation. [2] Of every clean animals

(10) take with you by sevens, male and his female, and of the

(11) animals that are not clean by two, the male and his female.

(12) [3] Also of birds of the skies by sevens,

(13) the male and the female, to keep their offspring alive on the face

(14) of all the earth. [4] Because yet seven days, and I will cause it to rain

(15) on the earth forty days and forty nights, and I will destroy

(16) every living thing that I have created from off the face

(17) of all the earth.' [5] And Noah did everything as the

(18) Lord commanded him. [6] And Noah was six hundred years old,

(19) and the flood of waters was on the earth. [7] And

(20) Noah came in, and his sons, and his wife, and his sons' wives

(21) with him, into the ship, |to escape| from before the waters of the flood.

(1) [8] [Of clean animals, and of animals that are not

(2) clean, and of birds, and] everything that creeps on the ground:

(3) [9] They went into the ship by twos to Noah,

(4) male and his female, as God had commanded Noah. [10] And

(5) it was after seven days that the waters of the flood were

(6) on the earth. [11] In the six hundredth year of Noah's life,

(7) in the second month, the seventeenth day of the month,

(8) on that day all the springs [of] the great deep broke up,

(9) and the windows of the skies were opened. [12] And

(10) the rain was on the earth forty days and forty nights.

(11) In the very same day came Noah, and [Shem], 
(12) da Ḥam da Jefet uvullary Novaḥnyn da qatyny Novaḥnyn da ü[č $]^{1}$

(13) qatynlary uvullarynyn birgelerińa ol gerepge. המה [14]

(14) Alar da bar ol kijik žynsysajyn da bar ol tuvar žynsysajyn

(15) da bar ol qomuz ol tebrenedoġan ol jer üstüńa žynsy-

(16) [s]ajyn² da bar ol quš žynsysajyn bar quš bar qanatly. ויבאו. [15]

(17) $[\mathrm{D}] \mathrm{a}^{3}$ keldiler Novaḥqa ol gerepǵa ekš́ari ekšeri bar ${ }_{\mathrm{L}}[\mathrm{ol}$

(18) te[nd́an] ${ }^{14}$ ki anda nafsty tirliknin. והבאים. [16] Da [ [ol

(19) ke[lüvčülar] ${ }^{15}$ erkek da tiši bar tend́an keldilar ki ${ }_{\lfloor}$neč[ik

(20) buju[rdu $]^{16}$ anar Tenri da bekledi Adonaj anyn ašyra. ['יהי[י]

(21) Da $]^{17}$ edi ol mabul qyrq kün ol jer üstüńa da $[$ [köp bol-]

$10 v^{0} \quad$ (1) dular ${ }^{18}$ ol suvlar kötürdüler ošol ol gerepni da

(2) kötürüldü ol jer üstünd́an. ויגברו. [18] Da küčejdi-

(3) lar ol suvlar da köp boldular astry ol jer üstüńa

(4) da bardy ol gerep jüzleri üstüńa ol suvlarnyn. והמים. [19]

(5) Da ol suvlar küčejdilar astry astry ol jer üstüńa

(6) da qapladylar bar ol bijik tavlar ki tübünd́a bar ol kök-

(7) lernin. [20] On beš lokot jog̉artyn küčejdilar ol

(8) suvlar nečik qapladylar ol tavlar. ויגוע. [21] Da tyndy

(9) bar ten ol tebrenüvčü ol jer üstüńa qušta da

(10) tuvarda da kijikta da bar ol qomuzda ol qozlajdogian

(11) ol jer üstüńa da bar ol adam. כ2 [22] Barča neki

(12) nafsty tirliknin burnunda anyn baryndan neki quruda

(13) öldüĺlar. וימח [23] Da sürttü ošol bar ol halqny

(14) ki jüzlari üstüńa ol jernin adamdan tuvargaadejin qomuz-

(15) gadejin da qušunadejin ol kökĺarnin da sürtüldülar

(16) ol jerdan da qaldy ančaq Novaḥ da ne ki birgesińa gerep-

(17) de. de [24] Da küčejdiĺar ol suvlar ol jer üstü-

(18) ńa jüz enli kün.

Genesis 8

(19) ny da ošol bar ol kijikni da ošol bar ol tuvarny ki bir-

(20) gesińa gerepd́a da ašyrdy Tenri jel ol jer üstü-

\footnotetext{
1TKow.o1: üč. | H: ic. | C: üč. $\quad{ }^{2}$ TKow.o1: ̌̌ynsysajyn. | H: zynsysajyn. |C: žinsinä. $\quad{ }^{3}$ TKow.o1: da. | H: da. | C: da. $\quad{ }^{4}$ TKow.o1: ol tenden. | H: ol tenden. | C: ol tändän. $\quad{ }^{5}$ TKow.o1: kelüvčülar. | H: ol kelivciler. | C: kelgänlär. ${ }^{6}$ TKow.o1: nečik bujurdu. | H: necik bujurdu. | C: nečik ki symarlady.

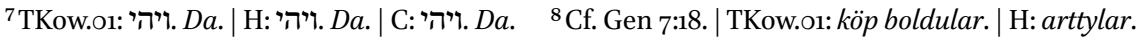
| C: köbäjdilär. | V: arttylar.
} 
(12) and Ham, and Japheth, the sons of Noah, and Noah's wife, and the [three]

(13) wives of his sons with them, to the ship. [14]

(14) They, and every wild animal according to its kind, and all the livestock according to their kind,

(15) and every creeping animal that creeps on the earth, according to its kind,

(16) and every bird, according to its kind, every winged bird. [15]

(17) And they came to Noah to the ship, two by two of all

(18) [flesh] in which is the breath of life. [16] And

(19) those that came, male and female of all flesh, came [as]

(20) God [had commanded] him. And the Lord shut it above him. [17]

(21) [And] the flood was forty days on the earth,

(1) and the waters [increased], and raised the ship, and

(2) it was raised above the earth. [18] And

(3) the waters increased, and multiplied greatly on the earth,

(4) and the ship was on the face of the waters. [19]

(5) And the waters increased very greatly on the earth,

(6) and they covered all the high mountains that were under all the skies.

(7) [20] Fifteen cubits above, the waters increased

(8) as they covered the mountains. [21] And all flesh expired

(9) that moved on the earth: among the birds and

(10) among the livestock and among the wild animals and among all the creeping animals that creep

(11) on the earth and all the man: [22] Everything

(12) that had the breath of life in its nostrils of all that was in the dry land,

(13) died. [23] And he destroyed every nation

(14) which was on the face of the earth, both man and livestock

(15) and creeping animals and birds of the skies, and they were destroyed

(16) from the earth. And only Noah was left, and those who were with him in the ship.

(17) [24] And the waters increased on the earth

(18) a hundred and fifty days.

Genesis 8

[1] And God remembered Noah,

(19) and every wild animal, and all the livestock that

(20) were with him in the ship. And God made a wind to pass over the earth 
(21) ńa da japtyryldylar ol suvlar. ויסכרו. [2] Da Leklendi-

$11 \mathrm{r}^{\circ} \quad$ (1) [ler köz suvlar darjanyn da terežaleri ol kökí[a]rnin da qaldy ol

(2) jamġur ol [1] [3] Däklardan. Dajtylar ol suvlar

(3) $\quad[\text { ol jer }]^{12}$ üstüńa bara da qajta da eksildilar ol suvlar

(4) [aheri]nd́an jüzz enli künnün. [4] Da toḥtady ol gerep

(5) [ol jed $]$ inči $^{4}$ janġajda on jedinči kününd́a janġajnyn tavlary

(6) [üst]üńa ${ }^{5}$ Araratnyn. והמים [5] Da ol suvlar L baryredilar

(7) [da e] ksiliredilar $^{16}$ ol onunču janġajġadejin onunču janġajda

(8) [burun] $\dot{g}^{7}$ kününde janġajnyn köründülar bašlary ol tavlarnyn.

(9) [יהי] [6] Da edi aherind́an qyrq künnün da ačty Novaḥ ošol

(10) [terež́asin ] $]^{9}$ ol gerepnin ki qyldy. [7] Da ijdi ošol ol

(11) [qarġany $]^{10}$ da čyqty čyġa da qajta qurugiunča ol suvlar ol

(12) L[jer ü]stüńa ${ }^{111}$. וישלח. [8] Da ijdi ošol ol kügürčünnü

(13) [[özü] $]^{12}[q]$ atyndan ${ }^{113}$ körma jengillendilarmo ol suvlar jüzleri üs-

(14) [tünd́a]n ${ }^{14}$ ol jernin. ולא. [9] Da tapmady ol kügürčün Ltynč-

(15) [lyq taba]nyna ${ }^{115}$ ajaġynyn da qajtty anar ol gerepǵa ki suvlar

(16) [edilar $]^{16}$ jüzlari üstüńa bar ol jernin da sundu qolun da aldy

(17) L[any da] ${ }^{117}$ keltirdi any özüńa ol gerepǵa. [10] Da tözdü daġyn

(18) „[jedi kü]nlar ${ }^{118}$ özgelar da arttyrdy ijḿa ošol ol kügür-

(19) [čünnü $]^{19}$ ol gerepd́an. [11] Da keldi anar ol kügürčün ingir

(20) [vahtta $]^{20}$ da muna japraggy zejtunnun jyrtqan avzunda anyn da

(21) [[bildi Novah $]^{121}$ ki jengillendiliar ol suvlar ol jer üstünd́an.

11 v vo (1) . 112] Da tözdü daggyn jedi künĺar özgeĺar da ijdi

(2) ol kügürčünnü da arttyrmady qajtma anar artyq.

(3) ויהי Da edi alty jüz birinči jylda burunġu janġajda

\footnotetext{
${ }^{1}$ Catchword (suffix): ler. Cf. Gen 7:11. | TKow.o1: beklandilar köz suvlar darjanyn da terežaleri ol köklarnin da qaldy ol jamġur ol. | H: beklendiler kez suvlar darjanyn da terezeleri ol keklernin da ajaldyoljamgur ol.| C: bekländilär čoġraqlary derjanyy da täräžäläriol köknin da tyjyldyoljamg்ur. ${ }^{2}$ TKow.o1: ol jer. | H: ol jer. | C: ol jerniy; different syntax. ${ }^{3}$ TKow.o1: aḥerinden. | H: aherinden. | C: ahyryndan. $\quad{ }^{4}$ TKow.o1: ol jedinči. | H: ol jedinci. | C: jedinži. $\quad{ }^{5}$ TKow.o1: üstüne. |H: istine. |C: üstünä. $\quad{ }^{6}$ TKow.o1: ediler bara da eksij. | H: ediler bara da eksij. | C: bara da eksilä. ${ }^{7}$ TKow.o1: burunġu. | H: burunġu. | C: birindä. $\quad{ }^{8}$ Heb. וㅣ. $\quad{ }^{9}$ TKow.or: teŕažesin. | H: terezesin. | C: täräzäsin. $\quad{ }^{10}$ TKow.o1: qarġany. | H: qarġany. | C: quzg்unny. $\quad{ }^{11}$ TKow.o1: jer üstünden. | H: jer istine. | C: üstündän ol jernin. $\quad{ }^{12} \mathrm{~K}$ : Uncertain reconstruction. | TKow.o1: deest. | H: deest. | C: deest. | V: deest. $\quad{ }^{13}$ TKow.o1: qatyndan. | H: birgesinden özünün. | C: qatyndan. | V: birǵasińdań. $\quad{ }^{14}$ TKow.o1: üstünden. | H: istinden. | C: üstündän. ${ }^{15}$ TKow.o1: tynčlyq tabanyna. | H: tynclyq tabanyna. | C: tynčlyq tabanyna. ${ }^{16}$ TKow.o1: edilar. | H: ediler. | C: deest. ${ }^{17}$ TKow.o1: any da. | H: andy da. | C: any da. ${ }^{18}$ TKow.o1: jedi künlar. | H: jedi künler. | C: jedi künlär. ${ }^{19}$ TKow.o1: kügürčünnü. | H: kigircinni. | C: kögürčünni. $\quad{ }^{20}$ TKow.o1: vahtta. | H: vahtta. | C: vahtyna. ${ }^{21}$ TKow.o1: bildi Novah. | H: bildi Novah. | C: bildi Novah.
} 
(21) and the waters were suppressed. [2] And

(1) [the springs of the deep and the windows of the skies were closed, $11 \mathrm{r}^{\mathrm{o}}$ and the rain]

(2) from heaven [was restrained]. [3] And the waters returned

(3) from off [the earth], going back continually, and the waters decreased

(4) in the course of one hundred and fifty days. [4] And the ship rested

(5) in [the seventh] month, on the seventeenth day of the month, [on] the mountains

(6) of Ararat. [5] And the waters went on

(7) and decreased until the tenth month. In the tenth month,

(8) on the [first] day of the month the tops of the mountains appeared.

(9) [6] And it was in the course of forty days that Noah opened the

(10) [window] of the ship which he had made. [7] And he sent forth a

(11) [raven], and it went forth to and fro, until the waters were dried up

(12) from off the earth. [8] And he sent forth a dove |to go|

(13) from him to see whether the waters were subsided from off the face

(14) of the earth. [9] But the dove found no rest

(15) for the [sole of its foot], and it returned to him to the ship, for the waters

(16) [were] on the face of the whole earth, and he reached out his hand, and took

(17) it and brought it to him to the ship. [10] And he waited yet

(18) another seven days, and again he sent forth the [dove]

(19) from the ship. [11] And the dove came to him at evening

(20) [time], and, lo, there was an olive leaf plucked off in its mouth. And

(21) [Noah knew] that the waters were subsided from on the earth.

(1) [12] And he waited yet another seven days, and sent forth $11 \mathrm{v}^{\mathrm{o}}$

(2) the dove; and it did not return to him anymore.

(3) [13] And it was in the six hundredth and first year, in the first month, 
(4) burungiu kününd́a janġajnyn ${ }_{\llcorner}$suvaldylar $\{[q] \text { urudular }\}^{11}$ ol suvlar jüzleri ü[s]-

(5) tünd́an ${ }^{2}$ ol jernin da keterdi Novaḥ ošol qaplavyn ol gere[p]-

(6) $\quad \operatorname{nin}^{3}$ da kördü da muna qurudular jüzlari ol jernin.

(7) ובחדש] Da ol ekinči janġajda egirmi jedinči [kün-]

(8) ünd́a jangajnyn qurudu ol jer. וידבר. [15] Da sözladi

(9) Tenri Novaḥqa ajtadog̀ač. צא. [16] Čyqqyn ol gerepd́an s[en] ${ }^{5}$

(10) da qatynyj da uvullaryj da qatynlary uvullaryjnyn birǵa[ja] .

(11) כל [17] Bar ol Ltiri [ki] ${ }^{17}$ birǵaja bar tend́an qušta da tuvar-

(12) da da bar ol qomuzda ol tebrenedogan ol jer üstüńa

(13) čyg̉arğyn birǵaja da qozlasynlar jerd́a da jajylsynlar da

(14) $\operatorname{artsynlar}_{L}\langle$ anda $\rangle\left\{\right.$ oljer üstüne ${ }^{18}$. ויצא. [18] Da čyqty Novaḥ da uvullary anyn

(15) da qatyny anyn da qatynlary uvullarynyn birgesińa. כל. [19]

(16) Bar ol kijik bar ol qomuz da bar ol quš bar tebrenedoġan

(17) ol jer üstüńa uruvlarysajyn čyqtylar ol gerepdan.

(18) ויבן Da qondardy Novah mizbeah Adonajğa da aldy bar ol aruv

(19) tuvardan da bar ol aruv quštan da čyğardy 'olalar mizbeahta.

(20) וירח Da qabul etti Adonaj ošol ol ij qabulluqnu da

(21) ajtty Adonaj fikirind́a arttyrmanmen qargaama artyq

$12 \mathrm{r}^{\mathrm{o}} \quad$ (1) [ [ošol ol jer]ni ${ }^{19} \mathrm{ol}$ adam üčün ki jecer jüreginin ol adamnyn

(2) [jamandy $]^{10}$ jašlyqlaryndan da arttyrmanmen artyq karatetme ošol

(3) [bar $]^{11}$ tirini ki nečik qyldym. עד [22] Hanuz bar künlarind́a

(4) $[\mathrm{ol}]^{12}$ jernin čačmaq da ormaq da suvuq da issi da jaz

(5) [da $]^{13}$ qyš da kün da keč́a eksilmaslar.

Genesis 9

(6) [al]ğgy̌lady ${ }^{14}$ Tenri ošol Novaḥny da ošol uvullaryn anyn da ajtty

\footnotetext{
${ }^{1}$ The word $[q]$ urudular was inserted by another hand in the outer margin probably as a correction or explanation of suvladylar; the latter word is not deleted. | TKow.o1: suvaldylar. | H: qurudular. | C: qurudylar. $\quad{ }^{2}$ TKow.o1: üstünd́an. | H: istinden. | C: üstündän. $\quad{ }^{3}$ TKow.o1: geŕapnin. | H: gerepnin. | C: geminin. $\quad{ }^{4}$ TKow.o1: kününde. | H: küninde. | C: künindä. $\quad{ }^{5}$ TKow.o1: sen. | H: sen. | C: sen. $\quad{ }^{6}$ TKow.o1: birgeja. | H: birgene. | C: birgäyä. $\quad{ }^{7}$ TKow.o1: tiri ki. | H: tirini ki. | C: tiri ki. $\quad{ }^{8}$ Correction by another hand. | TKow.ol: ol jer üstünáa. | H: ol jer istine. | C: ol jer üstünä. ${ }^{9}$ Catchword: ošol. | TKow.o1: ošol ol jerni. | H: osol ol jerni. | C: šol jerni. ${ }^{10}$ TKow.o1: jamandy. | H: jamandy. | C: jamandyr. ${ }^{11}$ TKow.o1: bar. | H: bar. | C: barča. $\quad{ }^{12}$ TKow.o1: ol. | H: ol. | C: ol. ${ }^{13}$ TKow.o1: $d a$. | H: $d a$. | C: $d a . \quad{ }^{14}$ TKow.o1: alġyšlady. | H: alġyslady. | C: ag̉yšlady.
} 
(4) on the first day of the month: the waters decreased $\{$ dried up $\}$ from off the face

(5) of the earth. And Noah removed the covering of the ship,

(6) and looked, and lo, the face of the ground had dried.

(7) [14] And in the second month, on the twenty-seventh [day]

(8) of the month, was the earth dried up. [15] And God spoke

(9) to Noah, saying, [16] 'Go out from the ship, [you],

(10) and your wife, and your sons, and your sons' wives with [you].

(11) [17] Every living thing that is with you, of all flesh, both birds and livestock

(12) and creeping animals that creep on the earth:

(13) Take $\mid$ them $\mid$ out with you that they may breed in the earth, spread, and

(14) multiply $\langle$ there $\rangle$ \{on the earth\}.' [18] And Noah came out, and his sons,

(15) and his wife, and his sons' wives with him. [19]

(16) Every wild animal, every creeping animal, and every bird, everything that moves

(17) on the earth went out by families from the ship.

(18) [20] And Noah built an altar to the Lord and took of every clean

(19) animal, and of every clean bird, and offered burnt offerings on the altar.

(20) [21] And the Lord accepted the pleasing aroma, and

(21) the Lord said in his thoughts, 'I will not go on to curse [the ground]

(1) for man's sake any more, because the inclination of the man's heart

(2) is evil from his youth, and I will not go on to punish

(3) every living creature again as I have done. [22] Even in all the days

(4) of [the] earth, sowing time and harvest, and cold and heat, and summer

(5) [and] winter, day and night will not cease.'

Genesis 9

(6) God [blessed] Noah and his sons, and said 
(7) [alar]ğa ${ }^{1}$ jajylyjyz da artyjyz da tolturujuz ošol ol jerni.

(8) [2] Da qorquvujuz da seskenmegijiz bolur bar

(9) [kijig]i² üstüńa ol jernin da bar qušu üstüńa ol kök-

(10) [ĺarn]in ${ }^{3}$ barynda neki tebŕańadi ol jer üstüńa da bar

(11) [baly]qlarynda ${ }^{4}$ ol tengiznin alynyqbyla ki barlary erk[i]jizǵa ${ }^{5}$

(12) [beri]ldiler6. כל [3] Bar qomuz ki ol tiridi sizǵa bolsun

(13) [jem] ǵa $^{7}$ ješilliginkibik kögötnün berdim sizǵa ošol

(14) [bary]syn ${ }^{8}$. [4] Ančaq etni žanybyla qanyn anyn ašamajyz.

(15) ואך [5] Da ančaq ošol qanyjyzny ža\{n\}laryjyz üčün izlermen

(16) [qo]lundan ${ }^{9}$ bar kijiknin izlerman any da qolundan \{ol adamnyn qolundan\} kišinin qaryn-

(17) [da]šyn ${ }^{10}$ anyn izlermán ošol žanyn ol adamnyn. שופך. [6 ] Tö-

(18) [g]üvčü11 qanyn ol adamnyn özǵa adam ašyra qany anyn tö-

(19) [g]ülür ${ }^{12}$ anyn üčün ki susubyla malahnnyn jaratty Tenri

(20) [o]šol ${ }^{13}$ ol adamny. [7אתם [ ] Da siz jajylyjyz da artyjyz

(21) [q]ozlajyz ${ }^{14}$ jerd́a da artyjyz anda. [8] Da ajtty

$12 \mathrm{v}^{\mathrm{o}} \quad$ (1) Tenri Novahqqa da uvullaryna anyn birgesińa ${ }_{[}[\text {ajtadog̉ač }]^{115}$.

(2) ואני [9] Da men muna men qajjam etarmen ošol [šertimni bir-]

(3) gejizǵa ${ }^{716}$ da urlugiujuzbyla özüjüzten sortun. [ [ת. [10] Da] $]^{117}$

(4) $\left\{\right.$ ošol\} bar ol tiri žanbyla ki birgejizǵa qušta da ${ }_{L} \mathrm{t}\left[\right.$ uvarda d]a [bar] ${ }^{118}$

(5) kijigind́a ol jernin birgejizǵa bar čyg̉uvčularyndan ol gerep-

(6) nin bar kijigibyla ol jernin. והקמתי [11] Da qajjam etermen

(7) ošol šertimni birgejizǵa da eksilmesti bar ten artyq

(8) suvlaryndan ol mabulnun da bolmasty daġyn suvlary mabulnun

(9) čejpama ol jerni. [12] Da ajtty Tenri budu belgi-

(10) si ol šertnin ki men bereḿan arama da arajyzg̉a da arasy-

(11) na bar tiri క̌annyn ki birgejizǵa dorlaryna dunjanyn. את. [13]

(12) Ošol jajamny berdim bulutta da bolur belgisińa šertnin

(13) arama da arasyna ol jernin. והיה [14] Da bolǵaj bulutlag̉anym-

(14) da bulut ol jer üstüńa da körünür ol jaja bulutta.

\footnotetext{
${ }^{1}$ TKow.o1: alarga | | H: alarġa. | C: alarġa. $\quad{ }^{2}$ TKow.o1: kijigi. | H: kijigi. | C: kijigi. $\quad{ }^{3}$ TKow.o1: köklarnin. | H: köklernin. | C: kökniq. ${ }^{4}$ TKow.o1: balyqlary byla. | H: balyqlarynda. | C: balyqlaryndan. $\quad{ }^{5} \mathrm{~K}$ : erkejizǵa; a scribal error. | TKow.o1: erkijizge. | H: erkinizge siznin. | C: qolyyyzġa. ${ }^{6}$ TKow.o1: berildilar. | H: berildiler. | C: berildilär. ${ }^{7}$ TKow.o1: jemǵa. | H: jemge. | C: ašamaġa. ${ }^{8}$ TKow.o1: barčany. | H: barysyn. | C: barčany. ${ }^{9}$ TKow.o1: qolundan.| H: qolundan.|C: qolundan. ${ }^{10}$ TKow.o1: qaryndašyn. | H: qaryndasyn. | C: qardašynyy. $\quad{ }^{11}$ TKow.o1: tögüvčü. | H: tegivci. | C: tögüvčü. $\quad{ }^{12}$ TKow.o1: tögülür. | H: tegilir. | C: tögülsin. $\quad{ }^{13}$ TKow.o1: deest. | H: osol. | C: šol. ${ }^{14}$ TKow.o1:qozlajyz. | H: qozlanyz.|C: qozalayyz. ${ }^{15}$ TKow.o1:ajtadoġač. | H: anyn ajtadoġac. | C: demä. $\quad{ }^{16}$ TKow.o1: šertimni birǵajizǵa. | H: sertimni birgenizge siznin.| C: šartymny birgäyizgä.

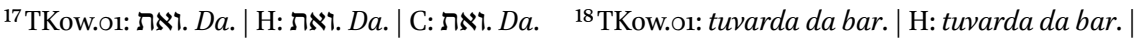
C: tuvarda da barča.
} 
(7) to [them], 'Spread, and multiply, and fill the earth.

(8) [2] And the fear of you and the dread of you will be on every

(9) wild animal of the earth, and on every bird [of] the skie[s],

(10) on all that moves on the earth, and

(11) on all the [fishes] of the sea. They are [given] into your rule.

(12) [3] Every moving thing that lives shall be for [food] for you;

(13) I have given everything to you like the greenness of plants.

(14) [4] Except you shall not eat flesh with its life: its blood.

(15) [5] And except I will require your blood, for you lives.

(16) I will require for it from the [hand] of every wild animal and from the hand of a man.

(17) I will require for a man's life from the hand of each man's [brother]. [6]

(18) One who sheds man's blood: his blood will be shed by another man,

(19) because God created man in the image of angels.

(20) [7] And you, spread, and multiply,

(21) multiply greatly on the earth and multiply in it.' [8] And God said

(1) to Noah, and to his sons with [him, saying],

(2) [9] 'And I, lo, I establish my [covenant with]

(3) you, and with your offspring after you. [10] And

(4) with every living creature that is with you, the birds, the [livestock, and every]

(5) wild animal of the earth with you that goes out of the ark,

(6) with every wild animal of the earth. [11] And I will establish

(7) my covenant with you that never again shall all flesh be killed

(8) by the waters of the flood, and never again shall there be waters of flood

(9) to destroy the earth'. [12] And God said, 'This is the sign

(10) of the covenant that I make between me and you and

(11) every living creature that is with you, for all generations of the world. [13]

(12) I have set my rainbow in the cloud, and it shall be a sign of the covenant

(13) between me and the earth. [14] And it shall be, when I bring a

(14) cloud over the earth, that the rainbow will be seen in the cloud: 
(15) וזכרתי [15] Da sag̉ynyrmen ošol šertimni ki arama da

(16) arajyzğa da arasyna bar tiri క̌annyn bar tend́a da bol-

(17) masty artyq ol suvlar mabulğa čejpama bar tenni.

(18) והיתה Da bolur ol jaja bulutta da bagarmen any

(19) sağynma šertin dunjanyn arasyna Tenrinin da arasyna bar

(20) tiri žannyn bar tend́a ki ol jer üstüńa. [17]

(21) Da ajtty Tenri Novaḥqa budu belgisi ol šertnin ki „qajjam

$13 \mathrm{r}^{\mathrm{0}} \quad$ (1) [ettim arama da arasyna bar tennin ki ol jer üstü-]

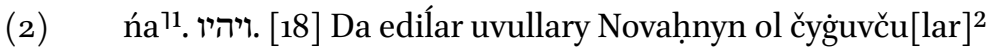

(3) ol gerepd́an Šem da Ḥam da Jefet da Ḥam oldu atasy $\{K\}[$ enáannyn $]^{3}$.

(4) שלשה [19] Üčövlendilar bular uvullary Novahnyn da b[ulardan]

(5) jajyldy bar eli ol jernin. [20] Da bašlady Novah bol[ma ${ }^{5}$

(6) jer išlevčü kiši da ornatty borlalyq. וישת [21]

(7) Ičti ol čaġyrdan da esirdi da ačyndy ortasynda

(8) člatyrynyn. [22] Da kördü Ḥam atasy Kena'annyn [ošol]

(9) ajibin atasynyn da anlatty eki qaryndašlaryna tyšqa[ry-]

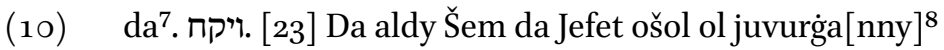

(11) da qojdular javrun üstüńa eksilerid́a da bardy[lar $]^{9}$

(12) Lartqary da qapladylar ošol ajibin atasynyn özleri[nin $]^{10111}$

(13) da jüzleri alarnyn edilar artqary da ajibin atasynyn [öz-]

(14) lerinin ${ }^{12}$ körmedilar. [24] Da ojandy Novah juqusun[dan] $]^{13}$

(15) esirikliginin čaġyrnyn da bildi ošol neki qyldy a[nar $]^{14}$

(16) uvlu anyn ol kičírak. [25] Da ajtty qarğ[yš]-

(17) lydy ${ }^{15}$ Kena'an qulu qullarnyn bolġaj qaryndašlaryna özünün.

(18) ויאמר (26] Da ajtty maḥtavludu Adonaj Tenrisi Šemn[in]

(19) da bolġaj Kena'an qul alarg̉a. יפת. [27] Kenertkej Tenri

(20) čegin Jefetnin da toḥtag̉aj šehinasy Tenrinin čatyrlary[nda $]^{17}$

(21) Šemnin da bolġaj Kena'an qul alarg̉a. ויחי [28] Da tiri

\footnotetext{
${ }^{1}$ Catchword: ettim. | TKow.ol:qajjam ettim arama da arasyna bartennin kioljer üstüńa.| H: qajjam ettim arama menim da arasyna bar tennin ki ol jer istine. | C: turg̉uzdym arama da arasyna barča tiri tänniy ki ol jer üstünä. $\quad{ }^{2}$ TKow.o1: čyg்uvčular. | H: cyg்uvcular. | C: čyqqanlar. $\quad{ }^{3}$ TKow.o1: Kena'annyn. | H: Kena'annyn.|C:Kena'annyy. ${ }^{4}$ TKow.o1: bulardan.|H: bulardan.|C: bulardan. ${ }^{5}$ TKow.o1: bolma. |H: bolma.|C: deest. ${ }^{6}$ TKow.o1: ošol. |H: osol.|C: šol. ${ }^{7}$ TKow.o1: tyšqaryda. | H: tysqaryda. | C: čyšary. $\quad{ }^{8}$ TKow.o1: juvurganny. | H: upraqny. | C: čaršafny. $\quad{ }^{9}$ TKow.o1: bardylar. | H: bardylar. | C: bardylar. ${ }^{10}$ TKow.o1: özlerinin. | H: deest. | C: deest. ${ }^{11}$ This line is not vocalised. Vocalised on the basis of TKow.ol. ${ }^{12} \mathrm{Cf}$. atasynyn özleri[nin] in the same verse above. | TKow.o1: özlerinin. | H: deest. | C: deest. ${ }^{13}$ TKow.o1: esirikliginden. | H: vinasyndan. | C: čaggyryndan. ${ }^{14}$ TKow.o1: anar. | H: anar. | C: ayar. ${ }^{15}$ TKow.o1: qarğy̌̌lydy. | H: qarġyslydy. | C: qargyšllydyr. $\quad{ }^{16}$ TKow.o1: Šemnin. | H: Šemnin. | C: Šemniz. $\quad{ }^{17}$ TKow.o1: čatyrlarynda. | H: catyrlarynda.|C: čatyrlarynda.
} 
(15) [15] And I will remember my covenant, which is between me and

(16) you and every living creature of all flesh. And

(17) the waters shall never again become a flood to destroy all flesh.

(18) [16] And the rainbow shall be in the cloud, and I will look on it

(19) to remember the everlasting covenant between God and every

(20) living creature of all flesh that is on the earth.' [17]

(21) And God said to Noah, 'This is the sign of the covenant, which I have established

(1) [between me and all flesh that is on the earth.']

(2) [18] And the sons of Noah who came out

(3) from the ship were Shem, and Ham, and Japheth. And Ham was the father of [Canaan].

(4) [19] These three are the sons of Noah, and

(5) all the people of the earth spread [from these]. [20] And Noah began [to be]

(6) a man working the ground, and he planted a vineyard. [21]

(7) He drank of the wine, and was drunk, and he was uncovered in the middle of

(8) his tent. [22] And Ham, the father of Canaan, saw [the]

(9) nakedness of his father, and told his two brothers outside.

(10) [23] And Shem and Japheth took a sheet,

(11) and put it on both their shoulders, and went

(12) backward, and covered the nakedness of their own father.

(13) And their faces were backward, and they did not see their [own] father's nakedness.

(14) [24] And Noah woke up [from] the dream

(15) of his drunkenness of wine, and knew what his

(16) younger son had done [to him]. [25] And he said,

(17) 'Canaan is [cursed]: he shall be a servant of servants to his brothers.'

(18) [26] And he said, 'Praised be the Lord God [of] Shem,

(19) and may Canaan be a servant to them. [27] May God widen

(20) Japheth, and the divine Presence of God shall dwell [in] the tents

(21) of Shem, and may Canaan be a servant to them.' [28] And 
$13 v^{0} \quad$ (1) boldu Novaḥ ol mabuldan sortun üč jüz jyl da enli jyl. [29]

(2) Da edilar bar künĺari Novaḥnyn toġuz jüz jyl da enli jyl da

(3) öldü.

Genesis 10

(4) nyn Šem Ḥam da Jefet da tuvdular alarğa uvullar ol mabul-

(5) dan sortun. [2] [2] Uvullary Jefetnin Gomer da Mag̉og da

(6) Madaj da Javan da Tuval da Mešeh da Tiras. [בני [3] Da

(7) uvullary Gomernin Ašḩenaz da Rifat da Tog̉arma. ובני [4] [4]

(8) Uvullary Javannyn Eliša da Taršiš Kitim da Dodanim.

(9) [5 [5] Bulardan jajdylar otračlary ol hạalqlarnyn

(10) jerĺarind́a özlerinin har kiši tilisajyn uruvlarysajyn

(11) hanlyqlarybyla. ובני [6] Da uvullary Ḥamnyn Kuš da

(12) Micraim da Put da Kena'an. ובני (7) Da uvullary Kušnun

(13) Seba da Ḥavila da Savta da Ra'ema da Savteha da

(14) uvullary Ra'emanyn Ševa da Dedan. וכוש. [8] Da Kuš tuv-

(15) durdu ošol Nimrodnu ol bašlady bolma bagatyr jerd́a.

(16) הוא [9] Ol edi avy bag̉atyr alnynda Adonajnyn anyn

(17) üčün ajttylar Nimrod kibik av baġatyry alnynda Adonaj-

(18) nyn. ותהי [10] Da edi bašlyğy bijliginin Babel da Ereh da

(19) Akad da Kalne jerind́a Šin'arnyn. מן. [11] Ol jerd́an čyqty

(20) Ašur da qondardy ošol Nineveni da ošol Roḥovot 'irni

(21) da ošol Kalahnny. ואת [12] Da ošol Resenni arasynda

$14 \mathrm{r}^{\mathrm{o}}$ (1) Ninevenin da arasynda Kalaḥnyn oldu ol ullu šahar. [ומצרים] [13]

(2) Da Micraim tuvdurdu ošol Ludimni da ošol 'Anamimn[i da ${ }^{2}$

(3) ošol Lahavimni da ošol Naftuhimni. ואת [14] Da oš[ol] $]^{3}$

(4) Patrusimni da ošol Kasluhimni ki čyqtylar andan Pelišti $[\mathrm{m}]^{4}$

(5) da ošol Kaftorimni. וכנען. [15] Da Kena'an tuvdurdu o[šol $]^{5}$

(6) Cidonnu tunġučun da ošol Ḥetni. [16] Da ošol ol

(7) Jebusini da ošol ol Emorini da ošol ol Girgašini.

(8) ואת [17] Da ošol ol Ḥivini da ošol ol 'Arqini da ošol [ol] $]^{6}$

(9) Sinini. ואת [18] Da ${ }_{\text {L }}$ ošol ol Arvadini da ošol ol Ḥamatin[i]

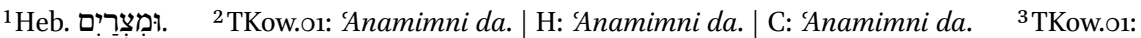
ošol. | H: osol. | C: šol. ${ }^{4}$ TKow.o1: Pelištim. | H: Pelištim. | C: Pelištimlär. ${ }^{5}$ TKow.o1: ošol. | H: osol.|C: šol. ${ }^{6}$ TKow.o1: ol. |H: ol.|C: deest. ${ }^{7}$ TKow.o1: Hamatini.|H: Hamatini.| C: Hamatini. ${ }^{8} \mathrm{~K}$ : da ošol ol Cemarini is missing due to scribal error; cf. TKow.o1. | TKow.o1: ošol ol Arvadini da ošol ol Hamatini. | H: osol ol Arvadini da osol ol Cemarini da osol ol Hamatini. | C: šol Arvadini da šol Čemarini da šol Hamatini.
} 
(1) Noah lived after the flood three hundred and fifty years. [29] $13 \mathrm{v}^{\mathrm{o}}$

(2) And all the days of Noah were nine hundred and fifty years, and

(3) he died.

Genesis 10

(3) [1] And these are the children of the sons of Noah,

(4) Shem, Ham, and Japheth: And sons were born to them

(5) after the flood. [2] The sons of Japheth: Gomer, and Magog, and

(6) Madai, and Javan, and Tubal, and Meshech, and Tiras. [3] And

(7) the sons of Gomer: Ashkenaz, Riphath, and Togarmah. [4]

(8) The sons of Javan: Elishah, and Tarshish, Kittim, and Dodanim.

(9) [5] From these, the islands of the nations spread

(10) in their own lands, everyone according to his language, according to their families,

(11) by their kingdoms. [6] And the sons of Ham: Cush, and

(12) Mizraim, and Put, and Canaan. [7] And the sons of Cush:

(13) Seba, Havilah, Sabtah, Raamah, and Sabteca, and

(14) the sons of Raamah: Sheba and Dedan. [8] And Cush

(15) begat Nimrod: he began to be a mighty one in the earth.

(16) [9] He was a mighty hunter before the Lord. Therefore

(17) it is said, 'A mighty hunter before the Lord like Nimrod.'

(18) [10] And the beginning of his kingdom was Babel, and Erech, and

(19) Accad, and Calneh in the land of Shinar. [11] Asshur came out from that land

(20) and built Nineveh, and Rehoboth-Ir,

(21) and Calah, [12] And Resen between

(1) Nineveh and Calah. That is the big city. [13]

(2) And Mizraim begat Ludim, and Anamim,

(3) and Lehabim, and Naphtuhim, [14] And

(4) Pathrusim, and Casluhim, from which the Philistines came out,

(5) and Caphtorim. [15] And Canaan begat

(6) Sidon, his firstborn, and Heth, [16] And the

(7) Jebusite, and the Amorite, and the Girgashite,

(8) [17] And the Hivite, and the Arkite, and [the]

(9) Sinite, [18] And the Arvadite ${ }^{20}$, and the Hamathite:

$20 \mathrm{~K}$ : and the Zemarite is missing here most probably due to scribal error. 
(10) da andan sortun jajyldylar uruvlary ol Kena'aninin. [19]

(11) Da edi čegi ol Kena'aninin bašlap Cidondan kelüvüj sary Gerarga

(12) 'Azag̉a dejin kelüvüj sary Sedomġa da 'Amorag̉a da

(13) Admag̉a da Cebojimǵa Laša ġa dejin. אלה. [20] Bulardylar

(14) uvullary Ḥamnyn uruvlary sajyn tillari sajyn jerlerind́a hanlyq-

(15) lary sajyn. [21] Da Šemge tuvdu dağgn olda

(16) atasyna bar uvullarynyn 'Evernin qaryndašyna Jefetnin ol

(17) agaraq. בני. [22] Uvullary Šemnin 'Elam da Ašur da

(18) Arpahšad da Lud da Aram. ובני (23] Da uvullary Aramnyn

(19) 'Uc da Ḥul da Geter da Maš. [24] Da Arpahšš[ad]1

(20) tuvdurdu ošol Šelaḥny da Šelaḥ tuvdurdu ošol ['Everni] ${ }^{2}$.

(21) ולעבר [25] Da 'Everǵa tuvdu eki Luvull[ar aty ol birnin] ${ }^{13}$

$14 \mathrm{~V}^{\mathrm{o}}$ (1) Peleg ki vahtlarynda anyn ajyryldy eli ol jernin da aty qaryn-

(2) dašynyn Jaqtan. ויקטן. [26] Da Jaqtan tuvdurdu ošol Elmodadny

(3) da ošol Šalefni da ošol Ḥacarmavetni da ošol Jarahnny.

(4) ואת [27] Da ošol Hadoramny da ošol Uzalny da ošol Diqla-

(5) ny. ואת [28] Da ošol 'Ovalny da ošol Avima’elni da ošol

(6) Šאת [29] Da ošol Ofirni da ošol Ḥavilany da

(7) ošol Jovavny bar bular uvullary Jaqtannyn. [30] Da edi

(8) olturušlary alarnyn bašlap Mešadan kelüvüj sary Sefaraġa

(9) tavy sary ol mizrahnyn. אלה [31] Bulardylar alar uvullary

(10) Šemnin uruvlary sajyn tilleri byla jerlerind́a hanlyqlary sajyn.

(11) [32] Bulardylar uruvlary uvullarynyn Novahnyn tuvmušlary

(12) sajyn hạnlyqlary byla da bulardan ajyryldylar ol ḥanlyqlar jerd́a

(13) ol mabuldan sortun.

Genesis 11

(14) tilli da bir sözlü. [2] Da edi köčkenlerind́a

(15) mizrah sartyn da taptylar eniš jerind́a Šincarnyn da

\footnotetext{
${ }^{1}$ TKow.o1: Arpahšad. | H: Arpahšad. | C: Arpahšad. $\quad{ }^{2}$ TKow.o1: 'Everni. | H: Everni. | C: 'Everni.

${ }^{3}$ TKow.o1: uvullar aty ol birnin. | H: uvullar aty ol birnin. | C: oglanlar aty ol birsinin.
} 
(10) and afterward the families of the Canaanites were spread. [19]

(11) And the border of the Canaanites was from Sidon, in the direction as you come to Gerar,

(12) as far as Gaza, in the direction as you come to Sodom, and Gomorrah, and

(13) Admah, and Zeboim, as far as Lasha. [20] These are

(14) the sons of Ham, according to their families, according to their languages, in their lands,

(15) according to their kingdoms. [21] |Children| were born also to Shem,

(16) to the father of all the children of Eber, the brother of Japheth the

(17) elder. [22] The sons of Shem: Elam, and Asshur, and

(18) Arpachshad, and Lud, and Aram. [23] And the sons of Aram:

(19) Uz, and Hul, and Gether, and Mash. [24] And Arpachshad

(20) begat Shelah, and Shelah begat Eber.

(21) [25] And two son[s] were born to Eber: [the name of one]

(1) is Peleg, for in his days the people of the earth was divided, and his $14 \mathrm{~V}^{\circ}$ brother's name

(2) was Joktan. [26] And Joktan begat Almodad,

(3) and Sheleph, and Hazarmaveth, and Jerah,

(4) [27] And Hadoram, and Uzal, and Diklah,

(5) [28] And Obal, and Abimael, and

(6) Sheba, [29] And Ophir, and Havilah, and

(7) Jobab: all these are the sons of Joktan. [30] And

(8) their place of dwelling was from Mesha, in the direction as you go to Sephar,

(9) to the mountain of the east. [31] These are the sons

(10) of Shem, according to their families, according to their languages, in their lands, according to their kingdoms.

(11) [32] These are the families of the sons of Noah, according to their children,

(12) by their kingdoms: and from these were the kingdoms divided on the earth

(13) after the flood.

Genesis 11

[1] And all the people of the earth was

(14) of one language, and of one speech. [2] And it was, when they journeyed

(15) from the east, that they found a plain in the lowland of Shinar, and 
(16) olturdular anda. [יאמרו. Da ajttylar kiši dos-

(17) tuna kel kirpičlejik kirpičlar da küvdürejik küvdür-

(18) mekka da boldu alarğa ol kirpič taš ornuna da ol

(19) kireč boldu alarg̉a balčyq ornuna. ויאמרו. [4] Da ajtty-

(20) lar kel qondarajyq özümüzǵa šahar da veža da bašy anyn

(21) jetadoġan köklarǵa da qylajyq özümüzǵa slava mag̉at

$15 \mathrm{r}^{\mathrm{r}}$ (1) tozulurbiz jüzleri üstüńa bar ol jernin. [5] Da e[ndi] $]^{1}$

(2) šehinasy Adonajnyn baqma ošol šaharny da ošol ol vežany

(3) ki qondardylar uvullary ol adamnyn. ויאמר. [6] Da ajtty

(4) Adonaj muna bir ulus da bir sözü barlaryna da budur

(5) bašlamaqlary alarnyn qylma da haligińa ajalmasty alardan barča

(6) neki sag̉yš etselar qylma. הבה [7] Kel eńajik da bulġajyq

(7) anda sözün erinlerinin ki anlamag̉ajlar kiši sözün dos-

(8) tunun. ויפץ [8] Da tozdurdu Adonaj alarny andan jüzleri

(9) üstüńa bar ol jernin da qaldylar qondarmaqtan ol šaharn[y $]^{2}$.

(10) על (9] Anyn üčün atady atyn anyn Bavel ki anda bulğad[y $]^{3}$

(11) Adonaj sözün bar elinin ol jernin da andan tozdurdu al[arny ${ }^{4}$

(12) Adonaj jüzlari üstüńa bar ol jernin. אלה. [10] Bulardylar

(13) tuvmušlary Šemnin Šem jüz jašar edi da tuvdurdu o[šol $]^{5}$

(14) Arpahšadny eki jyllar ol mabuldan sortun. [11]

(15) Da tiri edi Šem tuvdurganyndan sortun ošol Arpahša $[\text { dny }]^{6}$

(16) beš jüz jyl da tuvdurdu uvullar da qyzlar. וארפכשד. [12]

(17) Da Aprahšad tiri edi otuz beš jyl da tuvdurd[u $]^{7}$

(18) ošol Šalaḥny. [13] Da tiri edi Arpahšsad tuvd[ur-]

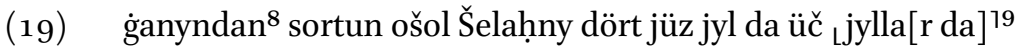

(20) tuvdurdu uvullar da qyzlar. ושלח [14] Da Šelah ti[ri edi]

(21) otuz jyl da tuvdurdu ošol 'Everni. ויחי [15] Da [tiri]

$15 \mathrm{~V}^{\mathrm{o}} \quad$ (1) edi ${ }^{111}$ Šelaḥ tuvdurg̉anyndan sortun Evarny dört jüz jyl

(2) da üč jyllar da tuvdurdu uvullar da qyzlar. ויחי [16] Da tiri

(3) edi 'Ever otuz dört jyl da tuvdurdu ošol Peleg̉ni.

(4) ויחי [17] Da tiri edi 'Ever tuvdurganyndan sortun ošol Peleğ-

(5) ni dört jüz jyl da otuz jyl da tuvdurdu uvullar da qyzlar.

(6) ויחי Da tiri edi Peleg otuz jyl da tuvdurdu ošol

${ }^{1}$ TKow.o1: endi. | H: endi. | C: endi. $\quad{ }^{2}$ TKow.o1: šaharny. | H: saharny. | C: šähärni. $\quad{ }^{3}$ TKow.o1: bulgady. | H: bolganystyrdy. | C: bulgady. $\quad{ }^{4}$ TKow.o1: alarny. | H: alarny.| C: alarny. $\quad{ }^{5}$ TKow.o1: ošol. | H: osol. | C: šol. $\quad{ }^{6}$ TKow.o1: Arpahšadny. | H: Arpahššdny. | C: Arpahšănny. ${ }^{7}$ TKow.o1: tuvdurdu. | H: tuvdurdu. | C: doġurdy. $\quad{ }^{8}$ TKow.o1: tuvdurganyndan. | H: tuvdurganyndan. | C: dogurganyndan. ${ }^{9}$ TKow.o1: jyllar da. $\mid \mathrm{H}:$ jyl da. $\mid \mathrm{C}:$ jyl da. ${ }^{10}$ TKow.o1: tiri edi.| H: tiri edi.|C: tirildi. ${ }^{11}$ TKow.or: tiri edi.| H: tiri.| C: tirildi. 
(16) they dwelt there. [3] And they said one to another,

(17) 'Come, let us make bricks and burn them in fire'.

(18) And they had brick for stone, and

(19) quicklime for clay. [4] And they said,

(20) 'Come, let us build ourselves a city and a tower with its top

(21) reaching to skies, and let us make a fame for ourselves, lest

(1) we be dispersed over the face of the whole earth. [5] And

(2) the divine Presence of the Lord came down to see the city and the tower,

(3) which the children of men built. [6] And the

(4) Lord said, 'Lo, the people are one, and they have all one language, and this is

(5) the beginning of $\mid$ what $\mid$ they $\mid$ will $\mid$ do. And now nothing will be restrained from them,

(6) that they would think to do. [7] Come, let us go down, and confuse there

(7) the words of their lips that they may not understand one another's speech.'

(8) [8] So the Lord dispersed them from there over the face

(9) of all the earth, and they left off building the city.

(10) [9] On account of this its name is called Babel, because there the Lord confused

(11) the language of all the people of the earth, and from there the Lord dispersed them

(12) over the face of all the earth. [10] These are the

(13) children of Shem: Shem was a hundred years old, and begat

(14) Arpachshad two years after the flood. [11]

(15) And Shem lived after he had begotten Arpachshad

(16) five hundred years, and begat sons and daughters. [12]

(17) And Arpachshad lived thirty-five years, and begat

(18) Shelah. [13] And Arpachshad lived after he [had begotten]

(19) Shelah four hundred and three [years, and]

(20) begat sons and daughters. [14] And Shelah [lived]

(21) thirty years, and begat Eber. [15] And Shelah [lived]

(1) after he had begotten Eber four hundred

(2) and three years, and begat sons and daughters. [16] And Eber lived

(3) four and thirty years, and begat Peleg.

(4) [17] And Eber lived after he had begotten Peleg

(5) four hundred and thirty years, and begat sons and daughters.

(6) [18] And Peleg lived thirty years, and begat 
(7) Ru'unu. [19] Da tiri edi Peleg tuvdurganyndan sortun

(8) ošol Ru'unu eki jüz jyl da tog̉uz jyllar da tuvdurdu uvul-

(9) lar da qyzlar. [20] Da tiri edi Ru'u otuz eki jyl

(10) da tuvdurdu ošol Seruğnu. [21] Da tiri edi

(11) Ru'u tuvdurg̉anyndan sortun ošol Serug̉nu eki jüz jyl

(12) da jedi jyllar da tuvdurdu uvullar da qyzlar. [22] Da

(13) tiri Serugg otuz jyl da tuvdurdu ošol Naḥornu.

(14) ויחי Da tiri edi Serug tuvdurganyndan sortun ošol

(15) Nahornu eki jüz jyl da tuvdurdu uvullar da qyzlar. ויחי [24]

(16) Da tiri edi Naḥor egirmi tog̉uz jyl da tuvdurdu ošol

(17) Terahnny. [יחי [25] Da tiri edi Nahoror tuvdurganyndan

(18) sortun ošol Teraḥny jüz jyl da ${ }_{L}[o n]$ toğuz ${ }^{11}$ da

(19) tuvdurdu uvullar da qyzlar. ויחי

(20) jetmiš jyl da tuvdurdu ošol Avramny ošol Naḥornu da

(21) ošol Haranny. ואלה. [27] Da bulardylar tuvmušlary

$16 \mathrm{r}^{\mathrm{o}} \quad$ (1) Terahnyn Terah tuvdurdu ošol Avramny ošol Naḥor[nu $]^{2}$

(2) da ošol Haranny da Haran tuvdurdu ošol Lotnu. [וימת] [28]

(3) Da öldü Haran tiri egend́a Teraḥ atasy anyn tuvmuš

(4) jerind́a özünün Ur Kasdimde. [29] Da aldy

(5) Avram da Nahoror özlerińa qatynlar aty qatynyn Avramnyn

(6) Saraj da aty qatynyn Naḥornun Milka qyzy Harannyn atasynyn

(7) Milkanyn da atasyny Jiskanyn. [30] Da edi Saraj

(8) bödev jog̉edi anar tuvmuš. ויקח [31] Da aldy Terah

(9) ošol Avramny uvlun da ošol Lotnu uvlun Harannyn uvl[un $]^{4}$

(10) uvlunun da ošol Sarajny kelinin qatynyn Avramnyn uvlu[nun $]^{5}$

(11) da čyqtylar birgelerińa Ur Hुasdimden barma jerińa

(12) Kena'annyn da keldilar Haranga dejin da olturdular anda.

(13) - ויהיו (32] Da edi künlari Terahnynn eki jüz jyl da beš jy[llar $]^{6}$

(14) da öldü Teraḥ Ḥaranda.

[Genesis 12]

פרשת לך לך (15) (16) (15) (19)

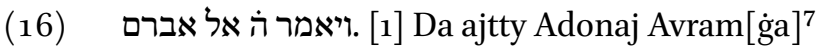

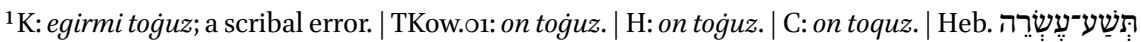
'nineteen'. $\quad{ }^{2}$ TKow.o1: Naḥornu. | H: Nahornu.| C: Naḥorny. $\quad{ }^{3}$ Heb. Iִ. $\quad{ }^{4}$ TKow.o1: uvlun. | H: uvlun. | C: oggly. $\quad{ }^{5}$ TKow.o1: uvlunun. | H: uvlunun. | C: og lynyy. $\quad{ }^{6}$ TKow.o1: jyllar. | H: jyl. | C: jyl. $\quad{ }^{7}$ TKow.o1: Avramġa.|H: Avramġa.|C: Avramga.
} 
(7) Ru'u. [19] And Peleg lived after he had begotten

(8) Ru'u two hundred and nine years, and begat sons

(9) and daughters. [20] And Ru'u lived thirty-two years,

(10) and begat Serug. [21] And Ru'u lived

(11) after he had begotten Serug two hundred

(12) and seven years, and begat sons and daughters. [22] And

(13) Serug lived thirty years, and begat Nahor.

(14) [23] And Serug lived after he had begotten

(15) Nahor two hundred years, and begat sons and daughters. [24]

(16) And Nahor lived twenty-nine years, and begat

(17) Terah. [25] And Nahor lived after he had begotten

(18) Terah a hundred and nine[teen ${ }^{21}$ years, and

(19) begat sons and daughters. [26] And Terah lived

(20) seventy years, and begat Abram, Nahor, and

(21) Haran. [27] And these are the children

(1) of Terah: Terah begat Abram, Nahor,

(2) and Haran, and Haran begat Lot. [28]

(3) And Haran died when his father Terah was alive in the land of his kindred,

(4) in Ur of the Chaldeans. [29] And

(5) Abram and Nahor took them wives. The name of Abram's wife was

(6) Sarai, and the name of Nahor's wife was Milcah, daughter of Haran, father

(7) of Milcah and father of Iscah. [30] But Sarai

(8) was barren. She had no child. [31] And Terah took

(9) Abram, his son, and Lot, son of Haran, his son's [son],

(10) and Sarai, his daughter in law, the wife of Abram, his son,

(11) and they went forth with them from Ur of the Chaldeans to go to the land

(12) of Canaan. And they came as far as Haran, and they dwelt there.

(13) [32] And the days of Terah were two hundred and five [years],

(14) and Terah died in Haran.

[Genesis 12]

(15) Parashat Lech-Lecha

(16) [1] And the Lord said [to] Abram,

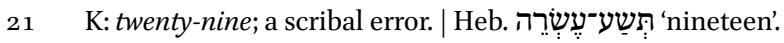


(17) $\mathrm{b}[\mathrm{a}]$ rg̉yn$^{1}$ özüja jerijd́an da tuvmušujdan da

(18) üvünd́an atyjnyn ol jerǵa ki körgüzsem saja. [ואעשך]2 [2]

(19) Da qylarmen seni ullu ḥanlyqqa da alġyšlarmen seni da ${ }_{L}[u l l u]$

$16 v^{0}$ (1) etarmen ${ }^{13}$ atyjny da bolursen alġyš. ואברכה. [3] Da

(2) alġyšlarmen alġyšlavčularyjny da qarg̉avčujnu qarğarmen

(3) da alġyšlanyr senin sartyn bar uruvlary ol jernin. וילך. [4]

(4) Da bardy Avram ki nečik sözledi anar H da bardy birgesińa

(5) Lot da Avram jetmiš beš jašar edi čyqqanynda Harandan.

(6) ויקח [5 [5a aldy Avram ošol Sarajny qatynyn da ošol Lot-

(7) nu uvlun qaryndašynyn da ošol bar mallaryn ki jyštyrdylar

(8) da ošol bar ol žanny ki Jisra’el qyldylar Ḥaranda da čyq-

(9) tylar barma jerińa Kenáannyn da keldiler jerińa Kenáannyn.

(10) [יעבר Da ašty Avram jerd́a ornuna dejin Šeḩemnin

(11) Elon Morege dejin da ol Kena'ani ol vahtta oltururedi

(12) jerd́a. וירא [7] Da aškara boldu šehinasy Adonajnyn

(13) Avramġa da ajtty urlugiuja senin berirmen ošol ol

(14) jerni ošpunu da qondardy anda mizbeah Adonajğa ol

(15) aškara boluvčuğa anar. ויעתק [8] Da köčürdü andan

(16) čatyryn ol tavğa mizrah sartyn Bet’elge da qurdu

(17) čatyryn Bet'el ma'arav sartyn da ol 'Aj kün tuvušu sartyn

(18) da qondardy anda mizbeaḥ Adonajğa da čag̉yrdy aty byla

(19) Adonajnyn. ויסע. [9] Da köčtü Avram bara da köče ol

(20) tüšlük sary. זיהי [10] Da edi ačlyq jerd́a da endi

(21) Avram Micriǵa tirilḿa anda ki küčejdi ol ačlyq

$17 \mathrm{r}^{\mathrm{o}} \quad$ (1) jerd́a. [11] Da edi ki nečik Ljuvut[t]u avulun ${ }^{14}$ kelḿa

(2) Micriǵa da ajtty Sarajǵa qatynyna muna endi bildi $[\mathrm{m}]^{5}$

(3) ki qatyn körklü körümlüdür sen. והיה. [12] Da bolġaj ki [kör-]

(4) seler ${ }^{6}$ seni ol Micrilílar da ajtyrlar qatynydy bu da [öl-]

(5) türürler meni da seni tiri tutarlar. אמר. [13] Ajt[qyn $]^{8}$

(6) qoltqabyla tuvdug̉umdur sen anyn üčün ki jaḥšy bolg̉aj [maja ${ }^{9}$

(7) senin üčün da tiri bolġaj žanym senin sibbajdan. [ויהי[10]

(8) Da edi kelgečoq Avram Micriǵa da kördülar o[1] $]^{11}$

(9) Micrililer ošol ol qatynny ki körklüdü ol ast $[\mathrm{ry}]^{12}$.

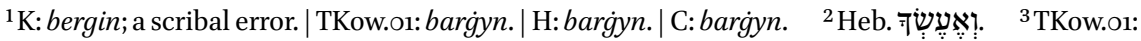
ullu etermen. | H: ulgajtymen. | C: ulgajtyrmyn. ${ }^{4}$ TKow.o1: juvudu. | H: juvuttu. | C: juvuqlašty. ${ }^{5}$ TKow.o1: bilamán. | H: bilemen. | C: bildim. $\quad{ }^{6}$ TKow.o1: körselar. | H: kerseler. | C: körsälär. ${ }^{7}$ TKow.o1: öltürürler. | H: eltirirler. | C: öldirirlär. $\quad{ }^{8}$ TKow.o1: ajtqyn. | H: ajtqyn. | C: ajtyqn. ${ }^{9}$ TKow.o1: maja. | H: mana. | C: maya. $\quad{ }^{10}$ Heb. $\quad{ }^{11}$ TKow.ol: deest. | H: ol. | C: ol. ${ }^{12}$ TKow.o1: astry. | H: astry. | C: asry.
} 
(17) '[Go] yourself from your land, and from your kindred, and

(18) from your father's house, to a land that I will show you. [2]

(19) And I will make of you a great kingdom, and I will bless you, and

(1) make your name [great], so that you will be a blessing. [3] And

(2) I will bless them that bless you, and curse him that curses you.

(3) And all families of the earth will be blessed through you.' [4]

(4) So Abram went, as the LORD had spoken to him, and Lot went with him.

(5) And Abram was seventy-five years old when he went out from Haran.

(6) [5] And Abram took Sarai, his wife, and Lot,

(7) his brother's son, and all their possessions that they had gathered,

(8) and the souls that they had made in Haran, and

(9) they left to go to the land of Canaan, and they came to the land of Canaan.

(10) [6] And Abram passed through the land to the place of Shechem,

(11) as far as to ${ }_{L}$ Elon Moreh ${ }^{122}$. And the Canaanites lived

(12) in the land then. [7] And the divine Presence of the Lord appeared

(13) to Abram, and said, 'I will give this land to your offspring.'

(14) And he built an altar there to the Lord, who

(15) appeared to him. [8] From there he moved

(16) his tent to a mountain on the east of Bethel, and he put up

(17) his tent-Bethel on the west and Ai on the east-

(18) and he built an altar there to the Lord and called upon the name

(19) of the Lord. [9] And Abram journeyed, journeying continually

(20) southward. [10] And there was a famine in the land, and

(21) Abram went down to Egypt to live there because the famine was getting stronger

(1) in the land. [11] And it was, when he brought closer his camp to enter $17 \mathrm{r}^{\circ}$

(2) Egypt, that he said to Sarai his wife, 'Lo now, [I] know

(3) that you are a woman beautiful in appearance. [12] And it shall be if

(4) the Egyptians [see] you that they will say, "This is his wife," and

(5) they will [kill] me, but they will keep you alive. [13] [Say],

(6) I pray you, that you are my sister, that it may go well with [me]

(7) on your count, and my soul shall live because of you.' [14]

(8) And it was, as Abram came to Egypt, that [the]

(9) Egyptians saw the woman: that she was [very] beautiful.

22 A אלון מוֹרֶה 'the oak of Moreh' or 'the land of Moreh'. | TKow.o1: Elon Moreh. | H: the land Moreh. | C: Elon Moreh. 
(10) (15] Da kördülar any ag̉alyqlary par'onun da [mah-]

(11) tadylar ${ }^{1}$ any par'og̉a da alyndy ol qatyn üvüńa pa[roc- $]^{2}$

(12) nun. ולאברם [16] Da Avramġa jahšy̌y etti anyn [üčün]

(13) da edi anar qoj da syğgyr da ešekĺar da q[u]llar ${ }^{4}$ da

(14) qaravašlar da ešeklar da teveler. [ינגע [17] Da has[tala-]

(15) tty ${ }^{5}$ Adonaj ošol par'onu $\left\{\{\text { ullu hastalyqlar\} [byla }]^{16}\right.$ da ošol elin üvün[ün $]^{7}$

(16) Saraj üčün qatyny üčün Avramnyn. [18] Da [ün-]

(17) dedi ${ }^{8}$ paro Avramny da ajtty ne bu qyldyj maja

(18) nek anlatmadyj maja ki qatynyjdy ol. למה [19] Nek a[jttyj]

(19) tuvdugiumdu ol da alybedim any özüḿa qatynlyq[qa]10

(20) da haligińa muna qatynyj alġyn da barg̉yn. ויצו. [20] Da

(21) symarlady anyn qatyna par'o erenĺar da uzattylar [any ${ }^{11}$

$17 \mathrm{v}^{\mathrm{o}} \quad$ (1) da ošol qatynyn anyn da ošol barča neki anyn.

[Genesis 13]

(2) Da bardy Avram Micridan ol da qatyny anyn da barča ne

(3) ki anyn da Lot birgesińa ol tüšlük sary. ואברם [2] Da

(4) Avram ḥoža edi astry tuvarda kümüšta da altynda.

(5) וילך [3] Da bardy köčüvlerisajyn tüšlüktan da Bet’elǵa

(6) dejin ol orunġa dejin ki edi anda čatyry anyn burundan

(7) arasyna Bet'elnin da arasyna ol 'Ajnyn. אל [4] Ornu-

(8) na ol mizbeaḥnyn ki qyldy anda burundan da čagyrdy anda

(9) aty byla Adonajnyn. וגם [5] Da dag̉yn Lotqa ol baruvču-

(10) ġa Avram byla edi qoj da syg̈yr da čatyrlar. ולא [6]

(11) Da syjyndyralmady alarny ol jer olturma birǵa ki

(12) edi mallary alarnyn köp da bolalmadylar olturma birǵa.

(13) ויהי [7 [7 Da edi talaš arasyna kütüvčülernin tuvaryn

(14) Avramnyn da arasyna kütüvčülernin tuvaryn Lotnun

(15) da ol Kena'ani da ol Perizi ol vaḥtta oltururedi

\footnotetext{
${ }^{1}$ TKow.o1: mahtadylar. | H: mahtadylar. | C: mahtadylar. $\quad{ }^{2}$ TKow.o1: paro'nun. | H: paro'nun. |C: paro'nyy. $\quad{ }^{3}$ TKow.o1: üčün. | H: ücün. | C: učun. $\quad{ }^{4} \mathrm{~K}$ : qollar; a scribal error. | TKow.o1: qullar. | H: qullar. | C: qullar. ${ }^{5}$ TKow.o1: hastalatty. | H: hastalatty. | C: hastalandyrdy. ${ }^{6}$ Interlinear insertion by another hand. | TKow.o1: ullu hastalyqlar byla; added by the copyist on the outer margin. | H: ullu hastalyqlar byla. | C: ulu hastalyqlar. ${ }^{7}$ TKow.o1: üvünün. | H: ivinin. | C: evin. ${ }^{8}$ TKow.o1: ünd́adi.|H: cagjyrdy.|C: čaqyrdy. ${ }^{9}$ TKow.o1:ajttyj.|H:ajttyn.|C:ajttyy. ${ }^{10}$ TKow.o1: qatynlyqqa. | H: qatynlyqqa. | C: hatynlyqqa. ${ }^{11}$ TKow.o1: any. | H: any. | C: any.
} 
(10) [15] And the rulers of Pharaoh also saw her, and

(11) they [praised] her to Pharaoh. And the woman was taken to [Pharaoh]'s

(12) house. [16] And he treated Abram well for her [sake]:

(13) and he had sheep, and cattle, and |male| donkeys, and [servants], and

(14) maidservants, |female| donkeys, and camels. [17] And

(15) the Lord made Pharaoh and the people of his house sick [with] \{great diseases\}

(16) because of Sarai, Abram's wife. [18] And

(17) Pharaoh [called] Abram, and said, 'What is this that you have done to me?

(18) Why did you not tell me that she is your wife? [19] Why did you say,

(19) "She is my sister," so I took her for a wife for myself?

(20) Now therefore, lo, take your wife, and go.' [20] And

(21) Pharaoh commanded his men concerning him: and they sent [him] away,

(1) and his wife, and all that he had.

[Genesis 13]

(2) And Abram went from Egypt, he, and his wife, and all that

(3) he had, and Lot with him, southward. [2] And

(4) Abram was very rich in livestock, in silver, and in gold.

(5) [3] And he went on his journeys from the south even as far as to Bethel

(6) to the place where his tent had been at the beginning,

(7) between Bethel and Ai, [4] To the place

(8) of the altar, which he had made there at the beginning: and there Abram called

(9) upon the name of the Lord. [5] And Lot, who was going

(10) with Abram, also had sheep, and cattle, and tents. [6]

(11) And the land was not able to give place to them, that they might dwell together, because

(12) their property were great, so that they could not dwell together.

(13) [7] And there was a strife between the herdsmen of Abram's cattle

(14) and the herdsmen of Lot's cattle:

(15) and the Canaanites and the Perizzites dwelt then 
(16) jerd́a. יויאמר [8] Da ajtty Avram Lotqa qoltqabyla

(17) bolmasyn talaš arama $\{[\mathrm{da}]\}^{1}$ araja da arasyna kütüvčülerim-

(18) nin da arasyna kütüvčülerijnin ki erenlar qaryndašlar-

(19) dyr biz. הלא. [9] Muna bar ol jer alnyjdady ajyrylg̈yn

(20) endi qatymdan eger son jary barsaj da on jary barajym

(21) da eger on jary barsaj da son jary barajym.

18 ro (1) [ישא

(2) majdanyn Jardennin ki ba\{ry\}sy edi suġaruvču čejpamastan burun

(3) Adonaj ošol Sedomnu da ošol 'Amorany bağy kibik Adonajnyn

(4) jeri kibik Micrinin kelüvüjsary Co'arġa. ויבחר. [11] Da sajlady

(5) özüńa Lot ošol bar majdanyn ol Jardennin da köčtü Lot

(6) kün tuvušu sartyn da ajyryldylar kiši qaryndašy qatyndan.

(7) (12] Avram olturdu jerind́a Kena'annyn da Lot oltur-

(8) du šaharlarynda ol majdannyn da qurdu čatyryn Sedomgadejin.

(9) ואנשי Da eli Sedomnun jamanlar da jazyqlylar edilar alnyn-

(10) da Adonajnyn astry. ואנשי [14] Da Adonaj ajtty Avram-

(11) ġa ajyrylyp sortun Lot anyn qatyndan kötürgün \{endi\} közlerijni

(12) da baqqyn ol orundan ki sen anda cafon sary da tüšlük sary

(13) da mizraḥ sary da ma'arav sary. כי [15] Ki ošol bar ol jerni

(14) ki sen köresen saja berirmen any da urlug̉uja dunjaġadejin.

(15) (16] Da qojarmen ošol urluğujnu topraġyn kibik ol

(16) jernin ki eger bolalsa kiši sanama ošol topraġyn ol jernin

(17) dag̉yn urlug̉ujda sanalyr. קום [17] Turg̉un jürügün jerd́a uz[u-]

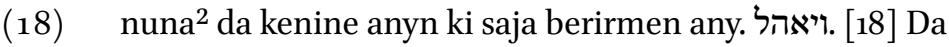

(19) qurdu Avram čatyryn da olturdu tüz jerlerind́a Mamre[nin $]^{3}$

(20) ki Ḥevronda da qondardy anda mizbeah alnynda Adonajnyn.

[Genesis 14]

(21) ויהי [1] Da edi vahtlarynda Amrafelnin bijinin Šincarnyn Arjo[h]-

$18 \mathrm{v}^{0} \quad$ (1) nun ${ }^{4}$ bij[i]nin ${ }^{5}$ Elasarnyn Kedarla'omernin bijinin 'Elamnyn da Tid'alnyn bijinin

(2) Gojimnin. עשו. [2] Qyldylar čerüv Bera byla bijibyla Sedomnun da

(3) Birša byla bijibyla 'Amoranyn Šinav byla bijibyla Admanyn da

(4) Šemever byla bijibyla Cevojimnin da bijibyla Bela'nyn oldur

(5) Co`ar. כ3 [3] Bar bular jyštyryldylar enišińa ol Sidimnin

${ }^{1}$ TKow.o1: $d a$. | H: da. | C: da. $\quad{ }^{2}$ TKow.o1: uzununa. | H: uzununa. | C: uzunluǵuna. $\quad{ }^{3}$ TKow.o1: Mamrenin.|H:Mamrenin. | C: Mamredä; different syntax. ${ }^{4}$ TKow.o1: Arjohnun. | H: Arjohnun. | C: Arjoh. $\quad{ }^{5} \mathrm{~K}$ : bijnin; a scribal error. | TKow.o1: bijinin. | H: bijinin. | C: hany. 
(16) in the land. [8] And Abram said to Lot, 'I pray you,

(17) let there be no strife between you and me, and between my herdsmen

(18) and your herdsmen, because we are kinsmen.

(19) [9] Lo, the whole land is before you, separate

(20) now yourself from me, if you go to the left, then let me go to the right,

(21) and if you go to the right, then let me go to the left.' [10]

(1) And Lot raised his eyes and saw all the valley of Jordan

(2) that it was all |well-|watered, before the Lord destroyed

(3) Sodom and Gomorrah, like the garden of the Lord,

(4) like the land of Egypt, in the direction as you came to Zoar. [11] So

(5) Lot chose for himself all the valley of Jordan, and Lot journeyed

(6) east. And they separated, the one from his brother.

(7) [12] Abram settled in the land of Canaan, and Lot

(8) in the cities of the valley. And he pitched his tent as far as Sodom.

(9) [13] But the men of Sodom were evil and sinned greatly

(10) before the Lord. [14] And the Lord said to Abram,

(11) after Lot was separated from him, 'Lift up now your eyes,

(12) and look from the place where you are northward, and southward,

(13) and eastward, and westward. [15] For all the land

(14) that you see, I will give to you and to your offspring forever.

(15) [16] And I will set your offspring like the dust

(16) of the earth, so that if a man could count the dust of the earth,

(17) your offspring also could be counted. [17] Arise, walk through the land

(18) to its length and to its width, because I will give it to you.' [18] So

(19) Abram pitched his tent and lived in the plain lands of Mamre,

(20) which is in Hebron, and built there an altar before the Lord.

[Genesis 14]

(21) [1] And it was in the days of Amraphel, king of Shinar, Arioch,

(1) king of Ellasar, Chedorlaomer, king of Elam, and Tidal,

(2) king of Goiim: [2] These kings made war with Bera, king of Sodom, and

(3) with Birsha, king of Gomorrah, with Shinab, king of Admah, and

(4) Shemeber, king of Zeboiim, and the king of Bela, that is,

(5) Zoar. [3] All these gathered in the Valley of Siddim, 
(6) oldu ol tuzlu tengiz. שתים. [4] On eki \{jyl\} qulluq ettilar

(7) Kedarlacomerǵa da on üčünčü jylda tandylar. ובארבע. [5]

(8) Da on dörtünčü jylda keldi Kedarla'omer da ol bijler ki

(9) birgesińa da qyrdylar ošol Refa'imni 'Ašterot Qarnajim-

(10) de da ošol Zuzimni Hamda da ošol Emimni Šave

(11) Qirjatajimde. ואת [6] Da ošol ol Ḥorini tavlarynda

(12) Se'irnin tüz jerińa dejin Parannyn ki ol midbar qatyna.

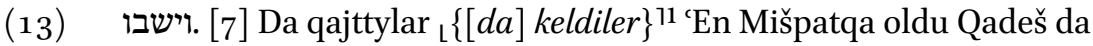
qyrdy-

(14) lar ošol bar elin tüzünün ol 'Amaleqnin da daġyn ošol ol

(15) Emorini ol olturuvčunu Ḥacacon Tamarda. ויצא. [8] Da

(16) čyqty biji Sedomnun da biji 'Amoranyn da biji Admanyn da

(17) biji Cevojimnin da biji Belányn oldu Cóar da tüzüdülar

(18) birgelerińa čerüv enišind́a ol Sidimnin. את. [9]

(19) Kedarla'omer byla bijibyla 'Elamnin da Tid'al byla bijibyla Gojim-

(20) nin da Amrafel byla bijibyla Šin'arnyn da Arjoh byla bijibyla

(21) Elasarnyn dört bijlar ol beš byla. ועמק [10] Da eniši

$19 \mathrm{r}^{\circ} \quad$ (1) ol Sidimnin qujular qujular balčyqly da qačtylar biji Sedomnun

(2) da Amoranyn da tüštülar ary jašynma da ol qalġanlar

(3) tavsary qačtylar. ויקחו [11] Da aldylar ošol bar malyn Sedom-

(4) nun da 'Amoranyn da ošol bar jemlerin alarnyn da bardylar.

(5) ויקחו [12] Da aldylar ošol Lotnu da ošol malyn anyn uvlun

(6) qaryndašynyn Avramnyn da bardylar da ol oltururedi Sedom-

(7) da. dis] Da keldi ol qutulgan da anlatty Avramġa

(8) ol Jisra’elǵa da ol toḥtaredi tüz jerlerind́a Mamre-

(9) nin ol Emorinin qaryndašynyn Eškolnun da qaryndašynyn 'Aner-

(10) nin da alar šert jesilari Avramnyn. וישמע [14] Da e-

(11) šitti Avram ki jesir boldu qaryndašy anyn da jasandyrdy

(12) ošol čynyqqan elin tuvġanlaryn üvünün üč jüz da on segiz

(13) da quvdu Danġadejin. [15] Da ülešindi alar üstü-

(14) ńa kečebyla ol da qullary anyn da qyrdy alarny da quvdu

(15) alarny Ḥova ündeledog̉an orunġa dejin ki son jantyn Dame-

(16) seqka. וישב [16] Da qajta aldy ošol bar ol malny da

(17) dag்yn ošol Lotnu qaryndašyn özünün da malyn anyn qajta

(18) aldy da daġyn ošol ol qatynlarny da ošol ol ulusnu.

(19) ויצא [17 Da čyqty biji Sedomnun uturusuna anyn qajtqanyn-

(2o) dan sortun qyrmaqtan ošol Kedarla'omerni da ošol ol bijlerni

\footnotetext{
${ }^{1}$ Marginal insertion by another hand. | TKow.o1: da keldiler. | H: da keldiler. | C: da keldilär.
} 
(6) that is the salt sea. [4] Twelve years they served

(7) Chedorlaomer, and in the thirteenth year they rebelled. [5]

(8) And in the fourteenth year came Chedorlaomer, and the kings that

(9) were with him, and smote the Rephaim in Ashteroth-Karnaim,

(10) and the Zuzim in Ham, and the Emim in Shaveh-

(11) -Kiriathaim. [6] And the Horites in the mountains

(12) of Seir as far as the plain El-Paran, which is by the wilderness.

(13) [7] And they returned \{and came $\}$ to Enmishpat, that is Kadesh, and smote

(14) all the people of the plain of the Amalekites and also the

(15) Amorites who were dwelling in Hazazon-Tamar. [8] And

(16) there went out the king of Sodom, and the king of Gomorrah, and the king of Admah, and

(17) the king of Zeboiim, and the king of Bela, that is, Zoar, and they lined up

(18) with them in |one army in the Valley of Siddim. [9]

(19) With Chedorlaomer, king of Elam, and with Tidal, king of Goiim,

(20) and Amraphel, king of Shinar, and Arioch, king of

(21) Ellasar; four kings with five. [10] And the Valley

(1) of Siddim was full of clay wells, and the kings of Sodom

(2) and Gomorrah fled, and fell there to be safe, and those who remained

(3) fled toward the mountain. [11] And they took all the goods of Sodom

(4) and Gomorrah, and all their food, and they went.

(5) [12] And they took Lot, and his goods, the son

(6) of Abram's brother, and they went. And he had been living in Sodom.

(7) [13] And an escapee came and told Abram

(8) the Hebrew, and he was living on the plains of Mamre

(9) the Amorite, brother of Eshcol, and brother of Aner;

(10) and they were covenant partners of Abram. [14] And

(11) Abram heard that his kinsman had been taken captive, and he armed

(12) his trained men, born in his house, three hundred and eighteen,

(13) and went in pursuit as far as Dan. [15] And he divided his forces against them,

(14) by night, he and his servants, and smote them, and pursued

(15) them to the place called Hobah, which is at the left of Damascus.

(16) [16] And he took back all the goods, and

(17) also his brother Lot, and his goods, he took

(18) back the women also, and the people.

(19) [17] And the king of Sodom went out to meet him after his return

(20) from beating Chedorlaomer, and the kings 
(21) ki birgesińa enišińa Šavenin oldu eniši ol bijnin.

$19 \mathrm{v}^{\circ}$ (1) ומלכי [18] Da Malkicedeq biji Šalemnin čyġardy ötmek da

(2) čag̀yr da kohen edi jog̉arg̉y Tenrinin alnynda. ויברכהו Da Da

(3) alġyšlady any da ajtty alġyšlydy Avram alnynda joġarġy

(4) Tenrinin bar etüvčünün köklarni da jerni. וברוך. [20] Da

(5) maḥtavludu jog̉arg̉y Tenri ki čyg̉ara berdi dušmanlaryjny qoluja

(6) da berdi anar Avram onča barysyndan. ויאמר Da

(7) ajtty biji Sedomnun Avramġa bergin maja ol క̌anny da

(8) ol malny alġyn özüja. [22] Da ajtty Avram bijińa

(9) Sedomnun kötürdüm qolumnu antbyla alnynda Adonajnyn

(10) jog̉arg̉y Tenrinin bar etüvčünün kökĺarni da jerni. אם. [23]

(11) Eger jipt́an da bavyna dejin etiknin da eger alsam baryn-

(12) dan neki senin da ajtmağyn men ḥožalattym ošol Avramny.

(13) (24] Andan bašqa tek neki ašadylar ol negerlar

(14) da ülüšünd́an ol erenlernin ki bardylar birgema 'Aner

(15) Eškol da Mamre alar alsynlar ülüšlarin.

Genesis 15

אחר . [1]

(16) Son ol išlard́an ušpulardan boldu navilik sözü Adonaj-

(17) nyn Avramġa körümü ašyra naviliknin ajtadoġač qorq-

(18) mag்yn e Avram men qalqan saja jalyj senin köptür astry

(19) Łanyn üčün ki körgüzdüj süverligin qaryndašlyqnyn da qut-

(20) qardy[j] Lotnu uvlun qaryndašyjnyn qolundan dušmanlarynyn ${ }^{11}$.

(21) ויאמר Da ajtty Avram e Adonaj Tenri nendij jal

2o $\mathrm{r}^{\mathrm{o}}$ (1) berirsen maja da men jürüjmen jalġyzaq uvulsuz da erkle-

(2) nüvčüsü üvümnün oldu Damešeqli Elicezer. ויאמר [3] Da

(3) ajtty Avram muna berm[e] $\mathrm{dij}^{2}$ maja urluq da muna ag̉arag்y

(4) üvümnün ol meresler meni. והנה [4] Da muna navilik

${ }^{1}$ Interpretative addition to the standard text. $\quad{ }^{2} \mathrm{~K}$ : bermidij; probably a scribal error. | TKow.o1: bermedij. | H: bermedin. | C: bermädin. 
(21) that were with him, at the Valley of Shaveh. That is, the King's Valley.

(1) [18] And Melchizedek, king of Salem, brought forth bread and

(2) wine. And he was the priest of the $\mid$ most $\mid$ high God before them. [19] And

(3) he blessed him, and said, 'Blessed be Abram before the |most| high

(4) God, creator of heaven and earth. [20] And

(5) praised is the $\mid$ most $\mid$ high God, who has donated your enemies to your hand.'

(6) And Abram gave him a tithe from everything. [21] And

(7) And the king of Sodom said to Abram, 'Give the souls to me, and

(8) take the goods for yourself.' [22] And Abram said to the king

(9) of Sodom, 'I have raised my hand with an oath to the Lord,

(10) the $\mid$ most $\mid$ high God, the creator of heaven and earth: [23]

(11) [ [I will not take $]^{123}$ a thread or a sandal strap from all

(12) that is yours, and you should not say, "I have made Abram rich."

(13) [24] Except only that which the servants have eaten,

(14) and the portion of the men who went with me, Aner,

(15) Eshcol, and Mamre: let them take their portion.'

Genesis 15

(16) After these things the words of prophecy of the Lord came

(17) to Abram through a vision of prophecy, saying, 'Do not fear,

(18) Abram, I am a shield for you. Your reward is very large,

(19) because you have shown the love of brotherhood and you have saved

(20) Lot, the son of your brother, from the hands of enemies ${ }^{124}$.

(21) [2] But Abram said, 'Oh Lord God, what reward

(1) will you give me: I walk alone, childless and the ruler

(2) of my house is Eliezer of Damascus?' [3] And

(3) Abram said, 'Lo, you have not given me offspring, and, lo, the elder

(4) of my house, he will inherit |from $\mid$ me.' [4] And, lo, the words of prophecy

23 K: if I take; a mistranslation repeated in a number of manuscripts resulting from literal translation of the Hebrew conditional clause, cf. Num 14:23, Num 14:30, Num 32:11, Deu 1:35. | TKow.o1: if I take. | H: if I take. | C: if I take. | M: if I take. | E: if I take. | V: if I take. | R: if Itake.

24 An interpretative addition to Gen 15:1. 
(5) sözü Adonajnyn anar ajtadoġač mereslemesti seni bu ančaq

(6) ki čyqsa bavursaqlaryjdan ol mereslar seni. ויוצא [5 Da

(7) čyġardy any ol tyšqaryġa da ajtty baqqyn endi ol kök-

(8) ĺarǵa da sanaġyn ol jolduzlarny bolalyrmosen sanama alarny

(9) da ajtty anar bu qadar bolur urlugiuj. והאמין. [6] Da

(10) inandy sözüńa Adonajnyn da sağyšlady anar Tenri any

(11) zehutqa. ויאמר. [7 Da ajtty anar \{men men\} Adonaj ki čygardym

(12) seni Ur Kasdimden berḿa saja ošol ol jerni ošpunu

(13) mereslaḿa any. ויאמר. [8] Da ajtty e Adonaj Tenri

(14) nebyla bilajim ki mereslerman any. [9יאמר [9 Da ajtty

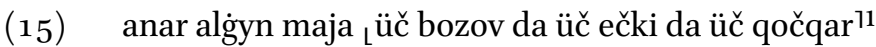

(16) da bedeńa da perepelića. [10] Da aldy özüńa

(17) ošol bar bularny da jartylady alarny ortada da berdi

(18) kišinin jartysyn uturusuna dostunun da ošol qušnu

(19) jartylamady. וירד [11] Da endi ol quš ol gövdeler üs-

(20) tüńa da üškürttü alarny Avram. ויהי [12] Da edi

(21) ol qujaš enmek vaḥtta da qaty juqu tüštü Avram üs-

$20 v^{o} \quad$ (1) tüne da muna qorquv ullu qaranğylyq tüšedi anyn üs-

(2) tüna. [13] Da ajtty Tenri Avramġa bilma

(3) bilgin ki garip bolur urlugiuj jerd́a tüvül özlerinin

(4) dört jüz jyl da qulluq eterlar alarbyla da qyjnarlar alarny.

(5) . 14] Da dag̉yn ošol ol ḥanlyqny ki qulluq etseĺar

(6) jarğu jararmen men da Landan sortun $^{72}$ čyġarlar ullu mal byla.

(7) [15] Da sen kelirsen atalaryja tynčlyqta astralyrsen

(8) jahšy pirlikt́a. ודור [16] Da dörtünčü dor qajtyrlar

(9) beri ki tügenmedi günehi ol Emorinin ol vaḥtqa dejin.

(10) Da edi ol qujaš endi da qarangylyq boldu

(11) da muna tütünlü ṕeč da otlu küsöv ki ašty arasyn-

(12) da ol jartylarnyn ošpularnyn. ביום. [18] Ol künd́a kes-

(13) ti Adonaj Avram byla šert ajtadog̉ač urlug̉uja berirmen

\footnotetext{
${ }^{1}$ A mistranslation repeated in a number of manuscripts; cf. Gen 15:10-11. | TKow.o1: üč bozov da üč ečki da üč qočqar. | H: ic buzov da ic ecki da ic qocqar. | C: byzov üč da ečki üč da qočqar üč. | M: byzov üč da ečki üč da qočqar üč. | E: byzov uč da ečki üč da qočqar üč. | V: buzov üč jašar da ečki

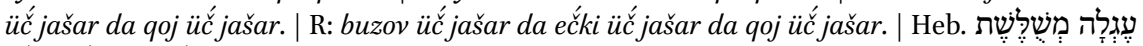
a heifer three years old, a female goat three years old, a ram three years old'. $\quad{ }^{2} \mathrm{~K}$ : alaj is inserted after sortun by another hand; the marginal insertion is, however, not motivated by the text. | TKow.o1: andan sortun. | H: andan sortun. | C: andan soyra.
} 
(5) of the Lord |came| to him, saying, 'He will not inherit |from| you, but

(6) he who will come out of your insides will inherit |from| you.' [5] And

(7) he brought him outside and said, 'Look now at the skies

(8) and count the stars, if you are able to count them.'

(9) And he said to him, 'So many will your descendants be.' [6] And

(10) he believed the words of the Lord, and God counted it to him

(11) on merit. [7] And he said to him, 'I am the Lord that brought you out of

(12) Ur of the Chaldees, to give you this land,

(13) to inherit it.' [8] And he said, 'Lord God,

(14) how shall I know that I will inherit it?' [9] And he said

(15) to him, "Take me ${ }_{L}$ three calves, and three goats, and three rams ${ }^{125}$,

(16) and a turtledove, and a quail.' [10] And he took to him

(17) all these, and he split them up the middle, and he set

(18) the half of one person opposite that of the other, but

(19) he did not divide the birds. [11] And the birds of prey came down on the carcasses,

(20) and Abram scared them off. [12] And when

(21) the sun was going down, a deep sleep fell on Abram.

(1) And, lo, fear, great darkness fell on him.

(2) [13] And the Lord said to Abram, 'Know for certain

(3) that your offspring will be strangers in a land that is not theirs

(4) for four hundred years, and they shall be servants, and they will be afflicted by them.

(5) [14] But I will adjudge that kingdom whom they shall serve,

(6) and afterward they will come out with great possessions.

(7) [15] And you shall go to your fathers in peace, you shall be buried

(8) in a good old age. [16] And they shall come back here in the fourth generation,

(9) because the sins of the Amorites are not yet complete to that time.'

(10) [17] And it was that the sun went down, and it was dark,

(11) and, lo, a smoking furnace and a burning torch that passed between

(12) those halves. [18] On that day

(13) the Lord made a covenant with Abram, saying, 'I will give this land to your offspring,

25 A mistranslation repeated in a number of manuscripts, cf. the text in Gen 15:10-11 and Heb.

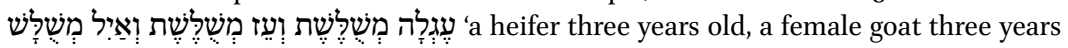
old, a ram three years old. Translated correctly in V, and R. 
(14) ošol ol jerni ošpunu bašlap özenind́an Micrinin ol

(15) ullu özenged́ajin özenined́ajin Peratnyn. את. [19] Ošol

(16) ol Qenini da ošol ol Qenizini da ošol ol Qadmonini.

(17) [20] Da ošol ol Ḥitini da ošol ol Perizini da ošol

(18) ol Refa'imni. ואת [21 Da ošol ol Emorini da ošol

(19) ol Kena'anini da ošol ol Girgašini da ošol ol Jevusini.

[Genesis 16]

(20) (1] Da Saraj qatyny Avramnyn töremedi anar da anar

(21) Micrili qaravaš da aty anyn Hag̉ar. [2] Da ajtty

$21 \mathrm{r}^{\circ} \quad$ (1) Saraj Avramġa muna endi ajady meni Adonaj töremek-

(2) tan kelgin endi qaravašyma šeme uvullu bolurmen andan

(3) da tynlady Avram sözüńa Sarajnyn. ותקח. [3] Da aldy

(4) Saraj qatyny Avramnyn ošol Hağarny ol Micrilini qaravašyn

(5) özünün aḥerind́an on jyllarnyn olturušuna Avramnyn jerin-

(6) de Kena'annyn da berdi any Avramġa erińa özünün

(7) anar qatynlyqqa. [4] Da keldi Hag̉arga da hamila

(8) boldu da kördü ki ḥamila boldu da jengil boldu bijčesi

(9) ותאמר közlerind́a anyn. Da ajtty Saraj Avram-

(10) ġa avanlyġym üstüja men berdim qaravašymny qojnu-

(11) ja da kördü ki ḥamila boldu da jengil boldum közle-

(12) rind́a anyn töŕa etḱaj Adonaj arama da araja

(13) .יאמר [6 Da ajtty Avram Sarajġa muna qaravašyj

(14) erkijdedi qylġyn anar ol jaḥšy körüngenni közle-

(15) rijda da qyjnady any Saraj da qačty alnyndan anyn.

(16) [ימצאה Da tapty any malahy Adonajnyn ol köz suv-

(17) qatyna midbarda ol köz suv qatyna jolunda Šurnun.

(18) .יאמר Da ajtty ol malah e Hag̉ar qaravašy Saraj-

(19) nyn qajdan bu keĺasen da qajry barasen da ajtty Haġar alnyndan

(20) Sarajnyn bijčemnin men qačamen. ויאמר [9] Da ajtty anar

(21) malahy Adonajnyn qajtqyn bijč́aje da qyjnalg̈yn qollary tübü[ńa $]^{1}$

$21 \mathrm{v}^{\mathrm{o}}$ (1) ויאמר. [10] Da ajtty anar malahy Adonajnyn arttyr-

(2) ma arttyryrmen ošol urlugiujnu da sanalmasty köplük-

(3) tan. יויאמר [11] Da ajtty anar malahy Adonajnyn muna sen

(4) ḥamila sen da törersen uvul da atag̉yn atyn anyn Jišmac-

1TKow.o1: tübüne. | H: tibine. | C: tibinä. 
(14) starting from the river of Egypt

(15) to the great river, the river Euphrates: [19] The

(16) Kenites, and the Kenizzites, and the Kadmonites,

(17) [20] And the Hittites, and the Perizzites, and the

(18) Rephaim, [21] And the Amorites, and the

(19) Canaanites, and the Girgashites, and the Jebusites.'

[Genesis 16]

(20) [1] And Sarai, Abram's wife, bore him no children. And she

(21) had an Egyptian maidservant whose name was Hagar. [2] And Sarai said

(1) to Abram, 'Lo, now, the Lord has restrained me from bearing: $21 \mathrm{r}^{\mathrm{o}}$

(2) Come to my maidservant. Maybe I will be childed through her.'

(3) And Abram listened to the words of Sarai. [3] And

(4) Sarai Abram's wife took Hagar her own maidservant the Egyptian,

(5) after Abram had dwelt ten years in the land

(6) of Canaan, and gave her to her own husband Abram

(7) to be his wife. [4] And he came to Hagar, and she conceived.

(8) And she saw that she had conceived, and her mistress was despised

(9) in her eyes. [5] And Sarai said to Abram,

(10) 'My wrong is on you! I gave my maidservant to your bosom,

(11) and she saw that she had conceived, and I became despised

(12) in her eyes. May the Lord judge between you and me!'

(13) [6] But Abram said to Sarai, 'Lo, your maidservant

(14) is in your hand. Do to her as it would seem good in your eyes.'

(15) And Sarai mistreated her, and she fled from before her.

(16) [7] And the angel of the Lord found her by a spring of water

(17) in the wilderness, by the spring on the way to Shur.

(18) [8] And he said, 'Oh Hagar, Sarai's maidservant,

(19) where have you come from and where are you going?' And Hagar said,

(20) 'I flee from the face of my mistress Sarai.' [9] And

(21) the angel of the Lord said to her, 'Return to your mistress, and suffer under her hands.'

(1) And the angel of the Lord said to her,

(2) 'I will surely multiply your offspring, and it will not be countable because of its multitude.'

(3) [11] And the angel of the Lord said to her, 'Lo, you

(4) are pregnant, and you will bear a son. You shall call his name Ishmael, 
(5) el ki ešitti Adonaj qyjynyjny. [12] Da ol bolur kijik

(6) adam qolu anyn barčada da qolu barčanyn anda da alnynda

(7) bar qaryndašlarynyn toḥtar. [ותקרא Da atady atyn mala-

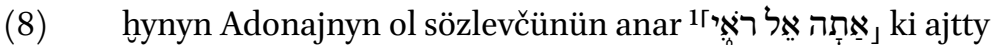

(9) daġyn haligineda kördüm malahny körgenimden sortun ü-

(10) vünd́a Avramnyn bijimnin. על [14] Anyn üčün atady ol

(11) atavču atyn ol qujunun Be'er Laḥaj Ro’i muna ol arasyna

(12) Qodešnin da arasyna Barednin. ותלד [15] Da töredi Hag̉ar

(13) Avramġa uvul da atady Avram atyn uvlunun Jišmacel

(14) ki töredi anar Haġar. ואברם [16] Da Avram seksen alty

(15) jašar edi töregend́a Haġar ošol Jišmacelni Avramġa.

Genesis 17

(16) ויהי [1] Da edi Avram toqsan tog̉uz jašar da aškara

(17) boldu $\left[\{\text { šehinasy }\}^{2} \text { Adonaj[nyn }\right]^{13}$ Avramġa da ajtty anar men küčlü Tenri

(18) jürügün alnymda da bolġun tügel. ואתנה. [2] Da berirmen

(19) ošol šertimni arama da araja da arttyryrmen seni

(20) astry astry. [יפל [3] Da tüštü Avram jüzĺari üs-

(21) tüńa da sözledi šeḩinasy Tenrinin birgesińa ajtadoġač.

$22 \mathrm{r}^{\circ}$ (1) [4] [4 Men muna šertim birgeja da bolursen atasyna

(2) jyjynyn ḥanlyqlarnyn. ולא. [5] Da ündelmesti artyq

(3) atyj senin Avram da bolur atyj senin Avraham ki atasy

(4) jyjynynyn ḥanlyqlarnyn berirmán seni. והפרתי [6] Da ja-

(5) jarmen seni astry astry da berirmen seni ḥanlyqlarğa

(6) da bijler send́an čyġarlar. והקמת [7] Da qajjam eter-

(7) men ošol šertimni arama da araja da arasyna ur-

(8) luggujnun özüjd́an sortun dorlarysajyn alarnyn ömürlük

(9) šertke bolma saja Tenriǵa da urlugiuja özüjdan

(10) sortun. [8] Da berirmen saja da urlugujaja ö-

(11) züjd́an sortun ošol tirilmüš jerlerijni ošol bar jerin

(12) Kena'annyn tutuvluguuna dunjanyn da bolurmen sizǵa ${ }^{4}$ Tenri-

(13) ǵa. [יאמר Da ajtty Tenri Avrahamġa da sen o-

(14) šol šertimni saqlaġyn sen da urluğuj özüjdan sortun

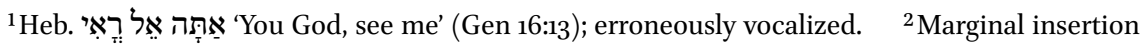
by another hand. | H: šehinasy. | C: kavody. $\quad{ }^{3}$ TKow.or: šehinasy Adonyn; a scribal error. | H: šehinasy H-nyn. | C: kavody H-nyy. $\quad{ }^{4}$ Most probably a scribal error instead of alarga | TKow.o1: sizge. | H: alarga | C: alarg்a. | Heb. לָּ 'to them'.
} 
(5) because the Lord has heard your affliction. [12] And he will be a wild

(6) man, his hand against everyone and everyone's hand against him, and

(7) he will dwell over against all his brethren.' [13] And she called the name of the angel

(8) of the Lord that spoke to her, 'You God, see me', for she said,

(9) 'Now, I have even seen the angel, after I had been seen

(10) in the house of Abram.' [14] Therefore the

(11) well was called, by him who called it, Beer-Lahai-Roi. Lo, it is between

(12) Kadesh and Bered. [15] And Hagar bore

(13) Abram a son: and Abram called his son's name Ishmael,

(14) whom Hagar bore. [16] And Abram was eighty-six

(15) years old when Hagar bore Ishmael to Abram.

Genesis 17

(16) [1] And Abram was ninety-nine years old, and

(17) the \{divine Presence $\}$ [of the] Lord appeared to Abram, and said to him, 'I am mighty God;

(18) walk before me, and be unblemished. [2] And I will give

(19) my covenant between me and you, and I will multiply you

(20) greatly.' [3] And Abram fell on his face:

(21) and the divine Presence of God talked with him, saying,

(1) [4] 'I: lo, my covenant is with you, and you will be a father

(2) of many kingdoms. [5] And your name will not be called

(3) Abram, but your name will be Abraham, because

(4) I will make you the father of a mass of kingdoms. [6] And

(5) I will spread you greatly, and I will make you into kingdoms,

(6) and kings will come out of you. [7] And I will establish

(7) my covenant between me and you and your

(8) offspring after you throughout their generations for an everlasting

(9) covenant, to be God to you and to your offspring after you.

(10) [8] And I will give to you and to your offspring

(11) after you the land of your sojourning, all the land of

(12) Canaan, for an everlasting possession, and I will be your ${ }^{26}$ God.'

(13) [9] And God said to Abraham, 'And you:

(14) you shall keep my covenant, you, and your offspring after you

26 Probably a scribal error, cf. Heb. לָ 'to them' (Gen 17:8). 
(15) dorlary sajyn. זאת. [10] Budur šertim ki saqlajyz arama

(16) da arajyzġa ${ }_{L}\{\text { da [arasyna urlug̉ujnun özüjd́an sortun] }\}^{11}$ ḥatna qylynma sizǵa bar erkek. ונמלתם. [11]

(17) Da ḥatna qylyjyz ošol etin aqlafyjyznyn da bolsun belgisi-

(18) ńa šertnin arama da arajyzġa. ובן. [12] Da segiz künlük

(19) hatna qylynsyn sizǵa bar erkek dorlaryjyzsajyn tuvġany üv-

(20) nün da satyn alġany kümüšnün bar jat eld́an ki tüvüldür

(21) urlug̉ujdan ol. המול. [13] Ḥatna qylynma hatna qylynsyn

$22 \mathrm{v}^{\mathrm{o}} \quad$ (1) tuvġany üvüjnün da satyn alġany kümüšüjnün da bolsun

(2) šertim gufujuzda ömürlük šertka. וערל [14] Da

(3) aqlafly erkak ki ḥatna qylmasa ošol etin aqlafynyn

(4) da eksilir ol క̌an ol uluslaryndan özüjnün ki alardy-

(5) lar jyjyny malahlarnyn anyn üčün ki ošol šertimni buz-

(6) du. dיאמר Da ajtty Tenri Avrahamga Saraj qatynyj

(7) ünd́amagin atyn anyn Saraj ki Sarady aty anyn.

(8) וברכתי Da alġyšlarmen any da daġyn berirmen saja an-

(9) dan uvul da alğyšlarmen any da bolur ana hanlyqlarg̉a

(10) bijlari uluslarnyn andan bolurlar. ויפול [17] Da tüštü

(11) Avraham jüzlari üstüńa da bijandi da ajtty köl-

(12) nünd́a jüz jašarlyqmo kišiǵa tuvar da Sara toqsan

(13) jašarmo töŕar. ויאמר [18] Da ajtty Avraham ol Tenriǵa

(14) keška Jišmacel tiri bolğaj alnyjda. ויאמר. [19] Da

(15) ajtty Tenri kertid́an Sara qatynyj töŕar saja uvul

(16) da atag̉yn ošol atyn anyn Jicḥaq da qajjam etarmen ošol

(17) šertimni birǵasińa ömürlük šertka urlug̉una

(18) anyn özünd́an sortun. [20 [20] Da Jišmacel üčün

(19) habar beŕamen saja muna alġyšlarmen any da jajarmen any

(20) da arttyryrymen any astry astry on eki nasilar

(21) tuvdurur da qojarmen any ullu hanlyqqa. [21] Da

$23 \mathrm{r}^{\mathrm{0}} \quad$ (1) ošol šertimni qajjam etermán Jichaqqa ki töŕar saja

(2) Sara ošpu vağdaġa ol ekinči jylda. ויכל [22] Da

(3) tügelledi sözĺaḿa birgesińa da bardy šehinasy Tenri-

(4) nin Avraham üstünd́an. ויקח [23] Da aldy Avraham o-

${ }^{1}$ Cf. Gen 17:7. | TKow.o1: da arasyna urlugijnun özüjden sortun. | H: siznin da arasyna urlug்unnun senin senden sortun. | C: da arayyż́a da arasyna urluġynnyy artyydan. 
(15) throughout their generations. [10] This is my covenant, which you shall keep, between me

(16) and you and [your offspring after you]: every male among you is to be circumcised. [11]

(17) And you shall circumcise the flesh of your foreskins, and it shall be a sign

(18) of the covenant between me and you. [12] And at eight days old

(19) every male shall be circumcised among you throughout your generations, he who is born in the house,

(20) or bought with silver of any foreign nation, who is not

(21) of your offspring. [13] He shall surely be circumcised

(1) who is born in your house, and he who is bought with your silver, and $22 \mathrm{v}^{\mathrm{o}}$

(2) my covenant shall be in your flesh for an everlasting covenant. [14] And

(3) the uncircumcised male child, whose flesh of his foreskin is not circumcised,

(4) that soul shall vanish from among his own people that

(5) are the congregation of angels, for he has broken my covenant.'

(6) [15] And God said to Abraham, 'Sarai, your wife:

(7) you shall not call her name Sarai, because her name is Sarah.

(8) [16] And I will bless her, and moreover, I will give you a son

(9) by her. I will bless her, and she will be a mother of kingdoms,

(10) kings of peoples will be from her.' [17] Then Abraham fell

(11) on his face, and was pleased, and said in his heart,

(12) 'Will a child be born to a man who is a hundred years old? And will Sarah, who is ninety,

(13) bear?' [18] And Abraham said to God,

(14) 'If only Ishmael might live before you!' [19] And

(15) God said, 'Sarah your wife will, indeed, bear you a son,

(16) and you shall call his name Isaac. And I will establish

(17) my covenant with him for an everlasting covenant, for his offspring

(18) after him. [20] And as for Ishmael:

(19) I inform you, lo, I will bless him, and will spread him,

(20) and will multiply him greatly. Twelve princes

(21) shall he beget and I will make him into a great nation. [21] But

(1) I will establish my covenant with Isaac, whom Sarah shall bear to you

(2) at this time next year.' [22] And

(3) he finished talking with him, and the divine Presence of God

(4) went up from Abraham. [23] And Abraham took 
(5) šol Jišmacelni uvlun da ošol bar tuvğanlaryn üvünün

(6) da ošol bar satyn alġanyn kümüšünün bar erkekni elin-

(7) da üvünün Avrahamnyn da ḥatna qyldy ošol etin

(8) aqlaflarynyn kensisind́a ošpu künnün ki nečik sözle-

(9) di birgesińa šehinasy Tenrinin. ואברהם. [24] Da Avraham

(10) toqsan toğuz jašar edi hatna qylynġanynda eti aqlafynyn.

(11) וישמעאל [25] Da Jišma'el uvlu anyn on üč jašar edi

(12) hatna qylyngianynda etind́an aqlafynyn. בעצם. [26] Ken-

(13) sisind́a ošpu künnün ḥatna qylyndy Avraham da

(14) Jišma'el uvlu anyn. זכ2 [27 Da bar eli üvünün tuvġany

(15) üvnün da satynalġany kümüšnün bar jat kišid́an ḥatna

(16) qylyndylar birgesińa.

[Genesis 18]

פרשת וירא (17) (18) (ורא (18)

(18) [18 Da aškara boldu šehina\{sy\} Adonaj-

(19) nyn Avrahamġa tüz jerlerind́a Mamrenin

$23 \mathrm{~V}^{0} \quad$ (1) da ol oltururedi ešigind́a ol čatyrnyn isingečoq

(2) ol kün. [2] Da kötürdü közlerin da kördü

(3) da muna üč erenĺar turaredilar juvuq anar da kördü

(4) da juvurdu utrularyna alarnyn ešigind́an ol čatyrnyn

(5) da bašurdu jerǵa. [3] Da ajtty e Adonaj

(6) eger endi taptym eśa širinlik 'enajatlaryjda qolt-

(7) qabyla ašmasyn šehinaj quluj qatyndan. יקח. [4] Da

(8) ol erenlerǵa ajtty alynsyn endi azġynaq suv da

(9) juvujuz ajaqlaryjyzny da taj[a]nyjyz ${ }^{1}$ ol ag̉ačtübüńa.

(10) . ואקחה [5 Da alajym tigim ötmak da kiplajiz jüregijiz-

(11) ni andan sortun ašyp baryrsiz qačan ki aštyjyz qulujuz

(12) qatyna da ajttylar alar qylg̀yn ki nečik sözladij.

(13) (6) Da žaḥtlady Avraham barma ol čatyrg̉a

(14) Sarag̉a da ajtty žaḥtlag̉yn üč sa’alar un özek

(15) basqyn da qylg̈yn jajmalar. [7] Da ol syġyrg̉a juvur-

(16) du Avraham da aldy balasyn syġyrnyn jašny da jaḥ̌̌yny da

${ }^{1} \mathrm{~K}$ : tajynyjyz; a scribal error; cf. Exo 21:19, Num 2:15. | TKow.o1: tajanyjyz. | H: tajanynyz. | C: tajanypyz. 
(5) Ishmael his son, and all that were born in his house,

(6) and all that were bought with his silver, every male

(7) among the people of Abraham's house, and he circumcised the flesh

(8) of their foreskins in the same day, as

(9) the divine Presence of God had spoken with him. [24] And Abraham

(10) was ninety-nine years old when he was circumcised, the flesh of his foreskin.

(11) [25] And Ishmael his son was thirteen years old

(12) when he was circumcised at the flesh of his foreskin. [26] In

(13) the same day was Abraham circumcised, and

(14) Ishmael, his son. [27] And all the men of his house, born

(15) in the house, and bought with silver from all foreigners, were

(16) circumcised with him.

[Genesis 18]

(16) Parashat Vayeira

(17) [1] And the divine Presence of Lord appeared

(18) to Abraham in the plain lands of Mamre,

(1) and he sat at the door of his tent just in the heat of

(2) the day. [2] And he raised his eyes and looked,

(3) and, lo, three men stood close to him. And he saw,

(4) and he ran to meet them from the tent door,

(5) and bowed himself to the ground. [3] And said, 'Oh Lord,

(6) if now I have found favour in your sight, I pray

(7) you, may your divine Presence not pass by your servant.' [4] And

(8) he said to the men, 'Take a little water, and

(9) wash your feet, and lean against |the tree| under the tree.

(10) [5] And let me get a morsel of bread, that you may strengthen your hearts.

(11) Afterward you will pass on and go-when you have passed by your servant.'

(12) And they said, 'Do as you have spoken.'

(13) [6] And Abraham hurried to the tent

(14) to Sarah, and said, 'Hurry, knead three seahs ${ }^{27}$ of fine flour

(15) and make cakes.' [7] And Abraham ran to the cattle

(16) and took a calf, young and good, and

27 Cf. Heb. סָזָ 'seah, i.e. a dry and liquid measure, one third of an ephah'. 
(17) berdi ol ulang̉a da žaḥtlady qylma any. [יקח [8]

(18) Da aldy saryjav da süt da balasyn ol syggyrnyn ki hadir-

(19) ledi da qojdu alynlarynda alarnyn da ol turaredi

(20) alynlarynda alarnyn ol ag̉ač tübüńa da ašadylar.

(21) ויאמרו Da Da ajttylar anar qajdady Sara qatynyj da ajtty

$24 \mathrm{r}^{0}$ (1) muna čatyrdady. ויאמר. [10] Da ajtty qajtma qajtyr-

(2) men saja bu vaḥtlaj jylyna savġa da muna uvul bolur

(3) Sarag̉a qatynyja da Sara ešitiredi turadoġač ešigin-

(4) da ol čatyrnyn da ol ešik edi ol malah ar-

(5) tyna. ואברהם. [11] Da Avraham da Sara qartlar edilar

(6) jetkenlar künlerǵa qartlyqta qalybedi bolma Sara-

(7) ga jol qatynlarga kibik. [12] Da küldü

(8) Sara ičind́a ajtadoġač qartlyğymdan sortun boldu

(9) maja jigitlik da bijim qartty. [13] Da ajtty

(10) Adonaj ${ }^{1}$ Avrahamġa nek bu küldü Sara aj-

(11) tadoġač ham kertidenmo törermen da men qartajdym.

(12) היפלא [14] Tamašamodu Adonajdan nerśa vag̉dag̉a

(13) qajtyrmen saja bu vahtlaj jylyna savğa da Sarag̉a

(14) uvul. ותכחש [15] Da tandy Sara ajtadog̉ač külmedim

(15) ki qorqtu da ajtty joq ki küldüj. [16] Da tur-

(16) dular andan ol erenlar da baqtylar uturusuna Sedom-

(17) nun da Avraham baryredi birgelerińa uzatma alarny.

(18) ויהוה [17 Da Adonaj ajtty jašyramenmo men Avrahamdan

(19) neki men qylamen. ואברהם [18] Da Avraham bolma bolur

(20) ullu hanlyqqa da küčlü da alġyšlanyrlar anyn sartyn bar

(21) hanlyqlary ol jernin. כי [19] Ki bilemen any [anyn] ücǚn ki zyn-

$24 \mathrm{v}^{0}$ (1) harlar ošol uvullaryn da ošol elin üvünün özünd́an sor-

(2) tun ki saqlag̉ajlar jolun Adonajnyn qylma rastlyq da töŕa keltir-

(3) mek üčün Adonaj Avrahamġa ošol ne ki sözledi anyn üs-

(4) tüńa. [20] Da ajtty Adonaj firjaty zulumlanganlarynyn

(5) Sedomnun da Amoranyn ki köp boldu da jazyqly išlari alarnyn

${ }^{1}$ K: šehinasy Adonaj; a scribal error. | TKow.or: Adonaj. | H: H. | C: H. $\quad{ }^{2} \mathrm{~K}:$ deest; a scribal error. | TKow.o1: anyn. | H: anyn. | C: anyy. 
(17) gave it to a young man, and he hastened to do it. [8]

(18) And he took butter, and milk, and the calf which he had

(19) prepared, and set it before them. And he stood

(20) before them under the tree, and they did eat.

(21) [9] And they said to him, 'Where is Sarah your wife?' And he said,

(1) 'Lo, she is in the tent.' [10] And he said, 'I will surely return

(2) to you about this time next year, to a healthy |you|, and, lo,

(3) Sarah your wife will have a son.' And Sarah was listening while standing at the tent door,

(4) and the door was behind the angel.

(5) [11] And Abraham and Sarah were old,

(6) well along in days of old age; it had ceased to be with Sarah

(7) after the way of women. [12] So Sarah laughed

(8) within herself, saying, 'After I have grown old

(9) I got youth, and my lord is old.' [13] And

(10) 〈the divine Presence of the $\rangle$ Lord said to Abraham, 'Why did Sarah laugh, saying,

(11) "Shall I indeed bear a child? But I grew old."

(12) [14] Is anything too wondrous for the Lord? At the appointed time

(13) I will return to you, about this time next year, to a healthy |you|, and Sarah will have

(14) a son.' [15] But Sarah denied, saying, 'I did not laugh,'

(15) because she was afraid. And he said, 'No, because you did laugh.' [16] And

(16) the men rose up from there, and looked toward ${ }^{28}$ Sodom.

(17) and Abraham went with them to accompany them.

(18) [17] And the Lord said, 'Shall I hide from Abraham

(19) that thing which I do? [18] But Abraham shall surely become

(20) a great and mighty kingdom, and in him shall be blessed all the

(21) kingdoms of the earth. [19] For I know him, that he may command

(1) his children and his household after him,

(2) and they shall keep the way of the Lord, to do righteousness and justice,

(3) and for the purpose of the Lord bringing upon Abraham what he spoke about him.'

(4) [20] And the Lord said, 'The cry of those oppressed by

(5) Sodom and Gomorrah: how great it has become. And their sinful deeds: 
(6) ki küčlü boldu astry. ארדה. [21] Ensin hašgaḥam

(7) da körejim firjatyna mo köŕa ol kelgen alnyma qyldylar

(8) tügelič́a jazyq da eger joq da bilajim. [22] Da qajyryl-

(9) dylar $\{\text { andan }\}^{1}$ ol erenlar da bardylar Sedomga da Avraham hanuz

(10) ol turaredi alnynda Adonajnyn. [יגש. Da juvudu Avraham

(11) da ajtty ham tasetermosen cadiqni rašabyla. אולי [24] Šeme

(12) bardy enli cadiqlar ortasynda ol šaharnyn ham tasetermosen

(13) da bošatmasmosen jazyğyn orunnun enli ol cadiqlarnyn zehutu

(14) üčün ki ortasynda anyn. חלילה. [25] Hašša bolġaj saja qyl-

(15) maqtan ošpu iš kibik \{öltürḿa cadiqni raša byla\} da bolgajdy nečik cadiq alaj raša

(16) hašša bolg̀aj saja tör[e]čisimo ${ }^{2}$ bar ol jernin qylmastyr

(17) rast töŕa. [26] Da ajtty Adonaj eger tapsam

(18) Sedomda enli cadiqlar ortasynda ol šaharnyn da bošatyrmyn

(19) jazyġyn bar ol orunnun alarnyn zehutu üčün. ויען [27] Da

(20) qaruv berdi Avraham da ajtty muna endi küvünlendim

(21) sözĺaḿa alnynda Adonajnyn da men topraq da külmen.

$25 \mathrm{r}^{\mathrm{o}}$ (1) אולי [28] Šeme eksilirlar enli ol cadiqlardan beš čejpar-

(2) mosen beš üčün ošol bar ol šaharny da ajtty Tenri čejpa-

(3) manmen eger tapsam anda qyrq da bešte. [29] Da

(4) arttyrdy dag்yn Avraham sözleme alnynda Tenrinin da

(5) ajtty šeme tabulurlar anda qyrq da ajtty Tenri

(6) qylmanmen karanja ol qyrq üčünda. [30] Da ajtty

(7) Avraham qoltqabyla ačuv bolmasyn Adonajğa da sözlejim

(8) šeme tabulurlar anda otuz da ajtty qylmanmen karanja

(9) eger tapsam anda otuznuda. [31] Da ajtty

(10) Avraham muna endi küvüllendim sözleme alnynda

(11) Adonjanyn šeme tabulurlar anda egirmi da ajtty Tenri

(12) čejpamanmen egirmi üčünd́a. [32] Da ajtty qolt-

(13) qabyla qabunmasyn ačuvu Adonajnyn da sözlajim tek bu vaḥtta

(14) šeme tabulurlar anda on cadiqlar da ajtty Tenri čejpaman-

(15) men ol onüčünd́a. וילך. [33] Da bardy šehinasy Adonaj-

(16) nyn ki nečik tügelledi sözlamáa Avraham byla da Avraham

(17) qajtty ornuna.

\footnotetext{
${ }^{1}$ Marginal insertion by another hand. | TKow.o1: andan. | H: andan. | C: andan. $\quad{ }^{2}$ TKow.o1: töričisimo. | H: terečisimo. | C: šara'atčysy.
} 
(6) how very grave they has become. [21] My providence shall go down

(7) and see whether they have sinned altogether according to the outcry that has come to me.

(8) And if not, let me know.' [22] And the men turned

(9) $\{$ from there $\}$ and went to Sodom, but Abraham, he still stood

(10) before the Lord. [23] And Abraham approached,

(11) and said, 'Will you also destroy the righteous with the wicked? [24] Maybe

(12) there are fifty righteous within the city. Will you also destroy

(13) and not absolve the sin of the place for the merit of the fifty righteous

(14) that are in it? [25] That be far from you to do

(15) a thing like this, to kill the righteous with the wicked, so that the righteous are like the wicked!

(16) Far be that from you! Will the Judge of all the earth

(17) not make the right judgement?' [26] And the Lord said, 'If I find

(18) in Sodom fifty righteous within the city, I will absolve

(19) the sin of all the place for their merits.' [27] And

(20) Abraham answered and said, 'Lo, now, I have decided

(21) to speak before the Lord, and I am dust and ashes.

(1) [28] Maybe five of the fifty righteous are lacking. Will you destroy

(2) all the city for lack of five?', and God said, 'I will not destroy

(3) even if I find forty-five there'. [29] And

(4) Abraham spoke before God yet again, and

(5) said, 'Maybe forty are found there.' And God said,

(6) 'I will not punish |them| even for the sake of forty.' [30] And

(7) Abraham said, 'I pray you, let not the Lord be angry, and let me speak.

(8) Maybe thirty will be found there.' And He said, 'I will not punish |them|

(9) even if I find thirty there.' [31] And

(10) Abraham said, 'Lo, now, I decided to speak before

(11) the Lord. Maybe twenty will be found there.' And God said,

(12) 'I will not destroy |it|, even for the sake of twenty.' [32] And he said,

(13) 'I pray you, let the anger of Lord be not kindled, and let me speak, but this once.

(14) Maybe ten righteous will be found there.' And God said, 'I will not destroy

(15) |it|, even for the sake of ten.' [33] And the divine Presence of the Lord went |His way|,

(16) when he had finished speaking with Abraham, and Abraham

(17) returned to his place. 
Genesis 1 $[9]^{1}$

ויבאו [1] Da keldilar eki ol elčílar

(18) Sedomgaa ingird́a da Lot oltururedi qabaġynda Sedomnun

(19) da kördü Lot da turdu utrularyna alarnyn da bašurdu

(20) jüzleribyla jerǵa. ויאמר. [2] Da ajtty muna qoltqabyla

(21) bijlerim qajyrylyjyz \{endi\} üvüńa qulujuznun da qonujuz da juvujuz

$25 \mathrm{v}^{\mathrm{o}} \quad$ (1) ajaqlaryjyzny da tünlej turarsiz da baryrsiz jolujuzġa da

(2) ajttylar joq ki oramda qonarbiz. ויפצר. [3] Da qystady

(3) alarny astry da qajyryldylar anar da keldilar üvüná

(4) anyn da qyldy alarg̉a ički da jajmalar biširdi da aša-

(5) dylar. טרם [4] Jatmaslaryndan burun da eli ol šaharnyn eli

(6) Sedomnun quršadylar ol üv üstüńa ulandan da qartqa-

(7) dejin bar ol ulus učtan. [5ראו Da ündediler

(8) Lotnu da ajttylar anar qajdady ol erenlar ki keldilar

(9) saja bu kečeni čyg̉arg̉yn alarny bizǵa da qyjnajyq alarny.

(10) . ויצא [6 Da čyqty alarg̉a Lot ol ešiḱka da ol qapa-

(11) qny bekladi özü artyna. [7] Da ajtty qolt-

(12) qabyla qa\{ry\}ndašlarym jaman etmejiz. הנה. [8] Muna endi

(13) maja eki qyzlar ki bilmedilar kišini čyğarajym endi alarny

(14) sizǵa da qylyjyz alarg̉a nečik jahš̌y \{körünse\} közlerijizd́a ančaq

(15) ošpu erenlarǵa qylmajyz neḿade anyn \{üčün\} qačan ki keldilar

(16) syjynma kölegesind́a farstymnyn. [9] Da ajtty-

(17) lar juvugiun arraq da ajttylar ol bir keldi tirilmáa da

(18) töŕa etti töŕa etḿa haligińa jamanraq eterbiz

(19) saja alardan da qystadylar kišini Lotnu \{astry\} da juvudular syndyrma

(20) ol ešikni. וישלחו. [10] Da sundular ol erenĺar ošol

(21) qollaryn da keltirdilar ošol Lotnu özlarińa ol ič-

$26 \mathrm{r}^{\mathrm{o}} \quad$ (1) keriǵa da ošol qapqačyn ol ešiknin bekledilar. ואת [11]

(2) Da ošol ol erenlerni ki ešigind́a ol üvnün urdu-

(3) lar soqurluqlar byla bašlap kičid́an da ulluggadejin da jadady-

(4) lar tapma ol ešikni. [12] Da ajttylar ol e-

(5) renler Lotqa dag்yn kim bardy saja bunda küjöv\{nü\} da

(6) uvullaryjny da qyzlaryjny da barysyn ne ki bardy senin

(7) šaharda čyġarġyn ol orundan. כי . [13] Ki čejpajdyr biz

${ }^{1}$ K: Gen 18; a scribal error. | TKow.o1: Gen 19. | H: Gen 19. | C: Gen 19. 
Genesis 1[9]

[1] And the two envoys came

(18) to Sodom in the evening, and Lot was sitting in the gate of Sodom,

(19) and Lot saw and rose up to meet them and he bowed

(20) with his face toward the ground. [2] And he said, 'Lo, I pray you,

(21) my lords, turn in now, into your servant's house, and spend the night and wash

(1) your feet, and you shall rise up early and go on your way.' And

(2) they said, 'No, for we will spend the night in the street.' [3] And he pressed

(3) them greatly, and they turned in to him, and entered his house,

(4) and he made for them drink and baked cake, and they ate.

(5) [4] But before they lay down, the men of the city, the men

(6) of Sodom, surrounded the house, both youth and old,

(7) all the people to the last $|\operatorname{man}|$. [5] And they called

(8) Lot, and said to him, 'Where are the men who came

(9) to you this night? Bring them out to us, and let us harass them.'

(10) [6] And Lot went out to them at the door, and

(11) shut the covering |of the door| behind him. [7] And he said, 'I pray

(12) you, brothers, do not do bad. [8] Lo, now,

(13) I have two daughters who have not known a man. Let me bring them out

(14) to you, and do you to them as it seems good in your eyes. Only

(15) to these men do nothing, because they have come

(16) to have shelter in the shadow of my ceiling.' [9] And they said,

(17) 'Move away!' And they said, 'This one came to live, and then

(18) he surely judged! Now we will do worse |things|

(19) to you than to them!' And they harassed Lot, the man, greatly and came near to break

(20) the door. [10] But the men reached

(21) their hand out and brought Lot into the house

(1) and shut the covering of the door. [11]

(2) And they smote the men that were at the door of the house

(3) with blindness, both small and great, and they wearied |themselves|

(4) with finding the door. [12] And the men

(5) said to Lot, 'Whom do you have here besides? Son-in-law, and

(6) your sons, and your daughters, and anyone you have

(7) in the city, bring them out of the place. [13] Because we are destroying 
(8) ošol ol orunnu ošpunu ki ullu boldu firjatlary

(9) alarnyn alnynda Adonajnyn da ijdi bizni Adonaj čejpama

(10) any. ויצא [14] Da čyqty Lot da sözledi küjövlerińa

(11) aluvčularg̉a qyzlaryn da ajtty turujuz čygjyjyz ol orundan

(12) ošpu ki čejpajdy Adonaj $\{[0] \text { šol }\}^{1}$ ol šaharny da edi kültkü

(13) külüvčü kibik közlerind́a küjövlerinin. וכמו. [15] Da

(14) nečik ol šaḥar kötürüldü da žaḥtlattylar ol elči-

(15) ĺar Lotnu ajtadog̉ač turg̉un alġyn ošol qatynyjny da ošol

(16) eki qyzlaryjny ol tabulganlarny mag̉at taspolursen güneḥi

(17) üčün ol šaharnyn. [16] Da kečikti da tu-

(18) ttular ol erenlar qolundan anyn da qolundan qatynyn da qolun-

(19) dan eki qyzlarynyn hajifsinḿagi byla Adonajnyn anyn üstü-

(20) ńa da čyg̉ardylar any da qojdular any tyšqartyn šaha $\{r\}$ ġa.

(21) ויהי [17] Da edi čyğarg̉anlaryndačoq alar alarny ol tyšqa-

$26 \mathrm{v}^{\mathrm{o}} \quad$ (1) ryğa ajtty qutulġun žanyjbyla baqmaġyn özüj artyna

(2) da toḥtamaġyn bar ol majdanda ol tavsary qutulgun mag̉at

(3) tos [18] Da ajtty Lot alarga qoltqabyla

(4) bijlerim. הנה [19] Muna endi tapty quluj širinlik közle-

(5) rijd́a da ulġajtyj šavagaatyjny ki qyldyj birǵama tiri

(6) qaldyrma ošol క̌anymny da men bolalmanmen qutulma ol

(7) tavsary magat jeter meni ol jamanlyq da ölerman. הנה [20]

(8) Muna endi ol šahar \{ošpu $\}$ juvuqtu qačma ary da kičidi qutalajym

(9) endi ary muna kičidi ol da tiri qalsyn žanym. [21]

(10) Da ajtty anar ol elči muna jüz ettim jüzlerija daġyn

(11) ošpuda iška aḥtarmasqa men ošol ol šaharny ki söz-

(12) ledij. מהר 22] Šah̆lağyn qutulgun ary ki bolalmanmen qylma

(13) nemad́a kelgenija dejin ary anyn üčün atady atyn ${ }_{L}\langle\operatorname{anyn}\rangle\{o l$ šaharnyn $\}^{12}$ Co'ar.

(14) השמש [23] Ol qujaš balqydy ol jer üstüńa da Lot

(15) keldi Co'arġa. ויהוה. [24] Da Adonaj javdurdu Sedom üs-

(16) tüńa da 'Amora üstüńa gügürt da ot alnyndan

(17) Adonajnyn ol köklerd́an. [25] Da aḥtardy ošol

(18) ol šaharlarny ošpularny da ošol bar ol majdanny da ošol

(19) bar olturuvčularyn ol šaharlarnyn da bitišin ol jernin.

(20) ותבט (26] Da baqty qatyny anyn artyndan anyn da boldu tuzlu

(21) stolp. וישכם Da tünlej turdu Avraham ertenbylada

\footnotetext{
1TKow.o1: ošol. | H: osol. | C: šol. $\quad{ }^{2}$ Correction by another hand. | TKow.o1: ol šaharnyn. | H: ol saharnyn. | C: ol šähärniy.
} 
(8) this place, because their cry has become big

(9) before the Lord, and the Lord has sent us to destroy

(10) it.' [14] And Lot went out, and spoke to his sons-in-law,

(11) who married his daughters, and said, 'Arise, get out of this place,

(12) because the Lord will destroy the city.' But he seemed

(13) as one who mocks in the eyes of his sons-in-law. [15] And

(14) when the morning arose, then the envoys urged

(15) Lot, saying, 'Arise, take your wife, and

(16) your two daughters who are here, lest you be perished because of the iniquity

(17) of the city.' [16] But he lingered, so

(18) the men seized his hand, and his wife's hand, and the hands

(19) of his two daughters, with the Lord's mercy on him,

(20) and they brought him out and set him outside the city.

(21) [17] And it was when they were bringing them out,

(1) $\mid$ and $\mid$ he said, 'Escape for your life. Do not look behind you,

(2) neither stay in all the valley, escape to the mountain, lest

(3) you be perished.' [18] And Lot said to them, 'I pray you,

(4) my lords. [19] Lo, now, your servant has found favour in your eyes,

(5) and you have magnified your kindness, which you have done to me in

(6) keeping my soul alive. But I cannot escape to the

(7) mountain, lest some evil reach me, and I die. [20]

(8) Lo, now, this city is near to flee there, and it is small. Let me escape

(9) now there — lo, it is small — and my soul shall stay alive.' [21]

(10) And the envoy said to him, 'Lo, I granted you a favour

(11) in this matter as well, not to ruin the city of which you have spoken.

(12) [22] Hurry, escape there, because I cannot do

(13) anything until you get there.' Therefore the name of $\langle$ it $\rangle\{$ the city $\}$ was called Zoar.

(14) [23] The sun was shining upon the earth when Lot

(15) came to Zoar. [24] Then the Lord rained

(16) sulphur and fire on Sodom and on Gomorrah, from

(17) the Lord out of the skies. [25] And he ruined those

(18) cities, and all the valley, and

(19) all the inhabitants of the cities, and what grew on the ground.

(20) [26] But his wife looked behind him, and she became

(21) a pillar of salt. [27] And Abraham rose up early at dawn 
$27 \mathrm{r}^{\mathrm{o}}$ (1) ol orunga ki turdu anda alnynda Adonaj\{nyn\}. וישקף. [28]

(2) Da baqty alnyna Sedomnun da 'Amoranyn da alnyna bar

(3) jerinin ol majdannyn da kördü da muna kötürüldü qoju tütünü

(4) ol jernin tütünü kibik ol kiŕač ṕečinin. [29] Da edi

(5) čajpaġanda Tenri ošol šaharlarny ol majdannyn da saġyndy

(6) Tenri ošol Avrahamny da ijdi ošol Lotnu ortasyndan

(7) ol ahtarylmaqnyn aḥtarg̉anda ošol ol šaharla $\{r\}$ ny ki biri-

(8) sind́a alardan olturdu Lot. [יעל [30] Da bardy Lot Co-

(9) 'ardan da olturdu tavda da eki qyzlary anyn birǵasińa

(10) ki qorqtu olturma Co'arda da olturdu pečorada

(11) ol da eki qyzlary anyn. ותאמר. [31] Da ajtty ol ag̉araq

(12) ol kičireḱka atamyz qartty da kiši joḥtur jerd́a

(13) kelḿa bizǵa jolu kibik bar ol jernin. לכה. [32] Kel

(14) ičiŕajik atamyzğa čag̉yr da jatajyq birǵasińa da tirgi-

(15) źajik atamyzdan urluq. ותשקין. [33] Da ičirdilar atasy-

(16) na özĺarinin čag̉yr ol keč́ani da keldi ol ag̉araq da jatty

(17) ויהי [34] atasy byla da bilmáni jatqanynda da turganynda.

(18) Da edi tanbyladan da ajtty ol ag̉araq ol kičíraḱka muna

(19) jattym bigeč́a atambyla ičiŕajik anar čag̉yr daġyn buda

(20) keč́ani da kelgin jatqyn birǵasińa da tirgiźajik atamyzdan

(21) urluq. ותשקין. [35] Da ičirdiĺar daġyn ol da keč́ani atasy-

$27 \mathrm{~V}^{\mathrm{o}}$ (1) na özlerinin čağyr da turdu ol kičiŕak da jatty birgesi-

(2) ńa da bilmedi jatqanynda da turganynda. ותהרין [36]

(3) Da ḥamila boldular eki qyzlary Lotnun atasyndan özlerinin.

(4) ותלד [37 Da töredi ol agaraq uvul da atady atyn

(5) anyn Mo’av ol edi atasy Mo’avnyn ol küngedejin.

(6) [38 [38 Da ol kičírak dağyn olda töredi uvul

(7) da atady \{atyn $\}$ anyn Ben 'Ami ol edi atasy ulanlarynyn 'Amonnun ol

(8) küngedejin.

Genesis $[20]^{1}$

עיסי [1] Da köčtü andan Avraham jerińa

(9) ol tüšlüknün da olturdu arasynda Qodešnin da arasyn-

(10) da Šurnun da tirildi Gerarda. [2] Da ajtty

${ }^{1}$ K: Gen 19; a scribal error. | TKow.o1: Gen 20. | H: Gen 20. | C: Gen 20. 
(1) to the place where he stood before the Lord. [28]

(2) And he looked toward Sodom and Gomorrah and toward all

(3) the land of the valley, and he looked, and, lo, thick smoke of the land was rising

(4) like the smoke of a lime kiln. [29] And it was,

(5) when God destroyed the cities of the valley, that God remembered

(6) Abraham, and sent Lot out of the midst

(7) of the ruining, when he ruined the cities

(8) in one of which Lot dwelt. [30] And Lot went up from Zoar,

(9) and dwelt in the mountain, and his two daughters with him,

(10) because he feared to dwell in Zoar, and he dwelt in a cave,

(11) he and his two daughters. [31] And the older said

(12) to the younger, 'Our father is old, and there is not a man on the earth

(13) to come to us after the way of all the earth. [32] Come,

(14) let us make our father drink wine, and we will lie with him, that

(15) we may revive offspring from our father'. [33] And they made their own father drink

(16) wine that night. And the older came and lay

(17) with her father. And he did not know when she lay down, or when she arose. [34]

(18) And it was after dawn that the older said to the younger, 'Lo,

(19) I lay last night with my father. Let us make him drink wine this night as well,

(20) and you come and lie with him, that we may revive offspring from our father.'

(21) [35] And they made their own father drink wine that night as well,

(1) and the younger arose and lay with him,

(2) and he did not know when she lay down, or when she arose. [36]

(3) And both the daughters of Lot became pregnant by their father.

(4) [37] The older bore a son and called his name

(5) Moab. He was the father of the Moabites to this day.

(6) [38] The younger also bore a son

(7) and called his name Ben-Ammi. He was the father of Ammon

(8) to this day.

Genesis [20]

(9) of the south and dwelt between Kadesh

(10) and Shur and lived in Gerar. [2] And 
(11) Avraham Sara qatyny üčün tuvdugiumdur ol da ijdi Avi-

(12) meleh biji Gerarnyn da aldy ošol Sarany. [3] Da

(13) keldi malah Avimelehḱka tüšü ašyra ol kečenin da aj-

(14) tty anar muna sen ölersen ol qatyn üčün ki aldyj da

(15) erlengenidi ernin. ואבימלך. Da Avimeleh juvumady

(16) anar da ajtty e Adonaj daġyn rasttamo hanlyqny öltü-

(17) rürsen. הלא. [5] \{Muna\} ol kiši ajtty maja tuvdug̉umdu ol

(18) da ol qatyn dağyn olda ajtty qaryndašymdy ol tügelligi

(19) byla jüregimnin da aruvlug̉ubyla uvučlarymnyn qyldym bunu.

(20) [יאמר [6 Da ajtty anar ol Tenri tüš ašyra daġyn

(21) mend́a bilemen ki tügelligibyla jüregijnin qyldyj bu\{nu\} anyn

$28 \mathrm{r}^{\circ} \quad$ (1) üčün ajadym daġyn mend́a seni jazyqly bolmaqtan maja anyn üčün

(2) berḿadim saja tijḿa anar. ועתה. [7] Da haligińa qajtarg̉yn

(3) qatynyn ol kišinin ki navidi ol da tefila etsin senin üčün

(4) da tiri bolursen da eger qajtarmajdesej bilgin ki ölma

(5) ölersen sen da barča neki senin. וישכם. [8] Da tünlaj

(6) turdu Avimeleh e\{r\}tenbylada da ündedi bar qullaryn özü-

(7) nün da sözladi ošol bar ol sözlarni ošpularny qulaqlary-

(8) ča alarnyn da qorqtular ol erenlar astry. ויקרא [9]

(9) Da ündedi Avimeleh Avrahamny da ajtty anar ne qyldyj

(10) bizǵa da ne jazyqly boldum saja ki keltirejezdij üstü-

(11) ma da bijligim üstüńa ullu jazyq išlar ki qylynmaj-

(12) dylar qyldyj birgeḿa. [10] Da ajtty Avimeleh

(13) Avrahamġa ne kördüj ki qyldyj ošol išni ošpunu.

(14) יויאמר (11] Da ajtty Avraham ki ajttym tek johtu

(15) qorquvu Tenrinin ošpu orunda da öltürürlar meni

(16) qatynym üčün. וגם [12] Da daġyn kertidan tuvdugium-

(17) du qyzydy atamnyn ol tek tüvüldü qyzym anamnyn da boldu

(18) maja qatynlyqqa. ויהי [13] Da edi ki nečik bujurdu

(19) maja Tenri barma üvünd́an atamnyn da ajttym anar

(20) bu bolsun šavag̉aty ki qylġyn birgemáa bar ol orunġa ki

(21) kelsek ary ajtqyn menim üčün qaryndašymdy ol.

$28 \mathrm{v}^{\mathrm{o}}$ (1) ויקח [14] Da aldy Avimeleh qoj da syğyr \{da qullar da qaravašlar\} da berdi Avraham- 
(11) Abraham said of Sarah his wife, 'She is my sister.' And Abimelech,

(12) king of Gerar, sent and took Sarah. [3] And

(13) an angel came to Abimelech through a dream of the night, and said

(14) to him, 'Lo, you will die because of that woman that you have taken, for

(15) she is wedded to a man.' [4] But Abimelech had not approached

(16) her, and he said, 'Oh Lord, will you kill a righteous kingdom as well?

(17) [5] Lo, that man said to me, "She is my sister."

(18) And the woman—she, too—said, "He is my brother." I did this in the integrity

(19) of my heart and in the cleanness of my palms.'

(20) [6] And God said to him through the dream, 'I know, too,

(21) that you did this in the integrity of your heart. Because of that

(1) I have kept you, too, from being sinful against me. Therefore

(2) I did not let you touch her. [7] Now, return

(3) the man's wife, because he is a prophet, and he shall pray for you,

(4) and you will live. But if you do not return her, know that you will surely die,

(5) you and all who are yours.' [8] So

(6) Abimelech rose up early at dawn and called all his servants

(7) and told them all these things in their ears.

(8) And the men were very much afraid. [9]

(9) And Abimelech called Abraham, and said to him, 'What have you done

(10) to us? And how did I sin against you, that you have almost brought a great sin on

(11) me and on my kingdom? You have done things

(12) with me that are not done.' [10] And Abimelech said

(13) to Abraham, 'What did you see, that you did this thing?'

(14) [11] And Abraham said, 'Because I said, "Yet there is no

(15) fear of God at all in this place, and they will kill me

(16) because of my wife." [11] And also she is, indeed, my sister,

(17) she is the daughter of my father, but not the daughter of my mother, and she became

(18) a wife to me. [13] And it was, when God ordered

(19) me to go from my father's house, that I said to her,

(20) "This shall be the kindness which you shall do with me: to every place where

(21) we come, say about me, "He is my brother." "'

(1) [14] And Abimelech took sheep, and cattle, and servants, and maid- $\quad 28 \mathrm{v}^{\mathrm{o}}$ servants, and gave them to Abraham, 
(2) ġa da qajtardy anar ošol Sarany qatynyn. [יאמר [15 Da

(3) ajtty Avimeleh Avrahamġa muna jerim alnyjdady jaḩšy

(4) körünǵan orunda közlerijde olturg̉un. ולשרה ]

(5) Da Saraġa ajtty muna berdim qaryndašyja min kümüš

(6) muna ol saja jabuvu közlerinin baryna neki qatyjda ${ }_{\iota} \mathrm{da}$

(7) ošol bar bu ešitip Sara da ügütlendi ajtmaqtan

(8) eri üčün qaryndašymdy ol11. ויתפלל [17] Da tefila

(9) etti Avraham ol Tenriǵa da ongaltty Tenri ošol

(10) Avimelehnni da ošol qatynyn anyn da qaravašlaryn anyn da

(11) töredilar. כי [18] Ki beklaḿa beklebedi Adonaj bar

(12) qursaq ašyra üvünd́a Avimelehnin Sara üčün qatyny

(13) üčün Avrahamnyn.

Genesis $2[1]^{2}$

ויהוה Da Adonaj sag̉yndy ošol

(14) Sarany ki nečik ajtty da qyldy Adonaj Sarag̉a ki nečik

(15) sözladi. ותהר [2] Da ḥamila boldu da töredi Sara

(16) Avrahamġa uvul qartlyq vahtlarynda anyn vag̉dagia ki

(17) sözledi anar Tenri. Da atady Abraham ošol

(18) atyn uvlunun ol tuvġannyn anar Jichaq ki töredi anar

(19) Sara. וימל [4] Da ḥatna qyldy Avraham ošol Jicḥaqny

(20) uvlun segiz künlüknü ki nečik bujurdu anar Tenri.

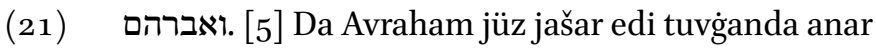

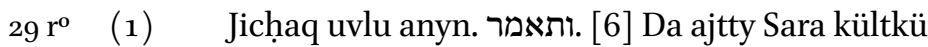

(2) byla qyldy maja Tenri bar ol ešitüvčü külar menim üčün.

(3) ותאמר [7 Da ajtty kim sözledi Avrahamga ki

(4) ömüzdürür ulanlar Sara ki töredim uvul qartlyq

(5) vahtlarynda anyn. [8] Da ulgajdy ol ulan da

(6) ömčektan ajyryldy da qyldy Avraham ullu ički öm-

(7) čektan ajyrylġan künd́a Jichạ. ותרא. [9] Da kördü

(8) Sara ošol uvlun Haġarnyn ol Micrilinin ki töredi

(9) Avrahamġa ojnajdoġanny Jichaq byla. ותאמר. [10] Da

(10) ajtty Avrahamġa sürgün ol qaravašny ošpunu da

(11) ošol uvlun anyn ki mereslemesti uvlu ol qa\{r\}avašnyn oš-

\footnotetext{
${ }^{1}$ Interpretative addition to the standard text. $\quad{ }^{2} \mathrm{~K}$ : Gen 20; a scribal error. | TKow.o1: Gen 21. | H: Gen 21. | C: Gen 21.
} 
(2) and returned Sarah, his wife, to him. [15] And

(3) Abimelech said to Abraham, 'Lo, my land is before you.

(4) Dwell at the place that would seem good in your eyes.' [16]

(5) And to Sarah he said, 'Lo, I have given your brother a thousand pieces of silver.

(6) Lo, it is a covering of eyes for you, for all that are with you.' ${ }_{\text {And }}$

(7) after hearing all of this, Sarah was reproved for saying

(8) about her husband, 'He is my brother.' ${ }^{129}$ [17] So

(9) Abraham prayed to God, and God healed

(10) Abimelech, and his wife and his maidservants, and

(11) they bore. [18] Because the Lord had surely closed every

(12) womb of the house of Abimelech, because of Sarah,

(13) Abraham's wife.

Genesis 2[1]

[1] And the Lord remembered

(14) Sarah, as he had said, and the Lord did to Sarah as he

(15) had spoken. [2] And Sarah conceived and bore

(16) a son for Abraham in his old age, at the appointed time of which

(17) God had spoken to him. [3] And Abraham called the

(18) name of his son that was born to him Isaac, whom Sarah bore to him.

(19) [4] And Abraham circumcised Isaac,

(20) his son, at eight days old, as God had commanded him.

(21) [5] And Abraham was a hundred years old when

(1) Isaac, his son, was born to him. [6] And Sarah said,

(2) 'God has made laughter for me. Everyone who hears will laugh for me.'

(3) [7] And she said, 'Who would have spoken to Abraham that

(4) Sarah would nurse children? Yet I have borne a son in his old

(5) age.' [8] And the child grew, and

(6) was weaned. And Abraham made a great feast

(7) on the day that Isaac was weaned. [9] And Sarah saw

(8) the son of Hagar, the Egyptian, whom she had borne

(9) to Abraham, making fun of Isaac. [10] So

(10) she said to Abraham, 'Throw out this maidservant and

(11) her son, for the son of this maidservant will not inherit

29 An interpretative addition to Gen 20:16. 
(12) punun uvlum Jichaqa byla. וירע. [11] Da jaman köründü ol

(13) söz astry közlerind́a Avrahamnyn uvlu üčün.

(13) ויאמר [12] Da ajtty Tenri Avrahamġa jaman körün-

(14) mesin közlerijda ol ulan üčün da qaravašyj üčün

(15) barča ne ki ajtsa saja Sara tynlag̉yn sözüne anyn ki

(16) Jichạaq sartyn ündelir saja urluq. וגם [13] Da daġyn

(17) ošol uvlun ol qaravašnyn ḥanlyqqa qojarmen any ki urlugiuj-

(18) du ol. וישכם [14] Da tünlaj turdu Avraham ertenby-

(19) lada da aldy ötmek da fleška suv da berdi Hag̉ar-

(20) ġa qojdu javrunu üstüńa da ošol ol ulanny da

$29 \mathrm{v}^{\mathrm{o}} \quad$ (1) da uzatty any da bardy da azašty midbarynda Be'er

(2) Šava'nyn. ויכלו [15] Da tügendilar ol suvlar ol fleške-

(3) den da tašlady ošol ol ulanny birisi tübüńa ol

(4) tereklernin. ותלך. [16] Da bardy da olturdu özüńa

(5) qaršydan jyraq etḿa oq atym jertekli jajdan ki

(6) ajtty körńajim ölgend́a ol ulan da bardy da ol-

(7) turdu qaršydan da kötürdü ošol avazyn da jylady.

(8) [17 Da ešitti Tenri ošol avazyn ol ulannyn

(9) da čaġyrdy malahy Tenrinin Haġarga ol köklerd́an da

(10) ajtty anar nedir saja e Hag̉ar qorqmaġyn ki ešitti

(11) Tenri avazyn ol ulannyn qajda ki ol anda. קומי. [18] Tur-

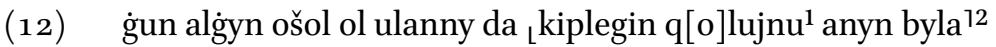

(13) ki ullu ḥanlyqqa qojarmen any. ויפקח. [19] Da ačty

(14) Tenri ošol közlarin anyn da kördü qujusun suvlarnyn

(15) da bardy da tolturdu ošol ol fleškeni suv da ičir-

(16) di ošol ol ulanny. [20] Da edi bolušlug̉u Tenri-

(17) nin ol ulanbyla da ulgaajdy da olturdu midbarda

(18) da edi oq atuvču da jajačy. [ישב. [21] Da oltur-

(19) du midbarynda Parannyn da aldy anar anasy anyn qatyn

(20) jerind́an Micrinin. [22] Da edi ol vaḥtta da

(21) ajtty Avimeleḩ da Fiḩol ag̉arag̉y čerüvünün Avraham-

3o $\mathrm{r}^{\mathrm{o}}$ (1) ġa ajtadog̉ač bolušluğu Tenrinin birgeja barynda neki sen qylasen.

(2) [23] Da haligińa antetkin maja Tenrid́an bunda eger

(3) aldasaj maja da unug̉uma da praunug̉uma šavag̉at kibik ki

\footnotetext{
${ }^{1} \mathrm{~K}$ : qulujnu; a scribal error. | TKow.o1: qolujnu. | H: qolunnu. | C: qolyy; different wording, see next footnote. ${ }^{2} \mathrm{~A}$ mistranslation. | TKow.or: kiplegin ošol qolujnu anynbyla. | H: küplegin osol qolunnu anyn byla. | C: kip tutqyn qolyy bilän. | V: tuthun qoluj byla any. | R: tuthun qoluj byla any.

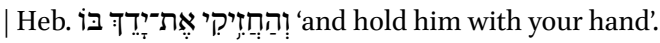


(12) with my son, Isaac.' [11] And these words seemed bad

(13) in Abraham's eyes because of his son.

(14) [12] And God said to Abraham, 'Let it not seem bad

(15) in your eyes because of the boy and because of maidservant.

(16) In all that Sarah has said to you, listen to her voice, for

(17) through Isaac shall your offspring be named. [13] And also

(18) of the son of the maidservant I will make a kingdom, because

(19) he is your offspring.' [14] And Abraham got up early in the morning,

(20) and took bread, and a bottle of water, and gave it to Hagar,

(21) he put it on her shoulder, and the child, and

(1) and sew her out. And she went away and wandered in the wilderness of Beersheba.

(2) [15] And the water was finished in the bottle,

(3) and she cast the child under one of the

(4) trees. [16] And she went, and sat down

(5) opposite him, being away about the span of a shot of an arrow from a bow, for

(6) she said, 'Let me not see the child in his death.' And she went and

(7) sat down opposite him and she raised her voice and wept.

(8) [17] And God heard the voice of the boy,

(9) and the angel of God called to Hagar out of heaven, and

(10) said to her, 'What is |wrong| to you, oh Hagar? Do not fear, because

(11) God has heard the voice of the boy where he is. [18] Arise,

(12) take the boy, [and strengthen your hand with him ${ }^{130}$,

(13) because I will make him into a great kingdom.' [19] And

(14) God opened her eyes, and she saw a well of water;

(15) and she went, and filled the bottle with water, and gave

(16) the boy a drink. [20] And God's help was

(17) with the boy, and he grew, and dwelt in the wilderness,

(18) and became an archer and bowman. [21] And he dwelt

(19) in the wilderness of Paran, and his mother took him a wife

(20) from the land of Egypt. [22] And it was at that time that

(21) Abimelech and Phicol, the superior of his army, said to Abraham,

(1) saying, 'God's help is with you in all that you do.

(2) [23] And now swear to me here by God, in case

(3) you were to deal falsely with me, or with my grandson, or with my great-grandson. Like the kindness that

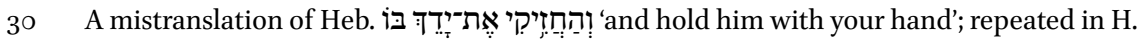
Translated correctly in $\mathrm{C}, \mathrm{V}$, and $\mathrm{R}$. 
(4) qyldym birǵaja qylg̀nn birgemáa da elibyla ol jernin ki ti-

(5) rildij anda. ויאמר Da ajtty Avraham men antetejim.

(6) - והוכח [25] Da ügütledi Avraham ošol Avimelehni iši

(7) üčün qujusunun ol suvlarnyn ki taladylar qullary Avimelehnnin. [ויאמר]'. [26]

(8) Da ajtty Avimeleh bilmejmen kim qyldy ošol ol išni

(9) ošpunu da dağyn send́a anlatmadyj maja da dag̉yn mend́a

(10) ešitmedim ančaq bügün. ויקח. [27] Da aldy Avraham

(11) qoj da syġyr da berdi Avimelehḱa da kestilar eksile-

(12) rid́a šert. [28] Da turg̉uzdu Avraham ošol jedi

(13) qozularyn ol qojnun jalgyzlarny. ויאמר. [29] Da ajtty Avi-

(14) meleh Avrahamġa negedi alar jedi qozular ošpular ki tur-

(15) ginguduj jalġyzlaryn. [30] Da ajtty Avraham ki

(16) ošol jedi ol qozularny alġyn qolumdan anyn üčün ki bolġaj

(17) maja tanyqqa ki qazdym ošol ol qujunu ošpunu. על. [31]

(18) Anyn üčün atady ol orunġa Be'er Šava' ki anda ant-

(19) ettilar eksilerid́a. ויכרתו. [32] Da kestilar šert

(20) Be’er Šava'da da turdu Avimeleh da Fihol ag̉araġy čerüvü-

(21) nün da qajttylar jerińa Pelištimnin. ויטע. [33] Da or\{n\}atty

$30 \mathrm{v}^{\mathrm{o}}$ (1) terek Be’er Šava'da da čagyrdy anda aty byla Adonajnyn Tenri-

(2) ויגר. [34] Da tinin dunjanyn Avraham jerind́a Pelištim-

(3) nin köp künlar.

Genesis $2[2]^{2}$

יויהי [1] Da edi son ol išlard́an ošpu-

(4) lardan da ol Tenri synady ošol Avrahamny da \{ajtty\} anar Avraham

(5) da ajtty munadyr men. [2] Da ajtty alğyn ošol

(6) uvlujnu ošol jalġyzġyjny ki süvdüj ošol Jicḥaqny da bar-

(7) ġyn özüja jerińa ol Morijanyn da mindirgin any biri-

(8) si üstüńa ol tavlarnyn \{ki ajtsam saja\} bolma anda 'olaġa. [3] [3]

(9) Da tünĺaj turdu Avraham ertenbylada da jerledi ošol

(10) ešegin da aldy ošol eki negerlarin birgesińa da ošol

(11) Jichaqny uvlun da jarčyqlady otunlaryn 'olanyn da turdu

(12) da bardy ol orunga ki ajtty anar ol Tenri. ביום [4]

(13) Ol üčünču künd́a da kötürdü Avraham ošol közlarin

(14) da kördü ošol ol orunnu jyraqtyn. ויאמר. [5] Da ajtty

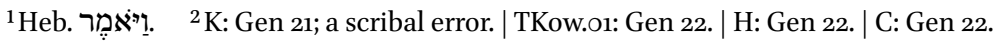


(4) I have done with you, you shall do with me, and with the people of the land in which

(5) you have lived.' [24] And Abraham said, 'Let me swear.'

(6) [25] And Abraham reproved Abimelech about

(7) a well of water, which Abimelech's servants had seized. [26]

(8) And Abimelech said, 'I do not know who has done this very thing;

(9) and also: you did not tell me; and also,

(10) I did not hear of it except for today.' [27] And Abraham took

(11) sheep and cattle, and gave them to Abimelech; and

(12) the two of them made a covenant. [28] And Abraham set seven

(13) lambs of the flock by themselves. [29] And Abimelech said

(14) to Abraham, 'What are these seven lambs that

(15) you have set by themselves?' [30] And Abraham said, 'Because

(16) you shall take these seven lambs from my hand that they may be

(17) a witness to me that I have dug this well.' [31]

(18) On account of this he called that place Beersheba, because

(19) the two of them swore there. [32] And they made a covenant

(20) at Beersheba. And Abimelech and Phicol, the superior of his army,

(21) rose up and returned to the land of the Philistines. [33] And Abraham planted

(1) a tree in Beersheba and called there on the name of the Lord,

(2) the God of eternity. [34] And Abraham lived in the land of the Philistines

(3) many days.

Genesis 2[2]

(3) [1] And it was after these things,

(4) and God tested Abraham, and said to him, 'Abraham!'

(5) And he said, "Lo, here I am." [2] And he said, "Take

(6) your son, your only son whom you loved, Isaac, and go

(7) to the land of Moriah, and help him up on

(8) one of the mountains, which I shall tell you of, for a burnt offering.' [3]

(9) And Abraham rose up early in the morning, and saddled

(10) his donkey, and took two of his young servants with him, and

(11) Isaac his son. And he cut the wood for the burnt offering, and rose up,

(12) and went to the place of which God had told him. [4]

(13) And on the third day Abraham raised his eyes,

(14) and saw the place from afar. [5] And 
(15) Avraham negerlerińa olturujuz özüjüzǵa bunda ol ešek

(16) byla da men da ol ulan baryrbiz berigedejin da bašururbiz

(17) da qajtyrbiz sizǵa. [6] Da aldy Avraham ošol

(18) otunlaryn ol 'olanyn da qojdu Jichaqq uvlu üstüńa da

(19) aldy qoluna ošol ol otnu da ošol ol ḥalafny da bardylar

(20) eksilerid́a birǵa. ויאמר [7] Da ajtty Jichaq Avraham-

(21) ga atasyna da ajtty atam da ajtty Avraham mundadyr

$3^{1} \mathrm{r}^{\mathrm{o}} \quad$ (1) men uvlum da ajtty Jichaq muna ol ot da otunlar

(2) da qajdadyr ol qoj 'olagia. [8 Da ajtty Avraham

(3) Tenri baqqaj özüńa ol qojnun 'olag̉a uvlum da bardylar

(4) eksilerid́a birǵa. ויבאו. [9] Da keldilíar ol orun-

(5) ga ki ajtty anar ol Tenri da qondardy anda Avraham

(6) ošol ol mizbeaḥny da tüzüdü ošol otunlarny da bajlady

(7) ošol Jicḥaqny uvlun da qojdu any ol mizbeah üstüńa

(8) jog̉artyn otunlardan. [10] Da sundu Avraham ošol

(9) qolun da aldy ošol ol ḥalafny sojma ošol uvlun.

(10) ויקרא [11] Da čaġyrdy anar malahy Adonajnyn ol köklerd́an

(11) da ajtty Avraham Avraham da ajtty Avraham munadyr

(12) men. [יאמר [12] Da ajtty sunmaġyn qolujnu ol ulanga

(13) da qylmaġyn anar nemed́a ki haligińa bildim ki qorquvču-

(14) dur Tenridan sen da ajamadyj ošol uvlujnu ošol jalg̀y-

(15) zag̉yjny mend́an. [ישא [13] Da kötürdü Avraham ošol köz-

(16) lerin da kördü da muna qočqar artynda ilinǵan bu-

(17) taqqa müvüzlerind́an da bardy Avaham da aldy ošol

(18) qočqarny da čyg̉ardy any 'olag̉a uvlu ornuna. [יקרא [14]

(19) Da atady Avraham atyn ol orunnun Adonaj Jir'e ki ajtylady

(20) bügünd́a tavda šehinasy Adonajnyn aškara bolady.

(21) ויקרא [15] Da čag̉yrdy malahy Adonajnyn Avrahamġa ekinči

31 v $^{0} \quad$ (1) keret ol köklerden. [16] Da ajtty özümd́an ante-

(2) ttim alaj ajtty Adonaj ki anyn üčün ki qyldyj ošol ol

(3) išni ošpunu da ajamadyj ošol uvlujnu ošol jalġyzġyjny.

(4) כי . 17] Ki alġyšlama alġyšlarmen seni da arttyrma arty-

(5) ryrmen ošol urlugiujnu jolduzlarynkibik ol köklernin da

(6) qumnu kibik ki qyryjüstüne ol tengiznin da mereslar

(7) urluğuj ošol qabaġyn dušmanlarynyn. והתברכו. [18] Da 
(15) Abraham said to his servants, 'Sit here with the donkey.

(16) And I and the boy will go to that place, and we will worship,

(17) and we will return to you.' [6] And Abraham took the

(18) wood of the burnt offering, and laid it on Isaac his son. And

(19) he took the fire in his hand, and a slaughtering knife. And

(20) the two of them went together. [7] And Isaac said to Abraham,

(21) his father, and said, 'My father!' And Abraham said, 'Lo, here I am,

(1) my son.' And Isaac said, 'Lo, here is the fire and the wood,

(2) but where is the sheep for a burnt offering?' [8] And Abraham said,

(3) 'May God take care himself of lamb for a burnt offering, my son.' And

(4) the two of them went together. [9] And they came to the place

(5) which God had told him of. And Abraham built there

(6) an altar, and laid the wood in order, and bound

(7) Isaac his son, and laid him on the altar

(8) on the wood. [10] And Abraham reached out

(9) his hand and took the slaughtering knife to slaughter his son.

(10) [11] And the angel of the Lord called to him from heaven,

(11) and said, 'Abraham, Abraham!' And he said, 'Lo, here

(12) I am.' [12] And he said, 'Do not reach out your hand toward the boy,

(13) and do not do anything to him, for now I know that you fear

(14) God, and you have not spared your son, your only one,

(15) from me.' [13] And Abraham raised his eyes,

(16) and looked, and, lo: behind him a ram, caught in

(17) branches by his horns. And Abraham went and took the

(18) ram and offered it as a burnt offering instead of his son. [14]

(19) And Abraham called the name of that place ${ }_{L}$ The Lord Jireh ${ }^{131}$, as it is said

(20) even today: 'The divine Presence of the Lord appears in the mountain.'

(21) [15] And the angel of the Lord called to Abraham a second

(1) time from heaven. [16] And he said, 'I swore by me,

(2) thus said the Lord, that because you have done this

(3) thing, and have not spared your son, your only son:

(4) [17] That I will surely bless you, and I will surely multiply

(5) your offspring like the stars of the skies, and

(6) like the sand which is on the seashore, and

(7) your offspring shall inherit the gate of its enemies. [18] And

31 A partial translation of Heb. יהוזה ירֶֶָה: 'the Lord will provide', 'the Lord will see'. 
(8) alġyšla[ny]rlar1 özleri özlarin urlug̉ujbyla bar hanlyqlary

(9) ol jernin anyn üčün ki tynladyj ünüma. [19] Da

(10) qajtty Avraham negerlerińa da turdular da bardylar birǵa

(11) Be’er Šavåğa da olturdu Avraham Be’er Šava'da.

(12) ויהי (20] Da edi son ol išlardan ošpulardan da anlatyldy

(13) Avrahamġa ajtadog̉ač muna töredi Milka daġyn olda ulanlar

(14) Naḥorg̉a qaryndašyja. את. [21] Ošol 'Ucnu tunġučun da

(15) ošol Buznu qaryndašyn anyn da ošol Qemu'elni atasyn Aram-

(16) nyn. [22] Da ošol Kesedni \{da ošol Ḥazonu\} da ošol Pildašny da ošol

(17) Jidlafny da ošol Betu'elni. ובתואל. [23] Da Betu'el tuvdurdu

(18) ošol Riveqany segizni bularny töredi Milka Naḥorg̉a qaryn-

(19) dašyna Avrahamnyn. ופילגשו. [24] Da qumasy anyn da aty

(20) anyn Ru'uma da töredi dag̉yn olda ošol Tevaḥny da

(21) ošol Gaḥamny da ošol Taḥašny da ošol Ma'aḩany.

(1) [1] Da edilar tirlikleri Saranyn

(2) jüz jyl da egirmi jedi jyllar jyllary tirliklarinin

(3) Saranyn. זיתמת [2] Da öldü Sara šaharynda Arbac-

(4) nyn oldu Ḥevron jerind́a Kena'annyn da keldi Avraham syjyt

(5) etŕa Sara üčün da jylama anyn üčün. ויקם [3] Da

(6) turdu Avraham alnyndan ölüsünün da sözledi ulanlaryn

(7) Hetnin ajtadoġač. ג4 [4] Ġarip esemd́a men vale očar

(8) klajmen bolma birgejizǵa berijiz maja tutuvlugiun zeretnin

(9) birgejizǵa da astrajym ošol ölümnü alnymdan.

(10) ויענו [5] Da qaruv berdilar ulanlary Hetnin Avrahamġa

(11) ajtadoġač anar. שמענו [6] Tynlag̉yn bizni bijim nasisi-

(12) dir Tenrinin sen ortamyzda sajlamasynda zeretlerimiz-

(13) nin astrag̉yn ošol ölüjnü kišid́a bizd́an ošol zeretin

(14) ajamasty send́an astramaqtan ölüjnü. ויקם [7 Da

(15) turdu Avraham da bašurdu ulusuna ol jernin uvullaryna

(16) Hetnin. [ידבר [8] Da sözladi birgelerińa ajtadog̉ač

(17) eger bar eśa klegijizd́a astrama ošol ölümnü

\footnotetext{
${ }^{1} \mathrm{~K}$ : alġyšlarlar; a scribal error. Cf. also the remark in South-Western Karaim written in pencil in Latin script (in Polish orthography) in the outer margin: atġystanyrtar. | TKow.o1: alġyšlarlar. | H: alg̈yslanyrlar. | C: alġyšlanyrlar. $\quad{ }^{2} \mathrm{~K}$ : Gen 22; a scribal error. | TKow.o1: Gen 23. | H: Gen 23. | C: Gen 23 .
} 
(8) in your offspring shall all the kingdoms of the earth [be] bless[ed],

(9) because you have listened to my voice.' [19] So

(10) Abraham returned to his servants, and they arose and went together

(11) to Beersheba. And Abraham lived in Beersheba.

(12) [20] And it was after these things, and it was told to

(13) Abraham, saying, 'Lo, Milcah, she has also borne children

(14) to your brother Nahor. [21] Uz his firstborn, and

(15) Buz his brother, and Kemuel, the father of Aram,

(16) [22] And Chesed, and Hazo, and Pildash, and

(17) Jidlaph, and Bethuel.' [23] And Bethuel begat

(18) Rebekah. These eight Milcah bore to Nahor,

(19) Abraham's brother. [24] And his concubine,

(20) whose name was Reumah, she bore also Tebah, and

(21) Gaham, and Thahash, and Maachah.

Genesis $2[3]^{32}$

(1) [1] And the life of Sarah was

(2) a hundred years and twenty-seven years, these were the years of the life

(3) of Sarah. [2] And Sarah died in the city of Arba,

(4) that is, Hebron, in the land of Canaan, and Abraham came to mourn

(5) for Sarah, and to weep for her. [3] And

(6) Abraham rose up from in front of his dead, and he spoke to the sons

(7) of Heth, saying, [4] 'Even if I am a stranger: but I want

(8) to be a settler with you. Give me a possession of a sepulchre

(9) with you, that I may bury my dead from in front of me'.

(10) [5] And the children of Heth answered Abraham,

(11) saying to him, [6] 'Hear us, my lord. You are a prince

(12) of God among us. Bury your dead in the choice of our sepulchres.

(13) None of us will begrudge you his sepulchre,

(14) |to hold you back| from burying your dead.' [7] And

(15) Abraham rose, and bowed himself to the people of the land, to the children

(16) of Heth. [8] And he spoke with them, saying,

(17) 'If you are willing to bury my dead

$32 \quad \mathrm{~K}$ : The beginning of parashat Chayei Sarah is not indicated. 
(18) alnymdan tynlajyz meni da qolujuz menim üčün 'Efronnu

(19) uvlun Coḥarnyn. [יתן [9] Ki berǵaj maja ošol ṕečora-

(20) syn ol Mahpelanyn ${ }_{L}\{[\mathrm{ki} \text { a }] n y n\}^{11}$ ki učunda tüzünün tügel kümüšška

(21) bersin any maja ortajyzda tutuvlugiuna zeretnin.

$32 \mathrm{v}^{\mathrm{o}}$ (1) [10] Da 'Efron oltururedi ortasynda ulanlarynyn

(2) Ḥetnin da qaruv berdi 'Efron ol Ḥitili Avrahamġa qulaqlaryča

(3) ulanlarynyn Ḥetnin bar kelüvčülarisajyn qabaġyna šaharynyn ajta-

(4) dog̉ač. לא. [11] Joq bijim tynlag̉yn meni beŕamen saja ol tüz-

(5) nü da ol ṕečorany ki anda saja beremen any közlerič́a

(6) elinin ulusumnun beremen any saja astrag̀yn ölüjnü.

(7) (12] Da bašurdu Avraham alnynda ulusunun ol

(8) jernin. וידבר [13] Da sözladi ${ }_{L}\langle$ Avraham $\rangle\left\{{ }^{\text {EEfronġa }}{ }^{12}{ }^{2}\right.$ qulaqlaryča ulusu-

(9) nun ol jernin ajtadoġač kertid́an ančaq sen kešḱa tynla-

(10) sajedij maja berejim kümüšün ol tüznün alġyn mend́an da

(11) astrajym ošol ölümnü anda. ויען [14] Da qaruv berdi

(12) 'Efron Avrahamġa ajtadoġač anar. [15] E bijim

(13) tynlag̉yn meni jer dört jüz mitqal kümüšlük arama da

(14) araja nedir ol da ošol ölüjnü astraġyn. וישמע [16] Da tynlady

(15) Avraham sözüne 'Efronnun da ölčadi Avraham

(16) 'Efrong̉a ošol ol kümüš-

(17) nü ki sözladi qulaqlaryča ulanlarynyn Ḥetnin dört jüz mit-

(18) qal kümüš ašadog̉an bezirgenǵa. ויקם. [17] Da qajjam boldu

(19) tüzü 'Efronnun ki Mahpelada ki alnynda Mamrenin ol

(20) tüz da ol ṕečora ki anda da bar ol ag̉ač ki tüzd́a

(21) ki bar čegind́a anyn čüvŕa. לאברהם [18] Avrahamġa

$33 \mathrm{r}^{\mathrm{o}} \quad$ (1) satyn almaqqa közlerič́a ulanlarynyn Ḥetnin bar kelüvčüle-

(2) ribyla qabag̀yna šaharynyn. ואחרי. [19] Da andan sortun

(3) $\quad\left\{\right.$ alaj $^{3}$ astrady Avraham ošol Sarany qatynyn ṕečorasynda tüzü-

${ }^{1}$ TKow.or: ki anyn. | H: ki anar. | C: ki anyy. $\quad$ 2 Correction by another hand. | TKow.o1: Efronġa. | H: 'Efronga. | C: 'Efronga. $\quad{ }^{3}$ Marginal insertion by another hand. | TKow.o1: deest. | H: alaj. | C: deest. 
(18) from in front of me, hear me and entreat for me Ephron

(19) the son of Zohar: [9] That he may give me the cave

(20) of Machpelah, [which is] his, which is in the end of his field. For the full silver ${ }^{33}$

(21) he shall give it to me among you as possession of a sepulchre.'

(1) [10] And Ephron was sitting among the children

(2) of Heth, and Ephron the Hittite answered Abraham in the hearing

(3) the children of Heth, of all who were coming to the gate of his city, saying,

(4) [11] 'No, my lord, hear me: I give you the field,

(5) and I give you the cave that is in it. In the sight of

(6) of my people I give it to you. Bury your dead.'

(7) [12] And Abraham bowed down before the people of the

(8) land, [13] And spoke to $\langle$ Abraham $\rangle\{$ Ephron $\}$ in the hearing of the people

(9) of the land, saying, 'Really, if only you would listen

(10) to me! I shall give you the silver for the field. Take it from me, and

(11) I shall bury my dead there.' [14] And Ephron answered

(12) Abraham, saying to him, [15] 'Oh my lord,

(13) listen to me. The land is worth four hundred mithqals of silver:

(14) what is that between me and you? And bury your dead.' [16] And Abraham listened

(15) to the words of Ephron, and Abraham weighed out

(16) for Ephron the silver

(17) that he had spoken of in the hearing of the children on Heth, four hundred weights

(18) of silver, current money with the merchants. [17] And

(19) the field of Ephron in Machpelah, which was to the east of Mamre, the

(20) field with the cave that was in it and all the trees that were in the field,

(21) that were in all the borders all around was established: [18] For Abraham

(1) as a purchase in the presence of the children of Heth, all who were $\quad 33 \mathrm{r}^{\circ}$ coming

(2) to the gate of his city. [19] And after this,

(3) Abraham buried $\{s o\}$ Sarah, his wife, in the cave of the field of

33 I.e., for full price. 
(4) nün ol Mahpelanyn alnynda Mamrenin oldu Hevron jerind́a

(5) Kena'annyn. ויקם. [20] Da qajjam boldu satyn almaġy ol tüznün

(6) da ol ṕečoranyn ki anda ulanlaryndan Hetnin Avrahamġa

(7) tutuvlugiuna zeretnin.

Genesis 2[4 $]^{1}$

ואברהם. [1] Da Avraham qartajdy

(8) jetti künlarǵa da Adonaj alğyšlady ošol Avrahamny bar-

(9) čada. ויאמר [2] Da ajtty Avraham q[u]luna² özünün qar-

(10) tyna üvünün ol erklenüvčüğa barynda neki anyn

(11) qojg̈un endi qolujnu butumtübüne. [3שביעך. Da

(12) antett[i] rejim ${ }^{3}$ seni qajjamlyġyndan Adonajnyn Tenrisinin ol kök-

(13) larnin da Tenrisinin ol jernin ki almaġajsen qatyn uvluma

(14) qyzlaryndan ol Kena'aninin ki men olturamen ortasynda.

(15) כי (4] Ki ančaq jeriḿa da tuvmušuma b[a]rg்yn ${ }^{4}$ da alğyn

(16) qatyn uvluma Jichaqqa. [5 [5a ajtty anar ol

(17) qul šeme kelmesti ol qatyn barma artymdan ol jerǵa ošpu

(18) qajtarma qajtarajymmo ošol uvlujnu ol jerǵa ki čyqtyj

(19) andan. ויאמר [6 Da ajtty anar Avraham saqlanġyn özüja

(20) mağat qajtaryrsen ošol uvlumnu ary. יהוה [7 Adonaj Tenri-

(21) si ol köklernin ki aldy meni üvünd́an atamnyn da jerin-

$33 \mathrm{v}^{\mathbf{o}} \quad$ (1) d́an tuvmušumnun da ki sözledi maja da ki antetti maja

(2) ajtadoġač urlug̉uja senin berirmen ošol ol jerni ošpu-

(3) nu ol ijer malahyn özünün aldyjda da alyrsen qatyn uv-

(4) luma andan. [8] Da eger klemeśa ol qatyn barma

(5) artyjdan da könü bolursen antymdan bu tek ošol uvlum-

(6) nu qajtarmaġyn ary. וישם. [9] Da qojdu ol qul ošol qolun bu-

(7) tu tübüńa Avrahamnyn bijinin da antetti anar ol iš

(8) üčün ošpu. [10] Da aldy ol qul on tev́alar tevele-

(9) rind́an bijinin da bardy da bar jaḩ̌ysys bijinin qolunda anyn

(10) da turdu da bardy Aram Naharimǵa šaharyna Naḥornun.

(11) (11] Da čöktürdü ol tevelerni tyšqartyn šahar-

(12) ga qujusu qatyna ol suvlarnyn ingir vaḥtta čyqmaq

\footnotetext{
${ }^{1} \mathrm{~K}$ : Gen 23; a scribal error. | TKow.o1: Gen 24. | H: Gen 23. | C: Gen 24. $\quad{ }^{2} \mathrm{~K}$ : qoluna; a scribal error. | TKow.o1: quluna. | H: quluna. | C: quluna. ${ }^{3} \mathrm{~K}$ : antetterejim; a scribal error. | TKow.o1: antettirejim. | H: antettirejim. | C: ant beräjim. $\quad{ }^{4} \mathrm{~K}$ : bergin; a scribal error. Cf. the remark written in Polish in pencil in the outer margin: baryyn, btad kopisty 'barginn, a scribal error'. | TKow.o1: barg்yn. | H: barg்yn. | C: bargajsyn.
} 
(4) Machpelah before Mamre, that is, Hebron, in the land

(5) of Canaan. [20] And the purchase of the plain,

(6) and of the cave that is in it was established, from the children of Heth for Abraham

(7) for a possession of a sepulchre.

Genesis 2[4]

(8) he was well along in days. And the Lord had blessed Abraham in all

(9) things. [2] And Abraham said to his own servant, the elder

(10) of his household that ruled over all that he had,

(11) 'Put now your hand under my thigh. [3] And

(12) let me make you swear by the power of the Lord, the God of the skies,

(13) and the God of the earth, that you shall not take a wife to my son

(14) of the daughters of the Canaanites, among whom I dwell. [4]

(15) But you shall go to my land and to my kindred, and take

(16) a wife to my son Isaac.' [5] And the servant said to him,

(17) 'Maybe the woman will not be willing to follow me to this land.

(18) Must I then bring your son again to the land from where you came?'

(19) [6] And Abraham said to him, "Beware

(20) lest you bring my son back. [7] The Lord God

(21) of heaven, who took me from my father's house and from the land

(1) of my kindred, and who spoke to me, and swore to me,

(2) saying, 'I will give this land to your offspring,'

(3) he will send his angel before you, and you shall take a wife

(4) for my son from there. [8] But if the woman is not willing to

(5) follow you, then you shall be free from this oath of mine. Only

(6) do not bring my son back.' [9] And the servant put his hand

(7) under the thigh of his lord Abraham, and swore to him

(8) about this matter. [10] And the servant took ten camels of the camels

(9) of his lord, and went away, and all the goods of his master were in his hand.

(10) And he arose, and went to Mesopotamia, to the city of Nahor.

(11) [11] And he made his camels kneel down outside the city

(12) by a well of water at evening time, at the 
(13) vaḥtta ol suv süzüvčü qyzlar. ויאמר [12] Da ajtty

(14) e Adonaj Tenrisi bijimnin Avrahamnyn učratqyn $\{\text { endi }\}^{1}$ alnyma

(15) bügün da qylġyn šavag̉at bijim Avraham byla. הנה. [13] Muna

(16) men turamen ol köz suv qatyna da qyzlary elinin ol šahar-

(17) nyn čyġadylar süzḿa suv. [היה [14] Da bolġaj ol qyz ki

(18) ajtsam anar qajyrğyn endi čelegijni da ičejim da ajtsa

(19) ičkin da daġyn tevelerijnid́a ičirejim any belgiledij quluja

(20) Jichaqqa da anlyq byla bilirmen ki qyldyj šavag̉at bijim byla.

(21) ויהי [15] Da edi ol tügellemestan burun sözleḿa da muna

$34 \mathrm{r}^{\mathrm{o}} \quad$ (1) Riveqa čyg̉ady ki tuvdu Betu'elǵa uvluna Milkanyn qatynyna

(2) Nahornun qaryndašyna Avrahamnyn da čelegi anyn javrunu

(3) üstüńa. והנער. [16] Da ol qyz jaḥšy körümlü edi

(4) astry boj qyz da kiši bilmedi any da endi ol köz

(5) suvġa da tolturdu čelegin da mindi. וירץ [17] Da juvur-

(6) du ol qul uturusuna anyn da ajtty tattyrġyn maja

(7) endi azg்ynaq suv čelegijd́an. ותאמר. [18] Da ajtty ič-

(8) kin bijim da žaḥtlady da endirdi čelegin \{qolu\} üstüńa da

(9) ičirdi any. [19] Da tügelledi ičirma any da

(10) ajtty daġyn tevelerijed́a süzejim neginč́a ki tügellegej-

(11) lóar ičḿa. [20] Da žaḥtlady da bošatty čelegin

(12) ol suvlavġa da juvurdu daġyn ol qujug̉a süzḿa da süzdü

(13) bar tevelerińa anyn. והאיש [21 Da ol kiši tamaša ete-

(14) redi baġyp anyn üstüńa tyjylyredi bilme onardymo Adonaj

(15) jolun anyn jemese joq. [22] Da edi ki nečik tügelledilar

(16) ol tevelar ičma da aldy ol kiši altyn syrgia gög

(17) ölčövü anyn da eki belezikĺar qojdu qollary üstüńa

(18) anyn on altyn ölčövlari alarnyn. ויאמר [23] Andan sortun

(19) nečik ajtty qyzy kimnindir sen anlatqyn endi maja barmo-

(20) du üvünd́a atajnyn orun bizni qondurma. ותאמר. [24]

(21) Da ajtty anar qyzy Betu'elnindir men uvlunun Milkanyn

$34 \mathrm{~V}^{\mathrm{o}}$ (1) ki töredi Naḥorg̉a. [25] Da ajtty anar dağgn bičen

\footnotetext{
${ }^{1}$ Marginal insertion by another hand. | TKow.o1: endi. | H: endi. | C: endi.
} 
(13) time when women who draw water go out. [12] And he said,

(14) 'Oh Lord, God of my lord Abraham, \{now $\}$ meet me

(15) today, and show kindness to my master Abraham. [13] Lo,

(16) I stand here by the well of water; and the daughters of the men of the city

(17) come out to draw water: [14] And let the girl to whom

(18) I shall say, "Tilt your bucket, that I may drink,", and if she says,

(19) "Drink, and I will water your camels, too,"- - let her be designated for your servant

(20) Isaac. And I will know by this that you have shown kindness to my lord.'

(21) [15] And it was before he had finished speaking, and, lo,

(1) Rebekah came out, who was born to Bethuel, son of Milcah, the wife $34 \mathrm{r}^{\mathrm{o}}$ of

(2) Nahor, Abraham's brother, and her bucket was on her shoulder.

(3) [16] And the girl was very fair in appearance,

(4) a virgin, and no man had known her. And she went down to the

(5) spring and filled her bucket and went up. [17] And the servant ran

(6) to meet her, and said, 'Let me taste

(7) a little water of your bucket.' [18] And she said, 'Drink,

(8) my lord.' And she hurried, and lowered her bucket on her hand, and

(9) gave him drink. [19] And she finished giving him drink, and

(10) she said, 'I will draw water for your camels, too, until they finish

(11) drinking.' [20] And she hurried and emptied her bucket

(12) into the trough, and ran again to the well to draw water, and drew

(13) for all his camels. [21] And the man wondered,

(14) gazing at her, and kept silent to learn whether the Lord had prospered

(15) his journey or not. [22] And it was, when the camels finished

(16) drinking, that the man took a golden earring of a $g \ddot{o g}{ }^{34}$

(17) weight, and put two bracelets on her hands

(18) of ten measures of gold, [23] after

(19) he had said, 'Tell me now, whose daughter are you? Is there

(20) room in your father's house for us to spend the night?' [24]

(21) And she said to him, 'I am the daughter of Bethuel, son of Milcah,

(1) whom she bore to Nahor'. [25] And she said moreover to him, 
(2) dağyn jem bardy köp birgemizǵa daġyn orun qonma.

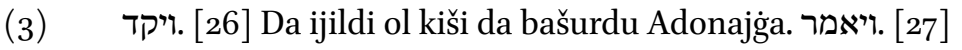

(4) Da ajtty mahtavludu Adonaj Tenrisi bijimnin Avrahamnyn

(5) ki kemišmedi šavagaatyn da kertiligin bijimd́an men edim

(6) jolda könderdi meni Adonaj üvüńa qaryndašynyn bijimnin.

(7) ותרץ (28] Da juvurdu ol qyz da anlatty üvüńa anasynyn

(8) ošpu sözler kibik. ולרבקה. [29] Da Riveqag̉a qaryndaš

(9) da aty anyn Lavan da juvurdu Lavan ol kišiǵa ol tyšqary-

(10) ga ol köz suvg̀a. [30] Da edi körgečoq Lavan o-

(11) šol ol syrg̉any da ošol ol bileziklerni qollary üs-

(12) tuńa tuvduğunun da ešitkenindečoq ošol sözlerin

(13) Riveqanyn tuvdugiunun ajtadog̉ač bulaj sözledi maja ol kiši

(14) da keldi ol kišiǵa da muna turady ol tevelar qatyna

(15) ol köz suvqatyna. [31] Da ajtty Lavan kelgin

(16) alġyšlag̉any Adonajnyn nek turasen tyšqaryda da men hadir-

(17) ledim ol üvnü alajoq orun hadirledim tevelerǵad́a.

(18) [יבא (32] Da keldi ol kiši ol ičkeriǵa da jerin češtirdi

(19) Lavan ol tevelernin da berdi bičen da jem tevelerǵa da suv

(20) juvma ajaqlaryn anyn da ajaqlaryn ol erenlernin birgesi-

(21) ńa. יויושם [33] Da qojuldu alnynda anyn ašama da ajtty

$35 \mathrm{r}^{\mathrm{o}} \quad$ (1) ašmanmen neginč́a ki sözlegejmen sözlerimni da ajtty

(2) sözlegin. ויאמר [34] Da ajtty qulu Avrahamnyndyr men.

(3) יויהוה [35] Da Adonaj alğyšlady ošol bijimni astry da

(4) ḥoža boldu da berdi anar qoj da syġyr da kümüš da

(5) altyn da qullar da qaravašlar da teveler da ešeklar.

(6) ותלד [36 Da töredi Sara qatyny bijimnin uvul bijima qart-

(7) lyğyndan sortun da berdi anar ošol barča neki özünün.

(8) [37 Da antettirdi meni bijim ajtadog̉ač alma-

(9) ġyn qatyn uvluma qyzlaryndan ol Kena'aninin ki men oltu-

(10) ramen jerind́a anyn. אם. [38] Özǵa tüslü tüvül ančaq

(11) üvüńa atamnyn barg̀yn da uruvuma da alg̀yn qatyn uvlu-

(12) ma. ואמר] Da ajttym bijima šeme barmasty ol

(13) quatyn menim artyna. [יאמר Da ajtty maja Adonaj

(14) ki jürüdüm alnynda anyn ijer malahyn özünü birgeja

(15) da onartyr jolujnu da alyrsen qatyn uvluma uruvumdan 
(2) 'We have both lot of hay and fodder with us, and even room to spend the night.'

(3) [26] And the man bowed down, and worshiped the Lord. [27]

(4) And he said, 'Blessed be the Lord God of my lord Abraham,

(5) who has not forsaken his mercy and his truth toward my lord. I was

(6) in the way, the Lord led me to the house of my master's brother'

(7) [28] And the girl ran, and told her mother's house

(8) these words. [29] And Rebekah had a brother,

(9) and his name was Laban, and Laban ran out to the man,

(10) to the well. [30] And it was, when Laban saw

(11) the earring and bracelets on the hands

(12) of his sister, and when he heard the words of

(13) Rebekah, his sister, saying, 'Thus spoke the man to me'

(14) that he came to the man. And, lo, he stood by the camels

(15) at the spring. [31] And Laban said, 'Come in,

(16) blessed of the Lord. Why do you stand outside? For I have prepared

(17) the house, as well as I have prepared room for the camels.'

(18) [32] And the man came into the room, and Laban ordered to take of the saddles

(19) of the camels, and gave hay and fodder for the camels, and water

(20) to wash his feet, and the men's feet that were with him.

(21) [33] And food was set before him to eat. But he said,

(1) 'I will not eat, until I have said my words.' And he said,

(2) 'Speak on.' [34] And he said, 'I am Abraham's servant.

(3) [35] And the Lord has blessed my lord greatly, and

(4) he has become wealthy. And he has given him flocks, and cattle, and silver, and

(5) gold, and servants, and maidservants, and camels, and donkeys.

(6) [36] And Sarah, my lord's wife, bore a son to my lord

(7) after she grew old, and he has given him all that was his.

(8) [37] And my master made me swear, saying,

(9) "You shall not take a wife for my son of the daughters of the Canaanites, in whose

(10) land I dwell, [38] You shall do nothing else but

(11) go to my father's house, and to my family, and take a wife

(12) to my son." [39] And I said to my lord, "Maybe the

(13) woman will not follow me." [40] And he said to me, "The Lord,

(14) before whom I have walked, will send his angel with you,

(15) and prosper your way, and you will take a wife for my son of my family, 
(16) da üvünd́an atamnyn. זא. [41] Ol vaḥtta könü bolur-

(17) sen qarğyšymdan ki kelśaj uruvuma da eger bermeselar

(18) saja da bolursen könü qarğyšymdan. ואבוא. [42] Da keldim

(19) bügün ol köz suvġa da ajttym e Adonaj Tenrisi bijim-

(20) nin Avrahamnyn onartyrmosen jolumnu ki men baramen anyn byla.

(21) הנה [43 Muna men turamen ol köz suv qatyna da bolġaj ol

$35 \mathrm{v}^{\mathrm{o}} \quad$ (1) qyz ol čyg̉uvču süzḿa da ajtsam anar ičirgin endi

(2) maja azġynaq suv čelegijdan. ואמרה. [44] Da ajtsa maja

(3) dag̉yn send́a ičkin da daġyn tevelerijed́a süzejim oldu

(4) ol qatyn ki belgiledi Adonaj uvluna bijimnin. [45] Men

(5) tügellemesimd́an burun sözlame kölnümd́a da muna

(6) Riveqa čyg̉ady da čelegi anyn javrunu üstüne da endi

(7) ol köz suvğa da süzdü da ajttym anar ičirgin

(8) maja endi. ותמהר [46] Da žaḥtlady da endirdi

(9) čelegin üstünd́an da ajtty ičkin da dağyn tevelerijni-

(10) da ičírajim da ičtim da daġyn ol tevelernid́a ičir-

(11) di. ואשאל [47 Da sordum andan da ajttym qyzy kimnin-

(12) dir sen da ajtty qyzy Betu'elnin uvlunun Naḥornun ki tö-

(13) redi anar Milka da qojdum ol syrgaany burnu üstü-

(14) ńa da ol bileziklerni qollary üstüńa anyn. ואקוד. [48]

(15) Da ijildim da bašurdum alnynda Adonajnyn da maḥtav

(16) berdim Adonajġa Tenrisińa bijimnin Avrahamnyn ki könderdi

(17) meni kerti jolbyla alma ošol qyzyn qaryndašynyn bijimnin

(18) uvluna. ועתה. [49] Da haligińa qylamosiz šavagat da ker-

(19) tilik bijimbyla anlatyjyz maja da eger joq anlatyjyz maja

(20) da qajyrylajym on jary jemese son jary. [50] Da qaruv

(21) berdi Lavan da Betu’el da ajttylar Adonajdan čyqty ol

${ }_{3} 6 \mathrm{r}^{\mathrm{o}} \quad$ (1) söz bolalmasbiz sözleḿa saja jamanny jemeśa jahšsyny.

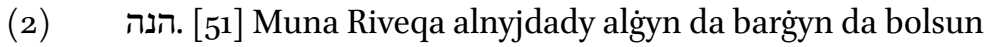

(3) qatyn uvluna bijijnin ki nečik sözĺadi Adonaj. [52 ]

(4) Da edi ki nečik ešitti qulu Avrahamnyn ošol sözlarin

(5) alarnyn da bašurdu jerǵa alnynda Adonajnyn. [53] Da

(6) čyġardy ol qul kümüš savutlar da altyn savutlar da up-

(7) raqlar da berdi Riveqag̉a da syjly bernelar berdi qarynda-

(8) šyna da anasyna anyn. ויאכלו [54] Da ašadylar da ič-

(9) tilar ol da ol erenlar ki birgesińa da qondular da 
(16) and of my father's house. [41] Then, you will be free

(17) from this curse of mine if you come to my family, and if they do not give

(18) |her| to you, you will be free from my curse." [42] And I came

(19) today to the spring, and said, "Oh Lord God of my lord

(20) Abraham, will you prosper my way which I go?

(21) [43] Lo, I stand by the well of water, and let there be

(1) a girl who comes out to draw. And if I say "Give me now a little water

(2) of your bucket to drink," [44] and if she says to me,

(3) "Drink, and I will draw for your camels also," she is

(4) the woman whom the Lord has designated for my lord's son. [45]

(5) Before I had finished speaking in my heart, lo,

(6) Rebekah came out with her bucket on her shoulder, and she went down

(7) to the spring, and drew. And I said to her, "Give me a drink,

(8) now." [46] And she hurried, and let down

(9) her bucket from on her, and said, "Drink, and I will give your camels

(10) drink, too." So I drank, and she made the camels drink, too.

(11) [47] And I asked her, and said, "Whose daughter

(12) are you?" And she said, "The daughter of Bethuel, Nahor's son, whom

(13) Milcah bore to him." And I put the ring on her nose,

(14) and the bracelets on her arms. [48]

(15) And I bowed down, and worshiped the Lord, and blessed

(16) the Lord God of my lord Abraham, who had led me

(17) in the right way to take my lord's brother's daughter

(18) for his son. [49] And now, will you deal kindly and truly

(19) with my lord? Tell me. And if not, tell me,

(20) that I may turn to right or to left.' [50] And

(21) Laban and Bethuel answered, and they said, 'The word has come from the Lord.

(1) We cannot speak bad or good to you.

(2) [51] Lo, Rebekah is before you, take her, and go, and let her be

(3) a wife to your lord's son, as the Lord has spoken.' [52]

(4) And it was, when Abraham's servant heard their words,

(5) that he bowed to the ground before the Lord. [53] And

(6) the servant brought out silver vessels, and gold vessels, and

(7) garments, and gave them to Rebekah, and he gave excellent gifts to her brother

(8) and to her mother. [54] And they ate and drank,

(9) he and the men that were with him, and spent the night. 
(10) turdular ertenbylada da ajtty ijijiz meni da b[a]r[a]jym ${ }^{1}$

(11) bijiḿa. [55] Da ajtty qaryndašy anyn da anasy

(12) anyn oltursun ol qyz birgemizǵa jyl jemeśa on janġaj $^{12}$

(13) andan sortun baryr. ויאמר. [56] Da ajtty ol qul alarga

(14) kečiktirmejiz meni da Adonaj onartty jolumnu ijijiz meni

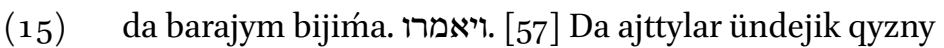

(16) da sorajyq avzundan anyn. ויקראו [58 Da ündedilar Riveqany

(17) da ajttylar anar baryrmosen ol kiši byla ošpu da

(18) ajtty baryrmen. וישלחו. [59] Da uzattylar ošol Riveqany

(19) tuvdug̉un özlarinin da ošol ömüzdürüvčüsün anyn da

(20) ošol q[u]lun ${ }^{3}$ Avrahamnyn da erenlerin anyn. ויברכו [6o] Da

(21) alğyšladylar ošol Riveqany da ajttylar anar tuvdug̉umuz

$36 \mathrm{v}^{\mathrm{o}} \quad$ (1) sen bolġajsen minlerińa tümennin da mereslegej urlugguj

(2) ošol qabag̉yn dušmanlarynyn. [6ים [61] Da turdu Riveqa

(3) da qyrqynlary anyn da atlandylar ol tevelar üstü-

(4) ne da bardylar ol kiši artyna da aldy ol qul ošol

(5) Riveqany da bardy. ויצחק. [62] Da Jichaqa keldi kelmektan

(6) ki barybedi Be’er Lahaj Ro’iǵa da ol oltururedi jerin-

(7) da ol tüšlüknün. [63] Da čyqty Jichaq sajran

(8) etḿa terekler arasyna tüzd́a ingir vaḥtynda da

(9) kötürdü közlerin da kördü da muna tevelar kelediler.

(10) [-164] Da kötürdü Riveqa ošol közlarin da kördü

(11) ošol Jichaqny da tüštü ol tev́a üstünd́an. ותאמר. [65]

(12) Da ajtty ol qulgaa kimdi ol kiši ol tigi ${ }^{4}$ ol jürüv-

(13) čü tüzd́a uturumuzġa da ajtty ol qul oldu bijim

(14) da aldy Riveqa ol bürünčekni da jabundu. [66]

(15) Da qotardy ol qul Jichaqqa ošol bar ol išlerni ki qyldy.

(16) [יבאה Da keltirdi any Jichaq ol čatyrg̉a čatyryna

(17) Saranyn anasynyn da aldy ošol Riveqany da boldu anar

(18) qatynlyqqa da süvdü any da uvundu Jichaq anasyndan

(19) sortun.

\footnotetext{
${ }^{1} \mathrm{~K}$ : berejim; a scribal error. Cf. Gen 24:56. | TKow.o1: barajym. | H: deest. |C: deest. $\quad{ }^{2}$ A mistranslation. | TKow.o1: jyljemese on jangaj. | H: jyl jemese on aj. | C: bir jyl ja on aj. | R: ńeča ḱuńlar hem

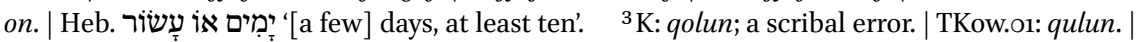
$\mathrm{H}$ : qulun.|C: qulun. $\quad{ }^{4} \mathrm{~K}$ : tigi; an obscure form. Perhaps a 3 rd person singular possessive form of tek 'only'. Used also in Gen 37:19 with reference to: 'man [i.e., Joseph] walking alone'. | TKow.o1: tigi. | H: deest. | C: deest. | V: ušpu. | R: ošpu.
} 
(10) And they rose up in the morning, and he said, 'Send me away, may I go

(11) to my lord.' [55] And her brother and her mother said,

(12) 'Let the girl abide with us a year, or ten months. ${ }^{135}$

(13) After that, she will go.' [56] And the servant said to them,

(14) 'Do not delay me, since the Lord has prospered my way. Send me away

(15) that I may go to my master.' [57] And they said, 'We will call the girl

(16) and ask her from her own mouth.' [58] And they called Rebekah

(17) and said to her, 'Will you go with this man?' And

(18) she said, 'I will go.' [59] And they sent away Rebekah

(19) their sister, and her nurse, and

(20) Abraham's servant, and his men. [6o] And

(21) they blessed Rebekah, and said to her, 'Our sister,

(1) may you become thousands of ten thousands, and may your offspring $36 \mathrm{v}^{\mathrm{o}}$ inherit

(2) the gate of his enemies! [61] And Rebekah arose,

(3) and her maids, and they rode on the camels,

(4) and followed the man, and the servant took

(5) Rebekah, and went his way. [62] And Isaac came from a trip,

(6) because he had gone to Beer-Lahai-Roi, and he was dwelling in the land

(7) of the south. [63] And Isaac went out to stroll

(8) in the evening among the trees in the field. And

(9) he raised his eyes, and saw, and, lo, the camels were coming.

(10) [64] And Rebekah raised her eyes, and she saw

(11) Isaac, and she fell from the camel. [65]

(12) And she said to the servant, 'Who is that man, [ ${ }^{\dagger}$ the one alone ${ }^{36}$, who walks

(13) in the field to meet us?' And the servant said, 'It is my lord.'

(14) So Rebekah took her veil and covered herself. [66]

(15) And the servant told Isaac all the things that he had done.

(16) [67] And Isaac brought her into his mother Sarah's tent.

(17) And he took Rebekah, and she became his

(18) wife, and he loved her. And Isaac was consoled

(19) after his mother.

35 A mistranslation, cf. Heb. יָמִים אוֹ עָשוֹר ' [a few] days, at least ten'. Repeated in TKow.o1, H,

C, and R. Translated correctly in V.

36 An uncertain inerpretation of tigi. 
Genesis $2[5]^{1}$

(19) [יסף [1] Da arttyrdy Avraham da aldy qatyn

(20) da aty anyn Qetura. [2] Da töredi anar ošol

(21) Zimranny da ošol Jaqšanny da ošol Medanny da ošol Midijan

$37 \mathrm{r}^{\mathrm{o}}$ (1) ny da ošol Jišbaqny da ošol Šuaḥny. [יקשן. [3] Da Jaqšan

(2) tuvdurdu ošol Ševany da ošol Dedanny da ulanlary Dedannyn

(3) ediĺar Ašurim da Letušim da Lu’umim. ובני [4] Da ulan-

(4) lary Midjannyn 'Efa da 'Efer da H̦anoh da Avida' da El-

(5) daca bar bular ulanlary Qeturanyn. ויתן. [5] Da berdi

(6) Avraham ošol barčany ki özünün Jichaqqa. ולבני [6] Da

(7) ulanlaryna ol qumalarnyn ki Avrahamnyn berdi Avraham ber-

(8) nelar da ijdi alarny Jichaq uvlu qatyndan hanuz tiri e-

(9) genind́a kün tuvušusary jerińa mizraḥnyn. ואלה [7 [7 Da

(10) bulardylar künleri tirlik jyllarynyn Avrahamnyn ki tiri edi

(11) jüz jyl da jetmiš beš jyl. ויגוע [8] Da tyndy da öl-

(12) dü Avraham jaḥšy pirlikt́a qart da tojg̉an künlerdan

(13) da jyštyryldy uluslaryna. ויקברו Da astradylar

(14) any Jichạa da Jišma'el uvullary anyn ṕečorasynda ol

(15) Mahpelanyn tüzünd́a 'Efronnun uvlunun Coḥarnyn ol

(16) Huitilinin ki alnynda Mamrenin. השדה. [10] Ol tüzd́a

(17) ki satyn aldy Avraham ulanlaryndan Ḥetnin anda astral-

(18) dy Avraham da Sara qatyny anyn. ויהי [11] Da edi ölüp

(19) sortun Avraham da alğyšlady Tenri ošol Jichaqny uvlun

(20) anyn da olturdu Jichạaq Be’er Lahaj Ro'ide. ואלה [12]

(21) Da bulardylar tuvmušlary Jišma'elnin uvlunun Avrahamnyn

$37 \mathrm{v}^{\mathrm{o}}$ (1) ki töredi Hag̉ar ol Micrili qaravašy Saranyn Avrahamġa.

(2) [13] Da bulardylar atlary uvullarynyn Jišma'elnin

(3) atlary byla tuvmušlary sajyn tunġuču Jišma'elnin

(4) Nevajot da Qedar da Adbe'el da Mivsam. ומשמע. [14] Da

(5) Mišma da Duma da Masa. חדי] [15] Hadad da Tema

(6) Jetur Nafiš da Qedema. אלה. [16] Bulardylar alar uvullary

(7) Jišma'elnin da bulardylar atlary alarnyn azbarlarynda

(8) da sarajlarynda on eki nasiler ümmetleri sajyn.

(9) [17 Da bulardylar tirlik jyllary Jišmaéelnin jüz jyl

(10) da otuz jedi jyllar da tyndy da öldü da jyštyryl-

(11) di de] Da toḥtadylar bašlap Ḥavila-

\footnotetext{
${ }^{1}$ K: Gen 24; a scribal error. | TKow.o1: Gen 25. | H: Gen 25. | C: Gen 25.
} 
Genesis 2[5]

(19) [1] And Abraham went on and took a wife,

(20) and her name was Keturah. [2] And she bore him

(21) Zimran, and Jokshan, and Medan, and Midian,

(1) and Ishbak, and Shuah. [3] And Jokshan

(2) begat Sheba, and Dedan. And the sons of Dedan

(3) were Asshurim, and Letushim, and Leummim. [4] And the sons

(4) of Midian: Ephah, and Epher, and Hanoch, and Abidah, and Eldaah.

(5) All these are the children of Keturah. [5] And Abraham gave

(6) to Isaac everything that was his. [6]

(7) And Abraham gave gifts to the sons of the concubines that Abraham had,

(8) and he sent them away from Isaac, his son, while he was still living:

(9) eastward, to the land of East. [7] And

(10) these are the days of the years of Abraham's life which he lived:

(11) a hundred and seventy-five years. [8] And Abraham rested and died

(12) at a good old age, an old man, and full of days;

(13) and was gathered to his people. [9] And

(14) his sons Isaac and Ishmael buried him in the cave

(15) of Machpelah, in the field of Ephron, son of Zohar, the

(16) Hittite, which is before Mamre. [10] In the field

(17) which Abraham purchased from the sons of Heth: there was Abraham buried,

(18) and Sarah, his wife. [11] And it was after the death

(19) of Abraham, and God blessed his son Isaac.

(20) And Isaac dwelt at Beer-Lahai-Roi. [12]

(21) And these are the children of Ishmael, Abraham's son,

(1) whom Hagar, the Egyptian, Sarah's maidservant, bore to Abraham:

(2) [13] And these are the names of the sons of Ishmael,

(3) by their names, according to their children: the firstborn of Ishmael,

(4) Nebaioth, and Kedar, and Adbeel, and Mibsam, [14] And

(5) Mishma, and Dumah, and Massa, [15] Hadad, and Tema,

(6) Jetur, Naphish, and Kedemah. [16] These are they, the sons

(7) of Ishmael, and these are their names, by their homesteads,

(8) and by their palaces, twelve princes according to their nations.

(9) [17] And these are the years of the life of Ishmael: a hundred years

(10) and thirty-seven years. And he rested and died, and was gathered

(11) to his people. [18] And they dwelt from Havilah 
(12) dan Šurgadejin ki alnynda Micrinin kelüvüjsary Ašur-

(13) ga burunraq bar qaryndašlaryndan toḥtady ülüšünd́a.

פרשת תולדות יצחק (14) (15) (15) (15)

(15) [15) Da bulardylar tuvmušlary

(16) Jichaqnyn uvlunun Avrahamnyn Avraham tuvdur-

(17) du ošol Jichaquny. [20] Da edi Jichạaq qyrq jašar

(18) alġanynda ošol Riveqany qyzyn Betu'elnin ol Aramlynyn

(19) Padan Aramdan tuvdugun Lavannyn ol Aramlynyn özüńa

$38 \mathrm{r}^{\circ}$ (1) qatynlyqqa. [21] Da tefile etti Jichaq qatyny üčün ki

(2) bödav edi ol da qabul etti tefilesin anyn Adonaj da ḥamila

(3) boldu Riveqa qatyny anyn. ויתרצו [22] Da qozġaldylar ol ulan-

(4) lar ičind́a anyn da ajtty qačan alajdy negedi bu men da

(5) bardy sorma sözün Adonajnyn. ויאמר [23] Da ajtty Adonaj

(6) anar eki ḥanlyqlar qursaġyjda da eki ümmetlar bavursaq-

(7) laryjdan ajyrylyrlar da ümmet ümmetten küčlürek bo-

(8) lur da ag̉araq qulluq eter kičireḱka. וימלאו. [24] Da

(9) toldular künĺari any töreme da muna egizeklar qursa-

(10) ġynda. [25] Da čyqty ol burunġusu qyzyl barčasy

(11) halilej tüklü da atadylar atyn anyn 'Esav. [26 Da andan

(12) sortun čyqty qaryndašy anyn da qolu tutaredi soġančyġyndan

(13) 'Esavnyn da atady atyn anyn Ja'aqov da Jichaq altymyš

(14) jašar edi töregend́a Riveqa alarny. יויגדלו [27 Da ul-

(15) ġajdylar ol ulanlar da edi `Esav kiši bilüvčü avny tüzlük

(16) kiši da Jaáaqov edi tügel kiši oḥujdoğač oltururedi

(17) čatyrlarda. [יאהב [28] Da süvdü Jichạaq ošol 'Esavny

(18) ki avlamaq beriredi avzuna anyn da Riveqa süveredi ošol

(19) Jacaqovnu. ויזד [29] Da biširdi Ja'aqov aš da keldi 'Esav ol

(20) tüzd́an da ol edi aryġan. [30] Da ajtty 'Esav

(21) Ja'aqovg̉a tattyrg்yn maja endi ol qyzyl aštan ošpu ki

$38 \mathrm{v}^{\mathbf{o}}$ (1) aryġandyr men anyn üčün atady atyn anyn Edom. ויאמר. [31] Da

(2) ajtty Ja'aqov satqyn bügünd́a ošol tunġučlug̉ujnu maja.

(3) ויאמר (32] Da ajtty 'Esav muna men baramen ölma da negedi

(4) bu maja tunġučluq. ויאמר [33] Da ajtty Ja'aqov antetkin

(5) bügün maja da antetti anar da satty ošol tunġučlugiun

(6) özünün Ja'aqovgaga. [34] Da Ja'aqov berdi 'Esavğa öt- 
(12) to Shur, which is before Egypt, in the direction as you come to Assyria.

(13) He dwelt in his part |of the land| before of all his brothers.

(14) Parashat Toledot

(15) [19] And these are the children

(16) of Isaac, Abraham's son: Abraham begat

(17) Isaac. [20] And Isaac was forty years old

(18) when he took Rebekah, daughter of Bethuel the Aramean

(19) of Paddan-Aram, sister of Laban the Aramean,

(1) to be his wife. [21] And Isaac entreated the Lord for his wife, because $\quad 38 \mathrm{r}^{\mathrm{o}}$

(2) she was barren, and the Lord accepted his entreaty, and

(3) his wife Rebekah conceived. [22] And the children were moving

(4) within her, and she said, 'If it is like this, why do I exist?' And

(5) she went to inquire of the Lord. [23] And the Lord said

(6) to her, 'Two kingdoms are in your womb, and two nations

(7) will be divided from your insides, and one nation will be stronger than the other nation,

(8) and the older will serve the younger.' [24] And

(9) her days to be delivered were filled, and, lo, there were twins

(10) in her womb. [25] And the first came out red, all

(11) over like a hairy carpet, and they called his name Esau. [26] And after that

(12) his brother came out, and his hand was holding Esau's heel,

(13) and his name was called Jacob. And Isaac was sixty

(14) years old when Rebekah bore them. [27] And

(15) the boys grew, and Esau was an skilled hunter, a man of the field,

(16) and Jacob was a perfect literate man, dwelling

(17) in tents. [28] And Isaac loved Esau,

(18) because he fed him of his game, but Rebekah loved

(19) Jacob. [29] And Jacob was cooking food, and Esau came

(20) from the field, and he was exhausted. [30] And Esau said

(21) to Jacob, 'Let me taste that red food, for

(1) I am exhausted.' On account of this he called his name Edom. [31] $\quad 38$ v $^{\mathbf{o}}$ And

(2) Jacob said, 'Sell your birthright to me, today.'

(3) [32] And Esau said, 'Lo, I am going to die, and what is

(4) this birthright to me for?' [33] And Jacob said, 'Swear

(5) to me, today.' And he swore to him, and he sold his birthright

(6) to Jacob. [34] Then Jacob gave Esau bread 
(7) mek da ašyn bürčümekĺarin da ašady da ičti da

(8) turdu da bardy da ḥor etti 'Esav ošol ol tunġučluq-

(9) nu.

Genesis 26

(9) - 11] Da edi ačlyq jerd́a bašqa ol burunğu

(10) ačlyqtan ki edi vaḥtlarynda Avrahamnyn da bardy Jichạaq

(11) Avimelehḱka bijińa Pelištimnin Gerarğa. וירא. [2] Da

(12) aškara boldu šehinasy Adonajnyn Jichaqqa da ajtty

(13) enmegin Micriǵa toḥtağyn jerd́a ki ajtsam saja.

(14) [3 [3 Tirilgin ošpu jerd́a da bolur bolušlug̉um

(15) birgeja da alğyšlarmen seni ki saja da urlug̉uja berir-

(16) men ošol bar ol jerlerni ošpularny da qajjam eterman

(17) ošol ol antny ki antettim Avrahamġa atyja.

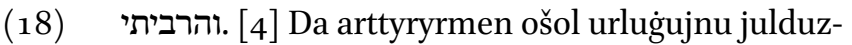

(19) laryn kibik ol köklernin da berirmen urlug̉uja ošol

(20) bar ol jerlerni ošpularny da alğyšlarlar özlerin ur-

(21) lug̉uj byla bar hanlyqlary ol jernin. עקב. [5] Anyn üčün

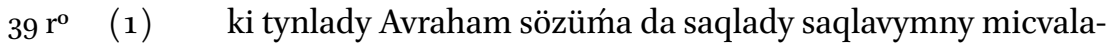

(2) rymny resimlerimni da üvretüvlerimni. [6] Da

(3) olturdu Jichaq Gerarda. וישאלו. [7] Da sordular eli ol

(4) orunnun qatyny üčün da ajtty tuvduğumdu ol ki

(5) qorqtu ajtma qatynymdy ajtadoġač maġat öltürür-

(6) ler meni eli ol orunnun Riveqa üčün ki jahšy körümlü-

(7) dür ol. [8] Da edi ki nečik uzardylar anar ol

(8) künlar da baqty Avimeleh biji Pelištimnin ol tereč́a

(9) ašyra da kördü da muna Jichaq ojnajdy Riveqa qatyny

(10) byla. ויקרא. [9] Da ündedi Avimeleh Jichaqny da ajtty

(11) kertid́an muna qatynyjdy ol da nečik ajttyj tuvduğum-

(12) du ol da ajtty anar Jichaq ki ajttym magat ölermen

(13) anyn üčün. ויאמר [10] Da ajtty Avimeleh ne bu qyldyj

(14) bizǵa azğynaq jatajezdi birisi ol ulusnun qatynyjbyla

(15) da keltirgejdij üstümüzǵa fašmanlyq. [11]

(16) Da zynharlady Avimeleh ošol bar ol ulusnu ajtadoġač ol

(17) tijüvčü ošpu kišiǵa da qatynyna anyn ölḿa öl-

(18) türülür. ויזרע. [12] Da čačty Jichaq jerd́a da tapty

(19) o jylda jüz anča da alğyšlady any Adonaj. ויגדל [13] 
(7) and lentil food, and he ate and drank, and

(8) got up, and went. Thus Esau despised the

(9) birthright.

Genesis 26

[1] And there was a famine in the land, other than the first

(10) famine that was in the times of Abraham. And Isaac went

(11) to Abimelech, king of the Philistines, to Gerar. [2] And

(12) the divine Presence of the Lord appeared to him, and said,

(13) 'Do not go down to Egypt. Dwell in the land which I shall tell you of.

(14) [3] Live in this land, and my help will be

(15) with you, and I will bless you, for I will give

(16) all these lands to you, and to your offspring, and I will establish

(17) the oath which I swore to Abraham, your father.

(18) [4] And I will multiply your offspring like the stars

(19) of the skies, and I will give to your offspring

(20) all these lands, and in your offspring

(21) shall all the kingdoms of the earth be blessed. [5] Because

(1) Abraham obeyed my voice and kept my guard, my commandments,

(2) my statutes, and my laws.' [6] And

(3) Isaac dwelt in Gerar. [7] And the men

(4) of the place asked him about his wife, and he said, 'She is my sister,' because

(5) he was afraid to say, 'She is my wife,' saying, 'Or else the people of the place will kill

(6) me for Rebekah, because she is fair in appearance.'

(7) [8] And it was, when his days were dragging on,

(8) that Abimelech, king of the Philistines, looked through a window,

(9) and saw, and, lo, Isaac was playing with Rebekah, his wife.

(10) [9] And Abimelech called Isaac, and said,

(11) 'Lo, she is in truth your wife. Why did you say, "She is my sister?"'

(12) And Isaac said to him, "Because I said, "Or else I will die

(13) over her."' [10] And Abimelech said, 'What is this you have done

(14) to us? One of the people has almost lain with your wife,

(15) and you would have brought guilt on us.' [11]

(16) And Abimelech ordered all his people, saying, 'He

(17) who touches this man or his wife shall surely

(18) be put to death.' [12] Then Isaac sowed in that land, and achieved

(19) a hundredfold in the same year. And the Lord blessed him. [13] 
(20) Da ulġajdy ol kiši da bardy bara da ulġaja neginč́a

(21) ki ullu boldu astry syjda da hožalyqta. ויהי

$39 \mathrm{v}^{\mathrm{o}} \quad$ (1) Da edi anar jyjyny qojnun jyjyny syġyrnyn da qulluq-

(2) čuluq köp da künüledilar anar Pelištim. וכל [15] Da

(3) bar ol qujular\{ny\} ki qazdylar qullary atasynyn vaḥtlarynda

(4) Avrahamnyn atasynyn japtylar alarny Pelištim da toldur-

(5) dular alarny topraqbyla. ויאמר [16] Da ajtty Avimeleh

(6) Jichaqqa barğyn qatymyzdan ki küčlürek bolduj bizd́an astry.

(7) (17] Da bardy andan Jichạaq da toḥtady özeni qatyna

(8) Gerarnyn da olturdu anda. וישב [18] Da qajtty Jichaq

(9) da qazdy ošol qujusun ol suvlarnyn ki qazdylar vaḥtlarynda

(10) Avrahamnyn atasynyn da japtylar alarny Pelištim ölüp sor-

(11) tun Avraham da atady alarga atlar kibik ki atady

(12) alarg̉a atasy anyn. ויחפרו. Da qazdylar qullary Jichaqnyn

(13) eništa da taptylar anda qujusun tiri suvlarnyn.

(14) (20] Da talaštylar kütüvčülari Gerarnyn kütüvčü-

(15) leribyla Jichạnyn ajtadoġač biznindi ol suvlar da atady

(16) atyn ol qujunun 'Eseq ki qavġalaštylar birgesińa.

(17) . ויחפרו (21] Da qazdylar özǵa quju da talaštylar \{dağy\} anyn

(18) üčünd́a da atady atyn anyn Sitnah. [22] Da

(19) köčürdü čatyryn andan da qazdy özǵa quju da talašmady-

(20) lar anyn üčün da atady atyn anyn Rohovot da ajtty

(21) ki haligińa avlaq etti Adonaj bizǵa da jajylyrbiz jerd́a.

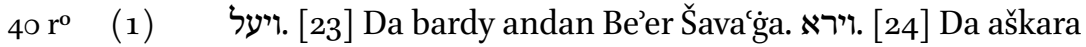

(2) boldu anar šehinasy Adonajnyn kečebyla da ajtty menmen

(3) Tenrisi Avrahamnyn atajnyn qorqmağyn ki birgejedi boluš-

(4) luğum menim da alġyšlarmen seni da arttyryrmen ošol

(5) urluġujnu Avraham qulum üčün. ויבן. [25] Da qondardy

(6) anda mizbeah da č $[\mathrm{a}] \dot{\mathrm{g}}[\mathrm{y}] \mathrm{rdy}^{1}$ atybyla Adonajnyn da qurdu

(7) anda čatyryn da qazdylar anda qullary Jichaqnyn quju.

(8) [26] Da Avimeleh bardy anar Gerardan da Ahuzat

(9) dostu anyn da Fihol ag̉arag்y čerüvünün. [27 Da

(10) ajtty alarg̉a Jichạ neüčün keldijiz maja da siz ḥor

(11) ettijiz meni da sürdüjüz meni qatyjyzdan. ויאמרו. [28]

(12) Da ajttylar körḿa kördük ki boldu bolušluğu Adonaj-

(13) nyn birgeja da ajttyq bolsun endi anty qarğyšnyn ara-

\footnotetext{
${ }^{1} \mathrm{~K}:$ čyg்ardy; a scribal error. | TKow.o1: čag்yrdy; unvocalized text. | H: cag்yrdy. | C: čaqyrdy.
} 
(20) And the man became great, and advanced, and grew until

(21) he became very esteemed and wealthy. [14]

(1) And he had plenty of sheep, and plenty of cattle, and

(2) many servants. And the Philistines envied him. [15] And

(3) all the wells which his father's servants had dug in the times

(4) of Abraham his father: the Philistines had covered them, and they filled

(5) them with earth. [16] And Abimelech said

(6) to Isaac, 'Go away from us, because you have become much mightier than we.'

(7) [17] And Isaac went away from there, and stopped by the river of

(8) Gerar, and he dwelt there. [18] And Isaac went back

(9) and dug the wells of water that they had dug in the times

(10) of Abraham his father and which the Philistines had covered after

(11) Abraham died, and he called them by names, like the names that his father had called

(12) them. [19] And Isaac's servants

(13) dug in the valley, and found there a well of springing water.

(14) [20] And the herdsmen of Gerar quarrelled

(15) with Isaac's herdsmen, saying, 'The water is ours.' So he called

(16) the name of the well Esek, because they argued with him.

(17) [21] And they dug another well, and quarrelled also over that,

(18) and he called the name of it Sitnah. [22] And

(19) he moved from there, and dug another well, and they did not quarrel

(20) over that. So he called the name of it Rehoboth, and he said,

(21) 'Because now the Lord has widened for us, and we will spread in the land.'

(1) [23] And he went up from there to Beersheba. [24] And the

(2) divine Presence of the Lord appeared to him at night, and said, 'I am

(3) your father Abraham's God. Do not fear, because my help

(4) is with you, and I will bless you, and multiply your

(5) offspring for my servant Abraham's sake'. [25] And he built

(6) an altar there, and called upon the name of the Lord, and pitched

(7) his tent there. And Isaac's servants dug a well there.

(8) [26] And Abimelech went to him from Gerar, and Ahuzzath,

(9) one of his friends, and Phicol, the superior of his army. [27] And

(10) Isaac said to them, 'Why have you come to me? You

(11) have despised me, and you have sent me away from beside you?' [28]

(12) And they said, 'We have surely seen that the Lord's help was

(13) with you, and we said, "Let there be now an oath of curse 
(14) myzda aramyzġa biznin da araja senin da kesejik šert

(15) birǵaja. אם. [29] Eger qylsaj birgemizǵa jamanny ki

(16) nečik biz tijḿadik saja jaman etḿa da ki nečik qyldyq

(17) birǵaja tek jahšynny da uzattyq seni bazlyqbyla sen haligińa

(18) alg̈yšlysy Adonajnyn. [30] Da qyldy alarg̉a ički da

(19) ašadylar da ičtilar. וישכימו [31] Da tünlej turdular

(20) ertenbylada da antettilar kiši qaryndašyna da uzatty

(21) alarny Jichaq da bardylar qatyndan bazlyq byla. [32] Da

$40 \mathrm{v}^{\circ} \quad$ (1) edi ol künd́a da keldílar qullary Jichaqnyn da anlattylar

(2) anar qujusu üčün ol suvlarnyn ki qazdylar da ajt [t]ylar ${ }^{1}$ anar

(3) taptyq suvlar. [33] Da atady atyn anyn Šiv'a anyn

(4) üčün edi aty ol šaharnyn Be'er Ša $\{v\} a^{c}$ ošpu küngedejin.

(5) ויהי Da edi 'Ešav² qyrq jašar da aldy özüńa qatyn ošol

(6) Juhuditni qyzyn Be'erinin ol Hitilinin da ošol Basematny qyzyn

(7) Elonnun ol Hitilinin. [35] Da edilar ačuvčular žanyn

(8) Jichaqnyn da Riveqanyn.

Genesis 27

ויהי. [1] Da edi ki nečik qartajdy

(9) Jichạ da tundular közlari anyn körmektan da ündedi \{ošol\}

(10) 'Esavny uvlun özünün ol agaraqny da ajtty anar uvlum da

(11) ajtty anar munadyr men. [2] Da ajtty muna

(12) men qartajdym bilmejmen ölgen künümnü. ועתה. [3 Da

(13) haligińa alġyn endi savutlaryjny qylyčyjny da jajny da

(14) čyqqyn ol tüzǵa da avlağyn maja avlamaq. [ועשה [4 Da

(15) qylg̀yn maja tatly ašlar ki nečik süvemen da keltirgin maja

(16) da ašajym anyn üčün ki alġyšlag̉aj seni క̌anym ölmegimd́an

(17) burun. ורבקה. [5] Da Riveqa ešitiredi sözlegend́a Jicḥaq

(18) Esavġa uvluna da bardy 'Esav ol tüzǵa avlama avlamaq

(19) keltirmáa. ורבקה. [6] Da Riveqa ajtty Ja'aqovġa uvluna

(20) ajtadoğač muna ešittim ošol atajny sözlejdog̉anny 'Esav-

(21) gara qaryndašyja ajtadoġač. הביאה. [7] Keltirgin maja avlamaq

$41 \mathrm{r}^{\mathrm{0}} \quad$ (1) da qylg̀yn tatly ašlar da ašajym da alġyšlajym seni alnyn-

(2) da Adonajnyn ölmegim alnyna. ועתה [8] Da haligińa

(3) uvlum tynlaġyn sözüḿa qylma any neki men bujuramen saja.

(4) לד [9] Bargynn endi ol qojğa da alg̀yn maja andan eki

\footnotetext{
${ }^{1} \mathrm{~K}$ : ajtylar; a scribal error. | TKow.o1: ajttylar. | H: ajttylar. | C: ajttylar. $\quad{ }^{2} \mathrm{~K}$ : Spelled עָשָׁ, with a shin dot (which is highly unusual in Karaim texts); a scribal error.
} 
(14) between us, even between us and you, and let us make a covenant

(15) with you: [29] In case you do harm toward us. Because

(16) we have not touched you to do bad to you, and because we have done

(17) only good to you and have sent you away in peace. You are now

(18) the blessed of the Lord."' [30] And he made them a feast, and

(19) they ate and drank. [31] And they rose up early

(20) in the morning, and swore one to his brother, and Isaac sent them away,

(21) and they went away from him in peace. [32] And

(1) it was in that day, and Isaac's servants came and told

(2) him about the waters that they had dug, and said to him,

(3) 'We have found water.' [33] And he called it Shibah. On account of this

(4) the name of the city is Beer-Sheba to this day.

(5) [34] And Esau was forty years old, and he took a wife,

(6) Judith, daughter of Beeri, the Hittite, and Basemath, daughter

(7) of Elon, the Hittite. [35] And they were those who made life bitter

(8) for Isaac and Rebekah.

\section{Genesis 27}

(9) and his eyes were too dim for seeing, that he called

(10) Esau, his older son, and said to him, 'My son!' And

(11) he said to him, 'Lo, here am I.' [2] And he said, 'Lo,

(12) I grew old, I do not know the day of my death. [3] So

(13) now take your weapons, your sword, and bow, and

(14) go out to the field, and hunt game for me. [4] And

(15) make me delicious food, such as I love, and bring it to me,

(16) and let me eat, that my soul may bless you before I die.'

(17) [5] And Rebekah was listening when Isaac spoke

(18) to his son Esau. And Esau went to the field to hunt

(19) to bring game. [6] And Rebekah said to her son Jacob,

(20) saying, 'Lo, I heard your father speaking to Esau,

(21) your brother, saying, [7] "Bring me game

(1) and make me delicious food, so I may eat it and bless you before

(2) the Lord, before I die." [8] Now therefore,

(3) my son, obey my voice to do what I am commanding you.

(4) [9] Go now to the flock, and take me from there two 
(5) ulaqlaryn ečkilernin jaḩ̌̌ylarny da qylajym alardan tatly

(6) ašlar ataja ki nečik süvdü. והבאת. [10] Da keltir-

(7) gin ataja da ašasyn anyn üčün ki alğyšlağaj seni ölme-

(8) gi alnyna. ויאמר Da ajtty Jacaqov Riveqag̉a anasy-

(9) na muna 'Esav qaryndašym tüklü kišidi da men jalan kišimen.

(10) אולי (12] Šeme qarmar meni atam da bolurmen közlerinda

(11) anyn azaštyruvču kibik da keltirirmen üstüma qarğyš

(12) da tüvül alg̀yš. [13] Da ajtty anar anasy

(13) anyn üstüḿa bolur qarg்yšyj uvlum ${ }_{\mathrm{L}}$ ki eger tanysa

(14) seni ataj ajtyrsen ki men bujurdum saja qylma bunu ${ }^{11}$ tek

(15) sen tynlag்yn sözüma da barg்yn alg̀yn maja. וילך. [14] Da bardy

(16) da aldy da keltirdi anasyna da qyldy anasy anyn tatly

(17) ašlar ki nečik süvdü atasy anyn. ותקח. [15] Da aldy

(18) Riveqa ošol upraqlaryn 'Esavnyn uvlunun ol agaraqnyn ol

(19) suqlančylarny ki birgesińa üvd́a da kijdirdi Ja‘aqovġa

(20) uvluna ol kičirekke. ואת. [16] Da ošol terilarin ulaqla-

(21) rynyn ol ečkilernin kijdirdi qollary üstüńa da jalan

$41 \mathrm{v}^{\mathrm{o}}$ (1) ornu üstüńa bojunlaryna. ותתן. [17] Da berdi ošol ol

(2) tatly ašlarny da ošol ol ötmekni ki qyldy qoluna Ja'aqov-

(3) nun uvlunun. ויבוא [18] Da keldi atasyna da ajtty atam

(4) da ajtty munadyrmen kim sen sen uvlum. ויאמר Da

(5) ajtty Ja'aqov atasyna menmen 'Esav tunğučuj qyldym barčany

(6) ki sözledij maja turg்un endi da olturg்un da ašag்yn av-

(7) lamağymdan anyn üčün alğyšlar meni žanyj. [20] Da

(8) ajtty Jichaq uvluna ne bu žật $\}$ ladyj tapma uvlum da ajtty

(9) ki učratty Adonaj Tenrij alnymda. ויאמר. [21] Da ajtty

(10) Jichaq Ja'aqovġa juvugun endi da qarmajym seni uvlum senmusen

(11) bu uvlum 'Esav jemese joq. ויגש. [22] Da juvudu Ja'aqov Jichaq-

(12) qa atasyna da qarmady any da ajtty ol avaz avazy Ja'aqov-

(13) nun da ol qollar qollary 'Esavnyn. ולא [23] Da tanymady any

\footnotetext{
${ }^{1}$ Interpretative addition to the standard text.
} 
(5) good kids of the goats, so that I may make from them delicious

(6) food for your father, such as he loves. [10] And bring it

(7) to your father, that he may eat, and that he may bless you

(8) before his death.' [11] And Jacob said to Rebekah his mother,

(9) 'Lo, Esau my brother is a hairy man, and I am a smooth man.

(10) [12] Maybe my father will touch me, and I will seem in his eyes

(11) as a deceiver, and I will bring a curse on me

(12) and not a blessing. [13] And his mother said to him,

(13) 'Your curse will be on me, my son, Lecause if

(14) your father recognizes you, you will say that it was I who commanded you to do this. ${ }^{137}$ Only

(15) obey my voice, and go take them for me.' [14] And he went

(16) and took and brought them to his mother, and his mother made delicious

(17) food, such as his father loved. [15] And

(18) Rebekah took the garments of Esau, her older son, the

(19) finest of them, which were with her in the house, and she put them on Jacob,

(20) her younger son. [16] And she put the skins of the

(21) goat kids on his hands and on the smooth

(1) part of his neck. [17] And she gave the

(2) delicious food and the bread, which she had prepared, into the hand of Jacob,

(3) her son. [18] And he came to his father, and said, 'My father.'

(4) And he said, 'Lo, I am here. Who are you, my son?' [19] And

(5) Jacob said to his father, 'I am Esau your firstborn. I have done all

(6) as you spoke to me. Get up, now, sit and eat of my game,

(7) so your soul will bless me.' [20] And

(8) Isaac said to his son, 'What is this? You hurried to find, my son.' And he said,

(9) 'Because the Lord your God made me meet it before me.' [21] And Isaac said

(10) to Jacob, 'Come near, now, let me touch you, my son: is this you,

(11) my very son Esau, or not.' [22] And Jacob went near to Isaac

(12) his father, and he touched him, and said, 'The voice is Jacob's voice,

(13) but the hands are the hands of Esau.' [23] And he did not recognize him, 
(14) ki edilar qollary anyn qollary kibik 'Esavnyn qaryndašynyn tüklü-

(15) Ílar da alġyšlady any. [יאמר Da ajtty senmusen bu

(16) uvlum 'Esav da ajtty menmen. יויאמר. [25] Da ajtty juvut-

(17) qun maja da ašajym avlamaġyndan uvlumnun anyn üčün alġyš-

(18) lar seni žanym da juvuttu anar da ašady da keltirdi anar

(19) čag̀yr da ičti. [26] Da ajtty anar Jichaq atasy

(20) anyn juvugiun maja da öpkün meni uvlum. [27 Da

(21) juvudu da öptü any da ijiskedi ošol ijisin upraqlarynyn

$42 \mathrm{r}^{\mathrm{o}} \quad$ (1) da alğyšlady any da ajtty körun ijisin uvlumnun ijisi

(2) kibik tüznün ki alġyšlady any Adonaj. ויתן. [28] Da berǵaj

(3) saja ol Tenri čyġyndan ol köklernin da semizliklerind́an

(4) ol jernin da köp bürtük da šarbet. יעבדוך. [29] Qulluq

(5) etkejlar saja uluslar da bašurgajajlar saja ümmetlar

(6) bolġajsen ag̉araq qaryndašlaryja da bašurgajlar saja ulanlary

(7) anajnyn qarg̉avčularyj qarg̉yšlydy da alġyšlavčularyj alġyš-

(8) lydy. [30] Da edi ki nečik tügelledi Jichaq alġyšlama

(9) ošol Jacaqovnu da edi tek čyqma čyqty Ja'aqov alnyndan Jichaq-

(10) nyn atasynyn da 'Esav qaryndašy anyn keldi avlamaġyndan.

(11) ויעש [31 Da qyldy dag̉yn ol da tatly ašlar da keltirdi ata-

(12) syna da ajtty atasyna tursun atam da ašasyn avlama-

(13) ġyndan uvlunun anyn üčün alğyšlar meni žanyj. [32]

(14) Da ajtty anar Jichaq atasy anyn kim sen sen da ajtty menmen

(15) tunguuč uvluj 'Esav. ויחרד. Da qaltrady Jichaq ullu qalt-

(16) ravuq astryġadejin ${ }_{\mathrm{L}} \mathrm{ki}$ aškarmady anar bu nerśa navilik

(17) ašyra ${ }^{11}$ da ajtty kim edi bunda ol avlavču avlamaq da

(18) keltirdi maja da ašadym baryndan neki küsendim kelmesijden

(19) burun da alğyšladym any dag̉yn alġyšly bolsun. כשמוע. [34]

(20) Ešitkečoq 'Esav ošol sözlerin atasynyn da firjat etti

(21) ullu firjat da ačy astryg̉adejin da ajtty atasyna alğyš-

$42 \mathrm{v}^{\mathrm{o}}$ (1) lag̉yn menid́a dag̉yn mend́a uvlujmen atam. ויאמר [35] Da

(2) ajtty Jichạaq keldi qaryndašyj jaltajlyq byla da aldy

${ }^{1}$ Interpretative addition to the standard text. 
(14) because his hands were hairy, like his brother Esau's hands,

(15) and he blessed him. [24] And he said, 'Are you my very

(16) son Esau?' And he said, 'I am.' [25] And he said, 'Bring

(17) it near to me, and let me eat of my son's game, so that

(18) my soul will bless you.' And he brought it near to him, and he ate; and he brought him

(19) wine, and he drank. [26] And Isaac, his father, said to him,

(20) 'Come near now, and kiss me, my son.' [27] And

(21) he came near, and kissed him, and he smelled the smell of his garments,

(1) and he blessed him, and said, 'See, the smell of my son is like the $42 \mathrm{r}^{\circ}$ smell

(2) of a field which the Lord has blessed. [28] And may

(3) God give you from the dew of the skies, and from the fatness

(4) of the earth, and plenty of grain and must. [29]

(5) Let peoples serve you, and nations bow down to you.

(6) Be superior over your brothers, and let your mother's sons bow down to you.

(7) Cursed be everyone that curses you, and blessed be everyone who blesses you.'

(8) [30] And it was, when Isaac had finished blessing

(9) Jacob, and Jacob had scarcely gone out from before Isaac,

(10) his father, that Esau his brother came from his hunting.

(11) [31] And he, too, had made delicious food and brought it

(12) to his father, and said to his father, 'Let my father get up and eat

(13) of his son's game, so your soul will bless me.' [32]

(14) And Isaac his father said to him, 'Who are you?' And he said, 'I am

(15) your firstborn son Esau.' [33] And Isaac trembled very

(16) exceedingly, for this thing did not appear to him through a prophecy ${ }^{138}$,

(17) and said, 'Who was it here, he that hunted game and

(18) brought it to me? And I ate of all that I wanted before you came,

(19) and I even blessed him. He shall be blessed.' [34]

(20) As soon as Esau heard the words of his father, he cried

(21) with a great and exceedingly bitter cry, and said to his father, "Bless

(1) me also, I am your soon, too, oh my father'. [35] And

(2) he said, 'Your brother Isaac came with deceitfulness, and he took

$38 \quad$ An interpretative addition to Gen 27:33. 
(3) alğyšyjny. ויאמר [36] Da ajtty 'Esav kertid́an atady

(4) atyn anyn Ja'aqov da aldady meni bu eki keretlar ošol

(5) tunğučlug̉umnu aldy da muna haligińa aldy ošol alğy-

(6) šymny da ajtty atasyna muna astravyjda qaldyr-

(7) madyjmo maja alğgš. ויען [37] Da qaruv berdi Jichaq da

(8) ajt[t] $\mathrm{y}^{1}$ 'Esavğa muna ag̉araq qojdum any saja da ošol

(9) bar qaryndašlaryn berdim qullarğa da bürtük byla

(10) da šarbet byla kipledim any da saja bunda ne qylajym

(11) uvlum. ויאמר [38] Da ajtty 'Esav atasyna birmo ol

(12) alğyš edi send́a atam alğyšlag̉yn menid́a dag்yn mend́a

(13) uvlujmen atam da kötürdü 'Esav ošol avazyn da jylady.

(14) [יען Da quaruv berdi Jichạ atasy anyn da ajtty anar

(15) muna semiz orunlarynda ol jernin bolur olturušuj

(16) senin da čyg்yndan ol köklernin jogartyn bolur bögövremegi

(17) jerijnin. [4ל [4] Da qylyčyjbyla beslenirsen da ošol

(18) qaryndašyja qulluq etersen da bolġaj ki nečik küčejśaj da

(19) özersen bojunsasyn anyn bojnujüstünd́an. וישטום. [41]

(20) Da dušman boldu 'Esav Ja'aqovğa ol alğyš üčün ki alğyš-

(21) lady any atasy anyn da ajtty 'Esav kölnünd́a juvusalar

$43 \mathrm{r}^{\mathrm{o}} \quad$ (1) jas künleri atamnyn öltürürmen Jaćaqovnu qaryndašym-

(2) ny. [42] Da anlatyldy Riveqag̉a ošol sözleri 'Esav-

(3) nyn ol ag̉araq uvlunun da ijdi da ündedi ošol Ja'aqov-

(4) nu uvlun ol kičirekni da ajtty anar muna 'Esav qaryn-

(5) dašyj mahtanady üstüja öltürḿa seni. ועתה. [43]

(6) Da haligińa e uvlum tynlağyn sözüḿa da turğun qač-

(7) qyn özüja Lavanġa qaryndašyma Haranġa. וישבת [44] Da

(8) olturğun birgesińa bir zamanlar neginče ki qajtqaj

(9) qahiri qaryndašyjnyn. עד. [45] Qajtqynča ačuvu qaryndašyj-

(10) nyn send́an da unutsa ošol neki qyldyj anar da ijermen

(11) da alyrmen seni andan nek tuv bolurmen eksijizdend́a

(12) bir künd́a ${ }_{L}$ ki nečik ol öltürse seni daġyn anyda

(13) öltürürlar ${ }^{12}$. ותאמר [46] Da ajtty Riveqa Jichaqqa

(14) jadadym tirliklerimd́an alnyndan qyzlarynyn Hetnin eger

\footnotetext{
${ }^{1} \mathrm{~K}$ : ajty; a scribal error. | TKow.or: ajtty. | H: ajtty. | C: ajtty. $\quad{ }^{2}$ Interpretative addition to the
} standard text. 
(3) your blessing.' [36] And Esau said, 'Was his name really called

(4) Jacob? And he cheated me these two times.

(5) He took my birthright, and, lo, now he has taken

(6) my blessing.' And he said to his father, 'Lo, have you not left in secret

(7) a blessing for me?' [37] And Isaac answered and

(8) said to Esau, 'Lo, I have made him your superior, and

(9) I have given all his brothers as servants, and

(10) I have sustained him with grain and must. And what shall I do here for you,

(11) my son?' [38] And Esau said to his father,

(12) 'Is it one blessing that you had, my father? Bless me also, I am

(13) your soon, too, oh my father' And Esau raised his voice, and wept.

(14) [39] And Isaac his father answered and said to him,

(15) 'Lo, your dwelling will be in the fatness of the earth,

(16) and the dew of the skies from above will quench the thirst

(17) of your land. [40] And by your sword you will live on, and

(18) you will serve your brother. And it shall be, when you shall gain strength,

(19) that you shall crush his yoke from your neck.' [41]

(20) And Esau became hostile to Jacob because of the blessing

(21) with which his father blessed him, and Esau said in his heart,

(1) 'When the days of mourning for my father will get closer, I will kill my $43 \mathrm{r}^{\circ}$ brother Jacob.'

(2) [42] And these words of Esau her older son were told to Rebekah.

(3) So she sent and called Jacob,

(4) her younger son, and said to him, 'Lo, your brother Esau

(5) brags concerning you, to kill you. [43]

(6) So now, oh my son, listen to my voice and get up, flee

(7) to Laban, my brother, to Haran. [44] And

(8) live with him some time, until your brother's fury turns back.

(9) [45] Until your brother's fury turns back

(10) from you and he forgets what you have done to him. And I will send

(11) and take you from there. Why should I be deprived of the two of you as well

(12) in one day? ${ }_{\text {For }}$ if he kills you, he

(13) will be also killed.'139 [46] And Rebekah said to Isaac,

(14) 'I am weary of my life before the daughters of Heth. If

39 An interpretative addition to Gen 27:45. 
(15) aladese Ja'aqov qatyn qyzlaryndan Hetnin bularny kibik qyzla-

(16) ryndan ol jernin negedi maja tirlik.

Genesis 28

(16) ויקרא [1] Da ün-

(17) dedi Jicḥaq Ja'aqovnu da alğyšlady any da zynharlady any da

(18) ajtty anar almaġyn qatyn qyzlaryndan Kena`annyn. קום [2] Turğun

(19) b[a]rg்yn ${ }^{1}$ Padan Aramġa üvüńa Betu’elnin ${ }_{L}\langle$ anasynyn $\rangle\{$ atasyny[n] $\}^{12}$ anajnyn

(20) da alg̀yn özüja andan qatyn qyzlaryndan Lavannyn qaryndašynyn

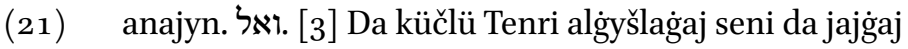

$43 \mathrm{v}^{\mathrm{o}} \quad$ (1) seni da arttyrg்aj seni da bolgajsen jyjynyna uluslarnyn.

(2) [4] Da bergej saja ošol alğyšyn Avrahamnyn saja

(3) da urluğuja birgeja meresleḿa sen ošol tirilmüš

(4) jerijni ki berdi Tenri Avrahamġa. [5] Da ijdi

(5) Jicḥaq ošol Ja'aqovnu da bardy Padan Aramġa Lavang̉a uvluna

(6) Betu'elnin ol Aramlynyn qaryndašyna Riveqanyn anasynyn Ja'aqov-

(7) nun da 'Esavnyn. [6] Da kördü 'Esav ki alğyšlady Jichạaq

(8) ošol Jacaqovnu da ijdi any Padan Aramġa alma andan

(9) özüńa qatyn alğyšlag̉anynda any da zynharlady anar ajt[a]-

(10) doğač almag்yn özüja qatyn qyzlaryndan Kena'annyn. וישמע. [7

(11) Da tynlady Ja'aqov sözüńa atasynyn da anasynyn da bardy

(12) Padan Aramġa. [8] Da kördü 'Esav ki jamandylar

(13) qyzlary Kena'annyn közlerind́a Jichaqnyn atasynyn. וילך. [9]

(14) Da bardy 'Esav Jišma'elǵa da aldy ošol Maḥalatny qyzyn

(15) Jišma‘elnin uvlunun Avrahamnyn tuvdug̉un Nevajotnun qatyn-

(16) lary qatyna özüńa qatynlyqqa.

פרשת ויצא (17) (18) (19)

(18] Da čyqty Ja'aqov Be'er

(19) Ševa'dan da bardy Haranga. I11 Da

$44 \mathrm{r}^{\mathrm{o}} \quad$ (1) jetti orunga da qondu anda ki endi ol qujaš da

(2) aldy birni tašlaryndan ol orunnun da qojdu bašlary tübü-

(3) ńa da jatty ol orunda. ויחלום. [12] Da tüš kördü

${ }^{1} \mathrm{~K}$ : bergin; a scribal error. | TKow.o1: bargyn. | H: bargyn. | C: bargynn. $\quad{ }^{2}$ TKow.o1: atasynyn. | H: atasynyn. | C: atasy. $\quad{ }^{3} \mathrm{~K}$ : ajtdoġač; a scribal error; cf., however, Gen 40:7. | TKow.o1: ajtadoġač. | H: ajtadoġac. | C: demä. 
(15) Jacob takes a wife of the daughters of Heth like these

(16) daughters of the land, what for is a life to me?'

Genesis 28

[1] And

(17) Isaac called Jacob, and blessed him and commanded him, and

(18) he said to him, 'You shall not take a wife of the daughters of Canaan. [2] Arise,

(19) go to Paddan-Aram, to the house of Bethuel, your mother's father,

(20) and take you a wife from there of the daughters of Laban, the brother

(21) of your mother. [3] And may the mighty God bless you and spread

(1) you and multiply you, that you may become a multitude of people. $43 \mathrm{v}^{\mathrm{o}}$

(2) [4] And may he give the blessing of Abraham to you

(3) and to your offspring with you, that you may inherit the land of your sojourning

(4) that God gave to Abraham!' [5] And Isaac

(5) sent Jacob, and he went to Paddan-Aram to Laban, son

(6) of Bethuel, the Aramean, brother of Rebekah, mother of Jacob

(7) and Esau. [6] And Esau saw that Isaac had blessed

(8) Jacob, and sent him to Paddan-Aram, to take him from there

(9) a wife when he blessed him, and he had commanded him, saying,

(10) 'You shall not take a wife of the daughters of Canaan.' [7]

(11) And Jacob listened to the words of his father and his mother, and went

(12) to Paddan-Aram. [8] And Esau saw that

(13) the daughters of Canaan seemed not good in the eyes of Isaac, his father. [9]

(14) And went Esau to Ishmael, and took Mahalath, daughter

(15) of Ishmael, son of Abraham, sister of Nebaioth,

(16) besides the wives whom he had, as a wife for him.

(17) Parashat Vayetze

(18) [10] And Jacob went out from

(19) Beersheba, and went toward Haran. [11] And

(1) he reached a place, and stayed the night there, because the sun had set. And

(2) he took one of the stones of that place, and he put it under his head,

(3) and lay down in that place. [12] And he dreamed. 
(4) da muna basqyč turg̉uzulġan jerǵa da bašy anyn jetadi

(5) köklerǵa da muna malahlary Tenrinin minediler da

(6) enedilar anyn ašyra. [13] Da muna šehinasy

(7) Adonajnyn turady anyn qatyna da ajtty menmen Adonaj Ten-

(8) risi Avrahamnyn atajnyn da Tenrisi Jichaqnyn ol jer ki

(9) sen jatasen anyn üstüńa saja berirmen any da urlug̉u-

(10) ja. והיה [14] Da bolur urlug̉uj topragy kibik ol jernin

(11) da jajylyrsen ma'arav sary da kün tuvušu sary da cafon sary

(12) da tüšlüksary da alg̀yšlanyrlar senin sartyn bar uruv-

(13) lary ol jernin da urluggujsartyn. [15נה Da muna

(14) bolušlug̉um menim birgeja da saqlarmen seni barča qajda

(15) ki jürüsen da qajtaryrmen seni ol jerǵa ošpu ki kemiš-

(16) menmen seni neginča ki ančaq qylġajmen ošol ne ki sözle-

(17) dim saja. וייקץ [16] Da ojandy Ja'aqov juqusundan da

(18) ajtty kertid́an bar šehinasy Adonajnyn ošpu orunda

(19) da men bilmedim. יירא. Da qorqtu da ajtty ne

(20) qorqunčludu ol orun ošpu joḥtur bu ki ančaq üvü-

(21) dü Tenrinin da budu qabaġy ol köklernin. וישכם [18] Da

$44 \mathrm{v}^{\mathrm{o}} \quad$ (1) tünlej turdu Jacaqov ertenbylada da aldy ošol ol tašny

(2) ki qojdu bašlary tübüńa da qojdu any maceva da qujdu

(3) jav bašyüstüńa anyn. [19] Da atady \{ošol\} atyn ol

(4) orunnun Bet'el da kertidan Luz edi aty ol šaharnyn

(5) burundan. וידר. [20] Da nijet etti Ja'aqov nijet ajtadoġač

(6) eger bolsa bolušlugu Tenrinin birgeńa da saqlasa

(7) meni jolda ošpu ki men barmen da berśa maja ötmek

(8) ašama da upraq kijḿa. ושבתי [21] Da qajtsam

(9) tynčlyqta üvüńa atamnyn da bolur Adonaj maja Tenri.

(10) והאבן [22] Da ol taš ošpu ki qojdum \{maceva\} bolur üvü

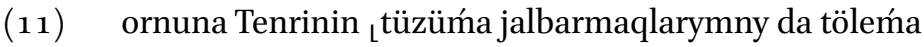

(12) nijetlerimni ${ }^{11}$ da barča neki bersej maja baryndan onča

(13) berḿa onča berirmen andan saja.

Genesis 29

וישא. [1] Da kö-

(14) türdü Jacaqov ajaqlaryn da bardy jerińa qedemnin. [2]

(15) Da kördü da muna quju tüzd́a da muna anda üč

\footnotetext{
${ }^{1}$ Interpretative addition to the standard text.
} 
(4) And, lo: a ladder set up on the earth, and the top of it reaches

(5) to heaven. And, lo, the angels of God ascend and

(6) descend on it. [13] And, lo, the divine Presence

(7) of the Lord stands above it, and said, 'I am the Lord God

(8) of Abraham your father, and the God of Isaac. The land on which

(9) you are lying: I will give it to you and to your offspring.

(10) [14] And your offspring will be like the dust of the earth,

(11) and you will spread to the west, and to the east, and to the north,

(12) and to the south. And in you will all the families

(13) of the earth be blessed. [15] And, lo,

(14) my help is with you, and I will keep you everywhere

(15) you go, and I will bring you back to this land. For I will not leave you,

(16) until I have done that which I have spoken

(17) to you of.' [16] And Jacob awoke from his sleep, and

(18) he said, 'Surely, the divine Presence of Lord is in this place,

(19) and I did not know.' And he was afraid, and said, 'How

(20) awesome is this place! This is none other but the house

(21) of God, and this is the gate of heaven.' [18] And

(1) Jacob rose up early in the morning, and took the stone

(2) that he had put under his head, and set it up for a pillar, and poured

(3) oil on the top of it. [19] And he called the name of that

(4) place Bethel, though in truth the name of that city was called Luz

(5) at first. [20] And Jacob vowed a vow, saying,

(6) 'If God's help will be with me and will keep

(7) me in this way that I go and will give me bread

(8) to eat, and clothing to put on, [21] And I come back

(9) to my father's house in peace, then the Lord will become God to me.

(10) [22] And this stone that I have set for a pillar will be

(11) for God's house, ${ }_{1}$ to compose my prayers and pay

(12) my vows ${ }^{140}$, and of everything that you will give me

(13) I will surely give the tenth to you.

Genesis 29

$$
\text { [1] And }
$$

(14) Jacob lifted his feet and went to the land of the East. [2]

(15) And he looked, and, lo: a well in the field, and, lo, there were three

40 An interpretative addition to Gen 28:22. 
(16) bölekleri qojnun jatadylar anyn qatyna ki ol qujudan ičiri-

(17) redilar ol böleklerni da ullu taš edi avzu üstüńa

(18) ol qujunun. [3אספו. [3] Da jyštyrylyredilar ary bar ol

(19) bölekĺar da töngečtirirediĺar ol kütüvčülar ošol

(20) ol tašny avzu üstünd́an ol qujunun da ičiriredilar

(21) ošol ol qojnu da qajtaryredilar ošol ol tašny avzu

$45 \mathrm{r}^{\mathrm{o}}$ (1) üstüńa ol qujunun ornuna. ויאמר [4] Da ajtty alar-

(2) ġa Ja'aqov qaryndašlarym qajdan siz siz da ajttylar Ḥarandandyr

(3) biz. ויאמר [5] Da ajtty alargia bilemosiz ošol Lavanny

(4) uvlun Nahornun da ajttylar bilebiz. ויאמר. [6] Da ajtty

(5) alarg̉a tynčlyqmodu anar da ajttylar tynčlyqty da muna

(6) $\quad\left\{[\text { Ra] hel }\}^{1}\right.$ qyzy anyn keledi ol qoj byla. ויאמר. [7] Da ajtty muna

(7) hanuz ol kün ulludu tüvüldü vaḥty jyštyrylmaġynyn ol

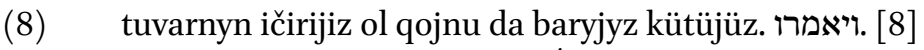

(9) Da ajttylar bolalmasbiz neginč́a ki jyštyrylğajlar bar ol

(10) bölekĺar da töngečtirgejlar ošol ol tašny avzu üs-

(11) tünd́an ol qujunun da ičirirbiz ol qojnu. [9]

(12) Hanuz ol sözleredi birgelerińa da Rahel keldi ol qojby-

(13) la ki atasynyn ki küteredi ol. [10] Da edi ki nečik

(14) kördü Jacaqov ošol Raḥelni qyzyn Lavannyn qaryndašynyn anasynyn

(15) da ošol qojnu Lavannyn qaryndašynyn anasynyn da juvudu Ja'aqov

(16) da töngečtirdi ošol ol tašny avzu üstünd́an ol

(17) qujunun da ičirdi ošol qojnu Lavannyn qaryndašynyn anasynyn.

(18) (11] Da öptü Ja'aqov Raḥelni da kötürdü ošol avazyn

(19) da jylady. [יוגד [12] Da anlatty Ja'aqov Rahẹelǵa ki qaryndašy-

(20) dy atasynyn ol da ki uvludu Riveqanyn ol da juvurdu da

(21) anlatty Raḥel atasyna. ויהי [13] Da edi ešitkečoq Lavan

$45 \mathrm{v}^{\mathrm{o}} \quad$ (1) ošol ḥabarny Ja'aqovnun uvlunun tuvdug̉unun da juvurdu utu-

(2) rusuna da qučtu any da öptü any da keltirdi any ü-

(3) vüńa da qotardy Lavanġa ošol bar išlerni ošpularny.

(4) יויאמר [14] Da ajtty anar Lavan tek süvegim da gufumdur

(5) sen da olturdu birgesińa janġaj künlar. ויאמר [15] Da

(6) ajtty Lavan Jacaqovġa kertid́an qaryndašymdyr sen da qulluq

${ }^{1}$ TKow.o1: Rahel. | H: Raḥel. | C: Raḥel. 
(16) flocks of sheep lying by it, because they watered

(17) the flocks from that well. And a great stone was on the well's mouth.

(18) [3] And all the flocks were gathered there,

(19) and the shepherds rolled

(20) the stone from the well's mouth, and they watered

(21) the sheep, and put the stone back

(1) in its place over the mouth of the well. [4] And Jacob said to them,

(2) 'My brothers, where are you from?' And they said, 'We are from Haran.'

(3) [5] And he said to them, 'Do you know Laban,

(4) son of Nahor?' And they said, [6] 'We know.' [6] And he said

(5) to them, ' ${ }_{L}$ Is he well ${ }^{41}$ ?' And they said, ' ${ }_{L} \mathrm{He}$ is well ${ }^{142}$. And, lo,

(6) Rachel, his daughter, is coming with the sheep.' [7] And he said, 'Lo,

(7) the day is still great, it is not the time for gathering the

(8) livestock. Water the sheep and go, pasture them.' [8]

(9) And they said, 'We cannot, until all the flocks are gathered,

(10) and they roll the stone from the mouth

(11) of the well. And we will water the sheep.' [9]

(12) He was still speaking with them, and Rachel came

(13) with the sheep that were of her father, because she pastured them. [10] And it was, when

(14) Jacob saw Rachel, daughter of Laban, his mother's brother,

(15) and the sheep of Laban, his mother's brother, that Jacob went near,

(16) and rolled the stone from the moth

(17) of the well, and watered the flock of Laban, his mother's brother.

(18) [11] And Jacob kissed Rachel, and raised his voice,

(19) and wept. [12] And Jacob told Rachel that he was the bother of

(20) her father, and that he was Rebekah's son, and she ran and

(21) told her father. [13] And it was, as soon as Laban

(1) heard the news of Jacob, his sister's son, that he ran

(2) to meet him, and embraced him, and kissed him, and brought him

(3) to his house. And he told Laban all these things.

(4) [14] And Laban said to him, 'Surely you are my bone and my flesh.'

(5) And he abode with him a month of days. [15] And

(6) Laban said to Jacob, 'It is right, you are my brother, should you therefore serve

41 K: lit. 'is peace to him?', a literal translation of Heb. הֶשָׁלוֹ לז 'is he well?'.

42 K: lit. 'peace is', a literal translation of Heb. שָז 'peace'. 
(7) etermosen maja muft anlatqyn maja nedir jalyn senin.

(8) (16] Da Lavanga edilar eki qyzlar aty ol ag̉araqnyn

(9) Le’a da aty ol kičireknin Raḥel. ועיביני [17] Da közleri

(10) Le’anyn jymšaqlar edilar da Raḥel edi körklü bojlu

(11) da körklü körümlü. [18] Da süvdü Jáaqov ošol

(12) Rahelni da ajtty qulluq etajim saja jedi jyllar Rahel qyzyj

(13) üčün ol kičirek. [יאמר. Da ajtty Lavan jaḥšyraq-

(14) ty bergenim any saja bergenimd́an any özǵa kišiǵa

(15) olturgun qatymda. [20] Da qulluq etti Ja'aqov

(16) Raḥel üčün jedi jyllar da edilar közlerind́a anyn bir

(17) jyl kibik süvgenisartyn any. [יאמר [21] Da ajtty Ja'aqov

(18) Lavanġa bergin ošol qaty\{ny\}mny ki toldular künlari qullug̉um-

(19) nun da kelajim anar. ויאסף [22] Da jyštyrdy Lavan ošol

(20) elin ol orunnun da qyldy ički. ויהי [23] Da edi

(21) ingird́a da aldy ošol Le’any qyzyn da keltirdi any anar

46 r $^{\circ}$ (1) da keldi anar. [24] Da berdi Lavan anar ošol Zilpany

(2) qaravašyn Le’ag̉a qyzyna qaravaš. ויהי. [25] Da edi erten-

(3) bylada da muna ol Le’ady da ajtty Ja'aqov Lavanga ne

(4) bu qyldyj maja muna tüvülmö Rahel üčün qulluq ettim

(5) saja da ne aldadyj meni. ויאמר [26] Da ajtty Lavan

(6) qylynmajdy alaj ornumuzda berḿa ol kičirekni burun-

(7) מלא [27 [27 Tolturg̉un jedi künlerin bu

(8) bijenčnin da berirbiz saja dağyn ošol bunuda qulluq ü-

(9) čün ki qulluq etersen birgeḿa daġyn jedi jyllar özgelar.

(10) ויעש Da qyldy Ja'aqov alaj da tügelledi jedi künle-

(11) rin bu bijenčnin da berdi anar ošol Rahẹelni qyzyn anar

(12) qatynlyqqa. ויתן. [29] Da berdi Lavan Rahelǵa qyzyna ošol

(13) Bilhany qaravašyn anar qaravašlyqqa. [30] Da keldi

(14) daġyn Raḥelge da süvdü daġyn ošol Raḥelni jaḥšyraq Le’a-

(15) dan da qulluq etti birgesińa daġyn jedi jylla\{r\} özgelar.

(16) וירא (31] Da kördü Adonaj ki ḥorlanġandy Le’a da ačty

(17) ošol qursag̉yn anyn da Rahel edi bödav. [32] Da

(18) hamila boldu Le’a da töredi uvul da atady atyn anyn

(19) Ru’uven ki ajtty ki kördü Adonaj qyjynymny ki haligińa

(20) süver menim erim. ותהר [33] Da hamila boldu daggyn

(21) da töredi uvul da ajtty ki ešitti Adonaj ki ḥor- 
(7) me for nothing? Tell me, what is your wages?'

(8) [16] And Laban had two daughters. The name of the older

(9) was Leah, and the name of the younger was Rachel. [17] And the eyes

(10) of Leah were tender, but Rachel was beautiful in form

(11) and beautiful in appearance. [18] And Jacob loved

(12) Rachel, and he said, 'I will serve you seven years for Rachel,

(13) your younger daughter.' [19] Laban said, 'It is better

(14) that I give her to you than that I should give her to any other man.

(15) Dwell beside me.' [20] And Jacob served

(16) seven years for Rachel, and they seemed in his eyes as one

(17) year, because of the love he had for her. [21] And Jacob said

(18) to Laban, 'Give me my wife, for the days of my service are filled,

(19) and let me come to her.' [22] And Laban gathered

(20) all the men of the place, and made a feast. [23] And it was

(21) in the evening, and he took Leah his daughter, and brought her to him,

(1) and he came to her. [24] And Laban gave his maidservant Zilpah to Leah, his daughter,

(2) as a maidservant. [25] And it was

(3) in the morning, and, lo, it was Leah. And Jacob said to Laban, 'What

(4) is this you have done to me? Did I not serve with you for Rachel?

(5) And why have you deceived me?' [26] And Laban said,

(6) 'It is not done like that in our place, to give the younger before

(7) the older. [27] Fulfil the seven days of this

(8) wedding, and we will give you this other also for the service

(9) which you shall serve with me yet seven other years.'

(10) [28] And Jacob did so, and filled the seven days

(11) of this wedding, and he gave him also Rachel, his daughter,

(12) for a wife. [29] And Laban gave to Rachel, his daughter,

(13) Bilhah, his maidservant, to be her maidservant. [30] And he came

(14) also to Rachel, and he loved Rachel as well, more than Leah,

(15) and served with him yet seven other years.

(16) [31] And the Lord saw that Leah was despised, and he opened

(17) her womb, and Rachel was barren. [32] And

(18) Leah conceived, and bore a son, and she called his name

(19) Reuben, because she said, 'Because the Lord looked at my affliction, so that now

(20) my husband will love me.' [33] And she conceived again,

(21) and bore a son, and she said, 'Because the Lord has heard that I was despised, 
$46 \mathrm{v}^{\mathrm{o}}$ (1) lanġan men da berdi ošol bunuda da atady atyn anyn Šim'on.

(2) ותר [34 Da hamila boldu daġyn da töredi uvul da ajtty

(3) haligine qošulur erim maja ki töredim anar üč uvullar

(4) anyn üčün atady atyn anyn Levi. ותהר [35] Da hamila boldu

(5) dag்yn da töredi uvul da ajtty bu vaḥtta šükür eterman

(6) Adonajgia anyn üčün atady atyn anyn Juhuda da qaldy töremek-

(7) ten.

Genesis 30

(7) (1] Da kördü Rahel ki töremedi Jacaqovğa da

(8) künüledi Rahel tuvduğuna da ajtty Ja'aqovġa bergin maja

(9) ulanlar da eger joq ölermen men. ויחר. [2] Da qabundu

(10) ačuvu Jacaqovnun Raḥel üstüńa da ajtty Tenrimo or-

(11) nunadyr men ki ajady send́an jemišin qursaqnyn. [3אמר [3]

(12) Da ajtty Raḥel muna qaravašym Bilha kelgin anar da töre-

(13) sin tizlerim üstüńa da uvullu bolajym daġyn mend́a andan.

(14) [ [4] Da berdi anar ošol Bilhany qaravašyn özünün

(15) qatynlyqqa da keldi anar Ja'aqov. ותהר. [5] Da hamila boldu

(16) Bilha da töredi Ja'aqovġa uvul. [6תאמר [6] Da ajtty

(17) Raḥel jarğu jardy meni Tenri da daġyn ešitti avazymny da

(18) berdi maja uvul anyn üčün atady atyn anyn Dan. [7 [7]

(19) Da ḥamila boldu daġyn da töredi Bilha qaravašy Rahelnin ekinči

(20) uvul Ja'aqovğa. [8] Da ajtty Raḥel ullu čengeš-

(21) mekler čengešdim tuvdug̉um byla dag̉yn jendim da atady

$47 \mathrm{r}^{\mathrm{r}} \quad$ (1) atyn anyn Naftali. [9] [9] Da kördü Le’a ki qaldy töre-

(2) mekten da aldy ošol Zilpany qaravašyn özünün da berdi any

(3) Jacaqovġa qatynlyqqa. ותלד. [10] Da töredi Zilpa qaravašy Le’a-

(4) nyn Ja'aqovga uvul. ותאמר [11] Da ajtty Le'a keldi mazal

(5) da atady ošol [atyn] $]^{1}$ anyn Gad. ותלד. [12] Da töredi Zilpa qaravašy

(6) Le’anyn ekinči uvul Jacaqovġa. ותאמרד. [13] Da ajtty

(7) Le’a maḥtalġanymda ki maḥtadylar meni qyzlar da atady \{ošol $\}$ atyn

(8) anyn Ašer. וילד] [14] Da bardy Ru'uven vahtlarynda ormaġynyn

(9) budajlarnyn da tapty čijelar tüzd́a da keltirdi alarny anasyna

\footnotetext{
${ }^{1} \mathrm{~K}$ : deest; a scribal error. | TKow.o1: atyn. | H: atyn. | C: atyn.
} 
(1) he has given me this one, too.' And she called his name Simeon. $46 \mathrm{v}^{\mathrm{o}}$

(2) [34] And she conceived again, and bore a son, and she said,

(3) 'Now my husband will be joined to me, because I have borne him three sons.'

(4) On account of this his name was called Levi. [35] And she conceived

(5) again, and bore a son, and she said, "This time I will praise

(6) the Lord.' Therefore she called his name Judah. And she ceased

(7) bearing.

Genesis 30

(8) Rachel envied her sister, and said to Jacob, 'Give me

(9) children, and if not: I will die!' [2] And Jacob's anger was kindled

(10) against Rachel, and he said, 'Am I in the

(11) place of God, who has withheld from you the fruit of the womb?' [3]

(12) And Rachel said, 'Lo, my maidservant Bilhah, come to her, and she shall bear

(13) on my knees, and let me be childed through her.

(14) [4] And she gave him Bilhah, her maidservant,

(15) for a wife. And Jacob came to her. [5] And Bilhah conceived,

(16) and bore Jacob a son. [6] And Rachel said,

(17) 'God has judged me and heard my voice as well, and

(18) he has given me a son.' On account of this she called his name Dan. [7]

(19) And Bilhah, Rachel's maidservant, conceived again, and bore a second

(20) son to Jacob. [8] And Rachel said, 'With great discord

(21) I have discorded with my sister. I have also prevailed.' And she called

(1) his name Naphtali. [9] And Leah saw that she had ceased bearing, $\quad 47 \mathrm{r}^{\mathrm{o}}$

(2) and she took Zilpah, her maidservant, and gave her

(3) to Jacob for a wife. [10] And Zilpah, Leah's maidservant, bore

(4) Jacob a son. [11] And Leah said, 'Good fortune has come.'

(5) And she called his name Gad. [12] And Zilpah, Leah's maidservant, bore

(6) Jacob a second son. [13] And Leah

(7) said, 'I am praised, for the daughters will praise me.' And she called his name

(8) Asher. [14] And Reuben went in the time of wheat harvest,

(9) and found berries in the field, and brought them to his mother. 
(10) da ajtty Raḥel Le’ag̉a bergin endi maja čijelerind́an uvluj-

(11) nun. ותאמר [15] Da ajtty anar Le’a azmodu almaġyj ošol

(12) erimni da klejsen alma dagyn čijelerin uvlumnun da ajtty

(13) Raḥel anyn üčün jatsyn birǵaja bu kečeni čijeleri üčün uv-

(14) lujnun. [יבא [16] Da keldi Ja'aqov ol tüzd́an ingird́a

(15) da čyqty Le’a uturusuna da ajtty maja kelgin ki jalġa

(16) tutma jalğa tuttum seni čijeleri üčün uvlumnun da

(17) jatty birgesińa ol kečeni. [17] Da tynlady Tenri

(18) jalbarmag̉yn Le’anyn da ḥamila boldu da töredi Ja'aqovğa

(19) bešinči uvul. ותאמר. [18] Da ajtty Le’a berdi Tenri

(20) jalymny ki berdim qaravašymny eriḿa da atady atyn anyn

(21) נותהר Jissahar. [19] Da hamila boldu dağyn Le’a da töredi

$47 \mathrm{~V}^{\circ}$ (1) ותאמר. [20] Da ajtty Le’a berne-

(2) ledi maja Tenri jaḩšy berńa bu vaḥtta ornun qojar mend́a

(3) erim ki töredim anar alty uvullar da atady ošol atyn

(4) anyn Zevulun. ואחר [21] Da andan sortun töredi qyz da atady

(5) ošol atyn anyn Dina. ויזכר [22] Da saġyndy Tenri ošol

(6) Raḥelni da ešitti ošol jalbarmag̉yn anyn Tenri da ačty

(7) ošol qursaġyn anyn. [23 [23 Da ḥamila boldu da töre-

(8) di uvul da ajtty jyštyrdy Tenri ošol rusvajlyġymny.

(9) ותקרא [24 Da atady ošol atyn anyn Josef ajtadog̉ač

(10) arttyrgaaj Adonaj maja özǵa uvul. ויהי [25] Da edi

(11) ki nečik töredi Rahel ošol Josefni da ajtty Ja'aqov Lavanġa

(12) ijgin meni da barajym ornuma da jerima. [26] Bergin

(13) ošol qatynlarymny da ošol ulanlarymny ki qulluq ettim

(14) saja alar üčün da $b[a] r[a] j y m^{1} k^{k i}$ sen bilesen ošol qullugiumnu

(15) ki qulluq ettim saja. ויאמר Da ajtty anar

(16) Lavan eger endi taptym ese širinlik közlerijd́a syn-

(17) čyladym da alġyšlady meni Adonaj senin sibbajdan. ויאמר [28]

(18) Da ajtty belgilegin jalyjny maja da berejim. ויאמר Da

(19) ajtty anar Jacaqov sen bilesen ošol ne ki qulluq ettim

(20) saja da ošol ki edi tuvaryj birgeḿa. כי. [30] Ki azġynaq

(21) ki edi saja menden burun da jajyldy köplükḱka da alğyš-

${ }^{1} \mathrm{~K}$ : berejim; a scribal error.| TKow.o1: barajym. | H: barajym. | C: barajym. 
(10) And Rachel said to Leah, 'Give me, I pray you, of your son's berries.

(11) And Leah said to her, 'Is your taking my man a small thing?

(12) And you want to take away my son's berries, too?' And

(13) Rachel said, 'Therefore he shall lie with you tonight for your son's berries'.

(14) [16] And Jacob came from the field in the evening,

(15) and Leah went out to meet him, and said, 'Come to me, because I have surely hired

(16) you with my son's berries.' And

(17) he lay with her that night. [17] And God heard

(18) Leah's cry, and she conceived, and bore Jacob

(19) a fifth son. [18] And Leah said, 'God has given

(20) my wages, because I have given my maidservant to my husband. And she called his name

(21) Issachar. [19] And Leah conceived again, and bore

(1) Jacob a sixth son. [20] And Leah said,

(2) 'God has gifted me with a good gift. Now my husband will set his place at me,

(3) because I have borne him six sons. And she called his name

(4) Zebulun. [21] And afterwards she bore a daughter, and called

(5) her name Dinah. [22] And God remembered

(6) Rachel, and God heard her cry, and opened

(7) her womb. [23] And she conceived, and bore

(8) a son, and said, 'God has collected my reproach.'

(9) [24] And she called his name Joseph, saying,

(10) 'May the Lord add another son to me.' [25] And it was

(11) when Rachel had borne Joseph: and Jacob said to Laban,

(12) 'Send me away, that I may go to my own place, and to my country.' [26] Give me

(13) my wives and my children for whom I have served

(14) you, and let me [go], for you know my service

(15) which I have done you.' [27] And Laban said to him,

(16) 'If I have found favour in your eyes, I

(17) have learned by experience that the Lord has blessed me for your sake.' [28]

(18) And he said, 'Designate me your wages, and let me give it.' [29]

(19) And Jacob said to him, 'You know how I have served you,

(20) and how your livestock were with me. [30] For it was little

(21) which you had before I came, and it is now spread into a multitude. And 
$48 \mathrm{r}^{\mathrm{o}} \quad$ (1) lady Adonaj seni menim ajaġym sartyn da haligine qačan qylar-

(2) men daġyn mend́a üvüme. ויאמר [31] Da ajtty Lavan ne

(3) berejim saja da ajtty Ja'aqov bermegin maja nemede

(4) eger qylsaj maja ol išni ošpunu qajtyrmen kütermen

(5) qojujnu saqlarmen. אעבר. [32] Ašajym bar qojujda bügün

(6) keterma andan bar qojnu bürtüklünü da alalyny da

(7) bar qara qojnu qozularda da alalyny da bürtüklünü

(8) ečkilerd́a da bolur jalym. וענתה. [33] Da tanyqlyq

(9) čyg̉ar rastlyğym menim üčün tanbylag̉y künd́a ki kelśa

(10) jalym üčün alnyja bar neki bolmasa bürtüklü da alaly

(11) ečkilerd́a da qara qozularda urla $\{n\}$ ġandyr ol qatymda.

(12) ויאמר [34] Da ajtty Lavan jaḥšy kešḱ bolġaj sözlerija

(13) köŕa. ויסר [35] Da keterdi Lavan ol künd́a ošol ol

(14) tegelerni ol čybarlarny da ol alalylarny da ošol bar ol

(15) ečkilerni ol bürtüklülerni da ol alaly\{l\}arny barča ne

(16) ki aq anda da bar qarany qozularda da berdi qoluna

(17) uvullarynyn. וישם. [36] Da qojdu jol üč künlük arasy-

(18) na özünün da arasyna Jacaqovnun da Ja'aqov küteredi

(19) ošol qojun Lavannyn ol qalġanlarny. [37] Da aldy ö-

(20) züńa Ja'aqov lipa tajag̉y jašny da četlevük ag̉ačy da kaštan

(21) ag̉ačy da jondu alarda aq jonmaqlar ačy $[\mathrm{p}]^{1} \mathrm{ol}\{a q n y\}^{2} \mathrm{ki}$ ol tajaq-

$48 \mathrm{v}^{\mathrm{o}}$ (1) lar üstüńa. [38] Da turg̉uzdu ošol ol tajaqlarny ki

(2) jondu korytalarda suvlavlarynda ol suvlarnyn ki kelsejdilar

(3) ol qoj ičḿa uturusuna ol qojnun issiniredi-

(4) lar kelgenlerind́a ičma. [39] Da issindilar

(5) ol qoj bag̉adoġač ol tajaqlar üstüńa da töredilar ol

(6) qoj čybarlarny bürtüklülerni da alalylarny. והכשבים. [40]

(7) Da ol qozularny ajyrdy Jacaqov da berdi alnyn ol qojnun

(8) čybarg̉a da bar qarany qojunda Lavannyn da qojdu özüńa

(9) bölekĺar bašqa da qojmady alarny qoju qatyna Lavannyn. והיה [41]

\footnotetext{
${ }^{1} \mathrm{~K}$ : ačyq; a scribal error. | TKow.o1: ačyq.| H: acyp.| C: ačmaġyn. $\quad{ }^{2}$ Marginal insertion by another
} hand. | TKow.o1: aq. | H: aqny. | C: aqnyy. 
(1) the Lord has blessed you because of my foot $^{143}$. And now, when

(2) shall I also work ${ }^{44}$ for my house?' [31] And Laban said,

(3) 'What shall I give you?' And Jacob said, 'You shall not give me anything,

(4) if you will do this thing for me: I will go back, pasture,

(5) keep your flock. [32] I will pass among all your flock today,

(6) to remove from there all the speckled and spotted sheep, and

(7) all the black sheep among the lambs, and the spotted and speckled

(8) among the goats: and I will have my wages. [33] So

(9) shall my rectitude testify for me in the day of tomorrow, when it shall come

(10) for my wages in front of you. Every one that is not speckled and spotted

(11) among the goats, and black among the lambs, it is stolen with me.'

(12) [34] And Laban said, 'Good! Let it be according to your word.'

(13) [35] But that day Laban removed the

(14) male goats that were striped and spotted, and all the

(15) |female| goats that were speckled and spotted, and every one that

(16) had some white in it, and all the black among the lambs, and gave them into the hand

(17) of his sons. [36] And he set three days' journey between

(18) himself and Jacob: and Jacob pastured

(19) the rest of Laban's flocks. [37] And

(20) Jacob took fresh rods of linden, and of hazelnut and of chestnut

(21) tree, and whittled white |stripes| in them, opening the \{white $\}$ which

(1) is on the rods. [38] And he set the rods

(2) which he had whittled in the gutter, in the watering troughs at which

(3) the flock came to drink, in front of the flock: They copulated

(4) when they came to drink. [39] And the flock copulated

(5) looking at the rods, and gave birth to

(6) striped, speckled, and spotted flock. [40]

(7) And Jacob separated the lambs, and set the front of the flock

(8) toward the striped and every black in the flock of Laban. And he put his own

(9) droves separately, and he did not set them by Laban's flock. [41]

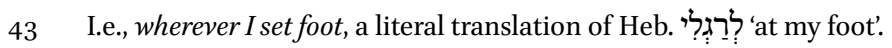

44 Lit. 'do', a literal translation of Heb. עָשָָׁ' '1. to do, to make; 2. to work; \&cc.'. 
(10) Da edi bar issinǵan vaḥtta ol qoj ol jazdag̉ylar

(11) da qojaredi Jacaqov ošol ol tajaqlarny közlerič́a ol qoj-

(12) nun korytalarda issitma alarny tajaqlar byla. ובהעטיף. [42]

(13) Da ol küzdegi qojġa qojmasedi da boluredi ol küzde-

(14) gilar Lavanġa da ol jazdaġylar Ja'aqovġa. ויפרץ [43] Da

(15) jajyldy ol kiši astry astry da boldu anar qoj köp

(16) da qaravašlar da qullar da tevelar da ešeklar.

Genesis 31

.ישמע [1]

(17) Da ešitti Jacaqov ošol sözlerin \{ulanlarynyn\} Lavannyn ajtadog̉ač aldy

(18) Ja'aqov ošol neki atamyznyn da atamyznynqydan qyldy ošol

(19) ol malny ošpunu. [2] Da kördü Ja'aqov ošol jüzlerin

(20) Lavannyn da muna tüvüldü anar tünelej biri künlej. [3]

(21) Da ajtty Adonaj Jacaqovġa qajtqyn jerińa atalaryjnyn da

$49 \mathrm{r}^{\circ}$ (1) tuvmušuja da bolur bolušluğum birgeja. וישלח. [4 Da

(2) ijdi Ja'aqov da ündedi Rahelni da Le’any ol tüzǵa qoju-

(3) na özünün. ויאמר [5] Da ajtty alarg̉a köremen

(4) men ošol jüzlerin atajyznyn ki tüvüldü maja tünelej biri

(5) künlaj da Tenrisi atamnyn edi qatymda. ואתנה. [6]

(6) Da siz bilesiz ki bar küčüm byla qulluq ettim atajyzġa.

(7) [7 [7 Da atajyz aldady meni da tüvšürdü ošol

(8) jalymny on tüslü da erk bermedi anar Tenri jaman et-

(9) me birgeḿa. אם. [8] Eger bulaj ajtsajedi bürtük-

(10) lülar bolur jalyj senin da töreredilar bar ol qoj bürtük-

(11) lülerni da eger bulaj ajtsajedi čybarlar bolsun jalyj senin

(12) da törerediĺar bar ol čybarlarny. ויצל [9] Da tonady

(13) Tenri ošol tuvaryn atajyznyn da berdi maja. [יהי [10]

(14) Da edi issinǵan vaḥtta ol qoj da kötürdüm köz-

(15) lerimni da kördüm tüš ašyra da muna ol tegeler

(16) ol baruvčular ol qojbyla čybarlar bürtüklülar da buz- 
(10) And it was at every breeding-heat of the ${ }_{L}$ summer|-born| sheep ${ }^{145}$ :

(11) Jacob laid the rods before the eyes of the sheep

(12) in the gutters, to make them breed by the rods. [42]

(13) ${ }_{L}$ But to the autumn|-born| sheep ${ }^{146}$, he would not put them in, so the autumn|-born|

(14) were Laban's, and the summer|-born|Jacob's. [43] Thus

(15) the man expanded very, very $\mid$ much $\mid$ and had many sheep,

(16) and maidservants, and servants, and camels, and donkeys.

\section{Genesis 31}

(17) And Jacob heard the words of Laban's sons, saying,

(18) 'Jacob has taken away all that was our father's, and he has made this fortune from that which was our father's.'

(19) [2] And Jacob saw the countenance

(20) of Laban, and, lo, it was not toward him as before. [3]

(21) And the Lord said to Jacob, 'Return to the land of your fathers, and

(1) to your kindred, and my help will be with you. [4] And

(2) Jacob sent and called Rachel and Leah to the field

(3) to his flock. [5] And he said to them, 'I see

(4) your father's countenance, that it is not toward me as before.

(5) And the God of my father has been with me. [6]

(6) And you know that with all my power I have served your father.

(7) [7] And your father has deceived me, and changed

(8) my wages in ten ways, but God did not let him

(9) hurt me. [8] If he said thus: "The speckled

(10) shall be your wages," then all the flock bore speckled.

(11) And if he said thus: "The striped shall be your wages,"

(12) then all the flock bore striped. [9] Thus

(13) God has taken away the livestock of your father, and given them to me. [10]

(14) And it was at the time that the flock conceived, and I raised

(15) my eyes, and saw in a dream: and, lo, the rams

(16) which walked with the flock were striped, speckled, and

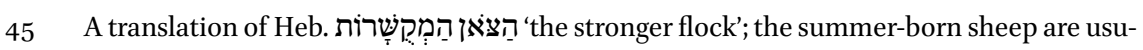
ally stronger, see Stritzke \& Whiteman (1982).

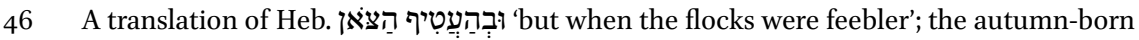
sheep are usually feebler, see Stritzke \& Whiteman (1982). 
(17) betlílar. ויאמר [11 Da ajtty maja malahy ol Tenrinin

(18) tiיאמר. [12]

(19) Da ajtty kötürgün endi közlerijni da körgün bar ol

(20) tegeler ol baruvčular ol qoj byla čybarlar bürtüklülar da

(21) buzbetlílar ki kördüm ošol barča neki Lavan qylady saja.

$49 \mathrm{v}^{\mathrm{o}}$ (1) אנכי (13] Menmen ol Tenri Tenrisi Bet'elnin ki jaġyndyrdyj

(2) anda maceva ki nijet ettij maja anda nijet haligińa turg̉un

(3) čyqqyn ol jerd́an ošpu da qajtqyn jerińa tuvmušujnun.

(4) [ [14 Da qaruv berdi Rahel da Le’a da ajttylar anar

(5) hanuzmo bardy bizǵa ülüš da tijiš üvünd́a atamyznyn.

(6) הלא [15] Muna jatlar kibik saġyšlandyq anar ki satty bizni

(7) da ašady daġyn ašama ošol kümüšümüznü. כי. [16] Ki bar

(8) ol ḥožalyq ki tonady Tenri atamyzdan bizgedi ol da ulan-

(9) larymyzġa da haligińa barča ne ki ajtty Tenri saja qylġyn.

(10) ויקם [17] Da turdu Ja'aqov da kötürdü ošol ulanlaryn da

(11) ošol qatynlaryn da olturg̉uzdu ol tevelar üstüne.

(12) .ינהג Da könderdi ošol bar tuvaryn özünün da ošol

(13) bar malyn ki mallady jyjynyn malnyn ki mallady Padan Aramda

(14) kelme Jichaqqa atasyna jerińa Kenáannyn. ולבן [19] Da

(15) Lavan bardy qyrqma ošol qojnun özünün da urlady Rahẹel

(16) ošol ol sturlaplarny ki atasynyn. [20] Da urlady

(17) Ja'aqov ošol kölnün Lavannyn ol Aramlynyn anlatmasqa anar

(18) ki qačady ol. ויברח [21] Da qačty ol da barča neki anyn

(19) da turdu da ašty ošol ol özenni da qojdu ošol jüzle-

(20) rin tavysary ol Gil'adnyn. [22] Da anlatyldy Lavanġa

(21) ol üčünčü künd́a ki qačty Jacaqov. ויקח. [23] Da aldy

$5^{\circ} \mathrm{r}^{\mathrm{o}} \quad$ (1) ošol qaryndašlaryn birgesińa da quvdu artyndan Ja'aqovnun

(2) jol jedi künlük $\_\langle\text {da quvdu }\rangle\{\text { da jetti }\}^{11}$ any tavynda ol Gil'adnyn. ויבוא. [24]

(3) Da keldi malaḩ Lavanġa ol Aramlyğa tüšüašyra ol keče-

(4) nin da ajtty anar saqlanġyn özüja maġat sözlersen Ja‘aqov

(5) byla jahšydan jamanġadejin. וישג. [25] Da jetti Lavan ošol

(6) Ja'aqovnu da Ja'aqov qurdu ošol čatyryn tavda da Lavan qurdu

(7) čatyryn qaryndašlarybyla tavynda ol Gil'adnyn. יויאמר. [26]

(8) Da ajtty Lavan Jacaqovġa ne qyldyj da urladyj ošol

(9) kölnümnü da könderdij ošol qyzlarymny jesirlengen-

(10) lerinkibik qylyčnyn. למה. 27] Nek jašyndyj qačma da

\footnotetext{
${ }^{1}$ Correction by another hand. | TKow.o1: da jetti. | H: da jetti.| C: da jetti.
} 
(17) spotted. [11] And the angel of God said to me

(18) in a dream, "Jacob," and I said, "Lo, I am here." [12]

(19) And he said, "Lift up now your eyes, and see, all

(20) the rams which walk with the livestock are striped, speckled, and

(21) spotted. Because I have seen everything that Laban is doing to you.

(1) [13] I am the God of Bethel, where you anointed

(2) the pillar, and where you vowed a vow to me. Now arise,

(3) go out from this land, and return to the land of your kindred."'

(4) [14] And Rachel and Leah answered, and they said to him,

(5) 'Is there still a portion or share for us in our father's house?

(6) [15] Lo, were are thought of as strangers by him, because he has sold us,

(7) and has devoured our silver as well. [16] Because all

(8) the wealth that God has taken from our father: it is ours and our

(9) children's. And now, do everything that God has said to you.'

(10) [17] So Jacob rose up, and lifted his sons and

(11) his wives and set them on camels.

(12) [18] And he drove away all his livestock, and

(13) all his goods which he gained, the multitude of goods which he had gotten in Paddan-Aram,

(14) to go to Isaac, his father, in the land of Canaan. [19] And

(15) Laban went to shear his sheep. And Rachel stole

(16) the household idols that were her father's. [20] And

(17) Jacob stole the heart of Laban, the Aramean, by not telling him

(18) that he was fleeing. [21] And he fled with all that he had,

(19) and he rose up, and crossed the river, and set his face

(20) toward mount Gilead. [22] And it was told to Laban

(21) on the third day that Jacob had fled. [23] And he took

(1) his brothers with him, and pursued Jacob

(2) seven days' journey, 〈and pursued $\rangle$ \{and he reached $\}$ him in Mount Gilead. [24]

(3) And an angel came to Laban, the Aramean, in a dream by night,

(4) and said to him, 'Take heed to yourself lest you speak with Jacob:

(5) from good to bad.' [25] Then Laban reached

(6) Jacob, and Jacob had pitched his tent in the mountain. And Laban

(7) with his brothers pitched his tent in the mount of Gilead. [26]

(8) And Laban said to Jacob, 'What have you done, that you have stolen

(9) my heart, and driven away my daughters like captives

(10) of a sword? [27] Why did you hide to flee away, and 
(11) urladyj kölnümnü da anlatmadyj maja da uzatqajedim

(12) seni bijenčbyla da širalar byla taf byla da qobuz byla.

(13) ולא (28] Da kemišmedij maja zaman öpma uvullarymny

(14) da qyzlarymny haligińa telilik etti[j]1 qylma. יש [29]

(15) Bardy küč qolumda qylma birgejizǵa jamanlyq ančaq ki

(16) Tenri[si $]^{2}$ atajyznyn bigič́a ajtty maja ajtadog̉ač saqlanġyn

(17) özüja sözlemektan Ja'aqov byla jahšyydan jamanġadejin.

(18) [ועתה [30] Da haligińa barma bardyj ki küsenma küsendij

(19) üvüńa atajnyn nek urladyj ošol abaġymny. ויען. [31] Da

(20) qaruv berdi Jacaqov da ajtty Lavanġa anyn üčün anlatmadym

(21) barg̉anymny \{ki qorqtum\} ki ajttym mag̉at talarsen ošol qyzlaryjny mend́an.

$5^{\circ} \mathrm{v}^{\mathrm{o}}$ (1) עם [32] [Vale abag்yjny almadym ${ }^{13}$ kim qatyna tapsaj ošol abag்yj-

(2) ny tiri bolmasyn qaršysyna qaryndašlarymyznyn tanyg்yn ned́a

(3) artyq qatymda da alğyn özüja da bilmedi Jacaqov ki

(4) Rahel urlady ol sturlaplarny. ויבא. [33] Da keldi Lavan čatyry-

(5) na Ja'aqovnun da čatyryna Le’anyn da čatyryna eki ol qara-

(6) vašlarnyn da tapmady da čyqty čatyryndan Le’anyn da keldi

(7) čatyryna Raḥelnin. ורחל. [34] Da Raḥel aldy ošol ol stur-

(8) laplarny da qojdu alarny jastyg்yna ol tevenin da oltur-

(9) du alar üstüńa da qarmady Lavan ošol bar ol čatyrny

(10) da tapmady. ותאמר. [35] Da ajtty Rahel atasyna özü-

(11) nün ačuv bolmasyn közlerind́a bijimnin ki bolalmanmen turma

(12) alnyjdan ki jolu qatynlarnyn maja da tyntty Lavan da tapmady

(13) ošol ol sturlaplarny. ויחר. [36] Da ačuv boldu Ja'aqov-

(14) ġa da talašty Lavan byla da bašlady Jacaqov da ajtty Lavan-

(15) ga nedir güneḥim nedir jazyg̉ym ki quvduj menim artyna.

(16) כי (37] Ki qarmadyj ošol bar savutlarymny ne taptyj bar

(17) savutlaryndan üvüjnün qojğun bunda qaršysyna qaryndaš-

(18) larymyn ki alardy qaryndašlaryj senind́a da ügütlesinlar

(19) arasyna eksimiznind́a. זה [38] Bu egirmi jyl men birgeje

(20) qozularyj da ečkilerij tuv etmedilar da qočqarlaryn qojuj-

(21) nun ašamadym. טרפה. [39] Jyrtylğanny keltirmedim saja

${ }^{1} \mathrm{~K}:$ etti; a scribal error. | TKow.o1: ettij. | H: ettin. | C: ettiy. $\quad{ }^{2} \mathrm{~K}$ : Tenri; a scribal error. | TKow.o1: Tenrisi.| H: Tenrisi. | C: Tägrisi. ${ }^{3}$ Interpretative addition to the standard text. 
(11) stole my heart, and did not tell me? And I would have sent you off

(12) with mirth, and with songs, with a tambourine, and with a qobuz ${ }^{47}$ ?

(13) [28] And have not left me time to kiss my sons

(14) and my daughters? Now you've been foolish to do this. [29]

(15) It is in the power of my hand to do bad to you, but

(16) the God of your father spoke to me last night, saying, "Take heed

(17) to yourself lest you speak with Jacob: from good to bad."

(18) [30] And now, you have gone away because you longed greatly

(19) for your father's house, but why did you steal my gods?' [31] And

(20) Jacob answered and said to Laban, 'I did not tell you

(21) that I go because I was afraid, because I said, "Lest you rob your daughters from me."

(1) [32] B But I did not take your gods ${ }^{148}$, anyone with whom you find your gods,

(2) shall not live. In front of our brothers recognize what is

(3) yours still with me, and take it to you.' And Jacob did not know that

(4) Rachel had stolen the household idols. [33] And Laban came in

(5) Jacob's tent, and in Leah's tent, and in the two maidservants' tents,

(6) but he did not find them. And came out from Leah's tent and came in

(7) Rachel's tent. [34] And Rachel had taken the household idols,

(8) and put them in the camel's saddle, and sat

(9) on them. And Laban felt |around| the whole tent,

(10) but he did not find them. [35] And she said to her father,

(11) 'Let there be no anger in my lord's eyes that I cannot rise up

(12) before you, because I have the way of women.' And he searched, but did not find

(13) the household idols. [36] And Jacob was angry,

(14) and he quarrelled with Laban. And started and said to Laban,

(15) 'What is my trespass? What is my sin, that you have pursued me,

(16) [37] That you have felt through all my vessels? What did you find of all

(17) your household vessels? Set it here, before my brothers

(18) that are also your brothers, that they may judge

(19) between us two. [38] These twenty years I have been with you.

(20) Your ewes and your |female| goats have not miscarried,

(21) and I have not eaten the rams of your flocks. [39] What was torn up |by wild beasts| I did not bring to you.

$47 \quad$ A kind of string instrument.

48 An interpretative addition to Gen 31:32. 
$51 \mathrm{r}^{\mathrm{o}} \quad$ (1) men žurumun kötürejim anyn qolumdan izlegin any urlatqa-

(2) nymny kündüz da urlatqanymny kečebyla. היית. [40] Edim

(3) kütüvčü qojujnu kündüz küvdürdü meni qurğaqlyġy

(4) qujašnyn da suvuq kečebyla da bürelip ketti juqum közle-

(5) rimd́an. זה [41] Bu maja egirmi jyl üvüjda qulluq et-

(6) tim saja [o]ndörtt ${ }^{1}$ jyl eki qyzlaryj üčün da alty jyllar

(7) qojuj üčün da tüvšürdüj ošol jalymny on tüslü.

(8) לולי [42] Eger bolušluğu Tenrisinin atamnyn ki oldu Tenrisi

(9) Avrahamnyn da qorquvu Jichaqnyn bolamsajedi maja ki haligi-

(10) ne bošnu ijgejdij meni ošol qyjynymny da ošol zaḥmetin

(11) uvučlarymnyn kördü Tenri da ügütledi bigeče.

(12) ולי [43] Da qaruv berdi Lavan da ajtty Ja'aqovga ol qyzlar

(13) qyzlarymdy da ol ulanlar ulanlarymdy da ol qoj qojumdu

(14) da barča neki sen köresen menimdi ol da qyzlaryma ne

(15) qylajym alarg̉a bügün jemese ulanlaryna alarnyn ki töredilar.

(16) (44] Da haligińa kel kesejik šert men da sen da bol-

(17) sun tanyq arama da araja. ויקח [45] Da aldy Ja'aqov taš

(18) da kötürdü any bolma maceva. [46] Da \{ajtty\} Jacaqov

(19) qaryndašlaryna čöplejiz tašlar da aldylar tašlar da qyldylar

(20) oba da ašadylar anda ol oba qatyna. [יקרא Da

(21) atady anar Lavan Jeġar Sahaduta da Jacaqov atady anar Gal'ed.

$51 \mathrm{~V}^{\mathrm{o}}$ (1) ויאמר (48] Da ajtty Lavan tanyqty ol oba ošpu arama

(2) da araja bügün anyn üčün atady atyn anyn Gal'ed. והמצפה. [49]

(3) Da ol baqma ${ }^{2}$ ki ajtty baqqaj Adonaj arama da araja ki

(4) jašynsaq kisi dostundan. אם. [50] Eger qyjnasaj ošol

(5) qyzlarymny da eger alsaj qatynlar qyzlarym qatyna johtur

(6) jat kiši birgemizǵa baqqyn Tenridi tanyq arama da araja.

(7) ויאמר [51 Da ajtty Lavan Ja'aqovğa muna ol oba ošpu

(8) da muna ol maceva ki saldym arama da araja. עמר [52]

\footnotetext{
${ }^{1} \mathrm{~K}:$ öndört; a scribal error. | TKow.o1: ondort [sic!].] | H: on dert. | C: on dört. ${ }^{2}$ A mistranslation. | TKow.o1: baqma. | H: baqma. | C: Mičpa. | V: Micpa. | R: Micpa. | Heb. מִצְּפָּה (Mizpah (a place in Gilead)'.
} 
(1) I would bear the punishment of it myself: you would require it from $\quad 5^{1} \mathrm{r}^{\mathrm{o}}$ my hand,

(2) whether stolen by day or stolen by night. [40] I was

(3) the herdsman of your flock, the drought of sun burned me by day,

(4) and the cold by night, and my sleep disturbed me and fled from my eyes.

(5) [41] These were for me twenty years in your house. I served

(6) you fourteen years for your two daughters, and six years

(7) for your flock, and you have changed my wages in ten ways.

(8) [42] If the help of the God of my father, the God

(9) of Abraham and the Fear of Isaac, had not been on my side,

(10) by now you would have sent me away empty. God saw my affliction and the labour

(11) of my hands and rebuked you last night.'

(12) [43] And Laban answered and said to Jacob, 'These daughters

(13) are my daughters, and these children are my children, and these flocks are my flocks,

(14) and all that you see is mine. But what can I do to my daughters, to these,

(15) today, or to their children whom they have borne?

(16) [44] So now come, let us make a covenant, I and you. And let it be

(17) for a witness between me and you.' [45] And Jacob took a stone,

(18) and set it up for a pillar. [46] And Jacob said

(19) to his brothers, 'Gather stones,' and they took stones and made

(20) a heap. And they ate there at the heap. [47] And

(21) Laban called it Jegar-Sahadutha, but Jacob called it Galeed.

(1) [48] And Laban said, 'This heap is a witness between me

(2) and you this day.' On account of this he called its name Galeed, [49]

(3) And Watchtower ${ }^{49}$, because he said, 'May the Lord watch between me and you

(4) when we hide from one another. [50] If you shall afflict

(5) my daughters, or if you shall take other wives beside my daughters, no

(6) other man is with us, see, God is witness between me and you.'

(7) [51] And Laban said to Jacob, 'Behold this heap,

(8) and behold this pillar, which I have set between me and you. [52]

49 A mistranslation based on the consfusion of Heb. מִצְפָָ 'Mizpah (a place in Gilead)' and Heb. מִ מִצֶפֶה . watchtower; 2. lookout'. Translated correctly in C, V, and R. 
(9) Tanyqty ol oba ošpu da tanyqty ol maceva eger

(10) men dušman bolsam saja ki ašmaġajmen saja ošol ol obany

(11) ošpunu da eger sen dušman bolsaj maja ki ašmag̉ajsen

(12) maja ošol ol obany ošpunu da ošol ol macevany oš-

(13) punu jamanlyqqa. אלהי. [53] Tenrisi Avrahamnyn da Tenrisi

(14) Nahornun töre etkejlar aramyzda ${ }_{\mathrm{L}}\langle$ Elohej $\rangle\{[\mathrm{T}] \text { enrisi }\}^{11}$ atalarynyn da

(15) antetti Ja'aqov qorquvubyla atasynyn Jichaqnyn. ויזבח [54]

(16) Da debeḥa etti Ja'aqov tavda da ündedi qaryndašlaryn aša-

(17) ma ötmek da ašadylar ötmek da qondular tavda.

Genesis $3^{2}$

(18) Da tünlej turdu Lavan ertenbylada da öptü

(19) ulanlaryn da qyzlaryn da alğyšlady alarny da bardy da qajtty

(20) Lavan ornuna. ויעקב. Da Ja'aqov bardy joluna da joluqtu-

(21) lar any malahlary Tenrinin. ויאמר [3] Da ajtty Ja'aqov ki

$5^{2} \mathrm{r}^{\mathrm{o}} \quad$ (1) nečik kördü alarny avuludu Tenrinin bu da atady atyn ol

(2) orunnun Mahanajim.

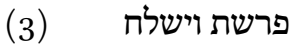

(4) [4] Da ijdi Ja'aqov elči-

(5) ler alnyndan özünün 'Esavğa qaryndašyna

(6) jerińa Se'irnin tüzüńa Edomnun. [5] Da bujurdu

(7) alarğa ajtadog̉ač bulaj ajtyjyz bijiḿa 'Esavğa bulaj ajtty

(8) quluj Ja'aqov Lavan qatyna tirildim da kečiktim bu zamangadejin.

(9) ויהי Da boldu maja ögüz da ešek qoj da qul da

(10) qaravaš da ijdim anlatma bijiḿa tapma širinlik köz-

(11) lerijd́a. [7] Da qajttylar ol elčilar Ja'aqov-

(12) ġa ajtadoġač keldik qaryndašyja 'Esavğa da dağyn bardy

(13) uturuja da dört jüz kiši birgesińa. ויירא. [8] Da

(14) qorqtu Ja'aqov astry da qysyq boldu anar da ajyrdy ošol

(15) ol ulusnu ki birgesińa da ošol ol qojnu da ošol ol

(16) syǵyrny da ol tevelerni eki avullarg̉a. ויאמר. [9] Da

\footnotetext{
${ }^{1}$ TKow.o1: Tenrisi. | H: Tenrisi. | C: Täyrisi. $\quad{ }^{2} \mathrm{~K}$ : Gen 32:1 is copied as Gen 31:55; a scribal error. | TKow.o1: Gen 32:1 had been initially copied as Gen 31:55, but this scribal error was later corrected by the copyist. | H: Gen 32 begins here. | ADub.III.82: Gen $3^{2}$ begins here. | C: Gen 32 begins here. | M: Gen 32 begins here. | R: Gen 32 begins here. | V: Gen 32 begins here. | Hebrew Bible: Gen 32 begins here.
} 
(9) This heap is a witness, and this pillar is a witness:

(10) that I may not pass over this heap to you if I were hostile to you,

(11) and, if you were hostile to me, that you may not pass over

(12) this heap and over this pillar to me,

(13) for bad. [53] The God of Abraham, and the God

(14) of Nahor, 〈Elohei〉 the God of their father, judge between us.' And

(15) Jacob swore by the Fear of his father Isaac. [54]

(16) And Jacob offered sacrifice in the mountain, and called his brothers to eat

(17) bread, and they ate bread, and spent the night in the mountain.

Genesis $3^{2^{50}}$

(18) [1] And early in the morning Laban rose up and kissed

(19) his sons and his daughters and blessed them. And Laban departed and returned

(20) to his place. [2] And Jacob went on his way, and

(21) the angels of God met him. [3] And Jacob said, when

(1) he saw them, 'This is God's camp!' So he called the name of

(2) that place Mahanaim.

(3) Parashat Vayishlach

(4) [4] And Jacob sent messengers

(5) before him to Esau his brother

(6) in the land of Seir, to the plain of Edom. [5] And he commanded

(7) them, saying, "Thus shall you say to my lord Esau: "Thus said

(8) your servant Jacob, "I have sojourned with Laban, and stayed there until now.

(9) [6] And I have bulls, and donkeys, flocks, and servants, and

(10) maidservants. And I have sent to tell my lord so as to find favour in your eyes." "'

(11) [7] And the messengers returned to Jacob,

(12) saying, 'We came to your brother Esau, and also he is coming

(13) to meet you, and four hundred men with him.' [8] And

(14) Jacob was very afraid and distressed. And he divided

(15) the people that were with him, and the flocks, and

(16) the cattle, and the camels, into two camps. [9] And

50 K: Gen 32:1 is copied as Gen 31:55; a scribal error. 
(17) ajtty eger kelśa 'Esav ol bir avulġa da qyrsa any

(18) da bolur ol avul ol qalġan qutulmaqqa. ויאמר [10] Da

(19) ajtty Jacaqov e Tenrisi atamnyn Avrahamnyn da Tenrisi

$52 \mathrm{v}^{\mathrm{o}} \quad$ (1) atamnyn Jicḥaqnyn Adonaj ol ajtuvču maja qajtqyn jerija da tuv-

(2) mušuja da jaḩšy etermen birgeja. קטנתי. [11] Kiči boldum

(3) bar ol šavağatlardan da bar ol kertilikten ki qyldyj quluj byla

(4) ki tajaġym byla aštym ošol ol Jardenni ošpunu da haligińa

(5) boldum eki avullarg̉a. הצילני. [12] Qutqarg̈yn meni qoltqabyla

(6) qolundan qaryndašymnyn qolundan 'Esavnyn ki qorqamen men andan

(7) mag̉at kelir da öltürür meni da öltürür anany ulanlar

(8) byla. ואתה [13] Da sen ajttyj jahšy etma jahšy eter-

(9) men birgeja da qojarmen ošol urlug̉ujnu qumun kibik ol

(10) tengiznin ki sanlamasty köplüktan. [ילן. [14] Da qondu

(11) anda ol kečeni da aldy ol kelgend́an qoluna tirki 'Esav-

(12) ġa qaryndašyna. [15] Ečkilar eki jüz da tegelar

(13) egirmi qozular eki jüz da qočqarlar egirmi. גמלים [16]

(14) Teveler ömüzdüredoġanlar balalarybyla otuz tiši tanalar

(15) qyrq da erkek tanalar on ešeklar egirmi da qatyrlar

(16) on. ויתן [17 Da berdi qoluna qullarynyn birer bölek bašqa

(17) da ajtty qullaryna ašyjyz alnymda da avlaqlyq ${ }^{1}$ qojujuz

(18) arasyna har bir böleknin. ויצו [18] Da bujurdu ol burun-

(19) ġug̉a ajtadoğač ki joluqsa seni 'Esav qaryndašym da sorsa

(20) send́an ajtadoġač kimnin sen sen da qajry barasen da kimgedi

(21) bular alnyjda. ואמרת] Da ajtqyn qulujnun Ja'aqovnun

$53 \mathrm{r}^{\mathrm{o}} \quad$ (1) tirkidi ol ijilǵan bijiḿa 'Esavġa da muna dag̉yn ol özü-

(2) de keledi biznin artyna. [20] Da bujurdu daggyn ol ekin-

(3) čiǵa daġyn ol üčünčúǵa dağyn barda ol baruvčularg̉a

(4) ol bölekler artyna ajtadoğač ošpu söz kibik sözlejiz

(5) 'Esavġa joluqqanyjyzda any. [21] Da ajt[y]jyz² daġyn

(6) muna quluj Ja'aqov keledi biznin artyna ki ajtty japyrajym

(7) ačuvun anyn tirkibyla ol baruvču alnymda da andan

\footnotetext{
${ }^{1} \mathrm{~K}$ : avalaqlyq; a scribal error. | TKow.o1: avlaqlyq. | H: avlaqlyq. | C: keyišlik. $\quad{ }^{2} \mathrm{~K}$ ajtajyz; a scribal error. | TKow.o1: ajtyjyz. | H: ajtynyz. | C: ajtyyyz.
} 
(17) he said, 'If Esau comes to the one camp, and smites it,

(18) then the other camp which is left shall escape.' [10] And

(19) Jacob said, 'Oh God of my father Abraham, and God

(1) of my father Isaac, the Lord who said to me, "Return to your country, $\quad 5^{2} \mathrm{v}^{\mathrm{o}}$

(2) and to your kindred, and I will deal well with you," [11] I became too small

(3) for all the mercies, and for all the truth, which you have done to your servant,

(4) because I crossed this Jordan with |just| my staff, and now

(5) I have become two camps. [12] Deliver me, I pray you,

(6) from the hand of my brother, from the hand of Esau, because I fear him,

(7) lest he will come and kill me, and kill the mother with the children.

(8) [13] And you said, "I will surely do well with you,

(9) and I will make your offspring like the sand

(10) of the sea, that it will not be countable because of its multitude."' [14] And he stayed

(11) there that night. And he took of that which came to his hand an offering for Esau

(12) his brother: [15] Two hundred |female| goats, and twenty male goats,

(13) two hundred ewes, and twenty rams, [16]

(14) thirty milking camels with their calves, forty heifers,

(15) and ten bull calves, twenty |female| donkeys, and ten male donkeys.

(16) [17] And he gave them to the hand of his servants, every drove separately,

(17) and said to his servants, 'Pass over before me, and put a space

(18) between each drove.' [18] And he commanded the first,

(19) saying, 'If Esau my brother meets you, and asks

(20) you, saying, "Whose are you? And where are you going? And whose are

(21) these before you?" [19] then you shall say, "They are your servant Jacob's.

(1) It is a present sent to my lord Esau. And, lo, he himself

(2) comes behind us as well."' [20] And he also commanded the second,

(3) also the third, also all that followed

(4) the droves, saying, 'You shall speak like this

(5) to Esau, when you find him, [21] And say,

(6) "Lo, your servant Jacob comes behind us as well."' Because he said, 'I will soothe

(7) his anger with the offering that goes before me, and afterward 
(8) sortun körermen jüzleri anyn šeme jüz eter jüzlerima.

(9) - ותעבר (22] Da ašty ol tirki alnynda anyn da

(10) ol qondu ol kečeni avulda. [23] Da turdu ol kečeni

(11) da aldy ošol eki qatynlaryn da ošol eki qaravašlaryn da

(12) ošol on bir uvullaryn da ašty ošol köčüvün Jaboq ${ }_{L}$ ün-

(13) deledog̉an ornun ol özennin ${ }^{11}$. ויקח [24] Da aldy alar-

(14) ny da ašyrdy alarny ol özenašyra da ašyrdy ošol

(15) neki özünün. [יותר [25] Da qaldy Ja'aqov jalġyz özü

(16) da čengešti malah birgesińa kötürülgünče ol šaḥar.

(17) וירא (26] Da kördü ki jenelmedi any da tijdi češka-

(18) syna butunun da qozġaldy češkasy butunun Ja'aqovnun čen-

(19) geškenind́a birgesińa. [27] Da ajtty ol

(20) malah Jacaqovğa ijgin meni ki kötürüldü ol šahar da

(21) ajtty Jacaqov ijmenmen seni ki ančaq eger alġyšlasaj

$53 \mathrm{v}^{0}$ (1) meni. ויאמר De [28 Da ajtty anar nedir atyj senin da ajtty

(2) Jacaqovdu. [יאמר [29] Da ajtty ajtylmasty artyq jalġyz

(3) atyj senin Ja'aqov ki ančaq Jisra’el de ki ag̉alyq bolduj malah

(4) byla da erenler byla da jendij alarny. וישאל. [30] Da

(5) sordu Ja'aqov da ajtty anlatqyn endi atyjny da ajtty

(6) nege bu sorasen atymny da alġyšlady any anda. ויקרא [31]

(7) Da atady Ja'aqov atyn ol orunnun Peni'el anyn üčün ki kör-

(8) düm malahnny aqyl aqylg̀a da qutuldu žanym. [32]

(9) Da balqydy anar ol qujaš ki nečik ašty ošol Penu'elni

(10) da ol aqs[a]redi² butu üstüńa. על [33] Anyn üčün

(11) ašamajdylar ulanlary Jisra’elnin ošol gid hanašeni ki češka-

(12) sy üstüńa ol butnun ošpu küngedejin ki tijdi

(13) malaḩ češkasyna butnun Ja'aqovnun gid hanašeǵa.

\section{Genesis 33}

(14) [1] Da kötürdü Ja'aqov közlerin da kördü da

(15) muna 'Esav keledi da dört jüz kiši birgesińa da

(16) ajyrdy ošol ol ulanlarny Le’a qatyna da Raḥel qatyna

(17) da eki ol qaravašlar qatyna. [2] Da qojdu ošol

(18) ol qaravašlarny da ošol ulanlaryn alarnyn burundan da

(19) ošol Le’any da ulanlaryn anyn sondraraq da ošol Raḥel-

\footnotetext{
${ }^{1}$ Interpretative addition to the standard text. $\quad{ }^{2} \mathrm{~K}$ : aqseredi; a scribal error. | TKow.o1: aqsaredi. | H: akseredi. | C: aqsar edi.
} 
(8) I will see his face; maybe he will favour me.'

(9) [22] And the offering passed before him. And

(10) he stayed that night in the camp. [23] And he rose up that night,

(11) and took his two wives, and his two maidservants, and

(12) his eleven sons, and crossed the ford-

(13) La place on the river called ${ }^{151}$ Jabbok. [24] And he took

(14) them, and made them cross the river, and he made pass $\mid$ all $\mid$

(15) that was his. [25] And Jacob was left alone.

(16) And there fought an angel with him until the dawn's rising.

(17) [26] And he saw that he was not able to prevail against him, and he touched the joint

(18) of his thigh, and the joint of Jacob's thigh was moved

(19) during his fighting with him. [27] And the angel said,

(20) 'Let me go, because the dawn has risen.' And

(21) he said, 'I will not let you go, except if you bless

(1) me.' [28] And he said to him, 'What is your name?' And he said,

(2) 'Jacob.' [29] And he said, 'Your name will not be said

(3) Jacob, only, any more, but also Israel, because you were like a ruler with angel

(4) and with men, and you have prevailed them.' [30] And

(5) Jacob asked him, and said, 'Tell me your name.' And he said,

(6) 'Why is this that you ask my name?' And he blessed him there. [31]

(7) And Jacob called the name of the place Peniel: 'Because I have seen

(8) the angel mind to mind, and my life has been delivered.' [32]

(9) The sun shone on him as he passed Penuel,

(10) and he was limping on his thigh. [33] On account of this

(11) the people of Israel to this day do not eat the sinew of the thigh

(12) that is on the joint of the thigh, because the angel touched

(13) the joint of Jacob's thigh, the sinew of the thigh.

Genesis 33

(14) [1] And Jacob raised his eyes, and looked, and,

(15) lo, Esau was coming, and with him four hundred men. And

(16) he divided the children to Leah, and to Rachel,

(17) and to the two maidservants. [2] And he put

(18) the maidservants and their children foremost, and

(19) Leah and her children after, and Rachel

$5^{1} \quad$ An interpretative addition to Gen 32:23. 
(20) ni da ošol Josefni sondraraq. והוא [3] Da ol özü

(21) ašty alynlarynda alarnyn da bašurdu jerǵa jedi keret-

$54 \mathrm{r}^{\circ}$ (1) ler juvuganynadejin qaryndašyna dejin. [4] Da juvurdu

(2) 'Esav uturusuna anyn da qučtu any da tüštü bojunlary-

(3) üstüńa anyn da öptü any da jyladylar. וישא [5] Da

(4) kötürdü ošol közlerin da kördü ošol ol qatynlarny

(5) da ošol ol ulanlarny da ajtty kimdi bular saja da

(6) ajtty ol ulanlar ki ḥajifsünüp berdi Tenri quluja.

(7) [6] Da juvudular ol qaravašlar berrek da ulanlary

(8) alarnyn da bašurdular. ותגש [7] Da juvudu daġyn Le'a

(9) da ulanlary anyn da bašurdular da andan sortun juvudu

(10) Josef da Raḥel da bašurdular. Da ajtty kim-

(11) gedi senin bar ol avul ošpu ki joluqtum da ajtty

(12) tapma širinlik közlerind́a bijimnin. [9] Da

(13) ajtty 'Esav bardy mend́a köbüsü qaryndašym bolsun

(14) saja neki senin. [10] Da ajtty Ja'aqov joq qolt-

(15) qabyla eger endi taptym ese širinlik közlerijda

(16) da alġyn tirkimni qolumdan anyn üčün ki kördüm

(17) jüzlerijni körgenlaj jüzlerin malahnnyn da süvdüj meni.

(18) קח [11] Alg̀yn endi ošol tirkimni ki keltiriledi saja

(19) ki ḥajifsündü meni Tenri da ki bardy maja baryndan da

(20) qustady any da aldy. [יאמר [12] Da ajtty 'Esav kö-

(21) čejik da barajyq da barajym alnyjda. יויאמר. [13] Da

$54 \mathrm{v}^{\mathrm{o}} \quad$ (1) ajtty Ja'aqov 'Esavğa bijim biledi ki ol ulanlar jaštylar

(2) da ol qoj da syġyr balalylar qatymda da qystasalar alar-

(3) ny bir kün da ölerlar bar ol qoj. יעבר . [14] Ašsyn

(4) endi bijim alnynda qulunun da men könderilirmen aqyr-

(5) tynlyqbyla jürüšüńa köŕa ol tuvarnyn ki alnymda

(6) da jürüšüńa köŕa ol ulanlarnyn neginč́a ki kelgejḿan

(7) bijima Secirǵa. ויאמר [15] Da ajtty 'Esav qaldy-

(8) rajym endi birgeja ol ulustan ki qatymda da ajtty

(9) Ja'aqov negedir bu tabajym širinlik közlerind́a bijimnin.

(10) וישב (16) Da qajtty ol künd́a Esav joluna özünün

(11) Secirǵa. ויעקב [17] Da Ja'aqov köčtü Sukotqa

(12) da qondardy özüna üv da tuvaryna qyldy alačyq-

(13) lar anyn üčün atady atyn ol orunnun Sukot.

(14) [יבוא Da keldi Ja'aqov tynč šaharyna Šehemnin ki 
(20) and Joseph after. [3] And he himself

(21) passed over before them, and bowed himself to the ground seven times,

(1) until he came near to his brother. [4] And Esau ran

(2) to meet him, and embraced him, and fell on his neck,

(3) and kissed him. And they wept. [5] And

(4) he raised his eyes, and saw the women

(5) and the children, and said, 'Who are these to you?' And

(6) he said, 'The children which God has graciously given your servant.'

(7) [6] And the maidservants came here, and their children,

(8) and they bowed down. [7] And Leah also came near

(9) with her children, and bowed down. And afterwards

(10) Joseph and Rachel came near, and they bowed down. [8] And he said, 'For whom

(11) is all this camp of yours that I met?' And he said,

(12) 'To find favour in the eyes of my lord.' [9] And

(13) Esau said, 'I have many |things|, my brother. What is yours

(14) shall be yours.' [10] And Jacob said, 'No, I pray you,

(15) if I have now found favour in your eyes,

(16) then take my offering from my hand, because I have seen

(17) your face, which is like seeing the face of an angel, and you loved me.

(18) [11] Take, now, my offering that is brought to you,

(19) because God had mercy on me, and because I have everything.' And

(20) he pressed him, and he took it. [12] And Esau said,

(21) 'Let us journey, and let us go, and let me go before you.' [13] And

(1) Jacob said to Esau, 'My lord knows that the children are young,

(2) and the flocks and cattle beside me are with young. If they press them

(3) one day, all the flock will die. [14] My lord shall pass on

(4) in front of his servant, and I will lead on

(5) carefully, according to the gait of the livestock that is before me,

(6) and according to the gait of the children, until I come

(7) to my lord to Seir. [15] And Esau said, 'Let me now leave

(8) with you |some| of the people that are with me.' And

(9) Jacob said, 'Why is that? Let me find favour in the eyes of my lord.'

(10) [16] So Esau returned that day on his way

(11) to Seir. [17] And Jacob journeyed to Succoth,

(12) and built himself a house, and made huts for his livestock:

(13) therefore he called the name of the place Succoth.

(14) [18] And Jacob came quietly to the city of Shechem, 
(15) jerind́a Kena‘annyn kelgenind́a Padan Aramdan da toḥ-

(16) tady alnynda ol šaharnyn. [19] Da satyn aldy ošol

(17) ülüšün ol tüznün ki qurdu anda čatyryn qolundan

(18) ulanlarynyn Ḥamornun atasynyn Šehemnin jüz L $\langle$ qešitaǵa $\rangle$ $\{\text { qozuga }\}^{11}$.

(20] Da turg̉uzdu anda mizbeah da atady anar El

(20) Elohej Jisra'el.

Genesis 34

(20) ותצא [1] Da čyqty Dina qyzy Le’anyn ki

(21) töredi Jaáaqovġa körmáa qyzlaryn ol jernin. וירא. [2]

$55 \mathrm{r}^{\mathrm{r}} \quad$ (1) Da kördü any Šehem uvlu Ḥamornun ol Ḥivilinin nasisi-

(2) nin ol jernin da aldy any da jatty birgesińa da qyjnady

(3) ותדבק . [3] Da jabuštu žany anyn Dinag̉a qyzyna

(4) Ja'aqovnun da süvdü ošol ol qyzny da sözledi kölnü-

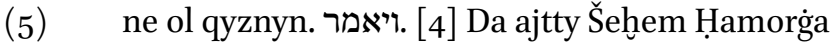

(6) atasyna özünün ajtadog̉ač alg̀yn maja ošol ol qyzny

(7) ošpunu qatynlyqqa. [5] [5a Jacaqov ešitti ki

(8) murdar etti ošol Dina qyzyn da uvullary edilar

(9) tuvarybyla anyn tüzd́a da tyjyldy Jáaqov kelgenlerinedajin.

(10) ויצא [6 Da čyqty Ḥamor atasy Šehemnin Ja'aqovğa söz-

(11) leme anyn byla. [7] Da uvullary Ja'aqovnun keldilar

(12) ol tüzd́an ešitkenlerindečoq da ačyrg̉andylar ol

(13) erenĺar astry da ačuv boldu alarğa ki jerenči iš

(14) qyldy Jisra’elde jatma qyzy byla Jacaqovnun da alaj qylyn-

(15) majdy. [8] Da sözledi Ḥamor birgelerińa aj-

(16) tadoġač Šehemnin uvlumnun süvdü క̌any anyn qyzyjyzny

(17) berijiz endi any anar qatynlyqqa. והתחתנו. [9] Da

(18) qudalašyjyz biznin byla qyzlaryjyzny berijiz bizǵa da ošol qyz-

(19) larymyzny alajyz özüjüzǵa. ואתנו. [10] Da birgemiz-

(20) ǵa olturujuz da ol jer bolsun alnyjyzda olturujuz

(21) da satuv etijiz anda da tutuvlanyjyz anda. יויאמר [11]

$55 \mathrm{v}^{\mathrm{o}}$ (1) Da ajtty $\{\text { Šehem }\}^{2}$ atasyna anyn da qaryndašlaryna anyn tabajym

(2) širinlik közlerijizd́a da neki ajtsajyz maja berirmen.

${ }^{1}$ Correction by another hand; cf., however, Heb. קְשְׁיטָה 'old weight of unknown value' used in the original. | TKow.o1: qozugia. | H: qozuġa.|C: tiši qozuġa. ${ }^{2}$ Insertion by another hand (above the first line). | TKow.o1: Šehem. | H: Šehem. | C: Šehem. 
(15) which is in the land of Canaan, when he came from Paddan-Aram; and

(16) sojourned in front of the city. [19] And he bought a

(17) section of a field, where he had pitched his tent,

(18) at the hand of the children of Hamor, Shechem's father, for a ${ }_{L}$ hundred qesitah ${ }^{152}$.

(19) [20] And he erected there an altar, and called it El-

(20) -Elohe-Israel.

\section{Genesis 34}

[1] And Dinah, daughter of Leah, which

(21) she bore to Jacob, went out to see the daughters of the land. [2]

(1) And when Shechem, son of Hamor, the Hivite, the prince

(2) of the country, saw her, he took her, and lay with her, and tormented

(3) her. [3] And his soul clung to Dinah, daughter

(4) of Jacob, and he loved the girl, and spoke to the heart

(5) of the girl. [4] And Shechem said to Hamor,

(6) his father, saying, 'Get me this girl

(7) for a wife.' [5] And Jacob heard that

(8) he had defiled Dinah, his daughter. And his sons were

(9) with his livestock in the field. And Jacob kept quiet until they came.

(10) [6] And Hamor, father of Shechem, went out to Jacob

(11) to speak with him. [7] And the sons of Jacob came

(12) from the field when they heard it, and the men were very annoyed,

(13) and they became very angry because he had done a repulsive

(14) thing among Israel, to lie with Jacob's daughter and such a thing is not done.

(15) And Hamor spoke with them,

(16) saying, 'The soul of my son Shechem loves your daughter.

(17) Give now her to him for a wife. [9] And

(18) make marriages with us: and give your daughters to us, and

(19) take our daughters for yourselves. [10] And with us

(20) shall you dwell: and the land shall be before you. Dwell

(21) and trade in it, and get possessions in it.' [11]

(1) And $\{$ Shechem $\}$ said to her father and to her brothers, 'Let me find

(2) favour in your eyes, and I will give whatever you say to me.

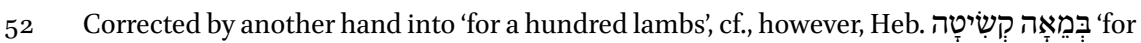
a hundred qesitah'. | TKow.o1: 'lambs'. | H: 'lambs'. | C: 'female lambs'. 
(3) הרבו . [12] Arttyryjyz üstüḿa astry qalyn da berńa

(4) da berejim ki nečik ajtsajyz maja da berijiz maja ošol

(5) ol qyzny qatynlyqqa. [13] Da qaruv berdiĺar uvul-

(6) lary Jacaqovnun Šehemǵa da Ḥamorg̉a atasyna anyn jaltaj-

(7) lyq byla da sözledilar ki murdar etti ošol Dinany

(8) tuvdugiun alarnyn. Da ajttylar alarg̉a

(9) bolalmasbiz qylma ošol ol išni ošpunu berḿa ošol

(10) ${ }_{\llcorner}\langle$qyzymyzny $\rangle\{[\mathrm{t}] \text { uvduġumuznu }\}^{11}$ kišiǵa ki aqlaf anar ki rusvajlyqtyr ol

(11) bizǵa. אך. [15] Tek bununbyla jarašyrbiz siznin byla

(12) eger bolsajyz biznin kibik ḥatna qylynma sizǵa bar

(13) erkek. ונתנו. [16] Da berirbiz ošol qyzlarymyzny

(14) sizǵa da ošol qyzlaryjyzny alarbiz özümüzǵa da

(15) oltururbiz birgejizǵa da bolurbiz bir ulusqa.

(16) [17] Da eger tynlamasajyz bizǵa hatna qylynma

(17) da alyrbiz ošol qyzymyzny da baryrbiz. וייטבו [18)

(18) Da jaḥšy köründülar sözlari alarnyn közlerind́a Ḥamor-

(19) nun da közlerind́a Šehemnin uvlunun Ḥamornun. ולא. [19]

(20) Kečiktirmedi ol ulan qylma ol išni ki süvdü qyzyn

(21) Jacaqovnun da ol syjlyraq edi bar elind́an üvünün atasynyn.

$56 \mathrm{r}^{\mathrm{o}} \quad$ (1) יויבוא 5 [20] Da keldi Ḥamor da Šehem uvlu anyn qabağyna

(2) šaharnyn özlerinin da sözledilar elińa šaharynyn özle-

(3) rinin ajtadoğač. האנשים. [21] Ol erenler ošpular

(4) bazdylar alar birgemizǵa da oltursunlar ${ }_{L}\langle$ anda $\rangle\{\text { jerde }\}^{12} \mathrm{da}$

(5) satuv etsinlar anda da ol jer muna avlaq orunludu

(6) alynlarynda alarnyn ošol qyzlaryn alarnyn alyrbiz özümüz-

(7) ǵa qatynlarg̉a da ošol qyzlarymyz berirbiz alarğa.

(8) אך . 22] Tek bunluq byla jarašyrlar biznin byla ol eren-

(9) lar olturma birgemizǵa bolma bir ulusqa hatna

(10) qylyngaanda bizge bar erkek ki nečik alar ḥatna qylyna-

(11) dylar. מקנהם. [23] Jyjynlary alarnyn da mallary alarnyn

(12) da bar tuvarlary anyn muna biznindi alar ančaq jarašajyq

(13) alar byla da oltursunlar birgemizǵa. וישמעו [24] Da

${ }^{1}$ Correction by another hand. | TKow.o1: tuvduġumuznu. | H: tuvduġumuznu. | C: qyz qardašymyzny. $\quad{ }^{2}$ TKow.o1: birgemizge. | H: jerde. | C: jerdä. | V: jerd́a. | R: jerd́a. 
(3) [12] Go on asking me for dowry and gifts,

(4) and I will give whatever you shall say to me, and give me the

(5) girl for a wife.' [13] And the sons of Jacob answered

(6) Shechem and Hamor, his father, deceitfully,

(7) and spoke, because he had defiled Dinah

(8) their sister. [14] And they said to them,

(9) 'We cannot do this thing, to give

(10) ${ }_{L}\langle$ our daughter $\rangle\{\text { our sister }\}^{153}$ to one who has a foreskin, because that is a disgrace

(11) to us. [15] Only on this |condition| will we bargain with you:

(12) if you will become like us, |in that| every male among you be circumcised.

(13) [16] And we will give our daughters

(14) to you, and we will take your daughters to us, and

(15) we will dwell with you, and we will become one people.

(16) [17] But if you do not listen to us, to be circumcised,

(17) then we will take our daughter, and we will go.' [18]

(18) And their words seemed good in Hamor's eyes,

(19) and in the eyes of Shechem, Hamor's son. [19]

(20) And the young man did not delay to do the thing, because he loved the daughter

(21) of Jacob. And he was more honourable than all the house of his father.

(1) And Hamor and Shechem, his son, came to the gate

(2) of their city, and spoke with the men of their city,

(3) saying, [21] 'These men

(4) are peaceable with us. And they shall dwell ${ }_{L}\langle$ there $\rangle$ in $\mid$ the $\mid$ land ${ }^{154}$, and

(5) trade there. Lo, the land is spacious

(6) before them. We will take their daughters to us

(7) for wives. And we will give them our daughters.

(8) [22] Only this way will the men bargain with us,

(9) to dwell with us, to be one people: if

(10) every male among us is circumcised, as they are circumcised.

(11) [23] Their crowds and their property

(12) and all the livestock: they are, lo, ours. Only let us bargain

(13) with them, and they shall dwell with us.' [24] And

53 Correction by another hand.

54 Correction by another hand. 
(14) tynladylar sözüńa Ḥamornun da Šehemnin uvlunun bar

(15) čyġuvčulary qabag்ynyn šaharnyn da hatna qylyndylar bar er-

(16) kek bar čyğuvčulary qabaġynyn šaharnyn. ויהי [25] Da edi ol

(17) üčünčü künd́a bolġanlarynda syzlavlylar da aldylar

(18) eki uvullary Jacaqovnun Šim'on da Levi qaryndašlary Dina-

(19) nyn kiši qylyčyn da keldiĺar ol šahar üstüńa emin-

(20) lik byla da qyrdylar bar erkekni. [26] Da ošol

(21) Ḥamornu da ošol Šehemni uvlun anyn öltürdüler

$56 v^{\circ} \quad$ (1) qylyč avzundan da aldylar ošol Dinany üvünd́an Šehemem[nin $]^{1}$

(2) da čyqtylar. בני [27] Uvullary Ja'aqovnun keldilar ol qyran-

(3) lar üstüńa da taladylar ol šaharny ki murdar ettilar

(4) tuvduğun alarnyn. את. [28] Ošol qojlaryn alarnyn da ošol

(5) syğyrlaryn da ošol ešeklerin da ošol neki šaharda da

(6) ošol neki tüzd́a aldylar. [29] Da ošol bar mallaryn

(7) da ošol bar jašlaryn da ošol qatynlaryn alarnyn jesir etti-

(8) ler da taladylar da ošol barča neki üvd́a. [30]

(9) Da ajtty Ja'aqov Šim`onġa da Leviǵa čejpadyjyz meni dušman-

(10) laštyrma meni olturuvčusubyla ol jernin Kena'ani byla

(11) da Perizi byla da men sanly el da jyštyrylsalar üstü-

(12) ḿa da öltürürlar meni da taspolurmen men da eli

(13) üvümnün. ויאמרו. [31] Da ajttylar zonanymo kibik

(14) qylġajedi ošol tuvduğumuznu.

Genesis 35

ויאמר [1] Da ajtty

(15) Tenri Jacaqovġa turg̉un barg்yn Bet’elǵa da olturg̉un

(16) anda da qylġyn anda mizbeah Tenriǵa ol aškara boluvču-

(17) ġa saja qačqanyjda alnyndan 'Esavnyn qaryndašyjnyn. [יאמר [2]

(18) Da ajtty Ja'aqov elińa üvünün da baryna neki birgesi-

(19) ńa keterijiz ošol ol jat tenrilerni ki ortajyzda da

(20) arynyz da tüvšürüjüz upraqlaryjyzny. ונקומה. [3] Da

(21) turajyq da barajyq Bet'elge da qylajym anda mizbeah Tenri-

$57 \mathrm{r}^{\mathrm{o}}$ (1) ge ol qaruv berüvčüğa maja tar vaḥtymda da boldu

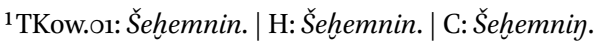


(14) to the word Hamor and to Shechem his son listened

(15) all who went out of the gate of his city. And every male was circumcised,

(16) all that went out of the gate of his city. [25] And it was on the

(17) third day, when they were sore, and

(18) two of the sons of Jacob, Simeon and Levi, Dinah's brothers,

(19) took each man his sword, and came against the city calmly,

(20) and slew every male. [26] And

(21) they slaughtered Hamor and Shechem, his son,

(1) with the edge of the sword, and took Dinah from Shechem's house, $\quad 56 \mathrm{v}^{\mathrm{o}}$

(2) and went out. [27] The sons of Jacob had come upon the slain,

(3) and plundered the city, because they had defiled

(4) their sister. [28] They took their sheep,

(5) and their cattle, and their donkeys, and that which was in the city, and

(6) that which was in the field. [29] And they captured all their possessions,

(7) and all their infants, and their wives,

(8) and plundered all that was in the house. [30]

(9) And Jacob said to Simeon and Levi, 'You have destroyed me, making me

(10) an enemy among the inhabitants of the land, among the Canaanites,

(11) and among the Perizzites, and I am people few in number. And if they gather themselves against

(12) me, they will kill me, and I will be destroyed, both I and my

(13) household.' [31] And they said, 'Shall he treat

(14) our sister like a harlot?'

\section{Genesis 35}

$$
\text { [1] And }
$$

(15) God said to Jacob, 'Arise, go up to Bethel, and dwell

(16) there. And make there an altar to God, who appeared

(17) to you when you fled from before Esau your brother.' [2]

(18) So Jacob said to his household, and to all that were with him,

(19) 'Put away the foreign gods that are among you, and

(20) purify yourselves, and change your garments. [3] And

(21) let us arise, and go up to Bethel, and let me make there an altar to God,

(1) who answered me in the day of my distress, and 
(2) bolušlug̉u anyn birgeḿa jolda ki jürüdüm. ויתנו. [4] Da

(3) berdilar Ja'aqovg̉a ošol bar ol jat tenrilerin ki qolla-

(4) rynda da ošol ol syrgaalarny ki qulaqlarynda alarnyn

(5) da kömdü alarny Jacaqov ol lipa tübüńa ki Šehem qaty-

(6) na. ויסעו [5] Da köčtülar da edi qorquvu Tenri-

(7) nin eli üstüńa ol šaharlarnyn ki čüvrelerind́a alar-

(8) nyn da quvmadylar uvullary artyna Jacaqovnun. [6וא [6]

(9) Da keldi Jacaqov Luzġa ki jerind́a Kena'annyn oldu Bet’el

(10) ol da bar ol ulus ki birgesińa. [7] Da qondardy

(11) anda mizbeah da atady orunġa El Bet’el ki anda

(12) aškara boldular anar ol malahllar qačqanynda alnyndan

(13) qaryndašynyn. ותמת [8] Da öldü Devora ömüzdü-

(14) rüvčüsü Riveqanyn da astraldy ašag̉arraq Bet’elge

(15) ol emen tübüńa da atady atyn anyn [A] lon $^{1}$ Bahut.

(16) וירא [9] Da aškara boldu šehinasy Tenrinin Ja'aqovġa

(17) dag̉yn kelgenind́a Padam Aramdan da alġyšlady any. [10]

(18) Da ajtty anar Tenri atyj senin Ja'aqovdu ündelmesti

(19) atyj senin jalg̀yz Jacaqov ki ančaq Jisra’el de bolur atyj

(20) senin da atady $\{[\text { oš }] \text { ol }\}^{2}$ atyn anyn Jisra'el. ויאמר. [11] Da ajtty

(21) anar Tenri men küčlü Tenri jajylg̀yn da artqyn ḥanlyq

$57 \mathrm{~V}^{\mathrm{o}}$ (1) da jyjyny ḥanlyqlarnyn bolur send́an da bijleri belílarijdan čyġarlar.

(2) ואת [12] Da ošol jerni ki berdim Avrahamġa da Jichaqqa

(3) saja berirmen any da urluguuja özüjd́an sortun berirmen

(4) ošol ol jerni. [13] Da bardy šeḩinasy Tenrinin Ja'aqov

(5) üstünd́an orunda ki sözledi birgesińa. ויצב [14] Da

(6) turğuzdu Ja'aqov maceva ol orunda ki sözledi birgesi-

(7) ne tašly maceva da $\mathrm{q}[\mathrm{u}] \mathrm{jdu} \mathrm{u}^{3}$ anyn üstüńa neseh da $\mathrm{q}[\mathrm{u}] \mathrm{jdu} \mathrm{u}^{4}$

(8) anyn üstüńa jav. [יקרא [15] Da atady Jáaqov ošol

(9) atyn ol orunnun Bet’el anyn üčün ki sözledi Tenri

(10) birgesińa anda. [16] Da köčtülar Bet'eld́an

(11) da edi hanuz ašmaq orun jertekli edi kelḿa Efrat-

(12) qa da töredi Raḥel da qatylandy töregenind́a. [17]

(13) Da edi qatylanġanynda töregenind́a da ajtty anar

(14) ol anača qorqmaġyn ki daġyn buda saja uvuldu. [18

${ }^{1} \mathrm{~K}$ : Elon; a scribal error. | TKow.o1: Alon. | H: Alon. | C: Alon. $\quad{ }^{2}$ TKow.o1: deest. | H: deest. | C: šol. $\quad{ }^{3} \mathrm{~K}$ : qojdu; a scribal error. | TKow.o1: qujdu.| H: qujdu. |C: qojdy. $\quad{ }^{4} \mathrm{~K}: q o j d u$; a scribal error. | TKow.o1: qujdu. | H: qujdu. | C: tökti. 
(2) his help was with me in the way that I went.' [4] And

(3) they gave to Jacob all the foreign gods which were in their hand,

(4) and all their earrings which were in their ears.

(5) And Jacob buried them under the linden which was by Shechem.

(6) [5] And they journeyed, and the terror of God

(7) was on the people of the cities that were around them,

(8) and they did not pursue after the sons of Jacob. [6]

(9) And Jacob came to Luz, which is in the land of Canaan, that is, Bethel,

(10) he and all the people that were with him. [7] And he built

(11) there an altar, and he called the place El-bethel because

(12) the angels appeared to him there, when he fled from before

(13) his brother. [8] But Deborah, Rebekah's nurse, died,

(14) and she was buried beneath Bethel,

(15) under an oak. And he called its name Allon-Bacuth.

(16) [9] And God's divine Presence appeared to Jacob

(17) again, when he came out of Paddan-Aram, and blessed him. [10]

(18) And God said to him, 'Your name is Jacob. Your name will not be called Jacob, only, anymore,

(19) but also Israel will be your name.'

(20) And he called his name Israel. [11] And

(21) God said to him, 'I am the mighty God. Spread and multiply. A kingdom

(1) and a multitude of kingdoms will be of you, and kings will come out from your hips.

(2) [12] And the land that I gave to Abraham and to Isaac:

(3) I will give it to you, and I will give the land to your offspring after you.'

(4) [13] And the divine Presence of God went up from on Jacob

(5) in the place where he had spoken with him. [14] And

(6) Jacob set up a pillar in the place where he had spoken with him,

(7) a pillar of stone. And he [poured] a drink offering on it, and he [poured]

(8) oil on it. [15] And Jacob called the

(9) name of the place Bethel, because God spoke

(10) with him there. [16] And they journeyed from Bethel.

(11) And there was still a span of the land to pass to come to Ephrath,

(12) and Rachel travailed, and she she hardened in labour. [17]

(13) And it was, when she hardened in labour, that the

(14) midwife said to her, 'Do not fear, because this, too, is a son for you.' [18] 
(15) Da edi čyqqanda žany anyn ki öldü da atady atyn anyn

(16) Ben Oni da atasy atady anar Binjamin. [19] Da

(17) öldü Rahel da astraldy jolunda Efratnyn oldu Bet

(18) Lahem. יויצב [20] Da turgiuzdu Ja'aqov maceva zereti üs-

(19) tüńa anyn oldu macevasy zeretinin Rahelnin ol künge-

(20) dejin. ויסע [21] Da köčtü Jisra’el da qurdu čatyryn arraq

(21) Miġdal 'Ederden. [22] Da edi toḥtag̉anda Jisra’el

$58 \mathrm{r}^{\mathrm{o}} \quad$ (1) ol jerd́a da bardy Ru'uven da jatty Bilha byla qumasybyla

(2) atasynyn da ešitti Jisra’el da edilar uvullary Jisra’elnin

(3) on ekövlan. בני [23] Uvullary Le’anyn tunġuču Ja'aqovnun

(4) Ru'uven da Šimon da Levi da Juhuda da Jissahar da Zevulun.

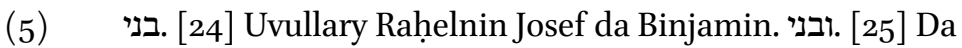

(6) uvullary Bilhanyn qaravašynyn Raḥelnin Dan da Naftali. [26]

(7) Da uvullary Zilpanyn qaravašynyn Le’anyn Gad da Ašer bular-

(8) dylar uvullary Ja'aqovnun ki tuvdu anar Padam Aramda.

(9) ויבוא [27 Da keldi Ja'aqov Jichaqqa atasyna Mamrege šahary-

(10) na ol Arba'nyn oldu Hevron ki tirildi anda Avraham

(11) da Jichaq. [יהיו [28] Da edilar künĺari Jichaqnyn jüz jyl da

(12) seksen jyl. ויגוע. [29] Da tyndy Jichaq da öldü da

(13) jyštyryldy uluslaryna qart da tojg̉an künlerd́an da

(14) astradylar any 'Esav da Ja'aqov uvullary anyn.

Genesis 36

(15) Da bulardylar tuvmušlary 'Esavnyn oldu Edom. עשו. [2]

(16) 'Esav aldy ošol qatynlaryn qyzlaryndan Kena'annyn ošol 'Ada-

(17) ny qyzyn Elonnun ol Ḥitilinin da ošol Ahalivamany qyzyn

(18) 'Ananyn qyzyn Civ'onnun ol Ḥivilinin. [3א [3] Da ošol

(19) Basematny qyzyn Jišma'elnin tuvdugiun Nevajotnun. ותלד [4]

(20) Da töredi 'Ada 'Esavğa ošol Elifazny da Basemat tuv-

(21) durdu ošol Ru'u'elni. ואהליבמה. [5] Da Ahalivama töredi

$5^{8} \mathrm{~V}^{\mathrm{o}} \quad$ (1) ošol Ju'ušnu da ošol Jacelamny da ošol Qoraḥny bulardylar

(2) alar uvullary 'Esavnyn ki tuvdular anar jerind́a Kena'annyn.

(3) ויקח [6] Da aldy 'Esav ošol qatynlaryn da ošol uvullaryn

(4) da ošol qyzlaryn da ošol bar క̌anlaryn üvünün da ošol

(5) jyjynyn da ošol bar tuvaryn da ošol bar malyn ki jyštyrdy 
(15) And it was, as her soul was departing, because she died, that she called his name

(16) Ben-Oni. And his father called him Benjamin. [19] And

(17) Rachel died. And she was buried on the way to Ephrath. It is BethLehem.

(18) [20] And Jacob set a pillar on her grave.

(19) It is the pillar of Rachel's grave to this day.

(20) [21] And Israel journeyed, and pitched his tent beyond

(21) Migdal Eder. [22] And it was, when Israel sojourned

(1) in that land, that Reuben went and lay with Bilhah, the concubine. $\quad 58 \mathrm{r}^{\circ}$

(2) of his father. And Israel heard it. Now the sons of Jacob were

(3) twelve. [23] The sons of Leah: Jacob's firstborn,

(4) Reuben, and Simeon, and Levi, and Judah, and Issachar, and Zebulun.

(5) [24] The sons of Rachel: Joseph, and Benjamin. [25] And

(6) the sons of Bilhah, Rachel's maidservant: Dan, and Naphtali. [26]

(7) And the sons of Zilpah, Leah's maidservant: Gad, and Asher. These are

(8) the sons of Jacob, who were born to him in Paddan-Aram.

(9) [27] And Jacob came to Isaac his father to Mamre, to the city

(10) of Arbah, it is Hebron, where Abraham

(11) and Isaac lived. [28] And the days of Isaac were a hundred and

(12) eighty years. [29] And Isaac rested and died, and

(13) was gathered to his people, being old and full of days. And

(14) his sons Esau and Jacob buried him.

Genesis 36

(15) And these are the children of Esau. He is Edom. [2]

(16) Esau took his wives of the daughters of Canaan: Adah,

(17) daughter of Elon, the Hittite, and Oholibamah, daughter

(18) of Anah, daughter of Zibeon, the Hivite. [3] And

(19) Basemath, daughter of Ishmael, sister of Nebaioth. [4]

(20) And Adah bore to Esau Eliphaz, and Basemath

(21) bore Reuel. [5] And Oholibamah bore

(1) Jeush, and Jalam, and Korah. These are

(2) the sons of Esau, who were born to him in the land of Canaan.

(3) [6] And Esau took his wives, and his sons,

(4) and his daughters, and all the souls of his house, and

(5) his crowd, and all his livestock, and all his possessions, which he had gathered 
(6) jerind́a Kena‘annyn da bardy özǵa jerǵa alnyndan Ja'aqov-

(7) nun qaryndašynyn. כי . [7 [ Ki edi mallary alarnyn köbüsü

(8) olturmaqtan birǵa da bolalmady jeri tirilmüšlerinin

(9) kötürḿa alarny alnyndan tuvarlarynyn alarnyn. וישב. [8]

(10) Da olturdu 'Esav tavynda Secirnin 'Esav oldu Edom.

(11) [ואלה (9] Da bulardylar tuvmušlary 'Esavnyn atasynyn Edom-

(12) nun tavynda Se'irnin. אלה [10] Bulardylar atlary uvul-

(13) larynyn 'Esavnyn Elifaz uvlu 'Adanyn qatynynyn 'Esavnyn Ru'u'el

(14) uvlu Basematyn qatynynyn 'Esavnyn. ויהיו. [11] Da edilar

(15) uvullary Elifaznyn Teman Omar Cefo da Ga'tam da Qenaz.

(16) [ותמנע [12] Da Timna edi quma Elifazg̀a uvluna

(17) Esavnyn da töredi Elifazġa ošol 'Amaleqni bulardylar

(18) uvullary 'Adanyn qatynynyn 'Esavnyn. ואלה [14]

(19) \{ב Da bulardylar uvullary Ahalivamanyn qyzynyn 'Adanyn qyzynyn

(20) Civ'onnun qatynynyn 'Esavnyn da töredi 'Esavġa ošol Ju'ušnu

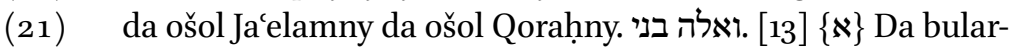

59 r $^{\circ} \quad$ (1) dylar uvullary Ru'u'elnin Naḥat da Zerah Šama da Miza bular

(2) edilar uvullary Basematnyn qatynynyn 'Esavnyn. ${ }^{11}$. [15] Bular-

(3) dylar aluflary uvullarynyn 'Esavnyn uvullary Elifaznyn tungu-

(4) čunun 'Esavnyn aluf Teman aluf Omar aluf Cefo aluf Qenaz.

(5) אלוף Aluf Qorah aluf Ga'tam aluf 'Amaleq bulardylar

(6) aluflary Elifaznyn jerind́a Edomnun $b\{u\}$ lardylar uvullary

(7) 'Adanyn. ואלה [17] Da bulardylar uvullary Ru'u'elnin uv-

(8) lunun 'Esavnyn aluf Naḥat aluf Zeraḥ aluf Šama aluf Miza

(9) bulardylar aluflary Ru'u'elnin jerind́a Edomnun bulardylar

(10) uvullary Basematnyn qatynynyn 'Esavnyn. ואלה. [18] Da bulardy-

(11) lar uvullary Ahalivamanyn qatynynyn 'Esavnyn aluf Ju'uš aluf

(12) Ja'elam aluf Qorah bulardylar aluflary Ahalivamanyn qyzynyn 'Ana-

(13) nyn qatynynyn 'Esavnyn. אלה. [19] Bulardylar uvullary 'Esavnyn

(14) da bulardylar aluflary alarnyn oldu Edom. אלהלה. [20] Bulardy-

(15) lar uvullary Se'ir ol Horinin olturuvčulary ol jernin

(16) Lotan da Šoval da Civ'on da 'Ana. [21] Da Dišon da

(17) Ecer da Dišan bulardylar aluflary ol Ḥorinin ulanlary

\footnotetext{
${ }^{1}$ The order of these two verses was corrected by the copyist by numbering the verse-beginning words with $\boldsymbol{\aleph}$ and , respectively. Gen 36:13 was initially omitted by the copyist due to homeoarchy and was added after Gen 36:14.
} 
(6) in the land of Canaan. And he went to another land, from the face of

(7) his brother Jacob. [7] Because their possessions were to many

(8) to dwell together. And the land of their sojourning was not able

(9) to lift them because of their livestock. [8]

(10) So Esau dwelt in Mount Seir: Esau is Edom.

(11) [9] And these are the children of Esau, father of the Edom,

(12) in Mount Seir: [10] These are the names

(13) of Esau's sons: Eliphaz, son of Adah, wife of Esau, Reuel,

(14) son of Basemath, wife of Esau. [11] And

(15) the sons of Eliphaz were Teman, Omar, Zepho, and Gatam, and Kenaz.

(16) [12] And Timna was concubine to

(17) Eliphaz Esau's son, and she bore to Eliphaz Amalek. These are

(18) the sons of Adah, Esau's wife. [ [14]

(19) $\{$ 2nd $\}$ And these were the sons of Oholibamah, daughter of Anah, daughter

(20) of Zibeon, Esau's wife: and she bore to Esau Jeush,

(21) and Jalam, and Korah. [13] \{1st\} And these

(1) are the sons of Reuel: Nahath, and Zerah, Shammah, and Mizzah. These

(2) were the sons of Basemath, Esau's wife. ${ }^{155}$ [15] These

(3) are the chiefs of the sons of Esau: the sons of Eliphaz,

(4) Esau's firstborn: chief Teman, chief Omar, chief Zepho, chief Kenaz,

(5) [16] Chief Korah, chief Gatam, and chief Amalek. These are

(6) the chiefs of Eliphaz in the land of Edom, these are the sons

(7) of Adah. [17] And these are the sons of Reuel,

(8) Esau's son: chief Nahath, chief Zerah, chief Shammah, chief Mizzah.

(9) These are the chiefs of Reuel in the land of Edom. These are

(10) the sons of Basemath, Esau's wife. [18] And these are

(11) the sons of Oholibamah, Esau's wife: chief Jeush, chief

(12) Jalam, chief Korah. These are the chiefs of Oholibamah the daughter of Anah,

(13) Esau's wife. [19] These are the sons of Esau,

(14) and these are their chiefs. That is Edom. [20] These are

(15) the sons of Seir, the Horite, the inhabitants of the land:

(16) Lotan, and Shobal, and Zibeon, and Anah, [21] And Dishon, and

(17) Ezer, and Dishan. These are the chiefs of the Horites, the children

55 The order of these two verses was corrected by the copyist. 
(18) Secirnin jerind́a Edomnun. ויהיו. [22] Da ediĺar uvul-

(19) lary Lotannyn Ḥori da Hemam da tuvdug̉u Lotannyn Timnac.

(20) - ואלה Da bulardylar uvullary Šovalnyn 'Alvan da Manahat

(21) da 'Eval Šefo da Onam. ואלה. [24] Da bulardylar uvullary

$59 v^{\circ} \quad$ (1) Civ'onnun da Aja da 'Ana oldu 'Ana ki tapty ošol ol kijik

(2) atlarny midbarda kütkenind́a ošol eš́aklarni Civ'onnun

(3) atasynyn. ואלה [25] Da bulardylar uvullary 'Ananyn Dišon da

(4) Ahalivama qyzy 'Ananyn. ואלה [26] Da bulardylar uvullary Dišan-

(5) nyn Ḥemdan da Ešban da Jitran da Keran. אלה [27] Bulardylar uvul-

(6) lary Ecernin Bilhan da Za'avan da 'Aqan. אלה. [28] Bulardylar uvullary

(7) Dišannyn 'Uc da Aran. אלה. [29] Bulardylar aluflary ol Ḥori-

(8) nin aluf Lotan aluf Šoval aluf Civ'on aluf 'Ana. אלוף. [30] Aluf

(9) Dišon aluf Ecer aluf Dišan bulardylar aluflary ol Ḥorinin

(10) aluflarysajyn jerind́a Secirnin. ואלה [31] Da bulardylar ol

(11) bijler ki bijlik ettilar jerind́a Edomnun bij bolmastan burun

(12) bij ulanlarynda Jisra'elnin. וימלך. [32] Da bij boldu Edom-

(13) da Belac uvlu Bocornun da aty šaharynyn Dinhava. [33]

(14) Da öldü Bela da bij boldu anyn ornuna Jovav uvlu Zerah-

(15) nyn Bacradan. [ימת [34] Da öldü Jovav da bij boldu anyn

(16) ornuna Ḥušam jerind́an ol Temaninin. I35 Da

(17) öldü Ḥušam da bij boldu anyn ornuna Hadad uvlu Bedad-

(18) nyn ol vatuvču ošol Midjanny tüzünd́a Mo’avnyn da aty

(19) šaharynyn 'Avit. וימת. [36] Da öldü Hadad da bij boldu anyn

(20) ornuna Samla Masreqadan. [37] Da öldü Samla

(21) da bij boldu anyn ornuna Šảul Roḥovot ol nahardan.

6o ro (1) [ימת [3] [38] Da öldü Šảul da bij boldu anyn ornuna Ba'al Ḥanan uvlu

(2) 'Ahbornun. [39] Da öldü Ba'al Ḥanan uvlu 'Ahbor-

(3) nun da bij boldu anyn ornuna Hadar da \{aty\} šaharynyn Pa'u da

(4) aty qatynynyn Mehetav'el qyzy Matrednin qyzy Mezahavnyn.

(5) [40] Da bulardylar atlary aluflarynyn 'Esavnyn uruvlary-

(6) sajyn orunlarybyla atlary byla aluf Timna' aluf 'Alva

(7) aluf Jetet. [4וף] Aluf Ahalivama aluf Ela aluf

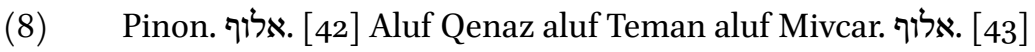

1'Catchword: וימת. Heb. וימת. 
(18) of Seir in the land of Edom. [22] And the sons

(19) of Lotan were Hori and Hemam, and Lotan's sister is Timna.

(20) [23] And these are the children of Shobal: Alvan, and Manahath,

(21) and Ebal, Shepho, and Onam. [24] And these are the sons

(1) of Zibeon: and Aiah, and Anah; that is Anah who found the wild

(2) horses in the wilderness when he pastured the donkeys of Zibeon,

(3) his father. [25] And these are the sons of Anah: Dishon, and

(4) Oholibamah, daughter of Anah. [26] And these are the sons of Dishon:

(5) Hemdan, and Eshban, and Ithran, and Cheran. [27] These are the sons

(6) of Ezer: Bilhan, and Zaavan, and Akan. [28] These are the sons

(7) of Dishan: Uz, and Aran. [29] These are the chiefs of the Horites:

(8) chief Lotan, chief Shobal, chief Zibeon, chief Anah, [30] Chief

(9) Dishon, chief Ezer, chief Dishan. These are the chiefs of Hori,

(10) according to their chiefs in the land of Seir. [31] And these are the kings

(11) that reigned in the land of Edom, before there reigned any king

(12) over the children of Israel. [32] And Bela the son of Beor reigned in Edom,

(13) and the name of his city was Dinhabah. [33]

(14) And Bela died, and Jobab, son of Zerah of Bozrah reigned in his place.

(15) [34] And Jobab died, and Husham of the land of the Temanites reigned

(16) in his place. [35] And

(17) Husham died, and Hadad, son of Bedad reigned in his place,

(18) who smote Midian in the field of Moab, and the name

(19) of his city was Avith. [36] And Hadad died, and

(20) and Samlah of Masrekah reigned in his place. [37] And Samlah died,

(21) and Shaul of Rehoboth by the river reigned in his place.

(1) And Shaul died, and Baal-Hanan, son of Achbor reigned in his place. $\quad 60 \mathrm{r}^{\circ}$

(2) [39] And Baal-Hanan, son of Achbor died,

(3) and Hadar reigned in his place, and the name of his city was Pau; and

(4) his wife's name was Mehetabel, daughter of Matred, daughter of Mezahab.

(5) [40] And these are the names of the chiefs of Esau, according to their families,

(6) by their places, by their names: chief Timnah, chief Alvah,

(7) chief Jetheth, [41] Chief Oholibamah, chief Elah, chief

(8) Pinon, [42] Chief Kenaz, chief Teman, chief Mibzar, [43] 
(9) Aluf Maġdi’el aluf 'Iram bulardylar aluflary Edomnun ol-

(10) turušlarysajyn jerind́a tutuvluqlarynyn oldu 'Esav atasy

(11) Edomnun.

\section{Genesis 37}

פרשת וישב (12) (12)

(13 Da olturdu

(14) Jacaqov jerind́a tirilmüšlerinin atasynyn

(15) jerind́a Kena'annyn. אלה. [2] Bulardylar učurlary

(16) Ja'aqovnun Josef on jedi jašar edi küteredi qaryndašlary

(17) byla qojnu da ol ulan edi uvullary qatyna Bilhanyn da

(18) uvullary qatyna Zilpanyn qatynlarynyn atasynyn da keltirdi

(19) Josef ošol ajiplerin alarnyn jamanny atasyna özlerinin

6o vo (1) Lki qojdular any jumuš etüvčü uvullaryna Bilhanyn da Zilpa-

(2) nyn ${ }^{11}$. [3] Da Jisra'el süvdü ošol Josef jahšyraq bar

(3) uvullaryndan ki uvul qart qylyqly edi ol anar da qyldy

(4) anar ojuvlu kölḿak. [4] Da kördülar qaryndaš-

(5) lary anyn ki süvdü atasy alarnyn jaḥšyraq bar qaryndaš-

(6) laryndan anyn da dušman boldular anar da bolalmadylar söz-

(7) lema anar bazlyqbyla. [5ל [5] Da tüš kördü Josef

(8) tüš da anlatty qaryndašaryna özünün da arttyr-

(9) dylar daġyn dušman bolma anar. ויאמר [6 [6 ajtty

(10) alarg̉a tynlajyz endi ol tüšnü ki tüš kördüm.

(11) [7 [7 Da muna biz bajlajbiz külteĺar ortasynda

(12) ol tüznün da muna turdu kültam da daġyn toḥtady da

(13) muna qajyryldylar kültelerijiz da bašurdular külteme.

(14) ויאמרו (8] Da ajttylar anar \{[q]aryndašlary² anyn $\}$ bijmo bolma bij bolursen

(15) üstümüzǵa biznin klegimiz byla erklenmemo

(16) erklenirsen üstümüzge küčbyla da

(17) arttyrdylar dušman bolma anar tüšlari üčün da

(18) sözĺari üčün anyn. [9] Da tüš kördü öz-

\footnotetext{
${ }^{1}$ Interpretative addition to the standard text. $\quad{ }^{2}$ TKow.o1: qaryndašlary. | H: qaryndaslary. | C: qardašlary.
} 
(9) Chief Magdiel, chief Iram. These are the chiefs of Edom,

(10) according to their dwelling places in the land of their possession. That is Esau, father

(11) of Edom.

\section{Genesis 37}

(12) Parashat Vayeshev

(13) [1] And Jacob dwelt

(14) in the land of his father's residences,

(15) in the land of Canaan. [2] This is the fate

(16) of Jacob. Joseph was seventeen years old, he was pasturing the flock with his brothers.

(17) And he was a boy with the sons of Bilhah, and

(18) with the sons of Zilpah, his father's wives: and Joseph brought

(19) a bad |report| of their shame to their father,

(1) that they made him a servant to the sons of Bilhah and Zilpah. ${ }^{156}$

(2) [3] And Israel loved Joseph more than all

(3) his sons, ${ }_{1}$ because he was the son [with] the habits of an old man ${ }^{157}$. And he made

(4) him a shirt of many patterns. [4] And his brothers saw

(5) that their father loved him more than all his brothers,

(6) and they were hostile to him, and were not able speak

(7) peacefully to him. [5] And Joseph had a dream,

(8) and he told it to his own brothers, and they

(9) went on to be hostile to him even more. [6] And he said

(10) to them, 'Listen now to this dream which I dreamed:

(11) [7] And, lo, we were binding sheaves in

(12) the field, and, lo, my sheaf arose and stood |upright|, too. And,

(13) lo, your sheaves stood all around and bowed down to my sheaf.'

(14) [8] And his brothers said to him, 'Will you indeed reign

(15) over us? Will you rule over us according to our wish

(16) |or| by force?' And

(17) they were hostile to him even more because of his dreams, and

(18) because of his words. [9] And he dreamed

$56 \quad$ An interpretative addition to Gen 37:2.

57 K: an uncertain translation of ki uvul qart qylyqly edi ol anar; cf also Gen 44:20. | TKow.o1: ki uvul qart qylyqly edi ol anar; the same translation as in K. | H: ki uvul qart qylyqly edi ol anar; the same translation as in K. | C: qartlyq ogul edi ol anar 'he had a son of his old age'. 
(19) ga tüš da qotardy any qaryndašlaryna da ajtty mu-

(20) na tüš kördüm tüš dag̉yn muna ol qujaš da

(21) ol aj da on bir jolduzlar baš uradylar maja. ויספר [10]

$61 \mathrm{r}^{\circ} \quad$ (1) Da qotardy atasyna da qaryndašlaryna da jüreklendi anyn

(2) üstüńa atasy anyn da ajtty anar nedir ol tüš

(3) ošpu ki tüš kördüj kelmemo kelirbiz men da anaj da

(4) qaryndašlaryj bašurma saja jerge. ויקנאו [11] Da künüle-

(5) dilar qaryndašlary anyn da atasy anyn saqlady ošol ol söz-

(6) nü. וילכו [12] Da bardylar qaryndašlary anyn kütḿa o-

(7) šol qojun atasynyn özlerinin Šehemde. ויאמר [13] Da

(8) ajtty Jisra’el Josefke muna qaryndašlaryj kütedilar

(9) Šehemd́a kel da ijejim seni alarg̉a da ajtty \{anar\} muna

(10) men Lhadirmen qylma sözüjnü ${ }^{11}$. ויאמר [14] Da ajtty

(11) anar barğyn endi baqqyn ošol savluğun qaryndašlaryjnyn

(12) da ošol savlugiun ol qojnun da qaruv qajtarġyn maja

(13) söz da ijdi any enišind́an Ḥevronnun da keldi Šeḩem-

(14) ge. וימצאהו. Da joluqtu any kiši da muna aza-

(15) Šady tüzd́a da sordu andan ol kiši ajtadoġač ne

(16) izlejsen. [16] Da ajtty ošol qaryndašlarym-

(17) ny men izlejmen anlatqyn endi maja qajda alar küte-

(18) dilar. ויאמר [17] Da ajtty $\{\text { ol k[i]šs [i] }\}^{2}$ köčtülar bundan ki e-

(19) šittim ajtyredilar barajyq Dotanga da bardy Josef

(20) qaryndašlary artyna da tapty alarny Dotanda. ויראו. [18]

(21) Da kördülar any jyraqt $[\mathrm{y}] \mathrm{n}^{3}$ da juvumasyndan burun alarg̉a

61 v (1) da jaman saġyš ettilar anar öltürma any. 119 Da

(2) ajttylar kiši qaryndašyna muna jesisi ol tüšlernin ol tigi ${ }^{4}$

(3) keladi ${ }^{5}$. ועתה [20] Da haligińa kel da öltürejik any da tašlajyq

(4) any birisińa ol qujularnyn da ajtyrbiz jaman kijik ašady any

(5) da körejik ne bolurlar tüšleri anyn. [21] Da eši-

(6) tti Ru'uven da keldi qutqarma any qolundan alarnyn da ajtty

\footnotetext{
${ }^{1}$ Interpretative addition to the standard text. $\quad{ }^{2} \mathrm{~K}: k \ddot{u} s[i]$, a hypercorrect form of SWKar. kiši inserted by another hand in the outer margin. | TKow.o1: ol kiši. | H: ol kisi. | C. ol kiši. ${ }^{3} \mathrm{~K}$ :

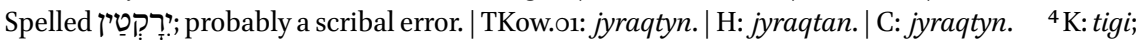
an obscure form. Perhaps a 3 rd person singular possessive form of tek 'only'. Used also in Gen 24:65. | TKow.o1: tigi. | H: deest. | C: deest. ${ }^{5}$ K: Spelled בֵילִ; a scribal error. | TKow.o1: keladi. | H: keledi. | C: keläydir.
} 
(19) another dream, and told it to his brothers, and said, 'Lo,

(20) I have dreamed again. Lo, the sun and

(21) the moon and the eleven stars bow down to me.' [10]

(1) And he told it to his father, and to his brothers. And

(2) his father was angry at him, and said to him, 'What is this dream

(3) that you have dreamed? Will I and your mother and

(4) your brothers indeed come to bow down to you to the earth?' [11] And

(5) his brothers envied him, but his father kept the words.

(6) [12] And his brothers went to pasture

(7) their father's flock in Shechem. [13] And

(8) Israel said to Joseph, 'Lo, your brothers pasture

(9) in Shechem. Come, and let me send you to them.' And he said to him, 'Lo,

(10) I am here, ${ }_{L}$ I am ready to do your words ${ }^{758}$. [14] And he said

(11) to him, 'Go, see your brothers' health,

(12) and the health of the flock, and bring me a word of answer.'

(13) And he sent him from the valley of Hebron. And he came to Shechem.

(14) [15] And a man met him, and, lo,

(15) he was wandering in the field. And the man asked him, saying, 'What

(16) are you looking for?' [16] And he said, 'I am looking for my brothers.

(17) Tell me now where are they pasturing?'

(18) [15] And \{the man\} said, "They journeyed from here. Because

(19) I heard them say, "Let us go to Dothan."' And Joseph went

(20) after his brothers, and found them in Dothan. [18]

(21) And they saw him from afar, and before he came near to them,

(1) and they had evil thoughts against him to slay him. [19] And

(2) they said one to another, 'Behold, this master of dreams is coming $\left[{ }^{\dagger}\right.$ alone ${ }^{59}$.

(3) [20] And now, come on and let us kill him and cast him

(4) into one of the wells, and we will say that an evil beast has devoured him,

(5) and we shall see what his dreams will be. [21] And

(6) Reuben heard it, and he came to deliver him out of their hands. And he said,

59 An uncertain inerpretation of tigi. 
(7) vatmajyq any čyqqynča క̌any anyn. [22] Da ajtty

(8) alarg̉a Ru'uven tökmejiz qan salyjyz any ol qujug̉a ošpu ki

(9) midbarda da qol sunmajyz anar da anyn üčün ol bulaj keneš

(10) berdi alarg̉a ki qutqarğaj any qolundan alarnyn qajta ijme

(11) ויהי [23] Da edi ki nečik keldi Josef qaryndaš-

(12) laryna da češindirttiliar Josefke ošol kölmegin ošol

(13) ol ojuvlu kölmekni ki anyn üstüńa. ויקחהו [24 Da

(14) aldylar any da saldylar any ol qujugia da ol quju boš

(15) edi jog̉edi anda suv. [25] Da olturdular ašama

(16) ötmek da kötürdülar közlerin da kördülar da muna

(17) polku Jišma'ellernin keledi Gil'addan da teveleri alarnyn

(18) eltirediler otjamlar da tirjak da mastik baryredilar

(19) endirma Micriǵa. ויאמר [26] Da ajtty Juhuda qaryn-

(20) dašlaryna ne fajda bolur ki öltürsek ošol qaryndašy-

(21) myzny da jašyrsaq ošol tökmegimizni qanyn anyn. לכו. [27]

$62 \mathrm{r}^{\mathrm{o}} \quad$ (1) Kelijiz da satajyq any Jišmacellerǵa da qolumuz bolmasyn anda

(2) ki qaryndašymyz et [i]mizdi ${ }^{1}$ ol da tynladylar qaryndašlary anyn

(3) Lsözüńa anyn ${ }^{12}$. ויעברו [28] Da aštylar Midjanly erenlar bezir-

(4) genlar da tarttylar qaryndašlary Josefnin da čyğardylar ošol

(5) Josefni ol qujudan da sattylar ošol Josefni Jišmaceller-

(6) ge egirmi kümüške da keltirdilar ošol Josefni

(7) Micriǵa. וישב. [29] Da qajtty Ru'uven ol qujug̉a da muna

(8) joḥtu Josef qujuda da jyrtty ošol upraqlaryn. [30]

(9) Da qajtty qaryndašlaryna da ajtty ol ulan joḥtu da

(10) men qajry kelejim. ויקחו. [31] Da aldylar ošol kölme-

(11) gin Josefnin da sojdular ulaġyn ečkilernin da mančty-

(12) lar ošol ol kölmekni qanġa. [32] [Da qylyčbyla

(13) čančqaladylar ošol ol ojuvlu kölmekni ${ }^{13}$ da keltirdiler

(14) atasyna özlerinin da ajttylar bunu taptyq tanyg்yn

(15) endi kölmegimodu uvullujnun ol jemeśa joq. ויכירה [33]

(16) Da tanydy any da ajtty kölmegidi uvlumnun jaman kijik

(17) ašady any jyrtylma jyrtyldy Josef. ויקרע. [34] Da jyrtty

(18) Jacaqov upraqlaryn da qojdu kijiz bellerind́a da jasly

\footnotetext{
${ }^{1} \mathrm{~K}$ : etemizdi; a scribal error. | TKow.o1: gufumuzdu. | H: qanymyzdy. | C: tänimizdir. $\quad{ }^{2}$ Interpret-
} ative addition to the standard text. ${ }^{3}$ Interpretative addition to the standard text. 
(7) 'Let us not smite him that his soul leaves him.' [22] And

(8) Reuben said to them, 'Shed no blood. Cast him into this well that

(9) is in the wilderness, and reach no hand toward him.' And he gave them such advice

(10) in order to rescue him out of their hands, to send him again

(11) to his father. [23] And it was, when Joseph came to his brothers,

(12) that they ordered Joseph to take off his shirt,

(13) the shirt of many patterns that was on him. [24] And

(14) they took him, and cast him into a well. And the well was empty,

(15) there was no water in it. [25] And they sat down to eat

(16) bread. And they raised their eyes and looked, and, lo,

(17) a company of Ishmaelites was coming from Gilead with their camels

(18) carrying spices, and balm, and mastic, they were going to bring

(19) them down to Egypt. [26] And Judah said

(20) to his brothers, 'What profit is it if we kill our brother,

(21) and conceal the shed of his blood? [27]

(1) Come on and let us sell him to the Ishmaelites, and let our hand not $\quad 62 \mathrm{r}^{\mathrm{o}}$ be on him,

(2) because he is our brother and our flesh.' And his brothers listened to

(3) his words ${ }^{160}$. [28] And Midianite men passed by,

(4) merchants. And the brothers of Joseph pulled and lifted

(5) Joseph from the well, and sold Joseph to the Ishmaelites

(6) for twenty pieces of silver. And they brought Joseph

(7) to Egypt. [29] And Reuben returned to the well, and, lo,

(8) Joseph was not in the well. And he tore his clothes. [30]

(9) And he returned to his brothers, and said, 'The child is not! And

(10) I, where shall I go?' [31] And they took

(11) Joseph's shirt, and slaughtered a kid of the goats, and dipped

(12) the shirt in the blood. [32] A And with swords

(13) they stabbed many times the shirt of many patterns ${ }^{161}$, and they brought

(14) it to their father, and said, 'We found this. Recognize

(15) now: is it your son's shirt or not?' [33]

(16) And he recognized it, and said, 'It is my son's shirt. An evil beast

(17) devoured him. Joseph is surely torn up!' [34] And Jacob tore

(18) his clothes, and put sackcloth on his hips, and mourned

6o An interpretative addition to Gen 37:27.

61 An interpretative addition to Gen 37:32. 
(19) boldu uvlu üčün köp künĺar. ויקמו. [35] Da turdular

(20) bar uvullary anyn da bar qyzlary uvutma any da klemedi

(21) uvunma da ajtty ki enermen uvluma jasly [g]örǵa ${ }^{1}$

$62 v^{0} \quad$ (1) da \{jylady\} baġyp anyn üstüńa Jichaq atasy anyn. והמדנים [36 ]

(2) Da ol Midjanlylar sattylar any Micriǵa Potifargaa veziri-

(3) ne par'onun ag̉arag̉yna ol qasapčylarnyn.

Genesis 38

(4) ol vaḥtta da endi Juhuda qaryndašlaryndan da qurdu

(5) čatyryn 'Adulamly kišigedejin da aty anyn Ḥira. [2]

(6) Da kördü anda Juhuda qyzyn Kena'anly kišinin da aty anyn

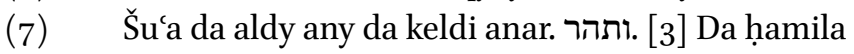

(8) boldu da töredi uvul da atady ošol atyn anyn 'Er.

(9) ותהר [4 Da hamila boldu \{daġyn\} da töredi uvul da atady atyn

(10) anyn Onan. ותסף. [5] Da arttyrdy dag்yn da töredi

(11) uvul da atady anasy atyn \{anyn $\}$ Šela da Juhuda edi Heziv

(12) ündeledog̉an orunda töregenind́a ošol Šelany.

(13) (6) Da aldy Juhuda qatyn 'Erge tunġučuna özünün

(14) da aty anyn Tamar. ויהי Da edi $\left\{{ }^{\prime} E r\right\}^{2}$ tunġuču Juhudanyn

(15) jaman 'enajatlary alnyna Adonajnyn da öltürdü any Adonaj.

(16) יויאמר (8) Da ajtty Juhuda Onanga kelgin qatynyna qaryn-

(17) dašyjnyn da juvuqluq etkin anar da qajjam etkin urluq

(18) qaryndašyja. וידע [9] Da bildi Onan ki anar tüvül bolur

(19) ol urluq da edi eger kelsejedi qatynyna qaryndašynyn da

(20) čejparedi jerǵa bermesḱka urluq qaryndašyna. וירע. [10]

(21) Da jaman köründü 'enajatlary alnyna Adonajnyn ki qyldy da

$63 \mathrm{r}^{\mathrm{o}}$ (1) öltürdü dağyn anyda. [יאמר. [11] Da ajtty Juhuda Tamar-

(2) ga kelinine olturgun tul üvünd́a atajnyn neginče

(3) ki öskej Šela uvlum ki ajtty mag̉at öler daġyn ol-

(4) da qaryndašlary kibik da bardy Tamar da olturdu üvün-

(5) de atasynyn. [12] Da köp boldular ol künlar

(6) da öldü qyzy Šu'anyn qatyny Juhudanyn da uvundu Juhuda

(7) da bardy qyrquvčular qatyna qojun ol da Ḥira dostu

(8) anyn ol 'Adulmaly Timnatqa. [13] Da anlatyldy

\footnotetext{
${ }^{1} \mathrm{~K}$ : körǵa; an erroneous variant of gör 'grave', cf. TKow.o1. | TKow.o1: körgede. | H: gerge. | C: görgä.

${ }^{2}$ Marginal insertion by another hand. | TKow.o1: 'Er. | H: 'Er. | C: 'Er.
} 
(19) for his son many days. [35] And

(20) all his sons and all his daughters rose up to comfort him, but he did not want

(21) comfort, and he said, 'Because I will go down to the mourning grave to my son.'

(1) Thus his father wept for him. [36]

(2) And the Midianites sold him to Egypt, to Potiphar, a vizier

(3) of Pharaoh, superior of the executioners.

Genesis 38

[1] And it was

(4) at that time, and Judah went down from his brothers, and pitched

(5) his at an Adullamite man, whose name was Hirah. [2]

(6) And Judah saw there a daughter of a Canaanite man, whose name

(7) was Shua. And he took her, and came to her. [3] And she conceived,

(8) and bore a son, and he called his name Er. [4]

(9) And she conceived again, and bore a son; and she called his name

(10) Onan. [5] And she yet again conceived, and bore

(11) a son, and called his name Shelah. And Judah was at

(12) a place called Chezib, when she bore Shelah.

(13) [6] And Judah took a wife for Er, his firstborn,

(14) and her name was Tamar. [7] And \{Er\}, Judah's firstborn, was

(15) wicked in the eyes of the Lord, and the Lord killed him.

(16) And Judah said to Onan, 'Come to your brother's wife,

(17) and get close to her, and set offspring

(18) to your brother.' [9] And Onan knew that the offspring would not be his.

(19) And it was when he came to his brother's wife,

(20) and he laid waste |it| on the ground so as not to give offspring to his brother. [10]

(21) And what he did was bad in the eyes of the Lord, and

(1) he killed him, too. [11] And Judah said to Tamar,

(2) his daughter-in-law, 'Dwell as a widow at your father's house until

(3) Shelah, my son, grows up', because he said, 'Lest he die, too,

(4) like his brothers.' And Tamar went and dwelt in her

(5) father's house. [12] And the days were many,

(6) and Judah's wife, daughter of Shua, died. And Judah was comforted,

(7) and went up to his sheep shearers, he and his friend Hirah

(8) the Adullamite, to Timnah. [13] And it was told 
(9) Tamarg̉a ajtadog̉ač muna qajnataj bardy Timnatqa qyrq-

(10) ma qojun. ותסר [14] Da ketirdi Tamar tulluq upraq-

(11) laryn üstünd́an da jabundu bürünček byla da čörgen-

(12) di da olturdu ajryč jol qatyna ki jolu üstüńa Tim-

(13) natnyn ki kördü ki ulġajdy Šela da ol berilmedi anar

(14) quatynlyqqa. [15] Da kördü any Juhuda da saġyš-

(15) lady any zona ornuna ki qaplady jüzlerin. [16] Da

(16) qajyryldy Juhuda anar ol jolġa da ajtty kel endi kelejim

(17) saja ki bilmedi ki kelinidi ol da ajtty anar Tamar

(18) ne berirsen maja ki kelgejsen maja. ויאמר Da

(19) ajtty men ijermen ulaġyn ečkilernin ol qojdan da ajtty

(20) Tamar eger bersej tusnaq ijgenijedejin. ויאמר [18] Da

(21) ajtty Juhuda nedi ol tusnaq ki bergejmen saja da ajtty

$63 \mathrm{v}^{\mathrm{o}} \quad$ (1) Tamar mohuruj da beliba\{v\}yj da tajaġyj ki qolujda da berdi

(2) anar da keldi anar da hamila boldu anar. [19] Da

(3) turdu Tamar da bardy da keterdi bürünčegi üstünd́an

(4) da kijdi tulluq upraqlaryn. [20] Da ijdi Juhuda

(5) ošol ulag̉yn ol ečkilernin qolu ašyra dostunun ol

(6) Adulamlynyn alma ošol ol tusnaqny qolundan ol qatynnyn

(7) da tapmady any. [ישאל. [21] Da sordu elind́an ornunun

(8) ajtadoġač qajdady ol qedeša ol ajyryč jol qatyna da ajtty-

(9) lar jog̉edi bunda qedeša. [22] Da qajtty Juhudag̉a da

(10) ajtty tapmadym any da dagyn eli ol orunnun ajtty-

(11) lore lar jog̉edi bunda qedeša. Da ajtty Juhuda

(12) alsyn özüńa magat bolurbiz ḥorluqqa muna ijdim

(13) ošol ol ulaqny \{ošpunu\} da sen tapmadyj any. [24] Da edi

(14) üč ajlardan tekli da anlatyldy Juhudag̉a ajtadoġač azdy

(15) Tamar kelinij da daġyn muna ḥamilady azmaqlardan da ajt-

(16) ty Juhuda čyğaryjyz any da kövdürülsün. היא. [25] Ol

(17) čyg̉arylyredi da ol ijdi qajnatasyna ajtadog̉ač kišiǵa

(18) ki bolur anyn men hamilamen ${ }_{L}\{[d] a \text { ajtty }\}^{11}$ tanyg்yn endi kimnindi ol mohor

\footnotetext{
${ }^{1}$ Marginal insertion by another hand. | TKow.o1: da ajtty. | H: da ajtty. | C: da ajtty.
} 
(9) to Tamar, saying, 'Lo, your father-in-law goes up to Timnah

(10) to shear his sheep.' [14] And she took her widow's garments off

(11) from her, and covered herself with a veil, and wrapped herself,

(12) and sat alone by a road, that is by the road to Timnah.

(13) For she saw that Shelah was grown, and she was not given to him

(14) for a wife. [15] And Judah saw her, he thought

(15) her to be a harlot because she had covered her face. [16] And

(16) he turned to her by the road, and said, 'Come now, let me come

(17) to you, for he did not know that she was his daughter-in-law. And Tamar said to him,

(18) 'What will you give me, that you may come to me?' [17] And

(19) he said, 'I will send you a kid of the goats from the flock.' And Tamar said,

(20) 'If you give me a security until you send it.' [18] And

(21) Judah said, 'What is the security that I shall give you?' And Tamar said,

(1) 'Your signet, and your belt, and your staff that is in your hand.' And he $63 \mathrm{v}^{\mathrm{o}}$ gave

(2) it to her, and came to her, and she conceived by him. [19] And

(3) she arose, and went away, and took of her veil from her,

(4) and put on the garments of her widowhood. [20] And Judah sent

(5) the kid by the hand of his friend, the

(6) Adullamite, to receive his security from the woman's hand,

(7) but he did not find her. [21] And he asked the men of that place,

(8) saying, 'Where is the temple prostitute that was there alone by the road?' And

(9) they said, 'There was no temple prostitute here.' [22] And he returned to Judah, and

(10) said, 'I have not found her. And also the men of the place said,

(11) “There was no temple prostitute here."' [23] And Judah said,

(12) 'Let her keep it to her, lest we be shamed. Lo, I have sent

(13) this kid, and you did not find her.' [24] And it was

(14) about three months later, and it was told to Judah, saying, "Tamar,

(15) your daughter-in-law, fell into harlotry. And, lo, she is pregnant by harlotry as well'. And

(16) Judah said, 'Bring her forth, and let her be burnt.' [25] She

(17) was brought forth, and she sent to her father-in-law, saying, 'By the man,

(18) whose these are, I am pregnant.' \{And she said\}, 'Recognize now: whose are this signet, 
(19) da ol belibav da ol tajaq ošpular. ויכר [26] Da tanydy

(20) Juhuda da ajtty rast boldu mend́an ol hamilady anyn ü-

(21) čün ki bermedim any Šelag̉a uvluma da arttyrmady

$64 \mathrm{r}^{\mathrm{o}}$ (1) artyq bilme any. [27] Da edi töremek vaḥtynda

(2) da muna ekizeklar qursaggynda anyn. [28] Da edi

(3) töregenind́a da berdi ol ulan qol da aldy ol anača

(4) da bajlady qolu üstüńa anyn qyrmyzy jipek ajtadoġač

(5) bu čyqty burundan. ויהי [29] Da edi qajtarg̉ačoq qolun da

(6) muna čyqty qaryndašy anyn da ajtty ol anača ne bu-

(7) zuqluq qyldyj Łeger ölsejedi qaryndašyj üstüja bolġaj-

(8) dy žurumu ol buzuqluqnun ${ }^{11}$ da atady atyn anyn Parec.

(9) ואחר [30] Da andan sortun čyqty qaryndašy anyn ki qolu

(10) üstüńa ol qyrmyzy jipek da atady atyn anyn Zarah.

\section{Genesis 39}

(11) ויוסף [1] Da Josef endirildi Micriǵa da satyn aldy

(12) any Potifar veziri par'onun ag̉arag̉y ol qasapčylarnyn

(13) Micrili kiši qolundan ol Jišma'ellernin ki endirdiler

(14) any ary. [2] Da edi bolušluğu Adonajnyn Josef byla

(15) da edi onaruvču \{kiši $\}$ išlerind́a da edi üvünd́a

(16) bijinin ol Micrilinin. [3] Da kördü biji anyn ki

(17) bolušlug̉u Adonajnyn birgesińa da barča neki ol qylare-

(18) di Adonaj onartyredi qolunda anyn. [4 [4] Da tapty

(19) Josef širinlik közlerind́a anyn da jumuš etti anar

(20) da vakil etti any ag̉araq üvü üstüńa da barysyn

(21) neki özünün berdi erkińa anyn. ויהי [5] Da edi ne

$64 \mathrm{v}^{\mathrm{o}} \quad$ (1) vaḥttan ki vakil etti any ag̉araq bolma üvünd́a da

(2) barysy üstüńa neki bardy anar da alġyšlady Adonaj ošol

(3) üvün ol Micrilinin sibbasyndan Josefnin da edi alğyšy

(4) Adonajnyn barynda neki bardy anar üvd́a da tüzd́a.

(5) (6] Da kemišti ošol barysyn neki özünün qolu-

\footnotetext{
${ }^{1}$ Interpretative addition to the standard text.
} 
(19) and this belt, and this staff? [26] And Judah recognized

(2o) them, and said, 'She has been more righteous than I am, she is pregnant because

(21) I did not give her to Shelah, my son.' And he did not go on

(1) to know her again. [27] And it was in the time of her labour,

(2) that, lo, twins were in her womb. [28] And it was

(3) when she was in labour, and one child gave his hand, and the midwife

(4) took and bound a scarlet silk |thread| on his hand, saying,

(5) 'This came out first.' [29] And it was, as he drew back his hand,

(6) that, lo, his brother came out. And the midwife said, 'What a

(7) breach have you made? If your brother died,

(8) the punishment for this breach would be on you!' 162 And she called his name Perez.

(9) [30] And afterward came out his brother that

(10) had the scarlet silk |thread| on his hand. And she called his name Zerah.

Genesis 39

(11) [1] And Joseph was brought down to Egypt. And

(12) Potiphar, a vizier of Pharaoh, superior of the executioners,

(13) an Egyptian man, bought him from the hand of the Ishmaelites, who had brought him down

(14) there. [2] And the help of the Lord was with Joseph,

(15) and he was man whom fate favoured in his deeds, and he was in the house

(16) of his lord, the Egyptian. [3] And his lord saw

(17) that the Lord's help was with him, and all that he did:

(18) the Lord made it prosper in his hand. [4] And Joseph found

(19) favour in his eyes, and he served him.

(20) And he appointed him superior over his house,

(21) and all put him in charge of everything that he had. [5] And it was

(1) from the time that he appointed him superior in his house, and

(2) over all that he had |that| the Lord blessed the

(3) Egyptian's house for Joseph's sake, and the blessing

(4) of the Lord was on all that he had in the house, and in the field.

(5) [6] And he left all that he had in Joseph's hand,

62 An interpretative addition to Gen 38:29. 
(6) na Josefnin da bilmedi birgesińa nemed́a ki ančaq ol

(7) ötmekni ki ol ašaredi da edi Josef körklü bojlu da

(8) körklü körümlü. ויהי [7] Da edi son ol išlerd́an

(9) ošpulardan da kötürdü qatyny bijinin ošol közlerin Josef

(10) üstüńa da ajtty jatqyn birgeḿa. וימאן [8] Da

(11) klemedi da ajtty qatynyna bijinin muna bijim bilmejdi

(12) birgeḿa ne bolunady üvd́a da barysyn neki bardy anyn

(13) berdi erkima. [יננו. [9] Joḥtu ag̉araq ošpu üv-

(14) de mend́an da ajamady mend́an nemed́a ančaq seni anyn

(15) üčün ki sen qatynysen da nečik qylajym ol jamanlyqny ošpu-

(16) nu ol ullunu da jazyqly bolurmen Tenriǵa. ויהי [10] Da

(17) edi sözlegenind́ačoq anar har kün da tynlamady anar

(18) jatma qatynda bolma janynda anyn. ויהי [11] Da edi

(19) bir künnü da keldi Josef ol üvǵa qylma išin özü-

(20) nün da ol vaḥtta jog̀edi kišid́a elinden üvnün

(21) anda ičkerid́a. ותתפשהו. [12] Da tuttu any ol qatyn

$65 \mathrm{r}^{\mathrm{o}} \quad$ (1) uprag்yndan ajtadoġač jatqyn birgeḿa da kemišti Josef

(2) upraġyn özünün qolunda anyn da qačty da čyqty ol

(3) ty\{̌şqaryġa. ויהי [13] Da edi körgenindečoq ol qatyn ki ke-

(4) mišti Josef uprag̉yn qolunda anyn da qačty ol tyšqary-

(5) gàa. ותקרא Da čag̀yrdy elińa üvünün da ajtty

(6) alarg̉a ajtadog̉ač bağyjyz keltirdi Jisra’el kišini külme

(7) bizd́an keldi maja jatma birgema da čag̀yrdym ullu

(8) avaz byla. יויהי [15] Da edi ešitkenindečoq ki kötür-

(9) düm avazymny da čağyrdym da kemišti upraġyn ö-

(10) zünün qatymda da qačty da čyqty ol tyšqaryğa.

(11) [ותנח [16] Da qojdu upraġyn qatynda kelginče biji anyn

(12) üvüńa. ותדבר [17] Da sözledi anar ošpu sözler

(13) kibik ajtadoğač keldi maja ol Jisra’el qul ki keltirdij

(14) bizge külḿa mend́an. ויהי [18] Da edi kötürgenim-

(15) dečoq avazymny da čag̉yrdym da kemišti uprag̉yn ö-

(16) zünün qatymda da qačty ol tyšqaryġa. ויהי [19] Da edi

(17) ešitkečoq biji anyn ošol sözlerin qatynynyn ki sözledi anar

(18) ajtadog̉ač ošpu sözlar kibik qyldy maja quluj da qabundu

(19) ačuvu anyn. ויקח. [20] Da aldy biji Josef\{nin\} any da berdi any ol

(20) zyndan üvǵa orunġa ki tutqunlary ol bijnin tutqun-

(21) lanġan ediĺar da edi anda ol zyndan üvd́a. [21]

$65 \mathrm{v}^{\mathrm{o}} \quad$ (1) Da edi bolušlugiu Adonajnyn Josef byla da sundu anar šavağat 
(6) and he did not know anything he had, except the

(7) bread which he ate. And Joseph was a handsome in form and

(8) handsome in appearance. [7] And it was after these things,

(9) and his lord's wife lifted her eyes on Joseph,

(10) and she said, 'Lie with me.' [8] But

(11) he did not want to, and said to his lord's wife, 'Lo, my lord does not know

(12) what is with me in the house, and all that he has

(13) he put in my charge. [9] There is no superior in this house

(14) except me, and he has not spared anything from me but you, because

(15) you are his wife: how could I do this great wrong?

(16) And would sin against God.' [10] And

(17) it was, when she spoke to Joseph every day, he did not listen to her,

(18) to lie by her, to be with her. [11] And it was

(19) one day, and Joseph came to the house to do his work,

(20) and there was none of the people of the house

(21) there in the room. [12] And the woman caught him

(1) by his garment, saying, 'Lie with me.' And Josef left

(2) his own garment in her hand, and fled, and went

(3) outside. [13] And it was, when she saw that

(4) he had left his garment in her hand, and had fled outside,

(5) [14] That she called to the men of her house, and said

(6) to them, saying, 'See, he has brought in a Hebrew to us to

(7) laugh at us. He came in to me to lie with me, and I cried with a loud

(8) voice. [15] And it was, when he heard that I lifted

(9) up my voice and cried, that he left his garment

(10) beside me, and fled, and went outside.'

(11) [16] And she laid up his garment by her, until his lord came

(12) home. [17] And she spoke to him according to these words,

(13) saying, "The Hebrew servant, which you have brought

(14) to us, came in to me to laugh at me. [18] And it was, when I raised

(15) my voice and cried, that he left his garment

(16) beside me and fled outside.' [19] And it was,

(17) when his master heard the words of his wife, which she spoke to him,

(18) saying, 'Your servant did matters like these to me', that

(18) his anger was kindled. [20] And Joseph's lord took him, and put him in

(19) prison, a place where the lord's prisoners were imprisoned,

(20) and he was there in the prison. [21]

(1) But the help of the Lord was with Joseph and showed him mercy, $\quad 65 \mathrm{v}^{\mathrm{o}}$ 
(2) da berdi ošol širinligin közlerind́a ag̉arag̉ynyn ol zyndan

(3) üvünün. ויתן [22] Da berdi ag̉araġy ol zyndan üvünün er-

(4) kine Josefnin ošol bar ol tutqunlanganlarny ki ol zyndan üvd́a

(5) da ošol barča neki alar qylaredilar anda olda qylaredi.

(6) .אין [23] Ag̉arag̉y ol zyndan üvünün baqmasedi ošol heč nemeni-

(7) de qolunda anyn anlyqbyla ki bolušluğu Adonajnyn edi bir-

(8) gesińa da neki ol qylaredi Adonaj onartyredi.

Genesis 40

(9) Da edi son ol išlerd́an ošpulardan jazyqly boldular ički

(10) berüvčüsü bijinin Micrinin da ol ötmek biširüvčü bijle-

(11) rińa özlerinin bijińa Micrinin. [יקצף Da ačuvlandy

(12) par'o eki vezirleri üstüńa ag̉arag̉y üstüna ol ički

(13) berüvčülernin da ag̉araġy üstüńa ol ötmek biširiv-

(14) čülernin. [3] Da berdi alarny saqlavyna üvünün ag̉ara-

(15) g gynyn ol qasapčylarnyn ol zyndan üvǵa ol orunġa ki Josef

(16) tutqunlanġan edi anda. [4] Da symarlady ag̉arag̉y

(17) ol qasapčylarnyn ošol Josefni birgelerińa da jumuš etti

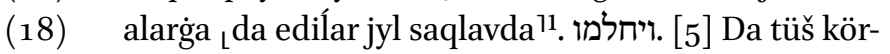

(19) dülar tüš eksilerid́a kiši tüšün bir kečed́a kiši jorasy-

(20) na köŕa tüšünün ol ički berüvčü da ol ötmek

(21) biširüvčü ki bijinin Micrinin ki tutqunlanġan edilar ol

66 ro (1) zyndan \{üvd́a\}. ויבא [6] Da keldi Josef alargaa ertenbylada da kör-

(2) dü alarny da muna alar qubargandylar. וישאל [7] Da sordu

(3) vezirlerind́an $\left\{\right.$ paróonun $^{2}$ ki birgesińa saqlavynda üvünün bijinin ajt[a]-

(4) dog̉ač ${ }^{3}$ neüčün jüzlerijiz jamandylar bügün. ויאמרו. [8] Da

(5) ajttylar anar tüš tüš kördük da joralavču joḥtur any

(6) da ajtty alargaa Josef muna Tenrinin erkindedir joralar

(7) qotaryjyz endi maja. [9] Da qotardy agaaraġy ol

(8) ički berüvčülernin ošol tüšün özünün Josefke da

\footnotetext{
${ }^{1}$ Interpretative addition to the standard text. $\quad{ }^{2}$ Marginal insertion by another hand. | TKow.o1: par'onun. | H: par'onun. | C: par'onyy. $\quad{ }^{3} \mathrm{~K}$ : ajtdogač; a scribal error; cf., however, Gen 28:6. | TKow.o1: ajtadoġač. | H: ajtadogac. | C: demä.
} 
(2) and gave him favour in the eyes of the superior of the prison.

(3) [22] And the superior of the prison put Joseph in charge of

(4) all the prisoners that were in the prison.

(5) And whatever they did there, he was the one who did it.

(6) [23] The superior of the prison did not look to anything

(7) that was under his hand, but the help of the Lord was with him.

(8) And whatever he did, the Lord made it to prosper.

Genesis 40

(9) And it was after these things, the cup-bearer

(10) of the king of Egypt and his baker sinned against

(11) their lord the king of Egypt. [2] And Pharaoh

(12) was angry at his two officers, at the superior of the cup-bearers,

(13) and at the superior of the bakers.

(14) [3] And he put them under the guard of the house of the superior

(15) of the executioners, into prison, the place where Joseph

(16) was imprisoned. [4] And the superior

(17) of the executioners assigned Joseph with them, and he served

(18) them. [And they were one year under guard. ${ }^{163}$ [5] And

(19) the two of them dreamed a dream, each his dream, in one night, each man

(20) according to the interpretation of his dream, the cup-bearer and the baker

(21) of the king of Egypt, who were imprisoned

(1) in the prison. [6] And Joseph came in to them in the morning, and $66 \mathrm{r}^{\circ}$ saw

(2) them, and, lo, they turned pale. [7] And he asked

(3) $\{$ Pharaoh's $\}$ officers that were with him under guard in his lord's house, saying,

(4) 'Why do your faces look so bad today?' [8] And

(5) they said to him, 'We have dreamed a dream, and there is no interpreter of it.'

(6) And Joseph said to them, 'Lo, interpretations are in the hand of God.

(7) Now, tell me them.' [9] And the superior

(8) cup-bearer told his dream to Joseph, and

63 An interpretative addition to Gen 40:4. 
(9) ajtty anar tüšümd́a da muna borlalyq alnymda.

(10) (10] Da borlalyqta üč butaqlar da ol jašarg̉ačoq

(11) üstü čečegi anyn jetištirdilar solqunlary anyn borlalar.

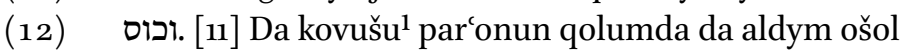

(13) ol borlalarny da ezdim alarny kovušuna par'onun da

(14) berdim ošol ol kovušnu uvuču üstüńa par'onun.

(15) Da ajtty anar Josef budur jorasy anyn üč ol

(16) butaqlar üč künlerdilar alar. בעוד. [13] Hanuz üč künler-

(17) den kötürür paro ošol bašyjny da qajtaryr seni ornu-

(18) ja da berirsen kovušun par'onun qoluna anyn ol burunġu

(19) kečinmekke köŕa ki edij ički berüvčüsü anyn.

(20) כי (14] Ki ančaq saġynġyn meni $\{\text { birgene }\}^{2}$ ki nečik jahšy̌y bolsa saja da

(21) qylġyn endi birgemáa šavag̉at da saġyndyrg்yn meni paro

$66 \mathrm{v}^{\mathrm{o}}$ (1) ġa da čyggarg̉yn meni ol üvd́an ošpu. כי [15] Ki urlanma

(2) urlandym jerind́an ol Jisra’ellernin da dag்yn bundada qylmadym

(3) nemed́a ki qojdular meni zyndanġa. וירא. [16] Da kördü

(4) ag̉araġy ol ötmek biširüvčülernin ki jaḩšy joralady da

(5) ajtty Josefke ham men tüšümd́a da muna üč četen-

(6) leri aq ötmeknin bašymüstüne. [17 [17 Da ol

(7) bijikrek četend́a bar jemind́an par'onun iši ötmek

(8) biširüvčünün da ol quš ašajdy alarny ol četend́an bašym

(9) üstünd́an. ויען [18] Da qaruv berdi Josef da ajtty bu-

(10) dur jorasy anyn üč ol četenĺar üč künlerdilar alar.

(11) בעוד [19] Hanuz üč künlerd́an kötürür par'o ošol

(12) bašyjny üstüjd́an da asar seni ag̉ač üstüńa da ašar

(13) ol quš ošol etijni üstüjd́an. [20] Da edi

(14) ol üčünčü künd́a tuvġan künü edi par'onun da

(15) qyldy ički bar qullarynda da kötürdü ošol bašyn ag̉araġy-

(16) nyn ol ički berüvčülernin da ošol bašyn ol ötmek

(17) biširüvčülernin ortasynda qullarynyn. וישב. [21] Da qaj-

(18) tardy ošol ag̉araġy ol ički berüvčülernin ornuna

(19) ički bermeginin da berdi ošol ol kovušnu uvuču

(20) üstüńa par'onun. [22] Da ošol ag̉araġy ol

(21) ötmek biširüvčülernin asty ki nečik joralady alarg̉a

$67 \mathrm{r}^{\mathrm{o}} \quad$ (1) Josef. [ולא. [23] Da saġynmady ag̉araġy ol ički berüvčülernin

(2) ošol Josefni da unuttu any.

${ }^{1} \mathrm{~K}$ : Spelled with word-initial kaph throughout the manuscript (also in TKow.o1). | TKow.o1: kovušu. | H: kuvusu. | C: syrčasy. $\quad{ }^{2} \mathrm{~K}$ : deest; a scribal error. SWKar. birgene was inserted by another hand. | TKow.o1: birgeje. | H: birgene. | C: birgäyä. 
(9) said to him, 'In my dream, lo, a vine was before me,

(10) [10] And in the vine were three branches. As soon as it budded,

(11) its blossoms shot forth, and its bunches ripened into grapes.

(12) [11] And Pharaoh's cup was in my hand. And I took the

(13) grapes, and pressed them into Pharaoh's cup, and

(14) I gave the cup into Pharaoh's hand.'

(15) [12] And Joseph said to him, "This is the interpretation of it: The three

(16) branches are three days. [13] Yet within three days

(17) Pharaoh shall lift up your head, and restore you to your place,

(18) and you shall give Pharaoh's cup to his hand, after the former

(19) manner of life when you were his cup-bearer.

(20) [14] But only remember me \{with you $\}$ when it shall be good for you, and

(21) practice kindness with me, and make mention of me to Pharaoh,

(1) and bring me out of this house. [15] Because I was stolen

(2) away out of the land of the Hebrews, and also here I have done

(3) nothing that they should put me into the prison.' [16] And

(4) the superior of the bakers saw that the interpretation was good, and he

(5) said to Joseph, 'Me too. In my dream: and, lo, I had three white

(6) bread baskets on my head. [17] And in the

(7) highest basket were |some| of all of Pharaoh's foods, the work of

(8) bakers, but the birds ate them out of the basket on my head.'

(9) [18] And Joseph answered and said, 'This

(10) is the interpretation thereof: The three baskets are three days.

(11) [19] Yet within three days Pharaoh shall lift your head up from you,

(12) and shall hang you on a tree. And the birds shall eat

(13) your flesh from you.' [20] And it was

(14) on the third day, it was Pharaoh's birthday, and

(15) he made a feast for all his servants. And he lifted up the head of the superior

(16) of the cup-bearers and of the superior baker

(17) among his servants. [21] And he

(18) restored the superior of the cup-bearers to his position

(19) of cup-bearership, and he gave the cup

(20) in Pharaoh's hand. [22] But he hanged the superior of the

(21) bakers, as Joseph had interpreted to them.

(1) [23] And the chief cupbearer did not remember

(2) Joseph. And he forgot him. 
Genesis 41

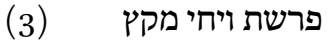

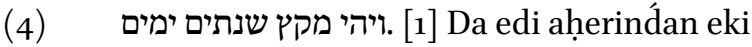

(5) jyllarnyn da par'o tüš köreredi da muna tu-

(6) rady ol Nil qatyna. 20 [הנה Da muna ol Nildan čyġadylar

(7) jedi tanalar körklü körümlülar da semiz etliler da

(8) kütüldüler qamušluqta. והנה. [3] Da muna jedi tanalar

(9) özgelar čyġadylar alar artyna ol Nildan jaman körümlü-

(10) ler da boš etliler da turdular janynda ol tanalarnyn

(11) qyryj üstüńa ol Nilnin. ותאכלנה. [4] Da ašadylar

(12) ol tanalar jaman ol körümlülar da uvaq etlílar ošol jedi

(13) ol tanalarny körklü ol körümlülerni da ol semizlerni

(14) da ojnady par'o. [5] Da juqlady da tüš kördü

(15) ekinči keret da muna jedi koloslar ösedilar bir

(16) qamušta semizlar da jaḩ̌ylar. והנה. [6] Da muna jedi

(17) koloslar uvaqlar da vatylġanlar qadim jelind́an ösedilar alar

(18) artyna. ותבלענה. [7] Da juttular jedi ol koloslar ol boš-

(19) lar ošol jedi ol koloslarny ol savlarny da ol tolularny da

(20) ojandy par'o da muna tügendi tüš. ויהי [8] Da edi

$67 \mathrm{~V}^{\mathrm{o}} \quad$ (1) ertenbylada da qopsalady క̌any anyn da ijdi da ündedi

(2) ošol bar filosoflary Micrinin da ošol bar uslularyn anyn

(3) da qotardy alarg̉a ošol tüšnü da jog̉edi joralavču ala $\{r\}$ dan

(4) par`og̉a. וידבר [9] Da sözledi ag̉arag̉y ol ički berüv-

(5) čülernin par`og̀a ajtadog̉ač ošol jazyqlarymny men sağyndy-

(6) פרעה [10] Parco ačuvlandy qullary üstü-

(7) ńa da berdi meni saqlavynda üvünün ag̉araġynyn ol qasap-

(8) čylarnyn meni da ošol ag̉araġyn ol ötmek biširüvčülar-

(9) nin. ונחלמה. [11] Da tüš kördük tüš bir kečed́a

(10) men da olda kiši jorasyna köŕa tüšünün tüš kör-

(11) dük. ושם. [12] Da anda birgemizǵa edi Jisra’el ulan

(12) qul ag̉araġyna ol qasapčylarnyn da qotardyq anar da joralady

(13) bizǵa ošol tüšlerimizni kišiǵa jorasyna köŕa tü-

(14) šünün joralady. ויהי [13] Da edi ki nečik joralady bizǵa

(15) alaj boldu meni qajtyrdy ornuma da \{any\} asty. וישלח. [14]

(16) Da ijdi paro da ündedi ošol Josefny da juvur- 
Genesis 41

(3) Parashat Miketz

(4) [1] And it was in the course of two

(5) years, and Pharaoh dreamed: and, lo,

(6) he stands by the Nile. [2] And, lo, there came up out of the Nile

(7) seven cows beautiful-looking and plump, and

(8) they fed in the reeds. [3] And, lo, seven other cows

(9) came up after them out of the river, of bad-looking

(10) and thin, and they stood by the other cows

(11) on the bank of the river. [4] And

(12) the bad-looking and thin cows ate up the seven

(13) beautiful-looking and fat cows.

(14) And Pharaoh awoke. [5] And he slept and dreamed

(15) the second time: and, lo, seven ears of grain came up on one

(16) stalk, plump and good. [6] And, lo, seven

(17) thin ears and lashed by the east wind sprung up

(18) after them. [7] And the seven empty ears swallowed

(19) the seven healthy and full ears. And

(20) Pharaoh awoke, and, lo, the dream ended. [8] And it was

(1) in the morning, and his spirit was troubled, and he sent and called

(2) for all the magicians of Egypt, and all its wise men.

(3) And he told them his dream, but there was none of them that could interpret |them|

(4) to Pharaoh. [9] Then the superior of the cup-bearers spoke

(5) to Pharaoh, saying, 'I do remember my faults

(6) this day. [10] Pharaoh was angry with his servants,

(7) and put me under guard in the house of the superior of the executioners,

(8) me and the superior of the bakers.

(9) [11] And we dreamed a dream in one night,

(10) I and he, we dreamed each man according to the interpretation of his dream.

(11) [12] And a young man was there with us, a Hebrew,

(12) servant to the superior of the executioners. And we told him, and he interpreted

(13) to us our dreams: to each man according to his interpretation

(14) he did interpret. [13] And it was-as he interpreted to us,

(15) so it was: me he restored to my place, and him he hanged.' [14]

(16) And Pharaoh sent and called Joseph, and they made him run 
(17) ttular any ol zyndandan da jülüttü da tüvšürdü

(18) ošol upraqlaryn da keldi par'oğa. [יאמר [15] Da

(19) ajtty par'o Josefka tüš tüš kördüm da joralavču

(20) joḥtu any da men ešittim senin üčün ajtadoġač anlaj-

(21) sen tüšnü joralama any. ויען [16] Da qaruv berdi Josef

$68 \mathrm{r}^{\circ}$ (1) par'og̉a ajtadog̉ač mend́an bašqa Tenri arttyrg̉aj o-

(2) šol savlug̉un par'onun. וידבר [17] Da sözledi par'o

(3) Josefka tüšümd́a da muna men turamen qyryj üstü-

(4) ne ol Nilnin. והנה. [18] Da muna ol Nildan čyğadylar jedi

(5) tanalar semiz etlílar da körklü bojlular da kütüldü-

(6) Ílar qamušluqta. והנה. [19] Da muna jedi tanalar özgeĺar

(7) čyġadylar alar artyna aryqlar da jaman körümlülar ast-

(8) ry da uvaq etlilar körmedim alar kibik bar jerind́a

(9) Micrinin jamanlyqqa. ותאכלנה. [20] Da ašadylar ol tanalar

(10) ol uvaqlar da ol jamanlar ošol jedi ol tanalarny ol burun-

(11) gularny ol semizlerni. ותבאנה. [21] Da keldiĺar ičleri-

(12) ńa da bilinmedi ki kirdilar ičlerińa da körümleri

(13) alarnyn edi jaman ki edi burundan da ojandym. וארא. [22]

(14) Da kördüm tüšümd́a da muna jedi koloslar ösedi-

(15) ĺar bir qamušta tolular da jahšylar. והנה. [23] Da muna

(16) jedi koloslar bürüškenlar uvaqlar vatylġanlar qadim jelin-

(17) dan ösedilar alar artyna. ותבלען [24] Da juttular

(18) jedi ol koloslar ol uvaqlar ošol jedi koloslarny ol

(19) jaḥsylarny da ajttym ol filosoflarg̉a da anlatuvču joḥtu

(20) maja jorasyn alarnyn. [יאמר Da ajtty Josef paro-

(21) g ga tüšü par'onun birdi ol ošol ne ki ol Tenri

$68 \mathrm{v}^{\circ}$ (1) qylady anlatty par'og̉a. שבע. [26] Jedi tanalar ol jaḥ̌y-

(2) lar jedi jyllardylar alar da jedi ol koloslar ol jaḩšylar jedi

(3) jyllardylar alar bir tüštü ol. ושבע [27] Da jedi ol

(4) tanalar ol uvaqlar da ol jamanlar ol čyġuvčular alar

(5) artyna jedi jyllardylar alar da jedi ol koloslar ol bošlar

(6) vatylġanlar ol qadim jelind́an bolurlar jedi jyllar ačlyqnyn.

(7) הוא (28] Oldu ol söz ki sözledim par'og̉a neki ol

(8) Tenri qylady körgüzdü parog̉a. הנה. [29] Muna jedi

(9) jyllar keledilar ullu toqluq bolur bar jerind́a Micrinin.

(10) וקמו [30] Da turarlar jedi jyllary ačlyqnyn alardan sortun da

(11) unutulur bar ol toqluq jerind́a Micrinin da tavusur 
(17) from the prison, and he let him shave and change

(18) his clothes, and he came to Pharaoh. [15] And

(19) Pharaoh said to Joseph, 'I have dreamed a dream, and there is none that can interpret

(20) it. And I have heard about you, saying, you understand

(21) a dream to interpret it.' [16] And Joseph answered Pharaoh,

(1) saying, 'It is other than me: God shall restore

(2) the health of Pharaoh.' [17] And Pharaoh spoke

(3) to Joseph, 'In my dream, lo, I stand on the bank

(4) of the Nile: [18] And, lo, there came up out of the Nile seven

(5) cows, plump and beautiful in form and they fed

(6) in the reed. [19] And, lo, seven other cows

(7) came up after them, gaunt and very bad-looking

(8) and thin, such as I never saw in all the land

(9) of Egypt for badness. [20] And the cows,

(10) those thin and the ill ate up the first seven

(11) fat cows. [21] And they went inside them,

(12) and it could not be known that they had entered them, but they appearance

(13) was still ill as at the beginning. And I awoke. [22]

(14) And I saw in my dream, and, lo, seven ears came up

(15) on one stalk, full and good. [23] And, lo,

(16) seven ears, shrivelled, thin, and lashed by the east wind

(17) sprung up after them. [24] And

(18) the thin ears swallowed the seven

(19) good ears. And I told |this| to the magicians, but there was none that could explain

(20) its interpretation to me.' [25] And Joseph said to Pharaoh,

(21) 'The dream of Pharaoh is one: God

(1) has told Pharaoh what he is doing. [26] The seven good cows

(2) are seven years, and the seven good ears are seven

(3) years: the dream is one. [27] And the seven

(4) thin and ill cows that came up after them

(5) are seven years, and the seven empty ears

(6) lashed by the east wind will be seven years of famine.

(7) [28] This is the word which I have spoken to Pharaoh:

(8) It has shown to Pharaoh what God is doing. [29] Lo, seven

(9) years of great plenty are coming in all the land of Egypt.

(10) [30] And seven years of famine will arise after them, and

(11) all the plenty will be forgotten in the land of Egypt, and the 
(12) ol ačlyq ošol bar elin ol jernin. ולא. [31] Da bilinmes-

(13) ti ol toqluq jerd́a alnyndan ol ačlyqnyn andan sortun

(14) ki küčlü bolur ol ačlyq astry. ועל [32] Da ekilenmegi

(15) üčün ol tüšnün par'og̉a ki hadirdi ol söz alnyn-

(16) dan ol Tenrinin da žaḥtlajdy ol Tenri qylma any.

(17) (33] Da haligińa baqsyn paro _[aqully kišini da uslunu da qojsun any ag̉araq jeri üstüne Micrinin. יעשה. [34] Bulaj qylsyn par'o $^{11}$ da vakil etsin

(18) ag̉alyqlar ol jer üstüne da bešinči ülüšün alsyn

(19) jerind́a Micrinin jedi jyllarynda ol toqluqnun. ויקבו [35]

(20) Da jyštyrsynlar ošol bar bürtügün ol jahšy jyllarnyn

(21) ol kelüvčülernin ošpularnyn da jyštyrsynlar bürtük

69 r $^{\circ} \quad$ (1) erki tübüńa par'onun bürtük šaharlarda da saqlasyn-

(2) lar. והיה [36] Da bolsun ol bürtük amanatqa elińa jer-

(3) nin jedi jyllaryna ol ačlyqnyn ki bolurlar jerind́a Micri-

(4) nin da eksilmesin eli ol jernin ačlyqtan. וייטב [37]

(5) Da jaḥšy köründü ol söz közlerind́a par'onun da

(6) közlerind́a bar qullarynyn. ויאמר. [38 Da ajtty

(7) par'o qullaryna özünün tabarbizmo bundij kiši ki

(8) alhemi Tenrinin anda. [39] Da ajtty par'o

(9) Josefka bildirip sortun Tenri saja ošol bar bunu

(10) joḥtu aqylly da uslu senin kibik. אתה. [40] Sen bolg̈un

(11) ag̉araq üvüm üstüńa da senin sözüjbyla teb-

(12) rensin bar ulusum ančaq išibyla ol taḥtnyn ullu-

(13) raq bolurmen send́an. [41] Da ajtty paro

(14) Josefka baqqyn berdim seni ag̉araq bar jeri üstüńa

(15) Micrinin. ויסר [42] Da keterdi par'o ošol jüzügün

(16) qolu üstünd́an da berdi any qolu üstüńa Josefnin

(17) da kijdirdi anar bez upraqlar da qojdu altyn synžyr

(18) bojnu üstüńa anyn. וירכב [43] Da atlanġyzdyrtty

(19) any ol ekinči markavda ki özünün da čaġyrdylar

(20) alnynda anyn čökmek da berḿa any ag̉araq bar jeri

(21) üstüne Micrinin. [יאמר [4] Da ajtty paro

$69 \mathrm{v}^{\mathrm{o}}$ (1) Josef́ka menmen par'o da senin erkijdan bašqa kötürme-

\footnotetext{
${ }^{1} \mathrm{~K}$ : deest, a scribal error. Our reconstruction is based on the Hebrew original, TKow.o1, H, C, and Gen 41:39-40. | TKow.o1: aqylly kišini da uslunu da qojsun any aġaraq jeri üstüńa Micrinin. יעשה. Bulaj qylsyn par'o. | H: aqylly kisi da uslu da qojsun any agaraq jeri istine Micrinin. יעשה Qylsyn par'o bu isni. | C: aqylly da uslu kiši da qojsyn any jeri üstüne Mysyrnyy. יעשה. Qylsyn paro.
} 
(12) famine will consume all the people of the land. [31] And

(13) the plenty will not be known in the land by reason of the famine that will follow,

(14) for it will be very severe. [32] And the doubling of

(15) Pharaoh's, as for that, it is because the word is ready before

(16) God, and God hastens to do that.

(17) [33] Now let Pharaoh seek out $\mathrm{a}_{\mathrm{L}}$ [man rational and wise, and set him as a superior over the land of Egypt. [34] Let Pharaoh do this] ${ }^{164}$, and let him appoint

(18) rulers over the land, and take the fifth part

(19) over the land of Egypt in the seven years of plenty. [35]

(20) And let them gather all the grain of those good years

(21) that are coming, and gather the grain

(1) under the authority of Pharaoh, let them keep the grain in the cities. $69 \mathrm{r}^{\mathbf{o}}$

(2) [36] And that food shall be for reserve to the people of the land

(3) for the seven years of famine, which will be in the land of Egypt,

(4) that the people of the land may not perish through the famine.' [37]

(5) And the words seemed good in the eyes of Pharaoh, and

(6) in the eyes of all his servants. [38] And Pharaoh said

(7) to his servants, 'Will we find such a man as this is,

(8) a man in whom there is the inspiration of God?' [39] And Pharaoh said

(9) to Joseph, 'Since God has let you know about all this,

(10) there is none so rational and wise as you are. [40] Be

(11) a superior over my house, and according to your word

(12) shall all my people move. Only by the matters of the throne

(13) will I be greater than you.' [41] And Pharaoh said

(14) to Joseph, 'See, I have set you superior over all the land

(15) of Egypt.' [42] And Pharaoh took off his ring

(16) from his hand, and put it on Joseph's hand,

(17) and clothed him in linen clothing, and put a gold chain

(18) on his neck. [43] And he had him driven

(19) in the second chariot which he had, and they cried

(20) in front of him to bow the knee and to make him superior over all the land

(21) of Egypt. [44] And Pharaoh said

(1) to Joseph, 'I am Pharaoh, and without your authority shall no man lift $69 \mathrm{v}^{\mathbf{o}}$ up

64 Reconstructed on the basis of the Hebrew original, H, C, and Gen 41:39-40. 
(2) sin kišide ošol qolun da ošol ajaġyn erkejḿa bar

(3) jerind́a Micrinin. ויקרא [45 Da atady paro atyn Josef-

(4) nin Cafnat Pa'neaḥ da berdi anar ošol Asnatny qyzyn

(5) Potifera'nyn qara tonlusunun Onnun qatynlyqqa da čyq-

(6) ty ag̉alyqlyq slavasy Josefnin jeri üstüńa Micrinin.

(7) ויוסף [46] Da Josef otuz jašar edi turganynda alnyn-

(8) da par'onun bijinin Micrinin da čyqty Josef alnyndan

(9) paronun da ašty bar jerind́a Micrinin. ותעש [47]

(10) Da bittirdi ol jer jedi jyllarynda ol toqluqnun qoš

(11) uvučlar byla. ויקבץ Da jyštyrdy Josef ošol bar

(12) bürtügün jedi jyllarnyn ki edilar jerind́a Micrinin da

(13) berdi bürtük šaharlarda bürtügün tüzünün ol šahar-

(14) nyn ki čüvrelerind́a anyn berdi ortasynda anyn.

(15) יויצבר [49] Da jyštyrdy Josef bürtük qumun kibik ol

(16) tengiznin köbüsü astry neginče ki qaldy sanamaqtan

(17) ki jog̉edi san. וליוסף. [50] Da Josef́ka tuvdu eki u-

(18) vullar kelmesten burun jyly ačlyqnyn ki töredi anar

(19) Asnat qyzy Potifera'nyn qara tonlusunun Onnun.

(20) ויקרא [51] Da atady Josef ošol atyn ol tunġučnun

(21) Menaše ki unutturdu maja Tenri ošol bar qyjynymny

7o ro (1) da ošol bar üvün atamnyn. [52] Da ošol atyn

(2) ol ekinčinin atady Efrajim ki jajdy meni Tenri qyjyn-

(3) ly jerimáa. [5כלינה] Da tügendilar jedi jyllar ol

(4) toqluqnun ki edi ${ }_{L}\langle$ jedi $\rangle\{\text { jerinde }\}^{11}$ Micrinin. ותחלינה. [54] Da bašlan-

(5) dylar jedi jyllary ol ačlyqnyn kelḿa ki nečik ajtty Josef

(6) da edi ačlyq bar ol jerind́a da bar jerind́a Micrinin

(7) edi ötmek. [תרעב [55] Da ačyqty eli jerinin Mic-

(8) rinin ötmekke da firjat etti ol ulus par'o-

(9) ga ötmek üčün da ajtty paroo bar elińa Micri-

(10) nin baryjyz Josefke ne ki ajtsa sizǵa qylyjyz.

(11) והרעב [56 Da ol ačlyq edi bar jüzleri üstüne

(12) ol jernin da ačty Josef ošol ol ḥaznalarny ki alarda

(13) ol bürtük da satty bürtük bar elińa Micrinin

(14) da küčejdi ol ačlyq bar jerind́a Micrinin. וכל [57 ]

(15) Da bar eli ol jernin keldilar Micriǵa Josefke satyn

(16) alma bürtük ki küčejdi ol ačlyq bar ol jerda.

\footnotetext{
${ }^{1}$ Correction by another hand. | TKow.o1: jerind́a. | H: jerinde. | C: jerindä.
} 
(2) his hand or foot to rule in all

(3) the land of Egypt.' [45] And Pharaoh called Joseph's name

(4) Zaphenath-Paneah. And he gave him Asenath, daughter

(5) of Potiphera, priest of On, for a wife. And the

(6) fame of Joseph's rule went out over all the land of Egypt.

(7) [46] And Joseph was thirty years old when he stood before

(8) Pharaoh, king of Egypt. And Joseph went out from before

(9) Pharaoh, and passed over all the land of Egypt. [47]

(10) And in the seven plenteous years the earth produced

(11) by handfuls. [48] And he gathered up all

(12) the grain of the seven years, which were in the land of Egypt, and

(13) and he put the grain in the cities: he put the grain of the city's fields

(14) that were around it inside of it.

(15) [49] And Joseph gathered grain as the sand

(16) of the sea, in great abundance, until he ceased to number it,

(17) because it was without number. [50] And two sons were born to Joseph

(18) before the year of famine came, which Asenath,

(19) daughter of Potiphera, priest of On, bore to him.

(20) [51] And Joseph called the name of the firstborn

(21) Manasseh: 'Because God has made me forget all my affliction,

(1) and all my father's house.' [52] And the name

(2) of the second called the Ephraim: 'Because God has spread me

(3) in the land of my affliction.' [53] And the seven years

(4) of plenty, that was 〈seven〉 \{in the land $\}$ of Egypt, finished. [54] And

(5) the seven years of famine started to come, as Joseph had said.

(6) And the famine was in all lands, but in all the land of Egypt

(7) there was bread. [55] And when all the people of the land of Egypt starved

(8) for bread, and the people cried to Pharaoh

(9) for bread, and Pharaoh said to all the people

(10) of Egypt, 'Go to Joseph. Do what he says to you.'

(11) [56] And the famine was over all the face

(12) of the earth. And Joseph opened all the treasuries in which

(13) there was grain, and sold grain to all the people of Egypt.

(14) And the famine became stronger in all the land of Egypt. [57]

(15) And all the people of the earth came to Egypt, to Joseph, to buy

(16) grain, because the famine became stronger in all lands. 


\section{Genesis 42}

(17) Da kördü Jacaqov ki bardy bürtük Micrid́a

(18) da ajtty Ja'aqov uvullaryna nek körgüzesiz özüjüznü

(19) ${ }_{L}$ ki eksik tüvülsiz heč nemeged́a vali men köremen ki siz

(20) urušmaqqa kelirsiz eksikligind́an ötmeknin ${ }^{11}$.

(21) (2] Da ajtty muna ešittim ki bardy bür-

$70 \mathrm{v}^{\mathrm{o}}$ (1) tük Micrid́a enijiz da satyn alyjyz bürtük bizǵa

(2) andan da tiri bolajyq da ölmejik. וירדו [3] Da endi-

(3) ler qaryndašlary Josefnin onovlan satyn alma bürtük Mic-

(4) ridan. [4] Da ošol Binjaminni qaryndašyn Josefnin

(5) ijmedi Ja'aqov qaryndašlary byla ki ajtty mağat učrar

(6) any ölüm. [5] Da keldilar ulanlary Jisra’elnin

(7) satyn alma bürtük ortasynda ol kelüvčülernin ki

(8) edi ol ačlyq jerind́a Kena'annyn. ויוסף. [6] Da Josef

(9) ol edi ol erklenüvčü ol jer üstüne ol edi

(10) ol bürtük satuvču bar ulusuna ol jernin da keldilar

(11) qaryndašlary Josefnin da bašurdular anar jüzleri byla jerǵa.

(12) [7] Da kördü Josef ošol qaryndašlaryn da tanydy

(13) alarny da tanyg்ysyz boldu alarg̉a da sözledi birgelerińa

(14) qaty sözĺar da ajtty alarg̉a qajdan keldijiz da ajtty-

(15) lar jerind́an Kena'annyn satyn alma bürtük. ויכר. [8]

(16) Da tanydy Josef ošol qaryndašlaryn da alar tanymadylar any.

(17) (19] Da saġyndy Josef ošol ol tüšlerni ki tüš

(18) kördü alarg̉a da ajtty alarg̉a čejsylavčulardyrsiz kör-

(19) me ošol ajibin ol jernin keldijiz. ויאמרו. [10] Da ajt-

(20) tylar anar joq bijim vale qullaryj keldilar satyn alma bür-

(21) tük. כלנו. [11] Barymyz uvullary bir kišinindir biz könü-

$71 \mathrm{r}^{\mathrm{o}}$ (1) lerdir biz tüvül edilar qullaryj čejsylavčular. ויאמר. [12]

(2) Da ajtty alarg̉a joq ki ajibin ol jernin keldijiz körḿa.

(3) ויאמרו [13] Da ajttylar on ökövlen qullaryj qaryndaš-

(4) lardyr biz uvullary bir kišinin jerind́a Kena'annyn da

(5) ol kičisi bügünd́a atamyz qatynady da ol bir

(6) johtur. ויאמר [14] Da ajtty alarga Josef oldu ki

\footnotetext{
${ }^{1}$ Interpretative addition to the standard text.
} 


\section{Genesis 42}

(17) [1] And Jacob saw that there was grain in Egypt,

(18) and Jacob said to his sons, 'Why do you look at one another,

(19) L as if you were not lacking anything? But I see that you will

(20) get into fight because of the lack of bread.' 165 [2] And he said, 'Lo, I have heard that there is grain

(1) in Egypt. Go down and buy for us grain

(2) from there, and let us live, and let us not die. [3] And

(3) Joseph's ten brothers went down to buy grain in Egypt.

(4) [4] And Jacob did not send Benjamin, Joseph's brother,

(5) with his brothers, because he said, 'Lest

(6) death befall him.' [5] And the sons of Israel came

(7) to buy grain among those who were coming, because

(8) the famine was in the land of Canaan. [6] And Joseph

(9) was the one in charge over the land, he was

(10) the one that sold grain to all the people of the land. And

(11) Joseph's brothers came, and bowed down themselves with their faces to the earth.

(12) [7] And Joseph saw his brothers, and he recognized

(13) them, but he was unknown to them, and spoke rough words to them.

(14) And he said to them, 'From where have you come?' And

(15) they said, 'From the land of Canaan to buy grain.'

(16) [8] And Joseph recognized his brothers, but they did not recognize him.

(17) [9] And Joseph remembered the dreams which he dreamed

(18) of them, and said to them, 'You are spies.

(19) You have come to see the nakedness of the land.' [10] And they said

(20) to him, 'No, my lord, your servants have come to buy grain.

(21) [11] We are all one man's sons. We

(1) are honest. Your servants were not spies.' [12]

(2) And he said to them, 'No, but you have come to see the nakedness of the land.'

(3) [13] And they said, 'Your servants are twelve. We are brothers,

(4) the sons of one man in the land of Canaan, and

(5) the young is today with our father, and one

(6) is not.' [14] And Joseph said to them, 'It is as

65 An interpretative addition to Gen 42:1. 
(7) sözledim sizǵa ajtadoġač čejsylavčulardyr siz.

(8) בזאת [15] Bunun byla synalyjyz tirlikleri üčün paro-

(9) nun eger čyqsajyz bundan ki ančaq kelgend́a qaryndašyjyz

(10) ol kičirek beri. שלחו. [16] Ijijiz özüjüzden birni

(11) da alsyn ošol qaryndašyjyzny da siz tutqunlanyjyz da

(12) synalasynlar sözlerijiz kertilikmodu qatyjyzda da eger

(13) joq tirlikleri üčün par'onun ki čejsylavčulardyr

(14) siz. ויאסף] Da jyštyrdy alarny saqlavġa üč

(15) künĺar. יויאמר [18] Da ajtty alarg̉a Josef ol ü-

(16) čünčü künd́a bunu qylyjyz da tiri bolujuz ošol Ten-

(17) rid́an men qorqamen. אם. [19] Eger könüler esejiz siz

(18) qaryndašyjyz bir tutqunlansyn üvünd́a saqlavujuznun

(19) da siz baryjyz keltirijiz bürtük tojdurma ačlyg̉yn

(20) elinin üvlerijiznin. [20] Da ošol qaryndašyjyzny

(21) ol kičirekni keltirijiz maja da inamly bolurlar söz-

$71 \mathrm{~V}^{\mathrm{o}}$ (1) lerijiz da ölmessiz da qyldylar alaj. [21] Da ajt-

(2) tylar kiši qaryndašyna kertidan fašmanlylardyr biz qaryndašy-

(3) myz üčün ki kördük tarlyġyn žanynyn jalbarg̉anynda bizǵa

(4) da tynlamadyq anyn üčün keldi bizǵa ol tarlyq ošpu.

(5) ויען [22] Da qaruv berdi Ru'uven alarg̉a ajtadoğač muna

(6) ajtmadymmo sizǵa ajtadog̉ač jazyqly bolmajyz ulan üčün

(7) da tynlamadyjyz da dagynn qany anyn muna izlendi. והם [23]

(8) Da alar bilmedilar ki anlajdy Josef anlyq byla ki ol talmač

(9) edi aralarynda alarnyn. [יסב [24 Da qajyryldy Josef alardan

(10) da jylady da qajtty alarğa da sözledi alarbyla da aldy

(11) alardan ošol Šim'onnu da tutqunlady any közlerič́a alar-

(12) nyn. ויצו [25] Da bujurdu Josef da tolturdular ošol savutla-

(13) ryn alarnyn bürtük byla da qajtarma kümüšün alarnyn ki-

(14) šinin qabyna da berḿa alarg̉a azyq jolġa da qyldy alarg̉a

(15) alaj. וישאו [26] Da kötürdüler ošol bürtüklerin da

(16) qojdular ešekleri üstüńa da bardylar andan. [27]

(17) Da ačty ol bir ošol qabyn berḿa jem ešegińa qonar-

(18) lyqta da kördü ošol kümüšün da muna ol avzunda

(19) qabynyn. ויאמר [28] Da ajtty qaryndašlaryna qajtaryldy

(20) kümüšüm da daġyn ol muna avzundady qabymnyn da čyqty

(21) jürekleri alarnyn qorquvlaryndan da qaltradylar bağyp kiši qaryn- 
(7) I spoke to you, saying, "You are spies."

(8) [15] By this you shall be examined: by Pharaoh's life,

(9) if you go out from here, only when your younger brother comes here

(10) back. [16] Send one of you,

(11) and let him take your brother, and you shall be imprisoned, and

(12) your words shall be examined, whether the truth is with you. And if

(13) not, by Pharaoh's life you are spies.'

(14) [17] And he gathered them together under guard for three

(15) days. [18] And Joseph said to them the

(16) third day, 'Do this, and live.

(17) I fear God: [19] If you are honest men,

(18) let one of your brothers be imprisoned in the house of your prison,

(19) and you go, carry grain to satiate the hunger

(20) of the people of your households. [20] But bring your younger brother

(21) to me and your words will be trustworthy,

(1) and you will not die.' And they did so. [21] And

(2) they said one to another, 'We are verily guilty concerning our brother,

(3) in that we saw the distress of his soul, when he begged us,

(4) and we did not listen. That is why this distress come to us.'

(5) [22] And Reuben answered them, saying, 'Lo,

(6) did I not tell you, saying, "Do not sin against the child"?

(7) But you did not listen. And, lo, also his blood is searched.' [23]

(8) And they did not know that Joseph understood them, by the fact that there was an interpreter

(9) between them. [24] And he turned from them,

(10) and wept. And he returned to them again, and spoke with them, and took

(11) from them Simeon, and imprisoned him before their eyes.

(12) $[25]$ Then Joseph commanded, to fill their vessels

(13) with grain, and to give every man's silver

(14) into his sack, and to give them provision for the way. And

(15) thus was done for them. [26] And they lifted their grain and

(16) loaded them on donkeys, and departed from there. [27]

(17) And one of them opened his sack to give his donkey food

(18) at the place of overnight stay and he saw his silver, and, lo,

(19) it was in the mouth of his sack. [28] And he said to his brothers,

(20) 'My silver is put back: and, lo, it is in my sack's mouth!'

(21) And their hearts left them, and they were afraid, looking one at another, 
$72 \mathrm{r}^{\mathrm{O}} \quad$ (1) dašy üstüńa ajtadog̉ač ne bu qyldy Tenri bizǵa.

(2) יויבאו Da keldilar Ja'aqovğa atasyna özlerinin jerińa

(3) Kena'annyn da anlattylar anar ošol bar ol učrag̉anlarny alarny

(4) ajtadoğač. דבר . [30] Sözledi ol kiši biji ol jernin birge-

(5) mizǵa qaty sözĺar da berdi bizni čejsylavčularny kibik o-

(6) šol ol jerni. [3א [31] Da ajttyq anar könülerbiz

(7) biz tüvül edik čejsylavčular. שנים [32] Önökövlendir

(8) biz \{qaryndašlar $\}^{1}$ uvullary atamyznyn ol bir joḥtu da ol kičirek bügün-

(9) de atamyz qatynady jerind́a Kena'annyn. [33] Da

(10) ajtty bizǵa ol kiši biji ol jernin bunun byla bilirmen

(11) ki könülerdir siz qaryndašyjyzny ol birni qaldyryjyz birgema

(12) da ošol bürtüknü tojdurma ačlyġyn üvüjüznün alyjyz

(13) da baryjyz. והביאו [34] Da keltirijiz ošol qaryndašyjyzny \{ol kiči$\operatorname{rek}[\mathrm{ni}]\}^{2}$

(14) maja da bilirmen ki könülerdir siz ki tüvülsiz čejsylav-

(15) čular ošol qaryndašyjyzny berirmen sizǵa da eli byla ol

(16) jernin satuv etersiz. [35] Da edi alar bošatyre-

(17) dilar ošol qaplaryn da muna tüvünčügü \{kümüšünün\} kišinin qabynda

(18) da kördülar ošol tüvünčüklerin kümüšünün özle-

(19) rinin alar da atasy alarnyn da qorqtular. יויאמר Da

(20) ajtty alarg̉a Ja'aqov atasy alarnyn meni tuv ettijiz Josef

(21) joḥtu da Šimon joḥtu da ošol Binjaminni alsajyz maja

$72 v^{0}$ (1) jasqa bolurlar barlary. ויאמר. [37] Da ajtty Ru'uven ata-

(2) syna ajtadoġač ošol eki uvullarymny öltürürsen eger

(3) keltirmesem any saja bergin any qoluma da men qajta kelti-

(4) ויאמר (38) Da ajtty enmesti uvlum

(5) birgejizǵa ki qaryndašy anyn öldü da ol jalġyz özü qaldy

(6) da učrasa any ölüm jolda ki baryrsiz anyn byla da en-

(7) dirsiz ošol pirligimni qajğybyla görǵa.

Genesis 43

(8) ol ačlyq küčejdi jerd́a. [2] Da edi ki nečik tü-

\footnotetext{
${ }^{1}$ Marginal insertion by another hand. | TKow.o1: qaryndašlar. | H: qaryndaslar. | C: qardašlardyrbiz. $\quad{ }^{2}$ Marginal insertion by another hand. | TKow.o1: ol kičiŕakni. | H: ol kicirek. | C: šol kiči.
} 
(1) saying, 'What is this that God has done to us?'

(2) [29] And they came to Jacob their father to the land

(3) of Canaan, and told him all that had happened them,

(4) saying, [30] 'The man, the lord of the land,

(5) spoke rough words to us, and took us for spies

(6) of the land. [31] And we said to him, 'We are honest,

(7) we were not spies. [32] We are twelve

(8) $\{$ brothers $\}$, sons of our father, one is not, and the younger is even today

(9) with our father in the land of Canaan. [33] And

(10) the man, the lord of the land, said to us, "By this I will know

(11) that you are honest: leave one of your brothers here with me,

(12) and take grain to satiate the hunger of your households,

(13) and go. [34] And bring your \{younger $\}$ brother

(14) to me, and I will know that you are honest, that you are no spies.

(15) I will give you your brother, and you shall

(16) trade in the land."' [35] And it was: they were emptying

(17) their sacks, and, lo, every man's bundle of silver was in his sack.

(18) And when they saw the bundles of their own silver,

(19) they and their father, they were afraid. [36] And

(20) Jacob, their father, said to them, 'You have deprived me of my children: Joseph

(21) is not, and Simeon is not, and if you take Benjamin,

(1) they will all be mourning for me.' [37] And Reuben said $\quad 72 \mathrm{v}^{\mathrm{o}}$

(2) to his father, saying, 'You will kill my two sons, if

(3) I do not bring him to you. Give him in my hand, and I will bring

(4) him to you.' [38] And he said, 'My son will not go down

(5) with you, because his brother is dead, and he is left alone.

(6) If death befalls him on the way in which you will go with him: and

(7) you will bring down my grey hair with sorrow to the grave.'

Genesis 43

(8) the famine became stronger in the land. [2] And it was, when 
(9) gelledilar ašama ošol ol bürtüknü ki keltirdilar

(10) Micrid́an da ajtty alarg̉a atasy alarnyn qajtyjyz satyn alajyz

(11) bizǵa azġynaq bürtük. ויאמר [3] Da ajtty anar Juhuda

(12) ajtadog̉ač tanyq etḿa tanyq etti bizde ol kiši aj-

(13) tadoġač körmejiz jüzlerimni eger qaryndašyjyz bolmasa bir-

(14) gejizǵa. אם [4] Eger ijedesej ošol qaryndašymyzny

(15) birgemizǵa enerbiz da satyn alyrbiz saja bür-

(16) tük. [5ם [5] Da eger ijmejdesej enmesbiz ki ol

(17) kiši ajtty bizǵa körmejiz jüzlerimni bolmasa qaryndašyjyz

(18) birgejizǵa. ויאמר [6] Da ajtty Jisra’el nek jaman et-

(19) tijiz maja anlatma kišiǵa barmodu sizǵa qaryndaš.

(20) [יאמרו (7) Da ajttylar sorma sordu ol kiši bizni

(21) da tuvmušumuznu ajtadog̉ač hanuzmo atajyz tiridi barmo-

$73 \mathrm{r}^{\circ} \quad$ (1) du sizǵa qaryndaš da anlattyq anar ošpu sözlerge kö-

(2) ŕa bilma bildikmo ki ajtyr endirijiz ošol qaryndašyjyz-

(3) ny. ויאמר [8] Da ajtty Juhuda Jisra’elǵa atasyna ijgin

(4) ol ulanny birgeḿa da turajyq da barajyq da tiri bolajyq da

(5) ölmejik dağyn biz dağyn sen dağyn jašymyz. [9]כ] Men jükke

(6) alajym any qolumdan izlegin any eger keltirmesem any saja

(7) da turğuzmasam alnyjda da jazyqly bolurmen saja bar ol kün-

(8) lerni. כי [10] Ki eger kečikmesejdik ki haligińa qajtqa-

(9) jedik bu eki keŕatlar. ויאמר [11] Da ajtty alarg̉a

(10) Jisra’el atasy alarnyn qačan alaj bunda bunu qylyjyz al[y]jyz ${ }^{1}$ syjly

(11) jemišind́an ol jernin savutlaryjyzğa da endirijiz kišiǵa

(12) tirki azg்ynaq tirjak da azg்ynaq čyjbal otjamlar da mas-

(13) tik zymzymlar da badamlar. וכסף. [12] Da ekinči kümüš

(14) al[y]jyz ${ }^{2}$ qolujuzġa da ošol ol kümüšnü ol qajtarylġanny

(15) avzunda qaplaryjyznyn qajta alyjyz qolujuzğa šeme janġylyš-

(16) lyqty ol. ואת [13] Da ošol qaryndašyjyzny alyjyz da turu-

(17) juz qajtyjyz ol kišiǵa. ואל [14] Da küčlü Tenri berǵaj sizǵa

(18) raḥmetlar alnynda ol kišinin da ijgej sizǵa ošol qaryn-

(19) dašyjyzny birni da ošol Binjaminni da men ki nečik tuv boldum

\footnotetext{
${ }^{1} \mathrm{~K}$ : alajyz; a scribal error. See, however, Gen 43:12. | TKow.o1: alyjyz. | H: alynyz. | C: alyyyz. $\quad{ }^{2} \mathrm{~K}$ :
} alajyz; a scribal error. See, however, Gen 43:11. | TKow.o1: alyjyz. | H: alynyz. | C: alyyyz. 
(9) they had finished to eat up the grain which they had brought

(10) from Egypt, that their father said to them, 'Go again, buy

(11) us a little grain.' [3] And Judah said

(12) to him, saying, 'The man certified to us,

(13) saying, "You shall not see my face, if your brother is not

(14) with you." [4] If you are sending our brother

(15) with us, we will go down and buy you grain.

(16) [5] And if you are not sending, we will not go down, because the

(17) man said to us, "You shall not see my face, if your brother is not

(18) with you."' [6] And Israel said, 'Why have you done

(19) me wrong, to tell the man whether you had a brother?'

(20) [7] And they said, "The man asked about us

(21) and about our kindred, saying, "Is your father still alive?

(1) Do you have another brother?" And we told him according to these words.

(2) Could we have known that he would say, "Bring your brother down"?'

(3) [8] And Judah said to Israel, his father, 'Send

(4) the boy with me, and let us arise and go, and let us live and

(5) not die, we and you and our infants as well. [9] Let me take the responsibility

(6) for him. From my hand you shall seek him. If I do not bring him to you,

(7) and if I do not set him before you, then I will sin against you for all the days.

(8) [10] For if we had not delayed, by now we would have returned

(9) these two times.' [11] And Israel, their father, said to them

(10) 'If that is how it is here, do this: Take of the excellent

(11) fruits in the land in your vessels, and carry down the man

(12) a present: a little balm, and a little honey, spices, and

(13) mastic, pistachio nuts, and almonds. [12] And take ${ }_{L}$ double the ${ }^{166}$ silver

(14) in your hand; and the silver that was brought back

(15) in the mouth of your sacks, take it again in your hand. Maybe

(16) it was an oversight. [13] And take your brother, and arise,

(17) go back to the man. [14] And may the mighty God give you

(18) mercy before the man, that he may send your other

(19) brother and Benjamin to you. And I: when I was deprived of 
(20) Joseften ${ }^{1}$ alaj tuv boldum Šimondan². [15] Da aldylar

(21) ol erenĺar ošol ol tirkini ošpunu da ekinči kümüš

$73 \mathrm{v}^{\mathrm{o}} \quad$ (1) aldylar qollaryna da ošol Binjaminni da turdular da endi-

(2) ler Micriǵa da turdular alnynda Josefnin. Da

(3) kördü Josef birgelerińa ošol Binjaminni da ajtty anar ki

(4) ag̉araq edi üvü üstüńa keltirgin ošol ol erenler-

(5) ni ol ičkerige da sog̉um etkin sog̉um da hadirlegin

(6) ki birgeḿa ašarlar ol erenlar tüš vaḥtynda. ויעש. [17]

(7) Da qyldy ol kiši ki nečik ajtty Josef da keltirdi ol

(8) kiši ošol ol erenlerni üvüńa Josefnin. וייראו [18]

(9) Da qorqtular ol erenĺar ki keltirildilar üvüńa Josefnin

(10) da ajttylar ol kümüš üčün ol qajtqan qaplarymyzda

(11) burundan biz kijirilebiz syltav etḿa üstümüzǵa da

(12) jalajapma ${ }^{3}$ üstümüzǵa da alma bizni qullarğa da

(13) ošol ešeklerimizni. [19] Da juvudular ol kiši-

(14) ǵa ki ag̉araq üvü üstüńa Josefnin da sözledilar

(15) anar ešikind́a ol üvnün. ויאמרו. [20] Da ajttylar

(16) qoltqa byla bijim enme endik burundan satyn alma

(17) bürtük. ויהי [21] Da edi ki nečik $\{[k e] l d i k\}^{4}$ ol qonarlyqqa da

(18) ačtyq ošol qaplarymyzny da muna kümüšü kišinin av-

(19) zunda qabynyn kümüšümüz ölčövü byla da qajta aldyq

(20) any qolumuzǵa. וכסף. [22] Da özǵa kümüš endir-

(21) dik qolumuzda satyn alma bürtük bilmejbiz kim qojdu

$74 \mathrm{r}^{\circ}$ (1) kümüšümüznü qaplarymyzda. ויאמר. [23] Da ajtty

(2) ol kiši savluq sizǵa qormajyz Tenrijiz da Tenrisi ata-

(3) jyznyn berdi sizǵa ḥazna qaplaryjyzda kümüšü[jü $] z^{5}$ jetti

(4) maja da čyġardy alarga ošol Šim`onnu. ויבא [24] Da

(5) keltirdi ol kiši ošol ol erenlerni üvüńa Josefnin

(6) da berdi suv da juvdular ajaqlaryn da berdi jem ešek-

(7) lerińa alarnyn. [25] Da hadirlediler ošol ol

(8) tirkini kelginče Josef tüš vaḥtynda ki ešittiler

(9) ki anda ašarlar ötmek. [26] Da keldi Josef ol

\footnotetext{
${ }^{1}$ Interpretative addition to the standard text. $\quad{ }^{2}$ Interpretative addition to the standard text. ${ }^{3}$ Morphologically unclear form. It is perhaps a composition of the - $a$ converbial form of *jal- 'to tie' and jap- 'to close, to cover'. | TKow.o1: jalajapma. | H: jala takma.| C: tüšmä. $\quad{ }^{4}$ Marginal insertion by another hand. | TKow.o1: keldik. | H: keldik. |C: keldik. $\quad{ }^{5} \mathrm{~K}:$ kümüšüz; a scribal error. | TKow.o1: kümüšüjüz. | H: kimisiniz siznin. | C: ahčayyz.
} 
(20) Josef, so were I deprived of Simeon.' [15] And

(21) the men took that present, and they took L double the $^{167}$ silver

(1) in their hand and Benjamin. And they rose up and

(2) went down to Egypt and stood before Joseph. [16] And

(3) Joseph saw Benjamin with them, he said to him who

(4) was to the superior of his house, 'Bring these men

(5) to the room, and slaughter and make ready |an animal|,

(6) because these men will eat with me at noon.' [17]

(7) And the man did as Joseph told him, and the man brought the

(8) men to Joseph's house. [18]

(9) And the men were afraid, because they were brought to Joseph's house,

(10) and they said, 'Because of the silver that was returned in our sacks

(11) the first time are we brought in, that he may seek a pretext against us, and

(12) L[ [tie and close $]^{168}$ us, and take us for slaves — and

(13) our donkeys. [19] And they came near to the man

(14) that was the superior over Joseph's house, and they spoke

(15) with him at the door of the house. [20] And they said,

(16) 'We pray you, my lord, we came down the first time to buy

(17) grain. [21] And it was, when \{we came $\}$ to the place of overnight stay,

(18) that we opened our sacks, and, lo, every man's silver

(19) was in the mouth of his sack, our silver in its |full| weight. And we have brought it back

(20) in our hand. [22] And we have brought other silver

(21) down in or hand to buy grain. We do not know who put

(1) our silver in our sacks.' [23] And he said,

(2) 'Welfare to you, do not be afraid. Your God and the God of your father

(3) has given you treasure in your sacks: Your silver reached

(4) me.' And he brought Simeon out to them. [24] And

(5) the man brought the men to Joseph's house,

(6) and gave them water, and they washed their feet, and he gave food for their donkeys.

(7) [25] And they made ready the

(8) present for Joseph's coming at noon because they heard

(9) that they will eat bread there. [26] And Joseph came

67 Lit. 'second'.

68 An uncertain interpretation of jalajapma. 
(10) ičkeriǵa da keltirdiler anar ošol ol tirkini ki

(11) qolarynda ol ičkeriǵa da bašurdular anar jergedejin.

(12) [ישאל Da sordu alardan savluqnu da ajtty savmo-

(13) du atajyz ol qart ki ajttyjyz hanuzmo tiridi.

(14) ויאמרו Da ajttylar savdy quluj atamyz hanuz ol

(15) tiridi da ijildilar da bašurdular. [29] Da kö-

(16) türdü közlerin da kördü ošol Binjaminni qaryndašyn

(17) uvlun anasynyn da ajtty bumodu qaryndašyjyz ol kičirek

(18) ki ajttyjyz maja da ajtty Tenri hajifsüngej seni uv-

(19) lum. [ימהר [3o] Da žaḥtlady Josef ki qyzyštylar raḥmet-

(20) leri anyn qaryndašyna da keldi jylama da keldi ol hư̌ura-

(21) gisa da jylady anda. Da juvdu jüzlerin da čyqty

$74 \mathrm{~V}^{\mathrm{o}} \quad$ (1) da kiplendi da ajtty qojujuz ötmek. וישימו. [32] Da

(2) qojdular anar bašqa da alarg̉a bašqa da Micrililerǵa

(3) ol ašavčularg̉a birgesińa bašqa ki bolalmasedilar ol

(4) Micrililer ašama Jisra’ellerbyla ötmek ki jerinčilik

(5) edi ol Micriǵa. וישבו. [33] Da olturdular alnynda

(6) anyn ol tunġuč tunġučlugiuna köŕa da ol kičirek

(7) kičirekligine köŕa da tamaša ettilar ol erenlar

(8) bağyp kiši dostu üstüne. [34] Da kötürdü

(9) berneler alnyndan Josefnin alarga da köprek boldu berne-

(10) si Binjaminnin bernesind́an har birisinin beš ülüšler

(11) da ičtilar da esirdilar birgesińa.

\section{Genesis 44}

ויצו [1] Da

(12) bujurdu anar ki ag̉araq edi üvü üstüne ajtadoġač

(13) tolturg̉un ošol qaplaryn ol erenlernin bü $\{r\} t u ̈ k b y l a$

(14) ki nečik bolalsalar eltmá da qojg̉un kümüšün kišinin

(15) avzunda qabynyn. [2] Da ošol čaramny ol čarany

(16) qojğun avzunda qabynyn ol kičireknin da ošol kümü-

(17) šün bürtügünün da qyldy sözüne köŕa Josefnin ki

(18) Sözledi. הבקר. Ol tan jarydy da ol erenler

(19) ijildilar jolğa alar da ešekleri alarnyn. המה [4] [4] Alar

(20) čyqtylar ol šahardan jyraq ketmedilar da Josef ajtty ol

\footnotetext{
${ }^{1}$ Heb. החי.
} 
(10) to the room, and they brought the present for him which

(11) was in their hand to the room, and bowed themselves to him to the ground.

(12) [27] And he asked them of their health, and said,

(13) 'Is your old father of whom you spoke in |good| health? Is he still alive?'

(14) [28] And they answered, 'Your servant, our father, is in |good| health. He is still

(15) alive.' And they bowed down, and bowed themselves. [29] And

(16) he raised his eyes, and saw his brother Benjamin,

(17) his mother's son, and said, 'Is this your younger brother,

(18) of whom you spoke to me?' And he said, 'God be merciful to you,

(19) my son.' [30] And Joseph hurried because his compassion grew warm

(20) for his brother. And he came to weep and entered his chamber

(21) and wept there. [31] And he washed his face, and went out,

(1) and strengthened himself, and said, 'Put the bread.' [32] And

(2) they served him separately, and them separately, and for the Egyptians,

(3) who did eat with him, separately, because the Egyptians could not

(4) eat bread with the Hebrews, because that is an abomination

(5) to Egypt. [33] And they sat before him,

(6) the firstborn according to his birthright, and the younger

(7) according to his youth. And the men were amazed

(8) looking at one another. [34] And he lifted

(9) gifts to them from before Josef, but Benjamin's gift

(10) was five times more than the gift of all of them.

(11) And they drank, and got drunk with him.

Genesis 44

[1] And

(12) he commanded the man who was the superior over his house, saying,

(13) 'Fill the men's sacks with grain,

(14) as much as they can carry, and put every man's silver

(15) in his sack's mouth. [2] And my cup: put the cup,

(16) in the sack's mouth of the younger, and the silver

(17) for his grain.' And he did according to the word that Joseph

(18) had spoken. [3] The morning was light, and the men

(19) were sent away, they and their donkeys. [4] They

(20) had gone out of the city. They had not gone far, and Joseph said 
(21) kišiǵa ki ag̉araq edi üvü üstüne anyn turg̉un quvg̉un

$75 \mathrm{r}^{\mathrm{r}} \quad$ (1) ol erenler artyna da jetkin alarny da ajtqyn alarga ne

(2) töledijiz jamanlyq jahšylyq ornuna. הלוא. [5] Muna budur

(3) ki ičedi bijim anyn byla da \{ol\} synčylama synčylajdy anyn byla

(4) jaman ettijiz ki bunu qyldyjyz. וישגם. [6] Da jetti alar-

(5) ny da sözledi alarg̉a ošol ol sözlerni ošpularny. [7] [יאמרו [7]

(6) Da ajttylar anar nek sözlejdi bijim ošpu söz kibik hašša

(7) bolgaj qullaryja \{qylmaqtan $\}^{1}$ ošpu iškibik. הן. [8] Muna kümüšnü

(8) ki taptyq avzunda qaplarymyznyn qajta keltirdik any saja

(9) jerind́an Kena’annyn da nečik urlag̉ajedik üvünden bijijnin

(10) kümüš jemeśa altyn. אשר. [9] Kim ki tabulsa birgesi-

(11) ne qullaryjdan da öler da daġyn bizǵa bolurbiz bijima qul-

(12) larğa. [10] Da ajtty dağyn haligine sözlerijge

(13) köŕa alaj bolsun ol kim ki tabulsa birgesińa ol bo-

(14) liימהרו [11] Da

(15) క̌ahtladylar da endirdilar kiši ošol qabyn jerge da ač-

(16) tylar kiši qabyn. Da tyntty ulluda bašlady

(17) da kičid́a tügelledi da tabuldu ol čara qabynda Binjamin-

(18) nin. I13] Da jyrttylar upraqlaryn da jükledi kiši

(19) ešegi üstüńa da qajttylar ol šaharg̉a. ויבוא. [14]

(20) Da keldi Juhuda da qaryndašlary anyn üvüńa Josefnin da

(21) ol hanuz edi anda da tüštüler alnynda anyn jergedejin.

$75 \mathrm{v}^{\mathrm{o}}$ (1) ויאמר [15] Da ajtty alarg̉a Josef nedir ol iš ošpu

(2) ki qyldyjyz muna bilmejmosiz ki synčylama synčylajdy kiši

(3) ki menim kibik. ויאמר [16] Da ajtty Juhuda ne ajtajyq

(4) bijima ne sözlejik da rastlyġymyzny čyğarajyq ol Tenri

(5) tapty ošol güneḥin qullaryjnyn muna biz qullar bijima

(6) dag̀yn biz dağyn [olda $]^{2}$ ki tabuldu ol čara qolunda anyn.

(7) ויאמר [17 Da ajtty hašša bolġaj maja qylmaqtan bunu

(8) ol kiši ki tabuldu ol čara qolunda anyn ol bolsun maja

(9) qul da siz baryjyz savluqbyla atajyzğa.

פרשת ויגש (10) (10)

(18) [יגש אליו יהודה ויאמר (11) Da juvdu anar Juhuda

(12) da ajtty qoltqa byla bijim sözlesin endi

\footnotetext{
${ }^{1}$ Marginal insertion by another hand. | TKow.o1:qylmaqtan. | H: qylmaqtan.|C:qylmaqtan. $\quad{ }^{2} \mathrm{~K}:$ deest; probably a scribal error. | TKow.o1: olda. | H: kim. | C: deest; probably a scribal error. | V: kiḿd́a. | R: kiḿd́a.
} 
(21) to the man who was the superior over his house, 'Arise. Follow

(1) after the men, and reach them, and say to them, "Why

(2) did you pay back bad for good? [5] Lo, this is it

(3) from which my lord drinks. And he divines by it!

(4) You have done evil in doing this."' [6] And he reached them,

(5) and he spoke to them these same words. [7]

(6) And they said to him, 'Why speaks my lord words like these? Far be it

(7) from your servants to $\{d o\}$ a thing like this. [8] Lo,

(8) we brought the silver which we found in our sacks' mouths back to you

(9) from the land of Canaan, so how would we steal

(10) silver or gold from your lord's house? [9] The one from

(11) your servants with whom it is found, let him die, and also we will become my lord's servants.'

(12) [10] And he said, 'Now, also, it shall be according to your words:

(13) he with whom it is found shall

(14) be my servant. And you will be free.' [11] And

(15) they hurried and every man took down his sack to the ground, and every man opened

(16) his sack. [12] And he searched. He began at the oldest,

(17) and ended at the young. And the cup was found in Benjamin's sack.

(18) [13] And they tore their clothes, and loaded every

(19) man his donkey, and returned to the city. [14]

(20) And Judah and his brothers came to Joseph's house, and

(21) he was still there, and they fell before him on the ground.

(1) And Joseph said to them, 'What is this deed

(2) that you have done? Lo, don't you know that a man like me would divine?'

(3) [16] And Judah said, 'What shall we say

(4) to my lord? What shall we speak, and |how| shall we show our righteousness? God

(5) has found the iniquity of your servants. Lo, we are my lord's servants,

(6) both we and also he in whose hand the cup is found.'

(7) [17] And he said, 'Far be it from you to do this!

(8) The man in whose hand the cup is found, he shall be my

(9) servant, and you, you go in |good| health to your father.'

(10) Parashat Vayigash

(11) [18] And Judah came near to him,

(12) and said, 'Oh my lord, let your servant, I pray you, speak now 
(13) quluj söz qulaqlaryča bijimnin da qabunmasyn ačuvuj quluj

(14) üstüne ki nečik sen alaj paro. אדני [19] Bijim

(15) sordu qullaryndan ajtadog̉ač barmodu sizd́a ata jemese

(16) qaryndaš. [20] Da ajttyq bijima bardy bizǵa

(17) ata qart da uvul qart qylyqly kiči da qaryndašy anyn

(18) öldü da qaldy ol özü anasyna da atasy süvdü any.

(19) [21 Da ajttyj qullaryja endirijiz any maja

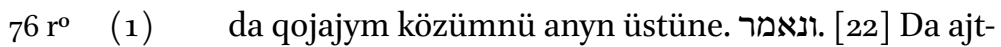

(2) tyq bijiḿa bolalmasty ol ulan kemišḿa ošol atasyn da

(3) öler. ותאמר [23] Da ajttyj qullaryja eger enmese

(4) qaryndašyjyz birgejizǵa arttyrmajyz körḿa jüzlerimni.

(5) ויהי Da edi ki nečik bardyq quluja atama da an-

(6) lattyq anar ošol sözlerin bijimnin. [25] Da ajt-

(7) ty atamyz qajtyjyz satyn alyjyz bizǵa azġynaq bürtük.

(8) . ונאמר Da ajttyq bolalmasbiz enma eger bare-

(9) se qaryndašymyz ol kičirek birgemizǵa da enerbiz

(10) ki bolalmasbiz körmá jüzĺarin ol kišinin da qaryndašymyz

(11) ol kičireq bolmasa birgemizǵa. ויאמר [27] Da ajtty

(12) quluj atam bizǵa siz bilesiz ki ekini töredi maja qaty-

(13) nym. ויצא [28] Da čyqty ol birisi qatymdan da ajt-

(14) tym tek butarlanma butarlandy da körmedim any beri-

(15) gedejin. ולקחתם [29] Da alsajyz dag̉yn ošol bunu qatym-

(16) dan da učrasa any ölüm da endirirsiz ošol pir-

(17) ligimni jamanlyq byla görǵa. [30] Da haligińa

(18) kelgenimdečoq quluja atama da ol ulan bolmasa qatym-

(19) da da žany anyn bajlanġandy žanyna anyn. והיה [31 Da

(20) bolġaj körgenindečoq ki joḥtur ol ulan da öler da

(21) endirirlar qullaryj ošol pirligin qulujnun atamyznyn

76 v $\mathrm{v}^{\mathrm{o}}$ (1) qajğy byla görǵa. כי [32] Ki quluj jükke aldy ošol ol 
(13) a word in my lord's ears, and let not your anger burn against your servant,

(14) because you are even as Pharaoh. [19] My lord

(15) asked his servants, saying, "Have you a father, or a

(16) brother?" [20] And we said to my lord, "We have

(17) a father, and ${ }_{L}$ a son [with] the habits of an old man ${ }^{769}$, a little one, and his brother

(18) died, and he alone is left of his mother, and his father loved him."

(19) [21] And you said to your servants, "Bring him down to me,

(1) and let me set my eyes on him." [22] And

(2) we said to my lord, "The boy cannot leave his father, and

(3) he will die." [23] And you said to your servants, "If

(4) your brother comes not down with you, you shall not see my face again."

(5) [24] And it was, when we went to your servant, my father,

(6) that we told him the words of my lord, [25] And

(7) our father said, "Go back, and buy us a little grain."

(8) [26] And we said, "We cannot go down: if our

(9) younger brother goes with us, then we will go down,

(10) because we cannot see the man's face, if our

(11) younger brother is not with us." [27] And your servant, my father, said

(12) to us, "You know that my wife bore two for me,

(13) [28] And one went away from me, and I said,

(14) "He is surely torn up, and I have not seen him since."

(15) [29] And if you take this also from me,

(16) and death befall him, you will bring down my grey

(17) hair with in wretchedness to the grave." [30] And now,

(18) as soon as I come to your servant, my father, and the boy is not with me,

(19) and his soul is bound to his soul, [31] And it shall be

(20) as soon as he sees that the boy is not, he will die. And

(21) your servants will bring down the grey hair of your servant, our father,

(1) with sorrow to the grave, [32] Because your servant took the respons- $\quad 76 \mathrm{v}^{\mathrm{o}}$ ibility for the

$69 \quad$ K: an uncertain translation of uvul qart qylyqly 'with the habits of old man'; cf. Gen 37:3. | TKow.o1: ulan qart qylyqly; the same translation as in K. | H: uvul qart qylyqly; the same translation as in K. | C: qartlyq og ul 'son of his old age'. 
(2) ulanny atamdan ajtadog̉ač eger keltirmesem any saja da

(3) jazyqly bolurmen atama bar ol künlerni. ועתה [33] Da

(4) haligine oltursun endi quluj ol ulan ornuna qul

(5) bijiḿa da ol ulan barsyn qaryndašla\{ry\} byla. כי [34] Ki

(6) nečik barajym atama da ol ulan bolmasa qatymda mağat

(7) körermen jamanny ki učrar ošol atamny.

Genesis 45

(8) bolalmady Josef čydama bar ol turuvlarğa alnynda da

(9) čağyrdy čyğaryjyz bar kišini alnymdan da turmady kišide

(10) birgesińa bilingend́a Josef qaryndašlarynda. ויתן [2] Da

(11) berdi ošol avazyn jylamaqbyla da ešittilar Micrililer

(12) da ešitti eli üvünün par`onun. I3 Da

(13) ajtty Josef qaryndašlaryna menmen Josef hanuzmo atam

(14) tiridi da bolalmadylar qaryndašlary anyn qaruv berme anar

(15) ki algasandylar alnyndan anyn. ויאמר. [4 Da ajtty Josef

(16) qaryndašlaryna juvujuz \{endi\} maja da juvudular da ajtty menmen

(17) Josef \{qaryndašyjyz\} ki sattyjyz meni Micriǵa. ועתה [5] Da haligine

(18) ačyrg̉anmajyz da ačuv bolmasyn közlerijizd́a ki sattyjyz

(19) meni beri ki beslenmekke sizǵa ijdi meni Tenri alnyjyz-

(20) da. [6] Ki bu eki jyllardy ol ačlyq ortasynda

(21) ol jernin da hanuz beš jyllar ki bolmasty saban sürmek da

77 ro (1) ormaq. [7 Da ijdi meni Tenri alnyjyzda qojma siz-

(2) ge qaldyq jerd́a da tiri tutma sizni ullu qutulmaqqa.

(3) [8 [8 Da haligina tüvül siz ijdijiz meni beri ki ančaq

(4) ol Tenri da qojdu meni ata ornuna par`oga da bijge

(5) bar üvüńa da erklenüvčü bar jerind́a Micrinin.

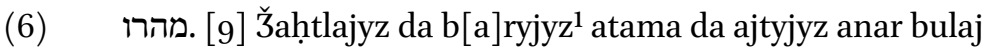

(7) ajtty \{uvluj\} Josef qojdu meni Tenri bijǵa bar Micriǵa engin maja

(8) toḥtamaġyn. [10] Da olturğun jerind́a Gošennin

(9) da bolġun juvuq maja sen da uvullaryj da uvullary uvullaryj-

(10) nyn da qojuj da syġyryj da barča neki senin. וכלכלתי. [11]

(11) Da beslermen seni anda ki hanuz beš jyllar ačlyq mağat jar-

\footnotetext{
${ }^{1} \mathrm{~K}$ : berijiz; a scribal error. | TKow.o1: baryjyz. | H: barynyz. | C: čygjyyyz.
} 
(2) boy from my father, saying, "If I do not bring him to you

(3) then I will sin against my father for all the days." [33] And

(4) now, let your servant abide instead of the boy, a servant

(5) to my lord, and let the boy go with his brothers. [34] Because

(6) how shall I go to my father, and the boy is not with me? Lest

(7) I see the evil that will find my father.'

Genesis 45

(8) Joseph was not able to endure before all them that stood by him,

(9) and he cried, 'Take away every man from before me.' And no one stayed

(10) with him when Joseph made himself known to his brothers. [2] And

(11) he wept aloud: and the Egyptians

(12) and the house of Pharaoh heard it. [3] And

(13) Joseph said to his brothers, 'I am Joseph! Is my father still

(14) alive?' And his brothers were not able to answer him,

(15) because they were troubled in front of him. [4] And Joseph said

(16) to his brothers, 'Come near to me, now.' And they came near. And he said, 'I am

(17) Joseph your brother, whom you sold to Egypt. [5] And now

(18) be not annoyed and may there be no anger in your eyes that you sold

(19) me here, because God did send me ahead of you to feed you.

(20) [6] For it is two years that the famine has been in

(21) the land, and it is five more years that there will be no ploughing

(1) or harvest. [7] And God sent me ahead of you to put

(2) for you a remnant on earth and to keep you alive for a great deliverance.

(3) [8] And now, it was not you who sent me here, but

(4) God. And he has made me a father to Pharaoh and lord

(5) of all his house and a ruler over all the land of Egypt.

(6) [9] Hurry, and go up to my father, and say to him, "Thus

(7) says your son Joseph, "God has made me lord of all Egypt. Come down to me,

(8) do not tarry. [10] And you shall dwell in the land of Goshen,

(9) and you shall be near to me, you, and your children, and your children's children,

(10) and your flocks, and your cattle, and all that is yours. [11]

(11) And I will nourish you there, because there are five more years of famine, lest 
(12) lylanyrsen sen da eli üvüjnün da barča neki senin. [12]

(13) Da muna közlerijizdi körüvčülar da közleri qaryndašym-

(14) nyn Binjaminnin ki avzumdu ol sözlevčü sizǵa ttüvüldü

(15) talmač ašyra ${ }^{11}$. והגדתם. [13] Da anlatyjyz atama ošol

(16) bar syjymny Micrid́a da ošol barča ne ki kördüjüz da క̌a $\{h\} t-$

(17) lajyz da endirijiz ošol atamny beri. ויפל [14 Da tüštü

(18) bojunlary üstüne Binjaminnin qaryndašynyn da jylady da Binja-

(19) min jylady bojnu üstüne anyn. וינשק [15] Da öptü

(20) bar qaryndašlaryn da jylady alar üstüńa da andan sortun

(21) sözledilar qaryndašlary anyn birgesińa. והקל [16] Da ol

$77 \mathrm{~V}^{\mathbf{o}} \quad$ (1) avaz \{ešitildi\} üvünde par'onun ajtadog̉ač keldilar qaryndašlary

(2) Josefnin da jaḥsyy köründü közlerind́a par'onun da közle-

(3) rind́a qullarynyn. ויאמר Da ajtty paróo Josefke

(4) ajtqyn qaryndašlaryja bunu qylyjyz qystajyz tuva\{r\}laryjyzny da

(5) baryjyz kelijiz jerińa Kena'annyn. וקחו. [18] Da alyjyz ošol

(6) atajyzny da ošol elin üvüjüznün da kelijiz da berejim

(7) sizǵa ošol jahšy ornun Micrinin da ašajyz ošol

(8) nametin ol jernin. ואתה [19] La sen bujurulduj ese

(9) de bermeske eltme bürtüknü arabalarbyla ${ }^{12}$ vale

(10) haligińa bujuramen saja bunu qylyjyz alyjyz özüjüzǵa ara-

(11) balar jerind́an Micrinin jašyjyzġa da qatynlaryjyzġa da alyjyz

(12) ošol atajyzny da kelijiz. ועינכם. [20] Da közlerijiz ḥajifsün-

(13) mesin savutlaryjyz üstüne ki jahšysy bar jerinin Micri-

(14) nin sizgedi ol. ויעשו. [21] Da qyldylar \{alaj\} uvullary Jisra'el-

(15) nin da berdi alargia arabalar bujrugiubyla par'onun da

(16) berdi alarg̉a azyq jolg̀a. לכלם [22] Barlaryna berdi ki-

(17) šiǵa tüslü upraqlar da Binjaminge berdi üč jüz

(18) kümüš da beš tüslü upraqlar. ולאביו. [23] Da ata-

(19) syna ijdi bunun kibik on ešeklar eltüvčüler

(20) nametind́an Micrinin da on ešeḱlar eltüvčüler bür-

(21) tük da ötmek da harč atasyna jolg̀a. וישלח. [24]

\footnotetext{
${ }^{1}$ Interpretative addition to the standard text. $\quad{ }^{2}$ Interpretative addition to the standard text.
} 
(12) you and your household and all that is yours will be impoverished." [12]

(13) And, lo, your eyes see, and the eyes of my brother

(14) Benjamin, that it is my mouth that speaks to you ${ }_{\mathrm{L}} \mid$ directly $\mid$ and not

(15) through an interpreter ${ }^{170}$. [13] And you shall tell my father

(16) of all my glory in Egypt and of all that you have seen, and you shall haste

(17) and bring down my father here.' [14] And he fell on

(18) his brother Benjamin's neck and wept, and Benjamin

(19) wept on his neck. [15] And he kissed

(20) all his brothers, and wept on them. And after that

(21) his brothers talked with him. [16] And the

(1) rumour was heard in Pharaoh's house, saying, 'Joseph's brothers have $77 \mathrm{~V}^{\mathrm{o}}$ come,'

(2) and it seemed good in Pharaoh's eyes and in the eyes of

(3) his servants. [17] And Pharaoh said to Joseph,

(4) 'Say to your brothers, "Do this: Press your livestock, and

(5) go, come to the land of Canaan. [18] And take

(6) your father and your households, and come to me: and let me give

(7) you the good of the land of Egypt, and you shall eat

(8) the goods of the land. [19] _And even if you were to be commanded

(9) not to let to carry the grain with wagons: ${ }^{171}$ but

(10) I now command you, do this: Take wagons for yourself

(11) from the land of Egypt, for your little ones and for your wives, and take

(12) your father, and come. [20] And let your eye not pity

(13) your vessels, for the good of all the land of Egypt

(14) is yours."' [21] And the sons of Israel did so.

(15) And Joseph gave them wagons, according to the command of Pharaoh, and

(16) gave them provisions for the way. [22] To all of them he gave

(17) each man change of clothes, but to Benjamin he gave three hundred

(18) pieces of silver, and five changes of clothes. [23] And to his father

(19) he sent after this manner: ten donkeys carrying |some|

(20) of the goods of Egypt, and ten donkeys carrying grain

(21) and bread and provision for his father for the way. [24]

70 An interpretative addition to Gen 45:12.

71 An interpretative addition to Gen 45:19. 
$78 \mathrm{r}^{\mathrm{o}} \quad$ (1) Da uzatty ošol qaryndašlaryn da bardylar da ajtty

(2) alarg̉a talašmajyz jolda. ויעלו. [25] Da bardylar Micrid́an

(3) da keldilar jerińa Kena'annyn atasyna özlerinin. יויגדו [26]

(4) Da anlattylar anar ajtadoggač hanuz Josef tiridi da ki ol

(5) erklenedi bar jerind́a Micrinin da qopsaldy jüregi anyn

(6) ki inanmady alarg̉a. [27 [ Da sözlediĺar anar

(7) ošol bar sözlerin Josefnin ki sözledi alarg̉a da kör-

(8) dü ošol ol arabalarny ki ijdi Josef alma any da tiril-

(9) di žany Jaaqavovnun atasynyn alarnyn. ויאמר [28] Da ajtty

(10) Jisra’el köp jaḥšy bolur maja qačan hanuz Josef uvlum

(11) tiridi barajym da körejim any ölmesimden burun.

$[\text { Genesis 46 }]^{1}$

(12) ויסע [1] Da köčtü Jisra’el da barča neki anyn da keldi

(13) Be’er Šaváğa da debeḥa etti debeḥalar Tenrisińa

(14) atasynyn Jichaqnyn. [ויאמר]2] Da keldi malahy Tenri-

(15) nin Jisra’elge körümleri ašyra ol kečenin da ajt-

(16) ty Ja'aqov Ja'aqov da ajtty munadyr men. ויאמר. [3]

(17) Da ajtty menmen ol Tenri Tenrisi atajnyn qorqma-

(18) ġyn enmektan Micriǵa ki ullu hanlyqqa qojarmen seni

(19) anda. אנכי [4] Men enermen \{birgeje\} Micriǵa da men čyġaryr-

(20) men seni dag̉yn čyğarma da Josef qojar qolun közlerij

(21) üstüne _ölgenijd́a ${ }^{13}$. ויקם [5] [5 [ Da turdu Jacaqov

$78 \mathrm{v}^{\mathrm{o}} \quad$ (1) Be’er Šava‘dan da aldylar uvullary Jisra’elnin ošol Ja'aqov-

(2) nu atasyn özlerinin da ošol jašlaryn da ošol qatynlaryn

(3) arabalarbyla ki ijdi par'o alma any. ויקחו. [6] Da

(4) aldylar ošol tuvarlaryn da ošol mallaryn ki malladylar jerin-

(5) de Kena'annyn da keldilar Micriǵa Ja'aqov da bar urlug̉u

(6) anyn birgesińa. [7] Uvullary anyn da uvullary

(7) uvullarynyn birgesińa qyzlary anyn da qyzlary uvullarynyn

(8) da bar urluggu özünün keltirdi birgesińa Micriǵa.

(9) ואלה Da bulardylar atlary ${ }^{5}$ uvullarynyn Jisra'elnin ol

(10) kelüvčülernin Micriǵa Ja'aqov da uvullary anyn tunġu-

\footnotetext{
${ }^{1} \mathrm{~K}$ : The chapter number is erroneously indicated, see Gen 46:5.

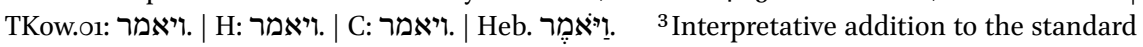
text. $\quad{ }^{4} \mathrm{~K}$ : Gen 46:1; a scribal error. This verse and Gen 46:1 were confused probably because of their similar content. | TKow.o1: Gen 46:5. | H: Gen 46:5. | C: Gen 46:5. | Hebrew Bible: Gen 46:5. ${ }^{5} \mathrm{~K}$ : atalary; a scribal error. | TKow.o1: atalary corrected to atlary by the copyist. | H: atlary. | C: atalary; a scribal error. | V: šemíari. | R: šemĺari.
} 
(1) So he sent his brothers away, and they went, and he said $78 \mathrm{r}^{\circ}$

(2) to them, 'Do not quarrel on the way'. [25] And they went up from Egypt,

(3) and came to the land of Canaan to Jacob their father. [26]

(4) And they told him, saying, 'Joseph is still alive,' and that he

(5) rules over all the land of Egypt. And Jacob's heart was troubled,

(6) because he did not believe them. [27] And they told him

(7) all the words of Joseph, which he had spoken to them, and

(8) he saw the wagons which Joseph had sent to carry him. And

(9) the spirit of Jacob, their father, revived. [28] And Israel said,

(10) 'It will be very good for me! If Joseph, my son,

(11) is still alive. Let me go and let me see him before I die.'

[Genesis 46]

(12) [1] And Israel journeyed with all that he had, and came

(13) to Beersheba, and offered sacrifices to the God

(14) of his father Isaac. [2] And God's angel came

(15) to Israel in the visions of the night, and said,

(16) 'Jacob, Jacob.' And he said, 'Lo, I am here.' [3]

(17) And he said, 'I am God, the God of your father. Do not fear

(18) to go down to Egypt, because I will make you into a great kingdom

(19) there. [4] I will go down with you to Egypt, and I will also

(20) surely bring you out again. And Joseph will put his hand on your eyes

(21) ¿when you die ${ }^{772}$. [5] And Jacob rose up

(1) from Beersheba. And the sons of Israel took Jacob,

(2) their father, and their little ones and their wives

(3) with the wagons which Pharaoh had sent to take him. [6] And

(4) they took their livestock, and their goods, which they had gained

(5) in the land of Canaan, and came to Egypt, Jacob, and all his offspring

(6) with him: [7] He brought his sons, and his sons' sons

(7) with him, his daughters, and his sons' daughters,

(8) and all his offspring with him to Egypt.

(9) [8] And these are the names of the sons of Israel,

(10) who came to Egypt, Jacob and his sons:

72 An interpretative addition to Gen 46:4. 
(11) ču Jaáaqovnun Ru’uven. ובני [9] Da uvullary Ru’uvennin

(12) Ḩanoh da Falu' da Ḥecron da Karmi. ובני (10] Da uvullary

(13) Šimonnun Jemu'el da Jamin da Ohad da Jahin da Coḥar da

(14) Ša’ul uvlu ol Kenáanly qatynnyn. ובני [11] Da uvullary

(15) Levinin Geršon da Qahat da Merari. [12] Da uvullary

(16) Juhudanyn 'Er da Onan da Šela da Perec da Zarah da öl-

(17) dü 'Er da Onan jerind́a Kena`an[n]yn ${ }^{1}$ da edilar uvullary

(18) Perecnin Hecron da Ḥamul. ובני [13] Da uvullary Jissahar-

(19) nyn Tola da Puva da Jov da Šimron. [ובני [14] Da u-

(20) vullary Zev[u]lunnun² Sered da Elon da Jahle’el. אלה. [15] Bulardy-

(21) lar uvullary Le’anyn ki töredi Jacaqovga Padam Aramda

$79 \mathrm{r}^{\circ} \quad$ (1) da ošol Dinany qyzyn anyn bar క̌any uvullarynyn da qy\{z\}lary-

(2) nyn otuz üč. ובני [16] Da uvullary Gadnyn \{Cifjon da Hagi $\}^{3}$ Šuni da

(3) Ecbon 'Eri da Arodi da Ar’eli. ובני [17] Da uvullary Ašer-

(4) nin Jimna da Jišva da Jišvi da Bería da Serah tuvduğu

(5) alarnyn da uvullary Beri'anyn Ḥever da Malki'el. אלה. [18]

(6) Bulardylar uvullary Zilpanyn ki berdi Lavan Le’aġa qyzyna

(7) da töredi ošol bularny Ja'aqovg̉a on alty žan. בני [19]

(8) Uvullary Rahelnin qatynynyn Ja'aqovnun Josef da Binjamin. ויולד. [20]

(9) Da tuvdu Josefke jerind́a Micrinin Menaše da Efrajim

(10) ki töredi anar Asnat qyzy Potife $\{r\} a a^{\prime} n y n$ qara tonlusunun On-

(11) nun. ובני [21] Da uvullary Binjaminnin Belac da Beher da Ašbel

(12) Gera da Na'aman Eḥi da Roš Mupim da Ḥupim da Ard.

(13) אלה (22] Bulardylar uvullary Rahelnin ki tuvdu Ja'aqovga bar

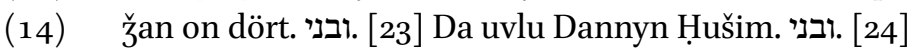

(15) Da uvullary Naftalinin Jahce’el \{da Guni\} da Jecer da Šilem. אלי

(16) Bulardylar uvullary Bilhanyn ki berdi Lavan Rahelǵa qyzyna ö-

(17) zünün da töredi ošol bularny Jacaqovg̉a bar žan jedi.

(18) כל כ26] Bar ol క̌an ol kelüvčü Ja'aqovnun Micriǵa čyguuvču-

(19) lary butunun bašqa qatynlaryndan uvullarynyn Jacaqovnun bar

(20) Žan altymyš da alty. ובני [27] Da uvullary Josefnin ki

(21) tuvdu anar Micrid́a eki క̌an bar ol క̌an üvünün Jacaqov-

$79 \mathrm{v}^{\mathrm{o}}$ (1) nun ol kelüvčü Micriǵa jetmiš. ואת. [28] Da ošol Juhu-

(2) dany ijdi alnynda özünün Josefka üvretḿa alnyn-

${ }^{1} \mathrm{~K}$ : Kena'anyn; a scribal error. | TKow.o1: Kena'annyn. | H: Kena'annyn. | C: Kena'annyy. $\quad{ }^{2} \mathrm{~K}$ : Zevalunnun; a scribal error. | TKow.o1: Zevulunnun. | H: Zevulunnun. | C: Zevulunnyy. $\quad{ }^{3}$ Marginal insertion by another hand. | TKow.o1: Cifjon da Hagi. | H: Cifjon da Hagi. | C: Čifjon da Hagi. 
(11) Reuben, Jacob's firstborn. [9] And the sons of Reuben:

(12) Hanoch, and Pallu, and Hezron, and Carmi. [10] And the sons

(13) of Simeon: Jemuel, and Jamin, and Ohad, and Jachin, and Zohar, and

(14) Shaul the son of a Canaanite woman. [11] And the sons

(15) of Levi: Gershon, and Kohath, and Merari. [12] And the sons

(16) of Judah: Er, and Onan, and Shelah, and Perez, and Zarah. And

(17) Er and Onan died in the land of Canaan. And the sons

(18) of Perez were Hezron, and Hamul. [13] And the sons of Issachar:

(19) Tola, and Puvah, and Iob, and Shimron. [14] And

(20) the sons of Zebulun: Sered, and Elon, and Jahleel. [15] These

(21) are the sons of Leah, whom she bore to Jacob in Paddan-Aram,

(1) and Dinah, his daughter, all the souls of his sons and his daughters,

(2) thirty-three. [16] And the sons of Gad: \{Ziphion, and Haggi\}, Shuni, and

(3) Ezbon, Eri, and Arodi, and Areli. [17] And the sons of Asher:

(4) Imnah, and Ishvah, and Ishvi, and Beriah, and Serah, their sister.

(5) And the sons of Beriah: Heber, and Malchiel. [18]

(6) These are the sons of Zilpah, whom Laban gave to Leah, his daughter,

(7) and these she bore to Jacob, sixteen souls. [19]

(8) The sons of Rachel, Jacob's wife: Joseph, and Benjamin. [20]

(9) And Manasseh and Ephraim were born to Joseph in the land of Egypt,

(10) whom Asenath, daughter of Potiphera, priest of On, bore to him.

(11) [21] And the sons of Benjamin were Belah, and Becher, and Ashbel,

(12) Gera, and Naaman, Ehi, and Rosh, Muppim, and Huppim, and Ard.

(13) [22] These are the sons of Rachel, who were born to Jacob. All

(14) the souls were fourteen. [23] And the son of Dan: Hushim. [24]

(15) And the sons of Naphtali: Jahzeel, and Guni, and Jezer, and Shillem. [25]

(16) These are the sons of Bilhah, whom Laban gave to Rachel his daughter,

(17) and she bore these to Jacob. All the souls were seven.

(18) [26] All the souls that came with Jacob into Egypt, who came out

(19) from his thigh, besides Jacob's sons' wives, all

(20) the souls were sixty-six. [27] And the sons of Joseph,

(21) who were born to him in Egypt, were two souls. All the souls of the house of Jacob,

(1) who came to Egypt, were seventy. [28] And he sent Judah $79 \mathrm{v}^{\mathrm{o}}$

(2) before him to Joseph, to teach the way before him 
(3) da jolu Gošenǵa \{da keldiĺar jerine Gošennin. [29] Da jerledi Josef markavyn da bardy uturusuna Jisra’elnin atasynyn Gošenge\} da aškara bolundu anar da tüštü bojun-

(4) lory üstüne da jylady bojunlary üstüne daġyn. [30]

(5) Da ajtty Jisra’el Josefke ölajim bu vaḥtta körgenim-

(6) den sortun jüzlerijni ki hanuz sen tirisen. [31] Da

(7) ajtty Josef qaryndašlaryna da elińa üvünün atasynyn

(8) barajym da anlatajym par'og̉a da ajtajym anar qaryndaš-

(9) larym da eli üvünün atamnyn ki jerind́a Kena'annyn kel-

(10) diler maja. והאנשים. [32] Da ol erenler qoj kütüvčü-

(11) lerdi ki tuvar ${ }_{\text {k }}$ kütüvčü el [e]diler ${ }^{11}$ alar da qojun özlerinin

(12) da syġyryn özlerinin da barča neki alarnyn keltirdiler.

(13) והיה [33] Da bolġaj ki ündese sizni par'o da ajtsa

(14) nedir išijiz. ואמרתם. [34] Da ajtyjyz tuvar kütüv-

(15) čü el ediĺar qullaryj jašlyqlarymyzdan da haligedejin daġyn

(16) biz dağyn atalarymyz anyn üčün ki olturgajsiz jerind́a

(17) Gošennin ki ḥor etkenidi Micrinin bar kütüvčü qoj.

Genesis 47

(18) Da keldi Josef da anlatty par'og̉a da ajtty

(19) atam da qaryndašlarym da qoju alarnyn da syġyrlary alar-

(20) nyn da barča neki alarnyn keldilar jerind́an Kena'annyn da

(21) muna alar jerind́a Gošennin. ומקצה. [2] Da bi\{r\} nečesin-

80 ro (1) den qaryndašlarynyn aldy beš erenlar da turguzuzdu alarny

(2) alnynda par'onun. Da ajtty par'o qaryn-

(3) dašlaryna Josefnin nedi išijiz da ajttylar par'oġa

(4) kütüvčü qojdu qullaryj dağyn atalarymyz.

(5) [4] Da ajttylar par'og̉a tirilma jerd́a

(6) keldik ki joḥtur kütüv qojğa ki qullaryjny ki küčejdi

(7) ol ačlyq jerind́a Kena'annyn da haligine oltursunlar

(8) endi qullaryj jerind́a Gošennin. ויאמר [5] Da ajtty

(9) paro Josefka ataj da qaryndašlaryj keldiĺar saja.

(10) ארץ. [6] Jeri Micrinin alnyjdady ol jaḥšyraq ornunda

(11) ol jernin olturgiuzġun ošol atajny da ošol qaryn-

(12) dašlaryjny oltursunlar jerind́a Gošennin da biledesej

\footnotetext{
${ }^{1} \mathrm{~K}$ : kütüvčü eldiler; a scribal error, cf. Gen 46:34. | TKow.o1: tuvarlyq el ediler. | H: tuvar eli ediler. | C: kišiläri sirövniฤ edilär.
} 
(3) to Goshen. And they came to the land of Goshen. [29] And Joseph harnessed his chariot, and went up to meet Israel, his father, to Goshen, and appeared himself to him, and he fell on his neck,

(4) and wept on his neck as well. [30]

(5) And Israel said to Joseph, 'Let me die now,

(6) after I have seen your face, that you are still alive.' [31] And

(7) Joseph said to his brothers, and to the people of his father's house,

(8) 'I will go up, and tell Pharaoh, and say to him, "My brothers,

(9) and the people of my father's house, who were in the land of Canaan, came

(10) to me. [32] And the men are shepherds,

(11) because they were keepers of livestock, and they have brought their flocks,

(12) and their cattle, and all that they have."

(13) [33] And it shall be, if Pharaoh calls you and says,

(14) "What is your work?": [34] And you shall say, "Your servants

(15) were keepers of livestock from our youth until now, both

(16) we and our fathers as well," in order that you may dwell in the land

(17) of Goshen, because every shepherd is an abomination to the Egyptians.'

Genesis 47

(18) [1] And Joseph came and told Pharaoh, and said,

(19) 'My father and my brothers, and their flocks, and their cattle,

(20) and all that they have, came out of the land of Canaan. And,

(21) lo, they are in the land of Goshen.' [2] And he took some

(1) of his brothers, five men, and presented them

(2) before Pharaoh. [3] And Pharaoh said

(3) to Jacob's brothers, 'What is your work?' And they said to Pharaoh,

(4) 'Your servants are shepherds, and our fathers, too.'

(5) [4] And they said to Pharaoh, 'We came to live in the land

(6) because your servants have no pasture for their flocks because

(7) the famine became stronger in the land of Canaan. And now may your servants dwell

(8) in the land of Goshen.' [5] And Pharaoh said

(9) to Joseph, 'Your father and your brothers have come to you.

(10) [6] The land of Egypt is before you.

(11) Settle your father and your brothers in the better place of the land.

(12) They shall dwell in the land of Goshen. And if you know, 
(13) da bar eśa alar arasyna tuvušlu el da qojg̉un alar-

(14) ny ${ }_{L}$ ag̉alyq $\{[\operatorname{lar}] y n\}^{11}$ tuvarnyn anyn üstüńa ne ki menim.

(15) (7) Da keltirdi Josef ošol Jacaqovnu atasyn da tur-

(16) guzdu any alnynda par'onun da alġyšlady Jacaqov ošol

(17) paronu. ויאמר [8] Da ajtty par'o Ja'aqovgia netek-

(18) lidi künleri tirlik jyllaryjnyn. [9יאמר. Da ajtty Jacaqov

(19) par'oġa künleri tirlik jyllarymnyn jüz otuz jyl azg்ynaq

(20) da jamanlar edilar künleri tirlik jyllarymnyn da jetelme-

(21) dilar ošol künlerin tirlik jyllarynyn atalarymnyn tirilmüš

$80 v^{\circ}$ (1) künlerind́a. ויברך. [10] Da šalom berdi Jacaqov parogga da

(2) čyqty alnyndan par'onun. [ויושב [11] Da olturg̉uzdu Josef

(3) ošol atasyn da ošol qaryndašlaryn da berdi alarg̉a tutuv-

(4) luq jerind́a Micrinin jahšyraq ornunda ol jernin jerin-

(5) da Ra'mesesnin ki nečik bujurdu paro. ויכלכל ] [12]

(6) Da besledi Josef ošol atasyn da ošol qaryndašlaryn da

(7) ošol bar elin üvünün atasynyn ötmekbyla jemińa

(8) köre ol jašnyn. ולחם [13] Da ötmek jog̉edi bar

(9) \{ol\} jerd́a ki küčejdi ol ačlyq astry da telirdi bar eli

(10) jerinin Micrinin da jerinin Kena‘annyn alnyndan ol ačlyqnyn.

(11) וילקט [14] Da čöpledi Josef ošol bar ol kümüšnü ol

(12) tabulġanny jerind́a Micrinin da jerind́a Kena'annyn bür-

(13) tük üčün ki alar satyn alyredilar da keltirdi Josef

(14) ošol bar ol kümüšnü üvüńa par'onun. ויתם [15]

(15) Da tügendi ol kümüš jerind́an Micrinin da jerid́an

(16) Kena‘annyn da keldiĺar bar eli Micrinin Josefka ajtadoġač

(17) bergin bizge ötḿak da nek ölejik alnyjda ki tügendi

(18) kümüš. ויאמר [16] Da ajtty Josef berijiz tuvarlaryjyzny

(19) da berejim sizǵa ötmek tuvarlaryjyz üčün qačan tügendi

(20) kümüš. ויביאו [17] Da keltirdilar ošol tuvarlarny Josef-

(21) ke da berdi alarg̉a Josef ötmek atlar üčün da jyjyny

$81 r^{\circ} \quad$ (1) üčü ol qojnun da jyjyny üčün ol syġyrnyn da ešek-

(2) ler üčün da könderdi alarny ötmek byla bar tuvarlary

(3) üčün ol jylda. ותתם. [18] Da tügendi ol jyl da keldi-

${ }^{1}$ TKow.o1: ag̉alyqlaryn. | H: ag̉araqlaryn. | C: bijläri. 
(13) or if there is any able men among them, then you shall make them

(14) livestock superiors over those that are mine.'

(15) [7] And Joseph brought in Jacob his father, and

(16) stood him before Pharaoh. And Jacob blessed

(17) Pharaoh. [8] And Pharaoh said to Jacob, 'How many

(18) are the days of the years of your life?' [9] And Jacob said

(19) to Pharaoh, 'The days of the years of my life are a hundred and thirty years.

(20) The days of the years of my life have been few and bad, and have not attained

(21) to the days of the years of the life of my fathers, in the days of their life.'

(1) [10] And Jacob offered peace to Pharaoh, and

(2) went out from before Pharaoh. [11] And Joseph settled

(3) his father and his brothers, and gave them a possession

(4) in the land of Egypt, in the better place of the land, in the land

(5) of Rameses, as Pharaoh had commanded. [12]

(6) And Joseph nourished his father, and his brothers, and

(7) all the people of his father's house, with bread,

(8) according to the food of the little ones. [13] And there was no bread in all

(9) the land, for the famine became very much stronger, so that the all the people of

(10) the land of Egypt and of the land of Canaan went insane by reason of the famine.

(11) [14] And Joseph gathered up all the silver

(12) that was found in the land of Egypt and in the land of Canaan

(13) for the grain which they bought. And Joseph brought

(14) the money to Pharaoh's house. [15]

(15) And when the silver came to an end from the land of Egypt and from the land

(16) of Canaan, all the Egyptians came to Joseph, saying,

(17) 'Give us bread! And why should we die before you? Because

(18) the silver came to an end.' [16] And Joseph said, 'Give your livestock,

(19) and I will give you bread for your livestock if the silver is gone.'

(20) [17] And they brought their livestock to Joseph,

(21) and Joseph gave them bread for the horses, and for the multitude of

(1) sheep, and for the multitude of cattle, and for the donkeys. $\quad 81 \mathrm{r}^{\circ}$

(2) And he led them out with bread for all their livestock

(3) in that year. [18] And that year was ended, and 
(4) ĺar ol ekinči jylda da ajttylar anar jašyrmajbiz

(5) bijimd́an ki kertid́an tügendi ol kümüš da jyjyny ol

(6) tuvarnyn bijimdedi qalmady alnynda bijimnin artyq nemed́a

(7) ančaq gövdemiz da jerimiz. למה [19] Nek ölejik köz-

(8) lerijč́a dag̉yn biz dag̉yn jerimiz satyn alġyn bizni da ošol

(9) jerimizni ötmek üčün da bolajyq \{biz da jerimiz\} qullar par'og̉a

(10) da bergin urluq da tiri bolajyq da ölmejik da ol jer

(11) veŕan bolmasyn. [20] Da satyn aldy Josef ošol bar jerin

(12) Micrinin par'og̉a ki sattylar eli Micrinin kiši tüzün ki

(13) küčejdi alar üstüne ol ačlyq da boldu ol jer

(14) parog̉a. [21] Da ošol ol ulusnu ašyrdy any

(15) šaharlarg̉a bašlap qyryjyndan čeginin Micrinin da qyjyrynadejin

(16) anyn. רק [22] Ančaq jerin ol qara tonlularnyn satyn alma-

(17) dy ki kem edi qara tonlularg̉a par'odan da ašaredilar

(18) ošol kemlerin özlerinin ki berdi alarg̉a par'o anyn

(19) üčün satmadylar ošol jerin özlerinin. [23] Da

(20) ajtty Josef ol ulusqa muna satynaldym sizni bügün

(21) da ošol jerijizni parog̣a muna sizǵa urluq da

81 v (1) čačyjyz ošol ol jerni. והיה [24] Da bolg̉aj bitišlerd́a

(2) da berirsiz bešinči ülüšnü par'og̀a da dört ol

(3) ülüšlar bolur sizǵa urlug̉una ol tüznün da ašama

(4) sizge da anar ki üvlerijizd́a da ašama jašyjyzğa.

(5) ויאמרו Da ajttylar tirgizdij bizni tabajyq širinlik

(6) közlerind[e] $]^{1}$ bijimnin da bolajyq qullar par'oġa. וישם [26]

(7) Da qojdu any Josef resimǵa ošpu küngedejin jeri üs-

(8) tüńa Micrinin par'og̉a bešinči ülüšḱa ančaq jeri

(9) ol qara tonlularnyn jalġyzlarnyn bolmady par'oġa.

(10) [ישב Da olturdu Jisra’el jerind́a Micrinin jerin-

(11) d́a Gošennin da tutuvlandylar anda da jajyldylar

(12) da köp boldular astry.

פרשת ויחי (13) (13) (14)

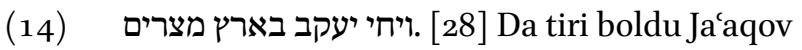

(15) jerind́a Micrinin on jedi jyl da edi künleri

(16) Ja'aqovnun tirlik jyllary anyn jüz da qyrq jedi jyl. ויקרבו [29]

(17) ${ }_{L}$ Da juvudular künlari Jisra’elnin ölḿa da ündedi uv-

\footnotetext{
${ }^{1} \mathrm{~K}$ : közlerindi; a scribal error. | TKow.o1: közlarind́a. | H: közlerinde. | C: közlärinä.
} 
(4) they came to him the second year, and said to him, 'We will not hide it

(5) from my lord that in truth the silver has come to an end, and

(6) my lord has the multitude of |our| livestock as well. There is nothing left before my lord,

(7) but our bodies, and our lands. [19] Why shall we die

(8) before your eyes, both we and our land? Buy us and

(9) our land for bread, and we and our land will be servants to Pharaoh.

(10) And give us seed, that we may live and not die, that the land

(11) may not be ruined. [20] And Joseph bought all the land

(12) of Egypt for Pharaoh, because the Egyptians sold every man his field,

(13) because the famine prevailed over them. So the land became

(14) Pharaoh's. [21] And the people: he ordered them to go

(15) to cities, from one edge of Egypt's borders even to its |other| edge.

(16) [22] Only the land of the priests he did not buy,

(17) because the priests had a portion assigned them of Pharaoh, and did eat

(18) their portion which Pharaoh gave them. On account of this

(19) they did not sell their land. [23] And

(20) Joseph said to the people, 'Lo, I have bought you

(21) and your land for Pharaoh today. Lo, here is seed for you, and

(1) you shall sow the land. [24] And it shall be, in the harvest,

(2) that you shall give the fifth part to Pharaoh, and four

(3) parts shall be your own, for field seed, and for your food,

(4) and for them in your houses, and for food for your little ones.'

(5) [25] And they said, 'You have revived us. Let us find favour

(6) in the eyes of my lord, and we will be Pharaoh's servants.' [26]

(7) And Joseph made it a statute to this day over the land

(8) of Egypt, that Pharaoh should have up to the fifth part. Only the land

(9) of the priests did not become Pharaoh's.

(10) [27] And Israel dwelt in the land of Egypt, in the land

(11) of Goshen. And they had possessions in it. And they spread,

(12) and multiplied very much.

(13) Parashat Vayechi

(14) [28] And Jacob lived

(15) in the land of Egypt seventeen years. So the days

(16) of Jacob, the days of his life, were a hundred and forty-seven years. [29]

(17) And Israel's days to die drew close. And he called 
(18) lun Josefni da ajtty anar eger endi taptym ese

(19) širinlik közlerijd́a qoltqabyla [qojg̉un endi qolujnu butum tübüne da qylġyn birgeḿa šavag̉at da kertilik qoltqabyla] astramag்yn meni Micri-

$82 \mathrm{r}^{\circ} \quad$ (1) iשכבתי [3o] Da jatajym atalarym qatyna da eltkin

(2) meni Micridan da astrag̀yn meni zeretlerind́a alarnyn da

(3) ajtty Josef men qylarmen sözlerija köŕa. ויאמר [31 Da

(4) ajtty antetkin maja da antetti anar da bašurdu

(5) Jisra’el bašy üstüne ol töšeknin.

Genesis 48

(7) Josefka muna ataj ḥastady da \{aldy\} ošol eki uvullaryn bir-

(8) gesińa ošol Menašeni da ošol Efrajimni. ויגד [2] [Da an- $\}$

(9) \{latty\} ol anlatuvču Jaaqovgga da ajtty muna uvluj Josef

(10) keledi saja da kiplendi Jisra’el da olturdu ol tö-

(11) šek üstüne. [3] Da ajtty Jacaqov Josefke

(12) küčlü Tenrinin šehinasy aškara boldu maja Luzda jerin-

(13) de Kena'annyn da alğyšlady meni. ויאמר. [4] Da ajtty maja

(14) muna men jajamen seni da arttyryrmen seni da berirmen

(15) seni jyjynyna uluslarnyn da berirmen ošol ol jerni oš-

(16) punu urlugujuja özüjden sortun tutuvlugiuna dunjanyn.

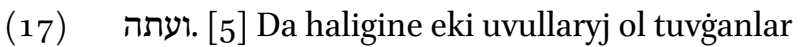

(18) saja jerind́a Micrinin kelgenime dejin saja Micriǵa

(19) menimdir alar Efrajim da Menaše Ru'uven kibik da Šim'on

(20) kibik bolurlar maja. ומולדתך. [6] Da tuvdurganyj senin

(21) ki tuvdursaj alardan sortun saja bolurlar aty byla qaryn-

$82 v^{0} \quad$ (1) dašlaryn ündelirlar ülüšlerind́a. [7] Da men kel-

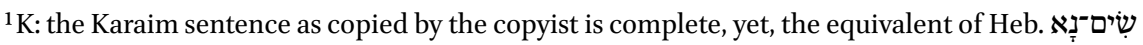
put your hand under my thigh and promise to deal kindly and truly with me' is missing. The repetition of the expression qolta byla 'please, I beg you' in $\mathrm{H}$ suggests an omission in $\mathrm{K}$-due to homeoteleuton or homeoarchy. Our reconstruction is based on the Hebrew original, TKow.o1, H, C, Gen 20:13, Gen 24:2, Gen 32:11. | TKow.o1: qojgun endi qolujnu butum tübüne da qylġyn birǵaḿa šavag்at da kertilik qoltqabyla. | H: Da juvudular künleri Jisra'elnin elme da cagyrdy uvlun Josefni da ajtty anar qoltqabyla eger taptym ese sirinlik közlerinde senin qojg̈un endi qolunnu butum tibine da qylg̀yn birgeme savagat da körti qoltqa byla astramaġyn

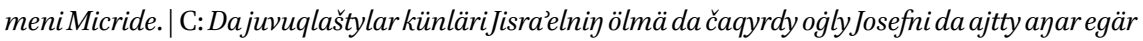
endi taptym esä širinlik közlärigä qojg̉yn endi qoluyny butum tibinä da qylġyn birgämä šaġavat da könülük endi kömmägin meni Mysyrda.
} 
(18) his son Joseph, and said to him, 'If, now, I have found

(19) favour in your eyes, I pray you, [put now your hand under my thigh, and do kindness and truth with me, I pray you,] do not bury me in Egypt.

(1) [30] But let me lie by my fathers. And carry

(2) me out of Egypt, and bury me in their cemetery.' And

(3) he said, 'I will do according to your words.' [31] And

(4) he said, 'Swear to me.' And he swore to him. And Israel bowed himself

(5) at the head of the bed.

Genesis 48

(5) [1] And it was

(6) after these things, and one ${ }^{73}$ said to

(7) Joseph, 'Lo, your father is sick.' And he took with him his two sons,

(8) Manasseh and Ephraim. [2] And

(9) a teller told Jacob, and said, 'Lo, your son Joseph

(10) comes to you.' And Israel strengthened himself, and sat

(11) on the bed. [3] And Jacob said to Joseph,

(12) 'The divine Presence of the mighty God appeared to me at Luz in the land

(13) of Canaan, and blessed me. [4] And said to me,

(14) "Lo, I will spread you, and multiply you, and I will make of you

(15) a multitude of people, and will give this land to your

(16) offspring after you for an everlasting possession."

(17) [5] And now, your two sons who were born

(18) to you in the land of Egypt by my coming to you to Egypt,

(19) they are mine: Ephraim and Manasseh, like Reuben and Simeon,

(20) will be mine. [6] And those whom you begat,

(21) whom you begat after them, will be yours.

(1) They will be called by the names of their brothers in their inheritance. [7] And

73 Lit. 'the speaker'. 
(2) genimd́a Padamdan öldü qatymda Rahel jerind́a Kena'annyn jol-

(3) da ${ }_{\llcorner}$hanuz [ašmaq] orun jertekli edi kelḿa ${ }^{11}$ Efratqa da ast-

(4) radym any anda jolunda Efratnyn oldu Bet Lahem.

(5) וירא [8] Da kördü 〈Josef〉 \{Jacaqov\} ošol uvullaryn Josefnin da aj-

(6) ויאמר ty [9] Da ajtty Josef atasyna

(7) uvullarymdy alar ki berdi maja Tenri bunda da ajtty

(8) alġyn endi alarny maja da alġyšlajym alarny. [10]

(9) Da közleri Jisra’elnin tundular qartlyqtan bolalmasedi kör-

(10) me da juvuttu alarny anar da öptü alarny Jacaqov da

(11) qučtu alarny. [11] Da ajtty Jisra’el Josefke

(12) körńa jüzlerijni töre etmedim da muna körgüzdü

(13) maja Tenri daġyn ošol urlugiujnuda. ויוצא. [12] Da čyğar-

(14) dy alarny Josef tizleri arasyndan da bašurdu jüzleri byla jer-

(15) ǵa. ויקח. [13] Da aldy Josef ošol eksilerind́a ošol

(16) Efrajimni on qolubyla son janyndan Jisra’elnin da ošol

(17) Menašeni son qolubyla on janyndan Jisra’elnin da juvuttu

(18) anar. וישלח Da sundu Jisra'el ošol on qolun da qoj-

(19) du bašy üstüne Efrajimnin da ol edi ol kičirek da

(20) ošol son qolun qojdu bašy üstüne Menašenin aqylby-

(21) la Łqojdu ošol qollaryn hote Menaše edi ol tunġuč 72 .

$83 \mathrm{r}^{\circ} \quad$ (1) (פשט שני על שכל את ידיו) (2čalyštyrdy ošol qollaryn

(2) ki Menaše edi ol tunġuč 13 . [15] Da alğyšlady ošol

(3) Josefni da ajtty ol Tenri ki jürüdüler atalarym al-

(4) nynda anyn Avraham da Jichạaq ol Tenri ol kütüvčü

(5) meni bar bolg̀anymdan ošpu küngedejin. המלאך. [16] Ol

(6) malah ol juluvču meni bar jamandan alġyšlaġaj ošol ol

(7) ulanlarny da atalġaj alarda atym da aty atalarymnyn

(8) Avrahamnyn da Jichaqnyn da balyqlar kibik artqajlar

(9) ortasynda ol jernin. [17] Da kördü Josef ki

(10) qojdu atasy on qolun bašy üstüńa Efrajimnin da

\footnotetext{
${ }^{1} \mathrm{~K}$ : ašmaq is reconstructed on the basis of Gen 35:16 translated in the same way in $\mathrm{K}$ and $\mathrm{H}$. | TKow.o1: hanuz ötmek ašamaq orun jer tekli edi kelmá. | H: in Gen 48:7, two different translations are offered: hanuz mil jol tekli and hanuz etmek asmaq vaht tekli.| C: dagjyn bir mil teglijer kelmä. | M: bir mil tegli jeri kelmä. | V: hanuz ašma vahty tékli jer keĺma. | R: hanuz ašma vahty tekli jer keĺma. $\quad{ }^{2}$ TKow.o1: qojdu ošol qollaryn hote Menaše edi ol tunġuč. | H: qojdu osol qollaryn hotej Menaše edi ol tunġuc.|Cf. the subsequent two footnotes. ${ }^{3} \mathrm{~K}$ : An alternative translation of Heb.

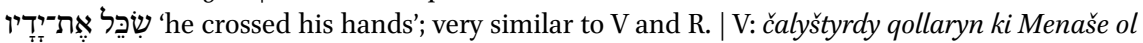
tunġuč. | R: čalyštyrdy qollaryn ki Menaše ol tunġuč.
} 
(2) when I came from Paddan, Rachel died by me in the land of Canaan on the way,

(3) when there was still a span of the land to pass to come to Ephrath, and

(4) I buried her there on the way of Ephrath, that is Bethlehem.'

(5) [8] And Israel saw Joseph's sons, and said,

(6) 'Who are these?' [9] And Joseph said to his father,

(7) 'They are my sons, whom God has given me here.' And he said,

(8) 'Take them to me and let me bless them.' [10]

(9) And the eyes of Israel were dim for age, so that he could not see.

(10) And he brought them near to him, and Jacob kissed them, and

(11) embraced them. [11] And Israel said to Joseph,

(12) 'I had not thought to see your face, and, lo, God has shown

(13) me your offspring as well.' [12] And Joseph brought

(14) them out from between his knees, and he bowed himself with his face

(15) to the earth. [13] And Joseph took them both,

(16) Ephraim in his right hand on Israel's left hand, and

(17) Manasseh in his left hand on Israel's right hand, and brought them near

(18) to him. [14] And Israel reached out his right hand, and laid it

(19) on Ephraim's head, and he was the younger, and

(20) he laid his left hand on Manasseh's head.

(21) He laid his hands knowingly, even though Manasseh was the firstborn.

(1) (A second translation of 'he crossed his hands ...'): ${ }_{\mathrm{L}} \mathrm{He}$ [reached out] $\quad 83 \mathrm{r}^{\circ}$ his hands

(2) because Manasseh was the firstborn ${ }^{174}$. [15] And he blessed

(3) Joseph, and said, 'God before whom my fathers walked,

(4) Abraham and Isaac, the God who has been my shepherd

(5) all my existence long to this day, [16] The

(6) Angel who redeemed me from all bad, may he bless the

(7) boys. And may my name be called on them, and the name of my fathers,

(8) Abraham and Isaac. And let them spawn like fish into a multitude

(9) in the midst of the earth.' [17] And Joseph saw that

(10) his father laid his right hand on the head of Ephraim, and

74 An alternative translation of the ending fragment of Gen 48:14. 
(11) jaman köründü közlerind́a anyn da tut $[\mathrm{t}] \mathrm{u}^{1}$ qolun atasy-

(12) nyn keterḿa any bašy üstünden Efrajimnin qojma

(13) bašy üstüne Menašenin. ויאמר [18] Da ajtty atasyna

(14) tüvüldü alaj atam ki budur ol tunġuč qojğun on

(15) qolujnu bašy üstüne anyn. [19] Da klemedi

(16) atasy anyn da ajtty bilemen uvlum bilemen dagyn olda

(17) bolur ulusqa da daġyn olda ulgaajyr da kertidan

(18) qaryndašy anyn ${ }_{L}\{$ ol ki[čirek $\left.]\right\}^{12}$ ulluraq bolur andan da urlugiu anyn bolur

(19) tolusu ol ḥanlyqlarnyn. [20] Da alġyšlady alarny

(20) ol künd́a ajtadoġač senin byla alg̀yšlag̉aj ulanlaryn özünün

(21) Jisra’el ajtadoğač qojg̉aj seni Tenri Efrajimni ${ }^{3}$ kibik

$83 v^{0} \quad$ (1) da Menašeni kibik da qojdu Efrajimni burun Menašeden.

(2) ויאמר (21] Da ajtty Jisra’el Josefke muna men ölermen da

(3) bolur bolušlug̉u Tenrinin birgejizǵa da qajtaryr sizni jerińa

(4) atalaryjyznyn. [22] Da men muna beremen saja bir ülüš

(5) artyq qaryndašla\{r\}yj üstüne ki aldym qolundan ol Emorinin

(6) qylyčym byla da jajym byla.

Genesis 49

(7) Jacaqov uvullaryn da ajtty jyštyrylyjyz da anlatajym siz-

(8) ge ošol neki učrar sizni sonġusunda ol künlernin.

(9) הקבצו Jaštyrylyjyz da tynlajyz e uvulla\{r\}y Ja'aqovnun

(10) da tynlajyz sözlerin Jisra’elnin atajyznyn. [ראובן. [3]

(11) Ru'uven tunġučumdur sen küčüm da ilki quvatymnyn

(12) syjy kohenliknin da syjy bijliknin jarašyredi saja. פח [4]

(13) Qavdurluq aqmaġy kibik suvlarnyn tabuldu send́a syjly bolmas-

(14) sen ki mindij töšeklerińa atajnyn ol vahttta jengil et-

(15) tij töšegim kesildi. שמעון. [5] Šim'on da Levi qaryn-

(16) dašlar avanlyq savutlar tirilmüš orunlarynda. בסדם. [6]

(17) Syrlaryna alarnyn kelmedi žanym jyštyrylmaqlaryna alarnyn

(18) bir bolmady syjly žanym ki ačuvlarybyla öltürdüler kišini

(19) da klekleribyla aḥtardylar kermenni. ארור. [7] Qarg̉yšlydy

\footnotetext{
${ }^{1} \mathrm{~K}$ : tutu; a scribal error. | TKow.o1: tuttu. | H: tuttu. | C: tuttu. $\quad{ }^{2}$ Marginal insertion by another hand. | TKow.o1: ol kičiŕak. | H: ol kicirek. | C: ol kiči. ${ }^{3} \mathrm{~K}$ : Efrajimnin; a scribal error; cf. Menašeni kibik in this verse below. | TKow.on: Efrajimni. | H: Efrajimni. | C: Efrajim. $\quad{ }^{4} \mathrm{~K}$ : etttij; a scribal error.
} 
(11) it seemed bad in his eyes, and he held up his father's hand

(12) to remove it from Ephraim's head to lay it

(13) on Manasseh's head. [18] And Joseph said to his father,

(14) 'It is not so, my father, for this is the firstborn, put your right

(15) hand on his head.' [19] And his father did not want to

(16) and said, 'I know, my son, I know. He, too,

(17) will become a people, and he, too, will be great. But, of a truth,

(18) his $\{$ younger $\}$ brother will be greater than he, and his offspring will become

(19) a plenty of kingdoms.' [20] And he blessed them

(20) that day, saying, 'By you Israel will bless his sons,

(21) saying, "May God make you like Ephraim

(1) and like Manasseh."' And he set Ephraim before Manasseh.

(2) [21] And Israel said to Joseph, 'Lo, I will die, but

(3) God's help will be with you and will bring you again to the land

(4) of your fathers. [22] And, lo, I give to you one portion

(5) above your brothers, which I took from the hand of the Amorite

(6) with my sword and with my bow.'

Genesis 49

(7) his sons, and said, 'Assemble and let me tell you

(8) what will befall you in the last days. [2]

(9) Assemble and listen, oh sons of Jacob,

(10) and listen to the words of Israel, your father. [3]

(11) Reuben, you are my firstborn, my might, and the beginning of my strength,

(12) the fame of priesthood and the fame of reign. [4]

(13) Recklessness like the flow of water is to be found in you, you will not be famous,

(14) because you went up to your father's bed, then you defiled,

(15) it was cut off |from you|. [5] Simeon and Levi

(16) are brothers: weapons of wickedness are in their habitations. [6]

(17) My soul did not come into their secret, into their assembly,

(18) my spirit did not become united. For in their anger they killed a man,

(19) and they wilfully ruined a stronghold. [7] Cursed is 
(20) ačuvlary alarnyn ki küčlüdü da qahịleri alarnyn ki qatydy

(21) ülešejim alarny Jacaqovda da tozdurajym alarny Jisra’elde

$84 \mathrm{r}^{\mathrm{o}}$ (1) יהודה [8] Juhuda sen mahtarlar seni qaryndašlaryj qoluj senin bolur

(2) ensesind́a dušmanlaryjnyn bašururlar saja uvullary ataj-

(3) גור. [9] Aryslan balasykibik Juhuda jyrtuvdan uvlum

(4) kötürüldüj čöktü jatty aryslankibik da tiši aryslan-

(5) ny kibik kim turguzlar any. לא. [10] Ketmesti bijlik

(6) Juhudadan da resim qojuvču uruvlary arasyndan neginče ki

(7) kelǵaj mašijah da anar bolur tynlamaġy uluslarnyn. אסרי [11]

(8) Bajlar borlalyqqa qatyryn da inčke butaqqa balasyn e-

(9) šeginin juvar čaǵyrbyla uprag̉yn da qanynbyla borlalarnyn jabu-

(10) nurun. חכלילי [12] Qyzyllyġy közlernin bolur köplügünd́an

(11) čaġyrnyn da aqlyğy tišlernin bolur köplügünd́an sütnün.

(12) זבולן [13] Zevulun bogozunda tengizlernin tohtar da

(13) ol boğozunda gereplernin da čegi anyn Cidon qatyna.

(14) (14] Jissahar bazyq süvekli jatady ol _eki tüzüv-

(15) ler arasyna ${ }^{11}$. וירא. [15] Da kördü tynčlyqny ki jahššydy

(16) da ošol ol jerni ki čeberdi da qajyrdy javrunun jük kö-

(17) türme jügün tora oḥumaqnyn da bol $\{\mathrm{du}\}$ jasaq berüvčü

(18) qulluq etüvčü ornuna. †. [16] Dan jarg̉u jarar ulusun

(19) birisi kibik ševetlerinin Jisra'elnin ${ }_{L}$ ki andan čyğar Šimšon

(20) da bolur törečisi Jisra'elnin ${ }^{12}$. יהי [17] Bolur Dan jylan kibik

(21) jolqatyna küvdürgüč jylan kibik izqatyna ol tišlevčü

$84 \mathrm{~V}^{\circ}$ (1) sog̉ančyqlaryndan atnyn da tüšedi atlanuvčusu artqary.

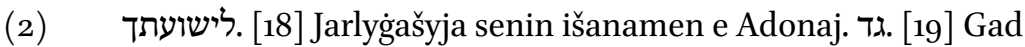

(3) üstüńa jyjyn jyštyrylsa da ol sondradada jyštyry-

(4) מאשר. [20] Ašerden semiz bolur ašy anyn da ol

(5) berir tatly ašajyš ašlaryn bijnin. נפתלי [21] Naftali soğag்-

(6) kibik ijilǵan ol berüvčü čeber ajtmaqlar. [בן. [22] Jašardoġan

\footnotetext{
${ }^{1} \mathrm{~K}$ : the meaning of tüzüvler is uncertain; cf. our commentary in the translation. | TKow.o1: eki tüzüvler arasyna. | H: eki cekler arasyna. | C: arasyna ol eki jasavu[n]larnyy. | V: eki tuźuv́lar arasyna. ${ }^{2}$ Interpretative addition to the standard text.
} 
(20) their anger, for it is fierce, and their fury, for it is cruel.

(21) I will divide them in Jacob, and scatter them in Israel.

(1) [8] Judah: You, your brothers will praise you. Your hand will be

(2) on the neck of your enemies, your father's children will bow down before you.

(3) [9] Judah is a lion's cub: from prey, my son,

(4) you are gone up. He kneeled down, he lay down as a lion, and as a lioness:

(5) who will rouse him? [10] Reign will not depart

(6) from Judah, or a statute-giver among his families, until

(7) the Messiah comes, and to him will be the obedience of the peoples. [11]

(8) He will tie his mule to the vine and his donkey's colt to a thin branch,

(9) he will wash his garments in wine and his quilt in the blood of grapes.

(10) [12] The redness of his eyes will be because of the plenty

(11) of wine, and the whiteness of his teeth will be because of the plenty of milk.

(12) [13] Zebulun will dwell at the haven of the seas, and

(13) he shall be for a haven for ships, and his border shall be at Sidon.

(14) [14] Issachar is of thick bones, lies down

(15) between two $\left[{ }^{\dagger} \text { cowsheds }\right]^{75}$. [15] And he saw rest, that it was good,

(16) and the land, that it was pleasant, and he bowed his shoulder to bear

(17) the burden of reading the Law, and became a tribute-payer,

(18) instead of a servant. [16] Dan will judge his people

(19) as one of the tribes of Israel ${ }_{L}$ from which Shimshon will come forth,

(20) and will be the judge of Israel ${ }^{176}$. [17] Dan will be like a serpent

(21) by the road, like a viper by the path, that bites

(1) the horse's heels, and its rider falls backward.

(2) [18] I hope for your salvation, oh Lord. [19] Gad,

(3) a troop gathers over him, but at the last he will gather

(4) and overcome. [20] About Asher: his food will be fat, and he

(5) will yield a king's heavenly food. [21] Naphtali

(6) is like a fawn ${ }_{L}$ let loose ${ }^{777}$, who gives pleasant words. [22]

75 K: an uncertain translation of tüzüv, cf. jasavun 'cowshed' in C. | TKow.o1: eki tüzüvler arsyna; the same translation as in K. | H: eki cekler arasyna 'between two borders'. | C: arasyna ol eki jasavu[n]larnyy 'between the two cowsheds'. | V: ol eki tuźuv́lar arasyna; the same translation as in K. | R: ol eki tuźuv́lar arasyna; the same translation as in K.

76 An interpretative addition to Gen 49:16.

77 Lit. 'sent'. 
(7) butaq kibik Josef jajyladoġan köz suv qatyna inčke butaq-

(8) lar atladylar kermen üstüńa. [23 Da ačy e-

(9) ttílar anar da attylar any dušman boldular anar oq jesi-

(10) leri. [תשב [24] Da olturdu kip orunda jajy anyn da

(11) kiplendilar qollarynyn küčünden küčlü Tenrisinin

(12) Jacaqovnun andan boldu kütüvčü fundamentin Jisra’elnin.

(13) מאל [25] Bujrug̉undan Tenrisinin atajnyn da bolušqaj saja

(14) da küčlü Tenri da alġyšlag̉aj seni alğyšlarybyla köklerinin

(15) jog̉arg̉y köklerdan alğyšlary byla darjanyn jatadoġan ašağa

(16) alğyšlarybyla töšlernin da qursaqnyn. ברכות. [26] Alg̈yš-

(17) lary atajnyn küčejdiliar alg̀yšlary üstüne tuvduruvču-

(18) larymnyn belgisinedejin qajalarynyn dunjanyn bolġajlar bašyna Josef-

(19) nin da töbesińa ajyrylğa\{n\}nyn qaryndašlaryndan. בנימין. [27]

(20) Binjamin börülej jyrtar ertenbylada ašar mal da ingird́a

(21) ülešir olక̌a. כל. [28] Bar bular ševetleri Jisra’elnin on eki

$85 \mathrm{r}^{\mathrm{o}} \quad$ (1) da budu ki sözledi alarg̉a atasy alarnyn da alğyšlady alarny

(2) kišini ki alġyšyna köre alġyšlady alarny. ויצו. [29] Da

(3) cava’a etti alarg̉a da ajtty alarg̉a men jyštyrylyrmen

(4) ulusuma astrajyz \{meni\} atalarym qatyna ol pečorada ki tüzün-

(5) de 'Efronnun ol Ḥitilinin. במערה. [30] Ṕečorada ki tüzü-

(6) nd́a ol Mahpelanyn ki alnynda Mamrenin jerind́a Kena`annyn

(7) ki satyn aldy Avraham ošol ol tüznü 'Efrondan ol Hitiliden

(8) tutuvlugiuna zeretnin. [3מה [31] Anda astradylar ošol

(9) Avrahamny da ošol Sarany qatynyn anda astradylar ošol

(10) Jicḥaqny da ošol Riveqany qatynyn da anda astradym ošol

(11) מקנה. [32] Satyn almag̉y ol tüznün da ol ṕečora-

(12) nyn ki anda uvullaryndan Ḥetnin. [33] Da tügelledi

(13) Ja'aqov cava’a etḿa uvullaryna özünün da jyštyrdy

(14) ajaqlaryn ol krovatqa da tyndy da jyštyryldy uluslary-

(15) na. 
(7) Joseph is like a bough at full strength, a spreading bough by a well, thin

(8) branches that strutted on a stronghold. [23] And

(9) the archers teased him, and shot at him, and were hostile to him.

(10) [24] But his bow dwelt in strength, and

(11) the arms of his hands were made strong by the strength of the mighty God

(12) of Jacob, from there is the shepherd, the foundation of Israel,

(13) [25] by the command of God of your father, and he shall help you,

(14) and by the mighty God, and he shall bless you with blessings of heavens

(15) from the heavens above, with blessings of the deep that lies beneath,

(16) with blessings of the breasts and of the womb. [26] The blessings

(17) of your father have prevailed above the blessings of my parents

(18) up to the tokens of the everlasting rocks. They shall be on the head of Joseph,

(19) and on the brow of the head of the one separate from his brothers. [27]

(20) Benjamin will tear up like a wolf, in the morning he will devour the cattle, and at night

(21) he will divide the spoil.' [28] All these are the twelve tribes of Israel:

(1) and this is it what their father spoke to them, and he blessed them. $\quad 85 \mathrm{r}^{\circ}$

(2) He blessed them each according to his blessing. [29] And

(3) he commanded them, and said to them, 'I will be gathered

(4) to my people. Bury me next to my fathers in the cave that is in the field

(5) of Ephron, the Hittite. [30] In the cave that

(6) is in the field of Machpelah, which is before Mamre, in the land of Canaan,

(7) where Abraham bought the field from Ephron, the Hittite,

(8) for a possession as a sepulchre. [31] There they buried

(9) Abraham and Sarah, his wife, there they buried

(10) Isaac and Rebekah, his wife, and there I buried

(11) Leah. [32] The purchase of the field and of the cave

(12) that is in it was from the children of Heth.' [33] And

(13) Jacob finished commanding his sons, and he gathered

(14) his feet into the bed, and rested, and was gathered

(15) to his people. 


\section{Genesis $5^{\circ}$}

(15) [1] Da tüštü Josef jüzleri üstüne atasy-

(16) nyn da jylady anyn üčün da öptü any. ויצו. [2] Da bujur-

(17) du Josef qullaryna özünün ol rofelerge hạanot etme

(18) ošol atasyn da hanot ettiler ol rofeler ošol Jisra’el-

(19) ni. וימלאו [3] Da toldular anar qyrq kün ki alaj tolaredi-

(20) lar künleri ol hanot etilgenlernin da jyladylar anyn üčün

(21) eli Micrinin jetmiš kün. ויעברו. [4] Da aštylar künleri

$85 \mathrm{v}^{\mathrm{o}}$ (1) jylamag்ynyn da sözledi Josef elińa üvünün par'onun ajta-

(2) dog̉ač eger endi taptym ese širinlik közlerijizd́a söz-

(3) lejiz endi qulaqlaryča parconun ajtadoġač. אבי. [5] Atam

(4) antettirdi meni ajtadoğač muna men ölermen zeretim-

(5) de ki qazdym özüḿa jerind́a Kena‘annyn anda astrag்yn

(6) meni da haligine barajym endi da astrajym ošol atamny

(7) da qajtyrmen. [יאמר. Da ajtty par'o barg்yn da

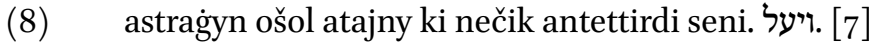

(9) Da bardy Josef astrama ošol atasyn da bardylar birgesi-

(10) ne bar qullary par'onun qartlary üvünün da bar qartlary

(11) jerinin Micrinin. וכל [8] \{Da\} bar eli üvünün Josefnin da qaryn-

(12) dašlary anyn da eli üvünün atasynyn ančaq _[jašlaryn da] ${ }^{11}$ qojlaryn da sy-

(13) ġyrlaryn kemištilar jerind́a Gošennin. [9] [9] Da bardy

(14) birgesińa dag்yn markav dag்yn jalan atlylar da boldu ol avul

(15) küčlü astry. [10] Da keldilar yndyrynadejin ol

(16) Atad ündeledogan orunnun ki köčüvünd́a ol Jardennin da

(17) syjyt ettilar anda ullu syjyt da küčlü astry da

(18) qyldy atasy üčün jas jedi künler. וירא [11 Da kördü

(19) olturuvčusu ol jernin ol Kena'annyn ošol ol jasny Goren

(20) ol Atad ündeledoġan ornunda da ajttylar küčlü jas-

\footnotetext{
${ }^{1} \mathrm{~K}$ : deest; a scribal error. | TKow.o1: jašlaryn da. | H: jaslaryn da. | C: jašlaryn da.
} 


\section{Genesis $5^{\circ}$}

And Joseph fell on his father's face,

(16) and wept over him, and kissed him. [2] And

(17) Joseph commanded his servants, the physicians, to embalm

(18) his father. And the physicians embalmed Israel.

(19) [3] And forty days were filled for him, because this is how

(20) the days of those who are embalmed are filled. And the Egyptians wept for him

(21) seventy days. [4] And the days of his weeping passed,

(1) and Joseph spoke to the house of Pharaoh, saying,

(2) 'If now I have found favour in your eyes, speak

(3) now in the ears of Pharaoh, saying, [5] "My father

(4) made me swear, saying, "Lo, I will die. In my grave,

(5) which I have dug for me in the land of Canaan: you shall bury me there."

(6) And now, let me go now, and let me bury my father,

(7) and I will come back."' [6] And Pharaoh said, 'Go and

(8) bury your father as he had you swear.' [7]

(9) And Joseph went to bury his father, and

(10) all the servants of Pharaoh went with him, the elders of his house, and all the elders

(11) of the land of Egypt, [8] And all the people of Joseph's house, and his brothers,

(12) and the people of his father's house. Only [their little ones and] their flocks and their

(13) cattle they left in the land of Goshen. [9] And

(14) both chariots and horsemen went with him. And it was a very great camp.

(15) [10] And they came to the threshing-floor of

(16) the place which is called Atad, which is at the ford of Jordan, and

(17) there they cried with a great and very strong cry. And

(18) he made a mourning for his father for seven days. [11] And

(19) the inhabitants of the land of Canaan saw the mourning in

(20) the place which is called ${ }_{L}$ Goren the Atad ${ }^{178}$, and they said, "This is a strong

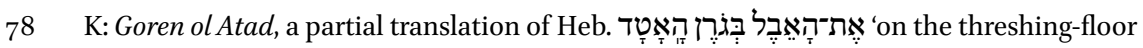
of Atad'. 
(21) tyr bu Micriǵa anyn üčün atady atyn anyn Avel Micrajim

86 r $^{\circ} \quad$ (1) ki köčüvünd́a ol Jardennin. [12] Da qyldylar uvullary

(2) anyn anar alaj ki nečik bujurdu alarg̉a. וישאו. [13] Da

(3) elttilar any uvullary anyn jerińa Kenáannyn da astrady-

(4) lar any ṕečorasynda ol Mahpelanyn ki satyn aldy Avraham

(5) ošol ol tüznü tutuvlugiuna zeretnin 'Efrondan ol Ḥitili-

(6) den alnynda Mamrenin. וישב Da qajtty Josef Micri-

(7) ge ol da qaryndašlary anyn da bar ol baruvčular birgesińa

(8) astrama ošol atasyn astrag̉anyndan sortun ošol atasyn.

(9) [15] Da kördülar qaryndašlary Josefnin ki öldü

(10) atasy alarnyn da ajttylar šeme dušman bolur bizǵa Josef

(11) da qajtarma qajtaryr bizǵa ošol bar ol jamanlyqny ki tö-

(12) ledik anar. ויצוו [16] Da sarydylar Josefka ajtadog̉ač

(13) ataj bujurdu ölmegi alnyna [ajtadoġač $]^{1}$. כה [17] Bulaj ajtyjyz

(14) Josefke qoltqabyla bošatqyn endi günehịn qaryndašla-

(15) ryjnyn da jazyqlaryn alarnyn ki jamanlyq töledilar saja da

(16) haligine bošatqyn endi günehin qullarynyn Tenrisinin ataj-

(17) nyn da jylady Josef sözlegenlerind́a anar. זילכו [18] Da

(18) bardylar dag̉yn qaryndašlary anyn da tüštüler alnynda anyn

(19) da ajttylar muna biz saja qullarg̉a. [19] Da

(20) ajtty alarg̉a Josef qorqmajyz ki Tenrimo ornundadyr

(21) men. ואתם [20] Da siz saggyšladyjyz üstüme jamanlyqny

$86 \mathrm{v}^{\mathrm{o}} \quad$ (1) Tenri sag̉yšlady any jahšyğa qylmaq üčün ošpu kün kibik tiri

(2) tutma köp ulusnu. [21] Da haligine qorqmajyz men

(3) beslermen sizni da ošol jašyjyzny da uvuttu alarny da söz-

(4) ledi kölünlerińa alarnyn. [22] Da olturdu Josef Micri-

(5) de ol da eli üvünün atasynyn da tiri boldu Josef jüz

(6) da on jyllar. [23] Da kördü Josef Efrajimge uvul-

(7) lar üčünčü dor daġyn uvullary Mahirnin uvlunun Menaše-

(8) nin östürüldülar tizleri üstüńa Josefnin. ויאמר [24]

(9) Da ajtty Josef qaryndašlaryna men ölermen da Tenri

(10) saġynma saġynyr sizni da čyġaryr sizni jerd́an ošpu

(11) ol jerǵa ki antetti Avrahamġa Jichaqqa da Jaáaqovga.

(12) Da antettirdi Josef ošol uvullaryn Jisra’el-

(13) nin ajtadoğač sağynma sag்ynyr Tenri sizni da čyg்aryjyz

(14) ošol süveklerimni bundan. וימת [26] Da öldü Josef

\footnotetext{
${ }^{1} \mathrm{~K}$ : deest; a scribal error. | TKow.o1: ajtadog்ač. | H: burun ajtadoġac. | C: burun demä.
} 
(21) mourning to the Egyptians.' Therefore the name of it was called AbelMizraim,

(1) which is at the ford of Jordan. [12] And his sons did

(2) to him as he had commanded them. [13] And

(3) his sons carried him to the land of Canaan, and buried

(4) him in the cave of the field of Machpelah, which Abraham bought

(5) with the field for a possession of a sepulchre from Ephron the Hittite,

(6) before Mamre. [14] And Joseph returned to Egypt,

(7) he, and his brothers, and all that went with him

(8) to bury his father, after he had buried his father.

(9) [15] And Joseph's brothers saw that their father was dead,

(10) and they said, 'Joseph will perhaps be hostile to us,

(11) and will certainly pay back to us all the evil which we payed

(12) to him.' [16] And they sent a message to Joseph, saying,

(13) 'Your father had command before he died: [17] "So shall you say

(14) to Joseph, "Forgive now, we pray you, the trespass of your brothers

(15) and their sin, because they payed you evil." And

(16) now, forgive the trespass of the servants of the God of your father.'

(17) And Joseph wept when they spoke to him. [18] And

(18) his brothers also went and fell down before him,

(19) and they said, 'Lo, we are your servants.' [19] And

(20) Joseph said to them, 'Do not fear, because am I in the place of God?

(21) [20] And you thought bad against me.

(1) God thought for good: to make it as it is this day, to save

(2) many people alive. [21] And now, do not fear: I

(3) will nourish you and your little ones.' And he comforted them, and spoke

(4) to their hearts. [22] And Joseph dwelt in Egypt,

(5) he and the people of his father's house. And Joseph lived a hundred

(6) and ten years. [23] And Joseph saw Ephraim's children

(7) of the third generation. Also the children of Machir, son of Manasseh,

(8) were brought up on Joseph's knees. [24]

(9) And Joseph said to his brothers, 'I will die. And God

(10) will surely remember you and bring you out of this land

(11) to the land which he swore to Abraham, to Isaac, and to Jacob.'

(12) [25] And Joseph made the sons of Israel swear,

(13) saying, 'God will surely remember you, and you shall take

(14) my bones from here.' [26] And Joseph died, 
(15) a hundred and ten |years| old. And they embalmed him, and he was put in a coffin

(16) in Egypt.

(17) With the help of Him who declares the end from the beginning

(18) the peshatim of the Book of Genesis are finished.

(19) And now I start to write the peshatim of the Book of Exodus

(20) with the help of Him who is praised by all the souls. 
$87 \mathrm{r}^{\mathrm{o}} \quad$ Exodus 1

ספר ואלה שמות (1) (2) (1) (2)

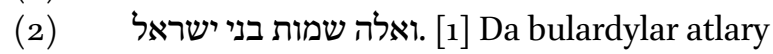

(3) uvullarynyn Jisra’elnin ol kelüvčülernin Micriǵa

(4) Jacaqov byla kiši da eli üvünün keldilar. ראובן. [2]

(5) Ru'uven Šim`on Levi da Juhuda. יששכר. [3] Jissahar Zevulun da

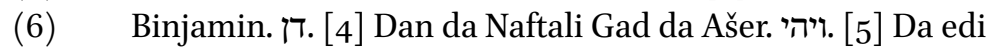

(7) bar క̌an čyğuvčulary butunun Ja'aqovnun jetmiš ̌̌an Josef byla

(8) ki edi Micrid́a. [6] Da öldü Josef da bar qaryn-

(9) dašlary anyn da bar ol dor. ובנת. [7] Da uvullary Jisra'el-

(10) nin jajyldylar \{da qozladylar\} da arttylar da küčlü boldular astry astry

(11) da toldu ol jer alardan. ויקם. [8] Da turdu jang்y bij

(12) Micri üstüne ki bilmedi ošol Josefni. [9]

(13) Da ajtty ulusuna özünün muna ulusu uvullarynyn Jisra’el-

(14) nin köprekti da küčlürekti bizd́an. הבה. [10] Kel

(15) ustatlyq qylajyq anar šeme artar da bolġaj ki učrasalar

(16) učurlary čerüvnün da artar dag்yn olda dušmanlarymyz üs-

(17) tüne da urušur biznin byla da čyġar ol jerd́an.

(18) Da qojdular anyn üstüne jasaq aluvču ag̉alyqlar

(19) qyjnamaq üčün any jüklerind́a alarnyn da qondardy hạana

(20) Šaharlaryn par'oġa ošol Pitomnu da ošol Ra‘amesesni

$87 \mathrm{~V}^{\mathrm{o}}$ (1) (12] Da ki nečik qyjnasajdylar any artyq artaredi

(2) da artyq jajylyredi da jadadylar alnyndan ulanlarynyn Jisra'el-

(3) nin. ויעבדו Da qulluq ettirdilar Micrililer ošol

(4) ulanlaryn Jisra’elnin hökümlük byla. וימררו. [14] Da ačy et-

(5) tilar ošol tirliklerinin alarnyn qaty qulluq byla balčyqbyla

(6) da kirpičler byla da bar qaty qulluq byla tüzd́a ošol

(7) bar qulluqlary alarnyn ki qulluq ettilar alarbyla edi họoüm-

(8) lükbyla. 15] Da ajtty biji Micrinin ol Jisra'el-

(9) ka anačalarg̉a ki aty ol birisinin edi Šifra da aty ol

(10) ekinčinin Pu'a. ויאמר [16] Da ajtty par'o töretke-

(11) nijizde ošol ol Jisra'elkalarny da baġyjyz ol törer orun

(12) üstüne eger uvul bolsa ol da öltürüjüz any da

(13) eger qyz bolsa ol da tiri bolsun. ותיראן. [17] Da qorq-

(14) tular ol anačalar ol Tenrid́an da qylmadylar ki nečik sözle-

(15) di alarğa biji Micrinin da tiri tuttular ošol ol er 
(1) Book of Exodus

(2) [1] And these are the names

(3) of the sons of Israel, who came to Egypt.

(4) With Jacob, each came with the people of his house: [2]

(5) Reuben, Simeon, Levi, and Judah, [3] Issachar, Zebulun, and

(6) Benjamin, [4] Dan, and Naphtali, Gad, and Asher. [5] And

(7) all souls who came out from Jacob's thigh were seventy souls, with Joseph

(8) who was in Egypt. [6] And Joseph died, and all

(9) his brothers, and all that generation. [7] And the sons of Israel

(10) spread, and multiplied, and increased, and grew very, very strong,

(11) and the land was filled with them. [8] And a new king rose

(12) over Egypt, who knew not Joseph. [9]

(13) And he said to his people, 'Lo, the people of the sons of Israel

(14) are more and stronger than we. [10] Come,

(15) let us deal wisely with them, maybe it will increase, and it shall be

(16) if war befall us, and it, too, will be added to our enemies,

(17) and the will fight against us and will go out from the land.'

(18) [11] And they set over them tax collector, rulers

(19) to oppress them with their burdens. And they built

(20) for Pharaoh treasure cities, Pithom and Raamses.

(1) [12] But the more they oppressed them, the more they multiplied

(2) and the more spread. And they weakened before the sons of Israel.

(3) [13] And the Egyptians made the

(4) sons of Israel to serve oppressively. [14] And

(5) they made their lives bitter with hard service, in clay,

(6) and in brick, and in all manner of hard service in the field:

(7) all their service, in which they made them serve, was oppressive.

(8) And the king of Egypt spoke to the Hebrew

(9) midwives, of whom the name of one was Shiphrah, and the name of the

(10) second was Puah, [16] And Pharaoh said, 'When you make Hebrew women give birth,

(11) and see them in the place for giving birth:

(12) if it is a son, then you shall kill him, and

(13) if it is a daughter, then she shall live.' [17] But

(14) the midwives feared God, and did not as

(15) the king of Egypt spoke to them, and they kept alive 
(16) ulanlarnyda. ויקרא. [18] Da ündedi biji Micrinin anačalary

(17) da ajtty alarg̉a ne üčün qyldyjyz ošol ol išni oš-

(18) punu da tiri tuttujuz ošol er ulanlarynda. ותאמרן [19]

(19) Da ajttylar ol anačalar par'og̉a ki tüvüldü ol Micrili

(20) qatynlar kibik ol Jisra'elkalar ki savdylar alar kelmesten burun

(21) alarg̉a ol anača da törejdilar. וייטב [20] Da

$88 \mathrm{r}^{\mathrm{o}} \quad$ (1) jahšyy etti Tenri anačalarğa da köp boldu ol ulus da küčlü

(2) boldular astry. [21] Da edi ki nečik qorqtular ol ana-

(3) čalar ol Tenridan da qyldy alarg̉a tynčlyqlar. ויצו [22] Da

(4) bujurdu par'o bar ulusuna ajtadoġač bar ol uvulnu ol

(5) tuvġanny ol Nilge tašlajyz any da bar ol qyzny tiri tutujuz.

Exodus 2

(6) וילך . 11] Da bardy kiši üvünd́an Levinin da aldy ošol qyzy

(7) Levinin. ותהר [2] Da hamila boldu ol \{hatyn $\}^{1}$ da töredi uvul

(8) da kördü any ki jahšsydy ol da astrady any üč janġaj-

(9) lar. ולא [3] Da bolalmady artyq astrama any da aldy

(10) özüne qamušlu sunduq da jaqty any balčyqbyla da smo-

(11) labyla da qojdu ary ošol ol ullany da qojdu qamušluq-

(12) ta qyryjy ü\{s\}tüńa ol Nilnin. ותתצב. [4] Da turdu tuv-

(13) dug̉u anyn jyraqtyn bilmáa ne qylynyr anar. ותרד [5] Da

(14) endi qyzy par'onun juvunma ol Nilǵa da qyrqynlary

(15) anyn jürürediler qyryj üstüne ol Nilnin da kördü o-

(16) šol ol sunduqnu ortasynda ol qamušluqnun da ijdi

(17) ošol qaravašyn da aldy any. ותפתח. [6] Da ačty da

(18) kördü ošol ol ulanny da muna ulan jylady da hajif-

(19) sündü anyn üstüne da ajtty ulanlaryndandy ol

(20) ותאמר. Jisra'ellernin bu Da ajtty tuvdugiu anyn qyzy-

(21) na par'onun barajymmo da ündejim saja ömüzdü-

$88 \mathrm{v}^{\mathrm{o}}$ (1) rüvčü qatyn ol Jisra’elkalardan da ömüzdürsün saja o-

(2) ותאמר. šol ol ulanny. Da ajtty anar qyzy paro-

(3) nun barg்yn da bardy ol qyz da ündedi ošol anasyn ol

(4) ulannyn. ותאמר. [9] Da ajtty anar qyzy par'onun eltkin

(5) ošol ol ulanny ošpunu da ömüzdürgün any maja da

\footnotetext{
${ }^{1}$ Marginal insertion by another hand in Eastern Karaim (or on the basis of an Eastern Karaim text). | TKow.o1: deest. | H: qatyn. | C: hatyn.
} 
(16) also the male children. [18] And the king of Egypt called for the midwives,

(17) and he said to them, 'Why have you done this thing,

(18) and have let the male children alive?' [19]

(19) And the midwives said to Pharaoh, 'Because the

(20) Hebrew women are not like the Egyptian women, because they are healthy,

(21) they give birth before the midwife comes to them.' [20] And

(1) God dealt well with the midwives. And the people multiplied, and grew

(2) very strong, [21] And it was because the midwives feared

(3) God, and he gave them rest. [22] And

(4) Pharaoh commanded all his people, saying, 'Every son who

(5) is born: you shall cast into the Nile. And every daughter you shall keep alive.'

Exodus 2

(6) [1] And a man of the house of Levi went and took a daughter

(7) of Levi. [2] And the \{woman $\}$ conceived, and bore a son.

(8) And she saw him that he was good, and she hid him three months.

(9) [3] And when she could no longer hide him, she took

(10) for him a chest of bulrushes, and daubed it with clay and with pitch,

(11) and put there the child, and she laid it among the reeds

(12) by the bank of Nile. [4] And his sister stood

(13) far off, to know what would be done to him. [5] And

(14) the daughter of Pharaoh came down to the Nile to wash herself, and her

(15) maidens walked along by the river's side. And she saw

(16) the chest among the reeds, she sent

(17) her maidservant, and she took it. [6] And she opened it, and

(18) she saw the child: and, lo, the child wept. And she took pity

(19) on him, and said, "This is one of the children

(20) of the Hebrews.' [7] Then his sister said

(21) to Pharaoh's daughter, 'Shall I go and call to you a nurse

(1) of the Hebrew women, that she may nurse

(2) the child for you?' [8] And Pharaoh's daughter said to her,

(3) 'Go.' And the girl went and called the child's mother.

(4) [9] And Pharaoh's daughter said to her, 'Take

(5) this child away, and nurse it for me, and 
(6) men berirmen ošol jalyjny da aldy ol qatyn ol ulanny da

(7) ömüzdürdü any. [10] Da ulgajdy ol ulan da

(8) keltirdi any qyzyna par'onun da boldu anar uvul or-

(9) nuna da atady anasy atyn anyn Moše da ajtty ki ol

(10) suvlardan tartty[m] $]^{1}$ any. [11] Da edi ol köp künler-

(11) de da ulġajdy Moše da čyqty qaryndašlaryna da kördü

(12) jüklerin alarnyn da kördü ki Micrili kiši vatyredi Jisra’el

(13) kišini qaryndašlaryndan. ויפן [12] Da qajyr\{y\}ldy bujary da

(14) bujary da kördü ki joḥtu kišída da öltürdü ošol

(15) ol Micrilini da kömdü any qumičine. [13] Da

(16) čyqty ol ekinči künd́a da muna eki $\left\{J_{i s r a} e^{\prime}\right\}^{2}$ erenlar uru-

(17) šadylar da ajtty raša ğa ne vatasen dostujnu.

(18) Da ajtty kim qojdu seni ag̉araq kišige da töreči üstü-

(19) müzǵa öltürmemo menid́a sen ajt[a] $\operatorname{sen}^{3}$ ki nečik öltür-

(20) düj ošol ol Micrilini da qorqtu Moše da ajtty kerti-

(21) den bilindi ol iš. וישמע [15] Da ešitti paro

$89 \mathrm{r}^{\mathrm{o}} \quad$ (1) ošol ol išni ošpunu da kledi öltürma Mošeni da

(2) qačty Moše alnyndan da olturdu jerind́a Midjannyn

(3) da olturdu ol quju üstüne. ולכהן. [16] Da qara tonlu-

(4) suna Midjannyn edi jedi qyzlar da keldilar da süzdülar

(5) da tolturdular ošol ol korytalarny ičirma ošol qojun

(6) atasynyn özlerinin. ויבואו [17] Da keldilar ol kütüvčü-

(7) ler da sürdüler alarny da turdu Moše da qutqardy alarny

(8) da ičirdi ošol qojnu alarnyn. ותבאנה [18 Da keldilar

(9) Ru'u'elǵa atasyna özlerinin da ajtty neüčün క̌aḥtla-

(10) dyjyz kelḿa bügün. [19 Da ajttylar

(11) Micrili kiši qutqardy bizni qolundan ol kütüvčülernin

(12) da dağyn süzḿa süzdü bizǵa da ičirdi ošol ol

(13) qojnu. [20] Da ajtty qyzlaryna da qajdady

(14) nek bu kemištijiz ošol ol kišini ündejiz any da aša-

(15) syn ötmek. [יואל [21] Da küvünlendi Moše oltur-

(16) ma ol kišiqatyna da berdi ošol Ciporany qyzy ö-

(17) zünün Mošeǵa. ותלד. [22] Da töredi uvul da atady

(18) Moše ošol atyn anyn Geršom ki ajtty garip boldum jat

(19) jerd́a. ויהי [23] Da ol köp künlerd́a öldü biji

\footnotetext{
${ }^{1} \mathrm{~K}$ : tarttyj; a scribal error. | TKow.o1: tarttyj. | H: tarttym. | C: tartyp aldym. $\quad{ }^{2}$ Marginal insertion by another hand. | TKow.o1: Jisra'eller. | H: Jisra'el. | C: Jisra'el. ${ }^{3} \mathrm{~K}$ : ajtsen; a scribal error. | TKow.o1: ajtasen. | H: sajys etesen. | C: ajtajdyrsen.
} 
(6) I will give you your wages.' And the woman took the child, and

(7) nursed it. [10] And the child grew, and

(8) she brought him to Pharaoh's daughter, and he became as her son.

(9) And she called his name Moses. And she said, 'Because

(10) $[\mathrm{I}]^{79}$ drew him out of the water.' [11] And it was in those many days,

(11) and Moses had grown up, and he went out to his brothers and looked

(12) on their burdens. And he saw that an Egyptian was smiting a Hebrew,

(13) one of his brothers. [12] And he shifted this way and

(14) that way, and he saw that there was no man, and he killed the

(15) Egyptian, and buried him in the sand. [13] And

(16) when he went out the second day, lo, two $\{$ Hebrew $\}$ men fought

(17) with each other. And he said to him that was guilty, 'Why do you strike

(18) your fellow?' [14] And he said, 'Who made you a superior and a judge over us?

(19) Are you saying you would kill me, too, the way you killed

(20) the Egyptian?' And Moses was afraid, and said,

(21) 'This thing is known for sure.' [15] And Pharaoh heard

(1) this thing, and he wanted to slay Moses. But

(2) Moses fled from before Pharaoh, and dwelt in the land of Midian.

(3) And he sat down by a well. [16] And the priest

(4) of Midian had seven daughters, and they came and drew water,

(5) and filled the gutter to water their

(6) father's flock. [17] And the shepherds came

(7) and drove them away, but Moses stood up and helped them,

(8) and watered their flock. [18] And they came

(9) to Reuel, their father, he said, 'How is it that you have hurried

(10) to come today?' [19] And they said,

(11) 'An Egyptian delivered us out of the hand of the shepherds,

(12) and he even drew water for us and watered the

(13) flock.' [20] And he said to his daughters, 'And where is he?

(14) Why is this that you have left the man? Call him, and

(15) he shall eat bread.' [21] And Moses decided to dwell

(16) with the man. And he gave Moses Zipporah, his daughter.

(17) [22] And she bore him a son, and Moses called

(18) his name Gershom, for he said, 'I have been a stranger in a foreign

(19) land.' [23] And during those many days the king

79 K: you; a scribal error. | Heb. מִשְׁיתִהו 'I drew him'. 
(20) Micrinin da küstündülar uvullary Jisra’elnin ol qulluqtan

(21) da firjat ettilar da kötürüldü firjatlary alarnyn

$89 v^{0} \quad$ (1) alnyna ol Tenrinin ol qulluqtan. [ישמע. [24] Da ešitti Ten-

(2) ri ošol firjatlaryn alarnyn da saġyndy Tenri ošol šertin ki

(3) kesti Avraham byla Jichaq byla da Ja'aqov byla. וירא. [25] Da kör-

(4) dü Tenri ošol ulanlaryn Jisra’elnin da süvdü Tenri.

Exodus 3

[1] [1] [ומשה

(5) Da Moše küteredi ošol qojun Jitronun qajnatasynyn qara ton-

(6) lusunun Midjannyn da könderdi ošol ol qojnu ol midbar

(7) artyna da \{keldi\} tavyna ol Tenrinin Horevǵa. [2] Da

(8) aškara boldu malahy Adonajnyn anar ortasynda otnun or-

(9) tasyndan ol tegeneknin da kördü da muna ol tegenek

(10) janady otta da ol tegenek örtenmejdi. ויאמר [3]

(11) Da ajtty Moše qajyrylajym endi da körejim ošol ol

(12) ullu körümnü ošpunu neüčün janmajdy ol tegenek.

(13) וירא [4] Da kördü Adonaj ki qajyryldy baqma da čaġyrdy

(14) anar Tenri ortasyndan ol tegeneknin da ajtty Moše

(15) Moše da ajtty munadyr men. ויאמר [5] Da ajtty

(16) Tenri juvumaġyn beri češkin ${ }_{\perp}\langle$ etigijni ajaġy $\rangle\{[$ e]tiklerijni [a]jaqlaryj\} üstünden ${ }^{11}$

(17) ki ol orun ki sen turasen anyn üstüne aziz jerdi ol.

(18) יויאמר Da ajtty menmen Tenrisi atajnyn Tenrisi Avra-

(19) hamnyn Tenrisi Jicḥaqnyn da Tenrisi Jacaqovnun da qaplady Moše

(20) jüzlerin ki qorqtu baqmaqtan ol šehina üstüne. ויאמר. [7]

(21) Da ajtty Adonaj körḿa kördüm ošol qyjynyn ulusumnun

9o ${ }^{\circ}$ (1) ki Micrid́a da ošol firjatlaryn ešittim alnyndan qystav-

(2) čularynyn ki bildim ošol syzlavlaryn anyn. [8 [8a Da

(3) endi bujrugum menim qutqarma any qolundan Micrinin da

(4) čyg̉arma any ol jerd́an jahšyraq jerge da avlaq jerge ag̉ado-

(5) gan süt da bal ornuna ol Kena'aninin da ol Ḥitinin da ol

(6) Emorinin da ol Perizinin da ol Ḥivinin da ol Jevusinin.

(7) (9] Da haligine muna firjaty ulanlarynyn Jisra’elnin kel-

(8) di alnyma da dag்yn kördüm ošol ol qysyqlyqny ki Micri-

${ }^{1}$ TKow.o1: etiklerijni ajaqlaryj. | H: etiklerinni ajaqlaryn istinden. | C: etiklärinni üstündän ajaqlaryynyy. 
(20) of Egypt died, and the children of Israel sighed from the captivity,

(21) and they cried, and their cry came up

(1) before God by reason from the captivity. [24] And God heard

(2) their groaning, and God remembered his covenant

(3) with Abraham, with Isaac, and with Jacob. [25] And

(4) God saw the children of Israel, and God loved.

Exodus 3

(5) And Moses pastured the flock of Jethro, his father-in-law, the priest

(6) of Midian. And he led the flock behind the wilderness,

(7) and came to the mountain of God, to Horeb. [2] And

(8) the angel of the Lord appeared to him in the midst of fire

(9) out of the midst of the blackthorn. And he looked, and, lo, the blackthorn

(10) burned with fire, and the blackthorn was not consumed. [3]

(11) And Moses said, 'Let me now turn aside, and see this

(12) great sight, why the blackthorn is not burnt.'

(13) [4] And the Lord saw that he turned aside to look at, and

(14) God called to him out of the midst of the blackthorn, and said, 'Moses,

(15) Moses.' And he said, 'Lo, am I here.' [5] And

(16) God said, 'Do not come near here. Take off your shoes from your feet,

(17) because the place on which you stand is holy ground.'

(18) [6] And He said, 'I am the God of your father, the God

(19) of Abraham, the God of Isaac, and the God of Jacob.' And Moses hid

(20) his face, because he was afraid to look on the divine Presence. [7]

(21) And the Lord said, 'I have surely seen the affliction of my people

(1) who are in Egypt, and have heard their cry in front of

(2) of their oppressors, because I learned their sorrows. [8] And

(3) my command has come down to rescue them from the hand of the Egypt, and

(4) to bring them up from that land to a better land and widespread land flowing

(5) |with $\mid$ milk and honey, to the place of the Canaanites, and the Hittites, and the

(6) Amorites, and the Perizzites, and the Hivites, and the Jebusites.

(7) [9] And now, lo, the cry of the children of Israel has come

(8) before me, and also I have seen the oppression with which 
(9) liler qysyqlyq etedilar alarg̉a. [10] Da haligine kel

(10) da ijejim seni par'og̉a da čyğarğyn ošol ulusumnu u-

(11) long] Da ajtty Moše

(12) ol Tenrige kimmen men ki barğajmen par'og̉a da ki čyġar-

(13) gajmen ošol ulanlaryn Jisra’elnin Micriden. [יאמר [12] Da

(14) ajtty Tenri ki bolur bolušlugium birgeje da budu saja

(15) ol belgi ki men ijemen seni čyġarg̉anyjda ošol ol ulusnu Mic-

(16) riden qulluq etersiz ol Tenrige ol tav üstüne

(17) ošpu. ויאמר [13] Da ajtty Moše ol Tenriǵa muna

(18) men kelśam ulanlaryna Jisra’elnin da ajtsam alarg̉a Tenrisi

(19) atalaryjyznyn ijdi meni sizge da ajtsalar maja nedi aty anyn

(20) ne ajtyrmen alarg̉a. ויאמר [14 Da ajtty Tenri Moše-

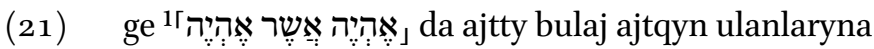

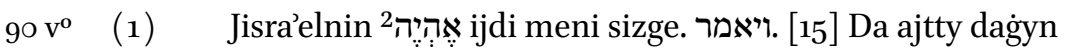

(2) Tenri Mošege bulaj ajtqyn ulanlaryna Jisra'elnin Adonaj Tenri-

(3) si atalaryjyznyn Tenrisi Avraham[nyn $]^{3}$ Tenrisi Jichaqnyn da Tenrisi

(4) Ja'aqovnun ijdi meni sizǵa budur atym menim dunjag̉adejin

(5) da budur sağynčym menim har bir dorg̉a. לך. [16] Barg̉yn da

(6) jyštyrğyn ošol bar qartlaryn Jisra’elnin da ajtqyn alarg̉a

(7) šehinasy Adonaj Tenrisinin atalaryjyznyn aškara boldu maja

(8) Tenrisi Avrahamnyn Jicḥaqnyn da Jacaqovnun ajtadog̉ač sag̉ynma

(9) saġyndym sizni da ošol ol qylynġanny sizge Micrida.

(10) ואמר [17] Da ajttym čyğarajym sizni qyjynyndan Micrinin

(11) jerińa ol Kenáaninin da ol Hitinin da ol Emorinin da ol

(12) Perizinin da ol Ḥivinin da ol Jevusinin jerǵa ag̉adog̉an süt

(13) da bal. ושמעו [18] Da tynlarlar sözlerijni da kelgin sen da

(14) qartlary Jisra’elnin bijine Micrinin da ajtyjyz anar Adonaj

(15) Tenrisi ol Jisra’ellernin uč\{r\}aldy üstümüzǵa da hali-

(16) gine barajyq endi jol üč künlük midbarda da debeḥa

(17) etejik Adonajġa Tenrimizǵa. ואני [19] Da men bilemen ki

(18) erk bermesti sizge biji Micrinin barma da tüvül küč-

(19) lü qolbylada. [20] Da sunarmen ošol hyššymym-

(20) ny da karatetermen ošol Micrini bar tamašalyqlarymbyla ki

(21) ונתתי [21]

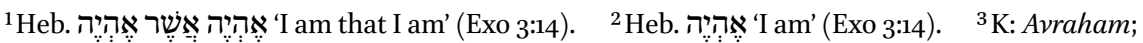
a scribal error; cf., e.g., Exo 3:16. | TKow.o1: Avrahamnyn. | H: Avrahamnyn. | C: Avrahamnyy.
} 
(9) the Egyptians oppress them. [10] And now come,

(10) and I will send you to Pharaoh, and bring out my people,

(11) the children of Israel from Egypt.' [11] And Moses said

(12) to God, 'Who am I that I should go to Pharaoh and that

(13) I should bring out the children of Israel from Egypt?' [12] And

(14) God said, 'Because my help will be with you, and this

(15) is a sign for you that I am sending you. When you will bring out the people

(16) from Egypt, you will serve God on this mountain.'

(17) [13] And Moses said to God, 'Lo,

(18) if I come to the children of Israel and say to them, "The God

(19) of your fathers has sent me to you," and if they say to me, "What is his name?",

(20) what will I say to them?' [14] And God said to Moses,

(21) 'I am who I am,' and He said, 'Thus shall you say to the children

(1) of Israel, "I Am has sent me to you."' [15] And God said moreover

(2) to Moses, "Thus you shall say to the children of Israel, "The Lord God

(3) of your fathers, the God [of] Abraham, the God of Isaac, and the God

(4) of Jacob, has sent me to you." This is my name forever,

(5) and this is my memorial to every single generation. [16] Go, and

(6) gather the elders of Israel together, and say to them,

(7) "The divine Presence of the Lord God of your fathers appeared to me,

(8) the God of Abraham, of Isaac, and of Jacob, saying, "I have surely remembered

(9) you and what has been done to you in Egypt.

(10) [17] And I have said let me bring you out from the affliction of Egypt

(11) to the land of the Canaanites and the Hittites and the Amorites and the

(12) Perizzites and the Hivites and the Jebusites, to a land flowing

(13) |with $\mid$ milk and honey." " [18] And they will listen to your voice, and you shall come, you and

(14) the elders of Israel, to the king of Egypt, and you shall say to him, "The Lord

(15) God of the Hebrews has met with us. And now

(16) let us go a three days' journey in the wilderness and let us

(17) offer a sacrifice to the Lord our God." [19] But I know that

(18) the king of Egypt will not empower you to go,

(19) and not by a mighty hand. [20] And I will reach out my wrath,

(20) and punish Egypt with all my wonders which

(21) I will do in the midst of it, and after that he will let you go. [21] 
$91 \mathrm{r}^{\mathrm{o}} \quad$ (1) Da berirmen ošol širinligin ol ulusnun ošpu közlerin-

(2) de Micrinin da bolġaj ki barasiz barmassiz boš. ושאלה [22]

(3) Da ötkünč alyr qatyn qonšusundan da tirilüvčüsün-

(4) den üvünün kümüš savutlar da altyn savutlar da up\{r\}aqlar

(5) da qojarsiz uvullaryjyz üstüne da qyzlaryjyz üstüne

(6) da tonarsiz ošol Micrini.

Exodus 4

(7) da ajtty da muna inanmaslar maja da tynlamaslar sözü-

(8) me ki ajtsalar aškara bolmady saja šehinasy Adonaj-

(9) nyn. ויאמר Da ajtty anar Adonaj nedir bu qolujda

(10) da ajtty tajaqty. [3] Da ajtty tašlağyn any

(11) jerge da tašlady any jerge da boldu jylanġa da qačty

(12) Moše alnyndan anyn. [יאמר [4 Da ajtty Adonaj Moše-

(13) ge sungiun qolujnu da tutqun qujrugiendan anyn da sundu

(14) qolun da tuttu any da boldu tajaqqa uvučunda anyn.

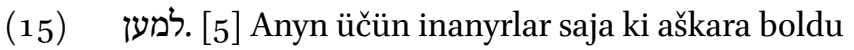

(16) saja šehinasy Adonajnyn Tenrisinin atalaryjnyn Tenrisi Av-

(17) rahamnyn Tenrisi Jichaqnyn da Tenrisi Jacaqovnun. ויאמר [6]

(18) Da ajtty anar Adonaj daġyn kijirgin qolujnu qojnuja da

(19) kijirdi qolun qojnuna da čyġardy any da muna boldu qolu

(20) anyn cara'atly qarkibik. [7] Da ajtty qajtarg̉yn

(21) qolujnu qojnuja da qajtardy qolun qojnuna da čyğardy any

$91 \mathrm{~V}^{\mathrm{o}} \quad$ (1) qojnundan da muna qajtty boldu gufukibik. [8] Da

(2) bolgaj eger inanmaslar saja da tynlamaslar sözüne ol burun-

(3) g̀ belginin da inanyrlar sözüne ol sondrag̀y belginin.

(4) והיה Da bolġaj eger inanmaslar dag்yn eksid́a ol bel-

(5) gilerge ošpularğa da tynlamaslar sözüja da alġyn suvla-

(6) ryndan ol Nilnin tökkün ol qurugian jer üstüne da 
(1) And I will put the favour of these people in Egypt's eyes, $91 \mathrm{r}^{\mathrm{o}}$

(2) and it shall be that when you go, you will not go empty. [22]

(3) And every woman shall take a loan from her neighbour, and of anyone who lives

(4) in her house: silver vessels, and golden vessels, and clothing.

(5) And you will put them on your sons, and on your daughters,

(6) and you will plunder Egypt.'

\section{Exodus 4}

\section{[1] And Moses answered}

(7) and said, 'But, lo, they will not believe me and will not listen to my word,

(8) because they will say, "The divine Presence of Lord has not appeared to you."'

(9) [2] And the Lord said to him, 'What is that in your hand?'

(10) And he said, 'A staff.' [3] And he said, 'Throw it

(11) on the ground.' And he threw it on the ground, and it became a serpent, and

(12) Moses fled from before it. [4] And the Lord said to Moses,

(13) 'Reach out your hand and take it by the tail.' And he reached out

(14) his hand and caught it, and it became a staff in his hand.

(15) [5] 'So that they will believe that

(16) the divine Presence of Lord God of their fathers, the God

(17) of Abraham, the God of Isaac, and the God of Jacob, has appeared to you.' [6]

(18) And the Lord said furthermore to him, 'Put now your hand into your bosom.' And

(19) he put his hand into his bosom, and he took it out, lo, his hand became

(20) leprous like snow. [7] And he said,

(21) 'Put your hand back into your bosom.' And he put his hand back into his bosom. And he took it out

(1) from his bosom, and, lo, it had gone back like its flesh. [8] 'And

(2) it shall be, if they do not believe you, neither listen to the word of the first

(3) sign, that they will believe the word of the latter sign.

(4) [9] And it shall be, if they also do not believe in these two

(5) signs and will not listen to your word: and you shall take

(6) of the water of the Nile, and pour it on the dry ground. And 
(7) bolurlar ol suvlar ki alsaj ol Nild́an da bolurlar qanġa quru-

(8) da. dio] Da ajtty Moše Adonajgia qoltqabyla e

(9) Adonaj tüvülmen sözler jesisi men daġyn tüneden daġyn biri

(10) künden dağyn sözlegen vaḥtyjdan qoluja ki avur sözlü da

(11) avur tillidir men. [יאמר Da ajtty Adonaj anar

(12) kim qojdu avuz adamġa jemese kim qojdu tilsizni

(13) jemese kim qojdu sandravnu ${ }^{1}{ }_{L}\{[$ jemes $]$ e ačyq közlü $[$ nü jeme $] s e$ soqurnu $\}^{12}$ muna men tüvülmo Adonaj.

(14) [12] Da haligine bargyn da men bolurmen avzujqaty-

(15) na da üvretirmen saja ošol neki sözlegejsen. ויאמר [13]

(16) Da ajtty qoltqabyla e Adonaj ijgin endi qolu ašyra

(17) kimnin de ijsej. [יחר] [14] Da qabundu ačuvu Adonajnyn Moše-

(18) üstüne da ajtty muna Aharon \{qaryndašyj\} ol Levili bilemen ki sözle-

(19) me sözler ol da dag்yn muna čyğar uturuja da körer

(20) seni da bijenir kölnünde. ודברת [15] Da sözlegin anar da

(21) qojğun ošol ol sözlerni avzuna anyn da men bolurmen avzuj-

$92 \mathrm{r}^{\mathrm{o}} \quad$ (1) qatyna da avzuqatyna anyn da üvretirmen sizǵa ošol

(2) neki qylgiajsiz. ודברת [16] Da sözler ol senin üčün ol

(3) ulusqa da bolġaj ol bolur saja avuz ornuna da sen bo-

(4) lursen anar malah ornuna. [17] Da ošol ol tajaqny L $\{\text { ol ošpu }\}^{14}$

(5) alg̀yn \{[qo]luja $\}^{5}$ ki qylarsen anyn byla ošol ol belgilerni. וילך. [18] Da

(6) bardy Moše da qajtty Jitr\{o\}g gaja qajnasyna da ajtty anar

(7) barajym endi da qajtajym qaryndašlaryma ki Micrid́a da

(8) bag̉ajym hanuzmo alar tiridiler da ajtty \{Jitro\} Mošege barg̉yn

(9) savluqbyla. יויאמר] Da ajtty H Mošege Midjanda

(10) barġyn qajtqyn Micriǵa ki öldülar bar ol erenler ol

(11) izlevčüler alma ošol žanyjny. [20] Da aldy Moše

(12) ošol qatynyn da ošol ulanlaryn da atlanġyzdyrdy alarny ol

(13) eš $[e] k^{6}$ üstüne da qajtty jerine Micrinin da aldy

(14) Moše ošol tajağyn ol Tenrinin qoluna. ויאמר [21 Da

(15) ajtty Adonaj Mošege barg̉anyjda qajtma Micriǵa kör-

(16) gün bar ol nišanlarny ki qojdum qoluja da qylġyn alarny

\footnotetext{
${ }^{1} \mathrm{~K}$ : sandaravnu; probably a scribal error, see Lev 19:14. | TKow.o1: probably sandravny; text unvocalized.|H:sandravny.|C: sayrov. $\quad{ }^{2}$ Marginal insertion by another hand.|TKow.o1: jemese ačyq közlünü jemese soqurnu; text unvocalized. | H: jemese acyq közlünü jemese soqurnu. | C: ya

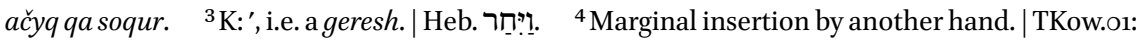
ošpunu; unvocalized text.|H: ol ospu.|C: deest. ${ }^{5}$ TKow.o1: qoluja; unvocalized text.| H: qoluna. | C: qoluya. $\quad{ }^{6} \mathrm{~K}$ : ešik; a scribal error. | TKow.o1: unvocalized text. | H: esek. | C: ešäk.
} 
(7) it will be the water which you take from the Nile, and it will become blood on the dry

(8) ground.' [10] And Moses said to the Lord, 'I pray you, oh

(9) Lord, I am not a man of words. Neither formerly nor

(10) the day before nor since the time you spoke to Your servant. Because I am heavy of speech and

(11) of a heavy of tongue.' [11] And the Lord said to him,

(12) 'Who set a mouth for man? Or who set the dumb,

(13) or who set the deaf, $\{[$ or $]$ the seeing, [or $]$ the blind? $\}$ Lo, have not I the Lord?

(14) [12] And now go, and I will be with be with your mouth,

(15) and I will teach you what you shall say.' [13]

(16) And he said, 'Oh my Lord, I pray you, send now by the hand

(17) of whom you will send.' [14] And the anger of the Lord was kindled against Moses,

(18) and he said, 'Lo, there is Aaron, the Levite, your brother. I know that he surely

(19) speaks well. And also, lo, he comes forth to meet you, and he will see

(20) you, and he will be glad in his heart. [15] And you shall speak to him, and

(21) put the words in his mouth, and I will be with your mouth,

(1) and with his mouth, and I will teach you what

(2) you shall do. [16] And he shall speak for you

(3) to the people. And it shall be that he will be for you instead of a mouth, and you

(4) will be for him instead of an angel. [17] And you shall take $\{$ this $\}$ staff

(5) in your hand, with which you will do the signs.' [18] And

(6) Moses went. And he returned to Jethro, his father-in-law, and said to him,

(7) 'Let me go now, and let me return to my brothers who are in Egypt and

(8) see whether they are still alive.' And Jethro said to Moses, 'Go

(9) in health.' [19] And the LORD said to Moses in Midian,

(10) 'Go, return to Egypt, because all the men

(11) who sought to take your life have died.' [20] And Moses took

(12) his wife and his children, and set them

(13) on a donkey, and he returned to the land of Egypt. And Moses took

(14) the staff of God in his hand. [21] And

(15) the Lord said to Moses, 'When you go to return to Egypt, see

(16) all those signs that I have put in your hand and do them 
(17) alnynda par'onun da men qattyryrmen ošol jüregin anyn

(18) da ijmesti ošol ol ulusnu. ואמרת. [22] Da ajtqyn

(19) par'og̉a ${ }_{L}\{\text { bulaj ajtty } H\}^{11}$ tunguuč uvlumdu Jisra’el. ואמר. [23] Da ajt-

(20) tym saja ijgin ošol uvlumnu da qulluq etsin maja

(21) da klemejdesej ijme any muna men öltürürmen ošol

$92 \mathrm{v}^{\mathrm{o}}$ (1) tunġuč uvlujnu. [24] Da edi jolda qonarlyqta da

(2) hastalatty any Adonaj da kledi öltürme any. [25]

(3) Da aldy Cipora jülüvüč da kesti ošol aqlafyn uvlunun

(4) da tijirdi ajaqlaryna anyn da ajtty ki janġyrmaġy qan-

(5) larnyn sen maja. [26] Da ongaldy andan ol vahtta

(6) ajtty janġyrmaġy qanlarnyn hatna qylynġanlarg̉a. [27]

(7) Da ajtty Adonaj Aharonġa barğyn uturusuna Mošenin ol

(8) midbarga da bardy da joluqtu any tavynda ol Tenrinin

(9) da öptü any. [28] Da anlatty Moše Aharonġa

(10) ošol bar sözlerni Adonajnyn ki ijdi any da ošol bar ol

(11) belgilerni ki bujurdu anar. [ילך] [29] Da bardy Moše da

(12) Aharon da jyštyrdylar ošol bar qartlaryn ulanlarynyn Jisra’el-

(13) nin. וידבר [30] Da sözledi Aharon ošol bar ol sözlerni ki

(14) sözledi Adonaj Mošege da qyldy ol belgilerni közleriče

(15) ol ulusnun. [יאמן Da inandy ol ulus da ešit-

(16) tiler ki saġyndy Adonaj ošol ulanlary Jisra’elnin da ki kör-

(17) dü ošol qyjynlaryn alarnyn da ijildiliar da bašurdular.

\section{Exodus 5}

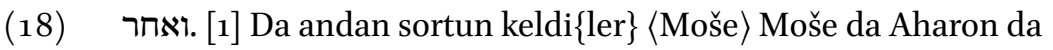

(19) ajttylar par'oga bulaj ajtty Adonaj Tenrisi Jisra’elnin

(20) ijgin ošol ulusumnu da hyy̌̌lasynlar maja midbarda.

(21) ויאמר (21 Da ajtty par'o kimdi Adonaj ki tynlag̉ajmen

$93 \mathrm{r}^{\circ} \quad$ (1) ününe anyn ijme Jisra’elni bilmejmen ošol Adonaj-

(2) ny da ošol Jisra’elnide ijmenmen. ויאמרו [3] Da

(3) ajttylar Tenrisi ol Jisra’ellernin ataldy üstümüz-

(4) ge barajyq endi üč künlük jol midbarda da debeḥa

(5) etejik Adonajgga Tenrimizge magat qyrar bizni ölet-

\footnotetext{
${ }^{1}$ Marginal insertion by another hand. | TKow.o1: bulajajtty Adonaj. | H: bulajajtty H. | C: bulajajtty $H$.
} 
(17) before Pharaoh. But I will harden his heart,

(18) and he will not let the people go. [22] And you shall say

(19) to Pharaoh, "\{Thus said the LORD\}, "Israel is my firstborn son. [23] And

(20) I said to you, "Let my son go, and he may serve me,

(21) And if you are not willing to let him go, lo, I will kill

(1) your firstborn son."” "' [24] And it was on the way at the place of overnight stay, and

(2) the Lord made him ill, and wanted to kill him. [25]

(3) And Zipporah took a razor and cut off her son's foreskin

(4) and touched his feet, and she said, 'Because you are a renewal of blood

(5) to me.' [26] And he recovered thanks to that. Then

(6) she said, 'A renewal of blood for those circumcised.' [27]

(7) And the Lord said to Aaron, 'Go to meet Moses to the

(8) wilderness.' And he went and met him in the Mountain of God,

(9) and he kissed him. [28] And Moses told Aaron

(10) all the words of the Lord that he had sent him and all the

(11) signs which he had commanded him. [29] And Moses and

(12) Aaron went and gathered all the elders of the children of Israel.

(13) [30] And Aaron spoke all the words which

(14) the Lord had spoken to Moses, and did the signs in the sight

(15) of the people. [31] And the people believed, and they heard

(16) that the Lord remembered the children of Israel, and that he had seen

(17) their affliction, and they bowed down and worshiped.

Exodus 5

(18) And afterward Moses and Aaron came, and

(19) told Pharaoh, "Thus says the Lord God of Israel,

(20) "Let my people go, that they may hold a feast to me in the wilderness."'

(21) [2] And Pharaoh said, 'Who is the Lord that I should obey

(1) his voice to let Israel go? I do not know the Lord,

(2) and I will not let Israel go.' [3] And

(3) they said, 'The God of the Hebrews fell on us.

(4) Let us go now three days' journey in the wilderness, and let us do sacrifice

(5) to the Lord our God, lest he kills us with pestilence or 
(6) byla jemese qylyč byla. ויאמר [4] Da ajtty alarg̉a

(7) \{biji\} Micrinin nek Moše da Aharon osallatasiz ošol ol ulus-

(8) nu išlerind́an anyn baryjyz jüklerijizǵa. ויאמר [5a

(9) ajtty par'o muna köptüler haligine ulusun ol

(10) jernin da ullu izjan išlejsiz ki qaldyrasiz alarny jüklerin-

(11) den alarnyn. ויצו [6] Da bujurdu par'o ol künde

(12) ol qystavčularg̉a ulusun da tajaqčylaryna anyn aj-

(13) tadoġač. לא. [7] Arttyrmajyz berme bičen ulus-

(14) qa kirpičleme ol kirpičlerni tünelej biri künlej alar

(15) barsynlar özleri da čöplesinler özlerińa bičen.

(16) ואת [8 Da ošol qyjasyn ol kirpičlernin ki alar qyla-

(17) dylar tünelej biri künlej qojujuz alar üstüne ek-

(18) sitmejiz andan ki osallandylar alar anyn üčün alar

(19) firjat etedilar ajtadog̉ač barajyq debeḥa etejik Tenri-

(20) mizǵa. תכבד . [9] Avur bolsun ol qulluq ol erenlar

(21) üstüne ${ }_{L}\{\text { da qylsynlar any }\}^{11}$ da qajyrylmasynlar jalġan sözlerǵa. ויצאו. [10]

$93 \mathrm{v}^{\mathrm{o}} \quad$ (1) Da čyqtylar qystavčulary ol ulusnun da tajaqčylary anyn da aj-

(2) ttylar ol ulusqa ajtadog̉ač bulaj ajtty par'o bermenmen

(3) sizge bičen. אתם. [11] Siz baryjyz alyjyz özüjüzǵa bičen qaj-

(4) dan ki tapsajyz ki eksilmesti qullug̉ujuzdan nemed́a. ויפץ. [12]

(5) Da tozdurdu par'o ošol ol ulusnu bar jerind́a Micrinin

(6) čöpleme qura bičen ornuna. [13] Da ol qystav-

(7) čular žaḥtlaredilar ajtadog̉ač tügellejiz išlerijizni kemin kün-

(8) nün kününde ki nečik bolġanda ol bičen. ויכו [14] Da vatyl-

(9) dylar tajaqčylar ulanlarynyn Jisra’elnin ki qojdular alar üstüne

(10) qystavčulary par'onun ajtadoġač neüčün tügenlemedijiz re-

(11) simijizni kirpičleme tünelej biri künlej daġyn tünegün dag்yn

(12) bügün. ויבואו [15] Da keldilar tajaqčylar ulanlarynyn Jisra’el-

(13) nin da firjat ettiler par'og̉a ajtadog̉ač nek qylasen bulaj

(14) qullaryja. תבן [16] Bičen berilmejdi qullaryja da kirpič-

(15) lerni ajtadylar bizǵa qylyjyz da muna qullaryj vatyldylar

(16) da jazyqly boldu ulusuj. Da ajtty osallanasiz

(17) siz osallanasiz anyn üčün siz ajtasiz barajyq debeḥa etejik

(18) Adonajğa. ועתה [18] Da haligine baryjyz qulluq etijiz da

(19) bičen berilmesin sizge da q[y]jasyn ${ }^{2}$ kirpičlernin berijiz.

\footnotetext{
${ }^{1}$ Marginal insertion by another hand. | TKow.o1: da qylsynlar any; unvocalized tex. | H: da qylsynlar any. | C: da qylsynlar alarny. $\quad{ }^{2} \mathrm{~K}$ : qajasyn; a scribal error, cf. Exo 5:8. | TKow.o1: unvocalized text. | H: qyjasyn. | C: qyjasyn.
} 
(6) with the sword.' [4] But the king of Egypt said to them,

(7) 'Why do you, Moses and Aaron, make the people shirk

(8) from their work? Go to your burdens.' [5] And

(9) Pharaoh said, 'Lo, the people of the land now are many,

(10) and you make a great mischief that you make them cease away from their burdens.'

(11) [6] And Pharaoh commanded the same day

(12) the oppressors of the people and their overseers,

(13) saying, [7] 'You shall no more give the people hay

(14) to make brick, as in the past. Let them

(15) go themselves and gather hay for themselves.

(16) [8] And the number of bricks, which they made

(17) in the past you shall lay on them.

(18) You shall not reduce it. Because they are idle. Therefore they

(19) cry, saying, "Let us go and do sacrifice to our God."

(20) [9] Let the service be heavy on the men,

(21) \{and they shall do it\}, and they shall not turn to lying words.' [10]

(1) And the oppressors of the people and their overseers went out, and $93 \mathrm{v}^{\mathrm{o}}$

(2) they said to the people, saying, 'Thus says Pharaoh, "I will not give

(3) you hay. [11] Go, get yourselves hay

(4) where you can find it, because nothing of your work shall be reduced."' [12]

(5) So Pharaoh scattered the people throughout all the land of Egypt

(6) to gather straw instead of hay. [13] And the oppressors

(7) urged them, saying, 'Complete your works every day,

(8) as when there was hay' [14] And

(9) the overseers of the children of Israel that Pharaoh's

(10) oppressors had set over them were beaten, saying, 'Why have you not fulfilled

(11) your orders to make brick like in the past, also yesterday, also

(12) today?' [15] Then the overseers of the children of Israel came

(13) and cried to Pharaoh, saying, 'Why do you do [a thing] like this

(14) to your servants? [16] No hay is given to your servants, and

(15) they say to us, "Make bricks!". And, lo, your servants are beaten,

(16) and the fault is in your own people.' [17] But he said, 'You are lazy,

(17) you are lazy! On account of this you say, "Let us go and do sacrifice

(18) to the Lord." [18] And go now, serve and

(19) there shall no hay be given to you, and shall you give the number of bricks.' 
(20) .יראו [19] Da kördüler tajaqčylary ulanlarynyn Jisra’elnin özle-

(21) rin jamanlyqta ajtadog̉ač eksitmejiz kirpičler[i]jizden ${ }^{1}$ kemin

$94 \mathrm{r}^{02}$ (1) künnün kününde. [20] Da joluqtular ošol Mošeni

(2) da ošol Aharonnu turg̉anlarny utrularyna alarnyn čyqqanlaryn-

(3) da alnyndan par'onun. [יאמרו Da ajttylar alarg̉a

(4) körgej Adonaj \{üstüj[üzge] $\}^{3}$ da töre etkej ki sasyttyjyz ošol ijisi-

(5) mizni közlerind́a par'onun da közlerind́a qullarynyn ber-

(6) me qylyč qoluna alarnyn öltürme bizni. וישב [22] Da

(7) qajtty Moše Adonajg̉a da ajtty e Adonaj nek jaman et-

(8) tij ošpu ulusqa nege bu ijdij meni. ומאז. [23] Da

(9) ol vaḥttan ki keldim $\left\{\text { par'og }^{\prime}\right\}^{4}$ sözleme šemijbyla jaman etti

(10) par'o ošpu ulusqa da qutqarma qutqarmadyj ošol

(11) ulusujnu.

Exodus 6

. ויאמר [1] Da ajtty Adonaj Mošeǵa

(12) haligine körersen neki qylarmen par`oġa ki küčlü qolbyla

(13) ijer alarny küčlü qolbyla sürer alarny jerind́an.

פרשת וארא (14) (15) (2)

(15) [2] Da sözledi Tenri

(16) Mošeǵa da ajtty anar menmen Adonaj.

(17) וארא [3] Da aškara boldu šehinam Avrahamġa Jichaq-

(18) qa da Jacaqovġa El Šadaj byla vale šemim byla Adonaj bilin-

(19) medim alarg̉a. וגם [4] Da dağyn qajjam ettim ošol

$94 \mathrm{~V}^{\circ} \quad$ (1) šertimni birgelerine berḿa alarg̉a ošol jerin Kenáannyn ošol

(2) tirilmüš jerlerin ki tirilediler anda. וגם. [5] Da dag̉yn men e-

(3) šittim ošol firjatyn ulanlarynyn Jisra’elnin ki Micrililer qul-

(4) luq ettirediler alarny da saġyndym ošol šertimni.

(5) לכן Anyn üčün ajtqyn ulanlaryna Jisra’elnin menmen Adonaj

${ }^{1} \mathrm{~K}$ : kirpičlerejizden; a scribal error. | TKow.o1: unvocalized text. | H: kirpiclerinizden. | C: kerpičlärinizdän. ${ }^{2} \mathrm{~K}$ : this sheet was skipped during numbering the folios by an archivist or the owner. ${ }^{3}$ TKow.or: üstüjüzge; unvocalized text. | H: siznin istine. | C: üstüyizgä. $\quad{ }^{4}$ Interlinear insertion by another hand. | TKow.o1: par'og a; unvocalized text. | H: par'óga. | C: par'óga. 
(20) [19] And the overseers of the children of Israel

(21) saw themselves in a bad $\mid$ state|, saying, 'You shall not reduce any from your bricks

(1) every day.' [20] And they met Moses

(2) and Aaron who were standing opposite them, as they came out

(3) from Pharaoh. [21] And they said to them,

(4) 'May the Lord look on you, and judge, that you have made us stink

(5) in the eyes of Pharaoh, and in the eyes of his servants, to give

(6) a sword in their hand to kill us.' [22] And

(7) Moses returned to the Lord, and said, 'Oh Lord, why have you done bad

(8) to this people? Why is this that you have sent me? [23] And

(9) since I came $\{$ to Pharaoh $\}$ to speak in your name, Pharaoh has done bad

(10) to this people, and you have surely not rescued

(11) your people.'

Exodus 6

(11) And the Lord said to Moses,

(12) 'Now you will see what I will do to Pharaoh, because with a strong hand

(13) he will let them go, and with a strong hand he will drive them out of his land.'

(14) Parashat Vaera

(15) [2] And God spoke

(16) to Moses, and said to him, 'I am the Lord.

(17) And I appeared to Abraham, to Isaac,

(18) and to Jacob by the name of God Almighty, and

(19) I was not known to them by my name: the Lord. [4] And I have also established

(1) my covenant with them, to give them the land of Canaan, the

(2) land of their sojourning, in which they lived. [5] And I have also

(3) heard the groaning of the children of Israel whom the Egyptians

(4) keep in slavery, and I have remembered my covenant.

(5) [6] Therefore, say to the children of Israel, I am the Lord,

8o In the manuscript this sheet was skipped during numbering the folios. 
(6) da čygaryrmen sizni jükleri tübünd́an Micrinin da qutqaryrmen

(7) sizni qulluqlaryndan alarnyn da julurmen sizni sunulgan quvatbyla

(8) da ullu karanjalarbyla. ולקחתי [7] Da alyrmen \{sizni\} ${ }^{1}$ özüme ulus-

(9) qa da bolurmen sizǵa Tenriǵa da bilirsiz ki menmen Adonaj

(10) Tenrijiz ol čyğaruvču sizni jükĺari \{tübün[d́an]\}² Micrinin. והבאתי [8]

(11) Da keltirirmen sizni ol jerǵa ki antettim ošol qudratym-

(12) dan berḿa any Avrahamġa da Jichaqqa da Ja'aqovġa da berir-

(13) men any sizge mereslik menmen Adonaj. וידבר. [9] Da sözledi

(14) Moše alaj ulanlaryna Jisra'elnin da tynlamadylar Mošege jadavyn-

(15) dan žannyn da qaty qulluqtan. וידבר [10] Da sözledi Adonaj

(16) Mošege ajtadoġač. בא. [11] Kelgin sözlegin \{parog̉a\} bijińa Micrinin

(17) da ijsin ulanlaryn Jisra’elnin jerind́an özünün. וידבר [12]

(18) Da sözledi Moše alnynda Adonajnyn ajtadoğač muna ulanlary

(19) Jisra’elnin tynlamadylar maja da nečik tynlar maja par'o da men

(20) aqlaf erinlimen. וידבר [13] Da sözledi Adonaj Mošeǵa da

(21) Aharonġa da sarydy alar ašyra ulanlaryna Jisra’elnin da

$95 \mathrm{r}^{\mathrm{r}} \quad$ (1) par'og̉a bijine Micrinin čyğarma ošol ulanlaryn Jisra’elnin jerin-

(2) den Micrinin. אלה [14] Bulardylar agaaraqlary üvünün atalary-

(3) nyn ulanlary Ru’uvennin tunġučunun Jisra’elnin Ḥanoh da Falu’

(4) da Hecron da Karmi bulardylar uruvlary Ru’uvennin. [15]

(5) Da ulanlary Šim`onnun Jemu’el da Jamin da Ohad da Jahin da

(6) Coḥar da Ša'ul uvlu ol Kena'anly qatynnyn bulardylar uruvlary

(7) Šimonnun. [16] Da bulardylar $\left\{\right.$ atlary $^{3}{ }^{3}$ ulanlarynyn Levinin tuvmušlary

(8) sajyn Geršon da Qahat da Merari da tirlik jyllary Levinin jüz da

(9) בני [17] Ulanlary Geršonnun Livni da Šim`i jedi jyl

(10) uruvlary sajyn. [18] Da ulanlary Qahatnyn 'Amram da

(11) Jichar da Ḥevron da 'Uzi'el da tirlik jyllary Qahatnyn jüz da

(12) otuz üč jyl. ובני [19] Da ulanlary Merarinin Maḥli da

\footnotetext{
${ }^{1}$ Marginal insertion by another hand. | TKow.o1: sizni; unvocalized text. | H: sizni. | C: sizni. ${ }^{2}$ TKow.or: tübünd́an; unvocalized text. | H: tibinden. | C: tibindän. $\quad{ }^{3}$ Marginal insertion by another hand. | TKow.o1: atlary; unvocalized text. | H: atlary. | C: atlary.
} 
(6) and I will bring you out from under the burdens of Egypt, and I will rescue

(7) you from their slavery, and I will redeem you with an outstretched arm,

(8) and with great punishments. [7] And I will take $\{y o u\}$ to me

(9) as a people, and I will become God to you, and you will know that I am the Lord

(10) your God, who brings you out from under the burdens of Egypt. [8]

(11) And I will bring you to the land that I swore with my hand

(12) to give it to Abraham, and to Isaac, and to Jacob. And I will give

(13) it to you for a heritage: I am the Lord.' [9] And Moses spoke

(14) so to the children of Israel, and they did not listen to Moses

(15) because of tiredness of spirit, and because of harsh slavery. [10] And the Lord spoke

(16) to Moses, saying, [11] 'Come, speak to Pharaoh, king of Egypt,

(17) that he should let the children of Israel go out of his land.' [12]

(18) And Moses spoke before the Lord, saying, 'Lo, the children

(19) of Israel did not listen to me, and how will Pharaoh listen to me? And I

(20) am uncircumcised of lips!' [13] And the Lord spoke to Moses and

(21) to Aaron, and sent a message through them to the children of Israel and

(1) to Pharaoh, king of Egypt, to bring the children of Israel

(2) out of the land of Egypt. [14] These are the superiors of their fathers'

(3) houses: The sons of Reuben, the firstborn of Israel: Hanoch, and Pallu,

(4) and Hezron, and Carmi. These are the families of Reuben. [15]

(5) And the sons of Simeon: Jemuel, and Jamin, and Ohad, and Jachin, and

(6) Zohar, and Shaul the son of a Canaanite woman. These are the families

(7) of Simeon. [16] And these are the $\{$ names $\}$ of the sons of Levi according to their children:

(8) Gershon, and Kohath, and Merari. And the years of the life of Levi were a hundred

(9) and thirty-seven years. [17] The sons of Gershon: Libni, and Shimei,

(10) according to their families. [18] And the sons of Kohath: Amram, and

(11) Izhar, and Hebron, and Uzziel. And the years of the life of Kohath were a hundred and

(12) thirty-three years. [19] And the sons of Merari: Mahli and 
(13) Muši bulardylar uruvlary ol Levinin tuvmušlarysajyn. ויקח. [20]

(14) Da aldy 'Amram ošol Johevedni tötesin özüne qatynlyq-

(15) qa da töredi anar ošol Aharonnu da ošol Mošeni da

(16) tirlik jyllary 'Amramnyn jüz da otuz jedi jyl. ובני [21] Da

(17) ulanlary Jicharnyn Qorah da Nefeg da Zihrri. ובני [22] Da ulan-

(18) lary 'Uzi'elnin Miša’el da Elcafan da Sitri. [יקחי [23] Da aldy

(19) Aharon ošol Eliševa'ny qyzyn 'Aminadavnyn tuvdug̉un Naḥšonnun

(20) özüne qatynlyqqa da töredi anar ošol Nadavny da ošol

(21) Avihu'nu ošol El'azarny da ošol Itamarny. [בני [24]

$95 \mathrm{v}^{\circ}$ (1) Da ulanlary Qorahnnyn Asir da Elqana da Aviasaf bulardylar uruv-

(2) lary ol Qorahnyn. [25] Da Elicazar uvlu Aharonnun aldy

(3) özüne qyzlaryndan Puti'elnin özüne qatynlyqqa da töredi

(4) anar ošol Pinaḥasny bulardylar ag̉araqlary atalarynyn ol Levi-

(5) lernin uruvlary sajyn. הוא. [26] Oldu Aharon da Moše ki ajtty

(6) Adonaj alarg̉a čyğaryjyz ošol ulanlaryn Jisra’elnin jerind́an Micri-

(7) nin jyjynlarybyla. הם. 27] Alar edilar ol sözlevčüler

(8) par'oġa bijine Micrinin čyġarma ošol ulanlaryn Jisra’elnin

(9) Micridan oldu Moše da Aharon. ויהי [28] Da edi sözlegen

(10) künde Adonaj Mošege jerind́a Micrinin. וידבר. [29]

(11) Da sözledi Adonaj Mošege ajtadog̉ač menmen Adonaj sözlegin

(12) par'oğa bijine Micrinin ošol barča neki men sözlejmen saja.

(13) ויאמר (30] Da ajtty Moše alnynda Adonajnyn muna men

(14) beltek erinlimen da neče tynlar maja paro.

Exodus 7

(15) Da ajtty Adonaj Mošege kör berdim seni malah ornuna

(16) paroga da Aharon qaryndašyj bolur navij senin. אתה. [2]

(17) Sen sözlegin Aharonġa ošol barča neki bujursam saja da

(18) Aharon qaryndašyj sözlesin par'og̉a ki ijgej ošol ulanlaryn

(19) Jisra’elnin jerind́an. ואני [3] Da men qattyryrmen ošol jüregin

(20) par'onun da arttyryrmen ošol belgilerimni da ošol

(21) nišanlarymny jerind́a Micrinin. ולא [4] Da tynlamasty 
(13) Mushi. These are the families of Levi according to their children. [20]

(14) And Amram took Jochebed, his aunt, for a wife,

(15) and she bore him Aaron and Moses. And

(16) the years of the life of Amram were a hundred and thirty-seven years. [21] And

(17) the sons of Izhar: Korah, and Nepheg, and Zichri. [22] And the sons

(18) of Uzziel: Mishael, and Elzaphan, and Sithri. [23] And

(19) Aaron took him Elisheba, daughter of Amminadab, sister of Nahshon,

(20) for a wife, and she bore him Nadab, and

(21) Abihu, Eleazar, and Ithamar. [24]

(1) And the sons of Korah: Assir, and Elkanah, and Abiasaph. These are $\quad 95 \mathrm{v}^{\mathrm{o}}$ the families

(2) of Korah. [25] And Eleazar, Aaron's son, took

(3) him one of the daughters of Putiel for a wife, and she bore

(4) him Phinehas. These are the superiors of the fathers of the Levites

(5) according to their families. [26] That is Aaron and Moses, to whom

(6) the Lord said, 'Bring out the children of Israel from the land of Egypt

(7) by their hosts.' [27] These were the ones who spoke

(8) to Pharaoh, king of Egypt, to bring out the children of Israel

(9) from Egypt. That is Moses and Aaron. [28] And it was

(10) on the day when the Lord spoke to Moses in the land of Egypt: [29]

(11) The Lord spoke to Moses, saying, 'I am the Lord. Speak

(12) to Pharaoh, king of Egypt, all that I say to you.'

(13) [30] And Moses said before the Lord, 'Lo, I am

(14) of stuttering ${ }^{81}$ lips, and how will Pharaoh listen to me?'

\section{Exodus 7}

(15) And the Lord said to Moses, 'See, I have made you for an angel

(16) to Pharaoh, and Aaron your brother will be your prophet. [2]

(17) You shall speak to Aaron all that I command you. And

(18) Aaron your brother shall speak to Pharaoh, that he shall send the children

(19) of Israel from his land. [3] And I, I will harden Pharaoh's heart,

(20) and multiply my signs and

(21) my tokens in the land of Egypt. [4] But Pharaoh will not listen

81 Or: lisping. 
$96 \mathrm{r}^{\mathrm{o}} \quad$ (1) sizǵa paro da berirmen ošol hyyššymymny Micride

(2) da čyğaryrmen ošol jyjynlarymny ošol ulusumnu ulanlaryn

(3) Jisra'elnin \{[je]rinden $\}^{1}$ Micrinin ullu karanjalarbyla. וידעו [5] Da bilirler

(4) Micrililer ki men men Adonaj sunganymda ošol hyyššymym-

(5) ny Micri üstüne da čyġaryrmen ošol ulanlaryn Jisra’el-

(6) nin ortasyndan alarnyn. [יעש [6] Da qyldy Moše da Aharon ki

(7) nečik bujurdu Adonaj alarg̉a alaj qyldylar. ומשה [7 Da

(8) Moše seksen jašar edi da Aharon seksen üč jašar edi

(9) sözlegenlerind́a par'og̉a. [8] Da ajtty

(10) Adonaj Mošeǵa da Aharonġa ajtadoġač. כי. [9] Ki

(11) sözlese sizge par'o ajtadoġač berijiz özüjüzge nišan

(12) da ajtqyn Aharonġa alġyn ošol tajaġyjny da tašlag̉yn alnynda

(13) par'onun bolsun aždahag̉a. ויבוא. [10] Da keldi Moše da

(14) Aharon par'og̉a da qyldylar alaj ki nečik bujurdu Adonaj

(15) da tašlady Aharon ošol tajaġyn alnynda par'onun da alnyn-

(16) da qullarynyn da boldu aždahaġa. ויקרא Da ündedi

(17) daġyn par'o uslularny da žaduvluq etüvčülerni da qyl-

(18) dylar daġyn alar filosoflary Micrinin köz bavčuluqlarybyla

(19) alaj. וישליכו Da tašladylar kiši tajag̉yn özünün da bol-

(20) dular aždahalarg̉a da juttu tajag̉y Aharonnun ošol tajaqlaryn

(21) alarnyn. ויחז [13] Da qatty jüregi par'onun da tynlama-

96 vo (1) dy alarg̉a ki nečik sözledi Adonaj. [14] Da ajtty

(2) Adonaj Mošege qatty jüregi par'onun klemejdi ijme ol

(3) ulusnu. לך . 115] Barġyn parog̉a ertenbylada muna čyg̉ady

(4) ol suvlarg̉a da turg̉un uturusuna anyn qyryj üstü-

(5) ne ol Nilnin da ol tajaqny ki čüvürüldü jylanġa alġyn

(6) qoluja. ואמרת [16] Da ajtqyn anar Adonaj Tenrisi ol

(7) Jisra’ellernin ijdi meni saja ajtadoğač ijgin ošol ulusum-

(8) nu da qulluq etsinlar maja midbarda da muna tynlama-

(9) dyj bu vaḥtqadejin. כה. [17] Bulaj ajtty Adonaj bunun byla

(10) bilirsin ki menmen Adonaj muna men urarmen tajaqbyla ki qolum-

(11) da ol suvlarny ki Nild́a da čüvürülürlar qanġa.

(12) והדגה Da ol balyq ki Nild́a öler da sasyr ol Nil da

(13) jadarlar Micrililer ičme suv ol Nild́an. [יאמר Da

${ }^{1}$ TKow.o1: jerinden; unvocalized text. | H: jerinden. | C: jerindän. 
(1) to you, and I will set my wrath on Egypt,

(2) and bring out my hosts, my people, the children

(3) of Israel, from the land of Egypt with great punishments. [5] And the Egyptians will know

(4) that I am the Lord, when I reach out my wrath

(5) on Egypt, and I will bring out the children of Israel

(6) from among them.' [6] And Moses and Aaron did

(7) as the Lord commanded them. They did so. [7] And

(8) Moses was eighty years old, and Aaron eighty-three years old

(9) when they spoke to Pharaoh. [8] And the Lord said

(10) to Moses and to Aaron, saying, [9] 'If the Pharaoh speaks

(11) to you, saying, "Give yourself a token,"

(12) you shall say to Aaron, "Take your staff and cast it before

(13) Pharaoh, and it shall become a serpent."' [10] And Moses and Aaron came

(14) to Pharaoh, and they did so as the Lord had commanded,

(15) and Aaron cast down his staff before Pharaoh and before

(16) his servants, and it became a serpent. [11] And

(17) Pharaoh, too, called the wise men and the sorcerers; and

(18) they, the magicians of Egypt, too, did so with their sorcery.

(19) [12] And they cast down every man his staff, and they

(20) became serpents. And Aaron's staff swallowed up their staffs.

(21) [13] And Pharaoh's heart hardened, and

(1) he did not listen to them, as the Lord had said. [14] And the Lord said $96 \mathrm{v}^{\mathrm{o}}$

(2) to Moses, 'Pharaoh's heart is hardened, he does not want to let the

(3) people go. [15] Go to Pharaoh in the morning. Lo, he goes out

(4) to the water. And you shall stand opposite him by the bank of the Nile,

(5) and you shall take the staff which was turned to a serpent

(6) in your hand. [16] And you shall say to him, "The Lord God

(7) of the Hebrews has sent me to you, saying, "Let my people go,

(8) So that they may serve me in the wilderness." And, lo,

(9) you did not listen so far. [17] Thus says the Lord, "By this

(10) you will know that I am the Lord: Lo, I will strike with the staff that is

(11) in my hand on the waters which are in the Nile, and they will be turned to blood.

(12) [18] And the fish that are in the river will die, and the river will stink, and

(13) the Egyptians will grow weary of drinking the water from the Nile." "' [19] And 
(14) ajtty Adonaj Mošege ajtqyn Aharonġa alġyn tajaġyjny da

(15) sunġun qolujnu suvlary üstüńa Micrinin özenleri üs-

(16) tüne Nilleri üstüne da ozeralary üstüne da bar

(17) jomulmaġy üstüne suvlarynyn da bolsunlar qan da bol-

(18) sun qan bar jerind́a Micrinin da ag̉ačly savutlarda da tašly

(19) savutlarda. ויעשו. [20] Da qyldylar alaj Moše da Aharon ki nečik

(20) bujurdu Adonaj da kötürdü tajaqbyla da urdu ošol

(21) ol suvlarny ki Nilde közlerič́a par'onun da közlerič́a

$97 \mathrm{r}^{\circ} \quad$ (1) qullarynyn da čüvürüldüler bar ol suvlar ki Nilde qanġa.

(2) (21] Da ol balyq ki Nild́a öldü da sasydy ol Nil da

(3) bolalmadylar Micrililer ičme suv ol Nilden da boldu ol

(4) qan bar jerind́a Micrinin. [22] Da qyldylar alaj filosof-

(5) lary Micrinin köz bavčuluqlarybyla da qatty jüregi par'onun

(6) da tynlamady alarg̉a ki nečik sözledi Adonaj. [23] Da

(7) qajyryldy paro da keldi üvüne da qojmady esin daġyn

(8) bunarda. ויחפרו. [24] Da qazdylar bar Micrililer čüvre-

(9) lerind́a ol Nilnin suvlar ičme ki bolalmadylar ičme

(10) suvlaryndan ol Nilnin. [25] Da toldu jedi künler

(11) karatetip sortun Adonaj ošol ol Nilni. [26] Da

(12) ajtty Adonaj Mošeǵa kelgin par'oğa da ajtqyn anar

(13) bulaj ajtty Adonaj ijgin ošol ulusumnu da qulluq

(14) etsinler maja. ואם [27 Da eger klemejdesej sen ijme

(15) muna men qyrarmen ošol bar čegijni bag̉alar byla. ושרץ. [28]

(16) Da qozlar ol Nil bag̉alar da čyġarlar da kelirler üvüjada

(17) da ḥužurasyna jatuvujnun da töšegij üstüne da ü-

(18) vüne $\mathrm{q}\left[\mathrm{u}\right.$ ]llaryjnyn ${ }^{1}$ da ulusuja da pečlerija da ötmek

(19) qužurajtadoġan savutlaryja. ובכה. [29] Da üstüje da

(20) ulusuj üstüne da bar qullaryj üstüne minerler ol

(21) bag̉alar.

Exodus 8

ויאמר [1] Da ajtty Adonaj Mošege ajtqyn Aharon-

$97 \mathrm{~V}^{\circ} \quad$ (1) ga sung்un ošol qolujnu tajaġyjbyla ol özenler üstü-

(2) ne ol Niller üstüne da ol ozeralar üstüne da

\footnotetext{
${ }^{1} \mathrm{~K}$ : qollaryjnyn; a scribal error. | TKow.o1: unvocalized text. | H: qullarynnyn. | C: qullarygnyy.
} 
(14) the Lord spoke to Moses, 'Say to Aaron, "Take your staff, and

(15) reach out your hand over the waters of Egypt, over their rivers,

(16) over their Niles, and over their lakes, and over all

(17) the concentrations of their water, and they shall become blood. And

(18) there shall be blood throughout all the land of Egypt, both in vessels of wood and

(19) in vessels of stone."' [20] And Moses and Aaron did so, as the

(20) Lord commanded. And he raised the staff, and smote the

(21) waters that were in the Nile, in the sight of Pharaoh, and in the sight

(1) of his servants, and all the waters that were in the Nile were turned into blood.

(2) [21] And the fish that were in the river died, and the river stank, and

(3) the Egyptians could not drink the water from the Nile. And there was

(4) blood throughout all the land of Egypt. [22] But the magicians

(5) of Egypt did so with their sorcery. And Pharaoh's heart was hardened,

(6) and he did not listen to them, as the Lord had said. [23] And

(7) Pharaoh turned and came into his house, and he did not pay attention

(8) even to this. [24] And all the Egyptians dug around

(9) the Nile for water to drink, because they could not drink

(10) from the Nile's waters. [25] And seven days were filled

(11) after the Lord had punished the Nile. [26] And

(12) the Lord spoke to Moses, 'Come to Pharaoh, and say to him,

(13) "Thus says the Lord, "Let my people go, so that they may

(14) serve me. [27] And if you are not willing to let go,

(15) lo, I will smite all your borders with frogs. [28]

(16) And the river will breed frogs, which will go up and come even in your house,

(17) and in your bedchamber, and on your bed, and

(18) in the house of your servants, and on your people, and in your ovens, and

(19) in your bread-leavening vessels. [29] And the frogs will come up on you,

(20) and on your people, and on all your servants." "'

Exodus 8

(21) [1] And the Lord said to Moses, 'Say to Aaron,

(1) "Reach out your hand with your staff over the rivers, $97 \mathrm{v}^{\circ}$

(2) over the Niles, and over the lakes, and 
(3) čygarg̉yn ošol ol bag̉alarny jeri üstüne Micrinin. ויט [2]

(4) Da sundu Aharon ošol qolun suvlary üstüne Micrinin

(5) da čyqty jyjyny ol bag̉anyn da qaplady ošol jerin Micrinin.

(6) ויעשו Da quldylar alaj ol filosoflar köz bavčuluqlary-

(7) byla da čyġardylar ošol ol bag̉alarny jeri üstüne Micri-

(8) nin. ויקרא. [4] Da ündedi paro Mošeni da Aharonnu

(9) da ajtty tefile etijiz Adonajgia da ketersin ol bagalar-

(10) ny mend́an da ulusumdan da ijejim ošol ol ulusnu

(11) da debeha etsinlar Adonajgia. Da ajtty

(12) Moše par'oġa belgilegin maja qačanġa tefila etejim

(13) Senin üčün da qullaryj üčün da ulusuj üčün eksit-

(14) me ol baġalarny sendan da üvlerijdan ančaq Nilde qalyr-

(15) lar. l6] Da ajtty par'o tanbylagia tefile

(16) etkin da ajtty sözüja köre alaj bolur anyn üčün

(17) ki bilǵajsen ki johtu Adonaj Tenrimiz kibik. וסרו [7] Da

(18) keterler ol bag̉alar senden da üvlerijdan da qullaryjdan da

(19) ulusujdan ančaq Nilde qalyrlar. ויצא. [8] Da čyqty Moše da

(20) \{Aharon\} alnyndan par'onun da firjat etti Moše Adonajğa iši

(21) üčün ol bag̉alarnyn ki qojdu par'og̉a. [9] Da qyldy

$98 \mathrm{r}^{\mathbf{0}} \quad$ (1) Adonaj sözüne köŕa Mošenin da öldülar ol bag̉alar

(2) ol üvlerd́an ol azbarlardan da ol tüzlerd́an. ויצברו [10]

(3) Da jyštyrdylar alarny obalar obalar da sasydy ol jer.

(4) יויא [11] Da kördü paro ki boldu ol avlaqlyq da ar-

(5) ttyrdy qattyrma ošol jüregin da tynlamady alarg̉a

(6) ki nečik sözledi Adonaj. [12] Da ajtty Adonaj

(7) Mošeǵa ajtqyn Aharonġa sunġun ošol tajağyjny da

(8) urg̉un ošol toprağyn ol jernin da bolsun bitke bar

(9) jerind́a Micrinin. [13] Da qyldylar alaj da sun-

(10) du Aharon ošol qolun tajaġy byla da urdu ošol topraġyn

(11) ol jernin da boldu ol bit adamda da tuvarda bar

(12) topraġy ol jernin boldu bitler bar jerind́a Micrinin.

(13) Da qyldylar alaj ol filosoflar köz bavčuluq-

(14) larybyla čygarma ol bitlerni da bolalmadylar da boldu

(15) ol bit adamda da tuvarda. ויאמרו. Da ajtty-

(16) lar ol filosoflar bujrugiudu Tenrinin ol da qatty jüre- 
(3) bring up the frogs on the land of Egypt."' [2]

(4) And Aaron reached out his hand over the waters of Egypt,

(5) and the frogs came up and covered the land of Egypt.

(6) [3] And the magicians did so with their sorcery,

(7) and brought up frogs on the land of Egypt.

(8) [4] And Pharaoh called for Moses and Aaron,

(9) and said, 'Pray to the Lord, that he may take away the frogs

(10) from me and from my people, and I will let the people go,

(11) so that they may do sacrifice to the Lord.' [5] And Moses said

(12) to Pharaoh, 'Mark me out when shall I pray

(13) for you and for your servants and for your people,

(14) to cut off the frogs from you and from your houses. They will remain only in the Nile.'

(15) [6] And Pharaoh said, 'Pray before tomorrow.'

(16) And he said, 'It will be it according to your word, so that

(17) you may know that there is no one like the Lord our God. [7] And

(18) the frogs shall depart from you, and from your houses, and from your servants, and

(19) from your people. They will remain only in the Nile.' [8] And Moses and Aaron went out

(20) from before Pharaoh, and Moses cried to the Lord about the issue

(21) of the frogs which he had brought on Pharaoh. [9] And

(1) the Lord did according to the word of Moses. And the frogs died

(2) from the houses, from the homesteads, and from the fields. [10]

(3) And they gathered them together in separate heaps, and the land stank.

(4) [11] But Pharaoh saw that there was prosperity, and

(5) he went on hardening his heart, and did not listen to them-

(6) as the Lord had said. [12] And the Lord said

(7) to Moses, 'Say to Aaron, "Reach out your staff and

(8) strike the dust of the land, and it shall become lice in all

(9) the land of Egypt."' [13] And they did so. And

(10) Aaron reached out his hand with his staff, and smote the dust

(11) of the earth, and it became lice in man, and in animal. All

(12) the dust of the earth became lice in all the land of Egypt.

(13) [14] And the magicians did so with their sorcery,

(14) to bring out the lice, but they were not able. And

(15) the lice was in man, and in animal. [15] And

(16) the magicians said to Pharaoh, 'This is the command of God.' But Pharaoh's heart was hardened, 
(17) gi par'onun da tynlamady alarğa ki nečik sözledi Adonaj.

(18) . ויאמר Da ajtty Adonaj Mošege tünlej turg̉un er-

(19) $\mathrm{t}[\mathrm{e}]$ nbylada $^{1}$ da turğun alnynda par'onun muna čyg̉ady ol

(20) suvlarg̉a da ajtqyn anar bulaj ajtty Adonaj ijgin ulusum-

(21) nu da qulluq etsinlar maja. כי. [17] Ki eger ijmejdesej

$98 \mathrm{v}^{\mathbf{o}} \quad$ (1) ošol ulusumnu muna men ijermen send́a da qullaryjda da

(2) ulusujda da üvlerijd́a ošol ol qatyš kijikni da tolar-

(3) lar üvleri Micrinin ol qatyš kijikten da daġyn ol jerd́a

(4) ki alar anyn üstüne. [הפליתי [18] Da ajyryrmen ol

(5) künd́a ošol jerin Gošennin ki ulusum toḥtajdy anyn üs-

(6) tüne bolmasqa anda qatyš kijik anyn üčün ki bilgej-

(7) sen ki hašgaḥam menim men Adonaj tergejdi ortasynda

(8) ol jernin. ושמתי [19] Da qojarmen juluv arasyna ulusum-

(9) nun da arasyna ulusujnun tanbylag̉a bolur ol belgi oš-

(10) pu. ויעש [20] Da qyldy Adonaj alaj da keldi qatyš kijik

(11) küčlü üvüne par'onun da üvüne qullarynyn da

(12) bar jerind́a Micrinin čejpal[dy $]^{2}$ ol jer alnyndan ol qatyš

(13) kijiknin. ויקרא [21 Da ündedi paro Mošeni da Aharon-

(14) nu da ajtty baryjyz debeḥa etijiz Tenrijizǵa jerd́a.

(15) ויאמר (22] Da ajtty Moše qolajly tüvüldü qylma

(16) alaj ki ${ }_{L}$ hor etk[e]nin ${ }^{13}$ Micrinin debeḥa eterbiz Adonajğa

(17) Tenrimizǵa muna debeḥa etsek ošol ḥorlug̉un

(18) Micrinin közlerič́a alarnyn da tašbyla tašlamaslarmo

(19) bizni. דרך. [23] Jol üč künlük baryrbiz midbarda da

(20) debeha eterbiz Adonajğa Tenrimizǵa ki nečik ajtsa

(21) bizge. ויאמר. [24] Da ajtty paro men ijermen sizni

$99 \mathrm{r}^{\circ} \quad$ (1) da debeha etijiz Adonajğa Tenrijizǵa midbarda tek jyraq

(2) etme jyraq etmejiz barma tefile etijiz menim üčün

(3) de. יויאמר [25] Da ajtty Moše muna men čyg̉armen

(4) alnyjdan da tefila etermen Adonajğa da keter ol qatyš

(5) kijik parodan qullaryndan da ulusundan tanbylada ančaq

(6) arttyrmasyn par'o aldama ijmeske ošol ol u-

(7) lusnu debeha etḿa Adonajğa. [26] Da čyqty

\footnotetext{
${ }^{1} \mathrm{~K}:$ ertinbylada; a scribal error. | TKow.o1: unvocalized text. | H: erten bylada. | C: ertä bilän. $\quad{ }^{2} \mathrm{~K}$ : čejpalyr; a scribal error. | TKow.o1: čejpaldy; unvocalized text. | H: čajpaldy. | C: čajpaldy. $\quad{ }^{3} \mathrm{~K}$ : hor etkinin; a scribal error. | TKow.o1: unvocalized text. | H: abaġyn. | C: iränčisin.
} 
(17) and he did not listen to them — as the Lord had said.

(18) [16] And the Lord said to Moses, 'Rise up early

(19) in the morning, and stand before Pharaoh. Lo, he is going out to the

(20) water. And say to him, "Thus says the Lord, "Let my people go,

(21) so that they may serve me. [17] Because if you are not letting my people go,

(1) lo, I will send wild beasts on you, and on your servants, and

(2) on your people, and on your houses. And

(3) the houses of the Egyptians will will be filled with wild beasts, and also the ground

(4) on which they are. [18] And I will set apart in that

(5) day the land of Goshen, in which my people dwell,

(6) for no wild beast to be there, so that you may know

(7) that my Providence-me, the Lord—explores the midst

(8) of the land. [19] And I will put redemption between my people

(9) and your people. This sign will be tomorrow."”'

(10) [20] And the Lord did so. And wild beasts came

(11) intensely to the house of Pharaoh, and to his servants' houses, and

(12) to all the land of Egypt. The land ${ }_{L}[$ was $]$ broken ${ }^{182}$ before the wild

(13) beasts. [21] And Pharaoh called for Moses and for Aaron,

(14) and said, 'Go, do sacrifice to your God in the land.' [22]

(15) And Moses said, 'It is not proper to do

(16) so, because we will sacrifice to the Lord

(17) our God an abominable thing to Egypt. Lo, if we sacrifice what is abominable

(18) to Egypt before their eyes: will they not stone

(19) us? [23] We will go three days' journey in the wilderness, and

(20) we will do sacrifice to the Lord our God, as he tells

(21) us.' [24] And Pharaoh said, 'I will let you go,

(1) so that you may do sacrifice to the Lord your God in the wilderness. $99 \mathrm{r}^{\circ}$ Only

(2) you shall not go far. Pray for me,

(3) too.' [25] And Moses said, 'Lo, I am going out

(4) from before you, and I will pray to the Lord that the wild

(5) beasts may depart from Pharaoh, from his servants, and from his people at daybreak. Only

(6) let Pharaoh not continue to cheat so as not to let the people go

(7) to do sacrifice to the Lord.' [26] And Moses went out

$82 \quad$ K: will be broken; a scribal error. 
(8) Moše \{alnyndan par'onun\} da tefile etti Adonajga. [27] Da qyldy

(9) Adonaj sözüne köre Mošenin da ketti ol qatyš

(10) kijik par'odan qullaryndan da ulusundan qalmady bird́a.

(11) ויכבד Da d28] Da qattyrdy paro ošol jüregin dag̉yn oš-

(12) puda kerette da ijmedi ošol ol ulusnu.

\section{Exodus 9}

(13) . ויאמר Da ajtty Adonaj Mošege kelgin paro-

(14) ġa da sözlegin anar ajtadoġač bulaj ajtty Adonaj

(15) Tenrisi ol Jisra’ellernin ijgin ošol ulusumnu da

(16) qulluq etsinler maja. כי. [2] Ki eger klemejdesej sen

(17) ijme da hanuzda sen kip tutasen alarny. הנה [3 Muna

(18) hyššymy Adonajnyn bolur tuvaryjda ki tüzd́a atlarda

(19) ešeklerda tevelerd́a syġyrda da qojda ölet küčlü

(20) astry. והפלה [4] Da ajyryr Adonaj arasyna tuvarynyn

(21) Jisra’elnin da arasyna tuvarynyn Micrinin da ölmesti baryn-

$99 \mathrm{v}^{\mathrm{o}}$ (1) dan neki ulanlarynyn Jisra’elnin nemede. [ישם. [5] Da qojdu

(2) Adonaj vağda ajtadoġač tanbylada qylar Adonaj ol išni

(3) ošpunu jerd́a. [6] Da qyldy Adonaj ošol ol

(4) išni ošpunu tanbyladan da öldü bar tuvary Micrinin

(5) vale tuvaryndan Jisra’elnin ölmedi bird́a. וישלח. [7] Da

(6) ijdi paro da muna ölmedi tuvaryndan Jisra’elnin bir-

(7) gedejin da qatty jüregi par'onun da ijmedi ošol

(8) ol ulusnu. [8] Da ajtty Adonaj Mošeǵa

(9) da Aharonġa alyjyz özüjüzǵa tolu qoš uvučlaryjyzny

(10) sopḥasyn kireč ṕečinin da bürksün any Moše ol kök-

(11) lerge közlerič́a paronun. [9יה Da bolsun toz-

(12) ġaqqa bar jeri üstüne Micrinin da bolsun ol adam

(13) üstüne da ol tuvar üstüńa čybanġa jajyladoġan

(14) tomalčyqlar bar jerind́a Micrinin. ויקחו. [10] Da aldylar

(15) ošol sopḥasyn ol kireč ṕečinin da turdular alnynda

(16) par'onun da bürktü any Moše ol köklerǵa da

(17) boldu čyban tomalčyqlar jajyladoğan adamda [da $]^{1}$ tuvarda.

(18) ולא (11] Da bolalmadylar ol filosoflar turma alnynda

(19) Mošenin alnyndan ol čybannyn ki edi ol čyban filosof-

\footnotetext{
${ }^{1} \mathrm{~K}$ : deest; a scribal error. | TKow.o1: deest; a scribal error. | H: da. | C: da.
} 
(8) from before Pharaoh, and prayed to the Lord. [27] And the Lord did

(9) according to the word of Moses, and removed the wild

(10) beasts from Pharaoh, from his servants, and from his people. Not even one remained.

(11) [28] And Pharaoh hardened his heart

(12) this time as well, and he did not let the people go.

Exodus 9

(13) And the Lord said to Moses, 'Come to Pharaoh,

(14) and speak to him, saying, "Thus says the Lord

(15) God of the Hebrews, "Let my people go, so

(16) may they serve me. [2] Because if you are not willing

(17) to let go and you are still holding them strongly, [3] Lo,

(18) the wrath of the Lord will be on your livestock that are in the field, on the horses,

(19) on the donkeys, on the camels, on the cattle, and on the sheep: a very severe pestilence.

(20) [4] And the Lord will separate between the livestock

(21) of Israel and the livestock of Egypt. And nothing will die of all

(1) that is of the children of Israel." "' [5] And the Lord has set

(2) an appointed time, saying, 'At daybreak the Lord will do this thing

(3) in the land.' [6] And the Lord did that

(4) thing after daybreak, and all the livestock of Egypt died,

(5) but of the livestock of Israel not one died. [7] And

(6) Pharaoh sent, and, lo, there was not one of the livestock of Israel dead.

(7) And the heart of Pharaoh was hardened, and he did not let

(8) the people go. [8] And the Lord said to Moses

(9) and to Aaron, 'Take to you handfuls

(10) of lime kiln soot, and Moses shall sprinkle it toward the skies

(11) in the sight of Pharaoh. [9] And it shall become fine dust

(12) over all the land of Egypt, and shall become

(13) boils spreading with abscesses on man and on livestock,

(14) all over the land of Egypt.' [10] So they took

(15) soot of the lime kiln, and stood before

(16) Pharaoh. And Moses sprinkled it up toward heaven, and

(17) it became boils spreading with abscesses on man, [and] on livestock.

(18) [11] And the magicians could not stand before

(19) Moses by reason of the boils, for the boils were on the 
(20) larda da bar Micrid́a. [12] Da qattyrdy Adonaj

(21) ošol jüregin par'onun da tynlamady alarg̉a ki nečik 10o ro (1) sözledi Adonaj Mošege. [13] Da ajtty Adonaj Mošege

(2) tünlej turg̉un ertenbylada turgun alnynda par'onun da

(3) ajtqyn anar bulaj ajtty Adonaj Tenrisi ol Jisra’ellernin ijgin

(4) ošol ol ulusumnu da qulluq etsinler maja. כ. [14] Ki ošpu

(5) kerette men ijermen ošol bar karanjalarymny jüregije da qullaryjda

(6) da ulusujda anyn üčün ki bilgejsen ki joḥtu menim kibik bar

(7) ol jerd́a. [15] Ki haligine sunġajedim ošol hyššymymny

(8) da urgajedim seni da ošol ulusujnu öletbyla da eksil-

(9) gejdij ol jerd́an. ואולם. [16] Da kertid́an bunun üčün tur-

(10) ġuzamen seni körgüzmek üčün saja ošol küčümnü da

(11) qotarmaq üčün šemimni bar ol jerde. עודך. [17 Hanuz

(12) sen ullulan[a] $\operatorname{sen}^{1}$ ulusum üstüne ijmeske alarny.

(13) . הנני (18] Muna men javdururmen bu vaḥtlaj tanbylada buz

(14) küčlü astry ki joġedi anyn kibik Micrid́a bunjat etilgen kü-

(15) nünden da haligedejin. ועתה [19] Da haligine ijgin jyštyr-

(16) g gyn ošol tuvaryjy da ošol barča neki saja tüzd́a bar ol

(17) adam da ol tuvar ki tabulsa tüzde da jyštyrylmasa ol

(18) üvge da ener alar üstüne ol buz da ölerler.

(19) [ירא (20] Ol qorquvču sözünden Adonajnyn qullaryndan par'o-

(20) nun qačyrdy ošol qullaryn da ošol tuvaryn özünün ol üv-

(21) lerge. ואשר [21 Da kim ki qojmady esin sözüne Adonajnyn

$100 v^{0} \quad$ (1) da kemišti ošol qullaryn da ošol tuvaryn tüzde.

(2) יויאמר (22] Da ajtty Adonaj Mošege sunġun ošol qoluj-

(3) nu ol köklerge da bolsun buz bar jerinde Micrinin ol

(4) adam üstüne da ol tuvar üstüne da bar kögütü

(5) üstüne ol tüznün jerinde Micrinin. ויט [23] Da sun-

(6) du Moše ošol tajag̉yn ol köklerge da Adonaj berdi avaz-

(7) lar da buz da čaġyldy ot jerge da javdurdu Adonaj buz jeri-

(8) üstüne Micrinin. [24] Da edi buz da ot čaǵyly-

(9) redi ortasynda ol buznun küčlü astry ki jog̉edi anyn

(10) kibik bar jerinde Micrinin ol vahttan ki boldu hanlyqqa.

(11) ויך [25] Da vatty ol buz bar jerind́a Micrinin ošol bar-

(12) ča neki tüzde adamdan da tuvargadejin da ošol bar kögö-

\footnotetext{
${ }^{1} \mathrm{~K}$ : ullulanesen; a scribal error. | TKow.o1: unvocalized text. | H: ullulanasen. | C: kötärilirmisin.
} 
(20) magicians, and on all Egypt. [12] And the Lord hardened

(21) the heart of Pharaoh, and he did not listen to them-as

(1) the Lord had spoken to Moses. [13] And the Lord said to Moses,

(2) 'Rise up early in the morning, stand before Pharaoh, and

(3) say to him, "Thus said the Lord God of the Hebrews, "Let

(4) my people go, so that they may serve me. [14] Because

(5) this time I will send all my punishments at your heart, and at your servants,

(6) and at your people, so that you may know that there is none like me in all

(7) the earth. [15] Because by now I could have reached out my wrath,

(8) and smite you and your people with pestilence, and you would have been

(9) cut off from the earth. [16] And, of a truth, for this reason

(10) I have raised you up: to show you my power, so

(11) that my name may be declared in all the earth. [17] If you are still

(12) exalting yourself against my people not to let them go:

(13) [18] Lo, at this time at daybreak I will cause very strong hail to fall,

(14) such as never has been in Egypt from the day it was founded

(15) until now. [19] And now send, gather

(16) your livestock and all that you have in the field. All the

(17) men and livestock that shall be found in the field and is not gathered

(18) home: the hail will come down on them, and they will die."”'

(19) $[20]$ The one who feared the word of the Lord among the servants of Pharaoh

(20) made his servants and his livestock flee to the houses.

(21) [21] And the one who did not pay attention to the word of the Lord

(1) left his servants and his livestock in the field.

(2) [22] And the Lord said to Moses, 'Reach out your hand

(3) toward the skies, so that there may be hail in all the land of Egypt,

(4) on man, and on livestock, and on every plant

(5) of the field in the land of Egypt.' [23] And

(6) Moses reached out his staff toward the skies, and the Lord gave thunder

(7) and hail, and sparked fire ran on the ground, and the Lord rained hail

(8) on the land of Egypt. [24] And there was hail, and fire was sparking

(9) in the midst of hail, very strong, such as there was none

(10) like it in all the land of Egypt since it became a kingdom.

(11) [25] And the hail smote in all the land of Egypt all

(12) that was in the field, both man and animal, and the hail smote 
(13) tün ol tüznün vatty ol buz da ošol bar ag̉ačyn ol tüz-

(14) nün syndyrdy. רק. [26] Ančaq jerind́a Gošennin ki anda

(15) ulanlary Jisra'elnin jog̉edi buz. [ישלח [27] Da ijdi par'o

(16) da ündedi Mošeni da Aharonnu da ajtty alarg̉a jazyq-

(17) ly boldum bu vahtta Adonajdy ol rast da men da ulusum

(18) ol raša lar. העתירו. [28] Tefile etijiz Adonajg̉a da jetsin

(19) bolmaqtan ullu avazlar da buz da ijejim sizni da arttyr-

(20) majyz toḥtama. [יאמר [29] Da ajtty anar Moše čyqqanym-

(21) dačoq ol šahardan jajarmen uvučlarymny alnynda Adonajnyn ol

$101 \mathrm{r}^{\mathrm{o}}$ (1) avazlar qalyrlar da ol buz bolmasty artyq anyn üčün ki bil-

(2) gejsen ki Adonajnyn erkindedi ol jerde. ואתה [30] Da sen

(3) da qullaryj bilemen ki ketmesten burun ol karanja qorq[ar] $\operatorname{siz}^{1}$

(4) alnyndan Adonaj ol Tenrinin. [31] Da ol üskülü

(5) da ol arpa vatyldy ki ol arpa baš qusqan edi da

(6) ol üskülü qamušlu edi. [32] Da ol budaj

(7) da ol qara budaj vatylmadylar ki jabuq edilar alar. [33]

(8) Da čyqty Moše alnyndan par'onun ol šahardan da jajdy

(9) uvučlaryn alnynda Adonajnyn da qaldylar ol avazlar da ol

(10) buz da jamġur tammady jerǵa. [34] Da kördü

(11) par'o ki qaldy ol jamgiur da ol buz da ol avazlar da

(12) arttyrdy jazyqly bolma da qattyrdy jüregin ol da qulla-

(13) ry anyn. [35] Da qatty jüregi par'onun da [i]jme-

(14) $\mathrm{di}^{2}$ ošol ulanlaryn Jisra’elnin ki nečik sözledi Adonaj navi-

(15) ligi ašyra Mošenin.

\section{Exodus 10}

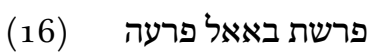

(17 Da ajtty Adonaj Moše-

(18) ge kelgin par'og̉a ki men qattyrdym ošol

(19) jüregin anyn da ošol jüregin qullarynyn qojg̉anym üčün belgi-

$101 \mathrm{v}^{\mathrm{o}}$ (1) losimni ošpularny ortasynda anyn. [2] Da anyn

(2) üčün ki qotarġajsen qulaqlaryča uvlujnun da uvlu-

(3) nun uvlujnun ne ki tamašalyq qyldym Micrida da ošol belgi-

\footnotetext{
${ }^{1} \mathrm{~K}$ : qorqsiz; probably a scribal error. | TKow.o1: qorqsiz or qorqasiz; unvocalized text. | H: qorqasiz.

| C: qorqarsyz. $\quad{ }^{2} \mathrm{~K}$ a ajmedi; a scribal error. | TKow.o1: unvocalized text. | H: ijmedi. | C: yibirmädi.
} 
(13) all the plants of the field and broke every tree of the field.

(14) [26] Only in the land of Goshen, where

(15) the children of Israel were, was there no hail. [27] And Pharaoh sent,

(16) and called for Moses and Aaron, and said to them, 'I sinned

(17) this time. The Lord is righteous, and I and my people

(18) are wicked. [28] Pray to the Lord, and may it be enough of

(19) mighty thundering and hail, and let me let you go, and

(20) you shall not continue to stay.' [29] And Moses said to him, 'As I go

(21) out of the city, I will reach out my hands before the Lord. The

(1) thunder will cease, and there will be no more hail, so that you may $101 \mathrm{r}^{\mathrm{o}}$

(2) know that, indeed, the earth is in the Lord's hand. [30] And you

(3) and your servants: ${ }_{L} \mathrm{I}$ know that until this punishment leaves, you will fear

(4) before the Lord God ${ }^{183}$. [31] And the flax

(5) and the barley was smitten, because the barley was in the ear, and

(6) the flax was in blades. [32] But the wheat

(7) and the rye were not smitten, because they were covered.' [33]

(8) And Moses went out of the city from before Pharaoh, and spread

(9) his hands to the Lord, and the thunders and the

(10) hail ceased, and the rain was not poured on the earth. [34] And Pharaoh saw

(11) that the rain and the hail and the thunders were ceased,

(12) and he sinned yet again, and hardened his heart, he and

(13) his servants. [35] And the heart of Pharaoh was hardened, and he did not let

(14) the children of Israel go - as the Lord had spoken through the

(15) prophecy of Moses.

Exodus 10

(16) Parashat Bo

(17) [1] And the Lord said to Moses,

(18) 'Come to Pharaoh, because I have hardened

(19) his heart and the heart of his servants for the purpose of my setting

(1) these my signs of mine in the midst of them, [2] And for the purpose $101 \mathrm{v}^{\mathrm{o}}$

(2) that you may tell in the ears of your son, and of your son's

(3) son, what I have done wonders in Egypt and my signs

83 An interpretative translation. 
(4) lerimni ki qojdum alarda da bilirsiz ki menmen Adonaj.

(5) ויבוא Da keldi Moše da Aharon parog̉a da ajtty-

(6) lar anar bulaj ajtty Adonaj Tenrisi ol Jisra’ellernin qačan-

(7) gadejin \{klemessen $\}$ synyqma alnymdan ijgin ulusumnu da qulluq et-

(8) sinler maja. כי [4] Ki eger klemejdesej sen ijme

(9) ošol ulusumnu muna men keltirirmen tanbyla čegirtke

(10) čegijde. [5סה [5] Da qaplar ošol jüzün ol jernin da

(11) bolalmasty kiši körme ošol ol jerni da ašar ošol qal-

(12) dyġyn ol qutulmaqnyn ol qalġanny sizge ol buzdan da ašar

(13) ošol bar ol ag̉ačny ol ösedoġanny sizge ol tüzden.

(14) (6] Da tolarlar üvlerij da üvleri bar qullaryjnyn

(15) da üvleri bar Micrinin ki körmejdilar atalaryj da atalary

(16) atalaryjnyn bolġan zamanlaryndan ol jer üstüne ošpu

(17) künge dejin da qajyryldy da čyqty alnyndan par'onun.

(18) [יאמרו Da ajttylar qullary par'onun anar qačanġadejin

(19) bu bolur bizge tuzaqqa ijgin ošol ol erenlerini da

(20) qulluq etsinler Adonajğa Tenrisińa özlerinin burun-

(21) raqmo ijmegijden alarny klejsen ki bilgejsen ki taspoldu

$102 \mathrm{r}^{\circ}$ (1) Micri. ויושב. [8] Da qajttyryldy ošol Moše da ošol

(2) Aharon par'og̀a da ajtty alarga baryjyz qulluq etijiz Adonaj-

(3) ge genrijizǵa kim da kim bolur ol baruvčular. [9] [9]

(4) Da ajtty Moše ulanlarymyz byla da qartlarymyz byla baryr-

(5) biz uvullarymyz byla da qyzlarymyz byla qojumuz byla da

(6) syġyrymyz byla baryrbiz ki hyž alnynda Adonajnyn hyžlama

(7) borčtu bizǵa. ויאמר [10] Da ajtty alarg̉a bolġaj

(8) alaj bolušluğu Adonajnyn birgejizǵa ki nečik ijermen sizni da

(9) ošol jašyjyzny bağyjyz ki jamandy qaršysyna jüzlerijiznin.

(10) לא [11] Tüvül alaj baryjyz endi ol jigitlar da qulluq

(11) etijiz Adonajğa ki any siz klejsiz da sürdü alarny al-

(12) nyndan par'onun. יויאמר Da ajtty Adonaj Mošeǵa

(13) sunġun qolujnu jeri üstüne Micrinin čegirtke byla

(14) da kelsin jeri üstüne Micrinin da ašasyn ošol bar

(15) kögütün ol jernin ošol barysyn ne ki qaldyrdy ol buz.

(16) ויט (13] Da sundu Moše ošol tajag̉yn jeri üstüńa

(17) Micrinin da Adonaj könderdi qadim jeli jerde bar ol kün-

(18) de da bar ol kečede ol tan boldu da ol qadim jeli kö- 
(4) which I have set among them, and that you may know that I am the Lord.'

(5) [3] And Moses and Aaron came to Pharaoh, and said

(6) to him, 'Thus said the Lord God of the Hebrews, "How long

(7) will you not want to break yourself before me? Let my people go, so that they

(8) may serve me. [4] Because if you are not willing to let

(9) my people go, lo, at daybreak I will bring locust

(10) in your border. [5] And they will cover the face of the earth, and

(11) one will not be able to see the earth. And they will eat the

(12) residue of that which is escaped, which remained to you from the hail, and will eat

(13) every tree which grows for you from the field.

(14) [6] And your houses will fill up, and the houses of all your servants,

(15) and the houses of all the Egyptians, which your fathers, or your fathers'

(16) fathers did not see from the times that they were on the earth to this

(17) day."' And he turned, and went out from before Pharaoh.

(18) [7] And Pharaoh's servants said to him, 'How long

(19) shall this be a snare to us? Let those men go, and

(20) may they serve the Lord their own God.

(21) Do you want to learn that Egypt is destroyed before you let them go?'

(1) [8] And Moses and Aaron turned to Pharaoh,

(2) and he said to them, 'Go, serve the Lord

(3) your God. But who will be they that shall go?' [9]

(4) And Moses said, 'We will go with our children and with our old,

(5) with our sons and with our daughters, we will go with our flocks and

(6) with our cattle, because we are obliged to hold a feast to the Lord'

(7) [10] And he said to them, 'Let the

(8) Lord's help be so with you when I will let you

(9) and your young ones go, see, because evil is before you.

(10) [11] Not so! Go now, you, young men, and serve

(11) the Lord, because you wanted this.' And he drove them out from

(12) before Pharaoh. [12] And the Lord said to Moses,

(13) 'Reach out your hand over the land of Egypt for the locusts,

(14) and it shall come up on the land of Egypt, and it shall eat every

(15) plant of the land, all that the hail has left.'

(16) [13] And Moses reached out his staff over the land

(17) of Egypt, and the Lord drove an east wind on the land all that day

(18) and all the night. It was morning, and the east wind 
(19) türdü ošol ol čegirtkeni. ויעל [14] Da kötürüldü

(20) ol čegirtke bar jeri üstüne Micrinin da toḥtady

(21) bar čegind́a Micrinin küčlü astry andan burun jog̉edi

$102 \mathrm{~V}^{0}$ (1) alaj čegirtke anyn kibik da andan sortun bolmasty alaj.

(2) ויכס [15] Da qaplady ošol jüzün \{bar\} ol jernin da qaranġy boldu

(3) jer da ašady ošol bar kögötün ol jernin da ošol bar

(4) jemišin ol ag̉ačnyn ki qaldyrdy ol buz da qalmady heč ješil-

(5) lik ag̉ačta da kögötünd́a ol tüznün bar jerind́a

(6) Micrinin. [ימהר [16] Da žahtlady paro ündeme Moše-

(7) ni da Aharonnu da ajtty jazyqly boldum Adonajġa Tenrijiz-

(8) ge da sizgede. ועתה [17 Da haligine bošatqyn endi

(9) jazyġymny tek bu vaḥtta da tefile etijiz Adonajğa Ten-

(10) rijizğa da ketersin menden tek ol ölümnü ošpunu.

(11) ויצא [18 Da čyqty alnyndan par'onun da tefile et-

(12) ti Adonajğa. [19 Da čüvürdü Adonaj ma'arav

(13) jeli küčlü astry da kötürdü ošol ol čegirtkeni

(14) da qadady any Jam Sufqa qalmady birde čegirtke

(15) bar čegind́a Micrinin. ויחז [20] Da qattyrdy Adonaj

(16) ošol jüregin par'onun da ijmedi ošol ulanlaryn Jisra-

(17) 'ויאמר. '21] Da ajtty Adonaj Mošege sungiun

(18) qolujnu ol köklerǵa da bolsun qarangylyq jeri üstü-

(19) ne Micrinin da qarmajdogan qaranġylyq. ויט. [22] Da sundu

(20) Moše ošol qolun ol köklerǵa da boldu qaranġylyq tuman

(21) bar jerinde Micrinin üč künler. לא. [23] Körmedilar

$103 \mathrm{r}^{\circ} \quad$ (1) kiši ošol qaryndašyn da turmadylar kiši ornundan üč

(2) künler da bar ulanlaryna Jisra’elnin edi jaryq olturuš

(3) orunlarynda. [24] Da ündedi \{paroo\} Mošeni da ajt-

(4) ty baryjyz qulluq etijiz Adonajğa ančaq qojujuz da syġy-

(5) ryjyz qalsyn daġyn jašyjyz barsyn birgejizge. ויאמר [25] Da

(6) ajtty Moše daġyn send́a bergin qolumuzġa debehalar da

(7) olalar da qylarbiz Adonajgga Tenrimizǵa. [26] Da

(8) dag்yn tuvarymyz baryr birgemizǵa qalmasty tujaqta

(9) ki andan alyrbiz qulluq etme Adonajg̉a Tenrimizǵa

(10) da biz bilmejbiz nendij క̌ynsy byla debeḥanyn qulluq eter-

(11) biz Adonajgia kelgenimizge dejin ary. ויחזק [27] Da

(12) qattyrdy Adonaj ošol jüregin par'onun da klemedi ij-

(13) me alarny. ויאמר. [28] Da ajtty anar par'o barg̉yn

(14) alnymdan saqlanġyn özüja arttyrmag்yn körme jüzle- 
(19) brought the locusts. [14] And the locusts went up

(20) over all the land of Egypt and lingered

(21) in all the borders of Egypt, very strong: before it there were no

(1) such locusts like it, and after them there will not be such.

(2) [15] And they covered the face of the whole earth, so that the land was darkened,

(3) and they ate every plant of the land, and all the

(4) fruit of the trees which the hail had left. And there remained not any green

(5) thing in the trees, or in the plants of the field, in all the land

(6) of Egypt. [16] And Pharaoh hurried to call for Moses

(7) and Aaron, and he said, 'I have sinned against the Lord your God,

(8) and against you. [17] And now, forgive

(9) my sin only this once, and pray to the Lord your

(10) God, that he may take from me just this death away.'

(11) [18] And he went out from before Pharaoh, and prayed to

(12) the Lord. [19] And the Lord turned back a

(13) very strong west wind, and took away the locusts,

(14) and drove them into the Red Sea. Not one locust was left

(15) in all the border of Egypt. [20] But the Lord hardened

(16) Pharaoh's heart, and he did not let the children

(17) of Israel go. [21] And the Lord said to Moses, 'Reach out

(18) your hand toward the skies, that there may be darkness over the land

(19) of Egypt, even darkness which may be touched.' [22] And Moses reached out

(20) his hand toward the skies, and there was a foggy darkness

(21) in all the land of Egypt three days. [23] They did not see

(1) one another, neither rose any from his place for three

(2) days. But all the children of Israel had light in their

(3) places of dwelling. [24] And Pharaoh called to Moses, and said,

(4) 'Go, serve the Lord, only let your flocks and your cattle

(5) be left. Your little ones shall go with you as well.' [25] And

(6) Moses said, 'You must give us also sacrifices and

(7) burnt offerings, so we will do them to the Lord our God. [26] And

(8) our livestock will go with us as well. Not a hoof will be left,

(9) because of them we will take to serve the Lord our God,

(10) and we do not know with what kind of sacrifice we will serve

(11) the Lord, until we come there.' [27] But

(12) the Lord hardened Pharaoh's heart, and he did not want to let

(13) them go. [28] And Pharaoh said to him, 'Go

(14) from before me, take heed to yourself, see my face no more, 
(15) rimni ki körgen künüjda jüzlerimni ölersin.

(16) יויאמר (29] Da ajtty Moše kerti sözledij arttyr-

(17) manmen artyq körma jüzlerijni.

Exodus 11

(18) Adonaj Mošeǵa hanuz bir karanja keltirirmen par'o

(19) üstüne da Micri üstüne andan sortun ijer sizni

(20) ijgenindečoq tügelič́a sürme sürer sizni bundan.

(21) דבר (20 Sözlegin endi qulaqlaryča ol ulusnun da öt-

$103 \mathrm{~V}^{0} \quad$ (1) künč alsynlar kiši dostundan da qatyn dostundan kümüš

(2) savutlar da altyn savutlar. ויתן [3] Da berdi Adonaj ošol

(3) širinligin ol ulusnun közlerinde elinin Micrinin dağyn

(4) ol navi Moše ullu edi astry jerind́a Micrinin köz-

(5) lerind́a qullarynyn par'o[nun $]^{1}$ da közlerind́a ol ulusnun.

(6) ויאמר Da ajtty Moše bulaj ajtty Adonaj jarty

(7) ol kečed́a tekli menim bujruğum čyğar ortasynda

(8) Micrinin. [מת [5] Da öler bar tunguuč jerind́a Micri-

(9) nin bašlap tunğučundan par'onun ol olturuvču tahty

(10) üstüne anyn tunġučunadejin ol qaravašnyn ki ol tijir-

(11) men artyna da bar tunġuču tuvarnyn. והיתה. [6] Da

(12) bolur ullu firjat bar jerind́a Micrinin ki anyn kibik

(13) bolunmady da anyn kibik arttyrmasty. ולכל. [7] Da

(14) bar ulanlary\{na\} Jisra’elnin tebretmesti itte tilin bašlap

(15) kišidan da tuvarg̉adejin anyn üčün ki bilgejsiz k[i $]^{2}$ ajyryryr

(16) Adonaj arasyna Micrinin da arasyna Jisra’elnin. וירדו [8]

(17) Da enerlar bar qullaryj bular maja da bašururlar maja aj-

(18) tadoġač čyqqyn sen da bar ol ulus ki qatyjda da andan sor-

(19) tun čyġarmen da čyqty alnyndan par'onun qahir ačuvbyla.

(20) ויאמר [9] Da ajtty Adonaj [Mošege] ${ }^{3}$ tynlamasty sizge par'o

(21) arttyrmaq üčün nišanlarymny jerind́a Micrinin.

$104 \mathrm{r}^{\mathrm{o}}$ (1) [ומשה [10] Da Moše da Aharon qyldylar ošol bar ol nišanlar-

(2) ny ošpularny alnynda par'onun da qattyrdy Adonaj

(3) ošol jüregin par'onun da ijmedi ošol ulanlarny Jisra-

(4) 'elnin.

${ }^{1} \mathrm{~K}$ : par'o; a scribal error. | TKow.o1: par'onun; unvocalized text. | H: par'onun. | C: par'onyy. $\quad{ }^{2} \mathrm{~K}$ : $k a$; a scribal error. | TKow.o1: ki; unvocalized text. | H: ki. | C: ki. ${ }^{3} \mathrm{~K}$ : deest; a scribal error. | TKow.o1: Mošege; unvocalized text. | H: Mošege. | C: Mošegä. 
(15) because in that day you see my face you shall die.'

(16) [29] And Moses said, 'You have spoken the truth,

(17) I will not see your face again.'

Exodus 11

(18) to Moses, 'I will bring one punishment more on Pharaoh

(19) and on Egypt after that he will let you go.

(20) When he will let you go, he will surely drive you out from here.

(21) [2] Speak now in the ears of the people, and

(1) let them borrow every man from another, and every woman from another, vessels of silver

(2) and vessels of gold.' [3] And the Lord put the

(3) people's favour in the eyes of the Egyptians. Also,

(4) the prophet Moses was very great in the land of Egypt, in the eyes

(5) of Pharaoh's servants, and in the eyes of the people.

(6) [4] And Moses said, "Thus said the Lord,

(7) "About midnight my command will go out to the midst

(8) of Egypt. [5] And all the firstborn in the land of Egypt will die,

(9) from the firstborn of Pharaoh that sits on his throne,

(10) to the firstborn of the maidservant that is behind the mill,

(11) and all the firstborn of the livestock. [6] And

(12) there will be a great cry in all the land of Egypt, such as there

(13) was none like it, nor shall be like it any more. [7] But

(14) against any of the children of Israel not a dog will move his tongue,

(15) from man to livestock, that you may know that the Lord does put a difference

(16) between Egypt and Israel. [8]

(17) And all these your servants will come down to me and bow down themselves to me,

(18) saying, "Go out, you and all the people that are with you." And after that

(19) I will go out."' And he went out from before Pharaoh in furious anger.

(20) [9] And the Lord said to Moses, 'Pharaoh will not listen to you

(21) in order to multiply my tokens in the land of Egypt.'

(1) And Moses and Aaron did all these tokens

(2) before Pharaoh, and the Lord hardened

(3) Pharaoh's heart, so that he did not let the children

(4) of Israel go. 
Exodus 12

(4) (1] Da ajtty Adonaj Mošege da Aharon-

(5) ga jerind́a Micrinin ajtadoġač. החדש. [2] Ol jangaj

(6) ošpu sizge bašydy janġajlarnyn burunġudu ol sizge

(7) jang̉ajlaryna ol jylnyn. דברו. [3] Sözlejiz bar žymatyna

(8) Jisra’elnin ajtadoġač onunču kününd́a ošpu janġaj-

(9) nyn da alsynlar özlerińa kiši qoj üvüsajyn atalar-

(10) nyn qoj üvsajyn. ואם [4] Da eger az bolsa eli

(11) ol üvnün bolmaqtan ašavčular qojnu da alsyn ol

(12) da qonšusu anyn ol juvuq üvüne anyn qyjasy byla

(13) క̌anlarnyn kiši jemine köre salyšyjyz ol qoj üstü-

(14) ne. שה [5] Qoj tügel erkek jyllyq balasy bolsun siz-

(15) ge ol qozulardan da ol ečkilerd́an alyjyz. והיה. [6]

(16) Da bolsun sizge saqlavğa ond[ö]rtünč $\ddot{u}^{1}$ kününe dejin

(17) ošpu janġajnyn da sojsunlar any bar qahaly žymaty Jis-

(18) ra’elnin ol eki ingirler arasyna. ולקחו Da

(19) alsynlar ol qandan da bersinler ol eki odv́erjalar

(20) üstüne da ol üst odv́erja üstüne ol

(21) üvler üstüne ki ašasalar any alarda. ואכלו. [8 ]

$104 \mathrm{~V}^{\mathbf{o}} \quad$ (1) Da ašasynlar ošol ol etni ošpu kečede šišlege[n] $\mathrm{ni}^{2}$ ot-

(2) ta da macalar marorlar byla ašasynlar any. אל. [9] Ašamajyz

(3) andan jahny da biširilme biširilgenni suvičine ki an-

(4) čaq šišl[e]ge[n]ni ${ }^{3}$ otta bašyn anyn tizleribyla da ičibyla.

(5) ולא (10] Da qaldyrmajyz andan tangadejin da ol qalganny andan

(6) tanġadejin otta küvdürüjüz. וככה. [11] Da bulaj ašajyz

(7) any bellerijiz bolsunlar bajlanganlar etiklerijiz bolsunlar

(8) ajaqlaryjyz üstüne da tajaġyjyz qolujuzda da ašajyz any

(9) ašağyšlyqbyla qarbanydy Pesaḥnyn ol Adonajğa. ועברתי [12]

(10) Da ašar bujruğum menim jerind́a Micrinin ošpu keče-

(11) de da qyrarmen bar tunğučnu jerind́a Micrinin bašlap

\footnotetext{
${ }^{1} \mathrm{~K}$ : ondürtünčü; probably a scribal error, cf., however, Exo 12:18 below. $\quad{ }^{2} \mathrm{~K}$ : šišlegeni; a scribal error. | TKow.o1: šišlegenni; unvocalized text. | H: šišlegenin; different wording. | C: šišligin. $\quad{ }^{3} \mathrm{~K}$ : šišligeni; a scribal error. | TKow.o1: šišlegenni; unvocalized text. | H: sislegenin; different wording. | C: šišligin.
} 


\section{Exodus 12}

(5) in the land of Egypt, saying, [2] 'This month

(6) is the beginning of months to you. It is the first

(7) month of the year for you. [3] Speak to all the congregation

(8) of Israel, saying, "In the tenth day of this month

(9) they shall take to them every man a sheep, according to the house of their fathers,

(10) a sheep for a house. [4] And if the people of the house be fewer

(11) than those who would eat the sheep, then he

(12) and his neighbour that is close to his house shall take according to the number of souls,

(13) according to every person's eating you shall appoint yourself for the lamb.

(14) [5] Your sheep shall be unblemished male, a one-year-old young;

(15) you shall take it from the sheep or from the goats. [6]

(16) And you shall keep it until the fourteenth day

(17) of the same month. And the whole assembly of the congregation of

(18) Israel shall slaughter it at twilight. [7] And

(19) they shall take of the blood, and put it on the two side posts

(20) and on the upper door post,

(21) on the houses in which they shall eat it. [8]

(1) And they shall eat the flesh in this night, they shall eat it roasted in fire

(2) with unleavened bread |on| bitter herbs. [9] Do not eat

(3) jahny ${ }^{84}$ or boiled in water,

(4) but roasted in fire: its head with its knees, and with the entrails.

(5) (10) And you shall let nothing of it remain until the morning, and that which remains of it

(6) until the morning you shall burn in fire. [11] And thus shall you eat

(7) it: your hips shall be girded, your shoes shall be

(8) on your feet, and your staff in your hand; and you shall eat it

(9) in haste. It is the Lord's Passover. [12]

(10) And my command will pass through the land of Egypt this night,

(11) and will slay all the firstborn in the land of Egypt,

84 A name of a meat dish; cf. Mam.Kipch. jahnny 'étuvée de viande' (A. Zajączkowski 1958: 23). 
(12) adamdan da tuvargadejin da bar abaqlarynda Micrinin qylar-

(13) men karanjalar menmen Adonaj. והיה [13] Da bolsun ol qan

(14) sizge belgiǵa ol üvler üstüne ki siz anda da

(15) körermen ošol ol qanny da ḥajifsünürmen üstüjüz-

(16) ge da bolmasty sizde qyranč čejpavčug̉a qyrg̉anymda

(17) jerinde Micrinin. והיה [14] Da bolsun ol kün ošpu

(18) sizge saġynčqa da hyyžlajyz any hyy̌̌ Adonajg̉a dorlaryjyz sajyn

(19) ömürlük resim hyy̌̌lajyz any. שבעת. [15] Jedi künler

(20) macalar ašajyz tek burun ol burunġu künden eksitijiz

(21) qužurnu üvlerijizden ki bar ašavču qužurajg̉anny bašlap

$105 \mathrm{r}^{\mathrm{o}} \quad$ (1) ol burunġu künden ol jedinči küngedejin da eksilir ol క̌an

(2) Jisra’elden. וביום [16] Da ol burunġu künde aziz ündel-

(3) miš da ol jedinči künde aziz ündelmiš bolsun sizge

(4) heč iš qylynmasyn alarda ančaq neki ašalady har žang̉a ol

(5) jalgyz qylynsyn sizge. ושמרתם. [17] Da saqlajyz ošol ol maca-

(6) larny ki kensisind́a ošpu künnün čyg̉ardym ošol jyjyn-

(7) laryjyzny jerinden Micrinin da saqlajyz ošol ol künnü ošpu-

(8) nu dorlaryjyz sajyn ömürlük resim. בראשן. [18] Burung̉u

(9) janġajda ond[ö]rtünčü ${ }^{1}$ kününde janġajnyn ingirde

(10) ašajyz macalar ol egirmi biriniči kününedejin janġajnyn in-

(11) girde. שבעת. [19] Jedi künler qužur tabulmasyn üv-

(12) lerijizd́a ki bar ašavču qužurajg̉anny da eksilir ol žan

(13) క̌ymatyndan Jisra'elnin garipde da $\mathrm{j}[\mathrm{e}] \mathrm{rl}[\mathrm{i}] \mathrm{s}[\mathrm{i}] \mathrm{de}^{2}$ ol jernin.

(14) כל [20] Heč qužurajğanny ašamajyz bar olturušlaryjyzda

(15) ašajyz macalar. ויקרא. [21] Da ündedi Moše bar qartlaryn

(16) Jisra’elnin da ajtty alarg̉a tartyjyz da alyjyz özüjüzge

(17) qoj uruvlaryjyz sajyn da sojujuz qarbanyn ol Pesahnyn.

${ }^{1} \mathrm{~K}$ : ondürtünčü; probably a scribal error, cf., however, also Exo 12:6 above. $\quad{ }^{2} \mathrm{~K}$ : jarlysynda; a scribal error; cf. Exo 12:48, Exo 12:49, Lev 16:29, Lev 17:15, and Lev 24:16. | TKow.o1: unvocalized text. | H: jerlisindede. | C: jerlisindä. 
(12) both man and beast, and I will do punishments against all the gods of Egypt.

(13) I am the Lord. [13] And the blood shall be

(14) to you for a sign on the houses where you are, and

(15) I will see the blood, and I will have mercy on you,

(16) and the plague will not be on you to destroy you when I slay

(17) in the land of Egypt. [14] And this day shall be

(18) to you for a memorial, and you shall keep it a feast to the Lord throughout your generations,

(19) as an eternal statute, you shall keep it as a feast. [15] Seven days

(20) shall you eat unleavened bread, but before the first day you shall remove

(21) leaven from your houses. Because anyone who eats leavened |bread| from

(1) the first day until the seventh day, that soul will be cut off

(2) from Israel. [16] And there shall be for you a holy convocation on the first day

(3) and a holy convocation on the seventh day.

(4) No work shall be done on them. Just what is eaten by every man: that

(5) alone shall be done for you. [17] And you shall observe the unleavened

(6) bread, because in this very day I have brought your hosts

(7) out from the land of Egypt. And you shall observe this day

(8) throughout your generations as an eternal statute. [18] In the first

(9) month, on the fourteenth day of the month, in the evening,

(10) you shall eat unleavened bread, until the twenty-first day of the month,

(11) in the evening. [19] Seven days leaven shall not be found in your

(12) houses, because anyone who eats that which is leavened, that soul shall be cut off

(13) from the congregation of Israel, both a stranger and a [native $]^{85}$ of that land.

(14) [20] You shall eat nothing leavened. In all your dwellings

(15) you shall eat unleavened bread.' [21] And Moses called for all the elders

(16) of Israel, and said to them, 'Pull out and take yourself

(17) a sheep according to your families, and slay the Passover sacrifice.

85 K: 'poor'; a scribal error, cf. Heb. וּבְאָזְרָ 'or a native'; cf. Exo 12:48, Exo 12:49, Lev 16:29, and Lev 17:15. 
(18) ולקחתם [22] Da alyjyz bav čabor da mančyjyz qang̉a ki \{savutta\}

(19) da tijijiz ol üst odv́erjag̉a da eki ol odv́erjalarg̉a

(20) ol qandan ki savutta da siz čyqmajyz kiši ešigind́an

(21) üvünün tanġadejin. ועבר [23] [2Da aša[r] $\}^{1}$ bujrug̉u Adonajnyn qyrma

$105 \mathrm{~V}^{\mathrm{o}} \quad$ (1) ošol Micrini da körer ošol ol qanny ol üst odver-

(2) ja üstüne da eki ol odv́erjalar üstüne da hajif-

(3) sünür Adonaj ol ešik üstüne da bermesti erk ol

(4) čejpavčuğa kelme üvlerijizǵa qyrma. ושמרתם. [24] Da

(5) saqlajyz ošol ol söznü ošpunu resimǵa saja da ulan-

(6) laryja dunjag̉adejin. [25] Da bolġaj ki kelsejiz ol jerge

(7) ki ber[ir] Adonaj sizge ki nečik sözledi da saqlajyz ošol

(8) ol qulluqnu ošpunu. והיה [26] Da bolġaj ki ajtsalar

(9) sizge uvullaryjyz nedir ol qulluq ošpu sizge.

(10) (27 Da ajtyjyz debeḥasydy qarbanynyn Pesahnyn ol

(11) Adonajgga ki ḥajifsündü üvleri üstüne ulanlarynyn Jisra-

(12) 'elnin Micrid́a qyrg̉anynda ošol Micrini da ošol üvleri-

(13) mizni qutqardy da ijildi ol ulus da bašurdular. וילכו [28]

(14) Da bardylar da qyldylar ulanlary Jisra’elnin ki nečik bujur-

(15) du Adonaj Mošege da Aharonġa alaj qyldylar. [29] Da

(16) edi jarty ol kečede da Adonaj qyrdy bar tunġučnu jerind́a

(17) Micrinin bašlap tunġučundan par'onun ol olturuvču taḥ-

(18) ty üstüne tunġučunadejin ol jesirnin ki ol syndan üv-

(19) de da bar tunġučun tuvarnyn. Da turdu par'o

(20) kečebyla ol da qullary anyn da bar Micrililer da boldu ullu

(21) firjat Micrid́a ki joġedi andij üv ki bolmaġaj anda

106 r $^{\circ} \quad$ (1) ölü. [31] Da ündedi paro Mošeni da Aharonnu

(2) kečebyla da ajtty turujuz čyġyjyz ortasyndan ulusumnun

(3) daġyn siz daġyn ulanlary Jisra'elnin da baryjyz qulluq etijiz Adonaj-

(4) ga sözlegenijizge köŕa. גם [32] Dag̉yn qojujuznu dag̉yn sy-

(5) ġyryjyzny alyjyz ki nečik sözledijiz da baryjyz da alġyšlajyz

(6) dağyn menide. [3חז [33] Da küčejdi eli Micrinin ol ulus-

\footnotetext{
${ }^{1}$ TKow.o1: da ašar; unvocalized text. | H: da asar. | C: da kečär. $\quad{ }^{2} \mathrm{~K}$ : berse; a scribal error. |
} TKow.o1: berir. | H: berse; a scribal error. | C: berir.| R: berir. 
(18) [22] And you shall take an aspergillum bunch and dip it in the blood that is in the vessel,

(19) and touch the lintel and the two side posts

(20) with some of the blood that is in the vessel. And you shall not go out at the door

(21) of the house until the morning. [23] For the command of the Lord [will] pass through to slay

(1) Egypt, and it shall see the blood on the lintel,

(2) and on the two side posts, and

(3) the Lord will have mercy on the door, and will not allow the

(4) destroyer to come in to your houses to slay. [24] And

(5) you shall observe this word for a statute to you and to your children

(6) forever. [25] And it shall be, when you come to the land

(7) which the Lord will ${ }^{86}$ give you as he has spoken, that you shall keep

(8) this service. [26] And it shall be, that

(9) your sons will say to you, "What is this service for you?"

(10) [27] And you shall say, "It is the sacrifice of the offering of the Passover

(11) to the Lord who had mercy on the houses of the children of Israel

(12) in Egypt, when he slew Egypt, and

(13) saved our houses."' And the people bowed down and worshiped. [28]

(14) And the children of Israel went away and did as the Lord had commanded

(15) Moses and Aaron. They did so. [29] And

(16) it was at midnight, and the Lord slew all the firstborn in the land

(17) of Egypt, from the firstborn of Pharaoh that sat on his throne

(18) to the firstborn of the captive that was in the prison,

(19) and all the firstborn of the livestock. [30] And Pharaoh rose up

(20) in the night, he, and all his servants, and all the Egyptians, and there was a great

(21) cry in Egypt, because there was not a house where there was not one

(1) dead. [31] And Pharaoh called for Moses and Aaron $106 \mathrm{r}^{\circ}$

(2) by night, and said, 'Rise up, and go out from among my people,

(3) both you and the children of Israel. And go, serve the Lord,

(4) as you have said. [32] Take your sheep also,

(5) your cattle, as you have said, and go and bless

(6) me as well.' [33] And the people of Egypt became forceful on the people 
(7) üstüne žaḥtlama sürme alarny ol jerden ki ajttylar

(8) barlarymyz ölülerbiz. וישא. [34] Da kötürüp qojdu ol

(9) ulus javrunlary üstüne ošol ḥamurun özünün qužuraj-

(10) mastan burun ötmek quگ̌urajtadog̉ač savutlary alarnyn tüvün-

(11) čüklengenĺar juvurğanlary ičine. ובני. [35] Da ulanlary Jis-

(12) ra’elnin qyldylar sözüne köre Mošenin da ötkünč aldy-

(13) lar Micriden kümüš savutlar da altyn savutlar da upraq-

(14) lar. l36] Da Adonaj berdi ošol širinligin ol ulus-

(15) nun közlerind́a elinin Micrinin da ötkünč berdilar

(16) alarg̉a da tonadylar ošol Micrini. [37] Da köčtü-

(17) ler ulanlary Jisra'elnin Ra'emsestan Sukotqa alty keret

(18) jüz min jajav ol jigitĺar bašqa jaštan. וגם. [38] Da dag̉yn

(19) qatyš ol köbüsü bardy birgelerińa alarnyn da qoj da syg்yr

(20) tuvar küčlü astry. [39] Da biširdilar ošol ol hamur-

(21) nu ki čyğardylar Micridan jajmalar macalar ki qužurajmag̉an edi

$106 \mathrm{~V}^{\mathrm{o}} \quad$ (1) ki sürüldüler Micriden da bolalmadylar kečikme da daġyn

(2) azyqta qylmadylar özlerińa. ומושב. [40] Da kečikmegi u-

(3) lanlarynyn Jisra’elnin ki kečiktiler Micride dört jüz jyl da

(4) otuz jyl. ויהי [41] Da edi aherind́an dört jüz da otuz

(5) jylnyn da edi kensisinde ošpu künnün čyqtylar bar

(6) jyjynlary Adonajnyn jerinden Micrinin. ליל יל י42] Saqlavlar kečesi-

(7) di ol Adonajğa čyğarma alarny jerinden Micrinin ol keče

(8) ošpu Adonajğa saqlavlardy bar ulanlaryna Jisra’elnin dorlary

(9) sajyn _čyġarma alarny buda galuttan ${ }^{11}$. ויאמר. [43] Da ajtty

(10) Adonaj Mošege da Aharonga budur resimi qarbanynyn ol

(11) Pesahnnyn heč jat kiši ašamasyn andan. וכל [44] Da bar qulu kiši-

(12) nin satyn alġany kümüšnün da ḥatna qylsaj any ol vaḥtta

(13) ašasyn andan. תושב. [45] Očar da jalčy ašamasyn andan.

\footnotetext{
${ }^{1}$ Interpretative addition to the standard text.
} 
(7) to hurry to drive them out from the land, because they said,

(8) 'We are all dead.' [34] And the people lifted and placed

(9) their dough on their shoulders before

(10) it leavened, their leavening vessels being

(11) bound up in their bedsheets. [35] And the children of Israel

(12) did according to the word of Moses, and they borrowed

(13) from the Egyptians vessels of silver and vessels of gold and clothing.

(14) [36] And the Lord gave the people's favour

(15) in the eyes of the people of Egypt, so that they lent

(16) to them. And they plundered Egypt. [37] And

(17) the children of Israel journeyed from Rameses to Succoth.

(18) The young men, besides children: six times a hundred thousand on foot. [38] And

(19) also a wild multitude went up with them, and sheep, and cattle,

(20) a very strong livestock. [39] And they baked

(21) unleavened dough which they brought out of Egypt: cakes of unleavened bread, because it was not leavened,

(1) because they were driven out of Egypt and could not delay, and

(2) they also had not prepared provisions for themselves. [40] And the stay

(3) of the children of Israel that they stayed in Egypt, was four hundred years and

(4) thirty years. [41] And it was in the course of the four hundred and thirty

(5) years, and it was on the very same day that all

(6) the hosts of the Lord went out from the land of Egypt. [42] It is a night

(7) to be observed for the Lord for bringing them out from the land of Egypt. This is this night

(8) to be observed for the Lord by all the children of Israel throughout their generations,

(9) for taking them out even from this exile ${ }^{187}$. [43] And the Lord said

(10) to Moses and Aaron, 'This is the statute of the

(11) Passover: no foreigner shall eat of it. [44] And every man's servant

(12) that is bought for silver, if you have circumcised him, then

(13) he shall eat thereof. [45] A settler and an hired servant shall not eat thereof.

87 An interpretative addition to Exo 12:42. 
(14) בבית [46] Bir üvde ašalsyn čyġarmag̉yn ol üvden ol et-

(15) ten tyšqaryğa da süvek syndyrmajyz anda. כל ב47 [4] Bar

(16) Žymaty Jisra’elnin qylsynlar any. וכי [48] Da ki tirilśa

(17) birgeja garip da klese qylma qarbanyn Pesahnnyn Adonajğa

(18) kereklidi ḥatna qylma anar bar erkekni da ol vaḥtta

(19) juvusun qylma any da bolur j[e]rl[i]s[i] ${ }^{1}$ kibik ol jernin da heč

(20) aqlafly ašamasyn andan. תורה. [49] Bir üvretüv bolsun j[e]rl[i-

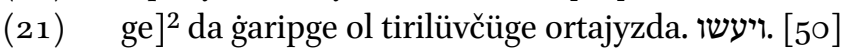

$107 \mathrm{r}^{\mathrm{o}} \quad$ (1) Da qyldylar bar ulanlary Jisra’elnin ki nečik bujurdu Adonaj

(2) Mošege da Aharongaa alaj qyldylar. ויהי [51] Da edi

(3) kensisinde ošpu künnün čyġardy Adonaj ošol ulanlaryn

(4) Jisra’elnin jerind́an Micrinin jyjynlarybyla alarnyn.

[Exodus 13]

(5) Da sözledi Adonaj Mošege ajtadoġač. קדש. [2] Aziz

(6) etkin maja bar tunġučnu ačylmaġyn qursaqny ulanlaryn-

(7) da Jisra'elnin adamda da tuvarda majady ol. ויאמר. [3]

(8) Da ajtty Moše ol ulusqa saġynġyn ošol ol künnü

(9) ošpunu ki čyqtyjyz Micriden qullar erkinden ki küčlü

(10) qudratbyla čyğardy Adonaj sizni bundan da ašalmasyn ḥamec.

(11) היום [4] Bügün siz čyğasiz ol baš qusqan janġajda.

(12) והיה [5] Da bolgaj ki keltirse seni Adonaj jerine ol Kenáani-

(13) nin da ol Ḥitinin da ol Emorinin da ol Ḥivinin da ol Jevusi-

(14) nin ki antetti atalaryja berḿa saja jer ag̉adog̉an süt

(15) da bal da qulluq etkin ošol ol qulluqnu ošpunu oš-

(16) pu janġajda. שבעת. [6] Jedi künler ašag̉yn macalar da

\footnotetext{
${ }^{1} \mathrm{~K}$ : jarlysy; a scribal error; cf. Exo 12:19, Exo 12:49, Lev 16:29, Lev 17:15, and Lev 24:16. | TKow.o1: unvocalized text. | H: jerlisi. | C: jerlisi. $\quad{ }^{2} \mathrm{~K}$ : jarlyg்a; a scribal error; cf. Exo 12:19, Exo 12:48, Lev 16:29, Lev 17:15, and Lev 24:16. | TKow.o1: unvocalized text. | H: jerlisi.| C: jerligä.
} 
(14) [46] It shall be eaten in one house, you shall not bring out any of the flesh

(15) outside of the house, and you shall not break a bone of it. [47] All

(16) the congregation of Israel shall do it. [48] And if

(17) a stranger shall live with you, and shall want to do the Passover sacrifice to the Lord,

(18) it is needed to let him be circumcised, every male, and then

(19) he may come near to do it, and he shall be as one of the [native ${ }^{88}$ of the land. But no

(20) uncircumcised person shall eat of it. [49] One teaching shall be to the [native ${ }^{89}$,

(21) and to the stranger who lives among you.' [50]

(1) And all the children of Israel did as the Lord commanded

(2) Moses and Aaron, so did they. [51] And it was

(3) the very same day: the Lord brought out the children

(4) of Israel from the land of Egypt with their hosts.

[Exodus 13]

(5) And the Lord spoke to Moses, saying, [2] 'Sanctify

(6) to me all the firstborn, the opening of the womb among the children

(7) of Israel, both of man and of animal: it is mine.' [3]

(8) And Moses said to the people, 'Remember this day,

(9) in which you came out from Egypt, from the reign of slaves, because

(10) the Lord brought you out from this place by a strong hand. And no leavened |bread| shall be eaten.

(11) [4] Today you are going out, in the month of Baš Qusqan.

(12) [5] And it shall be, when the Lord brings you to the land of the Canaanites,

(13) and the Hittites, and the Amorites, and the Hivites, and the Jebusites,

(14) which he swore to your fathers to give you, a land flowing $\mid$ with $\mid$ milk

(15) and honey, that you shall keep this service in this

(16) month. [6] Seven days you shall eat unleavened bread, and

88 K: 'poor'; a scribal error, cf. Heb. כְִּּזָ 'as a native'; cf. also Exo 12:19, Exo 12:49, Lev 16:29, and Lev 17:15.

89 K: 'poor'; a scribal error, cf. Heb. לִאיזזָרח 'to a native'; cf. also Exo 12:19, Exo 12:48, Lev 16:29, and Lev 17:15. 
(17) ol jedinči künde hyyž Adonajg̉a. מצות. [7] Macalar

(18) ašalsyn jedi ol künlerde da körünmesin saja ḥamec da

(19) körünmesin saja qužur bar čegijde. והגדת. [8] Da

(20) anlatqyn uvluja ol künd́a ajtadoġač bunun ücün qyldy

(21) Adonaj maja čyqqanymda Micriden. והיה. [9] Da bolsun saja

$107 \mathrm{v}^{\mathrm{o}} \quad$ (1) belgige $\mathrm{q}[\mathrm{o}] \mathrm{luj}{ }^{1}$ üstüne da saǵynčqa közlerij arasyna anyn

(2) üčün ki bolġaj torasy Adonajnyn avzujda ki küčlü qudrat-

(3) byla čyğardy seni Adonaj Micriden. ושמרת. [10] Da saqlaġyn ošol

(4) ol resimni ošpunu vağdasynda jyldan jylğa. והית [11 Da

(5) bolġaj ki keltirse seni Adonaj jerine ol Kena'aninin ki nečik

(6) antetti saja da atalaryja da berse any saja. והעברת [12]

(7) Da ašyrg̉yn bar ačylmaġyn qursaqnyn Adonajğa da bar ačylma-

(8) ġyn ijilmeginin tuvarnyn ki bolsa saja ol erkekler Adonaj-

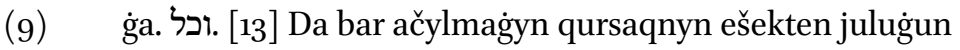

(10) qojbyla da eger julumasaj da enselegin any da bar tun-

(11) ġučun adamnyn ulanlaryjda julug̉un. והיה. [14] Da bolġaj ki sor-

(12) sa send́an uvluj qačanda ajtadoġač nedir bu da ajtqyn anar

(13) küčlü qudrat byla čyġardy bizni Adonaj Micriden qullar erkin-

(14) den. [15] Da edi ki nečik qattyrdy paro jüregin kle-

(15) mesedi ijme bizni da qyrdy Adonaj bar tunguučnu jerin-

(16) de Micrinin bašlap tunġučundan adamnyn $\{d a\}$ tunġučunadejin tuvar-

(17) nyn anyn üčün men debeḥa etemen Adonajg̉a bar ačylmag̉yn qur-

(18) saqnyn ol erkekĺarni da bar tunġučun ulanlarymnyn julujmen.

(19) והיה Da bolsun belgige q[o]lujüstüne ${ }^{2}$ da totafotqa

(20) közlerij arasyna ki küčlü qudrat byla čyğardy bizni Adonaj

(21) Micriden.

108 ro $^{\circ} \quad$ (1)

(17 Da edi ijgend́a paro

(3) ošol ol ulusnu da köndermedi alarny Tenri

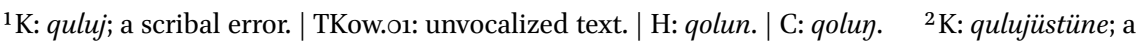
scribal error. | TKow.o1: unvocalized text. | H: qolun istine. | C: qoluך üstünä. 
(17) on the seventh day: a feast to the Lord. [7] Seven days shall unleavened bread

(18) be eaten, and there shall be no leavened |bread $\mid$ seen with you, and

(19) there shall be no leaven seen with you in all your borders. [8] And

(20) you shall tell your son in that day, saying, "Because of that |which|

(21) the Lord did to me when I went out from Egypt." [9] And it shall

(1) be for a sign to you on your [hand], and for a memorial between your $107 \mathrm{v}^{\mathrm{o}}$ eyes, that

(2) the Lord's Law may be in your mouth, because with a strong hand

(3) has the Lord brought you out from Egypt. [10] And you shall keep

(4) this statute at its appointed time from year to year. [11] And

(5) it shall be, when the Lord shall bring you to the land of the Canaanites, as

(6) he swore to you and to your fathers, and he would give it to you, [12]

(7) that you shall pass all the openings of the womb to the Lord; and every opening

(8) $\mid$ of the womb $\mid$ of the progeny of livestock which you have, the males, are the Lord's.

(9) [13] And you shall redeem every opening of the womb of a donkey

(10) with a sheep, and if you do not redeem it, then you shall stab it to death, and

(11) you shall redeem all the firstborn of man among your children. [14] And it shall be, when

(12) your son asks you some time, saying, "What is this?", you shall say to him,

(13) "The Lord brought us out from Egypt, from the reign of slaves by a strong hand.

(14) $[15]$ And it was, when Pharaoh hardened his heart and

(15) kept refusing to let us go, that the Lord slew all the firstborn in the land

(16) of Egypt, from the firstborn of man, to the firstborn of animal.

(17) On account of this I sacrifice to the Lord all openings of the womb,

(18) the males, and I redeem all the firstborn of my children."

(19) [16] And it shall be for a sign on your hand, and for frontlets

(20) between your eyes, because with strength of hand the Lord brought us out

(21) from Egypt.'

(1) Parashat Beshalach

$108 \mathrm{r}^{\mathrm{o}}$

(2) [17] And it was, when Pharaoh had let

(3) the people go, that God led them not 
(4) jolubyla jerinin Pelištimnin ḥote juvuq edi ol ki ajtty

(5) Tenri mag̉at fašman eter ol ulus kö\{r $r$ genlerind́a čerüvnü

(6) da qajtyrlar Micriǵa. [ויסב Da qajyrdy Tenri ošol

(7) ol ulusnu ${ }_{L}\{\text { jolubyla o[l] midbarnyn }\}^{11} \mathrm{Jam}$ Sufqa da jasanganlar čyqtylar ulanlary Jisra-

(8) 'ויקח [19] Da aldy Moše ošol

(9) süveklerin Josefnin birgesina ki antettirme antet-

(10) tirdi ošol ulanlaryn Jisra’elnin ajtadoġač saġynma saġynsa

(11) Tenri sizni da čyğaryjyz ošol süveklerimni bundan birgejizǵa.

(12) ויסעו (20] Da köčtüler Sukottan da toḥtadylar Etam-

(13) da učunda ol midbarnyn. ויהוה [21] Da \{šehinasy\} Adonajnyn baryr[e]-

(14) di alynlarynda alarnyn kündüz baġanasy byla bulutnun kön-

(15) derme alarny ol jolbyla da kečebyla bag̉anasybyla otnun

(16) jaryq etme alargaa barma kündüz da kečebylada. לא. [22]

(17) Eksilmesedi baġanasy ol bulutnun kündüz da baġanasy ol

(18) otnun kečebyla alnynda ol ulusnun.

Exodus 14

. וידבר [1] Da sözle-

(19) di Adonaj Mošege ajtadoġač. דבר. [2] Sözlegin ulanlaryna

(20) Jisra’elnin da qajtsynlar da toḥtasynlar alnynda Pi

$108 \mathrm{v}^{\mathrm{o}}$ (1) Hahirotnun arasyna Miğdolnun da arasyna ol tengiznin al-

(2) nynda Báal Čefonnun uturusuna anyn toḥtajyz ol tengizqa-

(3) tyna. ואמר [3] Da ajtyr par'o ulanlary üčün Jisra’elnin

(4) qobulušadylar alar jerde bekledi alar ašyra ol midbar³

(4) וחז [4 Da qattyry\{r\}men ošol jüregin par'onun da quvar

(6) artlaryndan alarnyn da syjymny körgüzürmen par'oda da

(7) bar čerüvünd́a anyn da bilirler Micrililer ki menmen Adonaj

(8) da qyldylar alaj. [5] Da anlatyldy bijine Micrinin ki

(9) qačty ol ulus da čüvürüldü jüregi par'onun da qullary-

\footnotetext{
${ }^{1}$ Marginal insertion by another hand. | TKow.o1: jolusary ol midbarnyn; unvocalized text. | H: joluna ol midbarnyn. | C: joluna ol jabannyy. $\quad{ }^{2} \mathrm{~K}$ : baryridi; probably a scribal error. | TKow.o1: unvocalized text. | H: baryr edi. | C: jürür edi. $\quad{ }^{3} \mathrm{~K}$ : midbarny; a scribal error. | TKow.o1: midbar; unvocalized text. | H: midbar. | C: jaban.
} 
(4) by way of the land of the Philistines, although that was near, because God said,

(5) 'Lest the people repent when they see war,

(6) and they return to Egypt.' [18] But God turned the

(7) people around \{by the way of the wilderness $\}$ toward the Red Sea. And the people of Israel went up armed

(8) from the land of Egypt. [19] And Moses took the

(9) bones of Joseph with him, for

(10) he had made the children of Israel surely swear, saying, 'God will surely

(11) remember you, and you shall carry up my bones with you from here.'

(12) [20] And they journeyed from Succoth and dwelt at Etham,

(13) on the edge of the wilderness. [21] And the divine Presence of Lord went

(14) before them by day in a pillar of cloud to lead

(15) them along the way, and by night in a pillar of fire

(16) to give them light, so as to go by day and by night. [22]

(17) The pillar of the cloud by day and the pillar

(18) of fire by night did not vanish from before the people.

Exodus 14

(19) the Lord spoke to Moses, saying, [2] 'Speak to the children

(20) of Israel, that they shall turn and dwell before Pi-

(1) -Hahiroth, between Migdol and the sea,

(2) in front of Baal-Zephon. You shall dwell opposite to it, by the sea.

(3) [3] And Pharaoh will say of the children of Israel,

(4) "They are confused in the land, the wilderness ${ }_{L}$ has closed them in 190 ."

(5) [4] And I will harden Pharaoh's heart, and he will pursue

(6) after them, and I will show my glory over Pharaoh, and

(7) over all his army, and the Egyptians will know that I am the Lord.'

(8) And they did so. [5] And it was told the king of Egypt that

(9) the people fled, and the heart of Pharaoh and of his servants was turned

$90 \quad$ Lit. 'has shut over them'. 
(10) nyn ol ulusqa da ajttylar nebu qyldy\{q\} ki ijdik ošol

(11) Jisra’elni qullugiumuzdan. ויאסר [6] Da jerledi par'o ošol

(12) markavyn özünün da ošol ulusun aldy birgesińa. ויקח. [7]

(13) Da aldy alty jüz markav sajlag̉an da bar markavyn Micrinin

(14) da ag̉alyqlar symarlady barysy üstüne. ויחז [8] Da

(15) qattyrdy Adonaj ošol jüregin par'onun bijinin Micrinin da

(16) quvdu artyndan ulanlarynyn Jisra'elnin da ulanlary Jisra'elnin

(17) čygaredilar küčlü qolbyla. [9] Da quvdular eli

(18) Micrinin alar artyna da jettiler alarny toḥtajdoġanlarny ol

(19) tengiz qatyna bar aty markavy par'onun da jalan atlylary da

(20) čerüvü anyn alnynda Pi Haḥirotnun uturusuna Ba'al Čefon-

(21) nun. ופרעה. [10] Da par'o juvuttu avulun da kötürdü-

$109 \mathrm{r}^{\circ} \quad$ (1) ler ulanlary Jisra’elnin ošol közlerin da muna eli Micrinin

(2) köčer alar artyna da qorqtular astry da firjat etti-

(3) ler ulanlary Jisra'elnin Adonajgja. [11] Da ajttylar

(4) Mošege zeretlermo jog̉undan Micride aldyj bizni ölma

(5) midbarda nebu qyldyj bizge čyğarma bizni Micriden. הלא. [12]

(6) Muna budur ol söz ki sözledik saja Micrid́a ajtadog̉ač

(7) qalġyn bizden da qulluq etejik Micriǵa ki jaḥšyraqty $\{\text { bizge }\}^{1}$ qulluq

(8) etma Micrige ölgenimizden midbarda. ויאמר [13] Da

(9) ajtty Moše ol ulusqa qorqmajyz turujuz da baġyjyz ošol

(10) jarlyğašyn Adonajnyn ki qylar sizge bügün ki nečik kördüjüz

(11) ošol Micrini bügün arttyrmassiz körḿa any dunjaġadejin.

(12) יהוה (14] Adonaj urušur siznin üčün da siz tyjylyp turar-

(13) siz. ויאמר] Da ajtty Adonaj Mošege ne firjat e-

(14) teśan maja sözlegin ulanlaryna Jisra’elnin da köčsünĺar.

(15) (16] Da sen kötürgün ošol tajaġyjny da sung̉un ošol

(16) qolujnu ol tengiz üstüne da [jarčyqlaġyn] $]^{2}$ any da kelsinler

(17) ulanlary Jisra’elnin ortasyna ol tengiznin qurubyla. ואני [17]

(18) Da men muna qattyryrmen ošol jüregin elinin Micrinin da

(19) kelirler alar artyna da syjymny körgüzürmen par'oda

(20) da bar čerüvünd́a anyn markavynda da jalan atlylarynda anyn.

\footnotetext{
${ }^{1}$ Interlinear insertion by another hand. | TKow.o1: bizge; unvocalized text. | H: bizge. | C: bizgä. ${ }^{2} \mathrm{~K}$ : jarčylgan; a scribal error, cf. Exo 14:21. | TKow.o1: jarčyqlaġyn; unvocalized text. | H: jarcyqlaġyn. | C: jarġyn.
} 
(10) against the people, and they said, 'What is this that we have done, that we have let

(11) Israel go from serving us?' [6] And Pharaoh harnessed

(12) his chariot and took his people with him. [7]

(13) And he took six hundred chosen chariots, and all the chariots of Egypt,

(14) and commanded rulers over all of them. [8] And

(15) the Lord hardened the heart of Pharaoh, king of Egypt, and

(16) he pursued the children of Israel, and the children of Israel

(17) went out with a strong hand. [9] And the people of Egypt pursued

(18) after them, and reached them, dwelling by the sea,

(19) all the horses, chariots of Pharaoh, and his horsemen, and

(20) his army before Pi-Hahiroth, in front of Baal-Zephon. [10]

(21) And Pharaoh drew near his camp, and

(1) the children of Israel raised their eyes, and, lo, the people of Egypt

(2) journeyed after them, and they feared greatly. And

(3) the children of Israel cried out to the Lord. [11] And they said

(4) to Moses, 'Is it because of an absence of graves in Egypt |that| you have taken us away to die

(5) in the wilderness? What is this you have done to us to bring us out of Egypt? [12]

(6) Lo, this is the word that we spoke to you in Egypt, saying,

(7) "Leave us alone and let us serve in Egypt." For it is better $\{$ for us $\}$ to serve

(8) Egypt than to die in the wilderness.' [13] And

(9) Moses said to the people, 'Do not fear, stand still, and see the

(10) salvation of the Lord, which he will work for you today. For, as you saw

(11) Egypt today, you will not see it again, ever.

(12) [14] The Lord will fight for you, and you will stand and be silent.'

(13) [15] And the Lord said to Moses, 'Why do you cry out

(14) to me? Speak to the children of Israel, and they shall journey forward.

(15) [16] And you: lift up your staff and reach out your

(16) hand over the sea and [split] it, and may

(17) the children of Israel go through the midst of the sea on dry ground. [17]

(18) And I: lo, I will harden the hearts of the people of Egypt and

(19) they will come after them, and I will show my glory over Pharaoh

(20) and over all his army, over his chariots, and over his horsemen. 


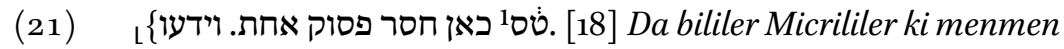
Adonaj syjymny körgüzgenimde par'oda markavynda da jalan atlylarynda.\} $]^{12}$. ו19] Da köčtü malahy ol Tenrinin ol baruvču alnynda

$109 \mathrm{v}^{\mathrm{o}} \quad$ (1) avulnun Jisra’elnin da bardy artlaryndan alarnyn da köčtü bag̉anasy

(2) ol bulutnun alynlaryndan alarnyn da turdu alar artyna. [20]

(3) Da keldi arasyna avulunun Micrinin da arasyna avulunun Jisra'el-

(4) nin da boldu ol bulut da ol qaranġylyq da jarytty ošol ol

(5) kečeni ${ }_{\text {L }}$ ulanlaryna Jisra'elni[ []$^{13}$ da ol bulut da ol qaranġylyq edi

(6) avuluna Micrinin anlyqbyla juvumady bu bunar bar ol kečed́a.

(7) ויט [21] Da sundu Moše ošol qolun ol tengiz üstüńa da

(8) jürüttü Adonaj ošol ol tengizni qadim jeli byla küčlü bar ol

(9) kečed́a da qojdu ošol ol tengizni qurug̉a andan sortun

(10) nečik jarčyqlandylar ol suvlar. ויבואו [22] Da keldilar ulanlary

(11) Jisra'el[nin $]^{4}$ ortasyna ol tengiznin qurubyla da ol [...] \{[suv $]$ lar $\}^{5}$ edi-

(12) ler alarga qalaornuna on janlaryndan da son janlaryndan.

(13) ויה [24 Da edi ol tan saruvunda da baqty $\left\{\right.$ Adonaj $^{6}$ avuluna

(14) Micrinin bag̉anasy byla otnun da bulutnun da bulġanyštyr-

(15) dy ošol avulun Micrinin. וירדפו [23] \{ $\boldsymbol{\aleph}\}$ Da quvdular

(16) Micrililer da keldiler alar artyna bar aty par'onun mar-

(17) kavy da jalan atlylary anyn ortasyna ol tengiznin.

(18) Da keterdi ošol küpčegin ma $\{r\}$ kavlarynyn da könderdi any

(19) avurluqbyla da ajtty $\mathrm{el}[\mathrm{i}] \mathrm{Micrinin}{ }^{18}$ qačajym alnyndan Jisra’el-

(20) nin ki Adonaj urušady alar üčün Micribyla. ויאמר [26 Da

(21) ajtty Adonaj Mošege sunġun ošol qolujnu ol tengiz üs-

$110 \mathrm{r}^{\mathrm{o}}$ (1) tüne da qajtsynlar ol suvlar Micri üstüne markavy üs-

(2) tüne da jalan atlylary üstüne. ויט [27] Da sundu Moše

(3) ošol qolun ol tengiz üstüne da qajtty ol tengiz tan

(4) saruvlarynda ornuna özünün da Micrililer qačarediler

\footnotetext{
${ }^{1}$ An abbreviation of Heb. טָעוּת סוֹפֵר 'scribal error'. $\quad{ }^{2}$ Marginal insertion by another hand. | TKow.o1: Da bilirler eli Micrinin ki menmen Adonaj syjymny körgüzgenimde par'oda markavynda da jalan atlylarynda anyn; unvocalized text. | H: Da bilirler Micrililer ki menmen H syjymny körgizgenimde paro'da markavynda anyn da jalan atlylarynda anyn. | C: Da bilgäjlär Mysyrlylar ki menmin H hörmätli bolganymda par'oġa markavyna da yspahilärinä. $\quad{ }^{3} \mathrm{~K}$ : Jisra’elni; a scribal error. | TKow.o1: Jisra'elnin; unvocalized text. | H: Jisra'elge. | C: deest. ${ }^{4} \mathrm{~K}$ : Jisra'el; a scribal error. | TKow.o1: Jisra'elnin; unvocalized text. | H: Jisra'elnin. | C: Jisra'elnin. $\quad{ }^{5}$ Marginal insertion by another hand. | TKow.or: suvlar; unvocalized text. | H: suvlar.| C: suvlar. ${ }^{6}$ Marginal insertion by another hand. | TKow.o1: Adonaj; unvocalized text. | H: Adonaj.|C: H. $\quad{ }^{7}$ The actual order of this and the next verse was corrected by the copyist by numbering the verse-beginning words with $\boldsymbol{\aleph}$ and $\mathrm{I}$, respectively. $\quad{ }^{8} \mathrm{~K}$ : ele Micrinin; a scribal error. | TKow.o1: unvocalized text. | H: Micri.| C: Mysyrlylar.
} 
(21) $[18]_{\perp}\{\text { Scribal error. One verse is missing here. }\}^{191}\{$ And the Egyptians will know that I am the Lord when I have shown my glory over Pharaoh, over his chariots, and over his horsemen.'\} [19] And the angel of God, the one that went before

(1) the camp of Israel, journeyed and went behind them, and the pillar of $109 \mathrm{v}^{\mathrm{o}}$ cloud journeyed

(2) from before them, and stood behind them. [20]

(3) And it came between the camp of Egypt and the camp of Israel.

(4) And there was the cloud and the darkness. And it ${ }^{92}$ lit up the

(5) night for the children of Israel, and there was darkness

(6) for the camp of Egypt, and by this, this $|\mathrm{camp}|$ did not come near to ${ }_{\text {t }}$ that $|\mathrm{camp}|{ }^{193}$ all the night.

(7) [21] And Moses reached out his hand over the sea, and

(8) the Lord caused the sea to walk with a strong east wind all that

(9) night, and made the sea into dry ground after

(10) the waters were split. [22] And the children

(11) of Israel went into the midst of the sea on dry ground. And the $\{$ waters $\}$ were

(12) a wall to them on their right side, and on their left side.

(13) ${ }_{L}[24]\{2 n d\}$ And it was in the morning watch, and $\{$ the Lord $\}$ looked at the camp of

(14) Egypt through the pillar of fire and the cloud, and caused a stir

(15) in the camp of Egypt. [23] \{1st\} And the Egyptians pursued,

(16) and came after them - even all Pharaoh's horses,

(17) his chariots, and his horsemen —into the midst of the sea, ${ }^{194}$ [25]

(18) And took off their chariot wheels, so that they drove them

(19) heavily. And the people of Egypt said, 'Let me flee from before Israel,

(20) because the Lord is fighting for them against Egypt.' [26] And

(21) the Lord said to Moses, 'Reach out your hand over the sea,

(1) and the waters shall come back over Egypt, over its chariots, $110 \mathrm{r}^{\mathrm{o}}$

(2) and over its horsemen.' [27] And Moses reached out

(3) his hand over the sea, and the sea returned

(4) to its place at dawn. And the Egyptians fled

$91 \quad$ Inserted by another hand in Hebrew.

92 I.e., the pillar of fire.

93 Lit. 'to this'.

94 The order of these two verses was corrected by the copyist. 
(5) uturusuna anyn da battyrdy Adonaj ošol Micrini or-

(6) tasynda ol tengiznin. [28] Da qajttylar ol suvlar

(7) da qapladylar ošol $\{$ ol markav[ny da $]\}^{11}$ ol jalanatlylarny bar čerüvün par'onun

(8) ol kelüvčülerni alar artyna tengizge qalmady alardan

(9) birgedejin. ובני [29] Da ulanlary Jisra'elnin bardylar $\{\text { quruby[la] }\}^{2}$ ortasy

(10) ašyra ol tengiznin da ol suvlar edilar alarg̉a qalaor-

(11) nuna on janlaryndan da son janlaryndan. [30] Da qut-

(12) qardy \{Adonaj\} ol künde ošol Jisra'elni qolundan Micrinin da

(13) kördü Jisra'el ošol Micrini ölgenni turadoġač qyryj-

(14) üstüne ol tengiznin. [31] Da kördü Jisra’el

(15) ošol ol ullu qudratyn ki qyldy Adonaj Micrid́a da

(16) qorqtular ol ulus Adonajdan da inandylar birligine

(17) Adonajnyn da naviligine Mošenin qulunun.

\section{Exodus 15}

(18) vaḥtta šira oḥudu Moše da ulanlary Jisra’elnin ošol

(19) ol širany ošpunu Adonajğa da ajttylar ajtadoġač

(20) šira ohujum Adonajğa ki ulluq ${ }^{3}$ qylma ulluq ${ }^{4}$ qyldy atny

(21) da atlanuvčusun qyjasa kötürüp saldy tengizge.

110 v $^{\mathrm{o}}$ (1) עז [2] Küčümdü da maḥtavumdu Tenri da boldu maja jarly-

(2) ġašqa budur Tenrim ${ }_{L}$ da orun hadirlejim šehinasyna anyn ${ }^{15}$

(3) Tenrisidi atamnyn da bijikligin qotarajym anyn. יהוה. [3] Adonaj

(4) čerüv jesisidi Adonajdy kensi šemi anyn. מרכבות. [4]

(5) Markavla\{r\}yn par'onun da čerüvün anyn oqlajyn ${ }^{6}$ atty tengiz-

(6) ge da sajlama agalyqlary battyryldylar Jam Sufta.

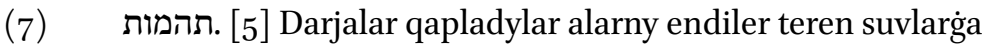

(8) taš kibik. ימינך. [6] On küčüj senin e Adonaj küčlüdü

(9) quvatbyla on hyš̌šymyj senin e Adonaj syndyrdy dušmanny.

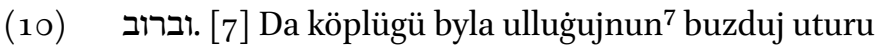

\footnotetext{
${ }^{1}$ Marginal insertion by another hand. | TKow.o1: ol markavny da; unvocalized text. | H: ol markavny da. | C: šol markavny da. $\quad{ }^{2}$ Marginal insertion by another hand. | TKow.o1: qurubyla; unvocalized text. | H: quru byla. | C: quru bilän. $\quad{ }^{3} \mathrm{~K}$ : haplologic form of ulluluq; cf. Exo 15:7, 15:16, 15:21, Deu 10:20. | TKow.o1: ulluluq. | H: ulluluq. | C: öktämlik. $\quad{ }^{4} \mathrm{~K}$ : haplologic form of ulluluq. | TKow.o1: ulluluq. | H: ulluluq. | C: öktämlik. ${ }^{5}$ Interpretative addition to the standard text. ${ }^{6}$ Interpretative addition to the standard text. $\quad{ }^{7} \mathrm{~K}$ : haplologic form of ullulugujnun.| TKow.o1: ulluluġujnun. | H: ulluluginnun. | C: öktämligin.
} 
(5) against it, and the Lord drowned Egypt

(6) in the midst of the sea. [28] And the waters returned,

(7) and covered \{the chariots, and $\}$ the horsemen, and all the army of Pharaoh

(8) that came after them in the sea. Not even one of them remained.

(9) [29] And the children of Israel went \{on dry ground $\}$ through the midst

(10) of the sea, and the waters were in place of a wall to them

(11) on their right side, and on their left side. [30] And

(12) the Lord saved Israel that day from Egypt's hand. And

(13) Israel saw Egypt dead standing

(14) on the sea shore. [31] And Israel saw

(15) that great power which the Lord had done against Egypt, and

(16) the people feared the Lord, and believed the oneness

(17) of the Lord, and the prophecy of his servant Moses.

\section{Exodus 15}

(18) Then Moses and the children of Israel sang this

(19) song to the Lord, and said, saying,

(20) 'Let me sing to the Lord, for he has certainly done greatness. Horse

(21) and its rider he has lifted in a way and thrown in the sea.

(1) [2] God is my strength and praise, and He became a salvation for me. $110 \mathrm{v}^{\mathrm{o}}$

(2) This is my God, and let me prepare a place for his divine Presence ${ }^{195}$.

(3) He is my father's God, and I will preach his exaltedness. [3] The Lord

(4) is a man of war. The Lord is his own name. [4]

(5) Pharaoh's chariots and his army he cast in the sea ${ }_{L}$ like an arrow ${ }^{196}$,

(6) and his chosen rulers were drowned in the Red sea.

(7) [5] The deeps have covered them, they went down to the deep waters

(8) like a stone. [6] Your right strength, oh Lord, is strong

(9) in power, your right hand, oh Lord, crashed the enemy.

(10) [7] And with the abundance of your exaltedness you destroyed

95 An interpretative addition to Exo 15:2.

96 An interpretative addition to Exo 15:4. 
(11) turuvčularyjny ijdij qahirijni örtedi alarny qurany kibik.

(12) (8) Da jeli byla ačuvujnun jüklendilar suvlar tur-

(13) dular bardaqtaġylaj ${ }^{1}$ ağyn suvlar tutuštular darjalar ortasyn-

(14) da tengiznin. אמר. [9] Ajtybedi paro dušman quvajym

(15) jetejim ülešejim olža tolsun alardan klegim suvurajym

(16) qylyčymny tasetsin alarny qolum. [שפת. [10] Ürdüj

(17) jelijbyla qaplady alarny tengiz battylar qorgasašyn kibik küč-

(18) lü suvlarda. מי. [11] Joḥtur senin kibik malahlar arasy-

(19) nada e Adonaj joḥtur senin kibik küčlü Tenri aziz kök-

(20) tede qorqunčlu bij maḥta $\{v\} l a r$ jarašady saja ki sensen qyluvču

(21) ažajip išler. נטית [12] Sunduj on hyyššymyjny juttu

$111 \mathrm{r}^{\mathrm{o}}$ (1) alarny jer. נחית. [13] Köndergin šavagatyjbyla bu ulusnu

(2) ki juluduj eltkin quvatyjbyla aziz ornuja ${ }_{L}$ ol jerge

(3) ki tutunduj atalaryna alarnyn berme alarga ${ }^{12}$. שמעו [14]

(4) Ešittiler uluslar ${ }_{\lfloor}$bu ullu tamašalyqlarny ${ }^{13}$ qaltradylar titre-

(5) vük tuttu olturuvčularyn Plešetnin. זא. [15] Ol vaḥtta

(6) alġasandylar aluflary Edomnun bijlerin Mo’avnyn tuttu

(7) alarny qaltravuq iridilar jürekleri ${ }^{4}$ bar olturuvčularynyn

(8) Kפול Kena' [16] Tüšsün alar üstüne qorquv

(9) da qobuv ullulug̉ubyla quvatyjnyn qaryšsynlar taš kibik

(10) neginče ašqaj öz jerińa ulusuj senin e Adonaj negin-

(11) če aškaj ortalary ašyra bu ulus ki bar ettij.

(12) תביאמו (17) Keltirgin alarny da ornatqyn alarny ü-

(13) lüš tavyjda tüzüv qajjam šehinajnyn toḥtamag̉yna qylġyn

(14) e Adonaj miqdašynda e Adonaj tüzüsünler qudratlaryj.

(15) יהוה [18] Adonaj bijlik eter dunjag̉adejin da ömürgedejin.

(16) כי (19] Ki keldi aty par'onun markavybyla da jalan atlyla-

\footnotetext{
${ }^{1}$ Interpretative addition to the standard text. $\quad{ }^{2}$ Interpretative addition to the standard text.

${ }^{3}$ Interpretative addition to the standard text. $\quad{ }^{4}$ Interpretative addition to the standard text.
} 
(11) those that rose up against you, you sent forth your fury, it consumed them like straw.

(12) [8] And with the wind of your anger the waters were piled up, the waters

(13) stood like ${ }_{\mathrm{L}}$ in a glass ${ }^{197}$, the depths congealed in the midst

(14) of the sea. [9] Pharaoh, the enemy, had said, "Let me pursue,

(15) let me catch up, let me divide the spoil, let my desire have its fill of them. Let me draw

(16) my sword. My hand shall destroy them." [10] You blew

(17) with your wind, the sea covered them, they sank like lead

(18) in the mighty waters. [11] LThere is none like you among the angels,

(19) oh Lord. There is none like you mighty God even in the holy

(20) sky, awesome lord, you deserve praises because you are who does

(21) wondrous things ${ }^{198}$. [12] You reached out your right hand,

(1) earth swallowed them. [13] Lead, in your mercy, this people

(2) whom you redeemed, guide them in your strength to your holy place - the ${ }_{L}$ land

(3) which you swore to their fathers to give it to them ${ }^{199}$. [14]

(4) Peoples heard ${ }_{L}$ these great wonders ${ }^{1100}$, they trembled,

(5) shiver took hold on the inhabitants of Philistia. [15] Then

(6) the chiefs of Edom were dismayed. Trembling took hold on the rulers of Moab.

(7) All the hearts ${ }^{1101}$ of inhabitants of Canaan melted away.

(8) [16] Fear and dread shall fall on them,

(9) by the greatness of your strength they shall be still like stone.

(10) Until your people pass over to their own land, oh Lord,

(11) until the people whom you have conquered pass through.

(12) [17] You shall bring them in, and plant them

(13) in your mountain of share, you shall make the edifice of your eternal divine Presence to dwell in,

(14) oh Lord, in your sanctuary, oh Lord, which your hands shall build.

(15) [18] The Lord will reign forever and ever.'

(16) [19] Because the Pharaoh's horse with his chariot and with his horsemen came

97 An interpretative addition to Exo 15:8.

98 A free interpretative translation of Exo 15:11.

99 An interpretative addition to Exo 15:13.

100 An interpretative addition to Exo 15:14.

101 An interpretative addition to Exo 15:15. 
(17) rybyla tengizge da qajtardy Adonaj alar üstüne ošol

(18) suvlaryn ol tengiznin da ulanlary Jisra’elnin bardylar quruby-

(19) la ortasy ašyra ol tengiznin. [20] Da aldy

(20) Mirjam ol navia tuvdugiu Aharonnun ošol ol tafny qoluna

(21) da čyqtylar bar ol qatynlar anyn artyna taflar byla da

$111 v^{0} \quad$ (1) $\tan [\mathrm{e}] \mathrm{cler}^{1}$ byla. [21] Da bašlady alarğa Mirjam ajtadog̉ač

(2) šira ohujuz Adonajgia ki ulluq ${ }^{2}$ qylma ulluq ${ }^{3}$ qyldy atny

(3) da atlanuvčusunda qyjasa kötürüp saldy tengizge.

(4) ויסע [22] Da köčürdü Moše ošol Jisra’elni Jam Suftan

(5) da čyqtylar midbaryna Šurnun da bardylar üč künler

(6) midbarda da tapmadylar suv. יויבואו [23] Da keldiler

(7) Marag̉a da bolalmadylar ičme suv Maradan ki ačy ediler

(8) alar anyn üčün atady atyn anyn Mara. [24] Da

(9) küvürdendiler ol ulus Moše üstüne ajtadog̀ač

(10) ne ičerbiz. ויצעק [25] Da tefile etti Moše Adonajgia

(11) da üvretti anar Adonaj ačy ag̉ač da tašlady ol suvlar-

(12) ga da tatly boldular ol suvlar anda qojdu anar resim

(13) da töre da anda synady any. [26] Da ajtty

(14) eger tynlama tynlasaj ününe Adonajnyn Tenrijnin da

(15) ol tüz körüngenni 'enajatlarynda anyn qylsaj da qulaq

(16) salsaj micvalaryna anyn da saqlasaj bar resimlerin anyn bar

(17) ol ḥastalyqny ki qojdum Micride qojmanmen üstüje

(18) ki menmen onġaltuvču seni. ויבואו. [27] Da keldiler Elim-

(19) ge da anda on eki köz suvlar da jetmiš ḥurma terek-

(20) leri da toḥtadylar anda ol suvlar qatyna.

Exodus 16

ויסעו [1]

(21) Da köčtüler Elimden da keldiĺar bar క̌ymaty ulanlarynyn

$112 \mathrm{r}^{\mathrm{o}}$ (1) Jisra’elnin midbaryna Sinnin ki arasyna Elimnin da ara-

(2) syna [Sinajnyn $]^{4}$ on bešinči kününd́a ol ekinči janġajnyn

(3) čyqmaqlaryna jerind́an Micrinin. וילונו. [2] Da küvürden-

\footnotetext{
${ }^{1} \mathrm{~K}$ : tanacler; a scribal error. | TKow.o1: tanecler. | H: tanecler. | C: horonlar. $\quad{ }^{2} \mathrm{~K}$ : haplologic form of ulluluq. | TKow.o1: ulluluq; unvocalized text. | H: ulluluq. | C: öktämlik. ${ }^{3} \mathrm{~K}$ : haplologic form of ulluluq. | TKow.o1: ulluluq; unvocalized text. | H: ulluluq. | C: öktämlik. $\quad{ }^{4} \mathrm{~K}$ : Seninin; a scribal error. | TKow.o1: Sinajnyn; unvocalized text. | H: Sinajnyn. | C: Sinajnyy.
} 
(17) in the sea, and the Lord brought back the waters of the sea upon them,

(18) and the children of Israel went on dry ground

(19) in the midst of the sea. [20] And

(20) Miriam, the prophetess, sister of Aaron, took a tambourine in her hand,

(21) and all the women went out after her with tambourines and

(1) with dances. [21] And Miriam started, saying to them,

(2) 'Sing to the Lord, for he has certainly done greatness. Horse

(3) and its rider he has lifted in a way and thrown in the sea.'

(4) [22] And Moses made Israel journey from the Red sea,

(5) and they went out to the wilderness of Shur. And they went three days

(6) in the wilderness, and found no water. [23] And they came

(7) to Marah, and they could not drink of the waters of Marah, for they were bitter.

(8) On account of this the name of it was called Marah. [24] And

(9) the people murmured against Moses, saying,

(10) 'What shall we drink?' [25] And Moses entreated the Lord,

(11) and the Lord taught him |about| a bitter tree, and he threw |it| into the waters,

(12) and the waters became sweet. He made a statute

(13) and an ordinance for them there, and he tested them there. [26] And he said,

(14) 'If you will indeed listen to the voice of the Lord your God, and

(15) if you will do what is right in his eyes, and if you will give ear

(16) to his commandments and keep all his statutes,

(17) I will set none of these diseases on you, which I have set in Egypt,

(18) because I am the Lord who heals you.' [27] And they came to Elim,

(19) and there were twelve springs of water, and seventy palm trees,

(20) and they dwelt there by the waters.

Exodus 16

(21) And journeyed from Elim, and all the congregation of the children of Israel came

(1) to the wilderness of Sin, which is between Elim and

(2) Sinai, on the fifteenth day of the second month

(3) after their departing from the land of Egypt. [2] And 
(4) diler bar žymaty ulanlarynyn Jisra’elnin Moše üstüne da

(5) Aharon üstüne midbarda. [3] Da ajttylar

(6) alarg̉a ulanlary Jisra’elnin kim bersejedi ölmegimizni

(7) bujrugudbyla Adonajnyn jerind́a Micrinin olturg̉anymyz-

(8) da ol qazan et qatyna ašaġanymyzda ötmek \{toj\}g̈unča ki

(9) čyğardyjyz bizni ol midbarğa ošpu öltürme ošol

(10) bar ol qahalny ošpunu ačlyqtan. [4 [4 Da

(11) ajtty Adonaj Mošege muna men javdururmen sizge öt-

(12) mek ol köklerd́an da čyğar ol ulus da čöplerler

(13) kemin künnün kününd́a anyn üčün ki synag̉ajmen any

(14) jürürmo jollarymbyla jemese joq. והיה [5] Da bolg̉aj

(15) ol altynčy künd́a da hadirlerler ošol neki keltir-

(16) seler da bolur eki anča anyn üstüne neki čöplej-

(17) diler har kün. ויאמר [6] Da ajtty Moše da Aharon

(18) bar ulanlaryna Jisra’elnin ingird́a da bilirsiz ki Adonaj

(19) čyğardy sizni jerind́an Micrinin. ובקר. [7] Da ertenbylada

(20) da körersiz ošol syjyn Adonajnyn ešitkenind́a ošol

(21) küvürdenmeklerijizni Adonajğa uturu da biz nebiz ki kü-

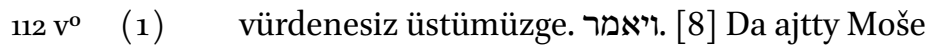

(2) bergend́a Adonaj sizge ingirda et ašama da öt-

(3) mek ertenbylada tojma ešitkend́a Adonaj ošol küvür-

(4) denmeklerijizni ki siz küvürdenesiz alnynda anyn da biz

(5) nebiz tüvüldü biznin üstüne küvürdenmeklerijiz ki

(6) Adonajğa utrudu. [9] Da ajtty Moše Aharon-

(7) g ga ajtqyn bar 3̌ymatyna ulanlarynyn Jisra’elnin juvujuz alnyna

(8) Adonajnyn ki ešitti ošol küvürdenmeklerijizni. [10]

(9) Da edi sözlegečoq Aharon bar క̌ymatyna ulanlarynyn Jisra’el-

(10) nin da qajyryldylar ol midbarga da muna šehinasy Adonaj-

(11) nyn aškara boldu bulutbyla. וידבר. [11] Da sözledi

(12) Adonaj Mošege ajtadoğač. שמעת. [12] Ešittim

(13) ošol küvürdenmeklerin ulanlarynyn Jisra’elnin sözlegin

(14) alarg̉a ajtadog̉ač ol eki ingi $\{r\} l$ ler arasyna ašarsyz

(15) et da ertenbylada tojarsiz ötmekten da bilirsiz

(16) ki menmen Adonaj Tenrijiz. ויהי [13] Da edi ingirde

(17) da kötürüldü ol perepelice da qaplady ošol ol avul- 
(4) the whole congregation of the children of Israel murmured against Moses

(5) and Aaron in the wilderness. [3] And

(6) the children of Israel said to them, 'Who would make it so that we had died

(7) by the command of the Lord in the land of Egypt, when we sat

(8) by the meat cauldrons, and when we ate bread to the full. Because

(9) you have brought us out to this wilderness to kill this

(10) whole assembly with hunger.' [4] And

(11) the Lord said to Moses, 'Lo, I will rain bread

(12) from the skies for you, and the people shall go out and gather

(13) every day, that I may test them,

(14) whether they will walk my ways or not. [5] And it shall be

(15) that on the sixth day they shall prepare that which they bring in,

(16) and it shall be twice as much as they gathered

(17) every day.' [6] And Moses and Aaron said

(18) to all the children of Israel, 'At evening you shall know that the Lord

(19) has brought you out from the land of Egypt. [7] And at dawn,

(20) you shall see the honour of the Lord because he has heard your

(21) murmurings against the Lord. And we: what are we that

(1) you murmur against us?' [8] And Moses said,

(2) 'When the Lord gives you meat to eat in the evening and

(3) bread to the full at dawn, because the Lord has heard your

(4) murmurings which you murmur before him - and

(5) we: what are we? Your murmurings are not against us, because

(6) |they are| against the Lord.' [9] And Moses spoke to Aaron,

(7) 'Say to all the congregation of the children of Israel, "Come near before

(8) the Lord, because he has heard you murmurings."' [10]

(9) And it was, as Aaron spoke to the whole congregation of the children of Israel,

(10) that they turned toward the wilderness, and, lo, the divine Presence of the Lord

(11) appeared in the cloud. [11] And the Lord spoke

(12) to Moses, saying, [12] 'I have heard

(13) the murmurings of the children of Israel. Speak

(14) to them, saying, "At twilight you shall eat

(15) meat, and at dawn you shall be filled with bread. And you shall know

(16) that I am the Lord your God."' [13] And it was in the evening,

(17) and the quails went up and covered the camp. 
(18) nu da ertenbylada edi tamčysy ol čyqnyn čüvre

(19) avulġa. ותעל [14] Da kesildi tamčysy ol čyqnyn da

(20) muna jüzleri üstüne ol midbarnyn uvaq buvgalaq uvaq

(21) moroz kibik ol jer üstüne. ויראו. [15] Da kördü-

$113 \mathrm{r}^{\mathrm{o}} \quad$ (1) ler ulanlary Jisra’elnin da ajttylar kiši qaryndašyna berne-

(2) dir Tenrid́an ol ki bilmedilar nedi ol da ajtty Moše

(3) alarg̉a oldu ol ötmek ki berdi Adonaj sizge jemge.

(4) זה [16] Budur ol söz ki bujurdu Adonaj čöplejiz andan

(5) kiši jemini köre 'omer ündeledog̉an ölčüv baš-

(6) sajyn sanyča žanlaryjyznyn har kiši anar neki čatyrynda

(7) alyjyz. ויעשו [17] Da qyldylar alaj ulanlary Jisra’elnin da

(8) čöpledilar ol köp jyštyruvču da ol az jyštyruv-

(9) ču. וימדו [18] Da ölčedilar 'omer ündeledog̉an

(10) ölčüv byla da artyġač jyštyrmady ol köp jyšty-

(11) ruvču da az jyštyruvču eksikrek jyštyrmady

(12) ančaq har kiši jemine köŕa čöplediler. יויאמר [19]

(13) Da ajtty Moše alarg̉a kišide qaldrymasiz andan

(14) tangadejin. ולא [20] Da tynlamadylar Mošege da qaldyr-

(15) dylar andan erenler tangadejin da [qurtlandy $]^{1}$ da boldu

(16) qurtlar andan sortun nečik sasydy da ačuvlandy alar

(17) üstüne Moše. וילקטו. [21] Da čoplerediler any har

(18) ertenbylada har kiši jemińa köre da nečik isinsejedi

(19) ol qujaš da iriredi. ויהי [22] Da edi ol altynčy

(20) künd́a čöpledi \{ler\} ötmek eki anča eki ol ölčüv

(21) birge da keldiler bar nasileri ol žymatnyn da anlattylar

$113 \mathrm{~V}^{0}$ (1) Mošege. ויאמר. [23] Da ajtty alarg̉a oldu ki sözledi

(2) Adonaj šabaton šabat aziz kün Adonajğa tanbyla ošol neki

(3) pečta biširsejiz biširijiz da ošol ne ki čölmekte

(4) biširsejiz biširijiz da ošol bar ol artyg̉ačny qaldyryjyz

(5) özüjüzǵa saqlavğa ol ertenbylag̉adejin. ויניחו [24] Da

(6) qojdular any ol ertenbylag̉adejin ki nečik bujurdu Moše

(7) da sasymady da qurt bolmady anda. [25] Da

(8) ajtty Moše ašajyz any bügün ki šabatty bügün Adonaj-

(9) ga bügün tapmassiz any tüzde. ששת. [26] Alty

\footnotetext{
${ }^{1} \mathrm{~K}$ : qurtlarndy; a scribal error. | TKow.o1: qurtlandy; unvocalized text. | H: qurtajdy. | C: qurtladı.
} 
(18) And at dawn drops of dew were around

(19) the camp. [14] And the drops of dew had gone up, and,

(20) lo, there were fine groats on the face of the wilderness, as fine

(21) as frost on the ground. [15] And

(1) the children of Israel saw it, they said one to another, 'It is a gift

(2) from God,' for they did not know what it was. And Moses said

(3) to them, "This is the bread which the Lord has given you for food.

(4) [16] This is the word which the Lord has commanded, "Gather of it

(5) every man according to his eating, a measure called omer for each person,

(6) according to the number of your souls, take every man for them who are in his tents."'

(7) [17] And the children of Israel did so, and

(8) gathered, the one who gathered much and the one who gathered little.

(9) [18] And they measured it with a measure called omer,

(10) and the one who gathered much did not gather too much,

(11) and the one who gathered little did not gather too less,

(12) but they gathered every man according to his eating. [19]

(13) And Moses said them, 'Let no man leave any of it

(14) until the morning.' [20] But they did not listen to Moses, and

(15) people left |some| of it until the morning, and to became maggot infested, and

(16) it bred worms after it stank. And Moses was angry with them.

(17) [21] And they gathered it at every

(18) dawn, every man according to his eating, and when the sun grew hot,

(19) it melted. [22] And it was: on the sixth

(20) day they gathered twice as much bread, two measures

(21) for $\mid$ each| one, and all the princes of the congregation came and told

(1) Moses. [23] And he said to them, 'This is what

(2) the Lord has said, "At daybreak is the day of complete rest, the holy Sabbath to the Lord.

(3) Bake that which you would bake in the stove, and boil that which

(4) you would boil in a pot, and all the surplus lay aside

(5) for yourself to be kept until dawn."' [24] And

(6) they laid it up until dawn, as Moses commanded,

(7) and it did not stink, and there was no worm in it. [25] And

(8) Moses said, 'Eat it today, because today is a Sabbath to the Lord.

(9) Today you will not find it in the field. [26] Six 
(10) künler čöplejiz any da ol jedinči künde šabatty bol-

(11) masty anda. ויהי [27] Da edi ol jedinči künde

(12) čyqutylar ol ulustan čöpleme da tapmadylar. ויאמר [28]

(13) Da ajtty Adonaj Mošege qačanġadejin klemessiz saqla-

(14) ma micvalarymny da üvretüvlerimni. ראו [29] Kö-

(15) rüjüz ki Adonaj berdi sizge ol šabatny anyn üčün ol

(16) beŕadi sizge ol altynčy künde ötmek eki künlük

(17) olturujuz kiši čegind́a özünün čyqmasyn kišide čegin $\{d e n\}$

(18) özünün ol jedinči künde. [ישבתו [3o] Da šabat tuttu-

(19) lar ol ulus ol jedinči künde. [31] Da atadylar

(20) üvü Jisra’elnin ošol atyn anyn man da ol edi urlug̉u

(21) kibik kölendranyn ulluluq[q] $\mathrm{a}^{1}$ vale türsünü anyn aq edi

$114 \mathrm{r}^{\mathrm{o}}$ (1) da tatuvu anyn edi tatuvu kibik solaqtaggy balnyn. [32]

(2) Da ajtty Moše budur ol söz ki bujurdu Adonaj alma

(3) tolu ol 'omer ündeledog̉an ölčüvnü man saqlavğa dor-

(4) laryjyz sajyn anyn üčün ki körgejler ošol ol ötmekni

(5) ki ašattym sizge midbarda čyğarğanymda sizni jerind́an

(6) Micrinin. [יאמר [33] Da ajtty Moše Aharonġa alg̈yn

(7) bir qošun da bergin ary tolu 'omer ündeledoġan

(8) ölčüvnü man da qojğun any alnynda Adonajnyn saqlavġa

(9) dorlaryjyzsajyn. כאשר. [34] Ki nečik bujurdu Adonaj Moše-

(10) ge da qojdu any Aharon alnynda ol šarajatnyn saqlavğa.

(11) ובני (35] Da ulanlary Jisra’elnin ašadylar ošol ol man-

(12) ny qyrq jyl kelgenlerinedejin olturuš jerge ošol ol

(13) manny ašadylar kelgenlerinedejin qyryjyna jerinin Kena'annyn.

(14) והועמר [36] Da ol 'omer onunču ülüšü ol

(15) efanyn edi ol.

\section{Exodus 17}

(16) ulanlarynyn Jisra’elnin midbaryndan Sinnin köčüvlerisajyn buj-

(17) ruguuna köŕa Adonajnyn da toḥtadylar Refidimde da

(18) jog̉edi suv ičme ol ulusqa. וירב. [2] Da talašty ol

\footnotetext{
${ }^{1} \mathrm{~K}$ : ulluluqa; a scribal error. | TKow.o1: ulluluqa; unvocalized text. | H: ulluluqqa. | C: deest.
} 
(10) days you shall gather it. And on the seventh day is a Sabbath,

(11) there will be none.' [27] And it was: on the seventh day

(12) some of the people went out to gather, but they found none. [28]

(13) And the Lord said to Moses, 'How long will you not want to keep

(14) my commandments and my teachings? [29] See

(15) that the Lord has given you the Sabbath. On account of this he

(16) gives you on the sixth day the bread of two days.

(17) Abide, each man in his borders. Let no man go out of his borders

(18) on the seventh day' [30] So the people rested

(19) on the seventh day. [31] And

(20) the house of Israel called the name of it: manna. And it was

(21) like coriander seed in size, and it looked white,

(1) and the taste of it was like the honey in the honeycomb. [32]

(2) And Moses said, 'This is the word which the Lord has commanded: to take:

(3) 'a full measure that is called omer of the manna to be kept

(4) for your generations, so that they may see the bread with

(5) which I have fed you in the wilderness, when I brought you out from the land

(6) of Egypt."' [33] And Moses said to Aaron, 'Take

(7) a basket, and put there a full measure called omer

(8) of manna in it, and place it before the Lord, to be kept

(9) for your generations,' [34] As the Lord commanded Moses.

(10) And Aaron placed it before the law, to be kept.

(11) [35] And the children of Israel ate manna

(12) forty years until they came to settled land.

(13) They ate the manna until they came to the border of the land of Canaan.

(14) [36] And an omer was the tenth part

(15) of an ephah.

Exodus 17

[1] And all the congregation

(16) of the children of Israel journeyed from the wilderness of Sin, after their journeys,

(17) according to the commandment of the Lord, and dwelt in Rephidim. And

(18) there was no water for the people to drink. [2] And the people did strive 
(19) ulus Moše byla da ajttylar bergin bizge suv da i-

(20) čejik da ajtty alarg̉a Moše ne talašasiz birgeme ne

(21) synajsiz ošol Adonajny. [3] Da suvsady \{anda\} ol ulus

$114 \mathrm{~V}^{\mathrm{o}}$ (1) suvğa da küvürdendi ol ulus Moše üstüne da aj-

(2) tty nege bu čyġardyj bizni Micriden öltürme meni da

(3) ošol ulanlarymny da ošol tuvarymny suvsaplyqta. ויצעק. [4]

(4) Da firjat etti Moše Adonajğa ajtadog̉ač ne qylajym ošpu

(5) ulusqa hanuz az zamandan da tašbyla tašlarlar meni. ויאמר [5]

(6) Da ajtty Adonaj Mošege ašqyn alnynda ol ulusnun da

(7) alġyn birgeje qartlaryndan Jisra'elnin da tajaġyjny ki vattyj anyn

(8) byla ošol ol Nilni alg̀yn qoluja da barġyn. הנני. [6] Muna

(9) šehinam turady alnyjda anda ol skala üstüne Horev-

(10) de da urg̉un skalany da čyğarlar andan suvlar da ičer

(11) ol ulus da qyldy alaj Moše közleriče qartlarynyn Jisra'el-

(12) nin. (7) Da atady atyn anyn ol orunnun Masa da Meriva

(13) talašy üčün ulanlarynyn Jisra’elnin da synag̉anlary üčün ošol

(14) Adonajny ajtadog̉ač barmodu hašgaḥasy Adonajnyn ortamyz-

(15) da joḥmodu. ויבוא Da keldi 'Amaleq da uruštu Jisra-

(16) 'ויאמר [9] Da ajtty Moše Johošua'-

(17) ga sajlag̉yn bizge erenler da čyqqyn urušqun 'Amaleq byla

(18) tanbyla men turarmen bašy üstüne ol qajanyn da tajag̉y ol

(19) Tenrinin qolumda. [יעש [10] Da qyldy Johošua ki nečik ajtty

(20) anar Moše urušma 'Amaleq byla da Moše Aharon da Ḥur

(21) mindiler bašyna ol qajanyn. והיה. [11] Da edi ki nečik kötür-

$115 \mathrm{r}^{0} \quad$ (1) sejedi Moše qolun da küčejiredi Jisra’el da ki nečik jebersejedi

(2) qolun da küčejiredi 'Amaleq. [12] Da qollary Mošenin avur-

(3) lar ediler da aldylar taš da qojdular tübüne da ol-

(4) turdu anyn üstüne da Aharon da Ḥur tuttular qollaryn-

(5) dan bu jantyn da bu jantyn bir da edi qollary anyn kip

(6) enginče ol qujaš. ויחלש] Da qyrdy Johošua ošol

(7) 'Amaleqni da ošol ulusun anyn qylyč avzundan. [14]

(8) Da ajtty Adonaj Mošege jazġyn bunu saġynčlyq bitikte

(9) da qojğun qulaqlaryna Johošua'nyn ki sürtme sürter-

(10) men ošol sag்ynčyn 'Amaleqnin tübünden ol köklernin. ויבן [15] 
(19) with Moses, and said, 'Give us water that

(20) we may drink.' And Moses said to them, 'Why do you strive with me? Why

(21) do you test the Lord?' [3] And the people thirsted there

(1) for water, and the people murmured against Moses, and said,

(2) 'Why is this that you have brought us up from Egypt, to kill me and

(3) my children and my livestock with thirst?' [4]

(4) And Moses cried to the Lord, saying, 'What shall I do

(5) to this people? A little time more and they will stone me with stones.' [5]

(6) And the Lord said to Moses, 'Pass before the people, and

(7) take with you of the elders of Israel, and take your staff with which you smote

(8) the Nile in your hand, and go. [6] Lo,

(9) my divine Presence stands before you there on the rock in Horeb,

(10) and you shall strike the rock, and water will come out of it and

(11) the people will drink.' And Moses did so in the sight of the elders of Israel.

(12) [7] And he called the name of the place Massah and Meribah,

(13) because of the striving of the children of Israel, and because they tested the

(14) Lord, saying, 'Is the providence of Lord among us

(15) or not?' [8] And Amalek came and fought with Israel

(16) in Rephidim. [9] And Moses said to Joshua,

(17) 'Choose men for us and go out, fight with Amalek.

(18) At daybreak, I will stand on the top of the rock with the staff

(19) of God in my hand.' [10] And Joshua did as Moses had said

(20) to him: he fought with Amalek. And Moses, Aaron, and Hur

(21) went up to the top of the rock. [11] And it was:

(1) when Moses lifted his hand, Israel prevailed; and when he lowered

(2) his hand, Amalek prevailed. [12] And Moses' hands were heavy.

(3) And they took a stone and put it under him, and

(4) he sat on it. And Aaron and Hur held up his hands,

(5) one on this side and one on that side, and his hands were strong

(6) until the sun went down. [13] And Joshua slaughtered

(7) Amalek and his people with the edge of the sword. [14]

(8) And the Lord said to Moses, 'Write this in the book of memorial,

(9) and set it in the ears of Joshua, because I will certainly blot out

(10) the remembrance of Amalek from under the skies.' [15] 
(11) Da qondardy Moše mizbeaḥ da atady atyn anyn Adonaj Nisi.

(12) ויאמר Da ajtty ki nečik bolsa küčü bijliknin taḥty

(13) üstüne bijliginin Jisra’elnin ki ol ündeledi tahty Tenri-

(14) nin ki bu remezdi bijligine Ša’ulnun ki ol vahttta bolur čerü-

(15) vü Adonajnyn 'Amaleq byla da anyn üčün ki Ša’ul qylmady bujru-

(16) ġuna köre Adonajnyn e $\{k\}$ sitme saġynčyn 'Amaleqnin anyn üčün

(17) har bir dorda borčtu eksitḿa sag̉ynčyn anyn ne vaḥtta

(18) bolsa erklenmegi bijliginin Jisra’elnin.

[Exodus 18]

(19) (19)

$115 v^{0} \quad$ (1) [1] Da ešitti Jitro qara

(2) tonlusu Midjannyn qajnatasy Mošenin ošol bar-

(3) ča ne ki qyldy Tenri Mošege da Jisra’elge ulusuna özü-

(4) nün ki čyğardy Adonaj ošol Jisra’elni Micrid́an. ויקח. [2] Da

(5) aldy Jitro qajnatasy Mošenin ošol Ciporany qatynyn Mošenin

(6) uzatqanyndan sortun any. [3] [3] Da ošol eki uvul-

(7) lary anyn ki aty ol birisinin Geršom ki ajtty garib boldum

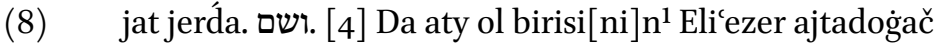

(9) ki Tenrisi atamnyn boldu bolušlugumda da qutqardy

(10) meni qylyčyndan par'onun. ויבוא [5] Da keldi Jitro qajnatasy

(11) Mošenin da uvullary anyn da qatyny anyn Mošege ol midbarg̉a

(12) ki ol toḥtaredi anda tavyna ol Tenrinin. Da

(13) ajtty Jitro elči ašyra Mošege men qajnataj Jitro kelemen

(14) saja da qatynyj da eki uvullary anyn birgesińa. [7]

(15) Da čyqty Moše uturusuna qajnatasynyn da bašurdu da

(16) öptü any da sordular kiši dostundan savluqnu da kel-

(17) diler ol čatyrg̉a. ויספר. [8] Da qotardy Moše qajnatasy-

(18) na ošol barča ne ki qyldy Adonaj paroog̀a da Micriǵa

(19) Jisra’el üčün ošol bar ol jadavny ki učrady alarny jolda ${ }_{L} \mathrm{ki}$

\footnotetext{
${ }^{1} \mathrm{~K}$ : birisin; a scribal error. | TKow.o1: birinin; unvocalized text. | H: ekincinin. | C: birsiniך.
} 
(11) And Moses built an altar, and called the name of it ${ }_{\mathrm{L}}$ The Lord Nissi ${ }^{1102}$.

(12) [16] ${ }_{\text {L }}$ And he said, 'Because when there is a hand of a kingdom over the throne

(13) of the kingdom of Israel, which is called the throne of God

(14) (which is an allegory of the kingdom of Shaul), then the war

(15) of the Lord with Amalek will take place. And because Shaul did not do

(16) according to the Lord's command to eradicate the memory of Amalek: for that reason

(17) every generation has the obligation to eradicate his memory, when the time

(18) of the rule of the kingdom of Israel comes.' ${ }^{1103}$

[Exodus 18]

(19) Parashat Yitro

(1) [1] And Jethro, the priest

(2) of Midian, Moses' father-in-law, heard of all

(3) that God had done for Moses, and for Israel his people,

(4) that the Lord had brought Israel out of Egypt. [2] And

(5) Jethro, Moses' father-in-law, took Zipporah, Moses' wife,

(6) after he had sent her away, [3] And her two sons,

(7) of which the name of the one was Gershom, because he said, 'I have been stranger

(8) in a foreign land.' [4] And the name of the one was Eliezer, saying,

(9) 'Because the God of my father was my help, too, and delivered

(10) me from the sword of Pharaoh.' [5] And Jethro, Moses' father-in-law,

(11) and his sons and his wife came to Moses in the wilderness

(12) where he dwelt at the mountain of God. [6] And

(13) Jethro said to Moses by a messenger, 'I, your father-in-law, Jethro, am coming

(14) to you and your wife and her two sons with her.' [7]

(15) And Moses went out to meet his father-in-law, and bowed, and

(16) kissed him. And they asked each other of their health, and

(17) they came to the tent. [8] And Moses told his father-in-law

(18) all that the Lord had done to Pharaoh and to Egypt

(19) for Israel's sake, and all the hardship that had befallen them in the way, that

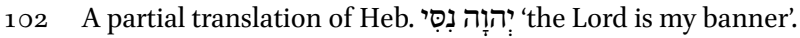

103 An interpretative translation of Exo 17:16. 
(20) uruštu alar byla Amaleq ${ }^{11}$ da qutqardy alarny Adonaj. ויחד. [9]

(21) Da bijendi Jitro bar ol jaḩšylyq üčün ki qyldy Adonaj Jisra’elge

$116 \mathrm{r}^{\circ}$ (1) ki qutqardy any qolundan Micrinin. ויאמר. [10] Da ajtty

(2) Jitro mahtavludu Adonaj ki qutqardy sizni qolundan Micrinin da

(3) qolundan par'onun ki qutqardy ošol ol ulusnu erkitü-

(4) bünd́an Micrinin. עתה. [11] Haligine bildim ki ulluraqty

(5) Adonaj bar ol malahlardan ki nendij iš byla ki čajalyq etti-

(6) ler alaj qajtardy tölev alarg̉a. [12] Da aldy Jitro

(7) qajnatasy Mošenin 'ola da debeḥalar Tenriǵa da keldi Aharon

(8) da bar qartlary Jisra’elnin ašama ötmek qajnatasy byla Moše-

(9) nin alnynda ol Tenrinin. [יהי [13] Da edi tanbyladan da

(10) olturdu Moše töre etḿa ošol ol ulusnu da tur-

(11) du ol ulus alnynda Mošenin ol tandan ol ingirgedejin.

(12) יוירא [14] Da kördü qajnatasy Mošenin ošol barča ne ki ol

(13) qyldy ulusqa da ajtty nedir ol iš ošpu ki sen qyla-

(14) sen ulusqa ne üčün sen olturasen jalg̀yz özüj töre

(15) etme da bar ol ulus köplügünd́an törelernin turady-

(16) lar alnyjda tandan ingirgedejin. Da ajtty

(17) Moše qajnatasyna ki keledi maja qacaty ol ulusnun sorma

(18) sözün Tenrinin. כי [16] Alajoq ki bolsa alarg̉a töre sö-

(19) zü kelediler maja da töre etemen $a\{r\}$ asyna kišinin da

(20) arasyna dostunun da ol soruvčularg̉a sözün Tenrinin da

(21) bildiremen alarg̉a ošol resimlerin ol Tenrinin da ošol

116 vo (1) üvretüvlerin anyn. [יאמר [17] Da ajtty qajnatasy Moše-

(2) nin anar jahšyy tüvüldü ol iš ki sen qylasen. נבמר [18] Upran-

(3) ma upranyrsen dag̉yn ol ulus ošpu ki birgeje ki

(4) avurdu send́an ol iš bolalmassen qylma any jalg̀yz özüj.

(5) עתה [19] Haligine tynlag̉yn sözüme keneš berejim saja da

\footnotetext{
${ }^{1}$ Interpretative addition to the standard text.
} 
(20) Amalek fought with them ${ }^{104}$, and that the Lord delivered them. [9]

(21) And Jethro rejoiced for all the goodness which the Lord had done to Israel,

(1) that he had delivered it from the hand of Egypt. [10] And Jethro said, $\quad 116 \mathrm{r}^{\circ}$

(2) 'Praised is the Lord, who has delivered you from the hand of Egypt, and

(3) from the hand of Pharaoh, who has delivered the people from under the rule

(4) of Egypt. [11] Now I know that the Lord is greater

(5) than all angels, because in whichever affair they plotted:

(6) so he paid them back.' [12] And Jethro,

(7) Moses' father-in-law, took a burnt offering and sacrifices to God. And Aaron came,

(8) and all the elders of Israel, to eat bread with Moses' father-in-law

(9) before God. [13] And it was after daybreak, and

(10) Moses sat to judge the people, and

(11) the people stood before Moses from the morning to the evening.

(12) [14] And Moses' father-in-law saw all that he

(13) did to the people, and he said, 'What is this thing that you do

(14) to the people? Why do you sit yourself alone to judge,

(15) and all the people stand due to the great number of judgements

(16) before you from the morning to the evening?' [15] And Moses said

(17) to his father-in-law, 'Because [ ${ }^{\dagger}$ a small part $]^{105}$ of the people come to me to inquire of

(18) the words of God. [16] And so, when there is a word of judgement for them,

(19) they come to me, and I judge between one man and

(20) another and for those who inquire of the words of God, and

(21) I make them know the statutes of God, and

(1) his teachings.' [17] And Moses' father-in-law said

(2) to him, 'The thing that you do is not good. [18]

(3) You will surely wear away, and even this people that is with you, because

(4) this thing is too heavy for you. You will not be able to do it yourself alone.

(5) [19] Listen now to my words, I will give you counsel, and

104 An interpretative addition to Exo 18:8.

$105 \mathrm{~K}$ : an uncertain translation of qacat. 
(6) bolsun bolušlugiu Tenrinin birgeje bolġun sen ulus üčün al-

(7) nynda ol Tenrinin da keltirgin sen ošol ol sözlerni alny-

(8) na ol Tenrinin. [הזהרתה [20] Da zynharlaġyn alarg̉a ošol

(9) ol resimlerni da ošol ol üvretüvlerni da bildirgin alar-

(10) ġa ošol ol jolnu ki barg̉ajlar anyn byla da ošol ol išni

(11) ki qylġajlar. ואתה. [21] Da sen baqqyn bar ol ulustan tuvušlu

(12) elni qorquvčularny Tenridan kerti elni ḥor etüvčülerni \{haram $\}^{1}$

(13) malny da qojğun alar üstüne ag̉alyqlaryn minlernin ag̉al[y]q-

(14) $\{\operatorname{laryn}\}^{2}$ jüzlernin ag̉alyqlaryn enlilernin da ag̉alyqlaryn onlarnyn.

(15) ושפטו Da töre etsinler ošol ol ulusnu har

(16) vaḥtta da bolg̀aj bar ol ullu išni keltirsinler saja

(17) da bar ol kiči išni töre etsinler özleri da jengillet-

(18) kin üstüjdan da kötürsünler birgeja. אם. [23] Eger

(19) išini ošpunu qylsaj da bujursa saja Tenri da bolalyr-

(20) sen turma da daġyn bar ol ulus ošpu ornuna kelir

(21) bazlyq byla. וישמע. [24] Da tynlady Moše sözüne qajnatasyna

$117 \mathrm{r}^{\mathrm{r}}$ (1) da qyldy barča ne ki ajtty. [25] Da sajlady Moše tuvuš-

(2) lu elni bar Jisra’elden da berdi alarny agaraq ol ulus üs-

(3) tüne ag̉alyqlaryn minlernin ag̉alyqlaryn jüzlernin agalyqlaryn en-

(4) lilernin da agalyqlaryn onlarnyn. ושפטו. [26] Da töre ete-

(5) rediler ošol ol ulusnu har vaḥtta ošol ol qaty söznü

(6) keltirirediler Mošege da bar ol kiči nerseni töre e-

(7) terediler özleri. [27] Da uzatty Moše ošol

(8) qajnatasyn da bardy özüne jerińa.

Exodus 19

(9) čü janġajda čyqmaġyna ulanlarynyn Jisra’el jerind́an Micrinin

(10) ošpu künde keldiler midbaryna Sinaj\{nyn\}. ויסעו. [2] Da

(11) köčtüler Refidimden da keldiler midbaryna Sinajnyn da

(12) toḥtadylar midbarda da toḥtady anda Jisra'el qaršysyna

(13) ol tavnyn. [3 Da Moše mindi alnyna ol Tenri-

(14) nin da čaǵyrdy anar Adonaj ol tavdan ajtadog̉ač bulaj ajt-

\footnotetext{
${ }^{1}$ Marginal insertion by another hand. | TKow.o1: deest. | H: qyngyrlyq. | C: haram. $\quad{ }^{2} \mathrm{~K}$ : agalayq; a scribal error; supplemented by another hand. | TKow.o1: agaraqlaryn; unvocalized text. | H: aġaraqlaryn. | C: bijläri.
} 
(6) God's help shall be with you. You be for the people's sake

(7) before God, and bring these words

(8) to God: [20] And you shall command them

(9) statutes and teachings, and you shall make them know

(10) the way in which they shall walk and the work that they

(11) shall do. [21] And look for able man from all the people,

(12) who fear God, merited men that despise \{stolen

(13) goods, and place them over the rulers of thousands the ruler $\{s\}$

(14) of hundreds the rulers of fifties and the rulers of tens.

(15) [22] And let them judge the people at all

(16) times. And it shall be: they shall bring every great matter to you,

(17) and they shall judge every small matter by their own. And you shall make it easier

(18) for yourself, and they shall bear |it| with you. [23] If

(19) you do this thing, and if God commands you so, then you shall be able

(20) to stand, and all this people shall also come to their place

(21) in peace.' [24] And Moses listened to the voice of his father-in-law,

(1) and did all that he had said. [25] And Moses chose merited

(2) men out of all Israel, and made them superiors over the people:

(3) rulers of thousands, rulers of hundreds, rulers of

(4) fifties, and rulers of tens. [26] And they were judging

(5) the people at all times. They were bringing the hard matters

(6) to Moses, and they were judging themselves every small matter

(7) [27] And Moses sent

(8) his father-in-law away, and he went away to his own land.

Exodus 19

third

[1] In the

(9) month, after the departure of the children of Israel from the land of Egypt,

(10) on that day they came to the wilderness of Sinai. [2] And

(11) they journeyed from Rephidim, and came to the wilderness of Sinai, and

(12) dwelt in the wilderness. And Israel dwelt there opposite

(13) the mountain. [3] And Moses went up before God,

(14) and the Lord called to him from the mountain, saying, "Thus shall you say 
(15) qyn üvüne Ja'aqovnun da anlatqyn ulanlaryna Jisra’elnin.

(16) [4] Siz kördüjüz ošol ne ki qyldym Micrige da

(17) kötürdüm sizni qyjasa nešer qanatlary üstüne da

(18) keltirdim sizni özüme. ועתה. [5] Da haligine eger

(19) tynlama tynlasajyz ünüme da saqlasajyz ošol šertimni

(20) da bolursiz maja onča bar ol uluslardan ki menimdi

(21) bar ol jer. ואתם. [6] Da siz bolursiz maja bijligi kohen-

$117 \mathrm{~V}^{\mathrm{o}} \quad$ (1) lernin da aziz ḥanlyq bulardylar ošol sözler ki sözlegin ulanlary-

(2) na Jisra’elnin. ויבוא. [7] Da keldi Moše da ündedi qartlaryn

(3) ol ulusnun da qojdu alynlarynda alarnyn ošol bar ol söz-

(4) lerin ošpularny ki sarydy any ašyra Adonaj. ויענו. [8] Da

(5) qaruv berdiler bar ol ulus \{birge\} da ajttylar barča ne ki sözledi

(6) Adonaj qylarbiz da qaruv qajtardy Moše ošol sözlerin ol

(7) ulusnun Adonajğa. ויאמר [9] Da ajtty Adonaj Moše-

(8) ge muna kelir šehinam menim saja bazyq bulut byla anyn ü-

(9) čün ki ešitkej ol ulus sözlegenimd́a birgeje da dağyn

(10) saja inamlyq bergejler dunjag̉a dejin da anlatty Moše ošol

(11) sözlerin ol ulusnun Adonajġa. ויאמר Da ajtty

(12) Adonaj Mošege barġyn ol ulusqa da aziz etkin alarny

(13) bügün da tanbyla da juvsunlar upraqlaryn özlerinin.

(14) והיו (11] Da bolsunlar hadirler ol üčünčü künge ki

(15) ol üčünčü künde ener šeḩinasy Adonajnyn közleriče

(16) bar ol ulusnun tavy üstüne Sinajnyn. והגבלת. [12]

(17) Da čeklegin ošol ol ulusnu čüvre ajtadogiač saqlanyjyz

(18) özüjüzge minmekten tavġa da tijmekten učuna anyn

(19) bar ol tijüvčü tavġa ölme öltürülsün. לא. [13]

(20) ${ }_{L}$ Da kim ki čyqsa ol čektan ${ }^{11}$ tijmesin anar qol ${ }_{L}$ ki ančaq

(21) eger juvuq bolsa ol tašbyla tašlanma tašlansyn a

$118 \mathrm{r}^{\mathrm{o}} \quad$ (1) eger jyraq bolsa oqbyla oqlanma oqlansyn ${ }^{12}$ hem kiši

(2) hem tuvar tiri bolmasyn tartqanda ol šofar išlengen

(3) qočqar müvüzünd́an ol vaḥtta barsynlar čatyrlaryndan tur-

(4) ma ol tav tübüne. וירד [14] Da endi Moše ol tavdan

\footnotetext{
${ }^{1}$ Interpretative addition to the standard text. ${ }^{2}$ Interpretative addition to the standard text.
} 
(15) to the house of Jacob and tell the children of Israel:

(16) [4] "You have seen what I did to Egypt, and

(17) I lifted you like on eagles' wings, and

(18) I brought you to myself. [5] And now, if

(19) you will indeed listen to my voice, and keep my covenant,

(20) you will be chosen to me among all peoples, for

(21) all the earth is mine. [6] And you shall be to me a kingdom of priests

(1) and a holy kingdom." These are the words which you shall speak to the children

(2) of Israel.' [7] And Moses came and called for the elders

(3) of the people, and laid before them all these words

(4) which the Lord conveyed through him. [8] And

(5) all the people answered together, and said, 'All that the Lord has spoken

(6) we will do.' And Moses reported the words of the

(7) people to the Lord. [9] And the Lord said to Moses,

(8) 'Lo, my divine Presence will come to you in a thick cloud, that

(9) the people may hear when I speak with you, and

(10) even that they may believe you forever' And Moses told the

(11) words of the people to the Lord. [10] And the Lord said

(12) to Moses, 'Go to the people, and sanctify them

(13) today and at daybreak, and let them wash their clothes.

(14) [11] And be ready by the third day, because

(15) the third day will come down the divine Presence of the Lord, in the sight

(16) of all the people on Mount Sinai. [12]

(17) And you shall set limits to the people all around, saying, "Take heed to

(18) yourselves, not to go up in the mountain or touch the edge of it.

(19) All those who touch the mountain shall be certainly put to death. [13]

(20) ${ }_{2}$ And whoever leaves the borders ${ }^{1106}$, a hand shall not touch him, but

(21) Lhe shall surely be stoned, if he is close, or

(1) he shall be shot with an arrow, if he is far away ${ }^{107}$ : both man

(2) and animal, it shall not live." At the blowing of the trumpet made of

(3) ram's horn: then shall they come from their tents

(4) to stand at the foot of the mountain.' [14] And Moses went down from the mountain

106 An interpretative addition to Exo 19:13.

107 An interpretative addition to Exo 19:13. 
(5) ol ulusqa da aziz etti ošol ol ulusnu da juvdular

(6) upraqlaryn özlerinin. [15] Da ajtty ol ulusqa

(7) bolujuz hadirler üč künlerǵa juvumajyz qatynġa.

(8) ויהי Da edi ol üčünčü künde bolġanda ol tan

(9) da boldu avazlar da jyldyrymlar da küčlü bulut ol tav üs-

(10) tüne da šofar avazy küčlü astry da qaltrady bar ol

(11) ulus ki avulda. [17] Da čyg̉ardy Moše ošol ol ulus-

(12) nu alnyna ol Tenrinin ol avuldan da turdular tübünde

(13) ol tavnyn. והר [18] Da tavy Sinaj\{nyn\} tütünlendi barčasy anyn

(14) üčün ki endi anyn üstüne šehinasy Adonajnyn ot-

(15) byla da kötürüldü tütünü kibik ol kireč ṕečinin da

(16) qaltrady bar ol tav astry. [19] Da edi ol šofar

(17) avazy baryredi da küčejiredi astry Moše sözleredi

(18) da ol Tenri ${ }_{L}$ arttyryredi anar küč avazynda ki ešit-

(19) kejler ulanlary Jisra’elnin sözlerin Mošenin tartmaq vaḥt-

(20) ta ol šofar11. וירד. [20] Da endi šehinasy Adonajnyn tavy

(21) üstüne Sinajnyn bašyna ol tavnyn da ündedi Adonaj

$118 v^{0}$ (1) Mošeni bašyna ol tavnyn da mindi Moše. [יאמר [21] Da

(2) ajtty Adonaj Mošege engin tanyq etkin ulusta magiat

(3) buzarlar ol čekni alnynda Adonajnyn baqma da tüšer andan

(4) köbüsü. וגם [22] Da dag̉yn ol kohenler ol juvuvčular alny-

(5) na Adonajnyn azizlensinlar maġat buzuqluq qylar alarda Adonaj.

(6) יויאמר (23] Da ajtty Moše Adonajgia bolalmasty ol ulus

(7) minme tavyna Sinajnyn ki sen tanyq ettij bizde ajtadog̉ač

(8) čeklegin ol tavny da aziz etkin any. [24] Da ajt-

(9) ty Adonaj anar barg்yn engin da minersen sen da Aharon birgeje

(10) Lol vahtta ki necik bujursam sizge ${ }^{12}$ da ol kohenler da

(11) ol ulus buzmasynlar čekni minme alnyna Adonajnyn mag̉at

\footnotetext{
${ }^{1}$ Interpretative addition to the standard text. $\quad{ }^{2}$ Interpretative addition to the standard text.
} 
(5) to the people, and sanctified the people, and they washed

(6) their own clothes. [15] And he said to the people,

(7) 'Be ready by the third day. Do not come close to a woman.'

(8) [16] And it was on the third day, when the morning came:

(9) and there were thunders and lightning and a strong cloud on the mountain

(10) and a very loud voice of trumpet, and all the people

(11) that were in the camp trembled. [17] And Moses brought out the people

(12) from the camp before God, and they stood at the foot

(13) of the mountain. [18] And Mount Sinai was all smoke, because

(14) the Lord's divine Presence descended on it in fire.

(15) And the smoke of it ascended like the smoke of a lime kiln, and

(16) the whole mount trembled greatly. [19] And it was: the voice of the trumpet

(17) went and grew very much louder, Moses spoke,

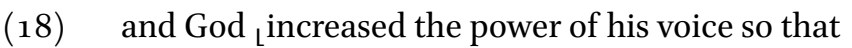

(19) the children of Israel might listen to the words of Moses when

(20) the trumpet blew. ${ }^{7108}$ [20] And the divine Presence of Lord came down

(21) on Mount Sinai, at the top of the mountain. And the Lord called

(1) Moses up to the top of the mountain, and Moses went up. [21] And

(2) the Lord said to Moses, 'Go down, testify among the people, lest

(3) they break through the border to the Lord, to watch, and

(4) many of them fall. [22] And also let the priests, who come before

(5) the Lord, sanctify themselves, lest the Lord cause destruction among them.'

(6) [23] And Moses said to the Lord, 'The people is not able

(7) to come up to Mount Sinai, because you have testified, saying,

(8) "Limit the mountain and sanctify it."' [24] And

(9) the Lord said to him, 'Go, get down, and you will come up, you and Aaron with you,

(10) L at the time I will command you ${ }^{1109}$. And the priests and

(11) the people shall not break through the border to come up before the Lord, lest

108 An interpretative addition to Exo 19:19.

109 An interpretative addition to Exo 19:24. 
(12) buzuqluq qylar alarda. וירד [25] Da endi Moše ol ulus-

(13) qa da ajtty alarg̉a.

Exodus 20

(13) [1] Da sözledi Tenri ošol

(14) bar ol sözlerni ošpularny ajtadoğač. אנכי [2] Mendir

(15) men Adonaj Tenrij senin ki čyğardym seni jerind́an Micrinin qullar

(16) erkinden. לא [3] Bolmasyn saja özge tenriler menim

(17) qajjamlyg்ym alnyna. לא. [4] Qylmaġyn özüja jonma abaq

(18) heč sufat byla ne ki körsej köklerde jog̉artyn da ne ki jer-

(19) de ašag̉artyn da ne ki suvlarda ašag̉araq jerge. לא [5]

(20) Bašurmag்yn alarg̉a da qulluq etmegin alarg̉a ki menmen

(21) Adonaj Tenrij künülevčü Tenri saġynuvču güneḥin atalarnyn

$119 \mathrm{r}^{\mathrm{o}} \quad$ (1) jaman ulanlar üstüne üčünčü dorg̉adejin da dörtünčü

(2) dorgadejin dušmanlaryma. [6] Da qyluvčudur men

(3) šavag̉at min dorlarg̉a süvüvčülerǵa oḥuma toramny da

(4) saqlavčularğa micvalarymny. לא. [7] Antetmegin šeminden

(5) Adonaj Tenrijnin jalġanga ki könü etmesti Adonaj anyda

(6) kim ki antetse šemind́an anyn muftqada. זכור [8]

(7) Saġynġyn ošol šabat künnü azizlikt́a tutma any.

(8) ששת [9] Alty künlerda išlegin da qylğyn bar išij-

(9) ni. ויום [10] Da ol jedinči kün šabatty mahtavuna Adonaj

(10) Tenrijnin qylmag̉yn heč iš sen da uvluj da qyzyj quluj da

(11) qaravašyj da tuvaryj da garipijde ki šaharlaryjda. כי. [11] Ki

(12) alty künlernin ičind́a jaratty Adonaj ošol ol köklerni

(13) da ošol ol jerni ošol ol tengizni da ošol barča ne ki

(14) alarda da tynč etti ol jedinči künde anyn üčün

(15) alğyšlady Adonaj ošol ol šabat künnü da aziz etti any.

(16) כבד (12] Syjlag̉yn ošol atajny da ošol anajny anyn üčün

(17) uzaryrlar künlerij ol jer üstüne ki Adonaj Tenrij beredi

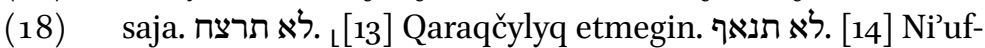

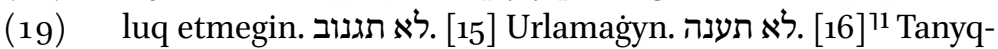

(20) lyq čyqmaġyn dostuj üčünde bolma jalġan tanyq. לא לא לא [17]

\footnotetext{
${ }^{1}$ Exo 20:13 in the standard Hebrew text.
} 
(12) he cause destruction among them.' [25] And Moses went down to the people,

(13) and said |it| to them.

Exodus 20

(14) all these words, saying, [2] 'I am

(15) the Lord your God, who has brought you out from land of Egypt,

(16) from the reign of slaves. [3] You shall have no other gods

(17) before my eternity. [4] You shall not make to yourself any carved idol

(18) of any image that you would see in the skies above or that is in the earth

(19) beneath, or that is in the water under the earth. [5]

(20) You shall not bow down to them, nor serve them, because I am

(21) the Lord your God, God that is jealous, remembering the iniquity of the fathers

(1) on the wicked children to the third generation and fourth

(2) generation for my enemies. [6] But I am he who shows

(3) mercy to thousands of generations that love reading my Law, and

(4) that keep my commandments. [7] You shall not swear to the name

(5) of the Lord your God falsely, because the Lord will not make him guiltless

(6) that who would swear to his name in vain. [8]

(7) Remember the Sabbath day, to keep it holy.

(8) [9] Six days shall you labour and do all your work,

(9) $[10]$ And the seventh day is the Sabbath for the praise of the Lord

(10) your God. You shall not do any work on it, you and your son and your daughter, your manservant and

(11) your maidservant, and your livestock and your stranger that is within your cities. [11] Because

(12) in six days the Lord created the skies,

(13) and the earth, the sea, and all that

(14) is in them, and he rested on the seventh day. On account of this

(15) the Lord blessed the Sabbath day and sanctified it.

(16) [12] Honour your father and your mother, so that your

(17) days may be prolonged on the land that the Lord your God is giving to

(18) you. [13] You shall not murder. [14] You shall not commit

(19) adultery. [15] You shall not steal. [16] You shall not

(20) testify against your fellow to be a false witness. [17] 
(21) Suqlanmaġyn üvüne dostujnun suqlanmaġyn qatynyna dostuj-

$119 \mathrm{v}^{\mathrm{o}} \quad$ (1) nun da quluna anyn da qaravašyna da ögüzüne da eš[e]gi-

(2) ne da barysynada ne ki dostujnun. וכל . [18] Da bar ol

(3) ulus körerediler ošol ol avazlarny da ošol ol küsöv-

(4) lerni da ošol ol šofar avazyn da ošol ol tavny tütün-

(5) lenedog̉anny ${ }_{L}\{[\mathrm{~d}] \mathrm{a} \text { kördü }[\mathrm{ol}] \text { ulus }\}^{12}$ da büreldiler da turdular jyraqtyn. ויאמרו. [19]

(6) Da ajttylar Mošege sözlegin sen birgemizge da tynlajyq

(7) da sözlemesin birgemizge Tenri mag̉at ölerbiz. ויאמר. [20]

(8) Da ajtty Moše ol ulusqa qorqmajyz ki čynyqtyrmaq

(9) üčün sizni qorquvuna özünün keldi šehinasy ol Tenrinin

(10) da bolmaq üčün qorquvu anyn jüzlerijiz üstüne anyn

(11) üčün ki jazyqly bolmag̉ajsiz. ויעמד [21] Da turdu ol u-

(12) lus jyraqtyn da Moše juvudu ol tumangia ki anda šehi-

(13) nasy ol Tenrinin. [יאמר [22] Da ajtty Adonaj Moše-

(14) ge bulaj ajtqyn ulanlaryna Jisra’elnin siz kördüjüz ki

(15) nečik sözledim birgejizge ol köklerden körmedijiz heč

(16) türsün. לא. [23] Anyn üčün qylmajyz alnymda kümüš

(17) abaqlar da altyn abaqlar qylmajyz özüjüzge. מזבח. [24]

(18) Mizbeah jerden qylg̀yn alnymda da debeha etkin anyn qaty-

(19) na ošol 'olalaryjny da ošol šelamimlerijni ošol qojujnu

(20) da ošol syġyryjny bar ol orunda ki saġyndyrsaj

(21) ošol šemimni kelirmen hašgaḥam byla saja da alġyšlarmen

$120 \mathrm{r}^{\mathrm{o}}$ (1) seni. [25] Da eger tašly mizbeah qylsaj alnymda

(2) qondarmag̉yn any čapma tašlardan ki qylyčyjny sunsaj anyn

(3) üstüne da jengil etersen any. ולא [26] Da minme-

(4) gin stupeńlerbyla anyn üstüne ki aškarmag̉aj ajibij

(5) anyn üstüne.

Exodus 21

(6) פרשת משפטים

(1) [1] Da bulardylar ol töreler

(8) ki qojg̈un alynlarynda alarnyn. [2] Ki satyn

(9) alsaj Jisra’el qolu alty jyllar qulluq etsin da jedinčide

${ }^{1} \mathrm{~K}$ : ešigine; a scribal error. | TKow.o1: unvocalized text. | H: esegine. | C: ešägin. $\quad{ }^{2}$ TKow.o1: $d a$ kördü ol ulus; unvocalized text. | H: da kördi ol ulus. | C: da kördü ol ulus. 
(21) You shall not covet your fellow's house, you shall not covet your fellow's wife

(1) or his manservant or his maidservant or his bull or his donkey

(2) or anything that your fellow has.' [18] And all the

(3) people saw the thunders and the torches

(4) and the sound of the trumpet and the mountain smoking.

(5) And the people saw, and they worried and stood far off. [19]

(6) And they said to Moses, 'Speak you with us, and we will listen,

(7) but let not God speak with us, lest we die.' [20]

(8) And Moses said to the people, 'Do not fear, because

(9) God's divine Presence has come to accustom you to the fear of him,

(10) and that the fear of him may be before your faces,

(11) so that you may not sin.' [21] And the people stood

(12) far off, and Moses drew near to the mist where

(13) God's divine Presence was. [22] And the Lord said to Moses,

(14) 'Thus shall you say to the children of Israel, "You have seen that

(15) I have talked with you from the skies \& and you have not seen any

(16) figure ${ }^{1110}$. [23] Therefore you shall not make before me

(17) idols of silver, and you shall not make idols of gold for yourselves. [24]

(18) You shall make an altar of earth before me, and you shall sacrifice on it

(19) your burnt offerings and your peace offerings, your sheep

(20) and your cattle. In every place where you would make my name remembered,

(21) I will come to you through my providence, and I will bless

(1) you. [25] And if you make before me an altar of stone,

(2) you shall not build it of hewn stone. Because if you elevate your sword

(3) over it, you will disrespect it. [26] And you shall go up

(4) by steps to it, that your nakedness should not appear

(5) on it."'

Exodus 21

(6) Parashat Mishpatim

(7) [1] And these are the judgments

(8) which you shall set before them. [2] If you

(9) buy a Hebrew servant, he shall serve six years and in the seventh

110 An interpretative addition to Exo 20:22. 
(10) čyqsyn azatlyqqa muft. אם. [3] Eger jalġyz özü kel-

(11) se jalġyz özü čyqsyn eger qatynly kiši bolsa ol da

(12) čyqsyn qatyny anyn birgesine. אם. [4] Eger biji anyn berse

(13) anar qatyn da törese anar uvullar jemese qyzlar ol

(14) qatyn da ulanlary anyn bolsun bijine anyn da ol čyqsyn jal-

(15) g gyz özü. [5ם [5 Da eger ajtma ajtsa ol qul

(16) süvdüm ol bijimni ošol qatynymny da ošol ulanlarymny

(17) čyqmanmen azat. והגישו. [6] Da juvutsun any biji anyn ol töre-

(18) čilerge da juvutsun any ol töreči ol ešikke jemese

(19) ol odv́erjaġa da čančsyn biji anyn ošol qulag̉yn anyn biz byla

(20) da qulluq etsin anar dunjagadejin ${ }_{L}$ ki oldu jyly jovelnin ${ }^{11}$.

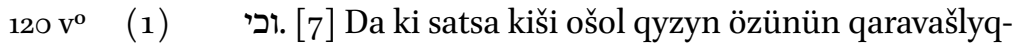

(2) qa čyqmasyn čyqmaġy kibik ol qullarnyn. אם. [8] Eger jaman

(3) körünse közlerinde bijinin ki özüne belgil[ $[\mathrm{e}] \mathrm{di}^{2}$ any

(4) da juludu any ${ }^{13}$ özge ulusqa erklenmesin satma any tan-

(5) ganynda anar. [9אם [9] Da \{eger\} uvluna özünün belgilese any

(6) kečinmegine köre ol qyzlarnyn qylsyn anar. אם. [10] Eger

(7) özgeni alsa özüne ašyn anyn kijitin anyn da ornun

(8) anyn eksitmesin. [11] Da eger üč bularny qylmasa

(9) anar da čyqsyn muft kümüšsüz. מכה. [12] Vatuvču kišini

(10) da ölse ölme öltürülsün. ואשר [13] Da ki avla-

(11) masa da ol Tenri syltav etse qoluna anyn da qojarmen

(12) saja orun ki qačqaj ary. וכי [14] Da ki čajalyq etse kiši

(13) dostu üstüne öltürme any [u]statlyq ${ }^{4}$ byla mizbeahym-

(14) dan ${ }^{5}$ alġyn anyn ölme. ומכה [15] Da vatuvču atasyn

(15) jemese anasyn ölme öltürülsün. וגנב [16] Da urlav-

(16) ču adamny da satsa any da tabulsa qolunda anyn ölme

(17) öltürülsün. ומקלל [17 Da qargavču atasyn jemese

(18) anasyn ölme öltürülsün. וכיל [18] Da ki talašsalar eren-

(19) ler da ursa kiši ošol dostun tašbyla jemese juduruq-

(20) byla da ölmese da tüšse töšekke. אם. [19] Eger

\footnotetext{
${ }^{1}$ Interpretative addition to the standard text. $\quad{ }^{2} \mathrm{~K}$ : belgilidi; a scribal error. | TKow.o1: unvocalized text. | H: belgiledi. | C: kelišti. $\quad{ }^{3} \mathrm{~K}$ : Possibly a mistranslation or a scribal error instead of

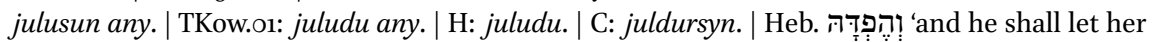
be redeemed'. $\quad{ }^{4} \mathrm{~K}$ : üstatlyq; a scribal error. | TKow.o1: ustatlyq. | H: ustatlyq. | C: jaltajlyq. $\quad{ }^{5} \mathrm{~K}$ : mizbeahymdanda; a scribal error.| TKow.o1: mizbeahym qatyndan. | H: mizbeahym qatyndan. | C: qatyndan mizbeahymnyy.
} 
(10) he shall go out free, for nothing. [3] If he, himself, comes in single,

(11) he, himself, shall go out in single. If he was a married man,

(12) then his wife shall go out with him as well. [4] If his master gives

(13) him a wife, and she bears him sons or daughters, the

(14) wife and her children shall be her master's, and he, himself, shall go out

(15) in single. [5] But if the servant plainly says,

(16) "I loved my master, my wife, and my children;

(17) I will not go out free:" [6] Then his master shall bring him to judges,

(18) and the judge shall bring him to the door or

(19) the door post, and his master shall pierce his ear with an awl,

(20) and he shall serve him forever, that is, |until| the year of jubilee ${ }^{1111}$.

(1) And if a man sells his daughter as a servant,

(2) she shall not go out as the $\mid$ men|servants go out. [8] If

(3) she would seem bad in the eyes of her master who has designed her for himself,

(4) and he redeemed her, he shall have no right to sell her to another people

(5) in his deceiving of her. [9] And if he designates her for his own son,

(6) he shall deal with her according to the manner of daughters. [10] If

(7) he takes another for himself, he shall not diminish her food, her clothing, and

(8) her place. [11] And if he does not do these three

(9) for her, she shall go out for nothing, without silver. [12] One who strikes a man,

(10) and if he dies, he shall be surely put to death. [13] But if he

(11) does not hunt, but God makes the opportunity in his hand: I will set

(12) a place for you where he may flee. [14] But if a man plots against

(13) another to kill him by cunning, you shall take him from my altar

(14) to die. [15] And one who strikes his father

(15) or his mother shall be put to death. [16] And one who steals

(16) a man and sells him, or if he is found in his hand,

(17) shall be surely put to death. [17] And one who curses his father or

(18) his mother shall be surely put to death. [18] And if men quarrel,

(19) and one strikes another with a stone, or with his fist,

(20) and he does not die, but falls to his bed: [19] If

111 An interpretative addition to Exo 21:6, cf. TKow.o1: 'the meaning of which is "until the jubilee"'. 
(21) tursa da jürüse $\left\{[\text { ty }]^{s} q a r y d a\right\}^{1}$ tajanyp tajaġy üstüne da könü bolsun

$121 \mathrm{r}^{\circ} \quad$ (1) ol vatuvču tek jalyn kečikmegi $\{n i\} \mathrm{n}^{2}$ bersin da onġaltma on-

(2) galtsyn. [20] Da ki vatsa kiši ošol qulun jemese ošol

(3) qaravašyn tajaqbyla da ölse qolu tübüne anyn öč alynma

(4) öč alynsyn. אך [21] Tek eger kün jemese eki kün tur-

(5) sa öč alynmasyn ki kümüšüdü anyn ol. וכי [22] Da

(6) ki uru\{šs $\}$ salar erenler da türtseler ḥamila qatynny da

(7) čyqsalar ulanlary anyn da bolmasa ölüm žurumlanma žurum-

(8) lansyn ki nečik qojsa anyn üstüne eri ol qatynnyn da

(9) eger jarašalmasalar da bersin törečilerge töre etme

(10) bu nerseni. [23] [23] Da eger ölüm bolsa da bergin

(11) Žan క̌an ornuna. עין [24] Köz köz ornuna tiš tiš

(12) ornuna qol qol ornuna ajaq ajaq ornuna. כ25]

(13) Küvük jara küvük jara ornuna ačyq jara ačyq jara

(14) ornuna bütüv jara bütüv jara ornuna. [26] Da

(15) ki ursa kiši ošol közün qulunun jemese közün qaravašy-

(16) nyn da čejpasa any azatlyqqa ijsin any közü üčün. ואם [27]

(17) Da eger tišin qulunun jemese tišin qaravašynyn tüšürse

(18) azatlyqqa ijsin any tiši üčün. וכי [28] Da ki süzse ö-

(19) güz ošol kišini jemese ošol qatynny da ölse tašbyla

(20) tašlanma tašlansyn ol ögüz da ašalmasyn ošol eti anyn

(21) da jesisi ol ögüznün könüdü. ואם [29] Da eger süzüv-

$121 \mathrm{~V}^{\mathrm{o}} \quad$ (1) čü ögüz bolsa ol tüneden biri künden da tanyq etilse

(2) jesisinde da saqlamasa any jesisi anyn da öltürse kiši-

(3) ni jemese qatynny ol ögüz tašbyla tašlansyn da dag̉yn

(4) jesiside öltürülsün. אם. [30] Eger juluv qojulsa

(5) anyn üstüne da bersin juluvun క̌anynyn barča nečik ki

(6) qojulsa anyn üstüne. [31] Jemese uvulnu süz-

(7) se jemese qyzny süzse ošpu törege köre qylynsyn

(8) anar. אם [32] Eger qulnu süzse ol ögüz jemese

(9) qaravašny kümüš otuz mitqallar bersin bijine anyn da ol

(10) ögüz tašbyla tašlansyn. [33] Da ki ačsa kiši

(11) quju jemese ki q[a]zsa ${ }^{3}$ kiši quju da japmasa any da tüš-

\footnotetext{
${ }^{1}$ Marginal insertion by another hand. | TKow.o1: tyšqaryda. | H: tysqaryda.| C: čyšary. ${ }^{2}$ Insertion by another hand. | TKow.o1: kečikmeginin. | H: kecikmeginin. | C: battal[l]yggyn. ${ }^{3} \mathrm{~K}: q y z s a$; a scribal error.| TKow.o1: qazsa.| H: qazsa.| C: qazsa.
} 
(21) he rises, and walks \{outdoors\} leaning against his staff, the one who struck him shall be guiltless.

(1) Only he shall pay the compensation for his loss, and shall have him

(2) healed. [20] And if a man strikes his servant or his

(3) maidservant with a staff, and he dies under his hand, he shall be surely

(4) avenged. [21] Just: if he stands for a day or two,

(5) he shall not be avenged, for he is his silver. [22] And

(6) if men fight, and they hit a pregnant woman, and

(7) her children go out, and there would be no death, he shall be punished

(8) according as the woman's husband will lay on him. But

(9) if they shall not be able to bargain, give this issue to the judges to judge.

(10) [23] But if there is death, then you shall give

(11) life for life, [24] Eye for eye, tooth for tooth,

(12) hand for hand, foot for foot, [25]

(13) Burning wound for burning wound, open wound for open wound,

(14) bruise for bruise. [26] And

(15) if a man strikes the eye of his servant or the eye of his maidservant

(16) and destroy it, he shall let him go free for his eye. [27]

(17) And if he causes his manservant's tooth or his maidservant's tooth to fall out,

(18) he shall let him go free for his tooth. [28] If a bull gores

(19) a man or a woman and they die,

(20) the bull shall be stoned with stones, and its flesh shall not be eaten,

(21) and the owner of the bull shall be guiltless. [29] And if the

(1) bull has been goring for long, and this is testified

(2) to its owner, and he does not watch it, and it kills a man

(3) or a woman, the bull shall be stoned with stones, and

(4) its owner shall be put to death as well. [30] If a ransom

(5) is laid on him, he shall give for the redemption of his life whatever

(6) is laid on him. [31] Whether it gores a son

(7) or it gores a daughter, according to this judgment shall it be done

(8) to it. [32] If the bull gores a $\mid$ man|servant or

(9) a maidservant, he shall give to its master thirty mithqals of silver, and the

(10) bull shall be stoned with stones. [33] And if a man opens

(11) a well, or if a man digs a well and does not cover it, and 
(12) se ary ögüz jemese ešek. בעל. [34] Jesisi ol quju-

(13) nun tölesin kümüš qajtarsyn jesisine anyn da ölü bol-

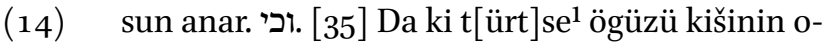

(15) šol ögüzün dostunun da ölse da satsynlar ošol

(16) ol tiri ögüznü da jarymġa ülešsinler ošol kümü-

(17) šün anyn da daġyn ošol ol ölünüde jarymġa üleš-

(18) sinler. או [36] Jemese bilinse ki süzüvčü ögüzdü

(19) ol tüneden biri künden da saqlamasa any jesisi anyn tö-

(20) leme tölesin ögüz ol ögüz üčün da ol ölü bolsun

(21) anar. כ37 [3i Ki urlasa kiši ögüz jemese qoj da sog̉um

$122 \mathrm{r}^{\mathrm{o}} \quad$ (1) etse any jemese satsa any beš syg்yr tölesin ol ö-

(2) güz üčün da dört qoj ol qoj üčün.

Exodus 22

(3) tyğyryqta tabulsa ol uru da vatylsa da ölse

(4) joḥtu anar borču qanlarnyn. אם. [2] Eger balqysa anyn

(5) üstüne ol qujaš borču qanlarnyn bardy anar kerekli

(6) edi ki tölegej da eger bolmasajedi nesibyla töleme

(7) da satylgajedi urulug̉u üčün. אם. [3] Eger tabulma

(8) tabulsa ol uruluq qolunda anyn ögüzden ešekke

(9) dejin qojğa dejin tiriler eki anča tölesin.

(10) čyqsa ot da örtese tegeneklerni da örtense

(11) styrta jemese ol turuq jemese ol tüz töleme

(12) tölesin ol jandyruvču ošol ol jandyrmaqny. כי[ [4] Ki

(13) küttürse tüznü jemese borlalyqny da

(14) ijse ošol tuvaryn da küttürse tüzünde özge-

(15) nin jaḩ̌syraq ornuna tüzünün ol izjanly boluvčunun

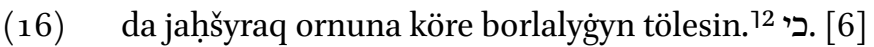

(17) Ki berse kiši dostuna kümüš jemese savutlar saq-

(18) lama da urlansa üvünden ol kišinin eger tabulma

(19) tabulsa ol uru tölesin eki anča. אם. [7] Eger

(20) tabulmasa ol uru da juvusun jesisi ol üvnün ol töre-

(21) čilerge sunmadyese qulun malyna dostunun.

\footnotetext{
${ }^{1} \mathrm{~K}$ : töretse; a scribal error, cf. Exo 21:32. | TKow.o1: türtse. | H: sizse. | C: süzsä. $\quad{ }^{2}$ The order of these two verses was corrected by the copyist by numbering the verse-beginning words with and $ב$, respectively. Gen 22:4 was initially omitted by the copyist due to homeoarchy and was added after Gen 22:5.
} 
(12) an bull or a donkey fall in it, [34] The owner of the well

(13) shall pay. He shall give back silver to its owner, and the dead one

(14) shall be his. [35] And if a man's bull [hits] ${ }^{112}$

(15) another's bull, and if it dies, they shall sell the

(16) live bull, and divide in half the silver

(17) for it, and they shall divide in half the dead one as well.

(18) [36] Or: if it is known that it is a goring bull for long,

(19) and its owner does not watch it,

(20) he shall pay a bull for the bull, and the dead one shall be

(21) his. [37] If a man steals a bull or a sheep and slaughters it

(1) or sells it, he shall pay him five oxen

(2) for a bull, and four sheep for a sheep.

Exodus 22

(3) a thief is found in a den, and is smitten, and he dies,

(4) there is no bloodguilt for him. [2] If the sun shines on him,

(5) there is bloodguilt for him. It is ${ }^{113}$ necessary

(6) that he pays. And if he has nothing to pay with,

(7) he shall be sold for his theft. [3] If the theft is

(8) found in his hand-from bull to donkey

(9) to sheep-alive, he shall pay twice as much. ${ }_{\mathrm{L}}[5]\{2 \mathrm{nd}\}$ If

(10) fire breaks out and burns thorns, and

(11) stacked or standing grain is consumed, or the field,

(12) the one who kindled the fire shall pay for the kindling. [4] \{1st\} If

(13) a man causes a field or vineyard to be pastured, and lets

(14) his livestock go, and if he pastures in another's field,

(15) he shall pay to the injured party of the best of his own field,

(16) and of the best of his own vineyard. ${ }^{1114}$ [6]

(17) If a man gives to another silver or vessels to keep,

(18) and it is stolen out of the man's house: if the

(19) thief is found, let him pay twice as much. [7] If

(20) the thief is not found, the owner of the house shall come near to the judges

(21) to show whether he has reached out his hand to another's property.

112 K: assists in birth; a scribal error. | TKow.o1: hits. | H: gores. | C: gores.

113 Lit. 'was'.

114 The order of these two verses was corrected by the copyist. 


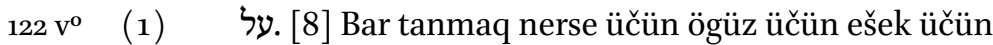

(2) qoj üčün upraq üčün bar taspolg̀an nerse üčün ki

(3) ajtsa ki oldu bu ol törečilergedejin kelsin sözü ek-

(4) silerininde $\left\{\right.$ kimni $^{1}{ }^{1}$ ki qyngyr etseler törečiler eki an-

(5) ča tölesin dostuna. כי [9] Ki berse kiši dostu-

(6) na ešek jemese ögüz jemese qoj da nendijda

(7) tuvar saqlama da ölse jemese sy[ns $] \mathrm{a}^{2}$ jemese jesir-

(8) lense bolmasa körüvčü. שבעת. [10] Anty Adonaj-

(9) nyn bolsun arasyna eksilerinind́a eger sunmadye-

(10) se qolun malyna dostunun da qabul etsin jesisi ol

(11) nersenin antny da tölemesin. ואם. [11] Da eger

(12) urlanma urlansa qatyndan anyn tölesin jesisine ol

(13) nersenin. אם. [12] Eger jyrtylma jyrtylsa keltirsin

(14) anar tanyq ol jyrtylg̈anny tölemesin. [13] Da ki

(15) ötkünč alsa kiši dostundan da synsa jemese öl-

(16) se jesisi anyn bolmasa birgesine töleme tölesin.

(17) אם [14] Eger jesisi anyn bolsa birgesine tölemesin

(18) eger jalčy ese ol keldi jaly üčün. וכי [15] Da ki jelde-

(19) se kiši boj qyzny ki kelešinmegenni da jatsa birge-

(20) sine qalynlama qalynlasyn any özüne qatynlyqqa. אם [16]

(21) Eger klemese atasy ol qyznyn berme any anar qatyn-

$123 \mathrm{r}^{\circ} \quad$ (1) lyqqa kümüš ölčesin qalynykibik ol boj qyzlarnyn.

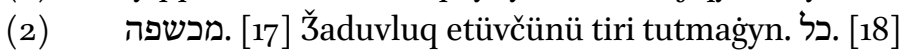

(3) Bar jatuvču tuvar byla ölme öltürülsün. [19] Debeḥa

(4) etüvčü šejtanlarg̉a ḥeremli bolsun ančaq Adonajğa

(5) jalg̀zġa. [20] Da garipni munajtmaġyn da qysyq-

(6) lyq etmegin anar ki garipler edijiz jerind́a Micrinin.

(7) כל כ21] Heč tulnu da öksüznü qyjnamajyn. אם. [22]

(8) Eger qyjnama qyjnasaj any ki eger firjat etma

(9) firjat etse maja tynlama tynlarmen firjatyn anyn.

(10) וחרה (23] Da qabunur ačuvum da öltürürmen sizni

(11) qylyč byla da bolurlar qatynlaryjyz tullar da ulanlaryjyz

(12) öksüzler. אם. [24] Eger kümüš ötkünč bersej

(13) ulusuma ol miskinge qatyjda bolmaġyn anyn borč-

(14) qa berüvčü kibik qojmajyz anyn üstüne aslam.

(15) אם [25] $[\text { Eger }\}^{3}$ tusnaq alma tusnaq alsaj upragiyn dostuj-

\footnotetext{
${ }^{1}$ Marginal insertion by another hand. | TKow.o1: kimni. | H: kimni. | C: kimni. $\quad{ }^{2} \mathrm{~K}$ : synasa; a scribal error. | TKow.o1: synsa. | H: synsa. | C: synsa. $\quad{ }^{3}$ Marginal insertion by another hand. | TKow.o1: eger.| H: eger. | C: egär.
} 
(1) [8] For every case of trespass, for a bull, for a donkey, $122 \mathrm{~V}^{\mathrm{o}}$

(2) for a sheep, for clothing, for any lost thing, of which

(3) one says, 'This is it,' the words of both of them shall come before the judges.

(4) And $\{$ whom $\}$ the judges convict,

(5) he shall pay double to the another. [9] If a man gives to another

(6) a donkey or a bull or a sheep or any kind of

(7) livestock to keep, and it dies or is injured or is seized-

(8) no one seeing-[10] An oath of the Lord

(9) shall be between the of them: whether he has not reached out

(10) his hand to another's property. And the owner of it shall accept

(11) the oath, and he shall not pay. [11] And if

(12) it is stolen from him, he shall pay the owner

(13) of it. [12] If it is torn, then let him bring

(14) it in witness; he shall not pay for the torn one. [13] And if

(15) a man borrows it of another, and it is injured or dies,

(16) its owner not being with it, he shall pay.

(17) [14] If the owner of it is with it, he shall not pay.

(18) If it is hired, it came for its hire. [15] And if a man seduces

(19) a virgin who is not betrothed, and lies with

(20) her, he shall give the dowry for her to be his wife. [16]

(21) If her father does not want to give her to him for a wife,

(1) he shall measure silver according to the dowry for virgins.

(2) [17] You shall not leave a sorceress alive. [18]

(3) All those who lie with an animal shall be put to death. [19]

(4) He who sacrifices to devils, except to the Lord only, shall be destroyed.

(5) $[20]$ You shall not torment a stranger, and you shall not oppress

(6) him, because you were strangers in the land of Egypt.

(7) [21] You shall not afflict any widow or orphan. [22]

(8) If you indeed afflict them, and they cry at all

(9) to me, I will hear their cry.

(10) [23] And my anger will burn, and I will kill you

(11) with a sword, and your wives shall be widows and your children

(12) orphans. [24] If you lend silver to

(13) my people, to the poor who is beside you, you shall not be to him

(14) as a lender, you shall not impose interest on him.

(15) $[25]\{I f\}$ you at all take another's clothing as security, 
(16) nun enginče ol kujaš qajtarg̉yn any anar. כי [26] Ki

(17) oldu uprağy anyn jalġyz oldu upraġy terisine ne

(18) ičine jatyr da bolġaj ki firjat etse maja da tyn-

(19) larmen ki ḥajif[sünüv]čüdür1 men. אלהים. [27] Törečini qarg̉amag̉yn

(20) da nasini ulusujda sökmegin. מלאתך. [28] Bürtü-

(21) güjnün da čağyrbentijnin terumasyn berme kečiktir-

$123 \mathrm{~V}^{0}$ (1) megin tunġučun ulanlaryjnyn bergin maja. כ2. [29] Alaj qylġyn ö-

(2) güzüje qojuja jedi künler bolsun anasy qatyna ol segizinči

(3) künde bergin any maja. ואנשי. [30] Da aziz el bolujuz maja da

(4) etni tüzde jyrtylġanny ašamajyz itke tašlajyz any.

Exodus 23

(5) Qabul etmegin jalġan ḥabarny qojmağyn qolujnu raša byla bolma

(6) jalğan tanyq. לא. [2] Bolmaġyn artyndan köplernin jamanlyqqa da

(7) tanyqlyq čyqmağyn talaš üčün qajyrylma artyndan köplernin tajdyr-

(8) ma töreni. ודל [3] Da jarlyny syjlamaġyn töresinde.

(9) כ [4 Ki joluqsaj ögüzün dušmanyjnyn jemese ešegin azašado-

(10) ġanny qajtarma qajtarg்yn any anar. כ5 [5i körsej ešegin

(11) dušmanyjnyn jatadog̉anny jügütübüne da qalğyn bu sağyštan ki kle-

(12) megejsen bolušma anar bolušma bolušqun birgesine. לא. [6]

(13) Tajdyrmağyn töresin miskinijnin jarg்usunda. מדבר. [7] Jalġan

(14) sözden jyraq ketkin da könünü da rastny öltürmegin ki rast

(15) etmenmen rašány. ושחד. [8] Da šoḥad almağyn ki ol šoḥad

(16) soqurajtady közlerin ačyq közlülernin da qyng்yrajtady sözle-

(17) rin rastlarnyn. [9] Da garipge qysyqlyq etmegin da

(18) siz bilesiz ošol క̌anyn ol garipnin ki garipler edijiz jerinde

(19) Micrinin. ושש. [10] Da alty jyllar čačqyn ošol jerijni da jyš-

(20) tyrg̉yn ošol bitišin anyn. והשביעת. [11] Da ol jedinči jylda

\footnotetext{
${ }^{1} \mathrm{~K}$ : hajiff̌üdür; a scribal error. | TKow.o1: hajifsünüvčüdür. | H: hajifsinivci. | C: jarylqavčydyrmen.
} 
(16) you shall return it to him by the time the sun goes down, [26] Because

(17) that is his only clothing, it is his clothing for his skin. In what

(18) will he lie down? And it shall be, if he cries to me,

(19) I will hear, because I am merciful. [27] You shall not curse the judge,

(20) and you shall not slender the prince among your people. [28]

(21) You shall not delay to give the heave offering of your grains and of your wine presses.

(1) You shall give me the firstborn of your sons. [29] Thus shall you do

(2) to your bulls |and| to your sheep: Seven days it shall be next to its mother. On the eighth

(3) day you shall give it to me. [30] And you shall be holy men to me. And

(4) you shall not eat any flesh in the field that is torn. You shall cast it to the dogs.

Exodus 23

(5) You shall not accept a false news. You shall not put your hand with the wicked to be

(6) a false witness. [2] You shall not follow many to do evil. And

(7) you shall not testify about a dispute following many to reject

(8) judgment. [3] And you shall not worship a poor in his lawsuit.

(9) [4] If you meet your enemy's bull or his donkey going astray,

(10) you shall bring it back to him. [5] If you see a donkey

(11) of your enemy lying under its burden, you shall refrain from the thought

(12) that you would not want to help him: you shall help with him. [6]

(13) You shall not reject the judgement of your poor in his verdict. [7]

(14) Keep far from a false word, do not kill the guiltless and righteous, because

(15) I will not justify the wicked. [8] And you shall take no bribe, because the bribe

(16) blinds the clear-sighted and distorts the words

(17) of the righteous. [9] And you shall not oppress a stranger, either.

(18) And you know the heart of a stranger, because you were strangers in the land

(19) of Egypt. [10] And six years you shall sow your land and

(20) gather its produce. [11] And the seventh year 
(21) šmita qylğyn anar da kemiškin išleme any da ašasynlar

$124 \mathrm{r}^{\mathrm{o}} \quad$ (1) miskinleri ulusujnun da qaldyqlaryn alarnyn ašasyn kijigi ol tüz-

(2) nün alaj qylg̈yn borlalyġyja zejtunuja. ששת. [12] Alty künlerd́a

(3) išlegin išlerijni da ol jedinči künde šabat tutqun anyn

(4) üčün ki tynč alġaj ögüzüj da ešegij da tynč alġaj uv-

(5) lu qaravašyjnyn da ol garipde. [13] Da barynda neki aj-

(6) ttym sizge saqlanyjyz da atyn özge tenrilernin sagyndyrt-

(7) majyz ešitilmesin avzujda. שלש. [14] Üč qurlalar hyyžla-

(8) ġyn maja jylda. את [15] Ošol hyžyn ol macalarnyn saqlag்yn

(9) jedi künler ašaġyn macalar ki nečik bujurdum saja vag̉dasynda

(10) ol baš qusqan janġajnyn ki ol vaḥtta čyqtyj Micriden da

(11) körünmesinler qyblalarym alnyna boš. וחו [16] Da hyžyn

(12) ol ormaqnyn jetilmeklerinin išlerijnin ki čačsaj tüzd́a

(13) da ḥyžyn ol jyštyrmaqnyn čyqqanda ol jyl jyštyrg̉anyjda

(14) ošol išlarijnin ol tüzden. שלש. [17] Üč keretler ${ }^{1}$

(15) jylda körünsün bar erkegij qyblalary alnyna ol bijnin Ado-

(16) najnyn. לא. [18] Debeḥa etmegin hamec qatyna qanyn debehamnyn

(17) da qonmasyn javy hyy̌ymmnyn tang̉adejin. ראשית. [19] Ilkin jetil-

(18) meklerinin jerijnin keltirgin üvüne Adonaj Tenrinin bišir-

(19) megin ulaqny sütü ičine anasynyn. הנה. [20] Muna men ije-

(20) men malah alnyjda saqlama seni jolda da keltirme seni

(21) ol orunga ki hadirledim. השמר. [21] Saqlangyn alnyndan

$124 \mathrm{~V}^{\mathrm{o}}$ (1) da tynlag̉yn sözüne anyn tanmaġyn anar ki bošatmasty günehle-

(2) rijni ki šemimde ičinde anyn. כ22] Ki eger tynlama

(3) tynlasaj sözüne anyn da qylsaj barča ne ki sözlesem da

(4) dušman bolurmen dušmanlaryja da qysyqlyq etermen qy-

(5) syqlyq etüvčülerije. כ2. [23] Ki baryr malahym alnyjda da

(6) keltirir seni ol Emorige da ol Ḥitige da ol Perizige

${ }^{1} \mathrm{~K}$ : Spelled בִירִיטְילֶיר; a scribal error. 
(21) you shall let it lie fallow and stop working on it, and

(1) the poor of your people shall eat, and what they leave the animal of $124 \mathrm{r}^{\circ}$ the field shall eat.

(2) Thus shall you do to your vineyard, and to your olives. [12] Six days

(3) you shall do your work, and on the seventh day you shall rest, so that

(4) your bull and your donkey may rest, and so that

(5) the son of your maidservant and even the stranger may rest. [13] And pay attention in all things that

(6) I have said to you, and make no mention of the name of other gods.

(7) Let it not be heard on your mouth. [14] You shall keep a feast

(8) to me three times in the year. [15] You shall keep the feast of unleavened bread.

(9) You shall eat unleavened bread seven days, as I commanded you, in the appointed time

(10) of the month Baš Qusqan, because then you came out from Egypt. And

(11) none shall appear before my directions empty. [16] And the feast

(12) of harvest, of the ripening of your work, which you have sown in the field.

(13) And the feast of ingathering, which is when the year leaves, when you have gathered

(14) what you have done from the field. [17] Three times

(15) in the year all your males shall appear before the directions of the lord: the Lord.

(16) [18] You shall not sacrifice the blood of my sacrifice with leavened bread.

(17) And the fat of my feast shall not stay overnight until the morning. [19] You shall bring the first

(18) of the ripening of your land to the house of the Lord your God.

(19) You shall not boil a kid in its mother's milk. [20] Lo, I send

(20) an angel before you, to keep you in the way, and to bring you

(21) to the place which I have prepared. [21] Be watchful in front of him,

(1) and obey his voice. Do not betray him, because he will not pardon your trespasses,

(2) because my name is in him, too. [22] Because if you

(3) obey his voice, and do all that I speak, then

(4) I will be an enemy to your enemies, and an oppressor to your oppressors.

(5) [23] Because my Angel will go before you and

(6) will bring you to the Amorites and the Hittites and the Perizzites 
(7) da ol Kena'anige ol Ḥivige da ol Jevusige da eksitir-

(8) men any. לא. [24] Bašurmaġyn tenrileriǵa alarnyn da qulluq

(9) etmegin alarga da qylmaġyn išleri kibik alarnyn ki buzma

(10) buzg்un alarny da syndyrma syndyrg்yn macevalaryn alarnyn.

(11) ועבדתם. [25] Da qulluq etijiz Adonajgia Tenrijizge da

(12) alġyšlar ošol ötmegijni da ošol suvlaryjny da keterir-

(13) men hastalyqny ičijden. לא. [26] Bolmasty tuv etüvčü da

(14) bödev qatyn jerijde ošol senin künlerijnin tügellermen.

(15) את . [27] Ošol qorquvumnu ijermen alnyjda da bulġanyšty-

(16) ryrmen ošol bar ol ulusnu ki kelirsen alarg̉a da berirmen

(17) ošol bar dušmanlaryjny ensebyla. ושלחת. [28] Da ijermen

(18) ošol ol hazmanny alnyjda da sürer ošol ol Ḥivini da

(19) ošol ol Kena'anini da ošol ol Ḥitini alnyjdan. לא. [29] Sür-

(20) menmen any alnyjdan bir jylda magat bolur ol jer veren da

(21) artar üstüje kijigi ol tüznün. מעט. [30] Azar

$125 \mathrm{r}^{\mathrm{o}} \quad$ (1) azar sürermen any alnyjdan neginče ki jajylġajsen da ülüš

(2) algajsen ošol ol jerni. ושתי [31] Da qojarmen ošol čegijni

(3) bašlap Jam Sufnun da tengizińadejin Pelištimnin da bašlap mid-

(4) bardan ol özengedejin ki berirmen qolujuzġa ošol ol turuv-

(5) čularyn ol jernin da sürersen alarny alnyjdan. לא. [32] Kesme-

(6) gin alarbyla da abaqlarybyla alarnyn šert. לא. [33] Oltur-

(7) masynlar jerijde magat jazyqly eterler seni maja ki qulluq

(8) etsej abaqlaryna alarnyn ki bolur saja tuzaqqa.

Exodus 24

(9) Da Mošege ajtty mingin alnyna Adonajnyn sen da Aharon

(10) Nadav da Avihu' da jetmiš kiši qartlaryndan Jisra’elnin da

(11) bašurujuz jyraqtyn. ונגש. [2] Da juvusun Moše jalġyz ö-

(12) zü alnyna Adonajnyn da alar juvumasynlar da ol ulus min-

(13) mesinler birgesińa. [3] Da keldi Moše da

(14) qotardy ulusqa ošol bar sözlerin Adonajnyn da ošol bar 
(7) and the Canaanites the Hivites and the Jebusites, and

(8) I will cut them off. [24] You shall not bow down to their gods, and you shall not serve

(9) them, and you shall not do like the things they do, but you shall smash

(10) them and break down completely their pillars.

(11) [25] And you will serve the Lord your God, and

(12) he will bless your bread and your water, and I will take

(13) sickness away from the midst of you. [26] There will be no miscarrying or

(14) barren woman in your land, I will fulfil your days.

(15) [27] I will send my fear ahead of you, and I will stir

(16) all the people to whom you shall come, and I will give

(17) all your enemies to you by the back of their head. [28] And I will send

(18) the hornet ahead of you, and it will drive out the Hivite and

(19) the Canaanite and the Hittite from before you. [29]

(20) I will not drive them out from before you in one year, lest the land become desolate,

(21) and the animals of the field multiply against you. [30] Little

(1) by little I will drive them out from before you, until you hall spread and inherit

(2) the land. [31] And I will set your border

(3) from the Red Sea even to the sea of the Philistines, and from

(4) the wilderness to the river, because I will put the inhabitants

(5) of the land in your hand, and you shall drive them out from before you. [32]

(6) You shall not make a covenant with them and with their gods. [33]

(7) They shall not dwell in your land, lest they make you sin against me, because

(8) if you serve their gods, it will be a snare to you.'

Exodus 24

(9) And he said to Moses, 'Come up before the Lord, you and Aaron,

(10) Nadab and Abihu, and seventy of the elders of Israel, and

(11) worship from afar. [2] And Moses himself alone shall come near

(12) before the Lord, but they shall not come near, and the people shall

(13) not go up with him.' [3] And Moses came and

(14) told the people all the words of the Lord, and all 
(15) törelerni da qaruv berdi bar ol ulus bir avazbyla da

(16) ajttylar bar ol sözlerni ki sözledi Adonaj qylarbiz.

(17) (4) Da jazdy Moše ošol bar sözlerin Adonajnyn da

(18) tünlej turdu ertenbylada da qondardy mizbeah ol tav tü-

(19) büne da on eki maceva on eki ševetleri sajyn Jisra'elnin.

(20) [ישלח [5] Da ijdi ošol tungučč ulanlaryn uvullarynyn Jis-

(21) ra’elnin da čyğardylar 'olalar da debeḥa ettiler šelamim

$125 \mathrm{~V}^{\mathrm{o}}$ (1) debeḥalary alnynda Adonajnyn tanalar. [6] Da aldy Moše

(2) jarymyn ol qannyn da qojdu laḥanlarga da jarymyn ol qannyn

(3) bürktü ol mizbeah ü üstüne. ויקח [7] Da aldy ošol

(4) seferin ol šertnin da oḥudu qulaqlaryča ol ulusnun da

(5) ajttylar barča neki sözledi Adonaj qylarbiz da tynlarbiz.

(6) ויקח Da aldy Moše ošol ol qanny da bürktü ol

(7) ulus üstüne da ajtty muna qany ol šertnin ki

(8) kesti Adonaj birgejizge bar ol sözler üčün ošpular.

(9) ויעל [9] Da \{mindi\} Moše da Aharon Nadav da Avihu' da jetmiš ki-

(10) ši qartlaryndan Jisra’elnin. [10] Da kördüler ošol

(11) šehinasyn Tenrisinin Jisra’elnin da bujruqlary tübüne

(12) anyn išikibik kirpičnin išlengen ${ }_{L}\{[b] \text { ölörü byla }\}^{11}$ safir tašynyn qyzyllyq-

(13) $[\mathrm{q}] \mathrm{a}^{2}$ da kensiligi kibik ol köklernin aruvluqqa.

(14) ואל (11] Da ag̉alyqlaryna ulanlarynyn Jisra'elnin ki alar Nadav

(15) da Avihu' da jetmiš kiši qartlaryndan Jisra'elnin sunmady

(16) naviligin berme Torany qollary ašyra alarnyn ki ḥote

(17) ki kördüler ošol šehinasyn ol Tenrinin jetkiligine kö-

(18) re aqyllarynyn anlyqbylada ašadylar šelamim debehalardan da

(19) ičtiler vale Moše ašamady tolġanča qyrq kün qabul et-

(20) kenine dejin ol luhotnu. ויאמר [12] Da ajtty Adonaj Moše-

(21) ge mingin ol tavğa alnyma da bolg̈un anda da berejim

$126 \mathrm{r}^{\mathrm{o}} \quad$ (1) saja ošol ol tašly luḥotnu da ol Torany da ol micvany

(2) ki jazdym üvretme alarny. ויקם. [13] Da turdu Moše

(3) da Johošua jumuščusu anyn da mindi Moše tavyna ol Tenri-

\footnotetext{
${ }^{1}$ TKow.or: deest. | H: balquvunun ol. | C: deest; different wording. $\quad{ }^{2} \mathrm{~K}$ : qyzyllyqra; a scribal error.
} 
(15) the ordinances, and all the people answered with one voice, and

(16) they said, 'We will do all the words which the Lord has spoken.'

(17) [4] And Moses wrote all the words of the Lord, and

(18) rose up early in the morning and built an altar at the foot of the mountain

(19) and twelve pillars according to the twelve tribes of Israel.

(20) [5] And he sent firstborn sons of the children of Israel,

(21) who offered burnt offerings, and sacrificed sacrifices of peace offerings

(1) of oxen before the Lord. [6] And Moses took

(2) half of the blood, and put it in basins and he sprinkled half of the blood

(3) on the altar. [7] And he took the

(4) scroll of the covenant, and read in the hearing of the people. And

(5) they said, 'We will do all that the Lord has spoken, and we will listen.'

(6) [8] And Moses took the blood and sprinkled it

(7) on the people, and he said, 'Lo, the blood of the covenant which

(8) the Lord has made with you concerning all these words.' [9]

(9) And Moses and Aaron, Nadab and Abihu, and seventy man

(10) of the elders of Israel went up. [10] And they saw the

(11) divine Presence of God of Israel. And below His commands:

(12) like a bricked work made of sapphire stone crystals for redness,

(13) and like the essence of the skies for clarity.

(14) [11 $]_{\mathrm{L}}$ And over the superiors of the children of Israel — that is, Nadab

(15) and Abihu and the seventy men of the elders of Israel—he did not elevate

(16) his prophethood to give the Law through their hands, because although

(17) they saw the divine Presence of God to the best of the abilities

(18) of their minds, they ate from the peace offerings

(19) and they drank, and Moses did not eat until forty days had passed,

(20) until he received the tablets. ${ }^{1115}$ [12] And the Lord said to Moses,

(21) 'Come up before me, to the mountain, and you shall be there, and may I give

(1) you stone tablets and the Law and the commandments $126 \mathrm{r}^{\circ}$

(2) which I have written to teach them.' [13] And Moses

(3) and Joshua, his attendant, rose up, and Moses went up to the Mountain of God.

115 An interpretative translation of Exo 24:11. 
(4) nin. ואל [14] Da ol qartlarg̉a ajtty tözüjüz bizni bunda

(5) neginče ki qajtqajbiz sizge da muna Aharon da Ḥur bir-

(6) ge $\{$ jizge $\}$ kim sözler jesisi töre išinde juvusun alarg̉a.

(7) ויעל [15] Da mindi Moše ol tavğa da qaplady ol bulut

(8) ošol ol tavny. [ישכון [16] Da toḥtady syjy Adonajnyn tavy

(9) üstüne Sinajnyn da qaplady any ol bulut alty künler

(10) da ündedi Mošeni ol jedinči künde ortasyndan ol

(11) bulutnun. ומראה. [17] Da körümü šehinasynyn Adonaj-

(12) nyn örtejdog̉an otkibik bašynda ol tavnyn közleri-

(13) če ulanlarynyn Jisra’elnin. ויבוא. [18] Da keldi Moše

(14) ortasyna ol bulutnun da mindi ol tavga da edi

(15) Moše tavda qyrq kün da qyrq keče.

Exodus 25

פרשת תרומה (16) (16)

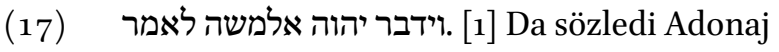

(18) Mošege ajtadog̉ač. דבר לבר (19) [2] Sözlegin

(19) ulanlaryna Jisra’elnin da alsynlar özlerind́an da bersinler

$126 \mathrm{~V}^{\mathrm{o}} \quad$ (1) maja teruma har kišiden ki žomartlatsa any jüregi anyn alyjyz

(2) וזאת [3] Da budu ol teruma ki alyjyz

(3) alardan altyn da kümüš da tuč. ותכלת. [4] Da kök da

(4) jipkin da qyrmyzy jipek da bez da junun ečkilernin.

(5) וערת [5 Da terilerin qočqarlarnyn qyzartylġanlarny da

(6) terilerin tahašlarnyn da šitim ag̉ačlaryn. שמן. [6] Jav

(7) jaryqlyqqa otjamlar ol jaġynmaq javgga da tütüsüne

(8) ol otjamlarnyn. אבני [7 Šoham tašlary efodġa da

(9) milu'im tašlary ḥošenge. ועשו. [8] Da qylsynlar maja \{miqdaš\}

(10) da toḥtar šehinam ortalarynda alarnyn. ככל [9] Barča

(11) nečik ki men körgüzemen saja ošol türsünün ol miškan-

(12) nyn da ošol türsünün bar savutlarynyn da alaj qylyjyz.

(13) (10] Da qylsynlar ošol ol aronnu šitim ag̉ačlaryn-

(14) dan eki lokotlar da jarym uzunlugiu anyn da lokot da

(15) jarym kenligi anyn da lokot da jarym turušu anyn.

(16) (11] Da qaplağgnn any aruv altyn byla ičkertin da

(17) tyšqartyn qaplag̉yn any da qylġyn anyn üstüne altyn

(18) quršov čüvre. ויצקת. [12] Da qujg̉un anar dört jüzük- 
(4) [14] And he said to the elders, 'Wait here for us

(5) until we return to you. And, lo, Aaron and Hur

(6) are with you. May he who is a man of words shall come near to them in matters to judge.'

(7) [15] And Moses went up to the mountain, and a cloud covered

(8) the mountain. [16] And the honour of the Lord dwelt on Mount

(9) Sinai, and the cloud covered it six days.

(10) And the seventh day he called to Moses from the midst of the

(11) cloud. [17] And the sight of the divine Presence of the Lord

(12) was like consuming fire on the top of the mountain in the eyes

(13) of the children of Israel. [18] And Moses went

(14) into the midst of the cloud, and went up into the mountain. And

(15) Moses was in the mountain forty days and forty nights.

Exodus 25

(16) Parashat Terumah

(17) [1] And the Lord spoke

(18) to Moses, saying, [2] 'Speak

(19) to the children of Israel, that they by themselves shall take and offer

(1) me heave offerings. From every man whose heart would make him generous you shall take a

(2) heave offering. [3] And this is the contribution which you shall take

(3) of them: gold, and silver, and bronze, [4] And blue and

(4) purple and scarlet silk, and linen, and goats' hair,

(5) [5] And rams' skins dyed red, and

(6) porpoise skins, and acacia wood, [6] Oil

(7) for the light, spices for anointing oil and for the fragrant incense,

(8) [7] Onyx stones for the ephod, and

(9) stones to be set for the breastplate. [8] And let them make me a sanctuary,

(10) and my divine Presence will dwell among them. [9]

(11) According to all that I show you: the appearance of the tabernacle

(12) and the appearance of all the vessels of it—so shall you do.

(13) [10] And they shall make an ark of acacia wood:

(14) two cubits and a half the length of it, and a cubit and

(15) a half the breadth of it, and a cubit and a half the height of it.

(16) [11] And you shall overlay it with pure gold, inside and

(17) outside shall you overlay it, and shall make on it a moulding of gold

(18) all around it. [12] And you shall cast four rings 
(19) ler altyndan da bergin dört müvüšleri üstüne

(20) da eki jüzükler ol bir jany üstüne da eki jüzük-

(21) ler ol ekinči jany üstüne. [13] Da qylġyn

$127 \mathrm{r}^{\mathrm{O}} \quad$ (1) tutqučlar šitim ag̉ačlaryndan da qaplaġyn alarny altyn byla.

(2) והבאת [14] Da kijirgin ošol ol tutqučlarny jüzükler-

(3) ge janlary üstüne ol aronnun eltme ošol

(4) ol aronnu alarbyla. בטבעות. [15] Jüzüklerind́a ol

(5) aronnun bolsunlar ol tutqučlar ketmesinler andan.

(6) ונתת [16 Da bergin ol aronġa ošol ol šarajatny ki ber-

(7) sem saja. ועשית. [17] Da qylg̈yn kaporet aruv altyndan

(8) eki lokotlar ${ }_{[}[\text {da jarym }]^{11}$ uzunlugiu anyn da lokot da jarym kenligi

(9) anyn. ועשית [18] Da qylġyn eki keruvlar altyndan qaqqan

(10) qylġyn alarny eki učlaryndan ol ${ }_{L}\langle$ ḥošennin $\rangle\{k a p o r e t n i n\}^{12}$. ועשה] [19] Da

(11) qylġyn bir keruv učtan bu jantyn da bir keruv učtan bu

(12) jantyn ol kaporetten qylyjyz ošol ol keruvlarny eki uč-

(13) lary üstüne anyn. [20] Da bolsunlar ol keruvlar

(14) jajuvčular qanatlar joġaryğa quršavčular qanatlarybyla ol

(15) kaporet üstüne da jüzleri alarnyn kišinin qaryndašyna

(16) ol kaporetke bolsunlar jüzleri ol keruvlarnyn. [21]

(17) Da bergin ošol ol kaporetni \{ol\} aron üstüne jog̉artyn

(18) da ol aronġa bergin ošol ol šarajatny ki bersem saja.

(19) ונועדתי [22] Da hadir bolur hammeše aškara bolma šehinam

(20) saja $a\{n\}$ da da sözlermen birgeje ol kaporet üstünden

(21) arasyndan ol eki keruvlarnyn ki aronu üstüne ol

$127 \mathrm{~V}^{\mathrm{o}} \quad$ (1) šarajatnyn ošol barča neki sarysam senin ašyra ulanlaryna

(2) Jisra’elnin. [23] Da qylġyn stol šitim ag̉ačlaryndan

(3) eki lokotlar uzunlugiu da lokot kenligi anyn da lokot da

(4) jarym turušu anyn. וצפית. [24] Da qaplag̉yn any aruv altyn

(5) byla da qylġyn anar altyn quršov čüvre. ועשית. [25] Da

(6) qylg̀yn anar beklevüč 3 tutam čüvre da qylg̀yn altyn quršov

(7) beklevüčüne anyn čüvre. ועשית. [26] Da qylg̀yn anar

(8) dört jüzükler altyndan da bergin ošol ol jüzüklerni dört

\footnotetext{
${ }^{1} \mathrm{~K}$ : deest; a scribal error.|TKow.o1: da jarym; unvocalized text.|H:dajarym.|C:dajarym. $\quad{ }^{2}$ Correction by another hand. | TKow.o1: kaporetnin; unvocalized text. | H: kaporetnin. | C: japqyčnyy. ${ }^{3}$ Here and henceforth: spelled בִיכלֵיובַיוּץ. The form beklüvüc was changed by the copyist to beklevüč during vocalization (consistently throughout the manuscript).
} 
(19) of gold for it, and put them in the four corners of it,

(20) and two rings shall be on the one side of it, and two rings

(21) on the second side of it. [13] And you shall make

(1) poles of acacia wood, and overlay them with gold.

(2) [14] And you shall put the poles into the rings

(3) by the sides of the ark, to carry the

(4) ark by them. [15] The

(5) poles shall be in the rings of the ark: they shall not depart from it.

(6) [16] And you shall place in the ark the law that I shall give

(7) you. [17] And you shall make a cover of pure gold:

(8) two cubits [and a half] $]^{116}$ the length of it, and a cubit and a half the breadth

(9) of it. [18] And you shall make two cherubim of gold,

(10) shall you make them of hammered work, at the two ends of the 〈breastplate $\rangle$ cover\}. [19] And

(11) make one cherub on the end, on this side, and one cherub on the end, on this

(12) side of the cover. You shall make the cherubim on the two ends

(13) of it. [20] And the cherubim shall

(14) spread out their wings above, encircling the cover with their wings,

(15) and their faces shall face one another:

(16) the faces of the cherubim shall be toward the cover. [21]

(17) And you shall put the cover on top of the ark, from above,

(18) and you shall place in the ark the testimony that I shall give you.

(19) [22] And my divine Presence will always be ready to appear

(20) to you there, and I will speak with you from above the cover,

(21) from between the two cherubim that are on the ark of the

(1) law, everything that I shall convey through you to the children

(2) of Israel. [23] And you shall make a table of acacia wood:

(3) two cubits the length of it, and a cubit the breadth of it, and a cubit and

(4) a half the height of it. [24] And you shall overlay it with pure gold

(5) and make for it a moulding of gold all around it. [25] And

(6) you shall make for it a border |of| a hand|breadth| around it, and you shall make a moulding of gold

(7) for the border all around. [26] And you shall make for it

(8) four rings of gold, and put the rings on

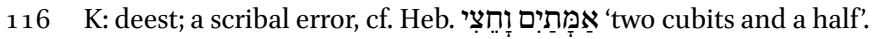


(9) ol müvüšler üstüne ki dört ajaqlaryna anyn.

(10) לעומת [27 Uturusuna ol beklevüčnün bolurlar ol

(11) jüzükler orunlar tutqučlarg̉a eltme ošol ol stolnu.

(12) (28] Da qylg̈yn ošol ol tutqučlarny šitim ag̉ačlaryn-

(13) dan da qaplaġyn alarny altyn byla da kötürüp eltinsin

(14) alarbyla ošol ol stol. ועשית. [29] Da qylġyn tepsi-

(15) lerin anyn da qašyqlaryn anyn da stolpeclerin anyn da ${ }_{\perp}$ aryt-

(16) qyčlaryn anyn ki qaplandy ${ }^{11}$ alarbyla aruv altyndan qylg̀yn alarny.

(17) ונתת [30] Da bergin ol stol üstüne eki jüzlü ötmek

(18) alnymda hammeše. ועשית. [31] Da qylg̈yn čyraqba aruv

(19) altyndan qaqqan qylynsyn ol čyraqba butu anyn da qamušu anyn

(20) čaralary anyn tüvmeleri da japraqlary anyn özünden bolsunlar.

(21) וששה [32] Da alty qamušlar čyg̉adog̉anlar janlaryndan anyn üč

$128 \mathrm{r}^{\circ} \quad$ (1) qamušlary čyraqbanyn ol janyndan da üč qamušlary čyraqbanyn

(2) ol ekinči janyndan. שלשה. [33] Üč čaralar qošulġanlar

(3) ol bir qamušta tüvme da japraq da üč čaralar qošulġan-

(4) lar ol bir qamušta tüvme da japraq alaj altysyda

(5) ol qamušlarg̉a ol čyg̉uvčularğa ol čyraqbadan. ובמנרה. [34]

(6) Da čyraqbada ${ }_{\llcorner}\langle$üč $\rangle\{d o ̈ r t\}^{12}$ čaralar qošulġanlar tüvmeleri anyn da

(7) japraqlary anyn. וכפתר. [35] Da tüvme eki ol qamuš-

(8) lar tübüne özünden da tüvme eki ol qamušlar tü-

(9) büne özünden da tüvme eki ol qamušlar tübüne

(10) özünden altysyda ol qamušlarg̉a ol čyg̉uvčularg̉a

(11) ol čyraqbadan. כפתריהם. [36] Tüvmeleri alarnyn da

(12) qamušlary alarnyn özünden bolsunlar barysy bir qaqqan

(13) aruv altyndan. ועשית. [37] Da qylġyn ošol čyraq orun-

(14) laryn anyn jedini da jandyrsyn ol kohen ošol čyraqlaryn anyn

(15) da jarytsyn janyna jüzlerinin. [מלקחיה. [38] Da qysqač-

(16) Jaryn anyn da mačmarlaryn anyn aruv altyndan. [39]

(17) Qantar aruv altyndan qylsyn any ošol bar ol savutlarny

\footnotetext{
${ }^{1}$ TKow.o1: arytqyčlaryn anyn ki qaplandy; unvocalized text. | H: arytqyčlaryn anyn \{\{ki qujulady\}\} kiqaplanady. | C: artqyčlaryn ki qylynyr.| M: artqyčlaryn kiqujulur.| R:arythyčlaryn kijabuluralar. | Evr I Bibl 143: olaq[la]ryny ki japulgaj. | This passage must have caused difficulties for translators. Note that arytqyč appears with or without $-y$-in the second syllable and it was used with four different verbs: qaplan- 'to cover', quj- 'to pour', qyl- 'to do', and jabul- 'to be covered'. See also Exo 37:16. $\quad{ }^{2}$ Correction by another hand. | TKow.o1: dört; unvocalized text. | H: dert. | C: dört.
} 
(9) the four corners that are at its four legs.

(10) [27] The rings shall be opposite to the border

(11) as places for the poles to carry the table.

(12) [28] And you shall make the poles of acacia wood

(13) and overlay them with gold, and the table shall be carried

(14) with these. [29] And you shall make its bowls,

(15) and its spoons, and its $\left[{ }^{\dagger} \text { tablecloths }\right]^{117}$, and its

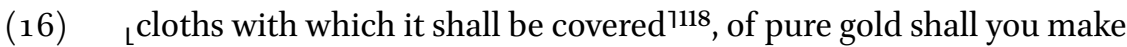
them.

(17) [30] And you shall place showbread on the table

(18) before me always. [31] And you shall make a lampstand of pure

(19) gold. The lampstand shall be made of hammered work—its shaft and its branches,

(20) its cups, its knobs, and its leaves shall be of the one same |piece|-

(21) [32] And six branches come out of the sides of it: three

(1) branches of the lampstand out of one side, and three branches of the $128 \mathrm{r}^{\mathrm{o}}$ lampstand

(2) out of the second side. [33] Three cups coupled,

(3) a knob and a leaf in one branch, and three cups coupled,

(4) with a knob and a leaf in one branch. So it is for the six

(5) branches that come out of the lampstand. [34]

(6) And in the lampstand shall be $\langle$ three $\rangle\{$ four $\}$ cups coupled, with their knobs and

(7) their leaves. [35] And a knob under the two branches

(8) of the same one piece, and a knob under the two branches

(9) of the same one piece, and a knob under the two branches

(10) of the same one piece-for the six branches that come out

(11) of the lampstand. [36] Their knobs and

(12) their branches shall be of the same piece, all of it shall be one hammered work

(13) of pure gold. [37] And you shall make its seven places for candles:

(14) and the priest shall light its candles,

(15) that they may give light next to his face ${ }^{1119}$. [38] And its tongs,

(16) and their censers of pure gold. [39]

(17) He shall make it—all these vessels—of a kantar of pure gold.

117 An uncertain translation of stolpec.

$118 \mathrm{~K}$ : arytqyč; there is an elaborate explanation of this item in Exo 37:16.

119 Interpretative translation. 
(18) ošpularny. [40] Da baqqyn da qylġyn türsünleribyla

(19) ki sen körgüzülesen tavda.

Exodus 26

(19) ואת [1] Da ošol ol miškanny

(20) qylġyn on enler ešken bezden da kökten da jipkinden

(21) da qyrmyzy jipekten keruvlar išin ojuvlavčunun qylġyn

128 v (1) alarny. (2] Uzunlugiu ol bir ennin egirmi segiz

(2) lokot da kenligi dört lokot ol bir ennin bir ölčöv

(3) bar ol enlerge. חמש [3] Beš ol enler bolsunlar

(4) qošadog̉anlar birin birisine da beš enler qošadoġanlar

(5) birin birisine. ועשית. [4] Da qylg̀yn ilgikler kökten

(6) qyryj üstüne ol bir ennin učtan qošar orunda da

(7) alaj qylġyn qyryjynda ol ekinči učtag̉y ennin qošar orun-

(8) da. חמשים [5] Enli ilgikler qylg̀yn ol bir ende

(9) da enli ilgikler qylg̀yn qyryjynda ol ekinči ennin

(10) ki qošar orunda otrulašadoġanlar ol ilgikler biri

(11) birisine. ועשית. [6] Da qylg̀yn enli eslar altyndan

(12) da qošqun ošol on enlerni birin birisine eślar byla

(13) da bolsun ol miškan bir. ועשית. [7] Da qylg̀yn enler

(14) junundan ečkilernin čatyrğa ol miškan üstüne

(15) onbir enler qylg̈yn alarny. ארך. [8] Uzunluggu ol bir

(16) ennin otuz lokotbyla da kenligi dört lokot byla ol

(17) bir ennin bir ölčöv onbirside enlerge.

(18) וחברת (9) Da qošqun ošol beš ol enlerni bašqa da

(19) ošol alty ol enlerni bašqa da qatlag̉yn ošol altyn-

(20) čy ol enni alnyna jüzlerinin ol čatyrnyn. ועשית. [10]

(21) Da qylġyn enli ilgikler qyryj üstüne ol bir učtağy

$129 \mathrm{r}^{\mathrm{o}}$ (1) ennin qošar orunda da enli ilgikler qyryj üstüne

(2) ol ekinči učtag̉y ennin qošar orunda. [ועשית]

(3) Da qylġyn enli eslar tučtan da kijirgin ošol ol eslar-

(4) ni ilgiklerge da qošqun ošol ol čatyrny da bolsun

(5) bir. וסרח [12] Da artyğačny ol artadog̉anny enlerin- 
(18) [40] And see and make them after their patterns

(19) that you are shown in the mountain.

Exodus 26

ernacle

(20) with ten curtains of twined linen, and blue and purple

(21) and scarlet silk, with cherubim-you shall make them of embroiderer's work.

(1) [2] The length of one curtain twenty-eight

(2) cubits, and the breadth of one curtain four cubits:

(3) all the curtains shall have the same measure. [3] The five curtains shall be

(4) coupled together, one to another, and the other five curtains shall be coupled

(5) one to another. [4] And you shall make loops of blue

(6) on the edge of the one outmost curtain in the place of coupling, and

(7) you shall do so in the edge of the second outmost curtain in the place of coupling.

(8) [5] You shall make fifty loops in the one curtain,

(9) and you shall make fifty loops in the edge of the second curtain

(10) in the place of coupling, loops opposite one

(11) another. [6] And you shall make fifty hooks of gold,

(12) and couple the curtains together with the hooks.

(13) And the tabernacle shall be one. [7] And you shall make curtains

(14) of goats' hair for a tent over the tabernacle.

(15) You shall make eleven curtains. [8] The length of one

(16) curtain thirty cubits, and the breadth of one curtain four cubits:

(17) one measure for eleven curtains.

(18) [9] And you shall couple five curtains separately and

(19) six curtains separately, and you shall double over the sixth

(20) curtain in the front of the tabernacle. [10]

(21) And you shall make fifty loops on the edge of the one outmost curtain

(1) in the place of coupling and fifty loops in the edge

(2) of the second curtain in the place of coupling. [11]

(3) And you shall make fifty hooks of bronze, and put the hooks

(4) into the loops, and couple the tent together. And it shall be

(5) one. [12] And the surplus that remains additionally of the curtains 
(6) de ol čatyrnyn jarymyn ol ennin ol artadog̉anny salğyn

(7) artyüstüne ol miškannyn. והאמה. [13] Da ol

(8) lokot bu jantyn da ol lokot bu jantyn artadoganda u-

(9) zunluğunda enlerinin ol čatyrnyn bolsun salynadogan jan-

(10) lary üstüne ol miškannyn bu jantyn da bu jantyn qap-

(11) lama any. I14] Da qylg̈yn qaplav čatyrg̉a terile-

(12) rinden qočqarlarnyn qyzartylganlarnyn da $\{\text { qaplav }\}^{1}$ terilerinden taḥaš-

(13) larnyn jog̉artyn. [15] Da qylğyn ošol ol taḥtalarny

(14) miškang̉a šitim ag̉ačlaryndan turadog̉anlarny. עשר. [16]

(15) On lokotlar uzunlugiu ol bir tahtanyn da lokot da jary-

(16) my ol lokotnun kenligi ol bir tahtanyn. שתי. [17 Eki

(17) tutqučlar ol bir taḥtağa teneštirilgenler biri birisi-

(18) ne alaj qylğyn bar taḥtalaryna ol miškannyn. ועשית. [18]

(19) Da qylğyn ošol ol taḥtalarny miškanġa egirmi taḥta

(20) tarafyna tüšlüknün temansary. וארבעים. [19] Da qyrq

(21) tabanlar kümüšten qylg̀yn egirmi ol tahta tübüne

$129 \mathrm{v}^{\mathrm{o}} \quad$ (1) eki tabanlar ol bir taḥta tübüne \{eki tutqučlaryna $\}$ da eki tabanlar ol bir

(2) taḥta tübüne eki tutqučlaryna anyn. ולצלע. [20] Da eki[nči] ${ }^{2}$

(3) janyna ol miškannyn tarafyna cafonnun egirmi taḥta.

(4) וארבעים [21] Da qyrq tabanlary alarnyn kümüšten eki taban-

(5) $\{$ lar $\}$ ol bir taḥta tübüne da eki tabanlar ol bir tahta $\left\{[\text { tü]büne }\}^{3}\right.$.

(6) (22] Da qyryjlaryna ol miškannyn macaravsary qylġyn

(7) alty taḥtalar. [23] Da eki taḥtalar qylğyn müvüšle-

(8) rine ol miškannyn qyryjlarda. ויהיו [24] Da bolsunlar ten-

(9) ler ašaġartyn da birge bolsunlar teppeten bašyna anyn

(10) ol bir jüzükke alaj bolsun eksilerinede eki ol müvüš-

(11) lerge bolsunlar. זהיו [25] Da bolsunlar segiz tahtalar da

(12) tabanlary alarnyn kümüšten on alty tabanlar eki tabanlar

(13) ol bir taḥta tübüne da eki tabanlar ol bir tahta tü-

(14) büne. [26] Da qylg̀yn beklevüčler šitim ag̉ačlaryn-

(15) dan bešni taḥtalaryna ol bir janynyn ol miškannyn.

(16) (27] Da beš beklevüčler taḥtalaryna ol ekinči

(17) janynyn ol miškannyn da beš beklevüčler ol ma‘aravsar-

\footnotetext{
${ }^{1}$ Marginal insertion by another hand. | TKow.o1: deest. | H: qaplavyn. | C: jabuvun. $\quad{ }^{2}$ TKow.o1: ekinči; unvocalized text. | H: ekinci. | C: ekinži. ${ }^{3}$ TKow.o1: tübüne; unvocalized text. | H: tibine. | C: tibinä.
} 
(6) of the tent: you shall hang the half of the curtain that remains in surplus

(7) over the back of the tabernacle. [13] And the

(8) cubit on the one side and the cubit on the other side of that which remains

(9) in the length of the curtains of the tent shall be hung over the sides

(10) of the tabernacle on this side and on this side, to cover

(11) it. [14] And you shall make a covering for the tent of

(12) rams' skins dyed red, and a \{covering $\}$ of porpoise skins

(13) above. [15] And you shall make boards

(14) for the tabernacle of acacia wood, standing: [16]

(15) Ten cubits the length of a board, and a cubit and a half

(16) the breadth of one board. [17] Two

(17) tenons shall there be in one board that fit together:

(18) thus shall you do for all the boards of the tabernacle. [18]

(19) And you shall make the boards for the tabernacle, twenty boards

(20) on the south side southward. [19] And

(21) you shall make forty bases of silver under the twenty boards,

(1) two bases under one board for its two tenons, and two bases

(2) under one board for its two tenons. [20] And for the [second] side

(3) of the tabernacle on the north side: twenty boards.

(4) [21] And their forty bases of silver, two bases

(5) under one board, and two bases under one board. [22]

(6) And for the sides of the tabernacle westward you shall make

(7) six boards. [23] And you shall make two boards for the corners

(8) of the tabernacle on the edges. [24] And they shall be in one line

(9) at the bottom, and they shall be integrated in one line at the top of it

(10) to one ring. It shall be so for the two of them; they shall be for the two corners.

(11) [25] And there shall be eight boards, and

(12) their bases of silver, sixteen bases; two bases

(13) under one board, and two bases under one board.

(14) [26] And you shall make bars of acacia wood;

(15) five for the boards of the one side of the tabernacle.

(16) [27] And five bars for the boards of the second

(17) side of the tabernacle, and five bars for the 
(18) ġy janyna ol miškannyn qyryjlarġa. והבריח. [28 Da ol

(19) ortančy beklevüč ortasynda ol taḥtalarnyn beklejdoġan

(20) ol učtan ol učqa. ואת [29] Da ošol ol taḥtalarny

(21) qaplaġyn altynbyla da ošol jüzüklerin alarnyn qylg̀yn altyn-

$130 \mathrm{r}^{\mathrm{o}}$ (1) dan orunlar beklevüčlerge da qaplag̉yn alarny L \{ošol o[1] beklevič [lerni] $\}^{11}$ altyn byla.

(2) והקמת [30] Da turg̉uzg̉un ošol ol miškanny kečinme-

(3) gine köre ki körgüzüldüj tavda. ועשת. [31] Da qylġyn

(4) parohet kökten da jipkinden da qyrmyzy jipekten da

(5) ešken bezden išin ojuvlavčunun qylsyn any keruvim.

(6) ונונתת [32] Da bergin any dört bagianalar üstüne šitim

(7) ag̉ačlaryndan qaplanġanlar altyn byla čüvleri alarnyn altyn

(8) da dört kümüš tabanlar üstüne. [3ת] Da

(9) bergin ošol ol parohyetni ol eslar tübüne da kijir-

(10) gin ary ičkertin parohnetke ošol ol šarajatny da

(11) ajyrsyn sizge ol parohet arasyna ol qodešnin da ara-

(12) syna qodeš ol qodešnin. [34] Da bergin ošol

(13) ol kaporetni aronu üstüne ol šarajatnyn qodešind́a

(14) ol qodešnin. ושמת [35] Da qojg̉un ošol ol

(15) stolnu tyšqartyn parohgetke da ošol ol čyraqbany

(16) uturusuna ol stolnun janynda ol miškannyn temansa-

(17) ry da ol stolnu bergin janynda cafonnun. [36 [36 ]

(18) Da qylg̈yn qaplav ešigine ol čatyrnyn kökten da jipkinden

(19) da qyrmyzy jipekten da ešken bezden iši nağyšlavčunun.

(20) (37] Da qylğyn qaplavg̉a baš bag̉analar šitim ag̉ačlaryndan

(21) da qaplagiyn alarny altyn byla čüvleri alarnyn altyndan da

$130 \mathrm{v}^{\mathrm{o}} \quad$ (1) $\quad \mathrm{q}[\mathrm{u}] \mathrm{jgjun}{ }^{3}$ alarg̉a beš tabanlar tučtan.

Exodus 27

(2) ošol ol mizbeaḥny šitim ag̉ačlaryndan beš lokotlar uzun-

(3) luq da beš lokotlar kenlik dört kül bolsun ol mizbeạ

(4) da üč lokotlar turušu anyn. ועשית. [2] Da qylğyn

(5) müvüzlerin anyn dört müvüšleri üstüne anyn

\footnotetext{
${ }^{1}$ Marginal insertion by another hand. | TKow.o1: ošol ol beklevüčlerni; unvocalized text. | H: osol ol bekleviclerni.| C: šol beklivičlärni. $\quad{ }^{2} \mathrm{~K}$ : temansasary; a scribal error (dittography). $\quad{ }^{3} \mathrm{~K}:$ qojg̈un; a scribal error. | TKow.o1: unvocalized text. | H: qujgun. | C: tökkin.
} 
(18) side of the tabernacle at the edge westward. [28] And

(19) there shall be a middle bar in the midst of the boards that fills $\mid$ the space|

(20) from end to end. [29] And you shall

(21) overlay the boards with gold, and you shall make their rings of gold

(1) for places for the bars, and you shall overlay them, $\{$ the bars\}, with gold.

(2) [30] And you shall erect the tabernacle according to the manner

(3) which you were shown in the mountain. [31] And you shall make

(4) a veil of blue and purple and scarlet silk and

(5) twined linen: he shall make of embroiderer's work with cherubim.

(6) [32] And you shall place it on four pillars of acacia

(7) wood overlaid with gold, their hooks shall be of gold,

(8) on the four bases of silver. [33] And

(9) you shall place the veil under the hooks. And you shall bring

(10) the law there, inside the veil, and

(11) the veil shall divide for you between the Holy and

(12) the Holy of Holies. [34] And you shall put the

(13) cover on the ark of the law in the Holy

(14) of Holies. [35] And you shall set the

(15) table outside the veil, and the lampstand

(16) opposite the table on the side of the tabernacle toward the south,

(17) and you shall put the table on the north side. [36]

(18) And you shall make a cover for the door of the tent, of blue and purple

(19) and scarlet silk and twined linen of embroiderer's work.

(20) [37] And you shall make five pillars of acacia wood for the cover,

(21) and overlay them with gold, their hooks shall be of gold, and

(1) you shall cast five sockets of bronze for them.

Exodus 27

(2) an altar of acacia wood. Five cubits long,

[1] And you shall make

(3) and five cubits broad, the altar shall be foursquare,

(4) and the height of it shall be three cubits. [2] And you shall make

(5) the horns of it on its four corners. 
(6) özünd́an bolsunlar müvüzlari anyn da qaplaġyn any tuč

(7) byla. ועשית. Da qylġyn qazanlaryn anyn külün keterma

(8) anyn da sibirtkilerin anyn da kuboklaryn da jyrgaa-

(9) laryn da mačmarlaryn anyn bar savutlaryn anyn qylġyn tučtan.

(10) [4] Da qylg̈yn anar elek iši avnyn tučtan

(11) da qylġyn ol av üstüne dört jüzükler tučtan

(12) dört müvüšleri üstüne anyn. ונתת [5] Da

(13) bergin any kruhu tübüne ol mizbeaḥnyn ašag̉artyn da

(14) bolsun ol av jarymyna dejin ol mizbeaḥnyn. [6שית. [6]

(15) Da qylġyn tutqučlar mizbeaḥqa šitim ag̉ačlaryndan da

(16) qaplag̉yn alarny tučbyla. והובא. [7] Da kijirilsin ošol

(17) tutqučlary anyn jüzüklerǵa da bolsunlar ol tutqučlar

(18) \{ekiside\} janlary üstüne ol mizbeahnyn eltkende any. [בוב [8]

(19) Quvuš taḥtalardan qylg̀yn any ki nečik körgüz[ül]d ü² saja

(20) tavda alaj qylsynlar. ועשית [9] Da qylġyn ošol qaḥra-

(21) syn ol miškannyn tarafyna tüšlüknün temansary

$131 \mathrm{r}^{\circ} \quad$ (1) enler qahragia ešken bezden jüz lokot byla uzunluq ol

(2) bir tarafqa. ועמדיו. [10] Da baganalary anyn \{egirmi\} da taban-

(3) lary anyn egirmi tučtan čüvleri alarnyn da čörgevleri

(4) alarnyn kümüšten. [וכן. [11] Da alaj tarafyna cafonnun

(5) uzunluqta enler jüz lokot byla uzunluq da baganalary

(6) anyn egirmi da tabanlary a \{lar\}nyn egirmi tučtan čüvleri

(7) ol bag̉analarnyn da čörgevleri alarnyn kümüštan.

(8) : ורוחב Da kenligi ol qahranyn tarafyna ma'aravnyn

(9) enler enli lokot baganalary alarnyn on da tabanlary alar-

(10) nyn on. ורוחב [13] Da kenligi ol qahranyn tarafyna miz-

(11) rahnnyn küntuvušusary enli lokot. [14] Da onbeš

(12) lokot enler tarafqa baġanalary alarnyn üč da tabanlary

(13) alarnyn üč. ף. [15] Da ol ekinči tarafqa on

(14) beš [lokot $]^{3}$ enler bağanalary alarnyn üč da tabanlar üč.

(15) (15) Da qabag̉yna ol qahranyn qaplav egirmi lokot

(16) kökten da jipkinden da qyrmyzy jipekten da ešken

(17) bezden iši naġyšlavčunun bag̉anasy alarnyn dört da taban-

(18) lary alarnyn dört. כל [17] Bar bagaanalary ol qahranyn čüvre

(19) čörgelgenler kümüšbyla čüvleri alarnyn kümüšten

\footnotetext{
${ }^{1}$ Marginal insertion by another hand. | TKow.or: eki; unvocalized text. | H: eki. | C: eki. $\quad{ }^{2} \mathrm{~K}: k o ̈ r-$ güzdü; a scribal error repeated in a number of manuscripts. Cf. Exo 25:40, Exo 26:30. | TKow.o1: körgüzdü.| H: kergizdi.| C: körgüzedi.| M: körgüzüldü.| R: korǵuźuld́u. ${ }^{3} \mathrm{~K}$ : deest; a scribal error. | TKow.o1: deest. | H: deest. | C: aršyn. | R: deest.
} 
(6) Its horns shall be one with it. And you shall overlay it with bronze.

(7) [3] And you shall make its cauldrons to remove its ashes,

(8) and its brushes and its cups and forks

(9) and its censers. You shall make all its equipment of bronze.

(10) [4] And you shall make for it a grate, a network of bronze,

(11) and on the net you shall make four bronze rings

(12) on its four corners. [5] And

(13) you shall put it under the ledge ${ }^{120}$ of the altar beneath

(14) so that the net may be halfway up the altar. [6]

(15) And you shall make poles of acacia wood for the altar and

(16) overlay them with bronze. [7] And the poles shall be put

(17) into the rings, and the poles shall be

(18) on $\{$ both $\}$ sides of the altar when it is carried. [8]

(19) You shall make it of hollow boards as [you were] shown

(20) in the mountain. They shall do it so. [9] And you shall make the court

(21) of the tabernacle: for the south side, southward,

(1) curtains for the court of twined linen of a hundred cubits long

(2) for one side, [10] And its twenty pillars and its twenty bases

(3) of bronze, their hooks and their bands

(4) of silver. [11] And so for the north side:

(5) in length, curtains of a hundred cubits long and its

(6) twenty pillars and their twenty bases of bronze, the hooks

(7) of the pillars and their bands of silver.

(8) [12] And the breadth of the court on the west side:

(9) curtains of fifty cubits, their pillars ten and their bases

(10) ten. [13] And the breadth of the court on the east side,

(11) eastward, fifty cubits. [14] And curtains of fifteen

(12) cubits for one side, their pillars three, and their bases

(13) three. [15] And on the second side:

(14) curtains of fifteen [cubits], their pillars three and their bases three.

(15) [16] And for the gate of the court: a cover of twenty cubits,

(16) of blue and purple and scarlet silk and twined

(17) linen of embroiderer's work, their pillars four and their

(18) bases four. [17] All the pillars all around the court:

(19) banded with silver, their hooks of silver 
(20) da tabanlary alarnyn tučtan. ארך. [18] Uzunlugiu ol qah-

(21) ranyn jüz lokot byla da kenligi enli lokot enli lokot

$131 \mathrm{~V}^{\mathrm{o}} \quad$ (1) byla da turuš beš lokotlar ešken bezden da tabanlary

(2) alarnyn tučtan. לכל [19] Bar savutlary ol miškannyn bar

(3) iši byla anyn da bar qazyqlary anyn da bar qazyqlary ol

(4) qaḥranyn tučtan.

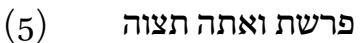

(20] Da sen bujurgun ulan-

(7) laryna Jisra’elnin da alsynlar saja zejtun

(8) javy aruvnu jančqanny jaryqlyqqa jandyrma čyraq hamme-

(9) še. באהל [21] Ohel mo'ed[de] ${ }^{1}$ tyšqartyn parohnetke ki

(10) ol šarajat üstüne tüzüsün any Aharon da uvullary

(11) anyn ingirden tanġadejin alnynda Adonajnyn ömürlük

(12) resim dorlarysajyn ulanlaryndan Jisra’elnin.

Exodus 28

ואתה [1]

(13) Da sen juvutqun özüje ošol Aharonnu qaryndašyjny da

(14) ošol ulanlaryn anyn birgesine ortasynda[n $]^{2}$ ulanlarynyn

(15) Jisra'elnin kohenlik etme maja Aharon Nadav da Avihu'

(16) El'azar da Itamar uvullary Aharonnun. ועשית. [2] Da

(17) qylg̀yn aziz upraqlar Aharongaa qaryndašyja syjğa da kör-

(18) kke. ואתה [3] Da sen sözlegin bar uslu jüreklilerge

(19) ki tolturdum any alhemi byla usnun da qylsynlar

(20) ošol upraqlaryn Aharonnun aziz etme any kohenlik etme

$132 \mathrm{r}^{\mathrm{o}}$ (1) maja. ואלה. [4] Da bulardylar ol upraqlar ki qylsynlar ḥošen da efod

(2) da qaftan da ojuvlu kölmek micnefet da avnet da qylsynlar aziz

(3) upraqlar Aharonġa qaryndašyja da uvullaryna anyn kohenlik et-

(4) me maja. והם [5] Da alar alsynlar ošol ol altynny da o-

(5) Šol ol köknü da ošol ol jipkinni da ošol ol qyrmyzy jipek-

(6) ni da ošol ol bezni. [6] Da qylsynlar ošol efodnu al-

(7) tyndan kökten da jipkinden da qyrmyzy jipekten da ešken

(8) bezden iši ojuvlavčunun. שתי. [7] Eki javrunlar qošadog̉an-

(8) lar bolsun anar eki učlaryna anyn da qošulsun. וחשב [8]

\footnotetext{
${ }^{1} \mathrm{~K}$ : mo'ed; a scribal error. | TKow.o1: mo'edde; unvocalized text. | H: mo'edde. | C: mo'eddä. $\quad{ }^{2} \mathrm{~K}$ : ortasynda; a scribal error.|TKow.o1: ortasyndan; unvocalized text.|H:ortasyndan.|C: ortasyndan.
} 
(20) and their bases of bronze. [18] The length of the court

(21) a hundred cubits, and the breadth of it fifty cubits, fifty cubits,

(1) and the height five cubits of twined linen, and their bases

(2) of bronze. [19] All the equipment of the tabernacle for all

(3) its service, and all its pegs, and all the pegs of the

(4) court: of bronze.

(5) Parashat Tetzaveh

(6) [20] And you shall command the children

(7) of Israel that they shall bring you

(8) pure beaten olive oil for the light, to kindle the lamp continually.

(9) $[21][\mathrm{In}]$ the tent of meeting, outside the veil which

(10) is above the Law, Aaron and his sons shall arrange

(11) it from evening until morning before the Lord. It shall be a statute forever

(12) throughout their generations from the children of Israel.

Exodus 28

(13) And bring near to you Aaron, your brother, and

(14) his sons with him, [from] among the children

(15) of Israel, to serve me as priests-Aaron, Nadab and Abihu,

(16) Eleazar and Ithamar, Aaron's sons. [2] And

(17) you shall make holy garments for Aaron, your brother, for glory and

(18) for beauty. [3] And you shall speak to all that are wise hearted,

(19) whom I have filled with the spirit of wisdom, that they shall make

(20) Aaron's garments to sanctify him, that he may serve

(1) me as priest. [4] And these are the garments which they shall make: a $132 \mathrm{r}^{\circ}$ breastplate, and an ephod,

(2) and a robe, and an embroidered shirt, a turban, and a girdle. And they shall make holy

(3) garments for Aaron, your brother, and his sons, to serve me as priests.

(4) [5] And they shall take gold, and

(5) blue and purple and scarlet silk,

(6) and the linen. [6] And they shall make the ephod of

(7) gold, of blue and of purple and of scarlet silk, and twined

(8) linen, embroiderer's work. [7] It shall have its two shoulders joined

(9) at their two edges, and so it shall be joined together. [8] 
(10) Da ojuvu bavynyn ki anyn üstüne išikibik anyn özünden

(11) bolsun altyndan kökten da jipkinden da qyrmyzy jipekten

(12) da ešken bezden. ולקחת. [9] Da alg̀yn ošol ol \{eki\} šoham taš-

(13) larny da tuǧurguun alar üstüne atlaryn uvullarynyn Jisra’el-

(14) nin. ששה (10] Altyny atlaryndan alarnyn ol bir taš üstüne

(15) da ošol atlaryn ol altynyn ol qalġanlarny ol ekinči taš

(16) üstüne tuvmušlaryna köre. מעשה. [11] Išin us-

(17) tasynyn tašnyn tužurmaqlaryn mohornun tužurg̉un ošol eki

(18) ol tašlarny atlarybyla uvullarynyn Jisra'elnin quršalġanlar al-

(19) tyn ojuvlar byla qylg̈yn alarny. ושמת [12] Da qojg̈un ošol

(20) eki ol tašlarny javrunlary üstüne ol efodnun sağynč-

(21) lyq tašlar uvullaryna Jisra’elnin da kötürsün Aharon ošol

$132 \mathrm{~V}^{\mathrm{o}} \quad$ (1) atlaryn alarnyn alynda Adonajnyn eki javrunlary üstüne saġynč-

(2) lyqqa. ועשית [13] Da qylġyn altyn ojuvlar. ושתי Da

(3) eki synžyrlar aruv altyndan čeklengenler qylġyn alarny iši

(4) örkennin da bergin ošol synžyrlary ol örkenler išinin

(5) ol ojuvlar üstüne. ועשית] [15] Da qylg̀yn ḥošen mišpat

(6) iši ojuvlavčunun iši kibik efodnun qylg̀yn any altyndan

(7) kökten da jipkinden da qyrmyzy jipekten da ešken bezden

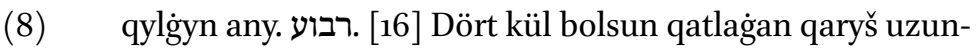

(9) luğu anyn da qaryš kenligi anyn. ומלאת. [17] Da tolturğun

(10) anda ${ }_{L}\{[\text { to }] \text { lturmag்yn tašnyn }\}^{11}$ dör $\{\mathrm{t}\}$ jergeler taštan jergesin rubinnin smaraknyn da

(11) karbankulisnin ol bir jerge. והטור. [18] Da ol ekinči

(12) jerge sürne tašy safir tašy da dijament. והטור. [19]

(13) Da ol üčünčü jerge lešem ševo da ahlama. והטור. [20]

(14) Da ol dörtünčü jerge taršiš tašy da šoham da jašfe

(15) ojuvlanġanlar altyn byla bolsunlar tolturmaqlarynda.

(16) והאבנים (21] Da ol tašlar bolsunlar atlarybyla uvullary-

(17) nyn Jisra'elnin on eki atlarybyla alarnyn tuక̌urmaqlary mo-

(18) hornun kiši atysajyn bolsunlar oneki ševetke. ועשית. [22]

(19) Da qylġyn ol ḥošen üstüne synžyrlar čeklengen iši ör-

(20) kennin aruv altyndan. ועשית. [23] Da qylg̀yn ol hošen üs-

(21) tüne eki jüzükler altyndan da bergin ošol eki ol

$133 \mathrm{r}^{\mathrm{o}} \quad$ (1) jüzüklerni eki učlary üstüne ol ḥošennin. [24] Da

(2) bergin ošol eki altyn örkenlerni eki ol jüzükler

\footnotetext{
${ }^{1}$ Marginal insertion by another hand. | TKow.o1: tolturmaġyn tašnyn; unvocalized text. | H: tolturmaġyn tasnyn. | C: tolmag̉yn tašnyy.
} 
(10) And the embroidered band, which is on it, shall be made like its work, and be of one piece with it:

(11) of gold, of blue and purple and scarlet silk,

(12) and twined linen. [9] And you shall take two onyx stones,

(13) and engrave on them the names of the sons of Israel:

(14) [10] Six of their names on one stone,

(15) and the other six names of the rest on the second stone,

(16) according to their birth. [11] With the work of an

(17) engraver in stone, |like| the engravings of a signet, you shall engrave the two

(18) stones with the names of the sons of Israel. You shall

(19) make them surrounded by golden filigree. [12] And you shall put the

(20) two stones on the shoulders of the ephod,

(21) stones of remembrance for the sons of Israel, and Aaron shall bear

(1) their names before the Lord on his two shoulders for remembrance.

(2) [13] And you shall make golden filigree, [14] And

(3) two chains finished in pure gold. You shall make them of

(4) rope work and put the rope chains

(5) on the filigree. [15] And you shall make the breastplate of judgment

(6) of embroiderer's work, you shall make it like the work of the ephod. You shall make it of gold,

(7) of blue and of purple and of scarlet silk, and of twined linen.

(8) [16] It shall be foursquare and doubled, the length

(9) of it a span, and the breadth of it a span. [17] And you shall put it

(10) there $\{$ a filling of stones $\}$ : four rows of stones. A row of a ruby, an emerald, and

(11) a carbuncle: the one row. [18] And the second

(12) row: a kohl stone, a sapphire, and a diamond. [19]

(13) And the third row: a jacinth, an agate, and an amethyst. [20]

(14) And the fourth row: a beryl, and an onyx, and a jasper.

(15) They shall be set in golden filigree.

(16) [21] And the stones shall be with the names of the sons

(17) of Israel, twelve, with their names; they shall be engravings

(18) of a signet, each with its name, for twelve tribes. [22]

(19) And you shall make chains finished in pure gold,

(20) rope work, on the breastplate. [23] And you shall make

(21) two rings of gold on the breastplate and shall put the two

(1) rings on the two ends of the breastplate. [24] And

(2) you shall put the two ropes of gold on the two rings 
(3) üstüne učlaryna ol ḥošennin. ואת [25] Da ošol eki

(4) učlaryn eki ol örkenlernin bergin eki ol ojuvlar üs-

(5) tüne da bergin javrunlary üstüne ol efodnun ut-

(6) rusuna jüzlerinin. ועשית. [26] Da qylġyn eki jüzükler altyn-

(7) dan da qojg̉un alarny eki učlary üstüne ol ḥošennin qy-

(8) ryj üstüne anyn ki janyna ol efodnun ičkerige.

(9) [יעשית Da qylġyn eki jüzükler altyndan da bergin

(10) alarny eki javrunlary üstüne ol efodnun ašagaartyn ut-

(11) rusundan jüzlerinin utrusuna qošar ornunun joġarraq oju-

(12) vundan ol efodnun. וירכסו. [28] Da atlanġyztyrsynlar o-

(13) šol ol ḥošenni jüzüklerinden anyn jüzükleri üstüne ol

(14) efodnun kök šnur byla bolma ojuvu üstüne ol

(15) efodnun da kötürülmesin ol ḥošen ol efod üstün-

(16) den. (29] Da kötürsün Aharon ošol atlaryn uvullary-

(17) nyn Jisra’elnin ḥošen ol mišpat byla jüregi üstüne kelgenin-

(18) de ol qodeške saġynčlyqqa alnynda Adonajnyn hammeše.

(19) ונתת [30] Da bergin ḥošen ol mišpatqa ošol ol urimni

(20) da ošol ol tumimni da bolsun jüregi üstüne Aharonnun

(21) kelgenind́a alnyna Adonajnyn da kötürsün Aharon

$133 \mathrm{v}^{\mathrm{o}} \quad$ (1) ošol töresin ulanlarynyn Jisra’elnin jüregi üstüne alny $\{\mathrm{n}\} \mathrm{da}$

(2) Adonajnyn hammeše. ועשית. [31] Da qylġyn ošol qaftanyn

(3) ol efodnun tügel kökten. והיה [32] Da bolsun qyryjy bašynyn

(4) ortasynda anyn jağa bolsun qyryjyna anyn čüvre iši to-

(5) huvčunun $\{q y r y j y\}\}^{1}$ iši kibik kübenin bolsun anar ki jyrtylmag̉aj.

(6) (33] Da qylg̈yn etekleri üstüne anyn narlar kökten

(7) da jipkinden da qyrmyzy jipekten etekleri üstüne

(8) anyn čüvre da altyn qunguravlar ortalarynda alarnyn

(9) čüvre. פעמון. [34] Altyn qunġurov da nar altyn qunġu-

(10) rov da nar etekleri üstüne ol qaftannyn čüvre.

(11) והיה [35] Da bolsun Aharon üstüne jumuš etme da e-

(12) šitilsin avazy anyn kelgeninde ol qodeške alnyna Adonaj-

(13) nyn da čyqqanynda da ölmesin. ועשית. [36] Da qylğyn čal-

\footnotetext{
${ }^{1}$ Marginal insertion by another hand. | TKow.o1: qyryjy; unvocalized text. | H: qyryjy. | C: aǵzy.
} 
(3) which are on the ends of the breastplate. [25] And you shall put the two

(4) ends of the two ropes on the two settings,

(5) and put them on the shoulders of the ephod opposite the front of it.

(6) [26] And you shall make two rings of gold,

(7) and you shall put them on the two ends of the breastplate

(8) in its edge, which is in the inside edge of the ephod.

(9) [27] And you shall make two rings of gold, and shall put

(10) them on the two shoulders of the ephod underneath,

(11) opposite the front of it, opposite the place of coupling, above the embroidered

(12) |band| of the ephod. [28] And they shall set

(13) the breastplate by its rings on the rings of the

(14) ephod with a blue string, so that it may be above embroidered |band|

(15) of the ephod, and that the breastplate shall not lifted from the ephod.

(16) [29] And Aaron shall bear the names of the sons

(17) of Israel in the breastplate of judgment on his heart when he comes in

(18) into the holy place, for a remembrance before the Lord always.

(19) [30] And you shall put in the breastplate of judgment the Urim

(20) and the Thummim, and they shall be on Aaron's heart

(21) when he goes in before the Lord. And Aaron shall bear

(1) the judgment of the children of Israel on his heart before

(2) the Lord always. [31] And you shall make the robe

(3) of the ephod all of blue. [32] And its head-opening ${ }^{121}$

(4) shall be within it. It shall have an edging for its opening all around,

(5) weaver's work, it shall have an $\{e d g e\}$ like that of a coat of mail so it will not be torn.

(6) [33] And you shall make on its hems pomegranates of blue

(7) and of purple and of scarlet silk, on its hems

(8) all around, and bells of gold among them

(9) all around. [34] A golden bell and a pomegranate, a golden bell

(10) and a pomegranate, on the robe's hems all around.

(11) [35] And it shall be on Aaron for ministering: and

(12) the sound of it shall be heard when he goes to the holy place before the Lord

(13) and when he comes out, and he shall not die. [36] And you shall make a diadem

121 Lit. 'edge for its head'. 
(14) ma aruv altyndan da tužurğun anyn üstüne tužur-

(15) maqlary mohornun qodeš la-H. ושמת. [37] Da qojg̈un any

(16) kök šnur üstüne da bolsun ol micnefet üstüne

(17) uturusuna ol micnefetnin bolsun. והיה [38] Da bolsun

(18) manlajy üstüne Aharonnun da kötürsün Aharon ol jazyġyn

(19) ol qadašimnin ki qodeš etseler ulanlary Jisra’elnin bar ber-

(20) neleri sajyn qodešlerinin da bolsun manlajy üstüne anyn hamme-

(21) še qabulluq[q]a ${ }^{1}\{[a] \text { lar üčün }\}^{12}$ alnynda Adonajnyn. ושבצת. [39] Da ojuvlaginn

$134 \mathrm{r}^{\circ} \quad$ (1) ol kölmekni bezbyla da qylg̀nn mic $\{\mathrm{n}\}$ efet bezden da avnet qyl-

(2) ġyn išin nağyšlavčunun. ולבני [40] Da uvullaryna Aharonnun

(3) qylġyn kölmekler da qylġyn alarg̉a avnetler da bijik börk-

(4) ler qylġyn alarg̉a syjg̈a da körkke. והלבשת. [41] Da

(5) kijdirgin alarny Aharonġa qaryndašyja da uvullaryna anyn bir-

(6) gesine da jaġyndyrg்yn alarny da tolturgun ošol qolun

(7) alarnyn da aziz etkin alarny da kohenlik etsinler maja.

(8) (42] Da qylg̈yn alarg̉a aq mihnesajimler ${ }^{3}$ qaplama etin

(9) ajipnin bellerden da butlargadejin bolsunlar. והיו [43] Da

(10) bolsunlar Aharon üstüne da uvullary üstüne anyn

(11) kelgenlerinde ohel mo'edge jemese juvuganlarynda ol

(12) mizbeaḥqa jumuš etḿa qodešte da kötürmesinler

(13) క̌urumun güneḥnin ${ }_{L}$ da öl[ [mesin]ler ${ }^{14}$ ömürlük resim anar

(14) da urlugiuna anyn özünden sortun.

Exodus 29

(15) ol iš ki qylg̀yn alarg̉a aziz etḿa alarny kohenlik et-

(16) me maja alġyn bir tana balasyn syġyrnyn da eki qočqar-

(17) lar tügellerni. ולחם. [2] Da ötmek macalar da hala-

(18) lar macalar jumurulgaanlar javbyla da juġa macalar jaġylġan-

(19) lar javbyla özeginden budajlarnyn qylg̈yn alarny. [3ת [3]

(20) Da bergin alarny bir četenge da juvutqun alarny četen byla

\footnotetext{
${ }^{1} \mathrm{~K}$ : qabulluqa; a scribal error. | TKow.o1: qabulluqqa; unvocalized text. | H: qabulluqa; a scribal error. | C: qabulluqqa. ${ }^{2}$ Marginal insertion by another hand. | TKow.o1: alarga; unvocalized text. | H: alarga. | C: alargia. $\quad{ }^{3} \mathrm{~K}$ : mihnasajimler amended into mihnesajimler.| TKow.o1: mihnesajimler; unvocalized text. | H: mihnesajimler. | C: könčäklär. $\quad{ }^{4} \mathrm{~K}:$ da ölerler; a scribal error; cf. also C. | TKow.o1: da ölmasinlar; unvocalized text. | H: mahat elerler. | C: da ölerler. | R: da ölmánińlar.
} 
(14) of pure gold, and engrave on it, like the engravings

(15) of a signet: "Holy to the Lord." [37] And you shall put it

(16) on a blue string, that it may be on the turban.

(17) It shall be on the front of the turban. [38] And it shall be

(18) on Aaron's forehead, that Aaron may bear the sin

(19) of the holy things, which the children of Israel shall consecrate according to all

(20) their holy gifts. And it shall be on his forehead always

(21) for acceptance \{for them $\}$ before the Lord. [39] And you shall embroider

(1) the shirt of linen, and you shall make the turban of linen, and you shall make the girdle

(2) of embroiderer's word. [40] And for Aaron's sons

(3) you shall make shirts, and you shall make for them girdles, and

(4) you shall make for them high caps - for glory and for beauty. [41] And

(5) you shall put them on Aaron, your brother, and on his sons with him-

(6) and you shall anoint them, and ordain them,

(7) and sanctify them, that they may serve me as priests.

(8) [42] And you shall make them white dual trousers to cover the flesh

(9) of their nakedness; they shall be from hips to thighs. [43] And

(10) they shall be on Aaron and on his sons

(11) when they come to the tent of meeting or when they come near to the

(12) altar to minister in the holy place, and they shall not bear

(13) a punishment of iniquity, and they will [not] die. It is an eternal statute for him

(14) and for his offspring after him.

Exodus 29

[1] And this is

(15) the thing that you shall do to them to consecrate them, that they may serve

(16) me as priests. Take one calf, the young of cattle, and two unblemished rams,

(17) [2] And unleavened bread, and unleavened cakes

(18) mixed with oil, and unleavened flans smeared

(19) with oil —you shall make them of fine wheat flour. [3]

(20) And you shall put them into one basket, and bring them in the basket 
(21) da ošol ol tanany da ošol eki ol qočqarlarny. ואת. [4]

$134 \mathrm{~V}^{\mathrm{o}}$ (1) Da ošol Aharonnu da ošol avullaryn anyn juvutqun ešigine

(2) ohel mocednin da juvg̉un alarny suvbyla. ולקחת [5] Da alġyn

(3) ošol ol upraqlarny da kijdirgin alarny Aharonġa ošol ol

(4) kölmekni da ošol qaftanyn ol efodnun da ošol ol efod-

(5) nu da ošol ol ḥošenni da bajlandyrg̉yn any ojuvu byla ol

(6) efodnun. [6] Da qojğun ol micnefetni bašyüstüne

(7) anyn da bergin ošol ol altyn tačny ol micnefet üstü-

(8) ולקחת [7 Da alğyn ošol ol jag̉ynmaq javny da

(9) qojg̉un bašyüstüne anyn da jag̉yndyrg̉yn any. [8 [8]

(10) Da ošol uvullaryn anyn juvutqun da kijdirgin alargaa kölmek-

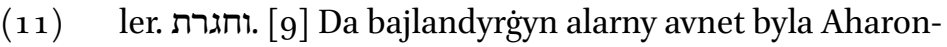

(12) nu da uvullaryn anyn da kijdirgin alarg̉a bijik börkler

(13) da bolsun alarga kohenlik ömürlük resimge da toltur-

(14) ġun qolun Aharonnun da qolun uvullarynyn. והקרבת Da

(15) juvutqun ošol ol tanany alnyna ohel mocednin da sunsun

(16) Aharon da uvullary anyn ošol qollaryn bašy üstüne ol tananyn.

(17) ושחטת Da sojğun ošol ol tanany alnynda Adonajnyn

(18) ešigind́a ohel mo'ednin. ולקחת [12] Da alg̀yn qanyndan ol tananyn

(19) da bergin müvüzleri üstüne ol mizbeahnnyn barmaġyj byla

(20) da ošol bar ol qanny tökkün bunjatyna ol mizbeahnnyn.

(21) ולקחת [13] Da alġyn ošol bar ol javny ol qaplajdoġanny ošol

$135 \mathrm{r}^{\mathrm{o}} \quad$ (1) ol qarynny da ošol artyğačny ol bavur üstüne da

(2) ošol eki ol büvreklerni da ošol ol javny ki alar üs-

(3) tüne da tütetkin ol mizbeaḥta. ואת [14] Da ošol e-

(4) tin ol tananyn da ošol terisin anyn da ošol jerenčiligin anyn

(5) küvdürgün otta tyšqartyn avulga hatatty ol.

(6) ואת [15 Da ošol ol bir qočqarny alġyn da sunsunlar Aharon

(7) da uvullary anyn ošol qollaryn bašy üstüne ol qočqarnyn.

(8) (16] Da sojğun ošol ol qočqarny da alğyn ošol

(9) qanyn anyn da bürkkün ol mizbeah üstüne čüvre. ואת [17]

(10) Da ošol ol qočqarny buvunlaġyn buvunlarysajyn da juvğun ičin

(11) anyn da tizlerin anyn da bergin buvunlary üstüne da 
(21) and the calf and the two rams. [4]

(1) And you shall bring Aaron and his sons to the door

(2) of the tent of meeting and wash them with water. [5] And you shall take

(3) the garments and put them on Aaron: the

(4) shirt, and the robe of the ephod, and the ephod,

(5) and the breastplate, and you shall gird him with the embroidered |band|

(6) of the ephod. [6] And you shall put the turban on his head,

(7) and you shall put the holy crown on the turban.

(8) [7] And you shall take the anointing oil, and

(9) put it on his head, and anoint him. [8]

(10) And you shall bring near his sons, and you shall put shirts on them.

(11) [9] And you shall gird them with girdles, Aaron

(12) and his sons, and put the high caps on them.

(13) And the priesthood shall be theirs for an eternal statute. And you shall ordain

(14) Aaron and his sons. [10] And

(15) you shall bring the calf before the tent of meeting, and

(16) Aaron and his sons shall reach out their hands over the head of the calf.

(17) [11] And you shall slaughter the calf before the Lord,

(18) by the door of the tent of meeting. [12] And you shall take of the blood of the calf,

(19) and put it on the horns of the altar with your finger,

(20) and pour all the blood out at the base of the altar.

(21) [13] And you shall take all the fat that covers the

(1) stomach, and the extra of it that is above the liver, and

(2) the two kidneys, and the fat that is on them,

(3) and burn them on the altar. [14] And you shall burn the

(4) flesh of the calf, and its skin, and its dung

(5) with fire outside the camp. It is a sin offering.

(6) [15] And you shall take the one ram, and Aaron

(7) and his sons shall reach out their hands over the head of the ram.

(8) [16] And you shall slaughter the ram, and you shall take

(9) its blood, and sprinkle it on the altar all around. [17]

(10) And you shall cut the ram into pieces according to its pieces, and wash its entrails,

(11) and its legs, and put them on its pieces, and 
(12) bašy üstüne. והקטרת [18] Da tütetkin ošol bar

(13) ol qočqarny ol mizbeaḥta 'oladyr ol Adonajgia ij qabul-

(14) luq otlu qarban Adonajgia ol. ולקחת [19] Da algyn ol ekin-

(15) či qočqarny da sunsun Aharon \{da uvullary anyn \} ošol qollaryn bašy üstüne ol

(16) qočqarnyn. ושחטת [20] Da sojg̉un ošol ol qočqarny da alġyn

(17) qanyndan anyn da bergin jymšaq ornu üstüne ol on jan-

(18) dağy qulag̉ynyn Aharonnun da jymšaq ornu üstüne ol on jan-

(19) daġy qulaqlarynyn uvullarynyn da baš barmaġy üstüne ol on

(20) jandag்y qollarynyn da baš barmag்y üstüne ol on jandaġy

(21) ajaqlarynyn da bürkkün ošol ol qanny ol mizbeah üstüne

$135 \mathrm{~V}^{\mathrm{o}}$ (1) čüvre. [21] Da alg̀yn ol qandan ol mizbeah üstü-

(2) ne da jaġynmaq javdan da bürkkün Aharon üstüne da up-

(3) raqlary üstüne anyn da uvullary üstüne anyn da upraq-

(4) lary üstüne ulanlarynyn birgesińa da aziz bolsun ol da

(5) upraqlary anyn [da uvullary $]^{1}$ da upraqlary uvullarynyn birgesińa. ולקחת [22]

(6) Da alğyn ol qočqardan ol javny da ol qujruqnu da ošol ol

(7) javny ol qaplajdog̉anny ošol ol qarynny da ošol artyġačyn

(8) ol bavurnun da ošol eki ol büvreklerni da ošol ol

(9) javny ki alar üstüne da ošol ol on jandag̉y inčikni ki

(10) qočqarydy milu'imnin ol. וככר [23] Da bohonon ötmek bir

(11) da hala ötmek javly bir da jog̉a bir četeninden ol maca-

(12) larnyn ki alnynda Adonajnyn. [24] Da qojg̉un ol barysyn u-

(13) vučlary üstüne Aharonnun da uvučlary üstüne uvullarynyn

(14) da sungun alarny tenufa alnynda Adonajnyn. [25 Da

(15) alġyn alarny qollaryndan alarnyn da tütetkin ol mizbeaḥta ol

(16) 'ola qatyna ij qabulluqqa alnynda Adonajnyn otlu qarban ol

(17) Adonajğa. ולקחת [26] Da alğyn ošol ol töšnü qočqaryn-

(18) dan ol milu'imnin ki Aharonnun da sungiun any tenufa alnynda

(19) Adonajnyn da bolsun saja ülüške. וקדשת. [27 Da aziz et-

(20) kin ošol töšün ol tenufanyn da ošol inčigin ol teruma-

(21) nyn ki sunuldu da ki ajyryldy qočqaryndan ol milu’imnin andan

${ }_{136} \mathrm{r}^{\mathrm{o}}$ (1) ki Aharonnun da andan ki uvullarynyn. [28] Da bolsun Aharon-

(2) ġa da uvullaryna anyn ömürlük resimge ulanlaryndan

${ }^{1} \mathrm{~K}$ : deest; a scribal error. | TKow.o1: da uvullary; unvocalized text. | H: da uvullary anyn. | C: da oǵlanlary. 
(12) on its head. [18] And you shall burn the whole

(13) ram on the altar. It is a burnt offering to the Lord, it is a pleasing aroma,

(14) an offering by fire to the Lord. [19] And you shall take the second

(15) ram, and Aaron and his sons shall reach out their hands over the head

(16) of the ram. [20] And you shall slaughter the ram, and you shall take

(17) of its blood, and put it on the the soft place of the right

(18) ear of Aaron, and on the the soft place of the right

(19) ear of his sons, and on the thumb of their right

(20) hand, and on the great toe of their right

(21) foot, and sprinkle the blood on the altar

(1) all around. [21] And you shall take of the blood that is on the altar,

(2) and of the anointing oil, and sprinkle it on Aaron, and

(3) on his garments, and on his sons, and on the garments

(4) of his sons with him. And he shall be holy, he and

(5) his garments, [and his sons], and his sons' garments with him. [22]

(6) And you shall take the fat from the ram and the |fat| tail, and the

(7) fat that covers the stomach, and its extra

(8) from the liver, and the two kidneys, and the

(9) fat that is on them, and the right thigh, because

(10) it is a ram of ordination, [23] And one loaf of bread, and one

(11) cake of bread with oil, and one flan from the basket

(12) of the unleavened bread that is before the Lord. [24] And you shall put all

(13) in the hands of Aaron, and in the hands of his sons;

(14) and you shall elevate them for a wave offering before the Lord. [25] And

(15) you shall take them from their hands, and burn them on the altar

(16) for a burnt offering, an aroma of acceptance before the Lord. It is an offering by fire

(17) to the Lord. [26] And you shall take the breast of the ram

(18) of Aaron's ordination, and elevate it for a wave offering before

(19) the Lord, and it shall be your part. [27] And you shall sanctify

(20) the breast of the wave offering, and the thigh of the heave offering,

(21) which is elevated, and which is separated from the ram of ordination, from what

(1) is Aaron's and from what is his sons'. [28] And it shall be for Aaron $\quad{ }_{13} 6 \mathrm{r}^{\mathrm{o}}$

(2) and for his sons as an eternal statute from the children 
(3) Jisra'elnin ki terumadyr ol da teruma bolsun ulanlaryndan

(4) Jisra’elnin debehalaryndan šelamimlerinin terumalary alarnyn

(5) Adonajgia. ובגדי [29] Da ol aziz upraqlar ki Aharonnun bol-

(6) sunlar uvullaryna özünden sortun jaġynma alarbyla kohen

(7) gadolluqqa da tolturma alarbyla ošol qolun alarnyn.

(8) שבעת [30] Jedi künler kijsin alarny ol kohen qajsy bolsa

(9) kohen gadol uvullaryndan anyn ornuna qajsy kelir ohel moced-

(10) ge jumuš etḿa qodešte. [ואת [31] Da ošol qočqaryn

(11) ol milu’imnin alğyn da biširgin ošol etin anyn aziz

(12) ואכל [32] Da ašasyn Aharon da uvullary anyn o-

(13) šol etin ol qočqarnyn da ošol ol ötmekni ki četen-

(14) de ešiginde ohel mo'ednin. ואכלו [33] Da ašasynlar

(15) alarny ki bošatlyq qolundu alarbyla tolturma ošol qolun

(16) alarnyn aziz etḿa alarny da jat ašamasyn ki azizdi alar.

(17) ואם [34] Da eger qalsa etinden ol milu'imnin da ol öt-

(18) mekten ol ertenbylagadejin da küvdürgün ošol ol qalġanny

(19) otta ašalmasyn ki azizdi ol. ועשית. [35] Da qylg̀yn Aharon-

(20) ġa da uvullaryna anyn alaj barča nečik ki bujurdum saja jedi

(21) künler tolturg̉un ošol qolun alarnyn. ופר. [36] Da bir tana

$136 \mathrm{v}^{\mathrm{o}} \quad$ (1) hatatqa qylg̀yn har kün ol bošatlyqlar üčün da bürkkün

(2) qanyn anyn ol mizbeah üstüne bošatlyq qolġanyjda anyn üs-

(3) tüne da jaġyndyrg்yn any aziz etme any. שבעת. [37] Jedi

(4) künler bošatlyq qolg̉un ol mizbeah üstüne da aziz et-

(5) kin any da bolsun ol mizbeaḥ qodeš qadašim bar ol tijüvčü mizbeah-

(6) qa aziz bolsun. [וזה [38] Da budur ki qylg̀yn ol mizbeah üs-

(7) tüne qozular jyllyq balalary eki künge hammeše. את. [39]

(8) Ošol ol bir qozunu qylg̀yn ertenbylada da ošol ol ekin-

(9) či qozunu qylg̀yn ol eki ingirler arasyna. ועשרן. [40] Da

(10) onunču ülüšü ol efanyn özek jumurulgian jančqan jav

(11) byla dörtünčüu ülüšü ol hinnin da neseh dörtünčü ü-

(12) lüšü ol hinnin čag̉yr ol bir qozugia. ואת [41] Da ošol

(13) ol ekinči qozunu qylg̀yn ol eki ingi\{r\}ler arasyna tir-

(14) kisikibik ol ertenbylanyn da nesehi kibik anyn qylgynn anar 
(3) of Israel, because it is an heave offering. And it shall be an heave offering from the children

(4) of Israel of the sacrifice of their peace offerings: their heave offering

(5) to the Lord. [29] And the holy garments of Aaron shall

(6) be for his sons after him, to be anointed for

(7) high-priesthood and to be ordained in them.

(8) [30] For seven days the priest who is

(9) the High Priest from among his sons in his place, who will come to the tent of meeting

(10) to serve in the holy place, shall wear them. [31] And you shall take the ram

(11) of ordination and boil its flesh in the holy

(12) place. [32] And Aaron and his sons shall eat

(13) the flesh of the ram, and the bread that is in the basket,

(14) by the door of the tent of meeting. [33] And they shall eat

(15) those things with which the atonement was asked, to ordain

(16) them and to sanctify them. And a foreigner shall not eat |of them|, because they are holy.

(17) [34] And if any of the flesh of the ordination or of the bread remains

(18) until the morning, then you shall burn the remainder

(19) with fire. It shall not be eaten, because it is holy. [35] And you shall do thus to Aaron,

(20) and to his sons, according to all things which I have commanded you.

(21) You shall ordain them for seven days, [36] And

(1) you shall offer every day a calf for a sin offering for atonement, and $136 \mathrm{v}^{\mathbf{o}}$ you shall sprinkle

(2) its blood on the altar when you ask for atonement for it,

(3) and you shall anoint it, to sanctify it. [37] Seven

(4) days you shall ask for atonement for the altar, and sanctify

(5) it, and the alter shall be holy of holies. Anyone who touches the altar

(6) shall be holy. [38] And this is what you shall do on the altar:

(7) two lambs, one-year-old, for a day, always. [39]

(8) You shall do the one lamb at dawn, and do the second

(9) lamb at twilight. [40] And

(10) a tenth part of an ephah of fine flour mingled with

(11) the fourth part of a hin of beaten olive oil, and the fourth part

(12) of a hin of wine for a drink offering for the first lamb. [41] And the

(13) other lamb you shall do at twilight,

(14) you shall do it according to the offering of the morning, and according to its drink offering 
(15) ij qabulluqqa otlu qarban Adonajğa. עלת. [42] Hammešelik

(16) 'ola dorlajyzsajyn eši[g]inde ${ }^{1}$ ohel mo'ednin alnynda Adonajnyn

(17) ki hadir bolur šehinam aškara bolma sizge anda sözleḿa

(18) saja anda. [43] Da hadir bolur šeḩinam aškara

(19) bolma ulanlaryna Jisra'elnin da aziz bolur syjym byla.

(20) וקדשתי Da aziz etermen ošol ohel mo'edni da ošol

(21) mizbeaḥny da ošol Aharonnu da ošol uvullaryn aziz etermen

$137 \mathrm{r}^{\mathrm{o}}$ (1) kohenlik etma maja. ושכנתי [45] Da toḥtarmen ortasynda

(2) ulanlarynyn Jisra’elnin da bolurmen alarġa Tenrige. [46] Da

(3) bilirler ki menmen Adonaj Tenrisi alarnyn ki čygardym alarny jerin-

(4) den Micrinin toḥtama men šehinam byla ortalarynda alarnyn

(5) menmen Adonaj Tenrisi alarnyn.

Exodus 30

(6) tetmekke tütü šitim ag̉ačlaryndan qylg̈yn any. אמה. [2]

(7) Lokot uzunluğu da lokot kenligi dört kül bolsun da eki

(8) lokotlar turušu anyn özünden bolsunlar müvüzleri anyn.

(9) וצפית [3 Da qaplag̉yn any aruv altyn byla ošol čardaġyn anyn

(10) da ošol farstlaryn anyn čüvre da ošol müvüzlerin

(11) anyn da qylg̀yn anar altyn quršov čüvre. ושתי [4] Da

(12) eki jüzükler altyndan qylġyn anar ašagaarraq quršovundan eki

(13) janlary üstüne qylġyn eki müvüšleri üstüne anyn

(14) da bolsun orunlar tutqučlarg̉a eltme any alar byla.

(15) ועשית [5] Da qylg̀yn ošol ol tutqučlarny šitim ag̉ačla-

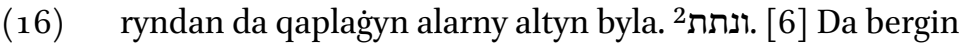

(17) any alnynda ol parohetnin $\mathrm{k}[\mathrm{i}]^{3}$ aronu üstüne ol šarajat-

(18) nyn alnynda ol kaporetnin ki ol šarajat üstüne ki hadir

(19) bolur šehinam aškara bolma saja anda. והקטיר [7 Da

(20) tütetsin anyn üstüne Aharon tütüsün otjamlarnyn har

(21) ertenbylada tüzetkeninde ${ }^{4}$ ošol ol čyraqlarny tütetsin

$137 \mathrm{~V}^{\mathrm{o}} \quad$ (1) any. [בהעלות. [8] Da jandyrg̉anda Aharon ošol ol čyraqlarny

(2) ol eki ingirlar arasyna tütetsin any hammešelik tü-

\footnotetext{
${ }^{1} \mathrm{~K}$ : ešikinde; a scribal error. | TKow.o1: ešikinde; a scribal error; unvocalized text. | H: esiginde. | C:

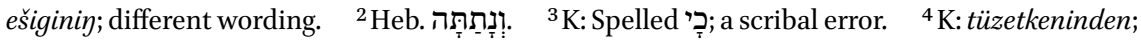
a scribal error. | TKow.o1: tüzetkeninde; unvocalized text. | H: tizetkeninde. | C: jaraštyrġanynda.
} 
(15) for a pleasing aroma, an offering by fire to the Lord, [42] A continual

(16) burnt offering throughout your generations at the door of the tent of meeting before the Lord,

(17) so that my divine Presence will be ready to appear to you there to speak

(18) to you there. [43] And my divine Presence will be ready to appear

(19) to the children of Israel, and they shall be sanctified by my glory.

(20) [44] And I will sanctify the tent of meeting, and the

(21) altar, and I will sanctify Aaron and his sons

(1) to serve me as priests. [45] And I will dwell among

(2) the children of Israel, and I will be God to them. [46] And

(3) they shall know that I am the Lord their God that brought them out from the land

(4) of Egypt, that I may dwell with my divine Presence among them.

(5) I am the Lord their God.

Exodus 30

(6) for burning incense. You shall make it of acacia wood. [2]

(7) A cubit the length of it, and a cubit the breadth of it, it shall be foursquare, and two

(8) cubits the height of it, its horns shall be of one piece with it.

(9) [3] And you shall overlay it with pure gold, the top of it,

(10) and the sides of it all around, and its horns.

(11) And you shall make a moulding of gold for it all around. [4] And

(12) you shall make two golden rings for it under its moulding, on the two

(13) sides of it, you shall make it by its two corners,

(14) and they shall be places for the poles with which to carry it.

(15) [5] And you shall make the poles of acacia wood,

(16) and overlay them with gold. [6] And you shall put

(17) it before the veil that is above the ark of the law,

(18) before the cover that is over the law,

(19) so that my divine Presence will be ready to appear to you there. [7] And

(20) Aaron shall burn on it fragrant incense every

(21) dawn, [when] he puts in order the lamps, he shall burn

(1) it. [8] And when Aaron lights the lamps

(2) at twilight, he shall burn it, a perpetual 
(3) tü alnynda Adonajnyn dorlaryjyzsajyn. לא. [9] Tütetmejiz anyn

(4) üstüne bašqa bu eki zamanlardan ki ol ündeledir

(5) jat tütü da 'ola tirki čygarmajyz anyn üstüne da

(6) neseh q[u]jmajyz ${ }^{1}$ anyn üstüne. וכפר [10] Da bošatlyq qol-

(7) sun anyn \{müvüzleri\} üstüne Aharon q[u]jmaqbyla² bir keret jylda qanyn-

(8) dan ḥatatynyn ol kipurim kününün bir keret jylda bošat-

(9) lyq qolsun anyn üstüne dorlaryjyz sajyn qodeš qadašim ol

(10) Adonajgia.

פרשת כי תשא (11) (11)

(112) [ידבר יהוה אל משה לאמר (11) Da sözledi Adonaj

(13) Mošege ajtadoġač. כידרות [12] Ki alsaj o-

(14) Šol sanyn bašynyn uvullarynyn Jisra’elnin sanalġanlarysajyn da

(15) bersinler kiši juluvun žanynyn Adonajğa \{sanag̉anda alarny da bolmasyn alarda qyranč $\}$ sanaġanda alarny.

(16) זה [13] Bunu bersinler bar ol ašuvču ol sanalġanlar qaty-

(17) na jarymyn ol mitqalnyn mitqaly byla ol qodešnin egirmi

(18) gögdü ol mitqal jarymyn ol mitqalnyn teruma Adonajğa.

(19) כל [14] Bar ol ašuvču ol sanalganlar qatyna egirmi jaštan

(20) da joġarraq bersin ošol terumasyn Adonajnyn. העשיר. [15]

${ }_{138} \mathrm{r}^{\mathrm{o}} \quad$ (1) Ol hoža artyq bermesin da ol jarly azraq bermesin jary-

(2) myndan ol mitqalnyn berme ošol terumasyn Adonajnyn bo-

(3) šatlyq qolma žanlaryjyz üčün. ולקחת. [16] Da alġyn ošol

(4) kümüšün ol juluvlarnyn ulanlaryndan Jisra’elnin da bergin

(5) any išine ohel mo'ednin da bolsun ulanlaryna Jisra’elnin

(6) sag̉ynčlyqqa alnynda Adonajnyn bošatlyq qolma žanlaryjyz

(7) ücünn. וידבר [17] Da sözledi Adonaj Mošege ajtadoġač.

(8) (18] Da qylġyn qumġan tučtan da ornun anyn tučtan

\footnotetext{
${ }^{1} \mathrm{~K}$ : qojmajyz; a scribal error. | TKow.o1: unvocalized text. | H: qujmajyz. | C: qujmaq qujmayyz.

${ }^{2} \mathrm{~K}$ : qojmaqbyla; a scribal error. | TKow.o1: unvocalized text. | H: deest. | C: deest. | R: deest.
} 
(3) incense before the Lord throughout your generations. [9] You shall not burn

(4) on it at other times than these, because it is called

(5) alien incense, and do not offer any burnt offering on it, and

(6) you shall not pour a drink offering on it. [10] And

(7) Aaron shall ask for atonement on its horns by pouring once in a year of the blood

(8) of the sin offering of the day of atonement: once in the year he shall

(9) ask for atonement on it throughout your generations. It is holy of holies

(10) to the Lord.'

(11) Parashat Ki Tisa

(12) [11] And the Lord spoke

(13) to Moses, saying, [12] 'When you count

(14) the number of the heads of the sons of Israel, according to their number:

(15) and each shall give a ransom for his soul to the Lord, when you count them, and there shall be no plague among them, when you count them.

(16) [13] Everyone who passes among them that are counted shall give this:

(17) half a mithqal by the mithqal of the Holy - twenty

(18) $g \ddot{o g} \mathrm{~s}^{122}$ is one mithqal. A half mithqal: the heave offering to the Lord.

(19) [14] Everyone who passes among them that are counted, from twenty years old

(20) and upward, shall give the heave offering of the Lord. [15]

(1) The rich shall not give more, and the poor shall not give less

(2) than half a mithqal, to give the heave offering of the Lord,

(3) to ask for atonement for your souls. [16] And you shall take the

(4) ransom silver of the children of Israel, and you shall give

(5) it for the service of the tent of meeting, and it shall be for a

(6) remembrance to the children of Israel before the Lord, to ask for atonement for your souls.'

(7) [17] And the Lord spoke to Moses, saying,

(8) [18] 'And you shall make a basin of bronze, and its place also of bronze,

122 Unidentified unit of weight. 
(9) juvunmaqqa da bergin any ohel moced byla mizbeah arasyna

(10) da bergin ary suv. [19] Da juvsunlar Aharon da

(11) uvullary anyn andan ošol qollaryn da ošol ajaqlaryn.

(12) בבואם (20] Kelgenlerind́a ohel mo'edge juvsunlar suvlar

(13) byla da ölmesinler jemese juvugaanlarynda ol mizbeaḥqa

(14) jumuš etḿa tütetme otlu qarban Adonajgia.

(15) ורחצו Da juvsunlar qollaryn da ajaqlaryn da ölme-

(16) sinler da bolsun alarg̉a ömürlük resim anar da

(17) urlugiuna dorla\{r\}ysajyn. וידבר [22] Da sözledi Adonaj Moše-

(18) ge ajtadoġač. ואתה. [23] Da sen alġyn özüje \{ilk\} otjam-

(19) lar mušk ijisli beš jüz [mitqal] ${ }^{1}$ da cynamon ijisli jarymyn anyn eki

(20) jüz da enli da körḱa ijisli eki jüz da enli.

(21) וקדה [24 Da qasja beš jüz ol aziz mitqal byla da

$138 \mathrm{v}^{\mathrm{o}}$ (1) zejtun javy hin. [25] Da qylg̈yn andan jag̉ynmaq jav aziz

(2) mažun mažunlanġan iši mažunlavčunun jag̉ynmaq jav aziz bolsun.

(3) (26] Da jag̉yndyrg̉yn anyn byla ošol ohel mocedni da

(4) ošol ol \{aronun\} šarajatnyn. ואת [27] Da ošol ol stolnu da ošol

(5) bar savutlaryn anyn da ošol ol čyraqbany da ošol savutlaryn

(6) anyn da ošol mizbeahyn ol tütünün. ואת [28] Da ošol mizbeahyn

(7) ol 'olanyn da ošol bar savutlaryn anyn da ošol ol qumġanny

(8) da ošol ornun anyn. [וקדשת Da aziz etkin alarny da

(9) bolsunlar qodeš qadašim bar ol tijüvčü alarg̉a kereklidi ki azizlen-

(10) gej. ואת [30] Da ošol Aharonnu da ošol uvullaryn anyn jaġyndyr-

(11) ġyn da aziz etkin alarny kohenlik etme maja. [31] Da

(12) ulanlaryna Jisra’elnin sözlegin ajtadog̉ač jaġynmaq jav aziz bolsun

(13) bu maja dorlaryjyzsajyn. על [32] Gufu üstüne adamnyn qojul-

(14) masyn da [qyjasy $]^{2}$ byla anyn qylmajyz özüjüzge anyn kibik azizdi

(15) ol aziz bolsun sizge. [3יש Kiši ki mažunlasa anyn kibik

(16) da ki berse andan jat üstüne da eksilir uluslaryndan.

(17) יויאמר Da ajtty Adonaj Mošege alġyn özüje otjam-

${ }^{1} \mathrm{~K}$ : deest; a scribal error. | TKow.o1: mitqal; unvocalized text. | H: mitqal. | C: mišqal. $\quad{ }^{2} \mathrm{~K}$ : qajsy; a scribal error. | TKow.o1: unvocalized text. | H: qyjasy. | C: oḥ̌ašynda. 
(9) for washing, and you shall put it between the tent of meeting and the altar,

(10) and you shall put water in it. [19] And Aaron and

(11) his sons shall wash their hands and their feet there.

(12) [20] When they come to the tent of meeting they shall wash with water,

(13) and they shall not die - or when they come near to the altar

(14) to serve, to burn offering by fire to the Lord.

(15) [21] And they shall wash their hands and their feet, and they shall not die.

(16) And it shall be a statute forever to them, to him and

(17) to his offspring throughout their generations.' [22] And the Lord spoke to Moses,

(18) saying, [23] 'And you, take to you the finest spices:

(19) fragrant musk, five hundred [mithqals], fragrant cinnamon, half as much, two

(20) hundred and fifty, and fragrant calamus, two hundred and fifty,

(21) [24] And cassia, five hundred by the mithqal of the Holy, and

(1) olive oil, a hin. [25] And you shall make of these a holy anointing oil,

(2) a medicine prepared, the work of an apothecary. It shall be a holy anointing oil.

(3) [26] And you shall anoint the tent of meeting with it and

(4) the ark of the law, [27] And the table and

(5) all its equipment, and the lampstand and its equipment,

(6) and the altar of incense, [28] And the altar

(7) of burnt offering with all its equipment, and the basin

(8) and its place. [29] And you shall sanctify them, and

(9) they shall be holy of holies. Anyone who touches them shall be holy.

(10) [30] And you shall anoint Aaron and his sons

(11) and consecrate them, that they may serve me as priests. [31] And

(12) you shall speak to the children of Israel, saying, "This shall be a holy anointing oil

(13) to me throughout your generations. [32] It shall it not be poured on man's body,

(14) and you shall not make anything else like it in its quantities. It is holy,

(15) and it shall be holy to you. [33] Anyone who prepares any like it,

(16) or anyone who puts any of it on a foreigner, shall be cut off from his people."'

(17) [34] And the Lord said to Moses, 'Take to you 
(18) lar mušk da revent da galban otjamlar da aruv levona baš-

(19) qa bašqa har birisi bolsun. [35] Da qylg̀yn andan tütü

(20) mažun iši mažunlavčunun qošulğan aruv aziz. ושחקת. [36] Da

(21) jančqyn andan uvaq da bergin andan alnynda ol šarajatnyn ohel

$139 \mathrm{r}^{\circ} \quad$ (1) mo ed[d] $\mathrm{e}^{1}$ ki hadir bolur šeḩinam aškara bolma saja anda qodeš

(2) qadašim bolsun sizge. [3קט] [37 Da ol tütü ki qylsaj qyjasy

(3) kibik \{anyn\} qylmajyz özüjüzge aziz bolsun saja ki ol qylynġandy

(4) qullugiuna Adonajyn. איש. [38] Kiši ki qylsa anyn kibik ijis-

(5) keme anda da nečik qylsa any eksilir uluslaryndan.

Exodus 31

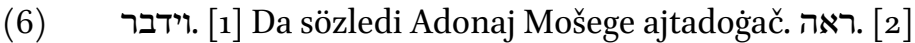

(7) Baqqyn ündedim atbyla Becal'elni uvlun Urinin uvlunun

(8) ואמלא Hurnun ševetinden Juhudanyn. Da toldurdum any al-

(9) hemi byla Tenrinin usbyla da aqylbyla da bilmek byla

(10) bar išni. לחשוב. [4] Ojuvlama ojuvlar išleme altyn-

(11) byla da kümüš byla da tuč byla. ובחרושת. [5] Da

(12) ustasy byla tašnyn tolturma da ustasy byla ag̉ačnyn iš-

(13) leme bar išni. [6] Da men muna berdim birgesine

(14) ošol Ahali’avny uvlun Ahisamaknyn ševetinden Dannyn da jüre-

(15) ginde bar uslu jüreklinin berdim us da qylsynlar ošol

(16) barča neki bujurdum saja. את. [7] Ošol ohel mo'edni

(17) da ošol ol aronnu šarajatqa da ošol ol kaporetni ki

(18) anyn üstüne da ošol bar savutlaryn ol čatyrnyn.

(19) (8) Da ošol ol stolnu da ošol savutlaryn anyn da

(20) ošol ol aruv čyraqbany da ošol bar savutlaryn anyn da o-

(21) šol mizbeahyyn ol tütünün. ואת [9] Da ošol mizbeahyyn ol

$139 \mathrm{v}^{\mathrm{o}} \quad$ (1) 'olanyn da ošol bar savutlaryn anyn da ošol ol qumġanny da

(2) ošol ornun anyn. [10] Da ošol ol bojavly upraqlarny

(3) da ošol ol aziz upraqlarny Aharonġa ol kohenge da ošol

(4) upraqlaryn uvullarynyn kohenlik etḿa. ואת [11] Da ošol

${ }^{1} \mathrm{~K}$ : mo'edge; a scribal error. Catchword: mo'edde. | TKow.o1: mo'edde; unvocalized text. | H: mo'edde. | C: mo'eddä. 
(18) spices: musk, and willowherb, and galbanum - spices and pure frankincense:

(19) each shall be separately. [35] And you shall make it incense,

(20) a medicine, the work of an apothecary, mixed, pure and holy. [36] And

(21) you shall beat some of it very small, and put of it before the law in the tent

(1) of meeting, so that my divine Presence will be ready to appear to you there.

(2) It shall be holy of holies to you. [37] And the incense that you make:

(3) you shall not make for yourselves in its quantities. It shall be holy to you, for it was made

(4) for the service of the Lord. [38] Anyone who will make anything like that

(5) to smell with it: when he makes it, he will be cut off from his people.'

\section{Exodus 31}

(6) And the Lord spoke to Moses, saying, [2]

(7) 'See, I have called by name Bezalel, son of Uri, son

(8) of Hur, of the tribe of Judah. [3] And I have filled him

(9) with the spirit of God, with wisdom and with reason and with knowledge

(10) and with every kind of work, [4] To make patterns, to work in gold

(11) and in silver and in bronze, [5] And

(12) to fill with a mason, and to do all kind of work with a woodworker

(13) [6] And I: lo, I have given with him

(14) Oholiab, son of Ahisamach, of the tribe of Dan. And

(15) I have put wisdom in the hearts of all that are wise hearted. And that they shall make

(16) all that I have commanded you: [7] The tent of meeting,

(17) and the ark of the law, and the cover that

(18) is on it, and all the equipment of the tent,

(19) [8] And the table and its equipment, and

(20) the pure lampstand and all its equipment, and the

(21) altar of incense, [9] And the altar

(1) of burnt offering and all its equipment, and the basin and

(2) its place, [10] And the colourful garments,

(3) and the holy garments for Aaron, the priest, and the

(4) garments of his sons, for their service as priests, [11] And the 


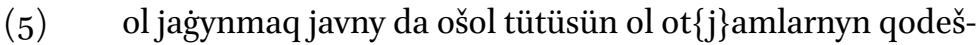

(6) ke barča nečik ki bujurdum saja alaj qylsynlar. ויאמר. [12] Da

(7) ajtty Adonaj Mošege ajtadog̉ač. ואתה. [13] Da sen sözlegin

(8) ulanlaryna Jisra’elnin ajtadoġač ančaq ošol šabatlarymny saq-

(9) lajyz ki belgidir ol arama da arajyzġa dorlaryjyzsajyn bilmá

(10) ki men men Adonaj aziz etüvčü sizni. ושמרתם. [14] Da saqlajyz

(11) ošol ol šabatny ki azizdi ol sizge jengil etüvčüleri anyn

(12) ölme öltürülsün ki bar ol išlevčü anda iš da

(13) eksilir ol žan ortasyndan uluslarynyn. ששת. [15] Alty

(14) künler qylynsyn iš da ol jedinči künde šabat šabaton

(15) aziz Adonajğa bar ol qyluvču iš ol šabat künde öl-

(16) me öltürülsün. ושמרו. [16] Da saqlasynlar ulanlary

(17) Jisra’elnin ošol ol šabatny azizlikte tutma ošol ol

(18) šabatny dorlarysajyn ömürlük šert. ביני [17] Arama da

(19) arasyna ulanlarynyn Jisra’elnin belgidi ol dunjagadejin ki alty

(20) künler ičine jaratty Adonaj ošol ol köklerni da ošol

(20) ol jerni da ol jedinči künd́a qaldy da tynč etti.

$140 \mathrm{r}^{\mathrm{o}} \quad$ (1) ויתן [18] Da berdi Mošege tügellegenindečoq sözleḿa bir-

(2) gesińa $\operatorname{tavyn}\{d\}$ a Sinajnyn eki luḥotlaryn ol šarajatnyn tašly luḥot-

(3) lar jazylġanlar bujrugubyla Tenrinin.

Exodus 32

(4) ol ulus ki kečigedi Moše enḿa ol tavdan da jyštyryldy

(5) ol ulus Aharonġa da ajttylar anar turgun qylġyn bizge

(6) könderüvčüler ki jürügejler alnymyzda ki bu Moše ol

(7) navi ki čyğardy bizni jerind́an Micrinin bilmejbiz ne boldu

(8) anar. ויאמר [2] Da ajtty alarg̉a Aharon üzüjüz o-

(9) šol altyn syrğalarny ki qulaqlarynda qatynlaryjyznyn uvullaryjyz-

(10) nyn da qyzlaryjyznyn da kelti\{ri\}jiz maja. ויתפרקו [3] Da üz-

(11) düler bar ol ulus ošol ol altyn syrgaalarny ki qulaqlaryn-

(12) da özlerinin da keltirdiler Aharonġa. [4] Da

(13) aldy qollaryndan alarnyn da tüvünčükledi anyn jančyqta da 
(5) anointing oil, and the fragrant incense for the Holy.

(6) They shall do everything as I have commanded you.' [12] And

(7) the Lord said to Moses, saying, [13] 'And you shall speak

(8) to the children of Israel, saying, "Just: you shall keep my Sabbaths,

(9) because it is a sign between me and you throughout your generations: to know

(10) that I am the Lord who sanctifies you. [14] And you shall keep

(11) the Sabbath, because it is holy to you. One who defiles it

(12) shall surely be put to death. Because anyone who does any work on it:

(13) that soul shall be cut off from among his people. [15] Six

(14) days work shall be done, and on the seventh day is the Sabbath, a day of complete rest,

(15) holy to the Lord. Anyone who does any work on the Sabbath day

(16) shall surely be put to death. [16] And the children of Israel shall keep

(17) the Sabbath, to consider the Sabbath holy

(18) throughout their generations, an eternal covenant. [17]

(19) It is a sign between me and the children of Israel forever, because in six

(20) days the Lord created the skies

(21) and the earth, and on the seventh day he rested and relaxed."'

(1) [18] And when he finished speaking with

(2) him on Mount Sinai, he gave the two tablets of law to Moses, tablets of stone,

(3) written by the command of God.

Exodus 32

[1] And the people saw

(4) that Moses was delaying to come down from the mountain, and the people were gathered

(5) to Aaron, and said to him, 'Get up. Make us

(6) leaders who shall go before us, because this Moses, the

(7) prophet, that brought us out from the land of Egypt, we do not know what has become

(8) of him.' [2] And Aaron said to them, 'Break off

(9) the golden earrings which are in the ears of your wives of your sons,

(10) and of your daughters, and bring |them| to me.' [3] And

(11) all the people broke off the golden earrings which were in their ears,

(12) and brought |them| to Aaron. [4] And

(13) he took them from their hand, and tied them in a pouch and 
(14) qyldy any qujma buzov da ajttylar bulardylar könderüvčü-

(15) lerij e Jisra’el ki čyg̉ardylar seni jerinden Micrinin. [5]

(16) Da kördü Aharon ${ }_{\lfloor}$ki bulaj bolundu ol nerse da nečikte ke-

(17) čiktirme alarny ${ }^{11}$ qondardy alnynda anyn mizbeah da čag̉yrdy

(18) Aharon da ajtty hyždy alnynda Adonajnyn tanbyla. וישכימו [6]

(19) Da tünlej turdular tanbyladan da čyġardylar 'olalar da juvu-

(20) ttular šelamimler da olturdu ol ulus ašama da ičme

(21) da turdular ojnama. [7] Da sözledi Adonaj Moše-

$140 \mathrm{v}^{\mathrm{o}} \quad$ (1) ge barg்yn engin ki čejpady jolun ulusuj ki čyğardyj jerind́an

(2) Micrinin. סרי [8] Kettiler tez ol joldan ki bujurdum alargia

(3) qyldylar özlerińa qujma buzov da bašurdular anar da debeḥa

(4) ettiler anar da ajttylar bulardylar könderüvčülerij

(5) e Jisra’el ki čyğardylar seni jerind́an Micrinin. ויאמר. [9] Da

(6) ajtty Adonaj Mošege kördüm ošol ol ulusnu ošpunu

(7) da muna ulus qaty ensel[i]dir ol. [10] Da haligine

(8) tynč bergin maja ${ }_{\llcorner}\{[$da qabu $]$nsun ačuvum [alarg̉a $]$da tasetejim $\}^{13} \mathrm{da}$ tavusajym alarny da qylarmen seni ullu

(9) hanlyqqa. [יחל. [11] Da qoldu Moše ošol qyblalaryn Adonajnyn

(10) \{Tenrisinin\} da ajtty nek e Adonaj qabunur ačuvuj ulusuj üstüne

(11) ki čyğardyj jerinden Micrinin ullu quvatbyla da küčlü qudrat

(12) byla. למה. [12] Nek ajtyrlar Micrililer ajtadoġač jamanlyq

(13) byla čyğardy alarny öltürme alarny tavlarda da tavusma

(14) alarny jüzleri üstünden ol jernin qajtqyn qahir ačuvujdan

(15) da fašman etkin ol jamanlyq üčün ulusuja. זכור [13]

(16) Saġynġyn šertin Avrahamnyn Jicḥaqnyn da Jisra’elnin qullaryjnyn

(17) ki antettij alarg̉a özüjden [da $]^{4}$ sözledij alargaa ajtadoġač

(18) arttyryrmen ošol urlugiujuznu jolduzlaryn kibik ol kök-

(19) lernin da bar ol jerni ošpunu ki ajttym urlug̉ujuzğa

(20) berirmen any da ülüš alyrlar dunjağadejin. וינחם [14] Da

\footnotetext{
${ }^{1}$ Interpretative addition to the standard text. $\quad{ }^{2} \mathrm{~K}$ : enseledir; a scribal error. | TKow.o1: unvocalized text. | H: enseli. | C: eysäli. $\quad{ }^{3}$ Marginal insertion by another hand. | TKow.o1: da qabunsun ačuvum alarda; unvocalized text. | H: qolmaġyn alar ücün da qabunur acuvum alarda. | C: qahirlänsin ačuvum alargia. $\quad{ }^{4} \mathrm{~K}$ : deest; a scribal error. | TKow.o1: da. | H: da. | C: da.
} 
(14) he made it a molten calf. And they said, 'These are your leaders,

(15) oh Israel, who brought you out from the land of Egypt.' [5]

(16) And Aaron saw that this was what happened,

(17) and he built an altar before it ${ }_{L}$ to delay somewhat the $\mid$ events $\left.\right|^{1123}$. And Aaron called,

(18) and he said, 'A feast to the Lord at daybreak.' [6]

(19) And they rose up early after daybreak and offered burnt offerings and brought

(20) peace offerings. And the people sat down to eat and to drink,

(21) and rose up to play. [7] And the Lord said to Moses,

(1) 'Go, go down, because your people whom you brought out from the land of Egypt have destroyed your path.

(2) [8] They have went quickly out of the way which I commanded them.

(3) They have made for themselves a molten calf, and they have worshiped it, and they have

(4) sacrificed to it, and they said, "These are your leaders,

(5) oh Israel, who have brought you from the land of Egypt." [9] And

(6) the Lord said to Moses, 'I have seen this people,

(7) and, lo, it is a stiff-necked people. [10] And now

(8) let me alone, \{and my anger shall kindle against them, and let me destroy $\}$ and consume them, and I will make you into a great

(9) kingdom.' [11] And Moses besought the directions of the Lord

(10) his God, and said, 'Oh Lord, why does your anger kindle against your people

(11) whom you have brought out from the land of Egypt with great power and with a mighty hand?

(12) [12] Why should the Egyptians speak, saying, "He brought them out with evil |intent|,

(13) to kill them in the mountains and to consume

(14) them from the face of the earth?" Turn back from your furious anger,

(15) and spare your people this evil. [13]

(16) Remember the covenant of Abraham, of Isaac, and of Israel, your servants,

(17) to whom you swore by your own self, [and] said to them, saying,

(18) "I will multiply your offspring like the stars of the skies,

(19) and I will give to your offspring all this land that I have spoken of,

(20) and they shall inherit it forever."' [14] And

123 An interpretative addition to Exo 32:5. 
(21) fašman etti Adonaj ol jamanlyq üčün ki sözledi qylma u-

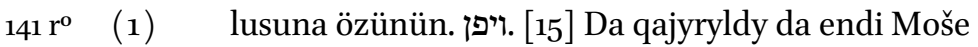

(2) ol tavdan da eki luhotlary ol šarajatnyn qolunda anyn luhot-

(3) lar jazylganlar ekside janlaryndan bu jantyn da bu jantyn alar

(4) jazylġanlar ediler. והלוחות [16] Da ol luḥot iši Tenri-

(5) nin alar da ol jazyš jazyšy Tenrinin ol tužurulġan ol luhot-

(6) lar üstüne. [17] Da ešitti Johošua ošol

(7) avazyn ol ulusnun qyčqyradog̉anny da ajtty Mošege

(8) črerüv avazy avulda. [18] Da ajtty tüvüldü

(9) avazy bek qyčqyrmaqnyn da tüvüldü avazy ḥalaš qyčqyrmaq-

(10) nyn jyr avazy men ešitemen. ויהי [19] Da edi ki nečik juvu-

(11) du ol avulg̀a da kördü ošol ol buzovnu da tanecler

(12) da qabundu ačuvu Mošenin da tašlady qollaryndan ošol ol

(13) luḥotnu da syndyrdy alarny ol tavtübüne. [20]

(14) Da aldy ošol ol buzovnu ki qyldylar da küvdürdü ot-

(15) ta da jančty neginče ki boldu uvaq da tozdurdu

(16) jüzleri üstüne ol suvarnyn da ičirdi ulanlaryna Jis-

(17) ra’elnin. [יאמר [21] Da ajtty Moše Aharonġa ne qyldy

(18) saja ol ulus ošpu ki keltirdij anyn üstüne ullu

(19) jazyq. ויאמר [22] Da ajtty Aharon qabunmasyn ačuvu bijimnin

(20) ויאמרו. sen bilesen ošol ol ulusnu ki jamandy ol Da

(21) ajttylar maja qylġyn bizge könde\{r\}üvčüler ki jürügejler

$141 \mathrm{v}^{\mathrm{o}} \quad$ (1) alnymyzda ki bu Moše ol navi ki čyğardy bizni \{jerinden\} Micrinin

(2) bilmejbiz ne boldu anar. [24] Da ajttym alarg̉a

(3) kimde bardy altyn üzdülar da berdiler maja da saldym

(4) any otqa da čyqty ol buzov ošpu. וירא [25] Da kör-

(5) dü Moše ošol ol ulusnu ki buzulġandy ol ki buzdu

(6) any Aharon ḥorluqqa utru turuvčularyna. [26]

(7) Da turdu Moše qabag̉ynda ol avulnun da ajtty kim

(8) Adonajnyn kelsin maja da jyštyryldylar anar bar uvullary

(9) Levinin. ויאמר [27 Da ajtty alarğa bulaj ajtty Adonaj

(10) Tenrisi Jisra’elnin qojujuz kiši qylyčyn butu üstüne

(11) ašyjyz qajtyjyz qabaqtan qabaqqa avulda da öltürüjüz

(12) kiši ošol qaryndašyn da kiši ošol dostun da kiši o-

(13) šol juvuġun. [יעשו [28] Da qyldylar uvullary Levinin sözüne

(14) köre Mošenin da tüštü ol ulustan ol künde üč

(15) min kiši. ויאמר [29] Da ajtty Moše tolturujuz qolu- 
(21) the Lord spared his people the evil which he had spoken, to do

(1) to his own people. [15] And Moses turned and went down

(2) from the mountain, and the two tablets of the law were in his hand,

(3) tablets written on both their sides, on this side and on this side

(4) they were written. [16] And the tablets were the work of God,

(5) and the writing was the writing of God, engraved on the tablets.

(6) [17] And when Joshua heard the

(7) noise of the shouting people, he said to Moses,

(8) 'There is a noise of war in the camp.' [18] And he said, 'It is not

(9) the voice of strong shouting, and it is not the voice of weak shouting:

(10) I hear the sound of a song.' [19] And it was, as soon as he

(11) came near to the camp, that he saw the calf and the dancing:

(12) and Moses' anger kindled, and he cast the tablets out of his hands

(13) and broke them at the foot of the mountain. [20]

(14) And he took the calf which they had made, and burned it in the fire,

(15) and ground it to fine |powder|, and scattered

(16) it on the water, and he made the children of Israel drink of it.

(17) [21] And Moses said to Aaron, 'What did

(18) this people do to you, that you have brought a great sin on it?'

(19) [22] And Aaron said, 'Let not the anger of my lord kindle:

(20) you know the people, that it is bad. [23] And

(21) [23] they said to me, "Make us leaders who shall go

(1) before us, because this Moses, the prophet, who brought us out from $141 \mathrm{v}^{\mathrm{o}}$ the land of Egypt:

(2) we do not know what has become of him." [24] And I said to them,

(3) "Who has any gold?" They broke it off and they gave it to me, and I cast

(4) it into the fire, and this calf came out.' [25] And

(5) Moses saw that the people went wrong, because

(6) Aaron had corrupted them — to shame for their adversaries. [26]

(7) And Moses stood in the gate of the camp, and said, 'Who

(8) is the Lord's? He shall come to me.' And all the sons of Levi were gathered to him.

(9) [27] And he said to them, 'Thus said the Lord,

(10) God of Israel, "Set, each man, his sword on his thigh,

(11) go to and fro from gate to gate in the camp, and kill

(12) each man his brother, and each man his friend, and each man

(13) his nearest."' [28] And the sons of Levi did according to the word

(14) of Moses, and three thousand men fell of the people in that day.

(15) [29] And Moses said, 'Fill your hands 
(16) juznu bügün jumuš etme Adonajg̉a ki kiši öltür-

(17) dü uvlun da qaryndašyn da berme üstüjüzge bügün

(18) alġyš. [30] Da edi tanbyladan da ajtty Moše ol

(19) ulusqa siz jazyqly boldujuz Adonajġa ullu jazyq da haligine

(20) barajym da bošatlyq qolajym alnyndan anyn jazyġyjyz üčün.

(21) [ישב [31] Da qajtty Moše Adonajğa da ajtty qoltqa-

$142 \mathrm{r}^{\circ} \quad$ (1) byla jazyqly boldu ol ulus ullu jazyq da qyldylar özlerińa

(2) altyn abaqlar. [ועתה [32] Da haligine eger bošatsaj jazyqlaryn

(3) alarnyn jahšy̌ da eger bošatmajdesej sürtkün meni en-

(4) di bitigijden ki jazdyj. [33] Da ajtty Adonaj Moše-

(5) ge kim jazyqly boldu maja sürtermen any bitigimden.

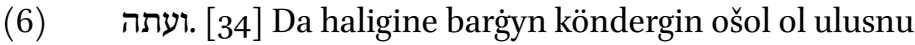

(7) ol orungia ki sözledim saja muna malahym baryr alnyj-

(8) da da saġyngan künümde [da saġynyrmen $]^{1}$ nendij jazyqlaryn alarnyn ¿da kara-

(9) tetermen alarny buda jazyġy üčüun alarnyn ${ }^{12}$.

(10) hastalatty Adonaj ošol ol ulusnu anyn üčün ki qyldylar

(11) ošol ol buzovnu ki qyldy Aharon.

Exodus 33

וידבר . 11] Da sözledi

(12) Adonaj Mošege ajtadog̉ač barġyn mingin ${ }_{\mathrm{L}}$ bu [o]rundan ${ }^{13}$ sen

(13) da ol ulus ki čyġardyj jerinden Micrinin ol jerge ki

(14) antettim Avrahamġa Jichaqqa da Ja'aqovġa ajtadog̉ač

(15) urlugguja berirmen any. ושלחתי. [2] Da ijermen alnyjda

(16) malah da sürermen ošol ol Kena'anini ol Emorini da

(17) ol Ḥitini da ol Perizini ol Ḥivini da ol Jevusini. אל [3]

(18) Jerge ag̉adoġan süt da bal ki barmasty šehinam menim

(19) ortajda ki ulus qaty ensel[i]dir ${ }^{4}$ sen magat tavusurmen

\footnotetext{
${ }^{1} \mathrm{~K}$ : deest; a scribal error. | TKow.o1: da sagynyrmen; unvocalized text, different wording. | H:

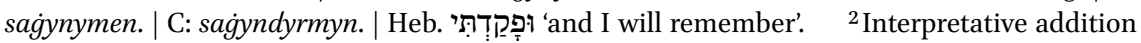
to the standard text. ${ }^{3} \mathrm{~K}$ : bu urundan; a scribal error. | TKow.o1: unvocalized text. | H: bundan. | C: mundan. $\quad{ }^{4} \mathrm{~K}$ : enseledir; a scribal error. | TKow.o1: unvocalized text. | H: enseli. | C: eysäli.
} 
(16) today to serve the Lord-because each man killed

(17) his son and his brother - and to put a blessing on you

(18) today' [30] And it was after daybreak, and Moses said to the

(19) people, 'You have sinned against the Lord a great sin. And now

(20) I will go to the Lord, and I shall ask for atonement for your sin.'

(21) [31] And Moses returned to the Lord, and said, 'I beg You,

(1) the people have sinned a great sin, and they have made them

(2) idols of gold. [32] And now, if you will forgive their sin

(3) - good. But if you still will not forgive, blot me out now

(4) from your book that you have written.' [33] And the Lord said to Moses,

(5) 'The one who has sinned against me, I will blot him out from my book. [34]

(6) And now, go. Lead the people

(7) to the place of which I have spoken to you. Lo, my angel shall go before you.

(8) And, in the day when I remember: and I will remember what sins they have,

(9) $\quad$ and I will punish them for this sin of theirs ${ }^{124}$. [35] And

(10) the Lord made the people sick, because they had made

(11) the calf, which Aaron had made.

Exodus 33

(12) to Moses, saying, 'Go, go up from here, you

(13) and the people whom you have brought out from the land of Egypt, to the land which

(14) I swore to Abraham, to Isaac, and to Jacob, saying,

(15) "I will give it to your offspring." [2] And I will send

(16) an angel before you - and I will drive out the Canaanite, the Amorite, and

(17) the Hittite, and the Perizzite, the Hivite, and the Jebusite- [3]

(18) To a land flowing $\mid$ with $\mid$ milk and honey, because my divine Presence will not go

(19) in the midst of you, because you are a stiff-necked people, lest I consume

124 An interpretative addition to Exo 32:34. 
(20) seni jolda. וישמע [4] Da ešitti ol ulus ošol ol

(21) jaman söznü ošpunu da jasly boldular da qojmadylar kiši

$142 \mathrm{~V}^{0}$ (1) bözövün üstüne. [5] Da ajtty Adonaj Mošeǵa

(2) ajtqyn uvullaryna Jisra’elnin siz ulus qaty enseli bir köz

(3) jumčuguna barsa šehinam ortajda da tavusurmen seni

(4) da haligine endirgin bözövüjnü üstüjden da bilirmen

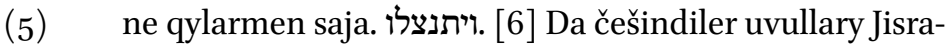

(6) 'elnin bözövlerind́an tavyndan Ḥorevnin. ומשה. [7 Da Moše

(7) aldy ošol ol čatyrny da qurdu özüne tyšqartyn avulğa

(8) jyraq etme ol avuldan da atady anar ohel mo'ed da edi

(9) bar izlevčü sorma sözün Adonajnyn čyġaredi ohel mo'edge

(10) ki tyšqartyn avulġa. והיה [8] Da bolġaj čyqqačoq Moše

(11) ol čatyrga turaredi\{ler\} bar ol ulus da toḥtarediler kiši

(12) ešiginde čatyrynyn da bag̉arediler Moše artyna kelgenine-

(13) dejin ol čatyrg̉a. והיה [9] Da bolg̉aj kelgečoq Moše ol

(14) čatyrg̉a eniredi bag̉anasy ol bulutnun da turaredi ešigin-

(15) de ol čatyrnyn da sözleredi Moše byla. וראה [10] Da

(16) köreredi bar ol ulus ošol baġanasy ol bulutnun turadoġan-

(17) ny ešiginde ol čatyrnyn da turaredi bar ol ulus da

(18) bašururediler kiši ešiginde čatyrynyn. ודבר. [11] Da

(19) sözleredi šehinasy Adonajnyn Mošege aqyl aqylgia ki nečik

(20) sözlejdi kiši dostubyla da qajtyredi ol avulg̀a da jumuš-

(21) čusu anyn Johošua uvlu Nunnun jumuš etüvčü jumušun ulan-

$143 \mathrm{r}^{0}$ (1) nyn eksilmesedi ortasyndan ol čatyrnyn. [12]

(2) Da ajtty Moše Adonajğa kör sen ajtasen maja elt-

(3) kin ošol ol ulusnu ošpunu da sen bildirmedij maja

(4) ošol kimni ki ajyrsen birgeme da sen ajttyj bildim seni

(5) atbyla da daġyn taptyj širinlik 'enajatlarymda.

(6) יועתה [13] Da haligine eger endi taptym ese širin-

(7) lik 'enajatlaryjda bildirgin \{maja\} qoltqabyla ošol kečinmek-

(8) lerijni jaratylmyšlaryjbyla anyn üčün ki tapqajmen širin- 
(20) you in the way.' [4] And the people heard this

(21) evil word, and they mourned, and no man did put

(1) on him his ornaments. [5] And the Lord said to Moses,

(2) 'Say to the children of Israel, "You are a stiff-necked people.

(3) If f for a blink of an eye ${ }^{1125}$ my divine Presence should go in the midst of you, I would consume you.

(4) And now take off your ornaments from you, and I will know

(5) what to do to you."' [6] And the sons of Israel stripped themselves

(6) of their ornaments from Mount Horeb |onward|. [7] And Moses

(7) took the tent, and pitched it for himself outside the camp,

(8) to make it be far off from the camp, and called it the tent of meeting. And it was:

(9) everyone who sought to ask the word of the Lord went out to the tent of meeting

(10) which was outside the camp. [8] And it would be: when Moses went out

(11) to the tent, all the people rose up and stood each man

(12) at his tent door, and looked after Moses, until he came

(13) to the tent. [9] And it would be: as Moses came

(14) to the tent, the pillar of cloud descended and stood at the door

(15) of the tent, and the Lord spoke with Moses. [10] And

(16) all the people saw the pillar of cloud standing

(17) at the tent door, and all the people rose up and

(18) worshiped, each man in his tent door. [11] And

(19) the divine Presence of the Lord spoke to Moses mind to mind, as a man

(20) speaks to his friend. And he turned again to the camp. And his servant

(21) Joshua, son of Nun, who served the service of a young man,

(1) did not depart from the tent. [12]

(2) And Moses said to the Lord, 'See, you say to me, "Bring

(3) up this people," and you have not let me know

(4) whom you will send with me. And you have said, "I know you

(5) by name, and you have also found favour in my sight."

[13] And now, if I have now found

(7) favour in your sight, let me know, I beg you, , the way you will act

(8) toward those whom you created ${ }^{1126}$ that I may find favour

125 I.e., for a single moment.

126 An interpretative translation. 
(9) lik 'enajatlaryjda jalbarganymda alnyjda ulusuj üčün ${ }^{11}$

(10) da körgün ki ulusujdu ol hanlyq ošpu. [יאמר ]

(11) Da ajtty Adonaj qyblalarym baryrlar da tynč etermen

(12) saja. ויאמר [15] Da ajtty Moše Adonajğa eger

(13) qyblalaryj barmaslar ortamyzda čyğarmaġyn bizni bundan.

(14) (16] Da nebyla bilinir bunda ki taptym širinlik

(15) 'enajatlaryjda men da ulusuj muna barg̉anda šehinaj

(16) birgemizge da ajyrylganlar bolur biz men da ulusuj

(17) bar ol ulustan ki jüzleri üstüne ol jernin. ויאמר [17 ]

(18) Da ajtty Adonaj Mošege daġyn ol söznü ošpunu ki

(19) sözledij qylarmen anyn üčün ki taptyj širinlik 'enajatlarym-

(20) da da bildim seni atbyla. [18 Da ajtty Moše

(21) Adonajg̉a körgüzgün maja qoltqabyla ošol syjyjny.

$143 \mathrm{~V}^{\mathrm{o}}$ (1) יויאמר [19] Da ajtty Adonaj men ašyryrmen bar jaḥšymny

(2) alnyjda da čag̀yryrmen atybyla Adonajnyn alnyjda da hajif-

(3) sünürmen ošol kimni ki ušajdy ki hajajifsüngejmen da

(4) raḥmetlermen ošol kimni ki ušajdy ki raḥmetlegejmen.

(5) ויאמר (20] Da ajtty Adonaj bolalmassen körme ošol

(6) qyblalarymny ki körmejdi meni ol adam ani malahta.

(7) ויאמר Da Da ajtty Adonaj muna orun bardy birgeme

(8) da turġun ol skala üstüne. והיה [22] Da bolg̉aj aš-

(9) qanda syjym da qojarmen seni bučqag̉ynda ol skalanyn da

(10) qaplarmen bujrugumbyla üstüje ašqanynadejin šehinamnyn.

(11) והסרותי [23] Da ketirirmen ošol bujruğumnu da

(12) körersen ošol sondrag̉y jaratylmyšlarymny da qyblalarym

(13) körünmesler.

Exodus 34

(13) ויאמר [1] Da ajtty adonaj Moše-

(14) ge jonġun özüje eki tašly luḥotlar burunğularny ki-

(15) bik da jazarmen ol luhotlar üstüne ošol ol sözler-

(16) ni ki ediler ol burunġu luhotlar üstüne ki syndyr-

(17) dyj. והיה [2] Da bolg̈un hadir ertenbylag̉a da mingin

${ }^{1}$ Interpretative addition to the standard text. 
(9) in your eyes ${ }_{L}$ when I beg before you for your people ${ }^{7127}$.

(10) And see that this kingdom is your people.' [14]

(11) And the Lord said, 'My directions will go |with you|, and I will give you rest.'

(12) [15] And Moses said to the Lord, 'If

(13) your directions are not going among us, do not bring us out from here.

(14) [16] And by what will it be known here that I have found favour

(15) in your eyes, I and your people? Lo, in that your divine Presence goes

(16) with us. And we shall be separated, I and your people,

(17) from all the people that are on the face of the earth.' [17]

(18) And the Lord said to Moses, 'I will do this thing that

(19) you have spoken as well, because you have found favour in my eyes,

(20) and I have known you by name.' [18] And Moses said

(21) to the Lord, 'I pray you, show me your glory.'

(1) [19] And the Lord said, 'I will make all my goodness pass

(2) before you, and I will call the name of the Lord before you. And I

(3) will have mercy on the man who is equal to my mercy, and

(4) I will be gracious to the man who is equal to my grace.'

(5) [20] And the Lord said, 'You cannot see

(6) my directions, because neither man nor angel sees me.'

(7) [21] And the Lord said, 'Lo, there is a place by me,

(8) and you shall stand on the rock. [22] And it shall be,

(9) while my glory passes by, I will put you in a cleft of the rock, and

(10) I will cover you with my command until my divine Presence has passed by.

(11) [23] And I will take away my command, and

(12) you shall see my hindmost creation, but my directions

(13) will not be seen.'

Exodus 34

[1] And the Lord said to Moses,

(14) 'Cut for yourself two tablets of stone like the first,

(15) and I will write on the tablets the words

(16) that were on the first tablets, which you broke.

(17) [2] And be ready until dawn, and come up

127 An interpretative addition to Exo 33:13. 
(18) ertenbylada tavyna Sinajnyn da turg̉un maja anda

(19) bašy üstüne ol tavnyn. ואיש [3] Da kišide minme-

(20) sin birgeje da daġyn kišid́a körünmesin bar ol tavda

(21) dag்yn ol qoj\{nu\} da ol syġyrny kütmesinler uturusuna

$144 \mathrm{r}^{0}$ (1) ol tavnyn. [4] Da jondu Moše eki tašly luhot-

(2) lar burungularny kibik da tünlej turdu Moše erten-

(3) bylada da mindi tavyna Sinajnyn ki nečik bujurdu Adonaj

(4) anar da aldy qoluna eki tašly luhotlarny. וירר. [5] Da

(5) endi šehinasy Adonajnyn bulut byla da toḥtady birge-

(6) ויעבור. sine anda da č č

(7) Da ašady šehinasy Adonajnyn alnynda anyn da čağyrdy

(8) Adonaj Adonaj küčlü Tenri rah [metle]včü da hajifsünüv-

(9) čü uzaq ačuvlu da köp šavag̉atly da kerti. נוצר. [7]

(10) Abravču šavağ[a] tny ${ }^{3}$ min dorlarğa bošatuvču günehni da

(11) tanmaqny da jazyqny da könü etme könü etmejdi sağy-

(12) nuvču jazyġyn atalarnyn jaman ulanlar üstüne da ulan-

(13) lary üstüne ulanlarnyn üčünčü dorg̉adejin da dörtün-

(14) čü dorgandejin. Da žahtlady Moše da ijildi

(15) jerge da bašurdu. ויאמר [9] Da ajtty eger en-

(16) di tapty ese širinlik 'enajatlaryjda e Adonaj bar-

(17) syn endi šehinasy Adonajnyn ortamyzda ki ulus qaty

(18) enselidi ol da bošatqyn günehịimizni da jazyg்ymyzny da

(19) ülüš alġyn bizni. ויאמר [10] Da ajtty Adonaj muna

(20) men kesirmen šert alnynda bar ulusujnun qylarmen tamaša-

(21) lyqlar ki jaratylmadylar bar ol jerde da bar ol hanlyqlarda

$144 \mathrm{v}^{\mathrm{o}} \quad$ (1) da körerler bar ol ulus ki sen ortasynda anyn ošol

(2) išin Adonajnyn ki qorqunčludu ol ki men qylamen birgeje.

(3) שמר . [11] Saqlag̀yn özüje ošol neki men bujuramen saja bü-

(4) gün muna men sürermen alnyjda ošol ol Emorini da ol

(5) Kena'anini da ol Ḥitini da ol Perizini da ol Ḥivini da ol

(6) Jevusini. השמר. 12] Saqlaġyn özüje magat kesersen

(7) šert olturuvčusu byla ol jernin ki sen kelsen anyn üs-

(8) tüne mag̉at bolur tuzaqqa ortajda. כי. [13] Ki ančaq

(9) ošol mizbeaḥlaryn alarnyn qavšatyjyz da ošol macevalaryn

(10) alarnyn syndyryjyz da ošol ašeralaryn alarnyn kesijiz.

(11) כי (14] Ki bašurmag்yn özge tenrige ki Adonaj könü-

\footnotetext{
${ }^{1} \mathrm{~K}$ : čygardy; a scribal error. | TKow.o1: čag்yrdy. | H: cag்yrdy. | C: čaqyrdy. $\quad{ }^{2} \mathrm{~K}$ : rahemlenüvčü; a scribal error. | TKow.o1: rahmetlevčü; unvocalized text. | H: raḥmetlevčü. | C: rahimlävči. $\quad{ }^{3} \mathrm{~K}$ : šavaġtny; a scribal error. | TKow.o1: unvocalized text. | H: savaġatny. | C: šag்avat.
} 
(18) at dawn to Mount Sinai, and stand there for me

(19) on the top of the mountain. [3] And no man shall come up

(20) with you, and no man shall be seen in all the mountain.

(21) Also let the flocks or cattle not pasture opposite

(1) that mountain.' [4] And Moses cut out two tablets of stone

(2) like the first. And Moses rose up early at dawn,

(3) and he went up to Mount Sinai, as the Lord had commanded

(4) him, and took in his hand the two tablets of stone. [5] And

(5) the divine Presence of the Lord descended in the cloud and stood with him

(6) there, and he called the name of the Lord. [6]

(7) And the Lord passed by before him, and called,

(8) 'The Lord, the Lord, mighty God, gracious and merciful,

(9) slow to anger and abundant in kindness, and true, [7]

(10) Keeping kindness for thousand generations, forgiving iniquity and

(11) trespass and sin, though not making one innocent,

(12) reckoning the sin of the fathers on evil children and

(13) on children's children to the third and to the fourth

(14) generation.' [8] And Moses hurried and bowed

(15) toward the earth, and worshiped. [9] And he said, 'If

(16) now I have found favour in your sight, oh Lord,

(17) let my Lord go now among us, because it is a stiff-necked people,

(18) and forgive our iniquity and our sin, and

(19) take us for your inheritance.' [10] And the Lord said, 'Lo,

(20) I make a covenant. Before all your people I will do wonders,

(21) that have not been done in all the earth and in all the kingdoms.

(1) And all the people whom you are among will see the

(2) work of the Lord, because it is an awesome thing that I will do with you.

(3) [11] Watch yourself regarding what I command you this day:

(4) lo, I am driving out before you the Amorite, and the

(5) Canaanite, and the Hittite, and the Perizzite, and the Hivite, and the

(6) Jebusite. [12] Watch yourself, lest you make

(7) a covenant with the inhabitants of the land where you go,

(8) lest it become a snare among you. [13] But

(9) you shall destroy their altars, and break their pillars,

(10) and cut down their idol poles.

(11) [14] Because you shall worship no other god-because the Lord: 
(12) levčüdü aty anyn könülevčü Tenridi ol. [15]

(13) Mag̉at kesersen šert olturuvčusu byla ol jernin da

(14) azarlar artyndan qullugiunun abaqlarynyn da debeḥa

(15) eterlar abaqlaryna özlerinin da ünder seni

(16) da ašarsen debehasyndan anyn. ולקחת [16] Da alyrsen

(17) qyzlaryndan anyn uvullaryja da azarlar qyzlary anyn qullugiu

(18) artyna abaqlarynyn özlerinin da azġyryrlar ošol uvul-

(19) laryjny qullugiu artyna abaqlarynyn özlerinin. אלהי [17

(20) Qujma abaqlar qylmaġyn özüje. את. [18] Ošol ḥyžyn

(21) ol macalarnyn saqlaġyn jedi künler ašaġyn macalar ki bujurdum

$145 \mathrm{r}^{\circ} \quad$ (1) saja vağdasyna ol baš qusqan janġajnyn ki ol baš qusqan

(2) janġajda čyqtyj Micriden. כל. [19] Bar ačylmag̉y qursaqnyn

(3) majady da bar tuvaryj ol erkek ačylmag̉y \{ögüznün da qojnun\}1.

(4) ופטר [20] Da ačylmağyn ešeknin juluggun qojby-

(5) la da eger julumasaj da enselegin any da bar tunġu-

(6) čun uvullaryjnyn julugiun da körünmesinler qyblalarym

(7) alnyna boš. ששת. [21] Alty künlerde išlegin išle-

(8) rijni da ol jedinči künde šabat tutqun saban sürmek

(9) zamanda da ormaq zamanda šabat tutqun. [22]

(10) Da hyy̌̌yn Šavu'otnun qylġyn özüje jetilmeklerin or-

(11) maqlarynyn budajlarnyn da hyžyn ol jyštyrmaqnyn ajlanma-

(12) ġynda ol jylnyn. שלוש. [23] Üč keretler jylda körün-

(13) sün bar erkegij qyblalary alnyna ol bijnin Adonajnyn Tenri-

(14) sinin Jisra’elnin. כ2 [24] Ki tasetermen hananlyqlarny alnyjdan

(15) da kenertirmen ošol čegijni da suqlanmasty kišida

(16) ošol jerije barg̉anyjda körünme qyblalar alnyna Adonaj

(17) Tenrijnin üč keretler jylda. לא. [25] Sojmaġyn hamec qaty-

(18) na da bürkmegin qanyn debehamnyn da qonmasyn erten-

(19) bylag̉a debeḥasy hyyžynyn ol Pesaḥnyn. ראשית. [26] Ilkin jetil-

${ }^{1} \mathrm{~K}$ : Originally qojnun da ögüznün; the word order was corrected by the copyist. 
(12) his name is Jealous. He is a jealous God- $-[15]$

(13) Lest you make a covenant with the inhabitants of the land, and

(14) they will prostitute themselves after the service of their gods, and do sacrifice

(15) to their gods, and he will call to you,

(16) and you will eat of his sacrifice. [16] And you will take

(17) |some| of his daughters to your sons, and his daughters will prostitute themselves after the service

(18) of their gods and make your sons prostitute themselves

(19) after the service of their gods. [17]

(20) You shall not make molten gods for yourself. [18] You shall keep the feast

(21) of unleavened bread. Seven days you shall eat unleavened bread, as I commanded

(1) you, in the appointed time of the month Baš Qusqan, because in the $145 \mathrm{r}^{\mathrm{r}}$ month when grains come into ear

(2) you came out from Egypt. [19] Every |first| opening of a womb

(3) is mine, and all your livestock, male |first| opening |of a womb|, cattle or sheep.

(4) [20] And you shall redeem the |first| opening |of a womb| of a donkey with a sheep,

(5) and if you do not redeem it, then you shall butcher it. And you shall redeem all the firstborn

(6) of your sons. And none shall appear before my directions

(7) empty. [21] Six days you shall do your work,

(8) but on the seventh day you shall rest. In ploughing

(9) time and in harvest, you shall rest. [22]

(10) And you shall observe the feast of Shavuot, of the ripening

(11) of wheat harvest, and the feast of ingathering

(12) when the year passes. [23] Three times in the year

(13) all your male children shall appear before the directions of the Lord, God

(14) of Israel. [24] For I will destroy the kingdoms before you,

(15) and widen your border, and no man will covet

(16) your land when you will go up to appear before the directions of Lord

(17) your God three times in the year. [25] You shall not slaughter

(18) and sprinkle the blood of my sacrifice next to that which is leavened, and

(19) the sacrifice of the Passover shall not stay overnight until dawn. [26] 
(20) meklerinin jerijnin keltirgin üvüne Adonaj Tenrijnin

(21) biširmegin ulaqny sütü ičine anasynyn. [יאמר [27]

$145 \mathrm{~V}^{\mathrm{o}} \quad$ (1) Da ajtty Adonaj Mošege jazġyn özüje ošol bar ol

(2) sözlerni ošpularny ki ošpu sözlerge köre kestim

(3) birgeje šert da Jisra’el byla. ויהי [28] Da edi anda

(4) alnynda Adonajnyn qyrq kün da qyrq keče ötmek

(5) ašamady da suv ičmedi da jazdy ol luḥotlar üstü-

(6) ne ošol sözlerin ol šertnin on ol sözlerni.

(7) ויהי [29] Da edi engende Moše tavyndan Sinajnyn da

(8) eki ol luhotlary šarajatnyn qolunda Mošenin engenin-

(9) de ol tavdan da Moše bilmedi ki balqydy \{terisi \}üzlerinin

(10) sözlegeninde birgesine. [30] Da kördü

(11) Aharon da bar ulanlary Jisra'elnin ošol Mošeni da muna

(12) balqydy \{terisi \} jüzlerinin da qorqtular juvumaqtan anar.

(13) ויקרא (31] Da ündedi alarny Moše da qajttylar anar

(14) Aharon da bar ol nasiler క̌ymatta da sözledi

(15) ואחרי [32] Da andan sortun juvudular

(16) ulanlary Jisra’elnin da bujurdu alarg̉a ošol neki söz-

(17) ledi Adonaj birgesińa tavynda Sinajnyn. Da

(18) tügelledi Moše sözlemekten birgelerine da berdi

(19) jüzleri üstüne qaplav. ובבוא. [34] Da kelgende Moše

(20) alnyna Adonajnyn sözleme birgesińa keteri\{r\}edi ošol

(21) ol qaplavny čyqqanynadejin da čyġaredi da sözleredi

$146 \mathrm{r}^{\circ}$ (1) ulanlaryna Jisra’elnin ošol neki bujurulsajedi. [35]

(2) Da körerediler ulanlary Jisra’elnin ošol jüzlerin Mošenin

(3) ki balqydy terisi jüzlerinin Mošenin da qajtaryredi $\{M o s ̌ e\}^{1} \mathrm{o}-$

(4) šol ol qaplavny jüzleri üstüne kelgeninedejin sözleme

(5) birgesine.

$[\text { Exodus } 35]^{2}$

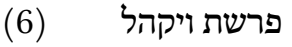

(1] Da

(8) jyštyrdy Moše ošol bar žymatyn ulanlary-

(9) nyn Jisra’elnin da ajtty alarg̉a bulardylar ol sözler

(10) ki bujurdu Adonaj qylma alarny. ששת. [2] Alty künler-

\footnotetext{
${ }^{1}$ Marginal insertion by another hand. | TKow.o1: Moše; unvocalized text. | H: Moše. | C: deest. ${ }^{2} \mathrm{~K}$ : The chapter number is not indicated. | TKow.o1: Exo 35. | H: Exo 35. | C: Exo 35.
} 
(20) You shall bring the first of the ripening of your land to the house of the Lord, your God.

(21) You shall not boil a kid in its mother's milk.' [27]

(1) And the Lord said to Moses, 'Write these words for yourself,

(2) because in accordance with these words I have made

(3) a covenant with you and with Israel. [28] And he was there

(4) before the Lord forty days and forty nights.

(5) He did not eat bread, and he did not drink water. And he wrote on the tablets

(6) the words of the covenant, the ten commandments.

(7) [29] And it was, when Moses came down from Mount Sinai and

(8) the two tablets of law were in Moses' hand, when he came down

(9) from the mountain, that Moses did not know that the skin of his face shone

(10) while he talked with him. [30] And

(11) Aaron and all the children of Israel saw Moses, and, lo,

(12) the skin of his face shone, and they were afraid to come near him.

(13) [31] And Moses called to them. And

(14) Aaron and all the princes of the congregation returned to him,

(15) and Moses spoke with them. [32] And afterward

(16) all the children of Israel came near. And he commanded them all that

(17) the Lord had spoken with him on Mount Sinai. [33] And

(18) Moses finished speaking with them, and

(19) he put a veil over his face. [34] But when Moses went

(20) in before the Lord to speak with him, he took the

(21) veil off until he came out. And he came out, and spoke

(1) to the children of Israel that which he was commanded. [35]

(2) And the children of Israel saw the face of Moses,

(3) that the skin of Moses' face shone, and \{Moses\} put the veil back

(4) over his face, until he went in to speak

(5) with him.

Exodus 35

(6) Parashat Vayakhel

(7) [1] And

(8) Moses gathered all the congregation of the children

(9) of Israel together, and said to them, "These are the words

(10) which the Lord commanded, that you should do them. [2] Six days 
(11) de qylynsyn iš da ol jedinči künde bolsun sizge

(12) aziz šabat šabaton Adonajğa bar ol qyluvču anda iš

(13) ölme öltürülsün. לא. [3] Jandyrmajyz ot bar

(14) olturušlaryjyzda ol šabat kününde. [יאמר [4]

(15) Da ajtty Moše bar žymatyna ulanlarynyn Jisra'elnin

(16) ajtadoġač budur ol söz ki bujurdu Adonaj ajtadoġač.

(17) קחו [5] Alyjyz özüjüzden teruma Adonajgia bar žomart

(18) jürekli keltirsin ošol terumasyn Adonajnyn altyn da

(19) kümüš da tuč. ותכלת. [6] Da kök da jipkin da

(20) qyrmyzy jipek da bez da junun ečkilernin. וערות. [7]

$146 \mathrm{v}^{\mathrm{o}} \quad$ (1) da terilerin qočqarlarnyn qyzartylġanlarny da terilerin taḥašlarnyn

(2) da šitim ag̉ačlaryn. ושמן Da jav jaryqlyqqa da otjamlar

(3) ol jag̀ynmaq javġa da tütüsüne ol otjamlarnyn. ואבני. [9]

(4) Da šoham tašlary efodg̀a da milu'im tašlary hošenge. וכלני [10]

(5) Da bar uslu jürekli sizde kelsinler da qylsynlar ošol bar-

(6) ča neki bujurdu Adonaj Mošege. את. [11] Ošol ol miškan-

(7) ny da ošol čatyryn anyn da ošol qaplavyn anyn ošol eslarin

(8) anyn da ošol taḥtalaryn anyn da ošol beklevüčlerin anyn ošol

(9) bag̉analaryn anyn da ošol tabanlaryn anyn. את. [12] Ošol ol

(10) aronnu da ošol tutqučlaryn anyn ošol ol kaporetni da ošol

(11) parohyetin ol qaplavnyn. את [13] Ošol ol stolnu da ošol

(12) tutqučlaryn anyn da ošol bar savutlaryn anyn da ošol ol eki

(13) jüzlü ötmekni. ואת [14] Da ošol čyraqbasyn ol jaryqlyq-

(14) nyn da ošol bar savutlaryn anyn da ošol čyraq orunlaryn

(15) anyn da ošol javyn ol jaryqlyqnyn. ואת [15] Da ošol

(16) mizbeahynn ol tütünün da ošol tutqučlaryn anyn da ošol

(17) ol jag̉ynmaq javny da ošol tütüsün ol otjamlarnyn da

(18) ošol qaplavyn ol ešiknin ešigine ol miškannyn. את [16]

(19) Ošol mizbeahyn ol 'olanyn da ošol ol tuč elekni ki anar

(20) ošol tutqučlaryn da ošol bar savutlaryn anyn ošol ol qum-

(21) ganny da ošol ornun anyn. את. [17] Ošol enlerin ol

$147 \mathrm{r}^{\circ} \quad$ (1) qahranyn ošol bag̉analaryn anyn da ošol tabanlaryn anyn da ošol

(2) qaplavyn qabaġynyn ol qaḥranyn. את. [18] Ošol qazyqlaryn ol miškan-

(3) nyn da ošol qazyqlaryn ol qaḥranyn da ošol šnurlaryn alarnyn.

(4) ת [19] Ošol ol bojavly upraqlarny jumuš etḿa qodešte

(5) ošol ol aziz upraqlarny Aharonġa ol kohenge da ošol

(6) upraqlaryn uvullarynyn kohenlik etḿa. ויצאו. [20] Da čyqtylar 
(11) work shall be done, but on the seventh day you shall have

(12) Sabbath, a day of complete rest holy to the Lord. Everyone who does work on it

(13) shall be put to death. [3] You shall kindle no fire in all

(14) your dwelling places on the Sabbath day.' [4]

(15) And Moses spoke to all the congregation of the children of Israel,

(16) saying, "This is the word which the Lord has commanded, saying,

(17) [5] "Take from among you an heave offering to the Lord. Everyone who has a generous

(18) heart shall bring the heave offering of the Lord: gold, and

(19) silver, and bronze, [6] And blue and purple and

(20) scarlet silk, and linen, and goats' hair, [7]

(1) And rams' skins dyed red, and porpoise skins,

(2) and acacia wood, [8] And oil for the light, and spices

(3) for anointing oil and for the sweet incense. [9]

(4) And onyx stones for the ephod, and stones to be set for the breastplate. [10]

(5) And every wise hearted among you shall come and make all

(6) that the Lord has commanded Moses. [11] The tabernacle,

(7) and its tent, and its covering, its hooks,

(8) and its boards, and its bars,

(9) its pillars, and its bases, [12] The

(10) ark, and its poles, the cover |of the ark|, and the

(11) veil of the covering, [13] The table, and

(12) its poles, and all its equipment, and the

(13) showbread, [14] And the lampstand for the

(14) light, and its equipment, and its places for candles,

(15) and the oil for the light, [15] And the

(16) incense altar, and its poles, and the

(17) anointing oil, and the incense of sweet spices, and

(18) the cover for the door, for the door of the tabernacle, [16]

(19) The altar of burnt offering, and the bronze grate of it,

(20) its poles, and all its equipment, the basin

(21) and its place, [17] The curtains

(1) of the court, its pillars, and their bases, and the

(2) cover for the gate of the court, [18] The pegs of the tabernacle,

(3) and the pegs of the court, and their cords,

(4) [19] The colourful garments to do service in the Holy,

(5) the holy garments for Aaron, the priest, and the

(6) garments of his sons, for their service as priests."' [20] And 
(7) bar 3̌ymaty ulanlarynyn Jisra’elnin alnyndan Mošenin. ויבואו. [21]

(8) Da keldiler bar kiši ki \{qunušturdu $\}^{1}$ any jüregi anyn da bar-

(9) ča kim ki \{̌̌omartlatty $\}^{2}$ క̌any anyn any keltirdiler ošol

(10) terumasyn Adonajnyn išine ohel mo'ednin da bar qullugiu-

(11) na anyn da ol aziz upraqlarga. [22] Da keldiler ol

(12) erenler ol qatynlar byla bar žomart jürekli keltirdiler ḥal-

(13) ha da syrg̉a da jüzük da pižma bar altyn savut da bar

(14) kiši ki sundu tanufasyn altynnyn Adonajnyn. וכל [23] Da

(15) bar kiši ki tabuldu birgesine kök da jipkin da qyrmyzy jipek

(16) da bez da junun ečkilernin da terilerin qočqarlarnyn qyzartyl-

(17) ganny da terilerin taḥašlarnyn keltirdiler. כל. [24] Bar ajyruv-

(18) ču terumasyn kümüšnün da tučnun keltirdiler ošol

(19) terumasyn Adonajnyn da barča kim ki tabuldu birgesine šitim

(20) ag̉ačlary bar išine ol qulluqnun keltirdiler. וכל. [25] Da bar

(21) qatyn uslu jürekli qollarybyla ijirdiler da keltirdiler ${ }_{\mathrm{L}} \mathrm{ijir}-$

$147 \mathrm{~V}^{0} \quad$ (1) [genni] $]^{13}$ ošol ol köknü da ošol jipkinni da ošol qyrmyzy

(2) jipekni da ošol ol bezni. וכל. [26] Da bar ol qatynlar ki qunuš-

(3) turdu jürekleri alarnyn alarny usbyla ijirdiler ošol junun

(4) ol ečkilernin. והנשיאים [27] Da ol nasiler keltirdiler

(5) ošol ol šoham tašlaryn efodg̉a da ošol ol milu’im

(6) tašlaryn ḥošenge. [28] Da ošol ol otjamny da ošol

(7) ol javny jaryqlyqqa da ol jag̉ynmaq javğa da tütüsüne

(8) ol otjamlarnyn. כל [29] Bar kiši da qatyn ki žomar\{t\}latty jü-

(9) regi alarnyn alarny keltirme bar ol iške ki bujurdu Adonaj

(10) qylma naviligi ašyra Mošenin keltirdiler ulanlary Jisra'elnin

(11) ל̌omartlyq Adonajğa. [30] Da ajtty Moše ulanlary-

(12) na Jisra’elnin baġyjyz čaġyrdy Adonaj atbyla Becal'elni uvlun U-

(13) rinin uvlunun Ḥurnun ševetinden Juhudanyn. [31] Da

(14) tolturdu any alhemi byla Tenrinin usbyla aqylbyla da

(15) bilü\{v\}byla bar ište. ולחשוב. [32] Da ojuvlama ojuvlar

(16) qulma altyn byla da kümüš byla da tučbyla. ובחרשת. [33]

(17) Da ustasybyla tašnyn tolturma da ustasybyla ag̉ač-

(18) nyn qylma bar ojuvlu išni. ולהורות. [34] Da üvretme

(19) berdi kölnünde anyn ol da Ahali'av uvlu Ahisamaknyn

\footnotetext{
${ }^{1}$ Originally copied in the next line: in this verse, the words žomartlatty and qunušturdu were swapped for each other by the copyist. $\quad{ }^{2}$ Originally copied in the previous line; see the respective footnote. ${ }^{3} \mathrm{~K}$ : ijir ajyrganny; a scribal error, cf. M. | TKow.o1: ijirgenni; unvocalized text. | H: ijirgenni. | C: yjyrmaq. | M: ajyrdylar (Exo 35:26); a scribal error. | R: ijirmak.
} 
(7) all the congregation of the children of Israel departed from before Moses. [21]

(8) And they came, everyone whose heart guided him and everyone

(9) whom his spirit made generous brought the

(10) Lord's heave offering for the work of the tent of meeting, and for all its service,

(11) and for the holy garments. [22] And they came,

(12) men and women. And all the generous hearted brought

(13) bracelets, and earrings, and rings, and trinkets, every |kind of | gold item: and every

(14) man who gave a wave offering of gold to the Lord. [23] And

(15) every man with whom was found blue and purple and scarlet silk,

(16) and linen, and goats' hair, and rams' skins dyed red,

(17) and porpoise skins: they brought |them|. [24] Everyone

(18) who donated an heave offering of silver and bronze brought the

(19) Lord's heave offering. And every man with whom was found acacia

(20) wood for any work of the service: they brought |it|. [25] And all

(21) the women who were wise hearted spun with their hands and brought

(1) [yarn], the blue, and the purple, and the scarlet

(2) silk, and the linen. [26] And all the women whose

(3) heart guided them in wisdom spun

(4) goats' hair. [27] And the princes brought

(5) onyx stones, and stones for the ephod, and stones to be set

(6) for the breastplate, [28] And the spice, and the

(7) oil for the light and for the anointing oil and for the sweet

(8) incense. [29] Every men and women whose heart made them generous

(9) to bring for all the work that the Lord had commanded

(10) to do by the prophecy of Moses: the children of Israel brought

(11) a freewill offering to the Lord. [30] And Moses said to the children

(12) of Israel, 'See, the Lord has called by name Bezalel, son of Uri,

(13) son of Hur, of the tribe of Judah. [31] And

(14) he has filled him with the spirit of God, with wisdom, with understanding, and

(15) with knowledge in every |kind| of work, [32] And to make patterns,

(16) to work in gold and in silver and in bronze, [33]

(17) And to fill with a mason, and to do

(18) all kind of patterned work with a woodworker. [34] And

(19) he put teaching in his heart: he and Oholiab, son of Ahisamach, 
(20) מלא [35evetinden Dannyn Toldurdu alarny usubyla jürek-

(21) nin qylma bar išin ustanyn da ojuvlavčunun da nağyšlavču-

$148 \mathrm{r}^{\circ}$ (1) nun kökbyla da jipkinbyla qyrmyzy jipekbyla bezbyla da

(2) toḥuvčunun qyluvčunun bar išnin da ojuvlavčularnyn bar

(3) ojuvlarny.

Exodus 36

(3) (1] Da qylsyn Becal'el da Ahali'av da bar

(4) kiši uslu jürekli ki berdi Adonaj us da aqyl jüregind́a

(5) alarnyn bilme qylma ošol bar išin qullug̉unun ol qodešnin

(6) barysajyn neki bujurdu Adonaj. ויקרא [2] Da ündedi Moše

(7) Becal'elni da Ahali'avny da bar uslu jürekli kišini ki berdi

(8) Adonaj us jüregind́a anyn barysyn kimni ki qunušturdu

(9) any jüregi anyn juvuma ol iške qylma any. ויקחו. [3]

(10) Da aldylar alnyndan Mošenin ošol bar ol terumany ki

(11) keltirdiler ulanlary Jisra’elnin išine ol aziz qulluqnun

(12) qylma any da ulanlary Jisra'elnin keltirdiler anar daġyn

(13) Šomartlyq har ertenbylada. ויבואו [4] Da keldiler

(14) bar ol uslular ol qyluvčular ošol bar ol aziz išni

(15) har kiši öz išinden ki alar išlerediler. ויאמרו. [5]

(16) Da ajttylar Mošege \{ajtadoġač\} arttyrdylar ol ulus keltirma

(17) artyq kereginden ol qulluqnun iške ki bujurdu Adonaj

(18) qylma any. ויצי [6] Da bujurdu Moše da ašyrdylar avaz

(19) avulda ajtadoġač kiši da qatyn qylmasynlar artyq iš

(20) terumasyna ol qodešnin da qaldy ol ulus keltirmek-

(21) ten. [7] Da ol iš edi jetkilikleriče alarnyn

$148 \mathrm{v}^{\mathrm{o}}$ (1) qylma any da qaldyrmada. [8] Da qyldylar bar uslu

(2) jürekli qyluvčularda ol išni ošol ol miškanny on en-

(3) ler ešken bezden da kökten da jipkinden da qyrmyzy

(4) jipekten keruvlar išin ojuvlavčunun qyldy alarny. ארך. [9]

(5) Uzunlugu ol bir ennin egirmi segiz lokot byla da

(6) kenligi dört lokot byla ol bir ennin bir ölčöv $<$ 〈bar ol- 
(20) of the tribe of Dan. [35] He has filled them with wisdom of heart,

(21) to do all the work of master |workmen|, and of the embroiderer, and of needlework

(1) in blue and in purple in scarlet silk and in linen, and

(2) of the weaver: of those who do any work, and of those that make all

(3) |kind of $\mid$ patterns.

Exodus 36

[1] And Bezalel and Oholiab

(4) and every wise hearted man in whose heart the Lord has put wisdom and understanding

(5) to know how to do all the work of the service of the Holy

(6) shall do according to all that the Lord had commanded. [2] And Moses called

(7) Bezalel and Oholiab, and every wise hearted man in whose

(8) heart the Lord had put wisdom, everyone whose heart guided

(9) him to come for the work, to do it. [3]

(10) And they took from in front of Moses all the heave offering that

(11) the children of Israel had brought for the work of the holy service,

(12) to make it. And the children of Israel even brought him

(13) freewill offerings at every dawn. [4] And

(14) all the wise men who were doing all the holy work

(15) came, every man from his work that they were doing. [5]

(16) And they said to Moses, saying, "The people are bringing

(17) more than needed for the service of the work which the Lord commanded

(18) to make.' [6] And Moses gave command, and they caused a voice to pass

(19) throughout the camp, saying, 'Let no man or woman do any more work

(20) for the heave offering of the Holy.' And the people ceased bringing.

(21) [7] And the work they had was sufficient for them

(1) to do it and to be left over. [8] And every wise

(2) hearted man among them who were doing the work made the tabernacle of ten

(3) curtains of twined linen, and of blue and purple and scarlet

(4) silk— they made them with cherubim of embroiderer's work. [9]

(5) The length of one curtain twenty eight cubits, and

(6) the breadth of one curtain four cubits: 
(7) čöv $>\rangle^{11}$ bar ol enlerge. [10] Da qoštu ošol beš ol

(8) enlerni birin birisine da beš ol enlerni qoštu birin

(9) birisine. יויעש [11] Da qyldy ilgikler kökten qyryjy üs-

(10) tüne ol bir ennin učtan qošulur orunda alaj qyldy

(11) qyryjynda ol ekinči učtağy ennin qošulur orunda.

(12) חמשים [12] Enli ilgikler qyldy ol bir ende da

(13) enli ilgikler qyldy qyryjynda ol ekinči učtag̉y ennin

(14) ki qošulur orunda uturulašadoġanlar ol ilgikler biri

(15) birisine. ויעש. [13] Da qyldy enli eslar altyndan

(16) da qoštu ošol ol enlerni birin birisine eslar byla da

(17) boldu ol miškan bir. ויעש. [14] Da qyldy enler junundan

(18) ečkilernin čatyrg̉a ol miškan üstüne on bir enler

(19) qyldy alarny. ארך. [15] Uzunlugiu ol bir ennin otuz lokot

(20) byla da dört lokotlar kenligi ol bir ennin bir ölčöv

(21) \{on\} bir ol enlerge. ויחבר [16] Da qoštu ošol beš ol enlerni

$149 \mathrm{r}^{02}$ (1) bašqa da alty ol enlerni bašqa. [17] Da qyldy enli

(2) ilgikler qyryj üstüne ol učtag̉y ennin qošulur orun-

(3) da da enli ilgikler qyldy ol ekinči qyryjy üstüne

(4) ol ennin ol qošadoġannyn. [18] Da qyldy eslar

(5) tučtan enlini qošma ošol ol čatyrny bolma bir.

(6) ויעש [19] Da qyldy qaplav čatyrg̉a terilerinden qočqarlar-

(7) nyn qyzartylġanlarnyn da qaplav terilerinden taḥašlarnyn jog̉ar-

(8) tyn. ויעש. [20] Da qyldy ošol ol taḥtalarny miškang̉a šitim

(9) ag̉ačlaryndan turadoġanlarny. עשר. [21] On lokot uzunlug̉u ol

(10) bir taḥtanyn da lokot da jarymy ol lokotnun kenligi ol bir

(11) taḥtanyn. שתי. [22] Eki tutqučlar ol bir tạ̣tağa teneš-

(12) tirilgenler biri birisine alaj qyldy bar tahtalaryna ol

(13) miškannyn. ויעש [23] Da qyldy ošol ol taḥtalarny miškang̀a

(14) egirmi taḥtalar tarafyna tüšlüknün temansary.

(15) (24] Da qyrq tabanlar kümüšten qyldy egirmi

(16) ol taḥtalar tübüne eki tabanlar ol bir taḥta tübü-

(17) ne eki tutqučlaryna anyn da eki tabanlar ol bir tah-

(18) ta tübüne eki tutqučlaryna anyn. ולצלע. [25] Da

(19) ekinči janyna ol miškannyn tarafyna cafonnun qyldy

(20) egirmi tahtalar. [26] Da qyrq tabanlary alarnyn

\footnotetext{
1'A scribal error. ${ }^{2}$ Heb. "I want to say the Book of Exodus of the Chumash in a translation in the language of Qedar' is written by another hand on the upper margin. Qedar is a Biblical term for an Ishmaelite tribe (mentioned in Genesis 25:13) which in early modern Hebrew often refers to the Turks.
} 
(7) on size for all curtains. [10] And he coupled the five

(8) curtains one to another, and he coupled the other five curtains one

(9) to another. [11] And he made loops of blue on the edge

(10) of the one outmost curtain in the place of being coupled. He did so

(11) in the edge of the second outmost curtain in the place of being coupled.

(12) [12] He made fifty loops in one curtain, and

(13) he made fifty loops in the edge of the second curtain

(14) in the place of being coupled. The loops were opposite one

(15) another. [13] And he made fifty hooks of gold,

(16) and coupled the curtains one to another with the hooks. And

(17) the tabernacle was one. [14] And he made curtains of

(18) goats' hair for the tent over the tabernacle. He made them eleven curtains.

(19) [15] The length of one curtain thirty cubits,

(20) and four cubits the breadth of one curtain:

(21) on size for the eleven curtains. [16] And he coupled five curtains

(1) separately, and six curtains separately. [17] And he made fifty

(2) loops on the edge of the one outmost in the place of being coupled,

(3) and fifty loops he made on the edge of the second

(4) connecting curtain. [18] And he made fifty hooks

(5) of bronze to couple the tent together, to be one.

(6) [19] And he made a covering for the tent of rams' skins

(7) dyed red, and a covering of porpoise skins above that.

(8) [20] And he made boards for the tabernacle of acacia

(9) wood, standing. [21] Ten cubits the length

(10) of a board, and a cubit and a half the breadth of a

(11) board. [22] One board had two tenons

(12) that fit together: so he made for all the boards

(13) of the tabernacle. [23] And he made boards for the tabernacle:

(14) twenty boards for the south side, southward.

(15) [24] And he made forty bases of silver under the twenty

(16) boards, two bases under one board

(17) for its two tenons, and two bases under one

(18) board for its two tenons. [25] And

(19) for the other side of the tabernacle, toward the north side, he made

(20) twenty boards, [26] And their forty bases 
(21) kümüšten eki tabanlar ol bir taḥta tübüne da eki

$149 \mathrm{v}^{\mathrm{o}}$ (1) tabanlar ol bir tahta tübüne. 27 [27 Da qyryjlaryna

(2) ol miškannyn ma'aravsary qyldy alty taḥtalar. ושני קרשים. [28]

(3) Da eki taḥtalar qyldy müvüšlerinde ol miškannyn qyjyrlar-

(4) da. והיו Da ediler tenler ašağartyn da birge edi-

(5) ler tepeten bašyna anyn ol bir jüzükke alaj qyldy eksi-

(6) lerinde eki ol müvüšlerge. [30] Da ediler

(7) segiz taḥtalar da tabanlary alarnyn kümüšten on alty tabanlar

(8) eki tabanlar ol bir tahta tübüne da eki tabanlar ol

(9) bir tahta tübüne. ויעש. [31] Da qyldy beklevüčler

(10) šitim ag̉ačlaryndan bešni ol bir janyna ol miškannyn.

(11) [12] Da beš beklevüčler tahtalaryna ekinči janynyn

(12) ol miškannyn da beš beklevüčler taḥtalaryna ol miškannyn

(13) qyryjlarda ma'aravsary. ויעש. [33] Da qyldy ošol ol ortan-

(14) čy beklevüčnü bekleme ortasynda ol tahtalarnyn ol

(15) učtan ol učqa. ואת [34] Da ošol ol tahtalarny

(16) qaplady altynbyla da ošol jüzüklerin alarnyn qyldy altyn-

(17) dan orunlar bekĺavüčlarǵa da qaplady ošol ol beklevüčler-

(18) ni altyn byla. ויעש [35] Da qyldy ošol parohetni kökten

(19) da jipkinden da qyrmyzy jipekten da ešken bezden išin

(20) ojuvlavčunun qyldy any keruvlar. ויעש [36] Da qyldy anar

(21) dört bag̉analar šitim ag̉ačlaryndan da qaplady alarny altyn by-

150 ro (1) la da čüvleri alarnyn altyndan da qojdu alarğa dört tabanlar

(2) kümüšten. ויעש. [37] Da qyldy qaplav ešigine ol čatyrnyn

(3) kökten da jipkinden da qyrmyzy jipekten da ešken bezden

(4) iši nağyšlavčunun. [38] Da ošol bağanalaryn anyn bešni

(5) da ošol čüvlerin alarnyn da qaplady bašlaryn alarnyn da čör-

(6) gevleri alarnyn altyn da tabanlary alarnyn beš tučtan.

Exodus 37

(7) ויעש Dacal'el ošol ol aronnu šitim ağač-

(8) laryndan eki lokotlar da jarym uzunluğu anyn da lokot

(9) da jarym kenligi anyn da lokot da jarym turušu anyn.

(10) [2] Da qaplady any aruv altyn byla ičkertin da

(11) tyšqartyn da qyldy anar altyn quršov čüvre. ויצוק. [3] Da

(12) $q[u] j d u^{1}$ anar dört jüzükler altyndan dört müvüšleri

\footnotetext{
${ }^{1} \mathrm{~K}: q o j d u$; a scribal error. | TKow.o1: unvocalized text. | H: qujdu. | C: töktü.
} 
(21) of silver, two bases under one board, and two

(1) bases under one board. [27] And for the edges

(2) of the tabernacle, westward, he made six boards. [28]

(3) And he made two boards for the corners of the tabernacle in the edges.

(4) [29] And they were in one line at the bottom and integrated

(5) in one line at the top of it, to one ring. He made it so

(6) for the two of them, for the two corners. [30] And there were

(7) eight boards, and their bases of silver; sixteen bases,

(8) two bases under one board, and two bases

(9) under one board. [31] And he made bars

(10) of acacia wood: five for the boards of the one side of the tabernacle,

(11) [32] And five bars for the boards of the second side

(12) of the tabernacle, and five bars for the boards of the tabernacle

(13) at the edges, westward. [33] And he made the middle

(14) bar in midst of the boards to fill |the space|

(15) from end to end. [34] And

(16) he overlaid the boards with gold, and made their rings of gold,

(17) places for the bars, and overlaid the bars

(18) with gold. [35] And he made a veil of blue

(19) and purple and scarlet silk, and twined linen:

(20) he made it embroiderer's work with cherubim. [36] And he made for it

(21) four pillars of acacia wood, and overlaid them with gold:

(1) and their hooks were of gold, and he cast for them four bases

(2) of silver. [37] And he made a cover for the door of the tent

(3) of blue and purple and scarlet silk, and twined linen,

(4) of needlework, [38] And the five pillars of it

(5) with their hooks, and he overlaid their capitals and

(6) their bands with gold, and their five bases were of bronze.

Exodus 37

(7) [1] And Bezalel made the ark of acacia wood:

(8) two cubits and a half the length of it, and a cubit

(9) and a half the breadth of it, and a cubit and a half the height of it.

(10) [2] And he overlaid it with pure gold inside and

(11) out, and made a moulding of gold for it around it. [3] And

(12) he [cast] for it four rings of gold four on the corners of it, 
(13) üstüne da eki jüzükler ol bir jany üstüne da

(14) eki jüzükler ol ekinči jany üstüne. ויעש [4] Da

(15) qyldy tutqučlar šitim ag̉ačlaryndan da qaplady alarny altyn

(16) byla. יובא [5] Da kijdi ošol ol tutqučlarny jüzük-

(17) lerge janlaryüstüne ol aronnun eltme ošol

(18) ol aronnu. ויעש. [6] Da qyldy kaporet aruv altyndan

(19) eki lokot da \{jarym $\}$ uzunlugiu anyn da lokot da jarym [kenligi $]^{1}$ anyn.

(20) ויעש [ [ [ Da qyldy eki keruvlar altyndan qaqqan qyldy alarny

(21) eki učlaryndan ol kaporetnin. כרוב. [8] Bir keruv učtan

$150 \mathrm{v}^{\mathrm{o}} \quad$ (1) bu jantyn da bir keruv učtan bu jantyn ol kaporetten qyldy ošol

(2) ol keruvlary eki učlaryndan. [יהי [9] Da ediler ol keruvlar

(3) jajuvčular qanatlar jog̉aryg̉a quršavčular qanatlarybyla ol kaporet

(4) üstüne da jüzleri alarnyn kiši qaryndašyna ol kaporetke

(5) ediler jüzleri ol keruvlarnyn. [10] Da qyldy ošol ol

(6) stolnu šitim ag̉ačlaryndan eki lokotlar uzunluggu da lokot ken-

(7) ligi anyn da lokot da jarym turušu anyn. Da qaplady

(8) any aruv altyn byla da qyldy anar altyn quršov čüvre.

(9) ויעש [12] Da qyldy anar beklevüč tutam čüvre da qyldy

(10) Laltyn anar ${ }^{12}$ altyn quršov beklevüčüne anyn čüvre.

(11) ויצוק [13] Da qujdu anar dört jüzükler altyndan da ber-

(12) di ošol ol jüzüklerni dört ol müvüšler üstüne ki

(13) dört ajaqlaryna anyn. לעמת. [14] Uturusuna ol bek-

(14) levüčünün ediler ol jüzükler orunlar tutqučlarg̉a elt-

(15) me ošol ol stolnu. [ošol ol] tutqučlarny [šitim] ag̉ačlaryndan [da qaplady] alarny [altyn] byla elt [me o]šol stolnu.\} ${ }^{13}$. ויעש. [16] Da qyldy ošol ol savut-

(16) larny ki ol stol üstüne ošol tepsiler[in $]^{4}$ anyn ki alar

(17) ičine biširirediler ošol eki jüzlü ötmekni da ošol

(18) ol qašyqlarny ki alarbyla ölčeredi ol kohen ošol ol tütünü

\footnotetext{
${ }^{1} \mathrm{~K}$ : turušu; a scribal error (or a mistranslation). | TKow.o1: kenligi; unvocalized text. | H: kenligi.

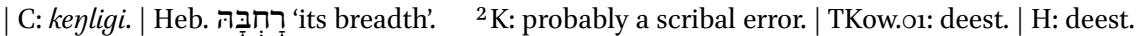
| C: deest. $\quad{ }^{3}$ Marginal insertion by another hand.| TKow.o1: ויעש. Da qyldy ošol ol tutqučlarny šitim aǵačlaryndan da qaplady alarny altynbyla eltme ošol ol stolnu; unvocalized text. | H: ויעש. Da qyldy osol ol tutquclarny šitim agaclaryndan da qaplady alarny altyn byla eltme osol ol stonu. | C: ויעש. Da qyldy šol suvruqlarny ag்ačlaryndan šitimniy da qaplady alarny altyn kötärmä šol tyrapezni. ${ }^{4} \mathrm{~K}$ : tepsiler; a scribal error. | TKow.o1: tepsilerin; unvocalized text. | H: tepsilerin. | C: tepsilärin.
} 
(13) and two rings on the one side of it, and

(14) two rings on the second side of it. [4] And

(15) he made poles of acacia wood and overlaid them with gold.

(16) [5] And he put the poles into the rings

(17) on the sides of the ark, to carry

(18) the ark. [6] And he made the cover of pure gold:

(19) two cubits and a half the length of it, and one cubit and a half the [breadth] of it.

(20) [7] And he made two cherubim of gold, he made them of hammered work,

(21) on the two ends of the cover. [8] One cherub on the end

(1) on this side, and one cherub on this side. He made

(2) the cherubim from the cover on the two ends of it. [9] And the cherubim

(3) spread out their wings above, encircling the cover with their wings,

(4) with their faces one to another:

(5) the faces of the cherubim were toward the cover. [10] And he made the

(6) table of acacia wood: two cubits the length of it, and a cubit

(7) the breadth of it, and a cubit and a half the height of it. [11] And he overlaid

(8) it with pure gold, and made for it a moulding of gold around it.

(9) [12] And he made for it a border |of $\mid$ a hand|breadth| around it, and he made

(10) a moulding of gold for the border all around.

(11) [13] And he cast for it four rings of gold, and

(12) put the rings on the four corners that

(13) are at its four legs. [14] Opposite to the

(14) border were the rings, the places for the poles to

(15) carry the table. ${ }_{L}\{[$ The $]$ verse 'And he made the poles' [is missing here].\} $\}^{128}[15]$ \{And he made [the] poles of acacia wood, [and overlaid] them with [gold, to] carry the table.\} [16] And he made the vessels

(16) which were on the table: its bowls 1 in which

(17) they baked the showbread, and

(18) its spoons with which the priest measured the incense,

128 Inserted by another hand in Hebrew. 
(19) da ošol arytqyčlarny da ošol ol stolpeclerni ki alar

(20) üstüne edi ol arytqyčlar ki qaplanyredi alarbyla arasy-

(21) na har bir ötḿak \{nin\} ki barg̉aj jel ortalary ašyra alarnyn ki

$151 \mathrm{r}^{0}$ (1) šemirlenmegej bar savutlarny qyldy altyndan. ויעש [17]

(2) Da qyldy ošol ol čyraqbany aruv altyndan qaqqan qyldy ošol

(3) ol čyraqbany butun anyn da qamušun anyn čaralary anyn tüvmeleri

(4) anyn da japraqlary anyn özünden ediler. וששה [18] Da alty

(5) qamušlar čyğarediler janlaryndan anyn üč qamušlary čyraqbanyn ol

(6) bir janyndan da üč qamušlary čyraqbanyn ol ekinči janyndan.

(7) שלושה. [19] Üč čaralar qošulgianlar ol bir qamušta tüvme

(8) da japraq da üč čaralar qošulgaanlar ol bir qamušta tüvme

(9) da japraq alaj [altysyda] ${ }^{1}$ ol qamušlarg̉a ol čyg்uvčularg̉a

(10) ol čyraqbadan. ובמנורה. [20] Da čyraqbada ${ }_{\perp}\langle$ üč $\rangle\{d o ̈ r t\}^{12}$ čaralar qošul-

(11) ganlar tüvmeleri anyn da japraqlary anyn. וכפתר. [21 Da

(12) tüvme eki ol qamušlar tübüne özünden da tüvme

(13) eki ol qamušlar tübüne özünden da tüvme eki ol

(14) qamušlar tübüne özünden altysy[da ${ }^{3}$ ol qamušlarğa

(15) ol čyg̉adog̉anlarg̉a andan. כפתוריהם. [22] Tüvmeleri

(16) alarnyn da qamušlary alarnyn özünden ediler ba\{ry\}sy bir qaq-

(17) qan aruv altyndan. ויעש [23] Da qyldy ošol čyraq orun-

(18) laryn anyn jedini da qysqačlaryn anyn da mačmarlaryn anyn aruv

(19) altyndan. ככר . 24] Qantar aruv altyndan qyldy any da ošol

(20) bar savutlaryn anyn. ויעש. [25] Da qyldy ošol ol mizbeahyn

(21) ol tütünün šitim ag̉ačlaryndan lokot uzunlugiu da lokot

$15^{1} \mathrm{~V}^{\mathrm{o}} \quad$ (1) kenligi anyn ${ }_{\mathrm{L}}\left\{\right.$ dört külli\} ${ }^{14}$ da eki lokotlar turušu anyn özünden ediler

(2) müvüzleri anyn. ויצף [26] Da qaplady any aruv altyn byla ošol

(3) čardag̉y anyn da ošol farstlaryn anyn čüvre da ošol

(4) müvüzlerin anyn da qyldy anar altyn quršov čüvre.

${ }^{1} \mathrm{~K}$ : altysynda; a scribal error; cf. Exo 25:33. | TKow.o1: alty; unvocalized text. | H: altysyda. | C: deest; different wording. $\quad{ }^{2}$ Correction by another hand in the outer margin. | TKow.o1: dört; unvocalized text. | H: dert. | C: dört. ${ }^{3} \mathrm{~K}$ : altysynda; a scribal error, cf. Exo 25:35. | TKow.o1: alty; unvocalized text. | H: altysyda. | C: deest; different wording. $\quad{ }^{4}$ Marginal insertion by another hand; cf. Exo 27:1. | TKow.o1: dört kül; unvocalized text. | H: dert tirli; a scribal error. | C: dörtkül. 
(19) and its cloths |used for covering the showbread|, and its [ ${ }^{\dagger}$ tablecloths] $]^{129}$

(20) on which were the cloths ${ }_{L}$ with which

(21) adjacent breads were separated ${ }^{1130}$ so that there would be airflow between ${ }^{131}$ them,

(1) so that they would not go mouldy. He made all the vessels of pure gold. ${ }^{1132}[17]$

(2) And he made the lampstand of pure gold. He made the lampstand of hammered work:

(3) its shaft, and its branch; its cups, its knobs,

(4) and its leaves were of the one same |piece|. [18] And six

(5) branches were going out of the sides of it, three branches of the lampstand

(6) out of one side, and three branches of the lampstand out of the second side,

(7) [19] Three cups coupled, a knob and a leaf in one branch,

(8) and three cups coupled, with a knob and a leaf in one branch,

(9) so for the six branches that come out of the lampstand,

(10) [20] And $\langle$ three $\rangle\{$ four $\}$ cups coupled in the lampstand,

(11) their knobs and their leaves, [21] And

(12) a knob under the two branches of the one same piece, and a knob

(13) under the two branches of the one same piece, and a knob

(14) under the two branches of the one same piece, for the six branches

(15) coming out of it. [22] Their knobs

(16) and their branches were of the same piece, all of it was one hammered

(17) work of pure gold. [23] And he made its seven places for candles,

(18) and its tongs, and their censers of pure

(19) gold. [24] He made it and all its vessels of a kantar of pure gold.

(20) [25] And he made the incense altar

(21) of acacia wood: a cubit the length of it, and

(1) a cubit the breadth of it, \{foursquare\}, and two cubits the height of it, $151 \mathrm{v}^{\mathrm{o}}$

(2) the horns of it were of one piece with it. [26] And he overlaid it with pure gold:

(3) the top of it and the sides of it all around, and the

(4) horns of it. And he made a moulding of gold for it all around.

129 An uncertain translation of stolpec.

130 Lit. 'with which it was covered between every bread'.

131 Lit. 'through among'.

132 Interpretative translation. 
(5) (27] Da eki jüzükler altyndan qyldy anar ašağarraq

(6) quršovuna eki janlary üstüne eki müvüšleri üs-

(7) tüne orunlar tutqučlarg̉a eltme any alarbyla.

(8) ויעש Da quldy ošol ol tutqučlarny šitim ağačlaryndan

(9) da qaplady alarny atlyn byla. ויעש [29] Da qyldy ošol ol

(10) jaġynmaq javny aziz da ošol ol tütüsün ol otjamlar-

(11) nyn aruv iši mažunlavčunun.

Exodus 38

[1] Da qyldy ošol

(12) mizbeaḥyn ol 'olanyn šitim ag̉ačlaryndan beš lokotlar uzunluğu

(13) anyn da beš lokotlar kenligi anyn dört kül da üč lokot-

(14) lar turušu anyn. [2] Da qyldy müvüzlerin anyn

(15) dört müvüšleri üstüne özünden ediler müvüzle-

(16) ri anyn da qaplady any tuč byla. [3] Da qyldy ošol

(17) bar savutlaryn ol mizbeaḥnyn ošol ol qazanlaryn da ošol ol

(18) sibirtkilerni da ošol ol kuboklarny da ošol ol jyr-

(19) ġaqlarny da ošol ol mačmarlarny bar savutlaryn anyn qyldy

(20) tučtan. [יעש. [4] Da qyldy mizbeaḥqa elek iši avnyn

(21) tučtan kruhu tübüne anyn ašaġartyn jarymynadejin. ויצוק. [5]

$15^{2} \mathrm{r}^{\mathrm{o}} \quad$ (1) Da q[u]jdu dört jüzükler dört ol učlarda ol tuč elek-

(2) ke orunlar tutqučlarg̉a. ויעש. [6] Da qyldy ošol ol

(3) tutqučlarny šitim ag̉ačlaryndan da qaplady alarny tučby-

(4) la. la [ ] Da kijirdi ošol ol tutqučlarny jüzükler-

(5) ge janlary üstüne ol mizbeaḥnyn eltme any alarbyla

(6) quvuš taḥtalardan qyldy any. [8] Da qyldy ošol

(7) ol qumġanny tučtan da ošol ornun anyn tučtan küz-

(8) gülerinden ol jyštyryluvču qatynlarnyn ki jyštyryldylar

(9) ešigine ohel mo`ednin. ויעש. [9] Da qyldy ošol ol qah-

(10) rany tarafyna tüšlüknün temansary enleri ol qaḥranyn

(11) ešken bezden jüz lokot. עמודיהם. [10] Baġanalary alarnyn

(12) egirmi da tabanlary alarnyn egirmi tučtan čüvleri ol

(13) bag̉analarnyn da čörgevleri alarnyn kümüšten. ולפאת. [11]

(14) Da tarafyna cafonnu[n] $]^{2}$ enler jüz lokot baġanalary alarnyn egir-

(15) mi da tabanlary alarnyn egirmi tučtan čüvleri ol baġana-

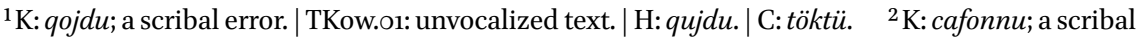
error. | TKow.o1: cafonnun. | H: cafonnun. | C: čafonnyy.
} 
(5) [27] And he made two rings of gold for it under

(6) its moulding on the two sides of it, on the two corners of it,

(7) the places for the poles to carry it with them.

(8) [28] And he made the poles of acacia wood,

(9) and overlaid them with gold. [29] And he made the

(10) holy anointing oil, and the pure incense of sweet spices,

(11) the work of apothecary.

Exodus 38

[1] And he made the

(12) altar of burnt offering of acacia wood, five cubits the length

(13) of it, and five cubits the breadth of it, foursquare, and three cubits

(14) the height of it. [2] And he made its horns

(15) on the four corners of it. Its horns were of one piece with it,

(16) and he overlaid it with bronze. [3] And he made

(17) all the equipment of the altar: the cauldrons, and the

(18) brushes, and the cups, and the forks,

(19) and the censers. He made all of its equipment

(20) of bronze. [4] And he made a grate for the altar, network

(21) of bronze, under its ledge ${ }^{133}$, below, halfway up. [5]

(1) And he [cast] four rings for the four ends of the bronze grate:

(2) places for the poles. [6] And he made the

(3) poles of acacia wood, and overlaid them with bronze.

(4) [7] And he put the poles to the rings

(5) on the sides of the altar, to carry it with them.

(6) He made it of hollow boards. [8] And he made the

(7) basin of bronze, and the place of it of bronze,

(8) with the mirrors of the women who gathered

(9) at the door of the tent of meeting. [9] And he made the court:

(10) on the south side, southward, the court's curtains

(11) of twined linen, a hundred cubits, [10] Their pillars

(12) twenty, and their bronze bases twenty, the hooks of the

(13) pillars and their bands of silver. [11]

(14) And for the north side: the curtains were a hundred cubits, their pillars were twenty,

(15) and their bases of bronze twenty, the hooks of the pillars

133 Lit. 'rim'. 
(16) larnyn da čörgevleri alarnyn kümüšten. [12] Da

(17) tarafyna ma'aravnyn enler enli lokot baġanalary alarnyn on

(18) ¿da tabanlary alarnyn on čüvleri ol bag̉analarnyn da čörgevleri ${ }^{11}$

(19) alarnyn kümüšten. ולפאת [13] Da tarafyna kün tuvušunun

(20) mizrah sary enli lokot. קלעים. [14] Enler on beš lokot ol

(21) bir janġa bag̉analary alarnyn üč da tabanlary alarnyn üč.

$152 \mathrm{v}^{\mathrm{o}}$ (1) ולכתף] [15] Da ol ekinči janġa bu jantyn da bu jantyn qabağy\{n\}a ol

(2) qaḥranyn enler on beš lokot bag̉analary alarnyn üč da tabanlary alar-

(3) nyn üč. כל [16] Bar [enleri] ${ }^{2}$ ol qaḥranyn čüvre ešken bezden.

(4) [17] Da ol tabanlar bag̉analarg̉a tučtan čüvleri ol bag̉ana-

(5) larnyn da čörgevleri alarnyn kümüšten da qaplavy bašlarynyn da

(6) kümüšten da alar čörgelgenler kümüšbyla bar baġanalar ol

(7) qahranyn. ומסך. [18] Da qaplavy qabağynyn ol qaḥranyn iši nag்yš-

(8) lavčunun kökten da jipkin[d]en ${ }^{3}$ da qyrmyzy jipekten da ešken

(9) bezden da egirmi lokot uzunluq da turuš kenlikte beš

(10) lokotlar uturusuna enlerinin ol qahranyn. ועמדיהם. [19]

(11) Da baġanalary alarnyn dört da tabanlary alarnyn dört tučtan

(12) čüvleri alarnyn kümüšten \{da qaplavy bašlarynyn\} da čörgevleri alarnyn kümüšten.

(13) (20] Da bar ol qazyqlar miškanġa da qahrag̉a čüvre

(14) tučtan.

פרשת אלה פקודי (15) (15) (15) (21)

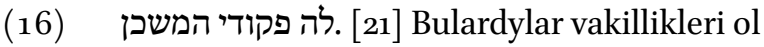

(17) miškannyn miškanynyn ol šarajatnyn ki vakillen-

(18) di sözübyla Mošenin qullug̉u ol Levilernin qolu ašyra

(19) Itamarnyn uvlunun $\{\text { Aharonnun }\}^{4}$ ol kohennin. ובצלאל. [22] Da Becal'el uvlu

(20) Urinin uvlunun Hurnun ševetinden Juhudanyn qyldy ošol barča

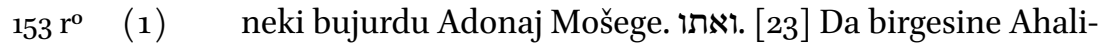

(2) 'av uvlu Ahisamaknyn ševetinden Dannyn usta da ojuvlavču

(3) da nağyšlavču kökbyla da jipkinbyla da qyrmyzy jipekby-

(4) la da bezbyla. כ2 [24 Bar ol altyn ol qylyngan iške

(5) bar išinde ol qodešnin da edi altyny ol tenufanyn

${ }^{1}$ This line is not vocalized. $\quad{ }^{2} \mathrm{~K}$ : bag்analary; a scribal error. | TKow.o1: enleri; unvocalized text. | H: enleri.|C: örmäkläri. ${ }^{3} \mathrm{~K}$ : jipkinten; a scribal error. |TKow.o1: jipkinden; unvocalized text. |H: jipkinden.|C: jipkin. $\quad{ }^{4}$ Marginal insertion by another hand.| TKow.o1: Aharonnun; unvocalized text. | H: Aharonnun. | C: Aharon. 
(16) and their bands of silver. [12] And

(17) for the west side: curtains of fifty cubits, their pillars ten,

(18) and their bases ten, the hooks of the pillars and their bands

(19) of silver. [13] And for the east side,

(20) eastward: fifty cubits. [14] Curtains of fifteen cubits

(21) to the one side, their pillars three, and their bases three.

(1) [15] And for the second side, on this side and on this side of the court $15^{2} \mathrm{~V}^{\mathrm{o}}$ gate

(2) curtains of fifteen cubits, their pillars three, and their bases

(3) three. [16] All the [curtains] of the court all around were of twined linen.

(4) [17] And the bases for the pillars were of bronze, the hooks of the pillars

(5) and their bands of silver, and the overlaying of their capitals also

(6) of silver, and all the pillars of the court were banded with silver.

(7) [18] And the cover for the gate of the court was the work of

(8) embroiderer, of blue and purple and scarlet silk, and twined

(9) linen, and twenty cubits in the length, and five cubits the height in its breadth,

(10) opposite to the curtains of the court. [19]

(11) And their pillars were four, and their bases of bronze four,

(12) their hooks of silver, and the overlaying of their capitals and their bands of silver.

(13) $[20]$ And all the pegs of the tabernacle and of the court all around

(14) of bronze.

(15) Parashat Pekudei

(16) [21] This is the supervision

(17) of the tabernacle, of the tabernacle of law, as it was destined,

(18) according to the word of Moses, the work of the Levites by the hand

(19) of Ithamar, son \{of Aaron\}, the priest. [22] And Bezalel, son

(20) of Uri, son of Hur, of the tribe of Judah, made all

(1) that the Lord commanded Moses. [23] And with him was Oholiab,

(2) son of Ahisamach, of the tribe of Dan, a master |workman|, and an embroiderer,

(3) and a needleworker in blue and in purple and in scarlet silk,

(4) and linen. [24] All the gold that was used for the work,

(5) in all the work of the Holy: and the gold of the wave offering 
(6) egirmi togiuz qantar da jedi [jüz $]^{1}$ da otuz mitqal mitqaly

(7) וכסף. [25] Da kümüš juluvlarnyn alğan

(8) sanalġanlaryndan ol క̌ymatnyn jüz qantar da min da jedi jüz

(9) da jetmiš beš mitqal mitqaly byla ol qodešnin. בקע. [26]

(10) Gög baštan jarymy ol mitqalnyn mitqaly byla ol qodešnin

(11) bar ol ašuvčudan bolma ol sanalġanlar qatyna egirmi jaštan

(12) da jog̉arraq alty keret jüz minden da üč minlerden da

(13) beš jüz enliden. ויהי [27] Da edi jüz qantar ol kümüš

(14) qujma ošol tabanlaryn ol qodešnin da ošol tabanlaryn ol

(15) parohetnin jüz tabanlar jüz ol qantardan qantar tabanġa.

(16) ואת (28] Da ol minden da jedi ol jüzden da jetmiš

(17) $\mathrm{b}[\mathrm{e}] \mathrm{št}[\mathrm{e}] \mathrm{n}^{2}$ qyldy čüvler bag̉analarğa da qaplady bašlaryn alarnyn da

(18) čöörgedi alarny. [29] Da tuču ol tenufanyn jet-

(19) miš qantar da eki min da dört jüz mitqal. ויעש [30]

(20) Da qyldy anyn byla ošol tabanlaryn ešiginin ol ohel mocednin da

(21) da ošol ol tuč mizbeaḥny da ošol ol tuč elekni ki anar

$153 \mathrm{~V}^{\mathrm{o}}$ (1) da ošol bar savutlaryn ol mizbeahnyn. [131] Da ošol taban-

(2) laryn ol qaḥranyn čüvre da ošol tabanlaryn qabaġynyn ol qaḥra-

(3) nyn da ošol bar qazyqlaryn ol miškannyn da ošol bar qazyqlaryn

(4) ol qahranyn čüvre.

Exodus 39

ומן [1] Da ol kökten da ol

(5) jipkinden da ol qyrmyzy jipekten qyldylar bojavly up-

(6) raqlar jumuš etme qodešte da \{qyldylar\} ošol aziz upraqlarny

(7) ki Aharonğa ki nečik bujurdu Adonaj Mošege. ויעש [2]

(8) Da qyldy ošol ol efodnu altyndan kökten \{da jipkinden\} da qyrmyzy

(9) jipekten da ešken bezden. וירקעו. [3] Da jugiarttylar

(10) ošol ol altyn blehalarny da qypčydy šnurlar qylma or-

(11) tasynda ol köknün da ortasynda jipkinnin da

(12) ortasynda ol qyrmyzy jipeknin da ortasynda ol

(13) b[e]znin ${ }^{3}$ iši ojuvlavčunun. כתפת. [4] Javrunlar qyldylar

(14) anar qošadoġanlar eki učlary üstüne qošuldu.

\footnotetext{
${ }^{1} \mathrm{~K}$ : deest; a scribal error. | TKow.o1: jüz; unvocalized text. | H: $i z . \mid$ C: jüz. $\quad{ }^{2} \mathrm{~K}$ : baštan; a scribal error. | TKow.o1: unvocalized text. | H: besten. | C: bešni; different wording. ${ }^{3} \mathrm{~K}$ : biznin; a scribal error; cf. Exo 39:27. | TKow.o1: unvocalized text. | H: beznin. | C: kisäjinin.
} 
(6) was twenty-nine kantar, and seven [hundred] and thirty mithqals, by the mithqal

(7) of the Holy. [25] And the ransom silver taken

(8) from them that were counted of the congregation was a hundred kantars, and a thousand and seven hundred

(9) and seventy-five mithqals, by the mithqal of the Holy. [26]

(10) A gög ${ }^{134}$ per head, that is, half a mithqal, by the mithqal of the Holy,

(11) for every one that went to be counted, from twenty years old

(12) and upward, for six hundred thousand and three thousand and

(13) five hundred and fifty. [27] And the hundred kantars of silver

(14) were for casting the bases of the Holy and the bases of the

(15) veil, a hundred bases of the hundred kantars, a kantar for a base.

(16) [28] And of the thousand and seven hundred and seventy-

(17) [five] he made hooks for the pillars, and overlaid their capitals, and

(18) banded them. [29] And the bronze of the wave offering was

(19) seventy kantars and two thousand and four hundred mithqals. [30]

(20) And with it he made the bases of the door of the tent of meeting, and

(21) the bronze altar, and the bronze grate which was for it,

(1) and all the equipment of the altar, [31] And the bases

(2) of the court all around, and the bases of the court gate,

(3) and all the pegs of the tabernacle, and all the pegs

(4) of the court all around.

Exodus 39

(5) purple and scarlet silk they made colourful garments,

(6) for doing service in the Holy, and made the holy garments

(7) that were for Aaron, as the Lord commanded Moses. [2]

(8) And he made the ephod of gold, blue and purple and scarlet

(9) silk, and twined linen. [3] And they did flatten

(10) the gold metal sheets, and cut out wires, to work

(11) it in the blue, and in the purple, and

(12) in the scarlet silk, and in the

(13) linen-embroiderer's work. [4] They made shoulders

(14) for it, joined: by the two edges it was joined together.

134 Unidentified unit of weight. 
(15) [5 [5] Da ojuvu bavynyn ki anyn üstüne özünden

(16) edi ol išikibik anyn Laltyndan kökten [da jipkinden da qyrmyzy jipekten] ${ }^{11}$ da ešken

(17) bezden ki nečik bujurdu Adonaj Mošege. ויעש. [6] Da

(18) qyldylar ošol ol šoham tašlaryn quršalġanlar altyn ojuvlar

(19) byla tužurulgaanlar tužurmaqlaryn mohurnun atlary üstü-

(20) ne uvullarynyn Jisra’elnin. ויעשו [7] Da qojdu alarny javrun-

(21) lary üstüne ol efodnun saġynčlyq tašlar ulanlaryna

$154 \mathrm{r}^{\mathrm{O}} \quad$ (1) Jisra’elnin ki nečik bujurdu Adonaj Mošege. [8] Da

(2) qyldylar ošol ol ḥošenni iši ojuvlačunun iši kibik

(3) efodnun kökten da jipkinden da qyrmyzy jipekten da

(4) ešken bezden. רבוע. [9] Dört kül edi qatlanġan qyldy-

(5) lar ošol ol ḥošenni qaryš uzunluğu da qaryš kenligi qat-

(6) longan. [10] Da tolturdular anda dört jer-

(7) geler taštan jergesi rubinnin šmaraknyn da karbankulis-

(8) nin ol bir jerge. והטור. [11] Da ol ekinči jerge

(9) sürne tašy safir tašy da dijament. והטור. [12] Da

(10) ol üčünčü jerge lešem ševo da aḥlama. [13 ]

(11) Da ol dörtünčü jerge taršiš šoham da jašfe

(12) quršalġanlar altyn ojuvlarbyla tolturmaqlarynda.

(13) (14] Da ol tašlar ediler atlary üstü-

(14) ne uvullarynyn Jisra’elnin alar ol on eki atlarybyla tužur-

(15) maqlary mohurnun kiši atybyla ol eki ševetsajyn.

(16) ויעשו Da qyldylar ol ḥošen üstüne synžyrlar čeklen-

(17) gen iši örkennin aruv altyndan. ויעשו [16] Da

(18) qyldylar eki altyn ojuvlar da eki jüzükler altyndan

(19) da berdiler ošol eki ol jüzüklerni eki učlary

(20) üstüne ol hošennin. Lויתנו. [17] Da berdiler eki ol altyn erkenlerni eki ol jüzükler üstüne uclary üstüne ol ḥošennin.\} ${ }^{12}$. [18] Da ošol eki učla-

(21) ryn eki ol örkenlernin berdiler eki ol ojuvlar-

$154 \mathrm{~V}^{\mathrm{o}} \quad$ (1) üstüne da berdiler javrunlary üstüne ol efodnun $\mathrm{u}-$

(2) turusuna jüzlerinin. [19] Da qyldylar eki jüzükler altyn-

\footnotetext{
${ }^{1} \mathrm{~K}$ : altyndan kökten; a scribal error. | TKow.o1: altyndan kökten da jipkinden da qyrmyzy jipekten; unvocalized text. | H: altyndan kökten da jipkinden da qyrmyzy jipekten. | C: altyn kök da jipkin da qyrmyzy iränkli. $\quad{ }^{2}$ Marginal insertion by another hand in South-Western Karaim; cf. Exo 28:24. | TKow.o1: ויתנו. Da berdiler eki ol altyn örkenlerni eki ol jüzükler üstüne učlary üstüne ol hošennin; unvocalized text. | H: Da berdiler eki ol altyn erkenlerni eki ol izikler istine uclary istine ol hošennin. | C: ויתנו. Da berdilär eki ol altyn tellärni eki ol halqalar üstünä qyjyrlary üstünä ol hošennị.
} 
(15) [5] And the embroidery of his band that was on it was of one piece with it,

(16) according to its work: of gold, blue [and purple and scarlet silk], and twined

(17) linen, as the Lord commanded Moses. [6] And

(18) they worked onyx stones enclosed in settings of gold,

(19) engraved with signet engravings, above the names

(20) of the children of Israel. [7] And he set them on the shoulders

(21) of the ephod: stones of remembrance for the children

(1) of Israel, as the Lord commanded Moses. [8] And

(2) he made the breastplate, embroiderer's work, like the work

(3) of the ephod: of gold, blue and purple and scarlet silk, and

(4) twined linen. [9] It was foursquare. They made the breastplate doubled,

(5) a span was the length of it, and a span the breadth of it,

(6) being doubled. [10] And they filled there four rows

(7) of stones. A row of a ruby, an emerald, and a carbuncle:

(8) the one row. [11] And the second row:

(9) a kohl stone, a sapphire stone, and a diamond. [12] And

(10) the third row: a jacinth, an agate, and an amethyst. [13]

(11) And the fourth row: a beryl, an onyx, and a jasper,

(12) enclosed in settings of gold filigree settings.

(13) [14] And the stones were above the names

(14) of the children of Israel, twelve, with their names,

(15) signet engravings, everyone with its name, according to the twelve tribes.

(16) [15] And they made chains finished in pure gold,

(17) rope work, on the breastplate. [16] And

(18) they made two settings of gold, and two gold rings,

(19) and put the two rings on the two ends

(20) of the breastplate. $\{[17]$ And they put the two ropes of gold on the two rings on the ends of the breastplate.\} [18] And they put the two ends

(21) of the two ropes on the two settings,

(1) and put them on the shoulders of the ephod,

(2) in the front. [19] And they made two rings of gold, 
(3) dan da qojdular eki učlary üstüne [o $]^{1}$ ḥošennin qyryj üstü-

(4) ne anyn ki janyna ol efodnun ičkerige. ויעשו. [20] Da qyldy-

(5) lar eki jüzükler altyndan da berdiler alarny eki javrunlary

(6) üstüne ol efodnun ašagiartyn uturusundan jüzlerinin u-

(7) turusuna qošulur ornunun joġarraq ojuvuna ol efodnun.

(8) וירכסו 21] Da atlanġyz\{dyr\}dylar ošol ol ḥošenni jüzüklerin-

(9) den anyn jüzüklerińa ol efodnun kök šnur byla bolma o-

(10) juvu üstüne ol efodnun da ki kötürülmegej ol ḥošen

(11) ol efod üstünden ki nečik bujurdu Adonaj Mošege.

(12) ויעש [22] Da qyldy ošol qaftanyn ol efodnun iši tohuvču-

(13) nun tügel kökten. ופי [23] Da avzu ol qaftannyn edi or-

(14) tasynda anyn avzu kibik kübenin jaga edi avzuna anyn

(15) čüvre ki jyrtylmaġaj. [יעשו. 24] Da qyldylar etekleri

(16) üstüne ol qaftannyn narlar kökten da jipkinden da qyr-

(17) myzy jipekten ešken. ויעשו [25] Da qyldylar qungiurovlar aruv

(18) altyndan da berdiler ošol ol qungiurovlarny ortasynda

(19) ol narlarnyn etekleri üstüne ol qaftannyn čüvre orta-

(20) synda ol narlarnyn. פעמון. [26] Altyn qungurov da nar al-

(21) tyn qunġurov da nar etekleri üstüne ol qaftannyn čüvre

$155 \mathrm{r}^{\mathrm{r}} \quad$ (1) jumuš etme ki nečik bujurdu Adonaj Mošege. ויעשו. [27]

(2) Da qyldylar ošol ol kölmeklerni b[e]zden² iši toḥuvčunun Aharon-

(3) ga da uvullaryna anyn. [28] Da ošol ol micnefet-

(4) $\mathrm{ni}^{3}$ bezden da ošol ol bijik börklerni bezden da ošol ol

(5) mihnnesajimlerni ešken bezden. ואת [29] Da ošol ol avnet-

(6) ni ešken bezden da kökten da jipkinden da qyrmyzy jipek-

(7) ten iši nağyšlavčunun ki nečik bujurdu Adonaj Mošege.

(8) ויעשו [30] Da qyldylar ošol čalmasyn ol aziz tačnyn aruv

(9) altyndan da jazdylar anyn üstüne jazyšyn tužurmaqlarynyn

(10) mohurnun ויתנו. [31] Da berdiler anyn üs-

(11) tüne kök šnur berme ol micnefet üstüne jog̉ar-

(12) tyn ki nečik bujurdu Adonaj Mošege. ותכל. [32] Da tügen-

(13) di bar qullugu miškanynyn ohel mo'ednin da qyldylar ulanlary

(14) Jisra’elnin barča nečik ki bujurdu Adonaj Mošege alaj qyl-

(15) dylar. [יביאו Da keltirdiler ošol miškanny Mošege o-

(16) šol ol čatyrny da ošol bar savutlaryn anyn eslarin tahtalaryn

\footnotetext{
${ }^{1} \mathrm{~K}$ : el; a scribal error. | TKow.o1: ol. | H: ol. | C: ol. $\quad{ }^{2} \mathrm{~K}$ : bizden; a scribal error; cf. Exo 39:3. ${ }^{3}$ Changed to čalma $[n y]$ by another hand. | TKow.or: micnefetni; unvocalized text. | H: calmany. |

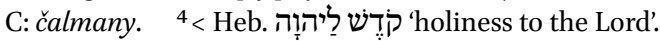


(3) and put them on the two ends of the breastplate, in its edge,

(4) which was on the inside edge of the ephod. [20] And they made

(5) two golden rings and put them on the two shoulders

(6) of the ephod underneath, in the front of it,

(7) toward the front of the place of being coupled, above the embroidered |band| of the ephod.

(8) [21] And they set the breastplate by its rings

(9) to the rings of the ephod with a blue string, that it may be

(10) above the embroidered |band| of the ephod, and that the breastplate might not be lifted

(11) from the ephod, as the Lord commanded Moses.

(12) [22] And he made the robe of the ephod of weaver's work,

(13) all of blue. [23] And the opening of the robe in the middle of it

(14) was like the opening of a coat of mail, there was an edging around the opening

(15) so it would not be torn. [24] And they made on the hems

(16) of the robe pomegranates of blue and purple and scarlet

(17) silk, twined. [25] And they made bells of pure

(18) gold, and put the bells among

(19) the pomegranates on the hems of the robe, all around

(20) among the pomegranates: [26] A golden bell and a pomegranate,

(21) a golden bell and a pomegranate, around the hems of the robe

(1) to serve in, as the Lord commanded Moses. [27]

(2) And they made shirts of linen, weaver's work, for Aaron

(3) and for his sons. [28] And a turban

(4) of linen, and high caps of linen, and

(5) dual trousers of twined linen, [29] And a girdle of

(6) twined linen and blue and purple and scarlet silk,

(7) of embroiderer's work, as the Lord commanded Moses.

(8) [30] And they made the diadem of the holy crown of pure

(9) gold, and wrote on it a writing, signet engraving,

(10) "Holy to the Lord." [31] And they put a blue string on it

(11) to put it on the turban above,

(12) as the Lord commanded Moses. [32] And

(13) all the service of the tabernacle of the tent of meeting was finished, and the children

(14) of Israel did according to all that the Lord commanded Moses. They did so.

(15) [33] And they brought the tabernacle to Moses,

(16) the tent and all its equipment, its hooks, its boards, 
(17) anyn beklevüčlerin da bag̉analaryn da tabanlaryn anyn. [35]

(18) Ošol qaplavny išlengen terilerinden ol qočqarlarnyn ol

(19) qyzartylġanlar da ošol qaplavny terilerinden ol taḥašlarnyn da

(20) ošol parohetin ol qaplavnyn. את [35] Ošol aronun ol šarajatnyn

(21) da ošol tutqučlaryn anyn da ošol ol kaporetni. את. [36]

$155 \mathrm{~V}^{\mathrm{o}} \quad$ (1) Ošol ol stolnu ošol bar savutlaryn anyn da ošol eki jüzlü

(2) את ötmekni. [37] Ošol ol čyraqbany ol aruvnu ošol

(3) čyraq orunlaryn čyraqlarynyn ol tüzüvnün da ošol bar savut-

(4) laryn anyn da ošol javyn ol jaryqlyqnyn. [38] Da ošol

(5) ol altyn mizbeaḥny da ošol jag̉ynmaq javny da ošol tütü-

(6) sün ol otjamlarnyn da ošol qaplavyn eši $[\mathrm{g}] \operatorname{inin}^{1}$ ol čatyr-

(7) nyn. את n39] Ošol ol tuč mizbeaḥny da ošol tuč elek-

(8) ni ki anar ošol tutqučlaryn da ošol bar savutlaryn anyn

(9) ošol ol qumġanny da ošol ornun anyn. את. [40] Ošol

(10) enlerin ol qaḥranyn ošol bag̉analaryn da ošol tabanlaryn anyn

(11) da ošol ol qaplavyn qabag̉yna ol qaḥranyn ošol šnurlaryn da

(12) qazyqlaryn anyn da ošol bar savutlaryn qullugiunun ol miškannyn

(13) ohel mo'edge. [4] [4s Ošol ol bojavly upraqlarny jumuš

(14) etḿa qodešte da ošol ol aziz upraqlarny Aharon-

(15) ġa ol kohenge da ošol upraqlaryn uvullarynyn kohenlik

(16) etḿa. בכל [42] Barča nečik ki bujurdu Adonaj Mošege

(17) alaj qyldylar ulanlary Jisra’elnin ošol bar ol qulluqnu.

(18) . וירא [43] Da kördü Moše ošol bar ol išni da muna

(19) qyldylar any ki nečik bujurdu Adonaj alaj qyldylar da alġyš-

(20) lady alarny Moše.

Exodus 40

וידבר [1] Da sözledi Adonaj Mošege aj-

(21) tadoġač. ביום. [2] Ol burunğu janġaj kününde burung்u

$156 \mathrm{r}^{\mathrm{o}} \quad$ (1) kününde janğajnyn turğuzg்un ošol miškanyn ohel mo`ednin.

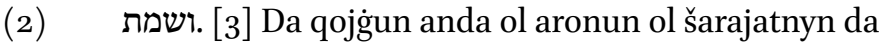

(3) qaplag̉yn ol aron üstüne ošol ol parohetni. והבאת [4]

(4) Da kijirgin ošol ol stolnu da tüzügün tüzüvün anyn

(5) da kijirgin ošol ol čyraqbany da jandyrğyn ošol čyraqlaryn

(6) anyn. [5] [5] Da bergin ošol altyn mizbeaḥny tütüge al-

(7) nynda aronunun ol šarajatnyn da qojgun ošol qaplavyn ol

(8) ešiknin miškanğa. ונתת. [6] Da bergin ošol mizbeahyyn

\footnotetext{
${ }^{1}$ K: ešikinin; a scribal error. | TKow.o1: ešiginin; unvocalized text. | H: esiginin. | C: ešiginin.
} 
(17) its bars, and its pillars, and its bases, [34]

(18) The covering of rams' skins

(19) dyed red, and the covering of porpoise skins, and

(20) the veil of the covering, [35] The ark of the law,

(21) and its poles, and the cover, [36]

(1) The table, and all its vessels, and the showbread,

(2) [37] The pure lampstand,

(3) its places for candles, candles for the row, and all its vessels,

(4) and the oil for light, [38] And the

(5) golden altar, and the anointing oil, and the fragrant

(6) incense, and the cover for the tent door,

(7) [39] The bronze altar, and its grate of bronze,

(8) its poles, and all its vessels,

(9) the basin and its place, [40] The

(10) curtains of the court, its pillars, and its bases,

(11) and the cover for the court gate, its cords, and

(12) its pegs, and all the vessels of the service of the tabernacle

(13) for the tent of meeting, [41] The colourful garments

(14) to do service in the Holy, and the holy garments for Aaron,

(15) the priest, and the garments of his sons, to serve as priests.

(16) [42] All that the Lord commanded Moses:

(17) so the children of Israel did all the work.

(18) [43] And Moses saw all the work, and, lo,

(19) they had done it as the Lord had commanded. They did so. And Moses blessed

(20) them.

Exodus 40

(20) [1] And the Lord spoke to Moses,

(21) saying, [2] 'On the day of the first month, on the first

(1) day of the month, you shall erect the tabernacle of the tent of meet- $156 \mathrm{r}^{\mathrm{o}}$ ing.

(2) [3] And you shall put in it the ark of the law, and

(3) cover the ark with the veil. [4]

(4) And you shall bring in the table, and arrange its arrangement,

(5) and you shall bring in the lampstand, and light its candles.

(6) [5] And you shall put the altar of gold for the incense

(7) before the ark of the law, and put the cover

(8) of the door to the tabernacle. [6] And you shall put the altar 
(9) ol 'olanyn alnynda ešiginin ol miškanynyn ohel mo'ednin.

(10) [7 [7 Da bergin ošol ol qumġanny arasyna ohel

(11) mo'ednin da arasyna ol mizbeahnynn da bergin ary suv.

(12) (8] Da qojğun ošol ol qahrrany čüvre da bergin

(13) ošol qaplavyn qabag̉ynyn ol qahranyn. ולקחת [9] Da alġyn ošol

(14) ol jag̉ynmaq javny da jag̉yndyrg̉yn ošol ol miškanny da o-

(15) šol barča neki anda da aziz etkin any da ošol bar

(16) savutlaryn anyn da bolsun aziz. ומשחת. [10] Da jag̉yndyrg̉yn

(17) ošol mizbeahyn ol 'olanyn da ošol bar savutlaryn anyn da'

(18) aziz etkin ošol ol mizbeaḥny da bolsun ol mizbeaḥ qodeš

(19) qadašim. [11] Da jag̉yndyrğyn ošol ol qumġanny da

(20) ošol ornun anyn da aziz etkin any. והקרבת. [12] Da

(21) juvutqun ošol Aharonnu da ošol uvullaryn anyn ešigine

$156 \mathrm{v}^{\mathrm{o}}$ (1) ohel mo'ednin da juvg̉un alarny suvbyla. והלבשת. [13] Da kijdir-

(2) gin Aharonġa ošol ol aziz upraqlarny da jağyndyrg்yn any da

(3) aziz etkin any da kohenlik etsin maja. ואת [14] Da ošol

(4) uvullaryn anyn juvutqun da kijdirgin alarg̉a kölmekler.

(5) ומשחת [15] Da jaġyndyrg̉yn alarny ki nečik jaġyndyrdyj ošol

(6) atasyn alarnyn da kohenlik etsinler maja da bolsun bolma alar-

(7) ġa jaġynmaqlary alarnyn ömürlük kohenlikke dorlarysajyn.

(8) ויעש [16] Da qyldy Moše barča nečik ki bujurdu Adonaj anar

(9) alaj qyldy. ויהי [17] Da edi ol burungiu jangajda ol ekin-

(10) či jylda burunġu kününde janġajnyn turğuzuldu ol miškan.

(11) ויקם [18] Da turg̉uzdu Moše ošol ol miškanny da berdi

(12) ošol tabanlaryn anyn da qojdu ošol taḥtalaryn anyn da berdi

(13) ošol beklevüčlerin anyn da turg̉uzdu ošol bag̉analaryn anyn.

(14) ויפרוש Da jajdy ošol ol čatyrny ol miškan üs-

(15) tüne da qojdu ošol qaplavyn ol čatyrnyn anyn üstüne

(16) jog̉artyn ki nečik bujurdu Adonaj Mošege. [20] Da aldy

(17) da berdi ošol ol šarajatny ol aronġa da qojdu ošol

(18) ol tutqučlarny ol aron üstüne da berdi ošol ol kaporet-

(19) ni ol aron üstüne joġartyn. [21] Da keltirdi ošol

(20) ol aronnu ol miškanġa da qojdu ošol parohetin ol qaplav-

(21) nyn da qaplady aronu üstüne ol šarajtnyn ki nečik bujurdu

$157 \mathrm{r}^{\circ} \quad$ (1) Adonaj Mošege. [22] Da berdi ošol ol stolnu ohel

(2) mo`edde jany üstüne ol miškannyn cafon sary tyšqartyn

(3) parohetke. ויערוך. [23] Da tüzüdü anyn üstüne tüzü-

(4) vün eki jüzlü ötmeknin alnynda Adonajnyn ki nečik bujur-

${ }^{1} \mathrm{~K}: d a d a$; a scribal error. | TKow.o1: $d a .|\mathrm{H}: d a.| \mathrm{C}: d a$. 
(9) of the burnt offering before the door of the tabernacle of the tent of meeting.

(10) [7] And you shall put the basin between the tent

(11) of meeting and the altar, and you shall put water there.

(12) [8] And you shall put up the court all around, and put on

(13) the cover for the gate of the court. [9] And you shall take

(14) the anointing oil and anoint the tabernacle, and

(15) all that is in it, and shall sanctify it, and all its

(16) vessels, and it shall be holy. [10] And you shall anoint

(17) the altar of the burnt offering, and all its vessels, and

(18) sanctify the altar, and the altar shall be holy

(19) of holies. [11] And you shall anoint the basin and

(20) its place, and sanctify it. [12] And

(21) you shall bring Aaron and his sons to the door

(1) of the tent of meeting and wash them with water. [13] And

(2) you shall put on Aaron the holy garments, and anoint him, and

(3) sanctify him, that he may serve me as priest. [14] And

(4) you shall bring his sons and put on them the shirts.

(5) [15] And you shall anoint them, as you did anoint

(6) their father, so that they may serve me as priests. And it shall be that their anointing is

(7) an everlasting priesthood throughout their generations.'

(8) [16] And Moses did it, according to all that the Lord commanded him,

(9) he did so. [17] And it was in the first month, in the second

(10) year, on the first day of the month: the tabernacle was erected.

(11) [18] And Moses erected the tabernacle and put on

(12) its bases and set up its boards and put in

(13) its bars and raised up its pillars. [19]

(14) And he spread out the tent over the tabernacle

(15) and put the covering of the tent over it,

(16) as the Lord commanded Moses. [20] And he took

(17) the law and put it into the ark, and he set the

(18) poles on the ark and put the cover

(19) on top of the ark. [21] And he brought the

(20) ark into the tabernacle and set up the veil of the cover

(21) and covered the ark of the law, as the Lord commanded

(1) Moses. [22] And he put the table in the tent

(2) of meeting, on the north side of the tabernacle, outside

(3) the veil. [23] And he arranged the arrangement

(4) of the showbread before the Lord, as the Lord had commanded 
(5) du Adonaj Mošege. וישם. [24] Da qojdu ošol ol čyraq-

(6) bany ohel mo'edde qaršysyna ol stolnun jany üstü-

(7) ne ol L $\langle$ mizbeaḥnyn $\rangle\{\text { miškannyn }\}^{11}$ tüšlük sary. ויעל [25] Da jandyrdy o-

(8) Šol ol čyraqlarny alnynda Adonajnyn ki nečik bujurdu Adonaj

(9) ošol Mošege. וישם [26] Da qojdu ošol altyn mizbeaḥny

(10) ohel mo`edde alnynda ol parohyetnin. [27 Da tütetti

(11) anyn üstüne tütüsün otjamlarnyn ki nečik bujurdu

(12) Adonaj Mošege. [28] Da qojdu ošol qaplavyn ol

(13) eš[i]knin² miškanġa. ואת [29] Da ošol mizbeahyn ol 'olanyn

(14) qojdu ešiginde [miškanynyn $]^{3}$ ohel mo`ednin da čyġardy anyn üstü-

(15) ne ošol ol ‘olany da ošol ol tirkini ki nečik bujurdu

(16) Adonaj Mošege. וישם. [30] Da qojdu ošol ol qumġanny

(17) arasyna ohel mo`ednin da arasyna ol mizbeaḥnyn da berdi

(18) ary suv juvunma. ורחצו. [31] Da juvarediler andan $\{\text { Moše } d a\}^{14}$

(19) Aharon da uvullary anyn ošol qollaryn da ošol ajaqlaryn.

(20) בבואם (32] Kelgenlerinde ohel mo'edge da juvugaganlaryn-

(21) da ol mizbeaḥqa juvarediler ki nečik bujurdu Adonaj Moše-

$157 \mathrm{~V}^{\mathrm{o}}$ (1) ge. [33] Da turğuzdu ošol ol qahrany čüvre miškanğa

(2) da mizbeaḥqa da berdi ošol qaplavyn qabag̉ynyn ol qaḥranyn da

(3) tügelledi Moše ošol ol išni. L\{] [בכאן ח]סר פסוק [ויכס]. [34] Da] qaplady ol [bulut] ošol ohel [mo'edni] da šehinasy [H-ny] ${ }_{\text {L }}$ tolu [etti] ${ }^{15}$ ošol ol [miškan]ny. ${ }^{16}$ ולא. [35] Da bolalmady Moše

(4) kelma ohel mo'edge ki toḥtady anyn üstüne ol bulut

(5) da šehinasy Adonajnyn toldu ol miškanda. ובהעלות. [36] Da

(6) kötürülgende ol bulut ol miškan üstünden köčere-

(7) diler ulanlary Jisra’elnin bar köčüvlerind́a. ואם [37] Da

(8) eger kötürülmesejedi ol bulut köčmesediler kötürül-

(9) gen kününedejin. כי [38] Ki bulutu Adonajnyn ol miškan üs-

(10) tüne edi kündüz da ot boluredi kečebyla anda

(11) közleriče bar üvünün Jisra’elnin bar köčüvlerinde.

${ }^{1}$ Correction by another hand in the outer margin. | TKow.o1: miškannyn; unvocalized text. | H: miškannyn.|C: miškannyy. $\quad{ }^{2} \mathrm{~K}$ : ešeknin; a scribal error. | TKow.o1: unvocalized text.| H: esiknin. | C: ešiknin. $\quad{ }^{3} \mathrm{~K}$ : deest; a scribal error. | TKow.o1: miškanynyn; unvocalized text. | H: miškanynyn. | C: miškanynyy. $\quad{ }^{4}$ Marginal insertion by another hand. | TKow.o1: Moše $d a$; unvocalized text. | H: Moše da. | C: Moše da. ${ }^{5}$ TKow.o1: toldu; unvocalized text. | H: tolu edi; unintelligible form; syntactically, it does not fit in with the context because it is an intransitive form. | C: toldu. ${ }^{6}$ Marginal insertion by another hand.| TKow.o1: Da qaplady ol bulut ošol ohel mo'edni da šehinasy Adonajnyn toldu ošol ol miškanda; unvocalized text. | H: Da qaplady ol bulut osol ohel mo'edni da šehinasy H-nyn tolu edi osol ol miškandan. | C: Da japty ol bulut šol ohel mo'edni da kavodu H-nyy toldu šol miškanny. | R: Da qaplady ol bulut ohel mo'édni da šehinasy H-nyn toldu ol miškan. 
(5) Moses. [24] And he put the lampstand

(6) in the tent of meeting, opposite the table, on the

(7) side of the $\langle$ altar $\rangle\{$ tabernacle $\}$, southward. [25] And he lighted

(8) the candles before the Lord, as the Lord commanded

(9) Moses. [26] And he put the golden altar

(10) in the tent of meeting before the veil. [27] And he burned

(11) fragrant incense on it, as the Lord commanded

(12) Moses. [28] And he set up the cover

(13) of the door to the tabernacle. [29] And he put the altar of burnt offering

(14) at the door of [the tabernacle of] the tent of meeting, and he offered on it

(15) the burnt offering and the grain offering, as the Lord commanded

(16) Moses. [30] And he set the basin

(17) between the tent of meeting and the altar, and he put

(18) water there, for washing. [31] And \{Moses and

(19) Aaron and his sons washed their hands and their feet there.

(20) [32] When they came to the tent of meeting, and when they came near

(21) to the altar, they would wash, as the Lord commanded Moses.

(1) [33] And he erected the court around the tabernacle

(2) and the altar, and he set up the cover of the court gate. And

(3) Moses finished the work. ${ }_{1}\{$ The verse ['And covered' is missing here.] $\}^{1135}\{[34]$ [And] the [cloud] covered the tent of [meeting], and the divine Presence [of the Lord] fill[ed in] the [tabernacle]\}. [35] And Moses was not able

(4) to come into the tent of meeting, because the cloud abode on it,

(5) and the divine Presence of the Lord was full in the tabernacle. [36] And

(6) when the cloud was taken up from over the tabernacle,

(7) the children of Israel journeyed, in all their journeys. [37] And

(8) if the cloud was not taken up, then they did not journey

(9) until the day that it was taken up. [38] Because the cloud of the Lord

(10) was on the tabernacle by day, and fire was there by night,

(11) in the sight of all the house of Israel, throughout all their journeys.

135 Inserted by another hand in Hebrew. 


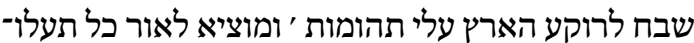

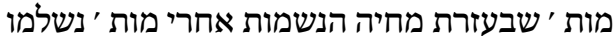

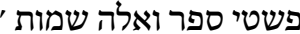

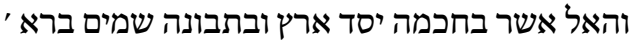

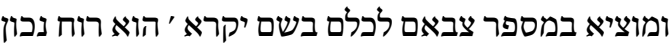
(16) ולב טהור לי יברא 'ויסייעני לכתוב פשטי ספר יקר ויקרא ' ויקוח 
(12) Praise be to Him who stretches the land above great depths and brings out to the light all the mysteries:

(13) that with the help of Him who revives the souls after death

(14) the peshatim of the Book of Exodus are completed.

(15) And God who in his wisdom established the land and created heaven with his reason

(16) and in great numbers brings out their hosts, He will call all of them by name. He will create a true spirit

(17) and a pure heart for me and will help me to write the peshatim of the Book of Leviticus. 
$158 \mathrm{r}^{\mathrm{o}} \quad$ Leviticus 1

(1) (2) ספר ויקרא

(1] Da ündedi Mošeni da sözledi

(3) anar šehinasy Adonajnyn ohel mo`edden ajtadoġač.

(4) דבר (2] Sözlegin ulanlaryna Jisra’elnin da ajtqyn alarġa

(5) nendij adam sizden ki juvutsa qarban Adonajga ol tuvardan

(6) ol syğyrdan da ol qojdan juvutujuz ošol qarbanyjyzny.

(7) אם. [3] Eger 'ola bolsa qarbany anyn ol syġyrdan erkek-

(8) ni tügelni juvutsun any ešigine ohel mo`ednin juvutsun

(9) any qabulluqqa özü üčün alnyna Adonajnyn. וסמך. [4]

(10) Da sunsun ošol qolun bašy üstüne ol colanyn da

(11) qabul bolur anyn üčün bošatlyq qolma anyn üčün. ושחט. [5]

(12) Da sojsun ošol balasyn ol syğyrnyn alnynda Adonajnyn da

(13) juvutsunlar uvullary Aharonnun ol kohenler ošol ol

(14) qanny da bürksünler ${ }_{L}\{\text { ošol ol qanny }\}^{11}$ ol mizbeah üstüne čüvre ki

(15) ešiginde ohel mo'ednin. והפשיט. [6] Da šyptyr-

(16) syn ošol ol ‘olany da buvunlasyn any buvunlarysajyn anyn.

(17) [7 Da bersinler ulanlary Aharonnun ol kohennin

(18) ot ol mizbeah üstüne da tüzüsünler otunlar ol ot

(19) üstüne. [8] Da tüzüsünler uvullary Aharon-

(20) nun ol kohenler ošol ol buvunlarny ošol ol bašny da

$15^{8} \mathrm{v}^{\mathrm{o}} \quad$ (1) ošol ol jelkeni ol otunlar üstüne ki ol \{ot\} üstüne ki

(2) ol mizbeah üstüne. וקרבו. [9] Da ičin anyn da tizlerin anyn

(3) juvsun suvbyla da tütetsin ol kohen ošol ol barysyn ol miz-

(4) beahta 'oladyr ol otlu qarban ij qabulluq Adonajga.

(5) ואם (10] Da eger ol qojdan bolsa qarbany anyn ol qozulardan

(6) jemese ol ečkilerden 'olag̉a erkekni tügelni juvutsun

(7) any. (11] Da sojsun any janynda ol mizbeahnyn tarafyn-

(8) \{da\} cafonnun alnynda Adonajnyn da bürksünler uvullary Aharon-

(9) nun ol kohenler ošol qany anyn ol mizbeaḥ üstüne čüvre.

(10) [12] Da buvunlasyn any buvunlary sajyn ošol bašyn anyn

(11) da ošol jelkesin anyn da tüzüsün ol kohen alarny ol

(12) otunlar üstüne ki ol ot üstüne ki ol mizbeah

(13) üstüne. והקרב. Da ol ični da ol tizlerni juv-

\footnotetext{
${ }^{1}$ Marginal insertion by another hand. | TKow.o1: ošol ol qanny; unvocalized text. | H: osol ol qanny. | C: šol qanny.
} 
(1) Book of Leviticus

(2) [1] And the divine Presence of the Lord called Moses, and spoke

(3) to him from the tent of meeting, saying,

(4) [2] 'Speak to the children of Israel, and say to them,

(5) "If any man from you brings an offering to the Lord,

(6) you shall bring your offering of livestock from the cattle, and from the flock.

(7) [3] If his offering is a burnt offering from the cattle,

(8) he shall offer an unblemished male. He shall bring it to the door of the tent of meeting

(9) for his acceptance before the Lord. [4]

(10) And he shall reach out his hand over the head of the burnt offering, and

(11) it shall be accepted for him to ask for atonement for him. [5]

(12) And he shall slaughter the young of cattle before the Lord, and

(13) Aaron's sons, the priests, shall bring the

(14) blood, and sprinkle $\{$ the blood $\}$ on the altar, all around, that

(15) is at the door of the tent of meeting. [6] And he shall flay

(16) the burnt offering, and cut it into pieces according to its pieces.

(17) [7] And the sons of Aaron, the priest, shall put

(18) fire on the altar, and lay the wood in order on the fire.

(19) [8] And Aaron's sons, the priests, shall arrange

(20) the parts, the head, and

(1) the neck in order on the wood that is on the fire which

(2) is on the altar. [9] And he wash with water its entrails and its knees.

(3) And the priest shall burn all on the altar.

(4) It is a burnt offering, an offering by fire, an aroma of acceptance to the Lord.

(5) [10] And if his offering is from the flock, from the lambs

(6) or from the goats, for a burnt offering, he shall bring an unblemished male.

(7) [11] And he shall slaughter it on the northward side of the altar

(8) before the Lord, and Aaron's sons,

(9) the priests, shall sprinkle its blood on the altar, all around.

(10) [12] And he shall cut it into pieces according to its pieces, its head,

(11) and its neck, and the priest shall arrange them in order

(12) on the wood that is on the fire which is on the altar.

(13) [13] And he shall wash the entrails and the knees 
(14) sun suvbyla da juvutsun ol kohen ošol ol barysyn da tü-

(15) tetsin ol mizbeahta 'oladyr ol otlu qarban \{ij qabulluq\} Adonajga.

(16) [14] Da eger ol quštan bolsa 'ola qarbany anyn Adonaj-

(17) ga da juvutsun ol bedenelerden jemese ol kögürčün balala-

(18) ryndan ošol qarbanyn özünün. והקריבו. 15] Da juvutsun any

(19) ol kohen ol mizbeaḥqa da [jumuluqlasyn $]^{1}$ ošol bašyn anyn da tütet-

(20) sin ol mizbeaḥta da tamyzdyrylsyn qany anyn farsty üstü-

(21) ne ol mizbeaḥnyn. והסיר. [16] Da ketersin ošol volesin anyn

$159 \mathrm{r}^{\mathrm{o}} \quad$ (1) junubyla da tašlasyn any janynda ol mizbeaḥnyn kün tuvušu

(2) sary ornuna ol külnün. ושסע. [17] Da jartylasyn any qanat-

(3) larybyla ajyrmasyn da tütatsin any ol kohen ol mizbeahta

(4) ol otunlar üstüńa ki ol ot üstüńa oladyr

(5) ol otlu qarban ij qabulluq Adonajğa.

Leviticus 2

(6) ki juvutsa qarban tirki Adonajğa öźak bolsun qarbany anyn

(7) da qujsun anyn üstüńa jav da bersin anyn üstüńa

(8) levona. I 2] Da keltirsin any uvullaryna Aharon-

(9) nun ol kohenĺarǵa da ajyrsyn andan tolu uvuču öźagind́an

(10) da javyndan anyn bar levonasy byla da tutatsin ol kohen

(11) ošol tütüsün anyn ol mizbeaḥta otlu qarban ij qabulluq

(12) Adonajğa. [3נ: Da ol qalġan ol tirkidan bolsun

(13) Aharonga da uvullaryna anyn qodeš qadašim otlu qarban-

(14) laryndan Adonajnyn. Iי [4 Da ki juvutsaj qarban tirki

(15) biširilǵan ṕečta öźak ḥalalar macalar jumurulganlar jav-

(16) byla da juġa macalar jaġylganlar javbyla. ואם [5] Da

(17) eger tirki išlanǵan ol tava üstüńa bolsa qarbanyj

(18) öźak jumurulgan javbyla maca bolsun. פתות. [6] Tigim-

\footnotetext{
${ }^{1} \mathrm{~K}$ : jylmalasyn; a scribal error (or a mistranslation). | TKow.o1: jylmalasyn; unvocalized text. | H: jumuluqlasyn. | C: meliqa etsin (< Heb. מליקָָ 'nipping of the neck of a bird'). | R: kessiń.
} 
(14) with water. And the priest shall bring it all and

(15) burn it on the altar. It is a burnt offering, an offering by fire, an aroma of acceptance to the Lord.

(16) [14] And if his offering to the Lord is a burnt offering of birds,

(17) then he shall bring his offering of turtledoves or of young pigeons.

(18) [15] And the priest shall bring it

(19) to the altar, and [wring off $]^{136}$ its head, and burn

(20) it on the altar, and the blood thereof shall be drained out on the side

(21) of the altar. [16] And he shall remove away its crop

(1) with its feathers, and he shall cast it beside the altar eastward

(2) to the place of the ashes. [17] And he shall halve it by its wings,

(3) but shall not divide it. And the priest shall burn it on the altar,

(4) on the wood that is on the fire. It is a burnt offering,

(5) an offering by fire, an aroma of acceptance to the Lord.

Leviticus 2

person

(6) brings a grain offering to the Lord, his offering shall be of fine flour.

(7) And he shall pour oil on it and put frankincense on it.

(8) [2] And he shall bring it to Aaron's sons,

(9) the priests. And he shall take from there the fill of his fist from its fine flour

(10) and from its oil with all the frankincense, and the priest shall burn

(11) its incense on the altar, an offering by fire, an aroma of acceptance

(12) to the Lord. [3] And the remnant of the grain offering shall be

(13) for Aaron and his sons, the holy of holies from the Lord's

(14) offerings by fire. [4] And if you bring an offering of a grain offering

(15) baked in the oven, [it shall be] unleavened cakes of fine flour mixed with oil

(16) or unleavened flans smeared with oil. [5] And

(17) if your offering is a grain offering made on a griddle,

(18) it shall be of fine flour mixed with oil, unleavened. [6] _Break it into pieces $^{1137}$,

136 K: shave; a scribal error (or a mistranslation), cf. Heb. וּמָלָ ' 'and wring off'.

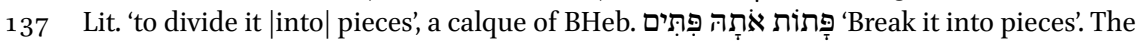
same Karaim construction is used in $\mathrm{H}$, and in $\mathrm{C}$. 
(19) ĺaḿa any tigimĺar da qujğun any üstüńa jav tirkidi

(20) ol. [7] Da \{eger\} tirki išlanǵan panv́ada bolsa qarbanyj

(21) öźak javbyla qylynsyn. והבאת. [8] Da keltirgin ošol ol

$159 \mathrm{v}^{\mathrm{o}}$ (1) tirkini ki qylynsa bulardan Adonajğa da juvutsun any ol

(2) kohenǵa da ol kohen juvutsun any ol mizbeahqa. והרים. [9]

(3) Da ajyrsyn ol kohen ol tirkid́an ošol tütüsün anyn da

(4) tütatsin ol mizbeaḥta otlu qarban ij qabulluq Adonajgia.

(5) והנותרת [10] Da ol qalġan ol tirkidan Aharongaa da ulan-

(6) laryna anyn bolsun qodeš qadašim otlu qarbanlaryndan Adonajnyn.

(7) כל . [11] Bar ol tirki ki juvutsajyz Adonajġa qylynmasyn ḥamec

(8) ki heč qužur da heč čyjbal tütatmajiz andan otlu qarban Adonaj-

(9) ga. gara. [12] Qarbanyn ilknin juvutujuz alarny Adonajga

(10) da ol mizbeaḥqa minḿasinlar ij qabuluqqa. [13] Da

(11) bar qarbanyn tirkijnin tuzbyla tuzlag̉yn da eksitḿagin tuz-

(12) nu šertin Tenrijnin tirkij üstünd́an bar qarbanyj üs-

(13) tüńa juvutqun tuz. ואם [14] Da ki nečik juvutsaj

(14) tirkisin bikurlarnyn Adonajğa kolos ütülǵan otta jyrt-

(15) qan kurpa juvutqun ošol tirkisin bikurlaryjnyn. [15ת]

(16) Da bergin anyn üstüńa jav da qojğun anyn üstüńa

(17) levona tirkidi ol. [16 Da tütatsin ol kohen

(18) ošol tütüsün anyn kurpasyndan da javyndan anyn bar levona-

(19) sybyla otlu qarban Adonajgia.

Leviticus 3

(20) nin bolsa qarbany anyn eger ol syġyrdan ol juvutady eśa

(21) hem erḱakni hem tišini tüǵalni juvutsun any alnynda Adonaj- 
(19) and pour oil on it. It is a grain offering.

(20) [7] And if your offering is a grain offering baked in a pan,

(21) it shall be made of fine flour with oil. [8] And you shall bring the

(1) grain offering that is made of these things to the Lord, and it shall be $159 \mathrm{v}^{\mathrm{o}}$ brought

(2) to the priest, and the priest shall bring it to the altar. [9]

(3) And the priest shall separate from the grain offering its incense, and

(4) he shall burn it on the altar, an offering by fire, an aroma of acceptance to the Lord.

(5) [10] And that which is left of the grain offering shall be Aaron's and

(6) his sons': the holy of holies of the offerings by fire of the Lord.

(7) [11] Every grain offering that you bring to the Lord shall not be made leavened,

(8) because you shall burn no leaven or any honey as an offering by fire to the Lord.

(9) [12] The offering of a first thing: you shall bring them to the Lord,

(10) but they shall not go up to the altar for an aroma of acceptance. [13] And

(11) you shall salt every offering of your grain offering with salt, and you shall not let the salt of the covenant of your God cease

(12) from on your grain offering; you shall bring salt

(13) on all your offerings. [14] And if you offer

(14) a grain offering of firstfruits to the Lord, you shall bring forward

(15) a grain offering of your firstfruits: ears |of grain| parched in fire, [†torn $]^{138}$ groats. [15]

(16) And you shall put oil on it and lay

(17) frankincense on it. It is a grain offering. [16] And the priest shall burn

(18) its incense, some of the groats, and some of the oil with all the frankincense,

(19) an offering by fire to the Lord.

Leviticus 3

[1] And if his offering is a sacrifice of a peace offering,

(20) if he offers it from the cattle,

(21) whether male or female, he shall bring it forward unblemished before the Lord.

138 An uncertain interpretation of jyrtqan. 


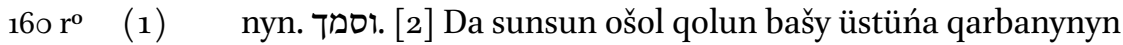

(2) da sojsun any ešigind́a ohel mo`ednin da bürksünlar

(3) uvullary Aharonnun ol kohenĺar ošol ol qanny ol mizbeah

(4) üstüńa čüvŕa. והקריב. [3] Da juvutsun ol šelamim

(5) debeḥasyndan otlu qarban Adonajg̉a ošol ol javny ol qap-

(6) lajdog̉anny ošol ol qarynny da ošol bar ol javny ki ol

(7) qaryn üstüńa. [4] Da ošol eki ol büvŕak-

(8) larni da ošol ol javny ki alar üstüńa ki ol qamču

(9) tijḿaslar üstüńa da ošol ol artyg̉ačny ol bavur-

(10) üstüńa ol büvŕaklar byla ketarsin any. והקטירו. [5]

(11) Da tütatsinĺar any uvullary Aharonnun ol mizbeạ̣ta

(12) ol 'ola qatyna ki ol otunlar üstüńa ki ol ot

(13) üstüńa otlu qarban ij qabulluq Adonajğa. ואם. [6]

(14) Da eger ol qojdan bolsa qarbany anyn ol šelamim debeḥasy-

(15) na Adonajğa hem erḱkakni hem tišini tüǵalni juvutsun

(16) any. אם. [7] Eger qozunu ol juvutady eśa ošol qarbanyn

(17) özünün da juvutsun any alnyna Adonajnyn. וסמך. [8] Da

(18) sunsun ošol qolun bašy üstüńa qarbanynyn da sojsun any

(19) alnynda ohel mo'ednin da bürksünlar uvullary Aharonnun

(20) ošol qanyn anyn ol mizbeah üstüńa čüvía. והקריב. [9]

(21) Da juvutsun ol šelamim debeḥasyndan otlu qarban Adonajğa

$160 \mathrm{v}^{\mathrm{o}}$ (1) javyn anyn ol qujruqnu tüǵalni uturusuna ol ${ }_{\perp}$ qysylyr orun-

(2) nun ${ }^{11}$ ketarsin any da ošol ol javny \{ol qaplajdog̉anny\} ošol ol qarynny da

(3) bar ol javny ki ol qarynüstüńa. ואת. [10] Da ošol ol

(4) $\quad\{[e] k i\}^{2}$ büvŕakĺarni da ošol ol javny ki alar üstüńa ki ol

(5) qamču tijmáálar üstüńa da ošol ol artyğačny ol bavur

(6) והקטירו

(7) Da tütatsin any ol kohen ol mizbeaḥta ötmáak otlu qarban

(8) Adonajgia. ואם [12] Da eger ečki bolsa qarbany anyn da

(9) juvutsun any alnyna Adonajnyn. וסמך [13] Da sunsun ošol

${ }^{1} \mathrm{~K}$ : Probably a mistranslation. | TKow.o1: qysylyr orunnun; unvocalized text. | H: qysar orunnun; probably a mistranslation. | C: jumulgannyy. | Heb. הֶֶֶֶֶ 'the spine'. $\quad{ }^{2}$ Marginal insertion by another hand. | TKow.o1: eki; unvocalized text. | H: eki.| C: eki. 
(1) [2] And he shall reach out his hand over the head of his offering

(2) and slaughter it at the door of the tent of meeting, and

(3) Aaron's sons, the priests, shall sprinkle the blood on the altar

(4) all around. [3] And he shall bring forward from

(5) the sacrifice of the peace offering an offering by fire to the Lord: the fat that

(6) covers the stomach, and all the fat that is

(7) on the stomach, [4] And the two kidneys,

(8) and the fat that is on them, which is at the loins,

(9) and the extra of it that is above the liver:

(10) he shall take it away with the kidneys. [5]

(11) And Aaron's sons shall burn it on the altar

(12) next to the burnt offering, which is on the wood that is

(13) on the fire, an offering by fire, an aroma of acceptance to the Lord. [6]

(14) And if his offering for a sacrifice of peace offering to the Lord is from the flock,

(15) male or female, he shall offer it unblemished.

(16) [7] If he brings forward a lamb for his offering,

(17) he shall bring it forward before the Lord. [8] And

(18) he shall reach out his hand over the head of his offering and slaughter it

(19) before the tent of meeting, and Aaron's sons shall sprinkle

(20) its blood on the altar all around. [9]

(21) And he shall bring forward from the sacrifice of the peace offering an offering by fire to the Lord:

(1) its fat, and the entire |fat| tail—he shall take it away from opposite the ['backbone $]^{139}$ -

(2) and the fat that covers the stomach, and

(3) all the fat that is on the stomach, [10] And the

(4) $\{t w o\}$ kidneys, and the fat that is on them, which is

(5) at the loins, and the extra fat above the liver:

(6) he shall take it away with the kidneys. [11]

(7) And the priest shall burn it on the altar: bread, an offering by fire

(8) to the Lord. [12] And if his offering is a goat, then

(9) he shall bring it forward before the Lord. [13] And he shall reach out

139 An uncertain interpretation of qysylyr orun. Probably a mistranslation of BHeb. הֶֶֶֶָה 'the spine' (a hapax legomenon, Lev 3:9); lit. 'the place which is squeezed'. The Hebrew word could have been confused with the Heb. root עסה 'to squeeze, to press'. 
(10) qolun bašy üstüńa qarbanynyn da sojsun any alnynda ohel

(11) mo'ednin da bürksünlar uvullary Aharonnun ošol qanyn

(12) anyn ol mizbeah üstüńa čüvía. והקריב. [14] Da juvut-

(13) sun andan qarbanyn özünün otlu qarban Adonajğa ošol ol jav-

(14) ny ol qaplajdoġanny ošol ol qarynny da ošol bar ol javny

(15) ki ol qarynüstüńa. ואת [15] Da ošol eki ol büv-

(16) ŕaḱlarni \{da ošol ol javny ki alar üstüńa\} ki ol qamču tijmáaslar üstüńa da ošol

(17) ol artyg̉ačny ol bavur üstüńa ol büvŕaklar byla ke-

(18) tarsin any. [והקטירם. [16] Da tütatsin alarny ol kohen

(19) ol mizbeahta \{ötḿak\} otlu qarban ij qabulluqqa bar jav Adonajgia.

(20) חק [17] Ömürlük resim dorlaryjyzsajyn bar olturušla-

(21) ryjyzda heč javny da heč $\{$ qanny\} ašamajyz.

Leviticus 4

(1) Adonaj Mošeǵa ajtadog̉ač. דבר. [2] Sözlagin ulanlaryna Jis-

(2) ra’elnin ajtadog̉ač žan ki jazyqly bolsa janġylyšlyqbyla qylma

(3) birni bar micvalaryndan Adonajnyn ki qylynmajdylar da qylsa

(4) birisind́an alardan. אם. [3] Eger ol jaġyndyrylgan kohen ki

(5) ol kohen gadol jazyqly bolsa fašmanly jazyğysartyn ol ulus-

(6) nun da juvutsun jazyġy üčün özünün ki jazyqly boldu tana

(7) balasyn syġyrnyn tüǵalni Adonajg̉a ḥatatqa. [והביא [4 Da

(8) keltirsin ošol ol tanany ešigińa ohel mo`ednin alnyna

(9) Adonajnyn da sunsun ošol qolun bašyüstüńa ol tananyn

(10) da sojsun ošol ol tanany alnynda Adonajnyn. [5 [5 [ ]

(11) Da alsyn ol jaġyndyrylg̀an kohen qanyndan ol tananyn da keltir-

(12) $\sin \{$ any\} ohel mo'edǵa. וטבל [6] Da mančsyn ol kohen ošol bar-

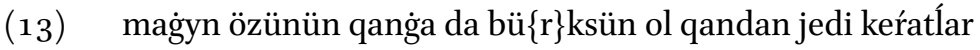

(14) alnynda Adonajnyn alnynda parohyetinin ol qodešnin. ונתן [7]

(15) Da bersin ol kohen ol qandan müvüzlari üstüńa mizbeaḥnyn

(16) ol tütüsünün ol otjamlarnyn alnynda Adonajnyn ki ohel

(17) mo`edd́a da ošol bar qanyn tanasynyn ol hatatnyn töksün

(18) bunjatyna ol mizbeahnynn mizbeahynnyn ol 'olanyn ki ešigind́a

(19) ohel mo'ednin. ואת Da ošol bar javyn tanasynyn ol ḥatat- 
(10) his hand over the head of it and slaughter it before the tent

(11) of meeting, and the sons of Aaron shall sprinkle its blood

(12) on the altar all around. [14] And he shall offer

(13) from it his offering, an offering by fire to the Lord: the fat

(14) that covers the stomach, and all the fat

(15) that is on the stomach, [15] And the two kidneys,

(16) and the fat that is on them, which is at the loins, and the

(17) extra fat above the liver: he shall take it away with the kidneys.

(18) [16] And the priest shall burn them

(19) on the altar: bread, an offering by fire, an aroma of acceptance. All fat is the Lord's.

(20) [17] It shall be an eternal statute throughout your generations, in all your dwelling

(21) places: you shall not eat any fat and any blood.

\section{Leviticus 4}

(1) to Moses, saying, [2] 'Speak to the children of Israel,

[1] And the Lord spoke

(2) saying, "A soul who sins by mistake by doing

(3) any of the commandments of the Lord that are not to be done, and does

(4) any one of them: [3] If the anointed priest, which

(5) is the High Priest, is guilty according to the sin of the people,

(6) he shall bring forward for his sin, which he has sinned, a calf,

(7) unblemished young of cattle, to the Lord for a sin offering. [4] And

(8) he shall bring the calf to the door of the tent of meeting before

(9) the Lord and shall reach out his hand over the calf's head

(10) and slaughter the calf before the Lord. [5]

(11) And the anointed priest shall take of the calf's blood and bring

(12) it to the tent of meeting. [6] And the priest shall dip

(13) his finger in the blood and sprinkle some of the blood seven times

(14) before the Lord, before the veil of the Holy. [7]

(15) And the priest shall put some of the blood on the horns of the altar

(16) of sweet incense before the Lord, which

(17) is in the tent of meeting. And he shall pour all the blood of the calf of the sin offering

(18) at the base of the altar, of the altar of the burnt offering, which is at the door

(19) of the tent of meeting. [8] And he shall take off all the fat of the calf 
(20) nyn ajyrsyn andan ošol ol javny ol qaplajdoġanny ol qarynny

(21) da bar ol javny ki ol qarynüstüńa. ואת [9] Da ošol

$161 v^{\circ} \quad$ (1) eki ol büvŕakĺarni da ošol ol javny ki alar üs-

(2) tüńa ki ol qamču tijḿaslar üstüńa da ošol ol arty-

(3) ġačny ol bavur üstüńa ol büvŕakĺar byla ketarsin any.

(4) כאשר. [10] Ki nečik ajyrylady ögüzünd́an ol šelamim debehasy-

(5) nyn da tütatsin alarny ol kohen mizbeahy üstüńa ol 'o-

(6) lanyn. יואת [11 Da ošol terisin ol tananyn da ošol bar

(7) etin anyn bašybyla da tizlaribyla da ičin anyn da jiŕanči-

(8) ligin anyn. [12] Da čyğarsyn ošol bar ol tanany tyš-

(9) qartyn avulġa aruv orunġa tögülür ornuna ol kül-

(10) nün da küvdürsün any otunlar üstüńa otta tö-

(11) gülür ornu üstüńa ol külnün küvdürülsün.

(12) ואם [13] Da eger bar 3̌ymaty Jisra’elnin janġylsalar da jašy-

(13) ryn bolsa söz agaaraqlaryndan ol qahalnyn da qylsalar birni bar

(14) micvalaryndan Adonajnyn ki qylynmajdylar da fašmanly bolsa-

(15) lar. ונודעה [14] Da bilinśa ol jazyq ki jazyqly boldular anyn

(16) üčün da juvutsunlar ol qahal tana balasyn syġyrnyn hatatqa

(17) da keltirsinlar any alnyna ohel mo'ednin. וסמכו [15] Da

(18) sunsunlar qartlary ol žymatnyn ošol qollaryn bašyüstüńa

(19) ol tananyn alnynda Adonajnyn da sojsun ošol ol tanany alnyn-

(20) da Adonajnyn. והביא Da kijirsin ol jaġyndyrylġan kohen

(21) qanyndan ol tananyn ohel mo'edǵa. וטבל [17] Da mančsyn ol

$162 \mathrm{r}^{\circ}$ (1) kohen ošol barmaġyn qanġa da bürksün jedi keŕatlar al-

(2) nynda Adonajnyn alnynda parohetinin ol qodešnin. ומן. [18]

(3) Da ol qandan bersin müvüzlari üstüńa ol mizbeaḥnyn ki

(4) alnynda Adonajnyn \{ki\} ohel mo'edd́a da ošol bar ol qanny

(5) töksün bunjatyna mizbeahynyn ol 'olanyn ki ešigind́a

(6) ohel mo'ednin. [19] Da ošol bar javyn ajyrsyn andan

(7) da tütatsin ol mizbeaḥta. [20] Da qylsyn tanag̉a

(8) ki nečik qyldy tanasyna ol ḥatatnyn ki özünün alaj qyl-

(9) syn anar da bošatlyq qolsun alar üčün ol kohen da 
(20) of the sin offering from it: all the fat that covers the stomach

(21) and all the fat that is on the stomach, [9] And the

(1) two kidneys, and the fat that is on them,

(2) which is at the loins, and the extra of it that is

(3) above the liver: he shall take it away with the kidneys,

(4) [10] As it is taken off from the bull of the sacrifice of peace offerings.

(5) And the priest shall burn them on the altar of the burnt offering,

(6) [11] And the skin of the calf, and all its

(7) flesh, with its head, and with its knees, and its entrails, and its dung.

(8) [12] And he shall he carry forth the whole calf

(9) outside the camp to a clean place, at the place where the ashes are poured out,

(10) and burn it on the wood with fire.

(11) It shall it be burned at the place where the ashes are poured out.

(12) [13] And if the whole congregation of Israel makes a mistake, and

(13) the matter is hidden from the superiors of the assembly, and they do one of any

(14) of the commandments of the Lord that are not to be done and are guilty,

(15) [14] And the sin over which they have sinned is known,

(16) the assembly shall bring forward a calf, the young of cattle for a sin offering,

(17) and bring it before the tent of meeting. [15] And

(18) the elders of the congregation shall reach out their hands over the head

(19) of the calf before the Lord and he shall slaughter the calf before

(20) the Lord. [16] And the anointed priest shall bring

(21) some of the calf's blood to the tent of meeting. [17] And the priest shall dip

(1) his finger in the blood and sprinkle it seven times

(2) before the Lord, before the veil of the Holy. [18]

(3) And he shall put some of the blood on the horns of the altar which

(4) is before the Lord, that is in the tent of meeting, and shall pour all of the blood

(5) at the base of the altar of the burnt offering, which is at the door

(6) of the tent of meeting. [19] And he shall separate all its fat from it,

(7) and burn it on the altar. [20] And he shall do to the calf

(8) as he did to the calf of the sin offering, which is his own. So shall he do

(9) to it. And the priest shall ask for atonement for them, and 
(10) bošatylyr jazyğy alarnyn. והוציא [21] Da čyğarsyn ošol

(11) ol tanany tyšqartyn avulg̀a da küvdürsün any ki nečik

(12) küvdürdü ošol burunġu tanany hatatydy ol qahalnyn ol.

(13) אשר (22] Ki nasi jazyqly bolsa da qylsa birni bar

(14) micvalaryndan Adonajnyn Tenrisinin ki qylynmajdylar

(15) janġylyšlyqbyla da fašmanly bolsa. או [23] Jemeśa bil-

(16) dirilśa anar jazyġy anyn ki jazyqly boldu anyn byla da keltir-

(17) sin ošol qarbanyn özünün ulaġyn ečkilarnin erḱakni

(18) tüǵalni. וסמך [24] Da sunsun qolun bašyüstüńa ol

(19) ulaqnyn da sojsun any ne orunda ki sojady ošol ol

(20) 'ולקח. '25] Da alsyn

(21) ol kohen qanyndan ol hatatnyn barmaġy byla da bersin müvüz-

$162 \mathrm{v}^{\mathrm{o}}$ (1) lari üstüńa mizbeahynyn ol 'olanyn da ošol qanyn anyn tök-

(2) sün bunjatyna mizbeahynyn ol 'olanyn. ואת [26] Da ošol

(3) bar javyn anyn tütatsin ol mizbeaḥta javynkibik ol šelamim

(4) debeḥasynyn da bošatlyq qolsun anyn üčün ol kohen jazyġyndan

(5) da bošatylyr anar. ואם [27] Da eger bir క̌an jazyqly bol-

(6) sa janġylyšlyq byla ulusundan ol jernin qylġanynda birni

(7) micvalaryndan Adonajnyn ki qylynmajdylar da fašmanly bolsa.

(8) או [28] Jemeśa bildirilśa anar jazyg̉y anyn ki jazyqly bol-

(9) du da keltirsin qarbanyn özünün ulaggyn ečkilarnin

(10) tüǵalni tišini jazyġy üčün ki jazyqly boldu. [29]

(11) Da sunsun ošol qolun bašy üstüńa ol hatatnyn

(12) da sojsun ošol ol ḥatatny ne orunda ki sojady

(13) ošol ol 'olany. ולקח. [3o] Da alsyn ol kohen qanyndan

(14) anyn barmaggy byla da bersin müvüzlari üstüńa

(15) mizbeahynyn ol 'olanyn da ošol bar qanyn anyn töksün

(16) bunjatyna \{ol\} mizbeahnnyn. ואת [31] Da ošol bar javyn anyn

(17) ketarsin ki nečik ketaríladi jav debehasy üstünd́an ol

(18) šelamimnin da tütatsin ol kohen ol mizbeaḥta ij qabul-

(19) luqqa Adonajg̉a da bošatlyq qolsun anyn üčün ol kohen

(20) da bošatylyr anar. [ואם [32] Da eger qozunu keltir-

(21) śa qarbanyn özünün hatatqa tišini tüğalni keltir- 
(10) their sin will be forgiven. [21] And he shall carry the

(11) calf outside the camp and burn it as

(12) he burned the first calf. It is a sin offering of the assembly.

(13) [22] When a prince sins and does one of any

(14) of the commandments of the Lord his God that are not to be done,

(15) by mistake and is guilty, [23] Or

(16) if his sin which he has sinned is made known to him, then he shall bring

(17) his offering, a kid of the goats, an unblemished male.

(18) [24] And he shall reach out his hand over the head of the

(19) kid and slaughter it in the place where he slaughters the

(20) burnt offering before the Lord. It is a sin offering. [25] And the priest shall take

(21) some of the blood of the sin offering with his finger and put it on the horns

(1) of the altar of burnt offering and shall pour out its blood

(2) at the base of the altar of burnt offering. [26] And

(3) he shall burn all its fat on the altar, as the fat of the

(4) sacrifice of peace offerings. And the priest shall ask for atonement over him from his sin,

(5) and it shall be forgiven for him. [27] An if a soul of the people of the land sins by

(6) mistake by doing one of the

(7) commandments of the Lord that are not to be done and is guilty,

(8) [28] Or if his sin which he has sinned is made known to him,

(9) then he shall bring his offering, a kid of the goats,

(10) an unblemished female, for his sin which he has sinned. [29]

(11) And he shall reach out his hand over the head of the sin offering

(12) and slaughter the sin offering in the place he slaughters

(13) the burnt offering. [3o] And the priest shall take some of the blood

(14) with his finger and put it on the horns

(15) of the altar of burnt offering and shall pour all of its the blood

(16) at the base of the altar. [31] And he shall take away all its fat,

(17) as the fat is taken away from the sacrifice

(18) of peace offerings, and the priest shall burn it on the altar for a pleasing aroma

(19) to the Lord. And the priest shall ask for atonement for him,

(20) and it shall be forgiven him. [32] And if he brings a lamb

(21) as his offering for a sin offering, he shall bring it an unblemished female. 


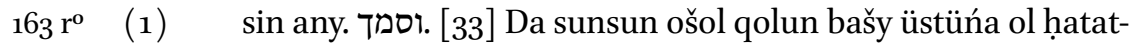

(2) nyn da sojsun any hatatqa ne orunda ki sojady ošol ol 'ola-

(3) ny. ולקח [34 Da alsyn ol kohen qanyndan ol hatatnyn barmag̉y byla da

(4) bersin müvüzlari üstüńa mizbeahynyn ol 'olanyn da ošol bar

(5) qanyn anyn töksün bunjatyna ol mizbeahnnyn. ואת [35] Da ošol bar

(6) javyn ketirsin ki nečik ketariladi javy ol qozunun ol šelamim debe-

(7) hasyndan da tütatsin ol kohen alarny ol mizbeahta otlu qarban-

(8) lary qatyna Adonajnyn da bošatlyq qolsun anyn üčün ol kohen jazyg்y

(9) üčün ki jazyqly boldu da bošatylyr anar.

\section{Leviticus 5}

ונפש. [1] Da క̌an ki

(10) jazyqly bolsa da ešitśa avazyn qarg̉yšnyn da ol bolsa tanyq

(11) jemeśa körśa jemeśa bilśa eger anlatmasa da kötür-

(12) sün žurumun. או. [2] Jemeśa క̌an ki tijśa nendijd́a mur-

(13) dar nerśaǵa jemeśa gövd́asińa murdar kijiknin jemeśa

(14) gövd́asińa murdar tuvarnyn jemeśa gövd́asińa murdar

(15) qumuznun da jašyryn bolsa andan da ol murdar boldu da

(16) fašmanly bolsa. [1א [3] Jemeśa $k$ [i tijśa] murdarlyg்[yna adam]nyn bar [murdarlyġy] sajyn ki m[urdar bolsa] anyn byla [da jašyryn] bolsa an[dan da ol] bildi da fa [šmanly] boldu. ${ }^{11}$. [4] Jemeśa žan ki antetśa eqrar

(17) etḿa erinĺarbyla jaman etḿa jemeśa jaḥšy etḿa

(18) barysajyn neki eqrar etadi ol adam antbyla da jašyryn

(19) bolsa andan da ol bilśa da fašmanyly bolsa birisi üčün

(20) bulardan. והיה [5] Da bolġaj ki fašmanly bolsa birisi üčün

(21) bulardan da mode bolsun ki jazyqly boldu anyn üčün. והביא. [6]

$163 v^{0} \quad$ (1) Da keltirsin ošol fašmanlyq qarbanyn Adonajğa jazyg்y üčün ki

(2) jazyqly boldu tišini ol qojdan qozunu jemeśa ulaġyn ečkilar-

(3) nin ḥatatqa da bošatlyq qolsun anyn üčün ol kohen jazyġyndan

(4) anyn. ואם [7] Da eger jetńaśa küčü qolunun jetkiligića

\footnotetext{
${ }^{1}$ Marginal insertion by another hand. | TKow.o1: Jemeśa ki tijśa murdarlyġyna adamnyn bar murdarlyġy sajyn ki murdar boldu anyn byla da jašyryn bolsa andan da ol bilse da fašmanly bolsa; unvocalized text. | H: Jemese ki tijse murdarlygyna adamnyn bar murdarlygy sajyn ki murdar bolsa anyn byla da jasyryn bolsa andan da ol bildi da fasmanly boldu. | C: Ja ki tijsä mundarlyġyna adamnyy barča mundarlyġyna da jašyryn bolsa andan da ol bildi da günähli boldu.
} 
(1) [33] And he shall reach out his hand over the head of the sin offering $163 \mathrm{r}^{\circ}$

(2) and slaughter it for a sin offering in the place where he slaughters the burnt offering.

(3) [34] And the priest shall take some of the blood of the sin offering with his finger and

(4) put it on the horns of the altar of burnt offering and shall pour all of

(5) its blood at the base of the altar. [35] And he shall take away all

(6) its fat, as the fat of the lamb is taken away from the sacrifice of the peace offerings,

(7) and the priest shall burn them on the altar, next to the offerings made by fire

(8) to the Lord. And the priest shall ask for atonement for his sin

(9) which he has sinned, and it shall be forgiven him.

Leviticus 5

(10) sins: and hears the voice of a curse, and is a witness,

(11) whether he has seen or known of it: if he does not tell of it,

(12) he shall bear his punishment. [2] Or if a soul who touches any

(13) unclean thing, whether it be a carcass of an unclean wild animal or

(14) a carcass of unclean cattle, or a carcass of unclean

(15) creeping animal, and it is hidden from him, and he had become unclean and

(16) guilty, [3] \{Or if [he touches] the uncleanness of [a man], of whatever sort [the uncleanness] may be with which [he becomes unclean, and] it is [hidden from him], and then he had come to know and had become [guilty], [4] Or if a soul swears so as to express

(17) with his lips to do bad or to do good-

(18) whatsoever it be that a man shall express with an oath — and it is hidden

(19) from him, and he comes to know of it and he is guilty in one

(20) of these: [5] And it shall be that when he shall become guilty by one

(21) of these things that he shall confess that he has sinned in that thing, [6]

(1) And he shall bring his guilt offering to the Lord for his sin

(2) which he has sinned, a female from the flock, a lamb or a kid of the goats,

(3) for a sin offering. And the priest shall ask for atonement for him

(4) from his sin. [7] And if his hand cannot attain enough for 
(5) qojnun da keltirsin ošol fašmanlyq qarbanyn ki jazyqly boldu

(6) eki bedeńalar jemeśa eki kügürčün balalary Adonajg̉a bir-

(7) ni hatatqa da birni 'olag̉a. [8ביא Da keltirsin

(8) alarny ol kohenǵa da juvutsun ošol neki ḥatatqa burun-

(9) raq da [jumuluqlasyn $]^{1}$ ošol bašyn anyn utrusundan enśasinin da

(10) ajyrmasyn. והזה [9] Da bürksün qanyndan ol ḥatatnyn

(11) farsty üstüńa ol mizbeaḥnyn da ol qalġan qandan tamyzdy-

(12) rylsyn bunjatyna ol mizbeaḥnyn hatatty ol. [10] Da

(13) ošol ol ekinčini qylsyn 'ola kečinḿaḱka köŕa da

(14) bošatlyq qolsun anyn üčün ol kohen jazyġyndan anyn ki jazyqly bol-

(15) du da bošatylyr anar. ואם [11] Da eger jetmaśa küčü

(16) qolunun eki bedeńalarǵa jemeśa eki kügürčün balalaryna

(17) da keltirsin ošol qarbanyn anyn üčün neki jazyqly boldu onun-

(18) ču ülüšün ol efanyn öźak hatatqa qojḿasin anyn

(19) üstüńa jav da berḿasin anyn üstüńa levona ki ḥatat-

(20) ty ol. [12] Da keltirsin any ol kohenǵa da ajyr-

(21) syn ol kohen andan tolu qoš uvučun ošol tütüsün anyn da

$164 \mathrm{r}^{\mathrm{o}} \quad$ (1) tütatsin ol mizbeahta otlu qarbanlary qatyna Adonajnyn \{hatatty\}

(2) ol. וכפר [13] Da bošatlyq qolsun anyn üčün ol kohen jazyg்y ü-

(3) čün anyn ki jazyqly boldu anyn üčün birisind́an bulardan da boša-

(4) tylyr jazyġy anyn da bolsun kohenǵa tirkikibik. וידבר. [14]

(5) Da sözladi Adonaj Mošeǵa ajtadoġač. נפש. [15] Žan

(6) ki tansa tanmaq da jazyqly bolsa janġylyšlyqbyla qodešla-

(7) rind́an Adonajnyn da keltirsin ošol fašmanlyq qarbanyn Adonaj-

(8) ga qočqarny tüğalni ol qojdan qyjasyjbyla \{kümüšs mitqallar mitqaly

(9) byla ol qodešnin fašmanlyq qarbanġa. ואת [16] Da ošol

(10) neki jazyqly boldu ol qodeštan tölasin da ošol bešinči ü-

(11) lüšün arttyrsyn anyn üstüńa da bersin any kohenǵa

(12) da ol kohen bošatlyq qolsun anyn üčün qočqarybyla ol

\footnotetext{
${ }^{1} \mathrm{~K}$ : jylmalasyn; a scribal error (or a mistranslation); see Lev 1:15. | TKow.o1: jylmalasyn; unvocalized text. | H: jumuluqlasyn. | C: meliqa etsin.
} 
(5) a sheep, he shall bring his guilt offering for having sinned:

(6) two turtledoves, or two young pigeons, to the Lord, one

(7) for a sin offering, and one for a burnt offering. [8] And he shall bring

(8) them to the priest, and he shall bring forward that which is for the sin offering first,

(9) and [wring off $]^{140}$ its head from the point opposite its back of the neck, but

(10) shall not separate it. [9] And he shall sprinkle some of the blood of the sin offering

(11) on the side of the altar, and the rest of the blood shall be drained out

(12) at the base of the altar. It is a sin offering. [10] And

(13) he shall make the second one a burnt offering, according to the |required| manner. And

(14) the priest shall ask for atonement for him from his sin which he has

(15) sinned, and it shall be forgiven him. [11] And if his hand cannot attain

(16) enough for two turtledoves, or two young pigeons,

(17) he shall bring as his offering for having sinned the tenth

(18) part of an ephah of fine flour for a sin offering. He shall put no

(19) oil on it and he shall put no frankincense on it, because it is a sin offering.

(20) [12] And he shall bring it to the priest, and

(21) the priest shall take a full handful of it, his incense, and

(1) burn it on the altar, next to the offerings by fire of the Lord. It is a $\sin \quad 164 \mathrm{r}^{\circ}$ offering.

(2) [13] And the priest shall ask for atonement for him, for his sin

(3) that he has sinned in one of these, and

(4) his sin will be forgiven. And it shall be the priest's, as a grain offering."' [14]

(5) And the Lord spoke to Moses, saying, [15] 'If a soul

(6) commits a trespass, and sins by mistake among the holy things

(7) of the Lord: he shall bring for his guilt offering to the Lord,

(8) an unblemished ram from the flock with your valuation by mithqals of silver,

(9) by the mithqal of the Holy, for a guilt offering. [16] And

(10) for what he sinned from the Holy he shall pay and add to it the fifth

(11) part of it and give it to the priest.

(12) And the priest shall ask for atonement for him with the ram

140 K: shave; a mistranslation, cf. Heb. 
(13) fašmanlyq qarbannyn da bošatylyr jazyġy anyn. ואם [17 Da

(14) eger క̌an ki jazyqly bolsa da qylsa birni bar micvlaryndan

(15) Adonajnyn ki qylynmajdylar da bilmaśa da fašmanly bolsa

(16) da kötürsün žurumun. והביא. [18] Da keltirsin qočqarny

(17) tüǵalni ol qojdan qyjasyjbyla fašmanlyq qarbanġa ol kohenǵa

(18) da bošatlyq qolsun anyn üčün ol kohen janġylyšlyġy üčün ki jan-

(19) ġyldy da ol bilḿadi da bošatylyr jazyg்y any. אשם. [19] Fašman-

(20) lyq qarbandy ol fašmanly bolma fašmanly boldu Adonajgia.

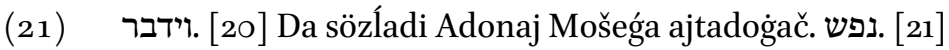

$164 \mathrm{v}^{\mathrm{o}}$ (1) Žan ki jazyqly bolsa da tansa tanmaq Adonajğa da tansa dos-

(2) tuna amanatta jemeśa qojmaġynda qolnun jemeśa talavbyla

(3) jemeśa zulumlasa ošol dostun. [22] Jemeśa tapsa tas-

(4) polġan nerśa da tansa anyn üčün da antetśa jalġanġa

(5) birisi ücün neki qylsa ol adam jazyqly bolma alar byla.

(6) והיה Da bolgaj ki jazyqly bolsa da fašmanly bolsa da qaj-

(7) tarsyn ošol ol talavny ki talady jemeśa ol zulumluqnu ki zu-

(8) lumlady jemeśa ošol ol amanatny ki amanatlandy birǵasi-

(9) ńa jemeśa ošol ol taspolġan nerśani ki tapty. [24]

(10) Jemeśa baryndan ki antetśa anyn üčün jalġanġa da töla-

(11) sin any bütünübyla da bešinči ülüšün anyn arttyrsyn

(12) anyn üstüńa anar ki ol anyndy bersin any fašmanly bolġan

(13) kününd́a. ואת [25] Da ošol fašmanlyq qarbanyn özünün kel-

(14) tirsin Adonajgia qočqarny tüǵalni ol qojdan qyjasyjbyla faš-

(15) manlyq qarbanga ol kohenǵa. וכפר. [26] Da bošatlyq qolsun

(16) anyn üčün ol kohen alnynda Adonajnyn da bošatylyr jazyġy anyn

(17) biri üčün baryndan neki qylsa fašmanly bolma anyn byla.

Leviticus 6

פרשת צו (18) (18)

[1] [ידבר יהוה אל משה לאמר 'צו את אהרן ואת בניו (19) (19)

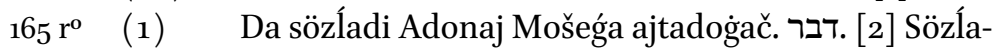

(2) gin Aharonga da uvullaryna anyn ajtadoġač budu 
(13) of the guilt offering, and his sin will be forgiven. [17] And

(14) if a soul who sins, commits one of the commandments

(15) of the Lord that are not to be done, and did not know and became guilty,

(16) he shall bear his punishment. [18] And he shall bring an unblemished ram

(17) from the flock with your valuation for a guilt offering, to the priest,

(18) and the priest shall ask for atonement for the mistake

(19) that he made and knew it not, and his sin will be forgiven. [19] It is a guilt

(20) offering: he has certainly become guilty to the Lord.'

(21) [20] And the Lord spoke to Moses, saying, [21]

(1) 'If a soul sins, and commits a trespass against the Lord, and deceives $164 \mathrm{~V}^{\mathrm{o}}$

(2) his friend in |a matter of | deposit or |something| set in hand or by robbery,

(3) or if he has oppressed his friend, [22] Or has found

(4) something lost and lies about it and swears to a falsehood

(5) - for one of any of these that a man does to sin by it:

(6) [23] And it shall be, if he has sinned and is guilty, he shall return

(7) the spoil that he robbed or what he got by oppression

(8) or the deposit that was deposited with him

(9) or the lost thing that he found, [24]

(10) Or anything about which he has sworn to a falsehood, and he

(11) shall pay it in full and shall add to it a fifth of it,

(12) he shall give it to him to whom it belongs on the day of his being guilty.

(13) [25] And he shall bring his guilt offering

(14) to the Lord: an unblemished ram from the flock with your valuation

(15) for a guilt offering, to the priest. [26] And the priest shall ask for atonement

(16) for him before the Lord, and his sin will be forgiven

(17) for any one out of all that he has done to become guilty through it.'

Leviticus 6

(18) Parashat Tzav

(19) [1]

(1) And the Lord spoke to Moses, saying, [2] 'Spoke $165 \mathrm{r}^{\mathrm{r}}$

(2) to Aaron and his sons, saying, "These are 
(3) üvŕatüvü ol 'olanyn oldu ol 'ola očaq üstüńa

(4) ol mizbeah üstüńa bar ol keč́ani ol tangadejin da ot

(5) ol mizbeahta jansyn anda. ולבש [3] Da kijsin ol kohen

(6) aq upraġyn da aq mihnnesajimĺar bolsunlar gufu üstüna $\{d a\}$

(7) ajyrsyn ošol ol külnü ki örtaśa ol ot ošol ol 'olany

(8) ol mizbeah üstüńa da qojsun any janynda ol mizbeaḥnyn.

(9) [4 [4 Da češsin ošol upraqlaryn özünün da kijsin

(10) özǵa upraqlar da čyğarsyn ošol ol külnü tyšqartyn

(11) avulg̀a aruv orunġa. [5אש [5a ol ot ol mizbeah

(12) üstüńa jansyn anda sönḿasin da jandyrsyn anyn

(13) üstüńa ol kohen otunlar har ertenbylada da tüzüsün

(14) anyn üstüńa ošol ol 'olany da tütatsin anyn

(15) üstüńa javlaryn ol šelamimnin. אש [6] Hammeš́alik

(16) ot jansyn ol mizebah üstüńa sönḿasin. [7] Da budu

(17) üvŕatüvü ol tirkinin juvutma any uvullary Aharonnun

(18) alnyna Adonajnyn alnyna ol mizbeaḥnyn. והרים. [8] Da ajyrsyn

(19) andan qoš uvuču byla öźagindán ${ }_{L}\{\text { ol ti }[\text { rki }] \operatorname{nin}\}^{11}$ da javyndan anyn da ošol bar

(20) ol levonany ki ol \{tirki\} üstüńa da tütatsin ol mizbeaḥta

(21) ij qabulluq tütüsü anyn Adonajğa. [9] Da

$165 \mathrm{~V}^{\mathrm{o}} \quad$ (1) ol qalġanny andan ašasynlar any Aharon da uvullary anyn macalar

(2) ašalsyn aziz orunda qaḥrasynda ohel mo'ednin a \{̌s $\}$ asynlar any.

(3) לא [10] Biširilmasin ḥamec ülüšĺarin alarnyn berdim any ot-

(4) lu qarbanlarymdan qodeš qadašimdir ol ḥatat kibik da ašam

(5) kibik. כל [11] Bar erḱkak ulanlarynda Aharonnun ašasyn any

(6) ömürlük resim dorlaryjyz sajyn otlu qarbanlaryndan Adonaj-

(7) nyn barča kim ki kĺaśa tijḿa alarg̉a keŕaklidi ki aziz-

(8) lianǵaj. וידבר [12] Da sözladi Adonaj Mošeǵa ajtadog̀ač.

(9) זה [13] Budu qarbany Aharonnun da uvlullarynyn ki juvutsunlar

\footnotetext{
${ }^{1}$ Marginal insertion by another hand. | TKow.o1: ol tirkinin; unvocalized text. | H: ol tirkinin. | C: ol minhanyy.
} 
(3) the teachings of the burnt offering. It is the burnt offering on the bonfire,

(4) on the altar all night until the morning, and the fire

(5) on the altar shall burn there. [3] And the priest shall put on

(6) his white garment, and his white dual trousers shall be on his body, and

(7) he shall separate the ashes to which the fire consumes the burnt offering

(8) on the altar, and he shall put them beside the altar.

(9) [4] And he shall take off his garments and put on

(10) other garments, and ha shall take the ashes outside

(11) the camp to a clean place. [5] And the fire on the altar

(12) shall be burning on it, it shall not be put out. And the priest shall burn

(13) wood on it at every dawn, and ha shall arrange

(14) the burnt offering in order on it, and he shall burn

(15) on it the fat of the peace offerings. [6] A continual

(16) fire shall be burning on the altar. It shall not go out. [7] And this is

(17) the teaching of the grain offering: that Aaron's sons shall bring it forward

(18) before the Lord, before the altar. [8] And he shall take

(19) a full handful of it, of the fine flour \{of the [grain offering]\}, and of its oil, and all

(20) the frankincense which is on the grain offering, and he shall burn it on the altar,

(21) its incense is a pleasing aroma to the Lord. [9] And

(1) Aaron and his sons shall eat the remainder of it. Unleavened bread

(2) shall be eaten in a holy place. They shall eat it in the court of the tent of meeting.

(3) [10] It shall not be baked |with| leaven. I have given it |as| their portions

(4) of my offerings by fire. It is the holy of holies, like the sin offering and like the guilt offering.

(5) [11] All the males among the children of Aaron shall eat it.

(6) It shall be an eternal statute throughout your generations from the offerings by fire of the Lord.

(7) Every one that wants to touch them must become holy."'

(8) [12] And the Lord spoke to Moses, saying,

(9) [13] 'This is the offering of Aaron and of his sons, which they shall bring forward 
(10) Adonajg̉a jaġyndyrylġan kününd́a kohen gadolluqqa onunču

(11) ülüšü ol efanyn öźak tirki hammeš́a jarymyn qylsyn

(12) ertanbylada da ekinči jarymyn i\{n\}girda. על [14] Tava

(13) üstüńa javbyla qylynsyn qatlanġanny keltirgin any biši-

(14) lirǵan tirkisi tigimĺarnin juvutqun ij qabulluq Adonajġa.

(15) [15] Da ol kohen ol jaġyndyrylgan ki oldu ol kohen gadol

(16) ki bolsa Aharon ornuna uvullaryndan anyn qylsyn any har kün

(17) ömürlük resim alnynda Adonaj[nyn $]^{1}$ tüǵal barysy tütatil-

(18) sin. וכל [16] Da barda tirkisi kohennin tüǵal barysy tüta-

(19) tilsin ašalmasyn. וידבר. 117] Da sözladi Adonaj Mošeǵa

(20) ajtadoġač. דבר. [18] Sözĺagin Aharong̉a da uvullaryna

(21) anyn ajtadoġač budu üvíatüvü ol hatatnyn ne orunda

$166 \mathrm{r}^{\circ} \quad$ (1) ki sojulsa ol ola sojulsun ol hatat alnynda Adonajnyn

(2) qodeš qadašimdi ol. הכהן. [19] Ol kohen ol bürküvčü qanyn

(3) anyn ašasyn any aziz orunda ašalsyn qahrrasynda ohel

(4) mo'ednin. כ2. [20] Barča kim ki tijśa anar keŕaklidi ki

(5) azizlanǵaj da ki bürkülśa qanyndan anyn ol upraq üs-

(6) tüńa ki bürkülśa anyn üstüńa juvulsun ${ }^{2}$ aziz orun-

(7) da. וכלי d21] Da čerepli savut ki biširilśa anyn ičińa

(8) synsyn da eger tuč savut ičińa biširilśa da jylt-

(9) ratylsyn da taštyrylsyn suvbyla. כל [22] \{Bar\} erkak kohen-

(10) lááda ašasyn any qodeš qadašimdir ol. [23] Da bar

(11) hatat ki kijirilśa qandan anyn ohel mo'edǵa bošatlyq

(12) qolma qodešta ašalmasyn otta küvdürülsün.

Leviticus 7

(13) [וזאת [1] Da budu üvŕatüvü ol fašmanlyq qarbannyn

(14) qodeš qadašimdi ol. במקום. [2] Ne orunda ki sojsalar

(15) ošol ol 'olany sojsunlar ošol ol fašmanlyq qarbanny

(16) da ošol qanyn bürksün ol mizbeah üstüńa čüvŕa.

${ }^{1} \mathrm{~K}$ : Adonaj; a scribal error. | TKow.o1: Adonajnyn; unvocalized text. | H: deest; different wording. | C: deest; different wording. $\quad{ }^{2} \mathrm{~K}$ : Possibly a mistranslation. | TKow.o1: juvgun; unvocalized text.

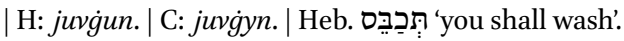


(10) to the Lord in the day when he is anointed for high priesthood: a tenth

(11) part of an ephah of fine flour for a grain offering perpetually, half of it he shall do

(12) at dawn and the second half of it in the evening. [14]

(13) It shall be made on a griddle with oil: you shall bring it put together.

(14) The pieces of the baked grain offering you shall bring forward: a pleasing aroma to the Lord.

(15) $[15]$ And the anointed priest, that is the High Priest

(16) in Aaron's place from among his sons, shall do it every day,

(17) an eternal statute to the Lord. The whole of it shall be burned.

(18) [16] And even every grain offering of a priest shall be wholly

(19) burnt. It shall not be eaten.' [17] And the Lord spoke to Moses,

(20) saying, [18] 'Speak to Aaron and to his sons,

(21) saying, "This is the teaching of the sin offering. In the place

(1) where the burnt offering is slaughtered shall the sin offering be slaughtered before the Lord.

(2) It is the holy of holies. [19] The priest that sprinkles its blood

(3) shall eat it. In a holy place shall it be eaten, in the court of the tent

(4) of meeting. [20] Anything that shall touch it must

(5) become holy. And when any of its blood is sprinkled on any garment,

(6) that on which it was sprinkled ${ }_{L}$ shall be washed ${ }^{1141}$ in the holy place.

(7) [21] But he shall break the earthen vessel in which it is boiled.

(8) And if it is boiled in a bronze vessel,

(9) then it shall be polished and rinsed with water. [22] All the males among the priests

(10) shall eat it. It is the holy of holies. [23] And every

(11) sin offering from which any of the blood is brought to the tent of meeting to ask for atonement

(12) in the Holy shall not be eaten. It shall be burnt in fire.

Leviticus 7

(13) [1] And this is the teaching of the guilt offering.

(14) It is the holy of the holies. [2] In the place where they slaughter

(15) the burnt offering they shall slaughter the guilt offering,

(16) and he shall sprinkle its blood on the altar all around.

141 K: Probably a mistranslation, cf. Heb. תתכְבְבָ 'you shall wash'. 
(17) ואת [3] Da ošol bar [javyn] $]^{1}$ anyn juvutsun andan ošol ol

(18) qujruqnu da ošol ol javny ol qaplajdoġanny ošol ol qaryn-

(19) ny. [4] Da ošol eki ol büvŕakĺarni da ošol ol

(20) javny ki alar üstüńa ki ol qamču tijmáaslar üstüńa

(21) da ošol ol artyğačny ol bavur üstüńa ol büvŕak-

$166 \mathrm{v}^{\mathrm{o}}$ (1) Ílar byla ketarsin any. והקטיר. [5] Da tütatsin alarny ol kohen

(2) ol mizbeahta otlu qarban Adonajğa fašmanlyq qarbandyr ol.

(3) כל . [6] Bar e\{r\}র́ak kohenlard́a ašasyn any aziz orunda ašal-

(4) syn qodeš qadašimdir ol. כחטאת. [7] Nečik ḥatat alaj

(5) ašam bir üvíatüv alarg̉a ol kohen ki bošatlyq qolsa anyn

(6) byla anar bolsun. והכהן. [8] Da ol kohen ol juvutuvču 'ola-

(7) syn kišinin terisi ol 'olany ki juvuttu kohenǵa anar bolsun.

(8) וכל [9] Da bar tirki ki biširilśa pečta da bar qylyn-

(9) ġan panv́ada da tavaüstüńa kohenǵa ol juvutuvčuğa

(10) anar bolsun. [10] Da bar tirki jumurulgan javbyla da

(11) quruğan bar uvullaryna Aharonnun bolsun nečik kišiǵa alaj

(12) qaryndašyna anyn. [11] Da budu üvíatüvü ol

(13) šelamim debeḥasynyn ki juvutsa Adonajğa. אם. [12] Eger

(14) šükürlük üčün juvutsa any da juvutsun debehasy qaty-

(15) na ol šükürlüknün halalar macalar jumurulġanlar javby-

(16) la da jug̉a macalar jag̉ylġanlar javbyla da öźak qatlanġan

(17) halalar jumurulġanlar javbyla. על [13] Ḥalalarybyla qužur

(18) ötḿaknin juvutsun qarbanyn özünün debehasy qatyna

(19) šükürlük šelamimlarinin. והקריב [14] Da juvutsun andan

(20) birni bar qarbandan teruma Adonajgia kohenǵa ol bürküv-

(21) čüǵa ošol qanyn ol šelamimnin anar bolsun. ובשר] [15]

$167 \mathrm{r}^{\mathrm{0}} \quad$ (1) Da eti debehasynyn šükürlük šelamimlarnin juvutqan künün-

\footnotetext{
${ }^{1} \mathrm{~K}$ : qanyn; a scribal error. | TKow.o1: javyn; unvocalized text. | H: javyn. | C: jagyn.
} 
(17) [3] And he shall bring forward all its [fat $]^{142}$,

(18) the |fat| tail, and the fat that covers the stomach,

(19) [4] And the two kidneys, and the

(20) fat that is on them, which is at the loins,

(21) and the extra that is above the liver:

(1) he shall take it away with the kidneys. [5] And the priest shall burn $166 \mathrm{v}^{\mathrm{o}}$ them

(2) on the altar for an offering by fire to the Lord. It is a guilt offering.

(3) [6] Every male among the priests shall eat it. It shall be eaten in the holy place.

(4) It is the holy of holies. [7] As with the sin offering, so with

(5) the guilt offering: there is one teaching for them. The priest that asks for atonement

(6) with it shall have it. [8] And the priest that brings forward

(7) any man's burnt offering shall have for himself the skin of the burnt offering brought forward to the priest.

(8) [9] And all the grain offering that is baked in the oven, and all that is prepared

(9) on a pan or on a griddle, shall be the priest's that brings it forward. It shall be his.

(10) [10] And every grain offering, mixed with oil or

(11) dry, shall be for all the sons of Aaron, one as much

(12) as another. [11] And this is the teaching of the

(13) sacrifice of peace offerings, which he shall bring forward to the Lord. [12] If

(14) he brings it forward for a thanksgiving, he shall bring forward with the sacrifice

(15) of thanksgiving unleavened cakes mixed with oil

(16) and unleavened flans anointed with oil and cakes of fine $\mid$ flour $\mid$

(17) mixed with oil. [13] With the cakes,

(18) he shall bring forward for his offering leavened bread with the sacrifice

(19) of thanksgiving of his peace offerings. [14] And he shall bring forward from it

(20) one of every offering for a heave offering to the Lord for the priest who sprinkles

(21) the blood of the peace offerings. It shall be his. [15]

(1) And the flesh of the sacrifice of his peace offerings for thanksgiving $\quad 167 \mathrm{r}^{\mathrm{o}}$

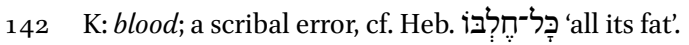


(2) da ašalsyn qaldyrmasyn andan tanġadejin. [16] Da eger

(3) nijet jemeśa žomartlyq bolsa debehasy qarbanynyn juvutqan

(4) künd́a ošol debeḥasyn ašalsyn da tanbyladanda ${ }^{1} \mathrm{ol}$

(5) qalġan andan ašalsyn. והנותר [17 Da ol qalġan etind́an

(6) ol debehasyn ol üčüčü künd́a otta küvdürül-

(7) sün. ואם [18] Da eger ašalma ašalsa etind́an

(8) debehasynyn ol šelamimlarinin ol üčünčü künd́a qabul

(9) bolunmasty ol juvutuvču any saġyšlanmasty anar nemeǵa-

(10) d́a bajat bolur da ol క̌an ol ašavču andan žurumun

(11) k[ö]türsün². והבשר. [19] Da ol et ki tijśa nendijd́a

(12) murdarğa ašalmasyn otta küvdürülsün da ol

(13) etni bar aruv kiši ašasyn etni. והנפש [20] Da

(14) ol క̌an ki ašasa et ol šelamim debehasyndan ki Adonaj-

(15) nyn da murdarlyggy anyn bolsun anyn üstüńa da taspo-

(16) lur ol žan uluslaryndan. [ונפש Da žan ki tijśa

(17) nendijda murdarg̉a murdarlyg்yna adamnyn jemeśa mur-

(18) darlyġyna tuvarnyn jemeśa nendijda murdar qusqunču-

(19) luqqa da ašasa etind́an ol šelamim debehasynyn ki Adonaj-

(20) nyn da taspolur ol žan uluslaryndan. וידבר [22] Da söz-

(21) Íadi Adonaj Mošeǵa ajtadog̉ač. דבר. [23] Sözĺagin ulanlary-

$167 \mathrm{v}^{\mathrm{o}} \quad$ (1) na Jisra'elnin ajtadog̀ač heč javyn ögüznün da qozunun da

(2) וחלב. 24 [24] Da javy qyrylğannyn da javy jyr-

(3) tylğannyn ${ }^{3}$ qylynsyn bar išḱ da ašama ašamajyz any.

(4) כ . 25] Ki bar ašavču ol javdan andij tuvardan ki juvutady

(5) andan otlu qarban Adonajğa da taspolur ol žan ol

(6) ašavču uluslaryndan. וכל [26] Da heč qanny ašamajyz bar

(7) olturušlaryjyzda qušnun da tuvarnyn. כל [27] Bar žan ki

(8) ašasa heč qanny da taspolur ol క̌an uluslaryndan.

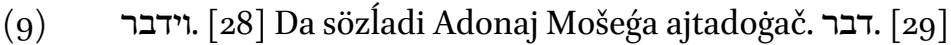

(10) Sözĺagin ulanlaryna Jisra’elnin ajtadoġač ol juvutuvču

(11) ošol šelamim debehalarynyn Adonajğa keltirsin ošol qarba-

(12) nyn özünün $\{[\mathrm{A}] \text { donajğ }\}^{4}$ debehasyndan šelamimlarinin. ידיו Qollary

\footnotetext{
${ }^{1} \mathrm{~K}$ : tanbyladanda da; a scribal error. | TKow.o1: tanbyladan da; unvocalized text. | H: tanbyladan. | C: tajdasyndan da. $\quad{ }^{2} \mathrm{~K}$ : kütürsün; a scribal error. | TKow.o1: kötürsün; unvocalized text. | H: ketirsin. | C: kötärsin. $\quad{ }^{3} \mathrm{~K}:$ jartylg̈annyn corrected to jyrtylgannyn by the copyist. $\quad{ }^{4}$ Marginal

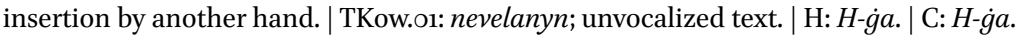


(2) shall be eaten on the day of being brought forward. He shall not leave any of it until the morning. [16] But if

(3) the sacrifice of his offering be a vow or a freewill offering,

(4) it shall be eaten on the day of his bringing forward his sacrifice, and even on the next day the

(5) remainder: of it shall be eaten. [17] And what remains of the flesh

(6) of the sacrifice on the third day shall be burnt in fire.

(7) [18] And if any of the flesh

(8) of the sacrifice of his peace offerings be eaten at all on the third day,

(9) it shall not be accepted, and it shall not be counted for anything for him that brings it forward.

(10) It shall be a defilement, and the soul that eats of it shall bear his punishment.

(11) [19] And the flesh that touches any

(12) unclean thing shall not be eaten. It shall be burnt in fire. And

(13) flesh: everyone who is clean shall eat flesh. [20] But

(14) the soul who eats of the flesh of the sacrifice of peace offerings that is the Lord's,

(15) having his uncleanness on him,

(16) that soul shall perish from among his people. [21] And the soul who touches

(17) any unclean thing, the uncleanness of man or the

(18) uncleanness of an animal or any unclean abominable

(19) thing, and eats of the flesh of the sacrifice of peace offerings that is the Lord's,

(20) that soul shall perish from among his people."' [22] And

(21) the Lord spoke to Moses, saying, [23] 'Speak to the children

(1) of Israel, saying, "You shall eat no fat, of cattle or of lamb or

(2) of goat. [24] And the fat of the animal that dies, and the fat

(3) of that which is torn, may be used in any use, but you shall not eat it.

(4) [25] Because everyone who eats of the fat from an animal from which one would bring forward

(5) an offering by fire to the Lord, then the soul that eats it shall perish

(6) from among his people. [26] And you shall not eat blood in all

(7) of your dwelling places, a bird's or an animal's. [27] Any soul who

(8) eats any blood, that soul will perish from among his people."'

(9) [28] And the Lord spoke to Moses, saying, [29]

(10) 'Speak to the children of Israel, saying, "The one who brings forward

(11) his sacrifice of peace offerings to the Lord shall bring his offering

(12) \{to the Lord $\}$ of the sacrifice of his peace offerings. [30] His hands 
(13) any özünün keltirsinlar ošol otlu qarbanlaryn Adonaj-

(14) nyn ošol ol javny ol töšbyla keltirsin any ošol ol

(15) \{töš\}nü sunma any tenufa alnynda Adonajnyn. והקטיר [31]

(16) Da tütatsin ol kohen ošol ol javny ol mizbeaḥta da

(17) ol töš bolsun Aharonġa da uvullaryna anyn. ואת. [32]

(18) Da ošol on jandaġy inčikni berijiz teruma kohenǵa debe-

(19) hasyndan šelamimĺarijiznin. המקריב. [33] Ol juvutuvču

(20) ošol qanyn ol šelamimĺarnin da ošol javny uvullaryndan

(21) Aharonnun anar bolsun ol on jandag̀y inčik ülüšḱka.

$168 \mathrm{r}^{\mathrm{o}}$ (1) כי את [34] Ki ošol töšün ol tenufanyn da ošol in-

(2) čigin ol terumanyn aldym ulanlaryndan Jisra’elnin debehalaryn-

(3) dan šelamimlarinin da berdim alarny Aharonġa ol kohenǵa da

(4) ulanlaryna anyn ömürlük resimǵa ulanlaryndan Jisra’elnin.

(5) זאת [35] Budur ülüšü jaġynmaġynyn Aharonnun da ülüšü

(6) jaġynmaġynyn uvullarynyn otlu qarbanlaryndan Adonajnyn juvutqan

(7) künd́a alarny kohenlik etḿa alnynda Adonajnyn.

(8) אשר (36] Ki bujurdu Adonaj berma alarg̉a jaġyndyrg̉an

(9) kününd́a alarny ulanlaryndan Jisra’elnin ömürlük resim

(10) dorlarysajyn. זאת [37] Budur ol üvŕatüv 'olag̉a da

(11) tirkiǵa da ḥatatqa da ašamġa da milu’imǵa da

(12) debehasyna ol šelamimnin. אשר. [38] Ki bujurdu Adonaj

(13) Mošeǵa tavynda Sinajnyn bujurgian kününd́a ulanlaryna

(14) Jisra’elnin juvutma ošol qarbanlaryn özĺarinin alnyna Adonaj-

(15) nyn midbarynda Sinajnyn.

Leviticus 8

וידבר [1] Da sözladi Adonaj Moše-

(16) ǵa ajtadog̉ač. קח. [2] Alġyn ošol Aharonnu da ošol u-

(17) vullaryn anyn birǵasińa da ošol ol upraqlarny da ošol

(18) jag̉ynmaq javny da ošol Ltanasyn ol ${ }^{11}$ ḥatatnyn da ošol eki

(19) ol qočqarlarny da ošol četanin ol macalarnyn. ואת [3] Da

\footnotetext{
${ }^{1} \mathrm{~K}$ : Originally ol tanasyn; the word order was corrected by the copyist.
} 
(13) shall bring the offerings by fire of the Lord,

(14) the fat with the breast, he shall bring it: the

(15) breast to be elevated for a wave offering before the Lord. [31]

(16) And the priest shall burn the fat on the altar, but

(17) the breast shall be for Aaron and his sons. [32]

(18) And you shall give the right thigh to the priest for a heave offering

(19) of the sacrifice of your peace offerings. [33] The one from the sons of Aaron

(20) who brings forward the blood of the peace offerings, and the fat,

(21) shall have the right thigh for his part.

(1) [34] Because I have taken the breast of the wave offering and the thigh

(2) of the heave offering of the children of Israel from the sacrifices

(3) of their peace offerings, and I have given them to Aaron, the priest, and

(4) to his sons as an eternal statute from the children of Israel."'

(5) $[35]$ This is the portion of the anointing of Aaron, and the portion

(6) of the anointing of his sons, from the Lord's offerings by fire, in the day he brought them forward

(7) to serve as priests before the Lord, [36]

(8) Which the Lord commanded to be given them in the day that he anointed

(9) them from among the children of Israel, an eternal statute

(10) throughout their generations. [37] This is the teaching of the burnt offering and

(11) of the grain offering and of the sin offering and of the guilt offering and of the ordination and

(12) of the sacrifice of the peace offerings, [38] Which the Lord commanded

(13) Moses on Mount Sinai, in the day that he commanded the children

(14) of Israel to bring forward their offerings before the Lord,

(15) in the wilderness of Sinai.

Leviticus 8

(16) saying, [2] 'Take Aaron and

(17) his sons with him, and the garments, and the

(18) anointing oil, and a calf of the sin offering, and two

(19) rams, and a basket of unleavened bread. [3] And 
(20) ošol bar ol క̌ymatny jyštyrg̉yn ešigińa ohel mo`ednin.

(21) (4) Da qyldy Moše ki nečik bujurdu anar Adonaj da

$168 \mathrm{v}^{0}$ (1) jyštyryldy bar ol žymat ešigińa ohel mo'ednin. ויאמר [5]

(2) Da ajtty Moše ol క̌ymatqa budur ol söz ki bujurdu Adonaj

(3) qylma. ויקרב. [6] Da juvuttu Moše ošol Aharonnu da ošol

(4) uvullaryn anyn da bujurdu alarga ki juvgajlar guflaryn suvby-

(5) la. la [7 Da berdi anyn üstüńa ošol ol kölḿak-

(6) ni da bajlandyrdy any avnet byla da kijdirdi anar ošol

(7) \{ol\} qaftanny da berdi anyn üstüńa ošol ol efodnu da

(8) bajlandyrdy any ojuvubyla ol efodnun da efodlady any

(9) anyn byla. וישם [8] Da qojdu anyn üstüńa ošol ol

(10) ḥošenni da berdi ol ḥošenǵa ošol \{ol\} urimni da ošol ol

(11) tumimni. [9] Da qojdu ošol ol micnefetni bašy

(12) üstüńa anyn da qojdu ol micnefet üstüńa uturu-

(13) suna jüzlarinin ošol čalmasyn ol altyn aziz tačnyn ki nečik

(14) bujurdu Adonaj Mošeǵa. ויקח [10] Da aldy Moše ošol

(15) jag̉ynmaq javny da jağyndyrdy ošol ol miškanny da ošol

(16) barča neki anda da aziz etti alarny. ויז [11] Da bürk-

(17) tü andan ol mizebah üstüńa jedi ke\{ŕ́ $\} a t$ tar da jaġyndyr-

(18) dy ošol mizbeaḥny da ošol bar savutlaryn anyn da ošol ol

(19) qumġanny da ošol ornun anyn aziz etḿa alarnyn.

(20) ויצוק (12] Da q[u]jdu ol jaġynmaq javdan bašy üstüńa

(21) Aharonnun da jag̉yndyrdy any aziz etḿa any. ויקרב [13]

$169 \mathrm{r}^{\mathrm{o}} \quad$ (1) Da juvuttu Moše ošol uvullaryn Aharonnun da kijdirdi

(2) alarg̉a kölmakĺar da bajlandyrdy alarny avnetbyla da

(3) kijdirdi alarg̉a bijik börklar ki nečik bujurdu Adonaj

(4) Mošeǵa. ויגש [14] Da juvuttu ošol tanasyn ol ḥatat-

(5) nyn da sundu Aharon da u\{v\}ullary anyn ošol qollaryn bašy

(6) üstüńa ol hatatnyn. [15] Da sojdu da

(7) aldy ol qandan da berdi müvüzlari üstüńa ol mizbeah-

(8) nyn čüvía barmag்y byla da bürktü ošol ol mizbeaḥny

(9) da ošol ol qanny qujdu bunjatyna ol mizbeahnyn da

(10) aziz etti any bošatlyq qolma anyn üstüńa.

(11) ויקח [16] Da aldy ošol bar ol javny ki ol qaryn üstü-

\footnotetext{
${ }^{1} \mathrm{~K}: q o j d u$; a scribal error. | TKow.o1: unvocalized text. | H: qujdu. | C: töktü.
} 
(20) assemble all the congregation to the door of the tent of meeting.'

(21) [4] And Moses did as the Lord commanded him, and

(1) the congregation was gathered to the door of the tent of meeting. [5] $168 \mathrm{v}^{\circ}$

(2) And Moses said to the congregation, 'This is the word which the Lord commanded

(3) to do.' [6] And Moses brought Aaron and

(4) his sons, and ${ }_{L}$ commanded them to wash their bodies ${ }^{1143}$ with water.

(5) [7] And he put on him the shirt,

(6) and tied him with the girdle, and clothed him

(7) with the robe, and put the ephod on him, and

(8) he tied him with the embroidered |band| of the ephod, and put on the ephod on him

(9) with it. [8] And he put on him the

(10) breastplate, and he put in the breastplate the Urim and the

(11) Thummim. [9] And he put the turban on his head,

(12) and he put on the turban, on its

(13) front, diadem of the holy crown, as

(14) the Lord commanded Moses. [10] And Moses took the

(15) anointing oil and anointed the tabernacle and

(16) all that was in it, and consecrated them. [11] And he sprinkled

(17) some of it on the altar seven times and anointed

(18) the altar and all its vessels, and the

(19) basin and its place, to consecrate them.

(20) [12] And he [poured] ${ }^{144}$ some of the anointing oil on Aaron's head,

(21) and anointed him, to consecrate him. [13]

(1) And Moses brought forward Aaron's sons, and put

(2) shirts on them, and tied them with girdles, and

(3) put high caps on them, as the Lord commanded

(4) Moses. [14] And he brought forward the calf of the sin offering,

(5) and Aaron and his sons reached their hands out over the head

(6) of the calf of the sin offering. [15] And he slaughtered it and

(7) took some of the blood and put it on the horns of the altar

(8) all around with his finger and sprinkled the altar

(9) and poured the blood at the base of the altar, and

(10) he consecrated it, to ask for atonement for it.

(11) [16] And he took all the fat that was on the stomach,

143 Interpretative translation.

144 K: put; a scribal error. 
(12) ńa da ošol artyġačyn ol bavurnun da ošol eki ol

(13) büvŕakĺarni da ošol javlaryn alarnyn da tütatti \{Moše\} ol

(14) mizbeaḥta. ואת [17] Da ošol ol tanany da ošol terisin

(15) anyn da ošol etin anyn da ošol jiŕančiligin anyn küv-

(16) dürdü otta tyšqartyn avulgaa ki nečik bujurdu

(17) Adonaj Mošeǵa. [18] Da juvuttu ošol qočqarny ol

(18) 'olanyn da sundular Aharon da uvullary anyn ošol qola-

(19) ryn bašyüstüńa ol qočqarnyn. וישחט. [19] Da sojdu

(20) da bürktü Moše ošol ol qanny ol mizbeah üstüńa

(21) čüvŕa. [20] Da ošol ol qočqarny buvunlady buvun-

$169 \mathrm{v}^{\mathrm{o}}$ (1) larysajyn da tütatti Moše ošol ol bašny da ošol ol buvun-

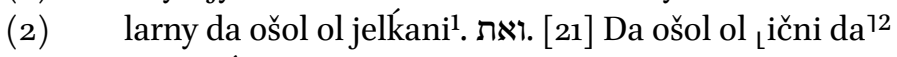

(3) ošol tizĺarni juvdu suvbyla da tütatti Moše ošol

(4) bar ol qočqarny ol mizbeaḥta oladyr ol ij qabulluqqa

(5) otlu qarban \{ol\} Adonajg̉a ki nečik bujurdu Adonaj Mošeǵa.

(6) ויקרב [22] Da juvuttu ošol ol ekinči qočqarny qočqaryn

(7) ol milu'imnin da sundular Aharon da uvullary anyn ošol

(8) qollary bašy üstüńa ol qočqarnyn. וישחט. [23] Da

(9) sojdu da aldy Moše qanyndan da berdi jymšaq ornu

(10) üstüńa ol on jandaġy qulaġynyn Aharonnun da baš barmag்y

(11) üstüńa ol on jandaġy qolunun da baš barmaġy üstü-

(12) ńa ol on jandag̉y ajaġynyn. ויקרב [24] Da juvuttu o-

(13) šol uvullaryn Aharonnun da berdi Moše ol qandan jymšaq

(14) ornu üstüńa ol on jandağy qulaqlarynyn da baš bar-

(15) maġy üstüńa ol on jandaġy qollarynyn da baš barmaq-

(16) lary üstüńa ol on jandaġy ajaqlarynyn da bürktü

(17) Moše ošol ol qanny ol mizbeaḥ üstüńa čüvŕa.

(18) ויקח [25] Da aldy ošol ol javny da ošol ol qujruqnu

(19) da ošol bar ol javny ki ol qaryn üstüńa da ošol

(20) artyğačyn ol bavurnun da ošol eki ol büvŕaklarni

(21) da ošol javlaryn alarnyn da ošol on jandag̉y inčikni.

$170 \mathrm{r}^{\mathrm{o}}$ (1) ומסל (26] Da četanind́an ol macalarnyn ki alnynda Adonajnyn

(2) aldy ḥala maca bir da ḥala ötḿak javly bir da juğa bir

(3) da qojdu ol javlar üstüńa da ol on jandag̉y inčik

(4) üstüńa. ויתן [27] Da berdi ošol ol barysyn uvuč-

\footnotetext{
${ }^{1}$ K: Possibly a mistranslation. | TKow.o1: javny; unvocalized text. | H: jelkinni. | C: qaryn jagnny. | Heb. הָּפָָָָר 'the fat'. $\quad{ }^{2} \mathrm{~K}$ : ični da da; a scribal error. | TKow.o1: ični da; unvocalized text. | H: qarynny da. | C: qarynny da.
} 
(12) and the extra |fat| of the liver, and the two

(13) kidneys, and their fat, and Moses burned it

(14) on the altar. [17] But the calf, and its skin,

(15) and its flesh, and its dung, he burned

(16) in fire outside the camp, as the Lord commanded

(17) Moses. [18] And he brought forward the ram

(18) of the burnt offering, and Aaron and his sons reached out their hands

(19) over the head of the ram. [19] And he slaughtered it,

(20) and Moses sprinkled the blood on the altar

(21) all around. [20] And he cut the ram into pieces

(1) according to its pieces, and Moses burned the head and the pieces

(2) and the neck ${ }^{145}$. [21] And he washed the entrails

(3) and the knees with water, and Moses burned the

(4) whole ram on the altar. It is a burnt sacrifice for a pleasing aroma,

(5) an offering by fire to the Lord, as the Lord commanded Moses.

(6) [22] And he brought forward the other ram, the ram of

(7) ordination, and Aaron and his sons reached out

(8) their hands over the head of the ram. [23] And

(9) he slaughtered it, and Moses took some of the blood of it and put it on the soft place

(10) of Aaron's right ear, and on the thumb

(11) of his right hand, and on the great toe

(12) of his right foot. [24] And he brought

(13) Aaron's sons forward, and Moses put some of the blood

(14) on the soft place of their right ears and

(15) on the thumbs of their right hands and on the great toes

(16) of their right feet. And Moses sprinkled

(17) the blood on the altar all around.

(18) [25] And he took the fat, and the |fat| tail,

(19) and all the fat that was on the stomach, and the

(20) extra |fat| of the liver, and the two kidneys,

(21) and their fat, and the right thigh.

(1) [26] And from the basket of unleavened bread that was before the $170 \mathrm{r}^{\mathrm{o}}$ Lord

(2) he took one unleavened cake, and a cake of oiled bread, and one flan,

(3) and put them on the fat and on the right thigh.

(4) [27] And he put all on Aaron's hands,

145 K: Possibly a mistranslation, cf. Heb. הָָָָּּר 'the fat'. 
(5) lary üstüńa Aharonnun da uvučlary üstüńa uvul-

(6) larynyn da sundu alarny tenufa alnynda Adonajnyn. [28 ]

(7) Da aldy Moše \{alarny\} uvučlary üstünd́an alarnyn da tütat-

(8) ti ol mizbeahta ol 'ola üstüńa milu'imdirlar alar

(9) ij qabulluqqa otlu qarban \{ol\} Adonajgia. ויקח. [29] Da aldy

(10) Moše ošol ol töšnü da sundu any tenufa alnynda

(11) Adonajnyn qočqaryndan ol milu’imnin Mošeǵa boldu ü-

(12) lüšḱka ki nečik bujurdu Adonaj Mošeǵa. [30] Da

(13) aldy Moše ol jaġynmaq javdan da ol qandan ki ol mizbeah

(14) üstüńa da bürktü Aharon üstüńa upraqlary

(15) üstüńa anyn da uvullary üstüńa anyn da up-

(16) raqlary üstüńa uvullarynyn birgesińa da aziz e-

(17) tti ošol Aharonnu ošol upraqlaryn anyn da ošol uvul-

(18) laryn anyn da ošol upraqlaryn uvullarynyn birgesińa.

(19) ויאמר (31] Da ajtty Moše Aharonġa da uvullaryna

(20) anyn biširijiz ošol ol etni ešigind́a ohel mo'ednin

(21) da anda ašajyz any da ošol ol ötḿakni ki četa-

$170 \mathrm{v}^{\mathrm{o}}$ (1) nind́a ol milu’imnin ki nečik bujurdum ajtadoġač Aharon

(2) da uvullary anyn ašasynlar any. והנותר. [32] Da ol qalg̉an-

(3) ny ett́an da ötḿakt́an otta küvdürüjüz.

(4) ומפתח [33] Da ešigind́an ohel mo'ednin čyqmajyz jedi

(5) künlar tolġan künǵadejin künĺari milu’imlarijiznin ki jedi

(6) künĺar tolturur ošol qollaryjyzny. כאשר. [34] Ki nečik

(7) qyldy ošpu künd́a bujurdu Adonaj qylma jedi kün-

(8) Ílar bošatlyq qolma siznin üčün. ופתח. [35] Da

(9) ešigind́a ohel móednin olturujuz kün da keč́a

(10) jedi künĺar da saqlajyz ošol saqlavyn Adonajnyn da ölmajiz

(11) ki alaj bujuruldum. [36] Da qyldy Aharon da u-

(12) vullary anyn ošol bar ol sözlarni ki bujurdu Adonaj

(13) naviligi ašyra Mošenin. 
(5) and on his sons' hands,

(6) and waved ${ }^{146}$ them for a wave offering before the Lord. [28]

(7) And Moses took them from off their hands, and burned

(8) them on the altar on the burnt offering: they were an ordination |offering|,

(9) a pleasing aroma, an offering by fire to the Lord. [29] And Moses took

(10) the breast, and elevated it for a wave offering before

(11) the Lord. It became Moses's portion of the ram of ordination,

(12) as the Lord commanded Moses. [30] And

(13) Moses took some of the anointing oil and of the blood which was on the altar,

(14) and sprinkled it on Aaron, on his garments,

(15) and on his sons, and

(16) on his sons' garments with him, and consecrated

(17) Aaron, his garments, and his sons,

(18) and his sons' garments with him.

(19) [31] And Moses said to Aaron and to his sons,

(20) 'Boil the flesh at the door of the tent of meeting,

(21) and eat it there, and the bread that is

(1) in the basket of ordination, as I commanded, saying, "Aaron

(2) and his sons shall eat it." [32] And you shall burn that which remains

(3) of the flesh and of the bread in fire.

(4) [33] And you shall not go out of the door of the tent of meeting for seven

(5) days, until the day of completion of the days of your ordination, because

(6) he will fill your hand for seven days. [34] As he has done

(7) this day, so the Lord has commanded to do,

(8) to ask for atonement for seven days for you. [35] And

(9) you shall sit at the door of the tent of meeting day and night

(10) seven days, and you shall keep the charge of the Lord, so that you do not die,

(11) for so I am commanded.' [36] And Aaron and

(12) his sons did all the things that the Lord commanded

(13) by the prophecy of Moses.

146 Lit. 'reached out'. 
Leviticus 9

פרשת שמיני (14) (15)

(15] Da edi ol

(16) segizinči künd́a ünd́adi Moše Aharonnu

(17) da uvullaryn anyn da qartlaryn Jisra'elnin. ויאמר. [2]

(18) Da ajtty Aharonġa alg̀yn özüja buzov balasyn syg்yr-

(19) nyn ḥatatqa da qočqar 'ola\{ġa\} tüğallarni da juvutqun

$171 \mathrm{r}^{\mathrm{o}}$ (1) alnynda Adonajnyn. ואל [3] Da ulanlaryna Jisra’elnin sözlagin aj-

(2) tadoġač alyjyz ulag̉yn ečkilarnin ḥatatqa da buzov da qozu

(3) jyllyq balalary \{tüğallarni\} 'olag̉a. ושור. [4] Da ögüz da qočqar šelamimǵa

(4) debeḥa etḿa alnynda Adonajnyn da tirki jumurulgan javbyla

(5) ki bügün šehinasy Adonajnyn aškara bolur sizǵa. ויקחו [5]

(6) Da aldylar ošol neki bujurdu Moše alnynda ohel mo'ednin

(7) da juvudular bar ol క̌ymat da turdular alnynda Adonajnyn.

(8) ויאמר [6] Da ajtty Moše budu ol söz ki bujurdu Adonaj

(9) qylyjyz da aškara bolur sizǵa šehinasy Adonaj\{nyn\}. ויאמר [7]

(10) Da ajtty Moše Aharonga juvug̉un ol mizbeaḥqa da qylg̀yn

(11) ošol ḥatatyjny da ošol ‘olajny da bošatlyq qolgun özüj

(12) üčün da ol ulus üčün da qylġyn ošol qarbanyn ol ulus-

(13) nun da bošatlyq qolġun alar üčün ki nečik bujurdu Adonaj.

(14) (8] Da juvudu Aharon ol mizbeaḥa da sojdu ošol bu-

(15) zovun ol ḥata\{t\}nyn ki özünün. ויקרבו [9] Da juvuttular

(16) ulanlary Aharonnun ošol \{ol\} qanny anar da mančty ošol barmag்yn

(17) qanġa da berdi müvüzlari üstüna ol mizbeaḥnyn da

(18) ošol ol qanny qujdu bunjatyna ol mizbeaḥnyn. ואת. [10]

(19) Da ošol ol javny da ošol ol büvŕaklarni da ošol ol

(20) artyğačny ol bavurdan ol ḥatattan tütatti ol mizbeah-

(21) ta ki nečik bujurdu Adonaj Mošeǵa. ואת [11] Da ošol

$171 \mathrm{v}^{\mathrm{o}} \quad$ (1) ol etni da ošol ol t $[\mathrm{e}] \mathrm{rini}^{2}$ küvdürdü otta tyšqartyn

(2) avulga. וישחט. [12] Da sojdu ošol ol 'olany da terk ${ }^{3}$

(3) berdilar ulanlary Aharonnun anar ošol ol qanny da bürktü

\footnotetext{
${ }^{1}$ Catchword: alnyna. | TKow.o1: alnyna; unvocalized text. | H: alnyna. | C: aldyna. $\quad{ }^{2} \mathrm{~K}$ : tirini; probably a scribal error. | TKow.o1: unvocalized text. | H: terini. | C: terini. $\quad{ }^{3} \mathrm{~K}$ : teŕak; a scribal error; cf. Lev 9:13. | TKow.o1: tez; unvocalized text. | H: tez. | C: deest.
} 


\section{Leviticus 9}

\section{(14) Parashat Shemini}

(15) [1] And it was

(16) on the eighth day, Moses called Aaron

(17) and his sons and the elders of Israel. [2]

(18) And he said to Aaron, "Take you a young calf of cattle

(19) for a sin offering, and a ram for a burnt offering, unblemished, and bring them forward

(1) before the Lord. [3] And you shall speak to the children of Israel,

(2) saying, "Take you a kid of the goats for a sin offering and a calf and a lamb,

(3) unblemished one-year-olds, for a burnt offering, [4] And a bull and a ram for peace offerings

(4) to sacrifice before the Lord, and a grain offering mixed with oil,

(5) because today the divine Presence of the Lord will appear to you."' [5]

(6) And they brought that which Moses commanded before the tent of meeting,

(7) and all the congregation drew near and stood before the Lord.

(8) [6] And Moses said, "This is the word which the Lord commanded

(9) that you should do, and the divine Presence of the Lord will appear to you.' [7]

(10) And Moses said to Aaron, 'Come forward to the altar, and make

(11) your sin offering and your burnt offering, and ask for atonement for yourself

(12) and for the people, and make the offering of the people,

(13) and ask for atonement for them, as the Lord commanded.'

(14) [8] And Aaron came forward to the altar and slaughtered the calf

(15) of the sin offering that he had. [9] And

(16) the sons of Aaron brought forward the blood to him, and he dipped his finger

(17) in the blood and put it on the horns of the altar and

(18) poured out the blood at the base of the altar. [10]

(19) And he burned the fat and the kidneys and the

(20) extra |fat| from the liver of the sin offering on the altar,

(21) as the Lord commanded Moses. [11] And

(1) he burned the flesh and the skin in fire outside

(2) the camp. [12] And he slaughtered the burnt offering,

(3) and Aaron's sons gave him promptly the blood, and he sprinkled 
(4) any ol mizbeah üstüńa čüvŕa. [13] Da ošol ol

(5) olany terk berdilar anar buvunlarysajyn da ošol ol bašny

(6) da tütatti any ol mizbeah üstüna. [14] Da

(7) juvdu ošol ol ični da ošol ol tizlarni da tütatti

(8) ol ola byla ol mizbeaḥta. ויקרב. [15] Da juvuttu ošol

(9) qarbanyn ol ulusnun da aldy ošol ulaġyn ol ḥatat\{n\}yn ki

(10) ulusnun da sojdu da ḥatat qyldy any burungiunu kibik.

(11) ויקרב (16] Da juvuttu ošol ol 'olany da qyldy any kečin-

(12) makkka köŕa. ויקרב [17] Da juvuttu ošol ol tirki-

(13) ni da tolturdu uvučun andan da tütatti ol mizbeah üs-

(14) tüńa bašqa 'olasyndan ol ertanbylany. וישחט [18] Da

(15) sojdu ošol ol ögüznü da ošol ol qočqarny ol šela-

(16) mim debehasyn ki ulusnun da terk berdilar ulanlary Aharon-

(17) nun ošol ol qanny anar da bürktü any ol mizbeah üs-

(18) tüńa čüvía. ואת [19] Da ošol ol javlarny ol ögüz-

(19) d́an da ol qočqardan ol qujruqnu da ol javny ol qaplajdo-

(20) ġanny ol qarynüstüńa da ol büvŕaklarni da artyğa-

(21) čyn ol bavurnun. [20] Da qojdular ošol ol javlar

$172 \mathrm{r}^{\mathrm{o}} \quad$ (1) ny ol töšlar üstüńa da tǘtatti ${ }_{\llcorner}\left\{\right.$ol javlarny $^{1}{ }^{1}$ ol mizbeaḥta.

(2) ואת [21] Da ošol ol töšlarni da ošol ol \{on\} jandağy inčik-

(3) ni sundu Aharon tenufa alnynda Adonajnyn ki nečik bujurdu

(4) Moše. וישא [22] Da kötürdü Aharon ošol qollaryn özü-

(5) nün ol ulusqa da alġyšlady alarny andan sortun nečik

(6) endi qylmaqtan ol hatatny da ol 'olany da ol šelamim-

(7) ni. ויבוא no [23] Da keldi Moše da Aharon ohel mo'edǵa

(8) barma alnynda ol Tenrinin ki endirǵaj ot ol köklar-

(9) d́an örtáma ol qarbanlarny ki mizbeah üstüńa ${ }^{72}$ da nečik

(10) čyqtylar ol vahttta alġyšladylar ošol ol ulusnu da

(11) aškara boldu šehinasy Adonajnyn bar ol ulusqa.

(12) ותצא [24] Da čyqty ot alnyndan Adonajnyn da örtadi

(13) ol mizbeah üstüńa ošol ol 'olanyn da ošol ol jav-

(14) larny da kördülar bar ol ulus da sarnadylar mahtavlar

(15) da tüštülar jüzlari üstüńa.

\footnotetext{
${ }^{1}$ Marginal insertion by another hand. | TKow.o1: ol javlarny; unvocalized text. | H: ol javlarny. | C:
} oljaglarny. $\quad{ }^{2}$ Interpretative addition to the standard text. 
(4) it on the altar all around. [13] And

(5) they gave him promptly the burned offering according to its pieces and the head,

(6) and he burned them on the altar. [14] And

(7) he washed the entrails and the knees, and he burned

(8) the burnt offering on the altar. [15] And he brought forward the

(9) people's offering and took the kid of the sin offering that

(10) was for the people and slaughtered it, and he made a sin offering like the first.

(11) [16] And he brought forward the burnt offering and made it

(12) according to the |required | manner. [17] And he brought forward the grain

(13) offering and filled his hand from it and burned it on the altar-

(14) besides the morning's burnt offering. [18] And

(15) he slaughtered the bull and the ram for

(16) a sacrifice of peace offerings that was for the people. And Aaron's sons

(17) gave him promptly the blood, and he sprinkled it on the altar

(18) all around, [19] And the fat from the bull

(19) and from the ram, the $\mid$ fat $\mid$ tail, and the fat which covers

(20) the stomach, and the kidneys, and the extra

(21) |fat $\mid$ of the liver. [20] And they put the fat

(1) on the breasts, and he burned \{the fat $\}$ on the altar.

(2) [21] And Aaron elevated the breasts and the right thigh

(3) for a wave offering before the Lord, as Moses commanded.

(4) [22] And Aaron raised his hands

(5) toward the people and blessed them after he

(6) had come down from making the sin offering and the burnt offering and the peace offerings.

(7) [23] And Moses and Aaron came to the tent of meeting

(8) to pray before God to make the fire come down from heavens

(9) to consume the offerings that were on the altar ${ }^{1147}$. And when they

(10) came out, they blessed the people, and

(11) the divine Presence of the Lord appeared to all the people.

(12) [24] And fire came out from before the Lord and consumed

(13) the burnt offering and the fat on the altar,

(14) and the people saw, they sang praises

(15) and fell on their faces.

147 Interpretative addition to Lev 9:23. 
Leviticus 10

[1] Da aldylar

(16) uvullary Aharonnun Nadav da Avihu' kiši mačmaryn da qoj-

(17) dular alarg்a ot da qojdular alar üstüńa tütü

(18) da juvuttular alnyna Adonajnyn jat ot ${ }_{\text {Li }}$ anlanma $[\dot{\mathrm{g} y}]^{1} \mathrm{ol}$

(19) jat otnun oldu ki bujurmady alarg̉a Adonaj tütatma

(20) tütü bašqa tütatmakt́an eki keŕat künd́a er-

(21) tanbylada da ingirda ${ }^{12}$. ותצא. [2] Da bunun üčün

$172 \mathrm{~V}^{\mathrm{o}} \quad$ (1) čyqty ot alnyndan Adonajnyn da örtadi alarny da öldülar

(2) alnynda Adonajnyn. ויאמר. [3] Da ajtty Moše Aharonġa

(3) oldu ki sözĺadi Adonaj ajtadoġač juvuq jürüvčülard́a alnym-

(4) da azizligimni körgüzürmen da bunluqbyla alnynda bar

(5) ol ulusnun qorqunčlu bolur syjym menim da tyjyldy Aharon

(6) ¿da bu zynharlamaq zynharlandy alarga Tora bermak alnyna

(7) nečik ajtty da dağyn ol kohenlard́a ol juvuvčular jumuš

(8) etḿa alnynda Adonajnyn azizlansinlar ki anlanmag்y ol

(9) azizĺanḿaknin oldu ki bolg̀ajlar inčkalavčülar išind́a

(10) qulluqlarynyn kečinma bujruğuna köŕa Adonajnyn mağat buzuq-

(11) luq qylar alarda Adonaj ${ }^{13}$. ויקרא. Da ünd́adi Moše Miša-

(12) 'elni da Elcafanny uvullaryn 'Uzi'elnin dadasinin Aharonnun da

(13) ajtty alarğa juvujuz alajyz ošol qaryndašlaryjyzny alnyndan

(14) ol qodešnin da eltijiz tyšqartyn avulġa. [5] Da

(15) juvudular da aldylar alarny kölmaklaribyla da elttilar

(16) alarny tyšqartyn avulġa ki nečik sözladi Moše. ויאמר. [6]

(17) Da ajtty Moše Aharonġa da El'azarg்a da Itamarğa

(18) uvullaryna anyn bašyjyzny ačmajyz da upraqlaryjyzny sökḿajiz

(19) da ölḿajiz da bar ol క̌ymat üstüńa ačuvlanyr da qaryn-

(20) dašlaryjyz bar üvü Jisra’elnin jylasynlar ol küvdürḿak ü-

(21) čün ki küvdürdü Adonaj. ומפתח. [7] Da ešigind́an ohel

${ }^{1} \mathrm{~K}$ : anlanmang்y; a scribal error. | TKow.o1: anlanmag்y; unvocalized text. | H: anlanmag்y. | C: deest. $\quad{ }^{2}$ Interpretative addition to the standard text. $\quad{ }^{3}$ Interpretative addition to the standard text. 


\section{Leviticus 10}

[1] And

(16) Nadab and Abihu, the sons of Aaron, took each of them his censer and

(17) put fire in them and put incense on them,

(18) and they brought forward strange fire before the Lord, , because the interpretation

(19) of a strange fire is that the Lord did not command them to burn

(20) incense besides the burnings twice per day:

(21) at dawn and in the evening ${ }^{1148}$. [2] And because of that

(1) the fire came out from before the Lord and consumed them, and they $172 \mathrm{v}^{\circ}$ died

(2) before the Lord. [3] And Moses said to Aaron,

(3) 'This is it that the Lord spoke, saying,

(4) "I will show my holiness in them who walk near me and by that

(5) my glory will be awesome before all the people."' And Aaron was silent.

(6) ${ }_{1}$ And this commandment was commanded them before giving the Law

(7) when he said that even the priests who come forward to serve

(8) before the Lord shall be consecrated-because the interpretation

(9) of consecration is that they should consider during their work

(10) of service to act according to the Lord's commandment, lest

(11) God cause destruction among them ${ }^{1149}$. [4] And Moses called Mishael

(12) and Elzaphan, sons of Uzziel, uncle of Aaron,

(13) and said to them, 'Come near, take your brothers from before

(14) the Holy and carry |them| out of the camp.' [5] So

(15) they went near and took them by their shirts and carried

(16) them out of the camp, as Moses had spoken. [6]

(17) And Moses said to Aaron and to Eleazar and to Ithamar,

(18) his sons, 'Do not uncover your heads and do not rip your clothes,

(19) so you will not die, and he will be angry at all the congregation. And

(20) your brothers, all the house of Israel will weep for the burning

(21) that the Lord has kindled. [7] And

148 Interpretative addition to Lev 10:1.

149 Interpretative addition to Lev 10:3. 
$173 \mathrm{r}^{\mathrm{o}} \quad$ (1) mocednin čyqmajyz magat ölarsiz ki jag̉ynmaq javy Adonajnyn

(2) üstüjüzd́a da qyldylar sözüna köŕa Mošenin.

(3) וידבר [8] Da sözladi Adonaj [Aharonġa] ${ }^{1}$ ajtadog̉ač. יין [9]

(4) Čaġyr da esirtüvčü ičḿagin sen da uvullaryj birǵasińa

(5) kelgenijizǵa ohel mo`edǵa da ölmajiz ömürlük resim

(6) dorlaryjyz sajyn. ולהבדיל [10] Alajoq ne vahttta ki keŕakli bol-

(7) sa ajyrma arasyna ol qodešnin da arasyna ol alaj[y]q-

(8) $\mathrm{n}[\mathrm{y}] \mathrm{n}^{2}$ da arasyna ol murdarnyn da arasyna ol aruvnun

(9) ולהורת [11] Alajoq ne vaḥtta ki keŕakli bolsa üvŕat-

(10) ḿa ulanlaryna Jisra’elnin ošol bar ol resimĺarni ki

(11) sözladi Adonaj alarg̉a naviligi ašyra Mošenin. וידבר. [12]

(12) \{Da\} sözladi Moše Aharonġa da El’azarg̉a da Itamarğa uvul-

(13) laryna anyn ol qalġanlarg̉a ajtadoġač alyjyz ošol ol tirki-

(14) ni ol qalġanny otlu qarbanlaryndan Adonajnyn da ašajyz any

(15) macalar janynda ol mizbeaḥnyn ki qodeš qadašimdi ol.

(16) [13] Da ašajyz any aziz orunda ki kemijdi ol

(17) da kemidi uvullaryjnyn otlu qarbanlaryndan Adonajnyn ki alaj

(18) bujuruldum. ואת [14] Da ošol töšün ol tenufanyn da

(19) ošol inčigin ol terumanyn ašajyz any aruv orunda sen

(20) da uvullaryj \{da\} qyzlaryj birǵaja ki kemij senin da kemi ulanla-

(21) ryjnyn berildilar šelamim debeḥalaryndan ulanlarynyn Jisra’elnin.

$173 \mathrm{~V}^{\mathrm{o}} \quad$ (1) שוק $\quad$ [15] Inčigin ol terumanyn da töšün ol tenufanyn

(2) keltirsinĺar javlarybyla otlu qarbanlaryndan sunma tenufa

(3) alnynda Adonajnyn ${ }_{\perp}$ da bolsun saja da uvullaryja birǵaja ö-

(4) mürlük ${ }^{13}$ resimǵa ki nečik bujurdu Adonaj. ואת [16] Da

(5) ošol ulag̉yn ol ḥatatnyn izlamáa izladi Moše da muna

(6) küvdürüldü da ačuvlandy Moše El'azar üstüńa da

(7) Itamar üstüńa ulanlary üstüńa Aharonnun ol qalġan-

(8) lar üstüńa ajtadoġač. [17] Neüčün ašamadyjyz

(9) ošol ol ḥatatny ol aziz orunda ki qodeš qadašimdir

(10) ol da any berdi sizǵa kötürma ošol günahịin ol

(11) Šymatnyn bošatlyq qolma alar üčün ${ }_{L}\{\text { alnynda } H-n y n\}^{14}$. הן. [18] Muna kijiril-

\footnotetext{
${ }^{1} \mathrm{~K}$ : Mošeǵa; a scribal error. | TKow.o1: Aharonġa; unvocalized text. | H: Aharonġa. | C: Aharonġa.

${ }^{2} \mathrm{~K}$ : alajoqnun; a scribal error.|TKow.o1: alajoqnun; unvocalized text; a scribal error.| H: alajyqnyn. | C: jeyilniy. $\quad{ }^{3}$ An unvocalized fragment. $\quad{ }^{4}$ Interlinear insertion by another hand. | TKow.o1: alnynda Adonajnyn; unvocalized text. | H: alnynda H-nyn. | C: aldyna H-nyy.
} 
(1) you shall not go out from the door of the tent of meeting, lest you die, $\quad 173 \mathrm{r}^{\mathrm{r}}$ for the anointing oil of the Lord

(2) is on you.' And they did according to the word of Moses.

(3) [8] And the Lord spoke to Aaron, saying, [9]

(4) 'Do not drink wine or strong drink, you and your sons with you,

(5) when you come to the tent of meeting, and you will not die-it is an eternal statute

(6) throughout your generations-[10] In the same way as when there is a need to

(7) distinguish between holy and [common],

(8) and between unclean and clean,

(9) [11] In the same way as when there is a need to teach

(10) the children of Israel all the statutes which

(11) the Lord has spoken to them through the prophecy of Moses.' [12]

(12) And Moses spoke to Aaron and to Eleazar and to Ithamar,

(13) his sons that were left, saying, "Take the grain offering

(14) that remains of the offerings by fire of the Lord and eat it

(15) unleavened beside the altar, because it is the holy of holies.

(16) [13] And you shall eat it in the holy place, because it is your share,

(17) and your sons' share from the offerings by fire of the Lord, because so

(18) I am commanded. [14] And you shall eat the breast of the wave offering and

(19) the thigh of the heave offering in a clean place, you

(20) and your sons and your daughters with you, because they are your share, and your sons' share,

(21) they have been given from the sacrifices of peace offerings of the children of Israel.

(1) $[15]$ They shall bring forward the thigh of the heave offering and the breast of the wave offering

(2) with the fat of the offerings by fire to elevate the wave offering

(3) before the Lord, and it shall be yours, and your sons' with you,

(4) as an eternal statute, as the Lord has commanded.' [16] And

(5) Moses sought the goat of the sin offering, and, lo,

(6) it was burnt. And Moses was angry at Eleazar and

(7) Ithamar, the sons of Aaron who were left,

(8) saying, [17] 'Why have you not eaten

(9) the sin offering in the holy place, because it is the holy of holies,

(10) and $|\mathrm{God}|$ has given it to you to bear the iniquity

(11) of the congregation, to ask for atonement for them \{before the Lord $\}$ ? [18] Lo, 
(12) ḿadi ošol qany anyn ol qodešḱa ičkariǵa keŕakli edi

(13) ki ašama ašağajsiz any qodešta ki nečik bujurdum.

(14) .וידבר (19] Da sözĺadi Aharon Mošeǵa ajtadog̉ač muna bügün

(15) juvuttular ošol ḥatatlaryn da ošol 'olalaryn ${ }_{L}\{[a l] n y n d a ~ H-n y n\}^{11} \mathrm{da}$ učra-

(16) dylar meni bular kibik da ašasajedim ḥatatny bügün jaḥšy

(17) körünǵajedimo 'enajatlarynda Adonajnyn. וישמע. [20] Da

(18) ešitti Moše da jahšš köründü közlarind́a anyn.

Leviticus 11

(19) . וידבר (19 Da sözĺadi Adonaj Mošeǵa da Aharonġa ajtadog̉ač

(20) alarg̉a. דברו [2] Sözlajiz ulanlaryna Jisra’elnin ajtadog̉ač bu-

(21) dur ol tiri ki ašajyz bar ol tuvardan ki ol jer üstüńa.

$174 \mathrm{r}^{\mathrm{o}} \quad$ (1) כ3 ] Bar tujaqlavčunu tujaq da ajyruvčunu ajyryčyn tujaqlarnyn

(2) güvün keltirüvčünü tuvardan any ašajyz. אך. [4] Tek ošol

(3) bunu ašamajyz güvün keltirüvčülardan jalg̀yz ol güvünnü da

(4) tujaqlavčulardan jalġyz ol tujaqny ošol ol tev́ani hota güvün

(5) keltiŕadi eśad́a ol da tujaq tujaqlamajdy murdardy ol

(6) sizǵa. ואת [5] Da ošol ol krolikni họota güvün kel-

(7) tiŕadi eśad́a ol da tujaq tujaqlamajdy murdardy ol

(8) sizǵa. ואת [6] Da ošol ol qojanny ḥota güvün kelti-

(9) radi eśad́a ol da tujaq tujaqlamajdy murdardy ol siz-

(10) ǵa. \{r. [7] Da ošol ol hazazirni hota tujaqlajdy tujaq ol da ajyrady ajyryčyn tujaqnyn da ol güvün güvünlamajdi murdardyr ol sizǵa.\} אבשרם Etĺarind́an alarnyn ašamajyz da gövd́aĺa-

(11) rińa alarnyn tijḿajiz murdardylar alar sizǵa. את. [9]

(12) Ošol bu\{nu\} ašajyz baryndan neki suvlarda barča neki anar qanat

(13) da qabuq suvlarda tengizlarda da öźanlarda alarny ašajyz.

(14) וכל (10] Da barča neki joḥtur anar qanat da qabuq suvlarda ${ }^{2}$

(15) da öźanlard́a bar qumuzundan ol suvlarnyn da bar ol

(16) tiri žandan ki suvlarda qusqunčudu alar sizǵa. ושקץ. [11]

(17) Da qusqunču bolsunlar sizǵa etĺarind́an alarnyn ašamajyz

\footnotetext{
${ }^{1}$ Marginal insertion by another hand. | TKow.o1: alnynda Adonajnyn; unvocalized text. | H: alnynda H-nyn. | C: deest. $\quad{ }^{2}$ K: Possibly a mistranslation. | TKow.o1: tengizlerde; unvocalized

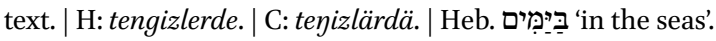


(12) the blood of it was not brought in within the Holy: you should

(13) have eaten it in the Holy, as I commanded.'

(14) [19] And Aaron said to Moses, saying, 'Lo, this day

(15) they have brought forward their sin offering and their burnt offering $\{$ before the Lord\}. And

(16) such |things| have befallen me, and if I had eaten the sin offering today

(17) would it seem good in the Lord's eyes? [20] And

(18) when Moses heard that, it was good in his eyes.

\section{Leviticus 11}

(19) [1] And the Lord spoke to Moses and to Aaron, saying

(20) to them, [2] 'Speak to the children of Israel, saying,

(21) "These are the beings which you shall eat from all the animals that are on the earth.

(1) [3] All that parts the hoof, and has a split of hooves,

(2) |and| regurgitates cud among the animals, you shall eat it. [4] Just:

(3) you shall not eat this out of those that only regurgitate the cud and

(4) of those that only part the hoof: The camel: even though it

(5) regurgitates the cud, it does not part the hoof. It is unclean

(6) to you. [5] And the rabbit: even though it regurgitates the cud,

(7) it does not part the hoof. It is unclean

(8) to you. [6] And the hare: even though it regurgitates the cud,

(9) it does not part the hoof. It is unclean

(10) to you. [7] And the pig, even though it parts the hoof and has a split of hooves, it does not chew the cud. It is unclean to you. [8] You shall not of their flesh, and

(11) you shall not touch their carcass. They are unclean to you. [9]

(12) You shall eat this out of all that are in the waters: everything that has fins

(13) and scales in the waters, in the seas, and in the rivers - you shall eat them.

(14) [10] And all that does not have fins and scales in the waters ${ }^{150}$

(15) and in the rivers, of all creeping animals of the waters and of all

(16) living creatures which are in the waters, is detestable to you. [11]

(17) And they shall be detestable to you. You shall not eat of their flesh,

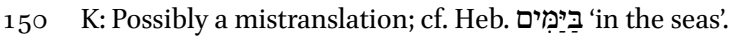


(18) da \{ošol\} gövd́alarin alarnyn jiŕanči etijiz. כל. [12] Barča neki

(19) joḥtu anar qanat da qabuq suvlarda qusqunčudu ol sizǵa.

(20) ואת [13] Da ošol bunu jiŕanči etijiz ol quštan ašalmasyn-

(21) lar qusqunčudur alar ošol ol nešerni da ošol ol peresni

$174 \mathrm{~V}^{\mathrm{o}}$ (1) da ošol ol 'aznijany. [14 [14 Da ošol ol da'any da ošol

(2) ol ajany žynsysajyn. ואת [15] Da ošol bar qarg̉any žynsysajyn.

(3) ואת [16] Ošol ol anqyt balasyn da ošol ol taḥmasny da

(4) ošol ol šahafny da ošol ol qyrg̉yjny žynsysajyn. ואת [17]

(5) Da ošol ol kosnu da ošol ol šalahny da ošol ol janšuf-

(6) nu. ואת [18] Da ošol ol tinšemetni da ošol ol qa'atny

(7) da ošol ol rahamny. [19] Da ošol ol hasidany

(8) ol anafany žynsysajyn da ošol duhifatny da ošol ol

(9) jary qanatyn. כ20] Bar qumuzu ol qušnun ol jürüvčü dört-

(10) ajaq üstüńa qusqunčudu ol sizǵa. אד. [21] Tek o-

(11) šol bunu ašajyz bar qumuzundan ol qušnun ol jürüvčünün

(12) dört ajaq üstüńa ki anar tizlar jog̉arraq ajaqlaryndan

(13) sekirma alarbyla ol jer üstüńa. את. [22] Ošol

(14) bunlary alardan ašajyz ošol ol arbeni žynsysajyn da ošol 
(18) and you shall find their carcasses repulsive. [12] All

(19) that does not have fins and scales in the waters: it is detestable to you.

(20) [13] And you shall find these repulsive out of the birds. They shall not be eaten,

(21) they are detestable: the eagle, and the bearded vulture,

(1) and the black vulture, [14] And the red kite, and the

(2) falcon by its kind. [15] Every raven by its kind.

(3) [16] And the young of the ostrich, and the tahmas ${ }^{151}$, and

(4) the seagull, and the hawk by its kind, [17]

(5) And the little owl, and the šalah ${ }^{152}$, and the ${ }_{L}$ long-eared owl ${ }^{1153}$,

(6) [18] And the ${ }_{L}$ white owl ${ }^{1154}$, and the pelican ${ }^{155}$,

(7) and the carrion vulture, [19] And the stork,

(8) the heron by its kind, and the hoopoe, and the

(9) bat. [20] Every creeping animal of flying creatures that goes on four legs

(10) is detestable to you. [21] Just:

(11) you shall eat these of every creeping animal of flying creatures that goes

(12) on four legs: that which have knees above their feet,

(13) to leap by them on the earth. [22]

(14) You shall eat these out of them: the locust by its kind, and the

151 Heb. תרתמְ of unclarified meaning: 'an unclean bird of prey' in Klein (1987: 698), 'an unclean bird of prey, perhaps a species of owl' in Koehler \& Baumgartner (1985: 1025). | Translated as 'nighthawk' in KJ20oo, Esv, and by Friedman (2003). | EKar. taḥmas in C is translated as 'nighthawk' by Jankowski \& Aqtay \& Cegiołka \& Çulha \& Németh (2019: II 142, 249).

152 Heb. שָלָּ, a bird name of uncertain meaning: 'probably the cormorant' in Klein (1987: 662), 'cormorant (?)', 'fish-owl (?)' in Koehler \& Baumgartner (1985: 978). | Translated as 'cormorant' in KJ200o, ESV, and by Friedman (2003). | EKar. šalah in C is translated as 'cormorant' by Jankowski \& Aqtay \& Cegiołka \& Çulha \& Németh (2019: II 142, 249).

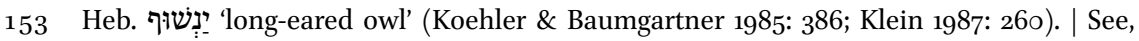
however, 'great owl' in the KJ20oo and in Friedman (2003), and 'short-eared owl' in ESv. | EKar. janšuf in C is translated as 'long-eared owl' by Jankowski \& Aqtay \& Cegiołka \& Çulha \& Németh (2019: II 142, 249).

154 Heb. תִּנְשֶׁמֶת 'a kind of owl, probably the white owl' (Klein 1987: 709), 'white owl' (Koehler \& Baumgartner 1985: 1035). | Translated as 'white owl' in KJ2000 and by Friedman (2003), translated as 'barn owl' in ESv. | EKar. tinšemet in C is translated as either as 'white owl' or as 'barn owl' by Jankowski \& Aqtay \& Cegiołka \& Çulha \& Németh (2019: II 142, 249).

155 Heb. קָָָָ 'pelican' (Klein 1987: 559), 'a species of owl (?)' (Koehler \& Baumgartner 1985: 817). | Translated as 'pelican' in KJ2000, and by Friedman (2003), translated as 'tawny owl' in ESv. | EKar. qa'at in C is translated as 'pelican' by Jankowski \& Aqtay \& Cegiołka \& Çulha \& Németh (2019: II 142, 249). 
(15) sal'amny žynsysajyn da ošol ol ḥargolnu žynsysajyn

(16) ošol ol ḥagavny క̌ynsysajyn. וכל. [23] Da bar qumuzu ol quš-

(17) nun ki anar dört ajaqlar qusqunčudu ol sizǵa. ולאלה. [24]

(18) Da bularbyla murdar bolunursiz bar ol tijüvčü \{gövd́álarińa\} alarnyn

(19) murdar bolsun ol ingirǵadejin. וכל. [25] Da bar ol eltüv-

(20) čü gövd́álarind́an alarnyn juvsun upraqlarnyn da murdar bolsun

(21) ol ingirǵadejin. לכל. [26] Bar ol tuvar ki ol tujaqlajdy tujaq

$175 \mathrm{r}^{\mathrm{o}} \quad$ (1) da ajyryč ajyrmajdy da güvün keltirmajdi murdardylar

(2) alar sizǵa bar ol tijüvčü alarğa murdar bolsun. וכל [27]

(3) Da bar ol jürüvčü uvučlary üstüńa bar ol tirida

(4) ol jürüvčü dört \{ajaq\} üstüńa murdardylar alar sizǵa

(5) bar ol tijüvčü gövdalarina alarnyn murdar bolsun \{ol ingirgedejin $\}^{1}$.

(6) [28] Da ol eltüvčü ošol gövd́alarinin alarnyn \{juvsun upraqlaryn

(7) $\{d a\}^{2}$ murdar bolsun ol ingirǵadejin murdarlardylar alar sizǵa.

(8) [וזה Da budur sizǵa ol murdar qumuzda ol tebŕa-

(9) ńadoġan ol jer üstüńa ol ḥoled da ol 'ahbar da ol

(10) cav 3̌ynsysajyn. והאנקה. [30] Da ol anaqa da ol kovaḥ da

${ }^{1}$ Marginal insertion by another hand in South-Western Karaim. | TKow.o1: ol ingirgedejin; unvocalized text. | H: ol ingirgedejin. | C: yyyrg்a degin. $\quad{ }^{2}$ Marginal insertion by another hand. | TKow.o1: $d a$; unvocalized text. | H: $d a$. | C: $d a$. 
(15) sal'am $^{156}$ by its kind, and the hargo/ ${ }^{157}$ by its kind, and

(16) the grasshopper ${ }^{158}$ by its kind. [23] And every creeping animal of flying creatures

(17) which have four legs, is detestable to you. [24]

(18) And you will become unclean by these. Everyone who touches the carcass of them

(19) shall be unclean until the evening. [25] And everyone who carries

(20) their carcass shall wash his clothes and be unclean

(21) until the evening: [26] Every animal that parts the hoof

(1) and does not have a split |of hooves $\mid$ and does not regurgitate its cud is unclean

(2) to you. Everyone who touches them shall be unclean. [27]

(3) And all that walk on their paws among all the animals

(4) that go on four legs, are unclean to you.

(5) Everyone who touches their carcass shall be unclean \{until the evening .

(6) [28] And the one who carries the carcass of them shall wash his clothes

(7) $\{$ and $\}$ be unclean until the evening. They are unclean to you.

(8) [29] And this is unclean to you among the creeping animals that move

(9) on the earth: the mole, and the mouse, and the

(10) L great $/$ lizard $^{1159}$ by its kind, [30] And the gecko, and the ${ }_{\text {L }}$ monitor $\operatorname{lizard}^{1160}$, and

156 Heb. סָזְָ 'a kind of locust' (Klein 1987:448), 'edible locust' (Koehler \& Baumgartner 1985: 66o). | Translated as 'bald locust' in KJ20oo, Esv, and by Friedman (2003). EKar. sal'am in C is translated as 'bald locust' by Jankowski \& Aqtay \& Cegiołka \& Çulha \& Németh (2019: II 143).

157 Heb. חחרִ 'a kind of locust' (Klein 1987: 230, Koehler and Baumgartner 1985: 331).| Translated as 'cricket' in KJ200o, ESv, Friedman (2003). | C: deest.

158 Heb. חָזגָ 'locust; grasshopper' (Klein 1987: 207), 'locust allowed for food' (Koehler \& Baumgartner 1985: 275). | Translated as 'grasshopper' in KJ20oo, Esv, and by Friedman (2003). | EKar. hagav in C is translated as 'grasshopper' by Jankowski \& Aqtay \& Cegiołka \& Çulha \& Németh (2019: II 143).

159 Heb. צָז 'a kind of a lizard' (Klein 1987: 539), 'thorn-tailed lizard' (Koehler \& Baumgartner 1985: 79o).| Translated as 'great lizard' in KJ200o, ESV, and by Friedman (2003). | EKar. čab in C is translated as 'great lizard' by Jankowski \& Aqtay \& Cegiołka \& Çulha \& Németh (2019: II 143).

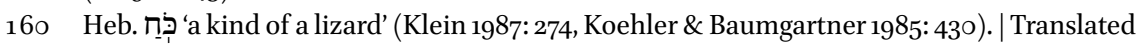
as 'monitor lizard' in KJ2000, ESv, translated as as 'spotted lizard' by Friedman (2003). | EKar. kovah in C is translated as 'monitor lizard' by Jankowski \& Aqtay \& Cegiołka \& Çulha \& Németh (2019: II 143). 
(11) ol leta'a da ol ḥomet da ol tinšamet. אלה. [31] Bulardy-

(12) lar ol murdarlar sizǵa bar ol qumuzda bar ol tijüvčü alar-

(13) ga ölǵanlarind́an sortun murdar bolsun ol ingirǵa-

(14) dejin. [32] Da barča neki tüšśa \{anyn üstüńa\} alardan ölǵanĺa-

(15) rindan sortun murdar bolsun bar ag̉ačly savutta jemeśa

(16) upraq jemeśa teri jemeśa qap bar savut ki qylyndy

(17) iši alarbyla suvġa kijirilsin da murdar bolsun ol

(18) ingirǵadejin da arynyr. [3ל [33] Da bar čerepli savut ki

(19) tüšśa alardan ortasynda anyn barča neki ortasynda anyn

(20) murdar bolsun da ol savutnuda syndyryjyz. מכל. [34] Bar

(21) ol jemd́an ki ašalady ki kelśa anyn üstüńa suv murdar

$175 \mathrm{~V}^{\mathrm{o}} \quad$ (1) bolsun da bar ički ki ičíladi bar tüslü savutta murdar bolsun.

(2) וכל [35] Da barča neki tüšśa gövdálarind́an anyn üstüńa

(3) murdar bolsun ṕeč da priṕečka qavšatylsyn murdarlardylar alar

(4) da murdarlar bolsunlar sizǵa. אד. [36] Tek köz suv da quju

(5) jumulmaggy suvlarnyn bolsun aruv ančaq tijvčü gövd́alarińa

(6) alarnyn murdar bolsun. וכי [37] Da ki tüšśa gövd́alarind́an

(7) alarnyn bar urluq üstüńa čačylġan ki čačylady aruv bolsun

(8) ol. וכי [38] Da ki berilśa suv urluq üstüńa da

(9) tüšśa gövdálarindan alarnyn anyn üstüńa murdardy

(10) ol sizǵa. [39] Da ki ölśa ol tuvardan ki ol ja\{r\}avlydy

(11) sizǵa jemǵa ol tijüvčü gövd́asińa anyn murdar bolsun

(12) ol ingirǵadejin. והאכל. [40] Da ol ašavču gövd́asind́an

(13) anyn juvsun upraqlaryn da murdar bolsun ol ingirǵadejin

(14) da ol eltüvčü ošol gövd́asin anyn juvsun ošol upraq-

(15) laryn da murdar bolsun ol ingirǵadejin. וכל [41 Da bar 
(11) the lizard ${ }^{161}$, and the ${ }_{L} \mid$ sand| lizard ${ }^{1162}$, and the chameleon. [31] These are

(12) unclean to you among the creeping animals. Whoever touches them

(13) after they died shall be unclean until the evening.

(14) [32] And everything on which any of them falls after they died

(15) shall be unclean, out of every wooden vessel or

(16) clothing or skin or sack, any vessel in which

(17) work is done, shall be put in water, and it shall be unclean

(18) until the evening, and it will become clean. [33] And every earthen vessel,

(19) in the middle to which any of them falls: everything that is inside

(20) shall be unclean, and you shall break the vessel as well. [34] Of all

(21) food which is eaten on which water comes

(1) shall be unclean, and all drink that is drunk in any kind of vessel shall be unclean.

(2) [35] And everything on which any part of their carcass falls

(3) shall be unclean. An oven or stove, they shall be destroyed. They are unclean,

(4) and shall be unclean to you. [36] Just: a fountain or well

(5) with a concentration of waters shall be clean. But one who touches their carcass

(6) shall be unclean. [37] And if any part of their carcass falls

(7) on any sowing seed which is to be sown, it shall be clean.

(8) [38] But if any water is put on the seed, and

(9) any part of their carcass falls on it, it shall be unclean

(10) to you. [39] And if any of the animals that are allowed

(11) for you for food dies: he who touches the carcass of it shall be unclean

(12) until the evening. [40] And he who eats of the carcass

(13) of it shall wash his clothes and be unclean until the evening.

(14) And he who carries the carcass of it shall wash his clothes

(15) and be unclean until the evening. [41] And every

161 Heb. לְטָָָה 'lizard' (Klein 1987: 299), 'gecko' (Koehler \& Baumgartner 1985: 480). | Translated as 'lizard' in KJ200O, ESV, and by Friedman (2003). | EKar. leta'a in C is translated as 'lizard' by Jankowski \& Aqtay \& Cegiołka \& Çulha \& Németh (2019: II 143).

162 Heb. חמכמט 'lizard; a kind of a lizard' (Klein 1987: 221), 'all reptiles that are not defined' (Koehler \& Baumgartner 1985: 310). | Translated as 'sand lizard' in KJ200o, ESv, and by Friedman (2003). | EKar. homet in C is translated as 'sand lizard' by Jankowski \& Aqtay \& Cegiołka \& Çulha \& Németh (2019: II 143). 
(16) ol qumuz ol tebŕańadog̉an ol jer üstüńa qusqunčudu

(17) ol ašalmasyn. כל [42] Bar jürüvčü\{nü\} qaryn üstüńa da bar

(18) jürüvčü dört ajaq üstüńa bar köp ajaqlyġadejin bar ol

(19) qumuznu ol tebŕanüvčünü ol jer üstüńa ašamajyz alarny

(20) ki qusqunčudu alar. [43] Jiŕanči etmajiz ošol žanlaryjyz-

(21) ny bar ol qumuzbyla ol tebŕańadogan da murdar bolunmajyz

$176 \mathrm{r}^{\mathrm{o}} \quad$ (1) alarbyla da jabulur aqylyjyz alardan. כ4 [4] Ki menmen Adonaj

(2) Tenrijiz da azizlanijiz da bolujuz azizlar ki azizdir men

(3) da murdar etmajiz ošol žanlaryjyzny bar ol qumuzbyla

(4) ol tebŕanüvčü ol jer üstüńa. כי. [45] Ki menmen Adonaj

(5) ol čyġaruvču sizni jerind́an Micrinin bolma sizǵa Tenri-

(6) ǵa da bolujuz azizlar ki azizdir men. זאת. [46] Budur

(7) üvŕatüvü ol tuvarnyn da ol qušnun da bar ol tiri

(8) క̌annyn ol tebŕańadoġannyn suvlarda da bar žannyn ol

(9) tebŕańadog̉annyn ol jer üstüńa. להבדיל. [47 Ajyrma

(10) arasyna ol murdarnyn da arasyna ol aruvnun da ara-

(11) syna ol tirinin ki ašalady da arasyna ol tirinin ki

(12) ašalmajdy.

Leviticus 12

פרשת תזריע (13) (13) (14)

(14] Da sözĺadi Adonaj Moše-

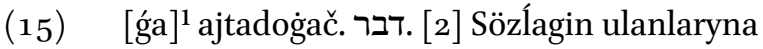

(16) Jisra’elnin ajtadoġač qatyn ki urluqlasa da töraśa er

(17) ulanny da murdar bolsun jedi künlar künlari kibik jyġys-

(18) lyġynyn hastalyg̉ynyn murdar bolsun. וביום [3] Da ol segizin-

(19) či künd́a ḥatna qylynsyn eti aqlafynyn. ושלשים. [4] Da

$176 \mathrm{v}^{\mathrm{o}} \quad$ (1) otuz kün da üč künlar oltursun arynmaq qanlary üčün

(2) bar aziz nerśaǵa tijmáasin da ol miqdašqa kelḿasin tolg̉un-

${ }^{1}$ TKow.o1: Mošege; unvocalized text. | H: Mošege. | C: Mošegä. 
(16) creeping animal that moves on the earth is detestable.

(17) It shall not be eaten. [42] Everything that goes on a belly, and everything

(18) that goes on four legs as well as everything that has many legs among all

(19) creeping animals that move on the earth: you shall not eat them,

(20) because they are detestable. [43] You shall not make your souls abominable

(21) with any creeping animal that moves, and you shall not make yourselves unclean

(1) with them, so that your mind will be closed by them. [44] Because I $\quad 176 \mathrm{r}^{\mathrm{o}}$ am the Lord

(2) your God. And you shall consecrate yourselves, and you shall be holy, because I am holy.

(3) And you shall not make your souls unclean with any creeping animal

(4) that moves on the earth. [45] Because I am the Lord

(5) that brings you up from the land of Egypt, to be God to you,

(6) and you shall be holy because I am holy."' [46] This

(7) is the teaching of the animals and of the birds and of every living

(8) creature that moves in the waters and of every creature that

(9) moves on the earth, [47] To distinguish

(10) between the unclean and the clean, and

(11) between the animal that is eaten and the animal that

(12) is not eaten.

Leviticus 12

(13) Parashat Tazria

(14) [1] And the Lord spoke to

(15) Moses, saying, [2] 'Speak to the children

(16) of Israel, saying, "If a woman conceives and bears a male

(17) child, she shall be unclean seven days. As in the days

(18) of her menstruation illness shall she be unclean. [3] And in the eighth

(19) day the flesh of his foreskin shall be circumcised. [4] And

(1) thirty days and three days she shall sit because of her blood of puri- $\quad{ }_{176 ~ \mathrm{v}^{\mathrm{o}}}$ fication.

(2) She shall not touch anything holy, and she shall not come to the sanctuary 
(3) ča arynmaq künlari. ואם [5] [Da eger $\}$ qyz ulanny töŕaśa da mur-

(4) dar bolsun eki jedilar jyğyslyq murdarlyg்y kibik da altymyš

(5) kün da alty künlar oltursun arynmaq qanlary üčün.

(6) (6] Da tolganda arynmaq künlari uvul üčün jeme-

(7) śa qyz üčün keltirsin qozu jyllyq balasy ‘olag̉a da kü-

(8) gürčün balasy jemeśa bedeńa ḥatatqa ešigińa ohel

(9) mo'ednin ol kohenǵa. והקריבו. [7 Da juvutsun any alnyna

(10) Adonajnyn da bošatlyq qolsun anyn üčün da arynyr čoġaraġyn-

(11) dan qanlarynyn budu üvŕatüvü ol töŕavčünün er ulanny

(12) jemeśa qyz ulanny. ואם [8] Da eger jetmaśa küčü

(13) qolunun jetkiligić́a qojnun da alsyn eki bedeńalar jemeśa

(14) eki kügürčün balalary birni L'olaġa da birni ḥatatqa ${ }^{11}$

(15) da bošatlyq qolsun anyn üčün ol kohen da arynyr.

Leviticus 13

. וידבר $[1]$

(16) Da sözladi Adonaj Mošeǵa \{da Aharonġa\} ajtadoġač. אדם. [2] Adam ki

(17) bolsa terisind́a gufunun küvḿak jemeśa šišik jeme-

(18) śa temgil da bolsa terisind́a gufunun ḥastalyġyna

(19) cara'atnyn da ketirilsin $[$ [Aharonga $]$ ol kohenǵa ${ }^{72}$ jemeśa

(20) birisińa uvullaryndan anyn ol kohenlarǵa. וראה. [3] Da

(21) baqsyn ol kohen ošol ol ḥastalyqny terisind́a ol gufnun

$177 \mathrm{r}^{\mathrm{o}} \quad$ (1) da čač ḥastalyqta čüvürüldü aq da körümü ol ḥastalyq-

(2) nyn teŕanŕakti ol terisind́an gufunun hastalyġydy cara'at-

(3) nyn ol da baqsyn any ol kohen da murdar etsin any. ואם. [4]

(4) Da eger aq temgil bolsa ol terisind́a gufunun da

(5) teŕanŕak bolmasa körümü anyn ol teridan da čačy anyn

(6) čüvürülḿa $\{$ di $\}$ aq da bekĺasin ol kohen ošol ol ḥastalyqny

(7) jedi künlar. [5 [5 Da baqsyn any ol kohen ol jedinči kün-

(8) da da muna ol ḥastalyq turdu türsününd́a jajylma-

\footnotetext{
${ }^{1} \mathrm{~K}$ : Originally hatatqa da birni olagia; the word order was corrected by the copyist. $\quad{ }^{2} \mathrm{~K}$ : ol kohenǵa; a scribal error. | TKow.o1: Aharonġa ol kohenǵa; unvocalized text. | H: Aharonġa ol kohenge. | C: Aharon ol kohengä.
} 
(3) until the days of her purification be filled. [5] And if she bears a female child,

(4) she shall be unclean two weeks, like in her menstrual impurity. And sixty

(5) days and six days she shall sit because of her blood of purification.

(6) [6] And when the days of her purification are filled, for a son or

(7) for a daughter, she shall bring a one-year-old lamb for a burnt offering and

(8) a young pigeon or a turtledove for a sin offering to the door

(9) of the tent of meeting, to the priest. [7] And he shall bring it forward before

(10) the Lord and ask for atonement for her. And she will be cleansed from the source

(11) of her blood. This is the teaching for her who bears a male child

(12) or a female child. [8] And if her hand

(13) cannot attain enough for a lamb, she shall take two turtledoves or

(14) two young pigeons, one for the burnt offering and one for a sin offering.

(15) And the priest shall ask for atonement for her and she will be clean."'

Leviticus 13

(16) And the Lord spoke to Moses and Aaron, saying, [2] 'When a man

(17) shall have a sore or a swelling or

(18) a spot in the skin of his body, and it becomes a disease

(19) of leprosy, and he shall be brought to Aaron the priest or

(20) to one of his sons the priests, [3] And

(21) the priest shall look on the disease in the skin of the body,

(1) and hair in the disease will have turned white, and the disease's appearance

(2) is deeper than the skin of his body, it is a disease of leprosy.

(3) And the priest shall look on him, and shall pronounce him unclean. [4]

(4) And if it is a white spot in the skin of his body, and

(5) its appearance is not deeper than the skin, and its hair

(6) has not turned white, the priest shall shut up the disease

(7) for seven days. [5] And the priest shall look on him the seventh day,

(8) and, lo, if the disease in its sight stayed |unchanged|, and 
(9) dy ol ḥastalyq terida da bekĺasin any ol kohen jedi kün-

(10) Íar ekinči keŕat. וראה. [6] Da baqsyn ol kohen any ol

(11) jedin\{či $\}$ künd́a ekinči keŕatt́a da muna tundu ol ḥasta-

(12) lyq da jajylmady ol hastalyq terid́a da aruv etsin

(13) any ol kohen mispaḥat ündaladoġan ḥastalyqtyr ol da

(14) juvsun upraqlaryn da arynyr. ואם [7] Da eger jajyl-

(15) ma jajylsa ol mispaḥat terid́a körünǵanindan sor-

(16) tun ol kohenǵa arynġanyndan sortun da körünsün ekinči

(17) keŕat ol kohenǵa. וראה. [8] Da körsün ol kohen da muna

(18) jajyldy ol mispahat terida da murdar etsin any ol

(19) kohen caracattyr ol. נגע. [9] Ḩastalyġy cara'atnyn ki bolsa adam-

(20) da keltirilsin ol kohenǵa. [10] Da baqsyn ol kohen

(21) da muna küvḿagi aq symannyn terid́a da ol čüvürdü

$177 \mathrm{~V}^{\mathrm{o}} \quad$ (1) [aq čač da savuqmağy čyj etnin küvḿak[ta]¹. [11] Qartaj-

(2) gan cara'atty ol terisind́a gufunun da murdar etsin any ${ }^{12}$

(3) _ol kohen beklamasin any ki murdardy ol. ואם [12] Da eger

(4) jajylma jajylsa ol cara'at terida da qaplasa ol cara'at

(5) ošol bar terisin ol ḥastalyqnyn bašlap bašyndan anyn da ajaq-

(6) larynadejin bar körümüńa közlarinin ol kohennin. 113]

(7) Da baqsyn any ol kohen da muna qaplady ol cara'at ošol bar

(8) gufun anyn da aruv etsin ošol ol ḥastalyqny barysy

(9) čüvürüldü boldu aq aruvdu ol. וביום . [14] Da körünǵan

(10) künd́a anda čyj et murdar bolsun. וראה [15] Da baqsyn

(11) ol kohen ošol čyj etni da murdar etsin any ol čyj et

(12) murdardy ol cara'atty ol. או. [16] Jemeśa ki \{qajtsa ol čyj et da\} čüvürül-

(13) śa bolma aq da kelsin ol kohenǵa. וראה. [17] Da baq-

(14) syn any ol kohen da muna čüvürüldü ol hastalyq bol-

(15) ma aq da aruv etsin any ol [kohen $]^{3}$ ki savuqtu ol

(16) hastalyq aruvdu ol. ובשר. Da guf ki bolsa teri-

(17) sind́a anyn čyban da savuqsa. והיה [19] Da bolsa or-

(18) nunda ol čybannyn aq symanly küvḿak jemeśa aq tem-

\footnotetext{
${ }^{1} \mathrm{~K}$ : küvmakte; a scribal error by another hand (see next footnote). $\quad{ }^{2}$ The first two lines of this pages were vocalised by another hand. ${ }^{3}$ TKow.o1: kohen; unvocalized text.|H:kohen.|C:kohen.
} 
(9) the disease has not spread in the skin, the priest shall shut him up seven days

(10) a second time. [6] And the priest shall look on him

(11) the seventh day a second time, and, lo, if the disease has faded,

(12) and the disease has not spread in the skin, the priest shall pronounce him clean.

(13) It is a disease called "scab", and

(14) he shall wash his clothes, and he will be clean. [7] But if

(15) the scab spreads much in the skin after he has shown himself

(16) to the priest, after his cleansing, he shall show himself to the priest

(17) a second time. [8] And the priest shall see, and, lo,

(18) if the scab has spread in the skin, the priest shall pronounce him unclean.

(19) It is a leprosy. [9] When the disease of leprosy is in a man,

(20) then he shall be brought to the priest. [10] And the priest shall look,

(21) and, lo, if there is a swelling appearing white in the skin, and it turned

(1) the hair white, and there is an efflorescence of raw flesh in the swell- $177 \mathrm{v}^{\mathbf{o}}$ ing: [11]

(2) It is an aging leprosy in the skin of his body, and the priest shall pronounce him unclean,

(3) and shall not shut him up, for he is unclean. [12] And if

(4) a leprosy, indeed, breaks out in the skin, and the leprosy covers

(5) all the skin of |one with| the disease from his head even to his foot,

(6) to wherever it is within sight of the priest's eyes, [13]

(7) Then the priest shall look, and, lo, if the leprosy has covered all

(8) his body, he shall pronounce clean |the one with| the disease: it has all

(9) changed and turned white. He is clean. [14] And on the day

(10) the raw flesh appears on him, he shall be unclean. [15] And the priest shall look

(11) on the raw flesh, and pronounce him unclean. The raw flesh

(12) is unclean. It is leprosy. [16] Or if the raw goes back again and turns

(13) to white, he shall come to the priest, [17] And

(14) the priest shall see him: and, lo, if the disease is turned

(15) to white, the [priest] shall pronounce clean |the one with| the disease.

(16) He is clean. [18] And if there is a body

(17) in the skin of which there is an abscess, and it heals, [19] And

(18) in the place of the boil there is a swelling appearing white or a white spot 
(19) gil qyzyl syman da körünsün ol kohenǵa. וראה [20] Da

(20) baqsyn ol kohen da muna körümü anyn juvuzraqty ol teriden

(21) da čačy anyn čüvürüldü boldu aq da murdar etsin any ${ }^{11}$

$178 \mathrm{r}^{\circ} \quad$ (1) ol kohen hastalyġydy cara'atnyn ol čyban byla jajyldy. [21]

(2) Da eger körśa any ol kohen da muna joḥtu anda aq

(3) čač da juvuzraq tüvüldü ol teridan da $\{$ ol $\}$ tundu da bekĺa-

(4) sin any ol kohen jedi künlar. ואם [22] Da eger jajylma ja-

(5) jylsa terid́a da murdar etsin any ol kohen hastalyqty

(6) ol. ואם [23] Da eger ornunda tursa ol temgil

(7) jajylmasa qyzuvu ol čybannyn ol da aruv etsin any ol

(8) kohen. או [24] Jemeśa guf ki bolsa terisind́a anyn küv-

(9) magi otnun da bolsa savuqmaġy ol küvḿaknin aq tem-

(10) gil qyzyl syman jemeśa aq syman. וראה. [25] Da baqsyn any

(11) ol kohen da muna čüvürüldü aq čač temgild́a da

(12) körümü anyn teŕanŕakti ol teridan caráatty ol küv-

(13) ḿak byla jajyldy da murdar etsin any ol kohen ḥasta-

(14) lygjydy cara'atnyn ol. ואם [26] Da eger körśa any ol

(15) kohen da muna joḥtu temgild́a aq čač da juvuzraq tü-

(16) vüldü ol teridan da ol tundu da bekĺasin any ol kohen

(17) jedi künĺar. וראה [27 Da baqsyn any ol kohen ol jedinči kün-

(18) d́a eger jajylma jajylsa terid́a da murdar etsin

(19) any ol kohen ḥastalyġydy cara'atnyn ol. ואם [28] Da eger or-

(20) nunda tursa ol temgil jajylmady terid́a da ol tundu

(21) [šišigidi $]^{2}$ ol küvḿaknin ol da aruv etsin any ol kohen

$178 \mathrm{v}^{\mathrm{o}} \quad$ (1) quzuvudu ol küvḿaknin ol. [29] [29] Daši jemeśa qatyn

(2) ki bolsa anda hastalyq bašta jemeśa sag̉alda. וראה. [30]

(3) Da baqsyn ol kohen ošol ol ḥastalyqny da muna körümü

(4) anyn teŕanŕakti ol teridan da anda balquvlu čač uvaq

(5) da murdar etsin any ol kohen neteqti ol cara'aty $\{\mathrm{ol}\}$ bašnyn

\footnotetext{
${ }^{1}$ The text in lines $3^{-21}$ was not vocalized. It was probably left out by mistake by the copyist when he added the vocalization signs to the text. ${ }^{2} \mathrm{~K}$ : küvmagidi; probably a scribal error (or a mistranslation); cf. C and Lev 13:43. | TKow.o1: šišigidi; unvocalized text. | H: sisigidi.| C: küjügü. | R: šišigi.
} 
(19) appearing red|dish|, and it is shown to the priest, [20]

(20) The priest shall look, and, lo, it its appearance is lower than the skin,

(21) and its hair has changed and turned white, the priest shall pronounce him unclean.

(1) It is a disease of leprosy. It spread with the boil. [21]

(2) But if the priest sees him, and, lo, there is no white hair in it,

(3) and if it is not lower than the skin and has faded, the

(4) priest shall shut him up seven days. [22] And if it spreads

(5) much in the skin, the priest shall pronounce him unclean. It is a disease.

(6) [23] But if the spot remains in one place

(7) and does not spread, it is a burning abscess, and the priest shall pronounce him clean.

(8) [24] Or if there is any body in the skin of which

(9) there is a burn from a fire, and the efflorescence of the burn is a white

(10) spot, appearing red|dish| or white, [25] And the priest shall look on it,

(11) and, lo, if the hair in the spot has turned white and

(12) its appearance is deeper than the skin, it is a leprosy

(13) spread with the burn, and the priest shall pronounce him unclean. It is the disease

(14) of leprosy. [26] And if the priest sees it,

(15) and, lo, there is no white hair in the spot and it is no deeper

(16) than the skin and has faded, the priest shall shut him up

(17) seven days. [27] And the priest shall look on him the seventh day:

(18) if it is spread much in the skin, the priest shall pronounce him unclean.

(19) It is the disease of leprosy. [28] And if

(20) the spot stays in its place and does not spread in the skin and has faded,

(21) it is $a_{[}\left[\right.$swelling] of the sore ${ }^{1163}$, and the priest shall pronounce him clean.

(1) It is a burn from the sore. [29] And when a man or woman

(2) has a disease on the head or the beard, [30]

(3) And the priest shall look on the disease, and, lo, if its appearance

(4) is deeper than the skin and there is in it bright thin hair,

(5) the priest shall pronounce him unclean. It is a scab, a leprosy of the head

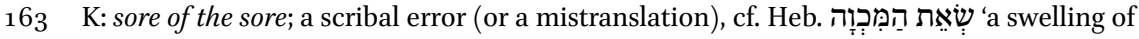
the burn'. 
(6) jemeśa ol sagaalnyn ol. וכי [31] Da ki körśa ol kohen

(7) ošol ḥastalyg்yn ol neteqnin da muna tüvüldü körümü

(8) anyn teŕanŕak ol teridan da qara čač joḥtu anda da

(9) bekĺasin ol kohen ošol hastalyg̉yn ol neteqnin jedi künlar.

(10) וראה [32] Da baqsyn ol kohen ošol ol ḥastalyqny ol jedinči

(11) künd́a da muna jajylmady ol neteq da bolmady anda

(12) balquvlu čač da körümü ol neteqnin teŕanŕak tüvüldü

(13) ol teridan. והתגלח. Da jülünsün da ošol ol neteq-

(14) ni jülüḿasin da bekĺasin ${ }_{\mathrm{L}}\{[\mathrm{o}] \text { l kohen }\}^{11}$ ošol ol neteqni jedi künĺar

(15) ekinči keŕat. וראה. [34] Da baqsyn ol kohen ošol ol

(16) neteqni ol jedinči künd́a da muna jajylmady ol neteq

(17) terid́a da körümü anyn tüvüldü teŕanŕak ol teri-

(18) dan da aruv etsin any ol kohen da juvsun upraqlaryn

(19) da arynyr. [35] Da eger jajylma jajylsa ol neteq

(20) terid́a arynganyndan sortun. וראהו. [36 Da baqsyn any

(21) ol kohen da muna jajyldy ol neteq terid́a terǵamasin ol

$179 \mathrm{r}^{\circ}$ (1) kohen ol balquvlu ča \{č $\}$ ny murdardy ol. [3ם [37] Da eger tür-

(2) sününd́a tursa ol neteq da qara čač ösśa anda

(3) ongaldy ol neteq aruvdu ol da aruv etsin any ol kohen.

(4) יואיש [38 [3 Da kiši jemeśa qatyn ki bolsa terisind́a gufla-

(5) rynyn temgillar aq temgillar. וראה. [39] Da baqsyn ol

(6) kohen da muna terisind́a guflarynyn tunuq temgillar

(7) aq symanlylar bohaq ünd́áladog̉an hastalyqty ol jajyldy

(8) gufta aruvdu ol. [4יש. [40] Da kiši ki julqunsa bašy

(9) anyn qereah ünd́aĺadi ol aruvdu ol. ואם [41] Da e-

(10) ger qyryjyndan jüzlarinin julqunsa bašy anyn gibeạ̣ ünd́a-

(11) ladi ol aruvdu ol. [42] Da ki bolsa artynda

\footnotetext{
${ }^{1}$ Marginal insertion by another hand. | TKow.o1: ol kohen; unvocalized text. | H: ol kohen. | C: ol kohen.
} 
(6) or the beard. [31] And if the priest sees

(7) the disease of the scab, and, lo, its appearance is no

(8) deeper than the skin and that there is no black hair in it,

(9) then the priest shall shut up |the one with| the disease of the scab seven days.

(10) [32] And on the seventh day the priest shall look on the disease,

(11) and, lo, if the scab does not spread, and there is no

(12) bright hair in it, and the appearance of the scab is not deeper

(13) than the skin: [33] And he shall shave himself, but the scab

(14) he shall not shave, and \{[the] priest $\}$ shall shut up |the one with| the scab seven days

(15) a second time. [34] And the priest shall look on

(16) the scab on the seventh day, and, lo, if the scab has not spread

(17) in the skin, and its appearance is not deeper than the skin,

(18) the priest shall pronounce him clean. And he shall wash his clothes

(19) and will be clean. [35] But if the scab spreads much

(20) in the skin after his cleansing: [36] And the priest shall look on him,

(21) and, lo, if the scab has spread in the skin, the priest shall not inspect

(1) for the bright hair. He is unclean. [37] And if

(2) the scab in its sight stayed |the same|, and black hair has grown in it,

(3) the scab is healed. He is clean. And the priest shall pronounce him clean.

(4) [38] And if a man or a woman has

(5) spots, white spots in the skin of their bodies: [39] And the priest shall look,

(6) and, lo, in the skin of their bodies there are dim spots

(7) appearing white in the skin, it is a disease called bohaq ${ }^{164}$ that has spread

(8) on the body. He is clean. [40] And if a man's head is gone bald,

(9) he is called qereah ${ }^{165}$. He is clean. [41] And

(10) if a man's head becomes bald from the edge of his face, he is called gibeah ${ }^{166}$.

(11) He is clean. [42] And if there is on the back

164 Heb. בּה 'a kind of disease' (Klein 1987: 65), 'harmless eruption of the skin, skin-disease' (Koehler \& Baumgartner 1985:111).| Translated as 'freckled spot' in KJ200o, as 'leukoderma' in ESV, as 'tetter' by Friedman (2003). | EKar. bohaq in C is translated as 'freckled spot' by Jankowski \& Aqtay \& Cegiołka \& Çulha \& Németh (2019: II 146).

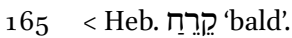

$166<$ Heb. 목 'bald on the forehead'. 
(12) bašynyn jemeśa alnynda bašynyn aq ḥastalyq qyzyl syman

(13) cara'at jajyladoġandy ol artynda bašynyn jemeśa alnyn-

(14) da bašynyn. [4ראה Da baqsyn any ol kohen da muna

(15) [šišigi $]^{1}$ ol ḥastalyqnyn aq qyzyl syman artynda bašynyn

(16) jemeśa alnynda bašynyn körümü kibik cara'atnyn teri-

(17) sind́a gufnun. איש [44] Cara'atly kišidi ol murdar-

(18) dy ol murdar etḿa murdar etsin any ol kohen bašyn-

(19) dady hastalyġy anyn. והצרוע. Da ol cara'atly ki anda

(20) ol ḥastalyq upraqlary bolsunlar sögülǵanlar da bašy bolsun

(21) ačyq ${ }_{\perp}\left\{\text { da mejyq }{ }^{2} \text { üstüne qaplansyn }\right\}^{13}$ da tame tame čag̉yrsyn ${ }_{\mathrm{L}} \mathrm{ki}$ saqlangajlar andan ašuv-

$179 \mathrm{v}^{0}$ (1) čular jolbyla ${ }^{14}$. כל [46] Bar künlard́a ki ol hastalyq bolsa anda

(2) murdar bolsun murdardy ol jalġyz oltursun tyšqartyn avulğa

(3) bolsun olturušu anyn. והבגד [47 Da ol upraq ki bolsa

(4) anda hastalyğy cara'atnyn junlu upraqta jemeśa üskülü-

(5) lü upraqta. [48] Jemeśa osnovada \{jemeśa\} utokta üs-

(6) külünün jemeśa junnun jemeśa terid́a jemeśa nendijd́a

(7) terili savutta. [49] Da bolsa ol hastalyq jašyl ${ }^{5}$ syman

(8) jemeśa qyzyl syman upraqta jemeśa terid́a jemeśa os-

(9) novada jemeśa utokta jemeśa nendijda terili savutta

(10) hastalyġydy caracatnyn ol da körgüzülsün ol kohenǵa. וראה. [50]

(11) Da baqsyn ol kohen ošol ol ḥastalyqny da beklasin ošol ol

(12) hastalyqny jedi künĺar. וראה [51] Da körsün ol kohen ošol

(13) ol ḥastalyqny ol jedinči künd́a eger jajyldy eśa ol

(14) hastalyq up\{r\}aqta jemeśa osnovada jemeśa utokta jeme-

(15) śa terid́a barysysajyn qylyndy ol teri išḱa caracat

(16) tavusadog̉an ol ḥastalyq murdardy ol. ושרף. [52] Da küv-

(17) dürsün ošol ol upraqny jemeśa ol osnovany jemeśa

(18) ošol ol utoknu junda jemeśa üskülüda jemeśa

(19) ošol bar ol terili savutnu ki bolsa anda ol ḥastalyq ki

(20) tavusadoġan cara'atty ol otta küvdürülsün. ואם [53]

(21) Da eger körśa any ol kohen da muna jajylmady ol ḥasta-

$180 \mathrm{r}^{\circ} \quad$ (1) lyq upraqta jemeśa osnovada jemeśa utokta jemeśa

\footnotetext{
${ }^{1} \mathrm{~K}$ : küvḿagi; probably a scribal error (or a mistranslation); cf. Lev 13:28. | TKow.o1: šišigi; unvocalized text. | H: sisigi. | C: šišigi. | R: šišigi. ${ }^{2} \mathrm{~K}$ : inserted by another hand, see next footnote, cf. Mod.NWKar. myjyh, SWKar. mijuq, and EKar. myjyq 'moustache'. $\quad{ }^{3}$ Marginal insertion by another hand. | TKow.o1: myjyggyn japsyn; unvocalized text. | H: da mijugu istine qaplansyn. | C: da erin üstünä japsyn. $\quad{ }^{4}$ Interpretative addition to the standard text. ${ }^{5} \mathrm{~K}$ : possibly a scribal error; cf., however, Lev 14:37. | TKow.o1: unvocalized text. | H: jesil. | C: ješil. | R: ješil.
} 
(12) of his head or on the front of his head a white disease appearing red|dish|,

(13) it is a leprosy spreading on the back of his head or on the front

(14) of his head. [43] And the priest shall look on it, and, lo,

(15) if the [swelling] ${ }^{167}$ of the disease appears red|dish| white on the back of his head

(16) or on the front of his head, like the appearance of leprosy in the skin

(17) of the body: [44] He is a leprous man. He is unclean.

(18) The priest shall pronounce him unclean.

(19) His disease is in his head. [45] And the leprous |man| in whom

(20) the disease is: his clothes shall be ripped, and his head shall be

(21) bare, $\{$ and he shall cover over his moustache $\}$, and shall cry out, “Unclean, unclean!”, , so that those who walk that way may take heed. 168

(1) [46] All the days in which the disease shall be in him

(2) he shall be unclean. He is unclean. He shall dwell alone.

(3) His place of dwelling shall be outside the camp. [47] And the garment: if there is

(4) the disease of leprosy in it - in garment of wool or

(5) in garment of linen, [48] Either in the warp or in the woof

(6) of the linen or of the wool or in leather or in any

(7) item made of leather-[49] And if the disease is greenish

(8) or reddish in the garment or in the leather, either

(9) in the warp or in the woof, or in any item of leather:

(10) it is a disease of leprosy and it shall be shown to the priest. [50]

(11) And the priest shall look on the disease, and shut in

(12) the disease seven days. [51] And the priest shall see the

(13) disease on the seventh day: if the disease has spread

(14) in the garment, either in the warp or in the woof, or

(15) in the leather, whatever is the use of the leather,

(16) the disease is a terminal leprosy. It is unclean. [52] And

(17) he shall therefore burn that garment or the warp or

(18) the woof either in the wool or in the linen or

(19) any leather item in which the disease is, because

(20) it is a terminal leprosy. It shall be burned in fire. [53]

(21) And if the priest sees it, and, lo, the disease has not spread

(1) in the garment, either in the warp or in the woof, or

167 K: sore; a scribal error (or a mistranslation), cf. Heb. שִֵֵׁת 'the swelling'.

168 An interpretative addition to Lev 13:45. 
(2) nendijda terili savutta. [5וה] Da bujursun ol kohen da

(3) juvsunlar any neki anda ol hastalyq da bekĺasin any jedi künlar

(4) ekinči keŕat. וראה [55] Da baqsyn ol kohen juvulup sortun ol

(5) nerśa ol ḥastalyqtan da muna čüvürḿadi ol ḥastalyq o-

(6) šol türsünün da ol hastalyq jajylmady murdardy ol ot-

(7) ta küvdürgün any pehetet ünd́aĺadog̉an hastalyqty ol

(8) artynda jemeśa alnynda. ואם [56] Da eger körśa any

(9) ol kohen da muna tundu ol hastalyq juvulup sortun ol da

(10) jyrtsyn any ol upraqtan jemeśa ol teridan jemeśa ol

(11) osnovadan jemeśa ol utoktan. ואם [57 Da eger körün-

(12) śa daġyn upraqta $\{[j e] m e s ́ a\}$ osnovada jemeśa utokta jemeśa

(13) nendijda terili savutta jajyladogan cara'atty ol otta

(14) küvdürgün any ošol neki anda ol ḥastalyq. והבגד [58 Da

(15) ol upraq jemeśa ol osnova jemeśa ol utok jeme-

(16) śa nendijd́a terili savut ki juvsaj da ketśa alardan

(17) ol ḥastalyq da juvulsyn ekinči keŕat da arynyr.

(18) זאת [59] Budur üvŕatüvü hastalyġynyn ol caracatnyn ol

(19) upraqnyn jundan jemeśa üskülüdan jemeśa osnovanyn

(20) jemeśa ol utoknun jemeśa nendijd́a terili savutnun

(21) aruv etḿa any jemeśa murdar etḿa any.

$180 \mathrm{v}^{\mathrm{o}} \quad$ Leviticus 14

פרשת תורת המצורע (1) (1) (1)

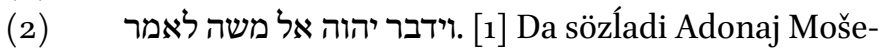

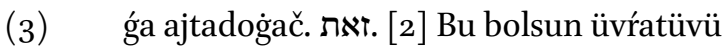

(4) ol cara‘atlynyn aryngaan kününd́a da keltirilsin ol kohen-

(5) ǵa. [יצא [3] Da čyqsyn ol kohen tyšqartyn avulğa da

(6) körsün ol kohen da muna ongaldy hạastalyğy ol cara'atnyn

(7) ol cara'atly kišidan. וצוה [4] Da bujursun ol kohen da

(8) alsynlar cara'attan arynuvču kišiǵa eki polnyj qušlar

(9) aruvlar da erez ag̉ačy da qyrmyzy jiṕak da čabor. וצוה. [5] 
(2) in any leather item, [54] Then the priest shall command, and

(3) they shall wash that in which is the disease, and he shall shut it in seven days

(4) a second time. [55] And the priest shall look after

(5) the thing has been washed from the disease, and, lo, the disease has not changed

(6) its appearance, and the disease has not spread, it is unclean.

(7) You shall burn it in the fire. It is a disease called pehetet ${ }^{169}$,

(8) on the back or on the front. [56] And if the priest sees it,

(9) and, lo, the disease has faded after it was washed,

(10) he shall rip it from the garment or from the leather or

(11) from the warp or from the woof. [57] And if it still appears

(12) in the garment, either in the warp or in the woof, or

(13) in any leather item, it is a spreading leprosy.

(14) You shall burn in fire that in which the disease is. [58] And

(15) the garment, either warp or woof, or

(16) any leather item which you shall wash: if the disease departs from it,

(17) it shall be washed a second time, and will be clean.'

(18) [59] This is the teaching of the disease of leprosy

(19) of a garment of wool or linen or warp

(20) or woof or any leather item,

(21) to pronounce it clean or to pronounce it unclean.

(1) Parashat Metzora

(2) [1] And the Lord spoke to Moses,

(3) saying, [2] 'This shall be the teaching

(4) of the leper in the day of his cleansing: And he shall be brought to the priest:

(5) [3] And the priest shall go out of the camp, and

(6) the priest shall see, and, lo, if the disease of leprosy has been healed

(7) from the leper, [4] The priest shall command, and

(8) one shall take for him that is to be cleansed from leprosy: two field birds,

(9) clean, and cedar wood and scarlet silk and aspergillum. [5]

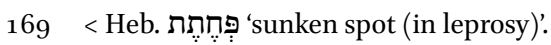


(10) Da bujursun ol kohen da sojsun ošol ol qušnu ol birisin

(11) čerepli savutqa tiri suvlar üstüńa. את [6] Ošol ol

(12) tiri qušnu alsyn any da ošol ol erez ag̉ačny da ošol ol

(13) qyrmyzy jiṕakni da ošol ol čabornu da mančsyn alarny

(14) da ošol ol tiri qušnu qanyna ol sojulġan qušnun ol tiri

(15) suvlar üstüńa. והזה [7] Da bürksün ol kohen ol

(16) arynuvču kiši üstüńa ol cara'attan jedi keráatlar

(17) da aruv etsin any da ijsin ošol qušnu jüzlari üs-

(18) tüńa ol tüznün. [8כס Da juvsun ol arynuvču o-

(19) šol upraqlarny da jülütsün ošol bar čačy anyn da juv-

(20) sun gufun suvlarbyla da arynyr da andan sortun kelsin

$181 \mathrm{r}^{\mathrm{o}} \quad$ (1) ol avulğa da oltursun tyšqartyn čatyryna jedi künlar.

(2) והיה Da bolg̉aj ol jedinči künd́a jülütsün ošol bar

(3) čačyn özünün ošol bašyn da ošol sag̉alyn da ošol qašlaryn

(4) közlarinin da ošol bar čačyn özünün jülütsün da juvsun

(5) ošol upraqlaryn da juvsun ošol gufun özünün suvby-

(6) la da arynsyn. [10] Da ol segizinči künd́a al-

(7) syn eki qozular tüǵallarni da tiši qozu jyllyq balasyn tü-

(8) ǵalni da üč 'esronlar öźak tirki jumurulg̀an javbyla

(9) da bir log̉ jav. והעמיד [11] Da turg̉uzsun ol kohen

(10) ol arytuvču ošol ol kiši \{ni\} ol arynuvčunu da alarny da

(11) alnynda Adonajnyn ešigind́a ohel mo'ednin. ולקח [12] Da

(12) alsyn ol kohen ošol ol bir qozunu da juvutsun any fašman-

(13) lyq qarbanġa da ošol log ol javny da sunsun alarny tenufa

(14) alnynda Adonajnyn. ושחט [13] Da sojsun ošol ol qozunu

(15) ne ornunda ki sojsa ošol ol ḥatatny da ošol

(16) ol 'olany ol aziz ornunda ki ḥatat kibikti ol ašam

(17) ol kohenǵadi qodeš qadašimdi ol. ולקח [14] Da alsyn ol

(18) qanyndan ol fašmanlyq qarbannyn da bersin ol kohen jymšaq

(19) ornu üstüńa ol on $\{\text { jandaġy }\}^{1}$ qulaġynyn ol arynuvčunun da baš

(20) barmaġy üstüńa ol on jandaġy qolunun da baš barmaġy

(21) üstüńa ol on jandaġy ajaġynyn. ולקח. [15] Da alsyn

\footnotetext{
${ }^{1}$ Marginal insertion by another hand. | TKow.o1: jandagy; unvocalized text. | H: jandag்y. | C: janynyy.
} 
(10) And the priest shall command and he shall slaughter one of the birds

(11) in an earthen vessel under running water. [6] The

(12) living bird: he shall take it and the cedar wood and the

(13) scarlet silk and the aspergillum, and shall dip them

(14) and the living bird in the blood of the bird that was slaughtered

(15) under the running water. [7] And the priest shall sprinkle

(16) on the one being purified from the leprosy seven times,

(17) and shall pronounce him clean, and shall let the living bird go

(18) over the surface of the field. [8] And the one being purified shall wash

(19) his clothes and shave off all his hair and

(20) wash his body in water, and he will be pure. And after that he shall come

(1) into the camp. And shall dwell outside of his tent seven days.

(2) [9] And it shall be, on the seventh day: he shall shave off all

(3) the hair of his head and his beard and the eyebrows

(4) of his eyes, even all his hair he shall shave off, and he shall wash

(5) his clothes, he shall wash his body in water,

(6) and he shall be clean. [10] And on the eighth day

(7) he shall take two unblemished |male| lambs, and one unblemished one-year-old female lamb,

(8) and three tenths |of a measure| of fine flour for a grain offering, mixed with oil,

(9) and one log of oil. [11] And the priest

(10) who is purifying shall set the man being purified, and them as well,

(11) before the Lord, at the door of the tent of meeting. [12] And

(12) the priest shall take one lamb and bring it forward for a guilt

(13) offering, and the log of oil, and elevate them for a wave offering

(14) before the Lord. [13] And he shall slaughter the lamb

(15) in the place where he shall slaughter the sin offering and the

(16) burnt offering, in the holy place, because the guilt offering is like the sin offering,

(17) it is the priest's. It is the holy of holies. [14] And he shall take

(18) some of the blood of the guilt offering, and the priest shall put it on the

(19) soft place of the ear on the right \{side $\}$ of the one being purified and

(20) on the thumb of his right hand and on the great toe

(21) of his right foot. [15] And 
$181 \mathrm{v}^{\mathrm{o}} \quad$ (1) ol kohen log ol javdan da $\mathrm{q}[\mathrm{u}] \mathrm{j} \mathrm{sun}^{1}$ ol kohen uvuču üstüńa ol

(2) son qolunun. וטבל [16] Da mančsyn ol kohen ošol barmaġy ol

(3) on qolunun ol javdan ki uvuču üstüńa ol son qolunun da

(4) bürksün ol javdan barmaġy byla jedi keŕatlar alnynda Adonaj-

(5) nyn. ומיתר. [17] Da ol qaldyq javdan ki uvuču üstüńa ber-

(6) sin ol kohen jymšaq ornu üstüńa ol on jandag̉y qulag̉ynyn

(7) ol arynuvčunun da baš barmaġy üstüńa ol on jandaġy

(8) qolunun da baš barmaġy üstüńa ol on jandaġy ajaġynyn qany

(9) üstüńa ol fašmanlyq qarbannyn. והנותר. [18] Da ol

(10) qalġanny javdan ki uvuču üstüńa ol kohennin bersin bašy

(11) üstüńa ol arynuvčunun da bošatlyq qolsun anyn üčün

(12) ol kohen alnynda Adonajnyn. ועשה] [19] Da qylsyn ol kohen ošol

(13) ol hatatny da bošatlyq qolsun ol arynuvču üčün mur-

(14) darlyġyndan anyn da andan sortun sojsun ošol ol 'olany.

(15) והעלה (20] Da čyg̉arsyn ol kohen ošol ol 'olany da ošol

(16) ol tirkini ol mizbeaḥta da bošatlyq qolsun anyn üčün

(17) ol kohen da arynyr. ואם [21] Da eger jarly bolsa ol ary-

(18) nuvču da jetmááa küčü qolunun da alsyn bir qozu qarbanyn

(19) ašamnyn tenufag̉a bošatlyq qolma özü üčün $\{$ da $\}$ bir 'isaron

(20) öźak jumurulġan javbyla tirkiǵa da bir log̉ jav.

(21) (22] Da eki bedeńalar jemeśa eki kügürčün balalary

$182 \mathrm{r}^{\mathrm{o}} \quad$ (1) neki jetśa küčü qolunun da bolsun birisi hatat da ol bir

(2) והביא 23] Da keltirsin alarny ol segizinči künd́a

(3) arynmaġyndan sortun ol kohenǵa ešigine ohel mo'ednin

(4) alnynda Adonajnyn. ולקח [24 Da alsyn ol kohen ošol qozusun ol

(5) fašmanlyq qarbannyn da ošol log̉ ol javny da sunsun ol

(6) kohen alarny tenufa alnynda Adonajnyn. ושחט [25] Da sojsun

(7) ošol qozusun ol fašmanlyq qarbannyn da alsyn ol kohen

(8) qanyndan ol fašmanlyq qarbannyn da bersin jymšaq ornu üs-

${ }^{1} \mathrm{~K}:$ qojsun; a scribal error. | TKow.o1: unvocalized text. | H: qujsun. | C: töksin. 
(1) the priest shall take some of the log of oil, and [pour] $]^{170}$ it on the $181 \mathrm{v}^{\mathrm{o}}$ palm

(2) of his left hand. [16] And the priest shall dip the finger

(3) of his right hand in the oil that is on his left palm and

(4) shall sprinkle some of the oil with his finger seven times before the Lord.

(5) [17] And shall the priest put the rest of the oil that is on his palm

(6) on the soft place of the right ear

(7) of the one being purified and on the thumb of his right

(8) hand and on the great toe of his right foot, over the blood

(9) of the guilt offering. [18] And he shall put

(10) what is left of the oil that is on the priest's palm on the head

(11) of the one being purified. And the priest shall ask for atonement for him

(12) before the Lord. [19] And the priest shall make the

(13) sin offering and ask for atonement for the one being purified

(14) from his uncleanness. And afterward he shall slaughter the burnt offering.

(15) [20] And the priest shall offer the burnt offering and the

(16) grain offering on the altar. And the priest shall ask for atonement for him,

(17) and he will be clean. [21] But if the one being purified is poor,

(18) and his hand cannot attain |enough|, then he shall take one lamb

(19) of the guilt offering for a waved offering, to ask for atonement for himself, and one tenth

(20) |of a measure of fine flour mixed with oil for a grain offering and a $\log$ of oil,

(21) [22] And two turtledoves or two young pigeons,

(1) whichever his hand can attain. And one shall be a sin offering and one

(2) a burnt offering. [23] And he shall bring them on the eighth day

(3) for his cleansing to the priest, to the door of the tent of meeting,

(4) before the Lord. [24] And the priest shall take the lamb

(5) of the guilt offering and the log of oil, and the priest shall elevate

(6) them for a wave offering before the Lord. [25] And he shall slaughter

(7) the lamb of the guilt offering, and the priest shall take

(8) some of the blood of the guilt offering and put it on the soft part

170 K: put; a scribal error. | TKow.o1: unvocalized text. | H: pour. | C: pour. 
(9) tüńa ol on jandaġy qulaġynyn ol arynuvčunun da baš barmaġy

(10) üstüńa ol on jandaġy qolunun da baš barmaġy üstüńa

(11) ol on jandaġy ajaġynyn. [מן . 26] Da ol javny qujsun ol kohen

(12) ol son uvuču üstüńa. ומהזה. [27] Da bürksün ol kohen

(13) barmağybyla ol [on $]^{1}$ qolunun ol javdan ki uvuču üstüńa ol

(14) son qolunun jedi keŕatĺar alnynda Adonajnyn. [28] Da

(15) bersin ol kohen ${ }_{L}$ ol javdan ki uvuču üstüńa jymšaq ornu

(16) üstüńa ${ }^{12} \mathrm{ol}$ on jandağy qulaġynyn ol arynuvčunun da baš

(17) barmaġy üstüńa ol on jandaġy qolunun da baš barmaġy üs-

(18) tüńa ol on jandaġy ajaġynyn ornu üstüńa qanynyn ol

(19) fašmanlyq qarbannyn. והנותר. [29] Da ol qalġanny \{ol\} javdan ki

(20) uvuču üstüńa ol kohe\{n\}nin bersin bašy üstüńa ol

(21) arynuvčunun bošatlyq qolma anyn üčün alnynda Adonajnyn.

$182 \mathrm{v}^{\mathrm{o}}$ (1) [30] Da qylsyn ošol birni ol bedeńalard́an jemeśa ol kügür-

(2) čün balalaryndan andan ki jetśa küčü qolunun. את. [31] Ned́an ki jet-

(3) śa küčü qolunun ošol ol birni hatat da ošol ol birni

(4) 'ola ol tirki qatyna da bošatlyq qolsun ol kohen ol arynuv-

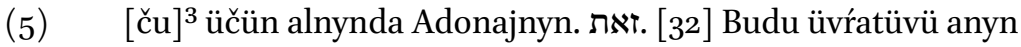

(6) ki bolsa anda ḥastalyggy ol cara'atnyn ki jetmaaśa küčü

(7) וידבר (33] Da sözĺadi Adonaj Mošeǵa

(8) da Aharonġa ajtadoġač. כי [34] Ki kelśajiz jerińa Kena'annyn

(9) ki men beŕamen sizǵa tutuvluqqa da berirmen ḥastalyğy cara-

(10) 'atnyn üvünd́a tutuvluq jerijiznin. [35] \{Da kelsin\} jesisi ol üv-

(11) nün ki anyndy ol üv da anlatsyn kohenǵa ajtadoġač hasta-

(12) lyq kibik köründü maja üvd́a. וצוה. [36] Da bujursun

(13) ol kohen da jyštyrsynlar ošol ol üvnü kelḿastan burun

(14) ol kohen baqma ošol ol ḥastalyqny ki murdar bolmag̉aj bar-

(15) ča neki bolsa üvd́a da andan sortun kelsin ol kohen

(16) baqma ošol ol üvnü. וראה. [37] Da baqsyn ol kohen ošol

(17) ol hastalyqny da muna ol ḥastalyq ${ }_{\llcorner}\left\{[\text {fa]rstlarynda [o]l üvnün }\}^{14}\right.$ jerǵálar jašyl ${ }^{5}$ symanlar

\footnotetext{
${ }^{1} \mathrm{~K}$ : deest; a scribal error. | TKow.o1: on; unvocalized text. | H: on. | C: o.$\quad{ }^{2}$ Unvocalized fragment. $\quad{ }^{3} \mathrm{~K}$ : arynuv-; a scribal error. | TKow.o1: arynuvču; unvocalized text. | H: arynuvcu. | C: aruv bolgan. $\quad{ }^{4}$ Marginal insertion by another hand. | TKow.o1: farstlarynda ol üvnün; unvocalized text. | H: farstlarynda ol ivnin. | C: duvarlarynda ol evnip. $\quad{ }^{5} \mathrm{~K}$ : possibly a scribal error; cf., however, Lev 13:49. | TKow.o1: unvocalized text. | H: jesil. | C: ješil. | R: ješil.
} 
(9) of the right ear of the one being purified and on the thumb

(10) of his right hand and on the great toe

(11) of his right foot. [26] And the priest shall pour the oil

(12) on his left palm. [27] And the priest shall sprinkle

(13) with his [right $]^{171}$ finger some of the oil that is on the palm

(14) of his left hand seven times before the Lord. [28] And

(15) the priest shall put some of the oil that is on his palm on the soft place

(16) of the right ear of the one being purified and on the

(17) thumb of his right hand and on the great toe

(18) of his right foot, over the place of the blood of the

(19) guilt offering. [29] And he shall put what is left of the oil that

(20) is on the priest's palm on the head

(21) of the one being purified, to ask for atonement for him before the Lord.

(1) [30] And he shall make one of the turtledoves or of the

(2) young pigeons, whichever his hand can attain. [31] Whichever

(3) his hand will attain: one a sin offering and one

(4) a burnt offering, with the grain offering. And the priest shall ask for atonement for the one being purified

(5) before the Lord. [32] This is the teaching of him

(6) in whom is the disease of leprosy, whose hand cannot attain

(7) for his cleansing.' [33] And the Lord spoke to Moses

(8) and to Aaron, saying, [34] 'When you come to the land of Canaan,

(9) which I am giving to you for a possession, and I will put the disease

(10) of leprosy in a house at the land of your possession. [35] And the owner of the house,

(11) the one whose house it is, shall come and tell the priest, saying,

(12) "It appears like a disease to me in the house." [36] And the priest shall command

(13) that they gather the house before

(14) the priest comes to see the disease, so that all

(15) that is in the house does not become unclean. And, after that, the priest shall come

(16) to see the house. [37] And the priest shall look

(17) on the disease, and, lo, if the disease is \{in the walls of the house $\}$ with layers appearing green

171 K: deest; a scribal error. 
(18) jemeśa qyzyl symanlar da körümĺari alarnyn juvuzraqty ol

(19) farsttan. ויצא [38] Da čyqsyn ol kohen ortasyndan ol üvnün

(20) [e]šigińa ${ }^{1}$ ol üvnün da beḱlasin ošol ol üvnü jedi

(21) künĺar. ושב [39] Da qajtsyn ol kohen ol jedinči künd́a da

$183 \mathrm{r}^{\mathrm{0}} \quad$ (1) körsün da muna jajyldy ol hastalyq farstlarynda ol

(2) üvnün. וצוה. [40] Da bujursun ol kohen da suvursunlar

(3) ošol ol tašlarny ki alarda ol ḥastalyq da tašlasynlar alar-

(4) ny tyšqartyn šaharg̉a murdar [o]runğa ${ }^{2}$. ואת. [41] Da ošol

(5) ol üvnü qyrsyn ičkartin čüvŕa da töksünĺar

(6) ošol ol topraqny ki qyrsalar tyšqartyn šaharg̉a murdar

(7) orunġa. ולקחו [42] Da alsynlar özǵa tašlar da keltir-

(8) sinlar ornuna ol tašlarnyn da özǵa topraq alsyn

(9) da jaqsyn ošol ol üvnü. ואם [43] Da eger qajtsa ol

(10) hastalyq da jajylsa üvd́a suvurup sortun ošol ol

(11) tašlarny da qyrmaqtan sortun ošol ol üvnü da jaqmaq-

(12) tan sortun. [4א [4] Da kelsin ol kohen da baqsyn da muna

(13) jajyldy ol ḥastalyq üvd́a tavusadoġan caráatty ol üv-

(14) da murdar bolsun ol. ונתץ. [45] Da qavšatsyn ošol ol

(15) üvnü ošol tašlaryn da ošol ağačlaryn anyn da ošol

(16) bar toprag̉yn ol üvnün da čyg̉arsyn tyšqartyn šaharg̉a mur-

(17) da\{r\} orunġa. והבא. [46] Da ol kelüvčü ol üvǵa bar

(18) bekĺaǵan künlard́a any murdar bolsun ol ingirǵadejin.

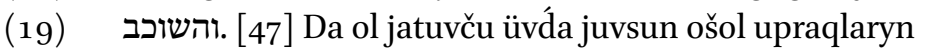

(20) da ol ašavču üvd́a juvsun ošol upraqlaryn. ואם [48]

(21) Da eger kelḿa kelśa ol kohen da körśa da muna jajyl-

$183 \mathrm{v}^{\circ} \quad$ (1) mady ol ḥastalyq üvd́a jaġyp sortun ošol ol üvnü da

(2) aruv etsin ol kohen ošol ol üvnü ki onġaldy ol ḥastalyq.

(3) ולקח [49 Da alsyn bürkḿa ošol ol üvnü eki qušlar da

(4) erez ag̉ačy da qyrmyzy jiṕak da čabor. ושחט. [50] Da sojsun

(5) ošol ol bir qušnu čerep savut üstüńa tiri suvlar üs-

(6) tüńa. ולקח [51] Da alsyn ošol ol erez ag̉ačyn da ošol ol

(7) čabornu da ošol ol qyrmyzy jiṕakni da ošol ol tiri quš-

(8) nu da mančsyn alarny qanyna ol sojulġan qušnun da ol tiri

(9) suvlarg̉a da bürksün ošol ol üv üstüńa jedi keŕatlar.

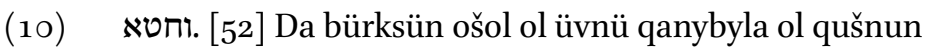

\footnotetext{
${ }^{1} \mathrm{~K}$ : išigińa; probably a scribal error. | TKow.o1: unvocalized text. | H: esigine. | C: ešiginä. $\quad{ }^{2} \mathrm{~K}$ :
} urunga; probably a scribal error. | TKow.o1: unvocalized text. | H: orunġa. | C: jergä. 
(18) or appearing red, and they appear to be deeper

(19) than |the surface of| the wall: [38] Then the priest shall go out from the middle of the house

(20) to the door of the house, and he shall shut the house up seven

(21) days. [39] And the priest shall go back on the seventh day and

(1) shall look, and, lo, if the disease is spread in the walls

(2) of the house: [40] Then the priest shall command that they take away

(3) the stones in which the disease is, and they shall cast them

(4) to an unclean place outside the city. [41] And

(5) he shall scrape the house inside all around, and they shall pour

(6) out the dust that they scrape off outside the city to an unclean place.

(7) [42] And they shall take other stones and

(8) bring them in place of the stones, and he shall take other dust,

(9) and shall smear the house. [43] And if the disease comes back

(10) and spreads in the house after taking away the

(11) stones and after scraping the house and after smearing it:

(12) [44] The priest shall come and look, and, lo,

(13) the disease has spread in the house, it is a terminal leprosy in the house.

(14) It shall be unclean. [45] And he shall demolish the

(15) house, its stones, and the wood of it, and

(16) all the dust of the house, and he shall carry them out of the city to

(17) an unclean place. [46] And he that comes into the house all

(18) the days that it is shut up shall be unclean until the evening.

(19) [47] And he that lies in the house shall wash his clothes,

(20) and he that eats in the house shall wash his clothes. [48]

(21) And if the priest shall come in and look on it, and, lo,

(1) the disease has not spread in the house after the house was smeared, $183 \mathrm{v}^{\circ}$

(2) the priest shall pronounce the house clean, because the disease is healed.

(3) [49] And to cleanse the house he shall take two birds and

(4) cedar wood and scarlet silk and aspergillum. [50] And he shall slaughter

(5) one of the birds over an earthen vessel over running water.

(6) [51] And he shall take the cedar wood and the

(7) aspergillum and the scarlet silk and the living bird,

(8) and dip them in the blood of the slaughtered bird and in the running

(9) water, and he shall sprinkle it at the house seven times.

(10) [52] And he shall cleanse the house with the blood of the bird 
(11) da ol tiri suvlar byla da ol tiri qušbyla da erez

(12) ag̉ačy byla da čabor byla da qyrmyzy ol jiṕak byla.

(13) ושלח [53] Da ijsin ošol ol tiri qušnu tyšqartyn šaharg̉a

(14) jüzlari üstüńa ol tüznün da bošatlyq qolsun ol üv ü-

(15) čün da arynyr. זאת [54] Budur ol üv'́atüv bar hastalyġyna

(16) ol caracatnyn da neteqḱa. ולצרעת [55] Da cara'atyna ol upraq-

(17) nyn da üvnün. ולשאת [56] Da küvḿaknin da šišiknin da

(18) temgilnin. להורות. [57 [Üváatma ol murdar vahtta da ol

(19) aruv vaḥtta budur üvŕatüvü ol caráatnyn.

\section{Leviticus 15}

(19) . וידבר $\quad$ (19) Da

(20) sözĺadi Adonaj Mošeǵa \{da Aharonġa\} ajtadog̉ač. [2] Sözĺajiz ulanlaryna Jisra-

(21) 'elnin da ajtyjyz alarg̉a nendij kiši ki bolsa aqmaq gufundan anyn

$184 \mathrm{r}^{\circ}$ (1) aqmaǵy anyn murdardyr ol. [3] Da bu bolsun murdarlyġy

(2) anyn zavlyġynda siliǵaj bolsa gufundan zavlyġynda jemeśa beklaśa

(3) gufun anyn zavlyggyndan murdarlyggydy anyn ol. כל [4] Bar ol tö-

(4) Š́ak ki jatsa anyn üstüńa ol zavly murdar bolsun da bar ol

(5) savut ki oltursa anyn üstüńa murdar bolsun. [5יש [5]

(6) Da kiši ki tijśa töšagińa anyn da juvsun upraqlaryn da juv-

(7) sun gufun suvbyla da murdar bolsun ol ingirǵadejin. והישב. [6]

(8) Da ol olturuvču ol savutüstüńa ki oltursa anyn üs-

(9) tüńa ol zavly juvsun upraqlaryn da juvsun gufun suvbyla da mur-

(10) dar bolsun ol ingirǵadejin. L והנוגע. [7] Da ol t[ijü] včü gufu[na] ol zavlyny [n] juvsun $u$ [praq] laryn da [juv] sun guf [un] suvbyla [da] murdar bo[lsun] ol in[gir] gedejin.\} $\}^{11}$. [8] Da ki tükürśa ol

(11) zavly kiši aruv kiši üstüńa da juvsun upraqlaryn da juv-

(12) sun gufun suvbyla da murdar bolsun ol ingirǵadejin. וכל [9]

\footnotetext{
${ }^{1}$ Marginal insertion by another hand. | TKow.o1: Da ol tijüvčü gufuna ol zavlynyn juvsun upraqlaryn \{da juvunsun suvlarbyla\} da murdar bolsun ol ingirgedejin; unvocalized text. | H: Da ol tijivci gufuna olzavlynynjuvsun upraqlaryn dajuvsun gufun suvlar byla da murdar bolsun ol ingirgedejin. | C: deest; an interesting similarity between K and C, cf. also Num 3:8. | M: Da ol tijgän etinä ol zavnyy juvsyn upraqlaryn da juvunsyn suvlar bilän da murdar bolsyn ol yyyrg்a degin. | R: Da ol tijuv́ću gufuna ol zavlunun juvsun uprahlaryn da juvunsun suvlar byla da murdar bolsun ol ińgirǵa dejiń.
} 
(11) and with the running water and with the living bird and with the cedar wood

(12) and with the aspergillum and with the scarlet silk.

(13) [53] And he shall let go the living bird out of the city

(14) over the surface of the fields, and ask for atonement for the house.

(15) And it will be clean.' [54] This is the teaching for every disease

(16) of leprosy, and for a scab, [55] And for the leprosy

(17) of a garment and of a house, [56] And for a sore, and for a swelling, and

(18) for a spot, [57] To teach when it is unclean and

(19) when it is clean. This is the teaching of leprosy.

Leviticus 15

[1] And

(20) the Lord spoke to Moses and to Aaron, saying, [2] 'Speak to the children

(21) of Israel, and say to them, "When any man has a discharge out of his flesh,

(1) his discharge: it is unclean. [3] And this shall be his uncleanness

(2) in his discharge: if, in his discharge, there be a [ ${ }^{\dagger}$ fluid $]^{172} \mid$ running $\mid$ from his flesh or

(3) his flesh is closed from his discharge, it is his uncleanness. [4] Every

(4) bed on which he lies that has the discharge shall be unclean, and any

(5) item on which he sits shall be unclean. [5]

(6) And a man who touches his bed shall wash his clothes and

(7) wash his body in water, and he shall be unclean until the evening. [6]

(8) And one who sits on any item on which

(9) the one who has the discharge has sat shall wash his clothes and shall wash his body in water, and

(10) he shall be unclean until the evening. \{[7] And the one who touches the flesh of the one who has the discharge shall wash his clothes and wash himself in water, and he shall be unclean until the evening.\} [8] And if

(11) the one who has the discharge spits on him that is clean, then he shall wash his clothes and

(12) wash himself in water, and he shall be unclean until the evening. [9]

172 An uncertain translation of siliǵaj. 
(13) Da bar ol atlanmaq ki atlansa anyn üstüńa ol zavly mur-

(14) dar bolsun. [10] Da bar ol tijüvčü baryna neki bolsa anyn

(15) tübüńa murdar bolsun ol ingirǵadejin da ol eltüvčü alar-

(16) ny juvsun upraqlaryn [da juvsun gufun suvbyla] $]^{1}$ da murdar bolsun ol ingirǵadejin. וכל [11]

(17) Da barča neki tijśa anar ol zavly da qollaryn juvmasa suvbyla

(18) da juvsun upraqlaryn da juvsun gufun suvbyla da murdar bolsun

(19) ol ingirǵadejin. [12] Da čerep savut ki tijsa anar ol

(20) zavly syndyrylsyn da bar ag̉ačly savut taštyrylsyn suvbyla. וכי [13]

(21) Da ki arynsa ol zavly zavlyġyndan da sansyn özüńa jedi künlar

$184 \mathrm{v}^{\mathrm{o}} \quad$ (1) arynmaq vahtyndan da juvsun upraqlaryn da juvsun gufun tiri suvlar

(2) byla da arynyr. וביום Da ol segizinči künd́a alsyn özü-

(3) ńa eki bedeńalar jemeśa eki kügürčün balalary da kelsin alny-

(4) na Adonajnyn ešigińa ohel mo'ednin da bersin alarny ol kohenǵa.

(5) (15] Da qylsyn alarny ol kohen birni hatat da ol birni 'ola

(6) da bošatlyq qolsun anyn üčün ol kohen alnynda Adonajnyn zavlyġyn-

(7) dan. ואיש d16] Da kiši ki čyqty andan tamčysy urluqnun da

(8) juvsun gufun suvbyla da murdar bolsun ol ingirǵadejin.

(9) וכל [17] Da bar upraq da bar teri ki bolsa anyn üstüńa

(10) tamčysy urluqnun da juvulsun suvbyla da murdar bolsun ol

(11) ingirǵadejin. ואשה [18] Da qatyn ki jatsa kiši anyn byla jatu-

(12) vun urluqnun da juvsunlar guflaryn suvbyla da murdar bolsunlar

(13) ol ingirǵadejin. ואשה] [19] Da qatyn ki bolsa zavly qan bolsa

(14) aqmaġy anyn gufundan jedi künlar bolsun jyggyslyggynda da bar ol

(15) tijüvčü anar murdar bolsun ol ingirǵadejin. וכל [20] Da bar-

(16) ča neki jatsa anyn üstüńa ol qatyn jyğyslyq vahtynda

(17) murdar bolsun da barča neki oltursa anyn üstüńa mur-

(18) dar bolsun. [21] Da bar ol tijüvčü töš́agińa anyn juvsun

(19) upraqlaryn da juvsun gufun suvbyla da murdar bolsun ol in-

\footnotetext{
${ }^{1} \mathrm{~K}$ : deest; a scribal error. | TKow.o1: da juvsun gufun suvbyla; unvocalized text. | H: da juvsun gufun suvlar byla. | C: da juvunsyn suvlar bilän.
} 
(13) And any saddle on which the one who has the discharge rides

(14) shall be unclean. [10] And anyone who touches anything that was

(15) under him shall be unclean until the evening. And the one who bears

(16) those things shall wash his clothes [and shall wash himself in water] and he shall be unclean until the evening. [11]

(17) And anyone whom the one who has the discharge touches, and has not washed his hands in water,

(18) he shall wash his clothes and wash himself in water, and he shall be unclean

(19) until the evening. [12] And the earthen vessel that the

(20) one who has the discharge touches shall be broken, and every wooden vessel shall be rinsed in water. [13]

(21) And if the one who has a discharge is cleansed of his discharge, then he shall count to himself seven days

(1) from the time of his cleansing and wash his clothes and wash his body in running water,

(2) and he will be clean. [14] And on the eighth day he shall take for him

(3) two turtledoves or two young pigeons, and he shall come before

(4) the Lord to the door of the tent of meeting and give them to the priest.

(5) [15] And the priest shall do them: one a sin offering and one a burnt offering,

(6) and the priest shall ask for atonement for him before the Lord for his discharge.

(7) [16] And if a drop of a man's semen comes out from him,

(8) he shall wash his body in water and be unclean until the evening.

(9) [17] And any garment and any leather on which is

(10) a drop of semen shall be washed with water and be unclean

(11) until the evening. [18] And if a man lies with a woman

(12) —an intercourse of seed - they shall wash their bodies in water and be unclean

(13) until the evening. [19] And a woman who has a discharge: if

(14) her discharge from her body is blood, she shall be in her menstruation seven days: and anyone

(15) who touches her shall be unclean until the evening. [20] And everything

(16) on which the woman lies during her menstruation

(17) shall be unclean and everything on which she sits shall be unclean.

(18) [21] And anyone who touches her bed shall wash

(19) his clothes and wash his body in water and be unclean 
(20) girǵadejin. וכל [22] Da bar ol tijüvčü bar savutqa ki oltur-

(21) sa anyn üstüńa juvsun upraqlaryn da juvsun gufun suvbyla

$185 \mathrm{r}^{\mathrm{o}}$ (1) da murdar bolsun ol ingirǵadejin. [2] [23] Da eger ol

(2) töšak üstüńa jemeśa ol savut üstüńa ki ol qatyn

(3) olturady anyn üstüńa tijǵanind́a anar murdar bolsun ol

(4) ingirǵadejin. ואם [24] Da eger jatma jatsa kiši anyn-

(5) byla da bolsa qany jyġyslyġynyn ol qatynnyn ol kiši üstüna

(6) da murdar bolsun ol kiši jedi künĺar da bar ol töšak ki

(7) jatsa anyn üstüńa ol kiši murdar bolsun. [25]

(8) Da qatyn ki aqsa aqmaġy qanynyn köp künlar vaḥtyndan bašqa

(9) jyġyslyġynyn jemeśa ki aqsa juvuq vahtyna jyġyslyg்ynyn bar

(10) künlarind́a aqmaġynyn murdarlyġynyn künlari kibik jyġyslyġynyn

(11) bolsun murdardy ol. כל [26] Bar ol töšak ki ${ }_{L}\langle$ oltursa $\rangle\{j a t s a\}^{11}$ anyn

(12) üstüńa bar zavly künlarind́a töš́agi kibik jyggyslyg̉ynyn bol-

(13) sun anar da bar ol savut ki oltursa anyn üstüńa murdar

(14) bolsun murdarlyġy kibik jyġyslyġynyn. וכל [27] Da bar ol tijüvčü

(15) alargaa murdar bolsun da juvsun upraqlaryn da juvsun gufun

(16) suvlarbyla da murdar bolsun ol ingirǵadejin. ואם [28] Da

(17) eger arynsa zavlyg̉yndan da sansyn özüńa jedi künĺar da

(18) andan sortun arynyr. וביום. [29] Da ol segizinči künd́a al-

(19) syn özüńa eki bedeńalar jemeśa eki kügürčün balalary da

(20) keltirsin alarny ol kohenǵa ešigińa ohel mo'ednin. ועשה. [30]

(21) Da qylsyn ol kohen ošol birni hatat da ošol ol birni 'ola

$185 \mathrm{~V}^{\mathrm{o}} \quad$ (1) da bošatlyq qolsun anyn üčün ol kohen alnynda Adonajnyn zavlyġyn-

(2) dan murdarlyġynyn. והזרתם. [31] Da ajyryjyz ošol ulanlaryn Jis-

(3) ra’elnin murdarlyqlaryn \{d\}an da ölḿasinlar murdarlyqlary üčün

(4) murdar etkanlarind́a ošol miškanymny ki ortalarynda.

(5) זאת [32] Budur üvŕatüvü ol zavly kišinin da ki čyqsa

(6) andan tamčysy urluqnun murdar bolma anyn byla. והדוה. [33]

\footnotetext{
${ }^{1}$ Correction by another hand. | TKow.o1: jatsa; unvocalized text. | H: jatsa. | C: jatsa.
} 
(20) until the evening. [22] And anyone who touches any item that

(21) she sat on shall wash his clothes and wash his body in water

(1) and be unclean until the evening. [23] And if

(2) it is on her bed or on anything on which the woman

(3) sits when he touches it, he shall be unclean

(4) until the evening. [24] And if any man lies

(5) with her at all, and the blood of the women's menstruation is on him,

(6) he shall be unclean seven days, and all the beds on which

(7) the man lies shall be unclean. [25]

(8) And if a woman has an emission of blood many days other than the time

(9) of her menstruation or if it runs close to the time of her menstruation: all

(10) the days of the discharge of her uncleanness shall be as the days of her menstruation.

(11) She shall be unclean. [26] Every bed on which she $\langle$ sits $\rangle$ \{lies\}

(12) all the days of her discharge shall be to her as the bed of her menstruation.

(13) And any item that she sits on shall be unclean,

(14) like the uncleanness of her menstruation. [27] And anyone who touches

(15) them shall be unclean and shall wash his clothes and shall wash his body

(16) in water and shall be unclean until the evening. [28] But

(17) if she is cleansed of her discharge, then she shall count to herself seven days, and

(18) after that she will be clean. [29] And on the eighth day

(19) she shall take to her two turtledoves or two young pigeons and

(20) bring them to the priest, to the door of the tent of meeting. [30]

(21) And the priest shall make one a sin offering and one a burnt offering,

(1) and the priest shall ask for atonement for her before the Lord for the $185 \mathrm{~V}^{\circ}$ discharge

(2) of her uncleanness. [31] And you shall separate the children

(3) of Israel from their uncleanness, so as they do not die because of their uncleanness

(4) when they defile my tabernacle that is among them."'

(5) [32] This is the teaching of the one who has a discharge and of him

(6) from whom a drop of semen goes out, so as to become unclean by it, [33] 
(7) Da $\{$ ol $\}$ ḥasta qatynnyn jyg்yslyg்ynda da ol zavly\{nyn $\}$ zavlyg்ynda erkak-

(8) nin da qatyn kišinin da kišinin ki jatsa murdar qatyn byla.

Leviticus 16

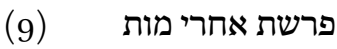

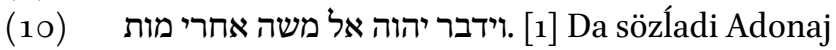

(11) Mošeǵa ölüp sortun eki ulanlary Aharon-

(12) nun juvugananlar\{y\}nda alnyna Adonajnyn da öldülar. ויאמר. [2]

(13) Da ajtty Adonaj Mošeǵa sözĺagin Aharonġa qaryndašyja da

(14) kelḿasin har vaḥtta ol qodešḱ ičkartin parohetḱka alnyna

(15) ol kaporetnin ki ol aron üstüńa da ölḿasin ki bulut

(16) byla aškara bolur šehinam menim ol kaporet üstüńa.

(17) B B] Bunluq byla kelsin Aharon ol qodeška qany byla tananyn

(18) balasynyn syg்yrnyn ḥatatqa da qanybyla qočqarnyn ‘olag̉a.

(19) Aq kölmak azizni kijsin da aq mihneśajimlar bolsun-

$186 \mathrm{r}^{\mathrm{o}}$ (1) lar gufu üstüńa da aq avnetbyla bajlansyn da aq micne-

(2) fetbyla čörǵansin aziz upraqlardylar alar da juvsun suvbyla

(3) ošol gufun da kijsin alarny. ומאת. [5] Da žymatyndan ulan-

(4) larynyn Jisra’elnin alsyn eki ulaqlaryn ečkilarnin ḥatatqa

(5) da bir qočqar 'olag̉a. והקריב. [6] Da juvutsun Aharon

(6) ošol tanasyn ol ḥatatnyn ki özünün da bošatlyq qolsun özü-

(7) üčün da üvü üčün. ולקח. [7] Da alsyn ošol eki ol

(8) ulaqlarny da turğuzsun alarny alnynda Ado\{naj\}nyn ešigind́a

(9) ohel mo'ednin. ונתן [8] Da bersin Aharon eki ol ulaqlar

(10) üstüńa gorallar bir goral Adonajğa da bir goral 'Aza'zelǵa.

(11) והקריב. [9] Da juvutsun Aharon ošol ol ulaqny ki mindi anyn

(12) üstüńa ol goral Adonajg̉a da qylsyn any ḥatat.

(13) ] (10] Da ol ulaq ki mindi üstüńa ol goral

(14) 'Aza'zelǵa turğuzulsun tiri alnynda Adonajnyn bošatlyq qolma

(15) anyn üstüńa ijḿa any 'Aza'zelǵa ol midbarg̉a. והקריב. [11]

(16) Da juvutsun Aharon ošol ol tan\{a\}syn ḥatatnyn ki özünün da 
(7) And of her that is sick in her menstruation, and of the one who has a discharge, a discharge of a man,

(8) and of a woman, and of the one who lies with an unclean woman.

Leviticus 16

(9) Parashat Acharei Mot

(10) [1] And the Lord spoke

(11) to Moses after the death of the two sons of Aaron-

(12) when they came forward before the Lord, and died. [2]

(13) And the Lord said to Moses, 'Speak to Aaron, your brother, that

(14) he shall not come at all times to the Holy within the veil before

(15) the cover which is over the ark, so that he may not die, because

(16) my divine Presence will appear in a cloud over the mercy seat.

(17) [3] Aaron shall come to the Holy with this: with the blood of a calf,

(18) the young of cattle, for a sin offering, and with the blood of a ram for a burnt offering.

(19) [4] He shall put on the holy white shirt, and the white dual trousers shall be

(1) on his body and shall be girded with the white girdle, and he shall $\quad 186 \mathrm{r}^{\mathrm{o}}$ wrap himself with the white turban.

(2) They are the holy clothes. And he shall wash

(3) his body in water and put them on. [5] And he shall take from the congregation

(4) of the children of Israel two kids of the goats for a sin offering

(5) and one ram for a burnt offering. [6] And Aaron shall bring forward

(6) his calf of the sin offering, which is for himself, and ask for atonement

(7) for himself and for his house. [7] And he shall take the two

(8) goats and set them before the Lord at the door

(9) of the tent of meeting. [8] And Aaron shall cast lots over the two goats,

(10) one lot for the Lord and one lot for Azazel.

(11) [9] And Aaron shall bring forward the goat on which

(12) the lot for Lord arose and he shall make it a sin offering.

(13) [10] And the goat, on which the lot for Azazel arose

(14) shall be stood alive before the Lord to ask for atonement

(15) over it, to let him go to Azazel, to the wilderness. [11]

(16) And Aaron shall bring forward the calf of the sin offering, which is for himself, and 
(17) bošatlyq qolsun özü üčün da üvü üčün da sojsun ošol

(18) tanasyn ol hatatnyn ki özünün. ולקח. [12] Da alsyn tolu ol

(19) mačmarny otlu kömürlar ol mizbeah üstünd́an alnyndan Adonaj-

(20) nyn da tolu qoš uvučlaryn tütüsün otjamlarnyn uvaqny da

(21) kijirsin ičkartin parohetka. ונתן. [13] Da bersin ošol ol

$186 \mathrm{v}^{\circ}$ (1) tütünü ol ot üstüńa alnynda Adonajnyn da qaplasyn bulut ol

(2) tütünün ošol ol kaporetni ki ol šarajat üstüńa da ölḿasin.

(3) ולקח [14] Da alsyn qanyndan ol tananyn da bürksün barmag்y byla alnynda

(4) ol kaporetnin kün tuvušusary da alnynda ol kaporetnin bürksün

(5) jedi keŕatlar ol qandan barmaġy byla. ושחט [15] Da sojsun ošol

(6) ulaġyn ol ḥatatnyn ki ulusnun da keltirsin ošol qanyn anyn ičkar-

(7) tin parohetḱa da qylsyn qanyna anyn ki nečik \{qyldy\} qanyna ol tananyn da

(8) bürksün any ol kaporet üstüńa da alnynda ol kaporetnin.

(9) וכפר [16 Da bošatlyq qolsun ol qodeš üčün murdarlyqlaryndan

(10) ulanlarynyn Jisra’elnin da tanmaq jazyqlaryndan alarnyn bar jazyqlarysajyn

(11) da alaj qylsyn ohel mo'edǵa ol toḥtavčug̉a birǵalarińa or-

(12) tasynda murdarlyqlarynyn. וכל [17] Da bird́a adam bolmasyn

(13) ohel mo'edd́a kelǵanind́a bošatlyq qolma qodešta čyqqanynadejin

(14) da bošatlyq qolsun özü üčün da üvü üčün da bar qahaly

(15) üčün Jisra’elnin. יויצא. [18] Da čyqsyn ol mizbeahqua ki alnyn-

(16) da Adonajnyn da bošatlyq qolsun anyn üčün da alsyn qanyndan

(17) ol tananyn da qanyndan ol ulaqnyn da bersin müvüzlari üstü-

(18) ńa ol mizbeahnyn čüv'́a. והזה [19] Da bürksün anyn üstü-

(19) ńa ol qandan barmaġy byla jedi keŕatlar da aruv etsin any da

(20) aziz etsin any murdarlyqlaryndan ulanlarynyn Jisra’elnin. וכלה. [20]

(21) Da tüǵallíaśa bošatlyq qolmaqtan ol qodeš üčün da ohel

$187 \mathrm{r}^{\circ} \quad$ (1) mo'ed üččn da ol mizbeah üčün da juvutsun ošol ol tiri

(2) ulaqny. וסמך [21] Da sunsun Aharon ošol eki qollaryn bašy üs-

(3) tüńa ol tiri ulaqnyn da mode bolsun anyn üstüńa ošol 
(17) shall ask for atonement for himself and for his house, and shall slaughter the

(18) calf of the sin offering which is for himself. [12] And he shall take

(19) a censer full of burning coals of fire from off the altar before the Lord,

(20) and a handful of fine sweet incense, and

(21) he shall bring it within the veil. [13] And he shall put the

(1) incense on the fire before the Lord, so that the cloud of the incense may cover

(2) the cover that is on the testimony, so that he does not die.

(3) [14] And he shall take of the blood of the calf and sprinkle it with his finger before

(4) the cover eastward, and he shall sprinkle of the blood with his finger

(5) before the cover seven times. [15] Then he shall slaughter the

(6) goat of the sin offering that is for the people and bring its blood within

(7) the veil and do with that blood as he did with the blood of the calf, and

(8) he shall sprinkle it on the cover and before the cover.

(9) [16] And he shall ask for atonement over the Holy, because of the uncleanness

(10) of the children of Israel and because of their transgressions in all their sins.

(11) And he shall do so for the tent of meeting that dwells with them

(12) in the midst of their uncleanness. [17] And there shall be no man

(13) in the tent of meeting when he comes to ask for atonement in the Holy, until he comes out,

(14) and he shall ask for atonement for himself and for his household and for all the congregation

(15) of Israel. [18] And he shall go out to the altar that

(16) is before the Lord and ask for atonement for it, and he shall take of the blood

(17) of the calf and of the blood of the goat, and he shall put it on the horns

(18) of the altar all around. [19] And he shall sprinkle

(19) of the blood on it with his finger seven times and cleanse it and

(20) sanctify it from the uncleanness of the children of Israel. [20]

(21) And when he finishes atoning for the Holy and the tent

(1) of meeting and the altar, then he shall bring forward the live

(2) goat. [21] And Aaron shall reach out both his hands over the head

(3) of the live goat and confess over him 
(4) bar güńaḥlarin ulanlarynyn Jisra’elnin da ošol bar tanmaq jazyqlaryn

(5) alarnyn bar jazyqlarysajyn alarnyn da bersin alarny bašyüstüńa

(6) ol ulaqnyn da ijsin qolu ašyra ol vaḥtlyq kišinin ol midbar-

(7) ga. [22] Da eltsin ol ulaq özü üstüńa ošol

(8) bar güńaḥlarin alarnyn pusta jerǵa da ijsin ošol ol ulaq-

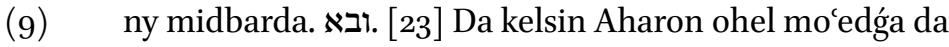

(10) češsin ošol ol aq up\{r\}aqlarny ki kijdi kelǵanind́a ol qodeš-

(11) ka da qojsun alarny anda. ורחץ [24] Da juvsun ošol gu-

(12) fun suvbyla aziz orunda da kijsin ošol upraqlaryn da čyq-

(13) syn da qylsyn ošol 'olasyn özünün da ošol 'olasyn ol

(14) ulusnun da bošatlyq qolsun özü üčün da ol ulus üčün.

(15) יואת [25] Da ošol javyn ol tananyn tütatsin ol mizbeaḥta.

(16) [-126] Da ol ijüvčü ol ulaqny 'Aza’zelǵa juvsun up-

(17) raqlaryn da juvsun ošol gufun suvbyla da andan sortun kel-

(18) sin ol avulg̀a. ואת [27] Da ošol tanasyn ol ḥatatnyn da

(19) ošol ulaġyn ol ḥatatnyn ki kijirildi qanlary alarnyn bošatlyq

(20) qolma qodešta čyġarsyn tyšqartyn avulg̉a da küvdürsün-

(21) ĺar otta ošol terilarin alarnyn da ošol etĺarin da

$187 \mathrm{~V}^{\circ}$ (1) ošol jiŕančiliklarin alarnyn. והשרף. [28] Da ol küvdürüvčü alar-

(2) ny juvsun upraqlaryn da juvsun ošol gufun suvbyla da andan sortun

(3) kelsin ol avulġa. והיתה. [29] Da bolsun sizǵa ömürlük resimǵa

(4) ol jedinči janġajda onunču kününd́a janġajnyn qyjnajyz ošol žan-

(5) laryjyzny da heč iš qylmajyz ol j[e]rl[i] $]^{1}$ da ol garip ol tirilüvčü

(6) ortajyzda. כ30] Ki ošpu künd́a bošatlyq qolar siznin üčün

(7) aruv etḿa sizni bar jazyqlaryjyzdan alnynda Adonajnyn arynyjyz.

(8) Sבת S31 Šabat šabatondur ol sizǵa da qyjnajyz ošol žanlaryjyzny

${ }^{1} \mathrm{~K}$ : jarly; a scribal error; cf. Exo 12:19, Exo 12:48, Exo 12:49, Lev 17:15, and Lev 24:16. | TKow.o1: jarly. | H: jarly. | C: jerli. 
(4) all the iniquities of the children of Israel and all their transgressions

(5) in all their sins, putting them on the head of the goat,

(6) and he shall send him away by the hand of man in readiness to the wilderness.

(7) $[22]$ And the goat shall carry on itself

(8) all their iniquities to the desert. And he shall let the goat go

(9) in the wilderness. [23] And Aaron shall come to the tent of meeting and

(10) shall take off the white garments that he put on when he came to the Holy,

(11) and he shall leave them there. [24] And he shall wash his body

(12) with water in the holy place and put on his garments, and

(13) he shall go out and make his burnt offering and the burnt offering of the

(14) people and ask for atonement for himself and for the people.

(15) [25] And he shall burn the fat of the calf on the altar.

(16) [26] And the one who let the goat go to Azazel shall wash

(17) his clothes and wash his body in water, and after that

(18) he shall come to the camp. [27] And he shall carry the calf for the sin offering and

(19) the goat for the sin offering whose blood was brought in to ask for atonement

(20) in the Holy, outside the camp. And they shall burn

(21) their skins and their flesh and

(1) their dung in fire. [28] And the one who burns them

(2) shall wash his clothes and wash his body in water, and after that

(3) he shall come to the camp. [29] And it shall be a statute forever to you:

(4) in the seventh month, on the tenth day of the month, you shall afflict your souls

(5) and do no work at all, either [a native $]^{173}$ or a stranger who lives

(6) among you. [30] Because on this day he will ask for atonement for you,

(7) to cleanse you. You shall be clean from all your sins before the Lord.

(8) [31] It is a Sabbath, the day of complete rest to you, and you shall afflict your souls-

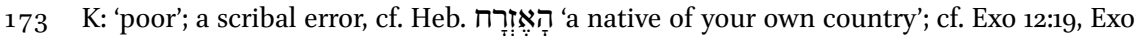
12:48, Exo 12:49, and Lev 17:15. 
(9) ömürlük resim. וכפר. [32] Da bošatlyq qolsun ol kohen

(10) ki jaġyndyrsa any da ki toltursa ošol qolun anyn kohenlik et-

(11) ḿa atasy ornuna da kijsin ošol ol aq upraqlarny ol aziz

(12) upraqlarny. וכפר [33] Da bošatlyq qolsun ol aziz miqdaš ǔčün

(13) da ohel mo`ed üčün da ol mizbeah ücün bošatlyq qolsun da ol

(14) kohenĺar üčün da bar ulusu üčün ol qahalnyn bošatlyq qolsun.

(15) (34] Da bolsun bu sizǵa ömürlük resimǵa bošat-

(16) lyq qolma ulanlary üčün Jisra’elnin bar jazyqlaryndan bir keŕat

(17) jylda da qyldy barča ki nečik bujurdu Adonaj Mošeǵa.

\section{Leviticus 17}

(18) יוידבר (18) Da sözladi Adonaj Mošeǵa ajtadoġač. [2]

(19) Sözĺagin Aharonġa da ulanlaryna anyn da bar ulanlaryna Jisra’el-

(20) nin da ajtqyn alarğa budur ol söz ki bujurdu Adonaj ajta-

(21) dog̉ač. איש. [3] Nendij kiši üvünd́an Jisra’elnin ki sojsa

$188 \mathrm{r}^{\circ} \quad$ (1) ögüz jemeśa qozu jemeśa ečki avulda jemeśa ki sojsa

(2) tyšqartyn avulġa. ואל [4] Da ešigińa ohel mo'ednin keltirma-

(3) śa any juvutma qarban Adonajğa alnynda miškanynyn Adonajnyn

(4) qan tökḿak kibik saġyšlanyr ol kišiǵa qyjasa adam qanyn

(5) töktü da eksilir ol kiši ortasyndan ulusunun.

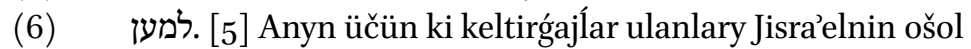

(7) debehalaryn özlarinin ki alar debeha etadilar jüzlari üstü-

(8) ńa ol tüznün da keltirsinlar alarny Adonajg̉a ešigińa

(9) ohel mo'ednin ol kohenǵa da debeḥa etsinĺar šelamim debehala-

(10) ry Adonajgga alarny. זי [6] Da bürksün ol kohen ošol

(11) ol qanny mizbeahy üstüńa Adonajnyn ešigind́a ohel

(12) mocednin da juvutsun ol javny ij qabulluqqa Adonajgia.

(13) ולא [7] Da debeha etḿasinlar artyq ošol debehalaryn öz-

(14) ĺarinin šajtanlarg̉a ki alar azadylar alar artyna ömürlük 
(9) a statute forever. [32] And the priest,

(10) whom one shall anoint and who will fill his hand to serve as a priest

(11) in his father's place shall ask for atonement and shall put on the white clothes, the holy

(12) clothes. [33] And he shall ask for atonement for the holy sanctuary,

(13) and he shall ask for atonement for the tent of meeting and for the altar, and

(14) he shall ask for atonement for the priests and for all the people of the congregation.

(15) [34] And this shall be an everlasting statute to you,

(16) to ask for atonement for the children of Israel for all their sins once

(17) a year.' And he did as the Lord commanded Moses.

Leviticus 17

(18) [1] And the Lord spoke to Moses, saying, [2]

(19) 'Speak to Aaron and to his children and to all the children of Israel,

(20) and say to them: "This is the word which the Lord has commanded,

(21) saying, [3] "Any man of the house of Israel who slaughters

(1) a cattle or a lamb or a goat in the camp, or who slaughters

(2) |it| outside the camp, [4] And if he does not bring it to the door of the tent of meeting

(3) to bring forward an offering to the Lord before the tabernacle of the Lord,

(4) bloodshed will be counted to that man, as if he shed the blood of a man,

(5) and that man will be cut off from among his people.

(6) [5] So that the children of Israel may bring

(7) their sacrifices which they offer over the surface of the

(8) fields, and that they may bring them to the Lord, to the door

(9) of the tent of meeting, to the priest, and sacrifice them for peace offerings

(10) to the Lord. [6] And the priest shall sprinkle the

(11) blood on the altar of the Lord at the door of the tent

(12) of meeting and bring forward the fat for a pleasing aroma to the Lord.

(13) [7] And they shall no more sacrifice their sacrifices to other

(14) devils, after whom they went astray. 
(15) resim bolsun bu alarg̉a dorlarysajyn. ואליהם. [8] Da alarg̉a

(16) ajtqyn nendij kiši üvünd́an Jisra’elnin da ol garipd́an ki

(17) tirilśa ortalarynda ki čyg̉arsa 'ola jemeśa debeḥa.

(18) יואל [9] Da ešigińa ohel mo'ednin keltirmaśa any qylma

(19) any Adonajgga da eksilir ol kiši uluslaryndan. ואיש. [10]

(20) Da nendij kiši üvünd́an Jisra’elnin da ol garipd́an ol tiri-

(21) lüvčü ortalarynda ki ašasa heč qanny da berirmen hyyššy-

$188 \mathrm{v}^{\circ}$ (1) mymny క̌anda ol ašavčuda ošol ol qanny da eksitirmen any

(2) כי כ11 Ki Ǩany ol etnin qandady ol

(3) da men berdim any sizǵa ol mizbeah üstüńa bošatlyq qolma

(4) Žanlaryjyz üčün ki ol qan ol žan üčün bošatlyq qolady. על. [12]

(5) Anyn üčün ajttym ulanlaryna Jisra’elnin heč žan sizdan ašamasyn

(6) qan da ol ġarip ol tirilüvčü ortajyzda ašamasyn qan.

(7) ואיש Da nendij kiši ulanlaryndan Jisra’elnin da ol garip-

(8) dan ol tirilüvčü ortajyzda ki avlasa avlamaq kijik jemeśa

(9) quš ki ašaldy da töksün ošol qanyn anyn da japsyn any

(10) topraqbyla. כ. [14] Ki క̌any bar tennin qany anyn žanyndady

(11) ol da ajttym ulanlaryna Jisra’elnin qanyn heč tennin ašamajyz

(12) ki žany bar tennin qanydyr ol har birisi ašavčularyndan

(13) eksilir. וכל [15] Da nendij žan ki ašasa qyrylġanny da

(14) jyrtylġanny j[e]rl[i $]$ da $^{1}$ da garipd́a da juvsun upraqlaryn

(15) da juvsun gufun suvbyla da murdar bolsun ol ingirǵadejin

(16) da arynyr. [16] Da eger upraqlarny juvmasa da gu-

(17) fun juvmasa da kötürür žurumun.

${ }^{1} \mathrm{~K}$ : jarlyda; a scribal error; cf. Exo 12:19, Exo 12:48, Exo 12:49, Lev 16:29, and Lev 24:16. | TKow.o1: jerlide. | H: jerlide. | C: jerli da. 
(15) This shall be a statute forever to them throughout their generations."” [8] And

(16) you shall say to them: "Any man from the house of Israel or from the strangers who

(17) live among them who offer a burnt offering or sacrifice,

(18) [9] And does not bring it to the door of the tent of meeting to make it

(19) to the Lord: that man will be cut off from among his people. [10]

(20) And if any man from the house of Israel or from the strangers who live

(21) among you eats any blood: then I will set my wrath

(1) against that soul that eats blood, and I will cut him off

(2) from among his people. [11] Because the life of the flesh is in the blood,

(3) and I have given it to you on the altar to ask for atonement

(4) for your souls, because it is the blood that askes for atonement for the soul. [12]

(5) On account of this I have said to the children of Israel: "No soul among you shall eat blood,

(6) nor shall the stranger that lives among you eat blood."

(7) [13] And any man from the children of Israel or from the strangers

(8) who live among you who hunts game, animal or

(9) bird that is eaten: he shall pour out the blood thereof and cover it

(10) with earth. [14] Because the life of all flesh is its blood: it is in the life of it.

(11) And I said to the children of Israel: "You shall not eat the blood of any flesh,

(12) because the life of all flesh is the blood of it. Every one of those who eat it

(13) will be cut off." [15] And any soul that eats that which died, or

(14) that which was torn up, whether it be [a native] ${ }^{174}$ or a stranger, he shall wash his clothes

(15) and shall wash himself in water and shall be unclean until the evening:

(16) and he will be clean. [16] But if he does not wash them or

(17) wash his flesh, then he shall bear his punishment."'

174 K: 'poor'; a scribal error; cf. Heb. בָָָּזָ 'of a native of your own country'; cf. also Exo 12:19, Exo 12:48, Exo 12:49, and Lev 16:29. 
Leviticus 18

(17) וידבר (1] Da

(18) sözladi Adonaj Mošeǵa ajtadoġač. דבר. [2] Sözĺagin ulanlary-

(19) na Jisra’elnin da ajtqyn alarg̉a men men Adonaj Tenrijiz.

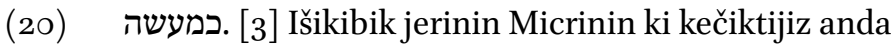

(21) qylmajyz da išikibik jerinin Kena'annyn ki men keltíramen sizni

$189 \mathrm{r}^{\mathrm{o}}$ (1) ary qylmajyz da resimlaribyla alarnyn jürümajiz. את. [4] O-

(2) Šol töŕálarimni qylyjyz da ošol resimlarimni saqlajyz jürü-

(3) ma alarbyla menmen Adonaj Tenrijiz. ושמרתם. [5] Da saqlajyz

(4) ošol resimlarimni da ošol töŕálarimni ki qylsa alarny

(5) ol adam da tiri bolady alarsartyn menmen Adonaj. איש. [6]

(6) Nendij\{d́a\} kiši bar juvug̉una gufunun juvumajyz aškartma ajip

(7) menmen Adonaj. ערות. [7] Ajipin atajnyn da ajipin anajnyn

(8) aškartmağyn anajdy ol aškartmağyn ajipin anyn. ערות. [8]

(9) Ajipin qaty\{ny\}nyn atajnyn aškartmaġyn ajipidi atajnyn ol.

(10) ערות. Ajipin tuvdug̉ujnun qyzynyn atajnyn jemeśa qyzy-

(11) nyn anajnyn tuvġannyn üvd́a jemeśa tuvġannyn tyšqaryda

(12) aškartmag̉yn ajiplarin alarnyn. ערות. [10] Ajipin qyzynyn uv-

(13) lujnun $\{[j e]$ ḿa $\}$ śa $^{1}$ qyzynyn qyzyjnyn aškartmaġyn ajiplarin alarnyn.

(14) (11] Ajipin qyzynyn qatynynyn atajnyn tuvdurganyn atajnyn

(15) tuvdug̉ujdu ol aškartmağyn ajipin anyn. ערות. [12] Ajipin

(16) tuvduğunun atajnyn aškartmaġyn juvug̉udu atajnyn ol.

(17) ערות. Aj] Ajipin tuvdug̉unun anajnyn aškartmag̉yn ki juvu-

(18) ġudu anajnyn ol. ערות. [14] Ajipin qaryndašynyn atajnyn aš-

(19) kartmag்yn qatynyna anyn juvumaġyn qatynydy dadajnyn ol.

(20) ערות [15] Ajipin kelinijnin aškartmağyn qatynydy uvluj-

${ }^{1}$ TKow.o1: jemese. | H: jemese. | C: ja. 


\section{Leviticus 18}

(18) the Lord spoke to Moses, saying, [2] 'Speak to the children

(19) of Israel, and say to them: I am the Lord your God.

(20) [3] You shall not do like what is done in the land of Egypt, wherein you stayed,

(21) and you shall not do according like what is done in the land of Canaan, to which I am bringing you.

(1) And you shall not walk by their statutes. [4]

(2) You shall do my ordinances and keep my statutes, to walk

(3) by them. I am the Lord your God. [5] You shall keep

(4) my statutes and my judgments which, if

(5) a man does them, he lives through them. I am the Lord. [6]

(6) Any man, to any close relative of his flesh: you shall not come close to uncover nakedness.

(7) I am the Lord. [7] The nakedness of your father or the nakedness of your mother:

(8) you shall not uncover it. She is your mother. You shall not uncover her nakedness. [8]

(9) You shall not uncover the nakedness of your father's wife. It is your father's nakedness.

(10) [9] The nakedness of your sister, the daughter of your father or

(11) the daughter of your mother, born home or born outside:

(12) you shall not uncover her nakedness. [10] The nakedness of your son's daughter

(13) or of your daughter's daughter: you shall not uncover their nakedness.

(14) [11] The nakedness of your father's wife's daughter born of your father:

(15) she is your sister, you shall not uncover her nakedness. [12]

(16) You shall not uncover the nakedness of your father's sister. She is your father's close relative.

(17) [13] You shall not uncover the nakedness of your mother's sister, because

(18) she is your mother's close relative. [14] You shall not uncover the nakedness of your father's brother,

(19) you shall not come close to his wife: she is the wife of your uncle.

(20) [15] You shall not uncover the nakedness of your daughter-in-law: she is your son's wife. 
(21) nun ol aškartmag̉yn ajipin anyn. ערות. [16] Ajipin qaty-

$189 \mathrm{v}^{\circ}$ (1) ערות nynyn qaryndašyjnyn aškartmag̉yn ajipidi qaryndašyjnyn ol [17]

(2) Ajipin qatynnyn da qyzynyn aškartmaġyn ošol qyzyn uvlunun da

(3) ošol qyzyn qyzynyn almag̉yn aškartmaġyn ajipin anyn juvuqtular

(4) alar jiŕanči išti ol. ואשה. [18] Da qatynny tuvdug̉u qaty-

(5) na almaġyn künd́aš etḿa aškartma ajipin anyn anyn qatyna

(6) tirlikĺarind́a anyn. ולא [19] Da qatynga jyġyslyq vaḥtyn-

(7) da murdarlyg்ynyn juvumaġyn aškartma ajipin anyn. ואל [20]

(8) Da qatynyna dostujnun bermagin jatuvujnu urluqqa murdar

(9) bolma anyn byla. [21] Da urlugiujdan bermagin ašyr-

(10) ma abaqqa da jengil etmagin atyn Tenrijnin menmen Adonaj.

(11) ואת [22] Da erḱkakbyla jatmaġyn jatuvlaryn qatynnyn jiŕanči

(12) išti ol. ובכל [23] Da heč tuvarda bermagin jatuvujnu mur-

(13) dar bolma anyn byla da qatyn turmasyn alnynda tuvarnyn qo-

(14) šulma jí́anči išti ol. אל [24] Murdar bolunmajyz bar bular-

(15) byla ki bar bularbyla murdar bolundular ol hanlyqlar ki men

(16) süramen alarny alnyjyzdan. ותטמא. [25] Da murdar boldu

(17) ol jer da saġyndym güńahin anyn anyn üstüńa da qustu

(18) ol jer özünd́an ošol olturuvčularyn özünün. ושמרתם. [26]

(19) Da saqlajyz siz ošol resimĺarimni da ošol töŕálarimni

(20) da qylmajyz bar ol jí́anči išlard́an ošpulardan ol jerli da

(21) ol garip ol tirilüvčü ortajyzda. כ2. [27] Ki ošol bar ol

$190 \mathrm{r}^{\mathrm{o}} \quad$ (1) jiŕanči išlarni ošpularny qyldylar eli ol jernin ki edilar

(2) sizdan burun da murdar boldu ol jer. ואל. [28] Da qusmasyn

(3) siznid́a ol jer ${ }_{L}\{\text { murdar etkenijizd́a any }\}^{11}$ ki nečik qustu özünd́an ošol ol ḥanlyqny ki

${ }^{1}$ Unvocalized fragment. 
(21) You shall not uncover her nakedness. [16]

(1) You shall not uncover the nakedness of your brother's wife: it is your $189 \mathrm{v}^{\circ}$ brother's nakedness. [17]

(2) You shall not uncover the nakedness of a woman and her daughter.

(3) You shall not take her son's daughter or her daughter's daughter: you shall not uncover her nakedness. They are close relatives.

(4) It is an abominable thing. [18] And you shall not take a woman to her sister

(5) to be ${ }_{\Lambda}\left[{ }^{\dagger} \text { a rival wife }\right]^{1175}$, to uncover her nakedness beside the other

(6) in their lifetime. [19] And you shall not come close to a woman

(7) in the time of her menstrual uncleanness to uncover her nakedness. [20]

(8) And you shall not give your bed to your friend's wife for offspring, to become unclean

(9) by it. [21] And you not shall let any of your children to pass

(10) to a god, and you shall not defile the name of your God. I am the Lord.

(11) [22] You shall not lie with a man like lying with a woman. It is an abominable

(12) thing. [23] And you shall not give your bed to any animal to

(13) become unclean by it, neither shall any woman stand before an animal to join

(14) with it. It is an abominable thing. [24] You shall not become unclean by all of these,

(15) because by all these the kingdoms that I

(16) am driving out before you have become unclean. [25] And the land became unclean,

(17) and I reckoned its iniquity on it, and

(18) the land itself vomits out its inhabitants. [26]

(19) But you shall keep my statutes and my judgments,

(20) and shall not do any of these abominable things, the native and

(21) the stranger that lives among you- $[27]$ Because all

(1) the people of the land who were before you did all these abominable $190 \mathrm{r}^{\circ}$ things,

(2) and the land became unclean-[28] So the land shall not vomit you out

(3) as well for your making it unclean as it vomited out the kingdom[s] that

175 An uncertain translation of kündaš, lit. 'someone who shares the day with someone'. 
(4) ediĺar sizd́an burun. כ2 [29] Ki barča kim ki qylsa bar ol

(5) jiŕanči išlard́an ošpulardan da eksilirlar ol žanlar ol

(6) qyluvčular ortasyndan uluslarynyn. ושמרתם. [30] Da saqlajyz

(7) ošol saqlavumnu qylmasqa resimĺarind́an ol jeŕanči išlar-

(8) nin ki qylyndylar sizd́an burun da murdar bolunmajyz alarbyla men

(9) men Adonaj Tenrijiz.

Leviticus 19

פרשת קדושים (10) (10)

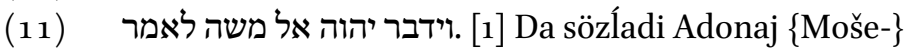

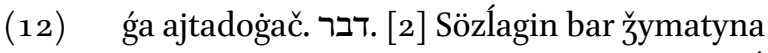

(13) ulanlarynyn Jisra’elnin da ajtqyn alargaa azizlar bolujuz ki

(14) azizdir men Adonaj Tenrijiz. איש. [3] Kiši anasyndan da ata-

(15) syndan qorqujuz da ošol šabatlarymny saqlajyz azizlikbyla

(16) tutma alarny menmen Adonaj Tenrijiz. אל. [4] Qajyrylmajyz ol

(17) hečliklarǵa da qujma abaqlar qylmajyz özüjüzǵa menmen

(18) Adonaj Tenrijiz. וכי [5] Da ki debeha etśajiz šelamim debehasy

(19) alnynda Adonajnyn qabulluqqa özüjüz üčün debeḥa etijiz

190 v $^{\circ} \quad$ (1) any. [6] Debeḥa etkan künüjüzd́a ašalsyn da tanbylada

(2) da ol qalġan ol üčüčü künǵadejin otta küvdürülsün.

(3) ואם [7 [7 Da eger ašalma ašalsa ol üčüčü künd́a bajat-

(4) ty ol qabul bolunmasty. ואכליו. [8] Da har birisi ašavču-

(5) larynda క̌urumun kötürsün ki ošol qodešin Adonajnyn jengil et-

(6) ti da eksilir ol žan uluslaryndan. ובקצרכם. [9] Da

(7) org̉anyjyzda ormaġy jerijiznin tüǵalĺaḿagin qyryjyn tüzüjnün or-

(8) ma da čöplövün ormaġyjnyn čöplááagin. וכרמך. [10] Da

(9) borlalyġyjny čirkillamáagin da tozulġan borlalyg்yjny čöplamáagin

(10) miskinǵa da ġaripǵa kemiškin alarny menmen Adonaj Tenrijiz.

(11) . לא [11] Urlamajyz da tanmajyz da aldamajyz kiši dostuna.

(12) ולא [12] Da antetmajiz atymdan jalġang̉a da jengil etarsen

(13) ošol atyn Tenrijnin menmen Adonaj. לא. [13] Zulumlamaġyn ošol 
(4) were before you. [29] Because anyone who does any

(5) of these abominable things: the souls that do them shall be cut off

(6) from among their people. [30] And you shall keep

(7) my charge not to do any one of these abominable statutes

(8) which were done before you, and you shall not become unclean by them. I

(9) am the Lord your God.'

\section{Leviticus 19}

\section{(10) Parashat Kedoshim}

(11) [1] And the Lord spoke to Moses,

(12) saying, [2] 'Speak to all the congregation

(13) of the children of Israel, and say to them, "You shall be holy: because

(14) I, the Lord your God, am holy. [3] You shall |each| man fear his mother and

(15) his father, and you shall keep my Sabbaths to keep them

(16) with holiness. I am the Lord your God. [4] Do not turn

(17) to vanities and you shall not make to yourselves molten gods. I am

(18) the Lord your God. [5] And if you do a sacrifice of peace offerings

(19) before the Lord, you shall offer it so that it will be accepted for you.

(1) [6] It shall be eaten the same day you offer it and at daybreak,

(2) and what is left until the third day shall be burned in fire.

(3) [7] And if it is eaten on the third day, it is a defilement.

(4) It shall not be accepted. [8] And everyone who eats

(5) it shall bear his punishment, because he has defiled the Holy of the Lord,

(6) and that soul shall be cut off from among his people. [9] And

(7) when you reap the harvest of your land, you shall not finish harvesting the edge of your field,

(8) and you shall not gather the gathering of your harvest. [10] And

(9) you shall not gather all fruits of your vineyard and you shall not gather the dispersed grapes.

(10) You shall leave them for the poor and the stranger. I am the Lord your God.

(11) [11] You shall not steal, and you shall not delude, and you shall not lie one to another.

(12) [12] And you shall not swear by my name falsely, so that you would not defile

(13) the name of your God. I am the Lord. [13] You shall not oppress 
(14) dostujnu da talamag̉yn qonmasyn jaly jalčynyn qatyjda tanġadejin.

(15) לא [14] Qarġamaġyn sandravny da alnynda soqurnun be\{r\}magin sü-

(16) rünč́ak \{da qorqqun Tenrijden\} menmen Adonaj. לא. [15] Qylmajyz avanlyq töŕada jüz et-

(17) ḿagin jüzlarińa jarlynyn da syjlamaġyn jüzlarin ḥožanyn rastlyq-

(18) byla töŕa etkin dostujnu. לא. [16] Jürümáagin qamazlajdog̉an

(19) ulusujda turmağyn qany üstüńa dostujnun menmen Adonaj.

(20) לא. [17] Dušman bolmaġyn qaryndašyja kölnüjda ügütlama ü-

(21) gütĺagin ošol dostujnu da kötürmagin anyn üčün žurum.

$191 \mathrm{r}^{\mathrm{o}}$ (1) לא

(2) da süvgün qylma dostuja neni süv́asen özüja menmen

(3) Adonaj. את. [19] Ošol resimlarimni saqlajyz tuvaryjny qoš-

(4) maġyn eki žyns tüzüjnü čačmaġyn eki žyns da up-

(5) raq eki žyns ša'atnez minḿasin üstüja. ואיש. [20]

(6) Da kiši ki jatsa qatyn byla jatuvun urluqnun da ol bolsa

(7) qaravaš belgilanǵan kišiǵa da julunma julunmady jemeśa azat-

(8) lyq berilmadi anar terǵav bolsun öltürülḿasinlar qačan

(9) hanuz azatlanmady. והביא. [21] Da keltirsin ošol fašmanlyq

(10) qarbanyn özünün Adonajğa ešigińa ohel mo'ednin qočqar

(11) fašmanlyq qarbanġa. וכפר [22] Da bošatlyq qolsun anyn

(12) üčün ol kohen qočqary byla ol fašmanlyq qarbannyn alnynda

(13) Adonajnyn jazyġy üčün ki jazyqly boldu da bošatylyr anar jazyġyn-

(14) dan anyn ki jazyqly boldu. וכי [23] Da ki kelśajiz ol jerǵa da

(15) ornatsajyz nendijda jemiš ag̉ačy da ajyryjyz aqlafyn anyn

(16) ošol jemišin anyn üč jyllar bolsun sizǵa aqlaflylar ašal- 
(14) your fellow, and you shall not rob. A hired worker's wages shall not stay with you until the morning.

(15) [14] You shall not curse the deaf, and you shall not put an obstacle before the blind.

(16) And you shall fear your God. I am the Lord. [15] You shall do no injustice in judgement.

(17) You shall not favour the poor, and you shall not favour the rich.

(18) You shall judge your fellow with justice. [16] You shall not walk as a slanderer

(19) among your people. You shall not stand by at your fellow's blood. I am the Lord.

(20) [17] You shall not be an enemy to your brother in your heart.

(21) You shall surely rebuke your fellow, so you shall not bear sin because of him.

(1) [18] You shall not take revenge, and you shall not hate the people of your people.

(2) ${ }_{L}$ And you shall love doing to your fellow that which you |would| love |to be done| to you ${ }^{176}$. I am

(3) the Lord. [19] You shall keep my statutes. Your livestock:

(4) you shall not mate two kinds. Your field: you shall not sow two kinds. And

(5) a garment of two kinds, shaatnez: it shall not go on you. [20]

(6) And if a man lies with a woman - an intercourse of seed-and she is

(7) a maidservant designated to a man and she has not been redeemed at all, or freedom

(8) has not been given to her: there shall be an investigation. They shall not be killed as

(9) she was not free yet. [21] And he shall bring his guilt

(10) offering to the Lord, to the door of the tent of meeting: a ram

(11) for a guilt offering. [22] And the priest shall ask for atonement for him

(12) with the ram of the guilt offering before

(13) the Lord for his sin which he has sinned, and it will be forgiven for him from his sin

(14) that he sinned. [23] And when you come to the land and

(15) plant all manner of fruit trees, you shall separate the foreskin

(16) of the fruit. It shall be uncircumcised for three years for you. It shall not be eaten.

${ }_{176}$ Interpretative translation. 
(17) masyn. ובשנה. [24] Da ol dörtünčü jylda bolsun bar jemi-

(18) Ši anyn aziz maḥtavlar Adonajğa. ובשנה [25] Da ol bešinči

(19) jylda ašajyz ošol jemišin anyn arttyrma sizǵa bitišin

(20) anyn menmen Adonaj Tenrijiz. לא. [26] Ašamajyz ol qanbyla synčy-

(21) lamajyz da sahatny sajlamajyz. לא. [27] Čüvŕa julumajyz qyryjyn bašyjyz-

$191 \mathrm{v}^{\mathrm{o}}$ (1) nyn da čajpa $\{m\}$ aġyn ošol qyryjyn sag̉alyjnyn. [28] Da čyzuv

(2) క̌anüčün bermajiz gufujuzda da belgili čyzmaq bermajiz

(3) özüjüzd́a menmen Adonaj. לא. [29] Jengil etmagin qyzyjny

(4) azg்yrma any da azmasyn eli ol jernin da tolar ol jer

(5) jiŕanči išlard́an. [30] Ošol šabatlarymny saqlajyz azizlik-

(6) ta tutma alarny da $\{\mathrm{m}\}$ iqdašymdan qorqujuz menmen Adonaj.

(7) אל [31] Qajyrylmajyz ol qamlarg̉a da ol bild́ačilarǵa izlaḿajiz

(8) murdar bolma alarbyla menmen Adonaj Tenrijiz. מפני. [32]

(9) Alnyndan pir kišinin turğun da syjlag̉yn jüzlarin qartnyn da

(10) qorqqun Tenrijd́an menmen Adonaj. וכי [3] Da ki tirilśa

(11) birǵaja ġarip jerijizd́a munajtmajyz any. כאזרח [34] Jerli

(12) kibik sizd́an bolsun sizǵa ol gaarip ol tirilüvčü ortajyz-

(13) da da süvgün qylma anar neni ki süv́asen özüja ki garip-

(14) lar edijiz jerind́a Micrinin menmen Adonaj Tenrijiz. לא. [35]

(15) Qylmajyz avanlyq kečinḿaklik nerśalard́a bürtük ölčü-

(16) vünd́a kümüšs ölčüvünd́a da jüvüš ölčüvd́a.

(17) מאזני (36] Rast tarazuvbyla \{rast tašlar\} bolsun kümüš ölč́amakḱa da

(18) rast efa bolsun bürtük ölč́aḿakḱa da rast hin bolsun

(19) sizǵa suvsun ölč́aḿakḱa menmen Adonaj Tenrijiz ki čyğardym

(20) sizni jerind́an Micrinin. ושמרתם [37 Da saqlajyz ošol bar resim-

(21) ĺarimni da ošol bar törálarimni da qylyjyz alarny menmen Adonaj. 
(17) [24] But in the fourth year all the fruit thereof shall be

(18) holy, praises for the Lord. [25] And in the fifth

(19) year shall you eat of its fruit, to increase its yield for you.

(20) I am the Lord your God. [26] You shall not eat with the blood, you shall not |practice| divination,

(21) and you shall not tell fortune. [27] You shall not shave around your head's edge,

(1) and you shall not destroy the edges of your beard. [28] And you shall $191 \mathrm{~V}^{\mathrm{o}}$ not draw a line

(2) in your flesh for a $|\mathrm{dead}|$ soul and you shall not draw marks

(3) on you. I am the Lord. [29] Do not defile your daughter

(4) to make her a prostitute, so that the people of the land will not fall into prostitution and the land will not become full of

(5) abominable things. [30] You shall keep my Sabbaths to reverence

(6) them, and fear my sanctuary. I am the Lord.

(7) [31] Do not turn to wizards and do not seek the soothsayers,

(8) to become unclean by them. I am the Lord your God. [32]

(9) You shall get up before an aged person, and you shall honour the face of the old man, and

(10) you shall fear your God. I am the Lord. [33] And if

(11) a stranger resides with you in your land, you shall not torment him. [34]

(12) The stranger that resides among you shall be to you as one of your own land

(13) and Lou shall love doing to him what you |would| love |to be done| to you ${ }^{1177}$, for you were strangers

(14) in the land of Egypt. I am the Lord your God. [35]

(15) You shall not do an injustice in things you do: in grain measures,

(16) in silver measures, and in wet measures.

(17) [36] There shall be just stones with just scales for measuring silver, and

(18) there shall be a just ephah for measuring grain, and you shall have a just hin

(19) for measuring drinks. I am the Lord your God, who brought you out

(20) from the land of Egypt. [37] And you shall keep all my statutes

(21) and all my judgments, and do them. I am the Lord."'

177 Interpretative translation. 
$192 \mathrm{r}^{\mathrm{o}}$ Leviticus 20

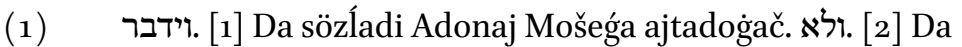

(2) ulanlaryna Jisra’elnin ajtqyn nendij kiši ulanlaryndan Jisra-

(3) 'elnin da ol garipd́an ol tirilüvčü Jisra’eld́a ki berśa

(4) urluggundan özüjnün abaqqa ölḿa öltürülsün ulusu

(5) ol jernin tašlasynlar any tašbyla. ואני. [3] Da men berirmen

(6) ošol hyššymymny ol kišid́a da eksitirmen any

(7) ortasyndan ulusunun ki urluğundan özüjnün berdi

(8) abaqqa murdar etḿak üčün ošol miqdašymny da jengil

(9) etḿa ošol aziz atymny. ואם. [4] Da eger jumma

(10) jumsalar ulusu ol jernin ošol közĺarin ol kišid́an berǵa-

(11) nind́a urlug̉undan abaqqa öltürmasḱa any. ושמתי [5]

(12) Da qo[ja]rmen ${ }^{1}$ men ošol hyššymymny ol kišid́a da uru-

(13) vunda anyn da eksitirmen any da ošol bar ol a[z]uv-

(14) čularnyn ${ }^{2}$ anyn artyna azma qulluğu artyna ol abaqnyn or-

(15) tasyndan uluslarynyn. והנפש. [6] Da ol žan ki qajyrylsa

(16) ol qamlarğa da ol bildačilarǵa azma alar artyna da

(17) berirmen ošol ḥyššymymny ol žanda da eksitirmen

(18) any ortasyndan ulusunun. והתקדשתם. [7 Da azizĺanijiz

(19) da bolujuz azizĺar ki menmen Adonaj Tenrijiz. ושמרתם. [8] Da

(20) saqlajyz ošol resimlarimni da qylyjyz alarny menmen Adonaj

(21) aziz etüvčü sizni. כי [9] Ki nendijd́a kiši qarğasa

$192 \mathrm{~V}^{\mathrm{o}} \quad$ (1) ošol atasyn jemeśa ošol anasyn ölḿa öltürülsün atasyn

(2) jemeśa anasyn qarğady ullu jazyq qyldy qanlary anyn bašyna. ואיש. [10]

(3) Da kiši ki n[i]'ufluq ${ }^{3}$ etśa qatynybyla kišinin ki ni’ufluq et-

(4) śa qatynybyla dostunun ölḿa ötürülsün ol ni’ufluq

(5) etüvčü kiši da ol ni’ufluq etüvčü qatyn. ואיש. [11] Da

(6) kiši ki jatsa qatyny byla atasynyn ajipin atasynyn aškartty

(7) ölḿa öltürülsünlar eksilarid́a qanlary alarnyn bašla-

(8) ryna. ואיש [12] Da kiši ki jatsa kelinibyla ölḿa öltü-

(9) rülsünĺar eksilarid́a jiŕanči iš qyldylar qanlary alarnyn

(10) bašlaryna. ואיש. [13] Da kiši ki jatsa erkakbyla jatuv-

(11) laryn qatynnyn jiŕanči iš qyldylar eksilarida ölḿa öl-

\footnotetext{
${ }^{1}$ TKow.o1: qojarmen; unvocalized text. | H: qojarmen. | C: qojarmyn. $\quad{ }^{2}$ TKow.o1: azuvčularny; unvocalized text. | H: azuvcularnyn. | C: azġanlarny. $\quad{ }^{3} \mathrm{~K}$ : ne’ufluq; a scribal error. | TKow.o1: unvocalized text. | H: ni'ufluq. | C: no'eflik.
} 
(1) [1] And the Lord spoke to Moses, saying, [2] 'And

(2) to the children of Israel you shall say: "Any man from the children

(3) of Israel or from the strangers that resides in Israel who gives

(4) any of his seed to an idol shall surely be put to death. The people

(5) of the land shall stone him with stones. [3] And I will set

(6) my wrath against that man and will cut him off

(7) from among his people, because he has given of his own seed

(8) to an idol, so as to make my sanctuary unclean and to defile

(9) my holy name. [4] And if

(10) the people of the land do in any way close their eyes from the man,

(11) when he gives of his seed to and idol, not to kill him, [5]

(12) Then I will set my wrath against that man and against his family

(13) and will cut off him and all who prostitute themselves

(14) after him, to prostitute themselves after the service of that god,

(15) from among their people. [6] And the soul that turns

(16) after wizards and soothsayers, to prostitute themselves after them:

(17) I will set my wrath against that soul and will cut him off

(18) from among his people. [7] And you shall sanctify yourselves,

(19) and you shall be holy: because I am the Lord your God. [8] And

(20) you shall keep my statutes and do them. I am the Lord

(21) who sanctifies you. [9] Because any man that curses

(1) his father or his mother shall be surely put to death.

(2) He has cursed his father or his mother, he has committed a great sin, his blood is on his head. [10]

(3) And the man who commits adultery with a man's wife, who commits adultery

(4) with his fellow's wife, shall be surely put to death: the adulterer

(5) and the adulteress. [11] And

(6) the man who lies with his father's wife has uncovered his father's nakedness:

(7) both of them shall surely be put to death. Their blood is on their heads.

(8) [12] And a man who lies with his daughter-in-law: the two of them shall surely be put to death.

(9) They have done an abominable thing, their blood is on

(10) their heads. [13] And a man who lies with a man like lying

(11) with a woman: the two of them have done an abominable thing. They shall 
(12) türülsünĺar qanlary alarnyn bašlaryna. ואיש. [14] Da kiši

(13) ki alsa ošol qatynny da ošol anasyn anyn jiŕanči išti

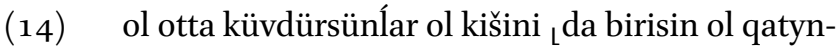

(15) lardan qajsyn alsa sondrada ${ }^{11}$ da bolmasyn jiŕanči iš orta-

(16) jyzda. ואיש [15] Da kiši ki berśa jatuvun tuvar[ $\left[\right.$ g] $\mathrm{a}^{2}$ ölḿa

(17) öltürülsün da ošol ol tuvarnyda öltürüjüz.

(18) [16 Da qatyn ki juvsa nendijda tuvarg̉a qošulma

(19) anyn byla da öltürgün ošol ol qatynny da ošol ol tuvar-

(20) nyda ölḿa öltürülsünlar qanlary alarnyn bašlaryna.

(21) ואיש [17 Da kiši ki alsa ošol tuvdugun qyzyn atasynyn

$193 \mathrm{r}^{\circ} \quad$ (1) jemeśa qyzyn anasynyn da körśa ošol ajipin anyn da olda

(2) körśa ošol ajipin anyn rusvajlyqty ol da eksilsinlar

(3) közlarič́a elinin ulusunun özlarinin ajipin tuvdug̉unun

(4) aškartty ullu jiŕanči iš qyldy žurumun kötürsün.

(5) (18] Da kiši ki jatsa ḥasta jyg̉ys qatyn byla da aškart-

(6) sa ošol ajipin anyn ošol čoġaraġyn anyn ačty da ol qatyn

(7) özüda aškartty ošol čog̉arag̉yn qanlarynyn da eksilsin-

(8) Íar eksilarid́a ortasyndan uluslarynyn. וערות [19] Da

(9) ajipin tuvdug̉unun anajnyn da tuvdug̉unun atajnyn aškart-

(10) mag̉yn kim ki bundij iš qylsa ajipin juvug̉unun aškartty

(11) ל̌urumlaryn kötürsünĺar. ואיש. [20] Da kiši ki jatsa

(12) tötasibyla ki ol qatynydy d́ad́asinin ajipin dedesinin aš-

(13) kartty ǰurumlaryn kötürsünlar jalġyzlar³ ölsünlar.

(14) ישיש [21] Da kiši ki alsa ošol qatynyn qaryndašynyn murdar-

(15) lyqty ol ajipin qaryndašynyn aškartty jalġyzlar ${ }^{4}$ bolsunlar.

(16) [22] Da saqlajyz ošol bar resimlarimni da ošol

\footnotetext{
${ }^{1}$ Interpretative addition to the standard text. $\quad{ }^{2} \mathrm{~K}$ : tuvarda; a scribal error. | TKow.o1: tuvarda; unvocalized text. |H: tuvarda.|C: tuvarga. $\quad{ }^{3}$ A mistranslation, cf. Lev 20:21. | TKow.o1: jalgyzlar; unvocalized text. | H: ulanlarsyz. | C: mährümler. | M: mährümler. | E: mahrimlär. | R: jalg̀yzlar. | Heb. עִרְרירִ 'childless'. ${ }^{4}$ A mistranslation, cf. Lev 20:20. | TKow.o1: jalgyzlar; unvocalized text. |

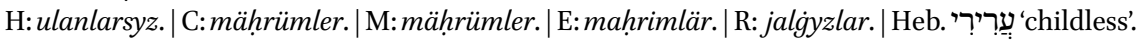


(12) surely be put to death, their blood is on their heads. [14] And a man

(13) who takes a wife and her mother: it is an abominable thing.

(14) They shall be burned with fire, he ${ }_{L}$ and one of the women:

(15) the one which he took later ${ }^{1178}$, so there shall be no abomination

(16) among you. [15] And a man who gives his bed to an animal:

(17) he shall surely be put to death, and you shall kill the animal as well.

(18) [16] And a woman who approaches any animal to join

(19) with it: you shall kill the woman and the animal.

(20) They shall surely be put to death, their blood is on their heads.

(21) [17] And a man who takes his sister, his father's daughter

(1) or his mother's daughter, and sees her nakedness, and she, too,

(2) sees his nakedness: it is a disgrace. And the two of them shall be cut off

(3) in the sight of their own people: he has uncovered his sister's nakedness,

(4) he has done a very abominable thing, he shall bear his punishment.

(5) [18] And a man who lies with an impure woman having her sickness and uncovers

(6) her nakedness: he has exposed her fountain, and the woman

(7) herself has uncovered the fountain of her blood as well. And

(8) both of them shall be cut off from among their people. [19] And

(9) you shall not uncover the nakedness of your mother's sister or of your father's sister:

(10) the one who does such a thing, uncovers his nearest.

(11) They shall bear their punishment. [20] And a man who lies

(12) with his aunt, who is the wife of is uncle: he has uncovered his uncle's nakedness.

(13) They shall bear their punishment: they shall die lonely ${ }^{179}$.

(14) [21] And a man who takes his brother's wife:

(15) it is an unclean thing. He has uncovered his brother's nakedness; they shall be lonely ${ }^{180}$.

(16) [22] And you shall keep all my statutes and

178 An interpretative addition to Lev 20:14.

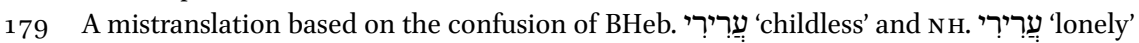
(Koehler \& Baumgartner 1985: 735; Klein 1987: 486). Translated correctly in H, C, M and E. See also Lev 20:21.

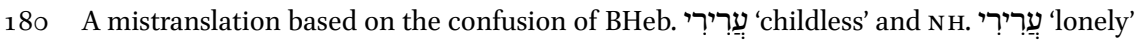
(Koehler \& Baumgartner 1985: 735; Klein 1987: 486). Translated correctly in H, C, M and E. See also Lev 20:20. 
(17) bar töŕálarimni da qylyjyz alarny da qusmasyn sizni ol jer

(18) özü üstünd́an ki men keltí́amen sizni ary olturma

(19) anda. ולא [23] Da jürümajiz resimĺari byla ol hanlyqnyn ki

(20) men süŕamen alnyjyzdan ki ošol bar bu jiŕanči išlarni qyldylar

(21) da bezdim alardan. ואומר [24] Da ajttym sizǵa siz me-

$193 \mathrm{~V}^{\circ} \quad$ (1) ŕaślajiz ošol jerin alarnyn da men berirmen any sizǵa mérasĺa-

(2) ḿa any jer ag̉adoġan süt da bal menmen Adonaj Tenrijiz ki ajyr-

(3) dym sizni ol uluslardan. [25] Da ajyryjyz arasyna

(4) ol aruv tuvarnyn murdar byla da arasyna ol murdar quš-

(5) nun aruv byla da jiŕanči etḿajiz ošol క̌a $\{n\}$ laryjyzny tuvarbyla

(6) da qušbyla da barybyla neki tebŕańadi ol jer üstüńa

(7) ki ajyrdym sizǵa murdar etḿa. [26] Da bolujuz

(8) maja azizlar ki azizdir men Adonaj da ajyrdym sizni ol

(9) uluslardan bolma maja. ואיש [27 Da kiši jemeśa qatyn ki bol-

(10) sa alarda qam jemeśa bild́ači ölḿa öltürülsünĺar

(11) tašbyla tašlasynlar alarny qanlary alarnyn bašlaryna.

Leviticus 21

פרשת אמור אל הכהנים (12) (12)

(13) [1] Da

(14) ajtty Adonaj Mošeǵa ajtqyn ol kohenlarǵa

(15) ulanlaryna Aharonnun da ajtqyn alarg̉a žanüčün murdar bol-

(16) masyn kohen uluslarynda. כי. [2] Ki ančaq juvug̉u üčün ol

(17) juvuq\{qa\} anar anasy üčün da atasy üčün da uvlu üčün da

(18) qyzy üčün da qaryndašy üčün. ולאחתו. [3] Da tuvduġu ü-

(19) čün ol boj qyz üčün ol juvuqraq anar ki jog̉edi er artyna

$194 \mathrm{r}^{\mathrm{o}} \quad$ (1) anyn üčün murdar bolsun. לא. [4] Murdar bolunmasyn kohen ulus-

(2) larynda jengil bolunma. [5] Julqmasynlar julquv bašlarynda

(3) da qyryjyn sagallarynyn julumasynlar da guflarynda čyzmasyn-

(4) lar čyzmaq. קדושים. [6] Azizlar bolsunlar Tenrisińa öz- 
(17) all my judgments and do them, and the land

(18) to which I am bringing you to dwell in it shall not vomit you out.

(19) [23] And you shall not walk by the statutes of the kingdom which

(20) I am driving out before you, because they have done all these abominable things,

(21) and I abhorred them. [24] And I have said to you: You

(1) shall inherit their land, and I will give it to you to inherit

(2) it, a land flowing |with $\mid$ milk and honey. I am the Lord your God, who

(3) has separated you from the peoples. [25] You shall make a distinction between

(4) the clean animal and the unclean, and between the unclean bird

(5) and the clean. And you shall not make your souls abominable by animal

(6) or by bird or by all that moves on the ground

(7) which I have separated for you to pronounce it unclean. [26] And you shall be

(8) holy to me, because I, the Lord, am holy and have separated you

(9) from the peoples to be mine. [27] And a man or woman: if there is

(10) among them a wizard or a soothsayer, they shall surely be put to death.

(11) They shall be stoned with stones, their blood is on their heads."'

Leviticus 21

(12) Parashat Emor

(13) [1] And

(14) the Lord said to Moses, 'Speak to the priests,

(15) the sons of Aaron, and say to them, "A priest shall not become unclean for a soul

(16) among his people. [2] But only for his nearest,

(17) who is near to him: for his mother, and for his father, and for his son, and

(18) for his daughter, and for his brother, [3] And for his sister,

(19) the virgin, who is nearest to him, who has not been a husband's:

(1) he may become unclean for her. [4] The priest shall not become unclean

(2) among his people, to defile himself. [5] They shall not make any bald place on their head,

(3) and they shall not shave off the edge of their beard and they shall draw no lines in their flesh.

(4) [6] They shall be holy to their God, 
(5) ĺarinin da jengil etmaasinlar atyn Tenrisinin özĺarinin

(6) ki ošol otlu qarbanlaryn Adonajnyn ötḿagin Tenrisinin öz-

(7) Ílarinin alar juvutadylar da bolsunlar aziz. אשה. [7 Zona

(8) qatynny da jengil bašlyny almasynlar da qatynny sürülǵanni

(9) erind́an almasynlar ki azizdi ol Tenrisińa özünün.

(10) (8] Da azizlikta tutqun any ki ošol qarbannyn

(11) Tenrijnin ol juvutady aziz bolsun saja ki azizdir men Adonaj

(12) aziz etüvčü sizni. ובת. [9] Da qyzy kohen kišinin ki jengil

(13) bolsa azma ošol atasyn ol jengil etadi otta küv-

(14) dürülsün. [והכהן [10] Da ol kohen ag̉araq qaryndašlaryn-

(15) dan ki qujulsa bašy üstüńa anyn ol jaġynmaq javy da

(16) toltursa ošol qolun anyn kijḿa ošol ol upraqlarny

(17) ošol bašyn ačmasyn da upraqlaryn sökḿasin. ועל [11] Da heč

(18) ölü క̌anlar qatyna kelmasin atasy üčün da anasy üčün

(19) murdar bolunmasyn. [12] Da ol miqdaštan čyqmasyn da

(20) jengil etmáasin ošol miqdašyn Tenrisinin ki tačy jag̉ynmaq javynyn

(21) Tenrisinin anyn üstüńa menmen Adonaj. וזהוא. [13] Da ol

$194 \mathrm{~V}^{\mathrm{o}}$ (1) kohen gadol qatynny bojluqlarybyla alsyn. אלמנה. [14] Tulnu da

(2) sürülǵanni erind́an da jengil bašlyny zonany ošol bularny alma-

(3) syn ki ančaq boj qyzny uluslaryndan özünün alsyn qatyn. ולא . [15]

(4) Da jengil etḿasin urlug̉un özünün uluslarynda ki menmen

(5) Adonaj aziz etüvčü any. וידבר. [16] Da sözladi Adonaj Moše-

(6) ǵ ga ajtadog̀ač. דבר. [17] Sözlagin Aharonġa ajtadoġač nendij

(7) kiši urlug̉ujdan dorlarysajyn ki bolsa anda ajip juvmasyn

(8) juvutma qarbanyn öz Tenri\{si\}nin. כי בי [18] Ki nendij kiši ki anda

(9) ajip juvumasyn soqur kiši jemeśa aqsaq jemeśa eksik

(10) buvunlu jemeśa artyg̉ač buvunlu. או [19] Jemeśa kiši ki bol-

(11) sa anda synyq ajaq jemeśa synyq qol. או. [20] Jemeśa

(12) bükrü jemeśa uvaq jemeśa belma közünd́a jemeśa 
(5) they shall not defile the name of their God,

(6) because they bring forward the offerings of the Lord made by fire, the bread of their God,

(7) and they shall be holy. [7]

(8) They shall not take a wife that is a harlot or with defiled head.

(9) And they shall not take a woman divorced from her husband, because he is holy to his God.

(10) [8] You shall regard him as holy, because he brings forward the offering

(11) of your God. He shall be holy to you, because I, the Lord,

(12) who sanctifies you, am holy. [9] And the daughter of a priest: if she becomes defiled,

(13) to prostitute, she defiles her father. She shall be burned in fire.

(14) [10] And the one who is the superior priest among his brothers

(15) on whose head the anointing oil was poured and

(16) whose hand was filled to put on the garments,

(17) shall not uncover his head and shall no rip his clothes, [11] And

(18) shall not come to any dead soul, he shall not become unclean for his father or for his mother.

(19) [12] And he shall go out of the sanctuary, and

(20) he shall not defile the sanctuary of his God, because the crown of the anointing oil

(21) of his God is on him. I am the Lord. [13] And the

(1) High Priest shall take a wife in her virginity. [14] A widow

(2) or a woman divorced from her husband or defiled headed harlot: he shall not take these,

(3) but he shall only take a virgin of his own people for a wife. [15]

(4) He shall not defile his offspring among his people, because I am

(5) the Lord who sanctifies him."' [16] And the Lord spoke to Moses,

(6) saying, [17] 'Speak to Aaron, saying, "Any

(7) man of your offspring throughout their generations that has any blemish shall not come near

(8) to bring forward the offering of his God. [18] Because any man in whom is a

(9) blemish shall not come near: a blind man or lame or the one who has any limb too short

(10) or the one who has any limb too long, [19] Or a man that has

(11) a broken leg or a broken hand, [20] Or

(12) a hunchbacked or a dwarfed or |with| a cataract in his eye or 
(13) quršanġy jemeśa qynġyrajg̉an jemeśa šiškan ajipli.

(14) כל [21] Nendijda kiši ki anda ajip urlug̉undan Aharonnun ol

(15) kohennin juvumasyn juvutma ošol otlu qarbanlaryn Adonajnyn ajip

(16) anda ošol qarbanyn Tenrisinin juvmasyn juvutma. לחם [22] Öt-

(17) ḿagin Tenrisinin qodešlarind́an ol qadašimnin da ol qadašimtan

(18) ašasyn. אך] [23] Tek ol parohetḱka kelḿasin da ol mizbeaḥa

(19) juvmasyn ki ajip anda da jengil etmáasin ošol miqdašlarymny

(20) ki menmen Adonaj aziz etüvčü alarny. [24] Da sözladi

(21) Moše Aharonġa da uvullaryna anyn da bar ulanlaryna Jisra'elnin.

$195 \mathrm{r}^{\mathrm{o}} \quad$ Leviticus 22

(1) (1) Da sözladi Adonaj Mošeǵa ajtadoġač. (2] Sözlagin

(2) Aharonga da uvullaryna anyn da ajyrylsynlar qodešlarind́an ulanla-

(3) rynyn Jisra’elnin da jengil etmasinlar osol aziz atymny ki alar

(4) aziz etadilar maja men men Adonaj. אמור. [3] Ajtqyn alarg்a

(5) dorlaryjyzsajyn nendij kiši ki juvusa urlug̉ujuzdan ol qadašimǵa ki

(6) aziz etśalar ulanlary Jisra’elnin Adonajğa da murdarlyg்y anyn bol-

(7) sa anyn üstüńa da eksilir ol žan alnymdan menmen Adonaj.

(8) [4 Nendij kiši urlug̉undan Aharonnun ol bolsa cara'at-

(9) ly jemeśa zavly qadašimd́an ašamasyn neginča ki arynġaj da ol

(10) tijüvčü bar murdar క̌anlyğa jemeśa \{kiši $\}$ ki čyqsa andan tamčysy

(11) urluqnun. [5] Jemeśa kiši ki tijśa nendijd́a qomuz-

(12) ga ki murdar bolady anynbyla jemeśa adamġa ki murdar

(13) bolady anyn byla bar murdarlyġysajyn. נפש. [6] Šan ki tijsa

(14) anar da murdar bolsun ol ingirǵadejin da ašamasyn ol qada- 
(13) [ ['swollen $]^{181}$ or distorted or of swollen nakedness.

(14) [21] Any man that has a blemish from the offspring of Aaron, the

(15) priest, shall come near to bring forward the offerings of the Lord made by fire. He has a blemish,

(16) he shall not come near to bring forward the offering of his God. [22]

(17) He shall eat the bread of his God from the holy of holies and from the holies.

(18) [23] Just: he shall come to the veil and he shall

(19) not come near to the altar, because he has a blemish. And he shall not defile my sanctuaries,

(20) because I am the Lord who sanctifies them."' [24] And

(21) Moses spoke to Aaron and to his sons and to all the children of Israel.

Leviticus 22

(1) [1] And the Lord spoke to Moses, saying, [2] 'Speak

(2) to Aaron and to his sons, that they separate themselves from the holy things

(3) of the children of Israel, so that they do not defile my holy name in those things which they

(4) hallow to me. I am the Lord. [3] Say to them,

(5) "Throughout your generations, any man who will come close, from your offspring, to the holy things that

(6) the children of Israel hallow to the Lord and the uncleanness

(7) is on him: that soul shall be cut off from before me. I am the Lord.

(8) [4] Any man from the offspring of Aaron who is a leper

(9) or has a discharge: he shall not eat of the holy things until he is clean. And the

(10) one who touches anyone with a defiled soul or a man from whom a drop of semen comes out,

(11) [5] Or any man who touches any moving thing

(12) by which he may become unclean, or a man by whom

(13) he may become unclean, whatever his uncleanness: [6] The soul who touches

(14) him shall be unclean until evening, and shall not eat of the holy things,

181 An uncertain translation of quršangiy, cf. BHeb. הָָָּ 'eczema and swell of the skin'. Cf. Lev 22:22. 
(15) Šimd́an ki ančaq juvsa gufu suvbyla. ובא [7 [7 Da enśa

(16) ol qujaš da arynyr da andan sortun ašasyn ol qadašimtán

(17) ki ötḿagidi anyn ol. נבלה [8] Qyrylġanny da jyrtylġanny

(18) ašamasyn murdar bolma anyn byla menmen Adonaj. ושמרו. [9]

(19) Da saqlasynlar ošol saqlavumnu da kötürḿasinĺar anyn ü-

(20) čün žurumun jazyqnyn da ölarlar anyn üčün ki jengil etśa-

(21) lar any menmen Adonaj aziz etüvčü alarny. וכל [10] Da

$195 \mathrm{~V}^{\text {o }} \quad$ (1) heč jat kiši ašamasyn qodešni očary kohennin da jalčy ašamasyn

(2) qodešni. וכהן. [11] Da kohen ki satyn alsa satynalmaġyn kümüšü-

(3) nün ol ašasyn andan da tuvġany üvünün alar ašasynlar öt-

(4) magind́an anyn. ובת [12] Da qyzy kohennin bolsa jat kiši ar-

(5) tyna ol terumasyndan ol qadašimnin ašamasyn. [13] Da

(6) qyzy kohen\{nin\} ki bolsa tul da sürülǵan da urluq bolmasa anar da

(7) qajtsa üvüńa atasynyn jašlyqlarynda kibik ötmagind́an

(8) atasynyn ašasyn da heč jat ašamasyn andan. [14] Da kiši

(9) ki ašasa qodešni janġylyšlyqbyla da arttyrsyn bešinči ülü-

(10) šün anyn üstüńa da bersin kohenǵa ošol ol qodešni. ולא [15]

(11) Da jengil etḿasinĺar ošol qodešlarin ulanlarynyn Jisra’elnin o-

(12) šol neki ajyrsalar Adonajg̀a. והשיאו. [16] Da kötürsünlar

(13) özĺari özĺarińa žurumun fašmanlyqnyn ašaġanlarynda ošol

(14) qodešlarin alarnyn ki menmen Adonaj aziz etüvčü alarny. [17]

(15) Da sözladi Adonaj Mošeǵa ajtadoġač. דבר. [18] Sözlagin Aharon-

(16) ga da uvullaryna anyn da bar ulanlaryna Jisra’el\{nin\} da ajtqyn alar-

(17) ġa nendij kiši üvünd́an Jisra’elnin da ol garipd́an Jisra’el-

(18) da ki juvutsa qarbanyn özünün bar nijetlarisajyn da bar žomartlyq-

(19) larysajyn alarnyn ki juvutsalar Adonajg̉a 'olagaa. לרצונכם. [19]

(20) Qabulluqqa özüjüzüčün tüǵal erḱkakni syġyrda qozularda

(21) da ečkilard́a. כל. [20] Barča neki ${ }_{\text {L }}$ anda ajip ${ }^{11}$ juvutmajyz

$196 \mathrm{r}^{\mathrm{o}}$ (1) ki bolmasty qabulluqqa siznin üčün. [21] Da kišsi ki juvut-

(2) sa šelamim debehasy Adonajg̉a ajyrma nijet jemeśa žomart-

\footnotetext{
${ }^{1} \mathrm{~K}$ : Originally ajip anda; the word order was corrected by the copyist.
} 
(15) unless he washes his body with water. [7] And when the sun goes down,

(16) he will be clean and after that shall eat of the holy things,

(17) because it is his food. [8] He shall not eat |an animal| which died or was torn up,

(18) to defile himself by it. I am the Lord. [9]

(19) They shall keep my charge so they will not bear

(20) the punishment of the sin for it and die therefore, if they defile

(21) it. I am the Lord who sanctifies them. [10] And

(1) any stranger shall not eat the holy thing: a settler of the priest or a hired servant shall not eat

(2) the holy thing. [11] But if the priest buys |a person| with his silver:

(3) he may eat of it; and the one who is born in his house: they

(4) may eat of his bread. [12] But if the priest's daughter becomes a stranger's,

(5) she may not eat of the heave offering of the holy things. [13] But

(6) if the priest's daughter is a widow or divorced and has no offspring and

(7) returns to her father's house as in her youth,

(8) she shall eat of her father's bread. But any stranger shall not eat of it. [14] And a man

(9) who eats of a holy thing by mistake shall add the fifth part of it

(10) to it and shall give it to the priest the holy thing. [15]

(11) And they shall not defile the holy things of the children of Israel

(12) which they separate for the Lord. [16] And they shall bear,

(13) they themselves, the punishment for the guilt when they eat

(14) their holy things. For I am the Lord who sanctifies them."' [17]

(15) And the Lord spoke to Moses, saying, [18] 'Speak to Aaron,

(16) and to his sons and to all the children of Israel, and say to them,

(17) "Any man from the house of Israel or of the strangers in Israel

(18) who will bring forward his offering-for all his vows and for all his freewill offerings

(19) which they will bring forward to the Lord for a burnt offering - [19]

(20) For acceptance for you: |it is to be| an unblemished male of the cattle, of the lambs,

(21) or of the goats. [20] You shall not offer everything that has a blemish,

(1) because it will be not accepted for you. [21] And a man who brings $196 \mathrm{r}^{\circ}$ forward

(2) a sacrifice of peace offerings to the Lord to dedicate his vow or a freewill offering 
(3) lyqqa syġyrda jemeśa qojda tüǵal bolsun qabulluqqa heč

(4) ajip bolmasyn anda. עורת. [22] Soqurnu jemeśa synġan-

(5) ny jemeśa kesilǵanni jemeśa belmalyny jemeśa quršanġy-

(6) ny jemeśa qynġyrajg̉anny juvutmajyz bularny Adonajğa da

(7) otlu qarban bermejiz alardan ol mizbeah üstüńa Adonajġa.

(8) ושור [23] Da ögüznü da qojnu artyg̉ač buvunlunu da čub-

(9) rajġanny žomartlyq qylġyn any da nijetḱa qabul bolunmasty.

(10) [ומעוך [24] Da ezilǵanni da jančylg̉anny da üzülǵanni da

(11) kesilǵanni juvutmajyz Adonajğa da jerijizd́a qylmajyz.

(12) ומדי [25] Da qolundan jat kišinin juvutmajyz ošol qarbannyn Ten-

(13) rijiznin bar bulardan ki čajpalmaqlary alarnyn alarda ajip alar-

(14) da qabul bolmaslar siznin üčün. [26] Da sözladi

(15) Adonaj Mošeǵa ajtadoġač. שור. [27] Ögüz jemeśa qozu

(16) jemeśa ečki ki tuvsa da bolsun jedi künlar anasy

(17) qatyna da ol segizinči ${ }_{\perp}$ künd́a $\{n \text { da arraq }\}^{11}$ qabul bolur siznin üčün

(18) juvutma any otlu qarban Adonajgga. ושור. [28] Da ögüznü

(19) jemeśa qojnu any da ošol balasyn anyn sojmajyz bir kün-

(20) da [29] Da ki debeha etśajiz šükürlük debehasy Adonaj-

(21) ga qabulluq[q]a² özüjüz üčün debeha etijiz. ביום [30] Ol

$196 \mathrm{~V}^{\mathrm{o}}$ (1) künd́a ašalsyn qaldyrmajyz andan tanġadejin menmen Adonaj. ושמרתם [31]

(2) Da saqlajyz micvalarymny da qylyjyz alarny menmen Adonaj. ולא. [32] Da

(3) jengil etḿajiz ošol aziz atymny da azizligim qotarylsyn or-

(4) tasynda ulanlarynyn Jisra’elnin menmen Adonaj aziz etüvčü sizni.

(5) המוציא [33] Ol čygaruvču sizni jerind́an Micrinin bolma siz-

(6) ǵa Tenriǵa menmen Adonaj.

Leviticus 23

(7) Mošeǵa ajtadoġač. דבר. [2] Sözĺagin ulanlaryna Jisra’el-

\footnotetext{
${ }^{1}$ Interlinear insertion by another hand. | TKow.o1: künden da arraq; unvocalized text. | H: kinden da arraq. | C: kündän [da] ary. ${ }^{2} \mathrm{~K}$ : qabuluqa; a scribal error.
} 
(3) in cattle or sheep: it shall be unblemished to be accepted.

(4) There shall be no blemish in it. [22] Blind or broken

(5) or slashed or having a cataract or [ ${ }^{\dagger}$ swollen $]^{182}$

(6) or distorted: you shall not bring forward these to the Lord and

(7) you shall not give an offering by fire of them on the altar to the Lord.

(8) [23] And a bull or a lamb that has a limb too long or [ ${ }^{\dagger}$ stunted $]^{183}$ :

(9) you may make it a freewill offering, but for a vow it shall not be accepted.

(10) [24] And that which is [ ${ }^{\dagger}$ smashed $]^{184}$ or crushed or torn

(11) or slashed: you shall not bring it forward to the Lord. And you shall not do it in your land.

(12) [25] And from a stranger's hand you shall not bring forward an offering of your God

(13) of any of these, because their defect is in them, a blemish is in them;

(14) they will not be accepted for you."' [26] And the Lord spoke

(15) to Moses, saying, [27] 'If a bull or a lamb

(16) or a goat is born, then it shall be seven days with its mother,

(17) and from the eighth day \{and thereafter $\}$ it will be accepted for you

(18) to bring it forward as an offering by fire to the Lord. [28] And a bull

(19) or a sheep: you shall not slaughter it and its young on the same day.

(20) [29] And when you will offer a sacrifice of thanksgiving to the Lord,

(21) you shall offer it for your own acceptance. [30]

(1) On that day it shall be eaten. Do not leave any of it until morning. I $196 \mathrm{v}^{\mathrm{o}}$ am the Lord. [31]

(2) And you shall keep my commandments and do them. I am the Lord. [32] And

(3) you shall not defile my holy name, and my holiness shall be preached

(4) among the children of Israel. I am the Lord who sanctifies you,

(5) [33] Who brought you out from the land of Egypt to be

(6) God to you. I am the Lord.'

Leviticus 23

(7) to Moses, saying, [2] 'Speak to the children of Israel,

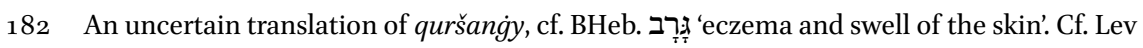
21:20.

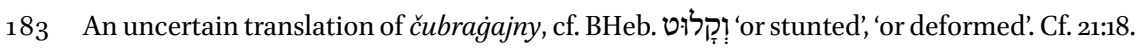

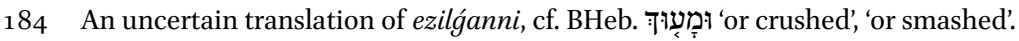


(8) nin da ajtqyn alargaa mo`edĺarin Adonajnyn ki ünd́ajiz alarny

(9) aziz ünd́almüšlar bulardylar alar mo'edĺarim. ששת. [3]

(10) Alty künĺard́a qylynsyn iš da ol jedinči künd́a šabat

(11) šabaton aziz ünd́almiš heč iš qylmajyz šabatty \{ol\} Adonajğa

(12) bar olturušlaryjyzda. אלה. [4 Bulardylar mo'edĺari Adonaj-

(13) nyn aziz ünd́almüšĺar ki ündajiz alarny vag̉dalarynda alarnyn.

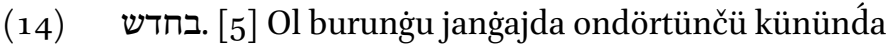

(15) janġajnyn ol eki ingirlar arasyna qarbany Pesaḥnyn Adonaj-

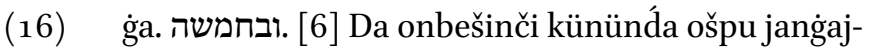

(17) nyn hyy̌̌y ol macalarnyn Adonajg̉a jedi künĺar macalar ašajyz.

(18) [7 [7 Ol burunġu künd́a aziz ünd́almiš bolsun siz-

(19) ǵa heč qulluq iši qylmajyz. והקרבתם. [8] Da juvutujuz

(20) otlu qarban Adonajg̉a jedi künlar ol jedinči künd́a aziz

(21) ünd́almiš heč qulluq iš qylmajyz. וידבר. [9] Da sözladi

$197 \mathrm{r}^{\circ} \quad$ (1) Adonaj Mošeǵa ajtadoġač. דבר. [10] Sözĺagin ulanlaryna Jisra-

(2) 'elnin da ajtqyn alarg̉a ki kelśajiz ol jerǵa ki men beŕamen

(3) sizǵa da orsajyz ošol ormaġyn anyn da keltirijiz ošol

(4) kültasin bašlyġynyn ormaġyjyznyn ol kohenǵa. והניף. [11] Da

(5) sunsun ošol ol kült́ani alnynda Adonajnyn qabulluqqa siz-

(6) nin üčün tanbylasyndan ol šabatnyn sunsun any ol kohen.

(7) ועשיתם [12] Da qylyjyz sunġan künüjüzd́a ošol ol külta-

(8) ni qozu tüǵal jyllyq balasy 'olag̉a Adonajg̉a. ומנחתו. [13]

(9) Da tirkisi anyn eki 'esronlar öźak jumurulġan javby-

(10) la otlu qarban Adonajgia ij qabulluq da neseḩi anyn čaġyr

(11) dörtünčü ülüšü ol hinnin. ולחם [14] Da ötḿak

(12) da ütḱan kolos da kurpa ašamajyz kensisińa dejin ošpu

(13) künnün keltirǵanijizǵadejin ošol qarbanyn Tenrijiznin ömür-

(14) lük resimdi dorlaryjyzsajyn bar olturušlaryjyzda.

(15) וספרתם [15] Da sanajyz özüjüzǵa tanbylasyndan ol šabatnyn

(16) keltirǵan künüjüzd́an ošol kültasin ol tenufanyn jedi 
(8) and say to them, "The feasts of the Lord, which you shall call

(9) holy convocations: these are my feasts. [3]

(10) Six days shall work be done, but in the seventh day is a Sabbath,

(11) the day of complete rest, a holy convocation. You not do any work. It is a Sabbath to the Lord

(12) in all your dwelling places. [4] These are the feasts of the Lord,

(13) the holy convocations, which you shall proclaim in their appointed times:

(14) [5] In the first month, on the fourteenth day

(15) of the month, at twilight, is the offering of the Passover to the Lord.

(16) [6] And on the fifteenth day of the same month

(17) is the feast of unleavened bread to the Lord. You shall eat unleavened bread seven days.

(18) [7] In the first day you shall have a holy convocation:

(19) you shall not do any slave labour on it. [8] And you shall bring forward

(20) an offering by fire to the Lord seven days. In the seventh day is a holy

(21) convocation: you shall not do any slave labour on it."' [9] And the Lord spoke

(1) to Moses, saying, [10] 'Speak to the children of Israel,

(2) and say to them, "When you will come to the land which I am giving

(3) to you and you shall reap its harvest, you shall bring

(4) the sheaf of the beginning of your harvest to the priest. [11] And

(5) he shall elevate the sheaf before the Lord, to be accepted for you.

(6) The priest shall elevate it the next day after Sabbath.

(7) [12] And that day when you elevate the sheaf you shall do

(8) an unblemished one-year-old lamb for a burnt offering to the Lord. [13]

(9) And its grain offering shall be two-tenths |of a measure $\mid$ of fine |flour $\mid$ mixed with oil,

(10) an offering by fire to the Lord, a pleasing aroma. And its drink offering shall be wine,

(11) the fourth part of a hin. [14] And

(12) you shall not eat bread or parched ear of grain or groats until that very same

(13) day that you have brought an offering for your God. It is an eternal

(14) statute throughout your generations in all your dwelling places.

(15) [15] And you shall count to you from the day after the Sabbath,

(16) from the day that you brought the sheaf of the wave offering: seven 
(17) šabatlar tügallar bolsunlar. עד. [16] Tanbylasynadejin ol

(18) jedinči šabatnyn sanajyz enli kün da juvutujuz janğy tirki

(19) Adonajg̉a. ממושבתיכם. [17] Olturušlaryjyzdan keltirijiz

(20) ötḿagin tenufanyn ekini eki 'esronlardan öźak bolsun-

(21) lar hamec biširilsinlar bikurim Adonajğa ${ }_{L}$ ki oldu jetilma-

$197 \mathrm{~V}^{\mathrm{o}}$ (1) gi budajlarnyn ${ }^{11}$. והקרבתם. [18] Da juvutujuz ol ötḿakqa-

(2) tyna jedi qozular tüǵalĺar jyllyq balalary da tana balasy syġyrnyn

(3) birni da qočqarlar ekini bolsunlar 'ola Adonajg̈a da tir-

(4) kilari alarnyn da nesehllari alarnyn otlu qarban ij qabulluq

(5) Adonajgia. ועשיתם] [19] Da qylyjyz ulaġyn ečkilarnin birni

(6) hatatqa da eki qozular jyllyq balalary šelamim debehasyna.

(7) והניף Da sunsun ol kohen alarny ötmagibyla ol bikurim-

(8) nin tenufa alnynda Adonajnyn eki qozular byla qodeš bolsun-

(9) וקראתם. Iar Adonajga ka kändajiz kensisin

(10) ošpu künnün aziz ünd́almiš bolsun sizǵa heč qulluq

(11) iš qylmajyz ömürlük resim bar olturušlaryjyzda dorla-

(12) ryjyzsajyn. ובקצרכם [22] Da org̉anyjyzda ošol ormaġyn

(13) jerijiznin tüǵallááagin qyryjyn tüzüjnün organyjda da čöp-

(14) lövün ormağyjnyn čöplamagin miskinǵa da garipǵa kemiš-

(15) kin alarny menmen Adonaj Tenrijiz. וידבר. [23] Da sözladi

(16) Adonaj Mošeǵa ajtadog̉ač. דבר. [24] Sözĺagin ulanlaryna Jis-

(17) ra’elnin ajtadoġač ol jedinči jang̉ajda burunġu kününd́a

(18) jang̉ajnyn bolsun sizǵa šabaton sag̉ynčy maḥtavnyn aziz ün-

(19) dalmiš. כל. [25] Heč qulluq iš qylmajyz da juvutujuz ot-

\footnotetext{
${ }^{1}$ Interpretative addition to the standard text.
} 
(17) Sabbaths shall be complete. [16] You shall count until the day after the

(18) seventh Sabbath fifty days and you shall bring forward a new grain offering

(19) to the Lord. [17] You shall bring from your dwelling places

(20) two breads for the wave offering. They shall be of two-tenths |of a measure| of fine flour,

(21) they shall be baked leavened, they are the firstfruits to the Lord, L because that is the ripeness

(1) of wheat ${ }^{7185}$. [18] And you shall bring forward with the bread

(2) seven unblemished one-year-old lambs and one calf, the young of cattle,

(3) and two rams. They shall be for a burnt offering to the Lord with

(4) their grain offering and their drink offerings, an offering by fire, a pleasing aroma

(5) to the Lord. [19] And you shall do one kid of the goats

(6) for a sin offering and two one-year-old lambs for a sacrifice of peace offerings.

(7) [20] And the priest shall elevate them with the bread of the firstfruits

(8) for a wave offering before the Lord with the two lambs. They shall be holy

(9) to the Lord for the priest. [21] And you shall proclaim on the same

(10) day that it may be a holy convocation to you. You shall not do any duty

(11) work. It shall be an eternal statute for you in all your dwelling places throughout your generations.

(12) [22] And when you reap the harvest

(13) of your land, you shall not finish harvesting the edge of your field and

(14) you shall not gather the gathering of your harvest: you shall leave them for the poor and for the stranger.

(15) I am the Lord your God."' [23] And the Lord spoke

(16) to Moses, saying, [24] 'Speak to the children

(17) of Israel, saying, "In the seventh month, on the first day

(18) of the month you shall have day of complete rest, a memorial of praise,

(19) a holy convocation. [25] You shall not do any slave labour on it, and you shall bring forward

185 An interpretative addition to Lev 23:17. 
(20) lu qarban Adonajġa. [26] Da sözladi Adonaj Mošeǵa

(21) ajtadoġač. אך. [27] Tek onunču kü\{nü\}nd́a ol jedinči janġaj-

$198 \mathrm{r}^{\circ} \quad$ (1) nyn ošpu künü ol kipurimnin ol aziz ünd́almüš bolsun

(2) sizǵa da qyjnajyz oruč byla ošol క̌anlaryjyzny da juvutujuz

(3) otlu qarban Adonajg̉a. וכל [28] Da heč \{iš\} qylmajyz kensisind́a

(4) ošpu künnün ki künüdü ol kipurim $\{$ nin $\}$ ol bošatlyq qolma

(5) siznin üčün alnynda \{Adonaj\} Tenrijiznin. כי. [29] Ki bar ol క̌an ki

(6) oruč byla qyjnalmasa kensisind́a ošpu künnün da ek-

(7) וכל [30] Da bar ol žan ki qylsa heč

(8) iš kensisind́a ošpu künnün da tasetarmen ošol ol

(9) כ̌anny ortasyndan ulusnun. [3] [31] Heč iš qylmajyz ö-

(10) mürlük resim dorlaryjyz sajyn bar olturušlaryjyzda.

(11) שבת (32] Šabat šabatondur ol sizǵa da qyjnajyz oručby-

(12) la ošol క̌anlaryjyzny t $[0]$ ġuzunču ${ }^{1}$ kününd́a janġajnyn in-

(13) gird́a ingirdan ingirǵadejin šabat tutujuz ošol

(14) šabatyjyzny. [33] Da sözladi Adonaj Mošeǵa aj-

(15) tadoġač. דבר (34] Sözĺagin ulanlaryna Jisra’elnin ajta-

(16) doġač onbešinči kününd́a ol jedinči janġajnyn ošpu

(17) hyžy ol Sukotnun jedi künlar Adonajg̉a. ב35] Ol

(18) burunġu künd́a aziz ünd́almüš heč qulluq iši qylmajyz.

(19) שבעת (36] Jedi künlar juvutujuz otlu qarban Adonajg̉a

(20) ol segizinči künd́a aziz ünd́almüš bolsun sizǵa da

(21) juvutujuz otlu qarban Adonajğa 'aceretti ol heč qulluq iš

$198 \mathrm{~V}^{\circ}$ (1) qylmajyz. אלה. [37] Bulardylar mo'edĺari Adonajnyn ki ünd́ajiz

(2) alarny aziz ünd́almüšlar juvutma otlu qarban Adonajğa 'ola da tirki

(3) debeḥa da neseḩlar kemin künnün kününd́a. מלבד. [38] Bašqa šabat-

(4) laryndan Adonajnyn da bašqa berńalarijizd́an da bašqa bar nijetlarijiz-

(5) dan da bašqa bar క̌omartlyqlaryjyzdan ki berśajiz Adonajgja. אך. [39]

(6) Tek onbešinči kününd́a ol jedinči janġajnyn jyštyrganyjyz-

${ }^{1} \mathrm{~K}$ : tuġuzunču; a scribal error. | TKow.o1: unvocalized text. | H: tog்uzuncu. | C: toquzunda. 
(20) an offering by fire to the Lord."' [26] And the Lord spoke to Moses,

(21) saying, [27] Just: on the tenth day of this seventh month,

(1) it is the day of atonement. There shall be a holy convocation

(2) to you, and you shall afflict your souls with a fast. And you shall bring forward

(3) an offering by fire to the Lord. [28] And you shall not do any work on that very same day,

(4) because it is a day of atonement, to ask for atonement

(5) for you before the Lord your God. [29] Because any soul who

(6) will not be afflicted with a fast on this very same day

(7) will be cut off from among his people. [30] And any soul who does any

(8) work on that very same day: I will destroy that

(9) soul from among his people. [31] You shall not do any work:

(10) an eternal statute throughout your generations in all your dwelling places.

(11) [32] It is a Sabbath, a day of complete of rest, for you, and you shall afflict

(12) your souls with fast: on the ninth day of the month

(13) at evening, from evening to evening, shall you keep

(14) your Sabbath."' [33] And the Lord spoke to Moses,

(15) saying, [34] 'Speak to the children of Israel, saying,

(16) "On the fifteenth day of this seventh month

(17) is the feast of Sukkot, seven days to the Lord. [35]

(18) On the first day is a holy convocation. You shall not do any slave labour.

(19) [36] For seven days you shall bring forward an offering by fire to the Lord.

(20) On the eighth day there shall be a holy convocation to you

(21) and you shall bring forward an offering by fire to the Lord. It is a solemn assembly, you shall not do any slave labour.

(1) [37] These are the feasts of the Lord, which you shall proclaim

(2) to be holy convocations, to offer an offering by fire to the Lord, a burnt offering, and a grain offering,

(3) a sacrifice, and drink offerings, each day's |thing| on its day, [38] Besides the Sabbaths

(4) of the Lord, and besides your gifts, and besides all your vows,

(5) and besides all your freewill offerings which you give to the Lord. [39]

(6) Just: On the fifteenth day of the seventh month, when you have gathered in 
(7) da ošol bitišin ol jernin hyyžlajyz ošol hyyžyn Adonajnyn jedi kün-

(8) lar ol burunğu künd́a šabaton da ol segizinči künd́a

(9) šabaton. [40] Da alyjyz özüjüzǵa burun ol burunġu

(10) künd́an ${ }_{\text {L }}$ sukot išĺamakḱka ${ }^{11}\langle$ butağyn $\rangle\{$ jemišin\} syjly ag̉ačnyn japraqlaryn

(11) $\quad \mathrm{h}[\mathrm{u}] \mathrm{rma}$ teŕakĺarinin ${ }^{12}$ da butag̉yn bazyq ag̉ačyn da tallaryn öźan-

(12) nin da bijanijiz alnynda Adonaj Tenrijiznin jedi künlar. וחגתם [41]

(13) Da hyy̌llajyz any hyy̌̌ Adonajğa jedi künlar jylda ömürlük re-

(14) sim dorlaryjyz sajyn ol jedinči jangaajda hyy̌̌lajyz any. בסכות. [42]

(15) Sukotta olturujuz jedi künĺar bar ol jerli Jisra’eld́a ol-

(16) tursunlar sukotta. למען [43] Anyn üčün ki bilǵajlar dorla-

(17) ryjyz ki sukotta olturg̉uzdum ošol ulanlaryn Jisra’elnin čyġarg̉anym-

(18) da alarny jerind́an Micrinin menmen Adonaj _Tenrisi alarnyn ${ }^{13}$.

(19) יוידבר [46] Da sözĺadi Moše ošol mo'edĺarin Adonajnyn ulanla-

(20) ryna Jisra'elnin.

Leviticus 24

וידבר Da sözladi Adonaj Mošeǵa ajtadoġač.

(21) צו [2] Bujurğun ulanlaryna Jisra’elnin da alsynlar saja zejtun

$199 \mathrm{r}^{\circ} \quad$ (1) javy aruvnu jančqanny jaryqlyqqa jandyrma čyraq hammeš́a.

(2) מ [3 ] Tyšqartyn parohetińa ol šarajatnyn ohel mocedd́a

(3) qyjaslasyn any Aharon ki jetḱaj ingird́an tanġadejin alnynda Adonaj-

(4) nyn hammeš́a ömürlük resim dorla[r]yjyzsajyn 4. על [4] Ol

(5) aruv čyraqba üstüńa tüzüsün ošol ol čyraqla $\{r\}$ ny alnyn-

(6) da Adonajnyn hammeš́a. [5 [5 [5 Da alğyn öźak da

(7) biširgin any on eki hạalalar ekš́ar isarondan bolsun ol

(8) bir hala. ושמת [6] Da qojğun any eki tüzüvlar altyšar

(9) hala bolsun ol bir tüzüvd́a ol aruv stol üstüńa

(10) alnynda Adonajnyn. [7] Da bergin ol tüzüv üstü-

\footnotetext{
${ }^{1}$ Interpretative addition to the standard text. $\quad{ }^{2} \mathrm{~K}$ : harma teraklarinin; a scribal error. | TKow.o1: hurma tereklerinin; unvocalized text. | H: hurma tereklerinin. | C: hurmalarnyy. $\quad{ }^{3}$ Probably a mistranslation, cf., however, Exo 29:46. | TKow.o1: Tenrijiz; unvocalized text. | H: Tenriniz siznin. | C: Tänriniz.| Heb. אֵלהֶיכֶ 'you God'. ${ }^{4}$ K: dorlasyjyzsajyn; a scribal error. | TKow.o1: dorlaryjyzsajyn; unvocalized text. | H: dorlaryjyzsajyn. | C: dävirlärinizgä.
} 
(7) the produce of the land, you shall celebrate a feast of the Lord seven days.

(8) On the first day is a day of complete rest and on the eighth day is

(9) a day of complete rest. [40] And before the first day you shall take for yourself,

(10) ${ }_{L}$ in order to make the booths ${ }^{7186}$, the fruit of splendid trees, the leaves

(11) of palm trees, and the boughs of thick trees, and willows of the river,

(12) and you shall rejoice before the Lord your God seven days. [41]

(13) And you shall celebrate it, a feast to the Lord, seven days in the year, an eternal statute

(14) through your generations. You shall celebrate it in the seventh month. [42]

(15) You shall dwell in booths seven days. All native Israelites

(16) shall dwell in booths, [43] So that your generations may know

(17) that I made the children of Israel to dwell in booths when I brought them out

(18) from the land of Egypt. I am the Lord [their God 1187."'

(19) [44] And Moses spoke the feasts of the Lord to the children

(20) of Israel.

Leviticus 24

[1] And the Lord spoke to Moses, saying,

(21) [2] 'Command the children of Israel, that they bring to you pure beaten olive oil

(1) for the light, to keep the candle burning continually.

(2) [3] Outside the veil of the law, in the tent of meeting,

(3) Aaron shall prepare it from the evening until morning before the Lord

(4) always, an eternal statute through your generations. [4]

(5) He shall arrange the candles on the pure lampstand before

(6) the Lord always. [5] And you shall take fine flour and

(7) bake twelve cakes of it: each cake shall be two-tenth |of a measure|.

(8) [6] And you shall set them in two rows, six

(9) cake shall be on a row, on the pure gold table

(10) before the Lord. [7] And you shall put

186 An uncertain translation of sukot išlamakka, an interpretative addition to Lev 23:40.

187 Possibly a mistranslation, cf. Heb. אלקלהיכֶ 'you God'. Cf., however, e.g. Exo 29:46. 
(11) ńa aruv levona da bolsun ötḿakḱa tütüǵa otlu qarban

(12) Adonajḡa. \{ביום. [8]\} Har šabat kününd́a har šabat kününd́a tüzü-

(13) sün any alnynda Adonajnyn hammeš́a

(14) arasyna tütatkanind́an sortun ol tütünü da jandyryp

(15) sortun ol čyraqlarny ki bolġaj issi qojulġan vahtynda ${ }^{11} \ddot{o}^{-}$

(16) mürlük šertti qylma bunu ulanlaryndan Jisra’elnin. ${ }^{2}$. [9] [9]

(17) Da bolsun bu ötḿak Aharonġa da uvullaryna anyn da aša-

(18) synlar any ol künd́a aziz orunda ki qodeš qadašimdir

(19) ol anar otlu qarbanlaryndan Adonajnyn ömürlük resim. יויצא [10]

(20) Da čyqty uvlu Jisra’elka qatynnyn da ol edi uvlu Micrili kiši-

(21) nin ortasynda ulanlarynyn Jisra’elnin da uruštular avulda

199 v $^{0}$ (1) uvlu ol Jisra’elkanyn da ol Jisra’el kiši. ויקב. [11] Da belgila-

(2) di ${ }^{3}$ uvlu ol Jisra’elka qatynnyn ošol atyn ol Tenrinin da qargady

(3) da keltirdilar any Mošeǵa da aty anasynyn Šelomit qyzy Divri-

(4) nin ševetind́an Dannyn. ויניחהו. [12] Da qojdular any saqlavda

(5) belgirtmáa alarg̉a ${ }_{\perp}$ nendij ölüm byla öltürńa any ${ }^{14}$ buj-

(6) ruğu byla Adonajnyn. וידבר [13] Da sözladi Adonaj Mošeǵa aj-

(7) tadoġač. הוצא. [14] Čyġarg̉yn ošol ol qarg̉avčunu tyšqartyn avul-

(8) ga da sunsunlar bar ol ešitüvčülar ošol qollaryn bašy

(9) üstüńa anyn da tašbyla tašlasynlar any bar ol žymat.

(10) ואל [15] Da ulanlaryna Jisra’elnin sözlagin ajtadoġač nendij

(11) kiši ki qarg̉asa Tenrisin da kötürsün žurumun. [16]

(12) Da belgilavčü ${ }^{5}$ atyn Adonajnyn ölḿa öltürülsün tašbyla

\footnotetext{
${ }^{1}$ Interpretative addition to the standard text. $\quad{ }^{2}$ Heb. repeated in a number of manuscripts, cf. also Lev 24:16.|TKow.o1: belgiladi; this word is vocalized.

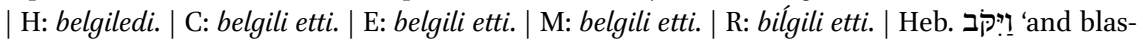
phemed'. $\quad{ }^{4}$ Interpretative addition to the standard text. ${ }^{5}$ Possibly a mistranslation repeated in a number of manuscripts, cf. also Lev 24:11. | TKow.o1: belgilevčü; unvocalized text. | H: bel-

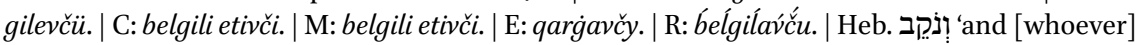
blasphemes'.
} 
(11) pure frankincense on $\mid$ each $\mid$ row, and it shall be for an incense for the bread, an offering by fire

(12) to the Lord. [8] On every Sabbath day, on every Sabbath day, he shall arrange

(13) it before the Lord always, _at twilight,

(14) after burning the incense and after lighting

(15) the candles, so that it is hot at the moment it is placed down ${ }^{1188}$,

(16) to make it an eternal statute from the children of Israel. [9]

(17) And this bread shall be Aaron's and his sons', and

(18) they shall eat it that day in the holy place, because it is the holy of holies

(19) to him from the offerings by fire of the Lord, an eternal statute.' [10]

(20) And a son of an Israelite woman - and he was a son of an Egyptian man-

(21) went out among the children of Israel, and

(1) the son of the Israelite woman and an Israelite man fought in the camp. [11] And

(2) the Israelite woman's son specified ${ }^{189}$ the name of the Lord and cursed.

(3) And they brought him to Moses. And his mother's name was Shelomith, daughter of Dibri,

(4) of the tribe of Dan. [12] And they put him under guard,

(5) to determine it for them, L by what kind of death to kill him ${ }^{7190}$

(6) by the Lord's command. [13] And the Lord spoke to Moses,

(7) saying, [14] 'Bring out the one who cursed to the outside of the camp

(8) and let all who heard him stretch out their hands over his head,

(9) and all the congregation shall stone him.

(10) [15] And you shall speak to the children of Israel, saying, "Any

(11) man who curses his God shall bear his punishment. [16]

(12) And the one who specifies ${ }^{191}$ the name of the Lord, shall surely be put to death.

188 An interpretative addition to Lev 24:8.

189 A mistranslation based on the confusion of Heb. נויְיקב 'and blasphemed' in the text) with Heb. נקב 'to specify, to mention' repeated in a number of manuscripts. Cf. Lev 24:16.

190 An interpretative addition to Lev 24:12.

191 A mistranslation based on the confusion of Heb. נקבב 'to curse, to blaspheme' (Heb. וְנְקבב 'and [whoever] blasphemes' in the text) with Heb. נקב 'to specify, to mention' repeated in a number of manuscripts. Translated correctly in E. Cf. Lev 24:11. 
(13) tašlasynlar any bar ol క̌ymat nečik garip alaj $\mathrm{j}[\mathrm{e}] \mathrm{rl}[\mathrm{i}]^{1}$ belgilaǵanin-

(14) da² atyn Tenrinin öltürülsün. ואיש. [17] Da kiši ki öl-

(15) türśa nendijda క̌anyn adamnyn ölḿa öltürülsün.

(16) ומכה (18] Da öltürüvčü žanyn [tuvar]nyn ${ }^{3}$ tölasin anyn üčün

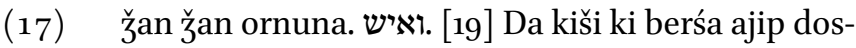

(18) tunda ki nečik qyldy alaj qylynsyn anar. שבר. [20] Synyqlyq

(19) synyqlyq ornuna köz köz ornuna tiš tiš ornuna ki

(20) nečik berśa ajip adamda alaj berilsin andada. ומכה. [21]

(21) Da öltürüvčü tuvarny tölasin anyn üčün da öltürüvčü

$200 \mathrm{r}^{\mathrm{o}}$ (1) adamny öltürülsün. [חפפט. [22] Bir töŕa bolsun sizǵa

(2) nečik garipǵa alaj jerliǵa bolsun ki menmen Adonaj Tenrijiz.

(3) וידבר (23] Da sözladi Moše ulanlaryna Jisra’elnin da čyġardy-

(4) lar ošol ol qargiavčunu tyšqartyn avulg̀a da tašladylar

(5) any tašbyla da ulanlary Jisra’elnin qyldylar ki nečik bujurdu

(6) Adonaj Mošeǵa.

Leviticus 25

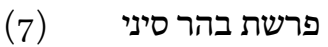

(1] Da sözladi Adonaj

(9) Mošeǵa tavynda Sinajnyn ajtadoġač. דבר. [2]

(10) Sözlagin ulanlaryna Jisra’elnin da ajtqyn alarg̉a ki kelśajiz

(11) ol jerǵa ki men beŕamen any sizǵa da šabat tutsun ol

(12) jer šabat Adonajgia. שש. [3] Alty jyllar čačqyn tüzüjnü

(13) da alty jyllar butağyn borlalyġyjny da jyštyrg̉yn ošol bitišin

(14) anyn. ובשנה. [4] Da ol jedinči jylda šabat šabaton bolsun jer-

(15) ǵa šabat Adonajğa tüzüjnü čačmag̉yn da borlalyğyjny

(16) butamaġyn. [5] [5 Ošol özünd́an bitkanin ormaġyjnyn or-

\footnotetext{
${ }^{1} \mathrm{~K}$ : jarly; a scribal error; cf. Exo 12:19, Exo 12:48, Exo 12:49, Lev 16:29, and Lev 17:15. | TKow.o1: unvocalized text. | H: jerli. | C: jerli. ${ }^{2}$ Possibly a mistranslation repeated in a number of manuscripts, cf. also Lev 24:11. | TKow.o1: belgilegeninde; unvocalized text. | H: belgilegeninde. |

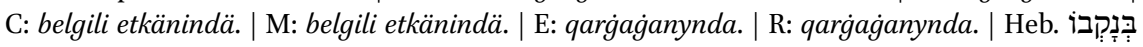
'when he blasphemes'. $\quad{ }^{3}$ TKow.o1: tuvarny; unvocalized text, different wording. | H: tuvarnyn. | C: tuvarnyy.
} 
(13) All the congregation shall stone him: as well the stranger as the native: when he specifies ${ }^{192}$

(14) the name of the Lord, he shall be put to death. [17] And a man who kills

(15) any man's life shall surely be put to death.

(16) [18] And one who kills an animal's life shall pay for it:

(17) a life for a life. [19] And a man who causes a blemish in his fellow:

(18) as he has done, so shall it be done to him. [20] Fracture

(19) for fracture, eye for eye, tooth for tooth:

(20) as he has caused a blemish in a man, so shall it be done to him, too. [21]

(21) And one who kills an animal shall pay for it, and one who kills

(1) a man shall be put to death. [22] You shall have one judgement,

(2) its shall be as well for the stranger, as for the native, because I am the Lord your God."'

(3) [23] And Moses spoke to the children of Israel. And they brought out

(4) the one who had cursed to the outside of the camp and stoned him

(5) with stones. And the children of Israel did as the Lord commanded

(6) Moses.

Leviticus 25

(7) Parashat Behar

(8) [1] And the Lord spoke

(9) to Moses on Mount Sinai, saying, [2]

(10) 'Speak to the children of Israel, and say to them, "When you come

(11) to the land which I give you, then the land shall keep a Sabbath

(12) for the Lord. [3] Six years you shall sow your field,

(13) and six years you shall prune your vineyard, and you shall gather its produce.

(14) [4] And in the seventh year shall be a Sabbath of complete rest to the land,

(15) a Sabbath for the Lord: you shall not sow your field and

(16) you shall not prune your vineyard. [5] That which grows of its own accord of your harvest you shall not reap,

192 A בּנְנקבבוֹ 'when he blasphemes' in the text) with Heb. נקב 'to specify, to mention' repeated in a number of manuscripts. Translated correctly in E, and R. Cf. Lev 24:11. 
(17) mag்yn da ošol tozulġan borlalyg்yjny jyštyrmaġyn šabaton jyly bol-

(18) sun jerǵa. והיתה. [6] Da bolsun šabaty ol jernin sizǵa jemǵa

(19) saja da quluja da qaravašyja da jalčyja da očaryja ol

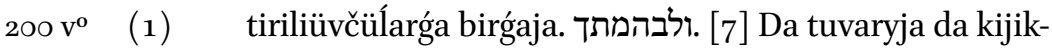

(2) ka ki jerijd́a bolsun bar bitiši anyn ašama. וספרת [8] Da

(3) sanağyn özüja jedi šabatlaryn jyllarnyn jedi jyllar jedi keŕatlar

(4) da bolurlar saja künĺari jedi šabatlarynyn ol jyllarnyn qyrq tog̉uz

(5) jyl. והעברת. [9] Da ašyrg̈yn qyčqyrmaqbyla šofar avazy

(6) ol jedinči janġajda onunču kününd́a janġajnyn ol kipurim

(7) kününd́a ašyryjyz šofar avazy bar jerijizd́a. וקדשתם. [10]

(8) Da aziz tutujuz ošol jylyn ol enlinči jylnyn da čaġyryjyz

(9) azatlyq jerd́a bar olturuvčularyna anyn joveldir ol bolsun

(10) sizǵa azatlyq da qajtyjyz har kiši tutuvlug̉una da har kiši

(11) uruvuna qajtyjyz. יובל. [11] Joveldi ol jyly ol enlinči jylnyn

(12) bolsun sizǵa čačmajyz da ormajyz ošol özünd́an bitkan-

(13) ĺarin anyn da jyštyrmajyz ošol tozulġanlaryn anyn. כי [12]

(14) Jovel jylydy ol aziz bolsun sizǵa ol tüzd́an ašajyz ošol

(15) bitišin anyn. בשנת. [13] Jylynda ol jovelnin ošpu qajtyjyz har

(16) kiši öz tutuvluğuna. [14] Da ki satsajyz satmaq

(17) dostuja jemeśa satyn alma satyn alsajyz qolundan dos-

(18) tujnun munajtmajyz kiši ošol qaryndašyn özü $\{n \ddot{\}}\}$.

(19) [15] Sanybyla jyllarnyn ol joveld́an sortun satyn alġyn

(20) dostujdan sanybyla jyllarynyn bitišlarnin satsyn saja. לפי [16]

(21) Köplügüńa köŕa ol jyllarnyn arttyrg̉yn bahasyn satyn alma-

$201 \mathrm{r}^{\mathrm{o}} \quad$ (1) gंynyn da azlyg்yna köŕa ol jyllarnyn az etkin bahasyn satyn

(2) almaġynyn ki sanybyla bitišlarnin ol satady saja. ולא [17]

(3) $\quad\{$ Da $\}$ munajtmajyz kiši ošol dostun da qorqqun Tenrijdan $\{k i\}$ men- 
(17) and you shall not gather the dispersed grapes. It shall be a year of complete rest

(18) to the land. [6] And the Sabbath of the land shall be for food for you:

(19) for you and for your servants and maidservants and for your hired man and for your settler that

(1) lives with you, [7] And for your livestock, and

(2) for the wild animals that are in your land shall be all its produce to eat. [8] And

(3) you shall count seven Sabbaths of years for you: seven times seven years.

(4) And the days of the seven Sabbaths of years will be for you forty-nine

(5) years. [9] And you shall have the calling voice of the trumpet pass

(6) in the seventh month, on the tenth day of the month: on the

(7) day of atonement you shall have the voice of the trumpet pass through all your land. [10]

(8) And you shall hallow the year of the fiftieth year and proclaim

(9) liberty in the land to all the inhabitants thereof. It is a jubilee, it shall be

(10) liberty for you. And you shall return every man to his possession, and

(11) you shall return, every man to his family. [11] The year of the fiftieth year is a jubilee,

(12) it shall be for you. You shall not sow, you shall not reap that which grows of itself

(13) in it and you shall not gather what is dispersed of it. [12]

(14) Because it is a year of jubilee. It shall be holy to you. You shall eat from the field.

(15) its produce. [13] In the year of this jubilee you shall return every

(16) man to his possession. [14] And if you sell anything

(17) to your fellow or buy anything of your fellow's hand,

(18) you shall not torment one his brother.

(19) [15] You shall buy from your fellow by the number of years after the jubilee,

(20) by the number of years of crops he shall sell to you: [16]

(21) According to the multitude of years you shall increase its selling price,

(1) and according to the fewness of years you shall diminish the selling $201 \mathrm{r}^{\circ}$ price of it,

(2) because according to the number of crops he sells to you. [17]

(3) You shall not torment one another, but you shall fear your God, because I am 
(4) men Adonaj Tenrijiz. ועשיתם. [18] Da qylyjyz ošol resimĺa-

(5) rimni da ošol töŕálarimni saqlajyz da qylyjyz alarny da

(6) olturursiz ol jer üstüńa eminlikbyla. ונתנה. [19]

(7) Da berir ol jer jemiši da ašarsiz tojğunča da ol-

(8) turursiz eminlikbyla anyn üstüńa. [20] Da

(9) ki ajtsajyz ne ašarbiz eger ol jedinči jylda čačmasaq

(10) da jyštyrmasaq ošol bitišimizni. וצויתי [21] Da symar-

(11) larmen ošol alğyšymny sizǵa ol altynčy jylda da ös-

(12) türür ošol ol bitišni üč jyllarg̉a. וזרעתם [22] Da

(13) čačarsiz ol segizinči jylda da ašarsiz ol bitištan qart-

(14) ny ol tog̉uzunču jylġa dejin kelginča bitiši anyn ašar-

(15) siz qartny. והארץ. [23] Da ol \{jer\} satylmasyn ovellikḱ ki menim-

(16) di ol jer ki gaariplar da očarlardyr siz birǵaḿa.

(17) ובכל Da bar jerind́a tutuvluggujuznun juluv berijiz jer-

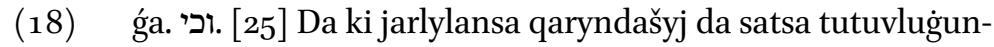

(19) dan özünün da kelsin juvug̉u anyn ol juvuqraq anar da julusun

(20) ošol satmaġyn qaryndašynyn. ואיש. [26] Da kiši ki bolmasa anar

(21) juvuq da jetśa küčü qolunun da tapsa jetkiligič́a julumaġy-

201 vo (1) nyn. [27] Da hešbontetsin ošol jyllaryn satmağynyn da

(2) qajtarsyn ošol ol artadoġanny kišiǵa ki satty anar da

(3) qajtsyn tutuvlugiuna özünün. ואם. [28] Da eger tapmasa

(4) qolu anyn jetkiligič́a qajtarmaqnyn anar da bolsun satmaġy anyn

(5) qolunda ol satyn aluvčunun any jylynadejin ol jovelnin da čyq-

(6) syn joveld́a da qajtsyn tutuvlugiuna özünün. ואיש. [29]

(7) Da kiši ki satsa olturuš üv qalaly šaharda da bolsun ju-

(8) lunmaġy anyn tüğanḿagińadejin jyly satmaġynyn jyl bolsun zamanyna

(9) julumagynyn. [3ם [30] Da eger julunmasa tolg̈unča anar

(10) tüǵal jyl da qajjam bolur ol üv ki šaharda ki anar qala o-

(11) vellikḱa satyn aluvčug̉a any dorlarysajyn čyqmasyn joveld́ad́a. 
(4) the Lord your God. [18] And you shall do my statutes

(5) and keep my judgments and do them, and

(6) then you will dwell in the land securely.

(7) [19] And the land will give its fruit, and you will eat to the full, and

(8) you will dwell on it securely. [20] And

(9) if you shall say, "What shall we eat, if in the seventh year we may not sow

(10) or gather in our produce?" [21] Then I will command

(11) my blessing on you in the sixth year, and

(12) it will make grow the produce for three years. [22] And

(13) you will sow the eighth year and eat the old produce

(14) until the ninth year: you will eat the old |produce| until its produce arrives to you.

(15) [23] The land shall not be sold $\left[{ }^{\dagger} \text { forever }\right]^{193}$, because

(16) the land is mine, because you are strangers and settlers with me.

(17) [24] And in all the land of your possession you shall give a redemption

(18) for the land. [25] If your brother becomes poor and sells any of his possession,

(19) then his closest relative shall come and shall redeem

(20) his brother's sale. [26] And a man who has no

(21) relative, but his hand can attain it and he finds enough for his redemption:

(1) [27] Then let him count the years of his sale and

(2) restore what has increased to the man to whom he sold it, and

(3) he shall return to his possession. [28] And if his hand has not found

(4) enough to restore it to him, his sale shall be

(5) in the hand of the one who bought it until the year of jubilee, and

(6) it shall come out in the jubilee, and he shall return to his possession. [29]

(7) And a man who sells a dwelling house in a walled city:

(8) its redemption shall be until the end of the year of its sale - there shall be a year

(9) for its redemption. [30] And if it is not redeemed by the completion of a

(10) full year, then the house that is in the walled city shall be established

(11) [ fforever] to the one who bought it throughout his generations. It shall not come out even in the jubilee.

193 An uncertain translation of ovelikka, cf. Heb. לִצִמִמִתִ 'forever'. 
(12) ובתי Da üvlari ol azbarlarnyn ki joḥtur alarg̉a qala

(13) čüvŕa tüzü ornuna ol jernin sag̉yšlansyn julunmaq bolsun

(14) anar da joveld́a čyqsyn. [32] Da šaharlary ol Levilarnin

(15) üvlari tutuvluq šaharlarynyn ömürlük julumaq bolsun Levilar-

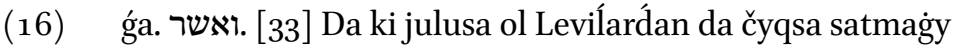

(17) üvnün da šahary tutuvlugiunun joveld́a ki üvlari šaharlary-

(18) nyn ol Levilarnin ol tutuvluqlarydy alarnyn ortasynda ulan-

(19) larynyn Jisra’elnin. [3דה Da tüzü sürüvünün šaharlarynyn

(20) satylmasyn ki ömürlük tutuvluqtur ol alarg̉a. וכי [35] Da

(21) ki jarlylansa qaryndašyj da tajsa qolu anyn qatyjda da kipla-

$202 \mathrm{r}^{\mathrm{o}} \quad$ (1) gin any gaaripni da očarny da tiri bolsun birǵaja. אל. [36]

(2) Almaġyn andan aslam da fajda da qorqqun Tenrijizd́an da tiri

(3) bolsun qaryndašyj birǵaja. את [37] Ošol kümüšüjnü ber-

(4) ḿagin anar aslambyla da fajda byla bermagin bürtügüjnü.

(5) אני (38] Menmen Adonaj Tenrijiz ki čyğardym sizni jerind́an Micri-

(6) nin berḿa sizǵa ošol jerin Kena'annyn bolma sizǵa Tenri-

(7) gá (39] Da ki jarlylansa qaryndašyj qatyjda da satyl-

(8) sa saja išlamagin anyn byla išin qulnun. כשכיר. [40]

(9) Očarkibik bolsun birǵaja jylynadejin ol jovelnin qul-

(10) lu lu etsin birǵaja. Da čyqsyn qatyjda ol da

(11) ulanlary anyn birǵasińa da qajtsyn uruvuna özünün da

(12) tutuvlugiuna atalarynyn qajtsyn. כי [42] Ki qullarymdy alar

(13) ki čyg̉ardym alarny jerind́an Micrinin satylmasynlar satylmaġyn

(14) qulnun. לא [43] Erkĺanmagin anda hökümlük byla da

(15) qorqqun Tenrijdan. ועבדך. [44] Da quluj da qaravašyj ki bolsalar

(16) saja ol ḥanlyqlardan ki čüvŕalarijizd́a alardan satyn alyjyz qul

(17) da qaravaš. וגם [45] Da dag̉yn ulanlaryndan ol očarlarnyn ol

(18) tirilüvčülarnin birǵajizǵa alardan satyn alyjyz da uruvlaryndan 
(12) [31] And the houses of the homesteads which have no wall

(13) around them shall be counted as the fields of the country. It shall

(14) have redemption, and it shall come out in the jubilee. [32] And the cities of the Levites,

(15) the houses of the cities of their possession: the Levites shall have eternal redemption.

(16) [33] And if one of the Levites redeems: then it comes out, a sale

(17) of a house or a city of his possession, in the jubilee, because the houses of the cities

(18) of the Levites are their possession among the sons

(19) of Israel. [34] But the field of pastureland of their cities

(20) shall not be sold, for it is their eternal possession. [35] And

(21) if your brother becomes poor and his hand slips with you, then

(1) you shall strengthen him-a stranger or a setter — and he shall live with you. [36]

(2) Do not take interest or profit from him, but you shall fear your God, and

(3) your brother shall live with you. [37] You shall not lend him your silver

(4) for interest, and you shall not give him your grain for profit.

(5) [38] I am the Lord your God, who brought you out from the land of Egypt,

(6) to give you the land of Canaan, to be God to you.

(7) [39] And if your brother becomes poor beside you and

(8) is sold to you, you shall not make him work a servant's work. [40]

(9) He shall be like a settler, he shall serve you until the year of jubilee.

(10) [41] And then he shall go out from you, he and

(11) his children with him, and shall return to his own family and

(12) to the possession of his fathers shall he return. [42] For they are my servants,

(13) whom I brought out from the land of Egypt. They shall not be sold like the sale

(14) of a servant. [43] You shall not rule over him oppressively, but

(15) shall fear your God. [44] And your servants and maidservants that you shall have

(16) shall be of the kingdoms that are around you: you shall buy servants

(17) and maidservants from them. [45] And also from the children of the settlers who

(18) live with you: you shall buy from them and of their families 
(19) alarnyn ki birǵajizǵa ki tuvdurdular jerijizd́a da bolsunlar siz-

(20) ǵa tutuvluqqa. והתנחלתם. [46] Da ülüš berijiz alarny ulan-

(21) laryjyzğa özüjüzd́an sortun meŕaslaḿa tutuvluq dunjag̉adejin

$202 \mathrm{v}^{\mathrm{o}} \quad$ (1) alarbyla qulluq etijiz da qaryndašlaryjyz byla ulanlarybyla Jisra’el-

(2) nin kiši qaryndašy byla erklanmágin anyn üstüńa ḥ̈ökumlük

(3) byla. וכי [47] Da ki jetśa küčü qolunun garipnin da očarnyn birǵaja

(4) da jarlylansa qaryndašyj birǵasińa da satylsa ġaripǵa očar-

(5) ġa birǵaja jemeśa dinsizǵa uruvuna ġaripnin. אחרי. [48]

(6) Satylyp sortun julunmaq bolsun anar biri qaryndašlaryndan julusun

(7) any. [49] Jemeśa dadasi jemeśa uvlu dadasinin julusun

(8) any jemeśa juvug̉undan gufunun uruvundan julusun any jemeśa

(9) jetśa küčü qolunun özünün da julusun. וחשב. [50] Da

(10) hešboncetsin satynaluvčusu byla jylyndan satylmag̉ynyn anar

(11) jylynadejin ol jovelnin da bolsun kümüšü satmaġynyn sanybyla

(12) jyllarnyn künlari kibik jalčynyn bolsun birǵasińa. אם. [51] Eger

(13) hanuz köp bolsa jyllarda alarg̉a köŕa qajtarsyn julumaġyn

(14) kümüšünd́an satynalmag̉ynyn. ואם [52] Da eger az qalsa

(15) jyllarda jylynadejin ol jovelnin da ḥešbontetsin anar jyllaryna

(16) köŕa qajtarsyn ošol julunmaġyn özünün. כשכיר. [53] Jalčy

(17) kibik har jylda bolsun birǵasińa erklanḿasin anyn üstü-

(18) ńa hökümlük byla közĺarijč́a. ואם [54] Da eger julunmasa

(19) bularda čyqsyn jylynda ol jovelnin ol da ulanlary anyn bir-

(20) ǵasińa. כ5 [5] Ki maja ulanlary Jisra’elnin qullardy qullarymdy

(21) alar ki čyğardym alarny jerind́an Micrinin menmen Adonaj Tenrijiz. 
(19) that are with you, whom they begat in your land. And they shall become

(20) a possession for you. [46] And you shall take them as an inheritance

(21) for your children after you, to inherit as a possession.

(1) You shall make them work forever. But your brothers, the children of $202 \mathrm{v}^{\mathrm{o}}$ Israel-

(2) a man toward his brother: you shall not rule over them oppressively.

(3) [47] And if the hand of a stranger and settler with you attains it,

(4) and your brother with him becomes poor and sells himself to the stranger |and| settler

(5) with you or to a godless of the stranger's family: [48]

(6) After he is sold he shall have redemption. One of his brothers shall redeem

(7) him. [49] Either his uncle or his uncle's son shall redeem

(8) him, or a close relative to his body of his family shall redeem him; or

(9) if his hand can attain it, he shall redeem himself. [50] And

(10) he shall calculate himself with the one who buys him from the year that he was sold to him

(11) to the year of jubilee: and the silver of his sale shall be

(12) by the number of years. Its shall be with him like the days of a hired worker. [51] If

(13) there are still many years, he shall pay back his redemption according to them

(14) from the silver that he was bought for. [52] And if a few years remain

(15) to the year of jubilee, he shall calculate it for him. According

(16) to his years shall he return him the silver of his redemption. [53]

(17) As a hired servant he shall be with him every year, and he shall not rule over him

(18) oppressively in your sight. [54] And if he is not redeemed

(19) in these |years|, he shall go out in the year of jubilee, he and his children with him.

(20) [55] Because the children of Israel are servants to me. They are my servants,

(21) whom I brought out from the land of Egypt. I am the Lord your God. 
[Leviticus 26]

$203 \mathrm{r}^{\circ} \quad$ (1) לא. [1] Qylmajyz özüjüzǵa hečlikĺar da jonma abaq da maceva

(2) [turg̉uzmajyz özüjüzǵa da tuక̌urg̉an taš bermajiz jerijizd́a ${ }^{12}$

(3) bašurma anyn üstüńa ki menmen Adonaj Tenrijiz. את. [2]

(4) Ošol šabatlarymny saqlajyz da miqdašymdan qorqujuz menmen $\mathrm{H}$.

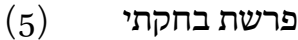

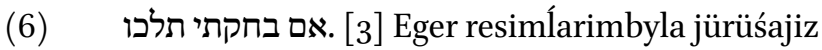

(7) da ošol mivalarymny saqlasajyz da qylsajyz alarny.

(4) [4 Da berirmen jamġurlaryjyzny vahtlarynda da berir

(9) ol jer bitišin da ag̉ačy ol tüznün berir jemišin. [5שיג

(10) Da jetar sizǵa qaqmaq jyštyrmaqqa da jyštyrmaq jetar

(11) čačmaqqa da ašarsiz ötḿagijizni tojğunča da oltu-

(12) rursiz eminlik byla jerijizd́a. . ורדפתם. [7] Da quvarsiz

(13) ošol dušmanlaryjyzny da tüšarlar alnyjyzda qylyčtan.

(14) Da berirmen tynčlyq jerd́a da jatsajyz da bol-

(15) masty sesḱandirüvčü da eksitirmen jaman kijikni ol

(16) jerd́an da qylyč ašmasty jerijiz ašyra. ${ }^{13}$ ורדפו. [8] Da

(17) quvarlar sizd́an bešövbyla jüznü da jüzövbyla sizd́an tümáanni

(18) quvarlar da tüš́arlar dušmanlaryjyz alnyjyzda qylyčtan.

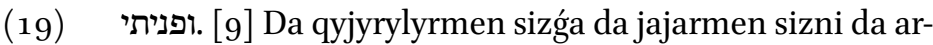

$203 \mathrm{v}^{\mathrm{o}} \quad$ (1) ttyryrmen sizni da qajjam etarmen šertimni birǵajizǵa.

(2) ואכלתם [10 Da ašarsyn qartny qartajg̉anny da qartny alnyn-

(3) dan janġyny čyġaryrsiz. ונתתי[11 Da berirmen toḥtar

(4) ornun šehinamnyn ortajyzda da bezḿasti klagim sizd́an.

(5) והתהלכתי Da je jürü šehinam ortajyzda da bolurmen siz-

(6) gena Tenriǵa da siz bolursiz maja ulusqa. [13] Men-

\footnotetext{
${ }^{1} \mathrm{~K}$ : Lev 26:1-2 is copied as Lev 25:56-57; a scribal error: the beginning of the parashat Bechukotai was confused with the beginning of Lev 26. | TKow.o1: Lev 26:1-2 is copied as Lev 25:56-57; a scribal error. | H: Lev 26 begins here. | ADub.III.82: Lev 26 begins here. | C: Lev 26 begins here. | M: Lev 26 begins here. | R: Lev 26:1-2 is copied as Lev 25:56-57; a scribal error. | Hebrew Bible: Lev 26 begins here. $\quad{ }^{2}$ Unvocalized fragment. $\quad{ }^{3}$ The actual order of this and the next verse was corrected by the copyist by numbering the verse-beginning words with $\aleph$ and, respectively.
} 
[Leviticus 26] $]^{194}$

(1) [1] You shall make no vanities for yourselves, and you shall not set up $203 \mathrm{r}^{\circ}$ a carved idol or a pillar

(2) for yourselves and you shall not set up any engraved stones in your land

(3) to bow down over it, because I am the Lord your God. [2]

(4) You shall keep my Sabbaths and fear my sanctuary. I am the Lord.

(5) Parashat Bechukotai

(6) [3] If you walk by my statutes,

(7) and if you keep my commandments and do them:

(8) [4] Then I will give you your rains in their time and

(9) the land will give its crop, and the tree of the field will give its fruit. [5]

(10) And your threshing shall reach to the gathering $\mid$ time $\mid$, and the gathering shall reach

(11) to the sowing |time|: and you will eat your bread to the full, and you will dwell

(12) in your land safely. [ [7] \{2nd\} And you will chase

(13) your enemies, and they will fall before you by the sword.

(14) [6] \{1st $\}$ And I will give peace in the land, and you shall lie down, and

(15) there will be no one making you afraid, and I will cut off evil wild animals

(16) out of the land, and a sword will not pass through your land. ${ }^{1195}$ [8] And

(17) five of you will chase a hundred, and a hundred of you

(18) will chase ten thousand, and your enemies will fall before you by the sword.

(19) [9] And I will turn to you, and I will make you spread, and

(1) I will multiply you, and I will establish my covenant with you.

(2) [10] And you will eat the old getting older, and you will take out the old

(3) before the new. [11] And I will set my dwelling

(4) place of my divine Presence among you, and my will won't abhor you.

(5) [12] And I will walk among you, and I will be a God

(6) to you, and you will be a people to me. [13] I

194 K: Lev 26:1-2 is copied as Lev 25:56-57; a scribal error.

195 The order of these two verses was corrected by the copyist. 
(7) men Adonaj Tenrijiz ki čyğardym sizni jerind́an Micrinin bolmaq-

(8) tan alarğa qullar da syndyrdym üśaḱarin bojunsajyznyn da

(9) jürüttüm sizni qanqajtyp bojunnu. ואם [14] Da eger

(10) tynlamasajyz sözüma da qylmasajyz ošol bar ol micvalar-

(11) ny ošpularny. ואם. [15] Da eger resimlarimni ḥor et-

(12) śajiz da eger törálarimd́an bezśa žanyjyz qylmasqa ošol

(13) bar micvalarymny buzma siz ošol šertimni. אף. [16] Ham

(14) mend́a bunu qylarmen sizǵa da symarlarmen üstüjüz-

(15) ǵa alġasavuq ošol suvuq ḥastalyqny da ošol ol issi

(16) hastalyqny tunduradoġanlar közlarni da syzlatadoġanlar žanny

(17) da čačarsiz bošqa urlug̉ujuznu da ašarlar any duš-

(18) manlaryjyz. ונתתי [17] Da berirmen hyyššymymny sizd́a

(19) da qyrylyrsiz alnynda dušmanlaryjyznyn da erkĺanirlar

(20) sizd́a dušmanlaryjyz da qačarsiz da bolmasada quvuvču

(21) sizni. ואם [18] Da eger bularg̉adejin tynlamasajyz maja da

$204 \mathrm{r}^{\circ} \quad$ (1) arttyryrmen adepĺaḿa sizni jedi anča jazyqlaryjyz üčün.

(2) (19] Da syndyryrmen ošol ullugiun quvatyjyznyn da be-

(3) rirmen ošol kökĺarijizni temirkibik da ošol jerijizni

(4) qurč kibik. ותם [20] Da tüǵanir bošqa küčüjüz da

(5) bermasti jerijiz ošol bitišin da ag̉ačy ol jernin ber-

(6) masti jemišin. ואם [21] Da eger jürüšajiz birǵama

(7) učurbyla da kĺaḿaśajiz tynlama sözüḿa da artty-

(8) ryrmen karanja üstüjüzǵa jedi anča jazyqlaryjyzġa kö-

(9) ra. iהשלחתי [22] Da ijarmen sizd́a ošol kijigin ol

(10) tüznün da tuv etar sizni da azartyr ošol tuvaryjyzny

(11) da az etar sizni da veŕan bolurlar jollaryjyz. [23] Da

(12) eger bularbylada adepĺanmááajiz alnymda da jürüśajiz

(13) birǵamáa učurbyla. והלכתי. [24 Da jürürmen ham men-

(14) da birǵajizǵa učurbyla da karatetarmen sizni dag̉yn

(15) mend́a jedi anča jazyqlaryjyz üčün. והבאתי. [25] Da kelti-

(16) rirmen üstüjüzǵa qylyč öč aluvču öčün šertnin da

(17) jyštyrylsajyz šaharla\{r\}yjyzğa da ijarmen ölat ortajyzda da

(18) berilirsiz qoluna dušmannyn. בשברי. [26 Syndyrg̉anymda 
(7) am the Lord your God, who brought you out from the land of Egypt,

(8) from being servants to them, and I have broken the beams of your yoke, and

(9) I made you walk after I had made you keep your head proud. [14] But if

(10) you do not listen to my word and not do all these commandments,

(11) [15] And if you despise my statutes,

(12) or if your soul abhors my judgments, so as not to do

(13) all my commandments, to break my covenant: [16]

(14) I, too, I will do this to you: I will even appoint over you

(15) terror, cold disease and fever

(16) that make eyes dim and cause suffering of heart,

(17) and you will sow your seed in vain, for your enemies will eat it.

(18) [17] And I will set my wrath against you,

(19) and you will die before your enemies, and

(20) your enemies will reign over you, and you will flee even if there is none who pursues

(21) you. [18] And if you do not listen to me even after these, then

(1) I will discipline you seven times more for your sins.

(2) [19] And I will break the greatness of your power, and

(3) I will make your heavens as iron, and your earth

(4) as copper. [20] And your strength will come to its end in vain, and

(5) your land will not give its crop, and the tree of the land

(6) will not give its fruits. [21] And if you walk with me

(7) unwittingly, and you will not be willing to listen to my word,

(8) I will bring seven times more punishments on you, according to your sins.

(9) [22] And I will send the wild animals of the fields on you,

(10) and they will bereave you, and they will deplete your cattle,

(11) and they will make you few in number, and your roads will be desolated. [23] And

(12) if you are not disciplined before me by these things, and if you walk

(13) with me unwittingly, [24] Then I will also walk

(14) with you unwittingly, and will punish you, I too,

(15) seven times for your sins. [25] And

(16) I will bring a sword over you that shall bring the vengeance of my covenant. And

(17) if you are gathered to your cities, I will send the pestilence among you, and

(18) you shall be given to the hand of the enemy. [26] And when I break 
(19) sizǵa kipligin ötmaknin da biširirílar on qatynlar

(20) ötḿagijizni bir pečta da qajtaryrlar ötḿagijizni ölčöv-

(21) byla da ašarsiz da tojmassiz. ואם [27 Da eger bunun

$204 \mathrm{~V}^{\mathrm{o}}$ (1) byla tynlamasajyz maja da jürüśajiz birǵama učurbyla. והלכתי. [28]

(2) Da jürürmen birǵajizǵa qahiribyla učurnun da adeplarmen sizni

(3) ham mend́a jedi anča jazyqlaryjyz üčün. ואכלתם [29] Da ašarsiz

(4) et[i]n1 uvullaryjyznyn da etin qyzlaryjyznyn ašarsiz. והשמדתי. [30]

(5) Da tasetarmen ošol bamalaryjyznyn da eksitirmen ošol qujaš

(6) sufatlaryjyzny da berirmen ošol gövd́alarijizni gövd́alari üstü-

(7) ná hečliklarijiznin da beźar kĺagim sizd́an. ונתתי [31] Da

(8) berirmen ošol šaharlaryjyzny veŕan da pusta etarmen ošol

(9) miqdašlaryjyzny da qabul etḿanmen ij qabullug̉ujuznu. והשימתי [32]

(10) Da veŕan etarmen men ošol ol jerni da veŕan bolurlar anyn üs-

(11) tüńa dušmanlaryjyz ol olturuvčular anda. [3ת [3] Da

(12) sizni tozdururmen ḥanlyqlar arasyna da suvururmen artyjyzdan

(13) qylyč da bolur jerijiz veŕan da šaharlaryjyz bolur pusta.

(14) [34] Ol vaḥtta tüğalĺar ol jer ošol šabatlaryn özünün

(15) _ki oldur ol šmitalar bar veŕan bolġan künlarind́a da siz

(16) bolursiz jerind́a dušmanlaryjyznyn ol vaḥtta veŕanliksartyn

(17) šabat tutar ol jer da tüǵallar šabatlar byla ünd́aladog̉an

(18) šmitalarny ne ki tutmadylar bar bijlik künlarind́a jazylġan-

(19) ga köŕa Torada ${ }^{12}$. כל . [35] Bar veŕan bolġan künlarind́a

(20) šabat tutar ošol ne ki tutmady šabatlaryjyzda olturğanyjyzda

(21) anyn üstüńa. והנשארים. [36] Da ol qalġanlar sizd́a da

$205 \mathrm{r}^{0} \quad$ (1) keltirirmen qorquv jürakálarińa alarnyn jerlarind́a duš-

(2) manlarynyn da quvar alarny avazy tüš́adog̉an japraqnyn da qačar-

(3) lar qačmaġy qylyčnyn da tüšarlar da bolmasty quvuvču.

(4) וכשלו [37] Da sürünürlar kiši qaryndašynda alnyndan

${ }^{1} \mathrm{~K}$ : eten; a scribal error. | TKow.o1: etin; the text was vocalized by another hand. | H: gufun. | C: etin. $\quad{ }^{2}$ Interpretative addition to the standard text. 
(19) the strength of your bread, then ten women shall bake

(20) your bread in one oven, and they shall give back your bread by weight,

(21) and you will eat and not be full. [27] And if,

(1) with this, you do not listen to me, and you will walk with me unwit- $204 \mathrm{v}^{\mathrm{o}}$ tingly, [28]

(2) Then I will walk with you with the fury of destiny, and I will discipline you,

(3) I also, seven times for your sins. [29] And you will eat

(4) the flesh of your sons, and you will eat the flesh of your daughters. [30]

(5) And I will destroy your hills, and I will cut off your sunny

(6) images, and I will cast your carcasses on the carcasses

(7) of your vanities, and my soul will abhor you. [31] And

(8) I will make your cities desolate, and I will bring

(9) your sanctuaries to desolation, and I will not accept your pleasing aroma. [32]

(10) And I will desolate the land, and

(11) your enemies who dwell in it will be devastated at it. [33] And

(12) I will scatter you among the kingdoms, and I will draw out a sword after you,

(13) and your land will become desolate, and your cities will become deserted.

(14) [34] Then the land shall cease its Sabbaths,

(15) that is the remission, in all the days of desolation, and you

(16) will be in your enemies' land. Then, because of the desolation,

(17) the land will keep the Sabbath and will cease the remissions that are called Sabbaths,

(18) which were not kept in all the days of kingdom, as it is written

(19) in the Torah. ${ }^{1196}$ [35] All the days of desolation

(20) it will keep the Sabbath, the |amount| that it did not keep on your Sabbaths when you lived

(21) on it. [36] And those among you who remain:

(1) I will bring fear in their hearts in the lands of their enemies,

(2) and the sound of a falling leaf will chase them, and they will flee

(3) like the flight from a sword, and they will fall, and there will be no one pursuing.

(4) [37] And they will stumble, each over his brother, as in front of

196 An interpretative addition to Lev 26:34. 
(5) kibik qylyčnyn da quvuvču bolmasada da bolmasty sizǵa

(6) turuš alnynda dušmanlaryjy\{z\}nyn. ואבדתם [38] Da taspo-

(7) lursiz ortasynda ḥanlyqlarnyn da tavusur sizni jeri duš-

(8) manlaryjyznyn. והנשארים. [39] Da ol qalġanlar sizd́a čirir-

(9) ĺar günaḥ̂lari üčün jerlarind́a dušmanlaryjyznyn da

(10) ham günahịlari üčün atalarynyn ${ }_{\text {L }}$ ki andij günahilar bardy ${ }^{11}$

(11) birǵalarińa alarnyn barlary üčün čirirlar. והתודו. [40]

(12) Da mode bolurlar ošol günahílarin özlarinin da ošol

(13) güńahin atalarynyn tanmaqlarybyla ki tandylar maja da ham

(14) neki jürüdülar birǵaḿa učurbyla. ףא. [41] Ham mend́a

(15) jürürmen birǵalarińa učurbyla da keltirirmen alarny

(16) jerińa dušmanlarynyn da ol vaḥtta synyġyr jüraklari

(17) alarnyn ol aqlafly da ol vaḥtta tüǵalĺarlar ošol

(18) güńaḥlarin özlarinin. [42] Da sag̉ynyrmen ošol

(19) šertimni ki kestim Ja'aqov byla da ham ošol šertimni

(20) ki kestim Jichaq byla da ham ošol šertin ki kestim

(21) Avraham byla saġynyrmen da ol jernida saġynyrmen.

$205 \mathrm{v}^{\mathrm{o}}$ (1) [הארץ [43] Da ol jer kemišilir alardan da tüǵalĺar ošol šabatlaryn

(2) özünün veŕan bolġanynda alardan da alar tügáalíarlar ošol günahạlarin

(3) özĺarinin anyn üčün ki töŕalarimni hor ettilar da anyn üčün

(4) ki resimlarimd́an bezdi žanlary alarnyn. ואף. [44] Da \{ham $\}$ dag்yn bunu-

(5) da qylarmen alarg̉a ki bolġanda jerind́a dušmanlarynyn kemišḿanmen

(6) alarny tüğalič́a galutta da bezḿanmen alardan tavusma alarny buz-

(7) ma ošol šertimni birǵalarińa ki menmen Adonaj Tenrisi alarnyn.

(8) וזכרתי [45] Da sagynyrmen alarg̉a šertin burunġularnyn ki čygardym

(9) alarny jerind́an Micrinin közlarič́a ol ḥanlyqlarnyn bolma alarg̉a

(10) Tenriǵa menmen Adonaj. אלה. [46] Bulardylar ol resimlar da

(11) ol töŕalar da ol üvŕatüvlar ki berdi Adonaj arasyna ö-

\footnotetext{
${ }^{1}$ Interpretative addition to the standard text.
} 
(5) a sword, and there is no one pursuing, and you will have no

(6) stopover before your enemies. [38] And

(7) you will perish among the kingdoms, and the land of your enemies will consume you.

(8) [39] And those of you who remain will rot

(9) for their iniquity in your enemies' lands, and

(10) also for the iniquities of their fathers - ${ }_{L}$ because there are such iniquities ${ }^{1197}$

(11) with them they will rot. [40]

(12) And they will confess their iniquity and the

(13) iniquity of their fathers for their trespass which they trespassed against me, and also that

(14) they have walked with me unwittingly. [41] And I, I also,

(15) will walk with them unwittingly, and I will bring them

(16) into the land of their enemies. And then their

(17) uncircumcised hearts will despond, and then they will fulfil

(18) their own iniquity. [42] And I will remember

(19) my covenant that I made with Jacob, and also my covenant

(20) that I made with Isaac, and I will also remember my covenant that I made

(21) with Abraham, and I will remember the land.

(1) [43] And the land will be left by them and it will fulfil its Sabbaths

(2) while it is desolate from them, and they will accept their own iniquities:

(3) because they despised my judgments, and because

(4) their soul abhorred my statutes. [44] And I will even do to them this too:

(5) when they are in the land of their enemies, I will not leave

(6) them completely in exile, and I will not abhor them, to destroy them

(7) and to break my covenant with them, because I am the Lord their God.

(8) [45] And I will remember for them the covenant of the first ones,

(9) whom I brought out from the land of Egypt in the sight of the kingdoms, to be

(10) God to them. I am the Lord."' [46] These are the statutes and

(11) judgments and teachings, which the Lord gave between him

197 An interpretative addition to Lev 26:39. 
(12) zünün da arasyna ulanlarynyn Jisra'elnin tavynda Sinajnyn navi'ligi

(13) ašyra Mošenin.

Leviticus 27

(13) [ידבר [1] Da sözladi Adonaj Mošeǵa

(14) ajtadoġač. דבר. [2] Sözlagin ulanlaryna Jisra’elnin da ajtqyn

(15) alarg̉a kiši ki ajyrsa nijet qyjasyjbyla žanlar Adonajg̉a. והיה. [3]

(16) Da bolsun qyjasyj ol erḱak igirmi jaštan da altymyš jaš-

(17) qadejin da bolsun qyjasyj enli mitqal kümüš mitqaly byla ol

(18) qodešnin. ואם [4] Da eger qatyn kiši bolsa ol da bolsun qyjasyj

(19) otuz mitqal. ואם [5] Da eger beš jyldan da igirmi jylġadejin

(20) da bolsun qyjasyj ol erḱak igirmi mitqallar da qatyn kišídan

(21) on mitqallar. ואם [6] Da eger aj jaštan da beš jyllarğadejin

$206 \mathrm{r}^{\mathrm{o}} \quad$ (1) da bolsun qyjasyj ol erḱk beš mitqallar kümüš da qatyn kiši-

(2) dan üč mitqallar kümüš. ואם [7] Da eger altymyš jaš-

(3) tan da jog̉arraq eger erkak bolsa da bolsun qyjasyj on beš

(4) mitqal da qatyn kišid́an on mitqallar. ואם. [8] Da eger jarly

(5) bolsa ol qyjasyjdan da turg̉uzsun any alnynda ol kohennin da

(6) qyjaslasyn any ol kohen anar köŕa nečik jetśa küčü qolunun

(7) ol nijet etüvčünün qyjaslasyn any ol kohen. [9] [9] Da eger

(8) andij tuvar bolsa ki juvutadyrlar andan qarban Adonajgia barča

(9) neki berśa andan Adonajgia bolsun aziz. לא. [10] Alyšmasyn da

(10) tüvšürmasin any jaḥ̌yny jamanġa jemeśa jamanny jahšy̌gga

(11) da eger tüvšürḿa tüvšürśa tuvarny tuvarg̉a da

(12) bolsun ol da alyšqanyda anyn bolsun aziz. ואם. [11] Da eger

(13) nendij \{murdar $\}^{1}$ tuvar bolsa ki juvutmajdylar anda qarban Adonajgia

(14) da turğuzsun ošol ol tuvarny alnynda ol kohennin.

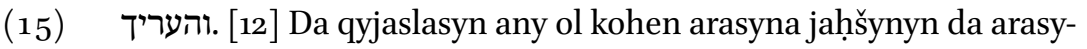

(16) na jamannyn qyjasyja köŕa e kohen alaj bolsun. [13] Da

(17) eger juluma julusa any jesisi anyn da arttyrsyn bešinči

(18) ülüšün anyn qyjasyj üstüńa. ואיש. [14] Da kiši ki

\footnotetext{
${ }^{1}$ Marginal insertion by another hand (without vocalization). | TKow.o1: murdar; unvocalized text. | H: murdar. | C: mundar.
} 
(12) and the children of Israel on Mount Sinai by the prophecy

(13) of Moses.

Leviticus 27

(13) [1] And the Lord spoke to Moses,

(14) saying, [2] 'Speak to the children of Israel, and say

(15) to them, "When a man will separate a special vow by your valuation of persons for the Lord, [3]

(16) Then your valuation shall be: A male from twenty years old even up to sixty years old:

(17) your valuation shall be fifty mithqals of silver, by the mithqal

(18) of the Holy. [4] And if it is a female, then your valuation shall be

(19) thirty mithqals. [5] And if it is from five years |old| even up to twenty years |old|,

(20) then your valuation shall be: |for| a male twenty mithqals, and for a female

(21) ten mithqals. [6] And if it is from a month old up to five years |old|,

(1) then your valuation shall be |for| the male five mithqals of silver and $206 \mathrm{r}^{\circ}$ for a female

(2) three mithqals of silver. [7] And if it is from sixty years old

(3) and above: if it is a male, then your valuation shall be fifteen

(4) mithqals, and for the female ten mithqals. [8] But if he is poorer

(5) than your valuation, then one shall stand him before the priest, and

(6) the priest shall value him. According to what the power of the hand

(7) of the one that vowed can attain shall the priest value him. [9] And if

(8) it is such an animal from which offering is brought forward to the Lord, all

(9) that is given of it to the Lord shall be holy. [10] He shall not exchange it or

(10) change it, good for bad or bad for good.

(11) And if he shall at all exchange animal for animal, then

(12) it and the one exchanged shall be holy. [11] And if

(13) it is any $\{$ unclean $\}$ animal from which sacrifice is not brought forward to the Lord,

(14) then one shall stand the animal before the priest.

(15) [12] And the priest shall value it, between good and

(16) bad: according to your valuation, oh priest, so shall it be. [13] And

(17) if its owner will at all redeem it, then he shall add a fifth

(18) part of it to your valuation. [14] And a man who 
(19) aziz etśa ošol üvün aziz Adonajğa da qyjaslasyn any ol

(20) kohen arasyna jaḥšynyn da arasyna jamannyn ki nečik qyjaslasa

(21) any ol kohen alaj qajjam bolsun. ואם [15] Da eger ol \{aziz\} etüvčü

$206 v^{o} \quad$ (1) julusa ošol üvün özünün da arttyrsyn \{bešinči ülüšün kümüšünün

(2) qyjasyjnyn anyn üstüńa da bolsun anar. ואם [16] Da eger

(3) tüzünd́an tutuvlug̉unun qodeš etśa kiši Adonajğa

(4) da bolsun qyjasyj urlug̉una köŕa tüz čačyladoġan urluq

(5) homer arpalar enli mitqal kümüška. אם. [17] Eger

(6) jylyndan ol jovelnin qodeš etśa tüzün özünün qyjasyja

(7) köŕa e kohen qajjam bolsun. ואם [18] Da eger ol joveld́an

(8) sortun qodeš etśa tüzün özünün da ḥešbontetsin anar

(9) ol kohen ošol ol kümüšnü ol jyllarg̉a köŕa ol qalġanlar

(10) jylynadejin ol jovelnin da eksilir qyjasyjdan. ואם. [19] Da

(11) eger juluma julusa ošol ol tüznü ol qodeš etüvčü

(12) any da arttyrsyn bešinči ülüšün kümüšünün qyjasyjnyn

(13) anyn üstüńa da qajjam bolsun anar. ואם [20] Da eger

(14) julumasa ošol ol tüznü da eger satsa ošol ol tüz-

(15) nü özǵa kišiǵa julunmasyn artyq. והיה. [21] Da bolur

(16) ol tüz čyqqanynda joveld́a qodeš Adonajğa tüzü kibik ol

(17) heremnin kohenǵa bolsun tutuvluguu anyn. ואם [22] Da

(18) eger tüzünd́an satynalmaġynyn ki tüvüldü tüzünd́an tutuv-

(19) lug̉unun qodeš etśa kiši Adonajg̀a. וחשב. [23] Da ḥešbon-

(20) tetsin anar ol kohen ošol sahyn ol qyjasyjnyn jylynadejin ol jovel-

(21) nin da bersin ošol ol qyjasyjnyn ol künd́a qodeš Adonajğa.

$207 \mathrm{r}^{\circ} \quad$ (1) בשנת [24] Jylynda ol jovelnin qajtsyn ol tüz anar ki satyn

(2) aldy andan anar ki anyndy tutuvlugiu ol jernin. [25] Da

(3) bar qyjasyj bolsun mitqaly byla ol qodešnin igirmi gög bolsun

(4) ol mitqal. אך. [26] Tek tunġuč ki tunġuč tuvsa Adonaj- 
(19) consecrates his house |to be| holy to the Lord, then the priest shall value it,

(20) between good and bad: as the priest values,

(21) it so shall it stand. [15] And if the one who consecrates

(1) it redeems his own house, then he shall add the fifth part of the silver $206 \mathrm{v}^{\mathrm{o}}$

(2) of your valuation to it, and it shall be his. [16] And if

(3) a man hallows to the Lord some part of a field of his possession,

(4) then your valuation shall be according to its seed: the sown seed of

(5) a homer of barley for fifty mithqals of silver. [17] If

(6) he consecrates his field from the year of jubilee, it shall stand, oh priest, according to your valuation.

(7) [18] But if he consecrates

(8) his field after the jubilee, then the priest shall calculate

(9) the silver for him according to the years that remain,

(10) until the year of the jubilee, and it shall be reduced from your valuation. [19] And

(11) if the one who consecrates the field will indeed redeem it,

(12) then he shall add the fifth part of the silver of your valuation

(13) to it, and it shall stand as his. [20] And if

(14) he does not redeem the field, and if he sells the field

(15) to another man, it shall not be redeemed anymore. [21] And

(16) when the field goes out in the jubilee, it |shall be| holy to the Lord, like a devoted field;

(17) his possession shall be the priest's. [22] And

(18) if a man hallows a field which he has bought, that is not from the fields

(19) of his possession, to the Lord, [23] Then

(20) the priest shall calculate for him the amount of your valuation, up to the year of the jubilee,

(21) and he shall give your valuation in that day, a holy |thing| to the Lord.

(1) [24] In the year of the jubilee the field shall return to him from whom $207 \mathrm{r}^{\mathrm{o}}$ it was bought,

(2) to whom the possession of the land belongs. [25] And

(3) all your valuations shall be by the mithqal of the Holy: twenty gög $g^{198}$ shall be

(4) the mithqal. [26] Just: the firstborn of the animals: if a firstborn is born to the Lord

198 Unidentified unit of weight. 
(5) ġa tuvarda qodeš etmánin kiši any hem ögüz hem qoj

(6) Adonajğady ol. [2] Da eger tunğuč tuvsa ol

(7) murdar tuvarda da julusun qyjasyj byla da arttyrsyn

(8) bešinči ülüšün anyn üstüńa da eger julu\{n\}masa da

(9) satylsa qyjasyjbyla senin e kohen. אך. [28] Tek bar herem

(10) ki ḥerem etśa kiši Adonajğa baryndan neki özünün bašlap

(11) adamdan da tuvardan da tüzünd́an tutuvluğunun satylmasyn

(12) an[i] $]^{1}$ julunmasyn bar ḥerem qodeš qadašimdir ol Adonajğa.

(13) כל [29] Bar herem ki ḥerem etilśa ol adamdan \{julunmasyn\} ölḿa

(14) öltürülsün. וכל [30] Da bar ončasy ol jernin urlug̉un-

(15) dan ol jernin jemišind́an ol ag̉ačnyn Adonajg̉ady ol qodeš

(16) Adonajğa. ואם. [31] Da eger juluma julusa kiši ončasyn-

(17) dan özünün bešinči ülüšün anyn arttyrsyn anyn üstü-

(18) ná [32] Da bar ončasy syğyrnyn da qojnun barča neki

(19) ašasa ol tajaq tübüńa ol onunču bolsun qodeš Adonajğa.

(20) לא [33] Terǵamasin arasyna jaḩ̌̌ynyn jamanbyla da alyšmasyn

(21) any da eger alyšma alyšsa any da bolsun ol da alyšqany

$207 \mathrm{v}^{\mathrm{o}}$ (1) anyn bolsun qodeš julunmasyn. אלה. [34] Bulardylar ol micvalar

(2) ki bujurdu Adonaj Mošeǵa üvŕatḿa ulanlaryna Jisra’el-

(3) $\quad \operatorname{nin}$ Lda bu micvalarny symarlady Adonaj Mošeǵa ${ }^{12}$ tavynda Sinajnyn.

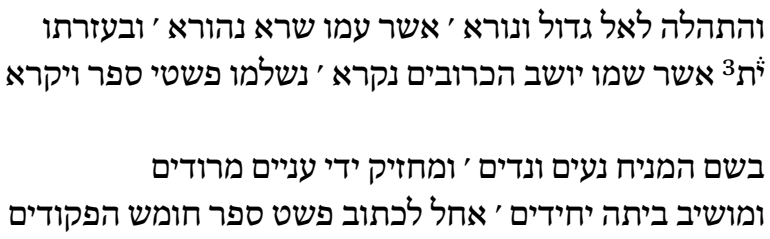

${ }^{1} \mathrm{~K}$ : ane; a scribal error. | TKow.o1: unvocalized text. | H: ani.| C: $d a . \quad{ }^{2}$ Interpretative addition to

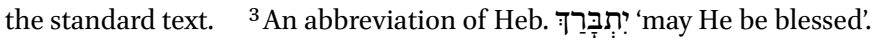


(5) no man shall consecrate it. Whether an ox, or sheep:

(6) it is the Lord's. [27] And if a firstborn is born

(7) to an unclean animal, then he shall redeem it according to your valuation, and shall add

(8) a fifth part to it. And if it is not redeemed, then,

(9) oh priest, it shall be sold according to your valuation. [28] Just: any devoted thing

(10) that a man shall devote to the Lord of all that he has-from human

(11) or animal or from a field of his possession - shall not be sold

(12) nor redeemed: every devoted thing is a holy of holies to the Lord.

(13) [29] Anyone devoted who is devoted from humans shall not be redeemed.

(14) He shall surely be put to death. [30] And all the tithe of the land, from of the seed

(15) of the land, from the fruit of the tree: to is the Lord's. It is holy

(16) to the Lord. [31] And if a man will at all redeem

(17) any of his tithes, he shall add to it the fifth part of it.

(18) [32] And all the tithe of the cattle or of the flock, everything that

(19) passes under the rod, the tenth shall be holy to the Lord.

(20) [33] He shall not inspect whether it be good or bad. And he shall not exchange

(21) it: and if he exchanges it at all, then both it and the one exchanged

(1) for it shall be holy. It shall not be redeemed."' [34] These are the com- $207 \mathrm{v}^{\mathbf{0}}$ mandments

(2) which the Lord commanded Moses to teach to the children of Israel.

(3) ${ }_{L}$ And the Lord commanded these commandments to Moses ${ }^{1199}$ on Mount Sinai.

(4) And praise be to the great and awesome God with whom light dwells, and with his help-

(5) may He be blessed whose name is He Who Dwells Between the Cherubim-the peshatim of the Book of Leviticus are completed.

(6) In the name of Him who gives rest to wanderers and vagabonds and strengthens the hand of the poor

(7) and seats them in His only home I will start to write the peshat of the book of Pentateuch - of the Book of Numbers.

199 An interpretative addition to Lev 27:34. 


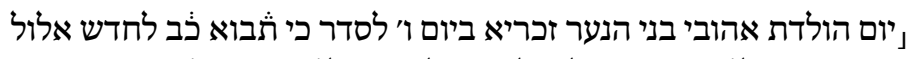

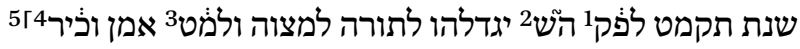

ניום הולדת אהובתי בתי הנערה מלכה [...] ביום ה' לסדר נצבי לו לחדש

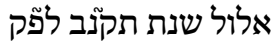

וידבר6

יום הולדת אהובתי בתי [...] הנערה אסתר [...] ביום ז' לסדר

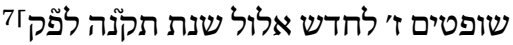

(14)

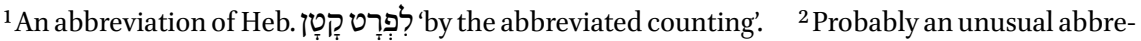
viation of Heb. הַשׁׁם 'God'. Some corrections were introduced above this abbreviation, but it is not entirely clear what was the intention of the writer. ${ }^{3} \mathrm{An}$ abbreviation of Heb. מַעַשׁים טוֹבִבים

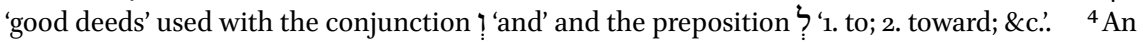

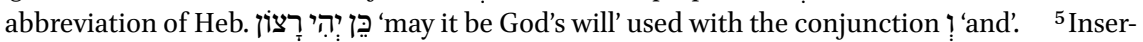
ted by another hand several decades later than the main text had been written. ${ }^{6}$ Catchword. ${ }^{7}$ Inserted by yet another hand (cf. line 8-9) several decades later than the main text had been written (except the catchword).
} 
(8) ${ }_{\mathrm{L}}$ The day of birth of my beloved young son Zecharia: the 6th day of the parashat Ki Tavo, ${ }_{L}$ the 22nd of the month Elul

(9) |of the| year 549 by the abbreviated counting ${ }^{1200}$, may God let him grow up for the Torah, for the commandments and for good deeds. Amen, and may it be God's will! ${ }^{201}$

(10) ${ }_{\mathrm{L}}$ The day of birth of my beloved daughter, the young girl Malka [...], the $5^{\text {th }}$ day of the parashat Nitzavim, ${ }_{1}$ the 26 th of the month

(11) Elul $\mid$ of the $\mid$ year $55^{2}$ by the abbreviated counting. ${ }^{1202}$

(12) 203

(13) The day of birth of my beloved daughter, the young girl Esther [...], the 7 th day of the parashat

(14) Shoftim, ${ }_{1}$ the 7 th of the month Elul $\mid$ of the| year 555 by the abbreviated counting. ${ }^{12041205}$

$200 \quad$ I.e., 13 September 1789.

201 Inserted by another hand in Hebrew.

202 I.e., 13 September 1792.

203 A catchword was written in this line.

204 I.e., 9 August 1795.

205 Inserted by yet another hand (except the catchword in line 12) in Hebrew. 
$208 \mathrm{r}^{\mathrm{o}} \quad$ Numbers 1

(1) (2) ספר במדבר א (2)

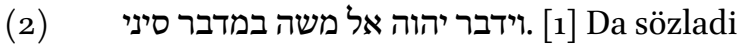

(3) Adonaj Mošeǵa midbarynda Sinajnyn ohel mo`ed-

(4) d́a burunğu kününd́a ol ekinči jangiajnyn ol ekinči

(5) jylda čyqmaqlaryna jerind́an Micrinin ajtadoġač. שאו. [2]

(6) Alyjyz sanyn bašynyn bar žymatynyn ulanlarynyn Jisra’elnin uruvlary-

(7) sajyn üvü sajyn atalarynyn sanybyla atlarnyn bar erkakni baš-

(8) מבן larysajyn. [3] Igirmi jaštan da jog̉arraq bar čyg்[u]včunu1

(9) čerüvǵa Jisra’eld́a sanajyz alarny \{čerüvlarisajyn\} sen da Aharon. [4] [4תכם

(10) Da birǵajizǵa bolsunlar biŕar kiši biŕar kiši ševett́an

(11) ag̉araq kiši üvüsajyn atalarynyn ol. ואלה. [5 Da bulardy at-

(12) lary ${ }^{2}$ ol éranlarnin ki tursunlar birǵajizǵa ševetind́an

(13) Ru'uvennin Elicur uvlu Šede’urnun. לשמעון. [6] Ševetin-

(14) dan Šim`onnun Šelumi’el uvlu Curišadajnyn. ליהודה. [7]

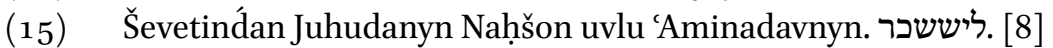

(16) Ševetind́an Jissaharnyn Netan’el uvlu Cu'arnyn. לזבולן. [9]

(17) Ševetind́an Zevulunnun Eli'av uvlu Helonnun. לבני. [10] Ulanlarynyn

(18) Josefnin ševetind́an Efrajimnin Elišama' uvlu 'Amihudnun ševe-

(19) tind́an Menašenin Gamli'el uvlu Pedahcurnun. לבנימן. [11]

(20) Ševetind́an Binjaminnin Avidan uvlu Gid'oninin. לדן. [12]

208 vo (1) Ševetind́an Dannyn Aḥi'ezer uvlu 'Amišadajnyn. לאשר. [13] Ševe-

(2) tind́an Ašernin Paġiel uvlu Akrannyn. לגד . לגד [14] Ševetind́an

(3) Gadnyn Elijasaf uvlu Du'u'elnin. לנפתלי. [15] Ševetind́an Naftali-

(4) nin Ahira` uvlu 'Enannyn. אלה. [16] Bulardylar ünd́almüšla-

(5) ri ol క̌ymatnyn nasilari ševetlarinin atalarynyn ag̉araqlary minla-

(6) rinin Jisra’elnin alar. ויקח [17] Da aldy Moše da Aharon ošol

(7) ol éranlarni ošpularny ki belgilandilar atlar byla. ואת [18]

(8) Da ošol bar ol క̌ymatny jyštyrdylar burunġu kününd́a ol

(9) ekinči janğajnyn da jaḥaslandylar uruvlarysajyn üvüsajyn atala-

(10) rynyn sany byla atlarnyn igirmi jaštan da jog̉ar $\{r\} a q$ bašlarysajyn.

(11) (19] Ki nečik bujurdu Adonaj Mošeǵa da sandy alarny

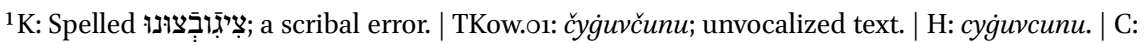
čyġyvčy. $\quad{ }^{2} \mathrm{~K}$ : atalary; a scribal error. | TKow.o1: unvocalized text. | H: atlary. | C: atlary. 
(1) The Book of Numbers 1

(2) [1] And the Lord spoke

(3) to Moses in the wilderness of Sinai, in the tent of meeting,

(4) on the first day of the second month, in the second

(5) year after they had come out from the land of Egypt, saying, [2]

(6) 'Take the sum of the heads of all the congregation of the children of Israel, by their families,

(7) by the house of their fathers, with the number of their names, every male

(8) by their heads. [3] From twenty years old and upward, all who go out

(9) to war in Israel: you and Aaron shall number them by their armies. [4]

(10) And a man of each tribe shall be with you,

(11) a man being the superior of the house of his fathers. [5] And these are

(12) the names of the men that shall stand with you: of the tribe

(13) of Reuben: Elizur, son of Shedeur. [6] Of the tribe

(14) of Simeon: Shelumiel, son of Zurishaddai. [7]

(15) Of the tribe of Judah: Nahshon, son of Amminadab. [8]

(16) Of the tribe of Issachar: Nethanel the son of Zuar. [9]

(17) Of the tribe of Zebulun: Eliab, son of Helon. [10] Of the children

(18) of Joseph: of the tribe of Ephraim: Elishama, son of Ammihud;

(19) of the tribe of Manasseh: Gamaliel, son of Pedahzur. [11]

(20) Of the tribe of Benjamin: Abidan, son of Gideoni. [12]

(1) Of the tribe of Dan: Ahiezer, son of Ammishaddai. [13] Of the tribe $208 \mathrm{v}^{\mathrm{o}}$

(2) of Asher: Pagiel, son of Ocran. [14] Of the tribe of

(3) Gad: Eliasaph, son of Deuel. [15] Of the tribe Naphtali:

(4) Ahira, son of Enan.' [16] These were the renowned

(5) of the congregation, princes of the tribes of their fathers. They are the superiors

(6) of thousands in Israel. [17] And Moses and Aaron took

(7) these men who had been designated by name. [18]

(8) And they assembled all the congregation on the first day

(9) of the second month, and they were proved by their families, by the house

(10) of their fathers, with the number of names, from twenty years old and upward, by their heads,

(11) [19] As the Lord commanded Moses. And he numbered them 
(12) midbarynda Sinajnyn. ויהיו [20] Da edilar uvullary Ru’uvennin

(13) tunğučunun Jisra’elnin tuvmušlary alarnyn uruvlarysajyn üvü-

(14) sajyn atalarynyn sanybyla atlarnyn bašlary sajyn bar erkak igir-

(15) mi jaštan da jog̉arraq bar čyg̉uvču čerüvǵa. פקודיהם. [21]

(16) Sanalġanlary alarnyn ševetinin Ru'uvennin qyrq alty min da beš-

(17) jüz. לבני (22] Uvullarynyn Šim'onnun tuvmušlary alarnyn u-

(18) ruvlarysajyn üvüsajyn atalarynyn sanalġanlary anyn sanybyla atlar-

(19) nyn bašlarysajyn bar erkak igirmi jaštan da jog̉arraq bar čy-

(20) ġuvču čerüvǵa. פקודיהם. [23] Sanalganlary alarnyn ševeti-

(21) nin Šimonnun enli tog̉uz min da üč jüz. לבני [24] Ulan-

$209 \mathrm{r}^{\mathrm{o}} \quad$ (1) larynyn Gadnyn tuvmušlary alarnyn uruvlarysajyn üvüsajyn ata-

(2) larynyn sanybyla atlarnyn igirmi jaštan da jog̉arraq bar čyg̉uv-

(3) ču čerüvǵa. פקודיהם. [25] Sanalġanlary alarnyn ševetinin

(4) Gadnyn qyrq beš min da alty jüz da enli. לבני [26] Uvul-

(5) larynyn Juhudanyn tuvmušlary alarnyn uruvlarysajyn üvüsajyn

(6) atalarynyn sanybyla atlarnyn igirmi jaštan da jog̉arraq bar

(7) čyg̉uvču čerüvǵa. פקודיהם. [27 Sanalg̉anlary alarnyn ševeti-

(8) nin Juhudanyn jetmiš dört min da alty jüz. לבסירני [28 [28 ]

(9) Uvullarynyn Jissaharnyn tuvmušlary alarnyn uruvlarysajyn ü-

(10) vüsajyn atalarynyn sanybyla atlarnyn igirmi jaštan da jog̉ar-

(11) raq bar čyg̉uvču čerüvǵa. פקודיהם. [29] Sanalġanlary alar-

(12) nyn ševetinin Jissaharnyn enli dört min da dört jüz. לבנקי [30]

(13) Uvullarynyn Zevulunnun tuvmušlary alarnyn uruvlarysajyn üvü-

(14) sajyn atalarynyn sanybyla atlarnyn igirmi jaštan da joġarraq

(15) bar čyġuvču čerüvǵa. פקודיהם. [31] Sanalgaanlary alarnyn

(16) ševetinin Zevulunnun enli jedi min da dört jüz. לבני [32]

(17) Uvullarynyn Josefnin uvullarynyn Efrajimnin tuvmušlary alar- 
(12) in the wilderness of Sinai. [20] And the sons of Reuben,

(13) Israel's firstborn, their children by their families,

(14) by the house of their fathers, with the number of names, by their heads, every male

(15) from twenty years old and upward, all who go out to war: [21]

(16) Those that were numbered of them, of the tribe of Reuben, were forty-six thousand and five

(17) hundred. [22] Of the sons of Simeon, their children

(18) by their families, by the house of their fathers, those that were numbered of them, with the number of names,

(19) by their heads, every male from twenty years old and upward, all

(20) who go out to war: [23] Those that were numbered of them, of the tribe

(21) of Simeon, were fifty-nine thousand and three hundred. [24]

(1) Of the sons of Gad, their children by their families, by the house of their fathers,

(2) with the number of names, from twenty years old and upward, all

(3) who go out to war: [25] Those that were numbered of them, of the tribe

(4) of Gad, were forty-five thousand and six hundred and fifty. [26] Of the sons

(5) of Judah, their children by their families, by the house

(6) of their fathers, with the number of names, from twenty years old and upward, all

(7) who go out to war: [27] Those that were numbered of them, of the tribe

(8) of Judah, were seventy-four thousand and six hundred. [28]

(9) Of the sons of Issachar, their children by their families,

(10) by the house of their fathers, with the number of names, from twenty years old and upward,

(11) all who go out to war: [28] Those that were numbered

(12) of them, of the tribe of Issachar, were fifty-four thousand and four

(13) hundred. [30] Of the sons of Zebulun, their children by their families,

(14) by the house of their fathers, with the number of names, from twenty years old and upward,

(15) all who go out to war: [31] Those that were numbered of them,

(16) of the tribe of Zebulun, were fifty-seven thousand and four hundred. [32]

(17) Of the sons of Joseph, of the sons of Ephraim, their children 
(18) nyn uruvlarysajyn üvüsajyn atalarynyn sanybyla atlarnyn igirmi

(19) jaštan da jog̉arraq bar čyg̉uvču čerüvǵa. פקודיהם. [33] Sanalġanlary

(20) alarnyn ševetinin Efrajimnin qyrq min da beš jüz. לבנדיה [34] [34]

(21) Uvullarynyn Menašenin tuvmušlary alarnyn uruvlarysajyn üvüsajyn

$209 \mathrm{v}^{0} \quad$ (1) atalarynyn sanybyla atlarnyn igirmi jaštan da jog̉arraq bar čy-

(2) ġuvču čerüvǵa. פקודיהם. [35] Sanalġanlary alarnyn ševetinin

(3) Menašenin otuz eki min da eki jüz. לביה [36] Uvullary-

(4) \{nyn\} Binjaminnin tuvmušlary alarnyn uruvlarysajyn üvüsajyn atalary-

(5) nyn sanybyla atlarnyn igirmi jaštan da jog̉arraq bar čyġuvču

(6) čerüvǵa. פקודיהם. [37 Sanalg̀anlary alarnyn ševetinin Binjamin-

(7) nin otuz beš min da dört jüz. לבני [38] Uvullarynyn Dannyn

(8) tuvmušlary alarnyn uruvlarysajyn üvüsajyn atalarynyn sanyby-

(9) la atlarnyn igirmi jaštan da joġarraq bar čyg̉uvču čerüvǵa.

(10) פקודיהם [39] Sanalġanlary alarnyn ševetinin Dannyn altymyš e-

(11) ki min da jedi jüz. לבני [40] Uvullarynyn Ašernin tuvmuš-

(12) lary alarnyn uruvlarysajyn üvüsajyn atalarynyn sanybyla atlar-

(13) nyn igirmi jaštan da jog̉arraq bar čyg̉uvču čerüvǵa.

(14) [4] Sanalganlary alarnyn ševetinin Ašernin qyrq bir

(15) min da beš jüz. לבני [42] Uv\{u\}llarynyn Naftalinin tuvmušlary alar-

(16) nyn uruvlarysajyn üvüsajyn atalarynyn sanybyla atlarnyn igir-

(17) mi jaštan da jog̉arraq bar čyg̉uvču čerüvǵa. פקודיהם. [43]

(18) Sanalġanlary alarnyn ševetinin Naftalinin enli üč min da dört 
(18) by their families, by the house of their fathers, with the number of names, from twenty

(19) years old and upward, all who go out to war: [33] Those that were numbered

(20) of them, of the tribe of Ephraim, were forty thousand and five hundred. [34]

(21) Of the sons of Manasseh, their children by their families, by the house

(1) of their fathers, with the number of names, from twenty years old and upward, all

(2) who go out to war: [35] Those that were numbered of them, of the tribe

(3) of Manasseh, were thirty-two thousand and two hundred. [36] Of the sons

(4) of Benjamin, their children by their families, by the house of their fathers,

(5) with the number of names, from twenty years old and upward, all

(6) who go out to war: [37] Those that were numbered of them, of the tribe of Benjamin,

(7) were thirty-five thousand and four hundred. [38] Of the sons of Dan,

(8) their children by their families, by the house of their fathers, with the number

(9) of the names, from twenty years old and upward, all who go out to war:

(10) [39] Those that were numbered of them, of the tribe of Dan, were sixty-

(11) -two thousand and seven hundred. [40] Of the sons of Asher, their children

(12) by their families, by the house of their fathers, with the number of names,

(13) from twenty years old and upward, all who go out to war:

(14) [41] Those that were numbered of them, of the tribe of Asher, were forty-one

(15) thousand and five hundred. [42] Of the sons of Naphtali, their children

(16) by their families, by the house of their fathers, with the number of the names,

(17) from twenty years old and upward, all who go out to war: [43]

(18) Those that were numbered of them, of the tribe of Naphtali, were fifty-three thousand and four 
(19) jüz. אלה. [44] Bulardylar ol sanalġanlar ki sanady Moše da

(20) Aharon da nasilari Jisra’elnin on eki kiši biŕar kiši ü-

(21) vüsajyn atalarynyn ediĺar. יויהיו. [45] Da edilar bar sanalġan-

$210 \mathrm{r}^{\circ}$ (1) lary uvullarynyn Jisra’elnin üvüsajyn atalarynyn igirmi jaštan

(2) da jog̉arraq bar čyg̉uvču čerüvǵa Jisra’eld́a. ויהיו [46] Da

(3) ediĺar bar ol sanalgaanlar alty keŕat jüz min da üč minlar

(4) da beš jüz da enli. והלוים [47 Da ol Levilar ševetisajyn ata-

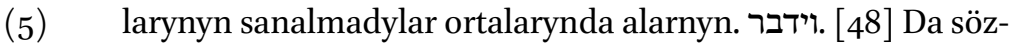

(6) ladi Adonaj Mošeǵa ajtadoġač. אך. [49] Tek ošol ševetin

(7) Levinin sanamaġyn da ošol sanyn bašlarynyn almag̉yn ortasynda

(8) uvullarynyn Jisra’elnin. ואתה. [50] Da sen symarlaġyn ošol

(9) ol Levilíarni miškany qatyna ol šarajatnyn da bar savutlary

(10) qatyna anyn da barysy qatyna neki anyn alar eltsinlar

(11) ošol ol miškanny da ošol bar savutlaryn anyn da alar

(12) jumuš etsinlar anar da čüvŕa miškan qatyna toḥta-

(13) synlar. ובנסוע [51 Da köčkand́a ol miškan endir-

(14) sinlar any ol Levilílar da toḥtag̉anda ol miškan turg̉uz-

(15) sunlar any ol Levilílar da ol jat ol juvuvču alardan özǵa

(16) öltürülsün. וחנו [52] Da toḥtasynlar uvullary Jisra’el-

(17) nin kiši avulu qatyna da har kiši alamy qatyna čerüvlari-

(18) sajyn. והלוים [53] Da ol Levililar toḥtasynlar čüvía miška-

(19) ny qatyna ol šarajatnyn da bolmasyn ačuv žymaty üstü-

(20) ńa ulanlarynyn Jisra’elnin da saqlasynlar ol Levilílar ošol

(21) saqlavyn miškanynyn ol šarajatnyn. ויעשו. [54] Da qyldylar

$210 v^{0} \quad$ (1) ulanlary Jisra’elnin barča nečik ki bujurdu Adonaj Mošeǵa alaj

(2) qyldylar.

Numbers 2

(2) וידבר [1] Da sözĺadi Adonaj Mošeǵa da Aharon-

(3) gaa ajtadoğač. אישר. [2] Har kiši öz alamy qatyna belgílar 
(19) hundred. [44] These are those that were numbered, that Moses and Aaron

(20) and the princes of Israel numbered; twelve men, each one

(21) was by the house of his fathers. [45] And all those that were numbered

(1) of the sons of Israel, by the house of their fathers, from twenty years old

(2) and upward, all who go out to war in Israel: [46] And

(3) all they that were numbered were six times a hundred thousand and three thousand

(4) and five hundred and fifty. [47] But the Levites after the tribe of

(5) their fathers were not numbered among them. [48] And

(6) the Lord spoke to Moses, saying, [49] 'Only the tribe

(7) of Levi you shall not number, and you shall not take the sum of their heads among

(8) the sons of Israel. [50] But you shall appoint the

(9) Levites over the tabernacle of law, and over all its vessels,

(10) and over all things that belong to it. They shall bear

(11) the tabernacle and all its vessels, and they

(12) shall serve it, and they shall camp around the tabernacle.

(13) [51] And when the tabernacle travels,

(14) the Levites shall take it down, and when the tabernacle camps,

(15) the Levites shall set it up. And the stranger who comes near, other than them,

(16) shall be put to death. [52] And the sons of Israel shall dwell,

(17) every man by his own camp, and every man by his own standard,

(18) by their armies. [53] And the Levites shall camp around the tabernacle

(19) of law, so there will be no anger on the congregation

(20) of the children of Israel, and the Levites shall keep the

(21) charge of the tabernacle of law.' [54] And

(1) the children of Israel did according to all that the Lord commanded $210 \mathrm{v}^{\mathrm{o}}$ Moses.

(2) They did so.

Numbers 2

[1] And the Lord spoke to Moses and to Aaron,

(3) saying, [2] 'Every man, the children of Israel, shall camp by his own standard with the signs 
(4) byla üvüsajyn atalarynyn toḥtasynlar ulanlary Jisra’elnin qaršy-

(5) dan čüvŕa ohel mo'ed qatyna toḥ $\{t\} a s y n l a r$. והחנים. [3] Da ol

(6) toḥtavčular kün tuvušusary mizraḥsary alamy avulunun Juhu-

(7) danyn čerüvlarisajyn da ag̉araq čerüvü üstüńa anyn Naḩšon

(4) uvlu 'Aminadavnyn. וצבאו [4] Da čerüvü anyn da sanalġan-

(9) lary alarnyn jetmiš dört min da alty jüz. והחנים. [5]

(10) Da ol toḥtavčular anyn qatyna ševeti Jissaharnyn da nasi

(11) ulanlaryna Jissaharnyn Netan’el uvlu Cu'arnyn. וצבאו. [6]

(12) Da čerüvü anyn da sanalġanlary alarnyn enli dört min da

(13) dört jüz. מטה [7 [ Da anyn qatyna ševeti Zevulunnun da

(14) nasi ulanlaryna Zevulunnun Eli'av uvlu Helonnun. וצבאו. [8]

(15) Da čerüvü anyn da sanalġanlary alarnyn enli jedi min da dört

(16) jüz. כל [9] Bar ol sanalganlar avulunun Juhudanyn jüz min da

(17) seksen min da alty minlar da dört jüz čerüvla $\{r\}$ isajyn bu-

(18) runġu jerǵad́a köčsünlar. דגל. [10] Alamy avulunun Ru’u-

(19) vennin temansary čerüvlarisajyn da nasi ulanlaryna Ru'uven-

(20) nin Elicur uvlu Šede’urnun. [וצבו. [11] Da čerüvü anyn

(21) da sanalġanlary alarnyn qyrq alty min da beš jüz. והחונם. [12]

$211 \mathrm{r}^{\circ} \quad$ (1) Da ol toḥtavčular anyn qatyna ševeti Šimonnun da nasi

(2) ulanlaryna Šim'onnun Šelumi'el uvlu Curišadajnyn. וצבאו. [13]

(3) Da čerüvü anyn da sanalġanlary alarnyn enli tog̉uz min da üč

(4) jüz. ומטה [14] Da ševeti Gadnyn da nasi ulanlaryna Gadnyn

(5) Elijasaf uvlu Dúu'elnin. וצבאו. [15] Da čerüvü anyn da sanal-

(6) ġanlary a\{lar\}nyn qyrq beš min da alty jüz da enli. כל. [16] Bar

(7) ol sanalġanlar avulunun Ru'uvennin jüz min da enli bir min

(8) da dört jüz da enli čerüvlarisajyn da ekinči jerǵad́a

(9) köčsünlar. ונסע [17] Da köčsün ohel mo'ed avulu ol 
(4) by their father's house: they shall camp opposite,

(5) all around the tent of meeting. [3] And the

(6) ones camping toward the rising of the sun: eastward is the standard of the camp of Judah

(7) by their armies. And the superior over the army is Nahshon,

(8) son of Amminadab. [4] And his army, and those that were numbered

(9) of them, are seventy-four thousand and six hundred. [5]

(10) And the ones camping next to him is the tribe of Issachar. And the prince

(11) of the children of Issachar is Nethanel, son of Zuar. [6]

(12) And his army, and those that were numbered of them, are fifty-four thousand and

(13) four hundred. [7] And next to him: the tribe of Zebulun. And

(14) the prince of the children of Zebulun is Eliab the son of Helon. [8]

(15) And his army, and those that were numbered of them, are fifty-seven thousand and four

(16) hundred. [9] All those numbered in the camp of Judah were a hundred and

(17) eighty thousand and six thousand and four hundred, by their armies.

(18) They shall set out in the first line. [10] The standard of the camp of Reuben

(19) is southward, by their armies. And the prince of the children of Reuben

(20) is Elizur, son of Shedeur. [11] And his army,

(21) and those that are numbered of them, are forty-six thousand and five hundred. [12]

(1) And the ones camping by him is the tribe of Simeon. And the prince $211 \mathrm{r}^{\mathrm{o}}$

(2) of the children of Simeon is Shelumiel, son of Zurishaddai. [13]

(3) And his army, and those that were numbered of them, are fifty-nine thousand and three

(4) hundred. [14] And the tribe of Gad. And the prince of the children of Gad

(5) is Eliasaph, son of Deuel. [15] And his army, and those that were numbered

(6) of them, are forty-five thousand and six hundred and fifty. [16] All

(7) those numbered in the camp of Reuben are a hundred thousand and fifty-one thousand

(8) and four hundred and fifty, by their armies. And they shall set out in the second line.

(9) [17] And the tent of meeting, the camp of the Levites, shall set out 
(10) Levilílarnin ortasynda ol avullarnyn ki nečik toḥtasalar

(11) alaj köčsünlar har kiši ornunda alamlarysajyn. דגל [18]

(12) Alamy avulunun Efrajimnin čerüvlarisajyn ma'arav sary da

(13) nasi ulanlaryna Efrajimnin Elišamac uvlu 'Amihudnun.

(14) [וצבאו Da čerüvü anyn da sanalġanlary alarnyn qyrq min

(15) da beš jüz. [20] Da anyn qatyna ševeti Menašenin da

(16) nasi ulanlaryna Menašenin Gamli'el uvlu Pedahcurnun.

(17) וצבאו (21] Da čerüvü anyn da sanalgaanlary alarnyn otuz eki

(18) min da eki jüz. ומטה. [22] Da ševeti Binjaminnin da nasi

(23) ulanlaryna Binjaminnin Avidan uvlu Gid'oninin. וצבאו [23)

(20) Da čerüvü anyn da sanalg̀anlary alarnyn otuz beš min da dört

(21) jüz. כל [24] Bar ol sanalganlar avulunun Efrajimnin jüz min da

$211 v^{0} \quad$ (1) segiz minlar da jüz 1 čerüvlarisajyn da üčünčü jerǵad́a köč-

(2) sünlar. דגל [25] Alamy avulunun Dannyn cafonsary čerüvlarisajyn

(3) da nasi uvullaryna Dannyn Ahi'ezer uvlu 'Amišadajnyn. וצבאו [26]

(4) Da čerüvü anyn da sanalġanlary alarnyn altymyš eki min da jedi

(5) jüz. והחנים [27] Da ol toḥtavčular anyn qatyna ševeti Ašernin

(6) dיםבאו [28]

(7) Da čerüvü anyn da sanalġanlary alarnyn qyrq bir min da beš jüz.

(8) ומטה [29] Da ševeti Naftalinin da nasi uvullaryna Naftalinin

(9) Ahira' uvlu 'Enannyn. וצבאו. [30] Da čerüvü anyn da sanalġanlary

(10) alarnyn enli üč min da dört jüz. כל. [31] Bar ol sanalġanlar

(11) avulunun Dannyn jüz min da enli jedi min da alty jüz sondra-

(12) da köčsünĺar alamlary sajyn. אלה. [32] Bulardylar sanalganlary u-

(13) vullarynyn Jisra'elnin üvüsajyn atalarynyn bar sanalganlary ol avul-

(14) larnyn čerüvlarisajyn alty keŕat jüz min da üč minlar da beš

(15) jüz da enli. והלוים [33] Da ol Levilílar sanalmadylar ortasyn-

(16) da uvullarynyn Jisra’elnin ki nečik bujurdu Adonaj Mošeǵa.

\footnotetext{
${ }^{1} \mathrm{~K}:$ jüzd́a; a scribal error. | TKow.o1: jüz. | H: jüz. | C: jüz.
} 
(10) in the midst of the camps. As they camp,

(11) so shall they set out, every man in his place by their standards. [18]

(12) The standard of the camp of Ephraim by their armies is westward. And

(13) the prince of the children of Ephraim is Elishama, son of Ammihud.

(14) [19] And his army, and those numbered of them, are forty thousand

(15) and five hundred. [20] And next to him is the tribe of Manasseh. And

(16) the prince of the children of Manasseh is Gamaliel, son of Pedahzur.

(17) [21] And his army, and those numbered of them, are thirty-two

(18) thousand and two hundred. [22] And the tribe of Benjamin. And the prince

(19) of the children of Benjamin is Abidan, son of Gideoni. [23]

(20) And his army, and those numbered of them, are thirty-five thousand and four

(21) hundred. [24] All those numbered of the camp of Ephraim are a hundred thousand and

(1) eight thousand and a hundred, by their armies. And they shall set out $211 \mathrm{v}^{\mathrm{o}}$ in the third line.

(2) $[25]$ The standard of the camp of Dan is northward, by their armies.

(3) And the prince of the sons of Dan is Ahiezer, son of Ammishaddai. [26]

(4) And his army, and those numbered of them, are sixty-two thousand and seven

(5) hundred. [27] And the ones camping by him is the tribe of Asher.

(6) And the prince of the sons of Asher is Pagiel, son of Ocran. [28]

(7) And his army, and those numbered of them, are forty-one thousand and five hundred.

(8) [29] And the tribe of Naphtali. And the prince of the sons of Naphtali

(9) is Ahira, son of Enan. [30] And his army, and those numbered

(10) of them, are fifty-three thousand and four hundred. [31] All those numbered

(11) of the camp of Dan are a hundred thousand and fifty-seven thousand and six hundred. They shall set out last

(12) by their standards.' [32] These are those numbered

(13) of the sons of Israel by the house of their fathers. All those numbered of the camps

(14) by their armies are six times a hundred thousand and three thousand and five

(15) hundred and fifty. [33] And the Levites were not numbered among

(16) the sons of Israel, as the Lord commanded Moses. 
(17) (34] Da qyldylar uvullary Jisra’elnin barča nečik ki bujur-

(18) du Adonaj Mošeǵa alaj toḥtadylar da alaj köčtülar har kiši

(19) uruvlarysajyn üvüsajyn atalarynyn.

\section{Numbers 3}

(20) tuvmušlary Aharonnun da Mošenin sözlaǵan künd́a Adonaj Moše-

(21) ga tavynda Sinajnyn. [2] Da bulardylar atlary \{uvullarynyn\} Aharonnun

$212 \mathrm{r}^{\mathrm{o}}$ (1) Ol tunġuč Nadav da Avihu' da El'azar da Itamar. אלה. [3] Bular-

(2) dylar atlary \{uvullarynyn Aharonnun\} ol kohenĺarnin ol jag̉yndyrylganlarnyn ki toldurdu ošol

(3) qolun alarnyn kohenlik etḿa. [ימת [4] Da öldü Nadav da

(4) Avihu' alnynda Adonajnyn juvutqanlarynda jat ot alnyna Adonaj-

(5) nyn midbarynda Sinajnyn da uvullar joggedilar alarg̉a da kohe\{n\}lik

(6) etti El'azar da Itamar tiri eǵand́a Aharon atasy alarnyn.

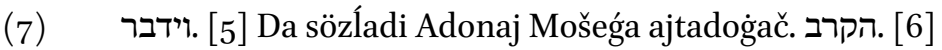

(8) Juvutqun ošol ševetin Levinin da turg̉uzğun any alnynda Aharon-

(9) nun ol kohennin da jumuš etsinĺar anar. ושמרו. [7 Da

(10) saqlasynlar ošol saqlavyn anyn da ošol saqlavyn bar ol žymatnyn

(11) alnynda ohel mo'ednin qulluq etḿa ošol qullugiun ol

(12) miškannyn. [בכאן חסר [פסוק] ושמרוץ] [8 Da saqlas[ynlar] ${ }^{1}$ ošol bar [savutlaryn] ${ }^{2}$ ohel ${ }_{L}$ mo'ed [nin da ošol] ${ }^{3}$ saqlavun u [vullarynyn $]^{4}$ Jisra'elnin [qulluq] ${ }^{5}$ etḿa ošol [qullugiun] ${ }^{6}{ }_{\text {[ }}$ ol miškannyn] ${ }^{17}$. [9] [9]תת Da bergin ošol ol Levililarni Aharonġa

\footnotetext{
${ }^{1}$ TKow.o1: saqlasynlar; unvocalized text. | H: saqlasynlar. | C: deest. | M: saqlasynlar. | R: deest. ${ }^{2}$ TKow.o1: savutlaryn; unvocalized text. | H: savutlaryn. | C: deest. | M: saggtlaryn. | R: deest. ${ }^{3}$ TKow.o1: mo'ednin da ošol; unvocalized text. | H: mo'ednin da osol. | C: deest. | M: mo'edniy da y̌sol. | R: deest. $\quad{ }^{4}$ TKow.o1: uvullarynyn; unvocalized text. | H: uvullarynyn. | C: deest. | M: oǵlanlarynyy. | R: deest. $\quad{ }^{5}$ TKow.o1: qulluq; unvocalized text. | H: qulluq. | C: deest. | M: qulluq. | R: deest. $\quad{ }^{6}$ TKow.o1: qulluginn; unvocalized text. | H: qullugiun. | C: deest. | M: qullugiyn. | R: deest. ${ }^{7} \mathrm{~K}$ : ohel mo'ednin; a scribal error. | TKow.o1: ol miškannyn; unvocalized text. | H: ol miskannyn. | C: deest. | M: miškannyy. | R: deest. $\quad{ }^{8}$ Marginal insertion by another hand (without vocalization).| TKow.o1: Da saqlasynlar ošol bar savutlaryn ohel mo'ednin da ošol saqlavun uvullarynyn Jisra'elnin qulluq etḿa ošol qulluġun ol miškannyn; unvocalized text. | H: Da saqlasynlar osol bar savutlaryn ohel mo'ednin da osol saqlavun uvullarynyn Jisra'elnin qulluq etme osol qullugiun ol miškannyn. | C: deest; an interesting similarity between K, C, and R, cf. also Lev 17:7. | M: Da saqlasynlaryšol

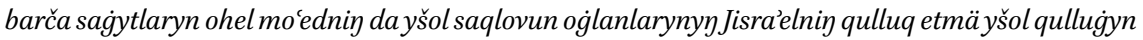
ol miškannyy. | R: deest; an interesting similarity between K, C, and R.
} 
(17) [34] And the sons of Israel did according to all that the Lord commanded

(18) Moses: so they camped, and so they set out, every man

(19) by their families, by the house of their fathers.

Numbers 3

[1] And these

(20) are the children of Aaron and Moses in the day that the Lord spoke with Moses

(21) on Mount Sinai. [2] And these are the names of the sons of Aaron:

(1) the firstborn Nadab, and Abihu, and Eleazar, and Ithamar. [3] These $212 \mathrm{r}^{\circ}$

(2) are the names of the sons of Aaron, the priests who were anointed, who filled

(3) their hand to serve as priests. [4] And Nadab and Abihu died

(4) before the Lord when they brought forward strange fire before the Lord

(5) in the wilderness of Sinai, and they had no sons. And

(6) Eleazar and Ithamar served as priests in the lifetime of Aaron their father.

(7) [5] And the Lord spoke to Moses, saying, [6]

(8) 'Bring forward the tribe of Levi, and stand it before Aaron

(9) the priest, that they may serve to him. [7] And

(10) they shall keep his charge, and the charge of all the congregation

(11) before the tent of meeting, to serve the service of the

(12) tabernacle. ${ }_{L}\{\text { The [verse] 'And they shall keep' is missing here. }\}^{1206}$ $\{[8]$ And [they shall] keep all the [vessels of] the tent of meeting, [and the] charge [of the sons] of Israel, to [serve] the [service] of the [tabernacle $\left.{ }^{207}.\right\}$ [9] And you shall give the Levites to Aaron

206 Inserted by another hand in Hebrew.

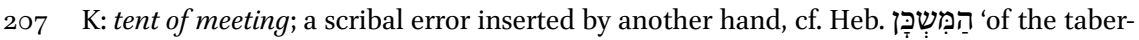
nacle'. 
(13) da uvullaryna anyn berilmüšlar berilmüšĺar alar anar

(14) uvullaryndan Jisra'elnin. ואת [10] Da ošol Aharonnu da

(15) ošol uvullaryn anyn symarlaġyn da saqlasynlar ošol kohenlikĺa-

(16) rin da ol jat ol juvuvču jerǵasińa kohenliḱ́arinin öltü-

(17) rülsün. וידבר [11] Da sözladi Adonaj Mošeǵa ajtadoġač.

(18) [12] Da men muna aldym ošol ol Levililarni ortasyndan

(19) ulanlarynyn Jisra’elnin bar tunġuč ornuna ačylmag̉yn qursaqnyn

(20) ulanlaryndan Jisra’elnin da bolsunlar maja ol Levilílar. כי. [13]

(21) Ki menimdi bar tunġuč qyrgaan künümd́a bar tunġučnu jerin-

$212 \mathrm{~V}^{\mathrm{o}}$ (1) d́a Micrinin aziz ettim özüḿa bar tunġučnu Jisra’eld́a

(2) adamdan tuvargadejin maja bolsunlar menmen Adonaj. [14] Da

(3) sözladi Adonaj Mošeǵa midbarynda Sinajnyn ajtadoġač. פקד. [15]

(4) Sanaġyn ošol uvullaryn Levinin üvüsajyn atalarynyn uruvlarysajyn

(5) bar erkakni aj jaštan da jog̉arraq sanag̉yn alarny. [יפקד. [16]

(6) Da sanady alarny Moše bujruguna köŕa Adonajnyn ki nečik

(7) bujuruldu. ויהיו Da edilar bular uvullary Levinin atlary-

(8) byla Geršon da Qahat da Merari. ואלה [18] Da bulardylar at-

(9) lary uvullarynyn Geršonnun uruvlarysajyn Livni da Šimci. ובני [19]

(10) \{Da $\}$ uvullary Qahatnyn uruvlarysajyn 'Amram da Jichar da Ḥevron da 'Uzi'el.

(11) ובני (20] Da uvullary Merarinin uruvlarysajyn Maḥli da Muši bular-

(12) dylar alar uruvlary ol Levinin üvüsajyn atalarynyn. לגרשון. [21]

(13) Geršonnun uruvu ol Livni da uruvu ol Šimci bulardylar

(14) alar uruvlary ol Geršoninin. פקודיהם. [22] Sanalġanlary

(15) alarnyn sanbyla bar erḱk aj jaštan da jog̉arraq sanalganlary

(16) alarnyn jedi minlar da beš jüz. משפחות. [23] Uruvlary ol

(17) Geršonnun ol miškan artyna toḥtasynlar macarav sary.

(18) [ונשיא [24] Da nasisi üvünün atanyn uruvunun Geršoninin

(19) Elijasaf uvlu La'elnin. ומשמרת [25 Da saqlavy uvullarynyn Geršon- 
(13) and to his sons. They are given - they are given - to him

(14) from the sons of Israel. [10] And you shall appoint Aaron and

(15) his sons, and they shall keep their priesthood,

(16) and the stranger that comes near to the line of their priesthood

(17) shall be put to death.' [11] And the Lord spoke to Moses, saying,

(18) [12] And I, lo, I have taken the Levites from among

(19) the children of Israel in place of all the firstborn that opens the womb

(20) among the children of Israel. And the Levites shall be mine. [13]

(21) Because all the firstborn are mine. On the day that I smote all the firstborn in the land

(1) of Egypt I sanctified to me all the firstborn in Israel,

(2) from human to animal. They shall be mine. I am the Lord.' [14] And

(3) the Lord spoke to Moses in the wilderness of Sinai, saying, [15]

(4) 'Number the children of Levi by the house of their fathers, by their families.

(5) You shall number them: every male from a month old and upward.' [16]

(6) And Moses numbered them according to the command of the Lord, as

(7) he was commanded. [17] And these were the sons of Levi by their names:

(8) Gershon, and Kohath, and Merari. [18] And these are

(9) the names of the sons of Gershon by their families: Libni, and Shimei. [19]

(10) And the sons of Kohath by their families: Amram, and Izehar, and Hebron, and Uzziel.

(11) [20] And the sons of Merari by their families: Mahli, and Mushi. These are

(12) the families of the Levites by the house of their fathers. [21]

(13) The family of Gershon are the Libnites and the family of the Shimites. These are

(14) the families of the Gershonites. [22] Those numbered

(15) of them, by the number of all the males, from a month old and upward, those numbered

(16) of them are seven thousand and five hundred. [23] The families of the

(17) Gershonites shall camp behind the tabernacle, westward.

(18) [24] And the prince of the house of the father of the Gershonites

(19) is Eliasaph, son of Lael. [25] And the charge of the sons of Gershon 
(20) nun ohel mo`edd́a ol miškan da ol čatyr qaplavy anyn da qaplavy

(21) ešiginin ohel mo'ednin. וקלעי [26] Da enĺari ol qahranyn

$213 \mathrm{r}^{\mathrm{0}} \quad$ (1) da ošol qaplavy ešiginin ol qahranyn ki ol miškan qatyna da

(2) ol mizbeah qatyna čüvŕa da ošol šnurlary anyn bar qulluğ[u]sajyn ${ }^{2}$.

(3) ולקהת [27 Da Qahatnyn \{u\}ruvu ol 'Amrami da uruvu ol Jichari

(4) da uruvu ol Hevroni da uruvu ol 'Uzi'eli bulardylar alar

(5) uruvlary ol Qahatinin. במספר. [28] Sanbyla bar erkak

(6) aj jaštan da jog̉arraq segiz minlar da alty jüz saqlavčular

(7) saqlavun ol qodešnin. משפחות. [29] Uruvlary uvullarynyn ol

(8) Qahatnyn toḥtasynlar janynda ol miškannyn teman sary.

(9) [30] Da nasisi üvünün atanyn uruvlarynyn ol Qahati-

(10) nin Elicafan uvlu 'Uzi'elnin. ומשמרתם. [31] Da saqlavlary

(11) alarnyn ol aron da ol stol da ol čyraqpa da ol miz-

(12) beaḥlar da ol aziz savutlar ki jumuš etadilar alarbyla da

(13) ol qaplav da bar qullugiu anyn. [32] Da nasisi nasi-

(14) Íarinin ol Levinin El'azar uvlu Aharonnun ol kohennin vakilligi

(15) saqlavčularnyn saqlavun ol qodešnin. למררי. [33] Merarinin uru-

(16) vu ol Mahli da uruvu ol Muši bulardylar alar uruvlary

(17) Merarinin. ופקודיהם] Da sanalganlary alarnyn sanbyla bar

(18) erḱkak aj jaštan da joğarraq alty minlar da eki jüz.

(19) [35] Da nasisi üvünün atanyn uruvlarynyn Merarinin

(20) Curi’el uvlu Aviḥajilnin janynda ol miškannyn toḥtasynlar

(21) cafon sary. ופקודת [36] Da vakilligi saqlavynyn uvullarynyn

$213 \mathrm{v}^{\mathrm{o}} \quad$ (1) Merarinin taḥtalary ol miškannyn da beklüvüčlari anyn da bag̉analary

(2) anyn da tabanlary anyn da bar savutlary anyn da bar qullugiu anyn.

(3) (37 Da bag̉analary ol qahranyn čüvŕa da tabanlary alarnyn

(4) da qazyqlary alarnyn da šnurlary alarnyn. [38 [38 Da ol

(5) toḥtavčular alnynda ol miškannyn kün tuvušusary alnynda

${ }^{1} \mathrm{~K}$ : qaplavyn; a scribal error.|TKow.o1:qaplavy.|H:qaplavu.|C: jabuvun; a scribal error. $\quad{ }^{2}$ TKow. o1: qullugiubyla; unvocalized text. | H: qullugiusajyn. | C: qulluġuna. 
(20) in the tent of meeting is the tabernacle, and the tent, its covering, and the cover

(21) of the door of the ten of meeting, [26] And the curtains of the court,

(1) and the covers for the door of the court which is by the tabernacle and

(2) by the altar all around, and the cords of it according to all its service.

(3) [27] And the family of Kohath are the Amramites and the family of the Izeharites

(4) and the family of the Hebronites and the family of the Uzzielites. These are they,

(5) the families of the Kohathites. [28] By the number of all the males,

(6) from a month old and upward: eight thousand and six hundred keeping

(7) the charge of the Holy. [29] The families of the sons

(8) of Kohath shall camp on the side of the tabernacle, southward.

(9) [30] And the prince of the house of the father of the families of the Kohathites

(10) is Elizaphan, son of Uzziel. [31] And their charge

(11) is the ark, and the table, and the lampstand, and the

(12) altars, and the holy vessels with which they minister, and

(13) the cover and all of its service. [32] And the prince of princes

(14) of the Levites is Eleazar, son of Aaron, the priest, and has the supervision

(15) of them that keep the charge of the Holy. [33] The family of Merari

(16) are the Mahlites and the family of the Mushites. These are they, the families

(17) of Merari. [34] And those numbered of them, by the number of all

(18) the males, from a month old and upward: six thousand and two hundred.

(19) [35] And the prince of the house of the father of the families of Merari

(20) is Zuriel, son of Abihail. They shall camp on the side of the tabernacle,

(21) northward. [36] And the supervision of the charge of the sons

(1) of Merari are the boards of the tabernacle, and its bars, and its pillars, $\quad 213 \mathrm{v}^{\mathrm{o}}$

(2) and its bases, and all its items, and all of its service,

(3) [37] And the pillars of the court all around, and their bases,

(4) and their pegs, and their cords. [38] And

(5) those who camp before the tabernacle, toward the rising of the sun, before 
(6) ohel mo'ednin mizraḥsary Moše da Aharon da uvullary anyn

(7) saqlavčular saqlavyn ol miqdašnyn saqlavy sajyn uvullarynyn Jisra’el-

(8) nin da ol jat alardan özǵa ol juvuvču öltürülsün.

(9) כל [39] Bar sanalgaanlary ol Leviliĺarnin ki sanady Moše da Aharon

(10) bujrugguna köŕa Adonajnyn uruvlarysajyn bar erkak aj

(11) jaštan da jog̉arraq igirmi eki min. [40] Da ajtty

(12) Adonaj Mošeǵa sanag̉yn bar erḱak tunġučnu uvullarynyn Jis-

(13) [ra]'elnin aj jaštan da jog̉arraq da alg̀yn ošol sanyn atlarynyn.

(14) ולקחת [41] Da alg̀yn ošol ol Levilílarni maja menmen Adonaj

(15) bar tunġuč ornuna uvullarynda Jisra'elnin da ošol

(16) tuvaryn ol Levilílarnin bar tunġuč ornuna tuvarynda uvul-

(17) larynyn Jisra’elnin. ויפקוד [42] Da sanady Moše ki nečik bujur-

(18) du Adonaj anar ošol bar tunġučnu uvullarynda Jisra’elnin.

(19) ויהי (43] Da edi bar erḱkak tungučč sanybyla atlarnyn aj

(20) jaštan da jog̉arraq sanalġanlarysajyn igirmi eki min eki jüz da

(21) jetmiš $\{\ddot{u} c ̌\}^{1}$. וידבר. [44] Da sözladi Adonaj Mošeǵa ajtadog̉ač.

$214 \mathrm{r}^{\mathrm{O}}$ (1) קח. [45] Alġyn ošol ol Levilíarni bar tunġuč ornuna uvulla-

(2) rynda Jisra’elnin da ošol tuvaryn ol Levilílarnin tuvarlary

(3) ornuna alarnyn da bolsunlar maja ol Levilílar menmen Adonaj.

(4) ואת [46] Da ošol juluvlaryn ol eki jüz da \{jetmiš üčnün ol ar-

(5) tadoġanlarnyn ol Levilílar üstüńa tunġučundan uvullarynyn

(6) Jisra’elnin. [47] Da alġyn bešar bešar mitqallar

(7) bašsajyn ol aziz mitqal byla alġyn igirmi gögdü ol mit-

(8) qal. [48] Da bergin ošol ol kümüš\{nü\} Aharonġa

(9) da uvullaryna anyn juluvlaryn ol artadoġanlarnyn alarda.

(10) ויקח [49] Da aldy Moše ošol kümüšün ol juluvnun ol

(11) artadoganlardan juluvlary üstüńa ol Levilílarnin. מאת. [50] \{Ošol\}

(12) tunġučundan uvullarynyn Jisra’elnin aldy ošol ol kümüšnü

(13) min da üč jüz da altymyš beš mitqal mitqaly byla ol

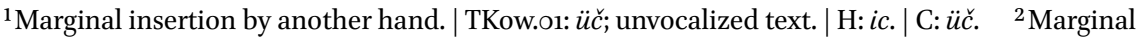
insertion by another hand. | TKow.o1: deest. | H: osol. | C: deest.
} 
(6) the tent of meeting, eastward, are Moses and Aaron and his sons,

(7) keeping the charge of the sanctuary for the charge of the children of Israel.

(8) And the stranger that comes near, other than them, shall be put to death.

(9) [39] All those numbered of the Levites, whom Moses and Aaron numbered

(10) according to the commandment of the Lord, by their families, all the males from a month

(11) old and upward: twenty-two thousand. [40] And the Lord said

(12) to Moses, 'Number all the firstborn of the males of the children of Israel

(13) from a month old and upward, and take the sum of their names.

(14) [41] And you shall take the Levites for me-I am the Lord-

(15) in place of all the firstborn among the children of Israel, and the

(16) livestock of the Levites in place of all the firstborns among the livestock

(17) of the children of Israel.' [42] And Moses numbered, as the Lord commanded

(18) him, all the firstborn among the children of Israel.

(19) [43] And all the firstborn males by the number of names, from a month

(20) old and upward, by those numbered: twenty-two thousand two hundred and

(21) seventy-\{three $\}$. [44] And the Lord spoke to Moses, saying,

(1) [45] 'Take the Levites instead of all the firstborn among the children

(2) of Israel, and the livestock of the Levites instead of their livestock,

(3) and the Levites shall be mine. I am the Lord.

(4) [46] And as for the redemption of the two hundred and seventy-three

(5) who are left over the Levites from the firstborn of the children

(6) of Israel: [47] You shall even take five mithqals each

(7) per head; you shall take it by the holy mithqal. The mithqal is twenty gögs.

(8) [48] And you shall give the silver to Aharon

(9) and to his sons - redemption of those left over among them.'

(10) [49] And Moses took the silver of the redemption

(11) from those left over above the redemption of the Levites. [50]

(12) He took the silver from $\{$ the $\}$ firstborn of the children of Israel:

(13) a thousand and three hundred and sixty-five mithqals, by the mithqal 
(14) qodešnin. ויתן. [51] Da berdi Moše ošol kümüšün ol julu-

(15) ganlarnyn Aharonġa da uvullaryna anyn bujrugiuna köŕa

(16) Adonajnyn ki nečik bujurdu Adonaj Mošeǵa.

Numbers 4

וידבר Da

(17) sözĺadi Adonaj Mošeǵa ${ }_{L}\{d a \text { Ag̉arong }[a]\}^{11}$ ajtadog̉ač. נשא. [2] Alġyn ošol

(18) „[sanyn bašynyn u]vullarynyn ${ }^{12}$ Qahatnyn ortasyndan uvullarynyn Levinin

(19) uruvlarysajyn üvüsajyn atalarynyn. מבן. [3] Otuz jaštan

(20) da jog̉arraq da enli jašqadejin bar ol kelüvčü jyjynġa

(21) qylma iš ohel mo`edd́a. זאת. [4] Budur qullug̉u uvullary-

$214 \mathrm{~V}^{0}$ (1) nyn Qahatnyn ohel mo'edd́a qodeš ol qadašim. [בא [5] Da kelsin

(2) Aharon da uvullary anyn köčḱand́a ol avul da endirsinĺar

(3) ošol parohetin ol qaplavnyn da qaplasynlar anyn byla ošol aronun

(4) ol šarajatnyn. ונתנו. [6] Da bersinlar anyn üstüńa qapla-

(5) vyn tahaš terisinin da ja $\{j\}$ synlar upraq tüǵal köktan jog̉ar-

(6) tyn da qojsunlar tutqučlaryn anyn ${ }_{\llcorner}$javrunu üstüńa ol

(7) eltüvčülarnin ${ }^{13}$. ועל [7 [ Da stolu üstüńa ol eki

(8) jüzlü ötḿaknin jajsynlar kök upraq da bersinlar anyn

(9) üstüńa ošol ol tepsílarni da ošol ol qašyqlarny da

(10) ošol ol arytqyčlarny ${ }^{4}$ da ošol stolpeclarin ol qaplavyn

(11) da ol hammešalik ötḿak anyn üstüńa bolsun.

(12) [8 [8 Da jajsynlar alar üstüńa upraq qyrmyzy

(13) jiṕaktan da qaplasynlar any qaplav byla taḥaš terisind́an

(14) da qojsunlar ošol tutqučlaryn anyn. ולקחו [9] Da alsyn-

(15) lar kök upraq da qaplasynlar ošol čyraqbasyn ol jaryqlyqnyn

(16) da ošol čyraq orunlaryn anyn da ošol qysqačlaryn anyn

(17) da ošol mačmarlaryn anyn da ošol bar jav tutadog̉an savut-

(18) laryn anyn ki jumuš etadilar anar alarbyla. ונתנו. [10] Da

(19) bersinlar any da ošol bar savutlaryn anyn qapla\{v\}g ga tahaš

(20) terisindan da bersinlar ol üśak üstünáa. [11]

\footnotetext{
${ }^{1}$ Marginal insertion by another hand. | TKow.o1: $d a$ Agaronga; unvocalized text. | H: deest. | C: deest. $\quad{ }^{2} \mathrm{~K}$ : deest; a scribal error; cf. Num 4:22. | TKow.o1: sanyn bašynyn uvullarynyn; unvocalized text. | H: basynyn uvullarynyn. | C: sanyn oglanlarynyy. $\quad{ }^{3}$ Interpretative addition to the standard text. $\quad{ }^{4}$ See our remark in Exo 25:29.
} 
(14) of the Holy. [51] And Moses gave the silver of those who were redeemed

(15) to Aaron and to his sons, according to the command of the Lord,

(16) as the Lord commanded Moses.

Numbers 4

$[1]$ And

(17) the Lord spoke to Moses \{and to Aaron\}, saying, [2] 'Take the

(18) [sum of the heads] of [sons] of Kohath from among the sons of Levi,

(19) by their families, by the house of their fathers: [3] From thirty years old

(20) and upward and up to fifty years old, all who come to the army,

(21) to do the work in the tent of meeting. [4] This is the service of the sons

(1) of Kohath in the tent of meeting: the Holy of Holies. [5] And

(2) Aaron and his sons shall come when the camp is to set out, and they shall take down

(3) the veil of the covering and cover with it the ark

(4) of the law. [6] And they shall put on it a cover

(5) of porpoise skin, and shall spread over it a cloth all of blue,

(6) and shall put its poles ${ }_{L}$ over the shoulders

(7) of those who carry it ${ }^{1208}$. [7] And on the table of

(8) showbread they shall spread a cloth of blue, and they shall put on it

(9) the bowls, and the spoons, and

(10) the cloth |used for covering the showbread|, and the tablecloths, the cover;

(11) and the continual bread shall be on it.

(12) [8] And they shall spread on them a cloth of scarlet

(13) silk, and they shall cover it with a covering of porpoise skin,

(14) and they shall set its poles. [9] And they shall take

(15) a blue cloth and cover the lampstand of the light,

(16) and its places for candles, and its tongs,

(17) and its censers, and all the vessels to keep the oil |in them|

(18) with which they serve to it. [10] And

(19) they shall put it and all its equipment into a covering of porpoise

(20) skin, and they shall put it on a beam. [11]

208 An interpretative addition to Num 4:6. 
(21) Da ol altyn mizbeah üstüńa jajsynlar kök upraq

$215 \mathrm{r}^{\mathrm{r}} \quad$ (1) da qaplasynlar any qaplav byla taḥaš terisind́an da qojsunlar

(2) ošol tutqučlaryn anyn. [ולקחו [12] Da alsynlar ošol bar

(3) jumušluq savutlarny ki jumuš etadilar alar byla qodešta

(4) da bersinlar kök upraqqa da qaplasynlar alarny qaplav

(5) byla taḥaš terisind́an da bersinlar ol üśak üs-

(6) tüńa. [13] Da külün ketarsinlar ošol ol

(7) mizbeaḥnyn da jajsynlar anyn üstüńa upraq jipkind́an.

(8) ונתנו [14] Da bersinlar anyn üstüńa ošol bar savut-

(9) laryn anyn ki jumuš etadilar anyn üstüńa alar byla

(10) ošol mačmarlarny da ošol ol jyrg̉aqlarny da ošol ol

(11) sibirtkilarni da ošol ol kuboklarny bar savutlaryn ol

(12) mizbeaḥnyn da jajsynlar anyn üstüńa qaplav taḥaš te-

(13) risind́an da qojsunlar tutqučlaryn anyn. וכלה [15] Da

(14) nečik tüǵallaśa Aharon da uvullary anyn qaplama ošol

(15) ol qodešni da ošol bar savutlaryn ol qodešnin köčkand́a

(16) ol avul da andan sortun kelsinlar uvullary Qahatnyn

(17) eltḿa da tijḿasinlar ol qodeška da ölarlar

(18) budur eltmagi uvullarynyn Qahatnyn ohel mo'edd́a.

(19) [16] Da vakilligi El'azarnyn uvlunun Aharonnun ol

(20) kohennin javy ol jaryqlyqnyn da tütüsü ol otjamlarnyn

(21) da ol hammešalik tirki da ol jag̉ynmaq javy vakilligi

$215 \mathrm{~V}^{\mathrm{o}} \quad$ (1) bar ol miškannyn da barča neki anda qodešta da savut-

(2) וידבר. larynda anyn Da sözĺadi Adonaj Mošeǵa da

(3) Aharonġa ajtadoġač. אל. [18] Zynharlanyjyz ki eksitmagáajsiz

(4) ošol ševetin uruvlarynyn ol Qahatinin ortasyndan ol Levililar-

(5) nin. [19] Da bunu qylyjyz alarga da tiri bolsunlar da

(6) ölḿasinĺar juvugaanlarynda qodeš ol qadašimǵa Aharon da

(7) uvullary anyn kelsinlar da qojsunlar alarny har kišini qullu-

(8) ġu qatyna da jügü qatyna. ולא [20] Da kelmasinlar baqma

(9) tağatqanda ošol ol qodešni da ölarlar. (פשט שני על (10)

(10) ולא יבאו לראות כבלע. Da kelḿasinlar baqma japqanda

(11) ošol ol qodešni da ölarlar.

פרשת נשא (12) (12)

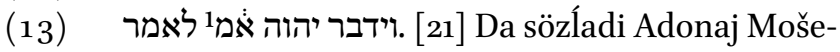

(14) ge ga ajtadog̉ač. [22] Alğyn ošol sanyn

\footnotetext{
1'An abbreviation of Heb. אֶל־שֶׁה 'to Moses'.
} 
(21) And on the golden altar they shall spread a blue cloth, and

(1) they shall cover it with a covering of porpoise skin, and they shall set $215 \mathrm{r}^{\mathrm{o}}$

(2) its poles. [12] And they shall take all the

(3) vessels of the service with which they serve in the Holy

(4) and put them in a blue cloth and cover them with a covering

(5) of porpoise skin and put them on a beam.

(6) [13] And they shall take away the ashes of the

(7) altar and spread a cloth of purple over it.

(8) [14] And they shall put on it all its equipment

(9) with which they serve at it-

(10) the censers, and the forks, and the

(11) brushes, and the cups-all the equipment

(12) of the altar, and they shall spread on it a covering of porpoise

(13) skin and set its poles. [15] And

(14) when Aaron and his sons will finish covering the

(15) Holy and all the equipment of the Holy when the camp sets out,

(16) after that the sons of Kohath shall come

(17) to carry. But they shall not touch the Holy: they will die.

(18) These are what the sons of Kohath are to carry in the tent of meeting.

(19) [16] And the supervision of Eleazar, son of Aaron, the

(20) priest, is the oil for the light, and the fragrant incense,

(21) and the continual grain offering, and the anointing oil—-the supervision

(1) of all the tabernacle, and of all that is in it, in the Holy, and in its ves- $215 \mathrm{v}^{\mathrm{o}}$ sels.'

(2) [17] And the Lord spoke to Moses and

(3) to Aaron, saying, [18] 'Beware not to cut off

(4) the tribe of the families of the Kohathites from among the Levites,

(5) [19] But do to them thus, that they may live, and

(6) not die when they approach to the Holy of Holies: Aaron and

(7) his sons shall go in and appoint them every one to his service

(8) and to his burden. [20] But they shall not go in to see

(9) the Holy when it is being covered: they will die.' A second translation of

(10) 'But they shall not go in to see': But they shall not go in to see

(11) the Holy when it is being covered: they will die.'

(12) Parashat Naso

(13) [21] And the Lord spoke to Moses,

(14) saying, [22] 'Take the sum 
(15) bašynyn uvullarynyn Geršonnun daġyn alarnynda üvüsajyn atalary-

(16) ny uruvlarysajyn. מבן. 23] Otuz jaštan da jog̉arraq enli

(17) jašqadejin sanaġyn alarny bar ol kelüvčünü jyjynlama jyjyn qulluq

(18) etḿa qulluq ohel mo`edd́a. זאת. [24] Budur qullug̉u u-

(19) ruvlarynyn ol Geršoninin qulluq etḿa da jük kötürḿa

216 r r $^{\circ}$ (1) [25] Da eltsinlar ošol enlarin ol miškannyn da

(2) ošol ohel mo'edni qaplavyn anyn da qaplavyn ol tahaš teri-

(3) sinin ki anyn üstüńa jog̉artyn da ošol qaplavyn ešiginin

(4) ohel mo'ednin. ואת [26] Da ošol enlarin ol qahranyn da

(5) ošol qaplavyn ešiginin qabag̉ynyn ol qahranyn ki ol miškan qaty-

(6) na da ol mizbeah qatyna čüvŕa da ošol šnurlaryn alarnyn

(7) da ošol bar savutlaryn qulluqlarynyn da ošol barča neki qy-

(8) lyndy alarg̉a da qulluq etsinlar. על ע27 Bujrugiuna kö-

(9) ŕa Aharonnun da uvullarynyn bolsun bar qullugiu uvullarynyn

(10) ol Geršoninin bar jüklari sajyn da bar qulluqlarysajyn alarnyn

(11) da symarlajyz alarg̉a saqlavbyla ošol bar jükĺarin alarnyn.

(12) . זאת [28] Budu qul[1]uguu uruvlarynyn uvullarynyn ol Geršoninin

(13) ohel mo'edd́a da saqlavlary alarnyn qolu ašyra Itamarnyn

(14) uvlunun Aharonnun ol kohennin. בני (29] Uvullaryn Merarinin

(15) uruvlarysajyn üvüsajyn atalarynyn sanaggyn alarny. מבן. [30] Otuz

(16) jaštan da jog̉arraq da enli jašqadejin sanaġyn alarny bar ol

(17) kelüvčünü jyjynġa qulluq etḿa ošol qullug̉un ohel mo'ed-

(18) nin. [31] Da budur saqlavy jükĺarinin bar qulluqlarysajyn

(19) ohel mo'edd́a tạ̣talary ol miškannyn da beklüvüčlari da

(20) bag̉analary da tabanlary anyn. ועמודי. [32] Da bag̉analary ol qah-

(21) ranyn čüvŕa da tabanlary alarnyn da qazyqlary da šnurlary alarnyn

$216 \mathrm{v}^{\mathrm{o}} \quad$ (1) bar savutlarysajyn da bar qulluqlarysajyn alarnyn da atlarbyla

(2) symarlajyz ošol savutlaryn saqlavynyn jükĺarinin. זאת [33] Budur

(3) qullugiu uruvlarynyn uvullarynyn Merarinin bar qulluqlarysajyn

(4) alarnyn ohel mo`edd́a qolu ašyra Itamarnyn uvlunun Aharon-

(5) nun ol kohennin. ויפקוד [34 Da sanady Moše da Aharon da 
(15) of the heads of the sons of Gershon, them as well, by the houses of their fathers,

(16) by their families. [23] From thirty years old and upward and up to fifty

(17) years old you shall number them, all who come to join up to do military service,

(18) to do service in the tent of meeting. [24] This is the service

(19) of the families of the Gershonites: to serve, and to carry burdens.

(1) [25] And they shall carry the curtains of the tabernacle, and

(2) the tent of meeting, its covering, and the covering of porpoise skin

(3) that is on it above, and the cover for the door

(4) of the tent of meeting, [26] And the curtains of the court, and

(5) the cover for the door of the gate of the court, which is by the tabernacle

(6) and by the altar all around, and their cords,

(7) and all the equipment of their service, and all that is made

(8) for them, and they shall serve. [27] According to the command

(9) of Aaron and his sons shall be all the service of the sons

(10) of the Gershonites, in all their burdens, and in all their service.

(11) And you shall appoint to them the charge of all their burdens.

(12) [28] This is the service of the families of the sons of the Gershonites

(13) in the tent of meeting. And their charge is in the hand of Ithamar

(14) the son of Aaron the priest. [29] The sons of Merari:

(15) you shall number them by their families, by the house of their fathers. [30] From thirty

(16) years old and upward and up to fifty years old you shall number them, all who

(17) comes to the army, to serve the service of the tent of meeting.

(18) [31] And this is the charge of their burdens, according to all their service

(19) in the tent of meeting: the boards of the tabernacle, and its bars, and

(20) its pillars, and its bases, [32] And the pillars

(21) all around the court, and their bases, and their pegs, and their cords,

(1) by all their equipment, and by all their service. And

(2) you shall entrust the equipment of the charge of their burdens by name. [33] This is

(3) the service of the families of the sons of Merari, by all their service

(4) in the tent of meeting in the hand of Ithamar, son of Aaron,

(5) the priest.' [34] And Moses and Aaron and 
(6) nasilari ol 3̌ymatnyn ošol uvullaryn ol Qahatinin uruvlary-

(7) sajyn \{da\} üvüsajyn atalarynyn. מבן [35] Otuz jaštan da jog̉arraq

(8) da enli jašqadejin bar ol kelüvčünü jyjynġa qulluq et-

(9) má ohel mo'edd́a. [36] Da edilar sanalganlary

(10) alarnyn uruvlarysajyn eki minlar jedi jüz da enli.

(11) [37 [37 Bulardylar sanalganlary uruvlarynyn ol Qahatinin bar ol

(12) qulluq etüvčü ohel mo'edd́a ki sanady Moše da Aharon

(13) bujrug̉una köŕa Adonajnyn naviligi ašyra Mošenin.

(14) ויפקוד Da sanalġanlary uvullarynyn Geršonnun uruv-

(15) larysajyn da üvüsajyn atalarynyn. [39] Otuz jaštan da

(16) jog̉arraq da enli jašqadejin bar ol kelüvčü jyjynġa qulluq-

(17) qa ohel mo'edd́a. [40] Da edilar sanalġanlary

(18) alarnyn uruvlarysajyn üvüsajyn atalarynyn eki minlar da

(19) alty jüz da otuz. אלה. [41] Bulardylar sanalganlary uruvlary-

(20) nyn uvullarynyn Geršonnun bar ol qulluq etüvčü ohel

(21) mo'edd́a ki sanady Moše da Aharon bujrug̉una köŕa

$217 \mathrm{r}^{\circ}$ (1) Adonajnyn. [42] Da sanalganlary uruvlarynyn uvullarynyn

(2) Merarinin uruvlarysajyn üvüsajyn atalarynyn. [43] Otuz

(3) jaštan da jog̉arraq da enli jašqadejin bar ol kelüvčü jyjyn-

(4) ġa qulluqqa ohel mo'edd́a. [44] Da edilar sanalġan-

(5) lary alarnyn uruvlarysajyn üč minlar da eki jüz. אלה. [45]

(6) Bulardylar sanalġanlary uruvlarynyn uvullarynyn Merarinin ki sanady

(7) Moše da Aharon \{bujrugiuna köŕa Adonajnyn naviligi ašyra Mošenin.

כל [46] Bar ol sanalġanlar ki sanady Moše da Aharon\} da nasilari Jisra’elnin ošol ol Levililíar-

(8) ni uruvlarysajyn da üvüsajyn atalarynyn. מבן [47 Otuz

(9) jaštan da jog̀arraq da enli jašqadejin bar ol kelüvčünü q\{u\}lluq

(10) etḿa qulluggun qulluqnun da qullug̉un jüknü eltmáa- 
(6) the princes of the congregation numbered the sons of the Kohathites by their families,

(7) and by the house of their fathers, [35] From thirty years old and upward

(8) and up to fifty years old, all who come to the army,

(9) for the service in the tent of meeting. [36] And those numbered

(10) of them by their families were two thousand seven hundred and fifty.

(11) [37] These were those numbered of the families of the Kohathites, all those

(12) who do service in the tent of meeting, whom Moses and Aaron did number

(13) according to the commandment of the Lord by the prophecy of Moses.

(14) [38] And those numbered of the sons of Gershon,

(15) by their families, and by the house of their fathers, [39] From thirty years old

(16) and upward and up to fifty years old, all who come to the army,

(17) for the service in the tent of meeting: [40] And those numbered

(18) of them, by their families, by the house of their fathers, were two thousand and

(19) six hundred and thirty. [41] These are those numbered of the families

(20) of the sons of Gershon, of all that serve in the tent

(21) of meeting, whom Moses and Aaron did number according to the commandment

(1) of the Lord. [42] And those numbered of the families of the sons

(2) of Merari, by their families, by the house of their fathers, [43] From thirty

(3) years old and upward and up to fifty years old, everyone that comes to the army,

(4) for the work in the tent of meeting: [44] And those numbered

(5) of them by their families were three thousand and two hundred. [45]

(6) These are those numbered of the families of the sons of Merari, whom

(7) Moses and Aaron numbered according to the command of the Lord by the prophecy of Moses. [46] All those numbered, whom Moses and Aaron and the princes of Israel numbered, the Levites,

(8) by their families, and by the house of their fathers, [47]

(9) From thirty years old and upward and up to fifty years old, all who comes to serve

(10) the service of service and the service of carrying the burden 
(11) nin ohel mo'edd́a. [48 [ Da edilar sanalg̉anlary alarnyn

(12) segiz minlar da beš jüz da seksen. על. [49] Bujruguuna kö-

(13) ŕa Adonajnyn sanady alarny naviligi ašyra Mošenin har kišini

(14) qulluğu qatyna da jügü qatyna da sanalġanlary anyn ki nečik

(15) bujurdu Adonaj Mošeǵa.

$[\text { Numbers } 5]^{1}$

. וידבר Da sözladi Adonaj

(16) Mošeǵa ajtadoġač. צ. [2] Bujurg̉un ulanlaryna Jisra’el-

(17) nin da sürsünlar ol avuldan bar caracatlyny da bar zavlyny

(18) da bar murdarny žanüčün. [3] [3] Erkaktan tiši-

(19) ǵadejin sürüjüz tyšqartyn avulg̀a sürüjüz alarny da murdar

(20) etḿasinlar ošol avullaryn özlarinin ki šehinam menim

(21) toḥtajdy ortalarynda alarnyn. ויעשו. [4] Da qyldylar alaj

$217 \mathrm{~V}^{\mathrm{o}} \quad$ (1) ulanlary Jisra’elnin da sürdülar alarny tyšqartyn avulğa

(2) ki nečik sözladi Adonaj Mošeǵa alaj qyldylar ulanlary Jisra’el-

(3) nin. [5] Da sözĺadi Adonaj Mošeǵa ajtadog̉ač.

(4) (6בר [6̈zlagin ulanlaryna Jisra’elnin kiši jemeśa qatyn

(5) ki qylsalar bar jazyqlaryndan ol adamnyn tanma tanmaq Adonaj-

(6) ġa da fašmanly bolsa ol žan. [7] Da mode

(7) bolsunlar ošol jazyqlaryn ki qyldylar da qajtarsyn ošol

(8) fašmanlyġyn bütünübyla da bešinči ülüšün arttyrsyn

(9) anyn üstüńa da bersin anar ki fašmanly boldu anar.

(10) ואם (8] Da eger bolmasa kišiǵa juvuq qajtarma ol

(11) fašmanlyqny anar ol fašmanlyq ol qajtarylġan bolsun Adonaj-

(12) ġa kohenǵa bašqa qočqaryndan ol bošatlyqlarnyn ki bošat-

(13) lyq qolar anyn byla anyn üčün. [9ד [9] Da bar teruma

(14) bar qodešlarisajyn ulanlarynyn Jisra’elnin ki juvutsalar kohenǵa

(15) anar bolsun. [יאש [10] Da kiši ošol qodeš etḱan nerśa-

(16) ĺari anyn erkind́a bolsunlar kiši ki berśa qajsy kohenǵa

(17) ki klaśa anar bolsun. וידבר. Da sözĺadi Adonaj Moše-

(18) ǵa ajtadog̉ač. דבר. [12] Sözlagin ulanlaryna Jisra’elnin da

${ }^{1} \mathrm{~K}$ : The chapter number is not indicated. | TKow.o1: Num 5; unvocalized text. | H: Num 5 . | C: Num 5. 
(11) in the tent of meeting: [48] And those numbered of them

(12) were eight thousand and five hundred and eighty. [49] According to the command

(13) of the Lord he numbered them by the prophecy of Moses, every man

(14) by his service and by his burden: and his counts |were|, as

(15) the Lord commanded Moses.

$[\text { Numbers } 5]^{209}$

(16) to Moses, saying, [2] 'Command the children of Israel,

(17) that they shall drive out of the camp every leper, and everyone who has a discharge,

(18) and everyone who is unclean by a soul. [3] From male to female:

(19) you shall drive |them $\mid$ outside the camp; you shall drive them, and that they shall not make

(20) their camps, in the midst of which my divine Presence

(21) dwells, unclean.' [4] And the

(1) children of Israel did so, and drove them out, outside the camp.

(2) As the Lord spoke to Moses, so did the children of Israel.

(3) [5] And the Lord spoke to Moses, saying,

(4) [6] 'Speak to the children of Israel, "A man or a woman

(5) who commits any of the sins of humans, to do a trespass

(6) against the Lord: and if that soul is guilty, [7] Then they shall confess

(7) their sin which they have done. And he shall pay back

(8) for his trespass wholly, and ha shall add to it its fifth part,

(9) and he shall give it to him against whom he has trespassed.

(10) [8] But if the man has no kinsman to pay him back

(11) for the trespass, the trespass that is payed back is the Lord's,

(12) for the priest, besides the ram of the atonement by which

(13) he will ask for atonement for him. [9] And every heave offering

(14) of all the holy things of the children of Israel which they bring forward to the priest,

(15) shall be his. [10] And a man's holy things

(16) shall be his possession. Whatever a man wants to give to a priest

(17) shall be his.' [11] And the Lord spoke to Moses,

(18) saying, [12] 'Speak to the children of Israel, and

209 The beginning of chapater 5 is not indicated in the manuscript. 
(19) ajtqyn alarg̉a nendij kiši ki azsa qatyny anyn da tansa

(20) anda tanmaq. ושכב [13] Da jatsa kiši anyn byla jatuvun

(21) urluqnun da jašyryn bolsa bu nerśa közĺarind́an erinin da

$218 \mathrm{r}^{\mathrm{o}} \quad$ (1) jašynsa da ol murdar bolundu da tanyq bolmasa anda

(2) da ol tutulmady. [14] Da tašsa anyn üstüńa

(3) saġyšy künülaḿaknin da künülaśa qatynyna da ol murdar

(4) bolundu jemeśa ašsa anyn ašyra sag̉yšy künülaḿaknin da

(5) ol murdar bolunmady. והביא. [15] Da keltirsin ol kiši ošol

(6) qatynyn özünün ol kohenǵa da keltirsin ošol qarbanyn anyn

(7) anyn qatyna onunču ülüšün ol efanyn unun arpalar-

(8) nyn qujmasyn anyn üstüńa jav da bermasin anyn üstü-

(9) ńa levona ki tirkisidi künülamaklarnin ol tirkisidi

(10) saġynčlyqnyn saġyndyradog̉an güńaḥni. והקריב. [16] Da juvut-

(11) sun any ol kohen da turğuzsun any alnynda Adonajnyn.

(12) ולקח [17 Da alsyn ol kohen aziz suvlar \{čerepli\} savutqa da ol

(13) topraqtan ki bolsa gruntunda ol miškannyn alsyn ol

(14) kohen da bersin ol suvlarg̉a. והעמיד. [18] Da turg̉uz-

(15) sun ol kohen ošol ol qatynny alnynda Adonajnyn da ačsyn

(16) ošol bašyn ol qatynnyn da bersin uvučlary üstüńa

(17) anyn ošol tirkisin ol saġynčlyqnyn tirkisidi ol künü-

(18) ĺaḿaḱlarnin ol da qolunda ol kohe\{n\}nin bolsunlar ol ačy suvlar

(19) ol qargiajdoġanlar. והשביע. Da antettirsin ${ }^{1}$ any ol kohen

(20) da ajtsyn ${ }_{\llcorner}\langle$anar $\rangle\{\text {ol qatyn }[\text { ġa }]\}^{12}$ eger jatmady eśa kiši senin byla da

(21) eger azmadyj eśa murdarlyq byla erij tübüńa könü

$218 \mathrm{v}^{\mathrm{o}} \quad$ (1) bolgajsen ol ačy $\langle\text { puvlar }\rangle^{3}$ suvlardan ol qargajdog̉anlardan ošpular-

(2) dan. [20] Da sen ki azdyj eśa boladoġač erki tübüńa

(3) erijnin da ki murdar bolunduj eśa da berdi eśa

(4) kiši send́a ošol jatuvun bašqa erijd́an. והשביע. [21]

(5) Da antet[t] irsin ${ }^{4}$ ol kohen ošol ol qatynny anty byla ol

(6) qarğyšnyn ošpu da ajtsyn \{kohen\} qatynġa berǵaj Adonaj seni

(7) qargyš́qa da antqa ortasynda ulusujnun berǵand́a

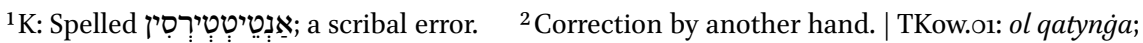
unvocalized text. | H: ol qatyg். | C: ol hatyng். $\quad{ }^{3} \mathrm{~A}$ scribal error. $\quad{ }^{4} \mathrm{~K}$ : antetirsin; a scribal error.
} 
(19) you shall say to them, 'Any man whose wife go astray and does a trespass:

(20) [13] And if a man lies with her-an intercourse

(21) of seed - and this thing is hidden from the eyes of her husband, and

(1) if she is hidden and becomes unclean, and if there is no witness against her,

(2) and she was not been caught, [14] And if the

(3) thought of jealousy overflows him, and he is jealous of his wife, and she became unclean,

(4) or if the thought of jealousy comes through him, and

(5) she did not become unclean: [15] Then the man shall bring

(6) his wife to the priest, and he shall bring her offering

(7) for her, the tenth part of an ephah of barley flour.

(8) He shall not pour oil on it and shall not put

(9) frankincense on it, because it is a grain offering of jealousy, a grain offering

(10) of remembrance, causing an iniquity to be recalled. [16] And

(11) the priest shall bring her forward and stand her before the Lord.

(12) [17] And the priest shall take holy water in an earthen vessel,

(13) and the priest shall take of the dust that is in the floor of the tabernacle

(14) and put it into the water. [18] And the priest shall stand

(15) the woman before the Lord and uncover

(16) the woman's head and put the grain offering of remembrance in her hands:

(17) it is the grain offering of jealousy.

(18) And in the hands of the priest there shall be bitter

(19) cursing water. [19] And the priest shall make her take an oath,

(20) and say 〈to her〉 \{to the woman\}, 'If no man has lain with you, and

(21) if you have not gone astray to uncleanness |while you were| under your husband's authority,

(1) you shall be innocent from his bitter water that causes the curse.

(2) [20] But you, if you have gone astray |while| being under your husband's authority,

(3) and if you have become unclean, and if

(4) a man other than your husband has given you his bed,' [21]

(5) Then the priest shall make the woman to take an oath

(6) of this curse, and the priest shall say to the woman, 'May the Lord give you

(7) a curse and an oath among your people when the Lord sets 
(8) Adonaj ošol butujnu tüškanni da ošol qursaġyjny šiš-

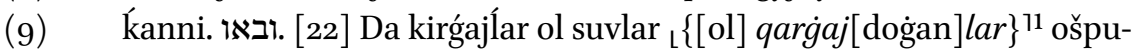
lar bavur-

(10) saqlaryja šištirma qursaqny da tüšürḿa butnu

(11) da ajtsyn ol qatyn amen amen. וכתב. 23] Da jazsyn ol

(12) kohen ošol ol qarğyšlarny ošpularny bitikka da sürt-

(13) sün ol ačy suvlarğa. והשקה. [24] Da ičirsin ol

(14) qatynġa ošol ol ačy suvlarny ol qarg̉ajdoġanlarny da

(15) kírarlar anar ol qarg̉ajdoġan suvlar ačylyqlarg̉a. [25]

(16) Da alsyn ol kohen qolundan ol qatynnyn ošol tirkisin ol

(17) künülaḿaklarnin da sunsun ošol ol tirkini alnynda

(18) Adonajnyn da juvutsun any ol mizbeahqa. וקמץ [26] Da

(19) ajyrsyn ol kohen ol tirkid́an ošol tütüsün anyn da

(20) tütatsin ol mizbeahta da andan sortun ičirsin ol

(21) qatynġa ošol ol suvlarny. והשקה. [27 Da ičirsin

$219 \mathrm{r}^{\mathrm{o}} \quad$ (1) ošol ol qatynga ol suvlarny da bolġaj eger murdar bolundu

(2) eśa da tandy eśa tanmaq erińa da kiŕarlar anar ol

(3) suvlar ol qarg̉ajdog̉anlar ačylyqlarg̉a da šišar qursaġy anyn

(4) da tüšar butu anyn da bolur ol qatyn qarġyšqa ortasyn-

(5) da ulusunun. ואם . [28] Da eger murdar bolunmady _eśa \{ol qatyn\} ${ }^{12}$

(6) da aruv eśa ol da könü bolur da urluqlanyr urluq

(7) ol ačy suvlardan. [29] Budur üvŕatüvü ol künüla-

(8) maḱlarnin ki azsa qatyn boladog̉ač erki tübüńa erinin

(9) da murdar bolunsa. [30] Jemeśa kiši ki ašsa anyn

(10) üstüńa saġyš künülaḿaknin da künülaśa qatynyna ö-

(11) züńa da turg̉uzsun ošol ol qatynny alnynda Adonajnyn

(12) da qylsyn anar ol kohen ošol bar ol üvŕatüvnü ošpunu.

(13) ונקה [31] Da könü bolur ol kiši günahạtan da ol qatyn

(14) kötürür ošol క̌urumun özünün.

Numbers 6

וידבר . [1] Da söz-

(15) ĺadi Adonaj Mošeǵa ajtadog̀ač. דבר. [2] Sözlagin ulan-

(16) laryna Jisra’elnin da ajtqyn alarg̉a kiši ${ }_{L}\{\text { jemeśa qatyn }\}^{13}$ ki ajyrsa nijet

\footnotetext{
${ }^{1}$ Marginal insertion by another hand; cf. Num 5:18. | TKow.o1: deest; unvocalized text. | H: ol qargajdog்anlar.|C: qarg்yšly. ${ }^{2} \mathrm{~K}:\{$ ol qatyn $\}$ eśa; the addition is misplaced.|TKow.o1: eśa ol qatyn.| H: ese ol qatyn. | C: esä ol hatyn. ${ }^{3}$ Marginal insertion by another hand. | TKow.o1: jemese qatyn; unvocalized text. | H: jemese qatyn. | C: ja hatyn.
} 
(8) your thigh sagging and your womb swelling.

(9) [22] And this $\{$ curs $[$ ing $]\}$ water shall go in your insides,

(10) to swell the womb and make the thigh sag.'

(11) And the woman shall say, 'Amen, amen.' [23] And

(12) the priest shall write these curses in a book, and

(13) he shall rub them into the bitter water. [24] And

(14) he shall cause the woman to drink the bitter cursing water and

(15) the bitter cursing water will come into her, to become bitterness. [25]

(16) And the priest shall take grain offering of jealousy out of the woman's hand,

(17) and shall wave the grain offering before

(18) the Lord, and he shall bring it forward to the altar. [26] And

(19) the priest separate from the grain offering its incense, and

(20) shall burn it on the altar, and afterward he shall make the woman drink

(21) the water. [27] And he shall make her drink

(1) the water, and it shall be: if she was unclean,

(2) and has trespassed a trespass against her husband,

(3) the cursing water will come into her, to become bitterness, and her womb will swell,

(4) and her thigh will sag, and the woman shall be a curse among

(5) her people. [28] And if the woman has not been made unclean,

(6) and she is clean, and she will be innocent and shall conceive seed

(7) from the bitter water. [29] This is the teaching of jealousies,

(8) when a wife goes astray being under her husband's authority

(9) and becomes unclean. [30] Or if the thought of jealousy overflows a man,

(10) and he is jealous over his wife,

(11) and he shall stand the woman before the Lord,

(12) and the priest shall do of this teaching to her.

(13) [31] And the man shall be innocent from iniquity, and that woman

(14) shall bear her punishment.

Numbers 6

[1] And

(15) the Lord spoke to Moses, saying, [2] 'Speak

(16) to the children of Israel, and say to them, "A man \{or a woman $\}$ who makes a separation 
(17) etḿa nijet bolma nazir ajyrma özün ičkisind́an borla

(18) čag̉yrynyn alnynda Adonajnyn. מיין [3] Vinadan da esirtüv-

(19) čüdan ajyrsyn özün sirḱasin vinanyn da esirtüvčünün

(20) ičmasin da bar šorbasyn borlalarnyn ičmaasin da jüvüš

(21) borlalarny da qurugian borlalarny ašamasyn. כל. [4] Bar nazirlik kün-

$219 \mathrm{v}^{\mathrm{o}}$ (1) ĺarind́a baryndan neki qylyndy borlalyqtan ol vina qabuqlardan da

(2) kippiǵadejin ašamasyn. כל [5] Bar nijetli künlarind́a nazirli-

(3) ginin jülüvüč ašmasyn bašy ašyra anyn tolg̀unča ol künlar ki

(4) ajyrsa özün Adonajğa aziz bolsun östürma kikil čač $[y] n^{1}$

(5) bašynyn. כל [6] Bar ajyrg̉an künlarind́a özün Adonajğa heč žany

(6) Gatyna ölü adamnyn kelḿasin. לאביו. [7] Atasy üčün

(7) da anasy üčün qaryndašy üčün da tuvdug̉u üčün murdar

(8) bolunmasyn alar üčün ölǵanlarind́a ki tačy Tenrisinin bašy

(9) üstüńa. כל [8] Bar nazirlik künlarind́a azizdir ol

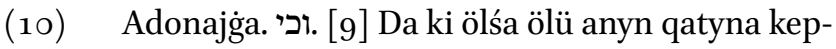

(11) keneta da murdar etśa bašyn nazirliginin da jülüsün čačyn

(12) bašynyn arynġan kününd́a ol jedinči künd́a jülüsün any.

(13) וביום [10] Da ol segizinči künd́a keltirsin eki bede-

(14) ńalar jemeśa eki kügürčün balalary ol kohenǵa ešigińa ohel

(15) mo'ednin. ועשה] [11] Da qylsyn ol kohen birni hatatqa da

(16) birni 'olag̉a da bošatlyq qolsun anyn üčün andan ki jazyqly

(17) boldu murdar bolunmaġy byla žanybyla ölü adamnyn da aziz

(18) etsin ošol bašyn anyn ol künd́a. והזיר. [12] Da ajyrsyn Adonaj-

(19) ga ošol künlarin nazirliginin da keltirsin qozu jyllyq balasy

(20) ašamġa da ol burunġu künlar tüšsünlar ki murdar

(21) boldu nazirligi anyn. [13] Da budur üvratüvü ol nazirnin

$220 \mathrm{r}^{\circ} \quad$ (1) tolġan künd́a künĺari nazirliginin keltirsin özün ešigińa ohel

(2) mo`ednin. והקריב [14] Da juvutsun ošol qarbanyn özünün Adonajg̀a

\footnotetext{
${ }^{1} \mathrm{~K}$ : Spelled צִָָָ a scribal error. | TKow.o1: čačyn; unvocalized text. | H: cacyn. | C: sačyn.
} 
(17) to vow a vow, to be a nazarite, to separate from the drink of grape

(18) wine before the Lord, [3] He shall separate himself from wine and strong drinks,

(19) he shall not drink vinegar of wine or of strong drink,

(20) and he shall not drink any juice of grapes, and

(21) he shall not eat moist or dried grapes. [4] All the days of his naziritehood

(1) he shall not eat anything that is made of the grapevine, of grape skin, $219 \mathrm{v}^{\mathrm{o}}$ and

(2) even of |grape| stones. [5] All the days of the vow of his naziritehood

(3) a razor shall not pass on his head - until the fulfilment of the days that

(4) he separates himself to the Lord he shall be holy-to let the locks of the hair

(5) of his head grow. [6] All the days that he separates himself to the Lord

(6) he shall not come to the soul of a dead man. [7] For his father

(7) and for his mother, for his brother and for his sister:

(8) he shall not become unclean for them when, because the crown of his God

(9) is on his head. [8] All the days of his naziritehood he is holy

(10) to the Lord. [9] And if any dead man dies beside him

(11) suddenly, and he has defiled the head of his naziritehood, then he shall shave his hair

(12) of his head in the day of his cleansing: he shall shave it on the seventh day.

(13) $[10]$ And on the eighth day he shall bring two turtledoves

(14) or two young pigeons to the priest, to the door of the tent

(15) of meeting. [11] And the priest shall do one for a sin offering and

(16) one for a burnt offering, and he shall ask for atonement for him, because he sinned

(17) by being with the soul of a dead person, and he shall consecrate

(18) his head on that day. [12] And he shall separate to the Lord

(19) the days of his naziritehood, and he shall bring a one-year-old lamb

(20) for a guilt offering, and the first days shall fall because

(21) his naziritehood became unclean. [13] And this is the teaching of the nazarite:

(1) On the day of fulfilment of the days of his naziritehood he shall bring $\quad 220 \mathrm{r}^{\circ}$ himself to the door of the tent

(2) of meeting. [14] And he shall bring forward his offering to the Lord: 
(3) qozu jyllyq balasy tüǵalni birni 'olag̉a da bir qozu jyllyq balasy tü-

(4) ǵalni ḥatatqa da bir qočqar tüǵalni šelamimǵa. וסל. [15]

(5) Da čétan macalar öźak halalar jumurulġanlar javbyla da jug̉a

(6) macalar jaggylġanlar javbyla da tirkilari alarnyn da nesehĺari alar-

(7) והקריב. I6] Da juvutsun ol kohen alnyna Adonajnyn da

(8) qylsyn ošol ḥatatyn anyn da ošol 'olasyn. [17]

(9) Da ošol ol qočqarny qylsyn šelamim debehasy Adonajğa četani

(10) qatyna ol macalarnyn qylsyn ol kohen ošol tirkisin da

(11) ošol neseḩin anyn. [18] Da jülütsün ol nazir ešigin-

(12) da ohel mo'ednin ošol nazir \{lik\} čačyn bašynyn da alsyn $\left\{o o^{\circ} o l\right\}^{1}$ nazir-

(13) lik čačyn bašynyn da bersin ol ot üstüńa ki ol šelamim

(14) debehasy tübüńa. ולקח [19] Da alsyn ol kohen ošol ol

(15) bilakni biškanni ol qočqardan da ḥala maca bir ol četan-

(16) dan da juğa maca bir da bersin uvučlary üstüńa ol

(17) nazirnin jülütḱkanind́an sortun ošol čačyn nazirliginin.

(18) [20] Da sunsun alarny ol kohen tenufa alnynda Adonaj-

(19) nyn qodešti ol kohenǵa töšübyla ol tenufanyn da inčigi

(20) byla ol terumanyn da andan sortun ičsin ol nazir vina.

(21) זאת [21] Budur üvŕatüvü nazirnin ki nijet etśa qarbany

$220 v^{0} \quad$ (1) anyn Adonajğa nazirligi üčün bašqa neki jetśa küčü qolu-

(2) nun nijetińa köŕa ki nijet etśa alaj qylsyn üvŕatüvü-

(3) ńa köŕa nazirliginin. [ידבר [22] Da sözladi Adonaj Mošeǵa

(4) ajtadoġač. דבר. [23] Sözlagin Aharong̉a da uvullaryna

(5) anyn ajtadog̉ač bulaj alġyšlajyz ošol ulanlaryn Jisra’elnin

(6) ajtma alarg̉a. יברכך [24] Alġyšlag̉aj seni Adonaj da saqlag̉aj

(7) seni. יאר . 25] Jarytqaj Adonaj qyblalaryn özünün saja da

(8) hajifsünǵaj seni. ישא. [26] Kötürǵaj Adonaj hašgaḥalaryn

(9) saja da qojğaj saja tynčlyq. ושמו. [27] Da qojarlar ošol

(10) atymny ulanlary üstüńa Jisra’elnin da men² alġyšlarmen bar-

(11) laryn.

${ }^{1}$ Marginal insertion by another hand. | TKow.o1: ošol; unvocalized text. | H: osol. | C: šol. $\quad{ }^{2} \mathrm{~K}$ : Spelled מָז; a scribal error. 
(3) one unblemished one-year-old lamb for a burnt offering and one unblemished one-year-old lamb

(4) for a sin offering and one unblemished ram for peace offerings, [15]

(5) And a basket of unleavened cakes of fine flour mixed with oil and

(6) unleavened flans anointed with oil, and their grain offering, and their drink offerings.

(7) [16] And the priest shall bring forward them before the Lord and

(8) shall do his sin offering and his burnt offering. [17]

(9) And he shall offer the ram for a sacrifice of peace offerings to the Lord

(10) with the basket of unleavened bread. The priest shall do his grain offering and

(11) his drink offering. [18] And the nazarite shall shave

(12) the head of his naziritehood at the door of the tent of meeting, and he shall take $\{$ the $\}$

(13) hair of his naziritehood of his head and put it on the fire which

(14) is under the sacrifice of the peace offerings. [19] And the priest shall take the

(15) cooked forearm of the ram and one unleavened cake out of the basket,

(16) and one unleavened flan, and he shall put them on the hands of the

(17) nazarite after he had shaved the hair of his naziritehood.

(18) $[20]$ And the priest shall elevate them for a wave offering before the Lord.

(19) It is holy for the priest with the breast of the wave offering and the thigh of the heave offering. And after that the nazarite shall drink wine.

(20) [21] This is the teaching of the nazarite who will vow his offering

(1) to the Lord for his naziritehood beside of what his hand may attain. $220 \mathrm{v}^{\mathrm{o}}$

(2) According to his vow which he vows, so he shall do

(3) after the teaching of his naziritehood."' [22] And the Lord spoke to Moses,

(4) saying, [23] 'Speak to Aaron and to his sons,

(5) saying, "Thus you shall bless the children of Israel,

(6) saying to them: [24] "May the Lord bless you and keep

(7) you. [25] May the Lord make his face shine to you and

(8) be gracious to you. [26] May the Lord raise his Providence

(9) to you and give you peace." " [27] And they shall put

(10) my name on the children of Israel, and I will bless them

(11) all.' 


\section{Numbers 7}

(11) ויהי [1] Da edi tügállaǵan künd́a Moše turğuz-

(12) ma ošol ol miškanny da jag̉yndyrdy any da aziz etti any

(13) da ošol bar savutlaryn da ošol ol mizeahny da ošol bar

(14) savutlaryn anyn da jaġyndyrdy alarny da aziz etti alarny.

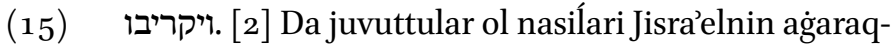

(16) lary üvünün atalarynyn alardylar nasilar ol ševetlarnin alar

(17) edilar ol turuvčular ol sanalġanlar qatyna. Da

(18) keltirdiĺar ošol qarbanlaryn özĺarinin alnyna Adonajnyn

(19) alty jabuq arabalar da on eki syġyr araba eki ol nasi-

(20) ĺardan da ögüz bird́an da juvuttular alarny alnyna ol

(21) miškannyn. ויאמר. [4] Da ajtty Adonaj Mošeǵa ajtadoġač.

$221 \mathrm{r}^{\mathrm{o}}$ (1) קח. [5] Alg̀yn alardan da bolsunlar qulluq etḿa ošol qullugiun

(2) ohel mo`ednin da bergin alarny ol Levililarǵa har kišiǵa qullu-

(3) guna köŕa. ויקח [6] Da aldy Moše ošol ol arabalarny da

(4) ošol ol syg̉yrny da berdi alarny Levililarǵa. את. [7] Ošol

(5) eki ol arabalarny da ošol dört ol syġyrny berdi uvullary-

(6) na Geršonnun qulluqlaryna köŕa. ואת. [8] Da ošol ol

(7) dört arabalarny da ošol ol segiz ol syg̈yrny berdi uvullary-

(8) na Merarinin qulluqlaryna köŕa alarnyn qolu ašyra Itamar-

(9) nyn uvlunun Aharonnun ol kohennin. ולבני [9] Da uvullaryna

(10) Qahatnyn bermadi ki ol qodeš qullugiu alar üstüńa javrun-

(11) byla eltiredilar. ויקריבו [10] Da juvuttular ol nasilar

(12) ošol qutlamaġyn ol mizbeaḥnyn jag̉yndyrylğan künd́a any da

(13) juvuttular ol nasílar ošol qarbanlaryn özlarinin alnyna ol

(14) mizbeaḥnyn. ויאמר Da ajtty Adonaj Mošeǵa biŕar

(15) nasi künǵa biŕar nasi künǵa juvutsunlar ošol qarbanla-

(16) ryn özlarinin qutlamaġyna ol mizbeahnyn. ויהי [12] Da edi ol

(17) juvutuvču ol burunġu künd́a ošol qarbanyn özünün Naḩšon

(18) uvlu Aminadavnyn ševetind́an Juhudanyn. וקרבנו. [13] Da qarbany

(19) anyn kümüš tepsi bir jüz otuz mitqal ölčüvü anyn bir ${ }_{L}$ kubok

(20) kümüš ${ }^{11}$ jetmiš mitqal ölčüvü anyn mitqaly byla ol qodešnin

(21) eksilarid́a tolular öźak jumurulgan javbyla tirkiǵa. ๆ. [14]

$221 \mathrm{v}^{\mathrm{o}}$ (1) Bir qašyq ${ }_{\mathrm{L}} \mathrm{O}\left\langle\mathrm{l}\langle\rangle\{n\}^{12}\right.$ altyndan tolu tütü. פר. [15] Bir tana balasy

\footnotetext{
${ }^{1} \mathrm{~K}$ : unusual word order, instead of kümüš kubok; it follows the standard Hebrew text-see also Num 7:19, 25, 31, 37, 43, 49, 55, 61, 67, 73, 79. Cf. kümüš kuboklar in Num 7:84. | TKow.o1: kubok kümüš. | H: kubok kimis. | C: kümüš tas. | M: kümüš tas. | R: kuḿuś kubok. ${ }^{2} \mathrm{~K}:$ ol amended into on by another hand. | TKow.o1: on; unvocalized text. | H: on. | C: on.
} 


\section{Numbers 7}

(11) [1] And it was on the day that Moses had finished setting up

(12) the tabernacle, and had anointed it and sanctified it

(13) and all its equipment and the altar and all

(14) its vessels. And he anointed them and sanctified them.

(15) [2] And the princes of Israel, the superiors

(16) of the house of their fathers who are the princes of the tribes-they

(17) were those standing over those numbered-brought forward, [3] And

(18) they brought their offering before the Lord:

(19) six covered wagons, and twelve oxen, a wagon for two of the princes,

(20) and for each one an ox. And they brought them closer before the

(21) tabernacle. [4] And the Lord spoke to Moses, saying, [5]

(1) 'Take it from them, and they shall be for serving the service

(2) of the tent of meeting. And you shall give them to the Levites, to every man

(3) according to his service.' [6] And Moses took the wagons and

(4) the oxen and gave them to the Levites. [7]

(5) He gave two wagons and four oxen to the sons

(6) of Gershon, according to their service. [8] And

(7) he gave four wagons and eight oxen to the sons

(8) of Merari, according to their service, under the hand of Ithamar,

(9) son of Aaron, the priest. [9] And he did not give to the sons

(10) of Kohath, because the service of the Holy is on them:

(11) they carry on shoulders. [10] And the princes brought forward

(12) the dedication of the altar in the day that it was anointed, and

(13) the princes offered their offering before the

(14) altar. [11] And the Lord said to Moses, 'Each

(15) prince on a day, each prince on a day, they shall bring forward their offering

(16) for the dedication of the altar'. [12] And

(17) the one who brought forward his offering the first day was Nahshon,

(18) son of Amminadab, of the tribe of Judah. [13] And his offering:

(19) one silver bowl, its weight one hundred and thirty mithqals, one

(20) silver cup, its weight seventy mithqals by the mithqals of the Holy,

(21) both of them were full of fine flour mixed with oil for a grain offering, [14]

(1) One gold spoon, $\{t e n\} \mid$ mithqals $\mid$, full of incense, [15] One calf, the $221 \mathrm{v}^{\mathrm{o}}$ young 
(2) syġyrnyn bir qočqar bir qozu jyllyq balasy 'olaġa. שעיר. [16]

(3) Ulaġyn ečkilarnin birni hatatqa. ולזבח [17 [ Da ol šelamim

(4) debeḥasyna eki syġyr qočqarlar beš teǵalar beš qozular jyllyq

(5) balalary beš budur qarbany Naḥšonnun uvlunun 'Aminadavnyn.

(6) ביום [18] Ol ekinči künd́a juvuttu Netan’el uvlu Cu'ar-

(7) nyn nasisi Jissaharnyn. הקרב. [19] Juvuttu ošol qarbanyn

(8) özünün kümüš tepsi bir jüz otuz mitqal ölčüvü anyn

(9) bir kubok kümüš ölčüvü anyn jetmiš mitqal mitqaly

(10) byla ol qodešnin eksilarida tolular öźak jumurulġan jav-

(11) byla tirkiǵa. כך. [20] Bir qašyq on altyndan tolu tütü.

(12) פר (21] Bir tana balasy syg்yrnyn bir qočqar bir qozu jyllyq

(13) balasy ‘olaġa. שעיר. [22] Ulag̀yn ečkilarnin birni hatat-

(14) qa. ולזבח (23] Da ol šelamim debehasyna eki syġyr qoč-

(15) qarlar beš teǵalar beš qozular jyllyq balalary beš budu qarbany Netane-

(16) 'elnin uvlunun Cu'arnyn. [24] Ol üčünčüü künd́a

(17) nasisi uvullarynyn Zevulunnun Eli'av uvlu Ḥelonnun. קרבנו. [25]

(18) Qarbany anyn kümüš tepsi bir jüz otuz mitqal ölčüvü anyn

(19) bir kubok kümüš jetmiš mitqal mitqaly byla ol qodešnin

(20) eksilarid́a tolular öźak jumurulġan javbyla tirkiǵa.

(21) כף [26] Bir qašyq on altyndan tolu tütü. [27 Bir tana

$222 \mathrm{r}^{\mathrm{o}}$ (1) balasy syg்yrnyn bir qočqar bir qozu jyllyq balasy 'olag̉a. שעיר. [28]

(2) Ulaġyn ečkilarnin birni hatatqa. ולזבח. [29] Da ol šelamim

(3) debehasyna eki syg்yr qočqarlar beš teǵalar beš qozular jyllyq balala-

(4) ry beš budur qarbany Eli'avnyn uvlunun Ḥelonnun. [30] Ol

(5) dörtünčü künd́a nasisi uvullarynyn Ru’uvennin Elicur uv-

(6) lu Šede’urnun. קרבנו. [31] Qarbany anyn kümüš tepsi bir

(7) jüz otuz mitqal ölčüvü anyn bir kubok kümüš jetmiš

(8) mitqal mitqaly byla ol qodešnin eksilarida tolular öźak

(9) jumurulġan javbyla tirkiǵa. כך. [32] Bir qašyq on altyndan

(10) tolu tütü. פר [33] Bir tana balasy syg்yrnyn bir qočqar

(11) bir qozu jyllyq balasy 'olag̉a. שעיר. [34] Ulag̉yn ečkilarnin 
(2) of cattle, one ram, one one-year-old lamb for a burnt offering, [16]

(3) One kid of the goats for a sin offering, [17] And for a

(4) sacrifice of peace offerings: two oxen, five rams, five male goats, five one-year-old lambs.

(5) This is the offering of Nahshon, son of Amminadab.

(6) [18] On the second day, Nethanel, son of Zuar,

(7) prince of Issachar, brought forward. [19] He brought forward his offering:

(8) one silver bowl, its weight a hundred and thirty mithqals,

(9) one silver cup, its weight seventy mithqals by the mithqal

(10) of the Holy, both of them full of fine flour mixed with oil

(11) for a grain offering, [20] One gold spoon, full of incense,

(12) [21] One calf, the young of cattle, one ram, one one-year-old lamb

(13) for a burnt offering, [22] One kid of the goats for a sin offering,

(14) [23] And for a sacrifice of peace offerings: two oxen,

(15) five rams, five male goats, five one-year-old lambs. This is the offering of Nethanel,

(16) son of Zuar. [24] On the third day

(17) the prince of the sons of Zebulun, Eliab, son of Helon, brought forward. [25]

(18) His offering: one silver bowl, its weight a hundred and thirty mithqals,

(19) one silver cup, its weight seventy mithqals by the mithqal of the Holy,

(20) both of them full of fine flour mixed with oil for a grain offering,

(21) [26] One gold spoon, ten |mithqals|, full of incense, [27] One calf,

(1) a young of cattle, one ram, one one-year-old lamb for a burnt offering, [28]

(2) One kid of the goats for a sin offering, [29] And for a sacrifice of peace offerings:

(3) two oxen, five rams, five male goats, five one-year-old lambs.

(4) This is the offering of Eliab the son of Helon. [30] On the

(5) fourth day, the prince of the sons of Reuben, Elizur, son

(6) of Shedeur, brought forward. [31] His offering: one silver bowl,

(7) its weight a hundred and thirty mithqals, one silver cup, its weight seventy

(8) mithqals by the mithqal of the Holy, both of them full of fine flour

(9) mixed with oil for a grain offering, [32] One gold spoon, ten |mithqals

(10) full of incense, [33] One calf, the young of cattle, one ram,

(11) one one-year-old lamb for a burnt offering, [34] One kid of the goats 
(12) birni ḥatatqa. ולזבח. [35] Da ol šelamim debeḥasyna

(13) eki syġyr qočqarlar beš teǵalar beš qozular jyllyq balalary beš

(14) budur qarbany Elicurnun uvlunun Šede’urnun. ביום [36]

(15) Ol bešinči künd́a nasisi uvullarynyn Šimonnun Šelumi'el

(16) uvlu Curišadajnyn. [קרבנו]. [37] Qarbany anyn kümüš tepsi bir jüz otuz

(17) mitqal ölčüvü anyn bir kubok kümüš jetmiš mitqal mitqa-

(18) ly byla ol qodešnin eksilarid́a tolular öźak jumurulġan jav-

(19) byla tirkiǵa. כך. [38] Bir qašyq on altyndan tolu tütü.

(20) פר (39] Bir tana balasy syġyrnyn bir qočqar bir qozu jyllyq

(21) balasy 'olaġa. שעיר. [40] Ulaġy ečkilarnin birni hatatqa.

$222 \mathrm{~V}^{0}$ (1) ולזבח. [41] Da ol šelamim debehasyna eki syğgyr qočqarlar beš teǵa-

(2) lar beš qozular jyllyq balalary beš budur qarbany Šelumi’elnin uvlunun

(3) Curišadajnyn. ביום. [42] Ol altynčy künd́a nasisi uvul-

(4) larynyn Gadnyn Elijasaf uvlu Du'u'elnin. קרבנו [43] Qarbany anyn

(5) kümüš tepsi bir jüz otuz mitqal ölčüvü anyn bir ku-

(6) bok kümüš jetmiš mitqal mitqaly byla ol qodešnin ek-

(7) silarid́a tolular öźak jumurulġan javbyla tirkiǵa.

(8) כ" כ4 [4] Bir qašyq on altyndan tolu tütü. [45] Bir tana

(9) balasy syġyrnyn bir qočqar bir qozu jyllyq balasy 'olag̉a.

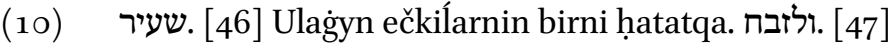

(11) Da ol šelamim debehasyna eki syġyr qočqarlar beš teǵalar

(12) beš qozular jyllyq balalary beš budur qarbany Elijasafnyn uvlunun

(13) Du'u’elnin. ביום [48] Ol jedinči künd́a nasisi uvulla-

(14) rynyn Efrajimnin Elišama' uvlu 'Amihudnun. קרבנו. [49]

(15) Qarbany anyn kümüš tepsi bir jüz otuz mitqal ölčüvü

(16) anyn bir kubok kümüš jetmiš mitqal mitqaly byla ol

(17) qodešnin eksiĺarida tolular öźak jumurulġan javbyla tir-

(18) kiǵa. כ" [50] Bir qašyq on altyndan tolu tütü. פר. [51 Bir

(19) tana balasy syġyrnyn bir qočqar bir qozu jyllyq balasy 'olaġa.

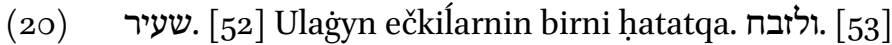


(12) for a sin offering, [35] And for a sacrifice of peace offerings:

(13) two oxen, five rams, five male goats, five one-year-old lambs.

(14) This is the offering of Elizur, son of Shedeur. [36]

(15) On the fifth day, the prince of the sons of Simeon, Shelumiel,

(16) son of Zurishaddai, brought forward. [37] His offering: one silver bowl, its weight a hundred and thirty

(17) mithqals, one silver cup, its weight seventy mithqals

(18) by the mithqal of the Holy, both of them full of fine flour mixed with oil

(19) for a grain offering, [38] One gold spoon, ten |mithqals|, full of incense,

(20) [39] One calf, the young of cattle, one ram, one one-year-old lamb

(21) for a burnt offering, [40] One kid of the goats for a sin offering,

(1) [41] And for a sacrifice of peace offerings: two oxen, five rams,

(2) five male goats, five one-year-old lambs. This is the offering of Shelumiel, son

(3) of Zurishaddai. [42] On the sixth day, the prince of the sons

(4) of Gad, Eliasaph, son of Deuel, brought forward. [43] His offering:

(5) one silver bowl, its weight a hundred and thirty mithqals, one

(6) silver cup, its weight seventy mithqals by the mithqal of the Holy,

(7) both of them full of fine flour mixed with oil for a grain offering,

(8) [4] One gold spoon, ten $\mid$ mithqals|, full of incense, [45] One calf,

(9) the young of cattle, one ram, one one-year-old lamb for a burnt offering,

(10) [46] One kid of the goats for a sin offering, [47]

(11) And for a sacrifice of peace offerings: two oxen, five rams, five male goats,

(12) five one-year-old lambs. This is the offering of Eliasaph, son

(13) of Deuel. [48] On the seventh day, the prince of the sons

(14) of Ephraim, Elishama, son of Ammihud, brought forward. [49]

(15) His offering: one silver bowl, its weight a hundred and thirty mithqals,

(16) one silver cup, its weight seventy mithqals by the mithqal

(17) of the Holy, both of them full of fine flour mixed with oil for a grain offering,

(18) [50] One gold spoon, ten $\mid$ mithqals $\mid$, full of incense, [51] One

(19) calf, the young of cattle, one ram, one one-year-old lamb for a burnt offering,

(20) [52] One kid of the goats for a sin offering, [53] 
(21) Da ol šelamim debehasyna eki syġyr qočqarlar beš teǵalar

$223 \mathrm{r}^{\circ} \quad$ (1) beš qozular jyllyq balalary beš budur qarbany Elišamac uvlunun

(2) 'Amihudnun. ביום [54] Ol segizinči künd́a nasisi

(3) uvullarynyn Menašenin Gamli'el uvlu Pedahcurnun. קרבנו. [55]

(4) Qarbany anyn kümüš tepsi bir jüz otuz mitqal ölčü-

(5) vü anyn bir kubok kümüš jetmiš mitqal mitqaly byla

(6) ol qodešnin eksilarid́a tolular öźak jumurulġan javbyla

(7) tirkiǵa. כ [56] Bir qašyq on altyndan tolu tütü.

(8) פר (57 ] Bir tana balasy syg்yrnyn bir qočqar bir qozu jyllyq

(9) balasy 'olag̉a. שעיר. [58] Ulag̉y ečkilarnin birni ḥatat-

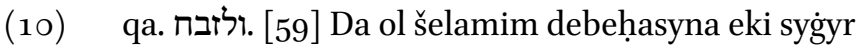

(11) qočqarlar beš teǵalar beš qozular jyllyq balalary beš budur

(12) qarbany Gamli'elnin uvlunun Pedahcurnun. [60] Ol

(13) tog̉uzunču künd́a nasisi uvullarynyn Binjaminnin Avidan

(14) uvlu Gid'oninin. קרבנו. [61] Qarbany anyn kümüš tepsi

(15) bir jüz otuz mitqal ölčüvü anyn bir kubok kümüš

(16) jetmiš mitqal mitqaly byla ol qodešnin e $\{\mathrm{k}\}$ silarid́a tolu-

(17) lar öźak jumurulgaan javbyla tirkiǵa. כ. [62] Bir qašyq

(18) on altyndan tolu tütü. פר. [63] Bir tana balasy syg்yrnyn

(19) bir qočqar bir qozu jyllyq balasy 'olag̉a. שעיר. [64] Ulağy

(20) ečkilarnin birni ḥatatqa. ולזבח [65] Da ol debehasyny šelamim-

(21) nin eki syġyr qočqarlar beš teǵalar beš qozular jyllyq balalary

$223 v^{\circ} \quad$ (1) beš budur qarbany Avidannyn uvlunun Gid'oninin. [66]

(2) Ol onunču künd́a nasisi uvullarynyn Dannyn Ahi'ezer uv-

(3) lu 'Amišadajnyn. קרבנו. [67 Q Qarbany anyn kümüš tepsi

(4) bir jüz otuz mitqal ölčüvü anyn bir kubok kümüš jet-

(5) miš mitqal mitqaly byla ol qodešnin eksilarida tolular

(6) öźak jumurulġan javbyla tirkiǵa. ๆ. [68] Bir qašyq on

(7) altyndan tolu tütü. פר. [69] Bir tana balasy syġyrnyn bir

(8) qočqar bir qozu jyllyq balasy 'olag̉a. שעיר. [70] Ulag̉y eč- 
(21) And for a sacrifice of peace offerings: two oxen, five rams, five male goats,

(1) five one-year-old lambs. This is the offering of Elishama, son

(2) of Ammihud. [54] On the eight day, the prince

(3) of the sons of Manasseh, Gamaliel, son of Pedahzur, brought forward. [55]

(4) His offering: one silver bowl, its weight a hundred and thirty mithqals,

(5) one silver cup, its weight seventy mithqals by the mithqal

(6) of the Holy, both of them full of fine flour mixed with oil

(7) for a grain offering, [56] One gold spoon, ten $\mid$ mithqals $\mid$, full of incense,

(8) [57] One calf, the young of cattle, one ram, one one-year-old lamb

(9) for a burnt offering, [58] One kid of the goats for a sin offering,

(10) [59] And for a sacrifice of peace offerings: two oxen,

(11) five rams, five male goats, five one-year-old lambs. This is

(12) the offering of Gamaliel the son of Pedahzur. [6o]

(13) On the ninth day, the prince of the sons of Benjamin, Abidan,

(14) son of Gideoni, brought forward. [61] His offering: one silver bowl,

(15) its weight a hundred and thirty mithqals, one silver cup,

(16) its weight seventy mithqals by the mithqal, of the Holy, both of them full

(17) of fine flour mixed with oil for a grain offering, [62] One gold spoon,

(18) ten |mithqals|, full of incense, [63] One calf, the young of cattle,

(19) one ram, one one-year-old lamb for a burnt offering, [64] One kid

(20) of the goats for a sin offering, [65] And for a sacrifice of peace offerings:

(21) two oxen, five rams, five male goats, five one-year-old lambs.

(1) This is the offering of Abidan the son of Gideoni. [66]

(2) On the tenth day, the prince of the sons of Dan, Ahiezer,

(3) son of Ammishaddai, brought forward. [67] His offering: one silver bowl,

(4) its weight a hundred and thirty mithqals, one silver cup,

(5) its weight seventy mithqals by the mithqal of the Holy, both of them full

(6) of fine flour mixed with oil for a grain offering, [68] One gold spoon, ten

(7) |mithqals $\mid$, full of incense, [69] One calf, the young of cattle, one

(8) ram, one one-year-old lamb for a burnt offering, [70] One kid 
(9) kilarnin birni hatatqa. ולזבח. [71] Da ol šelamim debehasy-

(10) na eki syġyr qočqarlar beš teǵalar beš qozular jyllyq balalary

(11) beš budur qarbany Ahii'ezernin uvlunun 'Amišadajnyn. ביום [72]

(12) Kününd́a on birinči künnün nasisi uvullarynyn Ašernin

(13) Paǵci’el uvlu Akrannyn. קרבנו. [73] Qarbany anyn kümüš

(14) tepsi bir jüz otuz mitqal ölčüvü anyn bir kubok kü-

(15) müš jetmiš mitqal mitqaly byla ol qodešnin eksilarid́a

(16) tolular öźak jumurulġan javbyla tirkiǵa. כ. [74] Bir

(17) qašyq o[n] $]^{1}$ altyndan tolu tütü. פר. [75] Bir tana balasy

(18) syġyrnyn bir qočqar bir qozu jyllyq balasy 'olag̉a. שעיר. [76]

(19) Ulaġy ečkilarnin birni hatatqa. ולזבח. [77] Da ol šelamim

(20) debeḥasyna eki syg̉yr qočqarlar beš teǵalar beš qozular jyllyq

(21) balalary beš budur qarbany Paǵ'i’elnin uvlunun Akrannyn. ביום. [78]

$224 \mathrm{r}^{\mathrm{o}} \quad$ (1) Kününd́a ol on ekinči künnün nasisi uvullarynyn Naftali-

(2) nin Ahira' uvlu 'Enannyn. קרבנו. [79] Qarbany anyn kümüš

(3) tepsi bir jüz otuz mitqal ölčüvü anyn bir \{kubok\} kümüš

(4) jetmiš mitqal mitqaly byla ol qodešnin eksilarid́a tolu-

(5) lar öźak jumurulġan javbyla tir\{ki\}ǵa. ๆ. [80] Bir qašyq

(6) on altyndan tolu tütü. פר. [81] Bir tana balasy syġyrnyn

(7) bir qočqar bir qozu jyllyq balasy `olag̉a. שעיר. [82] Ulag்y

(8) ečkilarnin birni hatatqa. ולזבח. [83] Da ol šelamim

(9) debehasyna eki syg்yr qočqarlar beš teǵalar beš qozular

(10) jyllyq balalary beš budur qarbany Ahira'nyn uvlunun 'Enannyn.

(11) זאת [84] Budur qutlamag̉y ol mizbeaḥnyn jag̉yndyrylġan kün-

(12) da any nasilarind́an Jisra’elnin kümüš tepsílar on

(13) eki kümüš kuboklar on eki altyn qašyqlar on eki.

(14) שלשים. [85] Jüz otuz mitqal kümüš edi har bir tep-

(15) sid́a da jetmiš mitqal kümüš edi har bir kubokta

(16) bar kümüšü ol savutlarnyn eki min da dört jüz mitqal

(17) mitqaly byla ol qodešnin. כפות. [86] Altyn qašyqlar on eki

(18) tolular tütü onar onar altyn ol bir qašyqta mitqaly

(19) byla ol qodešnin bar altyny ol qašyqlarnyn jüz igirmi.

\footnotetext{
${ }^{1} \mathrm{~K}$ : ol; a scribal error. | TKow.o1: on; unvocalized text. | H: on. | C: on.
} 
(9) of the goats for a sin offering, [71] And for a sacrifice of peace offerings:

(10) two oxen, five rams, five male goats, five one-year-old lambs:

(11) this is the offering of Ahiezer, son of Ammishaddai. [72]

(12) On the eleventh day, the prince of the sons of Asher,

(13) Pagiel, son of Ocran, brought forward. [73] His offering:

(14) one silver bowl, its weight a hundred and thirty mithqals, one silver cup,

(15) its weight seventy mithqals by the mithqal of the Holy, both

(16) of them full of fine flour mixed with oil for a grain offering, [74] One

(17) gold spoon, [ten] |mithqals $\mid$, full of incense, [75] One calf, the young

(18) of cattle, one ram, one one-year-old lamb for a burnt offering, [76]

(19) One kid of the goats for a sin offering, [77] And for a sacrifice of peace offerings:

(20) two oxen, five rams, five male goats, five one-year-old lambs.

(21) This is the offering of Pagiel the son of Ocran. [78]

(1) On the day of the twelfth day, the prince of the sons of Naphtali,

(2) Ahira, son of Enan, brought forward. [79] His offering: one silver

(3) bowl, its weight a hundred and thirty mithqals, one silver cup,

(4) its weight seventy mithqals by the mithqal of the Holy, both of them full

(5) of fine flour mixed with oil for a grain offering, [8o] One gold spoon,

(6) ten $\mid$ mithqals $\mid$, full of incense, [81] One calf, the young of cattle,

(7) one ram, one one-year-old lamb for a burnt offering, [82] One kid

(8) of the goats for a sin offering, [83] And for a sacrifice of peace offerings:

(9) two oxen, five rams, five male goats, five one-year-old lambs.

(10) This is the offering of Ahira the son of Enan.

(11) [84] This is the dedication of the altar on the day when it was anointed

(12) from the princes of Israel: twelve silver bowls of silver,

(13) twelve silver cups, twelve spoons of gold. [85]

(14) One hundred and thirty mithqals of silver was in each bowl,

(15) and seventy mithqals of silver was in each cup.

(16) All the silver of the vessels: two thousand and four hundred mithqals

(17) by the mithqal of the Holy. [86] The golden spoons twelve,

(18) full of incense, ten mithqals of silver in each spoon by the mithqal

(19) of the Holy. All the gold of the spoons was a hundred and twenty |mithqals|. 
(20) כל [87 Bar ol syg்yr 'olag̉a on eki tanalar qočqarlar on eki

(21) qozular jyllyq balalary on eki da tirkilari alarnyn da ulaq-

$224 \mathrm{~V}^{\mathrm{o}}$ (1) lary ečkilarnin hatatqa on eki. [88] Da bar syg்yry

(2) ol šelamim debeḥasynyn igirmi dört tanalar qočqarlar alty-

(3) myš teǵalar altymyš qozular jyllyq balalary altymyš budur

(4) qutlamaġy ol mizbeahnyn jaġyndyrylyp sortun any. ובבא. [89]

(5) Da kelǵand́a Moše ohel mo`edǵa sözĺaḿa birǵasińa

(6) da ešitiredi ošol ol ünnü sözlańadoġanny anar ol

(7) kaporet üstünd́an ki aronu üstüńa ol šarajatnyn

(8) arasyna eki ol keruvlarnyn da sözlaredi anar.

Numbers 8

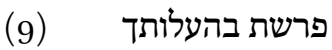

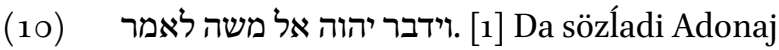

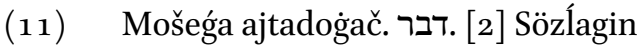

(12) Aharonġa da ajtqyn anar jandyrg̉anyjda ošol ol čyraq-

(13) larny alnyna jüzlarinin ol čyraqbanyn jaryq bersinlar jedisid́a

(14) ol čyraqlar. ויעש [3] Da qyldy alaj Aharon alnyna jüzlari-

(15) nin ol čyraqbanyn jandyrdy čyraqlaryn anyn ki nečik bujurdu

(16) Adonaj Mošeǵa. זי [4] Da budu iši ol čyraqbanyn qaqqan

(17) altyndan butunadejin japraġynadejin qaqqan edi ol körüm-

(18) ga köŕa ki körgüzdü Adonaj Mošeǵa alaj qyldy ošol

(19) ol čyraqbany. וידבר. [5] Da sözĺadi Adonaj Mošeǵa aj-

$225 \mathrm{r}^{\mathrm{o}} \quad$ (1) tadoġač. קח. [6] Alġyn ošol ol Levilílarni ortasyndan

(2) uvullarynyn Jisra’elnin da aruv etkin alarny. וכה [7 [7 Da

(3) bulaj qylġyn alarg̉a aruv etḿa alarny bürkkün alar üs-

(4) tüńa bürkünür suvlar da ašyrsynlar jülüvüč bar guf-

(5) lary ašyra özlarinin da juvsunlar upraqlaryn da arynsyn-

(6) lar. ולקחו Da alsynlar tana balasyn syġyrnyn da tir-

(7) kisi anyn öźak jumurulġan javbyla da ekinči tana balasyn

(8) syǵyrnyn alġyn hatatqa. והקרבת. [9] Da juvutqun o-

(9) šol ol Levilílarni alnyna ohel mo'ednin da jomdarġyn o-

(10) Šol bar žymatyn ulanlarynyn Jisra’elnin. והקרבת Da 
(20) [87] All the oxen for the burnt offering: twelve bullocks, the rams twelve,

(21) the lambs, one-year old young, twelve, and their grain offering, and

(1) the kids of the goats for sin offering twelve. [88] And all the oxen

(2) for the sacrifice of the peace offerings: twenty-four calves, the rams sixty,

(3) the male goats sixty, the lambs, one-year old young, sixty. This is

(4) the dedication of the altar, after it was anointed. [89]

(5) And when Moses came into the tent of meeting to speak with him,

(6) then he heard the voice of one speaking to him

(7) from off the cover that was on the ark of law,

(8) from between the two cherubim: and he spoke to him.

Numbers 8

(9) Parashat Behaalotecha

(10) [1] And the Lord spoke

(11) to Moses, saying, [2] 'Speak

(12) to Aaron, and say to him, "When you light the candles,

(13) the seven lamps shall give light opposite the front of the lampstand."'

(14) [3] And Aaron did so. He lighted its candles opposite the front of

(15) lampstand, as the Lord commanded

(16) Moses. [4] And this is the work of the lampstand: hammered work

(17) of gold, including its shaft, including its leaves, it was hammered work.

(18) According to the appearance that the Lord had shown Moses, so he made the

(19) lampstand. [5] And the Lord spoke to Moses, saying,

(1) 'Take the Levites from among

(2) the children of Israel and make them pure. [7] And

(3) thus shall you do to them, to make them pure: Sprinkle

(4) purifying water on them, and they shall pass a razor over all

(5) their body, and they shall wash their clothes and make themselves clean.

(6) [8] Then they shall take a calf, the young of cattle and

(7) its grain offering, fine flour mixed with oil, and you shall take a second calf, the young

(8) of cattle, for a sin offering. [9] And you shall bring forward

(9) the Levites before the tent of meeting, and you shall assemble

(10) the whole congregation of the children of Israel. [10] And 
(11) juvutqun ošol ol Levililarni alnyna Adonajnyn da sunsun-

(12) lar ulanlary Jisra’elnin ošol qollaryn özlarinin ol Levilíar

(13) üstüńa. והניף] [11] Da sunsun Aharon ošol ol Levililar-

(14) ni tenufa alnynda Adonajnyn ulanlaryndan Jisra'elnin da bolsun-

(15) lar qulluq etḿa ošol qullug̉un Adonajnyn. וזלוים [12] Da

(16) ol Leviliĺar sunsunlar ošol qollaryn özlarinin bašy üs-

(17) tüńa ol tanalarnyn da qylġyn ošol ol birni ḥatat da

(18) ošol ol birni 'ola Adonajğa bošatlyq qolma ol Levilílar

(19) üčün. והעמדת] [13] Da turg̉uzġun ošol ol Levililarni

(20) alnynda Aharonnun da alnynda uvullarynyn da sungun alarny

(21) tenufa Adonajğa. והבדלת. [14] Da ajyrg̉yn ošol ol Levilíarni

$225 \mathrm{~V}^{\mathrm{o}} \quad$ (1) ortasyndan ulanlarynyn Jisra’elnin da bolsunlar maja ol Levilílar.

(2) [15] Da andan sortun kelsinlar ol Levilílar qulluq

(3) etḿa ohel mo'edd́a nečik aruv etśaj alarny da sun-

(4) saj alarny tenufa. כי [16] Ki berilmišlar berilmišlar

(5) alar maja ortasyndan ulanlarynyn Jisra’elnin ačylmağy or-

(6) nuna bar qursaqnyn tunġučun barčanyn ulanlaryndan Jisra’elnin

(7) aldym alarny özüma. כי [17] Ki majady bar tunġuč u-

(8) lanlarynda Jisra’elnin adamda da tuvarda qyrg̉an künümd́a

(9) bar tunğučnu jerind́a Micrinin aziz ettim alarny özü-

(10) máa. ואקח [18] Da aldym ošol ol Levilílarni bar tunġuč or-

(11) nuna ulanlarynda Jisra’elnin. ואתנה. [19] Da berdim ošol

(12) ol Levilílarni berilmüšĺar Aharonġa da uvullaryna anyn

(13) ortasyndan ulanlarynyn Jisra’elnin qulluq etḿa ošol qullu-

(14) ġun ulanlarynyn Jisra’elnin ohel mo'edd́a da bošatlyq qolma

(15) ulanlary üčün Jisra’elnin da bolmasyn ulanlarynda Jisra’el-

(16) nin qyranč juvug̉unda ulanlary Jisra’elnin ol qodeška.

(17) (20] Da qyldy Moše da Aharon da bar žymaty ulanlary-

(18) nyn Jisra’ \{el\}nin Levililarǵa ki nečik bujurdu Adonaj Mošeǵa Levilílar

(19) üčün alaj qyldylar alarg̉a ulanlary Jisra’elnin. [21]

(20) Da bürkündülar ol Levililar da juvdular upraqlaryn öz-

(21) ĺarinin da sundu Aharon alarny tenufa alnynda Adonajnyn

$226 \mathrm{r}^{\mathrm{o}} \quad$ (1) da bošatlyq qoldu alar üčün Aharon aruv etḿa alarny.

(2) יואחרי [22] Da andan sortun \{alaj $\}^{1}$ keldilar ol Levilílar qulluq et-

(3) ḿa ošol qulluqlaryn özlarinin ohel mo`edd́a alnynda

${ }^{1}$ Marginal insertion by another hand. | TKow.or: deest; unvocalized text. | H: alaj. | C: deest. 
(11) you shall bring the Levites before the Lord: and

(12) the children of Israel shall reach out their hands over the Levites.

(13) [11] And Aaron shall elevate the Levites

(14) before the Lord for a wave offering from the children of Israel, and they shall be

(15) to serve the service of the Lord. [12] And

(16) the Levites shall reach out their hands over the heads

(17) of the calves. And make one a sin offering and

(18) one a burnt offering to the Lord, to ask for atonement for the Levites.

(19) [13] And you shall stand the Levites

(20) before Aaron and before his sons, and you shall elevate them

(21) for a wave offering to the Lord. [14] And you shall separate the Levites

(1) from among the children of Israel, and the Levites shall be mine.

(2) [15] And after that the Levites shall come to do the service

(3) in the tent of meeting: if you have made them pure and elevated

(4) them for a wave offering. [16] Because they are given, given,

(5) to me from among the children of Israel: In place of all opening

(6) of a womb, the firstborn of all the children of Israel,

(7) I have taken them to me. [17] Because all the firstborn

(8) of the children of Israel are mine, both man and animal. On the day that I struck

(9) every firstborn in the land of Egypt I sanctified them for myself.

(10) [18] And I have taken the Levites in place of all the firstborn

(11) among the children of Israel. [19] And I have given the

(12) Levites - they are given - to Aaron and to his sons

(13) from among the children of Israel, to serve the service

(14) of the children of Israel in the tent of meeting, and to ask for atonement

(15) for the children of Israel, so there will not be, among the children of Israel,

(16) plague when the children of Israel come near to the Holy'

(17) [20] And Moses and Aaron and all the congregation of the children

(18) of Israel did to the Levites as the Lord commanded Moses concerning the Levites;

(19) the children of Israel did so to them. [21]

(20) And the Levites were purified, and they washed their clothes,

(21) and Aaron elevated them as a wave offering before the Lord,

(1) and Aaron asked for atonement for them to purify them. $226 \mathrm{r}^{\circ}$

(2) [22] And after that, $\{s o\}$ came the Levites to serve

(3) their service in the tent of meeting before Aaron 
(4) Aharonnun da alnynda uvullarynyn ki nečik bujurdu Adonaj

(5) Mošeǵa ol Levililíar üčün alaj qyldylar alarg̉a.

(6) וידבר (23] Da sözladi Adonaj Mošeǵa ajtadog̉ač.

(7) זאת [24] Budur ol iš ki qylg̀yn Levililarǵa igirmi beš

(8) jaštan da jog̉arraq kelsin jyjynlama jyjyn qullug̉unda ohel

(9) mo'ednin. ומבן [25] Da enli jaštan qajtsyn jyjynyndan

(10) ol qulluqnun da qulluq etḿasin artyq. ושרת [26]

(11) Da jumuš etsin qaryndašlarybyla ohel mo'edd́a saqlama

(12) saqlav da qulluq qulluq etḿasin bulaj qylgynn Levililarǵa

(13) saqlavlarynda.

Numbers 9

וידבר [1] Da sözĺadi Adonaj Moše-

(14) ǵa midbarynda Sinajnyn ol ekinči jylda čyqmaqlaryna

(15) jerind́an $\{\text { Micrini[ }[\mathrm{n}]\}^{1}$ ol burunğu janġajda ajtadoġač. ויעשו. [2] $\mathrm{Ki}^{2}$

(16) qylġajlar uvullary Jisra’elnin ošol qarbanyn ol Pesaḥnyn vag̉da-

(17) בארבעה. Synda Ondörtünčü kününd́a ošpu

(18) janġajnyn ol eki ingirlar arasyna qylyjyz any vag̉dasynda

(19) bar resimlarińa köŕa da bar töŕalarińa köŕa anyn qyl-

(20) synlar any. וידבר [4] Da sözĺadi Moše uvullaryna Jisra-

(21) 'elnin qylma qarbanyn ol Pesahnyn. [5] Da qyldylar

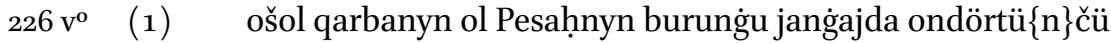

(2) kününd́a janġajnyn ol eki ingirlar arasyna midbaryn-

(3) da Sinajnyn barča ki nečik bujurdu Adonaj Mošeǵa alaj

(4) qyldylar uv\{u\}llary Jisra’elnin. ויהי [6] Da edi é́anlar

(5) ki edilar murdarlar žany üčün adamnyn da bolalmadylar

(6) qylma qarbanyn ol Pesaḥnyn ol künd́a da juvudular alnyna

(7) Mošenin da alnyna Aharonnun ol künd́a. [7 [7 ]

(8) Da ajttylar ol é́anlar anar biz murdarlar eśak

(9) Žany üčün adamnyn nek eksilajik juvutmasqa ošol

\footnotetext{
${ }^{1}$ TKow.o1: Micrinin; unvocalized text. | H: Micrinin.| C: Mysyrnyy. $\quad{ }^{2} \mathrm{~K}$ : Probably a scribal error.
} | TKow.o1: $d a$; unvocalized text. | H: $d a$. | C: $d a$. 
(4) and before his sons as the Lord had commanded

(5) Moses concerning the Levites; they did so to them.

(6) [23] And the Lord spoke to Moses, saying,

(7) [24] 'This is what you shall do to the Levites: from twenty-five

(8) years old and upward they shall join up to do military service by the tent

(9) of meeting. [25] And from the age of fifty years they shall return from the military

(10) service, and shall serve no more. [26]

(11) And he shall minister with their brothers in the tent of meeting, to keep

(12) the charge, and he shall do no service. Thus shall you do to the Levites

(13) regarding their charge.'

Numbers 9

[1] And the Lord spoke to Moses

(14) in the wilderness of Sinai, in the second year after they had come out

(15) from the land of Egypt, in the first month, of saying, [2] That ${ }^{210}$

(16) 'Let the children of Israel keep the sacrifice of Passover

(17) at its appointed time. [3] On the fourteenth day of this

(18) month at twilight you shall do it in its appointed time.

(19) You shall keep it according to all its statutes and according to all its customs.'

(20) [4] And Moses spoke to the children of Israel,

(21) that they should keep the sacrifice of the Passover. [5] And they kept

(1) the sacrifice of Passover in the first month, on the fourteenth $226 \mathrm{v}^{\mathrm{o}}$

(2) day of the month at twilight in the wilderness

(3) of Sinai. All that the Lord commanded Moses: so

(4) did the children of Israel. [6] And there were people

(5) who were unclean by the soul of a man and that they could not

(6) keep the sacrifice of Passover on that day. And they came forward before

(7) Moses and before Aaron on that day. [7]

(8) And those men said to him, 'If we are unclean

(9) by the soul of a man, why shall we cease bringing forward

210 K: Probably a scribal error, cf. BHeb. ! 'and'. 
(10) qarbanyn Adonajnyn vaġdasynda ortasynda uvullarynyn Jisra-

(11) 'יאמר. '8] Da ajtty alarg̉a Moše turujuz

(12) da tynlajym ne bujurur Adonaj siznin üčün. וידבר. [9]

(13) Da sözĺadi Adonaj Mošeǵa ajtadoġač. דבר. [10] Sözlagin

(14) ulanlaryna Jisra'elnin ajtadog̉ač nendij kiši ki bolsa mur-

(15) dar క̌an üčün jemeśa jyraq jolda siznin jemeśa dorla-

(16) ryjyzsajyn da kĺaśa qylma qarban Pesaḥnyn Adonajg̉a.

(17) בחדש [11] Ol ekinči jangajajda ondörtünčü künd́a

(18) ol eki ingirlar arasyna qylsynlar any macalar byla $\{$ da $\}$ maror-

(19) larbyla ašasynlar any. לא. [12] Qaldyrmasynlar andan tangadejin

(20) da süv́ak syndyrmasynlar anda bar resimińa köŕa

(21) qarbanynyn ol Pesahnynn qylsynlar any. והאיש. [13] Da ol

$227 \mathrm{r}^{\mathrm{o}} \quad$ (1) kiši ki ol aruvdu da jolda bolmasa ${ }_{\perp}$ ki ol jyraq jol ajtqany

(2) oldu kim ki juvuqta bolsa ol sajlanġan orungaa a

(3) kelalmáśa qylma qarbanyn ol Pesahnnyn vaġdasynda ki oldu

(4) ol eki ingirlar $\{[a] \text { rasy }\}^{1}$ vahty ${ }^{12}$ da andij kiši qalsa qylmaqtan qar-

(5) bany Pesaḥnyn da taspolur ol žan uluslaryndan ki qarbanyn Adonaj-

(6) nyn juvutmady vağdasynda క̌urumun kötürür ol kiši.

(7) (14] Da ki tirilśa birǵajizǵa garip da klaśa qylma

(8) qarbanyn Pesahnnyn Adonajğa resimi kibik qarbanynyn ol pesah-

(9) nyn da kečinḿagi kibik anyn alaj qylsyn bir resim bol-

(10) sun sizǵa da gaaripǵa da jerlisińa ol jernin.

(11) וביום [15] Da turg̈uzġan künd́a ošol ol miškanny qap-

(12) lady ol bulut ošol ol miškanny čatyrybyla ol šarajatnyn

(13) da ingird́a bolur edi ol miškan üstüńa körü-

(14) mü kibik otnun tanġadejin. כן [16] Alaj boluredi hamme-

(15) š́a ol bulut qaplaredi any da körümü otnun bolure-

(16) di keč́abyla. ולפי [17] Da kötürülmagina köŕa ol

${ }^{1}$ TKow.o1: deest. | H: deest. | C: deest. $\quad{ }^{2}$ Interpretative addition to the standard text. 
(10) offering of the Lord in its appointed time among the children of Israel?'

(11) [8] And Moses said to them, 'Stay, and

(12) let me hear what the Lord will command concerning you.' [9]

(13) And the Lord spoke to Moses, saying, [10] 'Speak

(14) to the children of Israel, saying, "If any man is unclean

(15) by soul or is in a long journey afar off-among you or your generations-

(16) and wants to keep the sacrifice of Passover to the Lord:

(17) [11] They shall keep it in the second month on the fourteenth day

(18) at twilight. And they shall eat it with unleavened bread and bitter herbs.

(19) [12] They shall not leave any of it until the morning,

(20) and they shall not break a bone of it. They shall keep it according to all the statutes

(21) of the sacrifice of Passover. [13] But if the

(1) man is clean and is not on a journey, because that is the message of $227 \mathrm{r}^{\mathrm{o}}$ the 'long journey',

(2) someone who is numbered is near the place but

(3) is not able to come to do the sacrifice of Passover in its appointed time, which is

(4) the time of twilight ${ }^{1211}$, and if such a man forsakes doing the sacrifice

(5) of Passover, then that soul will be cut off from among his people, because

(6) he did not bring forward the offering of the Lord in its appointed time. That man shall bear his punishment.

(7) [14] And if a stranger lives with you and wants to do

(8) the sacrifice of Passover to the Lord: according to the statute of the sacrifice of Passover

(9) and according to its manner, so he shall do. You shall have one statute

(10) for the stranger and for the native of the land.'

(11) [15] And on the day that the tabernacle was set up,

(12) the cloud covered the tabernacle with the tent of the law,

(13) and in evening it was over the tabernacle

(14) like the appearance of fire until the morning. [16] So it was always:

(15) the cloud covered it by day and the appearance of fire was there

(16) by night. [17] And according to when the cloud was lifted

211 An interpretative addition to Num 9:13. 
(17) bulutnun ol čatyr üstünd́an da andan sortun $\{a l[a j]\}^{1}$ köč́a-

(18) rediĺar ulanlary Jisra’elnin da ne orunda ki toḥtasa-

(19) jedi anda ol bulut anda toḥtaredilar ulanlary Jisra-

(20) 'elnin. [18] Bujrugguna köŕa Adonajnyn köč́aredilar

(21) ulanlary Jisra'elnin da bujrugiuna köŕa Adonajnyn toḥta-

$227 \mathrm{~V}^{\mathrm{o}}$ (1) redilar bar künĺard́a ki toḥtasajedi ol bulut ol miškan üs-

(2) tüńa toḥtaredilar. ובהאריך] Da uzaq turg̉anda ol

(3) bulut ol miškan üstüńa köp künlar da saqlaredilar u-

(4) lanlary Jisra’elnin ošol saqlavun Adonajnyn da köčḿasedilar.

(5) ויש [20] Da baredi ki boluredi ol bulut sanly künlar ol

(6) miškan üstüńa bujruġuna köŕa Adonajnyn toḥtaredilar

(7) da bujrug̉una köŕa Adonajnyn köč́arediĺar. ויש [21] Da

(8) baredi ki boluredi ol bulut ingird́an tangadejin da kötü-

(9) rülüredi ol bulut ertanbylada köč́aredilar jemeśa

(10) kün da keč́a da kötürülüredi ol bulut da köćaredilar.

(11) או [22] Jemeśa eki kün jemeśa janġaj jemeśa jyl uzaq tur-

(12) ġanda ol bulut ol miškan üstüńa toḥtama anyn üs-

(13) tüńa toḥtaredilar ulanlary Jisra’elnin da köčḿasedilar

(14) da kötürülǵanind́a köčaredilar. על [23] Bujrugiuna kö-

(15) ŕa Ado\{naj\}nyn toḥtaredilar da bujrugiuna köŕa Adonajnyn köčare-

(16) dilar ošol saqlavyn Adonajnyn saqlaredilar bujrugguna köŕa

(17) Adonajnyn naviligi ašyra Mošenin.

Numbers 10

.ידבר [1] Da sözĺa-

(18) di Adonaj Mošeǵa ajtadoġač. עשה. [2] Qylġyn özüja

(19) eki byrgyylar kümüštan qaqqan qylġyn alarny da bolsunlar

(20) saja ünd́aḿakḱa ol šymatny da köčürmáaḱka ol avul-

(21) larny. Da tartsynlar alarbyla da jyštyryl-

$228 \mathrm{r}^{\circ} \quad$ (1) synlar saja bar ol క̌ymat ešigińa ohel mocednin. [4] [4]

(2) Da eger birbyla tartsalar da jyštyrylsynlar saja bar ol

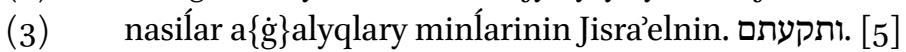

(4) Da tartyjyz qyčqyrmaqbyla da köčsünlar ol avullar ol

${ }^{1}$ Marginal insertion by another hand. | TKow.o1: deest. | H: alaj. | C: deest. 
(17) from over the tent, $\{s o\}$ after that

(18) the children of Israel set out. And in the place where the cloud

(19) camped, there the children of Israel camped.

(20) [18] By the command of the Lord the children of Israel set out,

(21) and by the command of the Lord they camped:

(1) All the days that the cloud camped over the tabernacle,

(2) they camped. [19] And when the cloud tarried long

(3) over the tabernacle many days, then the children of Israel kept

(4) the charge of the Lord, and did not set out.

(5) [20] And so it was: when the cloud was for a few days

(6) over the tabernacle, they camped according to the command of the Lord,

(7) and according to the command of the Lord they set out. [21] And

(8) so it was: when the cloud was there from evening until morning, and

(9) when the cloud lifted at dawn, then they set out: whether

(10) it was by day or by night, when the cloud lifted, they set out.

(11) [22] Whether it was two days, or a month, or a year, when the cloud tarried

(12) over the tabernacle to camp over it,

(13) the children of Israel camped, and did not set out.

(14) And when it was lifted, they set out. [23] According to the command

(15) of the Lord they camped, and according to the command of the Lord they set out.

(16) They kept the charge of the Lord, according to the command of the

(17) Lord by the prophecy of Moses.

Numbers 10

(18) the Lord spoke to Moses, saying, [2] 'Make you

(19) two trumpets of silver. You shall make them of hammered work and they shall be

(20) for you for the calling of the congregation and for the journeying of the

(21) camps. [3] And when they shall blow with them, all the

(1) congregation shall be gathered to you, to the door of the tent of meet- $228 \mathrm{r}^{\mathrm{o}}$ ing. [4]

(2) And if they blow with one, then all the princes,

(3) the superiors of the thousands of Israel, shall be gathered to you. [5]

(4) [5] When you blow a calling, then the camps that 
(5) toḥtavčular küntuvušusary. ותקעתם. [6] Da \{tartyjyz\}

(6) qyčqyrmaqbyla ekinči keŕat da köčsünĺar ol avullar

(7) ol toḥtavčular temansary qyčqyrmaqbyla tartsynlar

(8) köčḿak vah\{t\}larynda. ובהקהיל. [7] Da jyštyrgaan-

(9) da $\left\{[0]^{\text {šol }}\right\}^{1}$ ol qahalny tartyjyz da qyčqyrmajyz. ובני [8] [8 Davul-

(10) lary Aharonnun ol kohenlar tartsynlar byrgylar byla da bolsun-

(11) lar sizǵa ömürlük resimǵa dorlaryjyzsajyn. [9]

(12) Da ki kelśajiz čerüvǵa jerijizd́a ol dušman üstüńa

(13) qysyqlyq etüvčü sizǵa da qyčqyryjyz byrg̉ylar byla da

(14) saġynylyrsyz alnynda Adonajnyn da qutulursiz dušmanlaryjyz-

(15) dan. וביום [10] Da bijanč künüjüzd́a da mo'edĺarijizd́a da

(16) jangajlaryjyzda da tartyjyz byrgylar byla 'olalaryjyz qatyna

(17) da debehasy qatyna šelamimlarijiznin da bolsunlar sizǵa sag̉ynč-

(18) lyqqa alnynda Tenrijiznin menmen Adonaj Tenrijiz. ויהי. Da

(19) edi ol ekinči jylda ol ekinči janġajda igirminči

(20) kününd́a janġajnyn kötürüldü ol bulut miškany üstün-

(21) \{d́an\} ol šarajatnyn. [12] Da köčtülar ulanlary Jisra’elnin

$228 \mathrm{~V}^{\mathrm{o}}$ (1) köčüvlarisajyn midbaryndan Sinajnyn da toḥtady ol bulut mid-

(2) barynda Parannyn. ויסעו. [13] Da köčtülar burundan buj-

(3) rug̉una köŕa Adonajnyn naviligi ašyra Mošenin.

(4) יויסע] Da köčtü alamy avulunun uvullarynyn Juhudanyn

(5) burundan čerüvlarisajyn da ag̉araq čerüvü üstüńa anyn

(6) Nahšon uvlu 'Aminadavnyn. [15] Da ag̉araq čer[ü]vü üs-

(7) tüńa ševetinin uvullarynyn Jissaharnyn Netan’el uvlu Cu'ar-

(8) nyn. ועל [16] Da ag̉araq čerüvü üstüńa ševetinin uvullarynyn

(9) Zevulunnun Eli’av uvlu Ḥelon\{nun\}. והורד. [17] Da endirildi ol

(10) miškan da köčtülar uvullary Geršonnun da uvullary Merari-

(11) nin eltüvčülar ol miškanny. ונסע. [18] Da köčtü

(12) alamy avulunun Ru'uvennin čerüvlarisajyn da ag̉araq čerüvü

(13) üstüńa anyn Elicur uvlu Šede’urnun. ועל [19] Da

(14) aggaraq čerüvü üstüńa ševetinin uvullarynyn Šimonnun

(15) Šelumi'el uvlu Curišadajnyn. ועל [20] Da ag̉araq čerüvü

\footnotetext{
${ }^{1}$ TKow.o1: ošol; unvocalized text. | H: osol. | C: šol.
} 
(5) are camping toward the rising of the sun shall set out. [6] And you shall blow

(6) a calling a second time, and the camps

(7) that lie southward shall set out. They shall blow a calling

(8) in the time of their travels. [7] But when

(9) the assembly is to be gathered, you shall blow, but you shall not call. [8] And the sons

(10) of Aaron, the priests, shall blow with the trumpets, and they shall be

(11) to you for an eternal statute throughout your generations. [9]

(12) And if you come to war in your land against the enemy

(13) that oppresses you, then you shall call with the trumpets, and

(14) you shall be remembered before the Lord your God, and you shall be saved

(15) from your enemies. [10] Also in the day of your gladness, and in your holidays, and

(16) on your new moons: you shall blow with the trumpets next to your burnt offerings

(17) and next to the sacrifices of your peace offerings, and they shall be to you

(18) for a memorial before your God. I am the Lord your God. [11] And

(19) it was in the second year, in the second month, on the twentieth

(20) day of the month: the cloud was lifted from off the tabernacle

(21) of the law. [12] And the children of Israel set out

(1) on their travels from the wilderness of Sinai. And the cloud camped $228 \mathrm{v}^{\mathrm{o}}$

(2) in the wilderness of Paran. [13] And they set out first

(3) according to the command of the Lord by the prophecy of Moses.

(4) [14] The standard of the camp of the sons of Judah set out

(5) first according to their armies, and the superior over its army was

(6) Nahshon, son of Amminadab. [15] And the superior over the army

(7) of the tribe of the sons of Issachar was Nethanel, son of Zuar.

(8) [16] And the superior over the army of the tribe of the sons

(9) of Zebulun was Eliab, son of Helon. [17] And the

(10) tabernacle was taken down, and the sons of Gershon and the sons of Merari

(11) set out who carried the tabernacle. [18] And

(12) the standard of the camp of Reuben set out according to their armies, and the superior over its army

(13) was Elizur, son of Shedeur. [19] And

(14) over the army of the tribe of the sons of Simeon was

(15) Shelumiel, son of Zurishaddai. [20] And the superior over the army 
(16) üstüńa ševetinin uvullarynyn Gadnyn Elijasaf $\langle$ ben $\rangle\{u v l u\}$ Du'u'elnin.

(17) ונסע [21] Da köčtülar ol Qahatlilar eltüvčülar

(18) ol miqdašny da turg̉uzdular ulanlary Geršonnun da ulanlary

(19) Merarinin ošol ol miškanny kelginč́a ol Qahatliĺar.

(20) ונסע. [22] Da köčtü alamy avulunun uvullarynyn \{Efrajimnin\} čerüv-

(21) ĺarisajyn da ag̉araq čerüvü üstüńa anyn Elišama uvlu

$229 \mathrm{r}^{\mathrm{o}}$ (1) 'Amihudnun. [23 [23 Da agaraq čerüvü üstüńa ševeti-

(2) nin uvullarynyn Menašenin Gamli'el uvlu Pedahcurnun. ועל. [24]

(3) Da ag̉araq čerüvü üstüńa ševetinin uvullarynyn Binjaminnin

(4) ונסע. [25] Da köčtü alamy avu-

(5) lunun uvullarynyn Dannyn jyštyruvču bar ol avullarg̉a čerüv-

(6) larisajyn da ag̉araq čerüvü üstüńa anyn Ahi'ezer

(7) uvlu 'Amišadajnyn. [26] Da agaraq čerüvü üs-

(8) tüńa ševetinin uvullarynyn Ašernin Pağ'i'el uvlu Akran-

(9) nyn. ועל [27] Da ag̉araq čerüvü üstüńa ševetinin uvul-

(10) larynyn Naftalinin Ahira uvlu 'Enannyn. אלה. [28] Bulardylar

(11) köčḿakĺari uvullarynyn Jisra’elnin čerüvlarisajyn da köčtü-

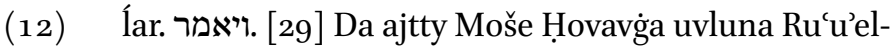

(13) nin ol Midjanlyg̉a qajnatasyna Mošenin ajtadog̉ač köč́adir

(14) biz ol orunga ki ajtty Adonaj any berirmen sizǵa

(15) kelgin birǵamizǵa da jahšy etarbiz saja ki Adonaj söz-

(16) Íladi jaḩ̌šnny Jisra’el üčün. [30] Da ajtty anar

(17) barmanmen ki ančaq jeriḿa da tuvmušuma baryrmen.

(18) יויאמר (31] Da ajtty qoltqabyla kemišḿagin bizni anyn

(19) üčün ki bildij toḥtağanymyzny midbarda da bolduj bizǵa

(20) közĺar ornuna. והיה [32] Da bolg̉aj ki barsaj birǵamiz-

(21) ǵa da bolg̉aj ol jahšylyq ki jahšy etśa Adonaj birǵa-

$229 \mathrm{v}^{0}$ (1) mizǵa da jaḥšy et́arbiz saja. ויסעו [33] Da köčtülar tavyn-

(2) dan Adonajnyn jol üč künlük da aron šerti Adonajnyn köčare-

(3) di alynlarynda alarnyn jol üč künlük čajsylama alarğa tynč-

(4) lyq. וענן Da bulutu Adonajnyn edi alar üstüna kün-

(5) düz köčḱkanlarind́a ol avuldan. ויהי [35] Da edi köč-

(6) kand́a ol aron da ajtyredi Moše turğun e Adonaj da

(7) tozulsunlar dušmanlaryj da qačsynlar kek tutuvčularyj al- 
(16) of tribe of the sons of Gad was Eliasaph, son of Deuel.

(17) [21] And the Kohathites set out who carried

(18) the tabernacle. And the sons of Gershon and the sons of

(19) Merari set up the tabernacle as they came.

(20) [22] And the standard of the camp of the sons of Ephraim set out

(21) according to their armies, and the superior over its army was Elishama, son

(1) of Ammihud. [23] And the superior over the army of the tribe

(2) of the sons of Manasseh was Gamaliel, son of Pedahzur. [24]

(3) And the superior over the army of the tribe of the sons of Benjamin was

(4) Abidan, son of Gideoni. [25] And the standard of the camp

(5) of the sons of Dan set out who were assembling all the camps

(6) according their armies, and the superior over its army was Ahiezer,

(7) son of Ammishaddai. [26] And the superior over the army

(8) of the tribe of the sons of Asher was Pagiel, son of Ocran.

(9) [27] And the superior over the army of the tribe of the sons

(10) of Naphtali was Ahira, son of Enan. [28] These were

(11) the travels of the sons of Israel according to their armies, and they set out.

(12) [29] And Moses said to Hobab, son of Reuel,

(13) the Midianite, Moses' father in law, saying, 'We are setting out

(14) to the place of which the Lord said, "I will give it to you."

(15) Come with us, and we will do you good, for the Lord has spoken

(16) good concerning Israel.' [3o] And he said to him,

(17) 'I will not go, but I will depart to my own land and to my kindred.'

(18) [31] And he said, 'Do not leave us, I pray you, because

(19) you knew how we camped in the wilderness, and you were eyes

(20) for us. [32] And it shall be, if you go with us,

(21) it shall be, that what goodness the Lord shall do with us,

(1) the same we will do to you.' [33] And they set out from the mountain

(2) of the Lord three days' journey. And the ark of the covenant of the Lord travelled

(3) before them in the three days' journey, to look out for a rest|ing place| for them.

(4) [34] And the cloud of the Lord was over them by day,

(5) when they set out from the camp. [35] And it was,

(6) when the ark travelled, that Moses said, 'Rise up, oh Lord, and

(7) let your enemies be scattered, and let them that hate you flee 
(8) nyjdan. ובנחה. [36] Da toḥtağanynda ajtyredi tynč et-

(9) kin e Adonaj tümanlarin minlarinin Jisra’elnin.

\section{Numbers 11}

(10) Da edi ol $\{[\mathrm{u}] \mathrm{lus}\}^{1}$ syltav izlavčüĺar jamanny ešitüvlarič́a

(11) Adonajnyn da ešitti Adonaj da qabundu ačuvu anyn da ör-

(12) tadi alarda otu Adonajnyn da tavustu učunda ol

(13) avulnun. ויצעק [2] Da firjat etti ol ulus Moše-

(14) ǵa da tefila etti Moše Adonajğa da batty ol ot.

(15) [יקרא (3) Da atady atyn ol orunnun Tav'era ki örta-

(16) di alarda otu Adonajnyn. [האספסף [4 Da ol qatyš

(17) el ki ortasynda anyn küśandilar küśanč da Łqajtty-

(18) lar [da jyladylar $]^{12}$ dag̉yn ulanlary Jisra’elnin da ajttylar ki $\{m\}$ ašatsajedi

(19) bizǵa et. זכרנו. [5] Sag்yndyq ošol ol balyqny ki ašare-

(20) dik Micrida muft ošol ol hyjarlarny da ošol ol

(21) harbuzlarny \{da ošol ol kapustalarny\} da ošol ol sog̉anlarny da ošol ol sarymsaq

230 ro (1) larny. [6] [6 Da haligińa žanymyz qurugandy joḥtu ne-

(2) med́a ančaq ol manġa telmáradilar ${ }^{3}$ közlarimiz.

(3) [7 Da ol man edi urlug̉u kibik kölandranin ol

(4) ulluluqqa da türsünü kibik ol inži tübünün aq-

(5) lyqqa edi türsünü anyn. שטו. [8] Jajylyredi\{lar\} ol ulus

(6) da jyštyryredilar da tartaredilar tijirḿand́a jemeśa

(7) jančarediĺar jančqyčta da biširiredilar čölḿakt́a

(8) jemeśa qylaredilar jajmalar da boluredi tatuvu anyn tatu-

(9) vu kibik semizliginin ol javnyn. וברדת. [9] Da enǵan-

(10) da ol čyq ol avul üstüńa kečabyla eńaredi ol

(11) man anyn üstüńa. וישמע. [10] Da ešitti Moše

(12) ošol ol ulusun jylajdog̉anny uruvlarysajyn kiši ešigind́a

(13) čatyrynyn da qa[b]undu ${ }^{4}$ ačuvu Adonajnyn astry da közĺa-

\footnotetext{
${ }^{1}$ TKow.o1: ulus; unvocalized text. | H: ulus. | C: ulus. $\quad{ }^{2} \mathrm{~K}$ : da jyladylar is missing; a scribal error, cf. TKow.o1, H and C. | TKow.o1: qajttylar da jyladylar; unvocalized text. | H: qajttylar da jyladylar. | C: qajttylar da jyladylar. ${ }^{3} \mathrm{~K}$ : tellmááadilar; a scribal error. | TKow.o1: telmerediler; unvocalized text. |H:telmerediler.|C: deest; a scribal error. $\quad{ }^{4} \mathrm{~K}:$ qavundu; a scribal error.|TKow.o1:qabundu; unvocalized text. | H: qabundu. | C: qahirländi; different wording.
} 
(8) before you.' [36] And when it camped, he said, 'Quieten,

(9) oh Lord, the ten thousands of thousands of Israel.'

Numbers 11

(9) [1]

(10) [1] And the people were seeking bad pretexts in the hearing

(11) of the Lord, and the Lord heard it and his anger was kindled, and

(12) the fire of the Lord burned among them and consumed at the edge

(13) of the camp. [2] And the people cried to Moses,

(14) and Moses prayed to the Lord, and the fire died down.

(15) [3] And he called the name of the place Taberah, because

(16) the fire of the Lord burned among them. [4] And the rabble

(17) that was among them craved a craving: and

(18) the children of Israel, as well, returned and said, 'Who shall feed

(19) us meat? [5] We remembered the fish that

(20) we ate in Egypt for free, the cucumbers, and the

(21) water-melons, and the cabbages, and the onions, and the garlic.

(1) [6] But now our soul is dried away. There is nothing,

(2) our eyes look with longing only at manna.'

(3) [7] And the manna was like coriander seed

(4) in size, and its appearance in whiteness like that of the bottom of a pearl.

(5) [8] And the people spread

(6) and gathered it and ground it in mills or

(7) beat it in a mortar and cooked it in a pot or

(8) made cakes |of it|: and the taste of it was

(9) as the oiliness of oil. [9] And

(10) when the dew descended on the camp at night, the

(11) manna descended on it. [10] And Moses heard

(12) the weeping people by their families, each man in the door

(13) of his tent, and the anger of the Lord was kindled greatly, and 
(14) rińa Mošenin jaman köründü. [11] Da ajtty

(15) Moše Adonajğa nek jaman ettij quluja da nek tapmadym

(16) širinlik 'enajetlaryjda ki kĺadij qojma ošol \{jügün\} bar ol

(17) ulusnun üstüma. האנכי [12] Menmo hamila et-

(18) tim ošol bar ol ulusnu ošpunu jemeśa menmo

(19) tuvdurdum any ki ajtasen maja eltkin any qyjasa qoj-

(20) nujda ol jerǵa ki ant etti $[j]^{1}$ atalaryna anyn ki nečik

(21) elt́adi ol östürüvčü ošol ol ömáadog̉an ulanny.

230 v $^{\circ}$ (1) מאין. [13] Qajdan kelsin maja et berma bar ulusqa

(2) ošpu ki jylajdylar alnymda ajtadog̉ač bergin bizǵa et

(3) da ašajyq. לא. [14] Bolalmanmen \{men\} jalġyz özüm kötürma

(4) jügün bar ol ulusnun ošpu ki avurdu ol mendan.

(5) ואם [15] Da eger bulaj qyladeśaj sen maja öltürgün \{meni\}

(6) \{endi $\}^{2}$ öltürmáa eger taptym eśa širinlik 'enajetlaryj-

(7) da da körmajim jamanymny. [16] Da ajtty

(8) Adonaj Mošeǵa jyštyrğyn maja jetmiš kiši qartlaryn-

(9) dan Jisra’elnin ki bilasen ki alardy qartlary ol ulusnun da

(10) tajaqčylary anyn da alg̀yn alarny ohel mo`edǵa da tur-

(11) sunlar anda birǵaja. [ירדתי [17 Da eńar šehinam

(12) da sözĺarmen birǵaja anda da ajyryrmen ol alhemd́an

(13) ki üstüjd́a da qojarmen alar üstüńa da kötü-

(14) rürlar birǵaja jügün bar ol ulusnun da kötürḿas-

(15) sen jalġyz özüj. ואל [18] Da ol ulusqa ajtqyn hadir-

(16) Ílanijiz tanbylag̉a da ašarsiz et ki jyladyjyz ešitüvlari-

(17) ča Adonajnyn ajtadog̉ač kim ašatsajedi bizǵa et ki

(18) jaḥšyraq edi bizǵa Micrid́a da berir Adonaj sizǵa et

(19) da ašarsiz. לא. [19] Tüvül bir kün ašarsiz da tüvül

(20) eki künĺar da tüvül beš künĺar da tüvül on künĺar

(21) da tüvül igirmi kün. עד. [20] Janġaj künlarǵadejin

$231 \mathrm{r}^{\mathrm{o}} \quad$ (1) neginč́a ki čyqqaj burnujuzdan da bolur sizǵa otalavğa

(2) anyn üčün ki ḥor ettijiz ošol sözün Adonajnyn ki ortajyz-

${ }^{1} \mathrm{~K}:$ ettim; a scribal error. | TKow.or: ettij; unvocalized text. | H: ettin. | C: ettin. $\quad{ }^{2}$ Marginal insertion by another hand. | TKow.o1: endi; unvocalized text. | H: endi. | C: endi. 
(14) it seemed bad in Moses's eyes. [11] And Moses said

(15) to the Lord, 'Why have you done bad to your servant, and why have I not found

(16) favour in your sight, that you wanted to lay the burden of all this

(17) people on me? [12] Did I conceive

(18) all this people? Or have I

(19) given birth to them, that you should say to me, "Carry them as if |they were|

(20) in your bosom to the land which [you $]^{212}$ swore to give to their fathers, like

(21) the one who brings up a sucking child?"

(1) [13] From where shall meat come to me to give it to all this people, $230 \mathrm{v}^{\mathrm{o}}$

(2) that they weep before me, saying, "Give us meat,

(3) that we may eat." [14] I am not able to carry

(4) the burden of all this people alone, because it is too heavy for me.

(5) [15] And if you deal thus with me, kill me

(6) $\{$ now $\}$, if I have found favour in your eyes,

(7) and let me not see my wretchedness.' [16] And the Lord said

(8) to Moses, 'Gather to me seventy men of the elders

(9) of Israel whom you know to be the elders of the people and

(10) their overseers, and bring them to the tent of meeting, that they may stand

(11) there with you. [17] And my divine Presence will come down

(12) and I will talk with you there. And I will separate some of the inspiration

(13) which is on you and I will put it on them, and they shall bear

(14) the burden of all the people with you, so that you may not bear it

(15) yourself alone. [18] And say to the people, "Prepare

(16) yourselves for the daybreak, and you will eat meat, for you have wept in the ears

(17) of the Lord, saying, "Who shall feed us meat, because

(18) we had it better in Egypt," and the Lord will give you meat,

(19) and you will eat. [19] You will not eat one day, and not

(20) for two days, and not for five days, and not for ten days,

(21) and not twenty days: [20] Until a month of days!

(1) Until it comes out of your nose and it becomes poison to you.

(2) Because you have despised the Lord's word who is among you,

212 K: I; a scribal error, cf. Heb. נִשְׁבַבְּעָת 'you swore'. 
(3) da da jyladyjyz alnynda anyn ajtadoġač neǵa bu čyqtyq

(4) Micrid́an. ויאמר. [21] Da ajtty Moše alty keŕat

(5) jüz min jajav ol ulus ki men ortasynda anyn da sen

(6) ajttyj et berirmen alarg̉a da ašarlar janġaj künlar.

(7) הצאן . 222] [Bunu qolamen ki anlatqajsen maja ${ }^{11}$ qojmo da

(8) syġyr sojulur alarg̉a ki jetkaj alarg̉a ošol balyqlary-

(9) mo ol tengiznin jyštyrylyr alarg̉a ki jetkaj alarg̉a.

(10) ויאמר (23] Da ajtty Adonaj Mošeǵa küčümö Adonaj-

(11) nyn jadady haligińa köŕarsen učrar $\{\mathrm{mo}\}$ seni sözüm jemeśa

(12) joq. ויצא [24] Da čyqty Moše da sözladi ol ulusqa

(13) ošol sözlarin Adonajnyn da jyštyrdy jetmiš kiši

(14) qartlaryndan ol ulusnun da turğuzdu alarny čüvŕa-

(15) ו́arind́a ol čatyrnyn. [25] Da endi šeḩina-

(16) sy Adonajnyn bulut byla da sözladi anar da ajyrdy ol

(17) alhemd́an ki anyn üstüńa da berdi jetmiš kiši üs-

(18) tüńa ol qartlar da edi toḥtaġačoq alar üstüńa

(19) ol alhem da navilik ettilar da arttyrmadylar.

(20) . וישארו Da qaldylar eki éranĺar avulda aty ol

(21) [bir]nin ${ }^{2}$ Eldad da aty ol ekinčinin Medad da toḥtady

$231 v^{0} \quad$ (1) alar üstüńa ol alhem da alar edilar jazylġanlar arasyna

(2) da čyqmadylar ol čatyrg̉a da navilik ettilar avulda.

(3) וירץ [27 Da juvurdu ol ulan da anlatty Mošeǵa da

(4) ajtty Eldad da Medad navilik etadilar avulda.

(5) ויען Mošenin saj-

(6) lanmušlaryndan anyn da ajtty bijim Moše syndanġa qoj-

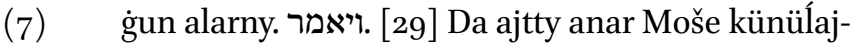

(8) musen sen menim üčün da kim berip barda ulusu Ado-

(9) najnyn bolsajedilar navilar ki berśajdi Adonaj ošol al-

(10) hemin alar üstüńa. [30] Da jyštyryldy Moše

(11) ol avulg̀a ol da qartlary Jisra’elnin. ורוח [31] Da

(12) jel köčtü alnyndan Adonajnyn da suvurdu perepelič́alar

(13) ol tengizd́an da tašlady ol avul qatyna künlük jol tak-

\footnotetext{
${ }^{1}$ Interpretative addition to the standard text. ${ }^{2}$ TKow.o1: birisinin; unvocalized text. | H: birnin. | C: birsiniy. $\quad{ }^{3}$ TKow.o1: uvlu Nunnun; unvocalized text. | H: uvlu Nunnun. | C: oġlu Nunnyy.
} 
(3) and you have wept before him, saying, "Why is this that we went out

(4) from Egypt?"”' [21] And Moses said,

(5) 'The people, among whom I am, are six times a hundred thousand footmen, and you

(6) have said, "I will give them meat, that they may eat a month of days."

(7) [22] $]_{\mathrm{L}}$ am asking you for this, so that you may explain to me $\mathrm{e}^{213}$ : will the flocks and

(8) cattle be slain for them to suffice them? Will the fish

(9) of the sea be gathered together for them to suffice them?'

(10) [23] And the Lord said to Moses, 'Does the Lord's strength

(11) get tired? Now you will see whether my word happens to you or

(12) not.' [24] And Moses went out and spoke to the people

(13) the words of the Lord, and gathered seventy men

(14) of the elders of the people, and stood them

(15) all around the tent. [25] And the Lord's divine Presence came down

(16) in a cloud and spoke to him, and he separated

(17) some of the inspiration that was on him and gave it to the seventy men,

(18) the elders. And it was when the spirit camped on them:

(19) and they prophesied. And they did not continue |doing it|.

(20) [26] But there remained two of the men in the camp, the name of the

(21) one was Eldad, and the name of the second was Medad. And

(1) the inspiration rested on them. And they were of them that were written,

(2) but they did not go out to the tent, and they prophesied in the camp.

(3) [27] And a boy ran and told Moses, and

(4) said, 'Eldad and Medad do prophesy in the camp.'

(5) [28] And Joshua, son of Nun, the servant of Moses

(6) from his chosen ones, answered and said, 'My lord Moses, put them in prison.'

(7) [29] And Moses said to him, 'Are you jealous

(8) for me? And who would make it |so| that all of the Lord's people

(9) were prophets, that the Lord would put his

(10) inspiration on them!' [30] And Moses was gathered back

(11) to the camp, he and the elders of Israel. [31] And

(12) a wind travelled from before the Lord and tore out quails

(13) from the sea and cast them by the camp, about a day's journey

213 An interpretative addition to Num 11:22. 
(14) li bu jary da künlük jolt́akli bujary čüvŕálarind́a

(15) ol avulnun da eki lokotlar takli jüzlari üstüńa ol

(16) jernin. [32] Da turdu bar ol ulus bar ol künnü

(17) da bar ol keč́ani da bar ol tanbylaggyda künnü da jyštyr-

(18) dylar ošol ol perepelićani ol az jyštyruvču jyštyrdy

(19) $\mathrm{o}[\mathrm{n}]^{1}$ obalar da jajdylar özlarińa jajmaq čüvŕalarin-

(20) da ol avulnun. הבשר. [33] Ol et hanuz edi tiš-

(21) ĺari arasyna alarnyn eksilḿastan burun da ačuvu Adonaj-

$232 \mathrm{r}^{\circ} \quad$ (1) nyn qabundu ulusta da qyrdy Adonaj ulusta ullu qyranč

(2) astry. ויקרא [34] Da atady atyn ol orunnun Qivrot

(3) Hata’ava ki anda astradylar ošol ol ulusun ol et kü-

(4) śanüvčülarni. מקברות. [35] Qivrot ol Hata’avadan köčtülar

(5) ol ulus Ḥacerotqa da edilar Ḥacerotta.

Numbers 12

(6) Da sözladi Mirjam da Aharon Moše üčün iši üčün ol

(7) kušlu qatynnyn ki aldy ki kušlu qatyn aldy. ויאמרו. [2]

(8) Da ajttylar tek ančak Moše bylamo sözladi Adonaj

(9) muna dag̉yn biznin byla da sözladi da ešitti Adonaj. והאיש. [3]

(10) Da ol navi Moše juvašraq edi astry bar ol adamdan

(11) ki jüzĺari üstüńa ol jernin. [4] Da ajtty

(12) Adonaj kenetááa[j] ${ }^{2}$ Mošeǵa da Aharonġa da Mirjamġa čyġyjyz

(13) üčsüjüzd́a ohel mo'edǵa da čyqtylar üčsülarid́a.

(14) יוירד [5] Da endi šehinasy Adonajnyn bag̉anasy byla bulut-

(15) nun da turdu ešigind́a ol čatyrnyn da čaġyrdy Aharon-

(16) nu da Mirjamny da čyqtylar eksilarid́a. ויאמר [6] Da

(17) ajtty tynlajyz endi sözlarimni eger bolsa navi sizd́an

(18) men Adonaj körüm byla anar bilinirmen tüš ašyra sözlarmen

(19) anyn byla. לא. [7 ] Tüvüldü alaj qulum Moše bar üvümd́a

${ }^{1} \mathrm{~K}$ : ol; a scribal error. | TKow.on: on; unvocalized text.|H: on. | C: on. $\quad{ }^{2} \mathrm{~K}$ : kenetala; a scribal error. Cf., however, Num 35:22. | TKow.o1: kenetele; unvocalized text. | H: kenetelej.| C: kep-kenätä. 
(14) in this direction, and about a day's journey in this direction, all around

(15) the camp, and about two cubits high above the face

(16) of the earth. [32] And the people stood up all that day

(17) and all that night and all the next day, and they gathered

(18) the quail. The one who had the least gathered

(19) [ten] piles. And they spread them out for themselves, spreading around

(20) the camp. [33] And the flesh was still

(21) between their teeth, before it vanished, and the anger of the Lord

(1) was kindled against the people, and the Lord struck the people with a $232 \mathrm{r}^{\circ}$ very great plague.

(2) [34] And he called the name of that place Kibroth-

(3) -Hattaavah, because they buried the people that craved for meat there.

(4) [35] And the people journeyed from Kibroth-Hattaavah

(5) to Hazeroth, and they were in Hazeroth.

Numbers 12

(6) And Miriam and Aaron spoke about Moses, about the matter of

(7) the Cushite woman whom he had taken-because he had taken an Cushite woman. [2]

(8) And they said, 'Has the Lord only just spoken by Moses?

(9) Lo, he has spoken also by us.' And the Lord heard it. [3]

(10) And Moses, the prophet, was much more humble than all the men

(11) who were on the face of the earth. [4] And

(12) the Lord spoke suddenly to Moses and to Aaron and to Miriam, 'Come out,

(13) even the three of you, to the tent of meeting.' And the three of them came out.

(14) [5] And the divine Presence of the Lord came down in the pillar of the cloud

(15) and stood in the door of the tent and called Aaron

(16) and Miriam, and they both went out. [6] And

(17) he said, 'Hear now my words: If there is a prophet among you,

(18) I, the Lord, will be known to him in a vision, I will speak with him through a dream.

(19) [7] Not so is my servant Moses; in all my house 
(20) inamlydy ol. פה [8] Aqyl aqylgaa sözlarmen anyn byla da

(21) körümbyla da tüvül hiǚ̆atlar byla da šehinasyn Adonaj-

$232 \mathrm{v}^{\mathrm{o}} \quad$ (1) nyn baġady da neüčün qorqmadyjyz sözlááa qulum Moše üčün.

(2) ויחר . [9] Da qabundu ačuvu Adonajnyn alar üstüńa da bardy

(3) šehinasy anyn. והענן. [10] Da ol bulut ketti ol čatyr

(4) üstünd́an da muna Mirjam boldu cara'atly qarkibik da qajyryldy

(5) Aharon Mirjamġa da muna caracatlydy. ויאמר [11] Da ajtty

(6) Aharon Mošeǵa qoltqa byla \{bijim $\}$ qojmag்yn üstümüzǵa క̌urumun

(7) jazyqnyn ki telilik qyldyq da ki jazyqly bolduq. אל. [12] Qoltqa-

(8) byla bolmasyn andij ölü kibik ki čyqqanynda qursaġyndan

(9) anasynyn da tavusuldu jarymy gufunun. [13] Da

(10) tefila etti Moše Adonajğa ajtadoġač e Tenri qoltqabyla

(11) ongaltqyn haligińa andoq any. [יאמר [14] Da ajtty

(12) Adonaj Mošeǵa da atasy anyn tükürńa tükürśajedi

(13) jüzlarińa anyn iḿanḿaǵajmo edi jedi künĺar bekĺansin

(14) jedi künĺar tyšqartyn avulġa da andan sortun jyštyrylyr.

(15) (15] Da bekĺandi Mirjam tyšqartyn avulġa jedi

(16) künĺar da ol ulus köčmadi jyštyrylg̀ynča Mirjam.

(17) (16] Da andan sortun köčtülar ol ulus Hacerot-

(18) tan da toḥtadylar midbarynda Parannyn.

Numbers 13

פרשת שלח לך (19)

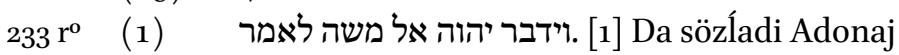

(2) Mošeǵa ajtadoğač. שלחר. [2] Ijgin ö-

(3) züja eŕanlar da čajsylasynlar ošol jerin Kena'annyn ki men

(4) beŕamen any ulanlaryna Jisra’elnin biŕar kiši biŕar kiši \{ševetind́an atalarynyn $\}$ iji-

(5) jiz bar nasini alarda. [ישלח. Da ijdi alarny Moše

(6) midbaryndan Parannyn bujrugubyla Adonajnyn barlary edilar

(7) syjly é́anĺar ag̉araqlary ulanarynyn Jisra’elnin alar. ואלה. [4]

(8) Da bular edilar atalary ševetind́an Ru'uvennin Šamu'a

(9) uvlu Zakurnun. למטה. [5] Ševetind́an Šim'onnun Šapat

(10) uvlu Horinin. למטה [6 S Ševetind́an Juhudanyn Kalev uvlu

(11) Jefunenin. למטה [7 Ševetind́an Jissaharnyn Jig̉al uvlu

(12) Josefnin. למטה [8 Ševetind́an Efrajimnin Hošéa uvlu Nun- 
(20) he is faithful. [8] Mind to mind I will speak with him and

(21) through vision and not through riddles, and he sees the divine Presence of the Lord.

(1) And why did you not fear to speak about my servant Moses?'

(2) [9] And the anger of the Lord was kindled against them, and

(3) his divine Presence went. [10] And the cloud departed

(4) from over the tent. And, lo, Miriam became leprous, like snow. And

(5) Aaron turned to Miriam, and, lo, she was leprous. [11] And Aaron said

(6) to Moses, 'I pray you, my lord, do not set the punishment

(7) of a sin on us which we did foolishly, and which we sinned. [12]

(8) I pray you, let her not be like the dead who, when he comes out of

(9) his mother's womb, half of his flesh is eaten up.' [13] And

(10) Moses prayed to the Lord, saying, 'I pray you, oh God,

(11) heal her though, now.' [14] And the Lord said

(12) to Moses, 'And if her father had but spit

(13) in her face, should she not be ashamed seven days? She shall be shut up

(14) outside the camp seven days, and after that let her be gathered back.'

(15) [15] And Miriam was shut up outside the camp seven

(16) days. And the people did not travel until Miriam was gathered back.

(17) [16] And afterward the people set out from Hazeroth,

(18) and they camped in the wilderness of Paran.

\section{Numbers 13}

(19) Parashat Shlach

(1) [1] And the Lord spoke

(2) to Moses, saying, [2] 'Send

(3) for yourself men, and they shall spy out the land of Canaan, which I

(4) am giving to the children of Israel. You shall send one man of every tribe of their fathers,

(5) everyone a prince among them.' [3] And Moses sent them

(6) from the wilderness of Paran by the command of the Lord. They were all

(7) honourable men, they: the superiors of the children of Israel. [4]

(8) And these were their names: of the tribe of Reuben, Shammua,

(9) son of Zaccur. [5] Of the tribe of Simeon, Shaphat,

(10) son of Hori. [6] Of the tribe of Judah, Caleb, son

(11) of Jephunneh. [7] Of the tribe of Issachar, Igal, son

(12) of Joseph. [8] Of the tribe of Ephraim, Hoshea, son of Nun. 
(13) nun. למטה. [9] Ševetind́an Binjaminnin Palti uvlu Rafu'-

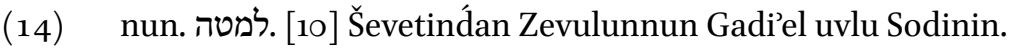

(15) למטה (11] Ševetind́an Josefnin ševetind́an Menašenin Gadi

(16) uvlu Susinin. למטה. [12] Ševetind́an Dannyn 'Ami'el uvlu

(17) Gemalinin. למטה [13] Ševetind́an Ašernin Setur uvlu

(18) Mi\{h\}a’elnin. למטה [14] Ševetind́an Naftalinin Naḥbi uvlu Vafsi-

(19) nin. למטה [15] Ševetind́an Gadnyn Gu'u'el uvlu Mahinin.

(20) אלה (16] Bulardylar atlary ol éranlarnin ki ijdi Moše

(21) čajsylama ošol ol jerni da atady Moše Hošeagia uvluna

$233 \mathrm{v}^{\mathrm{o}}$ (1) Nunnun Johošuac. [17] Da ijdi alarny Moše čajsylama o-

(2) šol ol jerni Kena'annyn da ajtty alarga baryjyz bu jary

(3) tüšlük byla da minijiz ol tavġa. וראיתם. [18] Da bag̈yjyz

(4) ošol ol jerni nedir ol da ošol ol ulusnu ol olturuv-

(5) čunu anyn üstüńa küčlümodu ol ḥalašmodu azmodu ol

(6) köpmodu. ומה [19] Da nedi ol jer ki ol olturady anda

(7) jahšymodu ol jamanmodu da nedi ol šaharlar ki ol olturady

(8) alarda avullarbyla modu bek kermanlarbyla modu.

(9) ומה 20] Da nedi ol jer semizmodu ol aryqmodu barmodu

(10) anda jemiš ag̉ačy joḥmodu da kiplanijiz da alyjyz jemišin-

(11) dan ol jernin da ol künĺar edilar künlari jetilmakĺa-

(12) rinin borlalarnyn. [יעלו [21] Da bardylar da čajsyladylar ošol

(13) ol jerni bašlap midbaryndan Cinnin ${ }_{L}$ Roḥov Levo' Hamatqadejin ${ }^{11}$.

(14) [יעלו Da bardylar tüšlükbyla da keldilar Hevronġadejin

(15) da anda Aḥiman Šešaj da Talmaj tuvmušlary ol 'Anaqnyn da

(16) Hevron jedi jyllar qondaryldy burunraq Co'an Micrajimd́an.

(17) ויבאו Da keldilar öźanińadejin Eškolnun da kesti-

(18) ĺar andan butaq da solqunun borlalarnyn birni da elttilar

(19) üśak byla ökövd́a da ol narlardan da ol inžirlar-

(20) dan. למקום [24] Ol orungaga atady Nahal2 Eškol iši üčün

\footnotetext{
${ }^{1}$ A mistranslation. | TKow.ol: oramynadejin Levo' Hamatnyn; unvocalized text. | H: oramynadejin kelivinin Hamatnyn. | C: Rohovġa degin kelivinä degin Hamatnyn. | R: Rohovġa dejiń keluv́uńa

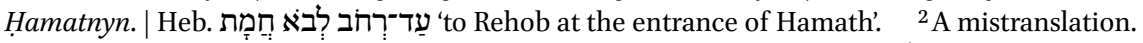
| TKow.or: Nahal; unvocalized text. | H: Nahal. | C: Nahal. | R: Nahal. | Heb. נַח 'torrent-walley, wady; torrent'.
} 
(13) [9] Of the tribe of Benjamin, Palti, son of Raphu.

(14) [10] Of the tribe of Zebulun, Gaddiel, son of Sodi.

(15) [11] Of the tribe of Joseph: of the tribe of Manasseh, Gaddi,

(16) son of Susi. [12] Of the tribe of Dan, Ammiel, son

(17) of Gemalli. [13] Of the tribe of Asher, Sethur, son

(18) of Michael. [14] Of the tribe of Naphtali, Nahbi, son of Vophsi.

(19) [15] Of the tribe of Gad, Geuel, son of Machi.

(20) [16] These are the names of the men whom Moses sent

(21) to spy out the land. And Moses called Hoshea, son

(1) of Nun Joshua. [17] And Moses sent them to spy out

(2) the land of Canaan, and said to them, 'Go up this way

(3) to the south ${ }^{214}$, and go up the mountain. [18] And see

(4) the land, what is it, and the people that dwell

(5) on it: are they strong, weak, few,

(6) many? [19] And what is the land that they dwell in:

(7) is it good, bad? And what are the cities that they dwell

(8) in: are they camps, strong fortresses?

(9) [20] And what is the land: is it fat or meagre, does it have

(10) fruit trees or not? And strengthen yourselves and bring some of the fruit

(11) of the land.' And it was the days of the ripening

(12) of grapes. [21] So they went up and spied the

(13) land from the wilderness of Zin ${ }_{\mathrm{L}}[$ to $]$ Rehob, to Lebo-Hamath ${ }^{1215}$.

(14) [22] And they went through the south ${ }^{216}$ and came to Hebron.

(15) And there were Ahiman, Sheshai, and Talmai, the children of Anak. And

(16) Hebron was built seven years before Zoan in Egypt.

(17) [23] And they came to the river of Eshcol and cut down

(18) from there a branch with one bunch of grapes - and they carried

(19) it on a pole by two |people|—and some of the pomegranates, and of the figs.

(20) $[24]$ The place was called Nahal ${ }^{217}$ Eshcol on account of the

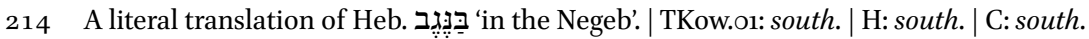

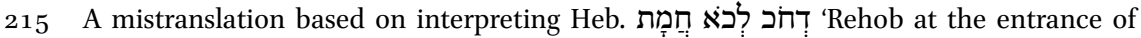
Hamath' as a place name. | TKow.o1: to the way of Lebo-Hamath. | H: to the way of the entrance of Hamath; a mistranslation. | C: to Rehob, to the entrance of Hamath.| R: to Rehob, to the entrance of Hamath.

216 A literal translation of Heb. בַּנְּב 'through Negeb'. | TKow.o1: south. | H: south. | C: south.

217 A mistranslation based on interpreting Heb. נַח 'torrent-walley, wady; torrent' as a place name. | TKow.o1: Nahal. | H: Nahal. | C: Nahal. | R: Nahal. 
(21) ol solqunnun ki kestilar andan ulanlary Jisra’elnin. וישבו. [25]

$234 \mathrm{r}^{\mathrm{o}} \quad$ (1) Da qajttylar čajsylamaqtan ošol ol jerni aherind́an qyrq kün-

(2) nün. וילכו [26] Da bardylar da keldilar Mošeǵa da Aharonġa

(3) da bar క̌ymatyna ulanlarynyn Jisra'elnin midbarynda Parannyn Qadeška

(4) da qaruv qajtardylar alarg̉a söz da ošol bar ol žymatqa da

(5) körgüzdülar alarg̉a ošol jemišin ol jernin. ויספרו. [27]

(6) Da qotardylar alargaa da ajttylar keldik ol jerǵa ki ijdij

(7) bizni da dag்yn ag̉adog̉an süt da bal ol da budu jemiši anyn.

(8) אפס . 28] Ančaq ki küčlüdü ol ulus ol olturuvču jerd́a

(9) da ol šaharlar bekĺardi ullular astry da daġyn tuvmušlaryn ol

(10) 'Anaqnyn kördük anda. עמלק. [29] 'Amaleq olturady jerind́a

(11) ol tüšlüknün da ol Ḥiti da ol Jevusi da ol Emori oltura-

(12) dy tavda da ol Kena'ani olturady ol tengiz qatyna da janynda

(13) ol Jardennin. [30] Da tijdi Kalev ošol ol ulusnu

(14) alnynda Mošenin da ajtty barma baryrbiz da meŕaslar-

(15) biz any ki jenḿa jeńarbiz any. והאנשים. [31] Da ol eŕanĺar

(16) ki bardylar birǵasińa ajttylar bolalmasbiz barma ol ulusqa

(17) ki küčlǘakti ol bizd́an. [32] Da čyğardylar ajipin ol jernin ki

(18) čajsyladylar any ulanlaryna Jisra’elnin ajtadog̉ač ol jer ki aštyq

(19) anda čajsylama any jer tavusadog̉an olturuvčularyn özünün ol

(20) da bar ol ulus ki kördü $\{\mathrm{k}\}$ ortasynda anyn ullu ölčüvlü

(21) eldi. ושם [33] Da anda kördük ošol ol alanqasarlarny

$234 \mathrm{v}^{\mathrm{o}} \quad$ (1) uvullaryn ol 'Anaqnyn ol alanqasarlardan da bolduq közlarimiz-

(2) da čegirtḱálar kibik da alaj bolduq közlarind́a alarnynda. 
(21) bunch |of grapes $\mid$ which the children of Israel cut down from there. [25]

(1) [25] And they returned from spying out the land after the time of $234 \mathrm{r}^{\mathrm{o}}$ forty days.

(2) [26] And they went and came to Moses and to Aaron

(3) and to all the congregation of the children of Israel, to the wilderness of Paran, to Kadesh,

(4) and they brought back word of answer to them and to all the congregation, and

(5) showed them the fruit of the land. [27]

(6) And they told him, and said, 'We came to the land where you sent

(7) us, and also it is flowing |with $\mid$ milk and honey, and this is the fruit of it.

(8) [28] Nevertheless the people are strong that dwell in the land,

(9) and the cities are strong and very big. And moreover we saw the children

(10) of Anak there. [29] Amalek dwells [in the land

(11) of the south ${ }^{1218}$, and the Hittites and the Jebusites and the Amorites dwell

(12) in the mountains, and the Canaanites dwell by the sea and along

(13) the Jordan.' [30] And Caleb quieted the people

(14) before Moses, and said, 'We will surely go and inherit it,

(15) for we will surely overcome it.' [31] But the men

(16) that went with him said, 'We will be not able to go up against the people,

(17) because they are stronger than we.' [32] And they brought the shame of the land

(18) which they had spied to the children of Israel, saying, 'The land, through which we passed

(19) to spy it, is a land that eats up its own inhabitants,

(20) and all the people that we saw in it are men of great stature.

(21) [33] And we saw the giants there,

(1) the sons of Anak from the giants, and we were in our own eyes

(2) like locust, and so we were in their eyes, too.'

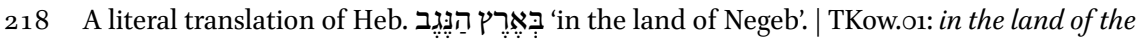
south. | H: in the land of the south.|C: in the land of the south. | R: in the land of the south. 


\section{Numbers 14}

(3) [1] Da kötürdü bar ol క̌ymat da berdilar

(4) ošol avazlaryn da jyladylar ol ulus ol keč́ani. וילנו. [2]

(5) Da küvürd́andiĺar Moše üstüńa da Aharon üstüńa

(6) bar ulanlary Jisra’elnin da ajttylar alarg̉a bar ol క̌ymat

(7) kešḱa ölśajdik jerind́a Micrinin jemeśa ošpu mid-

(8) barda kešḱka ölśajdik. ולמה. [3] Da nek Adonaj keltiŕadi

(9) bizni ol jerǵa ošpu tüšḿa qylyčtan qatynlarymyz da jašy-

(10) myz bolurlar talavġa jahšyraq tüvülmodu bizǵa qajtma

(11) Micriǵa. ויאמרו. [4] Da ajttylar kiši qaryndašyna beŕajik

(12) özümüzǵa ag̉alyq da qajtajyq Micriǵa. ויפל [5a

(13) tüštü Moše da Aharon jüzlari üstüńa alnynda bar

(14) qahalynyn క̌ymatynyn ulanlarynyn Jisra'elnin. ויהושע. [6] Da Johošua

(15) uvlu Nun\{nun\} da Kalev uvlu Jefunenin ol čajsylavčular ošol ol

(16) jerni jyrttylar upraqlaryn. ויאמרו [7 Da ajttylar bar

(17) 3̌ymatyna ulanlarynyn Jisra’elnin ajtadoġač ol jer ki aštyq

(18) anyn ašyra čajsylama any jahšydy ol jer astry astry. אם. [8]

(19) Ančaq süvḿa süvśajedi Adonaj bizni da keltirśajedi bizni ol

(20) jerǵa ošpu berśajedi any bizǵa jer ki ol ag̉adog̉an süt

(21) da bal. אך [9] Tek Adonajga tanmajyz da siz qorqmajyz

$235 \mathrm{r}^{\mathrm{o}} \quad$ (1) ulusundan ol jernin ki ötḿak ornunady bizǵa alar

(2) ketti kölaǵasi alarnyn üstĺarind́an vale bolušlug̉u Adonajnyn birǵa-

(3) mizǵadi qorqmajyz alardan. ויאמרו. [10] Da ajttylar bar ol

(4) 3̌ymat tašbyla tašlama alarny da šehinasy Adonajnyn aškara

(5) boldu ohel mo'edd́a bar ulanlaryna Jisra’elnin. ויאמר. [11] Da

(6) ajtty Adonaj Mošeǵa qačanġadejin ačyrğandyryrlar meni ol

(7) ulus ošpu da qačanġadejin inanmaslar maja bar ol belgilar-

(8) byla ki qyldym ortasynda anyn. אכנו [12] Urarmen any

(9) ölatbyla da tasetarmen anyn da qylarmen seni ullu hanlyq-

(10) qa da küčlürak[ḱk]a andan. ויאמר. [13] Da ajtty Moše

(11) Adonajg̉a da ešitśaĺar Micrililar ki čyġardyj quvatyjbyla

(12) ošol ol ulusnu ošpunu ortasyndan anyn. ויאמר. [14] Da

(13) ajtyrlar olturuvčusuna ol jernin ošpunun ešitti- 


\section{Numbers 14}

(3) [1] And all the congregation raised and let out

(4) their voices, and the people wept that night. [2]

(5) And all the children of Israel murmured against Moses and against Aaron,

(6) and the whole congregation said to them,

(7) 'If only we had died in the land of Egypt! Or in this wilderness,

(8) if only we had died! [3] And why is the Lord bringing us

(9) to this land, to fall by the sword? Our wives and our infants

(10) will become a prey! Isn't it better for us to return

(11) to Egypt?' [4] And they said one to another, 'Let's give

(12) us choose a superior, and let us return to Egypt.' [5] And

(13) Moses and Aaron fell on their faces before all

(14) the assembly of the congregation of the children of Israel. [6] And Joshua,

(15) son of Nun, and Caleb, son of Jephunneh - those who spied the

(16) land-tore their clothes. [7] And they spoke to all

(17) the congregation of the children of Israel, saying, 'The land, which we passed

(18) to spy it: that land is very, very good. [8]

(19) Only if the Lords loves us, then he will bring us

(20) to this land and give it to us, a land flowing $\mid$ with $\mid$ milk

(21) and honey. [9] Just do not betray the Lord. And you, do not fear

(1) the people of the land, because they are bread for us:

(2) their shadow is departed from over them, but the Lord's help is with us.

(3) Do not fear them.' [10] And all the

(4) congregation said to stone them with stones. And the divine Presence of the Lord appeared

(5) in the tent of meeting to all the children of Israel. [11] And

(6) the Lord said to Moses, 'How long will this people make me angry?

(7) And how long will they not believe me, with all the signs

(8) which I have done among them? [12] I will smite them

(9) with the pestilence, and I will destroy them, and I will make you into a great

(10) and more powerful kingdom than they.' [13] And Moses said

(11) to the Lord, 'And if the Egyptians hear it, because you brought

(12) this people out from among them with your power: [14] And

(13) they will tell it to the inhabitants of this land. They have heard 
(14) ĺar ki sen Adonaj ortasynda ol ulusnun ošpunun ki

(15) aqyl aqylġa aškara bolady šehinaj senin da bulutuj tu-

(16) rady alar üstüńa da bag̉anasy byla bulutnun sen barasen

(17) alynlarynda alarnyn kündüz da baġanasy byla otnun

(18) keč́abyla. והמתה] Da öltürśaj ošol ol ulusnu \{ošpunu\} bir

(19) kišini kibik da ajtyrlar ol ḥanlyqlar ki ešittilar ošol e-

(20) šitüvüjnü1 ajtadog̉ač. מבלתי. [16] Küčü jog̉undan Adonajnyn keltir-

(21) ḿa ošol ol ulusnu ošpunu ol jerǵa ki antetti

$235 \mathrm{v}^{\mathrm{o}}$ (1) alarğa da sojdu alarny midbarda. ועתה [17 Da haligińa

(2) ulġajsyn endi küčü Adonajnyn ki nečik sözladij ajtadoġač.

(3) יהוה [18] Adonaj uzaq ačuvlu da köp šavagiatly bošatuvču gü-

(4) ńaḥni da tanmaq jazyqlarny da könü etḿa könü etḿaj-

(5) di saġynuvču güńahin atalarnyn jaman ulanlar üstüńa üčün-

(6) čü dorġadejin da dörtünčü dorgadejin. [19] Bošatqyn

(7) endi qoltqabyla günahịin ol ulusnun ošpunun ullulugunaköŕa

(8) šavag̉atyjnyn da ki nečik bošattyj günahịin ošpu ulusnun

(9) čyqqan vaḥtlaryndan Micrid́an da haliǵadejin. [20]

(10) Da ajtty Adonaj bošattym \{jazyqlaryn alarnyn\} sözüja köŕa. ואולם. [21]

(11) Da kertid́an qajjamdyr men da nečik tolady syjym menim

(12) bar ol jerd́a. כ. [22] Alaj qajjam bolur sözüm ki bar ol éáan-

(13) ĺar ol körüvčülar ošol syjymny da ošol belgilarimni

(14) ki qyldym Micrid́a da midbarda da synadylar meni bu on

(15) keŕatlar da tynlamadylar sözümáa. [23] Eger

(16) körśalar ošol ol jerni ki ant ettim atalaryna alarnyn

(17) da barda ačyrg̉andyruvčularym körḿaślar any.

(18) [ועבדי (24) Vale qulum Kalev anyn üčün ki edi özǵa saġyš

${ }^{1} \mathrm{~A}$ mistranslation. | TKow.o1: ešitüvüjnü; unvocalized text. | H: esitivinni. | C: habaryyy. | M: habaryyy. | E: habaryyy. | R: ešituv́ujńu. | Heb. שָׁ 'hearsay’. 
(14) that you, Lord, are among this people, that

(15) your divine Presence has appeared mind to mind, and that your cloud

(16) stands over them, and that you go before them in a pillar of a cloud

(17) by daytime and in a pillar of fire

(18) by night. [15] And if you kill this people

(19) as one man, then the kingdoms which have heard the [hearsay $]^{219}$ of you will speak,

(20) saying, [16] "Because of the lack of the Lord's power to bring

(21) this people to the land which he swore

(1) to give to them, he has slain them in the wilderness." [17] And now,

(2) let the power of my Lord be great, according as you have spoken, saying,

(3) [18] "The Lord is slow to anger and abundant in kindness, forgiving

(4) iniquity and transgression, and he is surely not making anyone innocent:

(5) reckoning fathers' iniquity on evil children to the third

(6) generation and fourth generation." [19] Forgive

(7) now, I pray you, the iniquity of this people according to the greatness

(8) of your mercy, and as you have forgiven the iniquity of this people

(9) from the time they left Egypt even until now. [20]

(10) And the Lord said, 'I have forgiven their iniquity according to your word. [21]

(11) But truly, I am eternal. And as my glory is filling

(12) all the earth, [22] So will my word be eternal, because all those men

(13) who have seen my glory and my signs

(14) that I did in Egypt and in the wilderness, and who have tested me these ten

(15) times and have not listened to my voice: [23]

(16) [They will not see $]^{1220}$ the land which I swore to their fathers,

(17) all those that make me angry will not see it.

(18) [24] And my servant Caleb: because he had another though

219 K: hearing; a mistranslation based on the confusion of BHeb. שֶַׁ 'hearsay' (Num 14:15) with Heb. שַׁِע 'hearing'. Repeated in H, and R. Translated correctly in C, M, and E.

$220 \mathrm{~K}$ : if they see; a mistranslation repeated in a number of manuscripts resulting from literal translation of the Hebrew conditional clause, cf. Gen 14:23, Num 14:30, Num 32:11, Deu 1:35. | TKow.o1: if they see. | H: if they see. | C: if they see. | M: if they see. | E: if they see. | R: if they see. 
(19) birǵasińa da tüğallik byla jürüdü saruvumartyna

(20) da keltirirmen any ol jerǵa ki keldi ary da urlug̉una

(21) özünün meŕaslatir any. והעמלקי. [25] Da ol 'Amaleqi

${ }_{23} 6 \mathrm{r}^{\mathrm{o}} \quad$ (1) da ol Kena'ani olturady eništa tanbyla qajyrylyjyz da

(2) köčüjüz özüjüzǵa ol midbarg̉a jolusary Jam Sufnun.

(3) (26] Da sözladi Adonaj Mošeǵa da Aharonga ajta-

(4) doğač. עד [27] Qačangadejin men čydarmen ol jaman žymatqa

(5) ošpu ki alar küvürd́ańadilar üstümáa ošol kü-

(6) vürd́anḿakĺarin ulanlarynyn Jisra’elnin ki alar küvürd́ańadi-

(7) Ílar üstüma ešittim. אמור. [28] Ajtqyn alarg̉a

(8) qajjamdyr men \{alaj ajtty\} Adonaj özǵa tüslü tüvül ki nečik sözla-

(9) dijiz ešitüvlarimč́a alaj qylarmen sizǵa. במדבר. [29]

(10) Ošpu midbarda tüš́arlar gövdálarijiz da bar sanalġanla-

(11) ryjyz bar sanlaryjzybyla igirmi jaštan da jog̉arraq anyn

(12) üčün ki küvürd́andijiz üstüma. אם. [30] Eger

(13) siz kelśajiz ol jerǵa ki antettim qudratymdan toḥtat-

(14) ma sizni anda ki ančaq Kalev uvlu Jefunenin da Johošua

(15) uvlu Nunnun. וטפכם [31] Da jašyjyz ki ajttyjyz talavġa

(16) bolur da keltirirmen alarny da bilirlar ošol ol jerni

(17) ki hor ettijiz any. ופגריכם [32] Da gövd́alarijiz siz-

(18) nin özüjüznün tüš́[a]rí[a]r¹ ošpu midbarda. ובניכם. [33]

(19) Da ulanlaryjyz bolurlar jürüvčülar orundan orunġa midbarda

(20) Gyrq jyl kütüvčülar kibik ki toḥtamajdylar bir orunda

(21) da kötürürlar žurumun azmaqlaryjyznyn tüǵanginč́a göv-

$236 v^{0}$ (1) במספר dalarijiz midbarda. [34 Sanybyla ol künlarnin ki čaj-

(2) syladyjyz ošol ol jerni qyrḥkün kün üčün jyl kün üčün jyl

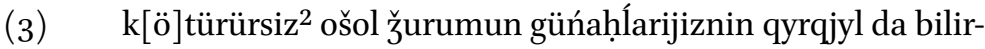

(4) siz ošol tyjuvumnu. אני [35] Men Adonaj sözĺadim özǵa

(5) tüslü tüvül bunu qylarmen bar ol jaman žymatqa ošpu ol

${ }^{1} \mathrm{~K}$ : tüširalir; a scribal error. | TKow.o1: unvocalized text. | H: tiserler.|C: tüšärlär. $\quad{ }^{2} \mathrm{~K}:$ kütürürsiz; a scribal error. | TKow.o1: unvocalized text. | H: ketirisiz. | C: kötärirsiz. 
(19) with him and walked after my order,

(20) I will bring him to the land where he went, and he will

(21) inherit it to his seed. [25] And the Amalekites

(1) and the Canaanites are dwelling in the valley. Turn at daybreak

(2) and get you to the wilderness by the way of the Red sea.'

(3) [26] And the Lord spoke to Moses and to Aaron, saying,

(4) [27] 'How long shall I endure with this evil congregation

(5) which murmurs against me?

(6) I have heard the murmurings of the children of Israel, which they murmur

(7) against me. [28] Say to them:

(8) "I am eternal—so said the Lord—in no other way but as you have spoken

(9) in my ears, so will I do to you. [29]

(10) Your carcasses shall fall in this wilderness; and all those numbered of you,

(11) according to your whole number, from twenty years old and upward,

(12) because you have murmured against me: [30]

(13) $\quad$ [You will not come $]^{1221}$ to the land which I swore by my hand

(14) to make you dwell therein, except Caleb, son of Jephunneh, and Joshua,

(15) son of Nun. [31] But your little ones, whom you said would become a prey:

(16) I will bring them, and they shall know the land

(17) which you have despised. [32] But your carcasses:

(18) they shall fall in this wilderness. [33]

(19) And your children shall walk from place to place in the wilderness

(20) forty years, like shepherds who do not dwell in one place,

(21) and bear the punishment of your wrongs until the end

(1) of your carcasses in the wilderness. [34] After the number of the days $236 \mathrm{v}^{\mathrm{o}}$

(2) that you spied the land, forty days, a day for a year, a day for a year

(3) you will [carry] the punishment of your iniquities, forty years, and you will know

(4) my reprimand. [35] I, the Lord, have spoken,

(5) I will do this—no other thing - to all this evil congregation

221 K: if you come; a mistranslation repeated in a number of manuscripts resulting from literal translation of the Hebrew conditional clause, cf. Gen 14:23, Num 14:23, Num 32:11, Deu 1:35. | TKow.o1: if you come. | H: if you come. | C: if you come. | M: if you come. | E: if you come. | R: if you come. 
(6) jyštyryluvčular alnyma ošpu midbarda tüǵanirlar da

(7) anda ölarlar. [36] Da ol eŕanlar ki ijdi

(8) Moše čajsylama ošol ol jerni da qajttylar da küvür-

(9) danttilar anyn üstüńa ošol bar ol žymatny čyġarma

(10) ajip ol jer üstüńa. וימתו. [37] Da öldülar

(11) ol éranlar čyg̉aruvčular ajipin ol jernin jamanny qyranč

(12) byla alnynda Adonajnyn. ויהושע. [38] Da Johošu'a uvlu

(13) Nunnun da Kalev uvlu Jefunenin tiri qaldylar ol éranlar-

(14) dan ol baruvčulardan čajsylama ošol ol jerni. וידבר. [39]

(15) Da sözladi Moše ošol ol sözlarni ošpularny bar ulanla-

(16) ryna Jisra'elnin da jasly boldular ol ulus astry.

(17) [40] Da tünlaj turdular ertanbylada da min-

(18) dilar bašyna ol tavnyn ajtadoġač muna biz da baryrbiz ol

(19) orunga ki ajtty Adonaj ki jazyqly bolduq. ויאמר. [41]

(20) Da ajtty Moše nekbu siz ašasiz ošol bujruğun Adonaj-

(21) nyn da ol sağyš onmasty. אל. [42] Barmajyz ki joḥtu bo-

$237 \mathrm{r}^{\circ} \quad$ (1) lušluğu Adonajnyn ortajyzda da qyrylmajyz alnynda dušmanlaryjyz-

(2) nyn. [43] Ki ol 'Amaleqi da ol Kena'ani anda

(3) alnyjyzda da tüšarsiz qylyčtan anyn üčün ki kedargi

(4) qajttyjyz saruvu artyndan Adonajnyn da bolmasty bolušluğu

(5) Adonajnyn birǵajizǵa. ויעפלו. [44] Da ökt́amlandilar min-

(6) ma bašyna ol tavnyn da aron šerti Adonajnyn da Moše

(7) qozġalmadylar ortasyndan ol avulnun. וירד. [45] Da

(8) endi ol 'Amaleqi da ol Kena'ani ol olturuvču ol tav-

(9) da da qyrdylar alarny da jančtylar alarny ol Harma ün-

(10) d́áladoġan orunġadejin.

Numbers 15

(11) Mošeǵa ajtadoġač. דבר. [2] Sözĺagin ulanlaryna Jisra’el-

(12) nin da ajtqyn alarg̉a ki kelśajiz jerińa olturušlaryjyznyn 
(6) gathered before me: they shall end in this wilderness, and

(7) they shall die there."' [36] And the men whom Moses sent

(8) to spy the land and returned and made

(9) all the congregation to murmur against him in order to bring up a

(10) slander on the land: [37] And

(11) the men that brought up an evil slander on the land died by the plague

(12) before the Lord. [38] But Joshua, son

(13) of Nun, and Caleb, son of Jephunneh stayed alive out of those men

(14) who went to spy the land. [39]

(15) And Moses told these words to all the children

(16) of Israel, and the people mourned greatly.

(17) [40] And they rose up early at dawn, and went up

(18) to the top of the mountain, saying, 'Lo, we are here, and we will go up

(19) to the place which the Lord has said, because we have sinned.' [41]

(20) And Moses said, 'Why is this that you transgress the command of the Lord?

(21) But this thought will not prosper. [42] Do not go up-because

(1) the Lord's help is not among you-so you will not die before your $237 \mathrm{r}^{\mathrm{o}}$ enemies.

(2) [43] Because the Amalekites and the Canaanites are there

(3) before you, and you shall fall by the sword, because you have turned aside

(4) from the order of the Lord, and the Lord's help will not be

(5) with you.' [44] But they were proud to go up

(6) to the top of the mountain. And the ark, the covenant of the Lord, and Moses

(7) set out from the camp. [45] And

(8) then the Amalekites came down, and the Canaanites who dwelt in that mountain,

(9) and slew them, and beat them, as far as the

(10) place called Hormah.

Numbers 15

[1] And the Lord spoke

(11) to Moses, saying, [2] 'Speak to the children of Israel,

(12) and say to them, "When you will come to the land of your habitations, 
(13) ki men beŕamen sizǵa. ועשיתם. [3] Da qylsajyz otlu qarban

(14) Adonajğa 'ola jemeśa debeḥa ajyrma nijet jemeśa žomart-

(15) lyq byla jemeśa mo'edĺarijizd́a qylma ij qabulluq Adonajġa

(16) ol syġyrdan jemeśa ol qojdan. והקריב [4] Da juvut-

(17) sun ol juvutuvču qarbanyn özünün Adonajğa öźak o-

(18) nunču ülüšün ol efanyn jumurulġan dörtünčü ülüšü

(19) ol hinnin javbyla. ויין [5] Da čag̀yr nesehḱka dör-

(20) tünčü ülüšü ol hinnin qylg̀yn ol 'ola qatyna jemeśa

(21) debehagàa ol bir qozuğa. או [6] Da qočqarga qylġyn

$237 \mathrm{~V}^{\mathrm{ol}}$ (1) tirki öźak eki 'esronlar jumurulġan javbyla üčünčü

(2) ülüšü ol hinnin. ייין [7] Da čaġyr nesehḱka üčünčü

(3) ülüšü ol hinnin juvutqun ij qabulluq Adonajğa. וכי. [8] Da

(4) ki debeḥa etśajiz balasyn syġyrnyn ola jemeśa debeha ajyrma

(5) nijet jemeśa šelamim Adonajg̉a. והקריב. [9] Da juvutsun

(6) balasy qatyna ol syġyrnyn tirki öźak üč 'esronlar jumu-

(7) rulgan javbyla jarymy ol hinnin. ויין [10] Da čaġyr juvut-

(8) qun nesehka jarymy ol hinnin otlu qarban ij qabulluq Adonaj-

(9) gàa. כ11 Bulaj qylynsyn ol bir ögüzǵa jemeśa ol bir

(10) qočqarg̉a jemeśa qojg̉a qozularda jemeśa ečkilard́a.

(11) (12] Sankibik qylsajyz bulaj qylyjyz birǵa sanlary-

(12) na köŕa. כל [13] Bar ol jerli qylsyn bulaj ošol bularny juvut-

(13) ma otlu qarban ij qabulluq Adonajgia. וכי [14] Da ki tiril-

(14) śa birǵajizǵa gaarip jemeśa ki ortajyzda dorlaryjyzsajyn

(15) da qylsa otlu qarban ij qabulluq Adonajgia ki nečik qyl-

(16) sajyz siz alaj olda qylsyn. הקהל. [15] E qahal bir resim

(17) sizǵa da garipǵa ol tirilivčüǵa ömürlü $[\mathrm{k}]^{2}$ resim

(18) dorlaryjyzsajyn nečik siz alaj garip bolsun alnynda Adonajnyn.

(19) תir [16] Bir üvratüv da bir töŕa bolsun sizǵa da

(20) garipǵa ol tirilüvčüǵa birǵajizǵa. וידבר [17 Da

\footnotetext{
${ }^{1}$ The text on this page is not vocalised.
} emirlik. | C: dunjanyy; different wording.

${ }^{2}$ K: ömürlü; a scribal error. | TKow.o1: ömürlük. | H: 
(13) which I am giving to you, [3] And when you will make an offering by fire

(14) to the Lord, a burnt offering, or a sacrifice in dedicating a vow or in a

(15) freewill offering or on your holidays, to make an aroma of acceptance to the Lord,

(16) of the cattle, or of the flock: [4] Then

(17) the one who brings forward his offering to the Lord shall bring forward fine flour,

(18) the tenth part of an ephah, mixed with the fourth part

(19) of a hin of oil. [5] And you shall make wine for a drink offering,

(20) the fourth part of a hin, with the burnt offering or

(21) for sacrifice for one lamb. [6] Or for a ram, you shall make

(1) a grain offering, fine flour, two tenths, mixed with the third

(2) part of a hin of oil. [7] And wine for a drink offering: you shall bring forward the third

(3) part of a hin, an aroma of acceptance to the Lord. [8] And

(4) when you offer the young of cattle for a burnt offering or for a sacrifice in dedicating

(5) a vow or peace offerings to the Lord: [9] Then he shall bring forward

(6) with a young of a cattle a grain offering, fine flour, three tenths, mixed

(7) with half a hin of oil. [10] And you shall bring forward

(8) for a drink offering half a hin of wine, an offering by fire, an aroma of acceptance

(9) to the Lord. [11] Thus shall it be done for one bull or for one

(10) ram or for a lamb of the sheep or for a goat. [12]

(11) According to the number that you will do, so shall you do to |each| one

(12) according to their number. [13] All those from this land shall do these things after this manner, to bring forward

(13) an offering by fire, an aroma of acceptance to the Lord. [14] And if

(14) a stranger lives with you — or the one who is among you - throughout your generations,

(15) and offers an offering by fire, an aroma of acceptance to the Lord: as you do,

(16) so he shall do, too. [15] Oh |you|, community, one statute

(17) is for you and for the stranger that lives |with you|, a statute

(18) throughout your generations: as you are, so shall the stranger be before the Lord.

(19) [16] One teaching and one judgement shall be for you and

(20) for the stranger that lives with you."' [17] And 
(21) sözladi Adonaj Mošeǵa ajtadog̉ač. דבר. [18] Sözĺagin ulan$238 \mathrm{r}^{\mathrm{o}} \quad$ (1) laryna Jisra’elnin da ajtqyn alarg̉a kelǵanijizd́a ol jerǵa ki

(2) men keltiŕamen sizni ary. והיה. [19] Da bolg̉aj ašag̉anyjyzdan bu-

(3) run ötḿagind́an ol jernin ajyryjyz teruma Adonajğa.

(4) -ראשית [20] Ilkin hamurlaryjyznyn hala ajyryjz teruma terumasy

(5) kibik yndyrnyn alaj ajyryjyz any. מראשית. [21] Ilkind́an

(6) hamurlaryjyznyn berijiz Adonajgga teruma dorlaryjy\{z\}sajyn. וכ22]

(7) Da ki janġylsajyz da qylmasajyz ošol bar ol micvalarny

(8) ošpularny ki sözladi Adonaj Mošeǵa. את [23] Ošol

(9) barča neki bujurdu Adonaj sizǵa naviligi ašyra Mošenin

(10) ol künd́an ki bujurdu Adonaj da arraq dorlaryjy\{z\}sajyn. [24]

(11) Da bolġaj eger ag̉araqlaryndan ol žymatnyn qylyndy eśa

(12) janġylyšlyqbyla da qylsynlar bar ol క̌ymat tana balasyn sy-

(13) ġyrnyn birni 'olag̉a ij qabulluqqa Adonajgia da tirkisi

(14) anyn da nesehi kečinmakḱka köŕa da ulag̉yn ečkilar-

(15) nin birni ḥatatqa. וכפר [25] Da bošatlyq qolsun ol

(16) [ [kohen bar $]^{11}$ žymaty üčün ulanlarynyn Jisra’elnin da bošatylyr

(17) alarg̉a ki janġylyšlyqty ol da alar keltirdilar ošol

(18) qarbanlaryn özlarinin otlu qarban Adonajğa da hatatlaryn

(19) özlarinin alnyna Adonajnyn janġylyšlyqlary üčün. ונסלח [26]

(20) Da bošatylyr bar žymatyna ulanlarynyn Jisra’elnin da garipǵa

(21) ol tirilüvčüǵa ortalarynda alarnyn ki bar ol ulusqa

$238 \mathrm{v}^{\mathrm{o}} \quad$ (1) boldu bu jazyq janġylyšlyqbyla. ואם

(2) bolsa janġylyšlyqbyla da juvutsun ečkini jyllyq balasyn ḥatat-

(3) qa. וכפר [28] Da bošatlyq qolsun anyn üčün ol kohen ol žan

(4) üčün ol janġyluvču jazyqly bolġanynda janġylyšlyq byla alnyn-

(5) da Adonajnyn bošatlyq qolma anyn üčün da bošatylyr anar.

(6) האזרח [29] Ol jerli ulanlarynda Jisra’elnin da garipǵa

(7) ol tirilüvčüǵa ortalarynda alarnyn bir üvŕatüv bol-

(8) sun sizǵa qyluvčug̉a janġylyšlyqbyla. והנפש. [30] Da

${ }^{1}$ TKow.o1: kohen bar; unvocalized text. | H: kohen bar. | C: kohen barča. 
(21) the Lord spoke to Moses, saying, [18] 'Speak to the children

(1) of Israel, and say to them, "When you come to the land where

(2) I am bringing you: [19] And it shall be that before you eat

(3) of the bread of the land, you shall dedicate a heave offering to the Lord.

(4) $[20]$ You shall dedicate a cake of the first of your dough as a heave offering. Like a heave offering

(5) of the threshing-floor, so shall you dedicate it. [21] Of the first

(6) of your dough you shall give to the Lord a heave offering throughout your generations. [22]

(7) And if you make a mistake and do not do all these commandments,

(8) which the Lord has spoken to Moses, [23] All

(9) that the Lord has commanded you by the prophecy of Moses,

(10) from the day that the Lord commanded Moses and onward throughout your generations, [24]

(11) Then it shall be that, if it was done by mistake, out of the |sight of $\mid$ the superiors of the congregation,

(12) then the congregation shall do one calf, the young of the cattle,

(13) for a burnt offering, an aroma of acceptance to the Lord, and its grain offering,

(14) and its drink offering, according to the |required| manner, and one kid of the goats

(15) for a sin offering. [25] And [the priest] shall ask for atonement

(16) for all the congregation of the children of Israel, and it shall be forgiven

(17) them, because it is a mistake, and they have brought

(18) their offering, a sacrifice by fire to the Lord, and their sin offering

(19) before the Lord for their mistake. [26]

(20) And it shall be forgiven for all the congregation of the children of Israel and the stranger

(21) who lives among them, because for all the people

(1) the sin was by mistake. [27] And if any soul sins

(2) by mistake, then he shall bring forward a one-year-old goat for a sin offering.

(3) [28] And the priest shall ask for atonement for the soul

(4) that is mistaken, when he sins by mistake before

(5) the Lord, to ask for atonement for him, and it will be forgiven him.

(6) $[29] \mid$ For $\mid$ the native among the children of Israel and for the stranger

(7) who lives among them: there shall be one teaching

(8) for you, for the one doing sins by mistake. [30] But 
(9) ol క̌an ki qylsa küčlü qol byla ol jerl[i]dan ${ }^{1}$ da ol garip-

(10) dan ošol sözün Adonajnyn ol ḥorlajdy da eksilir ol

(11) క̌an ortasyndan ulusunun. כי [31] Ki sözün Adonajnyn ḥor

(12) etti da ošol micvasyn anyn buzdu eksilmáa eksi-

(13) lir ol žan žurumu güńahininin anda. [32] Da edi-

(14) Íar ulanlary Jisra’elnin midbarynda da taptylar kišini čöp-

(15) Íavčünü otunlar ol šabat kününd́a. ויקריבו. [33] Da

(16) juvuttular any ol tabuvčular any čöplavčünü otunlar

(17) Mošeǵa da Aharonġa da bar ol šymatqa. ויניחו [34]

(18) Da qojdular any saqlavda ki hanuz belgirtilmadi nendij ö-

(19) lüm qylynyr anar. יויאמר [35] Da ajtty Adonaj Mošeǵa

(20) ölḿa öltürülsün ol kiši _tašlama [tašlasynlar] ${ }^{12}$ any tašlarbyla

(21) bar ol క̌ymat tyšqartyn avulg̉a. ויציאו [36] Da čyğar-

$239 \mathrm{r}^{\mathrm{o}} \quad$ (1) dylar any bar ol 3̌ymat tyšqartyn avulgaa da tašladylar any

(2) tašlarybyla da öldü ki nečik bujurdu Adonaj Mošeǵa.

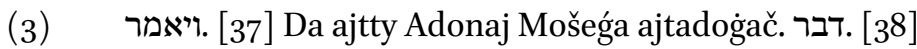

(4) Sözĺagin ulanlaryna Jisra’elnin da ajtqyn alarg̉a da qyl-

(5) synlar özlarińa cicit etakĺari üstüńa upraqlary-

(6) nyn dorlarysajyn da bersinlar cicit qatyna ol etaknin

(7) kök šnur. [39] Da bolsun sizǵa baqmaqqa da

(8) baġyjyz any da saġynyjyz ošol bar micvalaryn Adonajnyn da qy-

(9) lyjyz alarny da qajrylmajyz jüŕagijiz artyna da közĺarijiz

(10) למען. [40] Anyn

(11) üčün ki sag̉ynġajsiz da qylġajsiz ošol bar micvalary[mny $]^{3}$

(12) da bolġajsiz azizlar tenrijizǵa. אני. [41] Menmen Adonaj

(13) Tenrijiz ki čyğardym sizni jerind́an Micrinin bolma siz-

(14) ǵa Tenriǵa menmen Adonaj Tenrijiz.

Numbers 16

פרשת ויקח קרח (15) (15) (15)

(16] Da keńaš aldy Qoraḥ uvlu

(17) Jicharnyn uvlunun Qahatnyn uvlunun Levinin Datan by-

(18) la da Aviram byla uvullary byla Eli’avnyn da On byla

(19) uvlu byla Peletnin uvlunun Ru’uvennin. ויקמו [2] Da

\footnotetext{
${ }^{1} \mathrm{~K}$ : jerlááan; a scribal error. | TKow.o1: unvocalized text. | H: jerliden. | C: jerlidän. $\quad{ }^{2} \mathrm{~K}$ : tašlama; a scribal error; cf., however, C. | TKow.o1: tašlama tašlasynlar; unvocalized text. | H: taslama taslasynlar. | C: tašlama. $\quad{ }^{3} \mathrm{~K}$ : illegible text. | TKow.o1: micvalarymny. | H: micvalarymny. | C: mičvalarymny.
} 
(9) the soul that does anything with a strong hand, |whether he is $\mid$ of the native or of the strangers,

(10) he despises the word of the Lord, and that soul will be cut off

(11) from among his people, [31] Because he has despised the word of the Lord

(12) and has broken his commandment. That soul shall utterly be cut off:

(13) the punishment of his iniquity is on him."' [32] And

(14) the children of Israel were in the wilderness, and they found a man

(15) that gathered wood on the Sabbath day. [33] And

(16) those who found him gathering sticks brought him forward

(17) to Moses and Aaron and to all the congregation. [34]

(18) And they put him under guard, because it was not yet declared what

(19) death should be done to him. [35] And the Lord said to Moses,

(20) 'The man shall be surely put to death. All the congregation [shall] stone him with stones

(21) outside the camp.' [36] And

(1) all the congregation brought him outside the camp and stoned him

(2) with stones, and he died, as the Lord commanded Moses.

(3) [37] And the Lord spoke to Moses, saying, [38]

(4) 'Speak to the children of Israel, and you shall say to them that

(5) they shall make themselves tassels in the edges of their garments

(6) throughout their generations, and that they shall put on the tassel of the edges

(7) a thread of blue. [39] And it shall be to you that you may look on it

(8) and see, and remember all the commandments of the Lord and

(9) do them, and that you shall not turn after your own heart and your own eyes,

(10) after which you go astray: [40] That

(11) you may remember and do all my commandments,

(12) and be holy to your God. [41] I am the Lord

(13) your God, who brought you out from the land of Egypt,

(14) to be God to you. I am the Lord your God.'

Numbers 16

(15) Parashat Korach

(16) [1] And Korah, son

(17) of Izhar, son of Kohath, son of Levi, and Dathan

(18) and Abiram, sons of Eliab, and On,

(19) son of Peleth, sons of Reuben, took an advice: [2] 
$239 \mathrm{v}^{\mathbf{0}} \quad$ (1) turdular alnynda Mošenin da éranlar ulanlaryndan Jisra’el-

(2) nin eki jüz da enli nasila\{ri\} ̧̌ymatnyn ünd́almüšĺari vağdanyn

(3) slavaly el. ויקהלו [3] Da jyštyryldylar Moše üstüńa

(4) da Aharon üstüńa da ajttylar alarg̉a jetar sizǵa

(5) ki bar ol క̌ymat barlary azizlardi da ortalarynda alarnyn

(6) šehinasy Adonajnyn da neüčün ullulanasiz qahaly üstüńa

(7) Adonajnyn. [ישמע. Da ešitti Moše da tüštü jüz-

(8) lo lari üstüńa. Da sözĺadi Qoraḥqa da

(9) bar క̌ymatyna anyn ajtadoġač ertanbylada da bildirir

(10) Adonaj ošol kim ki anyn da ošol ol azizŕakni da juvu-

(11) tur özüńa da ošol kimni ki sajlasa any juvutur

(12) özüńa. זאת [6] Bunu qylyjyz alyjyz özüjüzǵa mač-

(13) marlar Qorah da bar క̌ymaty anyn. ותנו. [7] Da berijiz

(14) alarda ot da qojujuz alar üstüńa tütü alnynda

(15) Adonajnyn tanbyla da bolġaj ol kiši ki sajlasa Adonaj oldu

(16) ol aziz jetarar sizǵa e uvullary Levinin. [8 Da

(17) ajtty Moše Qoraḥqa tynlajyz endi ulanlary Levinin.

(18) [9] Azmodu sizd́an ki ajyrdy Tenrisi Jisra’elnin

(19) sizni క̌ymatyndan Jisra’elnin juvutma sizni özüńa qulluq

(20) etḿa ošol qullug̉un miškannyn Adonajnyn da turma al-

(21) nynda ol žymatnyn jumuš etḿa alar üčün. ויקרב. [10]

$240 \mathrm{r}^{\circ} \quad$ (1) Da juvuttu seni da ošol bar qaryndašlaryjny uvullaryn Levinin

(2) birǵaja da kĺajsiz daġyn kohenliknid́a. לכן. [11] Anyn ü-

(3) čün sen da bar žymatyj ol jyštyryluvčular alnyna Ado\{naj\}nyn

(4) da Aharon nedi ol ki küvürd́ańasiz anyn üstüńa.

(5) וישלח Da ijdi Moše ünd́aḿa Datanny da Aviram-

(6) ny uvullaryn Eliavnyn da ajttylar barmasbiz. המעט [13]

(7) Azmodu ki čyğardyj bizni jerd́an ag̉adoġan süt da bal

(8) öltürḿa bizni midbarda ki ag̉araqlyq étasin üstü-

(9) müzǵa dag̉yn ag̉araqlyq etḿa. אף [14] Ham jerǵa ag̉a-

(10) dogan süt da bal keltirńadij bizni da bermadij bizǵa 
(1) And they rose up before Moses - and

(2) two hundred and fifty men of the children of Israel: princes of the congregation, representatives of the appointed time,

(3) men of renown. [3] And they gathered themselves against Moses

(4) and against Aaron, and said to them, 'It is enough for you

(5) that all the congregation are holy, every one of them, and among them

(6) is the divine Presence of the Lord. And why do you exalt yourself against the assembly

(7) of the Lord?' [4] And Moses heard it, and he fell

(8) on his face: [5] And he spoke to Korah and

(9) to all his congregation, saying, 'At dawn the Lord will make known

(10) who is his and who is more holy, and

(11) he will cause him to come near to him. And he will cause the one he chooses to come near

(12) to him. [6] Do this: Take you censers,

(13) Korah and all his congregation, [7] And put

(14) fire in them, and set incense on them before

(15) the Lord at daybreak. And it shall be that the man whom the Lord will chose,

(16) he will be holy. You have enough, oh sons of Levi.' [8] And

(17) Moses said to Korah, 'Hear, now, you, sons of Levi:

(18) [9] Is it too small |a thing| to you that the God of Israel has separated

(19) you from the congregation of Israel, to bring you near to himself to do the service

(20) of the tabernacle of the Lord, and to stand

(21) before the congregation to minister to them? [10]

(1) And he has brought you near to him, and all your brothers the sons of $240 \mathrm{r}^{\mathrm{o}}$ Levi

(2) with you. And you want the priesthood as well? [11] Therefore

(3) you and all the congregation who are gathering are against the Lord!

(4) And what is Aaron that you murmur against him?'

(5) [12] And Moses sent to call Dathan and Abiram,

(6) sons of Eliab, and they said, 'We will not go. [13]

(7) Is it $|\mathrm{a}|$ small $\mid$ thing $\mid$ that you have brought us out from a land flowing |with| milk and honey

(8) to kill us in the wilderness, that you lord it over

(9) us as well, to lord it over? [14] Moreover

(10) you have not brought us to a land flowing |with| milk and honey, and you have not given us 
(11) ülüšün tüznün da borlalyqnyn közĺarinmo ol eŕanlar-

(12) nin alarnyn čygaryrsen baralmasbiz ol jerǵa bag̉atyrlyġy sartyn

(13) ol 'Anaqlylarnyn. ויחר] Da ačuv boldu Mošeǵa astry

(14) da ajtty Adonajgia qajyrylmaġyn tirkisińa alarnyn bir

(15) eš́akta jükḱa almadym alardan ani jamanlyq qylmadym

(16) birisińad́a alardan. יויאמר Da ajtty Moše Qoraḥqa

(17) sen da bar žymatyj bolujuz alnynda Adonajnyn sen da alar da

(18) Aharon tanbyla. וקחו [17] Da alyjyz kiši mačmaryn da berijiz

(19) alar üstüńa tütü da juvutujuz alnyna Adonajnyn kiši

(20) mačmaryn özünün eki jüz enli mačma $\{r\} l a r$ da sen da Aharon

(21) kiši mačmaryn. ויקחו. [18] Da aldylar kiši mačmaryn da

$240 v^{0}$ (1) berdilar alar üstüńa ot da qojdular alar üstü-

(2) ńa tütü da turdular ešigind́a ohel mo'ednin da Moše

(3) da Aharon. [19] Da jyštyrdy alar üstüńa Qorah

(4) ošol bar ol క̌ymatny ešigińa ohel mo'ednin da aškara

(5) boldu šehinasy Adonajnyn bar ol క̌ymatqa. וידבר [20] Da

(6) sözladi Adonaj Mošeǵa da Aharonġa ajtadoġač. הבדלו [21]

(7) Ajyrylyjyz ortasyndan ol క̌ymatnyn ošpunun da tavusajym

(8) alarny bir köz jumčug̉unda takli. ויפלו [22] Da

(9) tüštülar jüzlari üstüńa da ajttylar e Tenri

(10) Tenrisi bar ol žanlarnyn žanlarynyn bar tennin ol bir

(11) kiši jazyqly bolsa da bar ol žymat üstüńamo ačuvla-

(12) nyrsen. וידבר [23] Da sözĺadi Adonaj Mošeǵa ajtadog̉ač.

(13) דבר (24) Sözlagin ol žymatqa ajtadog̉ač ketijiz čüvŕad́an

(14) toḥtar ornundan Qorahnnyn Datannyn da Aviramnyn. [25]

(15) Da turdu Moše da bardy Datanġa da Aviramġa da

(16) bardylar anyn artyna qartlary Jisra’elnin. וידבר . 26] Da

(17) sözladi ol క̌ymatqa ajtadoġač ketijiz endi čatyrlary

(18) qatyndan ol raša éranlarnin ošpularnyn da tijḿajiz bary-

(19) na neki alarnyn mag̉at taspolursiz bar jazyqlary üčün alar-

(20) nyn. ויעלו. [27] Da kettilar toḥtar ornu qatyndan Qorahnnyn

(21) Datannyn da Aviramnyn čüvŕad́an da Datan da Aviram čyqty- 
(11) the portion of fields and vineyards. Will you put out the eyes of these men?

(12) We will not be able to go to that land because of the heroism

(13) of the Anakites.' [15] And Moses was very angry,

(14) and he said to the Lord, 'Do not turn to their grain offering. Not

(15) one donkey have I taken from them for the burden, and I have not done evil

(16) to any of them.' [16] And Moses said to Korah,

(17) 'Be you and all your congregation before the Lord, you, and they, and

(18) Aaron, at dawn. [17] And take every man his censer, and put

(19) incense on them, and bring before the Lord each man

(20) his censer, two hundred and fifty censers, and you and Aaron,

(21) each man his censer.' [18] And each man took his censer, and

(1) put fire on them and laid incense on them,

(2) and stood in the door of the tent of meeting, and Moses

(3) and Aaron. [19] And Korah gathered all the congregation against them

(4) to the door of the tent of meeting, and

(5) the divine Presence of the Lord appeared to all the congregation. [20] And

(6) the Lord spoke to Moses and to Aaron, saying, [21]

(7) 'Separate yourselves from among this congregation, that I may consume

(8) them ${ }_{L}$ in the blink of an eye ${ }^{1222}$ '. [22] And

(9) they fell on their faces, and said, 'Oh God,

(10) the God of the spirits, of the spirits of all flesh, will one

(11) man sin, and will you be angry at all the congregation?'

(12) [23] And the Lord spoke to Moses, saying,

(13) [24] Speak to the congregation, saying, 'Get away from around

(14) the dwelling places of Korah, Dathan, and Abiram.' [25]

(15) And Moses rose up and went to Dathan and Abiram, and

(16) the elders of Israel followed him. [26] And

(17) he spoke to the congregation, saying, 'Get away, now,

(18) from the tents of these wicked men, and do not touch anything

(19) that is theirs, lest you be destroyed by all their sins.'

(20) [27] So they got away from the dwelling places of Korah,

(21) Dathan, and Abiram, all around. And Dathan and Abiram came out,

222 I.e., in an instant. 
$241 \mathrm{r}^{\circ} \quad$ (1) lar turaredilar ešigind́a čatyrlarynyn da qatynlary alarnyn

(2) da uvullary da jašlary alarnyn. ויאמר [28 Da ajtty

(3) Moše bunun byla bilirsiz ki Adonaj ijdi meni qylma o-

(4) šol bar ol išlarni ošpularny ki tüvüldü öz kölnüm-

(5) dan. [2] Eger ölḿagi kibik har adamnyn ölśa-

(6) ĺar bular da vakilligi har adamnyn vakillanśa alar üs-

(7) tüńa Adonaj ijmadi meni. [30] Da eger janġy

(8) nerśa janġyrtsa Adonaj da ačsa ol jer ošol av-

(9) zun da jutsa alarny da ošol barča neki alarnyn da en-

(10) śalar tirilaj görǵa da bilirsiz ki ačyrg̉andyrdylar

(11) ol éanlar \{ošpu[lar] $\}^{1}$ ošol Adonajny. [31] Da edi tüğalĺa-

(12) ǵanind́ačoq sözlááa ošol bar ol sözlarni ošpularny

(13) da jarčyqlandy ol jer ki alar tübüńa. ותפתח. [32]

(14) Da ačty ol jer ošol avzun da juttu alarny da ošol

(15) elin üvlarinin da ošol bar ol adamny ki Qoraḥnyn

(16) da ošol bar ol malny. [ירדו [33] Da endilar

(17) alar da barča neki alarnyn tiríaj görǵa da qaplady

(18) alar üstüńa ol jer da taspoldular ortasyndan

(19) \{ol\} qahalnyn. וכל [34] Da bar Jisra’el ki čüvŕalarind́a alar-

(20) nyn qačtylar avazlaryndan alarnyn ki ajttylar maġat jutar

(21) biznida ol jer. ואש. [35] Da ot čyqty alnyndan

$241 \mathrm{v}^{\mathrm{o}} \quad$ (1) Adonajnyn da ört́adi ošol eki jüz ol enli kišini juvutuv-

(2) čularny ol tütünü.

Numbers 17

וידבר [1] Da sözĺadi Adonaj Mošeǵa

(3) ajtadoġač. אמר. [2] Ajtqyn El'azarg̉a uvluna Aharonnun

(4) ol kohennin da ajyrsyn ošol ol mačmarlarny arasyndan ol

(5) küvḿaknin da ošol ol otnu bürkkün arraq ki aziz boldu-

(6) lar. [3] Ošol mačmarlaryn ol jazyqlylarnyn ošpularnyn žan-

(7) larybyla da qylsynlar alardan jugga blaḥalar qaplav mizbeaḥqa ki

(8) juvuttular $\{[\mathrm{ala}] \mathrm{rny}\}^{2}$ alnyna Adonajnyn da aziz boldular da bolsunlar belgi-

(9) ga ulanlaryna Jisra’elnin. [4] Da aldy El'azar ol kohen

(10) ošol ol tuč mačmarlarny ki juvuttular ol küvǵanlar da ju-

\footnotetext{
${ }^{1}$ TKow.o1: deest. | H: ospular. | C: ušbu. ${ }^{2}$ TKow.o1: deest. | H: alarny. | C: alarny.
} 
(1) stood in the door of their tents, and their wives, $241 \mathrm{r}^{\mathrm{o}}$

(2) and their sons, and their little ones. [28] And Moses said,

(3) 'Hereby you shall know that the Lord has sent me to do

(4) all these works, for I have not done them from my own heart.

(5) [29] If these men die as all men die,

(6) or if they be cared after with the care of all men,

(7) then the Lord has not sent me. [30] But if

(8) the Lord makes a new thing, and the earth opens its mouth,

(9) and swallows them up with all that belongs to them, and

(10) they go down alive to the deep grave, then you shall know that

(11) these men have made the Lord angry.' [31] And it was

(12) as he was finishing speaking all these words,

(13) and the ground that was under them broke up, [32]

(14) And the earth opened its mouth and swallowed them and

(15) their households and all the men that belonged to Korah

(16) and all their goods. [33] And they went down,

(17) they and all that they had, alive to the deep grave. And

(18) the earth covered them over, and they perished from among

(19) the assembly. [34] And all Israel that were all around them

(20) fled at the cry of them, for they said, 'Lest the earth swallow

(21) us up also.' [35] And there came out a fire from before

(1) the Lord, and consumed the two hundred and fifty men that brought $241 \mathrm{v}^{\mathrm{o}}$ forward

(2) incense.

Numbers 17

(2) [1] And the Lord spoke to Moses,

(3) saying, [2] 'Speak to Eleazar, son of Aaron,

(4) the priest, that he shall separate the censers out of the

(5) blaze and sprinkle the fire |some distance| away, because they have become holy.

(6) [3] The censers of these sinners by their souls:

(7) and they shall make of them flat metal sheets for a covering of the altar, because

(8) they brought them forward before the Lord, and they became holy, and they shall be a sign

(9) to the children of Israel.' [4] And Eleazar, the priest, took

(10) the bronze censers that those who were burned had brought forward, and 
(11) ġarttylar alarny qylma qaplav mizbeaḥqa. זכרון. [5] Sag̉ynčlyq

(12) ulanlaryna Jisra’elnin anyn üčün ki juvumaġaj jat kiši ki tüvüldü

(13) urlugundan Aharonnun ol tütatma tütü alnynda Adonajnyn

(14) da ki bolmag̉aj Qorah kibik da 3̌ymaty kibik anyn ki nečik söz-

(15) ĺadi Adonaj naviligi ašyra Mošenin anar. וילנו. [6] Da

(16) küvürd́andiliar bar žymaty ulanlarynyn Jisra’elnin tanbyladan Moše

(17) üstüńa da Aharon üstüńa ajtadoġač siz öltürdü-

(18) jüz ošol ulusun Adonajnyn. ויהי [7] Da edi jyštyrylġanda

(19) ol žymat Moše üstüńa da Aharon üstüńa da qajyryldylar

(20) ohel mocedǵa da muna qaplady any ol bulut da aškara boldu

(21) Šehinasy Adonajnyn. ויבא [8] Da keldi Moše da Aharon alny-

$242 \mathrm{r}^{\circ}$ (1) וידבר. [9] Da ohel mo'edninzladi Adonaj Mošeǵa aj-

(2) tadoġač. הרמו. [10] Kötürülüjüz ortasyndan ol క̌ymatnyn

(3) ošpunun da tavusajym alarny köz jumčug̉unda takli da

(4) tüštülar jüzlari üstüńa. [11] Da ajtty Moše

(5) Aharonġa alġyn ošol ol mačmarny da bergin anyn üs-

(6) tüńa ot ol mizbeah üstünd́an da qojg̉un tütü da

(7) eltkin tez ol క̌ymatqa da bošatlyq qolg̀un alar üčün

(8) ki čyqty ol ačuv alnyndan Adonajnyn bašlandy ol qyranč.

(9) ויקח Da aldy Aharon ki nečik sözladi Moše da juvur-

(10) du ortasyna ol qahalnyn da muna bašlady ol qyranč

(11) ulusta da berdi ošol tütünü da bošatlyq qoldu

(12) ol ulus üčün. יעמד [13] Da turdu arasynda ol

(13) ölülarnin da arasynda ol tiríarnin da qaldy ol qyranč.

(14) Da edilar ol ölǵanlar qurančbyla ondört

(15) min da jedi jüz bašqa ol ölǵanlard́an iši üčün Qoraḥnyn.

(16) (15] Da qajtty Aharon Mošeǵa ešigińa ohel mo'ed-

(17) nin nečik ol qyranč qaldy. וידבר [16] Da sözladi Adonaj

(18) Mošeǵa ajtadog̉ač. דבר. [17] Sözlagin ulanlaryna Jisra-

(19) 'elnin da alġyn alardan biŕar tajaq üvüsajyn atanyn bar nasi- 
(11) they flattened them to do a covering for the altar: [5] A memorial

(12) to the children of Israel, so that no outsider, who is not

(13) of the offspring of Aaron, shall come near to burn incense before the Lord,

(14) and so he shall not be like Korah and as his congregation, as the Lord said

(15) to him by the prophecy of Moses. [6] And

(16) all the congregation of the children of Israel murmured after daybreak against Moses

(17) and against Aaron, saying, 'You have killed

(18) the people of the Lord.' [7] And it was, when the congregation was gathered

(19) against Moses and against Aaron that they turned

(20) toward the tent of meeting, and, lo, the cloud covered it, and the

(21) divine Presence of the Lord appeared. [8] And Moses and Aaron came

(1) before the tent of meeting. [9] And the Lord spoke to Moses,

(2) saying, [10] 'Get away from among this congregation,

(3) that I may consume them ${ }_{L}$ in the blink of an eye ${ }^{1223}$ '. And

(4) they fell on their faces. [11] And Moses said

(5) to Aaron, "Take a censer and put fire on it

(6) from off the altar and put on incense and

(7) carry it quickly to the congregation and ask for atonement for them,

(8) because there is anger gone out from before the Lord. The plague has begun.'

(9) [12] And Aaron took as Moses said, and ran

(10) into the midst of the assembly, and, lo, the plague had begun

(11) among the people. And he put on incense and asked for atonement

(12) for the people. [13] And he stood between

(13) the dead and the living, and the plague ceased.

(14) [14] And the dead in the plague were fourteen

(15) thousand and seven hundred, apart from the dead over the matter of Korah.

(16) [15] And Aaron returned to Moses to the door of the tent of meeting,

(17) when the plague ceased. [16] And the Lord spoke

(18) to Moses, saying, [17] 'Speak to the children of Israel,

(19) and take from them a staff, one for each of the house of their fathers, from all their princes

223 I.e., in an instant. 
(20) ĺarind́an alarnyn üvüsajyn atalarynyn on eki tajaqlar kišinin

(21) ošol atyn jazġyn tajag̉y üstüńa anyn. ואת [18] Da ošol

$242 \mathrm{v}^{\mathrm{o}} \quad$ (1) atyn Aharonnun jazg்yn tajaġy üstüńa Levinin ki bir tajaqty

(2) ag̉araġ $\{y n\} a$ üvünün atalarynyn. [19] Da qojg̉un

(3) alarny ohel mo'edd́a alnynda ol šarajatnyn ki hadirdi

(4) šehinam aškara bolma anda sizǵa. והיה. [20] Da

(5) bolġaj ol kiši ki sajlasa $[\mathrm{m}]^{1}$ any tajag̉y anyn jašaryr da

(6) japyryrmen özümd́an küvürdanḿaklarin ulanlarynyn Jis-

(7) ra’elnin ki alar küvürd́ańadilar üstüjüzǵa.

(8) וידבר (21] Da sözladi Moše ulanlaryna Jisra’elnin da

(9) berdilar anar bar nasilari Jisra’elnin biŕar tajaq nasi-

(10) dan biŕar tajaq nasidan üvüsajyn atalarynyn on eki

(11) tajaqlar da tajaġy Aharonnun ortasynda tajaqlarynyn alarnyn.

(12) יוינח Da qojdu Moše ošol ol tajaqlarny alnynda Adonaj-

(13) nyn čatyrynda ol šarajatnyn. [יהי [23] Da edi tanbyladan

(14) da keldi Moše čatyryna ol šarajatnyn da muna jašardy

(15) tajag̉y Aharonnun üvüsajyn Levinin da čyġardy japraq da

(16) čečakĺadi čeč́akḱa da östürdü badamlar. ויצא [24] Da

(17) čyğardy Moše ošol bar ol tajaqlarny alnyndan Adonajnyn bar

(18) ulanlaryna Jisra'elnin da kördülar da aldylar har kiši

(19) tajaġyn özünün. [25] Da ajtty Adonaj Mošeǵa

(20) qajtarğyn ošol tajaġyn Aharonnun alnyna ol šarajatnyn saqlav-

(21) ga tanuvču el üčün da tügallíagin küvürdanmáaklarin

$243 \mathrm{r}^{\mathrm{r}}$ (1) alarnyn mend́an da ölḿasinlar. ויעש [26] Da qyldy Moše

(2) ki nečik bujurdu anar Adonaj alaj qyldy. ויאמרו [27] Da

(3) ajttylar ulanlary Jisra’elnin Mošeǵa ajtadog̉ač muna

(4) tyndyq taspolduq barlarymyz taspolduq. כל. [28] Bar ol

(5) juvuvču ol juvuq kelüvčü miškanyna Adonajnyn öladi

(6) kertidanmo tüǵandik tynma.

Numbers 18

ויאמר [1] Da ajtty

(7) Adonaj Aharonga sen da uvullaryj da üvü atajnyn bir-

(8) ǵaja kötürüjüz ošol žurumun güńahinin ol miqdaš-

(9) nyn da sen da uvullaryj birǵaja kötürüjüz ošol క̌uru-

${ }^{1} \mathrm{~K}$ : sajlasa; a scribal error. | TKow.o1: sajlasam; unvocalized text. | H: sajlasam. | C: sajlasam. 
(20) by the house of their fathers, twelve staffs.

(21) You shall write each man's name on his staff. [18] And

(1) you shall write Aaron's name on the staff of Levi, because there is one $242 \mathrm{v}^{\mathrm{o}}$ staff

(2) for the superior of the house of their fathers. [19] And you shall place

(3) them in the tent of meeting before the testimony, because my

(4) divine Presence is ready to appear there to you. [20] And

(5) it shall be: the man [I] shall choose-his staff will blossom. And

(6) I will suppress from me the murmurings of the children of Israel,

(7) which they murmur against you.'

(8) [21] And Moses spoke to the children of Israel, and

(9) all of their princes gave him a staff, for each prince one,

(10) for each prince one, by their fathers' house, twelve

(11) staffs, and the staff of Aaron was among their staffs.

(12) [22] And Moses placed the staffs before the Lord

(13) in the tent of law. [23] And it was after daybreak,

(14) and Moses came to the tent of law, and, lo,

(15) the staff of Aaron for the house of Levi blossomed and brought out a leaf and

(16) and bloomed flowers, and yielded almonds. [24] And

(17) Moses brought out all the staffs from before the Lord

(18) to all the children of Israel, and they looked, and took every man

(19) his own staff. [25] And the Lord said to Moses,

(20) 'Bring Aaron's staff back before the law,

(21) to be kept for the rebellious people, and you shall end their murmurings

(1) against me, so they would not die.' [26] And Moses did

(2) so as the Lord commanded him, he did so. [27] And

(3) the children of Israel spoke to Moses, saying, 'Lo,

(4) we died, we perished, we all perished. [28] Everyone

(5) who comes near to the tabernacle of the Lord dies.

(6) Have we indeed come to the end of dying?'

Numbers 18

(7) the Lord said to Aaron, 'You and your sons and your father's house

(8) with you shall bear the punishment of the iniquity of the sanctuary,

(9) and you and your sons with you shall bear the punishment 
(10) mun güńahininin kohenligijiznin. וגם [2] Da daġyn ošol qaryn-

(11) dašlaryjny ševetin Levinin ševetin atajnyn juvutqun birǵaja

(12) da qošulsunlar qatyja da jumuš etsinlar saja da sen

(13) da uvullaryj birǵaja alnynda čatyrynyn ol šarajatnyn.

(34) Da saqlasynlar saqlavujnu da saqlavyn bar

(15) ol čatyrnyn tek \{savutlaryna\} ol qodešnin da ol mizbeahqua juvuma-

(16) synlar da ölḿasinlar daġyn alar daġyn sizd́a. ונלוו [4]

(17) Da qošulsunlar qatyja da saqlasynlar ošol saqlavun ohel

(18) mo'ednin bar qulluguusajyn ol čatyrnyn da jat juvumasyn siz-

(19) ǵa. ga [5] Da saqlajyz ošol saqlavun ol qodešnin

(20) da ošol saqlavun ol mizbeaḥnyn da bolmasyn artyq ačuv

(21) ulanlary üstüńa Jisra’elnin. ואני [6] Da \{men $\}$ muna aldym

$243 \mathrm{v}^{\mathrm{o}} \quad$ (1) ošol qaryndašlaryjyzny ol Levilílarni ortasyndan ulanlarynyn

(2) Jisra’elnin sizǵa berma berilmüšlar Adonajg̉a qulluq

(3) etḿa ošol qullug̉un ohel mo'edd́a. ואתה. [7] Da

(4) sen da uvullaryj birǵaja saqlajyz ošol kohenligijizni bar iši-

(5) sajyn ol mizbeaḥnyn da ičkartin parohetḱa da qulluq

(6) etijiz berńa qullug̉u berdim ošol kohenligijizni da ol

(7) jat ol juvuvču öltürülsün. [8] Da sözladi

(8) Adonaj Aharonga da men \{muna\} berdim saja ošol saqlavun teru-

(9) malarymnyn bar qodešlarisajyn ulanlarynyn Jisra’elnin saja

(10) berdim alarny jaġynmaqqa da uvullaryja ömürlük

(11) resimǵa. זה [9] Bu bolsun saja qodešind́an ol qadašim-

(12) nin ol ottan bar qarbanlarysajyn bar tirkilarisajyn da bar

(13) hatatlarysajyn da bar ašamlarysajyn ki qajtarsalar maja

(14) qodeš qadašimdi saja ol da uvullaryja. בקדש. [10]

(15) Qodeš ol qadašimd́a ašağyn any bar erḱkak ašasyn any

(16) qodeš bolsun saja. וזה [11] Da budu saja terumasy

(17) berńalar\{i\}nin bar tenufalarysajyn ulanlarynyn Jisra’elnin saja

(18) berdim alarny da uvullaryja da qyzlaryja birǵaja ömür-

(19) lük resimǵa bar aruv kiši üvüjda ašasyn any.

(20) כל [12] Bar javyn sajnyn da bar javyn šarbetnin da bürtük- 
(10) of the iniquity of your priesthood. [2] And bring forward your brothers,

(11) the tribe of Levi, the tribe of your father, with you as well,

(12) and they shall be joined to you and minister to you, and you

(13) and your sons with you |shall minister| before the tent of law.

(14) [3] And they shall keep your charge and the charge of all

(15) the tent, but they shall not come near the vessels of the Holy and the altar,

(16) so they will not die, both they and you. [4]

(17) And they shall be joined to you and keep the charge of the tent

(18) of meeting, for all the service of the tent, and an outsider shall not come near

(19) to you. [5] And you shall keep the charge of the Holy

(20) and the charge of the altar, so there will not be anger any more

(21) on the children of Israel. [6] And I, lo, I have taken

(1) your brothers, the Levites, from among the children

(2) of Israel, to give them as a gift to you for the Lord, to do the service

(3) in the tent of meeting. [7] And

(4) you and your sons with you shall keep your priesthood

(5) for everything at the altar, and within the veil, and you shall

(6) serve: I have given your priesthood to you as a gift for service. And the

(7) outsider that comes near shall be put to death.' [8] And

(8) the Lord spoke to Aaron, 'And I, lo, have given you the charge

(9) of my heave offerings of all the holies of the children of Israel.

(10) I have given them to you as an anointing, and to your sons, as an eternal

(11) statute. [9] This shall be yours of the holy of holies,

(12) from the fire: every offering of theirs, every grain offering of theirs, and every

(13) sin offering of theirs, and every guilt offering of theirs, which they shall pay back to me.

(14) It is holy of holies for you and for your sons. [10]

(15) In the holy of holies you shall eat it. Every male shall eat it.

(16) It shall be holy to you. [11] And this is yours: the heave offering

(17) of their gifts, with all the wave offerings of the children of Israel.

(18) I have given them to you and to your sons and to your daughters with you,

(19) as an eternal statute. Everyone who is clean in your house shall eat it.

(20) [12] All the oil of the olive oil, and all the oil of the must and of the grain, 
(21) nün ilkĺarin alarnyn ki berśalar Adonajg̉a saja berdim

$244 \mathrm{r}^{\circ}$ (1) בכורי. [13] Bikurlaryn bar nerśálarnin ki jerlarind́a

(2) ki keltirśálar Adonajg̉a saja bolsun bar aruv kiši ü-

(3) vüjd́a ašasyn any. כל [14] Bar herem etilǵan Jisra'el-

(4) da saja bolsun. כל [15] Bar ačylmaġy qursaġynyn bar ten-

(5) nin ki juvutsalar Adonajgia adamda $\{d a\}^{1}$ tuvarda bolsun saja

(6) tek juluvun alma juluvun alġyn tunġučunun ol adamnyn da

(7) ošol tunġučunun ol murdar tuvarnyn juluvun alġyn.

(8) (16) Da juluvlary anyn aj jaštan juluvun alğyn

(9) qyjasyj byla kümüš beš mitqallar mitqaly byla ol qodeš-

(10) nin igirmi gögdü ol. אד. [17] Tek tunġučunun

(11) ögüznün jemeśa tunġučunun qozunun jemeśa tunġuču-

(12) nun ečkinin juluvun almaġyn azizdi alar ošol qanlaryn

(13) alarnyn bürkkün ol mizbeah üstüńa da ošol javlaryn

(14) alarnyn tütatkin otlu qarban ij qabulluq Adonajġa.

(15) Da etĺari alarnyn bolsun saja töšü kibik

(16) ol tenufanyn da ol on jandaġy inčik kibik saja bo-

(17) Isun. [19] Bar terumalaryn ol qadašimnin ki ajyrsalar

(18) ulanlary Jisra’elnin Adonajgia berdim saja da uvullaryja

(19) da qyzlaryja birǵaja ömürlük resimǵa ömürlük

(20) kesilǵan šertti ol alnynda Adonajnyn saja da urluğu-

(21) ja birǵaja. [20] Da ajtty Adonaj Aharonġa jer-

$244 \mathrm{~V}^{\circ} \quad$ (1) ĺarind́a alarnyn ülüš almaġyn da tijiš bolmasyn saja

(2) ortalarynda alarnyn menmen ülüšüj da tijišij senin or-

(3) tasynda ulanlarynyn Jisra'elnin. ולבני (21] Da ulanlaryna Levinin

(4) muna berdim bar ončany Jisra’eld́a ülüšḱa jalyn qulluq-

(5) larynyn ki alar qulluq etadilar ošol qullugiun ohel mo'ed-

(6) nin. ולא [22] Da juvumasynlar artyq ulanlary Jisra’elnin

(7) ohel mo'edǵa kötürḿa žurumun jazyqnyn ölḿa.

(8) (23] Da qulluq etsin ol Levili özü ošol qullug̉un

(9) ohel mo`ednin da alar kötürsünĺar šurumun güńạ̣larinin

\footnotetext{
${ }^{1}$ Marginal insertion by another hand. | TKow.o1: $d a$; unvocalized text. | H: $d a$. | C: $d a$.
} 
(21) the firstfruits of them which they shall give to the Lord, I have given

(1) them to you. [13] And the firstfruits of all that is in their land

(2) which they will bring to the Lord, shall be yours. Everyone who is clean

(3) in your house shall eat it. [14] Everything devoted in Israel

(4) shall be yours. [15] Every opening of the womb of all flesh

(5) which they bring forward to the Lord, both among men $\{$ and $\}$ animals, shall be yours.

(6) Just: you shall surely redeem the firstborn of man, and

(7) you shall redeem the firstborn of unclean animals.

(8) [16] And those that are to be redeemed from a month old you shall redeem

(9) according to your valuation, five mithqals of silver according to the mithqal of the Holy:

(10) it is twenty gögs. [17] Just: you shall not redeem the firstborn

(11) of a cattle or the firstborn of a sheep or the

(12) firstborn of a goat. They are holy.

(13) You shall sprinkle their blood on the altar, and

(14) you shall burn their fat for an offering by fire, an aroma of acceptance to the Lord.

(15) [18] And their meat shall be yours, like the breast

(16) of the wave offering and like the right thigh it shall be yours.

(17) [19] All the heave offerings of the holy things which

(18) the children of Israel devote to the Lord I have given to you and to your sons

(19) and to your daughters with you, an eternal statute:

(20) it is a covenant made forever before the Lord to you and

(21) to your offspring with you.' [20] And the Lord said to Aaron,

(1) 'You shall take no portion in their land, and there shall be no share

(2) for you among them. I am your portion and your share

(3) among the children of Israel. [21] And to the children of Levi,

(4) lo, I have given every tenth in Israel for a portion, a reward for their service

(5) which they serve, the service of the tent of meeting.

(6) [22] And the children of Israel shall not come near

(7) the tent of meeting anymore, so as to bear the punishment of sin and die.

(8) [23] But the Levites shall do the service

(9) of the tent of meeting, and they shall bear the punishment of their iniquity, 
(10) ömürlük resim dorlaryjyzsajyn da ortasynda ulanlary-

(11) nyn Jisra’elnin ülüš almasynlar ülüš. \{כ. [24] Ki ošol ončasyn ulanlarynyn Jisra’elnin ki ajyrsalar Adonajğa teruma berdim [Levililarǵa] ${ }^{1}$ ülüška anyn üčün ajttym alarg̉a ortasynda ulanlarynyn Jisra’elnin ülüš almasynlar [ülüšs]

(12) sözĺadi Adonaj Mošeǵa ajtadog̉ač. ואל [26] Da ol

(13) Levilíarǵa sözlagin \{da\} ajtqyn alarg̉a ki alsajyz ulanlaryn-

(14) dan Jisra'elnin ošol ol ončany ki berdim sizǵa alardan

(15) ülüšüjüzd́a da ajyryjyz andan terumasyn Adonajnyn on-

(16) ča ol ončadan. [27 Da sağyšlanyr sizǵa teruma-

(17) jyz bürtük kibik ol yndyrdan da čaġyr kibik ol

(18) čaġyrbentt́an. כ2. [28] Alaj ajyryjyz daġyn sizd́a terumasyn

(19) Adonajnyn bar ončalaryjyzdan ki alsajyz ulanlaryndan Jisra’elnin

(20) da berijiz andan ošol terumasyn Adonajnyn Aharonġa

(21) ol kohenǵa. מכל [29] Bar berńalarijizdan ajyryjyz ošol

$245 \mathrm{r}^{\mathrm{o}} \quad$ (1) bar terumasyn Adonajnyn bar javyndan ošol azizŕagin anyn \{andan\}.

(2) ואמרת [30] Da ajtqyn alarg̉a ajyrg̉anyjyzda ošol javyn

(3) anyn andan da sag̉yšlanyr Levilílarǵa bitiši kibik yndyr-

(4) nyn da bitiši kibik čag̉yrbentnin. [ואכלתם. [31] Da ašajyz

(5) any bar orunda siz da eli üvüjüznün ki jaldy ol

(6) sizǵa jaly qullug̉ujuznun ohel mo'edd́a. ולא [32] Da

(7) kötürmajiz anyn üčün žurumun jazyqnyn ajyrġanyjyzda o-

(8) šol javyn anyn andan da ošol qodešlarin ulanlarynyn Jisra’el-

(9) nin jengil etḿajiz da ölḿajiz.

Numbers 19

פרשת חקת התורה (10) (10)

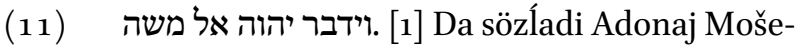

(12) ǵa da Aharonġa ajtadoġač. זאת. [2]

(13) Budur resimi ol Toranyn ki bujurdu Adonaj ajtadoġač

(14) sözĺagin ulanlaryna Jisra’elnin da alsynlar saja qyzyl

${ }^{1}$ TKow.o1: Levililerge; unvocalized text. | H: Levililerge. | C: Levilärgä. $\quad{ }^{2}$ TKow.o1: ülüš; unvocalized text. | H: ilis. | C: ̈̈lüš. 
(10) it is an eternal statute throughout your generations. And they shall not take a part among the children

(11) of Israel: [24] Because I have given to [the Levites] the tithes of the children of Israel which they dedicated as a heave offering to the Lord as a portion. On account of this I have said to them: they shall take no portion among the children of Israel.' [25] And

(12) the Lord spoke to Moses, saying, [26] 'And speak

(13) to the Levites and say to them, "When you take from the children

(14) of Israel the tithes which I have given you from them

(15) for your portion, then you shall dedicate of it a heave offering of the Lord,

(16) a tithe of the tithe. [27] And your heave offering shall be reckoned to you,

(17) like grain from the threshing-floor and like wine from the

(18) wine press. [28] Thus you also shall dedicate, you too, a heave offering

(19) of the Lord of all your tithes which you take from the children of Israel.

(20) And you shall give the Lord's heave offering from it to Aaron,

(21) the priest. [29] From all your gifts you shall separate

(1) every heave offering of the Lord, from all of the oil of its holier part." $245 \mathrm{r}^{\mathrm{o}}$

(2) [30] And you shall say to them, "When you have separated its oil

(3) from it, then it shall be reckoned to the Levites like the crop

(4) of the threshing-floor and like the crop of the wine press. [31] And you shall eat

(5) it in every place, you and your households, for it is a reward

(6) for you, a reward for your service in the tent of meeting. [32] And

(7) you shall bear no punishment for a sin when you have separated

(8) from it the oil of it. And you shall not defile the holy things of the children

(9) of Israel, and you will not die."'

Numbers 19

(10) Parashat Chukat

(11) [1] And the Lord spoke to Moses

(12) and to Aaron, saying, [2]

(13) 'This is the statute of the Law which the Lord has commanded, saying,

(14) "Speak to the children of Israel, that they bring you an unblemished red 
(15) tana tüǵalni ki joḥtu anda ajip ki minmadi anyn

(16) üstüńa bojunsa. ונתתם. [3] Da berijiz any El-

(17) 'azarg̉a ol kohenǵa da čyg̉arsyn any tyšqartyn avul-

(18) ga da sojsun any alnynda anyn. [ולקח.] [4] Da alsyn El'azar

(19) ol kohen qanyndan anyn barmaġy byla da bürksün utrusuna

$245 \mathrm{~V}^{\mathrm{o}} \quad$ (1) alnynyn ohel mo'ednin qanyndan anyn jedi keratlar. ושרף. [5]

(2) Da küvdürsün ol tanany közlarič́a anyn ošol teri-

(3) sin anyn da ošol etin anyn da ošol qanyn anyn jiŕan-

(4) čiligibyla küvdürsün. ולקח. [6] Da alsyn ol kohen

(5) erez ag̉ačy da čabor da qyrmyzy jiṕak da tašlasyn

(6) orta küvḿagińa ol tananyn. וכבס [7] Da juvsun

(7) upraqlaryn ol kohen da juvsun gufun suvlarbyla da an-

(8) dan sortun kelsin ol avulga da murdar bolsun ol

(9) kohen ol ingirǵadejin. והשרף. [8] Da ol küvdü-

(10) rüvčü any juvsun upraqlaryn suvlar byla da juvsun

(11) gufun suvlar byla da murdar bolsun ol ingirǵadejin.

(12) [9] Da jyštyrsyn aruv kiši ošol külün ol

(13) tanany da qojsun tyšqartyn avulğa aruv orunda

(14) da bolsun క̌ymatyna ulanlarynyn Jisra’elnin saqlavġa bür-

(15) künür suvlarğa ḥatatty ol. וכבס. [10] Da juvsun

(16) ol jyštyruvču ošol külün ol tananyn ošol upraqlaryn

(17) özünün da murdar bolsun ol ingriǵadejin da bolsun

(18) ulanlaryna Jisra’elnin da ġaripǵa ol tirilüvčüğa

(19) ortalarynda ömürlük resimǵa. הנוגע. [11 Ol

(20) tijüvčü ölüǵa bar žanyna adamnyn da murdar bolsun

(21) jedi künlar. הוא. [12] Ol bürkünsün anyn byla ol

246 r $^{\mathrm{o}}$ (1) üčünčü künd́a da ol 〈dörtünčü $\rangle^{1}$ jedinči künd́a ary-

(2) nyr da eger bürkünmaśa ol üčünčü künd́a da

(3) ol jedinči künd́a arynmasty. כל. [13] Bar ol tijüvčü

(4) ölüǵa క̌anyna ol adamnyn ki ölśa da bürkünmaśa

(5) ošol miškanyn Adonajnyn murdar etti da eksilir

(6) ol žan Jisra’eld́an ki bürkünür suvlary bürkülḿadi anyn

(7) üstüńa murdar bolsun hanuz murdarlyg்y anyn andady.

(8) Tr [14] Budur ol üvŕatüv adam ki ölśa čatyr-

(9) da bar ol kelüvčü ol čatyrğa da barča neki čatyr-

(10) da murdar bolsun jedi künlar. וכל [15] Da bar ačyq

(11) savut ki joḥtu qapqač qošulğan anyn üstüńa murdar-

${ }^{1}$ A scribal error. 
(15) heifer, wherein is no blemish, and on which never came

(16) a yoke. [3] And you shall give it

(17) to Eleazar, the priest, that he may bring it out outside the camp,

(18) and one shall slay it before him. [4] And Eleazar the priest shall take

(19) of its blood with his finger and sprinkle its blood toward

(1) the front of the tent of meeting seven times. [5]

(2) And one shall burn the heifer in his sight: its skin,

(3) and its flesh, and its blood, with its

(4) dung shall he burn it. [6] And the priest shall take

(5) cedar wood and hyssop and scarlet silk, and cast it

(6) into the midst of the burning of the heifer. [7] And the priest shall wash

(7) his clothes and he shall wash his body with water, and

(8) afterward he shall come to the camp. And the priest shall be unclean

(9) until the evening. [8] And the one who burns

(10) it shall wash his clothes with water and wash

(11) his body with water and he shall be unclean until the evening.

(12) [9] And a man that is clean shall gather up the ashes of the

(13) heifer and lay them up outside the camp in a clean place,

(14) and it shall be kept for the congregation of the children of Israel

(15) for a purifying water: it is a sin offering. [10] And

(16) the one who gathers the ashes of the heifer shall wash his clothes,

(17) and he shall be unclean until the evening. And it shall be

(18) for the children of Israel and for the stranger that lives

(19) among them as an eternal statute. [11] One

(20) who touches the dead body of any human soul: then he shall be unclean

(21) seven days. [12] He shall purify himself with it on the

(1) third day, and on the 〈fourth $\rangle$ seventh day he shall be clean. $246 \mathrm{r}^{\mathrm{o}}$

(2) And if he does not purify himself the third day, then

(3) the seventh day he will not become clean. [13] Anyone who touches

(4) the dead body of any human soul who has died and does not purify himself

(5) defiles the tabernacle of the Lord, and that soul shall be cut off

(6) from Israel. Because the purifying water was not sprinkled on him,

(7) he shall be unclean. His uncleanness is still in him.

(8) [14] This is the teaching: if a man dies in a tent,

(9) all who come into the tent and everything that is in the tent

(10) shall be unclean seven days. [15] And every open

(11) vessel which has no covering fastened on it: it is unclean. 
(12) dy ol. וכל [16] Da barča neki tijśa jüzlari üstü-

(13) ńa ol tüznün qyranyna qylyčnyn jemeśa ölüǵa jeme-

(14) śa süv́agińa adamnyn jemeśa zeŕatḱa murdar

(15) bolsun jedi künlar. ולקחו Da alsynlar murdar

(16) üčün topraġyndan küvḿaginin ol ḥatatnyn da ber-

(17) Sin anyn üstüńa tiri suvlar savutqa. ולקח [18

(18) Da alsyn čabor da mančsyn suvlarg̉a aruv kiši da

(19) bürksün ol čatyr üstüńa da bar ol savutlar

(20) üstüńa da ol žanlar üstüńa ki edilar

(21) anda da ol tijüvčü üstüńa süv́akḱa jemeśa

$246 \mathrm{v}^{\mathrm{o}}$ (1) qyrang̉a jemeśa ölüǵa jemeśa zeŕatka. והזה. [19]

(2) Da bürkündürsün ol aruv kiši ol murdar kiši üs-

(3) tüńa ol üčünčü künd́a da ol jedinči künd́a da bür-

(4) kündürsün any ol jedinči künd́a da juvsun upraqlaryn

(5) da juvsun gufun suvlar byla da arynyr ingird́a. [20]

(6) Da kiši ki murdar bolsa da bürkünḿaśa da eksilir

(7) ol క̌an ortasyndan ol qahalnyn ki ošol miqdašyn Adonajnyn

(8) murdar etti bürkünür suvlary bürkülmadi anyn üstü-

(9) náa murdardy ol. [21] Da bolsun alarga ömürlük

(10) resimǵa da bürküvčü ol bürkünür suvlaryn juvsun up-

(11) raqlaryn da ol tijüvčü ol bürkünür suvlarg̉a murdar

(12) bolsun ol ingirǵadejin. וכל [22] Da barča kim ki tijśa

(13) anar ol murdar murdar bolsun da ol žan ol tijüvčü mur-

(14) dar bolsun ol ingirǵadejin.

Numbers 20

ויבאו [1] Da keldiliar ulan-

(15) lary Jisra’elnin bar ol žymat midbaryna Cinnin ol burungu jan-

(16) gajda da kečikti ol ulus Qadešta da öldü anda Mirjam

(17) da astraldy anda. [2] Da jog̉edi suv žymatqa

(18) da jyštyryldylar Moše üstüńa da Aharon üstüńa.

(19) [ירב [3) Da talašty ol ulus Moše byla da ajttylar ajta-

(20) dog̉ač da kešḱa tynsajedik tynġanda qaryndašlarymyz al-

(21) ולמה [4] Dynda Adonajnyn nek keltirdijiz ošol qahalyn 
(12) [16] And anyone who, at an open field, touches

(13) a killed body slain by a sword or a dead body or

(14) a bone of a man or a grave shall be unclean

(15) seven days. [17] And they shall take

(16) for an unclean person some of the ashes of the sin offering,

(17) and one shall put running water on it in a vessel. [18]

(18) And a clean person shall take hyssop and dip it in the water and

(19) sprinkle it on the tent and on all the vessels

(20) and on the souls that were

(21) there and on the one who touched a bone or

(1) one slain or a dead or a grave. [19]

(2) And the clean person shall make the unclean sprinkled

(3) on the third day and on the seventh day. And

(4) on the seventh day he shall purify him and wash his clothes

(5) and wash himself with water, and he shall be clean at evening. [20]

(6) And if a man is unclean and he does not purify himself, then

(7) that soul shall be cut off from among the assembly, because he has defiled the sanctuary of the Lord.

(8) The purifying water has not been sprinkled on him:

(9) he is unclean. [21] And it shall be an eternal

(10) statute for them. And one who sprinkles the purifying water shall wash

(11) his clothes, and one who touches the purifying water

(12) shall be unclean until evening. [22] And whatever the unclean person touches

(13) shall be unclean, and any soul that touches |it|

(14) shall be unclean until evening.'

Numbers 20

[1] And

(15) the children of Israel, all the congregation, came to the wilderness of Zin in the first

(16) month, and the people stayed in Kadesh. And Miriam died there

(17) and was buried there. [2] And there was no water for the congregation,

(18) and they gathered themselves against Moses and against Aaron.

(19) [3] And the people quarrelled with Moses, and said, saying,

(20) 'If only we have passed away when our brothers passed away

(21) before the Lord! [4] And why have you brought the assembly 
$247 \mathrm{r}^{\mathrm{O}} \quad$ (1) Adonajnyn ol midbarğa ošpu ölḿa anda biz da

(2) turymyzda. [5 [5] Da nek čyğardyjyz bizni Micrid́an kel-

(3) tirḿa bizni ol jaman orunġa ošpu tüvüldü ornu

(4) čačmaqnyn da inžirliknin da borlalyqnyn da narlyqnyn da

(5) suvda joḥtu ičma. [6] Da keldi Moše da Aharon

(6) alnyndan ol qahalnyn ešigińa ohel mo'ednin da tüštülar

(7) jüzĺari üstüńa da aškara boldu šehinasy Adonajnyn

(8) alarğa. וידבר [7 Da sözĺadi Adonaj Mošeǵa ajtadog̉ač.

(9) ק. [8] Alġyn ošol ol tajaqny da jyštyrg்yn ošol ol

(10) క̌ymatny sen da Aharon qaryndašyj da sözlajiz ol [sk]alağa ${ }^{1}$

(11) közlarič́a alarnyn da bersin suvlaryn özünün da čygarargynn

(12) alarg̉a suv ol skaladan da ičirgin ošol ol žymatny da

(13) ošol tuvaryn alarnyn. [9 [ Da aldy Moše ol tajaqny

(14) alnyndan Adonajnyn ki nečik bujurdu anar. ויקהלו. [10] Da jyš-

(15) tyrdy Moše da Aharon ošol ol qahalny alnynda ol skalanyn da \{ajtty\}

(16) alarğa tynlajyz endi e tanuvčular ošpumo skaladan čyġarajyq

(17) sizǵa suv. יוירם [11] Da kötürdü Moše ošol qolun da urdu

(18) ošol ol skalany tajag̉ybyla eki keratálar da čyqtylar köp suvlar

(19) da ičti ol క̌ymat da tuvary alarnyn. ויאמר [12] Da ajtty

(20) Adonaj Mošeǵa da Aharonġa anyn üčün ki inamlyqbyla qyl-

(21) madyjyz bujruġumnu azizligimni körgüzḿa menim sözlaḿa

$247 \mathrm{~V}^{\mathrm{o}} \quad$ (1) skalağa ki berǵaj suvlaryn közlarič́a ulanlarynyn Jisra’elnin

(2) anyn üčün keltirmassiz ošol ol qahalny ošpunu ol

(3) jerǵa ki berdim alarg̉a. המה. [13] Alardylar talaš suvla-

(4) ry ki talaštylar ulanlary Jisra’elnin alnynda Adonajnyn da

(5) azizligin körgüzdü alarda. [14] Da ijdi Moše

(6) elčilar Qadeštan bijińa Edomnun bulaj ajtty qaryndašyj

(7) Jisra’el sen bilasen ošol bar ol jadavny ki učrady bizni.

(8) اירדו [15] Da endilar atalarymyz Micriǵa da kečiktik

${ }^{1}$ TKow.o1: skalaga; unvocalized text. | H: sqalaga. | C: qajaġa. 
(1) of the Lord to this wilderness to die there, we and

(2) our cattle? [5] And why have you brought us out from Egypt

(3) to bring us to this bad place? It is no place

(4) of sowing or of figs or of vines or of pomegranates, and

(5) there is even no water to drink. [6] And Moses and Aaron came

(6) from before the assembly to the door of the tent of meeting, and they fell

(7) on their faces, and the divine Presence of the Lord appeared

(8) to them. [7] And the Lord spoke to Moses, saying,

(9) [8] 'Take the staff and gather the

(10) congregation together, you and Aaron, your brother, and speak to the rock

(11) in the sight of them, and it shall give its water. And you shall bring

(12) water out of the rock for them, and you shall give a drink to the congregation and

(13) their livestock.' [9] And Moses took the staff

(14) from before the Lord as he commanded him. [10] And

(15) Moses and Aaron gathered the assembly together before the rock, and he said

(16) to them, 'Hear now, oh rebels: shall we bring out water of this rock

(17) for you?' [11] And Moses lifted his hand and struck

(18) the rock with his staff twice. And much water came out.

(19) And the congregation and their livestock drank. [12] And

(20) the Lord said to Moses and Aaron, 'Because you did not carry out

(21) my order with confidence to show my holiness, Lto speak

(1) to the rock that it may give you water ${ }^{1224}$ in the sight of the children $247 \mathrm{~V}^{\mathrm{o}}$ of Israel,

(2) therefore you will not bring this assembly

(3) to the land which I have given them.' [13] These are the waters ${ }_{L}$ of quarrel ${ }^{1225}$,

(4) because the children of Israel quarrelled before the Lord, and

(5) he showed his holiness among them. [14] And Moses sent

(6) envoys from Kadesh to the lord of Edom, "Thus says your brother

(7) Israel: You know all the tiredness that has befallen us.

(8) [15] And our fathers went down to Egypt, and we have stayed

224 Interpretative addition to the standard text.

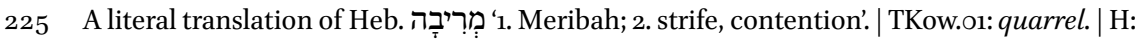
quarrel.|C:Meribah.| R: Meribah. 
(9) Micrid́a köp künĺar da jaman ettílar bizǵa eli

(10) Micrinin da atalarymyzġada. ונצעק [16] Da

(11) firjat ettik Adonajğa da ešitti avazymyzny da

(12) ijdi elči da čyğardy bizni Micrid́an da muna biz

(13) Qadešta učtağy šaharynda čegijnin. נעברה. [17] Ašajyq

(14) endi jerij ašyra ašmasbiz tüz ašyra da borlalyq

(15) ašyra da ičḿasbiz suvlaryn qujunun jolubyla ol bijnin

(16) baryrbiz qajrylmasbiz on jary ani son jary neginča ki

(17) ašqajbiz čegijni. ויאמר [18] Da ajtty anar Edom

(18) ašmassen jerimašyra magaat qylyč byla čygarmen utru-

(19) ja. ויאמרו [19] Da ajttylar anar ulanlary Jisra’elnin izby-

(20) la baryrbiz da eger suvlaryjny ičśak men da tuvarym da

(21) ber[i]rmen ${ }^{1}$ bahasyn alarnyn tek joḥtu neḿad́a ančaq jajav ašajym.

$248 \mathrm{r}^{\circ}$ (1) יויאמר [20] Da ajtty ašmassen da čyqty Edom utu-

(2) rusuna anyn köp ulusbyla da küčlü qolbyla. [ימאן. [21]

(3) Da kĺaḿadi Edom erk berḿa Jisra’elǵa ašma

(4) jer ašyra čeginin da qajyryldy Jisra’el anyn qatyndan.

(5) ויסעו Da köčtülar Qadeštan da keldilar ulanlary

(6) Jisra’elnin bar ol žymat Hor Haharg̉a. [23] Da aj-

(7) ty Adonaj Mošeǵa da Aharonġa Hor Haharda čegi qaty-

(8) na jerinin Edomnun ajtadoġač. יאסף. [24] Jyštyrylsyn

(9) Aha\{ro\}n uluslaryna ki kelmasti ol jerǵa ki berdim

(10) ulanlaryna Jisra’elnin anyn üčün ki tandyjyz bujrugiuma

(11) išind́a talaš suvlarynyn. קח. [25] Alġyn ošol Aharon-

(12) nu da ošol El’azarny uvlun anyn da mindirgin alarny

(13) Hor Haharg̉a. והפשט. [26] Da češindirtkin Aharong̀a

(14) ošol upraqlaryn da kijdirgin alarny El’azargia uvlu-

(15) na anyn da Aharon jyštyrylsyn da ölsün anda.

(16) ויעש [27] Da qyldy Moše ki nečik bujurdu Adonaj da

(17) mindiĺar Hor Haharg̉a közláari\}č́a bar ${ }_{\text {L }}[\mathrm{ol}$ క̌yma $]$ tnyn $^{12}$.

(18) ויפשט (28] Da češindirtti Moše Aharong̉a ošol

(19) upraqlaryn anyn da kijdirdi alarny El’azarg̉a uvluna

${ }^{1} \mathrm{~K}$ : berermen; a scribal error. | TKow.o1: unvocalized text. | H: berimen. | C: beräyim. $\quad{ }^{2}$ TKow.o1: ol žymatnyn; unvocalized text. | H: ol zymatnyn. | C: ol zamáatnyy. 
(9) in Egypt many days. And the people of Egypt was bad to us

(10) and also to our fathers, [16] And

(11) we cried to the Lord and he heard our voice and

(12) he sent an envoy and he has brought us out from Egypt. And, lo, we

(13) are in Kadesh, a city on the edge of your border. [17] Let us pass,

(14) now, through your land. We will not pass through the fields or through the vineyards,

(15) and we will not drink well waters. We will go by the king's road,

(16) we will not turn to the right hand nor to the left, until

(17) we pass your border.' [18] And Edom said to him,

(18) 'You will not pass through my land, lest I come out against you with the sword.'

(19) [19] And the children of Israel said to him,

(20) 'We will go by the way, and if I and my livestock drink of your water, then

(21) I will give their price. Only, there is nothing more, let me pass through on foot.'

(1) [20] And he said, 'You will not go through.' And Edom came out

(2) against him with much people, and with a strong hand. [21]

(3) And Edom did not want to empower Israel to pass

(4) through his border. And Israel turned away from him.

(5) [22] And they set out from Kadesh, and the children

(6) of Israel, the whole congregation, came to Mount Hor. [23] And

(7) the Lord said to Moses and Aaron at Mount Hor, by the border

(8) of the land of Edom, saying, [24] 'Aaron shall be gathered

(9) to his people, for he will not come to the land which I have given

(10) to the children of Israel, because you rebelled against my command

(11) in the matter at the water ${ }_{L}$ of quarrel ${ }^{1226}$. [25] Take Aaron

(12) and Eleazar, his son, and bring them up

(13) to Mount Hor. [26] And you shall take off Aaron's

(14) garments, and you shall put them on Eleazar, his son.

(15) And Aaron shall be gathered and die there.'

(16) [27] And Moses did as the Lord commanded. And

(17) they went up to Mount Hor in the sight of all [the congregation].

(18) [28] And Moses took of Aaron's

(19) garments and put them on Eleazar, his son.

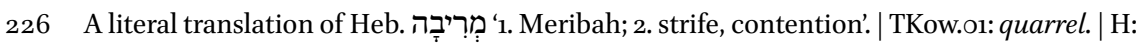
quarrel. | C: Meribah. | R: Meribah. 
(20) anyn da öldü Aharon anda bašynda ol tavnyn da endi

(21) Moše da El'azar ol tavdan. [29] Da kördülar

$248 \mathrm{v}^{\mathrm{o}} \quad$ (1) bar ol క̌ymat ki tyndy Aharon da jyladylar anyn üčün bar

(2) üvü Jisra’elnin otuz kün.

Numbers $21^{1}$

(2) (1] Da ešitti ol

(3) Kena'ani bij[i] $]^{2}$ 'Aradnyn olturuvčusu ol tüšlüknün ki keldi

(4) Jisra’el jolubyla ol čajsylavčularnyn da uruštu Jisra’el

(5) byla da jesir etti andan jesir. [2] Da nijet etti

(6) Jisra'el nijet Adonajğa da ajtty eger berḿa berśaj o-

(7) šol ol ulusnu ošpunu qoluma da ḥerem etarmen ošol

(8) šaharlaryn alarnyn. [ישמע Da tynlady Adonaj avazyna

(9) Jisra’elnin da berdi ošol ol Kena'anini da ḥerem etti alar-

(10) ny da ošol šaharlaryn alarnyn da atady atyn ol orunnun

(11) Harma. ויסעו [4] Da köčtülar Hor Hahardan jolusary Jam

(12) Sufnun quršama ošol jerin Edomnun da jadady žany ol

(13) ulusnun jolda. וידבר. [5] Däzĺadi ol ulus Tenri

(14) üčün da Moše üčün ajtadoġač nek čyġardyjyz bizni Micri-

(15) dan ölḿa midbarda ki joḥtu ötḿak da joḥtu suv

(16) da žanymyz jadady ol jengil ötḿaktan. וישלח [6 Da

(17) ijdi Adonaj ulusta ošol ol küvdürgüč jylanlarny

(18) da tišladilar ošol ol ulusnu da öldü köp ulus Jis-

(19) ra’eld́an. ויבוא. [7] Da keldi ol ulus Mošeǵa da ajtty-

(20) lar jazyqly bolduq ki sözladik Adonaj üčün da senin üčün

(21) tefila etkin Adonajğa da ketarsin bizd́an ošol ol jylanny

$249 \mathrm{r}^{\circ} \quad$ (1) da tefila etti Moše ol ulus üčün. [8] Da

(2) ajtty Adonaj Mošeǵa qylġyn özüja küvdürgüč jylan da

(3) qojğun any alam üstüńa da bolġaj bar ol tišlanǵan

(4) jylandan da baqsyn anyn üstüńa da savuguur. [9]

\footnotetext{
${ }^{1} \mathrm{~K}$ : Num 20:29 is copied as Num 21:1; a scribal error. | TKow.o1: Num 21 begins here. | H: Num 21 begins here. | ADub.III.82: Num 21 begins here. | C: Num 21 begins here. | M: Num 21 begins here. | R: Num 21 begins here. | Hebrew Bible: Num 21 begins here. ${ }^{2} \mathrm{~K}$ : bij; a scribal error. | TKow.o1: unvocalized text. | H: biji. | C: hany.
} 
(20) And Aaron died there on the top of the mountain. And

(21) Moses and Eleazar came down from the mountain. [29] And

(1) all the congregation saw that Aaron passed away, and they wept for $248 \mathrm{v}^{\mathrm{o}}$ him

(2) thirty days, all the house of Israel.

Numbers $21^{227}$

(3) the Canaanite, king of Arad, who dwelt in the south, heard

(4) that Israel came ${ }_{\perp}$ by the way of spies ${ }^{1228}$ and he fought against Israel,

(5) and took some of them captive. [2] And Israel vowed

(6) a vow to the Lord, and said, 'If you will indeed give this

(7) people into my hand, then I will devote

(8) their cities |to destruction|.' [3] And the Lord listened to the voice

(9) of Israel, and gave |over| the Canaanites, and he devoted them

(10) and their cities |to destruction|. And he called the name of the place

(11) Hormah. [4] And they set out from mount Hor by the way of the

(12) Red Sea, to go around the land of Edom. And the soul of the people got tired

(13) on the way. [5] And the people spoke about God

(14) and about Moses, saying, 'Why have you brought us out from Egypt

(15) to die in the wilderness? Because there is no bread, and there is no water,

(16) and our soul is tired of this worthless bread.' [6] And

(17) the Lord sent fiery serpents among the people,

(18) and they bit the people, and many people of Israel died.

(19) [7] And the people came to Moses, and said,

(20) 'We have sinned, because we have spoken about the Lord and about you.

(21) Pray to the Lord, that he shall take away the serpents from us.'

(1) And Moses prayed for the people. [8] And

(2) the Lord said to Moses, 'Make you a fiery serpent and

(3) set it on a standard. And it shall be, that everyone who is bitten

(4) by a serpent and he looks on it, he will recover. [9]

227 K: Num 20:29 is copied as Num 21:1; a scribal error.

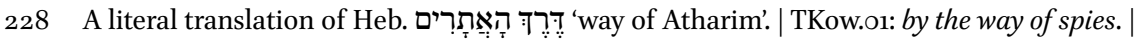

$\mathrm{H}$ : by the way of spies. | C: by the way of explorers. | R: by the way of spies. 
(5) Da qyldy Moše tuč jylan da qojdu any ol alam üstüńa

(6) da edi eger tišlaśajdi ol jylan ošol kišini da

(7) baqsajdy ol tuč jylan üstüńa da savuğuredi.

(8) (10] Da köčtülar ulanlary Jisra’elnin da toḥtadylar

(9) Ovotta. ויסעו [11] Da köčtülar Ovottan

(10) da toḥtadylar bič́anliklarind́a ol köčüvlarnin midbar-

(11) da ki alnynda Mo’avnyn ol qujaš balquvusary. משם. [12]

(12) Andan köčtülar da toḥtadylar öźanind́a Zarednin.

(13) Andan köčtülar da toḥtadylar köčüvünd́an

(14) Arnonnun ki midbarda ol čyg்uvču čegind́an ol Emorinin

(15) ki Arnon edi čegi Mo’avnyn arasyna Mo’avnyn da ara-

(16) syna ol Emorinin. על [14] Anyn üčün ajtylady seferin-

(17) d́a čerüvlarinin Adonajnyn ošol Vahevni Sufada da ošol

(18) ol öźanlarni Arnonda. [15 Da tašqyny ol öźan-

(19) ĺarnin ki qurdu olturušuna 'Arnin da tajandy čegińa

(20) Mo’avnyn. ומשם. [16] Da andan köčtülar Be’erǵa oldu

(21) ol quju ki ajtty Adonaj Mošeǵa jyštyrğyn ošol ol ulus-

$249 \mathrm{v}^{\mathrm{o}}$ (1) nu da beŕajim alarğa suv. [17] Ol vahtta šira

(2) oḥudu Jisra’el ošol ol širany ošpunu ajtadoġač kötür-

(3) gün e quju suvlaryjny šira oḥujuz anar. באר. [18]

(4) Quju qazdylar any ag̉alyqlar qazdylar any žomartlary ol ulus-

(5) nun resim qojuvču byla tajaqlary byla özlarinin da midbar-

(6) dan köčtülar Matanaġa. וממתנה. [19] Da Matanadan

(7) köčtülar Nahạalielǵa da Naḥali’eld́an Bamotqa. ומבמות. [20]

(8) Da Bamottan köčtülar ol LGaj’ ünd́aladoġan orunġa ${ }^{11} \mathrm{ki}$

(9) tüzünd́a Mo’avnyn bašyna ol singirnin da körünüre-

(10) di alnyna ol Ješimonnun². וישלח. [21] Da ijdi Jisra’el elči-

(11) lar Sihong̀a bijińa ol Emorinin ajtadoġač. אעברה. [22]

(12) Ašajym endi jerij ašyra qajyrylmasbiz tüzǵa da borlalyqqa

(13) da ičḿasbiz suvlaryn qujunun jolubyla ol bijnin baryrbiz

\footnotetext{
${ }^{1}$ A mistranslation. | TKow.o1: Gaj’ ündeledogan orunġa; unvocalized text. | H: Gaj indeledogan

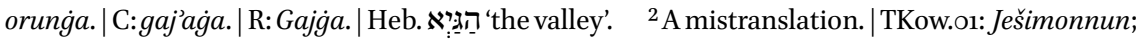
unvocalized text. | H: Ješimonnun. | C: jabannyy. | R: midbarnyn. | Heb. הַיְְׁיׁימן 'the wasteland'.
} 
(5) And Moses made a bronze serpent and put it on a standard,

(6) and it was, if a serpent bit a man, then

(7) he would look at the bronze serpent and recover.

(8) [10] And the children of Israel set out and camped

(9) in Oboth. [11] And they set out from Oboth

(10) and camped ${ }_{L}$ at the meadows of encampments ${ }^{1229}$, in the wilderness

(11) which is opposite Moab, toward the sun's rising. [12]

(12) From there they set out and camped in the |valley of| the river Zered.

(13) [13] From there they set out and camped across the ford

(14) of Arnon which is in the wilderness that extends from the border of the Amorites,

(15) because Arnon was the border of Moab, between Moab and

(16) the Amorites. [14] Therefore it is said in the Book

(17) of the Wars of the Lord: Waheb in Suphah and the

(18) rivers of Arnon, [15] And the riverbed of the rivers

(19) that he placed down to the dwelling of Ar, and leans to the border

(20) of Moab. [16] And from there they set out to Beer: that is

(21) the well of which the Lord spoke to Moses, 'Gather the people

(1) together, so that I may give them water.' [17] Then

(2) Israel sang this song, saying, 'Lift up,

(3) oh well, your waters, we sing to it. [18]

(4) The rulers dug the well, the nobles of the people dug it,

(5) with the one who gives statues, with their own staffs.' And from the wilderness

(6) they set out to Mattanah. [19] And from Mattanah

(7) they set out to Nahaliel. And from Nahaliel to Bamoth. [20]

(8) And from Bamoth they set out to a $^{\text {a place called Gay }}{ }^{1230}$ that

(9) is in the field of Moab, ${ }_{\text {t }}$ to the top of the summit ${ }^{1231}$, which appears

(10) before Jeshimon ${ }^{232}$. [21] And Israel sent envoys

(11) to Sihon, king of the Amorites, saying, [22]

(12) 'Let me pass through your land. We will not turn at a field and at a vineyard,

(13) and we will not drink well waters. We will go by the king's road,

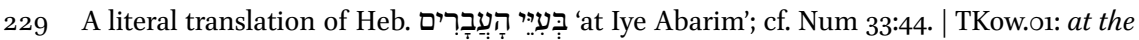
meadows of encampments. | H: at the meadows of encampments. | C: at the dwellings of encampments. | R: at the wastelands of encampments.

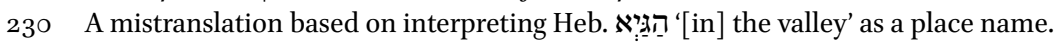

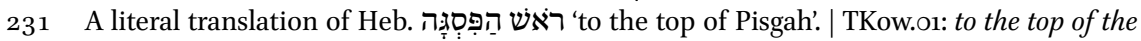
summit. | H: to the top of the summit. | C: to the top of the rock.

232 A mistranslation based on interpreting Heb. הַיְְשיׁימן 'the wasteland' as a place name. 
(14) neginč́a ki ašqajbiz čegijni. ולא. [23] Da erk bermadi

(15) Siḥon Jisra’elǵa ašma jeri ašyra čeginin da jyštyrdy

(16) Siḥon ošol bar ulusun özünün da čyqty uturusuna

(17) Jisra'el $\{$ nin $\}$ ol midbarg̉a da keldi Jahcag̉a da uruštu

(18) Jisra'elbyla. ויכהו [24] Da qyrdy any Jisra’el qylyč avzundan

(19) da meŕasladi ošol jerin anyn bašlap Arnondan Jaboqqadejin ulan-

(20) larynadejin 'Amonnun ki küčlü edi čegi ulanlarynyn 'Amonnun ${ }_{L}$ anyn

(21) üčün bolalmady ol Emori alma artyq jerind́an ulanlary-

25 r $^{\circ}$ (1) nyn 'Amonnun ${ }^{11}$. יויקח [25] Da aldy Jisra’el ošol bar ol šahar-

(2) larny ošpularny da olturdu Jisra’el bar šaharlarynda ol

(3) Emorinin Ḥešbonda da bar salalarynda anyn. כי. [26] Ki

(4) Hešbon edi šahary Siḥon[nun $]^{2}$ bijinin ol Emorinin ol da ol

(5) uruštu ol burungiu bijibyla Mo’avnyn da aldy ošol bar

(6) jerin anyn qolundan Arnongadejin. על ע2 [27 Anyn üčün aj-

(7) tyredilar ol mašal ajtuvčular kelijiz Ḥešbong̉a qonda-

(8) rylsyn da tüzülsün šahary Siḥonnun. כי. [28] Ki ot

(9) čyqty Ḥešbondan jalyn šaharyndan Siḥonnun ortady ‘Ar

(10) ünd́áladoġan šaharyn Mo’avnyn jesilarin bamalarynyn

(11) Arnonnun. [29] Vaj saja Mo’av taspolduj

(12) ulusu Kemošnun berdi uvullaryn özünün qutulganlar da

(13) qyzlaryn jesirlikt́a bijińa Emorinin Siḥonġa. [30] Da

(14) nečik attyq alarny oqlarbyla ol vaḥtta bijlik taspol-

(15) du Ḥešbondan Divonġa dejin da veŕan ettik Nofạ̣qadejin

(16) ki Medevaġadejin. וישב [31 Da olturdu Jisra’el jerind́a

(17) ol Emorinin. [32] Da ijdi Moše čajsylama ošol

(18) Jacezerni da tuttular salalaryn anyn da tasetti ošol ol

(19) Emorinin ki anda. [33] Da qajyryldylar da bardylar

(20) jolusary ol Bašannyn da čyqty 'Og biji ol Bašannyn uturulary-

(21) na alarnyn ol da bar ulusu anyn čerüvǵa Edreciǵa.

$250 \mathrm{v}^{\circ}$ (1) ויאמר [34] Da ajtty Adonaj Mošeǵa qorqmaġyn andan

(2) ki qoluja senin berirmen any da ošol bar ulusun anyn da ošol

(3) jerin anyn da qylg̀yn anar ki nečik qyldyj Siḥonġa bijińa ol

(4) Emorinin ki oltururedi Ḥešbonda. ויכו. [35] Da qyrdylar any

\footnotetext{
${ }^{1}$ Interpretative addition to the standard text. $\quad{ }^{2}$ K: Sịon; a scribal error. | TKow.o1: Sihonnun; unvocalized text. | H: Sihonnun. | C: Siḥonnyy.
} 
(14) until we pass your border' [23] And Sihon did not empower

(15) Israel to pass through his land. And Sihon gathered

(16) all his people together, and went out against Israel

(17) to the wilderness. And he came to Jahaz and fought

(18) against Israel. [24] And Israel killed him by the edge of the sword

(19) and inherited his land from Arnon to Jabbok,

(20) to the children of Ammon, because the border of the children of Ammon was strong:

(21) for that reason the Amorites could not take more from the land of the children

(1) of Ammon ${ }^{1233}$. [25] And Israel took all these cities,

(2) and Israel lived in all the cities of the

(3) Amorites, in Heshbon, and in all its villages, [26] Because

(4) Heshbon was the city of Sihon, he is the king of the Amorites, and he

(5) had fought against the first king of Moab and taken all

(6) his land from his hand, as far as Arnon. [27] On account of this

(7) the ones who say proverbs used to say, 'Come to Heshbon,

(8) let the city of Sihon be built and organized. [28] For fire

(9) went out of Heshbon, a flame from the city of Sihon. It consumed

(10) the city called Ar of Moab, the lords of the hills

(11) of Arnon. [29] Woe unto you, Moab:You have perished,

(12) people of Chemosh. He has made his sons fugitives and

(13) has given his daughters into captivity to the king of Amorites, to Sihon. [30] And

(14) when we have shot at them with arrows, then the reign of

(15) Heshbon has perished, as far as Dibon, and we have desolated them as far as Nophah

(16) which is as far as Medeba.' [31] And Israel lived in the land

(17) of the Amorites. [32] And Moses sent to spy out

(18) Jazer, and they captured its villages and destroyed the

(19) Amorites that were there. [33] And they turned and went up

(20) by the way of Bashan, and Og, king of Bashan, went out against

(21) them, he, and all his people, to the war of Edrei.

(1) [34] And the Lord said to Moses, 'Do not fear him,

(2) because I will give him and all his people and his land into your hand,

(3) and you shall do to him as you did to Sihon, king of the

(4) Amorites, who loved at Heshbon.' [35] And they defeated him

233 An interpretative addition to Num 21:24. 
(5) da ošol uvullaryn anyn da ošol bar ulusun qaldyrmajynča

(6) alarg̉a qaldyq da meŕaśladilar ošol jerin anyn.

Numbers $22^{1}$

(7) Da köčtülar ulanlary Jisra’elnin da tohtadylar bič́anlikĺa-

(8) rind́a Mo’avnyn köčüvünd́an Jardeninin Jerehọonun.

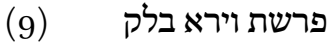

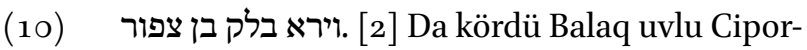

(11) nun ošol ne ki qyldy Jisra’el Emoriǵa.

(12) [יגר (3) Da qorqtu Mo'av alnyndan ol ulusnun astry

(13) ki köptü ol da jadady Mo’av alnyndan ulanlarynyn Jisra’el-

(14) nin. (4] Da ajtty Mo’av qartlaryna Midjan-

(15) nin haligińa jalarlar ol qahal ošol \{bar\} čüvŕalarimizni jalaġanlaj

(16) ol ögüz ošol j[e]šilligin ${ }^{2}$ ol tüznün da Balaq uvlu Cipornun

(17) bij edi Mo’avġa ol vaḥtta. [5 Da

(18) ijdi elčílar Bil'amġa uvluna Bo`ornun Petor ünd́aĺado-

(19) gan šaharğa ki ol öźan qatyna jerińa elinin

$251 \mathrm{r}^{\mathrm{o}}$ (1) ulusunun ünd́ama any ajtadoġač muna ulus čyqty

(2) Micrid́an muna qaplady ošol jüzün ol jernin da ol oltu-

(3) rady qaršymdan. ועתה. [6] Da haligińa kel endi qarğa-

(4) ġyn maja ošol ol ulusnu ošpunu ki küčlürakti ol

(5) mend́an ki bilamen ki nečik qarg̉asaj vadaj bolalyrmen vatma

(6) any da sürarmen any ol jerd́an ki men bilamen ošol

(7) kimni ki alġyšlasaj alğyšly bolady da ošol kimni ki qar-

(8) gasaj qarğyšly bolady. וילכו [7] Da bardylar qartlary Mo’avnyn

(9) da qartlary Midjannyn da qusnačylyqlar qollarynda alarnyn

(10) da keldilar Bil'amġa da sözĺadilar anar sözĺarin Balaq-

(11) nyn. ויאמר. [8] Da ajtty alarǵa qonujuz bunda buke-

(12) č́ani da qaruv qajtaryrmen sizǵa söz ki nečik sözlaśa

(13) Adonaj maja da olturdular ag̉alyqlary Mo’avnyn Bil'am by-

(14) la. la Da keldi malah Bil'amġa da ajtty

(15) kimdi ol éranlar ošpular birǵaja. ויאמר Da

\footnotetext{
${ }^{1} \mathrm{~K}$ : Num 22:1 is copied as Num 22:37; a scribal error. | TKow.o1: Num 22 begins here. | H: Num 22 begins here. |ADub.III.82: Num 22 begins here. | C: Num 22 begins here. | M: Num 22 begins here. | R: Num 22:1 is copied as Num 22:36; a scribal error. | Hebrew Bible: Num 22 begins here. ${ }^{2} \mathrm{~K}$ : jašyllyğyn; a scribal error. | TKow.o1: unvocalized text. | H: jesilligin. | C: otun.
} 
(5) and his sons and all his people until he did not have a remnant left,

(6) and they inherited his land.

Numbers $22^{234}$

(7) And the children of Israel set out and camped in the meadows

(8) of Moab across the ford of Jordan of Jericho.

(9) Parashat Balak

(10) [2] And Balak, son of Zippor, saw

(11) all that Israel had done to the Amorites.

(12) [3] And Moab was greatly afraid of the people

(13) because they were many. And Moab weakened before of the children of Israel.

(14) [4] And Moab said to the elders of Midian,

(15) 'Now this assembly will lick up all that are all around us, like the cattle licks

(16) up the grass of the field.' And Balak, son of Zippor,

(17) was the king of the Moabites at that time. [5] And

(18) he sent envoys to Balaam, son of Beor, to the city called Pethor

(19) which is by the river of the land of the men

(1) of his people, to call him, saying, 'Lo, a people has come out

(2) from Egypt. Lo, they cover the face of the earth, and they live

(3) opposite me. [6] And now, come, curse

(4) this people for me, because it is too powerful for me,

(5) because I know that if you curse them, I will certainly be able to smite

(6) them, and I will drive them out of the land-because I know:

(7) the one whom you bless is blessed, and the one whom

(8) you curse is cursed.' [7] And the elders of Moab

(9) and the elders of Midian went with witchcraft in their hand,

(10) and they came to Balaam and spoke to him the words of Balak.

(11) [8] And he said to them, 'Lodge here this night,

(12) and I will give you back a word of answer, as the

(13) Lord shall speak to me.' And the rulers of Moab abode with Balaam.

(14) [9] And an angel came to Balaam and said,

(15) 'What are these men with you?' [10] And

234 K: Num 22:1 is copied as Num 22:37; a scribal error. 
(16) ajtty Bil'am ol malahqa Balaq uvlu Cipornun biji

(17) Mo’avnyn ijdi maja. הנה. [11] Ajtadoġač muna ol

(18) ulus ol čyg̉uvču Micrid́an da qaplady ošol jüzün ol

(19) jernin haligińa kel qarg̉aġn maja any ki eger qarg̉asaj vadaj

(20) bolalyrmen urušma anyn byla da sürarmen any özümd́an.

(21) Da ajtty malah Bil'amġa barmaġyn birǵalarińa

$251 \mathrm{v}^{\mathrm{o}} \quad$ (1) qarg̉amag̉yn ošol ol ulusnu ki alğyšlydy ol. [13]

(2) Da turdu Bil'am ertanbylada da ajtty ag̉alyqlaryna

(3) Balaqnyn baryjyz jerijizǵa ki kĺaḿajdi Adonaj erk bermá maja

(4) barma birǵajizǵa. ויקומו. [14] Da turdular ag̉alyq-

(5) lary Mo’avnyn da keldilar Balaqqa da ajttylar kíamajdi

(6) Bil'am barma birǵamizǵa. ויסף. [15] Da arttyrdy

(7) daġyn Balaq ijḿa ag̉alyqlar ulluraqlar da syjlyraqlar

(8) bulardan. ויבוא Deldilar Bil'amga da ajttylar

(9) anar bulaj ajtty Balaq uvlu Cipornun qoltqabyla ajalmagiyn

(10) barmaqtan maja. כי [17] Ki syjlama syjlarmen seni astry

(11) da barča neki ajtsaj maja qylarmen da barg̉yn endi qarg̉a-

(12) ġyn maja ošol ol ulusnu ošpunu. [18] Da

(13) qaruv berdi Bil'am da ajtty qullaryna Balaqnyn eger

(14) berśajedi maja Balaq tolu üvün kümüš da altyn bolalman-

(15) men ašma ošol bujruğun Adonaj Tenrimnin qylma kiči

(16) nerśa jemeśa ullu nerśa. ועתה. [19] Da haligińa

(17) olturujuz daġyn sizd́a bunda bu keč́ani da bilajim ne

(18) arttyryr Adonaj sözlaḿa birǵama. [20] Da

(19) keldi malah Bil'amġa keč́abyla da ajtty anar eger

(20) ünd́ama seni keldilar eśa ol eŕanĺar turġun bar-

(21) ġyn birǵalarińa da ančaq ošol ol söznü ki sözlaśam

$252 \mathrm{r}^{\mathrm{o}} \quad$ (1) saja any qylgynn. [21] Da turdu Bil'am ertanbylada

(2) da jerladi ošol eš́agin da bardy ag̉alyqlarybyla Mo’avnyn.

(3) ויחר (22] Da qabundu ačuvu Adonajnyn ki bardy ol da turdu

(4) malahy Adonajnyn jolda šatanġa anar da ol atlanyredi

(5) ešagi üstüńa da eki neǵarlari anyn birǵasińa.

(6) ותרא [23] Da kördü ol eš́ak ošol malahyn Adonaj-

(7) nyn turadog̉anny jolda da qylyčy anyn suvurulġan qolunda

(8) anyn da qajyryldy ol eš́ak ol joldan da bardy tüzbyla 
(16) Balaam said to the angel, 'Balak, son of Zippor, king

(17) of Moab, has sent to me, [11] Saying, "Lo,

(18) here is a people who came out from Egypt, who cover the face of the

(19) earth. Come now, curse them for me, because if you curse them,

(20) I will certainly be able to fight with them and I will drive them away from me."'

(21) [12] And the angel said to Balaam, 'You shall not go with them.

(1) You shall not curse the people, because they are blessed.' [13]

(2) And Balaam rose up at dawn and said to the rulers

(3) of Balak, 'Go to your land, because the Lord does not want to empower me

(4) to go with you.' [14] And the rulers of Moab rose,

(5) and they went to Balak and said,

(6) 'Balaam does not want to come with us.' [15] And Balak went on again

(7) to send greater and more honourable rulers

(8) than these. [16] And they came to Balaam, and said to him,

(9) 'Thus says Balak, son of Zippor, "I pray you, do not delay

(10) with coming to me, [17] Because I will honour you very much,

(11) and I will do all that you would say to me. Come now, curse

(12) this people for me."' [18] And

(13) Balaam answered and said to the servants of Balak, "Though

(14) Balak were to give me his house full of silver and gold, I would not be able

(15) to go beyond the command of the Lord, my God, to do a small

(16) thing or a big thing. [19] And now,

(17) stay here, you as well, this night, so I may know what

(18) the Lord will add to speak with me.' [20] And

(19) an angel came to Balaam at night and said to him, 'If

(20) the men come to call you, rise up and go

(21) with them. And just the word which I shall speak

(1) to you-you shall do that.' [21] And Balaam rose up at dawn

(2) and saddled his donkey and went with the rulers of Moab.

(3) [22] And God's anger was kindled because he went. And

(4) the angel of the Lord stood in the way as an adversary against him. And he was riding

(5) on his donkey, and his two servants were with him.

(6) [23] And the donkey saw the angel of the Lord

(7) standing in the way and his sword drawn in his hand.

(8) And the donkey turned aside out of the way and went through the field. 
(9) da urdu Bil'am ošol ol eš́akni qajyrma any ol jolg̀a.

(10) ויעמד [24 Da turdu malahy Adonajnyn izind́a ol borla-

(11) lyqlarnyn qora edi bu jantyn da qora edi bu jantyn.

(12) ותרא [25] Da kördü ol ešak ošol malahyn Adonajnyn da

(13) qysyldy ol farstqa da qysty ošol ajaġyn Bil'amnyn ol

(14) farstqa da arttyrdy urma any. [26] Da art-

(15) tyrdy malahy Adonajnyn ašma da turdu tar orunda ki

(16) jogedi jol qajyrylma on jary ani son jary. ותרא [27]

(17) Da kördü ol ešak ošol malahyn Adonajnyn da jatty

(18) Bil'am tübüńa da qabundu ačuvu Bil'amnyn da urdu

(19) ošol ol eš́akni tajaqbyla. ויפתח [28] Da ačty Adonaj

(20) ošol avzun ol ešaknin da ajtty Bil'am\{ğa\} ne qyldym

(21) saja ki urduj meni bu üč kératlar. ויאמר [29] Da

$252 \mathrm{~V}^{\mathrm{o}} \quad$ (1) ajtty Bil'am eš́akḱ ki jengillik qyldyj maja ki eger

(2) bolsajedi qylyč qolumda ki haligińa öltürǵajedim seni.

(3) ותאמר [30] Da ajtty ol ešak Bil'amġa muna men

(4) eš́agij senin ki atlandyj üstümd́a jašlyġyjdan ošpu

(5) künǵadejin čynyqma čynyqtymmo qylma saja bulaj da

(6) ajtty joq. ויגל [31] Da ačty Adonaj ošol közlarin

(7) Bil'amnyn da kördü ošol malahyn Adonajnyn turadog̉anny

(8) jolda da qylyč anyn suvurulġan qolunda da ijildi da

(9) bašurdu jüzlariüstüńa. ויאמר [32] Da ajtty anar

(10) malahy Adonajnyn ne üčün urduj ošol eš́agijni bu

(11) üč qurlalar muna men čyqtym šatan bolmaqqa ki qynġyr

(12) köründü ol jol alnymda. ותראני [33] Da kördü meni

(13) ol eš́ak da qajyryldy alnymdan bu üč qurlalar šeme

(14) qajyrylmasajedi alnymdan ki haligińa dag்yn seni öltürǵaje-

(15) dim da any tiri qaldyrǵajedim. ויאמר. [34] Da ajtty

(16) Bil'am malahyna Adonajnyn jazyqly boldum ki bilmadim ki sen

(17) turasen utruma jolda da haligińa eger jaman körüńadi

(18) eśa közlarijda qajtajym özüma. ויאמר. [35] Da ajtty

(19) malahy Adonajnyn Bil'amġa barg̉yn ol éranlarbyla da ančaq

(20) ošol söznü ki sözĺaśam saja any sözlagin da bardy

(21) Bil'am ag̉alyqlary byla Balaqnyn. וישמע [36] Da 
(9) And Balaam struck the donkey, to turn it to the way.

(10) [24] But the angel of the Lord stood in a path of the vineyards,

(11) a fence being on this side and a wall on this side.

(12) [25] And the donkey saw the angel of the Lord and

(13) it pressed itself against the wall and pressed Balaam's foot

(14) against the wall, and he continued hitting it. [26] And

(15) the angel of the Lord continued passing on and stood in a narrow place where

(16) there was no way to turn to the right or to the left. [27]

(17) And the donkey saw the angel of the Lord and it lay

(18) down under Balaam. And Balaam's anger was kindled, and he struck

(19) the donkey with a staff. [28] And the Lord opened

(20) the mouth of the donkey, and it said to Balaam, 'What have I done

(21) to you that you have struck me these three times?' [29] And

(1) Balaam said to the donkey, 'Because you have done recklessness to me. If

(2) there were a sword in my hand I would have killed you by now!'

(3) [30] And the donkey said to Balaam, 'Lo, I

(4) am your donkey on which you have ever since your youth

(5) to this day. Was I ever accustomed to do so to you?' And

(6) he said, 'No.' [31] And the Lord opened the eyes

(7) of Balaam, and he saw the angel of the Lord standing

(8) in the way, and his sword drawn in his hand. And he bowed down and

(9) worshiped on his face. [32] And the

(10) angel of the Lord said to him, 'Why have you struck your donkey these

(11) three times? Lo, I went out to be an adversary against you, because

(12) your way is distorted before me. [33] And

(13) the donkey saw me and turned from me these three times.

(14) If it had not turned from before me, I would have killed you, too, by now

(15) and left it alive.' [34] And Balaam said

(16) to the angel of the Lord, 'I have sinned, because I did not know that you

(17) stand in the way against me. And now, if it seems bad in your eyes,

(18) let me go back to my place.' [35] And

(19) the angel of the Lord said to Balaam, 'Go with the men. And only

(20) the word that I shall speak to you, that you shall speak.' And

(21) Balaam went with the rulers of Balak. [36] And 
$253 \mathrm{r}^{\circ} \quad$ (1) ešitti Balaq ki keĺadi Bil'am da čyqty uturusuna anyn

(2) šaharyna Mo’avnyn ki čegi qatyna Arnonnun ki učunda

(3) ol čeknin. [יאמר [37] Da ajtty Balaq Bil'amġa muna

(4) ijḿa ijdim saja ünd́ama seni nek barmadyj maja

(5) kertid́an bolalmanmen $\{$ ויאמר . [38] Da sajtty\} Bil'am

(6) Balaqqa muna keldim eśad́a saja haligińa bolalma

(7) bolalyrmenmo sözĺaḿa ned́a ol söznü ki qojsa Tenri

(8) avzuma any sözlarmen. [ילך] [39] Da bardy Bil'am Balaq

(9) byla da keldilar Qirjat Hucotqa. [40] Da debeha

(10) etti Balaq syg்yr da qoj da ijdi Bil'amġa da ag̉alyq-

(11) larg̉a ki birǵasińa. [41] Da edi ert́anbylada

(12) da aldy Balaq ošol Bil'amny da mindirdi \{any\} Bamot Ba'alġa

(13) da kördü andan učun ol ulusnun.

Numbers 23

(13) ויאמר [1] Da

(14) ajtty Bil'am Balaqqa qondargiyn maja bunda jedi mizbeah-

(15) lar da hadirlagin maja bunda jedi tanalar da jedi qočqarlar.

(16) ויעש (2] Da qyldy Balaq ki nečik sözladi Bil'am da čyġardy

(17) Balaq da Bil'am biŕar tana da biŕar qočqar har mizbeaḥta.

(18] Da ajtty Bil'am Balaqqa turg̉un olaj qatyna

(19) da barajym šahat učralyr sözü Adonajnyn uturuma da

(20) nendij söz ki körgüsśa maja da anlatyrmen sajada

(21) da bardy jog̉ary. [4] Da učraldy malah Bil'amġa

$253 \mathrm{v}^{\mathrm{o}} \quad$ (1) da ajtty anar ošol jedi \{ol\} mizbeaḥlarny tüzüdüm da 'ola

(2) čyg̉ardym biŕar tana da biŕar qočqar har mizbeaḥta.

(3) (5) Da qojdu Adonaj söz avzuna Bil'amnyn da ajtty

(4) qajtqyn Balaqqa da bulaj sözlagin. וישב [6] Da qajtty anar

(5) da muna turady 'olasy qatyna ol da bar agalyqlary Mo'av-

(6) nyn. [7] Da kötürdü mašalyn da ajtty Aramdan kön-

(7) dardi meni Balaq biji Mo’avnyn tavlaryndan mizrahnynn ajtadog̉ač

(8) kelgin qargagagyn maja Ja'aqovnu da kelgin sökkün Jisra’elni.

(9) מה [8] Ne qarg̉ajym neni qarg̉amady Tenri da ne söǵajim

(10) neni sökḿadi Adonaj. כי [9] Ki bašyndan skalalarnyn köŕamen 
(1) Balak heard that Balaam was coming, and he went out to meet him $\quad 253 \mathrm{r}^{\mathrm{o}}$

(2) to a city of Moab that is on the border of Arnon, which is on the edge

(3) of the border. [37] And Balak said to Balaam, 'Lo,

(4) I sent to you to call you. Why did you not come to me?

(5) Am I indeed not able to honour you?' [38] And Balaam

(6) said to Balak, 'Lo, even though I have come to you. Now:

(7) will I be able to say any word? The word that God puts

(8) in my mouth: that I will speak.' [39] And Balaam went with Balak,

(9) and they came to Kiriath-Huzoth. [40] And

(10) Balak sacrificed oxen and sheep, and sent for Balaam and for the rulers

(11) that were with him. [41] And it was at dawn,

(12) and Balak took Balaam and brought him up to Bamoth-Baal,

(13) and he saw the |outer| edge of the people from there.

Numbers 23

(14) Balaam said to Balak, 'Build me here seven altars

[1] And

(15) and prepare me here seven oxen and seven rams.'

(16) [2] And Balak did as Balaam had spoken. And

(17) Balak and Balaam offered on every altar an ox and a ram.

(18) [3] And Balaam said to Balak, 'Stand by your burnt offering,

(19) and I will go. Maybe the Lord's word will come to meet me, and

(20) whatever word he shows me, I will tell you, too.'

(21) And he went up. [4] And the angel met Balaam,

(1) and he said to him, 'I have prepared seven altars and

(2) offered burnt offering: on each altar a bullock and a ram.'

(3) [5] And the Lord put a word in Balaam's mouth, and said,

(4) 'Return to Balak, and thus you shall speak.' [6] And he returned to him,

(5) and, lo, he stood by his burnt offering, he and all the rulers of Moab.

(6) [7] And he took up his parable, and said, 'Balak has led me from Aram,

(7) Moab's king from the mountains of the east, saying,

(8) 'Come, curse Jacob for me, and come, slander Israel!'

(9) [8] How shall I curse that which God has not cursed? And how shall I slander

(10) that which the Lord has not slandered? [9] Because from the top of the rocks I see 
(11) any da qajalardan közĺajmen any muna ulus jalġyz özü toh-

(12) tajdy da hanlyqlar arasyna sağyšlanmajdy. מי. [10] Kim

(13) bolalyr sanama topraġyn Ja'aqovnun da kim bolalyr haseb-

(14) Íama dörtünčü ülüšün Jisra’elnin ölǵaj žanym

(15) ölḿagi kibik tüzĺarnin da bolġaj sonġum anyn kibik.

(16) יויאמר (11] Da ajtty Bala[q] Bil'amga ne qyldyj maja

(17) qarg̉ama dušmanlarymny aldym seni da muna alġyšladyj

(18) alg̈yšlama. ויען [12] Da qaruv berdi Bil'am da ajtty

(19) muna ošol neki qojsa Adonaj avzuma any \{saqlarmen\} sözlaḿa.

(20) .יאמר Da ajtty anar Balaq barġyn endi birǵa-

(21) ḿa özǵa orunğa ki köŕarsen any andan ančaq

$254 \mathrm{r}^{\mathrm{O}} \quad$ (1) učun anyn köŕarsen da barysyn körḿassen da qarğag̉yn any

(2) maja andan. ויקחהו [14 Da aldy any tüzüńa qaravčular-

(3) nyn bašyna ol singirnin da qondardy jedi mizbeaḥlar da

(4) 'ola čyġardy biŕar tana da biŕar qočqar har mizbeaḥta.

(5) יויאמר Da [15 Dajtty\} Bil'am Balaqqa turgun bunda 'olaj qa-

(6) tyna da men učralyrmen bu jary. ויקר [16] Da uč-

(7) raldy malahy Adonajnyn Bil'amġa da qojdu söz avzu-

(8) na anyn da ajtty qajtqyn Balaqqa da bulaj sözlagin.

(9) ויבוא [17 Da keldi anar da muna turady 'olasy qaty-

(10) na da a $\{$ ġa\}lyqlary Mo’avnyn birǵasińa da ajtty anar

(11) Balaq ne sözladi Adonaj. וישא. [18] Da kötürdü maša-

(12) lyn da ajtty turg̉un Balaq da tynlag̉yn qulaq salġyn maja

(13) e uvlu Cipornun. לא. [19] Tüvüldü kiši kibik

(14) Tenri ki aldag̉aj da adam uvlu kibik ki fašman et-

(15) kaj ol Lajtsa da qylmasmodu da sözlaśa ${ }^{22}$ da

(16) _[qajjam et]mastimodu ${ }^{13}$ any. הנה. [20] Muna alğyšla-

(17) ma aldym keńaš da alğyšlag̉anny da qajtarlaman-

(18) men any. לא. 21] Baqmajdy avanlyqny Ja'aqovda da

(19) körmajdi qynġyrlyqny Jisra’eld́a bolušluğu Adonaj

\footnotetext{
${ }^{1}$ TKow.o1: Balaq; unvocalized text. | H: Balaq. | C: Balaq. ${ }^{2} \mathrm{~K}$ : ol sözlaśa da qylmasmodu da ajtsa; a scribal error; the word order was corrected by the copyist. $\quad{ }^{3}$ TKow.or: qajjam etmesmodu; unvocalized text. | H: qajjam etmestimo. | C: turg̈uzmasmydyr.
} 
(11) him, and from the rocks I look out for him: lo, a people dwelling alone

(12) and not reckoning itself among the kingdoms. [10] Who

(13) can count the dust of Jacob, and who can number

(14) the fourth part of Israel? May my soul die

(15) the death of the upright, and let my last end be like his!'

(16) [11] And Balak said to Balaam, 'What have you done to me?

(17) I took you to curse my enemies, and, lo, you have blessed them!'

(18) [12] And Balaam answered and said,

(19) 'Lo, I will watch out to say that which the Lord has put in my mouth.'

(20) [13] And Balak said to him, 'Come, now, with me

(21) to another place from which you may see them.

(1) You will see only the |outer| edge of them, and you will not see them all. And curse them

(2) from there for me.' [14] And he brought him ${ }_{\text {L }}$ to the field of watchmen ${ }^{1235}$,

(3) ${ }_{4}$ to the top of the summit ${ }^{1236}$, and he built seven altars and

(4) offered burnt offering: on each altar an ox and a ram.

(5) [15] And he said to Balak, 'Stand here by your burnt offering,

(6) and I will meet the Lord yonder.' [16] And

(7) the angel of Lord met Balaam and put a word in his mouth

(8) and said, 'Return to Balak, and thus you shall speak.'

(9) [17] And he came to him, and, lo, he stood by his burnt offering,

(10) and the rulers of Moab with him. And Balak said to him,

(11) 'What has the Lord spoken?' [18] And he took up his

(12) parable, and said, 'Rise up, Balak, and hear. Hearken to me,

(13) oh you, son of Zippor: [19] God is not like a man,

(14) that he should lie, neither like the son of man, that he should repent.

(15) Has he said, and will he not do it? Or has he spoken, and

(16) will he not consolidate it? [20] Lo, I have taken

(17) an advice to bless, and the one who is blessed, and I cannot give it back.

(18) [21] He has not spotted wickedness in Jacob,

(19) and he has not seen fault in Israel. The Lord God's help

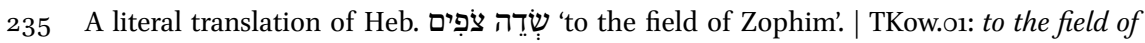
watchmen. | H: to the field of watchmen.|C: to the field of watchers. | R: to the field of watchers.

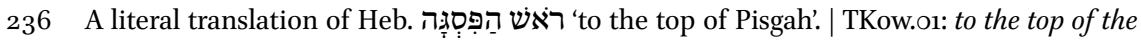
summit. | H: to the top of the summit.|C: to the top of the rock. | R: to the top of the rock. 
(20) Tenrisinin birǵasińa da qyčqyrmag̉y bijnin anda.

(21) אל [22] Tenri čyğaruvču alarny Micrid́an küčü kibik

$254 \mathrm{v}^{\mathrm{o}} \quad$ (1) karkedennin ${ }_{\llcorner}$küč berdi anar ki bolalmadylar dušmanlary anyn

(2) kiplanḿa alnynda anyn ${ }^{11}$. כי. [23] Ki joḥtu synčylamaq

(3) Ja'aqovda da joḥtu qusnačylyq etḿak Jisra’eld́a „ne vaḥt-

(4) ta kíaśálar bilmáa keĺasi nerśalarni ${ }^{12}$ ajtylady Ja'aqov-

(5) ġa da Jisra’elǵa ${ }_{L}$ navi ašyra ${ }^{13}$ ne qylar Tenri. הן. [24]

(6) Muna ulus tiši arslan kibik toḥtajdy da arslan-

(7) kibik kötürüladi jatmajdy neginč́a ašag̉aj jyrtuv

(8) da qanyn qyranlarnyn ičkaj. [25 Da ajtty Balaq

(9) Bil'amġa dag்yn qarğama qarğamag்yn ani dag̉yn alġyšlamada

(10) alġyšlamag̉yn any. [26] Da qaruv berdi Bil'am da

(11) ajtty Balaqqa muna sözĺaḿadimmo saja ajtadog̉ač

(12) barča neki sözlaśa Adonaj any qylarmen. ויאמר [27] Da [ajtty]

(13) Balaq Bil'amġa kelgin endi alajym seni özǵa orunġa

(14) šahat tüz körünür 'enajatlarind́a ol Tenrinin da

(15) qarg̉aġyn any maja andan. ויקח. [28] Da aldy Balaq ošol

(16) Bil'amni bašyna ol Po'ornun ol körüńadoǵan alnyna

(17) ol Ješimonnun ${ }^{5}$. יויאמר [29] Da ajtty Bil'am Balaqqa

(18) qondarğyn maja bunda jedi mizbeahlar da hadirlangin maja bun-

(19) da jedi tanalar da jedi qočqarlar. [30] Da qyldy

(20) Balaq ki nečik ajtty Bil'am da 'ola čyg̉ardy biŕar tana

(21) da biŕar qočqar har mizbeaḥta.

Numbers 24

וירא . [1] Da kördü

$255 \mathrm{r}^{\mathrm{o}} \quad$ (1) Bil'am ki jahšy̌dy ‘enajatlarynda Adonajnyn alğyšlama ošol

\footnotetext{
${ }^{1}$ Interpretative addition to the standard text. $\quad{ }^{2}$ Interpretative addition to the standard text.

${ }^{3}$ Interpretative addition to the standard text. $\quad{ }^{4} \mathrm{~K}$ : deest; a scribal error.|TKow.o1: ajtty; unvocalized text. | H: ajtty. | C: ajtty. ${ }^{5}$ A mistranslation. | TKow.o1: Ješimonnun; unvocalized text. | H:

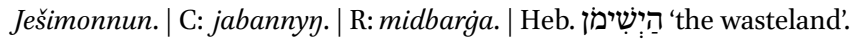


(20) is with him, and the shout of a king is in it.

(21) [22] God who brought them out from Egypt ${ }_{L}$ has

(1) given him strength ${ }^{7237}$ like the strength of a rhinoceros, ${ }^{\text {so }}$ that his $254 \mathrm{~V}^{\mathrm{o}}$ enemies were not able

(2) to grow stronger ${ }^{1238}$. [23] For there is no divination

(3) Lagainst Jacob ${ }^{1239}$ and there is no witchcraft ${ }_{\text {L }}$ against Israel ${ }^{1240 \text {, }}$ ¿ when

(4) they wish to know the future matters. ${ }^{1241}$ It is said to Jacob

(5) and to Israel, ${ }_{L}$ through a prophet, ${ }^{1242}$ "What will God do?". [24]

(6) Lo, the people dwell like a lioness, and

(7) they lift up themselves like a lion. It does not lie down until it eats the prey

(8) and drinks the blood of the slain.' [25] And Balak said

(9) to Balaam, 'Do not curse them nor even bless

(10) them at all.' [26] But Balaam answered and

(11) said to Balak, 'Did I not speak to you, saying,

(12) "All that the Lord speaks, that I will do?"' [27] And

(13) Balak [said] to Balaam, 'Come now, I will take you to another place.

(14) Maybe it will seem honest in the eyes of God, and

(15) you shall curse them from there for me.' [28] And Balak took

(16) Balaam to the top of Peor that looks toward

(17) Jeshimon ${ }^{243} \cdot$ [29] And Balaam said to Balak,

(18) 'Build me here seven altars and prepare me

(19) here seven oxen and seven rams.' [30] And

(20) Balak did as Balaam had said and offered burnt offering: an ox

(21) and a ram on each altar.

Numbers 24

[1] And

(1) Balaam saw that it was good in the eyes of the Lord to bless

237 An interpretative addition to Num 23:22, cf. Num 24:8.

238 An interpretative addition to Num 23:22.

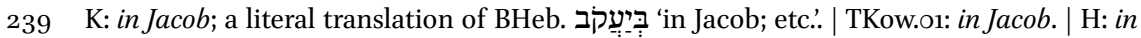
Jacob. | C: in Jacob.

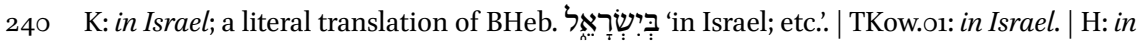
Israel. | C: in Israel.

241 An interpretative addition to Num 23:23.

242 An interpretative addition to Num 23:23.

243 A mistranslation based on interpreting Heb. הַיְְשימימן 'the wasteland' as a place name. 
(2) Jisra’elni da barmady özǵa vaḥtlaj bu vaḥtta uturusu-

(3) na synčylamaqlarnyn da qojdu ol midbarg̉a jüzlari.

(4) וישא [2] Da kötürdü Bil'am ošol közlarin da kör-

(5) dü ošol Jisra’elni toḥtajdog̉anny ševetlarisajyn da boldu

(6) anyn üstüńa naviligi Adonajnyn. [3] Da

(7) kötürdü mašalyn da ajtty alaj ajtady Bil'am uvlu

(8) Bơornun da alaj ajtady ol jigit ol ačyq közlü.

(9) נאם [4] Alaj ajtady tynlavču ajtmaqlaryn Tenrinin

(10) körümün küčlü Tenrinin köŕadi tüš́adi anyn üstü-

(11) náa navilik da anyn üčün bolady ačyq közlü. מה. [5]

(12) Ne jaḥšydylar čatyrlaryj senin e Ja'aqov toḥtar orunlaryj

(13) senin e Jisra’el. כנחלים. [6] Öźanlar kibik qajyrylġan-

(14) dylar bagglar kibik öźan qatyna [s] andallarny ${ }^{1}$ kibik ornatty

(15) Adonaj erezĺarni kibik suvlar qatyna. יז. [7] Ag̉ar suv inč-

(16) ka butaqlaryndan da urlugu anyn köp suvlarda anlyqby-

(17) la bijikŕak bolur Aggag̉dan biji anyn da kötürülür bijligi

(18) anyn. אל [8] Küčlü Tenridi čyggaruvču alarny Micridan kü-

(19) čükibik karkedennin ${ }_{\perp}$ küč berdi anar ${ }^{12}$ ol quvatbyla

(20) tavusur hananlyqlarny dušmanlaryn özünün da süv́aklarin

(21) alarnyn qavšatyr da oqlarybyla keśar. כרע. [9] Čök-

$255 \mathrm{~V}^{\mathrm{o}} \quad$ (1) tü jatty arslankibik da tiši arslannykibik kim turğu-

(2) zalyr any alġyšlavčularyj alġyšlydy da qarg̉avčularyj qarg்yšlydy.

(3) ויחר [10] Da qabundu ačuvu Balaqnyn Bil'am üstüńa

(4) da qaqty ošol uvučlaryn da ajtty Balaq Bil'am-

(5) ġa qarğama dušmanlarymny aldym seni da muna alğyš-

(6) ladyj alğyšlama bu üč keŕatĺar. [11] Da haligi-

(7) ńa qačqyn özüja ornuja ajttym syjlama syjlar-

(8) men seni da muna ajady seni Adonaj syjdan. [יאמר [12]

(9) Da ajtty Bil'am Balaqqa muna ajttym daġyn elčilarija

(10) ki ijdij maja ajtadog̉ač. אם. [13] Eger berśa maja

(11) Balaq tolu üvün kümüš da altyn bolalmanmen ašma ošol

(12) sözün Adonajnyn qylma jaḩ̌̌yny jemeśa jamanny öz köl-

(13) nümd́an ančaq neki sözlaśa Adonaj any sözĺarmen.

(14) [ועתה [14] Da haligińa muna men baramen ulusuma kel

\footnotetext{
${ }^{1} \mathrm{~K}$ : čandallarny; a scribal error. | TKow.o1: čandallarny corrected into sandallarny; unvocalized text. | H: sandallarny. | C: otlar. ${ }^{2}$ Interpretative addition to the standard text.
} 
(2) Israel, and this time he did not go as on other times to meet

(3) divinations. And he set his face toward the wilderness.

(4) [2] And Balaam raised his eyes and he saw

(5) Israel camping according to its tribes, and

(6) the prophecy of the Lord came on him. [3] And

(7) he took up his parable, and said, 'Thus says Balaam, son

(8) of Beor, and thus says the young man whose eyes are open:

(9) [4] The one who heard the speeches of God says thus,

(10) he sees the vision of the mighty God, prophecy falls on him

(11) and therefore his eyes are open. [5]

(12) How good are your tents, oh Jacob, and your places of dwelling,

(13) oh Israel! [6] They turn like rivers,

(14) the Lord has planted them like gardens by a river, like sandalwood trees,

(15) like cedar trees by the waters. [7] Water will flow

(16) from their delicate branches, and his seed is in many waters,

(17) and by that his king will be higher than Agag, and his kingdom will be exalted.

(18) [8] A strong God is he who brought them out from Egypt,

(19) ${ }_{L}$ he has given him strength ${ }^{1244}$ like the strength of a rhinoceros. With that power

(20) he will consume kingdoms, his enemies, and

(21) he will destroy their bones, and he will cut them with arrows. [9]

(1) He knelt, laid down as a lion, and as a lioness; who

(2) will be able to stand him up? Blessed are those who bless you, and cursed are those who curse you.'

(3) [10] And Balak's anger was kindled against Balaam,

(4) and he struck his hands together. And Balak said to Balaam,

(5) 'I took you to curse my enemies, and, lo, you have

(6) blessed them these three times. [11] And now

(7) flee to your own place. I said, "I would certainly honour

(8) you," but, lo, the Lord has begrudged honour to you.' [12]

(9) And Balaam said to Balak, 'Lo, I said also to your envoys

(10) whom you sent to me, saying, [13] "Though Balak were to give me

(11) his house full of silver and gold, I would not be able to go beyond the

(12) word of the Lord, to do good or bad of my own heart.

(13) And only what the Lord speaks: I will speak that."

(14) [14] And now, lo, I go to my people. Come,

244 An interpretative addition to Num 24:8, cf. Num 23:22. 
(15) keńaš berajim saja nečik kečinḿa haligińa ki ol iš-

(16) Íar neki qylar saja ol ulus ošpu da ulusuja senin

(17) ol barysy bolur sonġusunda ol künlarnin. [15 ]

(18) Da kötürdü mašalyn da ajtty alaj ajtady Bil'am uv-

(19) lu Bocornun da alaj ajtady ol jigit ol ačyq közlü.

(20) נאם [16] Alaj ajtady ešitüvčü ajtmaqlaryn Tenrinin

(21) da bilüvčü bilüvün jog̉arg̉y Tenrinin körümün küčlü Tenri-

$256 \mathrm{r}^{\mathrm{o}} \quad$ (1) nin köŕadi tüš́adi anyn üstüńa navilik da anlyqby-

(2) la bolady ačyq közlü. אראנו. [17] Köra\{r\}men any da tüvül

(3) haligińa közlarmen anyda tüvül juvuq zamadan basar jolduz

(4) Jacaqovdan da turar ševet Jisra’eld́an da keśar qyryjlaryn

(5) Mo’avnyn da aḥtaryr bar ulanlaryn Šetnin. והיה [18]

(6) Da $\{[\text { bo }] l u r\}^{1}$ Edom taspolmaqqa da bolur Se ir meŕaslikka

(7) dušmanlaryna özünün da Jisra’el qylar tuvušluq.

(8) וירד [19] Da erkĺanir Ja'aqovdan da tasetar qaldyqny

(9) šahardan. [20] Da kördü ošol 'Amaleqni da kötür-

(10) dü mašalyn da ajtty [i]llki ${ }^{2}$ hanlyqlarnyn 'Amaleq da song̉usu

(11) anyn taspolmaqqady. [21] Da kördü ošol ol

(12) Qenini da kötürdü ma[š] alyn ${ }^{3}$ da ajtty kip orundady

(13) olturušuj da qojduj skalada hujajny. כי [22] Ki

(14) kertid́an bolur taspolmaqqa Qajin neginča Ašur jesir

(15) $\{$ et\}kaja seni. [וישא.] [23] Da kötürdü mašalyn da ajtty

(16) vaj kim tiri bolur artyq ček qojġanyndan Tenrinin.

(17) וצים [24] Da gé́apĺar kelirĺar Kitimd́an da qyjnarlar

(18) Ašurnu da qyjnarlar 'Everni da daġyn olda bolur tas-

(19) polmaqqa. ויקם [25] Da turdu Bil'am da bardy da qajtty

(20) ornuna da daġyn Balaq bardy joluna.

Numbers 25

(21) ti Jisra’el Šitimd́a da bašlady ol ulus azma qyzlaryna

$256 \mathrm{v}^{\mathrm{o}}$ (1) Mo’av\{nyn\}. [תקראן. [2] Da ünd́adilar ulusnu debeḥalaryna

(2) abaqlarynyn da ašadylar ol ulus da bašurdular abaqlaryna

\footnotetext{
${ }^{1}$ TKow.o1: bolur; unvocalized text. | H: bolur. | C: bolur. $\quad{ }^{2}$ K: elki; a scribal error. | TKow.o1: unvocalized text. | H: ilki. | C: ilki. ${ }^{3}$ TKow.o1: mašalyn; unvocalized text. | H: mašalyn. | C: mašalyn. $\quad{ }^{4}$ The beginning of this word was inserted by another hand. | TKow.or: etkej; unvocalized text. | H: etkej. | C: etär.
} 
(15) I will advise you how to act now, because the deeds

(16) that this people will do to you and to your people:

(17) all that will happen in the latter days.' [15]

(18) And he took up his parable, and said, 'Thus says Balaam,

(19) son of Beor, and thus says the young man whose eyes are open,

(20) [16] The one who heard the speeches of God says thus,

(21) the one who knows the knowledge of the $\mid$ most $\mid$ high God; he

(1) sees the vision of the mighty God, prophecy falls on him and there- $\quad 256 \mathrm{r}^{\circ}$ fore

(2) his eyes are open. [17] I will see him, but not

(3) now. I will view him, but not soon. A star will step

(4) from Jacob, and a tribe will rise out of Israel and will cut the edges

(5) of Moab and will break down all the sons of Sheth. [18]

(6) And Edom will perish, and Seir will be a possession

(7) for its own enemies, and Israel will do a remarkable thing.

(8) [19] And one from Jacob will rule and will destroy that remains

(9) of the city.' [20] And he saw Amalek, and he took up

(10) his parable, and said, 'Amalek was the first of the kingdoms, but his end

(11) |arrives $\mid$ at destruction.' [21] And he saw the

(12) Kenites and took up his parable, and said, 'In a strong place is

(13) your dwelling place, and you put your nest in a rock. [22] But, indeed,

(14) Kain will be for destruction, until Asshur shall take

(15) you captive.' [23] And he took up his parable, and said,

(16) 'Woe, who will live more than the borders that God set him?

(17) [24] And ships will come from Kittim and will afflict

(18) Asshur and will afflict Eber, and he, too, will

(19) be for destruction. [25] And Balaam rose and went, and he returned

(20) to his place. And Balak, too, went his way.

Numbers 25

[1] And

(21) Israel stayed in Shittim, and the people began to fall into harlotry with the daughters

(1) of Moab. [2] And they called the people to the sacrifices

(2) of their gods, and the people ate and worshiped to their gods. 
(3) alarnyn. [יצמד [3] Da qošuldu Jisra’el qullugiuna Ba'al Po'or-

(4) nun da qabundu ačuvu Adonajnyn Jisra’eld́a. ויאמר [4] Da

(5) ajtty Adonaj Mošeǵa alġyn ošol bar ag̉araqlaryn ol ulus-

(6) nun birǵa da tirilaj qazg̉yn jerǵa ${ }_{\perp}$ alnynda Adonaj\{nyn $\}$ ol

(7) qošuluvčularny qullugiuna Ba'al Pocornun ${ }^{11}$ da bolsunlar alnyn-

(8) da ol qujašnyn da qajtyr qahir ačuvu Adonajnyn Jisra’el-

(9) dan. ויאמר d5 Da ajtty Moše töŕačílarińa Jisra’elnin

(10) öltürüjüz har kiši éranlarin özünün ol qošulġanlar-

(11) ny Bacal Po'org̀a. והנה. [6] Da muna kiši ulanlaryndan

(12) Jisra’elnin keldi da juvuttu qaryndašlaryna özünün o-

(13) šol ol Midjanly qatynny közlarič́a Mošenin da közlari-

(14) ča bar šymatynyn ulanlarynyn Jisra’elnin da alar jylaredilar

(15) ešigind́a ohel mo'ednin. וירא. [7] Da kördü Pinaḥas

(16) uvlu El'azarnyn uvlunun Aharonnun ol kohennin da turdu or-

(17) tasyndan ol žymatnyn da aldy süngü qoluna. [8 [8 ]

(18) Da keldi artyndan Jisra’el kišinin ol hužuraġa da čančty

(19) ošol eksilarind́a ošol Jisra’el kišini da ošol ol

(20) qatynny aqšynyna da qaldy ol qyranč ulanlaryndan Jisra’elnin.

(21) ויהיו [9] Da edilar ol ölǵanĺar qyrančbyla igirmi

$257 \mathrm{r}^{\mathrm{o}} \quad$ (1) dört min.

פרשת פינחס (2) (2) (2)

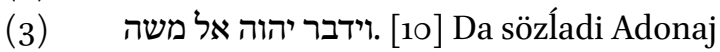

(4) Mošeǵa ajtadoğač. פינחס [11] Pin-

(5) has uvlu El'azarnyn uvlunun Aharonnun ol kohennin qaj-

(6) tardy ošol qahirimni ulanlary üstünd́an Jisra’el-

(7) nin künülaǵanind́a ošol künülügümnü ortalaryn-

(8) da alarnyn da tavusmadym ošol ulanlaryn Jisra’elnin kü-

(9) nülügüm byla. לכן [12] Anyn üčün ajtqyn muna men

(10) beŕamen anar ošol šertimni bazlyq byla. והיתה. [13]

(11) Da bolur anar da urlugguna anyn özünd́an sortun

(12) šerti ömürlük kohenliknin anyn üčün ki künüladi

(13) Tenri\{si\} üčün da bošatlyq qoldu ulanlary üčün Jisra’el-

(14) nin. ושם [14] Da aty ol Jisra’el kišinin ol [ö]ltü-

\footnotetext{
${ }^{1}$ Interpretative addition to the standard text.
} 
(3) [3] And Israel joined the service of Baal of Peor.

(4) And the anger of the Lord was kindled against Israel. [4] And

(5) the Lord said to Moses, "Take all the elders of the people

(6) together and ${ }_{L}$ bury them alive ${ }^{1245}{ }_{L}$ before the Lord, the ones

(7) who joined the service of Baal of Peor ${ }^{1246}$, and they shall be in

(8) the sun, and the furious anger of the Lord will be turned away

(9) from Israel.' [4] And Moses said to the judges of Israel,

(10) 'Each of you kill those of his men who were joined

(11) to Baal of Peor.' [6] And, lo, one man of the children

(12) of Israel came and brought to his brothers

(13) a Midianite woman in the sight of Moses and in the sight

(14) of all the congregation of the children of Israel, and they wept

(15) before the door of the tent of meeting. [7] And Phinehas,

(16) son of Eleazar, son of Aaron, the priest, saw, and he rose

(17) from among the congregation and took a spear in his hand. [8]

(18) And he came after the man of Israel to the chamber, and he pierced

(19) both of them, the man of Israel and the

(20) woman, to her stomach. So the plague was stayed from the children of Israel.

(21) [9] And those who died by the plague were twenty-

(1) -four thousand.

(2) Parashat Pinchas

(3) [10] And the Lord spoke

(4) to Moses, saying, [11] 'Phinehas,

(5) son of Eleazar, son of Aaron, the priest,

(6) has turned my fury from the children of Israel,

(7) in that he was jealous for my jealousy among

(8) them, so that I did not consume the children of Israel

(9) in my jealousy. [12] Therefore say, "Lo, I

(10) give to him my covenant of peace. [13]

(11) And it will be his and his offspring's after him,

(12) the covenant of an eternal priesthood, because he was jealous

(13) for his God, and he asked for atonement for the children of Israel."'

(14) [14] And the name of the Israelite man who was killed,

245 An interpretative translation or a mistranslation of Heb. 1ְi 'and hang |them|'.|TKow.o1: bury alive; different wording. | H: bury them alive. | C: hang them.

246 An interpretative addition to Num 25:4. 
(15) rülǵanni ${ }^{1}$ ki öltürüldü $\{o l\}^{2}$ Midjanly qatyn byla Zimri uv-

(16) lu Salu’nun nasisi üvünün atanyn ševetinin Šim'onnun.

(17) ושם (15] Da aty ol \{[Midjan]ly\} ${ }^{3}$ qatynnyn ol öltürülǵannin Kazbi

(18) qyzy Curnun agaaragyynyn ummalarnyn üvünün atanyn Midjan-

(19) da edi ol. [16] Da sözladi Adonaj Mošeǵa

(20) ajtadoġač. צרור. [17] Qysyqlyq etkin ol Midjanlylarg̉a

$257 \mathrm{v}^{0}$ (1) da qyryjyz alarny. [18] Ki qysyqlyq etadilar alar sizǵa

(2) jaman sağyšlarybyla özlarinin ki jaman saġyš ettilar sizǵa

(3) išibyla Po'ornun da išibyla Kazbinin qyzynyn nasisinin

(4) Midjannyn tuvduqlarynyn ol öltürǵannin ol qyranč künün-

(5) da iši üčün $P^{\prime} o r n u n$.

Numbers 26

(6) tan sortun da ajtty Adonaj Mošeǵa da El'azarğa uv-

(7) luna Aharonnun ol kohennin ajtadoġač. שאו. [2] Alyjyz

(8) ošol sanyn bašynyn bar žymatynyn ulanlarynyn Jisra’elnin igir-

(9) mi jaštan da jog̉arraq üvüsajyn atalarynyn bar čyg்uvču čerüv-

(10) ǵa Jisra’eld́a. וידבר [3] Da sözladi Moše da El-

(11) 'azar ol kohen alarg̉a jylġalyqlarynda Mo'avnyn Jardeni qatyna

(12) Jerehonun ajtadog̉ač. מבן. [4] Igirmi jaštan da jog̉ar-

(13) raq ki nečik bujurdu Adonaj Mošeǵa da ulanlaryna

(14) Jisra’elnin ol čyğuvčularg̉a jerind́an Micrinin. ראובן. [5]

(15) Ru'uven tunġuču Jisra'elnin ulanlary Ru’uvennin Hanohnun u-

(16) ruvu ol Ḥanohi Falu'nun uruvu ol Falu'i. לחצר. [6]

(17) Ḥecronnun uruvu ol Ḥecroni Karminin uruvu ol Karmi.

(18) [7 Bulardylar uruvlary ševetinin ol Ru'uvennin da

(19) edilar sanalġanlary alarnyn qyrq üč min da jedi jüz da

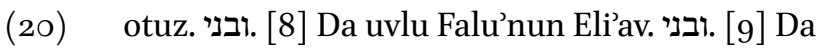

(21) ulanlary Eli'avnyn Nemu'el da Datan da Aviram oldu Datan

$258 \mathrm{r}^{\circ} \quad$ (1) da Aviram ünd́almüšĺari ol క̌ymatnyn ki qavġalaš-

(2) tylar Moše byla da Aharon byla žymatynda Qoraḥnyn qavğa-

${ }^{1} \mathrm{~K}$ : ültürülǵanni; a scribal error. | TKow.o1: unvocalized text. | H: vatylġan. | C: urulgan. $\quad{ }^{2}$ Marginal insertion by another hand. | TKow.o1: ol; unvocalized text. | H: ol. | C: ol. $\quad{ }^{3}$ TKow.o1: Midjanlynyn; different wording; unvocalized text. | H: Midjanly. | C: Midjanly. 
(15) who was killed with $\{$ the $\}$ Midianite woman, was Zimri,

(16) son of Salu, prince of a fathers' house of the tribe of the Simeon.

(17) [15] And the name of the [Midianite] woman who was killed was Cozbi,

(18) daughter of Zur, the superior of people of a father's house in Midian.

(19) [16] And the Lord spoke to Moses,

(20) saying, [17] 'Oppress the Midianites

(1) and break them. [18] Because they oppressed you

(2) with their evil thoughts, with which they have done evil thoughts to you

(3) in the matter of Peor, and in the matter of Cozbi, the daughter of a prince

(4) of Midian, their sister who was killed in the day of the plague

(5) over the matter of Peor.'

Numbers 26

(6) and the Lord spoke to Moses and to Eleazar,

(7) son of Aaron, the priest, saying, [2] 'Take

(8) the sum of all the congregation of the children of Israel,

(9) from twenty years old and upward, by the house of their fathers, everyone going out to the army

(10) in Israel.' [3] And Moses and Eleazar,

(11) the priest, spoke with them in the steppes of Moab by Jordan

(12) of Jericho, saying, [4] 'From twenty years old and upward,'

(13) as the Lord commanded Moses and the children

(14) of Israel, who went out from the land of Egypt. [5]

(15) Reuben, the firstborn of Israel; the children of Reuben: Of Hanoch:

(16) his family — the Hanochites. Of Pallu: his family—the Palluites. [6]

(17) Of Hezron: his family — the Hezronites. Of Carmi: his family—the Carmites.

(18) [7] These are the families of the tribe of Reubenites, and

(19) they that were numbered of them: forty-three thousand and seven hundred and

(20) thirty. [8] And the son of Pallu: Eliab. [9] And

(21) the sons of Eliab: Nemuel, and Dathan, and Abiram. These are the Dathan

(1) and Abiram, the representatives of the congregation, who quarrelled $258 \mathrm{r}^{\circ}$

(2) with Moses and with Aaron in the congregation of Korah, 
(3) lašqanlarynda alnynda Adonajnyn. [10] Da ač-

(4) ty ol jer ošol avzun da juttu alarny da ot ör-

(5) tadi ošol Qorahnny ölǵand́a ol žymat örtaǵan-

(6) d́a ol ot ol eki jüz da enli kišini da boldular

(7) neska. ובני [11] Da uvullary Qorahnyn ölmáadilar.

(8) בני (12] Ulanlary Šimonnun uruvlary sajyn Nemu'el-

(9) nin uruvu ol Nemu'eli Jaminnin uruvu ol Jamini Jahin-

(10) nin uruvu ol Jahini. לזרח [13] Zerahnnyn uruvu ol

(11) Zarhi Ša’ulnun uruvu ol Ša’uli. אלה. [14] Bulardylar

(12) uruvlary ol Šimonnun igirmi eki min da eki

(13) jüz. בני (15] Uvullary Gadnyn uruvlarysajyn Cefonnun

(14) uruvu ol Cefoni Ḥaginin uruvu ol Hagi Šuninin u-

(15) ruvu ol Šuni. לאזני [16] Azninin uruvu ol Azni

(16) 'לארוד. [17] Arodnun uruvu

(17) ol Arodi Ar'elinin uruvu ol Ar'eli. אלאל [18] Bular-

(18) dylar uruvlary uvullarynyn Gadnyn sanalganlarysajyn qyrq

(19) min da beš jüz. בני. [19] Uvullary Juhudanyn 'Er da

(20) Onan da öldü 'Er da Onan jerind́a Kena’annyn.

(21) יויהיו Da 20 [20 Dalar uvullary Juhudanyn uruvlarysajyn

$258 v^{\circ} \quad$ (1) Šelanyn uruvu ol Šelani Perecnin uruvu ol Parci Zeraḥ-

(2) nin uruvu ol Zarhịi. [יהיו [21] Da ediĺar uvullary Perec-

(3) nin Ḥecronnun uruvu ol Ḥecroni Ḥamulnun uruvu ol

(4) Hamuli. אלה [22] Bulardylar uruvlary Juhudanyn sanalganlary

(5) sajyn jetmiš alty min da beš jüz. בנלה [23] Uvullary

(6) Jissaharnyn uruvlarysajyn Tola'nyn uruvu ol Tolaci da Puva-

(7) nyn uruvu ol Puni. [24] [24] Jašuvnun uruvu ol Jašuvi Šimron-

(8) nun uruvu ol Šimroni. אלה. [25] Bulardylar uruvlary

(9) Jissaharnyn sanalġanlary sajyn altymyš dört min da üč

(10) jüz. בני [26] [Uvullary\} Zevulunnun uruvlary sajyn Serednin uruvu ol 
(3) when they quarrelled before the Lord, [10] And

(4) the earth opened its mouth, and swallowed them up,

(5) and consumed Korah, when that congregation died,

(6) when the fire consumed two hundred-fifty men: and they became

(7) a sign. [11] But the children of Korah died not.

(8) [12] The sons of Simeon by their families: Of Nemuel:

(9) his family — the Nemuelites. Of Jamin: his family—the Jaminites. Of Jachin:

(10) his family — the Jachinites. [13] Of Zerah: his family—the

(11) Zerahites. Of Shaul: his family — the Shaulites. [14] These are

(12) the families of the Simeon: twenty-two thousand and two

(13) hundred. [15] The children of Gad by their families: Of Zephon:

(14) his family — the Zephonites. Of Haggi: his family—the Haggites. Of Shuni:

(15) his family - the Shunites. [16] Of Ozni: his family — the Oznites.

(16) Of Eri: his family — the Erites. [17] Of Arod: his family-

(17) the Arodites. Of Areli: his family — the Arelites. [18] These

(18) are the families of the children of Gad by those that were numbered of them: forty

(19) thousand and five hundred. [19] The sons of Judah: Er and

(20) Onan. And Er and Onan died in the land of Canaan.

(21) [20] And the sons of Judah by their families were:

(1) Of Shelah: his family—the Shelanites. Of Perez: his family—the Perezites. Of Zerah:

(2) his family - the Zerahites. [21] And the sons of Perez were:

(3) Of Hezron: his family — the Hezronites. Of Hamul: his family— the

(4) Hamulites. [22] These are the families of Judah by those that were numbered:

(5) seventy-six thousand and five hundred. [23] The sons

(6) of Issachar by their families: Of Tola: his family—the Tolaites. Of Puvah:

(7) his family — the Punites. [24] Of Jashub: his family—the Jashubites. Of Shimron:

(8) his family - the Shimronites. [25] These are the families

(9) of Issachar by those that were numbered: sixty-four thousand and three

(10) hundred. [26] The sons of Zebulun by their families: Of Sered: his family-the 
(11) Sardi Elonnun uruvu ol Eloni Jaḥle'elnin uruvu ol

(12) Jahle’eli. אלה [27] Bulardylar uruvlary ševetinin Zevulunnun

(13) sanalġanlary sajyn altymyš min da beš jüz. בני [28] Uvul-

(14) lary Josefnin uruvlarysajyn Menaše da Efrajim. [29] U-

(15) vullary Menašenin Maḩirnin uruvu ol Mahiri da Maḩir

(16) tuvdurdu ošol Gil'adny Gil'adnyn uruvu ol Gil'adi.

(17) אלה (30] Bulardylar uvullary Gil'adnyn I'ezernin uruvu

(18) ol I'ezeri Ḥeleqnin uruvu ol Ḥelqi. ואלה (31] Da

(19) Asri’elnin uruvu ol Asri’eli da Šehemnin uruvu ol

(20) Šihmi. ושמידע. [32] Da Šemida'nyn uruvu ol Šemidaci

(21) da Hefernin uruvu ol Ḥeferi. [33] Da Celafahadğa

$259 \mathrm{r}^{\mathrm{o}} \quad$ (1) uvluna Ḥefernin joġedilar anar uvullar ki ančaq qyzlar

(2) da aty qyzlarynyn Celafạ̣adnyn Maḥla da No'a Hağla Milka

(3) da Tirca. אלה [34] Bulardylar uruvlary Menašenin da

(4) sanalġanlary alarnyn enli eki min da jedi jüz. אלה . [35]

(5) Bulardylar uvullary Efrajimnin uruvlarysajyn Šutelaḥnin

(6) uruvu ol Šutelaḥi Behernin uruvu ol Bahri Taḥannyn

(7) uruvu ol Taḥani. ואלה. [36] Da bulardylar uvullary Šu-

(8) telahnyn Erannyn uruvu ol Erani. אלדה. [37 Bulardylar

(9) uruvlary uvullarynyn Efrajimnin sanalganlarysajyn otuz

(10) eki min da beš jüz bulardylar ulanlary Josef\{nin\} uruvlary

(11) sajyn. בני (38] Uvullary Binjaminnin uruvlarysajyn Bela'nyn

(12) uruvu ol Bal'i Ašbelnin uruvu ol Ašbeli Ahiramnyn

(13) uruvu ol Ahịirami. לשפופם. [39] Šefufamnyn uru-

(14) vu ol Šufami Ḥufamnyn uruvu ol Ḥufami. [40] Da

(15) edilar uvullary Bela'nyn Ard da Na'aman Ardnyn uruvu

(16) ol Ardi Na'amannyn uruvu ol Nacami. אלה. [41 Bular-

(17) dylar uvullary Binjaminnin uruvlarysajyn da sanalganlary alar-

(18) nyn qyrq beš min da alty jüz. אלה. [42] Bulardylar uvul- 
(11) Seredites. Of Elon: his family—the Elonites. Of Jahleel: his family— the

(12) Jahleelites. [27] These are the families of the tribe of Zebulun

(13) by those that were numbered: sixty thousand and five hundred. [28]

(14) The sons of Joseph by their families: Manasseh and Ephraim. [29]

(15) The sons of Manasseh: Of Machir: his family—the Machirites. And Machir

(16) begat Gilead. Of Gilead: his family — the Gileadites.

(17) [30] These are the sons of Gilead: Of Iezer: his family-

(18) the Iezerites. Of Helek: his family — the Helekites. [31] And

(19) of Asriel: his family - the Asrielites. And of Shechem: his family — the

(20) Shechemites. [32] And of Shemida: his family — the Shemidaites.

(21) And of Hepher: his family — the Hepherites. [33] And Zelophehad,

(1) son of Hepher, had no sons, but only daughters.

(2) And the names of the daughters of Zelophehad: Mahlah, and Noah, Hoglah, Milcah,

(3) and Tirzah. [34] These are the families of Manasseh, and

(4) those that were numbered of them: fifty-two thousand and seven hundred. [35]

(5) These are the sons of Ephraim by their families: Of Shuthelah:

(6) his family — the Shuthelahites. Of Becher: his family—-the Becherites. Of Tahan:

(7) his family — the Tahanites. [36] And these are the sons

(8) of Shuthelah: Of Eran: his family — the Eranites. [37] These are

(9) the families of the sons of Ephraim by those that were numbered: thirty-

(10) -two thousand and five hundred. These are the sons of Joseph by their families.

(11) [38] The sons of Benjamin by their families: Of Bela:

(12) his family — the Belaites. Of Ashbel: his family — the Ashbelites. Of Ahiram:

(13) his family - the Ahiramites. [39] Of Shephupham:

(14) his family — the Shuphamites. Of Hupham: his family — the Huphamites. [40] And

(15) the sons of Bela were Ard and Naaman: of Ard: his family-

(16) the Ardites. Of Naaman: his family - the Naamites. [41] These are

(17) the sons of Benjamin by their families, and they that were numbered of them:

(18) forty-five thousand and six hundred. [42] These are the sons 
(19) lary Dannyn uruvlarysajyn Šuḥamnyn uruvu ol Šuḥami bular-

(20) dylar uruvlary Dannyn uruvlarysajyn. כל. [43] Bar uruvlary

(21) ol Šuhamininin sanalğanlarysajyn altymyš dört min da

259 v $^{0}$ (1) dört jüz. [44] Uvullary Ašernin uruvlarysajyn Jimna-

(2) nyn uruvu ol Jimna Jišvinin uruvu ol Jišvi Berianyn u-

(3) ruvu ol Beri'i. לבני [45] Uvullarynyn Beri'anyn Hevernyn u-

(4) ruvu ol Ḥeveri Malki'elnin uruvu ol Malki'eli. ושם. [46]

(5) Da aty qyzynyn Ašernin Sarah. אלה. [47 Bulardylar uruv-

(6) lary uvullarynyn Ašernin sanalġanlarysajyn enli üč min da

(7) dört jüz. בני. [48] Uvullary Naftalinin uruvlarysajyn Jaḥce-

(8) 'ליצר. 'ל ' 29]

(9) Jecernin uruvu ol Jicri Šilemnin uruvu ol Šilemi.

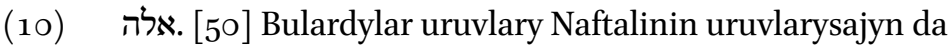

(11) sanalġanlary alarnyn qyrq beš min da dört jüz. אלה. [51]

(12) Bulardylar sanalġanlary ulanlarynyn Jisra’elnin alty keŕat jüz

(13) min da mind́a jedi jüz da otuz. וידבר [52] Da söz-

(14) ĺadi Adonaj Mošeǵa ajtadoġač. לאלה. [53] Bularg̉a üla-

(15) šinsin ol jer ülüšbyla sanybyla atlarnyn. לרב [54]

(16) Köpḱka köp bergin ülüšün anyn da azġa az bergin

(17) ülüšün anyn har kišiǵa sanalġanlaryna köŕa berilsin

(18) ülüšü anyn. אך. [55] Tek goral byla ülašinsin ol

(19) jer atlary sajyn ševetlarinin atalarynyn ülüš alsynlar.

(20) על (56] Ol goralġa köŕa ülašinsin ülüšü anyn ara-

(21) syna köpnün azbyla. ואלה. [57] Da bulardylar sanalganlary

26o $\mathrm{r}^{\mathrm{o}} \quad$ (1) ševetinin ol Levinin uruvlarysajyn Geršonnun uruvu ol

(2) Geršoni Qahatnyn uruvu ol Qahati Merarinin uruvu ol Merari.

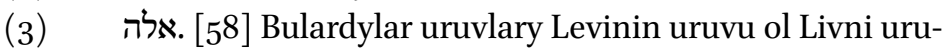


(19) of Dan by their families: Of Shuham: his family—the Shuhamites. These

(20) are the families of Dan by their families. [43] All the families

(21) of the Shuhamites, by those that were numbered: sixty-four thousand and

(1) four hundred. [44] The children of Asher by their families: Of Imna: $259 \mathrm{v}^{\mathrm{o}}$

(2) his family — the Imnites. Of Ishvi: his family — the Ishvites. Of Beriah:

(3) his family - the Beriites. [45] Of the sons of Beriah: of Heber:

(4) his family — the Heberites. Of Malchiel: his family—-the Malchielites. [46]

(5) And the name of the daughter of Asher: Serah. [47] These are

(6) the families of the sons of Asher by those that were numbered: fiftythree thousand and

(7) four hundred. [48] The sons of Naphtali by their families: Of Jahzeel:

(8) his family — the Jahzeelites. Of Guni: his family — the Gunites. [49]

(9) Of Jezer: his family of - Jezerites. Of Shillem: his family—-the Shillemites.

(10) [50] These are the families of Naphtali by their families, and

(11) they that were numbered of them: forty-five thousand and four hundred. [51]

(12) These were the numbered of the children of Israel, six times a hundred

(13) thousand and also a thousand seven hundred and thirty. [52] And

(14) the Lord spoke to Moses, saying, [53]

(15) 'The land shall be distributed to these as a portion with the number of names. [54]

(16) To many you shall give more portions, and to few less portions shall be given.

(17) To each man his portion shall be given according to those that were numbered.

(18) [55] Just: the land shall be divided by lot.

(19) By the names of the tribes of their fathers they shall inherit.

(20) [56] The portions of it shall be distributed according to the lot,

(21) between many and few. [57] And these are they that were numbered

(1) of the Levites by their families: Of Gershon: his family — the $260 \mathrm{r}^{\mathrm{o}}$

(2) Gershonites. Of Kohath: his family—the Kohathites. Of Merari: his family_the Merarites.

(3) [58] These are the families of the Levites: his family — the Libnites, 
(4) vu ol Ḥevroni uruvu ol Mahli \{uruvu\} ol Muši uruvu ol

(5) Qarhi da Qahat tuvdurdu ošol 'Amramny. ושם. [59] Da

(6) aty qaty\{ny\}nyn 'Amramnyn Joheved qyzy Levinin ki töŕadi any Levi-

(7) ǵa Micrid́a da töŕadi 'Amramġa ošol Aharonnu da ošol

(8) Mošeni da ošol Mirjamni tuvdug̉un alarnyn. [6o]

(9) Da tuvdu Aharonġa ošol Nadav da ošol Avihu' o-

(10) šol El'azar da ošol Itamar. [61] Da öldü

(11) Nadav da Avihu' juvutqanlarynda jat ot alnyna Adonaj-

(12) nyn. ויהיו [62] Da edilar sanalg̀anlary alarnyn igirmi

(13) üč min bar erḱak aj jaštan da jog̉arraq ki sanalma-

(14) dylar ortasynda ulanlarynyn Jisra’elnin ki berilmáadi

(15) alarg̉a ülüš ortasynda ulanlarynyn Jisra’elnin.

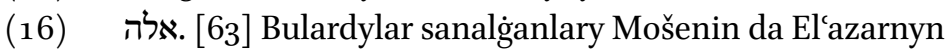

(17) ol kohennin ki sanadylar ošol ulanlaryn Jisra’elnin jylg̀alyq-

(18) larynda \{Mo’avnyn Jardeni qatyna\} Jerehononun. ובאלה [64] Da bular arasyna jogedi

(19) kišid́a sanalġanlarynda Mošenin da Aharonnun ol kohennin

(20) ki sanadylar ošol ulanlaryn Jisra’elnin midbarynda Sinajnyn.

$260 v^{o}$ (1) כי .

(2) da da qalmady alardan $\{k i s ̌ i d a\}^{1}$ ki ančaq Kalev uvlu Jefunenin da

(3) Johošua uvlu Nunnun.

Numbers 27

[1] Da juvudular qyzlary

(4) Celafahadnyn uvlunun Hefernin uvlunun Gil'adnyn uvlunun Mahir-

(5) nin uvlunun Menašenin uruvlarysajyn Menašenin uvlunun Josef-

(6) nin da bulardylar atalary qyzlarynyn Mahla No`a da Hag̉la

(7) da Milka da Tirca. ותעמדנה. [2] Da turdular

(8) alnynda Mošenin da alnynda El'azarnyn ol kohennin da al-

(9) nynda ol nasilarnin bar ol క̌ymatnyn ešigind́a

(10) ohel mo'ednin ajtadoġač. אבינו. [3] Atamyz öldü mid-

\footnotetext{
${ }^{1}$ Marginal insertion by another hand. | TKow.or: kišide; unvocalized text. | H: kiside. | C: kiši.
} 
(4) his family — the Hebronites, his family — the Mahlites, his familythe Mushites, his family- the

(5) Korathites. And Kohath begat Amram. [59] And

(6) the name of Amram's wife was Jochebed, daughter of Levi, whom |her mother| bore to Levi

(7) in Egypt. And she bore to Amram Aaron and

(8) Moses and Miriam, their sister. [6o]

(9) And to Aaron was born Nadab, and Abihu,

(10) Eleazar, and Ithamar. [61] And

(11) Nadab and Abihu died when they brought forward strange fire before the Lord.

(12) [62] And those that were numbered of them were twenty-

(13) -three thousand, all males from a month old and upward, because they were not numbered

(14) among the children of Israel, because there was no portion given

(15) them among the children of Israel.

(16) [63] These are they that were numbered by Moses and Eleazar,

(17) the priest, who numbered the children of Israel in the steppes

(18) of Moab by the Jordan of Jericho. [64] And among these there was not

(19) a man of them whom Moses and Aaron, the priest, numbered,

(20) when they numbered the children of Israel in the wilderness of Sinai.

(1) [65] For the Lord had said of them, "They will surely die in the wilder- $\quad 260$ v $^{\text {o }}$ ness.'

(2) And there was $\{$ not a man $\}$ was left of them, except Caleb, son of Jephunneh, and

(3) Joshua, son of Nun.

Numbers 27

[1] And the daughters

(4) of Zelophehad, son of Hepher, son of Gilead, son of Machir,

(5) son of Manasseh, by the families of Manasseh the son of Joseph, came forward.

(6) And these are the names of his daughters: Mahlah, Noah, and Hoglah,

(7) and Milcah, and Tirzah. [2] And they stood

(8) before Moses, and before Eleazar the priest, and

(9) before the princes and all the congregation, by the door

(10) of the tent of meeting, saying, [3] 'Our father died 
(11) barda $\{$ da $\}$ ol jog̉edi ortasynda ol క̌ymatnyn ol jyštyryluv-

(12) čular alnynda Adonajnyn 3̌ymatynda Qoraḥnyn ki öz jazyg்y

(13) üčün öldü da uvullary jog̀edi anar. למה [4] Nek

(14) eksilsin aty atamyznyn ortasyndan uruvunun ki joḥtu

(15) anar uvul b[e]rgin ${ }^{1}$ bizǵa tutuvluq ortasynda qaryndaš-

(16) ויקרב [5] Da juvuttu Moše ošol

(17) töŕasin alarnyn alnyna Adonajnyn. Da ajtty

(18) Adonaj Mošeǵa ajtadoġač. כן. [7] Qolajly qyzlar Celafaḥadnyn

(19) sözlajdilar berma bergin alarg̉a tutuvlug̉un ülüšnün or-

(20) tasynda qaryndašlarynyn atasynyn alarnyn da ašyrg்yn ošol

$261 \mathrm{r}^{\circ} \quad$ (1) ülüšün atasynyn alarnyn alargia. [8 [8 Da ulanlaryna

(2) Jisra’elnin sözĺagin ajtadog̉ač kiši ki ölśa da uvul bol-

(3) masa anar da ašyryjyz ošol ülüšün anyn qyzyna.

(4) ואם [9] Da eger bolmasa anar qyz da ašyryjyz ošol

(5) ülüšün anyn qaryndašlaryna atasynyn. [ואם.] [10] [[Da eger bolmasa anar qaryndašlar da berijiz ošol ülüšün anyn qaryndašlaryna atasynyn] ${ }^{12}$. ואם [11] Da

(6) eger bolmasa qaryndašlar atasyna anyn da berijiz ošol

(7) ülüšün anyn juvug̉una ol juvuqraqqa anar uruvundan

(8) anyn da mé́aslasin any da bolsun ulanlaryna Jisra’elnin

(9) resimińa töŕanin ki nečik bujurdu Adonaj Mošeǵa.

(10) ויאמר (12] Da ajtty Adonaj Mošeǵa mingin özüja

(11) tavyna ol köčüvlarnin ušpu da körgün ošol ol jerni

(12) ki berdim ulanlaryna Jisra'elnin. וראיתה. [13] Da baqqyn

(13) any da jyštyrylğyn uluslaryja daġyn send́a ki nečik jyš-

(14) tyryldy Aharon qaryndašyj. כאשר. [14] Ki nečik tandyjyz

(15) maja ki qylmadyjyz sözümnü midbarynda Cinnin talašynda

(16) ol క̌ymatnyn azizligimni körgüzḿa menim berḿakby-

(17) la suv skaladan sözlamáagibyla avuznun közlarič́a alar-

(18) nyn alardylar talaš suvlary Qadešnin midbarynyn Cinnin.

(19) וידבר [15] Da sözladi Moše Adonajğa ajtadog̉ač.

\footnotetext{
${ }^{1} \mathrm{~K}$ : birgin, probably a scribal error. | TKow.o1: unvocalized text. | H: bergin. | C: bergin. $\quad{ }^{2} \mathrm{~K}$ : desunt; a scribal error. | TKow.o1: Da eger bolmasa anar qaryndašlar da berijiz ošol ülüšün anyn qaryndašlaryna atasynyn; unvocalized text. | H: Da eger jogese anar qaryndaslar da beriniz osol ilisin anyn qaryndaslaryna atasynyn. | C: Da egär bolmasa ayar qardašlar da berijiz šol ülüšün qardašlaryna atasynyy.
} 
(11) in the wilderness, and he was not among the congregation who were gathered

(12) against the Lord, in the congregation of Korah, because he died for his own sin.

(13) And he had no sons. [4] Why

(14) should the name of our father be taken away from among his family, because

(15) he has no son? Give to us a possession among the brothers

(16) of our father. [5] And Moses brought their

(17) cause before the Lord. [6] And the Lord spoke

(18) to Moses, saying, [7] 'The daughters of Zelophehad speak right:

(19) you shall surely give them a possession of a portion

(20) among their father's brothers, and you shall cause

(1) the portion of their father to pass to them. [8] And

(2) you shall speak to the children of Israel, saying, "If a man dies, and has no son,

(3) then you shall cause his portion to pass to his daughter.

(4) [9] And if he has no daughter, then you shall cause

(5) his portion to pass to his brethren. [[10] And if he has no brothers, then you shall give his portion to his father's brothers.] [11] And

(6) if his father has no brothers, then you shall give

(7) his portion to his closest relative of his family,

(8) and he shall inherit it. And it shall be to the children of Israel

(9) a statute of judgment, as the Lord commanded Moses."' [12]

(10) And the Lord said to Moses, 'Get up

(11) ${ }_{L}$ to this mountain of encampments ${ }^{1247}$ and see the land

(12) which I have given to the children of Israel. [13] And you shall see

(13) it, and you shall be gathered to your people, you as well, as

(14) Aaron, your brother, was gathered, [14] Because you rebelled against

(15) me and you did not do my word in the desert of Zin, in the quarrel

(16) of the congregation, to show my holiness by giving

(17) water from the rock in their sight.

(18) That is the water ${ }_{L}$ of quarrel ${ }^{1248}$ of Kadesh of the wilderness of Zin.'

(19) [15] And Moses spoke to the Lord, saying,

247 A literal translation of Heb. אֶל־הַר הָעְבָברִ 'to Mount Abarim'. | TKow.o1: to this mountain of encampments. | H: to this mountain of encampments. | C: to mountain of these encampments. | R: to Mount Abarim.

248 A literal translation of Heb. מְרִיבָ '. Meribah; 2. strife, contention'. | TKow.o1: of quarrel.| H: of quarrel. | C: of quarrel. | R: of quarrel. 
(20) יפקד Symarlag̉aj Adonaj Tenrisi ol žanlarnyn žanlary-

(21) nyn bar tennin kiši ag̉araq ol క̌ymat üstüńa. אשר. [17]

$261 \mathrm{v}^{\mathrm{o}} \quad$ (1) Ki čyqqaj alynlarynda da ki kelǵaj alynlarynda alarnyn

(2) da ki čyġarg̉aj alarny da ki kijirǵaj alarny da ki bolmag̉aj

(3) క̌ymaty Adonajnyn qoj kibik ki joḥtu alarg̉a kütüvčü.

(4) ויאמר Da ajtty Adonaj Mošeǵa alg̀yn ošol

(5) Johošua'ny uvlun Nunnun kišini ki alhem anda da sun-

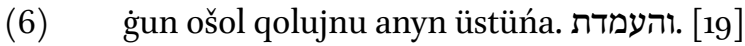

(7) Da turğuzg்un any alnynda El'azarnyn ol kohennin da

(8) alnynda bar ol žymatnyn da symarlag்yn any bolma

(9) ag̉araq közlarič́a alarnyn. ${ }^{1}$. [20] Da bergin syjy-

(10) jdan anyn üstüńa anyn üčün ki tynlag̉ajlar bar

(11) 3̌ymaty ulanlarynyn Jisra’elnin. ולפני (21] Da alnynda

(12) El'azarnyn ol kohennin tursun da sorsun anar kečinḿa-

(13) gibyla ol urimnin alnynda Adonajnyn anyn sözüná

(14) köŕa čyqsynlar da anyn sözüńa köŕa kelsinlar

(15) ol da bar ulanlary Jisra'elnin ${ }_{\mathrm{L}}\{[\mathrm{bi}] \text { rgesine anyn }\}^{12}$ da bar ol క̌ymat.

(16) ויעש [22] Da qyldy Moše ki nečik bujurdu Adonaj anar

(17) da aldy ošol Johošua'ny da turg̉uzdu any alnynda

(18) El'azarnyn ol kohennin da alnynda bar ol žymatnyn.

(19) ויסמך [23] Da sundu ošol qollaryn anyn üstüńa

(20) da symarlady any ag̉araq bolmaqqa ki nečik sözladi

(21) Adonaj naviligi ašyra Mošenin.

Numbers 28

[1] [ידבר יהוה אל [1] [-

$262 \mathrm{r}^{\mathrm{o}} \quad$ (1) Da sözladi Adonaj Mošeǵa ajtadog̉ač. [2] Bujur-

(2) gun ulanlaryna Jisra’elnin da ajtqyn alarg̉a ošol

(3) qarbanymny ötḿagimni otlu qarbanlarymbyla ij qabul-

(4) luqlarymny saqlajyz juvutma maja vaġdasynda. [3מרת [3]

(5) Da ajtqyn alarǵa budur ol otlu qarban ki juvutujuz

(6) Adonajg̉a qozular jyllyq balalary tüğalliarni ekini künǵa

(7) 'את [4] Ošol ol bir qozunu qyl-

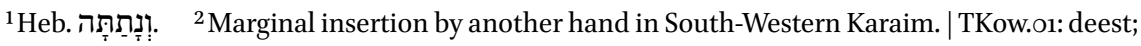
unvocalized text. | H: birgesine anyn. | C: birgäsinä.
} 
(20) [16] 'Let the Lord, the God of the spirits of the living beings of all flesh, appoint

(21) a man as a superior over the congregation: [17]

(1) Who may go out in front of them, and who may come in in front of them,

(2) and who may bring them out, and who may bring them in, so that the

(3) congregation of the Lord may not be like sheep that do not have a shepherd.'

(4) [18] And the Lord said to Moses, "Take

(5) Joshua, son of Nun, a man in whom is the inspiration, and

(6) reach out your hand over him. [19]

(7) And stand him before Eleazar, the priest, and

(8) before all the congregation, and appoint him to be

(9) superior in their sight. [20] And you shall put

(10) some of your honour on him, so that all

(11) the congregation of the children of Israel may hear. [21] And

(12) he shall stand before Eleazar, the priest, who shall ask him

(13) after the |required| manner of Urim before the Lord. According to his word

(14) they shall go out, and according to his word they shall come in,

(15) he and all the children of Israel \{with him $\}$ and all the congregation.'

(16) [22] And Moses did as the Lord commanded him.

(17) And he took Joshua and stood him before

(18) Eleazar, the priest, and before all the congregation.

(19) [23] And he reached out his hands over him

(20) and appointed him to be superior, as the

(21) Lord had spoken by the prophecy of Moses.

Numbers 28

(1) And the Lord spoke to Moses, saying, [2] 'Command

(2) the children of Israel and say to them,

(3) "My offering, my bread with my offerings by fire, and

(4) my aroma of acceptance: you shall watch out to bring |it| forward to me at its appointed time." [3]

(5) And you shall say to them, "This is the offering by fire which you shall bring forward

(6) to the Lord: two unblemished one-year-old lambs, per day,

(7) a continual burnt offering. [4] You shall do one lamb 
(8) ġyn ertanbylada da ošol ol ekinči qozunu qylġyn

(9) ol eki ingi\{r\}ĺar arasyna. ועשירית. [5] Da onunču

(10) ülüšün ol efanyn öźak tirkiǵa jumurulġan janč-

(11) qan javbyla dörtünčü ülüšü ol hinnin. עולת. [6]

(12) Hammešalik ola ol qylynġan tavynda Sinajnyn ij qabul-

(13) luqqa otlu qarban Adonajgia. ונסכו. [7] Da nesehi anyn

(14) dörtünčü ülüšü ol hinnin ol bir qozuğa qodešta

(15) qujma neseh esirtüvčü alnynda Adonajnyn. ואת [8]

(16) Da ošol ol ekinči qozunu qylg̀yn ol eki ingirlar

(17) arasyna tirkisi kibik ol ertanbylanyn da nesehi

(18) kibik anyn qylgyn otlu qarban ij qabulluq Adonajğa.

(19) (92] Da ol šabat kününd́a eki qozular jyllyq

(20) balalary tüǵallíarni da eki 'esronlar öźak tirki

(21) jumurulgan javbyla da nesehi anyn. עולת. [10] 'Olasyn

$262 \mathrm{v}^{\mathrm{o}} \quad$ (1) har šabatnyn šabatynda 'olasy qatyna ol hammeš́alik qar-

(2) bannyn da nesehi anyn. ובראשי [11] Da jangajlaryjyzda

(3) juvutujuz 'ola Adonajġa tanalar balalaryn syggyrnyn eki-

(4) ni da bir qočqar qozular jyllyq balalaryn jedini tüǵal-

(5) Íarni. ושלשה. [12] Da üč 'esronlar öźak tirki

(6) jumuru[1] gaan ${ }^{1}$ javbyla ol bir tanag̉a da eki 'esronlar

(7) öźak tirki jumurulġan javbyla ol bir qočqarg̉a.

(8) . Da bir ' isaron öźak tirki jumurulgan javby-

(9) la har bir qozugia 'ola ij qabulluq otlu qarban Adonajġa.

(10) (14] Da nesehlíari alarnyn jarymy ol hinnin bolsun

(11) ol bir tanagia da üčunčü [ülüšü] ${ }^{2}$ ol hinnin qočqargia da dör-

(12) tünčü ülüšü ol hinnin qozuğa čaġyr budur 'olasy

(13) janġajnyn janġajynda jangajlaryna ol jylnyn. ושעיר [15]

(14) Da ulag̉yn ečkilarnin birni ḥatatqa Adonajgga olasy

(15) qatyna ol hammešalik qarbannyn qylynsyn da neseḩi anyn.

(16) (16) Da ol burunġu janġajda ondörtünčü kü-

(17) nünd́a jang̉ajnyn qarbany Pesaḥnyn Adonajg̉a. ובחמשה Da

(18) [o]nbešinči ${ }^{3}$ kününd́a ošpu janġajnyn hyy̌̌ jedi künlar

(19) mačalar ašalsyn. ביום [18] Ol burunguu künd́a aziz ün-

\footnotetext{
${ }^{1} \mathrm{~K}$ : jumurulng்an; a scribal error (obscured by an ink stain). | TKow.o1: jumurulgan; unvocalized text. | H: jumurulgan. | C: bulgangan. ${ }^{2} \mathrm{~K}$ : deest; a scribal error. | TKow.o1: ülüs̈ü; unvocalized text. | H: ilisi. | C: pajy. $\quad{ }^{3} \mathrm{~K}$ : önbešinči; a scribal error. | TKow.o1: on bešinči; unvocalized text. | H: on besinci. | C: on bešinži.
} 
(8) at dawn, and you shall do the second lamb

(9) at twilight. [5] And a tenth

(10) part of an ephah of fine flour for a grain offering, mixed

(11) with the fourth part of a hin of beaten olive oil. [6]

(12) It is a continual burnt offering, which was done at Mount Sinai, an

(13) aroma of acceptance, an offering by fire to the Lord. [7] And its drink offering

(14) shall be the fourth part of a hin for one lamb; in the holy place, to

(15) pour the drink offering of strong drink before the Lord. [8]

(16) And the second lamb you shall offer at twilight.

(17) You shall do it like the grain offering of the dawn and like its drink offering:

(18) an offering by fire, an aroma of acceptance to the Lord.

(19) [9] And on the Sabbath day: two unblemished one-year-old lambs,

(20) and two-tenths of an ephah of fine flour, a grain offering,

(21) mixed with oil, and its drink offering: [10] The burnt offering

(1) of every Sabbath on its Sabbath, besides the continual burnt offering $\quad 262 \mathrm{v}^{\mathrm{o}}$

(2) and its drink offering. [11] And on your new moons

(3) you shall bring forward a burnt offering to the Lord: two calves, the young of cattle,

(4) and one ram, seven unblemished one-year-old lambs.

(5) [12] And three-tenths |of a measure| of fine flour, a grain offering,

(6) mixed with oil, for one calf, and two-tenths |of a measure|

(7) of fine flour, a grain offering, mixed with oil, for one ram.

[13] And a tenth |of a measure| of fine flour mixed with oil, a grain offering,

(9) for every lamb: a burnt offering, an aroma of acceptance, an offering by fire to the Lord.

(10) [14] And their drink offerings shall be half a hin

(11) for one calf, and the third [part] of a hin for a ram, and a fourth

(12) part of a hin for a lamb, of wine: this is the burnt offering

(13) of every month in its month throughout the months of the year. [15]

(14) And one kid of the goats for a sin offering to the Lord

(15) shall be done, besides the continual burnt offering, and its drink offering.

(16) [16] And in the first month on the fourteenth

(17) day of the month is the Passover to the Lord. [17] And

(18) on the fifteenth day of this month is a holiday: seven days

(19) shall unleavened bread be eaten. [18] On the first day there is a holy 
(20) dalmiš heč qulluq iš qylmajyz. והקרבתם. [19] Da juvutujuz

(21) otlu qarban 'ola Adonajğa tanalar balalaryn syġyrnyn

$263 \mathrm{r}^{\mathrm{o}} \quad$ (1) ekini da bir qočqar da jedi qozular jyllyq balalary tüǵal-

(2) Ílar bolsunlar. [20] Da tirkilari alarnyn

(3) [öźak $]^{1}$ jumu\{ru\}lġan javbyla üč 'esronlar tanaġa da

(4) eki 'esronlar qočqarg̉a qylyjyz. עשרון. [21] Bírar

(5) isaron qylġyn har bir qozug̉a jedisida ol qozularġa.

(6) ושעיר Da ulag̉yn hatatnyn birni bošatlyq qolma

(7) מלבד . מ23 [23] Bašqa 'olasyndan ol er-

(8) tanbylanyn ki olasyna ol hammešalik qarbannyn qylyjyz

(9) ošol bularny. כאלה. [24] Bular kibik qylyjyz har künǵa

(10) jedi künĺar $\{[0 ̈] \text { tḿak }\}^{2}$ otlu qarban ij qabulluq Adonajgga 'olasy

(11) qatyna ol hammešalik qarbannyn qylsyn da neseḩi anyn.

(12) וביום [25] Da ol jedinči künd́a aziz ünd́almiš

(13) bolsun sizǵa heč qulluq iš qylmajyz. וביום . [26] Da

(14) ol bikurim kününd́a juvutqanyjyzda janġy tirki Adonaj-

(15) gaa sanag̉anyjyzdan sortun jedi haftalaryjyzny aziz ünd́al-

(16) miš bolsun sizǵa heč qulluq iš qylmajyz.

(17) (27] Da juvutujuz 'ola ij qabulluqqa Adonaj-

(18) ġa tanalar balalaryn syġyrnyn eki bir qočqar jedi qozular

(19) jyllyq balalary. ומנחתם. [28] Da tirkilari alarnyn öźak

(20) jumurulġan javbyla üč 'esronlar ol bir tanag̉a eki

(21) 'esronlar ol bir qočqargia. עשרון. [29] Biŕar 'isaron

$263 \mathrm{v}^{\mathrm{o}}$ (1) har bir qozugaa jedisida ol qozularġa. [30]

(2) Ulaġyn ečkilarnin birni bošatlyq qolma siznin üčün.

(3) מלבד [31] Bašqa ol hammešalik oladan da tirkisin-

(4) dan anyn bularny qylyjyz tüǵallíar bolsunlar sizǵa da neseh-

(5) ĺarid́a alarnyn.

1'TKow.o1: özek; unvocalized text. | H: ezeq unu. | C: özäk. $\quad{ }^{2}$ TKow.o1: ötmek; unvocalized text. | H: etmek. | C: deest. 
(20) convocation: you shall not do any slave labour. [19] But you shall bring forward

(21) an offering by fire, a burnt offering to the Lord: two calves, the young of cattle,

(1) and one ram, and seven one-year-old lambs:

(2) they shall be unblemished. [20] And their grain offerings:

(3) [fine flour] mixed with oil: shall you do three-tenths |of a measure| for a calf and

(4) two-tenths |of a measure| for a ram. [21] You shall do one

(5) tenth |of a measure| for each lamb among the seven lambs.

(6) [22] And one goat of a sin offering to ask for atonement

(7) for you. [23] You shall do these besides the burnt offering

(8) at dawn that is for a continual burnt offering.

(9) [24] Like these shall you do, for every day,

(10) for seven days, the bread of the offering by fire, an aroma of acceptance to the Lord.

(11) It shall be offered besides the continual burnt offering and its drink offering.

(12) [25] And on the seventh day you shall have a holy convocation,

(13) you shall do no slave labour. [26] And

(14) on the day of the firstfruits, when you bring forward a new grain offering to the Lord,

(15) after you have counted your seven weeks,

(16) you shall have a holy convocation. You shall do no slave labour.

(17) [27] And you shall bring forward the burnt offering, an aroma of acceptance to the Lord:

(18) two calves, the young of cattle, one ram, seven one-year-old lambs,

(19) [28] And their grain offerings of fine flour

(20) mixed with oil, three-tenths |of a measure| for one calf, two-

(21) -tenths |of a measure| for one ram, [29] One tenth

(1) |of a measure| for each lamb among the seven lambs. [30]

(2) And one kid of the goats to ask for atonement for you.

(3) [31] You shall offer them besides the continual burnt offering

(4) and its grain offering, you shall do these, they shall be unblemished to you, and their drink

(5) offerings. 
Numbers 29

(6) burunġu kününd́a janġajnyn aziz ünd́almiš bolsun

(7) sizǵa heč qulluq iš qylmajyz qyčqyrmaqbyla maḥtav

(8) bermak kün bolsun sizǵa. ועשיתם. [2] Da qylyjyz

(9) 'ola ij qabulluqqa Adonajgia tana balasyn syggymyn birni

(10) bir qočqar qozular jyllyq balalary jedini tüǵallarni.

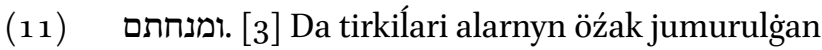

(12) javbyla üč 'esronlar tanag̉a eki 'esronlar qočqarg̉a.

(4) [ [13 Da biŕar ' isaron har bir qozugiga jedisida

(14) ol qozularg̉a. ושעיר [5] Da ulaġyn ečkilarnin birni

(15) hatatqa bošatlyq qolma siznin üčün. מלבד. [6]

(16) Bašqa olasyndan ol janġajnyn da tirkisind́an anyn

(17) da ol hammeš́alik 'oladan da tirkisind́an anyn da

(18) nesehĺari alarnyn kečinmáaḱlárińa\} köŕa ij qabulluqqa otlu

(19) qarban Adonajġa. ובעשור. [7 Da onunču kününd́a ol

(20) jedinči janğajnyn ošpu aziz ünd́almiš bolsun sizǵa

(21) da qyjnajyz ošol žanlaryjyzny heč iš qylmajyz. והקרבתם. [8]

$264 \mathrm{r}^{\circ}$ (1) Da juvutujuz ola Adonajg̉a ij qabulluq tana balasyn syġyr-

(2) nyn birni bir qočqar qozular jyllyq balalary jedini tügalĺar

(3) bolsunlar sizǵa. ומנחתם [9] Da tirkilari alarnyn

(4) öźak jumurulgan javbyla üč 'esronlar tanag̉a eki 'eš-

(5) עשרון [10] Birar 'isaron har

(6) bir qozug̉a jedisid́a ol qozularga. שעיר. [11] Ulag̉yn eč-

(7) kilarnin birni ḥatatqa bašqa ḥatatyndan ol kipurimnin

(8) da ol hammešalik 'oladan da tirkisind́an da neseh-

(9) Iarind́an alarnyn. [12] Da onbešinči künün-

(10) da ol jedinči janġajnyn aziz ünd́almüš bolsun siz-

(11) ga heč qulluq iš qylmajyz da hyy̌̌lajyz hyy̌̌ Adonajğa jedi

(12) künĺar. והקרבתם. [13] Da juvutujuz 'ola otlu qar-

(13) ban ij qabulluq Adonajğa tanalar jyllyq balalary onüčnü 
Numbers 29

(5) [1] And in the seventh month,

(6) on the first day of the month, you shall have a holy convocation,

(7) you shall do no slave labour. It shall be to you

(8) a day of praising with calling voice. [2] And you shall do

(9) a burnt offering, an aroma of acceptance to the Lord: one calf, the young of cattle,

(10) one ram, and seven unblemished one-year-old lambs.

(11) [3] And their grain offering: fine flour mixed

(12) with oil, three-tenths |of a measure| for a calf, two-tenths |of a measure| for a ram,

(13) [4] And one tenth |of a measure| for each lamb among the seven

(14) lambs, [5] And one kid of the goats

(15) for a sin offering to ask for atonement for you, [6]

(16) Besides the burnt offerings of the month and its grain offerings

(17) and the continual burnt offering and its grain offering, and

(18) their drink offerings according to the |required| manner, an aroma of acceptance,

(19) an offering by fire to the Lord. [7] And on the tenth day

(20) of this seventh month you shall have a holy convocation.

(21) And you shall afflict your souls, you shall not do any work. [8]

(1) And you shall bring forward a burnt offering to the Lord, an aroma of $264 \mathrm{r}^{\circ}$ acceptance: one calf, the young of cattle,

(2) one ram, and seven one-year-old lambs, they shall be unblemished

(3) to you. [9] And their grain offering:

(4) fine flour mixed with oil, three-tenths |of a measure| for a calf, twotenths

(5) |of a measure| for one ram, [10] One-tenth |of a measure| for each

(6) lamb among the seven lambs, [11] One kid

(7) of the goats for a sin offering, besides the sin offering of atonement

(8) and the continual burnt offering and its grain offering

(9) and their drink offerings. [12] And on the fifteenth day

(10) of the seventh month you shall have a holy convocation.

(11) You shall do no slave labour. And you shall keep a feast to the Lord seven

(12) days. [13] And you shall bring forward a burnt offering, an offering by fire,

(13) an aroma of acceptance to the Lord: thirteen one-year-old calves, 
(14) qočqarlar ekini qozular jyllyq balal[ar $] y^{1}$ ondört tügallíar bolsun-

(15) lar. [14] Da tirkílari alarnyn öźak jumurul-

(16) ġan javbyla üč cesronlar ol bir tanagia onüč tanalar-

(17) ga eki 'esronlar ol bir qočqargia eki ol qočqarlar-

(18) ga. ועשרון [15] Da biŕar 'isaron har bir qozuga on-

(19) dört qozularg̉a. ושעיר [16] Da ulag̉yn ečkilarnin birni

(20) hatatqa bašqa ol hammeš́alik oladan tirkisind́an da

(21) nesehind́an anyn. וביום [17] Da ol ekinči künd́a

$264 \mathrm{v}^{\mathrm{o}} \quad$ (1) tanalar balalaryn syg்yrnyn onekini qočqarlar eki qozular jyllyq

(2) balalary ondörtnü tüǵallarni. ומנחתם. [18] Da tirkila-

(3) ri alarnyn da nesehĺari alarnyn tanalarġa qočqarlarg̉a qozular-

(4) ġa sanlaryna köŕa kečinḿakḱa köŕa. ושעיר. [19]

(5) Da ulag̉yn ečkilarnin birni hatatqa bašqa ol hammeš́alik

(6) oladan da tirkisi anyn da nesehĺari alarnyn. [20]

(7) Da ol üčünčü künd́a tanalar onbir qočqarlar eki

(8) qozular jyllyq balalary ondörtnü tüğallarni. [21]

(9) Da tirkilari alarnyn da nesehĺari alarnyn tanalarg̉a qočqar-

(10) larg̉a \{da\} qozularg̉a sanlarybyla kečinmakkka köŕa.

(11) ושעיר (22] Da ulag̉yn ečkilarnin birni ḥatatqa bašqa

(12) ol hammeš́alik 'oladan da tirkisi anyn da nesehi anyn.

(13) (23] Da ol dörtünčü künd́a tanalar on qočqar-

(14) lar eki qozular jyllyq balalary ondörtnü tüǵalĺarni.

(15) Tirkilari alarnyn da nesehĺari alarnyn tanalar-

(16) ġa qočqarlarg̉a da qozularg̉a sanlarybyla kečinmakḱa kö-

(17) ŕa. (25] Da ulaġyn ečkilarnin birni hatatqa

(18) bašqa ol hammeš́alik 'oladan da tirkisi anyn da nesehi

(19) anyn. וביום (26] Da ol bešinči künd́a tanalar toğuz

(20) qočqarlar eki qozular jyllyq balalary ondörtnü tügáalíar-

(21) ni. ומנחתם [27] Da tirkilari alarnyn da nesehĺari

$265 \mathrm{r}^{\circ}$ (1) alarnyn tanalarg̉a qočqarlarg̉a \{da\} qozularğa sanlarybyla kečin-

\footnotetext{
${ }^{1} \mathrm{~K}$ : balaly; a scribal error. | TKow.o1: balalary; unvocalized text. | H: balalary. | C: balalary.
} 
(14) two rams, and fourteen one-year-old lambs, they shall be unblemished.

(15) [14] And their grain offering: fine flour mixed

(16) with oil, three-tenths |of a measure | for each calf, for the thirteen calves,

(17) two-tenths |of a measure| for each ram of the two rams,

(18) [15] And a tenth |of a measure| for each lamb, for the fourteen

(19) lambs, [16] And one kid of the goats

(20) for a sin offering, besides the continual burnt offering its grain offering and

(21) its drink offering. [17] And on the second day:

(1) twelve young calves, two rams, fourteen unblemished one-year-old lambs,

(2) [18] And their grain offerings

(3) and their drink offerings for the calves, for the rams, for the lambs,

(4) according to their number, according to the |required| manner, [19]

(5) [19] And one kid of the goats for a sin offering, besides the continual

(6) burnt offering and its grain offering and their drink offerings. [20]

(7) And on the third day: eleven calves, two rams,

(8) fourteen unblemished one-year-old lambs, [21]

(9) And their grain offerings and their drink offerings for the calves, for the rams,

(10) and for the lambs, according to their number, according to the |required| manner,

(11) [22] And one goat for a sin offering, besides

(12) the continual burnt offering and its grain offering and its drink offering.

(13) [23] And on the fourth day: ten calves, two rams,

(14) and fourteen unblemished lambs, one-year old young,

(15) [24] Their grain offerings and their drink offerings for the calves,

(16) for the rams, and for the lambs, according to their number, according to the |required| manner,

(17) [25] And one kid of the goats for a sin offering,

(18) besides the continual burnt offering, its grain offering, and its drink offering.

(19) [26] And on the fifth day: nine calves,

(20) two rams, and fourteen unblemished one-year-old lambs,

(21) [27] And their grain offerings and their drink offerings

(1) for the calves, for the rams, and for the lambs, according to their number, according to the |required| manner, 
(2) makḱa köŕa. [28] Da ulag̉yn ečkilarnin bir-

(3) ni ḥatatqa bašqa ol hammeš́alik coladan da tirki-

(4) si anyn da nesehi anyn. וביום [29] Da ol altynčy kün-

(5) da tanalar segiz qočqarlar eki qozular jyllyq balalary on-

(6) dörtnü tüğalĺarni. [30] Da tirkilari alar-

(7) nyn da nesehĺari alarnyn tanalarg̉a qočqarlarg̉a da qozularg̉a

(8) sanlarybyla kečinḿakḱa köŕa. ושעיר [31] Da ulag̉yn

(9) ečkilarnin birni ḥatatqa bašqa ol hammeš́alik

(10) 'וביום . [32] Da

(11) ol jedinči künd́a tanalar jedi qočqarlar eki qozular

(12) jyllyq balalary ondörtnü tüǵalliarni. ומנחתם. [33]

(13) Da tirkilari alarnyn da neseḩlari alarnyn tanalarg̉a qoč-

(14) qarlarg̉a da qozularg̉a sanlarybyla kečinḿaklarińa

(15) köŕa. ושעיר [34] Da ulag̉yn ečkilarnin birni ḥatat-

(16) qa bašqa 'olasyndan ol hammešalik qarbannyn tirki-

(17) si anyn da nesehi anyn. [35] Ol segi\{zi\}nči künd́a

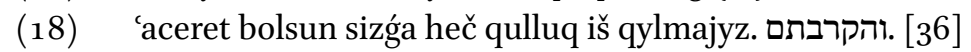

(19) Da juvutujuz 'ola otlu qarban ij qabulluq Adonajğa \{bir\} tana

(20) bir qočqar qozular jyllyq balalary jedini tüǵalĺarni.

(21) מנחתם. [37] Tirkilari alarnyn da nesehílari alarnyn [tanaġa] ${ }^{1}$ qočqar-

$265 \mathrm{v}^{\mathrm{o}} \quad$ (1) ġa da qozularg̉a sanlarybyla kečinmáaḱka köŕa.

(2) ושעיר [38] Da ulag̉yn ečkilarnin birni ḥatatqa bašqa

(3) ol hammeš́alik 'oladan da tirkisi anyn da nesehi anyn.

(4) . אלה Balardylar ol musaflary ki qylyjyz Adonajg̈a mo'ed-

(5) Íarijizd́a bašqa nijetĺarijizd́an da žomartlyqlaryjyzdan ola-

(6) laryjyzsajyn da tirkilarijizsajyn da nesehĺarijizsajyn da šelamim-

(7) ĺarijizsajyn.

\footnotetext{
${ }^{1} \mathrm{~K}$ : deest; a scribal error. | TKow.oı: tanag்a; unvocalized text. | H: tanag்a. | C: bug்ag்a.
} 
(2) [28] And one kid of the goats

(3) for a sin offering, besides the continual burnt offering, and its grain offering,

(4) and its drink offering. [29] And on the sixth day:

(5) eight calves, two rams, and fourteen unblemished one-year-old lambs,

(6) [30] And their grain offerings

(7) and their drink offerings for the calves, for the rams, and for the lambs,

(8) according to their number, according to the |required| manner, [31] And one kid

(9) of the goats for a sin offering, besides the continual

(10) burnt offering, its grain offering, and its drink offerings. [32] And

(11) on the seventh day: seven calves, two rams, and fourteen

(12) unblemished one-year-old lambs, [33]

(13) And their grain offerings and their drink offerings for the calves,

(14) for the rams, and for the lambs, according to their number, according to the |required| manner,

(15) [34] And one kid of the goats for a sin offering,

(16) besides the continual burnt offering, its grain offering,

(17) and its drink offering. [35] On the eighth day

(18) you shall have a solemn assembly. You shall do no slave labour. [36]

(19) But you shall bring forward a burnt offering, an offering by fire, an aroma of acceptance to the Lord: one calf,

(20) one ram, seven unblemished one-year-old lambs,

(21) [37] Their grain offerings and their drink offerings [for the calf], for the ram,

(1) and for the lambs, according to their number, according to the |required| manner,

(2) [38] And one kid of the goats for a sin offering, besides

(3) the continual burnt offering, and its grain offering, and its drink offering.

(4) [39] These are the additional things you shall do to the Lord in your holidays,

(5) besides your vows and your freewill offerings for your burnt offerings

(6) and for your grain offerings and for your drink offerings and

(7) for your peace offerings.' 
Numbers 30

(8) ra’elnin barča neki bujurdu Adonaj Mošeǵa.

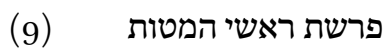

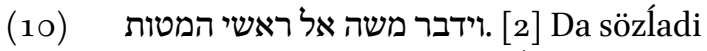

(11) Moše ag̉araqlaryna ol ševetĺarnin uvullary-

(12) nyn Jisra’elnin ajtadoġač budur ol söz ki bujurdu Adonaj.

(13) Kiši ki nijet etśa \{nijet\} Adonajg̉a jemeśa ant

(14) etśa ant bavlama bav క̌any üstüńa jengil et-

(15) masin sözün özünün bar ol čyqqanġa köŕa avzun-

(16) dan qylsyn. [15 Da qatyn ki nijet etśa nijet Adonaj-

(17) ga da bavlasa bav üvünd́a atasynyn jašlyqlarynda.

(18) [5 [5 [18šitśa atasy anyn ošol nijetin anyn

(19) da bavyn anyn ki bavlady žany üstüńa da tyjylsa

$266 \mathrm{r}^{\circ} \quad$ (1) anar atasy anyn da qajjam bolurlar bar nijetlari anyn da bar

(2) bav ki bavlasa žany üstüńa qajjam bolur. ואם [6] Da

(3) eger tyjsa atasy anyn any ešitkan kününd́a bar nijet-

(4) lari anyn da bar bavlary anyn ki bavlady žany üstüna

(5) qajjam bolmasty da Adonaj bošatyr jazyg்yn anyn ki tyjdy

(6) atasy anyn any. [7 Da eger bolma bolsa er

(7) artyna da nijetĺari anyn bolsalar anyn üstüńa jemeśa

(8) eqrari e\{r\}inlarinin ki bavlady žany üstüńa. ושמע. [8]

(9) Da ešitśa eri anyn ešitḱan kününd́a da tyjylsa

(10) anar da qajjam bolurlar nijetlari anyn da bavlary anyn ki bav-

(11) lady žany üstüńa qajjam bolurlar. ואם [9] Da eger

(12) ešitḱan künd́a eri anyn tyjsa any da buzsa ošol

(13) nijetin anyn ki anyn üstüńa da ošol eqrarin erin-

(14) larinin ki bavlady žany üstüńa da Adonaj bošatyr

(15) anar. ונדר [10] Da nijeti tulnun da sürülǵannin barča

(16) neki bavlady žany üstüńa qajjam bolsun anyn üs-

(17) tüńa. [11] Da eger üvünd́a erinin nijet et-

(18) ti eśa jemeśa bavlasa bav žany üstüńa antbyla.

(19) Da ešitśa eri anyn da tyjylsa anar tyj-

(20) masa any da qajjam bolurlar bar nijetlari anyn da bar bav

(21) ki bavlasa žany üstüńa qajjam bolur. ואם [13] Da 


\section{Numbers 30}

[1] And Moses told the children of Israel

(9) Parashat Matot

(10) [2] And Moses spoke

(11) to the superiors of the tribes of the children

(12) of Israel, saying, 'This is the word which the Lord has commanded.

(13) [3] A man who vows a vow to the Lord or

(14) swears an oath to bind his soul with a bond:

(15) he shall not disregard his word, he shall do according to all that comes out of his mouth.

(16) [4] And a woman who vows a vow to the Lord

(17) and binds $\mid$ herself by a bond in her father's house in her youth,

(18) [5] And her father hears her vow

(19) and her bond by which she has bound her soul, and

(1) her father keeps quiet to her, then all her vows will stand, and every $\quad 266 \mathrm{r}^{\circ}$

(2) bond by which she has bound her soul will stand. [6] But

(3) if her father forbids her on the day he heard all her vows

(4) and all her bonds by which she has bound her soul,

(5) it will not stand. And the Lord will forgive her sin because her father forbade

(6) it her. [7] And if she marries a husband,

(7) and her vows are on her or

(8) the utterance of her lips by which she bound her soul, [8]

(9) And her husband heard it and kept quiet to her on the day that he heard it,

(10) then her vows will stand, and her bonds by which she bound

(11) her soul will stand. [9] But if

(12) her husband forbade her on the day that he heard it and broke

(13) her vow which is on her and the utterance of her lips

(14) by which she bound her soul, then the Lord will forgive

(15) her. [10] And a vow of a widow and of her that is divorced, everything

(16) by which she has bound her soul, shall stand against her.

(17) [11] And if she vowed in her husband's house

(18) or bound her soul by a bond with an oath,

(19) [12] And her husband heard it and kept quiet to her,

(20) did not forbid her, then all her vows will stand, and every bond

(21) by which she bound her soul will stand. [13] But 
$266 \mathrm{v}^{\mathrm{o}} \quad$ (1) eger buzma buzsa alarny eri anyn ešitḱan künün-

(2) da bar čyġyšy erinlarinin nijetlarisajyn da bavysajyn žanynyn

(3) qajjam bolmasty eri anyn buzdu alarny da Adonaj bošatyr

(4) jazyġyn anyn. כל ב14] Bar nijet da bar anty bavnyn qyjnama

(5) క̌anny eri anyn qajjam etar any da eri anyn buzar

(6) any. [15] Da eger tyjylma tyjylsa anar eri

(7) anyn künd́an künǵa da qajjam etar ošol bar nijetlarin

(8) anyn jemeśa ošol bar bavlaryn anyn ki anyn üstüńa

(9) qajjam etti alarny ki tyjyldy anar ešitkan kününd́a.

(10) ואם [16] Da eger buzma buzsa alarny ešitkanin-

(11) dan sortun da kötürür eri ošol క̌urumun ol qatyn-

(12) nyn. אלה B Bulardylar ol resimlar ki bujurdu Adonaj

(13) Mošeǵa arasyna ernin qatynybyla arasyna atanyn qy-

(14) zybyla jašlyqlarynda üvünd́a atasynyn.

Numbers 31

(14) [ידבר [1]

(15) Da sözladi Adonaj Mošeǵa ajtadog̉ač. נקום [2] Öč

(16) alġyn öčün ulanlarynyn Jisra’elnin ol Midjanlylardan andan

(17) sortun jyštyrylyrsen uluslaryja. וידבר. [3] Da sözĺa-

(18) di Moše ol ulusqa ajtadoġač jasanyjyz özüjüzd́an

(19) é́anlar čerüvǵa da bolsunlar Midjan üstüńa

(20) berma öčün Adonajnyn Midjanda. אלף. [4] Mińar ki-

(21) ši ševetțan mińar kiši ševett́an bar ševetĺarind́an Jisra-

$267 \mathrm{r}^{\mathrm{o}} \quad$ (1) 'וימסרו . [5] Da symarlandylar

(2) minlarind́an Jisra’elnin mińar kiši ševett́an on eki min

(3) jasanganlary čerüvnün. וישלח. [6 Da ijdi alarny Moše

(4) mińar kiši ševett́an čerüvǵa alarny da ošol Pinaḥas-

(5) ny uvlun El'azarnyn ol kohennin čerüvǵa da savutlary

(6) ol qodešnin da byrg̉ylary ol qyčqyrmaqnyn qolunda anyn.

(7) ויצבאו [7] Da čerüv qurdular Midjan üstüńa ki ne-

(8) č[i] k bujurdu Adonaj \{Mošeǵa\} da qyrdylar bar erḱkakni. ואת [8]

(9) Da ošol bijlarin Midjannyn öltürdülar qyranlary üs-

(10) tüńa alarnyn ošol Evini da ošol Reqemni da ošol

\footnotetext{
${ }^{1} \mathrm{~K}$ : neček; a scribal error. | TKow.o1: unvocalized text. | H: necik. |C: nečik.
} 
(1) if her husband has truly broke them on the day he heard them,

(2) then all the came out of her lips concerning her vows and concerning her bond of her soul

(3) will not stand. Her husband has broken them and the Lord will forgive

(4) her sin. [14] Every vow and every binding oath to afflict

(5) the soul: her husband establishes it or her husband breaks

(6) it. [15] But if her husband altogether keeps quiet to her

(7) from day to day, then he establishes all her vows

(8) or all her bonds which are on her.

(9) He establishes them, because he kept quiet to her on the day he heard them.

(10) [16] But if he truly breaks them after that he has heard them,

(11) then he will bear the punishment of the women.'

(12) [17] These are the statutes which the Lord commanded

(13) Moses, between a man and his wife, between the father

(14) and his daughter while she is in her youth within her father's house.

\section{Numbers 31}

(15) And the Lord spoke to Moses, saying, [2] 'Avenge

(16) the children of Israel of the Midianites. After that

(17) you shall be gathered to your people.' [3] And

(18) Moses spoke to the people, saying, 'Arm men from among you

(19) for the war, and they shall be against the Midianites,

(20) to take the Lord's vengeance on Midian. [4] A thousand

(21) from each tribe, a thousand from each tribe, from all the tribes of Israel

(1) you shall send to the war.' [5] And

(2) from the thousands of Israel, a thousand from each tribe were commanded, twelve thousand

(3) armed for war. [6] And Moses sent them

(4) to the war, a thousand from each tribe, them and Phinehas,

(5) son of Eleazar, the priest, to the war, with the vessels

(6) of the Holy, and the trumpets of calling voice in his hand.

(7) [7] And they warred against the Midianites,

(8) as the Lord commanded Moses, and they killed every male. [8]

(9) And they killed the kings of Midian over their corpses:

(10) Evi, and Rekem, and 
(11) Curnu da ošol Ḥurnu da ošol Reva'ni beš bijlarin

(12) Midjannyn da ošol Bil'amni uvlun Bo'ornun öltür-

(13) dülar qylyčbyla. וישבו [9] Da jesir ettiĺar ulan-

(14) lary Jisra’elnin ošol qatynlaryn Midjannyn da ošol jašyn

(15) alarnyn da ošol bar tuvarlaryn da ošol jyjynlaryn ${ }^{1}$ alar-

(16) nyn da ošol bar mallaryn alarnyn taladylar. [10] Da

(17) ošol bar šaharlaryn alarnyn olturušlarynda da ošol

(18) bar sarajlaryn alarnyn küvdürdülar otta. ויקחו. [11]

(19) Da aldylar ošol bar ol olžany da ošol bar ol hạalqny

(20) $\operatorname{adam}\{$ da\} da tuvarda. [12] Da kel\{tir\}dilar Mošeǵa da

(21) El'azarğa ol kohenǵa bar క̌ymatyna ulanlarynyn Jis-

$267 \mathrm{v}^{\mathrm{o}} \quad$ (1) ra’elnin ošol ol jesirni da ošol ol ḥalqny da ošol

(2) ol olžany ol avulğa jylġalyqlaryna Mo'avnyn ki Jardeni

(3) qatyna Jerehononun. [13] Da čyqtylar Moše da El'azar

(4) ol kohen da bar nasilari ol ǰymatnyn uturularyna alar-

(5) nyn tyšqartyn avulğa. ויקצף] Da ačuvlandy Moše

(6) ag̉araqlary üstüńa ol čerüvnün ag̉araqlary üstüna

(7) ol minlarnin da ag̉araqlary üstüńa ol jüzlarnin

(8) ol kelüvčǔlar üstüńa jyjynyndan ol čerüvnün.

(9) ויאמר [15] Da ajtty alargàa Moše tiri qaldy\{r\}dyjyzmo

(10) bar qatyn kišini. הן. [16] Muna alar edilar azġyruv-

(11) čular ulanlaryn Jisra’elnin sözübyla Bil'amnin tanma

(12) tanmaq Adonajgia išibyla Po'ornun da boldu ol qyranč

(13) Žymatynda Adonajnyn. [17] Da haligińa öl-

(14) türüjüz bar erkakni jašta da bar qatynny bilüv-

(15) čünü kišini jatuvuna erḱkaknin öltürüjüz. וכל [18]

(16) Da bar ol jašny qatynlarda ki bilḿajdilar jatuvun

(17) e\{r\}ḱkaknin tiri qaldyryjyz özüjüzǵa. ואתם. [19] Da

(18) siz toḥtajyz tyšqartyn avulgaa jedi künlar bar ol öl-

(19) türüvčü క̌anny da bar tijüvčü qyranġa bürkünü-

(20) jüz ol üčünčü künd́a da ol jedinči künd́a siz

(21) da jesirijiz. וכל [20] Da bar upraqbyla da bar teri

\footnotetext{
${ }^{1}$ Possibly a scribal error (or a mistranslation); cf., however, Num 32:26. | TKow.o1: mallaryn;

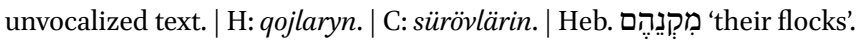


(11) Zur, and Hur, and Reba, the five kings

(12) of Midian. And they killed Balaam, son of Beor,

(13) with the sword. [9] And the children of Israel took captive

(14) all the women of Midian and their little ones,

(15) and took as plunder all their cattle and all their hosts ${ }^{249}$

(16) and all their goods. [10] And

(17) they burned all their cities in which they dwelt, and

(18) all their palaces, in fire. [11]

(19) And they took all the spoil and all the prey,

(20) human and animal. [12] And they brought to Moses and

(21) to Eleazar, the priest, and to the congregation of the children of Israel

(1) the captives and the prey and

(2) the spoil, to the camp at the steppes of Moab, which is by the Jordan

(3) of Jericho. [13] And Moses and Eleazar,

(4) the priest, and all the princes of the congregation went to meet

(5) them outside the camp. [14] And Moses was angry

(6) at the superiors of the army,

(7) at the superiors over thousands and at the superiors over hundreds,

(8) at those who came from the army of the war.

(9) [15] And Moses said to them, 'Did you keep alive

(10) all the women? [16] Lo, they were who deluded

(11) the children of Israel, through the word of Balaam, to

(12) commit trespass against the Lord in the matter of Peor, and there was a plague

(13) in the Lord's congregation. [17] And Now

(14) kill every male among the little ones, and kill every woman

(15) who has known a man for male intercourse. [18]

(16) But all the infants among the women who have not known a man's bed

(17) keep alive for yourselves. [19] And

(18) you must abide outside the camp seven days: everyone

(19) who has killed a life and everyone who has touched dead: purify

(20) on the third day and on the seventh day, you

(21) and your captives. [20] And you shall purify all your clothing and every

249 Possibly a scribal error (or a mistranslation), cf. Heb. מִקְנְהֶם 'their flocks'. Cf., however, Num 32:26. | TKow.o1: goods. | H: flocks. | C: flocks. 
$268 \mathrm{r}^{\circ}$ (1) li savutbyla da bar išibyla ečki jununun da bar ag̉ač-

(2) ly savut byla bürkünüjüz. [21] Da ajtty El-

(3) 'azar ol kohen elińa ol čerüvnün ol kelüvčülarǵa

(4) čerüvǵa budur resimi ol Toranyn ki bujurdu Adonaj

(5) Mošeǵa. אך. [22] Tek ošol ol altynny da ošol

(6) ol kümüšnü da ošol ol tučnu ošol ol temirni

(7) ošol ol cynny da \{ošol\} ol qorg̉ašynny. ל̌. [23] Bar nerśa

(8) ki keladi otqa ašyryjyz ot ašyra da arynsyn

(9) tek bürkünür suvlary byla bürkülsün da barča neki

(10) kelḿajdi otqa ašyryjyz suv ašyra. וכבסתם [24]

(11) Da juvujuz upraqlaryjyzny ol jedinči künd́a da

(12) arynyjyz da andan sortun kelijiz ol avulġa. [25]

(13) Da ajtty Adonaj Mošeǵa ajtadog̀ač. שא. [26] Alġyn

(14) sanyn bašynyn hạalqynyn ol jesirnin adamda da tuvarda

(15) sen da El'azar ol kohen da ag̉araqlary atalarynyn ol žymat-

(16) nyn. וחצית [27] Da ajyrgyyn jarymg̉a ošol ol ḥalqny

(17) arasyna tutuvčularnyn ol čerüvnü ol čyg̉uvčularnyn

(18) čerüvǵa da arasyna bar ol క̌ymatnyn. והרמת. [28]

(19) Da ajyrg்yn tymġa Adonajg̉a elind́an ol čerüvnün

(20) ol čyg̉uvčularnyn čerüvǵa bir šan beš ol jüzd́an \{ol\} adam-

(21) dan da ol syġyrdan da ol eš́akíard́an da ol qojdan.

$268 \mathrm{v}^{\circ} \quad$ (1) ממחציתם. [29] Jarymlaryndan alarnyn alyjyz da bergin El-

(2) וממחצת [30]

(3) Da jarymyndan ulanlarynyn Jisra’elnin alġyn bir ülüš ol

(4) enlidan ol adamdan ol syġyrdan ol eš́aklardan da

(5) ol qojdan bar ol tuvardan da bergin ${ }_{L}\langle$ any $\rangle\{\text { alarny }\}^{11}$ Levililarǵa

(6) saqlavčularg̉a saqlavy miškanynyn Adonajnyn. [יעש [31] Da

(7) qyldy Moše da El'azar ol kohen ki nečik bujurdu Adonaj

(8) Mošeǵa. ויהי [32] Da edi ol halq qaldyg̉y ol talavnyn

(9) ki taladylar ulusu ol čerüvnün qoj alty jüz min da

(10) jetmiš min da beš minlar. ובקר [33] Da syġyr jet-

(11) miš eki min. וחמרים [34] Da ešaḱlar altymyš

(12) bir min. ונפש [35] Da žany adamnyn ol qatynlardan

(13) ki bilmáadílar jatuvun erḱkaknin ${ }_{\mathrm{L}}\{[\mathrm{ba}] \mathrm{r} \text { žan }\}^{12}$ otuz eki min.

(14) יתהי [36] Da edi ol jarym ülüšü ol čyğuvčularnyn

(15) čerüvǵa sany ol qojnun üč jüz $\min _{\mathrm{L}}\{[\mathrm{d}] \mathrm{a} \text { otuz } \min \}^{13}$ da jedi minlar

${ }^{1}$ Correction by another hand. | TKow.o1: any; unvocalized text.|H: alarny.|C:alarny. $\quad{ }^{2}$ TKow.o1: bar žan; unvocalized text. | H: bar zan. | C: barča žan. ${ }^{3}$ TKow.o1: da otuz min; unvocalized text. | H: da otuz min. | C: üč jüz otuz jedi bin; different wording. 
(1) leather item and all work of goats' hair and every wood $268 \mathrm{r}^{\mathrm{o}}$

(2) item.' [21] And Eleazar,

(3) the priest, said to the men of war who went

(4) to the battle, "This is the statute of the Law which the Lord commanded

(5) Moses. [22] Just the gold, and

(6) the silver, the bronze, the iron,

(7) the tin, and the lead: [23] Every thing

(8) that goes in fire you shall pass through the fire, and it shall be clean.

(9) It shall be purified just with purifying water. And everything that

(10) does not go in fire you shall pass through water. [24]

(11) And you shall wash your clothes on the seventh day, and

(12) you shall be clean, and afterward you shall come to the camp.' [25]

(13) And the Lord spoke to Moses, saying, [26] 'Take

(14) the sum of the prey, human and animals,

(15) you, and Eleazar, the priest, and the superiors of the fathers of the congregation.

(16) [27] And divide the prey into halves,

(17) between the warriors who went out

(18) to the army and between all the congregation. [28]

(19) And separate a tax to the Lord from the men of war

(20) who went out to the army: one soul out of five hundred, of humans

(21) and of the cattle and of the donkeys and of the sheep.

(1) [29] Take it from their half, and give it to Eleazar,

(2) the priest, for a heave offering of the Lord. [30]

(3) And from the half of the children of Israel you shall take one portion

(4) out of fifty, of humans, of the cattle, of the donkeys and

(5) of the sheep, of all the livestock, and give $\langle$ it $\rangle\{$ them $\}$ to the Levites,

(6) who keep the charge of the tabernacle of the Lord.' [31] And

(7) Moses and Eleazar, the priest, did as the Lord commanded

(8) Moses. [32] And the prey, the rest of the plunder

(9) which the men of war took as plunder was six hundred thousand and

(10) seventy thousand and five thousand sheep, [33] And

(11) seventy thousand cattle, [34] And sixty-

(12) -one thousand donkeys, [35] And the human souls-of women

(13) who have not known a man's bed-all the persons were thirty-two thousand.

(14) [36] And the half, the portion of those who went out to war was:

(15) The number of sheep was three hundred thousand and thirty thousand and seven thousand 
(16) da beš jüz. ויהי [37] Da edi ol tymġa Adonajğa

(17) ol qojdan alty jüz da jetmiš beš. והבקר [38 Da ol

(18) syg்r otuz alty min da tymgialary alarnyn Adonajg̉a jet-

(19) miš eki. וחמרים] Da ešakĺar otuz min da

(20) beš jüz da tymġalary alarnyn Adonajğa altymyš bir.

(21) [40] Da క̌any adamnyn on alty min da tymgalary

$269 \mathrm{r}^{\mathrm{o}} \quad$ (1) alarnyn Adonajğg otuz eki žan. [41] Da berdi Moše

(2) ošol tymġasyn terumasynyn Adonajnyn El'azarga ol kohen-

(3) ǵa ki nečik bujurdu Adonaj Mošeǵa. וממחצית. [42] Da

(4) jarymyndan ulanlarynyn Jisra’elnin ki ajyrdy Moše ol eŕan-

(5) Ílardan ol čerüv quruvčulardan. [4ה [4] Da edi jary-

(6) my ol క̌ymatnyn ol qojdan üč jüz min da otuz min da

(7) jedi minlar da beš jüz. ובקר [45] Da syg̀yr otuz

(8) alty min. וחמרים. [45] Da eš́akĺar otuz min da

(9) beš jüz. ונפש. [46] Da žany adamnyn on alty min.

(10) ויקח [47 Da aldy Moše jarymyndan ulanlarynyn Jisra’elnin \{ošol\}

(11) ol bir ülüšnü ol enlid́an ol adamdan da ol tuvar-

(12) dan da berdi alarny Leviliĺarǵa saqlavčularg̉a saqlavun miškan-

(13) nyn Adonajnyn ki nečik bujurdu Adonaj Mošeǵa. ויקרבו. [48]

(14) Da juvudular Mošeǵa ol 〈sanalġanlar \{agaalyqlar\} ki minlarinin ol

(15) čerüvnün ag̉araqlary ol minlarnin da agaaraqlary ol jüz-

(16) Íarnin. [49] Da ajttylar Mošeǵa qullaryj al-

(17) dylar ošol sanyn bašynyn elinin ol čerüvnün ki qolumuz-

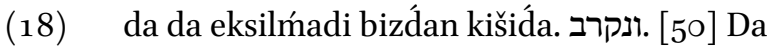

(19) juvuttuq ošol qarbanyn Adonajnyn kiši ki tapty da altyn

(20) savut ajaq bilazigi da qol bilazigi jüzük hạaḷa da pižma

(21) bošatlyq qolma క̌anlarymyz üčün alnynda Adonajnyn.

$269 v^{0} \quad$ (1) [יקח [5 [1] Da aldy Moše da El'azar ol kohen ošol ol altyn-

(2) ny alardan bar išlanǵan savutnu. ויהי [52] Da edi bar

(3) altyny ol terumanyn ki ajyrdylar Adonajgia on alty

(4) min jedi jüz da enli mitqal ag̉araqlaryndan ol minlar-

(5) nin da ag̉araqlaryndan ol jüzlarnin. אנשי [53] Eli ol

(6) čerüvnün taladylar har kiši özünáa. [54 [5] Da

(7) \{aldy\} Moše da El'azar ol kohen ošol ol altynny ag̉araqlaryn- 
(16) and five hundred. [37] And the tax for the Lord

(17) of the sheep was six hundred and seventy-five. [38] And the

(18) cattle were thirty-six thousand, and their tax for the Lord was

(19) seventy-two. [39] And the donkeys were thirty thousand and

(20) five hundred, and their tax for the Lord was sixty-one.

(21) [40] And the human souls were sixteen thousand, and their tax

(1) for the Lord was thirty-two persons. [41] And Moses gave

(2) the tax, the heave offering of the Lord, to Eleazar, the priest,

(3) as the Lord commanded Moses. [42] And

(4) of the half of the children of Israel which Moses divided from

(5) the men that warred: [43] And the half

(6) of the congregation was three hundred thousand and thirty thousand and

(7) seven thousand and five hundred sheep, [44] And

(8) thirty-six thousand cattle, [45] And thirty thousand and

(9) five hundred donkeys, [46] And sixteen thousand human souls.

(10) [47] And of the half of the children of Israel Moses took

(11) one portion of fifty, of humans and of animals,

(12) and gave them to the Levites who keep charge of the tabernacle

(13) of the Lord, as the Lord commanded Moses. [48]

(14) [48] And the superiors of thousands

(15) of the army, the superiors of thousands and superiors of hundreds, came near to Moses.

(16) [49] And they said to Moses, 'Your servants

(17) have taken the sum of the heads of the men of war who are in our hands,

(18) and there lacks not one man of us. [50] And

(19) we have brought forward the offering of the Lord, what each man found-golden

(20) items, leg bracelets and arm bracelets, rings, bracelets, and trinkets-

(21) to ask for atonement for our souls before the Lord.'

(1) [51] And Moses and Eleazar, the priest, took the gold

(2) from them, all the crafted items. [52] And all

(3) the gold of the heave offering that they separated for the Lord was sixteen

(4) thousand seven hundred and fifty mithqals, from the superiors of thousands

(5) and from the superiors of hundreds. [53] The men

(6) of war had plundered, every man for himself. [54] And

(7) Moses and Eleazar, the priest, took the gold of the superiors 
(8) dan ol minlarnin da ol jüzĺarnin da keltirdilar any

(9) ohel mo`edǵa sag̉ynčlyq ulanlaryna Jisra’elnin alnynda

(10) Adonajnyn.

Numbers $3^{2}$

ומקנה. [1] Da köbüsü tuvar edi ulan-

(11) laryna Ru'uvennin da ulanlaryna Gadnyn küčlü astry

(12) da kördülar ošol jerin Ja'ezernin da ošol jerin Gil'ad-

(13) nyn da muna ol jer tuvarlyq orunda. ייבואו [2] Da

(14) keldilar ulanlary Gadnyn da ulanlary Ru'uvennin da aj-

(15) ttylar Mošeǵa da El'azarg̉a ol kohenǵa da nasi-

(16) Ílarińa ol 3̌ymatnyn ajtadoġač. עטרות. [3] 'Atarot

(17) da Divon da Ja'ezer da Nimra da Ḥešbon da El'ale ${ }^{1}$

(18) da Ševam da Nevo da Boon. [4 Oארץ Ol jer ki qyrdy

(19) Adonaj olturuvčularyn anyn alnynda žymatynyn Jisra'elnin

(20) turarlyq jerdi ol da qullaryja bardy tuvar. ויאמרי [5]

(21) Da ajttylar eger taptyq eśa širinlik közlarij-

270 o $\mathrm{r}^{\mathrm{o}} \quad$ (1) da berilsin ošol ol jer ošpu qullaryja tutuvluqqa

(2) ašyrmaġyn bizni ol Jarden ašyra. ויאמר. [6] Da ajtty

(3) Moše ulanlaryna Gadnyn da ulanlaryna Ru'uvennin qaryndašla-

(4) ryjyzmo kelirlar čerüvǵa da $\{$ siz $\}$ olturursiz bunda.

(5) [7 [7 Da nek tyjasyz ošol jüŕagin ulanlarynyn Jisra’el-

(6) nin ašmaqtan ol jerǵa ki berdi alarg̉a Adonaj. כה ] [8 ]

(7) Bulaj qyldylar atalaryjyz ijǵanimd́a alarny Qadeš Barnea-

(8) dan körma ošol ol jerni. ויעלו [9] Da bardylar

(9) öźanińadejin Eškolnun da kördülar ošol ol jerni

(10) da tyjdylar ošol jüragin ulanlarynyn Jisra’elnin kelḿas-

(11) ka ol jerǵa ki berdi alarğa Adonaj. [10] Da

(12) qabundu ačuvu Adonajnyn ol künd́a da ant etti aj-

(13) tadog̉ač. אם. [11] Eger körśalar ol éranlar ol

(14) čyg்uvčular Micridan igirmi jaštan da jog̉arraq ošol

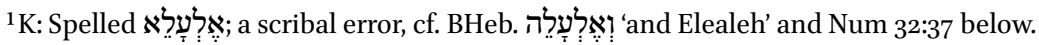


(8) of thousands and of hundreds, and brought it

(9) to the tent of meeting, a memorial for the children of Israel before

(10) the Lord.

Numbers 32

[1] And a great multitude of livestock was

(11) for the children of Reuben and the children of Gad.

(12) And they saw the land of Jazer and the land of Gilead,

(13) and, lo, the land was even a place for cattle. [2] And

(14) children of Gad and the children of Reuben came and

(15) spoke to Moses and to Eleazar, the priest, and to the princes

(16) of the congregation, saying, [3] Ataroth,

(17) and Dibon, and Jazer, and Nimrah, and Heshbon, and Elealeh,

(18) and Shebam, and Nebo, and Beon: [4] 'The land

(19) the inhabitants of which the Lord defeated before the congregation of Israel

(20) is a land for cattle, and your servants have cattle.' [5]

(21) And they said, 'If we have found favour in your sight,

(1) let this land be given to your servants for a possession,

(2) and do not have us cross over Jordan.' [6] And

(3) Moses said to the children of Gad and to the children of Reuben,

(4) 'Will your brethren go to war, and will you sit here?

(5) [7] And why do you hold back the heart of the children of Israel

(6) from crossing to the land which the Lord has given them? [8]

(7) Thus did your fathers, when I sent them from Kadesh-Barnea

(8) to see the land. [9] And they went up

(9) to the river of Eshcol and saw the land

(10) and they hold back the heart of the children of Israel,

(11) not to go to the land which the Lord had given them. [10] And

(12) the Lord's anger was kindled on that day, and he swore,

(13) saying, [11] "The man

(14) who came out from Egypt, from twenty years old and upward ${ }_{L}$ [will not see $]^{1250}$

$250 \mathrm{~K}$ : if they see; a mistranslation repeated in a number of manuscripts resulting from literal translation of the Hebrew conditional clause, cf. Gen 14:23, Num 14:23, Num 14:30, Deu 1:35. | TKow.o1: if they see. | H: if they see. | C: if they see. | M: if they see. | E: if they see. | R: if they see. 
(15) ol jerni ki antettim Avrahamġa Jichaqqa da Ja'a-

(16) qovg̉a ki tüǵallik byla jürümadilar saruvum arty-

(17) na. בלתי. [12] Ančaq Kalev uvlu Jefunenin ol Qenizi da

(18) Johošua uvlu Nunnun ki tüğallik byla jürüdülar saruvu

(19) artyna Adonajnyn. ויחר [13] Da qabundu ačuvu Adonaj-

(20) nyn Jisra’eld́a da tünḱaltti alarny midbarda qyrq

(21) jyl tüǵanginč́a bar ol dor ol qyluvču ol jaman körün-

270 vo (1) ǵanni 'enajatlarind́a Adonajnyn. [14 [14 Da muna tur-

(2) dujuz atalaryjyz ornuna artmaġy jazyqly eŕanlarnin art-

(3) tyrma dağyn qaḥir ačuvu üstüńa Adonajnyn Jisra’elǵa.

(4) כי . [15] Ki ked́argi qajtsajyz saruvu artyndan anyn da ar-

(5) ttyryr daġyn kemišḿa any midbarda da čajparsiz bar

(6) ol ulusnu ošpunu. [16] Da juvudular anar

(7) da ajttylar qoralaryn qojnun qondaryrbiz tuvarymyzgia

(8) bunda da šaharlar jašymyzġa. ואנחנו. [17] Da biz

(9) jasynyrbiz bolma jetizlar barma alnynda ulanlarynyn

(10) Jisra’elnin neginč́a ki keltirǵajbiz alarny orunlaryna

(11) da olturur jašymyz ol bek šaharlarda alnyndan ol-

(12) turuvčularynyn ol jernin. לא. [18] Qajtmasbiz üvlari-

(13) mizǵa ülüš alġynča ulanlary Jisra’elnin har kiši

(14) ülüšün özünün. כי [19] Ki ülüš almasbiz \{birǵalarińa\} kö-

(15) čüvünd́an Jardennin da arraq ki keldi ülüšümüz biz-

(16) ǵa köčüvünd́an ol Jardennin mizrah sary. ויאמר. [20]

(17) Da ajtty alarğa Moše eger qyls[a]jyz ${ }^{1}$ ošol ol išni

(18) ošpunu eger jasansajyz alnynda Adonajnyn čerüvǵa.

(19) (21] Da ašsa siznin bar jasanġan ol Jarden ašyra

(20) alnynda Adonajnyn tasetḱanińadejin ošol dušmanlaryn

(21) alnyndan. [20 [22] Da tutuvlansa ol jer alnynda

$271 \mathrm{r}^{\mathrm{o}} \quad$ (1) Adonajnyn da andan sortun qajtyrsiz da bolursiz könülar

(2) Adonajdan da Jisra’eld́an da bolur ol jer ošpu sizǵa

(3) tutuvluqqa alnynda Adonajnyn. ואם. [23] Da eger qyl-

(4) masajyz alaj muna jazyqly bolursiz Adonajğa da bilijiz

(5) jazyġyjyzny ki učrar sizni. בנו. [24] Qondaryjyz özüjüz-

(6) ǵa šaharlar jašyjyzġa da qoralar qojujuzğa da ol čyqqany

(7) avzujuzdan qylyjyz. (25] Da ajttylar ulanlary

(8) Gadnyn da ulanlary Ru'uvennin Mošeǵa ajtadoġač qulla-

(9) ryj qylarlar ki nečik bijim bujurady. טפנו. [26] Jašymyz

\footnotetext{
${ }^{1}$ TKow.o1: unvocalized text. | H: qylsanyz. | C: qylsayyz.
} 
(15) the land which I swore to Abraham, to Isaac, and

(16) to Jacob, they have not followed my order completely,

(17) [12] Except Caleb, son of Jephunneh, the Kenizzite, and

(18) Joshua, son of Nun, for they have wholly followed the order

(19) of the Lord." [13] And the Lord's anger was kindled

(20) against Israel, and he made them wander in the wilderness forty

(21) years, until the end of all the generation who were doing things

(1) that seemed bad in the eyes of the Lord. [14] And, lo, you

(2) have risen in your fathers' place, an increase of sinful men,

(3) to increase still more the furious anger of the Lord toward Israel.

(4) [15] Because if you turn away from his order,

(5) he will go on to leave them yet again in the wilderness, and you will destroy all

(6) this people.' [16] And they came near to him,

(7) and said, 'We will build sheepfolds here for our livestock

(8) and cities for our infants. [17] But we

(9) will arm ourselves to be diligent to go before the children

(10) of Israel until we have brought them to their place.

(11) And our infants shall dwell in the fortified cities in front of

(12) the inhabitants of the land. [18] We will not return to our houses

(13) until the children of Israel have taken every man his share.

(14) [19] Because we will not take a share with them

(15) from the ford of Jordan and beyond, because our share has come to us

(16) from the eastward |side| of the ford of Jordan.' [20]

(17) And Moses said to them, 'If you do this thing,

(18) if you arm yourselves before the Lord for war,

(19) [21] And pass all of you armed over Jordan

(20) before the Lord until he has destroyed his enemies

(21) from before him, [22] And the land is subdued before

(1) the Lord: after that you will return, and you will be free

(2) from the Lord and from Israel, and this land will be your

(3) possession before the Lord. [23] But if

(4) you will not do so, lo, you will be sinful for the Lord, and know

(5) that your sin will meet you. [24] Build you

(6) cities for your infants, and folds for your sheep, and do that which has come out

(7) of your mouth.' [25] And the children

(8) of Gad and the children of Reuben spoke to Moses, saying,

(9) 'Your servants will do as my lord commands. [26] Our infants, 
(10) qatynlarymyz jyjynymyz ${ }^{1}$ da bar tuvarymyz bolurlar anda

(11) šaharlarynda ol Gil'adnyn. ועבדיך. [27] Da qullaryj ašar-

(12) lar bar jasanġany čerüvnün alnynda Adonajnyn čerüvǵa

(13) ki nečik bijim sözlajdi. ויצו [28] Da bujurdu alar

(14) üčün Moše El'azarğa ol kohenǵa da Johošua'ğa uv-

(15) luna Nunnun da ag̉araqlaryna atalarynyn ol ševetlarnin

(16) ulanlarynyn Jisra’elnin. יויאמר [29] Da ajtty Moše alar-

(17) ga eger ašsalar ulanlary Gadnyn da ulanlary Ru’uven\{ni\}n bir-

(18) ǵajizǵa ol Jarden ašyra bar jasanġan čerüvǵa alnynda

(19) Adonajnyn da tutuvlansa ol jer alnyjyzda da berirsiz

(20) alarg̉a ošol jerin ol Gil'adnyn tutuvluqqa. [3ם [30] Da

(21) eger ašmasalar jasanġanlar birǵajizǵa da tutuvlansynlar

271 V (1) ortajyzda jerind́a Kena'annyn. [31] Da qaruv berdilar

(2) ulanlary Gadnyn da ulanlary Ru'uvennin ajtadog̉ač ošol ne ki

(3) sözĺadi Adonaj q[u]llaryja ${ }^{2}$ alaj qylarbiz. נחנו [32] Biz ašar-

(4) biz jasanġanlar alnynda Adonajnyn jerińa Kena’annyn da birǵa-

(5) mizǵa tutuvlug̣u ülüšümüznün köčüvünd́an Jardennin.

(6) ויתן [33] Da berdi alarg̉a Moše ulanlaryna \{Gadnyn da ulanlaryna\} Ru'uvennin da

(7) jarym ševetińa Menašenin uvlunun Josefnin ošol bijligin

(8) Siḥonnun bijinin ol Emorinin da ošol bijligin 'Og̉nun

(9) bijinin Bašannyn ol jerni šaharlarybyla čeklaribyla šahar-

(10) larynyn ol jernin čüvŕa. [34] Da qondardylar ulanlary

(11) Gadnyn ošol Divonnu da ošol 'Atarotnu da ošol 'Aro'er-

(12) ni. ואת [35] Da ošol 'Atrot Šofanny da ošol Ja'ezerni

(13) da Jag̉bahany. [36] Da ošol Bet Nimrany da ošol

(14) Bet Haranny bek šaharlar da qoralaryn qojnun. [3נ Da

(15) ulanlary Ru'uvennin qondardylar ošol Ḥešbonnu da ošol Ele-

(16) 'ואת [38] Da ošol Nevonu

(17) da ošol Bacalmo'onnu quršalġanlar atbyla da ošol

(18) Šivmany da atadylar atlarbyla ošol atlaryn ol šaharlar-

(19) nyn ki qondardylar. וילכו [39] Da bardylar ulanlary Mahir\{nin\} uvlu

(20) Menašenin Gil'a\{d\}g ga da tuttular any da tasetti ošol

\footnotetext{
${ }^{1}$ Possibly a scribal error (or a mistranslation); cf., however, Num 31:9. | TKow.o1: jyjynlarymyz; unvocalized text. | H: qojlarymyz.| C: sürövümuz.| Heb. 'מִקְנֵנוּ 'our flocks'. ${ }^{2} \mathrm{~K}:$ qollaryja, a scribal error. | TKow.o1: unvocalized text. | H: qullaryna. | C: qullaryna.
} 
(10) our wives, our hosts 251 and all our livestock shall be there

(11) in the cities of Gilead. [27] But your servants

(12) will pass over, every man armed for war, before the Lord to battle,

(13) as my lord says.' [28] So Moses gave command concerning them

(14) to Eleazar, the priest, and Joshua,

(15) son of Nun, and the superiors of the fathers of the tribes

(16) of the children of Israel. [29] And Moses said to them,

(17) 'If the children of Gad and the children of Reuben will pass

(18) with you over Jordan, every man armed to battle, before

(19) the Lord, and the land shall be subdued before you, then you shall give

(20) them the land of Gilead for a possession. [30] But

(21) if they will not pass over with you armed, they shall have possessions

(1) among you in the land of Canaan.' [31] And

(2) the children of Gad and the children of Reuben answered, saying, 'What

(3) the Lord has said to your servants, so will we do. [32] We will pass

(4) over armed before the Lord to the land of Canaan, and

(5) the possession of our share from |across| the ford of Jordan with us.'

(6) [33] And Moses gave to them, to the children of Gad and to the children of Reuben and

(7) to half the tribe of Manasseh, son of Joseph, the kingdom

(8) of Sihon, king of the Amorites, and the kingdom of Og,

(9) king of Bashan: the land with its cities within the borders of the cities

(10) of the land all around. [34] And the children

(11) of Gad built Dibon, and Ataroth, and Aroer,

(12) [35] And Atroth-Shophan, and Jazer,

(13) and Jogbehah, [36] And Beth-Nimrah, and

(14) Beth-Haran, fortified cities, and folds for sheep. [37] And

(15) the children of Reuben built Heshbon, and Elealeh,

(16) and Kiriathaim, [38] And Nebo,

(17) and Baalmeon, with their names being changed, and

(18) Sibmah, and gave other names to the cities

(19) which they built. [39] And the children of Machir, son

(20) of Manasseh, went to Gilead and took it, and they destroyed

251 Possibly a scribal error (or a mistranslation), cf. Heb. מִקְנְנוּ 'our flocks'. Cf., however, Num 31:9. 
(21) ol Emorinin ki anda. ויתן [40] Da berdi Moše ošol ol Gil'ady Mahirǵa uvluna Menašenin da olturdu anda.\} Menašenin bardy da tuttu ošol [s] alalaryn ${ }^{1}$ alarnyn [da atady alarg்a Havot Ja'ir] $\}^{12}$. ונבח. [42] Da Novah bardy da tuttu

$272 \mathrm{r}^{\mathrm{o}} \quad$ (1) L[ošol] $\{\text { Qenatny } d a\}^{13}$ ošol salalaryn anyn da atady anar Novaḥ öz atybyla.

Numbers 33

פרשת אלה מסעי (3) (2) (2) (2)

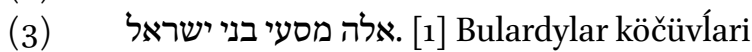

(4) ulanlarynyn Jisra’elnin ki čyqtylar jerind́an Micri-

(5) nin čerüvlarisajyn naviligi ašyra Mošenin da Aharonnun.

(6) (2] Da jazdy Moše ošol čyğyšlaryn alarnyn köčüv-

(7) ĺarisajyn bujrugguna köŕa Adonajnyn da bulardylar köčüv-

(8) lari alarnyn čyğyšlarysajyn. [3] Da köčtülar

(9) Ra'mesestan ol burunġu janġajda on bešinči künün-

(10) d́a \{ol burunġu janġajnyn tanbylasyndan qarbanynyn ol Pesaḥnyn čyqtylar

(11) ulanlary Jisra’elnin küčlü qolbyla. ומצרים. [4 Da eli

(12) Micrinin astrarediĺar ošol ne ki qyrdy Adonaj alar-

(13) $[\mathrm{d}] \mathrm{a}^{4}$ bar tunğučnu da abaqlarynda qyldy Adonaj karanjalar.

(14) [5] Da köčtülar ulanlary Jisra’elnin Ra'ameses-

(15) tan da toḥtadylar Sukotta. [6] Da köčtü-

(16) lar Sukottan da toḥtadylar Etamda ki učunda

(17) ol midbarnyn. [7] Da köčtülar Etamdan

(18) da qajttylar Pi Hahirotqa ki alnynda Ba'al Cefonnun

(19) da toḥtadylar alnynda Migdolnun. ויסעו. [8]

$272 \mathrm{v}^{\mathrm{o}} \quad$ (1) Da köčtülar Pne Haḥirottan da aštylar ortasy ašyra ol

(2) tengiznin ol midbarg̉a da bardylar üč künlar midbarybyla

(3) Etamnyn da toḥtadylar Marada. ויסעו. [9] Da köčtülar

(4) Maradan da keldilar Elimǵa on eki köz

\footnotetext{
${ }^{1} \mathrm{~K}$ : šalalaryn; a scribal error. $\quad{ }^{2}$ Added by another hand on the bottom margin. | TKow.o1: $D a$ Ja'ir uvlu Menašenin bardy da tuttu ošol salalaryn alarnyn da atady alarga HavotJa'ir; unvocalized text. | H: Da Jåir uvlu Menašenin bardy da tuttu osol salalaryn alarnyn da [atady] alarg̈a Havot Ja'ir; the word atady is missing in $\mathrm{H}$ due to scribal error. | C: Da Ja'ir og்lu Menašeniy bardy da tuttu šol salalaryn da atady a larga Havot Ja’ir. $\quad{ }^{3}$ Marginal insertion by another hand. | TKow.o1: ošol Qenatny da; unvocalized text. | H: osol Qenatny da. | C: šol Qenatny da. ${ }^{4}$ TKow.o1: alarda; unvocalized text. | H: alarda. | C: alarda.
} 
(21) the Amorites who were there. [40] And Moses gave Gilead to Machir, son of Manasseh, and he dwelt there. $\{[41]$ [And] Jair, son of Manasseh went and took their small villages [and called them Havoth-Jair]. [42] And Nobah went and took

(1) $\{$ Kenath $\}$, and its villages, and called it Nobah after his own name.

Numbers 33

(2) Parashat Masei

(3) [1] These are the travels

(4) of the children of Israel, who went out from the land of Egypt

(5) by their armies under the prophecy of Moses and Aaron.

(6) [2] And Moses wrote down their exits according their travels,

(7) according to the commandment of the Lord. And these are their travels

(8) according to their exits: [3] And they set out

(9) from Rameses in the first month, on the fifteenth day

(10) of the first month. The next day after the Passover

(11) the children of Israel went out with a strong hand. [4] And the people

(12) of Egypt buried what the Lord has killed among them,

(13) all their firstborn, and the Lord had made punishments on their gods.

(14) [5] And the children of Israel set out from Rameses

(15) and camped in Succoth. [6] And they set out

(16) from Succoth and camped at Etham which is at the edge

(17) of the wilderness. [7] And they set out from Etham,

(18) and turned back to Pi-Hahiroth, which is before Baal-Zephon,

(19) and they camped before Migdol. [8]

(1) And they set out from Pi-Hahiroth and passed through the midst

(2) of the sea to the wilderness and went three days across the wilderness

(3) of Etham and camped at Marah. [9] And they set out

(4) from Marah and came to Elim: twelve fountains 
(5) suvlar da jetmiš ḥurma teŕaklari da toḥtadylar anda.

(6) ויסעו Da köčtülar Elimd́an da toḥtadylar Jam Suf

(7) qatyna. ויסעו [11] Da köčtülar Jam Suftan da toḥta-

(8) dylar midbarynda Sinnin. ויסעו [12] \{Da köčtülar $\}$ midbaryndan Sinnin da

(9) tohtadylar Dafqada. [13] Da köčtülar Dafqadan da

(10) toḥtadylar Alušta. ויסעו [14] Da köčtülar Aluštan

(11) da toḥtadylar Refidimd́a da jog̉edi anda suv ulusqa

(12) ičma. ויסעו [15] Da köčtülar Refidimd́an da toḥtadylar

(13) midbarynda Sinajnin. [יסעו Da köčtülar midbaryndan

(14) Sinajnin da tohtadylar Qivrot ol Ta’avada. ויסעו [17 Da

(15) köčtülar Qivrot ol Ta’avadan L da toḥtadylar Ḥacerotta.

(16) יויסעו [18] Da köčtülar ${ }^{11}$ Hacerottan da toḥtadylar Ritmada.

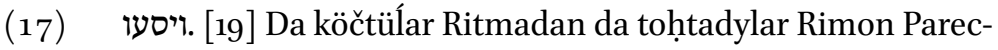

(18) ta. [יסעו [20] Da köčtülar Rimon Parectan da toḥtady-

(19) lar Livnada. ויסעו [21] Da köčtülar Livnadan da tohtady-

(20) lar Risada. יוסעו [22] Da köčtülar Risadan da toḥtady-

(21) lar Qahelatada. ויסעו [23] Da köčtülar Qahelatadan da

$273 \mathrm{r}^{\mathrm{o}} \quad$ (1) toḥtadylar Har Šaferd́a. [24] Da köčtülar Har

(2) Šaferdan da toḥtadylar Haradada. ויסעו [25] Da köčtü-

(3) lar Haradadan da toḥtadylar Maqhelotta. ויסעו [26] Da

(4) köčtülar Maqhelottan da toḥtadylar Tahatta. ויסעו [27]

(5) Da köčtülar Taḥattan da toḥtadylar Taraḥta. ויסעו [28]

(6) Da köčtülar Taraḥtan da toḥtadylar Mitqada. [יסעו [29]

(7) Da köčtülar Mitqadan da toḥtadylar Ḥašmunada.

(8) ויסעו [30] Da köčtülar Ḥašmunadan da toḥtadylar Mose-

(9) rotta. [31] Da köčtülar Moserottan da toḥ-

(10) tadylar Bene Ja'aqanda. [32] Da köčtülar Bene Ja'aqan-

(11) dan da toḥtadylar Ḥor Hagidgadda. [יסעו [33] Da köčtü-

(12) ĺar Ḥor ol Gidgaddan da toḥtadylar Jatvatada. [34]

(13) Da köčtülar J[a] tvatadan² da toḥtadylar 'Avronada.

(14) ויסעו Da köčtülar 'Avronadan da toḥtadylar 'Ecjon

(15) Gaverd́a. ויסעו [36] Da köčtülar 'Ecjon Gaverd́an da

(16) toḥtadylar midbarynda Cinnin oldu Qadeš. [37 Da

(17) köčtülar Qadeštan da toḥtadylar Hor Haharda učunda

(18) jerinin Edomnun. ויעל [38] Da mindi Aharon ol kohen Hor

(19) Haharga bujrugubyla Adonajnyn da öldü anda ol qyrqyn-

${ }^{1}$ Unvocalized fragment. $\quad{ }^{2} \mathrm{~K}$ : Jutvatadan; probably a scribal error; cf. Deu 10:7. | TKow: Jatvata-

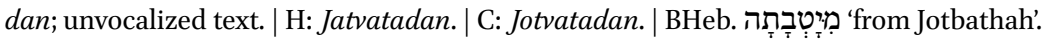


(5) of water and seventy palm trees |were there|, and they camped there.

(6) [10] And they set out from Elim and camped by the Red Sea.

(7) [11] And they set out from the Red Sea and camped

(8) in the wilderness of Sin. [12] And they set out from the wilderness of Sin and

(9) camped at Dophkah. [13] And they set out from Dophkah and

(10) camped at Alush. [14] And they set out from Alush

(11) and camped at Rephidim, and there was no water for the people

(12) to drink. [15] And they set out from Rephidim and camped

(13) in the wilderness of Sinai. [16] And they set out from the wilderness

(14) of Sinai and camped at Kibroth-Hattaavah. [17] And

(15) they set out from Kibroth-Hattaavah and camped at Hazeroth.

(16) [18] And they set out from Hazeroth and camped at Rithmah.

(17) [19] And they departed from Rithmah and camped at Rimmon-Perez.

(18) [20] And they set out from Rimmon-Perez and camped

(19) at Libnah. [21] And they set out from Libnah and camped

(20) at Rissah. [22] And they set out from Rissah and camped

(21) at Kehelathah. [23] And they set out from Kehelathah and

(1) camped at Mount Shepher. [24] And they set out from Mount

(2) Shepher and camped at Haradah. [25] And they set out

(3) from Haradah and camped at Makheloth. [26] And

(4) they set out from Makheloth and camped at Tahath. [27]

(5) And they set out from Tahath and camped at Terah. [28]

(6) And they set out from Terah and camped at Mithkah. [29]

(7) And they set out from Mithkah and camped at Hashmonah.

(8) [30] And they set out from Hashmonah and camped at Moseroth.

(9) [31] And they set out from Moseroth and

(10) camped at Bene-Jaakan. [32] And they set out from Bene-Jaakan

(11) and camped at Hor-Haggidgad. [33] And they set out from

(12) Hor-Haggidgad and camped at Jotbathah. [34]

(13) And they set out from Jotbathah and camped at Abronah.

(14) [35] And they set out from Abronah, and camped at Ezion-

(15) -Geber. [36] And they set out from Ezion-Geber, and

(16) camped in the wilderness of Zin. That is Kadesh. [37] And

(17) they set out from Kadesh and camped at Mount Hor, at the edge

(18) of the land of Edom. [38] And Aaron, the priest, went up to

(19) Mount Hor at the command of the Lord and died there, 
(20) čy jylda čyqmag̉yna ulanlarynyn Jisra’elnin jerind́an Micrinin

(21) ol bešinči janġajda burunġu kününd́a janġajnyn. ואהרן. [39]

$273 \mathrm{v}^{\circ} \quad$ (1) Da Aharon jüz igirmi üč jašar edi ölǵaninda Hor Haharda.

(2) וישמע [40] Da ešitti ol Kena'ani bij[i] 'Aradnyn da ol oltu-

(3) ruredi tüšlükt́a jerind́a Kena‘annyn kelǵand́a ulanlary

(4) Jisra’elnin. [41] Da köčtülar Hor Hahardan da toḥtady-

(5) lar Calmonada. [42] Da köčtülar Calmonadan da

(6) toḥtadylar Punonda. [43] Da köčtülar Punondan

(7) da toḥtadylar Ovotta. ויסעו [44] Da köčtülar

(8) Ovottan da toḥtadylar 'Ije ol 'Avarimd́a čegind́a

(9) Mo’avnyn. ויסעו [45] Da köčtülar 'Ijimd́an da toḥta-

(10) dylar Divon Gadda. [46] Da köčtülar Divon Gad-

(11) dan da toḥtadylar 'Almon Divlatajimd́a. [47 Da

(12) köčtülar 'Almon Divlatajimd́an da toḥtadylar tavlarynda

(13) ol köčüvĺarnin alnynda Nevonun. ויסעו [48] Da köčtü-

(14) ĺar tavlaryndan ol köčüvlarnin da toḥtadylar jylġalyqla-

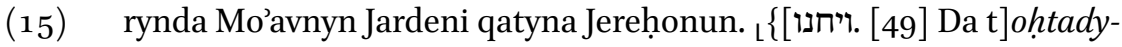
lar [ol] Jarden qatyna [bašlap Bet] ol Ješimot [tan] [Avel o]l Šitim[ǵadejin] jylgalyq[laryn]da Mo’avnyn. ${ }^{12}$. [50]

(16) Da sözĺadi Adonaj Mošeǵa jylġalyqlarynda Mo’avnyn Jardeni

(17) qatyna Jerehononun ajtadog̀ač. דבר. [51] Sözĺagin ulanlaryna

(18) Jisra’elnin da ajtqyn alarg̉a ki siz ašasiz ošol ol Jarden-

(19) ni jerińa Kena'annyn. והורשתם. [52] Da tasetijiz ošol bar

(20) olturuvčularny ol jernin alnyjyzdan da joq etijiz ošol bar

(21) tuక̌urg̉an orunlaryn alarnyn da ošol bar türsünlarin qujma

$274 \mathrm{r}^{\circ} \quad$ (1) abaqlarynyn eksitijiz da ošol bar bamalaryn alarnyn tasetijiz.

(2) והורשתם [53] Da meŕaslajiz ošol ol jerni da olturu-

(3) juz anda ki sizǵa berdim ošol ol jerni meŕaslama

(4) והתנחלתם. [5] Da ülašinijiz ošol ol jerni goral

\footnotetext{
${ }^{1} \mathrm{~K}$ : bij; a scribal error. | TKow.o1: unvocalized text. | H: biji. | C: hany. $\quad{ }^{2}$ Marginal insertion probably by another hand; cf. Num 34:3. | TKow.o1: Da tohtadylar ol Jarden qatyna bašlap Bet ol Ješimottan Avel ol Šitim ündeledog்an orunġadejin jylġalyqlarynda Jerehonun; unvocalized text. | H: Da tohtadylar ol Jarden qatyna baslap Bet ol Ješimottan Avel ol Šitim indeledoġan orunġadejin jylġalyqlarynda Mo’avnyn.|C:Da qondular olJarden üstünä Bet olJešimotdan Avel ol Šitimgä degin tüzlärindä Mo’avnyy.
} 
(20) in the fortieth year after the children of Israel had come out from the land of Egypt,

(21) in the fifth month, on the first day of the month. [39] And

(1) Aaron was a hundred and twenty-three years old when he died in Mount Hor.

(2) [40] And the Canaanite, king of Arad, who dwelt

(3) in the south in the land of Canaan, heard of the coming of the children

(4) of Israel. [41] And they set out from Mount Hor and camped

(5) at Zalmonah. [42] And they set out from Zalmonah and

(6) camped at Punon. [43] And they set out from Punon

(7) and camped at Oboth. [44] And they set out

(8) from Oboth and camped at Iye-Abarim, at the border

(9) of Moab. [45] And they set out from Iyim and camped

(10) at Dibon-Gad. [46] And they set out from Dibon-Gad

(11) and camped at Almon-Diblathaim. [47] And

(12) they set out from Almon-Diblathaim and camped ${ }_{L}$ in the mountains

(13) of encampments ${ }^{1252}$, in front of Nebo. [48] And they set out

(14) from the mountains of encampments ${ }^{1253}$ and camped in the steppes

(15) of Moab by the Jordan of Jericho. \{[49] [And] they camped by [the] Jordan, [from Beth]-Jeshimoth [unto Abel]-Shittim in the steppe[s] of Moab.\} [50]

(16) And the Lord spoke to Moses in the steppes of Moab by the Jordan

(17) of Jericho, saying, [51] 'Speak to the children

(18) of Israel, and say to them, "When you pass over the Jordan

(19) to the land of Canaan, [52] Then you shall destroy all the

(20) inhabitants of the land from before you and annihilate all

(21) their engraved places and remove all the images of their molten

(1) gods and destroy all their hills.

(2) [53] And you shall inherit the land and dwell

(3) there, because I have given you the land to inherit it.

(4) [54] And you shall divide the land by lot

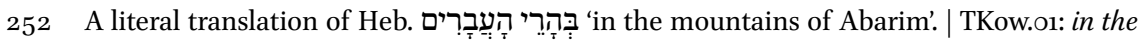
mountains of encampments. $\mid \mathrm{H}$ : in the mountains of encampments. $\mid \mathrm{C}$ : in the mountains of encampments. | R: in the mountains of Abarim.

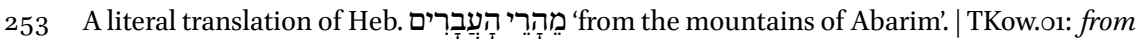
the mountains of encampments. | H: from the mountains of encampments. | C: from the mountains of encampments. | R: in the mountains of Abarim. 
(5) byla uruvlaryjyzsajyn köp ulusluga köp berijiz ošol

(6) ülüšün anyn da az uluslugga az bergin ošol ülüšün

(7) anyn qajry ki čyqsa anar anda ol goral anar bolsun ševet-

(8) Ílarisajyn atalaryjyznyn ülašinijiz. ואם [55] Da eger taset-

(9) maśajiz ošol olturuvčularyn ol jernin alnyjyzdan da bolġaj ki

(10) qaldyrsajyz alardan bolurlar šipšinlarǵa közlarijizd́a da

(11) tegeńakĺarǵa janlaryjyzda da qysyqlyq etarlar sizǵa

(12) ol jer üstüńa ki siz bolursiz olturuvčular anda.

(13) והיה [56] Da bolg̀aj ki nečik saġyš ettim qylma alarg̉a

(14) alaj qylarmen sizǵa.

[Numbers 34]

יוידבר [1] Da sözladi Adonaj

(15) Mošeǵa ajtadog̉ač. צו. [2] Bujurg̉un ulanlaryna Jisra’elnin

(16) da ajtqyn alarg̉a ki siz keĺasiz ol jerǵa jerińa Kena'an-

(17) nyn budur ol jer ki tüš́ar sizǵa ülüšbyla jeri Kena‘an-

(18) nyn čekĺari sajyn anyn. והיה [3] Da bolur sizǵa tarafy

(19) tüšlüknün bašlap midbaryndan Cinnin janynda Edomnun

(20) da bolur sizǵa čegi tüšlüknün bašlap qyryjyjndan ol tuzlu

(21) tengiznin kün tuvušusary. [4] [4] Da quršar

$274 \mathrm{~V}^{\mathrm{o}} \quad$ (1) sizǵa ol ček tüšlük sartyn kelüvüńa 'Aqrabimnin

(2) da ašar Cinǵa da bolurlar čyğyšlary anyn tüšlüksartyn

(3) Qadeš Barnea'ğa čyğar Ḥacar Adarg̉a da ašar 'Acmonġa.

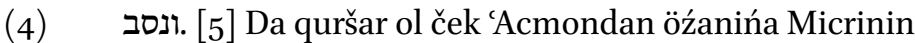

(5) da bolurlar čyğyšlary anyn ol tengizǵa. וגבול [6] Da

(6) čegi ma'aravnyn da bolur sizǵa ol ullu tengiz da ček

(7) bu bolur sizǵa čegi ma'aravnyn. וזה [7 [ Da bu bolur

(8) sizǵa čegi cafonnun ol ullu tengizden ${ }^{1}$ belgilajiz ö-

(9) züjüzğa Hor Haharg̉a. מהר. [8] Hor Hahardan belgilajiz Levo’

(10) Ḩamatqa da bolurlar čyggyšlary ol čeknin Cedadġa. [9]

(11) Da čyğar ol ček Zifronġa da bolurlar čyg̉yšlary anyn Ḥacar `Enan-

\footnotetext{
${ }^{1} \mathrm{~K}$ : tengizǵadejin; a scribal error, corrected to tengizden by the copyist.
} 
(5) among your families: you shall give a large share to that with many people,

(6) and to that with few people you shall give a little share.

(7) Wherever the lot falls for anyone, that shall be his.

(8) According to the tribes of your fathers you shall distribute it. [55] But if you

(9) do not destroy the inhabitants of the land from before you, then it shall be, that

(10) those of them whom you let remain shall be prickles in your eyes, and

(11) thorns in your sides, and shall oppress you

(12) in the land wherein you dwell.

(13) [56] And it shall be, that as I thought to do to them,

(14) so will I do to you."'

[Numbers 34]

[1] And the Lord spoke

(15) to Moses, saying, [2] 'Command the children of Israel,

(16) and say to them, "When you come to the land, to the land of Canaan,

(17) this is the land that will fall to you as a share, the land of Canaan

(18) by its borders: [3] And your will be the south side,

(19) from the wilderness of Zin next to Edom,

(20) and your will be the south border from the edge of the salt

(21) sea eastward. [4] And your border will turn

(1) from the south to the ascent of Akrabbim,

(2) and pass on to Zin. And its ends will be from the south

(3) to Kadesh-Barnea, and will go out to Hazar-Addar and pass on to Azmon.

(4) [5] And the border shall turn from Azmon to the river of Egypt,

(5) and the ends of it will be to the sea. [6] And

(6) the western border: you shall have the Great Sea for a border.

(7) This will be your west border. [7] And this will be

(8) your north border: from the Great Sea you shall mark |it| out

(9) for yourself to Mount Hor. [8] From Mount Hor you shall mark |it| out to Lebo-

(10) Hamath, and the ends of the border will be at Zedad. [9]

(11) And the border shall go out to Ziphron, and the ends of it will be at Hazar-Enan. 
(12) ġa bu bolur sizǵa čegi cafonnun. והתאויתם. [10] Da belgilajiz

(13) özüjüzǵa čegińa $\left[\right.$ [kün tuv]ušunun ${ }^{11}$ Ḥacar ${ }^{~ E n a n d a n ~ S ̌ e f a m g ̇ a . ~}$

(14) וירד [11] Da eńar ol ček [Šefam[dan] ol Rivlag̉a ${ }^{12}$ kün tuvušu-

(15) sary köz suvgia da eńar ol ček da urar janyna

(16) tengiznin Kineretnin kün tuvušusary. ו12] Da eńar

(17) ol ček ol Jardenǵa da bolurlar čyggyšlary anyn ol tuzlu ten-

(18) gizǵa bu bolur sizǵa ol jer čeklarisajyn čüvŕa. ויצו [13]

(19) Da bujurdu Moše ulanlaryna Jisra’elnin ajtadog̉ač budu ol

(20) jer ki ülašinijiz goral byla ki bujurdu Adonaj berma tog̉uz ol

(21) ševetlarǵa da jarym ol ševetḱa. כי. [14] Ki aldylar ševeti

$275 \mathrm{r}^{\mathrm{o}} \quad$ (1) ulanlarynyn Ru'uvennin üvüsajyn atalarynyn da ševeti ulanlarynyn Gadnyn

(2) üvüsajyn atalarynyn da jarym ševeti Menašenin aldylar ülüšlarin.

(3) שני [15] Eki ol ševetlar da jarym ol ševet aldylar ülüšlarin

(4) köčüvünd́an Jardeninin Jereḥonun kün tuvušusary mizraḥsary.

(5) וידבר. [16] Da sözladi Adonaj Mošeǵa ajtadog̉ač. [17 ]

(6) Bulardylar atalary ol eŕanlarnin ki ülüšsinlar sizǵa ošol

(7) ol jerni El'azar ol kohen da Johošua' uvlu Nunnun. [18]

(8) Da biŕar nasi biŕar nasi ševett́an alyjyz ülüš berḿa

(9) ošol ol jerni. ואלה [19] Da bulardylar atalary ol eŕanlar-

(10) nin ševetind́an Juhudanyn Kalev uvlu Jefunenin. ולמטה. [20] Da

(11) ševetind́an ulanlarynyn Šim'onnun Šemu’el uvlu 'Amihudnun.

(12) למטה (21) Ševetind́an Binjaminnin Elidad uvlu Kislonnun.

(13) (22] Da ševetind́an ulanlarynyn Dannyn nasi Buki uvlu

(14) Jug̈linin. לבני [23] Ulanlarynyn Josefnin ševetinin ulanlarynyn

(15) Menašenin nasi Ḥani’el uvlu Efodnun. ולמטה. [24] Da

(16) ševetinin ulanlarynyn Efrajimnin nasi Qemu’el uvlu Šiftannyn.

(17) ולמטה [25] Da ševetinin ulanlarynyn Zevulunnun nasi Elicafan

\footnotetext{
${ }^{1}$ TKow.o1: kün tuvušunun; unvocalized text. | H: mizrahnyn. | C: kün dog̉ušunyy. $\quad{ }^{2} \mathrm{~K}$ : Šefam ol Rivladan; a mistranslation. | TKow.o1: Šefam ol Rivladan; unvocalized text. | H: Šefam ol Rivladan.

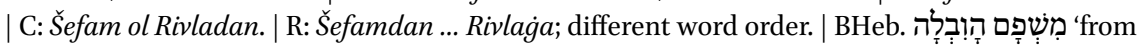
Shepham toward Riblah'.
} 
(12) This will be your north border. [10] And you shall mark out

(13) your [east] border from Hazar-Enan to Shepham. [11]

(14) And the border will go down ${ }_{L}[\text { from Shepham toward Riblah }]^{1254}$, on the east side

(15) to the fountain of water, and the border will go down and will reach

(16) to the eastern side of the Sea of Kinnereth. [12] And

(17) the border shall go down to the Jordan, and the ends of it will be at the Salt Sea.

(18) This will be your land by its borders all around.' [13]

(19) And Moses commanded the children of Israel, saying, "This is the

(2o) land which you shall divide by lot, which the Lord commanded to give to the nine

(21) tribes and to the half tribe: [14] Because the tribe

(1) of the children of Reuben by the house of their fathers and the tribe of the children

(2) of Gad by the house of their fathers and the half tribe of Manasseh had taken their share.

(3) $[15]$ The two tribes and the half tribe had taken their share

(4) across the ford of Jordan of Jericho toward the sun rising, eastward.'

(5) [16] And the Lord spoke to Moses, saying, [17]

(6) 'These are the names of the men who shall divide the land to you:

(7) Eleazar, the priest, and Joshua, son of Nun. [18]

(8) And you shall take one leader of each tribe, one leader of each tribe, to share

(9) the land. [19] And these are the names of the men:

(10) Of the tribe of Judah: Caleb, son of Jephunneh. [20] And

(11) of the tribe of the children of Simeon: Shemuel, son of Ammihud.

(12) [21] Of the tribe of Benjamin: Elidad, son of Chislon.

(13) [22] And the prince of the tribe of the children of Dan: Bukki, son

(14) of Jogli. [23] The prince of the children of Joseph, of the tribe of the children

(15) of Manasseh: Hanniel, son of Ephod. [24] And

(16) the prince of the tribe of the children of Ephraim: Kemuel, son of Shiphtan.

(17) [25] And the prince of the tribe of the children of Zebulun: Elizaphan,

254 A mistranslation based on interpreting BHeb. מִשְפָם הָרְברלָה 'from Shepham toward Riblah' as one place name. 
(18) uvlu Parnaknin. ולמטה. [26] Da ševetinin ulanlarynyn Jissahar-

(19) nyn nasi Palti'el uvlu 'Azannyn. ולמטה. [27] Da ševetinin ulan-

(20) larynyn Ašernin nasi Aḥihud uvlu Šelominin. ולמטה [28]

(21) Da ševetinin ulanlarynyn Naftalinin nasi Pedah'el uvlu 'Amihud-

$275 \mathrm{~V}^{\mathrm{o}}$ (1) nun. אלה. [29] Bulardylar ki bujurdu Adonaj ülašḿa ulanla-

(2) ryna Jisra’elnin jerind́a Kena'annyn.

Numbers 35

(3) di Adonaj Mošeǵa \{jylġalyqlarynda Mo’avnyn Jardeni qatyna Jereḥonun\} ajtadoġač. צ. [2] Bujurg̉un ulanla-

(4) ryna Jisra’elnin da bersinlar Levilílarǵa ülüšünd́an tutuv-

(5) luqlarynyn šaharlar olturma da sürüv šaharlarg̉a čüvía-

(6) Íarind́a alarnyn berijiz Levililarǵa. והיו. [3] Da bolsun ol

(7) šaharlar alarg̉a olturma da sürüvlari alarnyn bolsunlar

(8) tuvarlaryna da mallaryna da bar tirilarińa. ומגרשי. [4]

(9) Da sürüvlari ol šaharlarnyn ki berśajiz Levilílarǵa farstyn-

(10) dan ol šaharnyn da tyšqaryg̉a min lokot čüvŕa. ומדתם. [5]

(11) Da ölč́ajiz tyšqartyn šaharg̉a ošol tarafyn kün tuvušunun

(12) eki min lokotbyla da ošol tarafyn tüšlüknün eki min

(13) lokot byla da ošol tarafyn ma'aravnyn eki min lokotby-

(14) la da ošol tarafyn cafonnun eki min lokot byla da ol

(15) šahar ortada bu bolsun ${ }_{L}\langle$ sizǵa $\rangle\{\text { alarg̉ }\}^{11}{ }^{11}$ ürüvlari ol šaharlarnyn.

(16) ואת (6) Da ošol ol šaharlar ki berijiz Levililarǵa alty

(17) šaharlaryn \{ol\} miqlatnyn ki berijiz qačma ary ol qaraqčy da alar

(18) qatyna berijiz qyrq eki šahar. כל [7] Bar ol šaharlar ki

(19) berijiz Levilílarǵa qyrq segiz šahar alarny da ošol sürüv-

(20) Íarin alarnyn. [8 [8 Da ol šaharlar ki be\{r\}śajiz tutuvlu-

(21) \{gंundan\} ulanlarynyn Jisra’elnin ol köptan köp berijiz da ol azdan az

\footnotetext{
${ }^{1}$ Correction by another hand. | TKow.o1: alargia; unvocalized text. | H: alarga | | C: alarġa.
} 
(18) son of Parnach. [26] And the prince of the tribe of the children of Issachar:

(19) Paltiel, son of Azzan. [27] And the prince of the tribe

(20) of the children of Asher: Ahihud, son of Shelomi. [28]

(21) And the prince of the tribe of the children of Naphtali: Pedahel, son of Ammihud.'

(1) [29] These are the ones whom the Lord commanded to divide |the inheritance| to the children

(2) of Israel in the land of Canaan.

Numbers 35

[1] And the Lord spoke

(3) to Moses in the steppes of Moab by the Jordan of Jericho, saying, [2] 'Command the children

(4) of Israel that they give to the Levites of the share

(5) of their possession cities to dwell in, and

(6) you shall give to the Levites pasture lands for the cities all around them. [3] And

(7) the cities shall be theirs to dwell in, and their pasture lands shall be

(8) for their livestock and for their goods and for all their animals. [4]

(9) And the pasture lands of the cities which you shall give to the Levites

(10) |shall be| from the wall of the city and outward a thousand cubits all around. [5]

(11) And you shall measure from outside the city on the east side

(12) two thousand cubits, and on the south side two thousand

(13) cubits, and on the west side two thousand cubits,

(14) and on the north side two thousand cubits, and the

(15) city shall be in the middle. This shall be \{to them $\}$ the pasture lands of the cities.

(16) [6] And the cities which you shall give to the Levites: six

(17) cities of refuge that you shall give for the manslayer to flee there, and

(18) you shall give in addition to them forty-two cities. [7] All the cities which

(19) you shall give to the Levites: forty-eight cities, them and

(20) their pasture lands. [8] And the cities which you shall give from the possession

(21) of the children of Israel: from many you shall give many, and from few 
$276 \mathrm{r}^{\circ} \quad$ (1) berijiz kiši ülüšüńa köŕa ki ülüš alsalar bersin šahar-

(2) laryndan Levililarǵa. [9] Da sözladi Adonaj Mošeǵa aj-

(3) tadoġač. דבר. [10] Sözĺagin ulanlaryna Jisra’elnin da ajtqyn

(4) alarg̉a ki siz ašasiz ošol ol Jardennin jerińa Kenáannin.

(5) והקריתם [11] Da qondaryjyz özüjüzǵa šaharlar miqlat

(6) šaharlary bolsunlar sizǵa da qačsyn $\{$ ary $\}$ qaraqlavču $\{\text { öltü[rüvčü] }\}^{1}$ క̌anny janġylyš-

(7) lyqbyla. והיו [12] Da bolsunlar sizǵa ol šaharlar miqlatqa

(8) gečeǵad́an da ölḿasin ol qaraqčy turg̉anynadejin alnynda

(9) ol 3̌ymatnyn töŕaǵa. והערים. [13] Da ol šaharlar ki ber-

(10) śajiz alty šaharlary miqlatnyn bolsunlar sizǵa. את. [14] Ošol

(11) ol üč šaharlary berijiz köčüvünd́an Jardennin da ošol üč

(12) ol šaharlarny berijiz jerind́a Kena‘annyn miqlat šaharlary

(13) bolsunlar. לבני (15) Ulanlaryna Jisra’elnin da ġaripǵa da

(14) očarg̉a ortalarynda alarnyn bolsunlar alty ol šaharlar

(15) ošpular miqlatqa qačma ary bar öltürüvčü žanny

(16) janġylyšlyq byla. ואם [16] Da eger temirli savutbyla

(17) ursa any da ölśa qaraqčydy ol ölma öltürül-

(18) sün ol qaraqčy. ואם. [17] Da eger qolluq tašbyla ki öl-

(19) śa andan ursa any da ölśa qaraqčydy ol ölḿa

(20) öltürülsün ol qaraqčy. או [18] Jemeśa qolluq ag̉ačly

(21) savutbyla ki ölśa andan ursa any da ölśa qaraqčydy

$276 v^{0} \quad$ (1) ol ölḿa öltürülsün ol qaraqčy. גואל [19] Gečeǵa-

(2) si ol qannyn ol öltürsün ol qaraqčyny joluqqanynda

(3) any ol öltü $\{r\}$ sün any. [20] Da eger dušmanlyq

(4) byla taberśa any jemeśa tašlasa anyn üstüńa av-

(5) lamaqbyla da ölśa. או. [21] Jemeśa dušmanlyq byla

(6) ursa any qolubyla da ölśa ölḿa öltürülsün

(7) ol uruvču qaraqčydy ol gečeǵasi ol qannyn öltürsün

(8) ošol ol qaraqčyny joluqqanynda any. ואם [22] Da eger

(9) kenetala $[\mathrm{j}]^{2}$ dušmanlyqsyz taberdi any jemeśa saldy

(10) anyn üstüńa nendij savut avlamajynča. או. [23] Jemeśa

${ }^{1}$ Cf. Num 35:15. | TKow.o1: öltürüvčü; unvocalized text. | H: vatuvcu. | C: uruvčy. $\quad{ }^{2}$ K: kenetalá; a scribal error. Cf., however, Num 12:4. | TKow.o1: kenete; unvocalized text. | H: kenetelej. | C: kepkenätä. 
(1) you shall give few. Every man shall give from his cities to the Levites $\quad{ }_{27} 6 \mathrm{r}^{\circ}$ according to his share which he takes.'

(2) [9] And the Lord spoke to Moses,

(3) saying, [10] 'Speak to the children of Israel and say

(4) to them, "When you cross the Jordan to the land of Canaan:

(5) [11] And you shall build you cities: they shall be cities of refuge

(6) for you, and a manslayer who murders a life mistakenly shall flee there.

(7) [12] And they shall be to you cities for refuge

(8) from the avenger, that the manslayer may not die until he stands before

(9) the congregation for judgment. [13] And of these cities which

(10) you shall give: you shall have six cities for refuge. [14]

(11) You shall give three cities across the ford of Jordan, and three

(12) cities you shall give in the land of Canaan. They shall be cities of refuge.

(13) [15] These six cities shall be a refuge for the children of Israel and for the stranger and

(14) for the settler among them,

(15) so that everyone that kills a life mistakenly may flee there.

(16) [16] But if he strikes him with an iron item

(17) so that he dies: he is a murderer.

(18) The murderer shall surely be put to death. [17] And if he strikes him with a hand stone

(19) by which one could die, and he dies: he is a murderer.

(20) The murderer shall surely be put to death. [18] Or if he strikes him with a hand

(21) weapon of wood, by which one could die, and he dies: he is a murderer.

(1) The murderer shall surely be put to death. [19] The avenger

(2) of blood himself shall kill the murderer. When he meets him,

(3) he shall kill him. [20] And if he

(4) pushes him from enmity or hurls at him

(5) through hunting, and he dies, [21] Or if in enmity

(6) he strikes him with his hand, and he dies,

(7) the one who struck him shall surely be put to death, he is a murderer: the avenger of blood shall kill

(8) the murderer, when he meets him. [22] But if

(9) he pushed him suddenly without enmity or cast

(10) on him any item without hunting, [23] Or 
(11) nendij savutbyla ki ölśa andan körmajinč́a da tüšür-

(12) śa anyn üstüńa da ölśa da ol dušman tüvül

(13) edi anar da klamasedi jamanyn anyn. [24] Da

(14) töŕa etsinlar ol žymat arasyna ol uruvčunun

(15) da arasyna gečeǵasinin ol qannyn ošpu töŕalarbyla.

(16) [ 25] Da qutqarsynlar ol క̌ymat ošol ol qaraqčyny

(17) qolundan gečeǵasinin ol qannyn da qajtarsynlar any ol žymat

(18) šaharyna miqlatynyn ki qačty ary da oltursun anda

(19) ölgünč́a ol kohen gadol ki jag̉yndyrdy any ol aziz javbyla.

(20) ואם [26] Da eger čyqma čyqsa ol qaraqčy čegind́an šaharynyn

(21) miqlatynyn ki qačty ary. ומצא. [27] Da tapsa any gečeǵasi

$277 \mathrm{r}^{\mathrm{o}} \quad$ (1) ol qannyn tyšqartyn \{čegińa\} šaharynyn miqlatynyn da qaraqlasa geče-

(2) ǵasi ol qannyn ošol ol qaraqčyny joḥtu anar borču qan-

(3) larnyn. כ2 [28] Ki šaharynda miqlatynyn oltursun öl-

(4) günč́a ol kohen gadol da ölüm sortun ol kohen gadol

(5) qajtsyn ol qaraqčy jerińa tutuvlug̉unun. והיו [29] Da

(6) bolsunlar bular sizǵa resimińa töŕanin dorlaryjyzsajyn bar

(7) olturušlaryjyzda. כ30] Bar öltürüvčü žanny

(8) sözüńa köŕa tanyqlarnyn qaraqlasyn ošol ol qaraqčyny

(9) da bir tanyq tanyqlyq čyqmasyn žan üčün ölḿa.

(10) (31] Da almajyz juluv క̌any üčün qaraqčynyn ki ol

(11) raša‘dy ölḿa ki ančaq öltürülḿa öltürül-

(12) sün. ולא. [32] Alajoq almajyz juluv andijdan kimǵa

(13) keŕaklidi qačma šaharyna miqlatynyn qajtma olturma

(14) jerd́a ölgünč́a ol kohen gadol. ולא [33] Da murdar

(15) etḿajiz ošol ol jerni ki siz anda ki ol qan ol

(16) murdar etadi ošol ol jerni da jerǵa bošatylmas-

(17) ty qanüčün ki tögüldü anda ki ančaq qanybyla

(18) tögüvčüsünün. ולא [34] Da murdar etmagin ošol

(19) ol jerni ki siz olturasiz anda ki šehinam menim

(20) toḥtajdy ortasynda anyn ki men Adonaj šehuinam

(21) menim toḥtajdy ortasynda ulanlarynyn Jisra’elnin. 
(11) used any item by which one may die seeing him not, and dropped

(12) it on him, and he dies, and he was not his enemy,

(13) and he did not want his harm, [24] Then

(14) the congregation shall judge between the one who struck

(15) and the avenger of blood according to these judgments.

(16) [25] And the congregation shall rescue the manslayer

(17) from the hand of the avenger of blood, and the congregation shall restore him

(18) to the city of his refuge, where he had fled, and he shall live there

(19) until the death of the high priest, whom one anointed with the holy oil.

(20) [26] But if the manslayer shall indeed go beyond the border of the city

(21) of his refuge, where he had fled, [27] And the avenger of blood finds him

(1) outside the borders of the city of his refuge, and the avenger of blood $277 \mathrm{r}^{\circ}$ murders

(2) the manslayer, he shall not be guilty of blood.

(3) [28] Because he shall live in the city of his refuge

(4) until the death of the high priest, and after the death of the high priest

(5) the manslayer shall return to the land of his possession. [29] And

(6) these things shall be for a statute of judgment to you throughout your generations

(7) in all your dwelling places. [30] Anyone who kills a life,

(8) the murderer shall be murdered according to the word of witnesses.

(9) And one witness shall not testify against a person so as to die.

(10) [31] And you shall take no ransom for the life of a murderer, because he

(11) is guilty of death, but he shall be surely put to death.

(12) [32] In the same way, you shall take no ransom from the one

(13) who has to fled to the city of his refuge, that he may return to live

(14) in the land, until the death of the high priest. [33] And

(15) you shall not defile the land in which you are. Because blood:

(16) it defiles the land, and no atonement can be made for the land

(17) for the blood that is shed in it except by the blood

(18) of the one who shed it. [34] Do not defile

(19) the land in which you live, in the midst of which my divine Presence

(20) dwells, for I, the Lord, my divine Presence

(21) dwells among the children of Israel."' 
$277 \mathrm{v}^{\mathrm{o}} \quad$ Numbers 36

(1) ויקרבו Da juvudular agaaraqlary ol ata\{l\}arynyn uruvunun

(2) ulanlarynyn Gil'adnyn uvlunun Mahirnin uvlunun Menašenin

(3) uruvlaryndan ulanlarynyn Josefnin da sözladilar alnynda

(4) Mošenin da alnynda ol nasilarnin ag̉araqlarynyn atalarnyn

(5) ulanlarynyn Jisra’elnin. [2] Da ajttylar bijiḿa

(6) bujurdu Adonaj berma ošol ol jerni ülüšbyla goral byla

(7) ulanlaryna Jisra’elnin da bijim bujuruldu Adonajdan berma

(8) ošol ülüšün Celafaḥadnyn qaryndašymyznyn qyzlaryna anyn.

(9) [3] Da bolsunlar birisińa ulanlaryndan ševetlarinin

(10) ulanlarynyn Jisra’elnin \{qatynlarg̉a\} da eksilir ülüšĺari alarnyn ülüšün-

(11) dan atalarymyznyn da artar ülüšü üstüńa ol ševet-

(12) nin ki bolsalar alarga da goralyndan ülüšümüznün eksi-

(13) lir. [4] Da ki nečik bolsa ol jovel ulanlaryna

(14) Jisra’elnin da artar ülüšlari alarnyn ülüšü üs-

(15) tüńa ol ševetnin ki bolsalar alarg̉a da ülüšünd́an

(16) ševetinin atalarymyznyn eksilir ülüšlari alarnyn.

(17) [5 [5 Da bujurdu Moše ulanlaryna Jisra'elnin buj-

(18) ruguubyla Adonajnyn ajtadoġač qolajly ševeti ulanlarynyn

(19) Josefnin sözĺajdilar. זה [6] Budur ol söz ki bujurdu

(20) Adonaj qyzlaryna Celafaḥadnyn ajtadog̉ač jaḥšy körünǵanǵa

(21) közĺarind́a bolsunlar qatynlargaa ančaq uruvuna ševeti-

$278 \mathrm{r}^{\mathrm{o}}$ (1) nin atasynyn alarnyn bolsunlar qatynlarga. ולא. [7 [7 Da

(2) qajyrylmasyn ülüšü ulanlarynyn Jisra’elnin ševettan özǵa

(3) ševetḱa ki ančaq har kiši ülüšüńa ševetlarinin ata-

(4) larynyn jabušsunlar ulanlary Jisra’elnin. וכל [8] Da bar

(5) qyz meŕaslavčü ülüšnü ševetĺarind́an ulanlarynyn Jisra-

(6) 'elnin birisińa uruvundan ševetinin atasynyn bolsun

(7) qatynlyqqa anyn üčün ki méaślaǵajlar ulanlary Jisra-

(8) 'elnin har kiši ülüšün atalarynyn. [9] [9] Da qajyryl-

(9) masyn ülüš ševett́an özǵa ševetḱa ki ančaq har

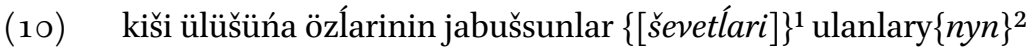
Jisra’elnin.

(11) כאשר. [10] Ki nečik bujurdu Adonaj Mošeǵa alaj

(12) qyldylar qyzlary Celafaḥadnyn. ותהיינה. [11] Da boldu-

\footnotetext{
${ }^{1}$ Marginal insertion by another hand. | TKow.o1: ševetleri; unvocalized text; added in the outer margin. | H: ševetleri. | C: ševetläri. $\quad{ }^{2}$ The genitive suffix was inserted by another hand within the line. | TKow.o1: uvullarynyn; unvocalized text. | H: uvullarynyn. | C: og lanlarynyy.
} 
(1) [1] And the superiors of the fathers of the families

(2) of the children of Gilead, son of Machir, son of Manasseh,

(3) of the families of the sons of Joseph, came near and spoke before

(4) Moses and before the princes- the superiors of the fathers-

(5) of the children of Israel. [2] And they said,

(6) 'The Lord commanded my lord to give the land for a share by lot

(7) to the children of Israel, and my lord was commanded by the Lord to give

(8) the share of Zelophehad our brother to his daughters.

(9) [3] And if they become wives to one of the sons of the tribes

(10) of the children of Israel, then their share will be taken from the share

(11) of our fathers, and will increase the share of the tribe

(12) to which they will belong, and it will be taken from the lot of our share.

(13) [4] And if there be a jubilee of the children of Israel,

(14) then their share will be added to the share

(15) of the tribe to which they will belong, and

(16) their share will be taken from the share of the tribe of our fathers.'

(17) [5] And Moses commanded the children of Israel

(18) according to the word of the Lord, saying, "The tribe of the sons

(19) of Joseph has spoken correctly. [6] This is the word which the Lord commanded

(20) the daughters of Zelophehad, saying,

(21) "They shall become wives for any in whose eyes it is good, only to the family of the tribe

(1) of their father shall they marry." [7] So

(2) the share of the children of Israel will not turn from tribe to another

(3) tribe, but the children of Israel shall each cling to the share of the tribe

(4) of his fathers. [8] And every

(5) daughter who inherits a share from the tribes of the children

(6) of Israel shall be wife to one of the family of the tribe of her father,

(7) so that the children of Israel may inherit

(8) every man the share of his fathers. [9] And

(9) the share shall not turn from one tribe to another tribe, but the

(10) $\quad$ tribes of $\}$ the children of Israel shall each cling to its own share."'

(11) [10] As the Lord commanded Moses, so

(12) the daughters of Zelophehad did: [11] And 
(13) lar Maḥla Tirca da Ḥağla da Milka da Noca qyzla-

(14) ry Celafạ̣adnyn uvullaryna dad́álarinin özlarinin qatyn-

(15) larg̉a. מממשפחת. [12] Uruvlaryndan ulanlarynyn Menaše-

(16) nin uvlunun Josefnin boldular qatynlarg̉a da boldu ülüš-

(17) ĺari alarnyn ševeti qatyna uruvunun atasynyn alarnyn.

(18) אלה [13 [13) Bulardylar ol micvalar da ol töŕalar ki

(19) bujurdu Adonaj naviligi ašyra Mošenin ulanlaryna Jisra-

(20) 'elnin jylg̈alyqlarynda Mo'avnyn Jardeni qatyna Jerehonun.

$278 \mathrm{v}^{\mathrm{o}}$ בעזר אשר עמו נהל ודבר 'והמציאהו בארץ מדבר ' והאכילהו לחם אבירים מן במקום הבר 'נשלמו פשטי ספר במדבר 'והר

והאל המצמיח חציר הרים 'ונותן צרכי כל בארעא דרים ' 
(13) Mahlah, Tirzah, and Hoglah, and Milcah, and Noah, the daughters

(14) of Zelophehad, became wives to their uncles' sons.

(15) [12] They became wives to |members| of the families of the sons of Manasseh,

(16) son of Joseph, and their share remained

(17) on the tribe of the family of their father.

(18) [13] These are the commandments and the judgments which

(19) the Lord commanded by the prophecy of Moses to the children

(20) of Israel in the steppes of Moab by the Jordan of Jericho.

(1) With the help of Him who led his people and spoke and made them find $278 \mathrm{v}^{\mathrm{o}}$ themselves in the wilderness

(2) and fed them with the food of the mighty, with manna instead of grain, the peshatim of the Book of Numbers are completed.

(3) And God makes grass grow on the hills, and he satisfies the needs of all the flesh that live therein.

(4) He will raise me from the dust of my folly, He will enlighten the eyes of my intellect in my writing of the peshatim

(5) of the Book of Deuteronomy. 
$279 \mathrm{r}^{\mathrm{o}} \quad$ Deuteronomy 1

(1) ספר אלה הדברים

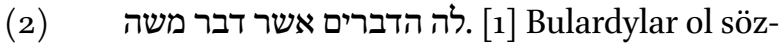

(3) ler ki sözledi Moše bar Jisra'elge köčüvün $\{[\text { de }]\}^{1}$

(4) ol Jardennin midbarda jylgalyqta oturusuna Sufnun ara-

(5) syna Paran\{nyn $\}$ da arasyna Tofelnin da Lavannyn da Hacerot-

(6) nun da Di Zahavnyn. אחד. [2] On bir künlük jol edi Horev-

(7) den jolu sary tavynyn Secirnin Qodeš Barnea'g̉adejin. ויהי [3] Da

(8) edi qyrqynčy jylda on birinči janġajda burunġu künün-

(9) de janġajnyn sözledi Moše ulanlaryna Jisra’elnin barča

(10) ne bujurdu Adonaj anyn ašyra alarg̉a. אחרי. [4] Qyrġa-

(11) nyndan sortun ošol Siḥonnun bijin ol Emorinin ki olturu-

(12) redi Ḥešbonda ošol 'Oggnu bijin ol Bašannyn ki olturure-

(13) di 'Aštarotta Edrecide. בעבר. [5] Köčüvünde ol

(14) Jardennin jerinde Mo’avnyn küvüllendi Moše belgirtme

(15) ošol ol Torany ošpunu ajtadoġač. יהוה. [6] Adonaj Tenri-

(16) miz sözledi bizge Horevde ajtadogač jeter sizge kečik-

(17) me ošpu tavda. \{פנו2 [7] Qajyrylyjyz da köčüjüz özüjüzge

(18) da kelijiz tavyna ol Emorinin da bar qonšularyna anyn

(19) jylğalyqta tavda da šefelada da tüšlükte da bog̉uzun-

(2o) $\quad[\mathrm{da}]^{3}$ ol tengiznin jerine ol Kena'annyn da ol Levanonga ol ullu

$279 v^{o}$ (1) özengedejin özenine Peratnyn. ראה. [8] Kör berdim al-

(2) nyjyzda ošol ol jerni kelijiz da mereslejiz ošol ol jerni

(3) ki antetti Adonaj atalaryjyzġa Avrahamġa Jichaq da Jacaqov

(4) berme alarg̉a da urlug̉una alarnyn özlerinden sortun.

(5) (9] Da ajttym sizge ol vaḥtta ajtadog̉ač bo-

(6) lalmanmen jalg̀yz özüm kötürme sizni. יהוה [10] Adonaj

(7) Tenrijiz arttyrdy sizni da muna siz bügün jolduzlary

(8) kibik ol köklernin köplükke. יהוה] [11] Adonaj Tenrisi

(9) atalaryjyznyn arttyrgaj $\{$ üstüjüzge $\} \operatorname{siznin}_{L}\{[\text { neci }] k \operatorname{siz}[\text { barsi }] z\}^{14}$ tekli min keretler da al-

(10) ġyšlag̉aj sizni ki nečik sözledi sizge. איכה. [12] Nečik

${ }^{1}$ TKow.o1: köčüvünd́a.|H: kecivinde.|C: kečivindä. $\quad{ }^{2}$ Marginal insertion by another hand.|Heb. פ. $\quad{ }^{3} \mathrm{~K}$ : boğuzun; a scribal error. | TKow.o1: bog்uzunda; unvocalized text. | H: bog்ozunda. | C: limanynda. $\quad{ }^{4}$ Marginal insertion by another hand in South-Western Karaim (see Deu 14-15). | TKow.o1: deest. | H: necik siz barsiz. | C: deest. | R: ńečik siź barsyz. 
(1) The Book of Deuteronomy

(2) [1] These are the words

(3) which Moses spoke to all Israel at the ford

(4) of Jordan in the wilderness, in the steppe opposite Suph,

(5) between Paran and Tophel and Laban and Hazeroth

(6) and Di-Zahab. [2] It was eleven days' journey from Horeb

(7) by the way of Mount Seir to Kadesh-Barnea. [3] And

(8) it was in the fortieth year, in the eleventh month, on the first day

(9) of the month: Moses spoke to the children of Israel

(10) everything that the Lord had commanded through him to them. [4]

(11) After he had slain Sihon, king of the Amorites, who dwelt

(12) in Heshbon, |and| Og, king of Bashan, who dwelt

(13) at Ashtaroth at Edrei, [5] At the ford

(14) of Jordan, in the land of Moab, Moses decided to explain

(15) this Law, saying, [6] 'The Lord our God

(16) spoke to us in Horeb, saying, "You have had enough of staying

(17) at this mountain. [7] Turn and set out and

(18) come to the mountain of the Amorites, and to all their neighbours,

(19) in the steppe, in the hills, and in the lowland, and in the south, and by the sea shore,

(20) to the land of the Canaanites and to Lebanon, to the great

(1) river, the river Euphrates. [8] See: I have set

(2) the land before you. Come and inherit the land

(3) which the Lord swore to your fathers, to Abraham, Isaac, and Jacob,

(4) to give to them and to their offspring after them."

(5) [9] And I spoke to you at that time, saying,

(6) "I am not able to carry you myself alone. [10] The Lord

(7) your God has multiplied you, and, lo, you are today as the stars

(8) of heaven for multitude. [11] May the Lord, God

(9) of your fathers, add on to you a thousand times so many more $\{[$ than $]$ you $[$ are $]\}$ and

(10) bless you, as he has promised you! [12] How 
(11) kötürejim jalġyz özüm avaralyġyjyzny da jügüjüznü da

(12) talašyjyzny. הבו [13] Berijiz özüjüzge erenler uslular

(13) da aqyllylar da belgililer ${ }_{L}\{[\text { še }] \text { vetleri }[\text { ni }] \text { z sajyn }\}^{11}$ da berejim alarny agaraqlar

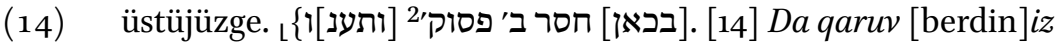
mana [da aj]ttynyz [jahssy]dy ol sez [ki se]zledin qylma. [ואקח.] [15] [D] a aldym [osol] [a] garaqlaryn [ševetler]iniznin [us]lu erenler da bilüvlüler da berdim alarny aġaraqlar siznin üstüne $\}^{13}$ aġaraqlaryn minlernin da ag̉araqlaryn jüzlernin

(15) da ag̉araqlaryn enlilernin da ag̉araqlaryn onlarnyn da tajaq-

(16) čylar ševetlerijizge. ואצוה. [16] Da zynharladym törečilerijiz-

(17) ge ol vaḥtta ajtadog̉ač tynlama arasyna qaryndašlaryjyz-

(18) nyn da töre etijiz rastlyqbyla arasyna kišinin da

(19) arasyna qaryndašynyn da arasyna garipnin. לא. [17] Jüz et-

(20) mejiz jüzlerge törede nečik kičini alaj ullunu tynlajyz qorq-

(21) majyz alnyndan kišinin ki ol töre Tenrinindi ol da ol

$280 \mathrm{r}^{\circ} \quad$ (1) söz ki qaty bolsa sizden a $\{$ n $\}$ lama any juvutujuz maja da

(2) tynlarmen any. [ואצוה. [18] Da bujurdum sizge ol vaht-

(3) ta ošol bar ol sözlerni ki qylġajsiz. ונסע [19] Da

(4) köčtük Ḥorevden da jürüdük bar ol midbarda ol

(5) ullu da qorqunčlu ki kördüjüz jolusary tavynyn ol

(6) Emorinin ki nečik bujurdu Adonaj Tenrimiz bizge da

(7) keldik Qadeš Barnea gigadejin. [20] Da ajttym siz-

(8) ge keldijiz tavynadejin ol Emorinin ki Adonaj Tenrimiz

(9) berdi bizge. ראה. [21] Körgün berdi Adonaj Tenrij

(10) alnyjda ošol ol jerni barg̉yn mereslegin ki nečik sözledi

(11) Adonaj Tenrisi atalaryjyznyn saja qorqmag்yn da synyqmag்yn.

(12) Da juvudujuz maja barlaryjyz da ajttyjyz

(13) ijejik erenler alnymyzda da čejsylasynlar bizge ošol

(14) ol jerni da qaruv qajtarsynlar bizge söz ošol ol jolnu

\footnotetext{
${ }^{1}$ Marginal insertion by another hand in South-Western Karaim (see Deu 14-15). | TKow.o1: ševetlerijizǵa.|H: ševetleriniz sajyn.|C: ševetlerinizgä. $\quad{ }^{2}$ An abbreviation of Heb. 'verses'. ${ }^{3}$ Marginal insertion by another hand in South-Western Karaim.| TKow.o1: Da qaruv berdijiz maja da ajttyjyz jahsydy ol söz ki sözledi[j] qylma. ואקח. Da aldym ošol agjaraqlaryn ševetlarijiznin uslu éanlar da belgililar da berdim alarny ag̉araqlar üstüjüzǵa.| H: ותענו. Da qaruv berdiniz mana da ajttynyz jahsydy ol söz ki sözledin qylma. ואקח. Da aldym osol ag்araqlaryn ševetleriniznin eren-

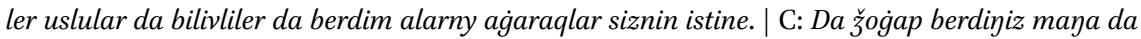

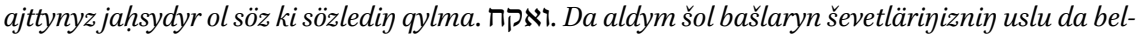
gili kišilär da berdim alarny bašlar üstünüzgä.
} 
(11) can I myself alone carry your stress and your burden and

(12) your strife? [13] Take you wise men,

(13) and rational, and known, \{according [to your tribes]\}, and I will set them superiors

(14) over you." ${ }_{L}\{$ Two verses are missing [here $\left.].\right\}^{1255}\{[14]$ And you answer [ed] me, [and said], "The word [which] you have [spoken] is [good] to do." [[15] And] I took [the] superiors of your [tribes, wise] men, and known, and set them superiors over you\}, superiors of thousands and superiors of hundreds

(15) and superiors of fifties and superiors of tens and overseers

(16) for your tribes. [16] And I directed your judges

(17) at that time, saying, "Hear between your brothers

(18) and judge righteously between every man and

(19) his brother and between the stranger. [17]

(20) You shall not favour in judgment, you shall hear the small as well as the great.

(21) You shall not be afraid before of man, because the judgment is God's. And the

(1) word that is too hard for you to understand it: bring it forward to me, $\quad 280 \mathrm{r}^{\mathrm{o}}$ and

(2) I will hear it." [18] And I commanded you at that time

(3) all the words which you should do. [19] And

(4) we set out from Horeb, we walked in all that great and awesome wilderness

(5) which you saw by the way of the mountain of the

(6) Amorites, as the Lord our God commanded us, and

(7) we came to Kadesh-Barnea. [20] And I said to you,

(8) "You have come to the mountain of the Amorites, which the Lord our God

(9) gave to us. [21] See: the Lord your God

(10) has set the land before you. Go up and inherit it, as the

(11) Lord God of your fathers has said to you. Do not fear and do not be broken down."

(12) [22] And you came near to me, every one of you, and said,

(13) "We will send men before us, and they shall spy for us out

(14) the land, and bring us back a word of answer of the way

255 Inserted by another hand in Hebrew. 
(15) ki baryrbiz anyn byla da ošol ol šaharlarny ki kelirbiz

(16) alarg̉a. יייטב [23] Da jahššy köründü közlerimizde ol

(17) söz da aldym sizden on eki erenler birer kiši ševet-

(18) ten. [24] Da qajyryldylar da mindiler ol tavgia da

(19) keldiler özenine dejin Eškolnun da čejsyladylar any.

(20) (25] Da aldylar qollaryna jemišinden ol jernin da endir-

(21) diler bizge da qaruv qajtardylar bizge söz da ajttylar

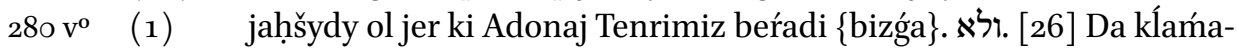

(2) dijiz barma da tandyjyz bujruguna Adonajnyn Tenrijiznin. ותרגנו [27 ]

(3) Da qavġalaštyjyz čatyrlaryjyzda da ajttyjyz ḥor etkani sar-

(4) tyn Adonajnyn bizni čyġardy bizni jerind́an Micrinin berḿa bizni

(5) qoluna ol Emorinin tasetḿa bizni. אנה. [28] Qajry biz

(6) barabiz qaryndašlarymyz irittilar ošol jüŕagimizni ajtadog̉ač

(7) ullu ulus da bijikŕak bizd́an ullu šaharlar da bekĺar jeta-

(8) doġanlar kökĺarǵa da daġyn tuvmušlaryn ol 'Anaqnyn kördük

(9) anda. ואומר [29] Da ajttym sizǵa synyqmajyz da qorq-

(10) majyz alynlaryndan alarnyn. יהומר. [30] Adonaj Tenrijiz ol baruvču

(11) alnyjyzda ol urušur siznin üčün barča nečik ki qyldy

(12) birǵajizǵa Micrid́a közlarijizća. ובמדבר. [31] Da midbar-

(13) da ki kördüj ki eltti seni Adonaj Tenrij ki nečik eltadi

(14) kiši ošol uvlun bar ol jolda ki jürüdüjüz kelǵanijizǵadejin ol

(15) orungadejin ošpu. ובדבר. [32] Da ošpuda nerśabyla inan-

(16) majsiz Adonajğa Tenrijizǵa. ההלך. [33] Ol baruvčug̉a alnyjyz-

(17) da jolda čajsylama sizǵa orun toḥtamaġyjyzğa otbyla

(18) keč́abyla körgüzḿa sizǵa jolnu ki barğajsiz anyn byla da

(19) bulut byla kündüz. וישמע [34] Da ešitti Adonaj ošol

(20) avazyn sözĺarijiznin da ačuvlandy da antetti ajtadoġač. אם. [35]

(21) Eger körśa kiši ošpu éranĺar arasyna ol jaman dor 
(15) by which we will go up and of the cities to which we will come."

(16) [23] And the thing seemed good in my eyes,

(17) and I took twelve men of you, one of each tribe.

(18) [24] And they turned and went up to the mountain and

(19) came to |the valley of the river of Eshcol and spied it out.

(20) [25] And they took of the fruit of the land in their hands and

(21) brought it down to us, and brought us a word of answer again, and said,

(1) "It is a good land which the Lord our God does give us." [26] But

(2) you did not want to go up, and you rebelled against the command of the Lord your God. [27]

(3) And you quarrelled in your tents, and said, "Because of the Lord's despise

(4) he has brought us out from the land of Egypt, to give us

(5) to the hand of the Amorites, to destroy us. [28] Where

(6) are we going? Our brethren have melted our heart, saying,

(7) "The people are greater and taller than we, the cities are walled and reach

(8) the heavens, and we even saw the children of the Anakim

(9) there." " [29] Then I said to you, "Do not be broken down and

(10) do not fear them. [30] The Lord your God who goes

(11) before you: he will fight for you according to all that he did

(12) with you in Egypt in your sight, [31] And in the wilderness,

(13) where you have seen that the Lord your God carried you, like a man carries

(14) his son, all the way that you walked until you came

(15) to this place." [32] And in this thing you do not trust

(16) the Lord your God, [33] Who went

(17) in the way before you to spy you out a place to camp,

(18) in fire by night to show you the way you should go, and

(19) in a cloud by day. [34] And the Lord heard the

(20) sound of your words and was angry and swore, saying, [35]

(21) [ [Not a man among these men, this evil generation, will see] $]^{1256}$

256 K: if a man among these men, this evil generation, sees; a mistranslation repeated in a number of manuscripts resulting from literal translation of the Hebrew conditional clause, cf. Gen 14:23, Num 14:23, Num 14:30, Num 32:11. | TKow.o1: if a man among these men, this evil generation, sees. | H: if a man among these men, this evil generation, sees. | C: if a man among these men, this evilgeneration, sees. | M: if a man among these men, this evil generation, sees. | E: if a man among these men, this evil generation, sees. | R: if a man among these men, this evilgeneration, sees. 
$281 \mathrm{r}^{\mathrm{o}} \quad$ (1) ošpu ošol ol jaḩ̌̌y jerni ki antettim berḿa atalaryjyz-

(2) פ̇a. [36] Ančaq Kalev uvlu Jefunenin ol köŕar any da

(3) anar berirmen ošol ol jerni ki basty anda da ulanlary-

(4) na anyn ki tüǵallik byla jürüdü saruvu artyna Adonajnyn.

(5) גם [37] Dag̉yn üstüḿad́a ačuvlandy Adonaj siznin sibbajyzdan

(6) ajtadog̉ač dag̉yn send́a kelmáassen ary. יהושע. [38] Johošua ${ }_{L}$ \{ $\{u v l u$ Nunnun $\}^{11}$

(7) olturuvču alnyjda ol kelir ary any kiplagin ki ol ü-

(8) lašir any Jisra’elǵa. וטפכם. [39] Da jašyjyz ki ajttyjyz

(9) talavğa bolur da uvullaryjyz ki bilmajdilar bügün jaḥšyny

(10) da jamanny alar kelirlar ary da alarg̉a berirmen any da

(11) alar meŕaslarlar any. ואתם. [40] Da siz qajyrylyjyz özüjü zzǵa

(12) da köčüjüz ol midbarg̉a jolusary Jam Sufnun. [41]

(13) Da qaruv berdijiz da ajttyjyz maja jazyqly bolduq Adonaj-

(14) ġa biz baryrbiz da urušurbiz barča nečik ki bujurdu

(15) Adonaj Tenrimiz bizǵa da bajladyjyz kiši ošol čerüv savut-

(16) laryn özünün da haskama qyldyjyz minḿa ol tavğa.

(17) יויאמר (42] Da ajtty Adonaj maja ajtqyn alarġa barmajyz

(18) da urušmajyz ki joḥtu bolušlugium ortajyzda da qyryl-

(19) majyz alnynda dušmanlaryjyznyn. ואדבר. [43] Da sözĺadim

(20) sizǵa da tynlamadyjyz da tandyjyz bujrugiuna Adonaj Tenrijiznin

(21) da čajalyq ajttyjyz da mindijiz ol tavğa. ויצא. [44] Da

$281 v^{0} \quad$ (1) $\quad$ čyqty\} ol Emori ol olturuvču ol tavda uturujuzğa da

(2) quvdular sizni ki nečik qyldylar ol bal čibinlari da jančtylar

(3) sizni Se ird́a Ḥarmag̉adejin. ותשובו. [45] Da qajttyjyz da

(4) jyladyjyz alnynda Adonajnyn da tynlamady Adonaj avazyjyzny da

(5) qajyrmady ešitüvün sizǵa. ותשבו. [46] Da kečiktijiz

(6) Qadešta köp künlar künlar takli ki kečiktijiz özǵa köč-

(7) maklard́a.

Deuteronomy 2

(8) ġa jolusary Jam Sufnun ki nečik sözĺadi Adonaj maja da quršadyq

(9) ošol tavyn Se'irnin köp künlar. ויאמר. [2] Da ajtty

(10) Adonaj maja ajtadoğač. רב [3] Jetar sizǵa quršama ošol

${ }^{1}$ Marginal insertion by another hand. | TKow.o1: uvlu Nunnun. | H: uvlu Nunnun. | C: oġlu Nunnyy. 
(1) the good land that I swore to give to your fathers, $281 \mathrm{r}^{\mathrm{o}}$

(2) [36] Just Caleb, son of Jephunneh: he shall see it, and

(3) I will give the land that he has trodden on to him and to his children,

(4) because he has followed the Lord's order fully."

(5) [37] The Lord was angry with me, too, because of you,

(6) saying, "You, too, shall not go there. [38] Joshua, \{son of Nun\},

(7) who stands before you, he will go there. Strengthen him, because he

(8) will cause Israel to divide it. [39] And your infants whom you said

(9) will be a prey, and your children who do not know today good

(10) and bad, they will go there, and I will give it to them, and

(11) they shall inherit it. [40] But you: turn

(12) and set out to the wilderness by the way of the Red Sea."

(13) [41] And you answered and said to me, "We have sinned against the Lord,

(14) we will go and fight, according to all that the Lord our God commanded

(15) us." And you each girded your weapons of war,

(16) you made an agreement to go up to the mountain.

(17) [42] And the Lord said to me, "Say to them, "You shall not go up,

(18) you shall not fight, because my help is not among you, so you will not be defeated

(19) before your enemies." " [43] And I spoke

(20) to you, and you did not listen but rebelled against the command of the Lord your God,

(21) and you intrigued and went up to the mountain. [44] And

(1) the Amorites, who dwelt in that mountain, came out against you, and $281 \mathrm{v}^{\mathrm{o}}$

(2) chased you, as bees do, and crushed

(3) you in Seir, as far as Hormah. [45] And you returned and

(4) wept before the Lord, but the Lord did not listen to your voice and

(5) did not give ear to you. [46] And you stayed

(6) in Kadesh many days - as many days as you stayed in other

(7) encampments.

\section{Deuteronomy 2}

(8) by the way of the Red Sea, as the Lord spoke to me. And we went around

(9) Mount Seir many days. [2] And the Lord spoke

(10) to me, saying, [3] "You have had enough of going around 
(11) ol tavny ošpunu qajyrylyjyz özüjüzǵa cafon sary. ואת. [4]

(12) Da ošol ol ulusnu zynharlag̉yn ajtadoġač siz ašasiz čegi

(13) ašyra qaryndašlaryjyznyn ulanlarynyn 'Esavnyn ol olturuvču-

(14) laryn Secird́a da qorqarlar sizdan da saqlanyjyz astry.

(15) אל [5] Čuqčušmajyz alarbyla bermanmen sizǵa jerlarind́an

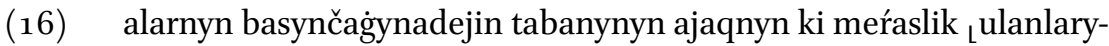

(17) [na] 'Esavnyn ${ }^{11}$ berdim ošol tavyn Se'irnin. אכל. [6] Jem satyn

(18) alyjyz alardan kümüška da ašajyz da $\{\text { daġyn }\}^{2}$ suv satyn alyjyz alar-

(19) dan kümüška da ičijiz. כי [7] Ki Adonaj Tenrij alġyšlady

(20) seni bar išind́a qollaryjnyn bildi jürüǵanijni ol ullu midbar-

(21) da ošpu bu qyrq jyl Adonaj Tenrij birǵaja eksik bolmadyj

$282 \mathrm{r}^{\mathrm{o}}$ (1) nemeǵad́a. [8] Da aštyq qaryndašlarymyzdan ulanla-

(2) ryndan 'Esavnyn ol olturuvčular Secird́a jolundan ol jylġalyq-

(3) nyn Elottan da 'Ecjon Gaverd́an da qajyryldyq da aštyq

(4) jolu sary midbarynyn Mo’avnyn. ויאמר. [9] Da ajtty Adonaj

(5) maja qysyqlyq etḿagin Mo’avġa \{da čuqčušmağyn alarbyla čerüv ki berḿanmen saja jerind́an anyn méraslik\} ki ulanlaryna Lotnun

(6) berdim ošol 'Arny méraslik. האמים. [10] Ol Emim

(7) olturdular anda burundan ullu ulus da köp da bijik

(8) 'Anaqlylar kibik. רפאים. [11] Refa’im sag̉yšlanyredilar ham

(9) alarda 'Anaqlylar kibik da ol Mo’avlylar ündarediĺar

(10) alarga Emim. ובשעיר. Da Se'ird́a olturdular

(11) ol Ḥorim burundan da ulanlary 'Esavnyn sürdülar alarny

(12) ulanlaryndan özlarinin da tasettilar alarny alynlaryndan

(13) özlarinin da olturdular orunlarynda alarnyn ki nečik qyl-

(14) dy Jisra’el jerińa meŕasliginin ki berdi Adonaj alarg̉a.

(15) עתה (13] Haligińa turujuz da ašyjyz \{özüjüzǵa\} ošol öźanin Zerednin

(16) da aštyq ošol öźanin Zerednin. והימים. [14] Da ol künlar

(17) ki bardyq Qadeš Barnea'dan neginč́a ki aštyq ošol öźanin

${ }^{1}$ K: ulanlary- 'Esavnyn; a scribal error. | TKow.o1: 'Esavg்a. | H: 'Esavġa.| C: 'Esavġa. $\quad{ }^{2}$ Interlinear insertion by another hand. | TKow.o1: dagyn. | H: daġyn. | C: daġyn. 
(11) this mountain. Turn northward. [4]

(12) And direct the people, saying, "You are passing

(13) through the border of your brothers, the children of Esau, who dwell in Seir.

(14) And they will be afraid of you, take good heed to yourself.

(15) [5] Do not get excited about them: I will not give you any of their land,

(16) |not so much as $\mid$ for the sole of the foot to tread on, because

(17) I have given Mount Seir to Esau for inheritance. [6] You shall buy food

(18) from them for silver and you shall eat. And you shall $\{a l s o\}$ buy water from them

(19) for silver, and you shall drink. [7] For the Lord your God has blessed

(20) you in all the works of your hand. He knows your walking through this great wilderness.

(21) These forty years the Lord your God is with you: you have not lacked

(1) a thing." " [8] And we passed by our brothers, the children

(2) of Esau, who dwelt in Seir, through the way of the steppe

(3) from Elath and from Ezion-Geber, and we turned and passed

(4) by the way of the wilderness of Moab. [9] And the Lord said

(5) to me, "Do not oppress the Moabites, and no not ready yourselves for a battle with them, for I will not give you any of their land for inheritance, because

(6) I have given Ar to the children of Lot for inheritance." [10] The Emim

(7) dwelt there originally, a people great and many and tall

(8) like the Anakim: [11] Who also were considered Rephaim ${ }^{257}$,

(9) like the Anakim, but the Moabites called

(10) them Emim. [12] And, originally, the Horites dwelt

(11) in Seir, but the children of Esau drove them out from before

(12) their children, and they destroyed them from before

(13) them, and dwelt in their place, as

(14) Israel did to the land of his inheritance, which the Lord gave to them.

(15) [13] "Now rise, and cross the river Zered."

(16) And we crossed the river Zered. [14] And the days

(17) that we went from Kadesh-Barnea, until we crossed the river

257 Heb. רְפִִָָים, i.e. the name of a Biblical race of giants, the pre-Israelite dwellers of the Land of Canaan. Cf. also Deu 2:20, Deu 3:11. 
(18) Zerednin otuz segiz jyl tüǵanginč́a bar ol dor eli ol čerüv-

(19) nün ortasyndan ol avulnun ki nečik antetti Adonaj alarğa.

(20) וגם [15] Da dag்yn hyššymy Adonajnyn edi alarda bulġanyštyr-

(21) ma alarny ortasyndan ol avulnun tügallíanǵanlarińadejin.

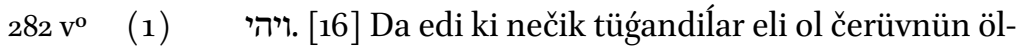

(2) máa ortasyndan ol ulusnun. [17] Da sözladi Adonaj

(3) maja ajtadoġač. אתה. [18] Sen ašasen bügün ošol čegin

(4) Mo'avnyn ošol 'Arny. [19] Da juvugiun uturusuna

(5) ulanlarynyn 'Amonnun qysyqlyq etḿagin alarg̉a da čuqčuš-

(6) maġyn alarbyla ki bermanmen jerind́an ulanlarynyn 'Amonnun

(7) saja meŕaslik ki ulanlaryna Lotnun berdim any meŕas-

(8) lik. [20] Jeri Refa'imnin saġyšlanyredi ham olda

(9) Refaim olturdular anda burundan da ol 'Amonlular

(10) ünd́aredilar alarg̉a Zamzumim. עם. [21] Ullu ulus

(11) da köp da bijik 'Anaqlylar kibik da tasetti alarny Adonaj

(12) alynlaryndan alarnyn da sürdülar alarny da olturdular

(13) alar ornuna. כאשר. [22] Ki nečik qyldy ulanlaryna 'Esav-

(14) nyn ol olturuvčular Se irdáa ki tasetti ošol ol

(15) Ḥorini alynlaryndan alarnyn da sürdülar alarny da oltur-

(16) dular alar ornuna ošpu künǵa dejin. והעוים. [23] Da

(17) ol 'Avim ol olturuvčular Ḥacerimd́a' 'Azag̉a dejin Kaf-

(18) torim ol čyg̉uvčular Kaftordan tasettilar alarny da

(19) olturdular alar ornuna. קומו [24] Turujuz köčüjüz

(20) da ašyjyz ošol öźanin Arnonnun kör berdim qoluja

(21) ošol Siḥonnu bijin \{Hešbonnun $\}$ ol Emorini da ošol jerin anyn bašlaġyn

$283 \mathrm{r}^{\circ} \quad$ (1) Tasetḿa da čuqčušqun anyn byla čerüv. [25] Bügün

(2) bašlarmen berma qobuvujnu da qorquvujnu jüzlari üstü-

(3) ńa bar ol uluslarnyn ki tübünd́a bar ol kökĺarnin ki

(4) ešitśalar habaryjny da qaltrarlar da qobarlar alnyjdan.

(5) - ואשלח Da ijdim elčílar midbaryndan Qedemot-

(6) nun Siḥonġa bijińa Ḥešbonnun bazlyq sözlarbyla ajta-

(7) dog̉ač. אעברה. [27] Ašajym jerij ašyra jolbyla jolbyla

(8) baryrmen qajyrylmanmen on jary ani son jary. אכלה [28] Jem

\footnotetext{
${ }^{1}$ A mistranslation. | TKow.o1: Hacerimde; unvocalized text. | H: Hacerimde. | C: salalarda. | R: salalarda.| Heb.
} 
(18) Zered, was thirty-eight years, until the end of all the generation, of the men of war,

(19) from among the camp, as the Lord swore to them.

(20) [15] For also the wrath of the Lord was against them and stirred

(21) them out from the midst of the camp until their end.

(1) [16] And it was, when all the men of war had ended,

(2) to die from among the people, [17] That the Lord spoke

(3) to me, saying, [18] "Today, you are passing over through Ar, the border

(4) of Moab. [19] And come near opposite

(5) the children of Ammon, do not oppress them, do not get excited

(6) about them, because I will not give you any of the land of the children of Ammon

(7) for inheritance, because I have given it to the children of Lot

(8) for inheritance." [20] That also was regarded as a land Rephaim:

(9) Rephaim dwelt there originally, and the Ammonites

(10) call them Zamzummim. [21] A people great

(11) and many and tall like the Anakim, but the Lord destroyed them

(12) before them, and they drove them out and dwelt

(13) in their place, [22] As he did to the children of Esau,

(14) who dwelt in Seir, when he destroyed the

(15) Horites from before them, and they drove them out and dwelt

(16) in their place to this day. [23] And

(17) the Avvim who dwelt in Hatzerim ${ }^{258}$ as far as Gaza,

(18) the Caphtorim who came out of Caphtor destroyed them and dwelt

(19) in their place. [24] "Rise up, set out

(20) and pass over the river Arnon. See: I have given to your hand

(21) Sihon the Amorite, king of Heshbon, and his land. Begin to destroy it.

(1) Ready yourselves for a battle with him. [25] Today

(2) I will begin to put the dread of you and the fear of you on the faces

(3) of the peoples that are under the whole heaven, so that

(4) they shall hear the news of you, and they shall tremble and dread before you."

(5) [26] And I sent messengers out of the wilderness of Kedemoth

(6) to Sihon, king of Heshbon, with words of peace, saying,

(7) [27] "Let me pass through your land by the road.

(8) I will go along the way, I will not turn either to the right or to the left.

258 A mistranslation based in interpreting Heb. חִִָּרים 'villages', 'settlement without walls' as a place name. 
(9) kümüšḱ satqyn maja da ašajym da suv kümüška

(10) bergin maja da ič́ajim tek ašajym jajav. כאשר. [29]

(11) Ki nečik qyldylar maja ulanlary 'Esavnyn ol olturuvčular

(12) Se'ird́a da ol Mo'avlylar ol olturuvčular 'Arda

(13) neginč́a ki ašqajmen ošol ol Jardenni ol jerǵa ki

(14) Adonaj Tenrimiz beŕadi bizǵa. ולא. [30] Da klamadi Siḥon

(15) biji Ḥešbonnun ašyrma bizni jeri ašyra ozünün ki

(16) qat [t]yrdy ${ }^{1}$ Adonaj Tenrij ošol క̌anyn anyn da küč́ajtti o-

(17) šol jǘragin anyn bermak üčün any qoluja ošpu kün

(18) kibik. ויאמר [31] Da ajtty Adonaj maja kör bašladym

(19) berḿa alnyjda ošol Siḥonnu da ošol jerin anyn bašlag̉yn

(20) tasetḿa meŕaslaḿa ošol jerin anyn. [32] Da

(21) čyqty Siḥon uturumuzğa $\{$ ol $\}$ da bar ulusu anyn čerüvǵa

$283 \mathrm{v}^{\mathrm{o}}$ (1) Jahcagia. ויתנהו. [33] Da berdi any Adonaj Tenrimiz alny-

(2) myzda da qyrdy\{q\} any da ošol uvullaryn anyn da ošol

(3) bar ulusun anyn. ונלכד. [34] Da tuttuq ošol bar šahar-

(4) laryn anyn ol vaḥtta da veŕan ettik ošol bar elin

(5) šaharnyn da ol qatynlarny da ol jašny qaldyrmadyq qaldyq.

(6) . [35] Tek ol tuvarny taladyq özümüzǵa da olžasyn

(7) ol šaharlarnyn ki tuttuq. מערער. [36] Bašlap 'Aro'er-

(8) dan ki qyryjy qatyna öźaninin Arnonnun da ol šahar ki

(9) öźand́a da ol Gil'adg̉adejin jog̉edi andij šahar ki küč-

(10) lüŕak bolġaj bizd́an ošol ol barysyn berdi Adonaj Tenri-

(11) miz alnymyzda. רק. [37] Tek jerińa ulanlarynyn 'Amonnun

(12) juvumadyj bar ornu öźaninin Jaboqnun da šaharlary ol tavnyn

(13) da barča neki [bujurdu $]^{2}$ Adonaj Tenrimiz.

\section{Deuteronomy 3}

ונפן [1] Da

(14) qajyryldyq da bardyq jolusary ol Bašannyn \{da čyqty 'Og biji ol Bašannyn \} uturumuzğa ol

(15) da bar ulusu anyn čerüvǵa Edre iğa. ויאמר. [2]

(16) Da ajtty Adonaj maja qorqmaġyn andan ki qoluja senin be-

(17) rirmen any da ošol bar ulusun anyn da ošol jerin anyn

(18) da qylg̀yn anar ki nečik qyldyj Siḥonġa bijińa ol Emorinin

\footnotetext{
${ }^{1} \mathrm{~K}$ : qatyrdy; a scribal error. | TKow.o1: qattyrdy. | H: qattyrdy. | C: qattyrdy. $\quad{ }^{2}$ TKow.o1: bujurdu; unvocalized text. | H: bujurdu. | C: symarlady.
} 
(9) [28] You shall sell me food for silver, that I may eat, and

(10) you shall give me water for silver, that I may drink. Only let me pass through on foot, [29]

(11) As the children of Esau who dwell

(12) in Seir, and the Moabites who dwell in Ar did for me,

(13) until I shall pass over Jordan to the land which

(14) the Lord our God gives us." [30] But Sihon,

(15) king of Heshbon, did not want to let us pass by his own land, because

(16) the Lord your God hardened his spirit and strengthened

(17) his heart in order to give him to your hand-

(18) as it is this day. [31] And the Lord said to me, "See: I have begun

(19) to give Sihon and his land before you. Begin

(20) to destroy it, to inherit his land." [32] And

(21) Sihon came out against us, he and all his people, for war

(1) at Jahaz. [33] And the Lord our God gave him

(2) before us, and we defeated him and his sons and

(3) all his people. [34] And we took all his cities

(4) at that time and we put to destruction all the men

(5) of the cities and the women and the infants. We did not leave a remnant.

(6) [35] Only the livestock we plundered for ourselves, and the spoil

(7) of the cities which we took. [36] From Aroer,

(8) which is by the bank of the river of Arnon, and the city that

(9) is at the river, and to Gilead, there was no city that was stronger

(10) than us. The Lord our God put it all

(11) before us. [37] Only to the land of the children of Ammon

(12) you did not come near, all the place of the river Jabbok and the cities of mountains,

(13) and all that the Lord our God [commanded].

Deuteronomy 3

(14) we turned and went up the way to Bashan. And Og, king of Bashan, came out against us, he

(15) and all his people, for war at Edrei. [2]

(16) And the Lord said to me, "Do not be afraid of him, because I will give him

(17) and all his people and his land to your hand,

(18) and you shall do to him as you did to Sihon, king of the Amorites, 
(19) ki oltururedi Ḥešbonda. ויתן [3] Da berdi Adonaj Tenri-

(20) miz qolumuzġa dag̉yn ošol 'Og̉nu bijin ol Bašannyn da ošol

(21) bar ulusun anyn da qyrdyq any qaldyrmajynča anar qaldyq.

$284 \mathrm{r}^{\mathrm{o}} \quad$ (1) [4] [4] Da tuttuq ošol bar šaharlaryn anyn ol vahtta

(2) joġedi šahar ki almaġajbiz alardan altymyš šahar bar čegi Ar-

(3) govnun bijligin 'Oġnun Bašanda. כל [5] Bar bular bek šahar-

(4) lar bijik qalaly ešikli da beklüvüčlü bašqa ol sala šaharla-

(5) ונחרם. [6] Da veŕan ettik alarny

(6) ki nečik qyldyq Siḥonġa bijińa Ḥešbonnun veŕan etḿa bar

(7) elin šaharnyn ol qatynlarny da ol jašny. וכל. [7] Da bar

(8) ol tuvarny da olžasyn ol šaharlarnyn taladyq özümüzǵa.

(9) ונקח [8] Da aldyq ol vaḥtta ošol ol jerni qolundan

(10) eki bijlarinin ol Emorinin ki köčüvünd́a ol Jardennin

(11) bašlap öźanind́an A $\{r\}$ nonnun tavyna dejin Ḥermonnun.

(12) צידנים (9) Cidonlular ündaredilar Hermonġa Sirjon da

(13) ol Emori ünd́aredilar anar Senir. כל. [10] Bar šaharla-

(14) ry ol tüz jernin da bar ol Gil'ad da bar ol Bašan Salhagagadejin

(15) da Edre'iğadejin bijlik šaharlary 'Oġnun Bašanda. כי. [11]

(16) Ki ančaq 'Og் biji ol Bašannyn qaldy qaldyg்yndan ol Refa’imnin

(17) muna krovaty anyn temirli krovat muna ol Rabasynda

(18) ulanlarynyn 'Amonnun toġuz lokotlar uzunlug̉u da dört

(19) lokotlar kenligi anyn lokotu byla kišinin. [12] Da

(20) ošol ol jerni ošpunu méáaśladik ol vahịtta baš-

(21) lap 'Aro'erd́an ki öźani qatyna Arnonnun da jarymyn

$284 \mathrm{v}^{\circ} \quad$ (1) $\quad{ }^{\operatorname{tav}}\{y\}$ nyn ol ${ }^{11}\left\{\right.$ Gilladnyn $^{2}$ da šaharlaryn anyn berdim $\langle$ jarym $\rangle$ ševetińa Ru’uvennin

(2) da ševetińa Gadnyn. [יתר] [13] Da qaldyġy ol Gil'adnyn da bar

(3) ol Bašanny bijligin 'Oġnun berdim jarym ševetińa $\{o l\}^{3}$ Menašenin

(4) bar čegi ol Argovnun bar ol Bašan byla $\{o l\}^{4}$ ünd́aliredi jeri Refa’im-

(5) nin. יאיר [14] Ja'ir uvlu Menašenin aldy ošol bar čegin Argov-

(6) nun čegińadejin ol Gešurinin da ol Máahatinin da atady alarğa

\footnotetext{
${ }^{1} \mathrm{~K}$ : ol tarynyn; the word order was corrected by another hand; the letter yodh was added to the word by another hand. | TKow.o1: taryn ol; different wording; unvocalized text. | H: tavyn ol; different wording. | C: tagynyy ol. $\quad{ }^{2}$ Insertion by another hand above the first line. | TKow.o1: Gil'adnyn; unvocalized text. | H: Gil'adnyn. | C: Gil'adnyy. $\quad{ }^{3}$ Interlinear insertion by another hand. | TKow.o1: ol; unvocalized text. | H: ol. | C: ol. $\quad{ }^{4}$ Interlinear insertion by another hand. | TKow.o1: deest. | H: ol. | C: deest; different wording.
} 
(19) who dwelt at Heshbon." [3] So the Lord our God gave

(20) to our hands Og, king of Bashan, and

(21) all his people as well, and we struck him until he did not have a remnant left.

(1) [4] And we took all his cities at that time.

(2) There was not a city which we did not take from them: sixty cities, all the border

(3) of Argob, the kingdom of Og in Bashan. [5] All these cities were fortified

(4) with high walls, gates, and bars-besides village-towns 259

(5) a great many. [6] And we desolated them

(6) as we did to Sihon, king of Heshbon, to put to destruction all

(7) the men of the cities, women and infants. [7] But all

(8) the livestock, and the spoil of the cities, we plundered for ourselves.

(9) [8] And we took at that time from the hand of the

(10) two kings of the Amorites the land that was at the ford of Jordan,

(11) from the river of Arnon to Mount Hermon,

(12) [9] Sidonians call Hermon Sirion, and

(13) the Amorites call it Senir, [10] All the cities

(14) of the plain and all Gilead and all Bashan as far as Salecah

(15) and as far as Edrei, cities of the kingdom of Og in Bashan. [11]

(16) Because only Og, king of Bashan, remained of the remnant of the Rephaim.

(17) Lo, his bedstead was a bedstead of iron, lo, in Rabbah,

(18) of the children of Ammon. Nine cubits was its length and four

(19) cubits its breadth, after the cubit of a man. [12] And

(20) we inherited that land at that time.

(21) From Aroer which is by the river Arnon, and half

(1) the mountains of $\{$ Gilead $\}$ and its cities: I gave it to the tribe of Reuben

(2) and to the tribe of Gad. [13] And the rest of Gilead, and all

(3) Bashan, the kingdom of Og, I gave to the half tribe of Manasseh.

(4) All the region of Argob, with all Bashan, was called the land of Rephaim.

(5) [14] Jair, son of Manasseh, took all the border of Argob

(6) as far as the border of the Geshurites and the Maacathites and called them,

259 I.e., un-walled towns. 
(7) öz atybyla ol Bašanġa Havvot Ja’ir ošpu künǵadejin.

(8) ולמכיר (15] Da Mahirğa berdim ošol ol Gil'adny.

(9) (16] Da ševetińa Ru'uvennin da ševetińa Gadnyn ber-

(10) dim bašlap ol Gil'addan da öźanińa dejin Arnonnun ortasyn

(11) ol öźannin da čekt́a da Jaboq ünd́áladoġan ornunadejin ol

(12) öźannin edi čegi ulanlarynyn 'Amonnun. והערבה Da

(13) ol jylgalyq da ol Jarden da čekt́a bašlap Kinerett́an da

(14) tengizińadejin ol jylġalyqnyn tuzlu tengizǵa tašqynlary

(15) tübüńa ol singirnin mizrah sary. ואצו. [18] Da bujurdum

(16) sizǵa ol vaḥtta ajtadog̉ač Adonaj Tenrijiz berdi sizǵa

(17) ošol ol jerni ošpunu meŕaślama any jasanġanlar ašyjyz

(18) alnynda qaryndašlaryjyznyn ulanlarynyn Jisra’elnin bar tuvušlu el.

(19) - רק (19] Ančaq qatynlaryjyz da jašyjyz da tuvaryjyz bilamen ki köp

(20) tuvar bardy sizǵa oltursunlar šaharlaryjyzda ki berdim

(21) sizǵa. עד (20] Neginča ki tynč etkaj Adonaj qaryndašlaryjyz-

$285 \mathrm{r}^{\mathrm{o}} \quad$ (1) ġada nečik sizǵa da meŕaślaśálar daġyn alarda ošol ol

(2) jerni ki Adonaj Tenrijiz beŕadi alarġa köčüvünd́a ol Jarden-

(3) nin da qajtyrsiz kiši mé́asligińa özünün ki berdim

(4) sizǵa. ואת Da ošol Johošua'ny zynharladym \{ol vahtta\} ajtadoġač

(5) közlarijdi ol körüvčülar ošol barča neki qyldy Adonaj Ten-

(6) rijiz eki ol bijlarǵa ošpularg̉a alaj qylar Adonaj barda

(7) ol bijlikĺarǵa ki sen ašasen ary. לא. [22] Qorqmajyz alardan

(8) ki Adonaj Tenrijiz oldu ol urušuvču siznin üčün.

פרשת ואתחנן (1) (19)

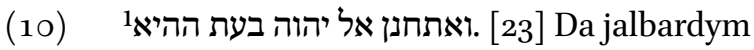

(11) Adonajğa ol vaḥtta ajtadog̀ač. ${ }^{2}$. [24]

(12) E Adonaj Tenri sen bašladyj körgüzḿa quluja ošol ullu-

(13) lug̉ujnu da ošol qudratyjny ol küčlü ki kim barmodu

(14) kökĺard́a da jerd́a andij küčlü qylalġaj išlarijkibik

(15) da bag̉atyrlyqlaryjkibik. אעברה. [25] Ašajym endi da

(16) köŕajim ošol ol jahšyy jerni ki köčüvünd́a ol Jardennin ol

(17) jahšy tavny ušpunu da ol Levanonnu. ויתעבר Da

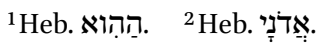


(7) the Bashan, after his own name, Havvoth-Jair, to this day.

(8) [15] And I gave Gilead to Machir.

(9) [16] And I gave to the tribe of Reuben and to the tribe of Gad

(10) from Gilead as far as the river Arnon the middle of

(11) the river, and |it is| on the border, and as far as the place of the river called Jabbok

(12) was the border of the children of Ammon, [17] and

(13) the steppe, and the Jordan, and |it is| on the border, from Kinnereth

(14) to the sea of the steppe, to the Salt Sea, under the riverbeds

(15) Lof the summit ${ }^{1260}$ eastward. [18] And I commanded

(16) you at that time, saying, "The Lord your God has given you

(17) this land to inherit it. You shall pass armed

(18) in front of your brothers, all able men, the children of Israel.

(19) [19] Only your wives and your infants and your livestock-I know that

(20) you have much livestock — shall abide in your cities which I have given

(21) you. [20] Until the Lord has given rest to your brothers,

(1) like to you, and they, too, inherit

(2) the land which the Lord your God has given them at the ford of Jordan.

(3) And you will return every man to his inheritance which I have given

(4) you." [21] And I commanded Joshua at that time, saying,

(5) "Your eyes have seen all that the Lord your God has done

(6) to these two kings: so shall the Lord do to all

(7) the kingdoms to which you are crossing. [22] You shall not fear them,

(8) because the Lord your God: He is the one fighting for you."

(9) Parashat Va'etchanan

(10) [23] And I besought

(11) the Lord at that time, saying, [24]

(12) "Oh Lord God, you have begun to show your servant your greatness,

(13) and your strong hand, because is there anyone so strong

(14) in heaven or in earth that is able to do works like yours

(15) and braveries like yours? [25] Now, let me cross

(16) and let me see the good land that is at the ford of Jordan, that

(17) good mountain and Lebanon." [26] But

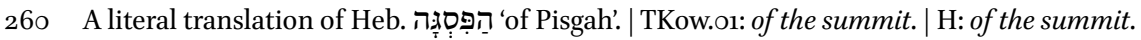
| C: of the rock. | R: of the rock. 
(18) ačuvlandy Adonaj üstüḿa siznin üčün da tynlamady

(19) maja da ajtty Adonaj maja jet́ar saja arttyrmaġyn sözĺama

$285 \mathrm{v}^{\mathrm{o}}$ (1) maja artyq ošpu söznü. 27 [27 Mingin bašyna ol

(2) singirnin da kötürgün közlarijni macaravsary da cafonsary

(3) da tüšlüksary da mizrah sary da baqqyn közlarijbyla ki

(4) ašmassen ošol ol Jardenni ošpunu. וצו [28] Da [sym]arla-

(5) lag̉yn ${ }^{1}$ ošol Johošua'ny da kiplagin any da küč́ajtkin any ki ol

(6) ašar alnynda ol ulusnun ošpu da ol ülašir alar-

(7) ga ga ošol ol jerni ki körśaj. [29] Da kečiktik

(8) ¿ Gaj’ ünd́aĺadogan orunda ${ }^{12}$ uturusuna Bet Po`ornun.

\section{Deuteronomy 4}

(9) [1] Da haligińa e Jisra’el tynlag்yn ol resimlarni

(10) da ol törálarǵa ki men üvŕatamen sizǵa qylma anyn

(11) üčün ki tiri bolġajsiz da kelǵajsiz da meŕaslaǵajsiz

(12) ošol ol jerni ki Adonaj Tenrisi atalaryjyznyn beŕadi sizǵa.

(13) לא [2] Arttyrmajyz ol söz üstüńa ki men bujuramen

(14) sizǵa da eksitmajiz andan saqlama ošol micvalaryn

(15) Adonaj Tenrijiznin ki men bujuramen sizǵa. עיניכם. [3] Közĺa-

(16) rijizdi ol körüvčülar ošol neki qyldy Adonaj Bacal Pocor-

(17) da ki bar ol kiši ki bardy qulluğu artyna Ba‘al Po`ornun

(18) tasetti any Adonaj Tenrij ortajdan. ואתם. [4] Da siz

(19) ol jabušuvčular qullug̉una Adonajnyn Tenrijiznin tirilarsiz

(20) barlaryjyz bügün. ראה. [5] Baqqyn üvŕattim sizǵa resim-

(21) ĺar da töŕálar ki nečik bujurdu maja Adonaj Tenrim

$286 \mathrm{r}^{\mathrm{o}} \quad$ (1) qylma alaj ortasynda ol jernin ki siz kelasiz ary me-

(2) raslama any. [6] Da saqlajyz da qylyjyz ki oldu

(3) usujuz da aqylyjyz közĺarič́a ol uluslarnyn ki ešit-

(4) śálar ošol bar ol resimlarni ošpularny da ajtyrlar

(5) tek uslu ulus da aqylly ol ullu hạlyq ošpu.

(6) כ [7 Ki kim ullu hạanlyq ki anar hašgaḥalary Tenrinin juvuq-

\footnotetext{
${ }^{1} \mathrm{~K}$ : synharlagyn; a scribal error; here, we cannot reconstruct the word zynharla- 'to command' (despite its similarity to *synharla-) because it governs the dative case (cf. the accusative in Johošua'ny and also symarla- '1. to appoint; 2. to recommend; 3. command' which governs the accusative case). | TKow.o1: symarlagyn; unvocalized text. | H: symarlagyyn. | C: symarlagyn. ${ }^{2}$ A mistranslation. | TKow.o1: Gaj' ündeledogan orunda; unvocalized text. | H: Gaj indeledogan

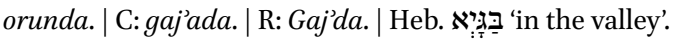


(18) the Lord was angry with me because of you and he did not listen

(19) to me. And the Lord said to me, "You have had enough. Do not go on speaking

(1) to me of this matter. [27] Get up to the top

(2) ${ }_{L}$ of the summit ${ }^{1261}$ and lift up your eyes westward and northward

(3) and southward and eastward and see it with your eyes: because

(4) you shall not go over this Jordan. [28] And command

(5) Joshua and reinforce him and strengthen him, because he

(6) will cross before this people and will divide between them

(7) the land which you shall see". [29] And we stayed

(8) in the place called Gay ${ }^{1262}$ opposite Beth-Peor.

Deuteronomy 4

(9) [1] And now, oh Israel, listen to the statutes

(10) and to the judgments, which I teach you to do them, so that

(11) you may live, and you may come and inherit

(12) the land which the Lord God of your fathers is giving you.

(13) [2] You shall not add to the word which I command

(14) you, and you shall not take away from it, in order to keep the commandments

(15) of the Lord your God which I command you. [3] It is your eyes

(16) that saw what the Lord did at Baal-Peor

(17) and that every men who went after Baal-Peor:

(18) the Lord your God has destroyed them from among you. [4] But you

(19) who were clinging to the Lord your God: you are alive,

(20) every one of you, today. [5] Look: I have taught you statutes

(21) and judgments as the Lord my God commanded me,

(1) that you should do so within the land to which you are coming

(2) to inherit it. [6] Keep therefore and do them, for this is

(3) your wisdom and your reason in the sight of the peoples which

(4) shall hear all these statutes and will say,

(5) "Only a wise and rational people is this great kingdom." [7]

(6) Because who is a great kingdom that has the Providence of God so near

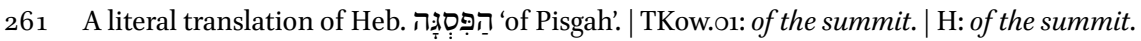
| C: of the rock. | R: of the rock.

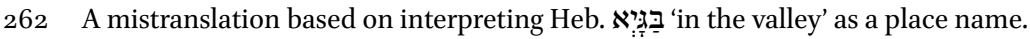


(7) lar anar Adonaj Tenrimiz kibik bar čaġyrg̉an vahtymyzda

(8) anar. [8 [8 Da kim ullu hanlyq ki anar resimlar

(9) da rast töŕálar bar ol Tora kibik ošpu ki men be-

(10) ŕamen alnyjyzda bügün. רק. [9] Tek saqlanġyn özüja

(11) da saqlag̉yn žanyjny astry magiat unutursen ošol ol

(12) sözlarni ki kördülar közlarij da mag̉at ketarláar

(13) esijd́an bar tirlik künlarijda da bildirgin alarny uvulla-

(14) ryja da uvullaryna uvullaryjnyn. וים [10] Künnü ki turduj

(15) alnynda Adonaj Tenrijnin Ḥorevd́a ajtqanda Adonaj

(16) maja jyštyrg̉yn maja ošol ol ulusnu da ešit-

(17) tiŕajim alarg̉a ošol sözlarimni ki üvŕanǵajlar

(18) qorqma mend́an bar ol kü\{n\}ĺard́a ki alar tiridilar ol

(19) jer üstüńa da ulanlaryna özlarinin üvŕatḱkajlar.

(20) ותקרבון Da juvudujuz da turdujuz ol tav tübü-

(21) ńa da ol tav janaredi otta ortasynadejin ol kökĺarnin

$286 \mathrm{v}^{\circ}$ (1) qarangylyq bulut da tuman. וידבר . [12] Da sözladi Adonaj

(2) sizǵa ortasyndan ol otnun avazyn sözlarnin siz eši-

(3) tiredijiz da türsün körḿasedijiz ančaq avaz.

(4) ויגד [13] Da anlatty sizǵa ošol šertin özünün

(5) ki bujurdu sizǵa qylma on ol sözlarni da jazdy

(6) alarny eki tašly luḥot üstüńa. ואתי. [14]

(7) Da \{maja\} bujurdu Adonaj ol vaḥtta üvŕatma sizǵa

(8) resimlar da töŕálar qylma siz alarny jerd́a

(9) ki siz ašasiz ary meŕaslaḿa any. ונשמרתם. [15]

(10) Da saqlanyjyz astry žanlaryjyz üčün ki körmadijiz

(11) heč sufat sözlaǵan künd́a Adonaj sizǵa Ḥorevd́a

(12) ortasyndan ol otnun. פן [16] Mag̉at čajparsiz jolla-

(13) ryjyzny da qylarsiz özüjüzǵa jonma abaq türsü-

(14) nün nendijd́a sufatnyn türsünün erkaknin jemeśa

(15) neqevanyn. תבנית. [17] Türsünün nendijda tuvaryn ki

(16) jerd́a türsünün nendijd́a qanatly qušnun ki učady

(17) köklaráa. תבנית. [18] Türsünün nendijda tebŕa-

(18) nüvčünün jerd́a türsünün nendijda balyqnyn ki suvlar-

(19) da ašag̉artyn jerǵa. ופן [19] Da mag̉at kötürürsen

(20) közlarijni ol kökĺarǵa da köŕarsen ošol ol qujašny

(21) da ošol ol ajny da ošol ol jolduzlarny bar čerüvün

$287 \mathrm{r}^{\circ} \quad$ (1) ol kökĺarnin da azašsaj da bašursaj alarg̉a da qulluq et- 
(7) to them, as the Lord our God is, in all times of our calling

(8) to him? [8] And who is a great kingdom that has statutes

(9) and judgments so righteous as all this Law, which I set

(10) before you this day? [9] Only take heed to yourself

(11) and watch your soul very much, lest you forget the

(12) things that your eyes have seen, and lest they depart

(13) from your reason, all the days of your life. But make them known to your sons,

(14) and to your sons' sons. [10] The day that you stood

(15) before the Lord your God in Horeb, when the Lord said

(16) to me, "Gather the people to me, and I will make them hear

(17) my words, that they may learn

(18) to fear me all the days that they shall live

(19) on the earth, and that they may teach their children."

(20) [11] And you came near and stood at the foot of the mountain,

(21) and the mountain burned with fire to the midst of heaven:

(1) darkness, clouds, and fog. [12] And the Lord spoke

(2) to you from the midst of the fire:You heard the voice of the words,

(3) but you saw no form, just sound.

(4) [13] And he told you his covenant,

(5) which he commanded you to do, the ten commandments, and he wrote

(6) them on two tablets of stone. [14]

(7) And the Lord commanded me at that time to teach you

(8) statutes and judgments, for you to do them in the land

(9) to which you are crossing to inherit it. [15]

(10) And take good heed to your souls-because you did not see

(11) any image on the day that the Lord spoke to you in Horeb

(12) from the midst of the fire-[16] Lest you corrupt your ways

(13) and make you a carved idol, a form

(14) of any image, a form of male or

(15) female, [17] A form of any animal that

(16) is on the earth, a form of any winged bird that flies

(17) in the skies, [18] A form of anything that creeps

(18) on the ground, a form of any fish that is in the waters

(19) beneath the earth, [19] And lest you lift up

(20) your eyes to heaven and you see the sun

(21) and the moon and the stars, all the host

(1) of heaven, and you go astray to worship them and serve 
(2) śaj alarg̉a ki ülüš berdi Adonaj Tenrij alarny bar ol ulus-

(3) largaa tübünd́a bar ol kökĺarnin. ואתכם [20] Da sizni

(4) aldy Adonaj da čyġardy sizni ol temir ḥalasttan Micri-

(5) dan bolma anar tijiš ulusqa ošpu künkibik. ויהוה [21]

(6) Da Adonaj ačuvlandy üstüḿa sözlarijiz üčün da ant-

(7) etti ašmasqa men ošol ol Jardenni da kelmáaska

(8) ol jaḥ̌yy jerǵa ki Adonaj Tenrij beŕadi saja ülüš.

(9) כי [22] Ki men ölarmen ošpu jerd́a ašmanmen ošol ol

(10) Jardenni da siz ašasiz da meŕaslarsiz ošol ol jaḥšy

(11) jerni ošpunu. השמרו. [23] Saqlanyjyz özüjüzǵa mag̉at

(12) unutursiz ošol šertin Adonaj Tenrijiznin ki kesti bir-

(13) ǵajizǵa da qylarsiz özüjüzǵa jonma abaq nendijda

(14) sufatbyla ki zynharlady saja Adonaj Tenrij qylmasqa any.

(15) כי (24] Ki Adonaj Tenrij otkibik örtajdoġan ol künilav-

(16) čü Tenridi. כי [25] Ki tuvdursaj ulanlar da ulanlaryn

(17) ulanlarnyn da qartajsajyz jerd́a da čajpasajyz jollaryjyzny

(18) da qylsajyz jonma abaq türsünün nendijd́a nerśanin

(19) da qylsajyz ol jaman körünǵanni ‘enajetlarynda Adonajnyn

(20) Tenrijnin ačyrg̉andyrma any. העידתי. [26] Tanyq turg̉u-

(21) zamen sizǵa bügün ošol ol kökĺarni da ošol ol jerni

$287 \mathrm{~V}^{\mathrm{o}} \quad$ (1) ki taspolma taspolursiz tez ol jer üstünd́an ki siz

(2) ašasiz ošol ol Jardennin ary meŕaslamáa any uzartmas-

(3) siz künĺar ol jer üstüńa ki taspolma taspolursiz.

(4) והפיץ [27 Da tozdurur Adonaj sizni uluslarda da qalyr-

(5) siz sanly el ḥanlyqlarda ki könd́arir Adonaj sizni ary.

(6) (28] Da qulluq etarsiz anda qulluq etüvčü-

(7) ĺarǵa abaqlarg̉a išińa qullarynyn adamnyn ag̉ačtan da

(8) taštan ki körḿajdilar da ešitmajdilar da ašamajdy-

(9) lar da ijisḱamajdilar. ובקשתם [29] Da jalbarsajyz

(10) andan Adonajgia Tenrija da tabarsen klakĺarijni ki jal-

(11) barsaj anar bar jüragij byla da bar žanyjbyla. בצר. [30]

(12) Tar bolġanda saja da učrasalar seni bar ol sözlar

(13) ošpular sonġusunda ol künlarnin da tešuva byla

(14) qajtsaj Adonajğa Tenrijǵa dejin da tynlasaj ünüńa

(15) anyn. כי [31] Ki raḥmet́lavčü Tenridi Adonaj Tenrij jeber-

${ }^{1} \mathrm{~K}$ : Spelled כיוּנילְיבְצִציו; a scribal error. 
(2) them, because the Lord your God has apportioned them to all peoples

(3) under all the skies. [20] But

(4) the Lord has taken you, and he brought you out from the iron furnace,

(5) from Egypt, to be to him a people of share, as it is this day. [21]

(6) And the Lord was angry with me because of you, and he

(7) swore that I should not cross the Jordan, and that I should come

(8) to that good land, which the Lord your God gives you for a share.

(9) [22] Because I will die in this land. I will not cross

(10) Jordan. But you are crossing, and you will inherit that good

(11) land. [23] Take heed to yourselves, lest

(12) you will forget the covenant of the Lord your God that he made

(13) with you and you will make a carved idol for yourself, of any

(14) image, which the Lord your God has commanded you not to do,

(15) [24] Because the Lord your God: he is like consuming fire, he is a jealous

(16) God. [25] Because if you beget children and children's children

(17) and grow old in the land, and if you corrupt your ways

(18) and make a carven idol, a form of anything,

(19) and if you do what is evil in the sight of the Lord

(20) your God, to make him angry, [26] I will call

(21) heaven and earth to witness against you today,

(1) that you will utterly perish from off the land to which you

(2) you are crossing the Jordan to inherit it. You will not prolong

(3) your days on earth, but you will be utterly destroyed.

(4) [27] And the Lord will scatter you among the peoples, and

(5) you will be left few in number among the kingdoms where the Lord will lead you.

(6) [28] And there you will serve those who serve

(7) gods, the work of human hands, of wood and

(8) stone, that do not see or hear or eat

(9) or smell. [29] But if from there you will beseech

(10) the Lord your God, you will find his wishes,

(11) if you beseech him with all your heart and with all your soul, [30]

(12) And if all these words come on you when you are in tribulation,

(13) in the latter days, and

(14) if you return with repentance as far as to the Lord your God and obey his voice,

(15) [31] Because the Lord your God is a merciful God, he will not leave 
(16) ḿasti seni da [čajpa]masty ${ }^{1}$ seni da unutmasty ošol

(17) šertin atalaryjnyn ki antetti alarg̉a. כי. [32] Ki sorg̉un

(18) endi burunġu künlar üčün ki edilar send́an burun ol

(19) künd́an ki jaratty Tenri adamny ol jer üstüńa da

(20) qyryjyndan ol kökĺarnin da qyryjynadejin ol kökĺarnin bolun-

(21) dumo ol ullu iš kibik ošpu jemeśa ešitildimo

$288 \mathrm{r}^{\mathrm{o}}$ (1) anyn kibik. השמע. [33] Ešittimo ulus ünün Tenri-

(2) nin sözlajdoġanny ortasyndan ol otnun ki nečik ešit-

(3) tij sen da tiri boldular. או. [34] Jemeśa čynyqtymo

(4) Tenri kelḿa alma özüńa hanlyqny ortasyndan ḥanlyq-

(5) nyn synavlarbyla belgilarbyla da nišanlar byla da čerüv

(6) byla da küčlü qudratbyla da sunulganan quvatbyla da

(7) ullu qorquvlarbyla barča nečik ki qyldy sizǵa Adonaj

(8) Tenrijiz Micrid́a közlarijč́a. אתה. [35] Sen körgüzül-

(9) düj bilḿa ki Adonaj oldu ol Tenri joḥtur artyq

(10) andan bašqa. מ36] Ol kökĺard́an ešittir\{di\} saja

(11) ošol ünün adeplamáa seni da ol jer üstüńa

(12) körgüzdü saja ošol otun ol ullu da sözlarin anyn

(13) ešittij ortasyndan ol otnun. ותחת [37 Da

(14) anyn üčün ki süvdü ošol atalaryjny da sajlady

(15) urlug̉un anyn özünd́an sortun da čyg̉ardy seni hašgaḥala-

(16) rybyla ol ullu Micridan. להוריש. [38] Tasetḿa ullu-

(17) raq ḥanlyqlarny da küčlürakĺarni send́an alnyjdan keltir-

(18) ḿa seni berḿa saja ošol jerlarin alarnyn ülüš

(19) ošpu künkibik. [ידעת] Da bilgin bügün da qajtar-

(20) ġyn esija ki Adonaj oldu ol Tenri kökĺard́a [joġartyn] ${ }^{2}$

(21) da ol jer üstüńa ašag̉artyn joḥtur artyq. ושמרת. [40]

$288 \mathrm{v}^{\circ} \quad$ (1) Da saqlag̉yn ošol resimlarin anyn da ošol micvalaryn

(2) ki men bujuramen saja bügün ki jaḥ̌y bolġaj saja da ulan-

(3) laryja özüjd́an sortun da anyn üčün uzartyrsen

(4) künĺar ol jer üstüńa ki Adonaj Tenrij beŕadi saja

(5) bar ol künlard́a. אז. [41] Ol vaḥtta ajyrdy Moše

(6) üč šaharlar köčüvünd́a ol Jardennin qujaš balquvusary.

(7) לנס [42] Qačma ary bar qaraqčy ki qaraqlasa ošol dos-

(8) tun bilmajinč́a da ol dušman tüvül edi anar tüńa-

(9) dan biri künd́an da qačsyn birisińa ol šaharlarnyn

(10) ošpularnyn da tiri bolsun. את [43] Ošol Becerni

${ }^{1}$ TKow.o1: čajpamasty. | H: cajpamasty. | C: čajpamastyr. $\quad{ }^{2}$ Cf. Deu 5:8. | TKow.o1: joǵartyn. | H: joġartyn. |C: jogartyn. 
(16) you and he will not destroy you and he will not forget the

(17) covenant of your fathers which he swore to them. [32] Because ask,

(18) now, of the first days that were before you, from the

(19) day that God created man on the earth, and

(20) from the one edge of the skies to the edge of the skies: has there been

(21) |anything| like this great thing? Or has |anything| like it been heard?

(1) [33] Did ever people hear the voice of God

(2) speaking from the midst of the fire the way you have heard-

(3) and lived? [34] Or has God ever been used to

(4) going and taking him a kingdom from the midst of another kingdoms

(5) with trials, with signs, and with tokens, and with war,

(6) and with a strong hand, and with an outstretched arm, and

(7) with great fears, like all that the Lord your God did for you

(8) in Egypt in your sight? [35] You have been shown

(9) in order to know that the Lord: he is the God. There is no other

(10) besides him. [36] From the skies he had you hear

(11) his voice in order to discipline you, and on the earth

(12) he showed you his great fire, and you heard his words

(13) from the midst of the fire. [37] And

(14) because he loved your fathers, he chose

(15) their offspring after them, and brought you out

(16) from great Egypt with his Providence, [38] To destroy

(17) nations from before you greater and mightier than you are, to bring you in,

(18) to give you their land for a share,

(19) as it is this day. [39] Know therefore today, and

(20) repeat it in your mind, that the Lord: he is the God in the skies above

(21) and on the earth beneath: there is none else. [40]

(1) And you shall keep therefore his statutes and his commandments

(2) which I command you today, so it will be good for you

(3) and to your children after you, and that you may prolong

(4) your days on the earth, which the Lord your God gives you,

(5) for all the days.' [41] Then Moses set apart

(6) three cities at the ford of Jordan toward the sun's rising,

(7) [42] That the manslayer might flee there, the one who would murder his neighbour

(8) without knowing — and he was not his enemy

(9) for long; and he shall flee to one of these cities

(10) and he shall live: [43] Bezer 
(11) midbarda jerind́a ol tüz orunnun ševetind́an Ru’uven-

(12) nin da ošol Ramotnu Gil'adda ševetind́an Gadnyn

(13) da ošol Golanny Bašanda ševetind́an Menašenin.

(14) . וזאת [44] Da budur ol Tora ki qojdu Moše al-

(15) nynda ulanlarynyn Jisra’elnin. אלה. [45] Bulardylar ol

(16) šarajatlar $\{d a\}^{1}$ ol resimlar da ol töŕalar ki sözladi

(17) Moše ulanlaryna Jisra’elnin čyqmaqlaryndan sortun jerin-

(18) dan Micrinin. בעבר [46] Köčüvüda ol Jardennin _Gaj’

(19) ünd́aladog̉an orunda ${ }^{12}$ uturusuna Bet Pocornun

(20) jerind́a Siḥonnun bijinin ol Emorinin ki oltururedi

(21) Ḥešbonda ki qyrdy Moše da ulanlary Jisra’elnin čyqqan-

$289 \mathrm{r}^{\mathrm{0}}$ (1) laryndan sortun jerind́an Micrinin. [47] Da meŕas-

(2) ĺadilar ošol jerin anyn da ošol jerin 'Og̉nun bijinin ol

(3) Bašannyn eki bijlarinin ol Emorinin ki köčüvünd́a

(4) ol Jardennin qujaš balquvusary. מערער. [48] Bašlap

(5) 'Aro`erd́an ki qyryjy üstüńa öźaninin Arnonnun da

(6) tavynadejin Si'onnun oldu Hermon. וכל [49] Da bar ol

(7) jylġalyq köčüvü ol Jardennin mizrah sary da tengizińa-

(8) dejin ol jylġalyqnyn tašqynlary tübüńa ol singirnin.

\section{Deuteronomy 5}

(9) ויקרא [1] Da čag̉yrdy Moše bar Jisra’elǵa da ajt-

(10) ty alarg̉a tynlaġyn e Jisra’el ošol ol resimlarni

(11) da ošol ol töŕalarni ki men sözlajmen qulaqlaryjyzča

(12) bügün da üvŕanijiz alarny da saqlajyz qylma alarny.

(13) יהוה [2] Adonaj Tenrimiz kesti birǵamizǵa šert

(14) Horevd́a. לא [3] Tüvül atalarymyz byla kesti Adonaj

(15) ošol ol šertin ošpunu ki birǵamizǵa biz bular

(16) bunda bügün barymyz tirilarbiz. פנים. [4] Aqyl aqyl-

(17) ga sözladi Adonaj birǵajizǵa tavda ortasyndan ol

(18) otnun. אנכי [5 [5 Men turaredim arasyna Adonajnyn

(19) da aryjyzda ol vaḥtta anlatma sizǵa ošol sözün

(20) Adonajnyn ki qorqtujuz alnyndan ol otnun da minḿa-

(21) dijiz tavğa ne vahtta ki kladi ajtma. [6]כי [6]

\footnotetext{
${ }^{1}$ Marginal insertion by another hand.|TKow.o1: $d a$.|H: $d a . \mid \mathrm{C}: d a . \quad{ }^{2}$ A mistranslation.|TKow.o1: Gaj' ündeledogan orunda. | H: Gajda. | C: Gajda. | R: Gaj'da. | Heb.
} 
(11) in the wilderness, in the plain country, of the tribe of Reuben,

(12) and Ramoth in Gilead, of the tribe of Gad,

(13) and Golan in Bashan, of the tribe of Manasseh.

(14) [44] And this is the Law which Moses set

(15) before the children of Israel. [45] These are the

(16) laws $\{$ and $\}$ the statutes and the judgments which Moses spoke

(17) to the children of Israel, after they came out from the land

(18) of Egypt, [46] At the ford of Jordan, ${ }_{L}$ in

(19) a place called Gay ${ }^{1263}$ opposite Beth-Peor,

(20) in the land of Sihon of the king of the Amorites who dwelt

(21) at Heshbon, whom Moses and the children of Israel defeated,

(1) after they come out from the land of Egypt. [47] And

(2) they inherited his land, and the land of Og, king

(3) of Bashan, the two kings of the Amorites, who were at the ford

(4) of Jordan toward the sun's shining, [48] From

(5) Aroer, which is by the bank of the river Arnon, and

(6) as far as to Mount Sion, that is Hermon, [49] And all the

(7) steppe, |from| the ford of Jordan eastward, and as far as to the sea

(8) of the steppe below the riverbeds ${ }_{1}$ of the summit ${ }^{1264}$.

Deuteronomy 5

(9) [1] And Moses called all Israel and

(10) said to them, 'Hear, oh Israel, the statutes

(11) and judgments which I speak in your ears

(12) today. And you shall learn them and be watchful to do them.

(13) [2] The Lord our God made a covenant with us

(14) in Horeb. [3] The Lord made this covenant not with our fathers,

(15) but with us. We, these,

(16) here, today — all of us are alive. [4]

(17) The Lord talked with you mind to mind in the mountain from the midst

(18) of the fire. [5] I was standing between the Lord

(19) and you at that time to tell you the word

(20) of the Lord because you were afraid before the fire, and did not go up

(21) in the mountain, when he wanted to say: [6]

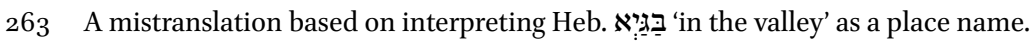

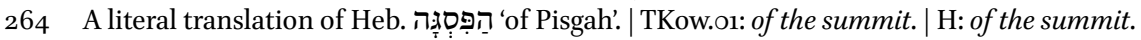

| C: of the rock| R: of the rock. 
$289 \mathrm{v}^{\mathrm{o}} \quad$ (1) mendir men Adonaj Tenrij ki čyğardym seni jerind́an Micrinin qul-

(2) lar erkind́an. לא [7 Bolmasyn saja özǵa tenrilar menim

(3) qajjamlyg்ym alnyna. לא. [8] Qylmaġyn özüja jonma

(4) abaq heč sufatbyla ne ki körśaj köklard́a jog̉artyn da

(5) neki jerd́a ašag̉artyn da ne ki suvlarda ašag̉arraq jerǵa.

(6) לא. [9] Bašurmaġyn alarg̉a da qulluq etmagin alarg̉a ki

(7) menmen Adonaj Tenrij künülavčü Tenri sag̉ynuvču güna-

(8) hị atalarnyn jaman ulanlar üstüńa da üčünčü dor-

(9) üstüńa da dörtünčü dor üstüńa dušmanlaryma.

(10) ] [10] Da qyluvčudur men šavag̉at min dorlarg̉a

(11) süvüvčülarǵa oḥuma toramny da saqlavčularg̉a

(12) micvalarymny. לא. [11] Antetmagin atyndan \{Adonaj\} Tenrijnin

(13) jalğang̉a ki könü etḿasti Adonaj anyda kim ki ant-

(14) etśa atyndan anyn muftqada. שמור. [12] Saqlag̉yn

(15) ošol šabat künnü azizlikt́a tutma any nečik bu-

(16) jurdu saja Adonaj Tenrij. ששת. [13] Alty künlard́a

(17) išlagin da qylğyn bar išijni. [14] Da ol jedinči

(18) kün šabatty maḥtavuna Adonaj Tenrijnin qylmaġyn heč iš

(19) sen da uvluj da qyzyj da quluj da qaravašyj da ögüzüj

(20) da ešagij da bar tuvaryj da gaaripij ki šaharlaryjda anyn

(21) üčün ki tynč alġaj quluj da qaravašyj senin kibik.

$290 \mathrm{r}^{\mathrm{o}}$ (1) וזכרת [15] Da saġynġyn ki qul edij jerind́a Micrinin

(2) da čyġardy seni Adonaj Tenrij andan küčlü qudratbyla

(3) da sunulġan quvatbyla anyn üčün bujurdu saja Adonaj

(4) tutma ošol ol šabat künnü. כבד. [16] Syjlaġyn o-

(5) Šol atajny da ošol anajny ki nečik bujurdu saja

(6) Adonaj Tenrij anyn üčün ki uzarg̉ajlar künlarij \{da anyn üčün ki jahšy bolġaj saja\} ol jer

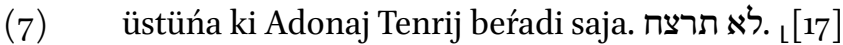

(8) Qaraqčylyq etḿagin. ולא תנאף [18] [Da\} ni’ufluq etḿagin.

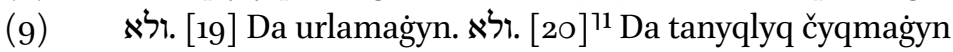

${ }^{1}$ Deu 5:17 in the standard Hebrew text. 
(1) "I am the Lord your God, who brought you out from the land of Egypt,

(2) from the reign of slaves. [7] You shall not have other gods

(3) before my power. [8] You shall not make for yourself any carved

(4) idol of any image that you would see in the skies above or

(5) that is in the earth beneath or that is in the water under the earth.

(6) [9] You shall not bow down to them, and you shall not serve them. Because

(7) I am the Lord your God, God that is jealous, remembering

(8) the iniquity of the fathers on the children wicked to the third

(9) generation and fourth generation of my enemies.

(10) [10] But I am the one who shows mercy to thousands of generations

(11) that love reading my Law, and that keep

(12) my commandments. [11] You shall not swear to the name of the Lord your God

(13) falsely, because the Lord will not make guiltless the one who

(14) would swear to his name in vain. [12] Keep

(15) the Sabbath day, to keep it holy, as the

(16) Lord your God commanded you. [13] Six days

(17) you shall labour and do all your work, [14] And the seventh

(18) day is the Sabbath for the praise of the Lord your God: you shall not do any work:

(19) you and your son and your daughter and your servant and your maidservant, and your cattle

(20) and your donkey and your livestock, and your stranger that is within your cities-

(21) in order that your manservant and your maidservant may rest like you.

(1) [15] And remember that you were a servant in the land of Egypt,

(2) and that the Lord your God brought you out from there with a strong hand

(3) and with an outstretched arm. On account of this the Lord your God commanded you

(4) to keep the Sabbath day. [16] Honour

(5) your father and your mother, as the

(6) Lord your God has commanded you, so that your days may be prolonged, and so that it may be good for you on the land

(7) which the Lord your God gives you. [17]

(8) You shall not murder. [18] And you shall not commit adultery.

(9) [19] And you shall not steal. [20] And you shall not testify against 
(10) dostuj üčünd́a bolma jalġan tanyq. ולא [21] \{Da küśanmagin qatynyna dostujnun\} da

(11) küśanmagin üvüńa dostujnun tüzüńa anyn da

(12) quluna anyn da qaravašyna da ögüzüńa da ešagi-

(13) ńa anyn da barysynada neki dostujnun. את. [22]

(14) Ošol ol sözlarni ošpularny sözladi Adonaj bar qahalyjyz-

(15) ga tavda ortasyndan ol otnun ol bulutnun da

(16) ol tumannyn ullu avazbyla da arttyrmady da jazdy

(17) alarny eki tašly luhot üstüńa da berdi alarny

(18) maja. ויהי [23] Da edi ešitkanijizd́ačoq ošol ol avazny

(19) ortasyndan ol qarangylyqnyn da ol tav janaredi otta

(20) da juvudujuz maja bar ag̉araqlary ševetlarijiznin da qart-

(21) lise [24] Da ajttyjyz muna körgüzdü Adonaj

$290 \mathrm{v}^{\circ} \quad$ (1) $\quad\{$ Tenrimiz\} bizǵa ošol syjyn da ošol ulluluğun da ošol ünün

(2) anyn ešittik ortasyndan ol otnun ošpu künnü

(3) kördük ki sözlajdi Tenri adam byla da tiri bolady.

(4) [ועתה [25] Da haligińa nek ölajik ki örtar bizni ol

(5) ullu ot ošpu eger arttyradeśak ešitma

(6) ošol ünün Adonajnyn Tenrimiznin \{daġy[n]\} da ölarbiz. כי [26]

(7) Ki kim bar ten ki ešitti ünün qajjam Tenrinin sözlajdo-

(8) ganny ortasyndan ol otnun biznin kibik da tiri qaldy-

(9) mo. קרב. [27] Juvugun sen da tynlag̉yn ošol barča neki

(10) ajtsa Adonaj Tenrimiz da sen sözlagin bizǵa ošol

(11) barča neki sözlaśa Adonaj Tenrimiz saja da tynlarbiz

(12) da qylarbiz. וישמע. [28] Da ešitti Adonaj ošol

(13) avazyn sözĺarijiznin sözlaǵanijizd́ačoq maja da ajtty

(14) Adonaj maja ešittim ošol avazyn sözlarinin ol ulus-

(15) nun ošpunun ki sözĺadilar saja jahšy ettilar neki

(16) sözĺadiĺar. מי [29] Kim berśajedi da bolsajedi sag̉yš-

(17) lary alarnyn bu alarg̉a qorqma mend́an da saqlama ošol

(18) bar micvalarymny bar ol künlard́a anyn üčün ki jaḥšy

(19) bolgajaj alargaa da ulanlaryna alarnyn dunjagadejin. לך. [30]

(20) Barg̉yn ajtqyn alarg̉a qajtyjyz özüjüzǵa čatyrlaryjyzġa.

(21) ואתה [31 Da maja ajtty da sen turg̉un birǵama da

$291 \mathrm{r}^{\circ} \quad$ (1) sözlajim saja ošol bar ol micvany da ol resimĺar-

(2) ni da ol töŕálarni ki üvŕatḱajsen alarg̉a da qylsyn-

(3) lar jerd́a ki men beŕamen alarg̉a meŕaslaḿa any.

(4) [32] Da saqlajyz qylma ki nečik bujurdu Adonaj 
(10) your fellow to be false witness. [21] And you shall not desire your fellow's wife, and

(11) you shall desire your fellow's house, his field, or

(12) his servant or his maidservant, or his cattle or his donkey,

(13) or anything that is your fellow's." [22]

(14) These words the Lord spoke to all your assembly

(15) at the mountain from the midst of the fire, the cloud and

(16) the fog, with a great voice. And he did not add. And he wrote

(17) them on two tablets of stone and gave them

(18) to me. [23] And it was, when you heard the voice

(19) from the midst of the darkness, and the mountain was burning in fire,

(20) that you came near to me, all the superiors of your tribes, and

(21) your elders. [24] And you said, "Lo, the Lord our God has showed

(1) us his glory and his greatness, and we have heard his voice

(2) from the midst of the fire. We have seen this day

(3) that God does talk with man, and he lives.

(4) [25] And now why should we die? Because this great fire will consume us.

(5) If we go on hearing

(6) the voice of the Lord our God any more, then we will die. [26]

(7) Because who, |of $\mid$ all flesh, is there who has heard the voice of the mighty God speaking

(8) from the midst of the fire as we have and lived?

(9) $[27]$ Go near and hear all that the

(10) Lord our God will say, and speak to us

(11) all that the Lord our God shall will speak to you, and we will listen

(12) and we will do |it|." [28] And the Lord heard the

(13) voice of your words when you were speaking to me, and

(14) the Lord said to me, "I have heard the voice of the words of

(15) this people that they have spoken to you. They have well said |all| that

(16) they have spoken. [29] Oh, who would set it so that they would have

(17) this thought, to fear me and keep all my

(18) commandments for all their days, so that it may be good

(19) for them and for their children forever! [30]

(20) Go, say to them, "Return to your tents."

(21) [31] And he said to me, "And you, stand here with me so

(1) I may speak to you all the commandments and the statutes

(2) and the judgments which you shall teach them, that they shall do

(3) |them| in the land which I am giving them to inherit it."

(4) [32] And you shall be watchful to do them as the Lord 
(5) Tenrijiz sizǵa qajyrylmajyz on jary ani son jary.

(6) בכל (33] Bar ol jolbyla ki bujurdu Adonaj Tenrijiz sizǵa

(7) baryjyz anyn üčün tiri bolursiz da jahššy bolur sizǵa

(8) da uzartyrsiz künĺar jerd́a ki meŕaśaśajiz.

Deuteronomy 6

(9) [וזאת [1] Da budu ol micva ol resimlar da ol tö-

(10) rálar ki bujurdu Adonaj Tenrijiz üvŕatmáa sizǵa

(11) qylma jerd́a ki siz ašasiz ary meŕaslamáa any.

(12) למען (2] Anyn üčün ki qorqajsen Adonaj Tenrijizd́an saq-

(13) lama ošol bar resimlarin anyn da micvalaryn anyn ki

(14) men bujuramen saja sen da uvluj da uvlu uvlujnun

(15) bar tirlik künlarijizd́a da anyn üčün ki uzargajlar

(16) künĺarij. ושמעת [3] Da tynlağyn e Jisra’el da saqlağyn

(17) qylma anyn üčün ki jaḥ̌y bolg̉aj saja da ki artqajsiz

(18) astry ki nečik sözladi Adonaj Tenrisi atalaryjnyn saja

(19) jer ag̉adoġan süt da bal. שמע ישראל יהוה

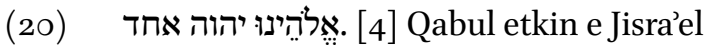

(21) ואהבת [5] Da süvgün

$291 \mathrm{~V}^{\mathrm{o}} \quad$ (1) ošol Adonaj Tenrijni bar jü\{ŕa\}gijbyla da bar žanyjbyla da

(2) bar astrylyggyj byla. והיו [6] Da bolsunlar ol sözlar

(3) ošpular ki men bujuramen saja esijd́a. ושננתם [7] [7]

(4) Da oḥutqun alarny ulanlaryja da sözlagin alarny ol-

(5) turgaanyjda üvüjd́a da jürüǵanijd́a jolda da jatqa-

(6) nyjdan burun da turganyjdan sortun. וקשרתם [8 Da

(7) qyjasa bajlap tutqun alarny belgiǵa qoluj üstüńa

(8) da bolsun saġynmaqlyqqa qyjasa hammeš́a tužurulġandy

(9) közĺarij arasyna. וכתבתם. [9] Da qyjasa jazyp tutqun

(10) alarny odv́erjalary üstüna üvlarijiznin da qabaqlaryjyzda

(11) _ki har kirǵanijizd́a da čyq[q]anyjyzda bolg̉ajlar micvalary Tora- 
(5) your God has commanded you. You shall not turn to the right or to the left.

(6) [33] You shall walk in all the ways which the Lord your God has commanded you,

(7) and because of that you will live, and it will be good for you,

(8) and you will prolong your days in the land which you shall inherit.

Deuteronomy 6

(9) [1] And this is the commandment, the statutes, and the

(10) judgments which the Lord your God commanded to teach you

(11) to do them in the land to which you are crossing to inherit it.

(12) [2] That you may fear the Lord your God,

(13) to keep all his statutes and his commandments which

(14) I am commanding you: you and your son and your son's son,

(15) all the days of your life, and that your days may be prolonged.

(16) [3] And you shall listen, oh Israel, and you shall be watchful

(17) to do it, that it may be good for you and that you may multiply

(18) very much, as the Lord God of your fathers has spoken to you:

(19) a land flowing $\mid$ with $\mid$ milk and honey. [4] Listen, Israel:

(20) YHWH is our God. YHWH is one. Accept, oh Israel:

(21) The Lord our God, the LORD is one. [5] And you shall love

(1) the Lord your God with all your heart, and with all your soul, and

(2) with all your might. [6] And the words,

(3) those which I command you this day, shall be in your mind.

(4) [7] And you shall teach them to your children, and you shall talk of them

(5) when you sit in your house and when you walk by the way and before you lie

(6) down and after you rise. [8] And,

(7) as if they were bound, keep them for a sign on your hand,

(8) and they shall be as if a memorial engraved

(9) between your eyes. [9] And keep them on

(10) the doorposts of your house and on your gates, as if they were written |there|,

(11) ${ }^{\text {so }}$ that the commandments of the Law may be in your mind every time you come in and go out ${ }^{1265}$.

265 An interpretative addition to Deu 6:9. 
(12) nyn esijda ${ }^{11}$. זיה [10] Da bolg̉aj ki keltirśa seni Adonaj

(13) Tenrij ol jerǵa ki antetti atalaryja Avrahamga

(14) Jichaqqa da Jáaqovg̉a berma saja ullu šaharlar da jaḥ-

(15) šylar ki qo\{n\}darmadyj. ובתים. [11] Da üvlari tolular bar

(16) jahšydan ki tolturmadyj da qujular qazylġanlar ki qazmadyj

(17) borlalyqlar da zejtunlar ki ornatmadyj da ašasaj da toj-

(18) saj. השמר. [12] Saqlanġyn özüja mag̉at unutursen ošol

(19) qullug̉un Adonajnyn ki čygardy seni jerind́an Micrinin qullar

(20) erkind́an. את. [13] Adonajdan Tenrijdáan qorq[q]un da anar

(21) qulluq etkin da atyndan anyn kertiǵa ant etkin.

$292 \mathrm{r}^{\mathrm{o}}$ (1) לא תלכון. [14] Jürümajiz qullug̉u artyna özǵa tenri-

(2) ĺarnin abaqlaryndan ol uluslarnyn ki čüvŕalarijizd́a.

(3) כ כ כ15] Ki künülavčü Tenridi Adonaj Tenrij ortajda

(4) mag̉at qabunur ačuvu Adonajnyn Tenrijnin send́a da

(5) tasetar seni jüzĺari üstünd́an ol jernin.

(6) לא . [16] Synamajyz ošol Adonaj Tenrijizni ki nečik syna-

(7) dyjyz Masada. שמור. [17] Saqlama saqlajyz ošol micva-

(8) laryn Adonaj Tenrijiznin da šarajatlaryn anyn da resimlarin

(9) anyn ki bujurdu sizǵa. ועשית. [18] Da qylg̀yn ol tüz

(10) da ol jaḥšy körünǵanni 'enajetlarynda Adonajnyn anyn

(11) üčün ki jahšy bolg̉aj saja da kelǵajsen da meŕaślaǵajsen

(12) ošol ol jahšy jerni ki antetti Adonaj atalaryja.

(13) (19] Taberma ošol bar dušmanlaryjny alnyjdan

(14) ki nečik sözladi Adonaj. כי [20] Ki sorsa send́an uvluj

(15) qačanda ajtadog̉ač nedi šarajatlar da ol resimĺar

(16) da ol töŕálar ki bujurdu Adonaj Tenrimiz sizǵa.

(17) ואמרת Da ajtqyn uvluja qullar edik par'o-

(18) ġa jerind́a Micrinin da čyġardy bizni Adonaj Micrid́an

(19) küčlü qudratbyla. ויתן [22] Da berdi Adonaj belgilar

(20) da tamašalyqlar ullular da jamanlar Micrid́a $\operatorname{par}^{\mathrm{c} o-}$

(21) da da bar üvünd́a anyn közlarimizč́a. ואותנו. [23]

$292 \mathrm{~V}^{\mathrm{o}} \quad$ (1) Da bizni čyġardy andan keltirmak üčün bizni bermáa biz-

(2) ǵa ošol ol jerni ki antetti atalarymyzg்a. ויצונו [24]

(3) Da bujurdu bizǵa Adonaj Tenrimiz qylma ošol bar ol re-

(4) simĺarni ošpularny qorqma Adonajdan Tenrimizd́an jahšy-

(5) ġa bizǵa bar ol künlarni tiri tutma bizni ošpu kün

(6) וצדקה . 25] Da zehut bolur bizǵa ki saqlasaq qyl-

\footnotetext{
${ }^{1}$ Interpretative addition to the standard text.
} 
(12) [10] And it shall be, when the Lord your God brings you

(13) to the land which he swore to your fathers, to Abraham,

(14) to Isaac, and to Jacob, to give you great and good cities

(15) that you did not build, [11] And houses full of everything

(16) good that you did not fill, and wells dug that you did not dig,

(17) vineyards and olive trees that you did not plant, and if you eat and satiate yourself,

(18) [12] Take heed to yourself, lest you forget the

(19) service of Lord who brought you out from the land of Egypt,

(20) from the reign of slaves. [13] You shall fear the Lord your God and

(21) serve him, and you shall swear to the truth by his name.

(1) [14] You shall not walk after the service of other gods,

(2) of the gods of the people who are around you,

(3) [15] Because the Lord your God is a jealous God among you,

(4) lest the anger of the Lord your God be kindled against you, and

(5) he destroy you from off the face of the earth.

(6) [16] You shall not test the Lord your God as you

(7) tested him in Massah. [17] You shall keep the commandments

(8) of the Lord your God and his laws and his statutes

(9) which he has commanded you. [18] And you shall do

(10) what seems right and good in the sight of the Lord, that

(11) it may be well with you, and that you may come and inherit

(12) the good land which the Lord swore to your fathers,

(13) [19] To push all your enemies from before you,

(14) as the Lord has spoken. [20] And if your son ever asks you,

(15) saying, "What are the laws and the statutes,

(16) and the judgments which the Lord our God has commanded you?",

(17) [21] Then you shall say to your son, "We were slaves to Pharaoh

(18) in the land of Egypt, and the Lord brought us out from Egypt

(19) with a strong hand. [22] And the Lord gave us signs

(20) and wonders, great and bad, in Egypt at Pharaoh

(21) and at all his household in our sight. [23]

(1) And he brought us out from there in order to bring us, to give us

(2) the land which he swore to our fathers. [24]

(3) And the Lord commanded us to do all these

(4) statutes, to fear the Lord our God for our good

(5) every day, to keep us alive, like today.

(6) [25] And it shall be a merit for us: if we observe to do 
(7) ma ošol bar ol micvany ošpunu alnynda Adonajnyn Tenri-

(8) miznin ki nečik bujurdu bizǵa.

Deuteronomy 7

[כ] [1] [1] Da bolgaj ki kel-

(9) tirśa seni Adonaj Tenrij ol jerǵa ki sen kelasen ary meŕas-

(10) ĺaḿa any da sürar köp hạanlyqlarny alnyjdan ol Ḥitinin

(11) da ol Girgašini da ol Emorini da ol Kena‘anini da ol

(12) Perizini da ol Ḥivini da ol Jevusini jedi ḥanlyqlarny köpŕak-

(13) larni da küčlǘrakĺarni send́an. ונתנם. [2] Da berir

(14) alarny Adonaj Tenrij alnyjda da qyrg்yn alarny veŕan etḿa

(15) veŕan etkin alarny kesmagin alar byla šert da hajifsün-

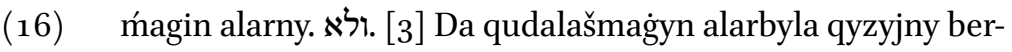

(17) magin uvluna anyn da qyzyn anyn almağyn uvluja. (4) [4]

(18) Ki ketarir ošol uvlujnu qulluğumartyndan da qulluq etar-

(19) lar özǵa tenrilarǵa da qabunur ačuvu Adonajnyn sizd́a

(20) da tasetar seni tezč́a. כ5] Ki ančaq bulaj qylyjyz alarğa

(21) mizbeaḥlaryn alarnyn qavšatyjyz da macevalaryn alarnyn syndyryjyz da

$293 \mathrm{r}^{\mathrm{o}} \quad$ (1) ašeralaryn alarnyn uvaltyjyz da jonma abaqlaryn alarnyn küv-

(2) dürüjüz otta. כ6] Ki aziz ulustur sen Adonajğa

(3) Tenrija seni sajlady Adonaj Tenrij bolma anar onča u-

(4) lusqa bar ol uluslardan ki jüzlari üstüńa ol jer-

(5) nin. לא. [7 Tüvül köpŕak bolganyjyz üčün bar ol ulus-

(6) lardan süvdü Adonaj sizni da sajlady sizni ki sizsiz ol

(7) azraq bar ol uluslardan. כי [8] Ki ančaq süvmagi

(8) sartyn Adonaj sizni da saqlag̉any sartyn ošol ol antny

(9) ki antetti atalaryjyzg்a čyġardy sizni Adonaj küčlü qud-

(10) rat byla da juludu seni qullar erkind́an qolundan par`o-

(11) nun bijinin Micrinin. וידעת. Da bilgin ki Adonaj Ten-

(12) rij oldu ol Tenri ol inamly Tenri saqlavču ol šertni

${ }^{1} \mathrm{~K}$ : והיה; a scribal error. | Heb. כִּי 
(7) all these commandments before the Lord our God,

(8) as he has commanded us."

Deuteronomy 7

(9) if the Lord your God brings you to the land to which you are coming to inherit

(10) it, he will drive many kingdoms before you, the Hittites, and the

(11) Girgashites, and the Amorites, and the Canaanites, and the

(12) Perizzites, and the Hivites, and the Jebusites, seven kingdoms

(13) greater and mightier than you. [2] And

(14) the Lord your God will give them over to you, and you shall strike them,

(15) utterly destroy them. You shall make no covenant with them and you shall show no mercy

(16) to them. [3] And you shall not make marriages with them:

(17) you shall not give your daughter to his son, and you shall not take his daughter for your son, [4]

(18) Because they will turn away your son from my service and they will

(19) serve other gods, and the anger of the Lord will be kindled against you,

(20) and he will destroy you quickly. [5] But thus shall you do to them:

(21) you shall destroy their altars and cut down their pillars and

(1) chop their idol poles and burn their carved idols

(2) in fire. [6] Because you are a holy people to the Lord

(3) your God. The Lord your God has chosen you to be a chosen

(4) people to himself of all the peoples that are on the face of the earth.

(5) [7] It was not because of you being more |numerous| than all the peoples

(6) that the Lord loved you so that he chose you, because you are the

(7) fewest of all people. [8] But because of the Lord's loving

(8) you and because of his keeping the oath

(9) which he had sworn to your fathers, the Lord brought you out with a strong hand

(10) and redeemed you out of the reign of slaves, from the hand of

(11) Pharaoh, king of Egypt. [9] And know that the Lord your God:

(12) he is God, the faithful God who keeps covenant 
(13) da ol šavag̉atny süvüvčülarǵa ${ }_{\text {L }}$ ḥuma Torasyn ${ }^{11} \mathrm{da}$

(14) saqlavčularg̉a micvalaryn anyn min dorg̉a. ומשלם [10]

(15) Da töĺadi dušmanlaryna özünün tirivünd́a anyn tas-

(16) etḿa any kečiktirmajdi dušmanyna tölüvün tiri

(17) eǵanind́a tölajdi anar. ושמרת] [11] Da saqlag̉yn ošol

(18) ol micvany da ošol ol resimlarni da ošol ol törááar-

(19) ni ki men bujuramen saja bügün qylma alarny.

פרשת והיה עקב (120)

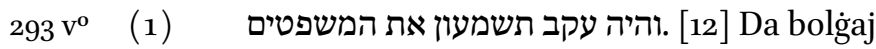

(2) anyn üčün ki tynlasajyz ošol ol törááarin oš-

(3) pularny da saqlasajyz qylsajyz alarny da saqlar Adonaj Tenrij

(4) saja ošol ol šertin da ošol ol šavagiatny ki antet-

(5) ti is atalaryja. [13 Da süv́ar seni da alğyšlar

(6) seni da arttyryr seni da alğyšlar jemišin qursaġyjnyn

(7) da jemišin jerijnin bürtügüjnü da šarbetijni da sajy-

(8) jny ijilmagin ullu tuvarlaryjnyn da tišilarin qojujnun

(9) ol jer üstüńa ki antetti atalaryja berma saja.

(10) ברוך. [14] Alġyšlyraq bolursen sen bar ol uluslardan bolmas-

(11) ty send́a böd́av erkiši da böd́av qatyn da tuvaryjdada.

(12) והסיר [15] Da ketarir Adonaj send́an bar hastalyqny da

(13) bar syzlavlaryn Micrinin ol jamanlarny ki bilasen qojmasty

(14) alarny send́a da berir alarny bar dušmanlaryjda.

(15) יואכלת Da tavusursen ošol bar ol uluslarny ki Adonaj

(16) Tenrij beŕadi saja hajifsünḿasin közüj alar üstü-

(17) ńa da qulluq etmagin abaqlaryna alarnyn ki tuzaqty ol

(18) saja. כי [17] Ki ajtsaj kölnüjda köpŕaktiĺar ol

(19) hanlyqlar ošpular mend́an nečik bolalyrmen tasetḿa alarny.

(20) לא . [18] Qorqmag்yn alardan saġynma saġyng்yn ošol neki qyl-

(21) dy Adonaj Tenrij par'og̉a da bar Micriǵa. המסת. [19]

$294 \mathrm{r}^{\mathrm{o}} \quad$ (1) Ol ullu synavlarny ki kördülar közlarij da ol belgi-

(2) ĺarni da ol nišanlarny da ol küčlü qudratny da ol su-

(3) nulğan quvatny ki čyğardy seni Adonaj Tenrij alaj qylar Ado-

\footnotetext{
${ }^{1}$ Interpretative addition to the standard text.
} 
(13) and mercy with them that love him to read his Law ${ }^{1266}$ and

(14) keep his commandments to a thousand generations, [10]

(15) And pays back to his enemies ${ }_{L}$ while they are $\mid$ still $\mid$ alive ${ }^{1267}$

(16) to destroy them. He will not hold back the payment to his enemies,

(17) he will repay them ${ }_{L}$ while they are alive ${ }^{1268}$. [11] You shall keep the

(18) commandments and the statutes and the judgments

(19) which I command you today, to do them.

(20) Parashat Eikev

(1) [12] And it shall be,

(2) because, if you listen to these judgments

(3) and keep |them and| do them, then the Lord your God

(4) will keep for you the covenant and the mercy which he swore

(5) to your fathers. [13] And he will love you and bless

(6) you and multiply you. And he will bless the fruit of your womb

(7) and the fruit of your land-your grain and your must and your olive oil,

(8) the progeny of your cattle and the females of your sheep-

(9) on the land which he swore to your fathers to give you.

(10) [14] You will be more blessed than all the peoples. There will not be

(11) a barren man or barren woman among you or among your cattle.

(12) [15] And the Lord will take away from you all sickness, and

(13) all the evil diseases of Egypt which you know: he will not put

(14) them on you, but he will lay them on all your enemies.

(15) [16] And you will consume all the people whom the Lord

(16) your God is giving you. Your eye shall have no pity on them,

(17) and you shall not serve their gods, because it is a snare

(18) to you. [17] If you say in your heart, "These kingdoms are more

(19) than I; how will I be able to destroy them?",

(20) [18] You shall not be afraid of them. And you shall remember what

(21) the Lord your God did to Pharaoh and to all Egypt: [19]

(1) The great trials which your eyes saw and the signs

(2) and the wonders and the strong hand and the

(3) outstretched arm by which the Lord your God brought you out. So will the Lord your God do

266 An interpretative addition to Deu 7:9.

267 Interpretative translation.

268 Interpretative translation. 
(4) naj Tenrij bar ol uluslarg்a ki sen qorqasen alynlaryndan

(5) alarnyn. וגם [20] Da dağyn ošol ol hazmanny ijar

(6) Adonaj Tenrij alarda taspolgunča ol qalġanlar da ol

(7) jašynġanlar alnyj[dan]1. לא. [21] Synyqmag்yn alynlaryndan alarnyn

(8) ki Adonaj Tenrij ortajda ullu Tenri da qorqunčlu.

(9) Da sürar Adonaj Tenrij ošol ol ḥanlyqlarny

(10) ošpularny alnyjdan azar azar bolalmassen tavusma alar-

(11) ny tez mag̉at artar üstüja kijigi ol tüznün.

(12) [ Da berir alarny Adonaj Tenrij alnyjda da

(13) bulġanyštyryr alarny ullu bulġančylyq taspolganlarynadejin.

(14) Da berir bijlarin alarnyn qoluja da tasetkin

(15) ošol atlaryn alarnyn tübünd́an ol köklarnin turalmas-

(16) ty kišid́a alnyjda tasetkanijadejin alarny. פסילי. [25]

(17) Jonma abaqlaryn alarnyn küvdürüjüz otta suqlanmaġyn

(18) kümüšḱa da altynġa ki alar üstüńa da almaġyn

(19) özüja maġat tuzaqlanyrsen anyn byla ki ḥor etkanidi

(20) Adonaj Tenrijnin ol. ולא [26] Da keltirmagin ḥor nerśa-

(21) ni üvüja da bolursen ḥerem kibik jiŕanči etŕa

$294 \mathrm{v}^{\mathrm{o}} \quad$ (1) jiŕanči etkin any da ḥor etḿa ḥor etkin any ki ḥerem-

(2) di ol.

\section{Deuteronomy 8}

(2) כל :1] Bar ol micvany ki men bujuramen saja bügün

(3) saqlajyz qylma anyn üčün ki tiri bolġajsiz da artqaj-

(4) siz da kelǵajsiz da meŕaślaǵajsiz ošol ol jerni ki

(5) antetti Adonaj atalaryjyzġa. וזכרת. [2] Da sag̉yng்yn

(6) ošol bar ol jolnu ki jürüttü seni Adonaj Tenrij bu

(7) qyrqjyl midbarda qyjnamaq üčün seni synama seni

(8) bilmá ošol neki kölnüjd́a saqlarmusen micvalaryn anyn

(9) jemeśa joq. [יענד. Da qajnady seni da ačyqtyr-

(10) dy seni da ašatty saja ošol ol manny ki bilmánedij

${ }^{1}$ TKow.o1: alnyjdan. | H: alnyndan senin. | C: deest. 
(4) to all the people before whom you fear.

(5) [20] And the Lord your God will send the hornet

(6) among them as well until those who are left and those who hide themselves

(7) from you, be destroyed from before you. [21] Do not be broken down before them,

(8) because the Lord your God is among you, a mighty and awesome God.

(9) [22] And the Lord your God will drive out those kingdoms

(10) before you little by little. You will not be able to consume them

(11) at once, lest the wild |animals| of the field will become many at you.

(12) [23] And the Lord your God will give them before you and

(13) will cause a stir among them with a great confusion, until they are destroyed.

(14) [24] And he will give their kings in your hand, and you shall destroy

(15) their name from under the skies.

(16) Not a man will be able to stand before you, until you have destroyed them. [25]

(17) You shall burn their carved idols in fire. You shall not desire

(18) the silver or gold that is on them, and you shall not take

(19) it to you, lest you be snared by it, because it is an abomination

(20) to the Lord your God. [26] And you shall not bring an abominable thing

(21) to your house, lest you become like a devoted thing. You shall utterly make it abominable,

(1) and you shall utterly despise it, because it is a devoted

(2) thing.

Deuteronomy 8

(2) [1] All the commandments which I command you today

(3) you shall be watchful to do, that you may live and multiply

(4) and come and inherit the land which

(5) the Lord swore to your fathers. [2] And you shall remember

(6) all the way which the Lord your God made you walk these

(7) forty years in the wilderness, to oppress you, to test you,

(8) to know what was in your heart, whether you would keep his commandments

(9) or not. [3] And he oppressed you and made you hunger

(10) and fed you with manna, which you had not known 
(11) da bilmadilar atalaryj bildirḿak üčün saja ki tüvül

(12) jalġyz ol ötḿak byla tiri bolady ol adam ki ančaq

(13) bar čyğyšybyla bujrugiunun Adonajnyn tiri bolady ol adam.

(14) [4 [4] Upraġyj senin upranmady üstüjdan

(15) da ajaġyj qabarčyqlanmady bu qyrq jyl. וידעת]

(16) Da bilgin aqylyjbyla ki nečik adeplajdir kiši ošol

(17) uvlun özünün alaj Adonaj Tenrij adeplajdi seni.

(18) (6] Da saqlag̉yn ošol micvalaryn Adonaj Tenrijnin

(19) jürüma jollarybyla anyn da qorqma andan. כי. [7 [ Ki

(20) Adonaj Tenrij keltíáadi seni jahšy jerǵa jer öźanli

(21) suvlu köz suvlar da darjalar čyg̉adylar eništa da

$295 \mathrm{r}^{\mathrm{r}}$ (1) tavda. ארץ. [8] Jer budajly da arpaly da borlalyqly da

(2) inžirlikli da narlyqly jer zejtun javly da bally. ארץ. [9]

(3) Jer ki tüvül miskinlikbyla ašarsen anda ötḿak ek-

(4) sik bolmassen nemeǵad́a anda jer ki tašlary anyn temir-

(5) di da tavlaryndan qazarsen tuč. ואכלת. [10] Da ašasaj

(6) tojsaj da maḥtav bergin Adonajğa Tenrija ol jaḥ̌sy

(7) üčün ki berdi saja. השמר. [11] Saqlanġyn özüja mag̉at

(8) unutursen qullugiun Adonaj Tenrijnin saqlamasqa micvalaryn

(9) da töŕálarin da resimĺarin anyn ki men bujuramen saja bü-

(10) gün. gag [12] Mag̉at ašarsen da tojarsen da jahšy üvlar

(11) qondaryrsen da olturursen. ובקרך. [13] Da syg்yryj da

(12) qojuj artarlar da kümüš da altyn artar saja da

(13) barča ne ki saja artar. ורם . [14] Da ökt́amlanir

(14) jüragij da unutursen qullug̉un Adonajnyn Tenrijnin ol čyġa-

(15) ruvčunun seni jerind́an Micrinin qullar erkind́an.

(16) [15] Ol jürütüvčünü seni midbarda ol

(17) ullu da ol qorqunčlu küvdürgüč jylanly da saruv́akli

(18) da suvsaply ki jog̉edi suv ol čyġaruvču saja suv almas

(19) skaladan. המאכילך. [16] Ol ašatuvču saja man midbarda

(20) ki bilḿadilar atalaryj qyjnamaq üčün seni da synamaq üčün

(21) seni jahšy etḿa saja song̉ujda. ואמרת. [17] Da

$295 \mathrm{~V}^{\text {0 }} \quad$ (1) ajtsaj kölnüjda küčüm da quvaty qolumnun qyldy 
(11) and your fathers had not known, to let you know that

(12) man does not live by bread alone, but

(13) a man lives by every word that proceeds out of the mouth of the Lord.

(14) [4] Your clothing did not wear away on you,

(15) and your foot did not become scabbed these forty years. [5]

(16) [5] You shall also know in your mind that, as a man disciplines his

(17) son, so the Lord your God disciplines you.

(18) [6] And you shall keep the commandments of the Lord your God,

(19) to walk in his ways and to fear him. [7] Because

(20) the Lord your God brings you to a good land, a land

(21) of rivers of water, of fountains and depths that spring out of valleys and

(1) hills, [8] A land of wheat and barley and vines and

(2) fig trees and pomegranates, a land of olive oil, and honey, [9]

(3) A land in which you will eat bread without poverty,

(4) you will not lack anything in it, a land whose stones are iron,

(5) and from whose hills you may dig copper. [10] And when you have eaten

(6) and are full, you shall bless the Lord your God for the good

(7) land which he has given you. [11] Take heed to yourself, lest

(8) you forget the service of the Lord your God so as not to keep his commandments

(9) and his judgments and his statutes which I command you

(10) today, [12] Lest you eat and are full and build fine houses

(11) and dwell |there|, [13] And your cattle and

(12) your flock is multiplied, and your silver and your gold is multiplied, and

(13) all that you have is multiplied, [14] And your heart be proud,

(14) and you forget the service of the Lord your God,

(15) who brought you out from the land of Egypt, from the reign of slaves,

(16) [15] Who made you walk in the

(17) great and awesome wilderness of fiery serpents and adders

(18) and thirst, because there was no water, who brought out water for you from the diamond

(19) rock, [16] Who fed you in the wilderness with manna,

(20) which your fathers had not known, in order to oppress you and in order to test

(21) you, to do good for you in the end, [17] And

(1) if you say in your heart, "My power and the strength of my hand $295 \mathrm{~V}^{\mathrm{o}}$ made 
(2) maja ošol ol malny ošpunu. וזכרת [18] Da saġynġyn

(3) ošol Adonaj Tenrijni ki oldu ol berüvčü saja küč yštyr-

(4) ma mal qajjam etmak üčün ošol šertin ki antetti

(5) atalaryja ošpu kün kibik. והיה [19] Da bolgaj eger

(6) unutma unutsaj ošol qulluğun Adonaj Tenrijnin da

(7) barsaj \{qulluğu artyna özǵa tenrilarnin\} da qulluq etśaj alarg̉a da bašursaj alarg̉a tanyq

(8) etamin sizd́a bügün ki taspolma taspolursiz. כגוים. [20]

(9) Ḥanlyqlar kibik ki Adonaj tasetadi alnyjyzdan alaj taspolur-

(10) siz anyn üčün ki tynlamasajyz ünüńa Adonaj Tenrijiznin.

\section{Deuteronomy 9}

(11) שמע. [1] Tynlag̉yn e Jisra’el sen ašasen bügün ošol

(12) ol Jardenni kelḿa meŕaslama hanlyqlarny ulluraqlarny

(13) da küčlürakĺarni send́an ullu šaharlar da bekĺar jet́ado-

(14) ganlar köklarǵa. עם. [2] Ullu ulus da bijik ulanlary

(15) 'Anaqlylarnyn ki sen bildij da sen ešittij \{ki\} kim turalyr

(16) alnynda ulanlarynyn 'Anaqnyn. וידעת [3] Da bilgin bügün

(17) ki Adonaj Tenrij oldu ol ašuvču alnyjda ot kibik ör-

(18) tajdoġan ol tasetar alarny da ol synyqtyryr alarny

(19) alnyjda da süŕarsen alarny da tasetarsen alarny tezća

(20) ki nečik sözĺadi Adonaj saja. אל. [4] Ajtmag̉yn köl-

(21) nüjda taberǵand́a Adonaj Tenrij alarny alnyjdan ajta-

$296 \mathrm{r}^{\mathrm{o}} \quad$ (1) dog̉ač rastlyġym üčün keltirdi meni Adonaj meŕaslama

(2) ošol ol jerni ošpunu da rašalyg̉y üčün ol ḥanlyq-

(3) larnyn ošpularnyn Adonaj tasetadi alarny alnyjdan. לא. [5]

(4) Tüvül rastlyğyj üčün da tüzlügü üčün jüragijnin sen

(5) kelasen méraślaḿa ošol jerin alarnyn ki ančaq raša lyggy

(6) üčün ol hanlyqlarnyn ošpularnyn Adonaj Tenrij tasetadi

(7) alarny alnyjdan da qajjam etḿak üčün ošol ol söznü

(8) ki antetti Adonaj atalaryja Avrahamġa Jichaqqa da

(9) Jacaqovġa. [6] Da bilgin ki tüvül rastlyġyj

(10) üčün Adonaj Tenrij beŕadi saja ošol ol jahšy jerni

(11) ošpunu meŕaslaḿa any ki ulus qaty enśalidir sen. 
(2) this wealth for me." [18] Then you shall remember

(3) the Lord your God, because it is he that gives you power to

(4) gather goods, so as to establish his covenant which he swore

(5) to your fathers, as it is this day. [19] And it shall be,

(6) if you indeed forget the Lord your God and

(7) go after the service of other gods and serve them and worship them,

(8) I call witness regarding you today that you will surely perish. [20]

(9) Like the kingdoms that the Lord destroys before you, so will you perish,

(10) because you would not listen to the voice of the Lord your God.

Deuteronomy 9

(11) [1] Listen, oh Israel: you are passing over Jordan today,

(12) to come to inherit kingdoms greater

(13) and mightier than you, great and fortified cities reaching

(14) to the skies. [2] A people great and tall, the children

(15) of the Anakim, whom you know, and of whom you have heard: "Who can stand

(16) before the children of Anak?!" [3] You shall know today

(17) that the Lord your God is the one who crosses before you consuming like fire.

(18) He will destroy them and he will break them down

(19) before you, and you will drive them out and destroy them quickly,

(20) as the Lord has said to you. [4] Do not speak in your heart,

(21) after that the Lord your God has pushed them out from before you,

(1) saying, "Because of my righteousness the Lord has brought me in to $296 \mathrm{r}^{\circ}$ inherit

(2) this land," but it is because of the wickedness of these

(3) kingdoms that the Lord destroys them from before you. [5]

(4) Not because of your righteousness or because of the uprightness of your heart

(5) you are coming to inherit their land, but because the wickedness

(6) of these kingdoms the Lord your God is destroying

(7) them from before you, and that he may establish the word

(8) which the Lord swore to your fathers, to Abraham, to Isaac, and

(9) to Jacob. [6] And you shall know that the

(10) Lord your God gives you this good land to inherit it not because of your righteousness,

(11) because you are a stiff-necked people. 
(12) זכור [7] Sag்ynġyn unutmaġyn ošol neki ačyrg்andyrdyj

(13) Adonaj Tenrijni midbarda ol künd́an ki čyqtyj jerind́an

(14) Micrinin kelǵanijizǵadejin ošpu orunġadejin tanuvčular

(15) edijiz sözüńa Adonajnyn. ובחורב. [8] Da Ḥorevd́a

(16) ačyrġandyrdyjyz ošol Adonajny da ačuvlandy Adonaj üs-

(17) tüjüzǵa tasetḿa sizni. בעלותי. [9] Minǵanim-

(18) d́a ol tavğa alma ${ }_{\llcorner}\{[\operatorname{taš}]$ ly $\}$ luḥotnu ${ }^{11}$ luḥotun ol šertnin ki

(19) kesti Adonaj birǵajizǵa da kečiktim tavda qyrq kün

(20) da qyrq keč́a ötmak ašamadym da suv ičḿa-

(21) dim. יויתן dio] Da berdi Adonaj maja ošol eki ol

$296 \mathrm{v}^{\mathrm{o}} \quad$ (1) tašly luhotlarny jazylġanlarny bujruğu byla Tenrinin da

(2) alar üstüńa bar ol sözlar kibik ki sözladi Adonaj bir-

(3) ǵajizǵa tavda ortasyndan ol otnun ol jyštyrylmaq

(4) kününd́a. [11] Da edi aherind́an qyrq künnün

(5) da qyrq keč́anin berdi Adonaj maja ošol eki tašly

(6) luhotnu luḥotun ol šertnin. [12] Da ajtty

(7) Adonaj maja turg̉un engin tez bundan ki čajpady jolun ulu-

(8) suj ki čyğardyj Micridan kettilar tez ol joldan ki bujur-

(9) dum alarg̉a qyldylar özlarińa qujma abaq. ויאמר. [13]

(10) Da ajtty Adonaj maja ajtadog̉ač kördüm ošol ol

(11) ulusnu ošpunu da muna ulus qaty enśalidir ol.

(12) הרך [14] Qalġyn mend́an da tasetajim alarny da sürtajim

(13) ošol atlaryn alarnyn tübünd́an ol kökĺarnin da qylajym

(14) seni küčlüŕak hạanlyqqa da köpŕakḱa andan. ואפן. [15]

(15) Da qajyryldym da endim ol tavdan da ol tav janaredi

(16) otta da eki luḥotu ol šert \{n\}in eki qollarym üstü-

(17) ńa. וארא [16] Da kördüm da muna jazyqly boldujuz

(18) Adonajğa Tenrijizǵa qyldyjyz özüjüzǵa qujma buzov

(19) ket[t]ijiz² tez ol joldan ki bujurdu Adonaj sizǵa. ואתפוש. [17]

(20) Da tuttum eki ol luḥotnu da tašladym alarny eki

(21) qollarym üstünd́an da syndyrdym alarny közlarijizč́a

${ }^{1}$ TKow.o1: tašly luḥotnu; unvocalized text. | H: tasly luhotlarny. | C: luvaḥlaryn ol tašlarnyy. $\quad{ }^{2} \mathrm{~K}$ : ketijiz; a scribal error. | TKow.o1: kettijiz; unvocalized text. | H: kettiniz. | C: azdyyyz. 
(12) [7] Remember and do not forget how you made the Lord your God angry

(13) in the wilderness. From the day that you went out from the land

(14) of Egypt until you came to this place, you have been rebellious against

(15) the word of the Lord. [8] And you made the Lord angry at Horeb,

(16) and the Lord became angry with you

(17) so as to destroy you. [9] When I went up

(18) the mountain to receive the tables of stone, the tablets of the covenant which

(19) the Lord made with you, then I stayed on the mountain forty days

(20) and forty nights. I did not eat bread and I did not drink water.

(21) [10] And the Lord gave to me two

(1) tablets of stone written with the order of God, and

(2) on them all the words, like those which the Lord spoke

(3) with you on the mountain from the midst of the fire in the day of assembly.

(4) [11] And it was: at the end of forty days

(5) and forty nights the Lord gave me the two tablets of stone,

(6) the tablets of the covenant. [12] And the Lord said

(7) to me, "Arise, go down quickly from here, because your people

(8) whom you have brought out from Egypt have lost the way. They have gone aside from the way which

(9) I commanded them. They have made them a molten god." [13]

(10) And the Lord spoke to me, saying, "I have seen

(11) this people, and, lo, it is a stiff-necked people.

(12) [14] Hold back from me that I may destroy them and that I may blot out

(13) their name from under heaven, and let me make

(14) of you a kingdom mightier and greater than they." [15]

(15) So I turned and came down from the mount, and the mount was burning

(16) in fire: and the two tablets of the covenant were on my two hands.

(17) [16] And I looked, and, lo, you had sinned

(18) against the Lord your God. You had made yourselves a molten calf.

(19) You had gone aside quickly from the way which the Lord had commanded you. [17]

(20) And I took the two tablets and cast them

(21) out of my two hands and broke them in your sight. 
$297 \mathrm{r}^{\mathrm{O}} \quad$ (1) [18] Da tüšüp jalbardym alnynda Adonajnyn

(2) burundag̉ylaj qyrq kün da qyrq keča ötḿak ašamadym

(3) da suv ičmadim bar jazyġyj üčün ki jazyqly boldujuz

(4) qylma jaman körünǵanni 'enajatlarynda Adonajnyn ačyr-

(5) gandyrma any. כי. [19] Ki qorqtum alnyndan ol ačuv-

(6) nun da ol qahirnin ki ačuvlandy Adonaj üstüjüzǵa

(7) tasetḿa sizni da tynlady Adonaj maja dag̉yn olda

(8) vaḥtta. ובאהרן. [20] Da Aharonda ačuvlandy Adonaj

(9) astry tasetḿa any da tefila ettim dağyn Aharon

(10) üčünd́a ol vaḥtta. [21] Da ošol jazyġyjyzny

(11) ki qyldyjyz ošol ol buzovnu aldym da küvdürdüm

(12) any otta da jančtym any tartma jaḩ̌̌y neginč́a

(13) ki boldu uvaq topraqqa da tašladym ošol toprağyn

(14) anyn ol özenǵa ol enüvčü ol tavdan. ובתבערה. [22]

(15) Da Tav'erada da Masada da Qivrot ol Ta’avada

(16) ačyrg̉andyruvčular edijiz ošol Adonajny. ובשלוח. [23]

(17) Da ijǵandi Adonaj sizni Qadeš Barne'adan ajtadog̉ač

(18) baryjyz da meŕaslajiz ošol ol jerni ki berdim sizǵa

(19) da tandyjyz bujrugiuna Adonajnyn Tenrijiznin da inanmadyjyz

(20) anar da tynlamadyjyz ünüńa anyn. ממרים. [24] Tanuvču-

(21) lar edijiz alnynda Adonajnyn bilǵan künümd́an sizni.

$297 \mathrm{~V}^{\mathrm{o}}$ (1) [יאתנפל [25] Da tüšüp jalbardym alnynda Adonajnyn

(2) qyrq kün da qyrq keč́a ašyra ki tüšüp jalbar-

(3) dym ki ajtybedi Adonaj tasetḿa sizni. [26] [26]

(4) Da tefile ettim Adonajga da ajttym e Adonaj

(5) Tenri čejpamaġyn ulusujnu da ülüšüjnü ki juluduj

(6) ulluluğujbyla ki čyġardyj Micriden küčlü qudratbyla.

(7) זכ. [27] Saġynġyn qullaryjny Avrahamny Jichaqny da

(8) Ja'aqovnu qajyrylmag்yn qatylyg்yna ol ulusnun ošpu da

(9) rašalyg̉yna anyn da jazyġyna anyn. [28] Mag̉at aj-

(10) tyrlar eli ol jernin ki čyğardyj bizni andan bolalmasly-

(11) ġy sartyn Adonaj keltirme alarny ol jerge ki sözle-

(12) di alarg̉a da ḥor etkeni sartyn alarny čygardy alarny

(13) öltürme alarny midbarda. והם [29 Da alardylar 
(1) [18] And I fell down and besought before the Lord,

(2) like the first $\mid$ time $\mid$, forty days and forty nights - I did not eat bread,

(3) and I did not drink water-because of all your sins which you sinned,

(4) in doing what seems bad in the eyes of the Lord, to

(5) make him angry, [19] Because I was afraid of the anger

(6) and fury with which the Lord was angry with you

(7) to destroy you. But the Lord hearkened to me at that

(8) time as well. [20] And the Lord was very angry with Aaron

(9) so as to destroy him. And I prayed for Aaron

(10) at that time as well. [21] And I took your sin,

(11) the calf which you had made, and burned it

(12) in fire and crushed it to grind it very well until

(13) it was as small as dust. And I cast the dust

(14) of it into the river that descended from the mountain. [22]

(15) And at Taberah and at Massah and at Kibroth-Hattaavah

(16) you were making the Lord angry. [23]

(17) And when the Lord sent you from Kadesh-Barnea, saying,

(18) "Go and inherit the land which I have given you,"

(19) then you rebelled against the command of the Lord your God, and you did not believe him,

(20) and you did not listen to his voice. [24] You have been rebellious against

(21) the Lord from the day that I knew you.

(1) [25] And I fell down and besought before the Lord

(2) through the forty days and forty nights that I had fallen down and besought

(3) because the Lord had said he would destroy you. [26]

(4) And I prayed to the Lord, and said, "Oh Lord

(5) God, do not crush your people and your share which you have redeemed

(6) through your greatness, whom you have brought out from Egypt with a strong hand.

(7) [27] Remember your servants, Abraham, Isaac, and

(8) Jacob, do not turn |your eyes| to the hardness of this people

(9) and to its wickedness and to its $\sin ,[28]$ Lest

(10) the peoples of the land from which you brought us out will say:

(11) "Because of the Lord not being able to bring them to the land of which he spoke

(12) to them, and because he rejected them. He has brought them out

(13) to kill them in the wilderness." [29] And they are 
(14) ulusuj da ülüšüj ki čyġardyj küčüj byla ol ullu

(15) da quvatyjbyla ol sunulgan.

\section{Deuteronomy 10}

בעת [1] Ol vaḥtta

(16) ajtty Adonaj maja jonğun özüje eki tašly luhot

(17) burungular kibik da mingin maja ol tavġa da qylgyn

(18) özüje ag̉ačly sunduq. ואכתב. [2] Da jazajym ol luhot

(19) üstüne ošol ol sözlerni ki ediler ol burunġu

(20) luhot üstüne ki syndyrdyj da qojğun alarny sun-

(21) duqta. ואעש. Da qyldym aron šitim ag̉ačlaryndan

$298 \mathrm{r}^{\mathrm{o}} \quad$ (1) da jondum eki tašly luhot burunğular kibik da min-

(2) dim ol tavg̉a da eki ol luhot qolumda. ויכתב. [4]

(3) Da jazdy ol luhot üstüńa ol burunġu jazyš ki-

(4) bik ošol on ol sözlarni ki sözladi Adonaj sizǵa

(5) tavda ortasyndan ol otnun ol jyštyrylmaq künün-

(6) da da berdi alarny Adonaj maja. ואפן. [5] Da qajyryl-

(7) dym endim ol tavdan da qojdum ošol ol luhot-

(8) nu aronda ki qyldym da boldular anda ki nečik bu-

(9) jurdu maja Adonaj. ובני [6] Da ulanlary Jisra'elnin

(10) köčtülar Be’erot Bene Ja'aqandan Moseraġa anda öl-

(11) dü Aharon da astraldy anda da kohenlik etti

(12) El'azar uvlu anyn anyn ornuna. משם. [7 Andan

(13) köčtülar ol Gudgodaġa da ol Gudgodan J[a]tvata-

(14) ga1 jerǵa öźanli suvlu. בעת [8] Nečik bošatlyq

(15) qoldum jazyg்y üčün ol bozuvnun ol vaḥtta ajyrdy

(16) Adonaj ošol ševetin ol Levinin eltme ošol aron šer-

(17) tin Adonajnyn turma alnynda Adonajnyn jumuš etme

(18) anar da alğyšlama Jisra’elni atybyla Adonajnyn ošpu

(19) küngedejin. על [9] Anyn üčün bolmady Levige ülüš da

(20) tijiš qaryndašlarybyla Adonaj oldu ülüšü anyn ki nečik

(21) sözledi Adonaj Tenrij anar. ואנכי [10] Da men turdum

$298 \mathrm{v}^{\mathrm{o}} \quad$ (1) tavda ol burunğu künler kibik qyrq kün da qyrq keče

(2) da tynlady Adonaj maja daġyn olda vahttta klemedi Adonaj

(3) čejpama seni. ויאמר [11 Da ajtty Adonaj maja turğun

(4) barğyn köčmekke alnynda ol ulusnun da kelsinler da

\footnotetext{
${ }^{1} \mathrm{~K}$ J Jutvatagia; probably a scribal error; cf. Num 33:34. | TKow: Jatvatag்; unvocalized text. | H:
}

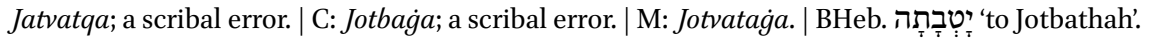


(14) your people and your share whom you brought out by your great power

(15) and by your outstretched arm."

Deuteronomy 10

[1] At that time

(16) the Lord said to me, 'Cut yourself two tablets of stone

(17) like the first ones, and come up to me at the mountain, and make

(18) a chest of wood. [2] And I will write on the tablets

(19) the words that were on the first

(20) tablets which you broke, and you shall put them in the chest.

(21) [3] And I made an ark of acacia wood,

(1) and I cut two tablets of stone like the first ones, and I went up

(2) the mountain, and the two tablets were in my hand. [4]

(3) And he wrote on the tablets like the first writing:

(4) the ten commandments, which the Lord spoke to you

(5) on the mountain from the midst of the fire in the day of the assembly.

(6) And the Lord gave them to me. [5] And I turned

(7) myself and came down from the mountain and put the tablets

(8) in the ark that I had made. And they have been there, as the Lord

(9) commanded me. [6] And the children of Israel

(10) set out from Beeroth-Bene-Jaakan to Moserah. There

(11) Aaron died and there he was buried. And

(12) Eleazar, his son, served as priest in his place. [7] From there

(13) they set out to Gudgodah, and from Gudgodah to Jotbathah,

(14) a land of rivers of waters. [8] When I asked for atonement

(15) because of the sin of the calf, at that time

(16) the Lord set apart the tribe of Levi, to carry the ark

(17) of the covenant of the Lord, to stand before the Lord to serve

(18) him and to bless Israel in his name, to this

(19) day. [9] Therefore Levi has no portion or

(20) share with his brothers. The Lord: he is his portion, as

(21) the Lord your God spoke to him. [10] And I stood

(1) in the mountain as in the first days: forty days and forty nights.

(2) And the Lord listened to me at that time as well. The Lord did not want

(3) to crush you. [11] And the Lord said to me, "Rise,

(4) set out on the journey before the people, that they may come and 
(5) mereslesinler ošol ol jerni ki antettim atalaryna ber-

(6) me alarg̉a. ועתה. [12] Da haligine e Jisra’el ne Adonaj

(7) Tenrij klejdi senden ki ančaq qorqma Adonaj Tenrijden

(8) jürüme bar jollarybyla anyn da süvme any qulluq etme

(9) Adonajğa Tenrije bar jüregij byla da bar žanyjbyla. לשמר. [13]

(10) Saqlama ošol micvalaryn Adonajnyn da ošol resimlerin ki

(11) men bujuramen saja bügün jahšygga saja. הן. [14] Muna er-

(12) kindedi Adonajnyn Tenrijnin ol kökler da qatlary ol kök-

(13) lernin ol jer da barča neki anda. $\{P[\urcorner]\}^{1} \cdot[15]$ Tek atalaryjny begen-

(14) di Adonaj süvme alarny da sajlady urlugiun alarnyn öz-

(15) lerinden sortun sizni jahšyraq bar ol uluslardan ošpu kün

(16) kibik. ומלתם. [16] Da ḥatna qylyjyz ošol aqlafyn jüre-

(17) gijiznin da ensejizni qattyrmajyz artyq. כ17] Ki Adonaj

(18) Tenrijiz oldu Tenrisi ol malahlarnyn da biji ol galgallarnyn

(19) ol Tenri ol ullu ol bag̉atyr da ol qorqunčlu ki jüz

(20) etmedi jüzlerge da almajdy šoḥad. עשה. [18] Qylady

(21) töresin öksüznün da tulnun da süvedi garipni berme

299 r $^{\circ}$ (1) anar ötmek da upraq. [19] Da süvüjüz ošol

(2) ol garipni ki garipler edijiz jerinde Micrinin. את [20]

(3) Adonajdan Tenrijden qorqqun anar qulluq etkin da Tora-

(4) syna anyn jabušqun da atyndan anyn kertiǵa antetkin.

(5) הוא (21] Oldu mahtavuj da oldu Tenrij ki qyldy birgeje

(6) ošol ol ulluqlarny ${ }^{2}$ da ošol ol qorqunčluluqlarny ošpu-

(7) larny ki kördüler közlerij. בשבעים. [22] Jetmiš žanby-

(8) la endiler atalaryj Micrige da haligine qojdu seni Adonaj

(9) Tenrij jolduzlaryn kibik ol köklernin köplükke.

Deuteronomy 11

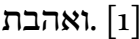

(10) Da süvgün Adonaj Tenrijni da saqlağyn saqlavyn anyn da resim-

(11) lerin da törelerin anyn da micvalaryn bar ol künlerde.

(12) (2] Da bilijiz bügün ki tüvül ulanlaryjyz byla ki

(13) bilmediler da ki körmediler ošol tyjuvun Adonajnyn Tenrijiz-

(14) nin ošol u[l]lulug̉un anyn ošol qudratyn ol küčlü da quvatyn

\footnotetext{
${ }^{1}$ Marginal insertion by another hand.| Heb. ㄱ. $\quad{ }^{2} \mathrm{~K}$ : haplologic form of ulluluqlarny.
} 
(5) inherit the land which I swore to their fathers to give

(6) to them." [12] And now, oh Israel, what the Lord

(7) your God wants from you is but to fear the Lord your God,

(8) to walk in all his ways and to love him and to serve

(9) the Lord your God with all your heart and with all your soul, [13]

(10) To keep the commandments of the Lord and his statutes which

(11) I command you today to be good for you. [14] Lo,

(12) the skies - and the rows of skies - are under the Lord your God's rule,

(13) and the earth and everything that is in it. [15] Only, the

(14) Lord had a delight in your fathers, to love them, and he chose their offspring

(15) after them: you, better than all the peoples, as it is this day.

(16) [16] And you shall circumcise the foreskin of your heart

(17) and you shall not harden your neck anymore. [17] Because the Lord

(18) your God: he is the God of angels and the Lord of globes,

(19) a great God, mighty and awesome, who does not favour

(20) and takes no bribe. [18] He

(21) is doing judgement for the orphan and the widow and loves the stranger, to give

(1) him food and clothing. [19] So you shall love the

(2) stranger, because you were strangers in the land of Egypt. [20]

(3) You shall fear the Lord your God, you shall serve him

(4) and you shall cling to his Law, and you shall swear to the truth by his name.

(5) [21] He is your praise and he is your God, who has done

(6) these great and awesome things with you

(7) which your eyes have seen. [22]

(8) Your fathers went down to Egypt with seventy souls, and now the Lord your God has made you

(9) like the stars of the skies for multitude.

Deuteronomy 11

(10) And you shall love the Lord your God and keep his charge and his statutes

(11) and his judgments and his commandments every day.

(12) [2] And you shall know today that it is not with your children who

(13) did not know and did not see the reprimand of the Lord your God,

(14) his greatness, his strong hand and 
(15) anyn ol sunulġan. [3] Da ošol belgilerin anyn da

(16) ošol išlerin ki qyldy ortasynda Micrinin par'og̉a biji-

(17) ne Micrinin da bar jerine anyn. ואשר [4] Da neki qyldy

(18) čerüvüne Micrinin a[tl] $\operatorname{aryna}^{1}$ anyn da markavyna ki jüzdür-

(19) dü ošol suvlaryn Jam Sufnun jüzleri üstüne alarnyn quv-

(20) ġanlarynda siznin artyna da tasetti alarny Adonaj ošpu

(21) küngedejin. ואשר] [5] Da neki qyldy sizge midbarda

$299 \mathrm{v}^{0}$ (1) kelgenijizgedejin ošpu orunġadejin. ואשר. [6] Da neki qyldy

(2) Datanğa da Aviramġa ulanlaryna Eli’avnyn uvlunun Ru’uven-

(3) nin ki ačty ol jer ošol avzun da juttu alarny da ošol

(4) üvlerin alarnyn da ošol čatyrlaryn alarnyn da ošol bar

(5) ol halqny ki alar qatyna ortasynda bar Jisra’elnin. כי [7]

(6) Ki közlerijizdi ol körüvčüler ošol bar išlerin Adonajnyn

(7) ol ullu ki qyldy. ושמרתם. [8] Da saqlajyz ošol bar ol

(8) micvany ki men bujuramen saja bügün anyn üčün ki küčejgejsiz

(9) da kelgejsiz da mereslegejsiz ošol ol jerni ki siz ašasiz

(10) ary meresleme any. \{r["ולמע]\}. [9] Da anyn üčün ki uzartqajsiz kün-

(11) ler ol jer üstüne ki antetti Adonaj atalaryjyzġa ber-

(12) me alarg̉a da urlug̉una alarnyn jer ag̉adog̉an süt da

(13) bal. כי [10] Ki ol jer ki sen kelesen ary meresleme

(14) any tüvüldü jeri kibik Micrinin ol ki čyqtyjyz andan

(15) ki čačsajedij ošol urlug̉ujnu da kerekli edi ki suğar-

(16) ġajsen ajaġyjbyla bağyn kibik ol ješilliknin. והארץ. [11] Da

(17) ol jer ki siz ašasiz ary meresleme any jer tavly da

(18) enišli jamġurundan ol köklernin ičedi suv. ארץ. [12]

(19) Jer ki Adonaj Tenrij tergejdi any hammeše 'enajatlary

(20) Adonaj Tenrijnin anda bašlyğyndan ol jylnyn da sofunadejin

(21) jylnyn. והיה] Da bolgaj eger tynlama tynlasajyz micva-

$300 \mathrm{r}^{\mathrm{o}} \quad$ (1) laryma ki men bujuramen sizge bügün süvme \{qullugiun\} Adonajnyn

(2) Tenrijiznin da qulluq etme anar bar jüregijizbyla da bar

(3) Žanyjyzbyla. \{ונתת. [14] Da berirmen jamġurun jerijiznin vahtynda

(4) jazġy jamġurnun da küzdegi jamġurnun da jyštyryrsen

(5) bürtügüjnü da šarbetijni da sajyjny. [ונתתי[ [15] Da ašarsen da

(6) tojarsen da berirmen kögöt tüzüjde tuvaryja da.

(7) השמרו Saqlanyjyz özüjüzge mag̉at jeldenir jüregijiz

\footnotetext{
${ }^{1} \mathrm{~K}$ : atalaryna; a scribal error. | TKow.o1: unvocalized text. | H: atlaryna. | C: atlaryna.
} 
(15) his outstretched arm, [3] And his miracles,

(16) and his deeds which he did in the midst of Egypt to Pharaoh,

(17) king of Egypt, and to all his land, [4] And what he did

(18) to the army of Egypt: to their horses and to their chariots, how

(19) he flowed the waters of the Red Sea over their faces

(20) when they pursued you, and how the Lord has destroyed them to

(21) this day, [5] And what he did to you in the wilderness

(1) until you came to this place, [6] And what he did

(2) to Dathan and Abiram, sons of Eliab, son of Reuben,

(3) how the earth opened its mouth and swallowed them up and

(4) their households and their tents and all

(5) the prey that was at their side, in the midst of all Israel, [7]

(6) Because it is your eyes that saw all the great deeds of the Lord

(7) which he did. [8] And you shall keep all the

(8) commandments which I command you this day, so that you may get strong

(9) and come and inherit the land that you are crossing

(10) there to inherit it, [9] And so that you may prolong

(11) your days in the land, which the Lord swore to your fathers to give

(12) to them and to their offspring, a land flowing |with| milk and

(13) honey. [10] Because the land, where you are coming to inherit

(14) it, is not as the land of Egypt, from where you came out,

(15) where you sowed your seed, and it was necessary to water

(16) it with your foot, as a garden of grass. [11] But

(17) the land to which you are crossing to inherit it is a land of mountains and

(18) valleys, and it drinks water from the rain of the skies. [12]

(19) A land which the Lord your God explores: the eyes

(20) of the Lord your God are always on it, from the beginning of the year to the end

(21) of the year. [13] And it shall be, if you will indeed listen to my commandments

(1) which I command you today, to love the service of the Lord

(2) your God and to serve him with all your heart and with all

(3) your soul, [14] Then I will give you the rain of your land in its due times,

(4) the summer rain and the autumn rain, that you may gather

(5) in your grain and your must and your olive oil. [15] And you will eat

(6) and be full, and I will also give grass in your fields for your cattle.

(7) [16] Take heed to yourselves, lest your heart be deceived 
(8) da qajyrylyrsiz jaḥšy joldan da qulluq etersiz özge

(9) tenrilerge da bašurursiz alarg̉a. וחרה [17] Da qabunur

(10) ačuvu Adonajnyn sizge da bekler ošol ol köklerni da

(11) bolmasty jamġur da ol jer bermesti ošol bitišin

(12) da taspolur[siz $]^{1}$ tez ol jahšy jer üstün[den $]^{2}$ ki Adonaj Ten-

(13) rijiz beredi sizge. ושמתם [18] Da qojujuz ošol söz-

(14) lerimni ošpularny jüregijizge da žanyjyzğa da bajlajyz

(15) alarny belgige qolujuz üstüne da bolsunlar totafot-

(16) qa közlerijiz arasyna. ולמדתם. [19] Da üvretijiz

(17) alarny uvullaryjyzġa sözleme alarny olturg̉anyjda üvüj-

(18) de da jürügenijde jolda da jatqanyjdan burun da turga-

(19) nyjdan sortun. [20] Da \{qyjasa\} jazġyn alarny odv́erjalary

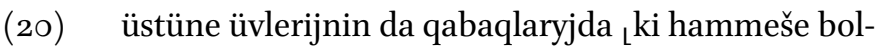

(21) ġaj sözleri Toranyn esijde ${ }^{13}$.למע. [21] Anyn üčün

$300 \mathrm{v}^{\mathrm{o}}$ (1) ki artqajlar künlerijiz da künleri ulanlaryjyznyn ol jer

(2) üstüne ki antetti Adonaj atalaryjyzgia berme alar-

(3) ga künlerikibik ol köklernin ol jerbyla. כי. [22]

(4) Ki eger saqlama saqlasajyz ošol bar ol micvany ošpu-

(5) nu ki men bujuramen sizge qylma any süvme ošol qul-

(6) lug̉un Adonaj Tenrijnin jürüme bar jollarybyla anyn da

(7) jabušma qullugiuna anyn. והוריש. [23] Da taseter

(8) Adonaj ošol bar ol ḥanlyqlarny ošpularny alnyjyzdan da

(9) mereslersiz ḥanlyqlarny ulluraqlarny da küčlüreklerni

(10) sizden. כל . 24] Bar ol orun ki bassa ta[ba]ny ajaġyjyznyn

(11) anda sizge bolur bašlap ol midbardan da ol Levanondan

(12) ol ullu özenden özeninden Peratnyn da ol máarav-

(13) sarg̉y tengizgedejin bolur čegijiz. לא. [25] Turalmasty ki-

(14) šide alnyjyzda qorquvujuznu da qobuvujuznu berir

(15) Adonaj Tenrijiz jüzleri üstüne bar ol jernin ki bassajyz

(16) anda ki nečik sözledi sizge.

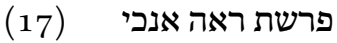

(18) [26 Baqqyn men beremen

\footnotetext{
${ }^{1} \mathrm{~K}$ : taspolur; a scribal error. | TKow.o1: taspolursiz; unvocalized text. | H: taspolursiz. | C: tas bolursyz. $\quad{ }^{2}$ TKow.o1: üstünden; unvocalized text. | H: istinden. | C: üstündän. $\quad{ }^{3}$ Interpretative addition to the standard text. $\quad{ }^{4} \mathrm{~K}$ : tavny; a scribal error. | TKow.o1: tabany; unvocalized text. | H: tabany. | C: tabany.
} 
(8) and you turn aside from the good way and serve other

(9) gods and worship them, [17] And

(10) the Lord's anger will be kindled against you, and he will shut up the heaven,

(11) and there will be no rain, and that the land will not give its fruit,

(12) and [you] will perish quickly from off the good land which the Lord

(13) your God is giving you. [18] And you shall lay up these my words

(14) in your heart and in your soul, and bind

(15) them for a sign on your hand that they may be as frontlets

(16) between your eyes, [19] And you shall teach

(17) them to your children, to speak about them when you sit in your house

(18) and when you walk by the way and before you lie down and

(19) after you rise, [20] And you shall write them in a way on the doorposts

(20) of your house, and on your gates, ${ }_{L}$ so that

(21) the words of the Law may always be in your mind, ${ }^{1269}$ [21] So that your

(1) days may be multiplied, and the days of your children, on the land

(2) which the Lord swore to your fathers to give them,

(3) as the days of the skies and the earth. [22]

(4) Because, if you will indeed keep all these commandments

(5) which I command you, to do it, to love the service

(6) of Lord your God, to walk in all his ways, and

(7) to cling to his service: [23] Then the Lord will destroy

(8) all these kingdoms before you, and

(9) you shall inherit kingdoms greater and mightier

(10) than you. [24] Every place on which the [soles] of your feet

(11) shall step will be yours, from the wilderness and Lebanon,

(12) from the great river, the river Euphrates, to the western

(13) sea will be your border. [25] Not a man will be able to stand

(14) before you. The Lord your God will put your fear of your dread

(15) on all the faces of all the land that you shall step

(16) on, as he spoke to you.

(17) Parashat Re'eh

(18) [26] See: I am giving

269 An interpretative addition to Deu 11:20. 
(19) alnyjzda bügün alġyšny da qarg்yšny. את. [27]

$301 \mathrm{r}^{\circ} \quad$ (1) Ošol ol alġyšny ki tynlasajyz micvalaryna Adonaj Tenrijiz-

(2) nin ki men bujuramen sizge bügün. והקללה. [28] Da ol qarġyš-

(3) ny eger tynlamasajyz micvalaryna Adonaj Tenrijiznin da ketsejiz

(4) ol joldan ki men bujuramen sizge bügün barma qullugu ar-

(5) tyna özge tenrilernin ki bilmejsiz. והיה. [29] Da bolġaj

(6) ki keltirse seni Adonaj Tenrij ol jerge ki sen kelesen ary

(7) meresleme any da bergin ošol ol alg̉yšny tavy üs-

(8) tüne Gerizimnin da ošol ol qarg̉yšny tavy üstü-

(9) ne Evalnyn. הלא. [30] Muna alar köčüvünde ol Jarden-

(10) nin ma‘aravsary jolusary enüvünün ol qujašnyn jerinde

(11) ol Kena'aninin ol olturuvču jylġalyqta uturusuna ol

(12) G[i] lgalnyn ${ }^{1}$ janynda tüz jerlerinin Morenin. כי [31] Ki siz

(13) ašasiz ošol ol Jardenni kelme meresleme ošol

(14) ol jerni ki Adonaj Tenrijiz beredi sizge da mereslesejiz

(15) any da oltursajyz anda. [32] Da saqlajyz

(16) qylma ošol bar ol resimlerni da ošol ol töreler-

(17) ni ki men beremen alnyjyzda bügün.

Deuteronomy $1[2]^{2}$

(18) resimler da ol töreler ki saqlajyz qylma jerde ki ber-

(19) di Adonaj Tenrisi atalaryjnyn saja meresleme any bar ol

(20) künlerni ki siz tirilirsiz ol jer üstüne. אבד. [2]

(21) Tasetme tasetijiz ošol bar ol orunlarny ki qulluq etti-

$301 \mathrm{v}^{\mathrm{o}} \quad$ (1) ler anda ol hanlyqlar abaqlaryna özlerinin ol bijik tavlar

(2) üstüne da ol qajalar üstüne da tübünde bar

(3) jašardog̉an ag̉ačnyn ki siz mereslejsiz alarny. ונתצתם [3]

(4) Da qavšatyjyz ošol mizbeaḥlaryn alarnyn da syndyryjyz maceva-

(5) laryn alarnyn da ašeralaryn alarnyn küvdürüjüz otta

(6) da jonma abaqlaryn uvaltyjyz da tasetijiz ošol atlaryn

${ }^{1}$ K: Galgalnyn; a scribal error. | TKow.o1: unvocalized text. | H: Gilgalnyn. | C: Gilgalnyy. | Heb.

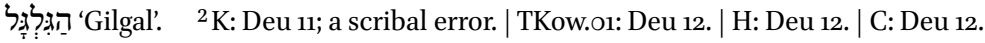


(19) before you today a blessing and a curse. [27]

(1) The blessing: if you listen to the commandments of the Lord your God

(2) which I command you this day. [28] And the curse:

(3) if you do not listen to the commandments of the Lord your God, but go

(4) aside from the way which I command you today, to go after the service

(5) of other gods, which you have not known. [29] And it shall be,

(6) when the Lord your God will bring you to the land to which you are coming

(7) to inherit it, that you shall put the blessing on Mount

(8) Gerizim, and the curse on Mount

(9) Ebal. [30] Lo, they are at the ford of Jordan,

(10) on the west |side|, by the way where the sun goes down, in the land

(11) of the Canaanites who dwell in the steppe opposite

(12) Gilgal, beside the lands of plains of Moreh. [31] Because you

(13) are passing over Jordan to come to inherit the

(14) land which the Lord your God is giving you. And when you inherit

(15) it and dwell therein, [32] Then you shall be watchful

(16) to do all the statutes and judgments

(17) which I set before you today.

Deuteronomy $1[2]^{270}$

[1] These are the

(18) statutes and judgments which you shall be watchful to do in the land which

(19) the Lord God of your fathers gave you, to inherit it, all the

(20) days that you live on the earth. [2]

(21) You shall surely destroy all the places in which

(1) the kingdoms served their gods: on the high mountains

(2) and on the rocks and under every

(3) greening tree which you shall inherit. [3]

(4) And you shall destroy their altars and break their pillars

(5) and burn their idol poles in fire,

(6) and you shall chop down the carved idols and destroy the name

$270 \quad$ K: erroneously indicated as Deuteronomy 11. 
(7) alarnyn ol orundan. [4] Qylmajyz alaj mizbeahlary-

(8) na Adonaj Tenrijiznin. כי לי ל] Ki ančaq ol orungia ki saj-

(9) lasa Adonaj Tenrijiz any bar ševetlerijizden qojma ošol

(10) šemin özünün anda toḥtar ornun anyn izlejiz da

(11) kelgin ary. והבאתם. [6] Da keltirijiz ary 'olalaryjyzny

(12) da debeḥalaryjyzny da ošol ončalaryjyzny da ošol teruma-

(13) syn qolujuznun da nijetlerijizni da žomartlyqlaryjyzny

(14) da tunġučlaryn syġyryjyznyn da qojujuznun. ואכלתם. [7 ]

(15) Da ašajyz anda alnynda Adonaj Tenrijiznin ${ }_{L}$ kimge neni

(16) jaravlydy ašama ${ }^{11}$ da bijenijiz bar sunuvubyla qolujuznun

(17) siz da eli üvüjüznün ki alğyšlar seni Adonaj Tenrij.

(18) לא. [8] Qylmajyz barča nečik ki biz qylabiz bunda bügün har

(19) kiši bar ol tüz körüngenni közlerinde. כי [9] Ki

(20) kelmedijiz haligedejin ol tynčlyqqa da ol ülüške ki

(21) Adonaj Tenrij beredi saja. ועברתם [10] Da ašsajyz

$302 \mathrm{r}^{\mathrm{o}} \quad$ (1) ošol ol Jardenni da oltursajyz jerde ki Adonaj Tenrijiz

(2) ülüš beredi sizge da tynč etse sizge bar dušman-

(3) laryjyzdan čüvreden da oltursajyz eminlik byla. והיה. [11]

(4) Da bolgaj ol orun ki sajlasa Adonaj Tenrijiz any toḥtatma

(5) šemin özünün anda ary keltirijiz ošol barča neki men

(6) bujuramen sizge 'olalaryjyzny da debehalaryjyzny ončalaryjyzny

(7) da terumasyn qolujuznun da bar sajlama nijetlerijizni ki nijet

(8) \{et\}śajiz Adonajgia. [12] Da bijenijiz alnynda Adonaj Ten-

(9) rijiznin siz da uvullaryjyz da qyzlaryjyz da qullaryjyz da qaravaš-

(10) laryjyz da ol Levi šaharlaryjyzda ki joḥtu anar ülüš da

(11) tijiš birgejizge. השמר. [13] Saqlanġyn özüje mag̉at čygaa-

(12) ryrsen 'olalaryjny har orunda ki körsej. כי [14] Ki ančaq

(13) ne orunda ki sajlasa Adonaj birisinden ševetlerijnin anda

(14) čyġarg̉yn 'olalaryjny da anda qylġyn barča neki men buju-

(15) ramen saja. רק. [15] Ančaq bar küsengende žanyj debeḥa

\footnotetext{
${ }^{1}$ Interpretative addition to the standard text.
} 
(7) of them out of that place. [4] You shall not do so to the altars

(8) of the Lord your God. [5] But to the place which

(9) the Lord your God shall choose from all your tribes to put

(10) his name there: you shall seek his dwelling place and

(11) there you shall come. [6] And there you shall bring your burnt offerings

(12) and your sacrifices and your tithes and the heave offerings

(13) of your hand and your vows and your freewill offerings

(14) and the firstborn of your herds and of your flocks. [7]

(15) And there you shall eat before the Lord your God, , each man that which

(16) he is allowed to eat, ${ }^{1271}$ and you shall rejoice in all that you reach your hand out to,

(17) you and your households, in which the Lord your God will bless you.

(18) [8] You shall not do like everything that we are doing here today,

(19) each one, everything that seems right in his eyes. [9] Because

(20) up to know you have not come to the rest and to the share which

(21) the Lord your God is giving you. [10] But when you will cross

(1) the Jordan and dwell in the land which the Lord your God

(2) is giving you as a share, and he will give you rest from all your enemies

(3) all around, so that you dwell in safety, [11]

(4) Then there shall be a place which the Lord your God shall choose to

(5) cause his name to dwell there: There shall you bring all that I

(6) command you: your burnt offerings and your sacrifices, your tithes

(7) and the heave offering of your hand, and all your choice vows which you vow

(8) to the Lord. [12] And you will rejoice before the Lord your God,

(9) you and your sons and your daughters, and your servants and your maidservants,

(10) and the Levite that is in your cities, since he has no portion and

(11) share with you. [13] Take heed to yourself, lest you offer

(12) your burnt offerings in every place that you see. [14] Because only

(13) in the place which the Lord shall choose in one of your tribes: there

(14) you shall offer your burnt offerings, and there you shall do all that I

(15) command you. [15] Only, every time when your soul desires you shall sacrifice

$271 \quad$ An interpretative addition to Deu 12:7. 
(16) etkin da ašaġyn et alġyšynaköre Adonaj Tenrijnin

(17) ki berdi saja bar šaharlaryjda ol ${ }_{L}$ murdar kiši da ol aruv ${ }^{11}$

(18) kiši ašasyn any jürnü kibik da sog̉ag̉ny kibik. רק. [16]

(19) Ančaq ol qanny ašamajyz ol jer üstüńa tökkün any

(20) suvnu kibik. לא. [17] Bolalmaġyn ašama šaharlaryjda onča-

(21) syn bürtügüjnün da šarbetijnin da sajyjnyn da tunġučla-

$302 \mathrm{v}^{\mathrm{o}} \quad$ (1) ryn syg̈yryjnyn da qojujnun da bar nijetlerijni ki nijet et-

(2) sej da žomartlyqlaryjny da terumasyn qolujnun. כי [18]

(3) Ki ančaq alnynda Adonaj Tenrijnin ašağyn any ${ }_{L}$ kimge neni

(4) jaravlydy ašama ${ }^{12}$ ne orunda ki sajlasa Adonaj Tenrij any

(5) sen da uvluj da qyzyj da quluj da qaravašyj da ol

(6) Levi ki šaharlaryjyzda da bijengin alnynda Adonaj Tenrijnin

(7) bar sunuvunda qolujnun. השמר. [19] Saqlanġyn özüje

(8) mag̉at kemiširsen ošol ol Levini bar künlerijde jerij-

(9) üstüne. כ20] Ki kenertse Adonaj Tenrij ošol

(10) čegijni ki nečik sözledi Adonaj saja da ajtsaj ašagaje-

(11) dim et ki küsense žanyj ašama et bar küsengen-

(12) de žanyj ašağyn et. כי [21] Ki jyraq bolsa senden

(13) ol orun ki sajlasa Adonaj Tenrij any qojma šemin ö-

(14) zünün anda da ${ }_{\mathrm{L}} \mathrm{d}[\mathrm{e}] \mathrm{b}[\mathrm{eh}] \mathrm{a}$ etkin ${ }^{13}$ syggyryjdan da qojujdan

(15) ki berdi Adonaj saja ki nečik bujurdum saja da ašağyn

(16) šaharla\{ry\}jda bar küsengende žanyj. אך. [22] Tek nečik

(17) ki ašaldy ošol ol jür da ošol ol sog̉ag alaj ašağyn

(18) any ol murdar kiši da ol aruv kiši \{birge\} ašasyn any.

(19) . 23] Tek küčejgin ašamaġyn ol qanny ki ol qan ol-

(20) du ol క̌an da ašamağyn ol žanny ol etbyla. לא. [24]

(21) Ašamaġyn anyn ol jer üstüne tökkün any suvnu kibik.

$303 \mathrm{r}^{\mathrm{o}} \quad$ (1) לא. [25] Ašamağyn any anyn üčün ki jaḩ̌y bolg̀aj saja

(2) da ulanlaryja senin özüjden sortun ki qylsaj ol jaḥšy

\footnotetext{
${ }^{1} \mathrm{~K}$ : Originally: aruv kiši da ol murdar; the word order was corrected by the copyist. $\quad{ }^{2}$ Interpretative addition to the standard text. ${ }^{3}$ TKow.or: deest; this verse was mistakenly omitted by the copyist. | H: debeha etkin. | C: sojgyn.
} 
(16) and eat meat according to the blessing of the Lord your God

(17) which he has given you in all your cities. The unclean man and the clean

(18) man shall eat it: like the deer and the fawn. [16]

(19) Only, you shall not eat the blood. You shall pour it like water on the earth.

(20) [17] You may not eat within your cities the tithe

(21) of your grain or of your must or of your olive oil or the firstborn

(1) of your herds or of your flock, or all your vows which you vow

(2) or your freewill offerings or the heave offering of your hand. [18]

(3) But you must eat them before the Lord your God, , each man that which

(4) he is allowed to eat, ${ }^{1272}$ in the place which the Lord your God shall choose,

(5) you and your son and your daughter, and your servant and your maidservant, and the

(6) Levite that is in your cities. And you shall rejoice before the Lord your God

(7) in all that you reach your hands out to. [19] Take heed to yourself,

(8) lest you leave the Levite, all your days

(9) on the earth. [20] When the Lord your God will widen

(10) your border as he spoke to you, and you will say,

(11) "Let me eat meat," because every time your soul desires to eat meat,

(12) you shall eat meat. [21] If

(13) the place which the Lord your God has chosen to put his name

(14) there is too far from you, then you shall sacrifice of your herd and of your flock

(15) which the Lord has given you, as I have commanded you, and you shall eat

(16) in your cities every time your soul desires it. [22] Just: as

(17) the deer and the fawn are eaten, so you shall eat

(18) it: the unclean and the clean shall eat of them alike.

(19) [23] Just: be strong not to eat the blood, because the blood:

(20) it is the life, and you shall not eat the life with the meat. [24]

(21) You shall not eat it, you shall pour it like water on the earth.

(1) [25] You shall not eat it, so it will be good for you

(2) and for your children after you, when you do what

272 An interpretative addition to Deu 12:18. 
(3) kör\{ü\}ngenni 'enajatlarynda Adonajny. קר. [26] Ančaq

(4) qadašimlarijni ki bolsalar saja da nijetlerijni alġyn da

(5) kelgin ol orunga ki sajlasa Adonaj. ועשית. [27] Da

(6) qylgyyn 'olalaryjny ol etni da ol qanny mizbeahy üs-

(7) tüne Adonaj Tenrijnin da qany debehalaryjnyn tögülsün

(8) mizbeahy üstüne Adonaj Tenrijnin da ol etni ašaġyn.

(9) שמור (28] Saqlag̉yn da tynlaġyn ošol bar ol sözler-

(10) ni ošpularny ki men bujuramen saja anyn üčün ki jahšy

(11) bolġaj saja da ulanlaryja özüjd́an sortun dunjagaadejin

(12) ki qylsaj ol jaḥšy körüngenni da ol tüz körüngenni

(13) 'enajatlarynda Adonaj Tenrijnin. כ2. [29] Ki eksitse

(14) Adonaj Tenrij \{alnyjda[n]\} $\}^{1}$ ošol ol ḥanlyqlarny ki sen kelesen ary

(15) meresleme alarny da mereslesej alarny da oltursaj

(16) jerlerinde alarnyn. השמר. [30] Saqlanġyn özüje

(17) mag̉at tuzaqlanyrsen alar artyna taspolganlaryndan sor-

(18) tun alnyjdan da mag̉at sorarsen abaqlary üčün alarnyn aj-

(19) tadoġač nečik qulluq eterediler ol ḥanlyqlar ošpular

(20) abaqlaryna özlerinin da qylajym alaj dağyn mende.

(21) לא. [31] Qylmaġyn alaj qullugiunda Adonaj Tenrijnin ki bar

$303 \mathrm{v}^{\mathrm{o}} \quad$ (1) hor etkenin Adonajnyn ki hor etti qyldylar abaqlaryna

(2) özlerinin ki dağyn ošol uvullaryn da ošol qyzlaryn

(3) özlerinin küvdürürediler otta abaqlaryna özleri-

(4) nin.

Deuteronomy $1[3]^{2}$

(4) את [1] Ošol bar ol söznü ki men bujuramen sizge

(5) any saqlajyz qylma arttyrmag்yn anyn üstüne da ek-

(6) sitmegin andan. כי [2] Ki tursa ortajda navi

(7) jemese tüš körüvčü tüš da berse saja belgi jeme-

(8) se nišan. ובא [3] Da kelsede ol belgi da ol nišan

(9) ki sözledi saja ajtadoġač barajyq qullug̉u artyna öz-

(10) ge tenrilernin ki bilmejsen alarny da qulluq etejik alar-

(11) ga. לא. [4] Tynlamag்yn sözlerine ol navinin jemese

\footnotetext{
${ }^{1}$ TKow.o1: deest. | H: alnyndan. | C: aldyydan. $\quad{ }^{2}$ K: Deu 12; a scribal error. | TKow.o1: see, next footnote. | H: Deu 13. | C: see, next footnote. ${ }^{3}$ TKow.o1: Deu 13:1. | C: Deu 13:1.
} 
(3) seems right in the eyes of the Lord. [26] Only,

(4) your holy things which you have and your vows, you shall take, and

(5) you shall go to the place which the Lord shall choose. [27] And

(6) you shall offer your burnt offerings, the meat and the blood, on the altar

(7) of the Lord your God. And the blood of your sacrifices shall be poured

(8) out on the altar of the Lord your God, and you shall eat the meat.

(9) [28] Keep and hear all these words

(10) which I command you, so it may be good

(11) for you and for your children after you forever

(12) when you do what seems good and seems right

(13) in the eyes of the Lord your God. [29] Because when the

(14) Lord your God will cut off the nations that you are coming there

(15) to inherit them from before you, and you will inherit them and dwell

(16) in their land, [30] Take heed to yourself

(17) that you are not snared by following them, after they are destroyed

(18) from before you, lest you inquire after their gods,

(19) saying, "How did these kingdoms serve

(20) their gods? And I will do likewise-I, too."

(21) [31] You shall not do so to the service of the Lord your God, because

(1) they did every abominable thing to the Lord which he despises for their gods,

(2) because they would also burn their sons and their daughters

(3) in the fire to

(4) their gods.

Deuteronomy $1[3]^{273}$

(4) [1] Every word I command you:

(5) you shall be watchful to do it. You shall not add to it or

(6) take away from it. [2] If a prophet arises among you,

(7) or a dreamer of dreams, and gives you a sign or

(8) a wonder, [3] And the sign or wonder

(9) of which he spoke to-saying, "Let us go after the service of

(10) other gods," whom you have not known, "and let us serve

(11) them,"-comes, [4] You shall not listen to the words of that prophet or

273 K: erroneously indicated as Deuteronomy 12. 
(12) tüš körüvčünün ol tüšnü ol ki synajdy Adonaj Tenrijiz

(13) sizni bilme süvemosiz ošol qulluguun Adonajnyn Tenri-

(14) jiznin bar jüregijizbyla da bar žanyjyzbyla. אחרי. [5]

(15) Saruvlary artyna Adonaj Tenrijiznin jürüjüz da andan

(16) qorqujuz da ošol micvalaryn anyn saqlajyz da ününe

(17) anyn tynlajyz da anar qulluq etijiz da Torasyna anyn

(18) jabušujuz. והנביא. [6] Da ol navi jemese tüš körüv-

(19) čü ol tüšnü öltürülsün ki sözledi tanmaq söz

(20) Adonaj üčün Tenrijiz üčün siznin ol čyğaruvču sizni jerin-

(21) den Micrinin da ol juluvčunun seni qullar erkinden azaš-

$304 \mathrm{r}^{\mathrm{o}} \quad$ (1) tyrma seni ol joldan ki bujurdu saja Adonaj Tenrij jürü-

(2) me anyn byla da eksitkin ol jamanny ortajdan.

(3) כי . [7 [ Ki jel[d́a] śa ${ }^{1}$ seni qaryndašyj uvlu anajnyn jemese

(4) uvluj jemese qyzyj jemese qojundaġy qatynyj jemese

(5) dostuj özüj kibik jašyrtynlyqbyla ajtadoġač

(6) barajyq $\{[\mathrm{da}]\}^{2}$ qulluq etejik özge tenrilerge ki bilmejsen sen

(7) da atalaryj. [8] Abaqlaryndan ol uluslarnyn

(8) ki čüvrelerijizde ol juvuqlar saja $\{\text { jeme[se] }\}^{3}$ ol jyraqlar

(9) senden qyryjyndan ol jernin da qyryjynadejin ol jernin. לא. [9]

(10) Klemegin maskim bolma jeldemegine anyn da tynlama-

(11) ġyn anar da hajiffünmesin közüj anyn üstüne

(12) da žallemegin da jašyrmaġyn günehịn anyn. כי [10] Ki

(13) ančaq öltürme öltürgün any qoluj senin bolsun an-

(14) da burunraq öltürḿa any da qolu bar ol ulusun

(15) sondrada. וסקלתו [11] Da tašlağyn any tašlarbyla da

(16) da ölsün ki kledi azaštyrma qulluğundan Adonaj

(17) Tenrijnin ol čug̉aruvčunun seni jerinden Micrinin qullar

(18) erkinden. וכל. [12] Da bar Jisra’el ešitsinler da

(19) qorqsunlar da arttyrmasynlar qylma ol jaman iški-

(20) bik ošpu ortajda. כי [13] Ki ešitsej birisinde

(21) šaharlaryjnyn ki Adonaj Tenri beredi saja olturma anda

$304 v^{0} \quad$ (1) יצאו I [14] Čyqtylar erenler bajdbaq el or-

(2) tajdan da azaštyrdylar ošol oltururvčularyn šaharynyn öz-

${ }^{1} \mathrm{~K}$ : jeladiśa; a scribal error. | TKow.o1: unvocalized text. | H: jeldese.| C: azg்yrsa. $\quad{ }^{2}$ TKow.o1: da; unvocalized text. | H: da. | C: da. $\quad{ }^{3}$ TKow.o1: jemese; unvocalized text. | H: jemese. | C: ja. $\quad{ }^{4} \mathrm{~K}$ : Copied twice; dittography. 
(12) that dreamer of dreams, because the Lord your God is testing you,

(13) to know whether you love the service of the Lord your God

(14) with all your heart and with all your soul. [5]

(15) You shall walk after the Lord your God's order and

(16) fear him and keep his commandments and listen his voice,

(17) and you shall serve him and cling to his Law.

(18) [6] And that prophet or that dreamer

(19) of dreams shall be put to death, because he has spoken words of contradiction

(20) about the Lord, about your God who brought you out from the land

(21) of Egypt and who redeemed you out of the reign of slaves,

(1) to make you go astray from the way which the Lord your God commanded you to walk

(2) in. So you shall remove the evil from among you.

(3) [7] If your brother, the son of your mother, or

(4) your son or your daughter or the wife of your bosom or

(5) your friend, who is like you, entices you secretly, saying,

(6) "Let us go and serve other gods," which you have not known, you

(7) and your fathers, [8] From the gods of the people

(8) who are all around you, near to you or far off

(9) from you, from the one edge of the earth even to the other edge of the earth, [9]

(10) You shall not want to consent to his enticement and you shall not listen

(11) to him, and your eye shall not pity him,

(12) and you shall not regret or conceal his iniquity. [10] But

(13) you shall surely kill him. Your hand shall be first on him

(14) to put him to death, and the hand of all the people thereafter.

(15) [11] And you shall stone him with stones, and

(16) he shall die, because he has sought to make you go astray from the service of the Lord

(17) your God who brought you out from the land of Egypt, from the reign of slaves.

(18) [12] And all Israel shall hear, and

(19) they shall fear, and the shall not continue to do a bad thing

(20) like this among you. [13] If you hear in one

(21) of your cities which the Lord your God has given you to dwell there

(1) anyone saying, [14] "Certain men, worthless people, have gone out

(2) from among you and have made the inhabitants of their city go astray, 
(3) lerinin ajtadog̉ač barajyq da qulluq etejik özge tenriler-

(4) ge ki bilmejsiz. ודרשת] [15] Da izlegin da tergegin

(5) da sorg̉un jahšsy da muna kerti duğrudu ol nerse

(6) qylyndy ol jerenči iš ošpu ortajda. הכה. [16] Qyr-

(7) ma qyrg்yn ošol olturuvčularyn ol šaharnyn qylyč av-

(8) zundan veren etkin any da ošol barča neki anda

(9) da ošol tuvaryn anyn qylyč avzundan. ואת [17] Da ošol

(10) bar malyn anyn jyštyrg̉yn ortasyna oramynyn da küv-

(11) dürgün otta ošol ol šaharny da ošol bar malyn

(12) anyn tügeliče Adonajġa Tenrije da bolsun ömürlük

(13) oba qondarylmasyn artyq. ולא [18] Da jabušmasyn qolu-

(14) ja nemede ol heremden anyn ücün ki qajtqaj Adonaj

(15) qaḥir ačuvundan da bergej saja rạ̣metler da $\{r\} a h ̣ m e t l e g e j$

(16) seni da arttyrg̉aj seni ki nečik antetti atalaryja.

(17) כי (19] Ki tynlasaj ününe Adonaj Tenrijnin saqlama o-

(18) šol bar micvalaryn anyn ki men bujuramen saja bügün qyl-

(19) ma ol tüz körüngenni 'enajatlarynda Adonajnyn Tenrijnin.

Deuteronomy $1[4]^{1}$

(20) בנים (1] Ulanlardyrsiz Adonajğa Tenrijizge čyzylmajyz

(21) da qojmajyz julquv közlerijiz arasyna ölü üčünde.

$305 \mathrm{r}^{\mathrm{r}} \quad$ (1) כי עם

(2) da seni sajlady Adonaj bolma özüne onča ulusqa

(3) bar ol uluslardan ki jüzleri üstüne ol jernin.

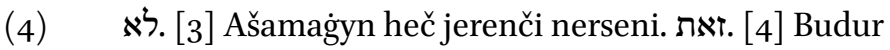

(5) ol tuvar ki ašajyz ögüznü qojnu qozularny da qojun

(6) ečkilernin. איל. [5] Sog̉ag̉ny da jürnü da bojvolnu

(7) da pole qojun da dišonnu da lośnu da žubrany.

(8) וכל [6] Da bar tuvarny tujaqlavčunu tujaq da ajyruv-

(9) čunu ajyryčyn eki tujaqlarnyn güvün keltirüvčünü

(10) tuvarda any ašajyz. אך. [7] Tek ošol bunu ašamajyz \{jalġyz\}

(11) keltirüvčülerden ol güvünnü da jalg̀yz tujaqlavču-

(12) lardan ol tujaqny ol ajyrylġanny ošol ol teveni da

\footnotetext{
${ }^{1}$ K: Deu 13; a scribal error. | TKow.o1: Deu 14. | H: Deu 14. | C: Deu 14.
} 
(3) saying, "Let us go and serve other gods,"

(4) which you have not known:" [15] And you shall make search and inquire,

(5) and ask well, and, lo, the thing is true-

(6) that abominable thing was done among you-[16] You shall surely

(7) strike the inhabitants of that city with the edge of the sword:

(8) you shall destroy it and all that is in it

(9) and its cattle with the edge of the sword. [17] And

(10) you shall gather all the goods of it to the middle of its street and

(11) you shall burn in fire the city and all its goods

(12) entirely to the Lord your God, and it shall be an eternal

(13) heap. It shall not be built again. [18] And nothing

(14) of the devoted thing shall cling to your hand, so that the Lord may turn

(15) from his furious anger and show you mercy. And he shall have mercy

(16) on you and multiply you as he has sworn to your fathers,

(17) [19] If you listen to the voice of the Lord your God to keep

(18) all his commandments which I command you today, to do

(19) what seems right in the eyes of the Lord your God.

Deuteronomy $1[4]^{274}$

(20) You are the children of the Lord your God. You shall not draw |on| yourselves,

(21) and you shall not make a bald place between eyes even for the dead.

(1) [2] Because you are a holy people to the Lord your God,

(2) and the Lord has chosen you to be a chosen people to himself,

(3) from among all the peoples that are on the earth.

(4) [3] You shall not eat any abominable thing. [4] These

(5) are the animals which you shall eat: cattle, lamb of sheep, and lamb

(6) of goats. [5] Fawn, deer, and buffalo,

(7) and field hare, and antelope, and moose, and wisent.

(8) [6] And every animal that parts the hoof, and has a split of

(9) hooves, that regurgitates the cud

(10) among the animals, you shall eat it. [7] Only these you shall not eat

(11) of them that only regurgitate the cud or of them that part

(12) the split hoof: the camel, and

274 K: erroneously indicated as Deuteronomy 13. 
(13) ošol qojanny da ošol ol krolikni ḥote güvün

(14) keltiredilerde ese alar da tujaq tujaqlamajdy-

(15) lar murdarlardylar alar sizge. [8] Da ošol

(16) ol ḥazirni ḥote tujaqlajdy esede tujaq ol da

(17) güvün keltirmejdi murdardy ol sizge etlerin-

(18) den alarnyn ašamajyz da gövdelerine alarnyn tijmejiz.

(19) את [9] Ošol bunu ašajyz baryndan neki suvlarda barča

(20) neki anar qanat da qabuq any ašajyz. וכל. [10] Da barča

(21) neki joḥtur anar qanat da qabuq ašamajyz murdardy

$305 \mathrm{v}^{\mathrm{o}}$ (1) ol sizge. כלוזה. [11] Bar aruv qušun ašajyz Dadur

(2) ki ašamajyz alardan ol nešerni da ol peresni da ol 'aznija-

(3) ny. והראה [13] Da ol ra’any da ošol ol ajany da

(4) ol dajany žynsysajyn. [14] Da ošol bar qarg̉any žynsy-

(5) sajyn. ואת [15] Da ošol ol anqyt balasyn da ošol tah-

(6) masny da ošol šaḥafny da ošol ol qyrg̉yjny žynsy-

(7) sajyn. את הכוס [16] Ošol ol kosnu da ošol ol

(8) janšufnu da ol ti\{n\}šemetni. והקאת [17] Da ol qa’a[t]-

(9) ny da ošol rahamamany da ošol ol šalahnny. והחסידה] [18]

${ }^{1} \mathrm{~K}$ : qa’any; a scribal error; cf. Leviticus 11:18. | TKow.o1: qa’atny; unvocalized text. | H: qa’atny. | C: qaatny. 
(13) the hare, and the rabbit - although they

(14) regurgitate the cud, they do not divide the hoof.

(15) They are unclean to you. [8] And the

(16) pig: although it parts the hoof,

(17) it does not regurgitate the cud. It is unclean to you.

(18) You shall not eat of their flesh, and you shall not touch their carcasses.

(19) These you shall eat of all that are in the waters: all

(20) that have fins and scales you shall eat. [10] And all

(21) that does not have fins and scales: you shall not eat it. It is unclean

(1) to you. [11] You shall eat every clean bird. [12] And this is

(2) what you shall not eat of them: the eagle, and the vulture, and the black vulture,

(3) [13] And the red kite, and the falcon, and

(4) the kite by its kind, [14] And every raven by its kind,

(5) [15] And the young of the ostrich, and the tahmas ${ }^{275}$,

(6) and the seagull, and the hawk by its kind,

(7) [16] The little owl, and the

(8) Llong-eared owl ${ }^{1276}$, and the ${ }_{\text {Lhite owl }}{ }^{1277},[17]$ And the pelican ${ }^{278}$,

(9) and the carrion vulture, and the šalah ${ }^{279}$, [18]

275 Heb. תרת תח of unclarified meaning: 'an unclean bird of prey' in Klein (1987:698), 'an unclean bird of prey, perhaps a species of owl' in Koehler \& Baumgartner (1985: 1025). | Translated as 'nighthawk' in KJ200o, ESV, and by Friedman (2003). | EKar. tahmas in C is translated as 'nighthawk' by Jankowski \& Aqtay \& Cegiołka \& Çulha \& Németh (2019: II 142, 249).

276 Heb. יִּנוּוּ 'long-eared owl' (Koehler \& Baumgartner 1985: 386; Klein 1987: 26o). | See, however, 'great owl' in the KJ200o and in Friedman (2003), and 'short-eared owl' in Esv. | EKar. janšuf in C is translated as 'long-eared owl' by Jankowski \& Aqtay \& Cegiołka \& Çulha \& Németh (2019: II 142, 249).

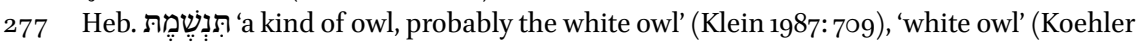
\& Baumgartner 1985: 1035). | Translated as 'white owl' in KJ2000 and by Friedman (2003), translated as 'barn owl' in ESv. | EKar. tinšemet $\sim$ tinšamet in C is translated as either as 'white owl' or as 'barn owl' by Jankowski \& Aqtay \& Cegiołka \& Çulha \& Németh (2019: II 142, 249).

278 Heb. קָָָ 'pelican' (Klein 1987: 559), 'a species of owl (?)' (Koehler \& Baumgartner 1985: 817). | Translated as 'pelican' in KJ200o, and by Friedman (2003), translated as 'tawny owl' in ESv. | EKar. qa'at in C is translated as 'pelican' by Jankowski \& Aqtay \& Cegiołka \& Çulha \& Németh (2019: II 142, 249).

279 Heb. שָָָׁ, a bird name of uncertain meaning: 'probably the cormorant' in Klein (1987: 662), 'cormorant (?)', 'fish-owl (?)' in Koehler \& Baumgartner (1985: 978). | Translated as 'cormorant' in KJ200o, ESv, and by Friedman (2003). | EKar. šalah in C is translated as 'cormorant' by Jankowski \& Aqtay \& Cegiołka \& Çulha \& Németh (2019: II 142, 249). 
(10) Da ol ḥasidany da ol anafany žynsysajyn da ol

(11) duhifatny da ol jary qanatyn. [19] Bar qomu-

(12) zu ol qušnun murdardy ol sizge ašalmasynlar.

(13) כל בל [20] Bar aruv qušnu ašajyz. [21 Ašamajyz heč

(14) qyrylġanny gaaripge ki qabaqlaryjda bergin any da

(15) ašasyn any jemese sat[qyn $]^{1}$ jatqa ki aziz ulus-

(16) tur sen Adonajğa Tenrije biširmegin ulaqny sütü

(17) ičine anasynyn. עשר. [22] Onča berme onča

(18) bergin bi\{ti\}šinden urlugiujnun ol čyg̉uvču ol tüzge

(19) har jylda. זאכלת [23] Da ašaġyn alnynda Adonajnyn

(20) Tenrijnin ne orunda ki sajlasa toḥtatma šemin

(21) özünün anda ončasyn bürtügüjnün ša $\{r\}$ betijnin da

$306 \mathrm{r}^{\circ} \quad$ (1) sajyjnyn da tunġučlaryn syğyryjnyn da qojujnun anyn ü-

(2) čün ki üvrengejsen qorqma Adonajdan Tenrijden bar

(3) ol künlerde. [24] Da ki köp bolsa senden ol

(4) jol ki bolalmasaj eltme any ki [jyraq $]^{2}$ bolsa senden

(5) ol orun ki sajlasa Adonaj Tenrij any toḥtatma šemin

(6) özünün ki alġyšlasa seni Adonaj Tenrij. ונתתה [25] Da

(7) bergin kümüšbyla da tüvünčüklegin ol kümüšnü

(8) qoluja da barg்yn ol orunga ki sajlasa Adonaj Tenrij

(9) any. ${ }^{3}$ (26] Da bergin ol kümüšnü baryna neki kü-

(10) sense క̌anyj syġyr üčün qojüčün da čaġyr üčün

(11) da esirtki üčün da bar nerse üčün ki klese

(12) senden žanyj da ašag̉yn anda alnynda Adonaj Tenrij-

(13) nin da bijengin sen da eli üvüjnün. והלוי. [27] Da

(14) ol Levini ki šaharlaryjda kemišmegin any ki joḥtu anar

(15) ülüš da tijiš birgeje. מקצה. [28] Ahẹerinden üč

(16) jyllarnyn čyğarg̉yn ošol bar ončasyn bitišijnin ol jylda

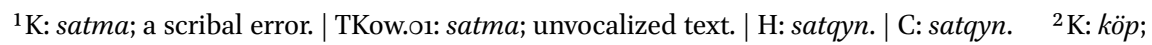
a scribal error (or a mistranslation). | TKow.o1: jyraq; unvocalized text. | H: jyraq. | C: jyraq. | M:

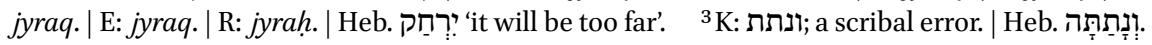


(10) And the stork, the heron by its kind, and the

(11) hoopoe, and the bat. [19] Every creeping animal

(12) of flying creature is unclean to you. They shall not be eaten.

(13) [20] You shall eat every clean bird. [21] You shall not eat any

(14) carrion. You shall give it to the stranger that is in your gates, and

(15) he shall eat it, or you shall sell it to a foreigner, because you are a holy people

(16) to the Lord your God. You shall not boil a kid in its

(17) mother's milk. [22] You shall tithe

(18) all the crop of your seed that comes from the field

(19) every year. [23] And you shall eat before the Lord

(20) your God, in the place which he shall choose to cause his name to dwell

(21) there, the tithe of your grain, of your must, and

(1) of your olive oil, and the firstborns of your herds and of your flocks, $\quad 306 \mathrm{r}^{\mathrm{o}}$ so that

(2) you may learn to fear the Lord your God

(3) all the days. [24] And if the way is too much ${ }^{280}$ for you,

(4) so that you are not able to carry it because

(5) the place which the Lord your God will choose to cause his name to dwell there is too [far $]^{281}$ from you

(6) when the Lord your God will bless you, [25] Then

(7) shall you give it in silver. And you shall bundle up the silver

(8) in your hand, and you shall go to the place which the Lord your God shall choose.

(9) [26] And you shall give that silver for anything your soul desires:

(10) for oxen or for sheep or for wine,

(11) or for strong drink or for anything your soul wants

(12) from you, and you shall eat there before the Lord your God,

(13) and you shall rejoice, you and your household. [27] And

(14) the Levite who is in your cities: You shall not leave him, because he has no

(15) portion or share with you. [28] In the course of three

(16) years you shall bring out all the tithe of your crop the same year,

280 A literal translation of Heb. ירֶֶֶ? 'it will be numerous'. | TKow.o1: much. | H: much. | C: much.

281 K: much; a scribal error (or a mistranslation), cf. Heb. ירְ̣?' 'it will be moved away; it will be too far'. 
(17) da qojg̉un šaharlaryjda. [29] Da kelsin ol Levi ki joḥ-

(18) tu anar ülüš da tijiš birgeje da ol garip da ol

(19) öksüz da ol tul ki šaharlaryjda da ašasynlar da

(20) tojsunlar anyn üčün ki alġyšlaġaj Adonaj Tenri seni bar

(21) išlerinde qollaryjnyn ki qylsaj.

Deuteronomy $1[5]^{1}$

מקץ [1] Aherin-

$306 v^{o} \quad$ (1) den jedi jyllarnyn qylg̈yn šmita. [2] Da budur iši ol

(2) šmitanyn kemišme har kiši borčun qolunun ki borč-

(3) qa berse dostuna qystamasyn ošol dostun da ošol

(4) qaryndašyn ki čaġyrdy šmita Adonajg̉a. את. [3] Ošol

(5) ol jatny qystağyn da neki bolsa senin qaryndašyjda kemiš

(6) bo\{r\}čun qolujnun. אפס. [4] Ančaq ki bolmasty sende j[a]r-

(7) ly ki \{alġyšlama\} alg̀yšlar seni Adonaj jerde ki Adonaj Tenrij beredi

(8) saja ülüš meresleme any. רק. [5] Ančaq eger tyn-

(9) lama tynlasaj ününe Adonaj Tenrijnin saqlama da qylma

(10) ošol bar ol micvany ošpunu ki men bujuramen saja bügün.

(11) כי (6] Ki Adonaj Tenrij alġyšlady seni ki nečik sözledi

(12) saja da tusnaqqa berirsen köp ḥanlyqlarğa da sen

(13) tusnaqqa almassen da erklenirsen köp ḥanlyqlarda

(14) da sende erklenmesler. כי [7] Ki bolsa sende

(15) miskin \{birisinden qaryndašlaryjnyn $\}$ birisinde šaharlaryjnyn jerijde ki Adonaj Tenrij

(16) beredi saja qattyrmaġyn ošol jüregijni da qysmaġyn

(17) ošol qolujnu qaryndašyjdan ol miskinden. כי [8] Ki

(18) ačma ačqyn ošol qolujnu anar da tusna[q] $\mathrm{qa}^{3}$ bergin

(19) anar jetkiligiče eksikliginin ki eksik bolsa

(20) anar. השמר. [9] Saqlanġyn özüje maġat bolur kölnüj-

(21) de bajdbaq söz ajtadoġač juvudu ol jedinči jyl jyly ol

\footnotetext{
${ }^{1} \mathrm{~K}$ : Deu 14; a scribal error. | TKow.o1: Deu 15. | H: Deu 15. | C: Deu 15. $\quad{ }^{2} \mathrm{~K}$ : jerli; a scribal error. | TKow.o1: unvocalized text. | H: miskin. | C: miskin. $\quad{ }^{3} \mathrm{~K}$ : tusnaqa; a scribal error. | TKow.o1: tusnaqqda; a scribal error; unvocalized text. | H: tusnaqqa. | C: borčqa.
} 
(17) and you shall lay it up in your cities. [29] And the Levite shall come, because

(18) he has no portion or share with you, and the stranger and the

(19) orphan and the widow who are in your cities, and they shall eat

(20) and be full, so that the Lord your God may bless you in all

(21) the work of your hand which you do.

Deuteronomy $1[5]^{282}$

(1) seven years you shall make a remission. [2] And this is the matter of the

(2) remission: every man is to release his debt of his hand that he

(3) lends to his fellow. He shall not press his fellow or

(4) his brother, because it is called the Lord's release. [3] A

(5) foreigner you may press, but whatever of yours is with your brother you shall release

(6) the debt of your hand. [4] Nonetheless, there will be no [needy] among you,

(7) because the Lord will surely bless you in the land which the Lord your God

(8) gives you for a portion to inherit it-[5] Only if

(9) you listen to the voice of the Lord your God to keep and to do

(10) all these commandments which I command you today.

(11) [6] Because the Lord your God blesses you, as he spoke

(12) to you, and you will give on pledge to many kingdoms, but you

(13) will not take one pledge. And you will reign over many kingdoms,

(14) but they will not reign over you. [7] If there is a poor man among you

(15) from one of your brothers in one of your cities in your land that the Lord your God

(16) is giving you, you shall not harden your heart and you shall not shut

(17) your hand from your poor brother. [8] Because

(18) you shall surely open your hand to him and shall surely give him on pledge,

(19) sufficient for his shortage, in that which he lacks.

(20) [9] Take heed to yourself, lest there will be

(21) a worthless word in your heart, saying, "The seventh year, the year of

282 K: erroneously indicated as Deuteronomy 14. 
$307 \mathrm{r}^{\mathrm{0}} \quad$ (1) Šmitanyn da jaman bag̉ar közüj qaryndašyj üstüne

(2) ol miskin da bermessen anar da čaġyryr senin üčün

(3) Adonajğa da bolur sende jazyq. נתון. [10] Berme

(4) bergin anar da bušurganmasyn jüregij bergenijde anar

(5) ki sibbasyndan ošpu išnin alġyšlar seni Adonaj Tenrij bar

(6) išlerijde da bar sunuvunda qolujnun. כי [11] Ki

(7) eksilmesti bolmaqtan miskin ortasyndan ol jer-

(8) nin anyn üčün men bujuramen saja ajtadoġač ačma ačqyn

(9) ošol qolujnu qaryndašyja miskinije da jarlyja jerijde.

(10) כי [12] Ki satylsa saja qaryndašyj ol Jisra’el jemese

(11) ol Jisra’elka da qulluq etsin saja alty jyllar da ol

(12) jedinči jylda ijgin any azat qatyjdan. וכי [13] Da ki ij-

(13) sej any azat qatyjdan ijmegin any bošnu. העי [14]

(14) Berneleme bernelegin anar qojujdan da yndyryjdan da

(15) čaġyrbentijden ki alġyšlady seni Adonaj Tenrij bergin

(16) anarda. [15] Da saġynġyn ki qul edij jerin-

(17) de Micrinin da juludu seni Adonaj Tenrij anyn üčün men

(18) bujuramen saja ošol ol söznü ošpunu bügün.

(19) (16] Da bolġaj ki ajtsa saja čyqmanmen qatyjdan

(20) ki süvse seni da ošol elin üvüjnün ki jaḥšy bolsa

(21) anar birgeje. ולקחת [17] Da alğyn ošol ol bizni da

$307 \mathrm{v}^{\mathbf{0}} \quad$ (1) bergin qulag̉yna anyn da ešikke da bolur saja qul jovel-

(2) gedejin da hem qaravašyja da qylg̀yn alaj ${ }_{L}$ ki ijmegejsen any bošnu

(3) ančaq berne bergin anar jetkiligine köre küčünün

(4) qolujnun ${ }^{11}$. לא. [18] Qaty körünmesin közlerijde ijgenij-

(5) de any azat qatyjdan ki eki jaly tekli jalčyny qulluq

(6) etti saja alty jyllar da alġyšlar seni Adonaj Tenrij

(7) bar išinde qullaryjnyn ki qylsaj. כל. [19] Bar ol tun-

\footnotetext{
${ }^{1}$ Interpretative addition to the standard text.
} 
(1) release, is getting close," and your eye will look evilly against your poor brother,

(2) and you will not give him, and he will cry to the Lord against you,

(3) and it will be sin in you. [10] You shall surely give

(4) to him, and your heart shall not refuse to comply when you give to him:

(5) because for this thing the Lord your God will bless you in all

(6) your works and in all that you reach your hand out to. [11] Because

(7) the poor will never cease out of the land.

(8) On account of this I command you, saying, "You shall open

(9) your hand to your brother, to your poor, and to your needy in your land.

(10) [12] And if your brother, a Hebrew man or a Hebrew woman, is sold to you:

(11) and he shall serve you six years, and in the

(12) seventh year you shall let him go free from you. [13] And when

(13) you send him out free from you, you shall not send him empty. [14]

(14) You shall present him some of your flock and of your threshing-floor and

(15) of your winepress; as the Lord your God has blessed you, you shall give

(16) him, too. [15] And you shall remember that you were a slave in the land

(17) of Egypt, and the Lord your God redeemed you. On account of this I

(18) command you this word today.

(19) [16] And it shall be, if he says to you, "I will not go away from you,"

(20) because he loves you and your house, because it was good

(21) for him with you, [17] Then you shall take an awl and

(1) put it in his ear and in the door, and he shall be your servant

(2) forever. And you shall also do this to your maidservant, ${ }_{L}$ because you shall not send her empty,

(3) but you shall present her with that which your hand can attain ${ }^{1283}$.

(4) [18] It shall not seem hard in your eyes when you send

(5) him away free from you, because he served you for a wages equal to two wages of a hired servant

(6) for six years, and the Lord your God will bless you

(7) in all the works of your servants that you will do. [19] All the firstborn

283 An interpretative addition to Deu 15:17. 
(8) g guč ki tuvsa syg்yryjda da qojujda ol erkekni

(9) azizlikte tutqun Adonajğa Tenrije išlemegin tunğu-

(10) čun byla ögüzüjnün da qyrqmaġyn tunġučun qojujnun.

(11) \{לפני (20] Alnynda Adonajnyn ašaġyn any Limge ki jaravlydy ašama

(12) any ${ }^{11}$ har jylda ne orunda ki sajlasa Adonaj sen da eli

(13) üvüjnün. וכ21 Da ki bolsa anda ajip aqsaq

(14) jemese soqur nendijde jaman ajip debeḥa etmegin

(15) any Adonajğa Tenrije. בשעריך. [22] Šaharlaryjda ašağyn

(16) any ol murdar kiši da ol aruv kiši $\left\{\{[b] i r \text { tišli }\}^{2}\right.$ jürnü kibik da

(17) sog̉ag̉ny kibik. רק. 23] Ančaq ošol qanyn anyn ašamag்yn

(18) ol jer üstüne tökkün any suvnu kibik.

[Deuteronomy 16$]^{3}$

שמור $[1]$

(19) Saqlağyn ošol baš qusqan janġajny da qylg̀yn qarbanyn pesaḥ-

(20) nyn Adonajğa Tenrije ki ol baš qusqan janġajda čyġar-

(21) dy seni Adonaj Tenrij Micriden kečebyla. [2] Da

$308 r^{\circ} \quad$ (1) debeḥa etkin qarbanyn Pesaḥnyn Adonajğa Te\{n\}rije qoj

(2) da syğyr debeḥasyna šelamimnin ne orunda $\{\mathrm{ki}\}$ sajlasa

(3) Adonaj toḥtatma šemin özünün anda. לא. [3]

(4) Ašamaġyn anyn qatyna qužur ötmek jedi künler

(5) ašag̉yn anyn qatyna macalar qyjynly ötmek ki ašag்yš-

(6) lyq byla čyqtyj ${ }_{L}\{$ jeri $[$ nden $]\} \operatorname{Micri}\langle\operatorname{den}\rangle\{n i n\}^{14}$

(7) _anyn üčün ki

(8) saġyngajsen ošol čyqqan künüjnü jerinden Micrinin ${ }^{15}$ bar

(9) tirlik künlerijde. ולא. [4] Da körünmesin saja qu-

(10) čur bar čegijde jedi künler da qonmasyn ol etten

(11) ki debeḥa etsej ingird́a ol burunġu künge er-

(12) tenbylag̉a. לא. [5] Bolalmag̉yn debeha etme ošol qar-

(13) banyn ol Pesaḥnyn birisinde šaharlaryjnyn ki Adonaj Tenrij

\footnotetext{
${ }^{1}$ Interpretative addition to the standard text. $\quad{ }^{2}$ Marginal insertion by another hand. | TKow.o1: deest. | H: bir tirli. | C: deest. $\quad{ }^{3} \mathrm{~K}$ : The chapter number is not indicated. | TKow.ol: Deu 16. | H: Deu 16. | C: Deu 16. $\quad{ }^{4}$ Correction by another hand. | TKow.o1: jerinden Micrinin; unvocalized

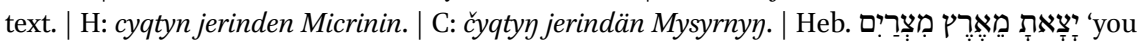
went out from the land of Egypt'. $\quad{ }^{5}$ Copied twice; dittography. The redundant repetition was crossed out by the copyist.
} 
(8) male that is born in your herd and in your flock

(9) you shall keep holy to the Lord your God. You shall do no work

(10) with the firstborn of your bull, and you shall not shear the firstborn of your sheep.

(11) [20] You shall eat it before the Lord your God, ${ }_{L}$ each man that which he is allowed to eat, ${ }^{1284}$

(12) every year in the place which the Lord shall choose, you and your

(13) household. [21] And if there is any blemish in it-lame

(14) or blind, any ill blemish-you shall not sacrifice

(15) it to the Lord your God. [22] You shall eat it within your cities,

(16) the unclean and the clean person |shall eat it| alike, like the deer and

(17) like the fawn. [23] Only: you shall not eat its blood.

(18) You shall pour it like water on the earth.

[Deuteronomy 16]

(19) Observe the month Baš Qusqan, and you shall make the a Passover sacrifice

(20) to the Lord your God, because in the month Baš Qusqan

(21) the Lord your God brought you out from Egypt at night. [2] And

(1) you shall make a Passover sacrifice to the Lord your God, sheep

(2) and cattle, for the sacrifice of the peace offering, in the place which

(3) the Lord shall choose to cause his name to dwell there. [3]

(4) You shall not eat leavened bread with it. Seven days

(5) you shall eat unleavened bread with it, the bread of affliction, because

(6) you went out from \{the land of $\}$ Egypt in haste-

(7) ${ }^{\text {so }}$ that you

(8) shall remember the day when you went out from the land of Egypt ${ }^{1285}$ all

(9) the days of your life. [4] And you shall not have leaven appear

(10) within all your borders for seven days, and none of the meat

(11) that you will sacrifice in the evening on the first day shall remain

(12) until dawn. [5] You may not sacrifice the

(13) Passover sacrifice within any of your cities which the Lord your God

284 An interpretative addition to Deu 15:20.

285 Copied twice; a scribal error. The redundant repetition was crossed out by the copyist. 
(14) beredi saja. כי [6] Ki ančaq ol orunga ki sajlasa

(15) Adonaj Tenrij any toḥtatma šemin özünün anda debe-

(16) ha etkin ošol qarbanyn ol Pesahnnyn ingirde enge-

(17) čoq ol qujaš vag̉dasynda čyqmag̉yjnyn Micriden.

(18) [7 [7 Da šišlegin da ašaġyn ne orunda ki

(19) sajlasa Adonaj Tenrij any da qajyrylgynn ertenbylada

(20) da barg̉yn čatyrlaryja. ששת. [8] Alty künler ašaġyn

(21) macalar da ol jedinči künde 'aceret Adonajğa Tenrije

$308 v^{0} \quad$ (1) Gylmaġyn iš. שבעה. [9] Jedi haftalar sanaġyn özüje bašlamaq

(2) vahttan $\{[\operatorname{sun}] m a\}^{1}$ oraq turuqta bašlagign sanama jedi haftalar.

(3) יועשית [10 [10 sanapsortun jedi haftalar ${ }^{12}$ ol vahtta

(4) qylġyn özüje hyžyn Šavu'otnun alnynda Adonaj Tenrijnin jet-

(5) kiliginden క̌omartlyġynyn qolujnun ki bersej ki nečik alġyšla-

(6) sa seni Adonaj Tenrij. ושמחת. [11] Da bijengin alnynda

(7) Adonaj Tenrijnin sen da uvluj da qyzyj da quluj da qaravašyj

(8) da ol Levi ki šaharlaryjda da ol garip da ol öksüz

(9) da ol tul ki ortajda ne orunda ki sajlasa Adonaj Ten-

(10) rij tohtatma šemin özünün anda. [12] Da

(11) saġynġyn ki qul edij jerinde Micrinin da saqlaġyn da qylġyn

(12) ošol ol resimlerni ošpularny. חג. [13] Hyžyn ol Sukotnun

(13) qylġyn özüje jedi künlük jyštyrg̉anyjda yndyryjdan da

(14) čaġyrbentijden. ושמחת] Da bijengin hyy̌̆lag̉anyjda sen da

(15) uvluj da qyzyj da quluj da qaravašyj da ol Levi da ol gararip

(16) da ol öksüz da ol tul ki šaharlaryjda. \{ושמחת.\} [15] Jedi künler

(17) hyžlağyn alnynda Adonaj Tenrijnin ne orunda ki sajlasa Adonaj

\footnotetext{
${ }^{1}$ TKow.o1: deest. | H: sunma. | C: deest. $\quad{ }^{2}$ Interpretative addition to the standard text.
} 
(14) is giving you. [6] But at the place which

(15) the Lord your God shall choose to cause his name to dwell there

(16) you shall sacrifice the Passover sacrifice at evening,

(17) at the going down of the sun, at the time that you went out from Egypt.

(18) [7] And you shall roast and eat it in the place which

(19) the Lord your God shall choose. And you shall turn at dawn,

(20) and you shall go to your tents. [8] Six days you shall eat

(21) unleavened bread. And on the seventh day: a solemn assembly to the Lord your God.

(1) You shall do no work |therein|. [9] Seven weeks you shall number to $308 \mathrm{v}^{\mathrm{o}}$ you:

(2) From the time the sickle begins to be [elevated] over the standing grain you shall begin to number the seven weeks.

(3) $[10]_{L}$ And after you have numbered seven weeks: ${ }^{1286}$ then

(4) you shall make for yourself the feast of Shavuot before the Lord your God,

(5) to the best of the abilities of the freewill offering of your hand, which you shall give as

(6) the Lord your God blesses you. [11] And you shall rejoice before

(7) the Lord your God-you and your son and your daughter and your servant and your maidservant

(8) and the Levite who is in your cities and the stranger and the orphan

(9) and the widow who are among you - in the place which the Lord

(10) your God will choose to cause his name to dwell there. [12] And

(11) you shall remember that you were a slave in the land of Egypt, and you shall keep and do

(12) these statutes. [13] Make yourself the feast of Sukkot,

(13) seven days long, when you gather from your threshing-floor and

(14) your winepress. [14] And you shall rejoice when you keep the feastyou and

(15) your son and your daughter and your servant and your maidservant and the Levite and the stranger

(16) and the orphan and the widow who are within your cities. [15] Seven days

(17) you shall keep the feast before the Lord your God in the place which the Lord will choose,

286 An interpretative addition to Deu 16:10. 
(18) ki alğyšlar seni Adonaj Tenri bar bitišijde da bar išinde

(19) qolujnun da bolursen tek bijenüvčü. שלוש. [16] Üč keretler

(20) jylda körünsün bar erkegij qyblalary alnyna Adonaj

(21) Tenrijnin ne orunda ki sajlasa hyžynda ol macalarnyn

$309 \mathrm{r}^{\mathrm{o}} \quad$ (1) da hyy̌ynda ol Šavu'otnun da hyžynda ol Sukotnun da

(2) körünmesinler alnynda qyblalarynyn Adonajnyn boš. איש. [17]

(3) Har kiši bernesine köre qolunun alġyšyna köre Adonaj-

(4) nyn Tenrijnin ki berdi saja.

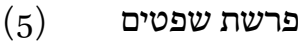

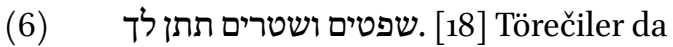

(7) tajaqčylar bergin özüje bar šaharlaryj-

(8) da ki Adonaj Tenrij ber[e]di ${ }^{1}$ saja ševetlarisajyn da töre

(9) etsinler ošol ol ulusnu rast törebyla.

(10) לא [19] Tajdyrmag்yn töreni jüz etmegin jüzlerge

(11) da almaġyn šoḥad ki ol šoḥad soqurajtady közlerin us-

(12) lularnyn da qyng்yrajtady sözlerin rastlarnyn. צדק. [20]

(13) Rastlyqny rastlyqny quvg̉un anyn üčün ki tiri bolġaj-

(14) sen da mereslegejsen ošol ol jerni ki Adonaj Tenrij

(15) beredi saja. לא. 21] Ornatmaġyn özüje ašera heč ag̉ač-

(16) tan mizbeahy qatyna Adonaj Tenrijnin ki qylsaj özüje.

(17) (22] Da turğuzmag்yn özüje maceva ki ḥor etti

(18) Adonaj Tenrij.

Deuteronomy $1[7]^{2}$

לא. [1] Debeha etmegin alnynda Adonaj-

(19) nyn ögüznü da qojnu ki bolsa anda ajip nendijde

$309 \mathrm{v}^{\mathbf{0}} \quad$ (1) jaman nerse ki hor etkenidi Adonajnyn Tenrijnin ol.

(2) כי . [2] Ki tabulsa ortajda birisind́a šaharlaryjnyn

(3) ki Adonaj Tenrij beredi saja kiši jemese qatyn ki qylsa

(4) ošol ol jamanlyqny 'enajatlary alnyna Adonaj Tenrijnin aš-

(5) ma šertin anyn. וילך [3] Da bardy da qulluq etti

(6) özge tenri\{ler\}ge da bašurdu alarg̉a da qujašqa

\footnotetext{
${ }^{1}$ K: Spelled ביריִירִ; a scribal error. | TKow.o1: unvocalized text. | H: beredi.| C: beräjdir. ${ }^{2}$ K: Deu 16; a scribal error. | TKow.o1: Deu 17. | H: Deu 17. | C: Deu 17.
} 
(18) because the Lord your God will bless you in all your produce and in all the works

(19) of your hands, and you shall just be happy. [16] Three times

(20) in a year all your males shall appear before the directions of the Lord

(21) your God in the place which he will choose: on the feast of Unleavened Bread,

(1) and on the feast of Shavuot and on the feast of Sukkot. And

(2) they shall not appear before the directions of the Lord empty: [17]

(3) each man according to the gift of his hand, according to the blessing of the Lord

(4) your God which he has given you.

(5) Parashat Shoftim

(6) [18] You shall put judges and

(7) overseers in all your cities

(8) which the Lord your God gives you, according to your tribes, and

(9) they shall judge the people with just judgment.

(10) [19] You shall not reject a judgment; you shall not favour,

(11) and you shall not take a bribe, because a bribe blinds the eyes

(12) of the wise and distorts the words of the righteous. [20]

(13) Justice, justice you shall follow, that you may live

(14) and inherit the land which the Lord your God

(15) is giving you. [21] You shall not plant any tree as an Asherah ${ }^{287}$

(16) beside the altar of the Lord your God that you shall make for yourself.

(17) [22] And you shall not set up a pillar which

(18) the Lord your God rejects.

Deuteronomy 1[7]

[1] You shall not sacrifice before the Lord

(19) any bull or sheep in which is a blemish, any

(1) bad thing, because that is an abomination to the Lord your God.

(2) [2] If there be found among you, within any of your cities

(3) which the Lord your God is giving you, a man or a woman who does

(4) what is bad in the eyes of the Lord your God,

(5) to transgress his covenant, [3] And has gone and served

(6) other gods and worshiped them, either the sun

287 Heb. אָאשָרָה 'Asherah; name of a sacred tree or pole'. 
(7) jemese ajġa jemese bar čerüvüne ol köklernin

(8) ki bujurmadym. [והוגד [4] Da anlatylsa saja da

(9) ešitsej da izlegin jahšy da muna kerti duğrudu

(10) ol söz qylyndy ol jerenči iš ošpu Jisra’elde.

(11) [והוצאת [5] Da čyg̉arg̉yn ošol ol kišini jemese o-

(12) šol ol qatynny ki qyldylar ošol ol jaman išni šahar-

(13) laryja ošol ol kišini jemese ošol ol qatynny da

(14) tašlag̉yn alarny tašlarbyla da ölsünler. על [6] Sözüne

(15) köre eki tanyqlarnyn jemese üč tanyqlarnyn öltürül-

(16) sün [o]11 ölümnü öltürülmesin sözüne köre bir

(17) tanyqnyn. יד [7] Qolu ol tanyqlarnyn bolsun anda burundan

(18) öltürme any da qolu bar ol ulusnun sonrada da ek-

(19) sitkin ol jamanny ortajdan. כי [8] Ki tamaša ${ }^{2}$ bolsa

(20) senden söz töre išinde arasyna qannyn qanbyla arasy-

(21) na jarg̉unu[n $]^{3}$ jarg̉ubyla da arasyna ḥastalyqnyn ḥastalyqbyla

$310 \mathrm{r}^{\mathrm{o}}$ (1) talaš sözleri šaharlaryjda da turg̉un barg̉yn ol orun-

(2) ga ki sajlasa Adonaj Tenrij any. ובאת. [9] Da kelgin ol

(3) kohenlerge ol Levililerge da ol törečige ki bolsa ol

(4) vaḥtlarda da sorgiun da a\{n\}latyrlar saja ošol sözün ol

(5) törenin. [10] Da qylgyyn ol sözge köre ki anlat-

(6) salar saja ol orundan ki sajlasa Adonaj da saqlag்yn qylma

(7) barča nečik ki üvretseler saja. על. [11] Ol üvre-

(8) tüvge köre ki üvretseler saja da ol törege

(9) köre ki ajtsalar saja qylġyn qajyrylmaġyn ol sözden ki

(10) anlatsalar saja on jary ani son jary. והאיש Da

(11) ol kiši ki qylsa čajalyq byla tynlamasqa ol kohenge ol

(12) turuvčuğa jumuš etme anda alnynda Adonaj Tenrijnin

(13) jemese ol törečige da ölsün ol kiši da eksit-

(14) kin ol jamanny Jisra'elden. וכל [13] Da bar Jisra'el ešit-

\footnotetext{
${ }^{1} \mathrm{~K}$ : Spelled איוֹ; a scribal error. | TKow.o1: ol; unvocalized text. | H: ol; different wording. | C: ol. ${ }^{2}$ Most likely a mistranslation repeated in a number of manuscripts. | TKow.o1: jašyryn; unvocal-

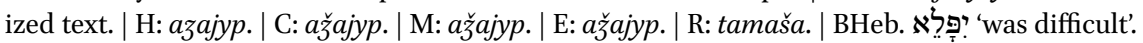

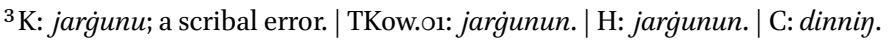


(7) or moon or any of the host of the skies

(8) which I have not commanded, [4] And it is told you, and

(9) you hear it, and you shall inquire diligently, and, lo, the word is true and certain,

(10) such a repulsive thing has been done in Israel,

(11) [5] Then you shall bring that man or that

(12) woman who has done that bad thing out to your cities,

(13) that man or that woman, and

(14) you shall stone them with stones, and they shall die. [6]

(15) According to the word of two witnesses or three witnesses,

(16) shall ${ }_{L}$ the one who is to die ${ }^{288}$ be killed. He shall not be killed according to the word of one

(17) witness. [7] The hands of the witnesses shall be first on him

(18) to kill him, and afterward the hands of all the people. And

(19) you shall remove the evil from among you. [8] If

(20) a matter ${ }_{L}$ is too wonderful ${ }^{1289}$ for you in judicial matters, between blood and blood,

(21) between verdict and verdict, and between illness and illness,

(1) matters of strife in your cities, then you shall arise and go

(2) up to the place which the Lord your God will choose. [9] And you shall come

(3) to the priests, the Levites, and to the judge that shall be

(4) in that time, and you shall inquire, and they will tell the word

(5) of judgment. [10] And you shall do according to the word which they

(6) will tell you from that place which the Lord shall choose, and you shall be watchful to do

(7) according to all that they will teach you. [11] You shall do |it|

(8) according to the teaching of the law which they will teach you and according to the judgment

(9) which they will say you. You shall not turn from the word which

(10) they will tell you, to the right or to the left. [12] And

(11) the man who will make an intrigue, not listening to the priest

(12) who is standing to minister there before the Lord your God,

(13) or to the judge: that man shall die. And you shall remove

(14) the evil from Israel. [13] And all the people

288 Lit. 'death'.

289 Most likely a mistranslation of BHeb. יפּּל the verb פ' פלא. to be extraordinary, to be difficult; to be wonderful'-instead of the correct will be too difficult. Repeated in a number of Karaim translations. 
(15) sinler da qorqsunlar da čajalyq etmesinler artyq.

(16) כי (14] Ki kelsej ol jerge ki Adonaj Tenrij beredi saja

(17) da mereslesej any da oltursaj anda da ajtsaj

(18) qojajym üstüme bij bar ol ḥanlyqlar kibik ki čüv-

(19) relerimde. שום [15] Qojma qojgiun üstüje bij

(20) ki sajlasa Adonaj Tenrij any ortasyndan qaryndašlaryjnyn

(21) qojğun üstüje bij bolalmaġyn berme üstüje jat

$310 v^{0}$ (1) kišini ki tüvüldü qaryndašyj ol. רק. [16] Ančaq ar-

(2) ttyrmasyn özüne atlar da qajtarmasyn ošol ol ulus-

(3) nu Micrige arttyrmaq üčün at da Adonaj ajtty

(4) sizge arttyrmajyz qajtma ošpu jolbyla artyq.

(5) ולא (17] Da arttyrmasyn özüne qatynlar da qajyrylma-

(6) syn jüregi anyn da kümüš da altyn arttyrmasyn ö-

(7) züne astry. [18] Da olturganyndačoq bijlik

(8) taḥty üstüne da jazsyn özüne ošol mišne ol

(9) Torany ošpunu sefer üstüne alnyndan ol kohen-

(10) lornin ol Levililernin. [19] Da bolsun birgesine

(11) da oḥusun any bar tirlik künlerinde anyn üčün

(12) ki üvrengej qorqma Adonaj Tenrisinden özünün

(13) saqlama ošol bar sözlerin ol Toranyn ošpunun da

(14) ošol ol resimlerni ošpularny qylma alarny.

(15) (20] Öktemrek bolmasqa jüregi any qaryndaš-

(16) laryndan da qajy\{ry\}lmasqa ol micvadan on jary ani son jary

(17) anyn üčün ki uzartqaj künler bijligi üstüne ol

(18) da uvullary anyn ortasynda Jisra’elnin.

Deuteronomy $1[8]^{1}$

(19) masyn kohenlerge ol Levililerge bar ševetine Levinin ülüšs

(20) da tijiš Jisra’el byla otlu qarbanlaryn Adonajnyn da

(21) ülüšün anyn ašasynlar. ונחלה. [2] Da ülüšs bolmasyn

$311 \mathrm{r}^{\circ} \quad$ (1) anar ortasynda qaryndašlarynyn Adonaj oldu ülüšü anyn

(2) ki nečik sözledi anar. [3] Da bu bolsun kečinmegi

(3) ol kohenlernin ol ulustan debeha etüvčülerden ol

\footnotetext{
${ }^{1}$ K: Deu 16. | TKow.o1: Deu 18. | H: Deu 18. | C: Deu 18.
} 
(15) shall hear and fear and make no intrigue anymore.

(16) [14] When you will come to the land which the Lord your God is giving you,

(17) and you will inherit it and dwell in it and say,

(18) "Let me set a king over me like all the kingdoms that

(19) are around me," [15] You shall surely set a king over you,

(20) whom the Lord your God shall choose. You shall set a king from among your brothers

(21) over you. You may not set a foreigner over you,

(1) who is not your brother. [16] But

(2) he shall not multiply horses to himself, and he shall not bring the people back

(3) to Egypt in order to multiply horses. And the Lord has said

(4) to you, "You shall not return that way anymore."

(5) [17] And he shall not multiply wives to himself so

(6) his heart will not turn away. And he shall not multiply greatly to himself silver and gold.

(7) [18] And when he sits on the throne of his kingdom,

(8) he shall write himself a copy of

(9) this Law on a scroll from in front of the priests

(10) the Levites. [19] And it shall be with him,

(11) and he shall read it all the days of his life, so that

(12) he will learn to fear the Lord his God,

(13) to keep all the words of this Law and

(14) these statutes, to do them,

(15) [20] So his heart will not be prouder than his brothers,

(16) and so he will not turn from the commandment, to the right or to the left;

(17) so that he may prolong his days over his kingdom, he

(18) and his children, among Israel.

Deuteronomy $1[8]$

$[1]$

(19) The priests, the Levites, all the tribe of Levi, shall have no portion or

(20) or share with Israel. They shall eat the Lord's offerings by fire

(21) and his portion. [2] But he shall have no portion

(1) among their brothers. The Lord: he is his portion,

(2) as he has spoken to him. [3] And this shall be the handling

(3) of the priests by the people, by those doing 
(4) debehany hem ögüznü hem qojnu da bersin kohenge

(5) ol bilekni da ol jajaqlarny da ol aqšynny.

(6) [4] [lkin bürtügüjnün šarbetijnin da sajy-

(7) jnyn da ilkin qyrqmağynyn qojujnun bergin anar. כ5] [5]

(8) Ki any sajlady Adonaj bar ševetlerijden turma jumuš et-

(9) me atybyla Adonajnyn ol da uvullary anyn bar ol

(10) künlerni. וכי [6] Da ki kelse ol Levi birisinden

(11) šaharlaryjnyn bar Jisra'elden ki ol tiriledi anda da

(12) kelse bar küsengende žany anyn ol orunġa ki

(13) sajlasa Adonaj. ושרת. [7 Da jumuš etsin atyby-

(14) la Adonaj Tenrisinin bar qaryndašlary kibik ol Levililer

(15) ol turuvčular anda alnynda Adonajnyn. חלק. [8]

(16) Har ülüšnü ten ašasynlar \{üvüsajyn ol atalarnyn\} bašqa satmaqlaryndan anyn

(17) kim ki satsa öz ülüšün. כי [9] Ki sen kelesen ol

(18) jerge ki Adonaj Tenrij beredi saja üvrenmegin qyl-

(19) ma jerenči išleri kibik ol ḥanlyqlarnyn alarnyn.

(20) לא (10] Tabulmasyn sende ašyruvču uvlun da qyzyn ot-

(21) ta qusnačylyq etüvčü qusnačylyqlar sahatny sajlavču

$311 v^{0} \quad$ (1) da ${ }_{\perp}\{\text { synčylavču da žaduvluq etüvčǔ }\}^{11}$. וחובר] $]^{2}$. [11] Da 〈jyštyruvču〉

(2) jyštyruvču jyštyrmaq [šajtanlarnyn] ${ }^{3}$ da soruvču qamdan da bildečiden

(3) da jalbaruvču ol ölülerge. כי. [12] \{Ki\} ḥor etkenidi

(4) Adonajnyn bar qyluvču bularny da sibbasyndan ol jerenči

(5) išlernin ošpularnyn Adonaj Tenrij tasetedi alarny

(6) alnyjdan. [13] Tügel bolg̀un qullugiunda Adonaj

(7) Tenrijnin. כי . [14] Ki ol ḥanlyqlar ošpular ki sen tase-

(8) tesen alarny sahatny sajlavčularg̉a da qusnačylyq etüv-

(9) čülerge tynlarediler da sen tüvül alaj berdi saja

(10) Adonaj Tenrij. [ביא] Navi ortajdan qaryndašlaryjdan

(11) menim kibik turg̉uzur saja Adonaj Tenrij anyn sözü-

(12) ne tynlajyz. ככל [16] Barča nečik ki kledij Adonaj

(13) Tenrijden Ḥorevde ol jyštyrylmaq künde ajtado-

(14) gač arttyrmajym ešitme ošol ünün Adonaj-

(15) nyn Tenrimnin da ošol ol ullu otnu ošpunu

\footnotetext{
${ }^{1} \mathrm{~K}$ : originally žaduvluq etüvčü da synčylavču; the word order was corrected by the copyist. $\quad{ }^{2} \mathrm{~K}$ :

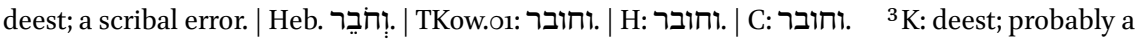
scribal error. | TKow.o1: deest; unvocalized text. | H: sajtanlarnyn. | C: deest; different wording. | $\mathrm{R}$ : deest; different wording.
} 
(4) a sacrifice, whether cattle or sheep: he shall give to the priest

(5) the forearm, and the cheeks, and the stomach.

(6) [4 You shall give him the first of your grain, of your must, and

(7) of your olive oil, and the first of the shearing of your sheep. [5]

(8) Because the Lord your God has chosen him from all your tribes to stand to minister

(9) in the name of the Lord, him and his sons, for all

(10) days. [6] And if a Levite comes from one of

(11) your cities, from all Israel, where he lives, and

(12) if he comes with all the desire of his soul to the place which

(13) the Lord shall choose, [7] Then he shall minister

(14) in the name of the Lord his God, like all his brothers, the Levites,

(15) who are standing there before the Lord. [8]

(16) They shall eat equal portion, according to the house of their fathers, besides his sales

(17) if he sales his own portion. [9] Because you are coming

(18) to the land which the Lord your God is giving you: you shall not learn to do

(19) like the repulsive things of their kingdoms.

(20) [10] There shall not be found among you anyone who makes his son or his daughter pass through fire,

(21) or who does witchcraft, tells fortune,

(1) practices divination, does sorcery, [11] Or who gathers

(2) the gathering [of devils], and who asks of a wizard or a soothsayer,

(3) and who prays to the dead. [12] Because everyone

(4) who does these things is an abomination to the Lord, and because of these repulsive

(5) things the Lord your God is destroying them

(6) from before you. [13] You shall be perfect in the service of the Lord

(7) your God, [14] Because these kingdoms which you are destroying

(8) hearkened to fortune tellers and to witchcraft doers.

(9) But you: the Lord your God has allowed not such for you.

(10) [15] The Lord your God will raise up for you a prophet from among you, from your brothers,

(11) like me. You shall listen to his word.

(12) [16] According to all that you desired of the Lord

(13) your God in Horeb in the day of the assembly, saying,

(14) "Let me not hear any more the voice of the Lord

(15) my God, and let me not see this great fire 
(16) körmejim artyq da ölmejim. [יאמר [17] Da ajt-

(17) ty Adonaj maja jaḩšy ettiler ošol neki sözledi-

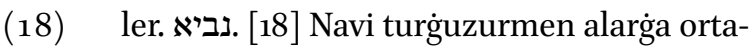

(19) syndan qaryndašlarynyn senin kibikni da berirmen söz-

(20) lerimni avzuna anyn da sözler alarg̉a ošol ne

(21) bujursam anar. והיה] [19] Da bolg̀aj ol kiši ki tyn-

$312 \mathrm{r}^{\mathrm{0}} \quad$ (1) lamasa sözlerime ki sözlese šemim byla men izler-

(2) men andan. אך. [20] Tek ol navi ki čajalyq etse söz-

(3) leme da ki sözlese aty byla özge tenriler-

(4) nin da öler ol navi ol. וכ2 [21 Da ki ajt-

(5) saj kölnüjden nečik bilejik ošol ol söznü ki söz-

(6) lemedi Adonaj. אשר. [22] Ki sözlese ol navi šemi-

(7) byla Adonajnyn da bolmasa ol söz da kelmese ol-

(8) du ol söz ki sözlemedi $\{[\text { any }]\}^{1}$ Adonaj čajalyqbyla sözledi

(9) any ol navi qorqmag்yn andan.

Deuteronomy $1[9]^{2}$

$$
\text { כ. [1] Ki eksit[se }]^{3}
$$

(10) Adonaj Tenrij alnyjdan ošol ol hanlyqlarny ki

(11) Adonaj Tenrij beredi saja ošol jerlerin alarnyn da

(12) mereslesej alarny da oltursaj šaharlarynda da

(13) üvlerinde alarnyn. שלוש. [2] Üč šaharlar ajyrg்yn

(14) özüje ortasynda jerijnin ki Adonaj Tenrij beredi

(15) saja meresleme any. תכ3] Tüzügün özüje

(16) ol jolnu da üčke üleškin ošol čegin jerijnin ki

(17) ülüš berse saja Adonaj Tenrij da bolsun qačma

(18) ary bar qaraqčy. וזה [4] Da budu iši ol qaraqčynyn

(19) ki qačsyn ary da tiri bolsun ki öltü\{r\}se ošol dos-

(20) tun bilmejinče da ol dušman tüvül edi anar tü-

(21) neden biri künden. ואשר. [5] Da ki kelse dostubyla

$312 \mathrm{~V}^{\mathrm{o}} \quad$ (1) ormanga kesme otunlar da sunulsa qolu anyn balt[a]-

(2) byla ${ }^{4}$ kesme ol ag̉ačny da suvurulsa ol temir ol

(3) ag̉ačtan da tapsa ošol dostun da ölse ol qačsyn

(4) birisine ol šaharlarnyn ošpularnyn da tiri bolsun.

\footnotetext{
${ }^{1}$ TKow.o1: any; unvocalized text. | H: any. | C: any. $\quad{ }^{2}$ K: Deu 17; a scribal error. | TKow.o1: Deu 19. | H: Deu 19. | C: Deu 19. $\quad{ }^{3} \mathrm{~K}$ : eksit saja; a scribal error. | TKow.o1: eksitse; unvocalized text. | H: eksitse. | C: kässe. $\quad{ }^{4} \mathrm{~K}$ : baltbyla; a scribal error. | TKow.o1: unvocalized text. | H: balta byla. | C: baltadan; different wording.
} 
(16) anymore, so I will not die." [17] And

(17) the Lord said to me, "They have well done that

(18) they have spoken. [18] I will raise up for them a prophet

(19) from among their brothers, one like you, and I will put my words

(20) in his mouth. And he will speak to them all that

(21) I shall command him. [19] And it shall be: the man who

(1) will not listen to my words which he shall speak in my name, I

(2) will seek it from him. [20] Just: the prophet who will intrigue

(3) to speak and who will speak in the name of other gods-

(4) that prophet will die". [21] And if you say

(5) from your heart, "How shall we know the word which

(6) the Lord has not spoken?"-[22] If a prophet speaks in the name

(7) of the Lord, and the word will not be and does not come |to pass|:

(8) that is the word that the Lord has not spoken. The prophet has spoken it insolently.

(9) You shall not be afraid of him.

Deuteronomy 1[9]

(10) the Lord your God will drive away the kingdoms whose

(11) land the Lord your God is giving you, and

(12) you will inherit them, and you will dwell in their cities and

(13) in their houses, [2] You shall set apart three cities

(14) for you in the midst of your land which the Lord your God gives

(15) you to inherit it. [3] You shall smoothen you

(16) a way and divide into three parts the border of your land that

(17) the Lord your God will give you for inheritance, and it shall be

(18) for any murderer to flee there. [4] And this is the case of the murderer,

(19) who shall flee there and live: If anyone kills his fellow

(20) without knowing, and he was not his enemy

(21) for long, [5] and if a man comes with his fellow

(1) into the forest to cut wood, and his hand is reached out with the axe

(2) to cut down the tree, and the iron comes off the

(3) wood and finds his fellow, and he dies: he shall flee

(4) to one of those cities, and live, 
(5) [6] Mag̉at quvar gečegesi ol qannyn artyndan ol

(6) qaraqčynyn ki qyzyšsa jüregi anyn da jeter any ki köp

(7) bolsa ol jol da vatyr any čyqqynča žany anyn da

(8) anar joḥtu ölüm töresi ki dušman tüvül edi ol

(9) anar tüneden biri künden. על [7] Anyn üčün men bujura-

(10) men saja ajtadoġač üč šaharlar ajyrġyn özüja.

(11) ואם (8] Da eger kenertse Adonaj Tenrij ošol

(12) čegijni ki nečik antetti atalaryja da berse saja

(13) ošol bar ol jerni ki sözledi berme atalaryja. כי. [9]

(14) Ki saqlasaj ošol bar ol micvany ošpunu qylma any ki

(15) men bujuramen saja bügün süvme ošol qullugiun Adonaj

(16) Tenrijnin da jürüme jollarybyla anyn bar ol künlerde

(17) da arttyrg்yn özüje daġyn üč šaharlar ol üč üs-

(18) tüne ošpular. ולא. [10] Da tögülmesin könü qan or-

(19) tasynda jerijnin ki Adonaj Tenrij beredi saja ülüš

(20) da bolur üstüje borču qanlarnyn. [11] Da ki

(21) bolsa kiši dušman dostuna da andysa anar da

$313 \mathrm{r}^{\circ} \quad$ (1) tursa anyn üstüne da vatsa any čyqqynča žany anyn

(2) da ölse da qačsa birisine ol šaharlarnyn oš-

(3) pularnyn. ושלחו [12] Da ijsinler qartlary šaharynyn da

(4) alsynlar any andan da bersinler ${ }^{1}$ any qoluna gečegesinin

(5) ol qannyn da ölsün. לא. [13] Hajifsünmesin közüj anyn

(6) üstüne da eksitkin borčun ol könü qannyn Jisra’el-

(7) den da jahšsy bolur saja. לא. [14] Jylyštyrmag̉yn čegin dos-

(8) tujnun ki čeklediler burungublar ülüšüjde ki ülüš

(9) alsaj jerde ki Adonaj Tenrij b[e]r[e]di² saja meresleme

(10) any. לא. [15] Turmasyn bir tanyq kiši üčün nendijde

(11) güneh üčün da nendijde jazyq üčün bar jazyq üčün ki

(12) jazyqly bolsa sözüne köre eki tanyqlarnyn jemese

(13) sözüne köre üč tanyqlarnyn qajjam bolsun söz. כי [16]

(14) Ki tursa avančy tanyq kišide tanyqlyq berme anyn

${ }^{1} \mathrm{~K}$ : beresinler; a scribal error. | TKow.o1: unvocalized text. | H: bersinler. |C: bersinlär. $\quad{ }^{2} \mathrm{~K}$ : biride; a scribal error. | TKow.o1: unvocalized text. | H: beredi. | C: beräjdir. 
(5) [6] Lest the avenger of blood will pursue after

(6) the murderer, while his heart grows warm and will catch up with him because

(7) the way is much ${ }^{290}$, and he smites him until his soul leaves $\mid$ him $\mid$, whereas

(8) he has no sentence of death, because he was not an enemy

(9) to him for a long. [7] On account of this I command

(10) you, saying, "You shall set apart three cities for you."

(11) [8] And if the Lord your God will widen

(12) your border, as he has sworn to your fathers, and will give you

(13) all the land which he promised to give to your fathers, [9]

(14) If you keep all these commandments to do them, which

(15) I command you today, to love the service of Lord

(16) your God and to walk in his ways every day,

(17) then you shall add three more cities for you, to these

(18) three. [10] So innocent blood will not be spilled

(19) in the midst of your land that the Lord your God is giving you for an inheritance,

(20) and the guilt of blood would be on you. [11] But if

(21) there is a man who is an enemy to his fellow and lies in wait for him and

(1) rises up against him and smites him until his soul leaves |him|,

(2) and he dies, and he flees to one of

(3) these cities, [12] Then the elders of his city shall send and

(4) take him from there and give him to the hand of the avenger

(5) of blood, so he will die. [13] Your eye shall not pity him,

(6) but you shall drive away the guilt of innocent blood from Israel,

(7) and it will be good for you. [14] You shall not move your neighbour's border

(8) that the first ones set, in your inheritance which you shall inherit

(9) in the land that the Lord your God is [giving] you to inherit

(10) it. [15] One witness shall not rise up against a man for any

(11) iniquity or for any sin, in any sin that

(12) he sins. According to the word of two witnesses or

(13) according to the word of three witnesses shall the matter be established. [16]

(14) If a sinful witness rises up against any man to testify

290 A literal translation of Heb. ירֶֶֶ? 'it will be numerous'. | TKow.or: much. | H: much. | C: much. 
(15) üstüne tanmaq söz. ועמדו [17] Da tursunlar eki

(16) ol erenler ki alarnyndy ol töre alnynda Adonajnyn

(17) alnynda ol kohenlernin da ol törečilernin ki bolsalar

(18) ol vaḥtlarda. ודרשו. [18] Da izlesinler jaḩ̌šy ol

(19) törečiler da muna jalġan tanyqty ol tanyq jalġanlyq-

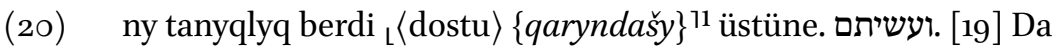

(21) qylyjyz anar ki nečik saġyš etti qylma qaryndašyna

$313 \mathrm{v}^{\mathrm{o}}$ (1) da eksitkin ol jamanny ortajdan. והנשארים. [20] Da

(2) ol qalğanlar ešitsinler da qorqsunlar da arttyrma-

(3) synlar qylma ol jaman iš kibik ošpu ortajda.

(4) ולא [21] Da hajifsünmesin közün žan క̌an ornuna

(5) köz köz ornuna tiš tiš ornuna qol qol or-

(6) nuna ajaq ajaq ornuna.

Deuteronomy $[20]^{2}$

(7) ge dušmanlaryj üstüne da körsej at da markav

(8) köprek ulus senden qorqmağyn alardan ki bolušluğu

(9) Adonaj Tenrijnin birgeje ol čyġaruvčunun seni jerinden Mic-

(10) rinin. [2] Da bolġaj juvuġanyjyzdačoq ol čerüv-

(11) ge da juvusun ol kohen da sözlesin ol ulusqa.

(12] Da ajtsyn alarg̉a tynlag̉yn e Jisra'el

(13) siz juvujsiz bügün čerüvge dušmanlaryjyz üstüne

(14) jymšalmasyn jüregijiz qorqmajyz da ašyqmajyz da

(15) Synyqmajyz alynlaryndan alarnyn. [4] Ki Adonaj Tenrijiz

(16) šehinasy anyn \{oldu $\}$ ol baruvču birgejizge urušma siznin üč[ün] $]^{3}$

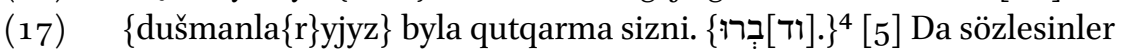
ol tajaqčylar

(18) ol ulusqa ajtadoġač qajsy ol kiši ki qondardy üv

(19) da qutlamady any barsyn da qajtsyn üvüne mag̉at öler

(20) čerüvde da özge kiši qutlar any. [6]

(21) Da qajsy ol kiši ki ornatty borlalyq da alajoqqa

$314 \mathrm{r}^{\mathrm{o}} \quad$ (1) čyġarmady any barsyn da qajtsyn üvüne mag̉at öler

(2) čerüvde da özge kiši alajoqqa čyğaryr any. ומי [7]

(3) Da qajsy ol kiši ki kelešti qatyn da almady any bar-

\footnotetext{
${ }^{1}$ Correction by another hand. | TKow.o1: qaryndašy; unvocalized text. | H: qaryndasy. | C: qardašy. $\quad{ }^{2}$ K: Deu 18; a scribal error. | TKow.o1: Deu 20. | H: Deu 20. | C: Deu $20 . \quad{ }^{3}$ TKow.o1: üčün; unvocalized text. | H: icin. | C: učun. ${ }^{4}$ Marginal insertion by another hand. | Heb. ודברו.
} 
(15) against him a word of trespass, [17] And the two

(16) men who have the trial shall stand before the Lord,

(17) before the priests and the judges who shall be

(18) in that time, [18] And the judges shall inquire well,

(19) and, lo, if the witness is a false witness and has

(20) testified falsely against his $\langle$ fellow $\rangle$ \{brother\}, [19] Then

(21) you shall do to him as he had thought to do to his brother.

(1) So shall you drive the evil away from among you. [20] And

(2) those who remain shall hear and fear, and they shall not continue

(3) to do anything like this bad thing among you.

(4) [21] And your eye shall not pity: life for life,

(5) eye for eye, tooth for tooth, hand for hand,

(6) foot for foot.

Deuteronomy [20]

[1] When you will go out to battle

(7) against your enemies, and you will see horses and chariots

(8) and a people more than you, you shall not be afraid of them, because the help

(9) of the Lord your God is with you, who brought you out from the land

(10) of Egypt. [2] And it shall be, when you come near to the war,

(11) the priest shall come near and speak to the people.

(12) [3] And he shall say to them, "Hear, oh Israel,

(13) you are coming near to war against your enemies today.

(14) Let not your hearts soften. Do not fear and do not panic and

(15) do not despond before them. [4] Because the Lord your God,

(16) his divine Presence is that goes with you to fight [for] you

(17) against your enemies, to save you." [5] And the overseers shall speak

(18) to the people, saying, "Which is the man who has built

(19) a house, and has not dedicated it? Let him go and return to his house, lest he die

(20) in the battle, and, in the same way, another man dedicate it. [6]

(21) And which is the man who has planted a vineyard, and, in the same way,

(1) has not yet harvested it? Let him go and return to his house, lest he die

(2) in the battle, and, in the same way, another man harvest it. [7]

(3) And which is the man who has betrothed a wife, and has not taken her? 
(4) syn da qajtsyn üvüne magiat öler čerüvde da öz-

(5) ge kiši alyr any. ויספו. [8] Da arttyrsynlar

(6) ol tajaqčylar sözleme ol ulusqa da ajtsynlar

(7) qajsy ol kiši ol qorquvču öltürme özgeni da

(8) jymšaq jürekli öltürülme özü andij barsyn da

(9) qajtsyn üvüne da iritmesin ošol jüregin qaryn-

(10) dašlarynyn öz jüregin kibik. והיה [9] Da bolġaj tü-

(11) gellegečoq ol tajaqčylar sözleme ol ulusqa da

(12) symarlasynlar ag̉alyqlaryn čerüvlernin bašynda ol ulus-

(13) nun. כי . [10] Ki juvusaj šaharg̉a urušma anyn byla

(14) da čaġyrg்yn anar ba\{z\}lyqqa. והיה [11] Da bolġaj eger

(15) bazlyqny qaruv berse saja da ačsa qabaġyn saja da

(16) bolġaj bar ol ulus ol tabulganan anda bolsunlar saja

(17) jasaq bermekke da qulluq etsinler saja. ואם. [12]

(18) Da eger bazlašmasa birgeje da qylsa birgeje čerüv

(19) da qysyqlyq etkin anar. [13] Da berse any

(20) Adonaj Tenrij qoluja da qyrg̉yn ošol bar erkegin anyn

(21) qylyč avzundan. רק. [14] Tek ol qatynlarny da ol jašny

$314 \mathrm{v}^{\mathrm{o}} \quad$ (1) da ol tuvarny da barča neki bolsa šaharda bar malyn anyn

(2) talağyn özüje da ašag̉yn ošol olక̌asyn dušmanlaryjnyn ki

(3) berdi Adonaj Tenrij saja. כן. [15] Alaj qylġyn bar ol šahar-

(4) larg̉a ol jyraqtagilarga senden astry ki tüvüldü šahar-

(5) laryndan ol hananlyqlarnyn ošpularnyn alar. רק. [16] Ančaq

(6) šaharlaryndan ol uluslarnyn ošpularnyn ki Adonaj Tenrij

(7) beredi saja ülüš tiri qaldyrmag̉yn heč žanny. כי. [17]

(8) Ki veren etme veren etkin alarny ol Ḥitini da ol

(9) Emorini ol Kena'anini da ol Perizini ol Ḥivini da ol

(10) Jevusini ki nečik bujurdu saja Adonaj Tenrij. למען. [18]

(11) Anyn üčün ki üvretmegejler sizni qylma bar jerenči

(12) išleri kibik özlerinin ki qyldylar abaqlaryna da jazyqly

(13) bolursiz Adonajgia Tenrijizge. כי. [19] Ki qysyqlyq

(14) etsej šaharga köp künler ${ }_{L}\{[\mathrm{u}] \text { rušma }[\text { any }] n \text { byla }\}^{11}$ tutma any čejpamaġyn o-

(15) šol jemiš ag̉ačyn anyn sunma anyn üstüne balta ki

(16) andan ašarsen da any kesmegin kelḿa alnyjdan qysyq-

(17) lyqqa ki tirlikĺa\{ri\}di ol adamnyn jemiš ağačy ol tüznün.

(18) - [20] Tek ag̉ačny ki bilsej ki tüvüldü jemiš berüvčü

\footnotetext{
${ }^{1}$ Marginal insertion by another hand. | TKow.o1: urušma anyn byla; unvocalized text. | H: orusma anyn byla. | C: urušma üstünä.
} 
(4) Let him go and return to his house, lest he die in the battle, and

(5) another man take her." [8] And the

(6) overseers shall continue speaking to the people, and they shall say,

(7) "Which is the man who fears to kill another $|\operatorname{man}|$ and

(8) is $\mid$ too $\mid$ soft-hearted to be killed? Let such a man go and

(9) return to his house, so he will not melt his brothers' heart

(10) like his heart." [9] And it shall be,

(11) when the overseers finish speaking to the people,

(12) that they shall appoint the superiors of the armies at the head of the people.

(13) [10] When you come near to a city to fight against it,

(14) you shall call to it for peace. [11] And it shall be,

(15) if it makes to you an answer of peace and opens its gates to you, then

(16) it shall be, that all the people that are found in shall be for you

(17) to pay tribute, and they shall serve you. [12]

(18) And if it makes no peace with you, but will make war against you,

(19) then you shall oppress it. [13] And when

(20) the Lord your God gives it into your hands, you shall slay all its males

(21) with the edge of the sword. [14] Just: the women and the infants

(1) and the cattle and all that is in the city, all its goods:

(2) you shall plunder for yourselves. And you shall eat the spoil of your enemies which

(3) the Lord your God has given you. [15] Thus you shall do to all the cities

(4) which are very far from you, which are not of the cities

(5) of these kingdoms. [16] But

(6) of the cities of these people which the Lord your God

(7) is giving you for an inheritance, you shall not leave any soul alive. [17]

(8) Because you shall utterly destroy them - the Hittites and the

(9) Amorites, the Canaanites and the Perizzites, the Hivites and the

(10) Jebusites - as the Lord your God has commanded you, [18]

(11) so that they may not teach you to do like all their repulsive

(12) things which they have done to their gods, and so you sin

(13) against the Lord your God. [19] When you oppress

(14) a city for many days, $\{$ to make war against [it]\}, to take it, you shall not destroy

(15) its fruit trees by elevating an axe against them, because

(16) you will eat from it, so you shall not cut them down so that they go from in front of you

(17) for oppression, because the fruit tree of the field is man's life.

(18) [20] Only a tree that you know that it is not a tree that gives fruits: 
(19) ag̉ač ol any čejpaġyn da keskin da qondarg̉yn beklik ol

(20) šahar qatyna ki ol qyldy birgeje čerüv engeninedejin.

Deuteronomy $[21]^{1}$

(21) כי (1) Ki tabulsa qyran jerde ki Adonaj Tenrij beredi saja

$315 \mathrm{r}^{\mathrm{o}} \quad$ (1) meresleme any tüšken tüzde bilinmese kim öltür-

(2) dü any. [2] Da čyqsynlar qartlaryj da törečilerij

(3) da ölčesinler ol šaharlarg̉a ki čüvrelerinde ol qyran-

(4) nyn. [3] Da bolgaj ol šahar ol juvuqraq ol qyranġa

(5) da alsynlar qartlary ol šaharnyn buzovun syġyrnyn ki iš-

(6) lenmedi anyn byla ki tartmady bojunsabyla. והורדו. [4]

(7) Da endirsinler qartlary ol šaharnyn ošol ol buzovnu

(8) qaty eniške ki išlenmejdi anda da čačylmajdy

(9) da enselesinler anda ošol ol buzovnu enište.

(50) [5] Da juvusunlar ol kohenler uvullary Levinin ki

(11) alarny sajlady Adonaj Tenrij jumuš etme özüne da

(12) alġyšlama Jisra’elni šemi byla Adonajnyn da alarnyn söz-

(13) lerine köre bolady bar jargiu da bar hastalyq. וכל. [6]

(14) Da bar qartlary ol šaharnyn ol juvuqraqlar ol qyranġa

(15) juvsunlar ošol qollaryn özlerinin ol buzov üstü-

(16) ne ol enselengen enište özen qatyna. וענו. [7]

(17) Da bašlasynlar da ajtsynlar qollarymyz tökmediler

(18) ošol ol qanny ošpunu da közlerimiz körmediler any

(19) kim ki öltürdü any. כפר. [8] Bošatqyn jazyġyn ulusuj-

(20) \{nun\} Jisra’elnin ki juluduj e Adonaj da bermegin borčun könü

(21) qannyn ortasynda ulusujnun Jisra'elnin da bošatylyr

$315 \mathrm{~V}^{\mathrm{o}}$ (1) alarg̉a borču ol könü qannyn. ואתה [9] Da \{sen\} eksitir-

(2) \{sen\} borčun ol könü qannyn ortajdan ki qylsaj ol tüz kö-

(3) rüngenni 'enajatlarynda Adonajnyn.

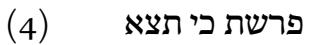

(5) (10] Ki čyqsaj čerüvge

(6) dušmanlaryj üstüne da berse any Adonaj

(7) Tenrij qoluja da jesir etsej jesirin anyn. וראית [11]

${ }^{1}$ K: Deu 19; a scribal error. | TKow.o1: Deu 21. | H: Deu 21. | C: Deu 21. 
(19) you shall destroy it and cut it down, and you shall build a fortress

(20) against the city that makes war with you, until it falls.

Deuteronomy [21]

(21) [1] If a dead $|\mathrm{man}|$ is found in the land which the Lord your God is giving to you

(1) to possess, fallen in the field, |and| if it is not known who has killed

(2) him, [2] Then your elders and your judges shall come out,

(3) and they shall measure to the cities which are around the dead $|\operatorname{man}|$.

(4) [3] And it shall be, the city which is nearest to the dead |man|:

(5) and the elders of that city shall take a calf of a cattle which

(6) has never been used for work and which has not pulled in the yoke. [4]

(7) And the elders of that city shall bring down the calf

(8) to a tough valley that is not worked with and it is not sown,

(9) and they shall stab the calf to death there in the valley.

(10) [5] And the priests, sons of Levi, shall come near, because

(11) the Lord your God has chosen them to minister to him and

(12) to bless Israel in the name of the Lord, and by their word

(13) is every verdict and every illness. [6]

(14) And all the elders of that city that are nearest to the dead |man|

(15) shall wash their hands over the calf

(16) which was stabbed to death in the valley by the river. [7]

(17) And they shall begin and say, "Our hands have not spilled

(18) this blood, and our eyes have not seen him

(19) who killed him. [8] Forgive the sin of your people

(20) Israel, whom you have redeemed, oh Lord, and do not set the guilt of innocent

(21) blood in the midst of your people Israel." And

(1) the guilt of innocent blood will be forgiven them. [9] So shall you drive away

(2) the guilt of innocent blood from the midst of you, when you will do what is right

(3) in the eyes of the Lord.

(4) Parashat Ki Teitzei

(5) [10] When you will go out to war

(6) against your enemies, and the Lord

(7) your God will give them into your hands, and you will take captive their captives, [11] 
(8) Da körsej jesirde qatyn körklü bojlu da süvsej

(9) any da alsaj any özüje qatynlyqqa. והבאתה. [12] Da

(10) keltirgin any ortasyna üvüjnün da julu\{t\}sun ošol

(11) čačyn bašynyn da kessin ošol tyrnaqlaryn özünün.

(12) (13] Da ketersin ošol jesirlik upraqlaryn

(13) özü üstünden da oltursun üvüjde da jylasyn

(14) atasy üčün da anasy üčün janġaj künler da andan

(15) sortun kelgin anar da erlik etkin anar da bolsun

(16) saja qatynlyqqa. והיה] [14] Da bolġaj eger süvmesej

(17) any da ijgin any öz erkińa da satma satmag̉yn any

(18) kümüške jumušlanmaġyn satuvbyla anyn byla anyn

(19) üčün ki qyjnadyj any. כי [15] Ki bolsalar kišige eki

$316 \mathrm{r}^{\circ} \quad$ (1) qatynlar ol birisi süvülgen da ol ekinči horlanġan da

(2) töreseler anar uvullar ol süvülgen da ol ḥorlanġan

(3) da bolsa ol tunġuč uvul ḥorlanġan qatynnyn. והיה [16]

(4) Da bolġaj ülešken kününde uvullaryna ošol neki

(5) bolsa anar bolalmasyn tunġuč etme ošol uvlun

(6) ol süvülgennin alnynda uvlunun ol ḥorlangannyn ol

(7) tunġučnun. כי. [17] Ki ošol uvlun ol ḥorlanġannyn

(8) tanytsyn berme anar eki ülüš barynda neki tabul-

(9) sa anar ki oldu ilki küčünün anardy töresi ol

(10) tunġučluqnun. כי (18] Ki bolsa kišige uvul azuvču

(11) da tanuvču tynlamavču sözüne atasynyn da sözüne

(12) anasynyn da adepleseler any da tynlamasa alarġa.

(13) Da Dasular any atasy da anasy anyn

(14) da čyğarsynlar any qartlaryna šaharynyn da töre üvü-

(15) ne ornunun. ואמרו. [20] Da ajtsynlar qartlary-

(16) na šaharynyn uvlumuz bu azuvču da tanuvčudu tynla-

(17) majdy sözümüzge köp et ašajdy da köp čaġyr

(18) ičedi. ורגמהו. [21] Da tašlasynlar any bar eli šahary-

(19) nyn tašlarbyla da ölsün da eksitkin ol jamanny

(20) ortajdan da bar Jisra'el ešitsinler da qorqsunlar.

(21) וכי (22] Da ki bolsa kišige jazyq ölüm töresi da 
(8) [11] And you will see a beautiful woman in captivity, and you will love

(9) her and take her to be your wife, [12] Then

(10) you shall bring her into your house, and she shall make the hair of her head be shaved,

(11) and she shall trim her nails,

(12) [13] And she shall remove the clothing of her captivity

(13) from off her. And she shall live in your house and cry

(14) because of her father and her mother a month of days. And

(15) after that you shall come to her and marry her, and she shall be

(16) your wife. [14] And it shall be, if you do not love

(17) her, you shall let her go into another |man's $\mid$ possession, and you shall not sell her

(18) for silver. You shall not get profit through her, because

(19) you have oppressed her. [15] If a man has two

(1) wives, one beloved and the other despised, and

(2) they have borne him children, both the beloved and the despised,

(3) and if the firstborn son be of the wife that is despised, [16]

(4) [16] Then it shall be, when he makes his sons to inherit that which

(5) he has, that he shall not be able to make the son of

(6) the beloved firstborn before the son of the despised,

(7) |before| the firstborn, [17] That he shall recognize the son of the despised,

(8) to give him two portions of all that

(9) he has, because he is the first of his strength. The right of the

(10) firstbornhood is his. [18] If a man has a stubborn

(11) and rebellious son who does not obey the voice of his father or the voice

(12) of his mother, and if they discipline him, and if he does not listen to them,

(13) [19] Then his father and his mother shall hold him

(14) and bring him out to the elders of his city and to the court of justice

(15) of his place. [20] And they shall say to the elders

(16) of his city, "This son of ours is stubborn and rebellious,

(17) he does not listen to our voice, he eats a lot of meat and drinks a lot of wine."

(18) [21] And all the people of his city shall stone him

(19) with stones, so that he dies. So shall you drive the evil away

(20) from the midst of you, and all Israel shall hear and fear.

(21) [22] And if a man has a sin, a sentence of death, and 
$316 v^{0} \quad$ (1) öltürülse da assaj any ol ag̉ač üstüne. לא. [23]

(2) Qonmasyn gövdesi anyn ol ag̉ač üstüne ki astra-

(3) ma astrag்yn any ol künde ki qarg̉ag̉anydy har adamnyn bu

(4) asylġan ullug̉u sartyn günehinin ki sözün Tenrinin ol ḥarap-

(5) lady da murdar etmegin ošol jerijni ki Adonaj Tenrij

(6) beredi saja ülüš.

Deuteronomy $[22]^{1}$

לא. [1] Körmemüš etmegin ošol

(7) ögüzün qaryndašyjnyn jemese ošol qojun anyn azašado-

(8) ganlarny da köz jummaġyn alardan qajtarma qajtarġyn alar-

(9) ny qaryndašyja. ואם [2] Da eger juvuq bolmasa qaryndašyj

(10) saja da bilmesej any da jyštyrg̉yn any ortasyna ü-

(11) vüjnün da bolsun birgeje izleginče qaryndašyj any da

(12) qajtarğyn any anar. וכן [3] Da alaj qylġyn ešegine da

(13) alaj qylġyn uprag்yna da alaj qylġyn bar taspolġan nerse-

(14) sine qaryndašyjnyn ki taspolsa andan da tapsaj any

(15) bolalmag̉yn köz jumma. לא. [4] Körmemüš etmegin

(16) ošol ešegin qaryndašyjnyn jemese ögüzün anyn tüšken-

(17) lerni jolda da köz jummag̉yn alardan turg̉uzma turg̉uzg̉un

(18) birgesine. לא. [5] Bolmasyn savutu erkišinin qatyn kiši

(19) üstüne da kijmesin erkiši upraġyn qatyn kišinin

(20) ki ḥor etkenidi Adonaj Tenrijnin bar qyluvču bularny.

(21) כי [6] Ki učralsa hujasy qušnun alnyjda jolda nendijde

$317 \mathrm{r}^{\mathrm{o}} \quad$ (1) ag̉ačta jemese ol jer üstüne balalar jemese jymyrt-

(2) qalar da ol ana jatady ol balalar üstüne jemese ol

(3) jymyrtqalar üstüne almaggyn ol anany ol ulanlarby-

(4) la. שלח. [7 [jme ijgin ol anany da ošol ol ulan-

(5) larny alġyn özüje anyn üčün ki jahš̌y bolġaj saja da

(6) uzartqajsen künler. כי. [8] Ki qondarsaj janġy üv

(7) da qylġyn tutquč čardaġyja da qojmaġyn qanlar üvüjde

${ }^{1}$ K: Deu 20; a scribal error. | TKow.o1: Deu 22. | H: Deu 22. | C: Deu 22. 
(1) he is put to death, and you hang him on a tree, [23] $316 \mathrm{v}^{\mathrm{o}}$

(2) His body shall not remain all night on the tree, because

(3) you shall surely bury him that day: because an accursed of every man is this

(4) hanged person by the greatness of his sin which insulted the word of God,

(5) and you shall not defile your land that the Lord your God

(6) is giving you as an inheritance.

Deuteronomy [22]

(7) your brother's cattle or his sheep that go astray,

(8) and shall not close your eyes from them: you shall certainly bring them back

(9) to your brother. [2] And if your brother is not near

(10) to you, or if you do not know him, then you shall gather it to the midst of your

(11) house, and it shall be with you until your brother seeks after it, and

(12) you shall give it back to him. [3] And you shall do that with his donkey, and

(13) you shall do that with his clothing, and you shall do that with any lost thing

(14) of your brother's which that will be lost by him and you find it:

(15) you cannot close your eyes. [4] You shall not make unseen

(16) your brother's donkey or his cattle fallen down

(17) by the way, and you shall not close your eyes from them. You shall surely lift |them| up

(18) with him. [5] There shall not be a man's item on a woman,

(19) and a man shall not put on a woman's garment,

(20) because all that do so are an abomination to the Lord your God.

(21) [6] If a bird's nest happens to be before you in the way in any

(1) tree or on the ground, whether they are young ones or eggs,

(2) and the mother sitting on the young or

(3) on the eggs, you shall not take the mother with the children:

(4) [7] You shall surely let the mother go and

(5) take the children for yourself, so that it will be good for you, and

(6) that you may prolong your days. [8] When you build a new house,

(7) then you shall make a handle for your attic, that you may not set blood in your house 
(8) šeme jyğylyr ol jyğgluvču andan. לא. [9] Čačmag̉yn

(9) bo $\{$ r $\}$ lalyğyjny eki žyns magat jaramas bolur saja ol jemiš ${ }_{L}\{k i$ $\check{c} a \check{c}[\operatorname{san}]\}^{11}$

(10) da bitiši ol borlalyqnyn. לא. [10] Saban sürmegin ögüz

(11) byla da ešekbyla birge. לא. [11] Kijmegin ša'atnez

(12) junnu da üskülünü birge. גדלים. [12] Jalavlar qylg̀yn

(13) özüje dört müvüšler üstüne jabunurujnun ki

(14) jabunsaj anyn byla. כי. [13] Ki alsa kiši qatyn da kel-

(15) se anar da horor etse any. ושם [14] Da qojsa

(16) anar syltav sözler da čyğarsa anyn üstüne jaman

(17) slava da ajtsa ošol ol qatynny ošpunu aldym

(18) da juvudum anar da tapmadym anar bojluqlar. [15]

(19) Da alsyn atasy ol qyznyn da anasy anyn da čyġarsyn-

(20) lar ošol bojluqlaryn ol qyznyn qartlaryna ol šaharnyn

(21) ol töre üvge. ואמר [16] Da ajtsyn atasy ol

$317 \mathrm{~V}^{\mathrm{o}} \quad$ (1) qyznyn ol qartlarğa ošol qyzymny berdim ošpu kiši-

(2) ge \{qatynlyqqa\} da horor etti any. והנה. [17] Da muna ol qojdu

(3) anar syltav sözleri ajtadoġač tapmadym qyzyja bojluq-

(4) lar da bulardylar bojluqlary qyzymnyn da jajsynlar

(5) ol juvurganny alnynda qartlarynyn ol šaharnyn. ולקחו [18 ]

(6) Da alsynlar qartlary ol šaharnyn ošol ol kišini

(7) da adeplesinler any. [19] Da žurum alsyn-

(8) lar andan jüz kümüš da bersinler atasyna ol qyz-

(9) nyn ki čyğardy jaman slava boj qyzy üstüne Jisra’el-

(10) nin da anar bolsun qatynlyqqa bolalmasyn sürme any

(11) bar tirlik künlerinde. ואם [20] Da eger kerti

(12) bolsa ol nerse ošpu tabulmasalar bojluqlar

(13) qyzġa. והוציאו. [21] Da čyg̉arsynlar ošol ol qyzny

(14) ešigine üvünün atasynyn da tašlasynlar any

(15) eli šaharnyn tašlar byla da ölsün ki qyldy jerenči

(16) iš Jisra’elde azma üvünde atasynyn da ek-

(17) sitkin ol jamanny ortajdan. כי. [22] Ki tabulsa kiši

(18) jatuvču qatyn byla erlengen erartyna da öl-

(19) sünler daġyn eksileride ol kiši ol jatuvču ol

(20) qatynbyla da ol qatynda da eksitkin ol jamanny

(21) Jisra’elde. כי [23] Ki bolsa boj qyz kelešingen kiši-

\footnotetext{
${ }^{1}$ Marginal insertion by another hand. | TKow.o1: deest. | H: ki cacsan. | C: ki sačsay.
} 
(8) if any falling man falls from there. [9] You shall not sow

(9) your vineyard with two kinds |of seed|: lest the fruit \{which you have sown

(10) and the produce of your vineyard be not good. [10] You shall not plough with a bull

(11) and a donkey together. [11] You shall not wear shaatnez:

(12) wool and linen together. [12] You shall make strings

(13) on the four corners of your quilt with which

(14) you cover yourself. [13] If any man takes a wife and

(15) comes to her and despises her, [14] And puts

(16) words of slander on her and brings out bad

(17) fame on her and says, "I took this woman,

(18) and I came to her, and did not find her virginity," [15]

(19) Then the father of the girl and her mother shall take and bring out

(20) the girl's virginity to the elders of the city

(21) in court of justice. [16] And the girl's father shall say

(1) to the elders, "I gave my daughter to this man

(2) for a wife, and he despises her, [17] And, lo, he put

(3) words of slander on her, saying, "I did not find your daughter's

(4) virginity," but this is my daughter's virginity," and he shall spread out

(5) the bedsheet before the elders of the city. [18]

(6) And the elders of that city shall take that man

(7) and punish him. [19] And they shall fine

(8) him a hundred silvers, and they shall give them to the father

(9) of the girl, because he has brought bad fame on a virgin of Israel.

(10) And she shall be his for a wife: he shall not be able to drive her out

(11) all the days of his life. [20] But if

(12) this thing is true, if they do not find her virginity

(13) in the girl, [21] Then they shall bring out the girl

(14) to the door of her father's house, and the people

(15) of her city shall stone her with stones, so that she dies, because she has done a repulsive

(16) thing in Israel, to prostitute herself in her father's house. And

(17) you shall drive the evil away from your midst. [22] If a man is found

(18) lying with a woman married to a husband, then

(19) both of them shall die, both the man that lay

(20) with the woman, and the woman, too. And you shall drive the evil away

(21) from Israel. [23] If there is a virgin girl that is betrothed 
$318 \mathrm{r}^{\circ} \quad$ (1) ge da tapsa any kiši šaharda da jatsa birgesine.

(2) והוצאתם Da čyğaryjyz ošol eksilerinde töre

(3) üvüne šaharnyn da tašlajyz alarny tašlarbyla da

(4) ölsünler ošol ol qyzny anyn üčün ki firjat et-

(5) medi šaharda da ošol ol kišini anyn üčün ki

(6) qyjnady ošol qatynyn dostunun da eksitkin ol

(7) jamanny ortajdan. [25] Da eger tüzde tapsa

(8) ol kiši ošol ol qyzny ol kelešingenni da tut-

(9) sa any ol kiši da jatsa birgesine da ölsün

(10) ol kiši ki jatty birgesine jalg̀yz özü. ולנערה. [26]

(11) Da qyzg்a qylmaġyn nemede johtu qyzğa žurumu ö-

(12) lümnün ki nečik tursa kiši dostu üstüne

(13) da qaraqlasa any క̌anybyla alajdy ol iš ošpu.

(14) כי (27] Ki tüzde tapty any firjat etti esede

(15) ol qyz ol kelešingen da jog̉edi qutqaruvču any.

(16) כי (28] Ki tapsa kiši boj qyzny ki kelešinmedi da

(17) tutsa any da jatsa birgesine da tabulsalar.

(18) [ונתן. [29] Da bersin ol kiši ol jatuvču birgesine

(19) atasyna ol qyznyn enli kümüš da anar bolsun qatyn-

(20) lyqqa anyn üčün ki qyjnady any bolalmasyn sürme

(21) any bar tirlik künlerinde.

Deuteronomy $[23]^{1}$

(2) synyn. [2] Kelmesin jančylġan ajipli da kesilip tögül-

(3) gen qahalyna Adonajnyn. לא. [3] Kelmesin mamzer qahalyna Adonaj-

(4) nyn daġyn onunču dor kelmesin anyn qahalyna Adonajnyn.

(5) לא. [4] Kelmesin 'Amonlu da Mo’avly qahalyna Adonajnyn dag்yn

(6) onunču dor kelmesin alarnyn qahalyna Adonajnyn dunjagiadejin.

(7) על [5] Anyn üčün ki uturulmadylar sizni ötmekbyla

(8) da suvbyla jolda čy[q] qanyjyzda ${ }^{2}$ Micriden da ki jalğa tut-

\footnotetext{
${ }^{1} \mathrm{~K}$ : Deu 21; a scribal error. | TKow.o1: Deu 23. | H: Deu 23. | C: Deu 23. $\quad{ }^{2} \mathrm{~K}:$ čyqanyjyzda; a scribal error. | TKow.o1: čyqqanyjyzda; unvocalized text. | H: cyqqanynyzda. | C: čyqqanyyyzda.
} 
(1) to a husband, and a man finds her in the city, and lies with her, $318 \mathrm{r}^{\circ}$

(2) [24] Then you shall bring them both out

(3) to the court of justice of that city, and you shall stone them with stones

(4) so that they die: the girl, because she cried not

(5) in the city, and the man, because

(6) he has violated his fellow's wife. And you shall drive the

(7) evil away from the your midst. [25] But if a man finds in the field

(8) a betrothed girl, and the man seizes

(9) her and lies with her, then

(10) only the man who lay with her shall die. [26]

(11) But you shall not do a thing to the girl. The girl does not have a sin deserving| a punishment

(12) of death, because, just as a man would rise against his fellow

(13) and murder him and his soul: this matter is like that,

(14) $[27]$ Because he found her in the field; though

(15) the betrothed girl cried, there was no one to save her.

(16) [28] If a man finds a virgin girl who is not betrothed, and

(17) he seizes her and lies with her, and they are found,

(18) [29] Then the man who lay with her shall give

(19) to the girl's father fifty silver, and she shall be his wife.

(20) Because he has violated her, he shall not be able to drive her out

(21) all the days of his life.

Deuteronomy [23]

[1] A man shall not take

(1) his father's wife, and he shall not uncover his father's nakedness.

(2) [2] One who has crushed nakedness or spilled by being cut off

(3) shall not come into the community of the Lord. [3] A bastard shall not come into the community of the Lord;

(4) even his tenth generation shall not come into the community of the Lord.

(5) [4] An Ammonite or Moabite shall not come into the community of the Lord; even

(6) their tenth generation shall not come into the community of the Lord forever,

(7) [5] Because they did not meet you with bread

(8) and with water in the way, when you came out from Egypt, and because they hired 
(9) tu üstüje ošol Bil'amny uvlun Bo'ornun Petor

(10) Aram Naharajimden qarg̉ama seni. ולא . [6] Da klemedi Adonaj

(11) Tenrij tynlama Bil'amġa da čüvürdü Adonaj Tenrij

(12) saja ošol ol qarg்yšny alġyšqa ki süvdü seni Adonaj

(13) Tenrij. לא. [7] Sormaġyn savluqlaryn alarnyn da jahšysyn

(14) alarnyn bar künlerijde dunjagadejin. לא . [8] Horlamag̀yn Edom-

(15) lunu ki qaryndašyjdy ol ḥorlamag̉yn Micrilini ki garip edij

(16) jerinde anyn. בנים . [9] Ulanlar ki ${ }_{\llcorner}\langle$bolsalar $\rangle\left\{t u v d u[\text { rul] salar }\}^{11}\right.$ alargaa

(17) üčünčü dor kelsin alarnyn qahalyna Adonajnyn. כי [10]

(18) Ki čyqsaj avulbyla dušmanlaryj üstüne da saqlanġyn

(19) bar jaman nerseden. כי [11] Ki bolsa sende kiši ki bol-

(20) masa aruv učurundan kečenin da čyqsyn tyšqartyn

(21) avulg̀a kelmesin ortasyna ol avulnun. והיה [12]

$319 \mathrm{r}^{\circ} \quad$ (1) Da bolg̉aj ingir vaḥtta juvsun gufun suvbyla da

(2) engečoq ol qujaš kelsin ortasyna ol avulnun.

(3) ויד [13] Da orun bolsun saja tyšqartyn avulġa da

(4) čyqqyn ary tyšqary. [ויתד [14] Da qazyq bolsun saja

(5) čerüv savutlaryj qatyna da bolġaj olturg̉anyjda tyšqa-

(6) ry da qazğyn anyn byla da qajtqyn da qaplag̉yn ošol čy-

(7) ġyšyjny. כי [15] \{Ki\} Adonaj Tenrij jürüjdü ortasynda avu-

(8) lujnun qutqarma seni da berme dušmanlaryjny alnyjda

(9) da bolsun avuluj senin aziz da körmesin sende ajip-

(10) li nerse da kedergi qajtyr artyjdan. לא. [16] Čyğara

(11) bermegin qulnu bijine ki qutulsa saja bijinden. עמך. [17]

(12) Qatyjda oltursun ortajda ne orunda ki sajlasa

(13) birisinde šaharlaryjnyn qajda ki jahšy körünse anar

(14) munajtmaġyn any. לא. [18] Bolmasyn qedeša qyzlaryndan

${ }^{1}$ Correction by another hand. | TKow.o1: tuvsalar; unvocalized text. | H: tuvdurulsalar. | C: do $\dot{g}-$ salar. 
(9) Balaam, son of Beor, of Pethor

(10) of Aram Naharaim against you to curse you. [6] But the Lord

(11) your God was not willing to listen to Balaam, and the Lord your God turned

(12) the curse into a blessing for you, because the Lord your God loved you.

(13) [7] You shall not seek their health or their well-being

(14) all your days forever. [8] You shall not despise an Edomite,

(15) because he is your brother. You shall not despise an Egyptian, because you were a stranger

(16) in his land. [9] The children that 〈they have $\rangle$ are born $\}$ to them:

(17) the third generation shall come into the community of the Lord. [10]

(18) When you go out encamped against your enemies, then you shall keep

(19) yourself from every evil thing. [11] If there is among you a man who

(20) is not clean by reason of some event in the night, then he shall go outside

(21) the camp, he shall not come inside the camp. [12]

(1) And it shall be: in the evening he shall wash his body with water, and

(2) when the sun sets he shall come inside the camp.

(3) [13] You shall have a place also outside the camp, and

(4) you shall go out there, outside. [14] And you shall have a peg

(5) with your weapons of war, and it shall be, when you will sit outside,

(6) you shall dig with it and shall go back and cover what comes out of you.

(7) [15] Because the Lord your God walks in the midst

(8) of your camp, to deliver you and to give up your enemies before you,

(9) so your camp shall be holy, so he shall not see in you

(10) any shameful thing and turn aside from you. [16] You shall not take

(11) and give $\mid$ back| to his master a servant who escapes ${ }^{291}$ to you from his master.

(12) [17] He shall dwell with you, in your midst, in that place which he shall choose

(13) in one of your cities, where it seems good for him.

(14) You shall not torment him. [18] There shall be no temple prostitute of the daughters

291 Lit. 'saves himself'. 
(15) Jisra’elnin da bolmasyn qadeš uvullaryndan Jisra’elnin.

(16) לא. [19] Keltirmegin bernesin zonanyn da bahasyn itnin

(17) üvüne Adonaj Tenrijnin bar nijetke ki ḥor etkenidi

(18) Adonaj Tenrijnin dagynn eksileride. לא. [20] Aslamġa

(19) bermegin qaryndašyja aslamyn kümüšnün aslamyn bür-

(20) tüknün aslamyn nendijde nersenin ki aslamġa beri-

(21) ledi. לנכרי [21] Jatqa aslamġa bergin da qaryndašyja

$319 \mathrm{v}^{\mathrm{o}} \quad$ (1) aslamġa bermegin anyn üčün ki alg̀yšlag̉aj seni Adonaj Ten-

(2) rij bar sunuvunda qolujnun ol jer üstüne ki sen kele-

(3) sen ary meresleme any. כ2. [22] Ki nijet etsej nijet Ado-

(4) najğa $\{\text { Tenrine }\}^{1}$ kečiktirmegin töleme any ki izleme izler

(5) Adonaj Tenrij senden da bolur sende jazyq. וכי [23] Da ki

(6) qalsaj nijet etmekten bolmasty sende jazyq. מוצאי [24]

(7) Čyġyšyn erinlerijnin saqlaġyn da qylġyn ki nečik nijet ettij

(8) Adonajg̉a Tenrije žomartlyq ki sözledij avzujbyla.

(9) כ . 25] Ki kelsej borlalyg்yna dostujnun da ašag்yn borlalar

(10) klegije köre tojg̉anyjadejin da savutuja bermegin. כי. [26]

(11) $\{\mathrm{Ki}\}$ kelsej turugiuna dostujnun da üzgün koloslar qolujby-

(12) la da oraq sunmag்yn turug̉u üstüne dostujnun.

$[\text { Deuteronomy 24 }]^{2}$

(13) כי (1] Ki alsa kiši qatyn da erlik etse anar

(14) da bolġaj eger tapmasa širinlik közlerinde anyn

(15) ki tapsa anda ajipli nerse da jazsyn anar get bi-

(16) tigi da bersin qoluna anyn da sürsün any üvün-

(17) den. [2] Da čyqsa üvünden anyn da barsa

(18) da bolsa özge kišige. I3 Da horlasa

\footnotetext{
${ }^{1}$ Marginal insertion by another hand in South-Western Karaim. | TKow.o1: Tenrijnin; different wording; unvocalized text. | H: Tenrine. | C: Tägrinä. $\quad{ }^{2} \mathrm{~K}$ : The chapter number is not indicated. | TKow.o1: Deu 24. | H: The chapter number is not indicated. | C: Deu 24. | Hebrew Bible: Deu 24.
} 
(15) of Israel, and there shall be no temple prostitute of the sons of Israel.

(16) [19] You shall not bring the endowment of a harlot or the price of a $\operatorname{dog}$

(17) into the house of the Lord your God for any vow, because these are an abomination

(18) to the Lord your God, even the two of them. [20]

(19) You shall not give for profit to your brother: profit on silver, profit on

(20) grain, profit on anything that is given for profit.

(21) [21] You may give for profit to a foreigner, but to your brother

(1) you shall not give for profit, so that the Lord your God may bless $319 \mathrm{v}^{\mathrm{o}}$ you

(2) in all that you reach out your hand to in the land where you are coming

(3) to inherit it. [22] If you make a vow to the Lord

(4) $\{$ your God $\}$, you shall not delay to pay it, because the Lord your God will surely require

(5) it of you, and it would be sin to you. [23] But if

(6) you refrain from vowing, there will be no sin in you. [24]

(7) You shall keep that which has passed from your lips and do as you vowed

(8) to the Lord your God: the freewill offering that you spoke with your mouth.

(9) [25] If you come into your neighbour's vineyard, then you may eat grapes

(10) as you wish, until you are full, but you shall not put any into your vessel. [26]

(11) If you come into your neighbour's the standing grain, then you may pluck the ears with your hand,

(12) but you shall not elevate a sickle over your neighbour's standing grain.

[Deuteronomy 24]

(13) [1] When a man takes a wife and marries her,

(14) and it shall be that, if she does not find favour in his eyes,

(15) because he has found something shameful in her, and he shall write a document of divorce for her,

(16) and he shall put it in her hand and drive her out of his house,

(17) [2] And if she goes out of his house, and goes

(18) and becomes another man's, [3] And if 
(19) any ol sonrag̉y kiši da jazsa anar get bitigi da

(20) berse qoluna anyn da sürse any üvünden

(21) jemese ki ölse ol sonraggy kiši ki aldy any özüne

$320 \mathrm{r}^{\circ} \quad$ (1) [qaty]nlyqqa ${ }^{1}$. לא. [4] Bolalmasyn eri anyn ol burungiu ki ij-

(2) di any qajtma alma any özüne qatynlyqqa andan

(3) sortun ki jaramas bolundu ki jerenči išti ol alnyn-

(4) da Adonajnyn da jazyqly etmegin ošol ol jerni ki Adonaj

(5) Tenrij beredi saja ülüš. כי. [5] Ki alsa kiši janğy

(6) qatyn čyqmasyn čerüvge da ašmasyn anyn ašyra heč

(7) nemede könü bolsun üvünde bir jyl da bijendir-

(8) sin ošol qatynyn ki aldy. לא. [6] Tusnaq almasyn

(9) kiši üsttašyn tijirmennin da tüptašyn tijirmen-

(10) nin ki jemin žannyn ol tusnaq aldy. כי. [7] Ki tabul-

(11) sa kiši urlavču క̌anny qaryndašlaryndan ulanlaryndan

(12) Jisra’elnin da savut išibyla jumušlansa anda da sat-

(13) sa any da ölsün ol uru da eksitkin ol jaman-

(14) ny ortajdan. השמר. [8] Saqlanġyn özüje hastalyġyn-

(15) dan ol cara'atnyn saqlama astry da qylma barča ne-

(16) čik ki üvretseler sizni ol kohenler ol Levililer ki

(17) nečik bujurdum alarg̉a saqlajyz qylma. [כור] [9] Sag்yn-

(18) ġyn ošol ne ki qyldy Adonaj Tenri Mirjamġa jolda

(19) čyqqanyjyzda Micriden. כי. [10] Ki borčqa bersej dostu-

(20) ja nendijde borč kelmegin üvüne anyn tusnaq

(21) alma tusnag̉yn. בחוץ [11] Tyšqaryda turg̉un da ol

$320 \mathrm{v}^{\mathrm{o}} \quad$ (1) kiši ki sen borčqa beresen anar čyġarsyn saja ol tusnaqny ol

(2) tyšqaryg̉a. ואם [12] Da eger miskin kiši ese ol jat-

(3) mag̉yn tusnaġybyla anyn. השב. [13] Qajtarma qajtarg̉yn anar

(4) ošol ol tusnaqny engečoq ol qujaš da jatsyn uprag̉yby-

(5) la da alġyšlar seni da saja bolur zehut alnynda Adonaj-

(6) nyn Tenrijnin. לא. [14] Zulumlamaġyn jalyn jalčynyn miskin-

(7) nin da jarlynyn qaryndašlaryjdan jemese garipdan ki jerij-

(8) de šaharlaryjda. [15] Kününde bergin anar

(9) jalyn da enmesin anyn üstüne ol qujaš ki miskin-

(10) dir ol da anar ol išandyrdy $\{o s ̌ o l\}^{2}$ žanyn özünün da čag̉yr-

\footnotetext{
${ }^{1}$ Catchword: qatynlyqqa. | TKow.o1: qatynlyqqa; unvocalized text. | H: qatynlyqqa. | C: hatynlyqqa.

${ }^{2}$ Marginal insertion by another hand. | TKow.o1: deest; unvocalized text. | H: osol. | C: šol.
} 
(19) the latter husband despises her and writes a document of divorce for her and

(20) puts it in her hand and drives her out of his house,

(21) or if the latter husband dies, who took her

(1) for a wife: [4] Her first husband who drove her away may not

(2) take her again to be his for a wife, after

(3) she became disgraceful, because that is a repulsive thing before

(4) the Lord, and you shall not make the land sinful which the Lord

(5) your God is giving you for an inheritance. [5] If a man takes a new

(6) wife, he shall not go out to war, and no matter shall go through him.

(7) He shall be free in his house one year and shall make

(8) his wife whom he has taken happy. [6] One shall not take

(9) a lower $\mid$ mill|stone of a mill or an upper $\mid$ mill|stone of a mill as security,

(10) because he takes a man's fruit as security. [7] If a man is found

(11) stealing any of a soul from his brethren of the children

(12) of Israel, and if he gets profit by |means of| a weaponry matter and sells

(13) him, then that thief shall die and you shall drive the evil away

(14) from your midst. [8] Take heed to yourself

(15) that you watch out, very much, for the disease of leprosy and do according to all

(16) that the priests the Levites shall teach you.

(17) As I commanded them, so you shall observe to do. [9] Remember

(18) what the Lord your God did to Miriam on the way,

(19) when you were coming out from Egypt. [10] If you give a loan

(20) to your fellow, any loan, you shall not go into his house to get

(21) his pledge. [11] You shall stand outside, and the

(1) man to whom you give a loan shall bring out the pledge

(2) outside to you. [12] And if the man is poor,

(3) you shall not lie down with his pledge. [13] You shall surely give back

(4) the pledge to him as the sun goes down, that he may lie down

(5) in his own clothing, and bless you, and it shall be a merit to you before the Lord

(6) your God. [14] You shall not oppress a hired servant that is poor

(7) and needy, from your brothers or from the strangers that are in your land

(8) in your cities. [15] In his day you shall give him

(9) his hire, and the sun shall not go down on it, because he is poor

(10) and he convinces his heart on it- 
(11) masyn ü\{s\}tüje Adonajğa da bolur sende jazyq. לא. [16]

(12) Öltürülmesinler atalar ulanlar üčün da ulanlar

(13) öltürülmesinler atalar üčün har kiši öz jazyğgy

(14) üčün öltürülsü $\{n\} l e r$. לא. [17] Tajdyrmaġyn töresin gari[pnin $]^{1}$

(15) da öksüznün da tusnaq almaġyn upraġyn tulnun.

(16) וזכרת (18] Da saǵynġyn ki qul edij jerinde Micrinin

(17) da juludu seni Adonaj Tenrij andan anyn üčün men bujuramen

(18) saja qylma ošol ol išni ošpunu. כי. [19] Ki or-

(19) saj ormag்yjny tüzüjde da unutsaj külte $\{t u ̈ z d e\}^{2}$ qajtmaġyn

(20) alma any garipke öksüzge da tulg̀a bolsun

(21) anyn üčün ki alġyšlag̉aj seni Adonaj Tenrij bar išinde

$321 \mathrm{r}^{\circ} \quad$ (1) qollaryjnyn. [20] Ki qaqsaj zejtunujnu inčkelemegin ö-

(2) züjartyna garipge öksüzge da tulga bolsun.

(3) כי . 21] Ki jyštyrsaj borlalyġyjny čirkillemegin özüj-

(4) artyna garipge öksüzge da tulġa bolsun.

(5) וזכרת [22] Da saǵynġyn ki qul edi[j] jerinde Micrinin

(6) anyn üčün men bujuramen saja $\{$ qylma\} ošol ol išni ošpunu.

[Deuteronomy 25] ${ }^{4}$

(7) כי (1] Ki bolsa talaš arasyna erenlernin da juvusa-

(8) lar ol törege da töre etseler alarny da rast

(9) etseler ošol ol rastny da qyng்yr etseler o-

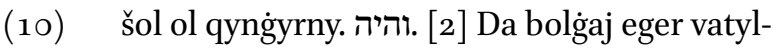

(11) maq kiši bolsa ošol ol raša da ahtartsyn any

(12) ol töreči da vattyrsyn any alnynda özünün

(13) rašalyğgna köre sanbyla. ארבעים. [3] Qyrq keret

(14) ursun any arttyrmasyn magiat arttyryr vatma

(15) any bular üstüne ullu vatmaq da jengil bolunur

(16) qaryndašyj közlerijče. לא. [4] Avuzluqlamaġyn ö-

\footnotetext{
${ }^{1}$ TKow.o1: garipnin; unvocalized text. | H: garipnin. | C: garipniy. $\quad{ }^{2}$ Marginal insertion by another hand. | TKow.or: tüzde; unvocalized text. | H: tizde.|C: tarlovda. ${ }^{3} \mathrm{~K}:$ edi; a scribal error. | TKow.o1: edij; unvocalized text. | H: edin. | C: ediy. ${ }^{4} \mathrm{~K}$ : The chapter number is not indicated. | TKow.o1: Deu 25. | H: Deu 25. | C: Deu 25.
} 
(11) and he shall not cry against you to the Lord, and it will be a sin in you. [16]

(12) Fathers shall not be killed for children, and children

(13) shall not be killed for fathers: every man

(14) shall be killed for his own sin. [17] You shall not reject judgement of a stranger

(15) or an orphan, and you shall not take a widow's clothing as security.

(16) [18] But you shall remember that you were a slave in the land of Egypt,

(17) and the Lord your God redeemed you from there. On account of this I command

(18) you to do this thing. [19] If

(19) you reap your harvest in your field and forget a sheaf $\{$ in the field $\}$, you shall not go back

(20) to get it. It shall be for the stranger for the orphan and for the widow,

(21) so that the Lord your God may bless you in all the work

(1) of your hands. [20] If you beat your olive tree, do not inspect it

(2) after yourself. It shall be for the stranger for the orphan and for the widow.

(3) [21] If you gather |the grapes of $\mid$ your vineyard, you shall not gather all of it

(4) after yourself. It shall be for the stranger for the orphan and for the widow.

(5) [22] And you shall remember that you were a slave in the land of Egypt.

(6) On account of this I command you to do this thing.

[Deuteronomy 25]

(7) [1] If there is a strife between men, and they approach

(8) the court, and the judges judge them, and they justify

(9) the righteous and convict the

(10) faulty: [2] And it shall be, if the

(11) wicked man is to be beaten, that the judge shall cause him to fall

(12) and to be beaten before him,

(13) according to his wickedness in number. [3] Forty times

(14) he shall strike him. And he shall not add, lest, in case he would go on to beat

(15) him with more beating than this, your brother become despised

(16) in your eyes. [4] You shall not muzzle 
(17) güznü bürtük jančqanynda. כי. [5] Ki oltursalar

(18) qaryndašlar birge da ölse birisi alardan da uvul

(19) bolmasa anar bolmasyn qatyny ol ölünün ol tyšqary-

(20) ġa jat kišige juvugiu anyn kelsin anar da alsyn any

(21) özüne qatynlyqqa da juvuqluq etsin anar. והיה [6]

$321 \mathrm{v}^{\mathrm{o}} \quad$ (1) Da bolġaj ol tunġuč ki törese tursun aty üstü-

(2) ne qaryndašynyn ol ölünün da sürtülmesin aty anyn

(3) Jisra’elden. ואם [7] Da eger klemese ol kiši alma

(4) ošol juvug̉un da barsyn juvuğu anyn ol töre üvge

(5) ol qartlarg̉a da ajtsyn klemejdi juvugum turg்uzma

(6) qaryndašyna at Jisra'elde klemejdi juvuqluq etme

(7) maja. וקראו [8] Da ündesinler any qartlary

(8) šaharynyn da sözlesinler anar da tursa da ajt-

(9) sa klemejmen alma any. [ונגשה. [9] Da juvusun juvugiu

(10) anyn anar közleriče ol qartlarnyn da suvursun eti-

(11) gin ajaġy üstünden anyn da tükürsün alnynda

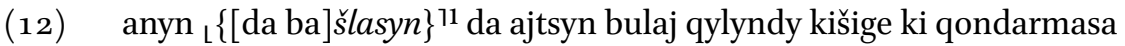

(13) ošol üvün qaryndašynyn. [10] Da [ü]ndelir²

(14) aty anyn Jisra’elde „Bet Ḥaluc Hana'al ${ }^{13}$. כי. [11] Ki uruš-

(15) salar erenler birge kiši da qaryndašy anyn da ju-

(16) vusa qatyny ol birnin qutqarma ošol erin özünün

(17) qolundan vatuvčusunun da sunsa qolun da tutsa aji-

(18) pinden anyn. וקצתה. [12] Da keskin ošol uvučun

(19) anyn hajifsinmesin közüj. לאה [13] Bolmasyn saja jan-

(20) čyğyjda ullu kümüš ölčüvü da kiči kümüš

(21) ölčüvü. לא. [14] Bolmasyn saja üvüjde ullu

322 ro (1) bürtük ölčüvü da kiči bürtük ölčüvü. אבן. [15]

(2) Tügel kümüš ölčüvü da rast bolsun saja tügel

(3) bürtük ölčüvü da rast bolsun saja anyn üčün

(4) ki uzargajlar künlerij ol jer üstüne ki Adonaj Ten-

(5) rij beredi saja. כי [16] Ki ḥor etkenidi Adonaj-

\footnotetext{
${ }^{1}$ Marginal insertion by another hand. | TKow.o1: da bašlasyn; unvocalized text. | H: da baslasyn. | C: $d a$ žoġap bersin. $\quad{ }^{2} \mathrm{~K}$ : öndelir; a scribal error. | TKow.o1: unvocalized text. | H: indelir. | C:

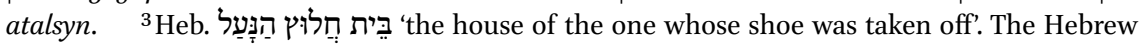
original orthography was not rendered accurately by the copyist.
} 
(17) the cattle when it treads out the grain. [5] If

(18) brothers live together, and one of them dies and

(19) has no child, the wife of the dead $|\operatorname{man}|$ shall not be

(20) for a stranger, outside. His close relative shall come to her and take her

(21) to him for a wife and be close to her. [6]

(1) And it shall be, that the firstborn that she bears shall stand over the name

(2) of his brother who is dead, that his name be not blotted out

(3) of Israel. [7] And if the man does not want to take

(4) his close |relative|, then his close |relative| shall go to the court of justice

(5) to the elders, and say, "My close |relative| does not want to preserve

(6) a name for his brother in Israel. He is not willing to be close

(7) to me." [8] Then the elders of his city shall call him,

(8) and they shall speak to him, and if he stands and says,

(9) "I do not want to take her," [9] Then his close |relative| shall approach

(10) him in the sight of the elders and pull his shoe

(11) off his foot, and she shall spit before

(12) him. And shall \{begin $\}$ and say, "So shall it be done to that man who does not build up

(13) his brother's house." [10] And his name shall be called

(14) in Israel ${ }_{L}$ Beit-Halutz-Hannaal ${ }^{2292}$. [11] When

(15) men fight together, a man and his brother, and

(16) the wife of the one draws near to rescue her husband

(17) from the hand of the one striking him and reaches out her hand and takes hold

(18) of his private parts, [12] Then you shall cut off her hand,

(19) your eye shall not pity her. [13] You shall not have

(20) in your bag a great silver measure and a small silver

(21) measure. [14] You shall not have in your house

(1) a great grain measure and a small grain measure. [15]

(2) You shall have a perfect and just silver measure,

(3) you shall have a perfect and just grain measure, so

(4) that your days may be prolonged on the land which the Lord

(5) your God is giving you. [16] Because everyone who does such things is an abomination

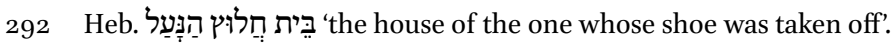


(6) nyn Tenrijnin bar qyluvču bularny bar qyluvču avanlyq-

(7) ny. זכור [17] Sag̉ynġyn ošol ne qyldy saja 'Amaleq

(8) jolda čyqqanyjyzda Micriden. אשר. [18] Ki učrady

(9) seni jolda da arttan qyrdy sende bar ol halašlanġan-

(10) larny artyjdan da sen edij aryġan da jadaġan da

(11) qorqmady Tenriden. והיה [19] Da bolġaj tynč et-

(12) kende saja Adonaj Tenrij bar dušmanlaryjdan čüv-

(13) reden jerde ki Adonaj Tenrij beredi saja ülüš

(14) meresleme any sürtkün ošol sag̉ynčyn 'Amaleq-

(15) nin tübünden ol köklernin unutmag̉yn.

[Deuteronomy 26] ${ }^{1}$

פרשת כי תבוא (16) (16) (17)

(17) [17 Da bolg̀aj ki kelsej

(18) ol jerge ki Adonaj Tenrij beredi saja ü-

(19) lüš da ${ }_{L}\{[\text { mereslesej any da }]\}^{12}$ oltursaj anda. ולקחת. [2] Da alġyn il-

$322 \mathrm{v}^{\mathrm{o}} \quad$ (1) kinden bar jemišnin ol jernin ki keltirsej jerijden ki Adonaj

(2) Tenrij beredi saja da qojğun četenge da barğyn ol orun-

(3) ga ki sajlasa Adonaj Tenrij toḥtatma šemin özünün anda.

(4) ובאת [3] Da kelgin ol kohenge ki bolsa ol vaḥtlarda

(5) da ajtqyn anar anlatamen bügün Adonajğa Tenrije ki keldim

(6) ol jerge ki antetti Adonaj atalarymyzga berme bizge.

(7) ולקח [4 Da alsyn ol kohen ol četenni qolujdan da qojsu[n] ${ }^{3}$

(8) any alnynda mizbeahnyn Adonaj Tenrijnin. וענית. [5] Da bašlaġyn

(9) da ajtqyn alnynda Adonaj Tenrijnin Aramly bolup jarly

(10) edi atam da endi Micrige da tirildi anda azg்y-

(11) naq elbyla da boldu anda ullu ḥanlyqqa küčlü da

(12) köp. וירעו. [6] Da jaman ettiler bizge ol Micrililer

(13) da qyjnadylar bizni da berdiler üstümüzge qaty qulluq.

(14) ונצעק Da firjat ettik Adonajgia Tenrisine ata-

(15) larymyznyn da ešitti Adonaj ošol avazymyzny da kördü

(16) ošol miskinligimizni da ošol qyjynymyzny da ošol qy-

\footnotetext{
${ }^{1} \mathrm{~K}$ : The chapter number is not indicated. | TKow.o1: Deu 26. | H: Deu 26. | C: Deu 26. $\quad{ }^{2}$ TKow.o1: mereslesej any da; unvocalized text. | H: mereslesen any da. | C: da miräsläsäy any. ${ }^{3}$ TKow.o1: qojsun; unvocalized text. | H: tohtatsyn. | C: qojsyn.
} 
(6) to the Lord your God, everyone who does

(7) wickedness. [17] Remember what Amalek did to you

(8) on the way when you came out from Egypt, [18] That he met you

(9) on the way and attacked from behind all feeble ones among you

(10) at your rear, and you were exhausted and tired, and

(11) he did not fear God. [19] So it shall be,

(12) when the Lord your God will give you rest from all your enemies all around

(13) in the land which the Lord your God is giving you for an inheritance

(14) to inherit it, you shall blot out the remembrance of Amalek

(15) from under heaven. You shall not forget.

[Deuteronomy 26]

(16) Parashat Ki Tavo

(17) [1] And it shall be, when you will come

(18) to the land which the Lord your God gives you

(19) for an inheritance, and [when you will inherit it] and dwell in it: [2] And you shall take

(1) of the first of all the fruit of the earth which you shall bring in from $322 \mathrm{v}^{\mathrm{o}}$ your land that the Lord

(2) your God is giving you, and you shall put it in a basket and go to the place

(3) which the Lord your God shall choose to cause his name to dwell there.

(4) [3] And you shall come to the priest who shall be in those days,

(5) and you shall say to him, "I announce today to the Lord your God that I have come

(6) to the land which the Lord swore to our fathers to give us."

(7) [4] And the priest shall take the basket from your hand and set it down

(8) before the altar of the Lord your God. [5] And you shall begin

(9) and say before the Lord your God, "Being an Aramean,

(10) my father was poor, and he went down to Egypt and lived there

(11) with a few people and became there a great kingdom, strong

(12) and numerous. [6] And the Egyptians were bad to us,

(13) and oppressed us and laid on us hard service.

(14) [7] And we cried to the Lord, to the God of our fathers,

(15) and the Lord heard our voice and saw

(16) our poverty and our affliction and that 
(17) syqlyq čydaġanymyzny. ויוצאנו. [8] Da čyg̉ardy $\left\{[\text { bizni] }\}^{1}\right.$ Adonaj

(18) Micriden küčlü qudrat byla da sunulġan quvat byla da

(19) ullu qorquvbyla da belgiler byla da nišanlar byla.

(20) ויבאנו [9] Da keltirdi bizni ol orunga ošpu da

(21) berdi bizge ošol ol jerni ošpunu jer ag̉adoġan süt

$323 \mathrm{r}^{\mathrm{o}}$ (1) da bal. ועתה. [10] Da haligine muna keltirdim ošol

(2) ilkin jemišinin ol jernin ki berdij maja e Adonaj da

(3) qojğun any alnynda Adonaj Tenrijnin da bašurğun al-

(4) nynda Adonaj Tenrijnin. ושמחת [11] Da bijengin bar ol

(5) jaḥ̌ybyla ki berdi saja Adonaj Tenrij da üvüje sen

(6) da ol Levi da ol garip ki ortajda. [12] Ki

(7) tügellesej onča berme ošol bar ončasyn bitišij-

(8) nin ol üčünčü jylda jylynda ol onča bermeknin

(9) da bergin Levige garipge öksüzge da tulg̀a da

(10) ašasynlar šaharlaryjda da tojsunlar. ואמרת [13] Da

(11) ajtqyn alnynda Adonaj Tenrijnin eksittim ol qodeš-

(12) ni ol üvden da dag்yn berdim any Levige da garip-

(13) ge öksüzge da tulğa bar bujruğuja köre ki

(14) bujurduj maja [aš]madym ${ }^{2}$ micvalaryjdan da unutmadym.

(15) לא. [14] Ašamadym jasly egenimde andan da eksit-

(16) medim andan murdarga da bermedim andan keregi-

(17) ne ölünün tynladym ününe Adonaj Tenrimnin qyldym

(18) barča nečik ki bujurduj maja. השקיפה. [15] Baqqyn

(19) aziz ornujdan ol köklerden da alġyšlag̉yn ošol ulusujnu

(20) ošol Jisra’elni da ošol ol jerni ki berdij bizge ki nečik

(21) ant ettij atalarymyzg்a jer ag̉adog̉an süt da bal

$323 v^{0} \quad$ (1) היום

(2) ošol ol resimlerni ošpularny da ošol ol töreler-

(3) ni da saqlaġyn alarny bar jüregijbyla da bar žanyj-

(4) byla. את [17] Ošol Adonajnyn ullugiun qotardyj bügün

${ }^{1}$ TKow.o1: bizni; unvocalized text. | H: bizni. | C: bizni. $\quad{ }^{2}$ K: ašamadym; a scribal error. | TKow.o1: unvocalized text. | H: asmadym. | C: kečmädim. 
(17) we suffered oppression. [8] And the Lord brought [us] out

(18) from Egypt with a mighty hand and with an outstretched arm and

(19) with great fear and with signs and with tokens.

(20) [9] And he has brought us to this place and

(21) gave us this land, a land flowing $\mid$ with $\mid$ milk

(1) and honey. [10] And now, lo, I have brought the

(2) first of the fruits of the land which you have given me, oh Lord." And

(3) you shall set it before the Lord your God, and you shall worship

(4) before the Lord your God. [11] And you shall rejoice in all the

(5) good which the Lord your God has given to you and to your house, you

(6) and the Levite and the stranger that is among you. [12] When

(7) you have finished tithing all the tithes of your produce

(8) the third year, the year of tithing,

(9) you shall give it to the Levite, the stranger, the orphan and the widow, and

(10) that they shall eat within your cities and be filled. [13] And

(11) you shall say before the Lord your God, "I have removed the holy

(12) from my house, and I have also given them to the Levite and to the stranger,

(13) to the orphan and to the widow, according to all your commandments which

(14) you have commanded me. I have not [transgressed] ${ }^{293}$ your commandments, and I have not forgotten them.

(15) [14] I have not eaten of it in my mourning, and I have not removed

(16) any of it for any unclean |use|, and I have not given any of it to the needs

(17) of the dead. I have listened to the voice of the Lord my God, I have done

(18) according to all that you have commanded me. [15] Look

(19) |down| from your holy abode, from the skies, and bless your people,

(20) Israel, and the land which you have given us as

(21) you swore to our fathers, a land flowing $\mid$ with $\mid$ milk and honey."

(1) [16] This day the Lord your God has commanded you to do

(2) these statutes and judgments.

(3) And you shall keep them with all your heart and with all your soul.

(4) $[17]$ You have proclaimed the greatness of the Lord today

293 K: eaten; a scribal error. 
(5) bolma saja Tenrige da jürüme jollarybyla anyn da

(6) saqlama resimlerin da micvalaryn da törelerin anyn da

(7) tynlama ününe anyn. (פשט שני על תיבת האמרת).

(8) (Adonajgia ajttyrdyj bügün). ויהוה [18] Da Adonaj

(9) ullu etti seni bügün bolma anar onča ulusqa ki ne-

(10) čik sözledi saja da saqlama bar micvalaryn anyn. פשיבר) (11)

(11) (שני על תיבת ויהוה האמירך). (Da Adonaj ajttyrdy

(12) saja bügün). ולתתך]. [19] Da berme seni jog̉arraq

(13) bar ol ḥanlyqlar üstüne ki qyldy mahtavğa da slavagaa

(14) da körkke da bolma sen aziz ulus Adonajġa Tenrije

(15) ki nečik sözledi.

[Deuteronomy 27 $]^{1}$

ויצו. [1] Da bujurdu Moše da qartlary

(16) Jisra’el[nin $]^{2}$ ol ulusqa ajtadog̉ač saqlaġyn ošol bar ol micva-

(17) ny ki men bujuramen sizge bügün. והיה [2] Da bolġaj ne

(18) künnü ki ašsajyz ošol ol Jardenni ol jerge ki Adonaj

(19) Tenrij beredi saja da turg̉uzġun özüje ullu tašlar

(20) da jaqqyn alarny kireč byla. וכתבת. [3] Da jazġyn alar

(21) üstüne ošol bar sözlerin ol Toranyn ošpunun

$324 \mathrm{r}^{\mathrm{o}} \quad$ (1) ašqanyjdan sortun anyn üčün ki kelgejsen ol $\{j e r g e\}^{3}$ ki Adonaj

(2) Tenrij beredi saja jer ag̉adog̉an süt da bal ki nečik

(3) sözledi Adonaj Tenrisi atalaryjnyn saja. והיה. [4] Da

(4) bolġaj ašqanyjyzda ošol ol Jardenni turg̉uzujuz ošol

(5) ol tašlarny ošpularny ki men bujuramen sizge bügün

(6) tavynda 'Evalnyn da jaqqyn alarny kirečbyla. ובנית. [5]

(7) Da qonda $\{r\}$ ġyn $\{[a] n d a\}^{4}$ mizbeah Adonajga Tenrije taštan mizbeah

(8) sunmaġyn alar üstüne temir. אבנים. [6] Tügel

(9) tašlardan qondarğyn ošol mizbeaḥyn Adonaj Tenrijnin da

(10) čyġarğyn anyn üstüne 'olalar Adonajğa Tenrije.

(11) וזבחת [7 Da debeḥa etkin šelamim debeḥalary da aša-

(12) ġyn anda da bijengin alnynda Adonajnyn Tenrijnin.

(13) וכתבת [8] Da jazg்yn ol tašlar üstüne ošol

(14) bar sözlerin ol Toranyn ošpunun belgirtme jah-

\footnotetext{
${ }^{1} \mathrm{~K}$ : The chapter number is not indicated. | TKow.o1: Deu 27. | H: Deu 27.| C: Deu $27 . \quad{ }^{2} \mathrm{~K}$ : Jisra'el; a scribal error. | TKow.o1: Jisra'elnin. | H: Jisra'elnin. | C: Jisra'elniy. $\quad{ }^{3}$ Marginal insertion by another hand.|TKow.o1: jerge; unvocalized text.|H: jerge.|C: jergä. $\quad{ }^{4}$ TKow.o1: anda; unvocalized text. | H: anda. | C: anda.
} 
(5) to be God to you, and to walk in his ways and

(6) to keep his statutes and his commandments and his judgments, and

(7) to listen to his voice. (A second translation of the expression 'you have proclaimed:)

(8) (And you made it said to the Lord today.) [18] And the Lord

(9) has made you great today to be a chosen people to him as

(10) he has spoken to you — and to keep all his commandments—- $A$ second translation

(11) of the expression 'and the Lord has proclaimed you':) (And the Lord made it said

(12) to you today.) [19] And to set you high

(13) above all kingdoms which he has made, for praise, for fame

(14) and for beauty, and that you may be a holy people to the Lord your God,

(15) as he has spoken.'

[Deuteronomy 27]

[1] And Moses and the elders of Israel commanded

(16) the people, saying, 'Keep all the commandments

(17) which I command you this day. [2] And it shall be,

(18) on the day when you shall cross Jordan to the land which the Lord

(19) your God is giving you, that you shall set yourselves up great stones

(20) and grease them with quicklime. [3] And you shall write

(21) on them all the words of this Law,

(1) after you had crossed, that you may come to the land which the Lord

(2) your God is giving you, a land flowing $\mid$ with $\mid$ milk and honey, as

(3) the Lord God of your fathers has promised you. [4] And

(4) it shall be, when you cross the Jordan, that you shall set up these

(5) stones which I command you today

(6) in Mount Ebal, and you shall grease them with quicksilver. [5]

(7) And you shall build there an altar to the Lord your God, an altar of stones.

(8) You shall not elevate iron over them. [6]

(9) You shall build the altar of the Lord your God of whole stones, and

(10) you shall offer burnt offerings on it to the Lord your God.

(11) [7] And you shall sacrifice the sacrifice of peace offerings, and

(12) you shall eat there, and you shall rejoice before the Lord your God.

(13) [8] And you shall write on the stones

(14) all the words of this Law, to declare it well.' 
(15) וידבר. [9] Da sözledi Moše da ol kohenler ol

(16) Levililer bar Jisra’elge ajtadog̉ač esijni qojğun \{da tynlag்yn\} e

(17) Jisra’el ošpu künnü bolunduj ulusqa Adonajg̉a Ten-

(18) rije. [10] Da tynlaġyn ününe Adonaj Ten-

(19) rijnin da qylġyn ošol micvalaryn da ošol resimlerin

(20) anyn ki men bujuramen saja bügün. ויצו. [11] Da bujurdu

(21) Moše ol ulusqa ol künde ajtadoğač. אלה. [12]

$324 \mathrm{~V}^{0} \quad$ (1) bular tursunlar alğyšlama ošol ol ulusnu tavy üs-

(2) tüne Gerizimnin ašqanyjyzdan sortun ošol ol Jardenni

(3) Šim`on da Levi da Juhuda da Jissahar da Josef da Binjamin.

(4) ואלה [13] Da bular tursunlar ol qarğyš qatyna tavynda

(5) 'Evalnyn Ru'uven Gad da Ašer da Zevulun Dan da Naftali.

(6) וענו Dasynlar ol Levililer da ajtsynlar

(7) bar eline Jisra’elnin bijik avazbyla. ארור. [15] Qarġyš-

(8) lydy ol kiši ki qylsa jonma abaq da qujma abaq

(9) hor etkenin Adonaj Tenrijnin išin qollarynyn ustanyn

(10) da qojsa jašyryn orunda da qaruv bersinler bar

(11) ol ulus \{da ajtsynlar\} amen. ארור. [16] Qarġyšlydy jengil etüvčü

(12) atasyn jemese anasyn da ajtsyn bar ol ulus amen.

(13) ארור [17] Qarġyšlydy jylyštyruvču čegin dostunun da

(14) ajtsyn bar ol ulus amen. ארור. [18] Qarg̉yšlydy janġyl-

(15) tuvču soqurnu jolda da ajtsyn bar ol ulus amen.

(16) ארור. [19] Qarg̉yšlydy tajdyruvču töresin garipnin ök-

(17) süznün da tulnun da ajtsyn bar ol ulus amen.

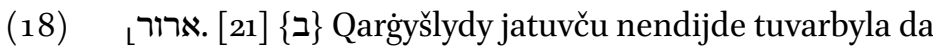

(19) ajtsyn bar ol ulus amen. ארור. [20] \{ א Q Q

(20) ču qatynybyla atasynyn ki aškartty ajipin atasynyn da

(21) ajtsyn bar ol ulus amen. ${ }^{11}$ ארור. [22] Qarġyšlydy jatuv-

$325 \mathrm{r}^{0} \quad$ (1) ču tuvdugiubyla qyzybyla atasynyn jemese qyzybyla

(2) anasynyn da ajtsyn bar ulus amen. ארור. [23] Qarğyšly-

(3) dy jatuvču qajnasybyla da ajtsyn bar ulus amen.

(4) ארור [24] Qarg̉yšlydy vatuvču dostun jašy\{r\}tynlyq-

(5) byla da ajtsyn bar ol ulus amen. ארור. [25]

\footnotetext{
${ }^{1}$ The order of these two verses was corrected by the copyist by numbering the verse-beginning words with $\aleph$ and, respectively.
} 
(15) [9] And Moses and the priests,

(16) the Levites, spoke to all Israel, saying, 'Take heed and listen, oh

(17) Israel: this day you have become a people to the Lord your God.

(18) [10] And you shall listen to the voice of the Lord your God

(19) and do his commandments and his statutes

(20) which I command you this day.' [11] And Moses commanded

(21) the people the same day, saying, [12]

(1) These shall stand on Mount Gerizim to bless the people

(2) after you had crossed the Jordan:

(3) Simeon and Levi and Judah and Issachar and Joseph and Benjamin.

(4) [13] And these shall stand for the curse on Mount Ebal:

(5) Reuben, Gad and Asher and Zebulun, Dan and Naphtali.

(6) [14] And the Levites shall begin and say

(7) to all the men of Israel with a loud voice: [15] "Cursed

(8) is the man who makes any carved god or molten god,

(9) an abomination to the Lord your God, the work of the hands of a craftsman,

(10) and puts it in a secret place." And all the people shall answer

(11) and say, "Amen." [16] "Cursed is the one who defiles

(12) his father or his mother." And all the people shall say, "Amen."

(13) [17] "Cursed is the one who moves his neighbour's border." And

(14) all the people shall say, "Amen." [18] "Cursed is the one

(15) who misleads the blind on the way." And all the people shall say, "Amen."

(16) [19] "Cursed is the one who rejects the justice of a stranger,

(17) an orphan and a widow." And all the people shall say, "Amen."

(18) ${ }_{\mathrm{L}}[21]$ \{2nd\} "Cursed is the one who lies with any kind of animal." And

(19) all the people shall say, "Amen." [20] \{1st\} "Cursed is the one who lies

(20) with his father's wife, because he has uncovered his father's nakedness." And

(21) all the people shall say, "Amen."1294 [22] "Cursed is the one who lies

(1) with his sister, the daughter of his father or the daughter

(2) of his mother." And all the people shall say, "Amen." [23] "Cursed

(3) is the one who lies with his mother-in-law." And all the people shall say, "Amen."

(4) [24] "Cursed is the one who smites his neighbour secretly."

(5) And all the people shall say, "Amen." [25]

294 The order of these two verses was corrected by the copyist. 
(6) Qarğyšlydy aluvču šoḥad öltürme žanny tök-

(7) me könü qan da ajtsyn bar ol ulus amen.

(8) ארור. [26] Qarğyšlydy kim ki qajjam etmese ošol

(9) sözlerin ol Toranyn ošpunun qylma alarny da ajt-

(10) syn bar ol ulus amen.

[Deuteronomy 28] ${ }^{1}$

(11) tynlama tynlasaj ününe Adonaj Tenrijnin saqlama da

(12) qylma ošol bar micvalarny anyn ki men bujuramen saja

(13) bügün da berir seni Adonaj Tenrij jog̉arraq bar ḥanlyq-

(14) lary üstüne ol jernin. [2] Da kelirler üs-

(15) tüje bar ol algyyšlar ošpular da jeterler seni ki

(16) tynlasaj ününe Adonaj Tenrijnin. [3] Alġyšly

(17) bolursen sen šaharda da alġyšly bolursen sen tüzde.

(18) ברוך [4 Alġyšly bolur jemiši qursaġyjnyn da jemi-

(19) ši jerijnin da jemiši tuvaryjnyn ijilmegi ullu tuvar-

(20) ברוך. [5] Alg̈yšly bolur

(21) četenij da ötmek qužurajtadoğan savutuj. ברוך. [6]

$325 \mathrm{~V}^{\mathrm{o}} \quad$ (1) Alg̈yšly bolursen sen kelgenijde da alğyšly bolursen sen

(2) čy[q]qanyjda ${ }^{2}$. ית . [7] Berir Adonaj ošol dušmanlaryjny ol

(3) turuvčularny üstüje qyryladoġanlarny alnyjda bir jol

(4) byla čyġarlar saja da jedi jollar byla qačarlar alnyjda.

(5) יצו [8 [8ymarlar Adonaj birgeje ošol ol algyšny zasekla-

(6) ryjda da bar sunuvunda qolujnun da alğyšlar seni jer-

(7) de ki Adonaj Tenrij beredi saja. יקימך. [9] Turg̉uzur

(8) seni Adonaj özüne aziz ulusqa ki nečik antetti

(9) saja ki saqlasaj ošol micvalaryn Adonaj Tenrijnin da jürü-

(10) sej jollarybyla anyn. [10] Da körerler bar uluslary

(11) ol jernin ki šemi Adonajnyn ataldy üstüje da qorqar-

(12) lar senden. והותרך. Da qaldyryr seni Adonaj jahšy-

(13) lyqqa jemišinde qursag̉yjnyn $\{d a\}$ jemišinde tuvaryjnyn da

\footnotetext{
${ }^{1} \mathrm{~K}$ : The chapter number is not indicated. | TKow.o1: Deu 28. | H: Deu 28. | C: Deu $28 . \quad{ }^{2} \mathrm{~K}$ : čyqanyjda; a scribal error. | TKow.o1: čyqqanyjda; unvocalized text. | H: cyqqanynda. | C: čyqqanyyda.
} 
(6) "Cursed is the one who takes a bribe to slay a soul

(7) to spill innocent blood." And all the people shall say, "Amen."

(8) [26] "Cursed is the one who does not strengthen

(9) the words of this Law to do them." And

(10) all the people shall say, "Amen."

[Deuteronomy 28]

[1] And it shall be,

(11) if you do listen to the voice of the Lord your God to keep and

(12) to do all his commandments which I command you

(13) today, then the Lord your God will set you high—above all kingdoms

(14) of the earth. [2] And

(15) all these blessings will come on you and will catch up with you when

(16) you will listen to the voice of the Lord your God. [3] You will be blessed

(17) in the city, and you will be blessed in the field.

(18) [4] Blessed will be the fruit of your womb and the fruit

(19) of your ground and the fruit of your livestock, the progeny of your great livestock,

(20) and the females of your sheep. [5] Blessed will be

(21) your basket and your bread-leavening vessels. [6]

(1) You will be blessed when you come in, and you will be blessed

(2) when you go out. [7] The Lord will give up your enemies,

(3) who rise up against you, broken, in front of you. By one way

(4) they will come out at you, and by seven ways they will flee before you.

(5) [8] The Lord will command the blessing

(6) for you within your abatises, and in all that you reach out your hand to, and he will bless you

(7) in the land which the Lord your God is giving you. [9] The Lord will

(8) raise you to be a holy people to himself as he has sworn

(9) to you, if you keep the commandments of the Lord your God and walk

(10) in his ways. [10] And all people of the earth will see

(11) the land, that you are called by the name of the Lord, and they will be afraid

(12) of you. [11] And the Lord will leave you

(13) in prosperity in the fruit of your body and in the fruit of your livestock and 
(14) jemišinde jerijnin ol jer üstüne ki antetti

(15) Adonaj atalaryja berme saja. יפתח. [12] Ačar Adonaj

(16) saja ošol ḥaznasyn özünün ol jaḩ̌̌yny ošol ol kök-

(17) lerni berme jamġurun jerijnin vaḥtynda da alğyšlama

(18) ošol bar išin qollaryjnyn da ötkünč berirsen köp

(19) hanlyqlarga da sen ötkünč almassen. ונתנך. [13] Da

(20) berir seni Adonaj ag̉araqqa da tüvül kičirekke da

(21) bolursen tek bijikke da bolmassen juvuzgia ki tynlasaj

$326 \mathrm{r}^{\mathrm{o}} \quad$ (1) micvalaryna Adonaj Tenrijnin ki men bujuramen saja bügün

(2) saqlama da qylma. ולא [14] Da qajyrylmaġyn bar ol söz-

(3) lerden ki men bujuramen sizge bügün on jary da son jary

(4) jürüme qullugiu artyna özge tenrilernin qulluq

(5) etme alarg̉a. [15] Da bolg̉aj eger tynlama-

(6) saj ününe Adonaj Tenrijnin saqlama qylma ošol bar

(7) micvalaryn da resimlerin anyn ki men bujuramen saja

(8) bügün da kelirler üstüje bar ol qarğyšlar

(9) ošpular da jeterler seni. [16] Qarğyšly bolur-

(10) sen sen šaharda da qarğyšly bolursen sen tüzde.

(11) ארור. [17] Qarğyšly bolur četenij da \{ötmek\} qužurajtadoġan

(12) savutuj. ארור. [18] Qarġyšly bolur jemiši qursaġyjnyn

(13) da jemiši jerijnin ijilmegi ullu tuvarlaryjnyn da tiši-

(14) leri qojujnun. ארור. [19] Qarġyšly bolursen sen kel-

(15) genijde da qarğyšly bolursen sen čyqqanyjda. ישלח. [20]

(16) Ijer Adonaj sende ošol ol qarğyšny ošol ol

(17) bulġančylyqny da ošol ol eksiklikni bar sunu-

(18) vunda qolujnun ki qylsaj taspolġanyjadejin da joq

(19) bolġanyjadejin tez alnyndan ${ }^{1}$ jamanlyġynyn jaman išlerijnin

(20) ki kemištij qullugiumnu menim. ידבק. [21] Jabuštu-

(21) rur Adonaj sende ošol ol öletni tavusqanyna-

$326 \mathrm{v}^{\mathrm{o}} \quad$ (1) dejin seni ol jer üstünden ki sen kelesen ary meresleme

(2) any. יככה. [22] Urar seni Adonaj suvuq hastalyq byla da

\footnotetext{
${ }^{1} \mathrm{~A}$ mistranslation repeated in a number of manuscripts. | TKow.o1: deest. | H: alnyndan. | C:
} aldyndan. | M: aldyndan. | E: alnyndan. | R: alnyndan. | Heb. 'because'. 
(14) in the fruit of your ground, on the land which the Lord swore

(15) to your fathers to give you. [12] The Lord will open

(16) to you his own good treasure, the skies

(17) to give rain to your land in its time and to bless

(18) all the work of your hand. And you will give a loan to many

(19) kingdoms, and you will not take a loan. [13] And

(20) the Lord will put you among the superiors and not among the little, and

(21) you will only be above, and you will not be below-if you listen

(1) to the commandments of the Lord your God which I command you $326 \mathrm{r}^{\mathrm{o}}$ today,

(2) to observe and to do them. [14] And you shall not turn from all the words

(3) which I command you today, to the right or to the left,

(4) to walk after the service of other gods to serve

(5) them. [15] And it shall be, if do not listen

(6) to the voice of the Lord your God to be watchful to do all

(7) his commandments and his statutes which I command you

(8) today, that all these curses shall come on you

(9) and catch up with you. [16] You will be cursed

(10) in the city, and you will be cursed in the field.

(11) [17] Cursed will be your basket and your bread-leavening

(12) vessel. [18] Cursed will be the fruit of your womb

(13) and the fruit of your land, the progeny of your livestock and

(14) the females of your sheep. [19] You will be cursed

(15) when you come in, and you will be cursed when you go out. [20]

(16) The Lord will send curses,

(17) confusion and shortages at you in all

(18) that you reach your hand out to do, until you are destroyed, and until you

(19) perish quickly from before $^{1295}$ the evil of your evil deeds,

(20) because you have forsaken me. [21]

(21) The Lord will make the pestilence cling to you until he consumes

(1) you from off the land which you are coming to inherit. $326 \mathrm{v}^{\mathrm{o}}$

(2) [22] The Lord will strike you with cold disease and

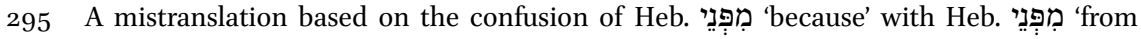
before'. Repeated in a number of Karaim translations. 
(3) issi hastalyq byla da küvmek byla da qararmaq byla

(4) da qurumaq byla da ${ }_{L}\{\text { sarylyqbyla da ješillikbyla }\}^{71}$ da

(5) quvarlar seni taspolganyjadejin. והיו [23] Da bolurlar

(6) köklerij ki bašyj üstüne tuč kibik da ol jer

(7) ki tübüjde temir kibik. י[ן [24] Berir Adonaj o-

(8) šol jamg்uru ornuna jerijnin tozġaq da topraq ol

(9) köklerden ener üstüje taspolganyjadejin. יתנך. [25]

(10) Berir seni Adonaj qyryladog̉anny alnynda dušmanlaryjnyn

(11) bir jolbyla čyġarsen anar da köp jollar byla qačarsen

(12) alnynda anyn da bolursen ḥorluqqa bar bijliklerine

(13) ol jernin. והיתה. [26] Da bolur gövdej jemge qušu-

(14) na ol köklernin da kijigine ol jernin da bolmasty

(15) üškürtüvčü alarny. יככה. [27] Urar seni Adonaj

(16) čybany byla Micrinin da tomalčyqlar byla da juvuš qo-

(17) tur byla da quru qotur byla ki bolalmassen ongalma.

(18) יככה (28] Urar seni Adonaj telirmekbyla da soqur-

(19) luq byla da alġasamaġy byla jüreknin. והית. [29] Da

(20) bolursen qarmanuvču tüš vaḥtynda ki nečik qarmana-

(21) \{dyr\} ol soqur tumanda da onarmassen ošol jollaryjny

$327 \mathrm{r}^{\mathrm{o}} \quad$ (1) da bolursen tek zulumlanġan da talanġan bar ol künler-

(2) de da bolmasty qutqaruvču. [3ה. [30] Qatyn kelešsej

(3) da özge kiši alyr any üv qondarsaj da oltur-

(4) massen anda borlalyq or\{na\}tsaj da alajoqqa čygar-

(5) massen any. שורך [31] Ögüzüj sog̉um etilgen bo-

(6) lur közlerijče da ašamassen andan ešegij talanġan

(7) bolur alnyjdan da qajtmasty saja qojuj senin beril-

\footnotetext{
${ }^{1} \mathrm{~K}$ : Originally ješillikbyla da sarylyqbyla; the word order was corrected by the copyist.
} 
(3) with fever and with inflammation and with gangrene 296

(4) and with withering and with blight and with mould. And

(5) they will pursue you until you perish. [23] And

(6) your skies that are over your head will be like bronze, and the earth

(7) that is under you like iron. [24] The Lord will give

(8) powder and dust instead of rain;

(9) it will come down on you from the skies until you perish. [25]

(10) The Lord will give you out, before your enemies, broken.

(11) By one way you will go out against them, and by many ways you will flee

(12) before them. And you will be a shame to all the kingdoms

(13) of the earth. [26] And your body will become food for the birds

(14) of the skies and for the wild |animals $\mid$ of the earth, and there will be no

(15) one frightening them. [27] The Lord will strike you

(16) with the boils of Egypt and with abscesses and with moist

(17) scabs and with dry scabs from which you will not be able to be healed.

(18) [28] The Lord shall strike you with madness and

(19) with blindness and with embarrassment of heart. [29] And

(20) you will grope at noon as

(21) the blind gropes in darkness, and you will not prosper in your ways.

(1) And you will be just oppressed and plundered every day,

(2) and there will be no saviour. [30] You will betroth a wife,

(3) and another man will take her. You will build a house, and

(4) you will not dwell in it. You will plant a vineyard, and, in the same way,

(5) you will not harvest it. [31] Your cattle will be slain

(6) in your sight, and you will not eat of it. Your donkey will be stolen

(7) from before you, and it will not come back to you. Your sheep will be given

296 K: qararmaq; BHeb. חַרְּוּר 'violent heat, fever' (Klein 1987: 232; Koehler \& Baumgartner

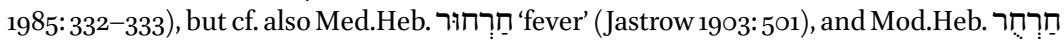
'gangrene, plough-staff' (Comey \& Tzur 2006: 240). | Translated as 'fiery heat' in KJ20oo, ESV, and as 'burning' by Friedman (2003). | Given that symptoms of gangrene may include a change in skin colour to black, we follow here the interpretation proposed in Jankowski \& Aqtay \& Cegiołka \& Çulha \& Németh (2019: II 266), where the word's equivalent, i.e., EKar. harhur, is translated as 'gangrene'. | TKow.o1: qararmaq. | H: qararmaq. | C: harhur. | M: qararmaq. | R: qara hastalyh. 
(8) genler bolurlar dušmanlaryja da bolmasty saja qut-

(9) בaruvču. [32] Uvullaryj da qyzlaryj berilgen bolur-

(10) lar özge ulusqa da közlerij körerler da telme-

(11) rirler alarg̉a har kün da bolmasty küčü qolujnun.

(12) פרי (33] Jemišin jerijnin da bar zaḥmetijni ašar ulus

(13) ki bilmejsen da bolursen tek zulumlangan da synyqqan

(14) bar ol künlerde. והיית] [34] Da bolursen telirgen

(15) körümünden közlerijnin ki körersin. יככה. [35]

(16) Urar seni Adonaj jaman čyban byla ol tizler üstü-

(17) ne da ol janbašlar ${ }^{1}$ üstüne ki bolalmassen onġal-

(18) ma bašlap tabanyndan ajagyyjnyn da töbejedejin. יולך. [36]

(19) Eltir Adonaj seni da ošol bijijni ki turğuzsaj

(20) üstüje hanlyqqa ki bilmejsen sen da atalaryj da

(21) qulluq etersiz anda qulluq etüvčülerge öz-

$327 \mathrm{~V}^{\mathbf{0}}$ (1) ge tenrilerge ag̉ačtan da taštan. והיית [37 Da bolur-

(2) sen verenlikke mašalğa da čejnavğa bar ol uluslar-

(3) da ki könderse seni Adonaj ary. זי[38] Köp ur-

(4) luq čyġaryrsen ol tüzge da az jyštyryrsen ki tüge-

(5) tir any ol arbe ündeledog̉an žynsy čegirtkenin.

(6) כרמים [39] Borlalyqlar ornatyrsen da išlersen da

(7) čaġyr ičmessen ani jyštyrmassen ki ašar any ol

(8) qurt. זיתים [40] Zejtun bolur saja bar čegijde

(9) da jav qujmassen ki qurur zejtunuj. בנים. [41] Uvul-

(10) lar da qyzlar tuvdurursen da bolmaslar saja ki baryr-

(11) lar jesirlikte. כל [42] Bar ag̉ačyjny da jemišin jerijnin

(12) taseter čylčalbyla ündeledogan qurt. פשט (12) (פל של (12)

(13) (על תיבת הצלצל) (Meresler ol dušman ki kelir avaz

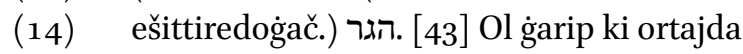

(15) miner üstüje bijikke bijikke da sen enersen juvuz-

${ }^{1}$ Possibly a mistranslation; the use of this word is unclear. | TKow.o1: janbašlar; unvocalized text. | H: inčikler. | C: inčiklär. | M: butlar. | E: butlar. | R: butlar. | Heb. הַשׁׁקַים 'the legs'. 
(8) to your enemies, and you will have no saviour.

(9) [32] Your sons and your daughters will be given

(10) to another people, and your eyes will look and long

(11) for them every day, and there will be no strength in your hand.

(12) [33] A people whom you do not know will eat the fruit of your land, and all your labours,

(13) and you will only be oppressed and crushed

(14) every day. [34] And you will be driven mad

(15) by the sight of your eyes which you will see. [35]

(16) The Lord will strike you with bad boils on the knees

(17) and over your [ ${ }^{\dagger}$ bedheads] ${ }^{297}$ that you will not be able to be healed,

(18) from the sole of your foot to the top of your head. [36]

(19) The Lord will bring you and your king which you will set

(20) over you to a kingdom which neither you nor your fathers know, and

(21) there you will serve the service of those who serve

(1) other gods, of wood and stone. [37] And you will

(2) become destruction, a proverb, and stuttering among all nations

(3) where the Lord shall lead you. [38]

(4) You will take out much seed to the field, but you will gather little, because

(5) the kind of locust called arbe 298 will finish it off.

(6) [39] You will plant vineyards and work them, but

(7) you will not drink wine or gather |grapes|, because the

(8) worms will eat them. [40] You will have olive trees within all your border,

(9) but you will not pour oil, because you olive will wither. [41]

(10) You will beget sons and daughters, but they will not be yours, because they will go

(11) into captivity. [42] All your trees and the fruit of your land

(12) will be destroyed by an insect called čylčal ${ }^{299}$. (A second translation

(13) of the expression 'the locust': $)_{L}$ (The enemy_-who will come

(14) letting his voice be heard - will inherit.) ${ }^{1300}$ [43] The stranger who is among you

(15) will rise up above you higher and higher, and you will come down lower

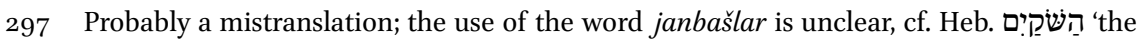
legs'.

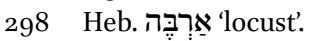

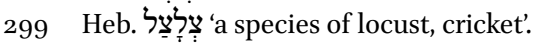

300 It remains unclear how does this addition relate to 'the locust'. 
(16) ġa juvuzġa. הוא. [44] Ol ötkünč berir saja da

(17) \{sen\} ötkünč bermess[e] $\mathrm{n}^{1}$ anar ol bolur ag̉araqqa da sen

(18) bolu\{r\}sen kičirekke. ובאו] [45] Da kelirler üstüje

(19) bar ol qarġyšlar ošpular da quvarlar seni da jeterler

(20) seni taspolġanyjadejin ki tynlamadyj ününe Adonaj Ten-

(21) rijnin saqlama micvalaryn anyn da resimlerin ki bujur-

$328 \mathrm{r}^{\mathrm{o}}$ (1) du saja. [46] Da bolurlar sende belgige da nišan-

(2) ga da urlugiujda dunjaġadejin. תח. [47] Anyn üčün

(3) ki qulluq etmedij Adonajğa Tenrije bijenč byla da

(4) šatyrlyġybyla jüreknin köplügünden barčanyn.

(5) (48] Da qulluq etersen dušmanlaryja ki ijer

(6) any Adonaj sende ačlyqta da suvsaplyqta da

(7) jalanġačlyqta da eksikliginde bar nersenin da

(8) berir temirli bojunsa bojnuj üstüne tasetke-

(9) ninedejin seni. ישא. [49] Qyjasa kötürüp keltirir

(10) Adonaj üstüje hanlyq jyraqtan qyryjyndan ol jernin ki

(11) nečik učady ol nešer andij ḥanlyq ki anlajalmassen sö-

(12) zün tilinin. [5ו [50] Ḥanlyq čaja jüzlü ki jüz etmesti

(13) jüzlerge qartqada ani ulan üstüne ḥajifsün-

(14) mesti. ואכל [1] Da ašar jemišin tuvaryjnyn da jemi-

(15) šin jerijnin ta\{s\}polġanyjadejin ki qaldyrmasty saja bürtük

(16) šarbet da saj ijilmegin ullu tuvarlaryjnyn da tišilerin

(17) qojujnun tasetkeninedejin seni. והצר. [52] Da qysyqlyq

(18) eter saja bar šaharlaryjda enginče qalalaryj ol bijikler

(19) da ol bekler ki sen išanasen qorunma alarda bar jerij-

(20) de da qysyqlyq eter saja bar šaharlaryjda bar jerij-

(21) de ki berdi Adonaj Tenrij saja. ואכלת [53] Da

$328 \mathrm{v}^{\mathrm{o}} \quad$ (1) ašarsen jemišin qursağyjnyn etin ulanlaryjnyn da qyzlaryjnyn

(2) ki berdi saja Adonaj Tenrij qysyqlyqta da tarlyqta ki

(3) qysyqlyq eter saja dušmanyj. האיש. [54] Ol jymšaq

(4) müžešli ${ }^{2}\{k i s ̌ i\}$ sende da ol ašajyš astry jaman bağar közü

\footnotetext{
${ }^{1} \mathrm{~K}$ : Spelled בירְמֵסְסִ a scribal error. | TKow.o1: bermassen. | H: bermessen. | C: different wording.

${ }^{2}$ Uncertain reading. | K: minžešli; uncertain reading. | H: minžesli. | C: deest. | R: qatyn.
} 
(16) and lower. [44] He will give you a loan, and

(17) you will not give him a loan. He will be the superior, and you

(18) will be the smaller. [45] And all these curses will come on you

(19) and will pursue you and catch up with

(20) you until you are destroyed, because you did not listen to the voice of the Lord

(21) your God, to keep his commandments and his statutes which he

(1) commanded you. [46] And they will be in you for a sign and for a token,

(2) and in your offspring forever. [47] Because

(3) you did not serve the Lord your God with joyfulness and

(4) with gladness of heart from the abundance of everything.

(5) [48] And you will serve your enemies which

(6) the Lord will send at you in hunger and in thirst and

(7) in nakedness and in lack of all things. And

(8) he will put a yoke of iron on your neck

(9) until he has destroyed you. [49] The Lord will in a way lift and carry

(10) a kingdom over you from far, from the end of the earth,

(11) the way an eagle flies, such a kingdom whose language you will be not able to understand,

(12) [50] A kingdom of fierce countenance which will not favour

(13) the old and will not show grace to the young,

(14) [51] And it will eat the fruit of your cattle and

(15) the fruit of your land until you are destroyed, who will not leave you grain,

(16) must or olive oil or the progeny of your great livestock or the female

(17) of your sheep until he has destroyed you. [52] And it will oppress

(18) you in all your cities until your high and fortified walls come down

(19) in which you trust to be defended in all your land.

(20) And it will oppress you in all your cities, in all your land

(21) which the Lord your God has given you. [53] And

(1) you shall eat the fruit of your womb, the flesh of your sons and of your daughters

(2) which the Lord your God has given you, in the oppression and in the distress with which

(3) your enemies shall oppress you. [54] The

(4) man [ that is soft in touch ${ }^{301}$ among you and very delightful: his eye will look |with| evil

301 Uncertain interpretation; the meaning of the word mǚ̌ešli is unclear. 
(5) anyn qaryndašy üstüne da qojundag̉y qatyny üstü-

(6) ne da qaldyq ulanlary üstüne ki qaldyrsa.

(7) מתת [55] Bermekten birisine alardan etinden uvulla-

(8) rynyn ki ašasa qaldyrmajynča anar qaldyq heč nemede

(9) qysyqlyqta da tarlyqta ki qysyqlyq eter saja duš-

(10) manyj bar šaharlaryjda. הרכה. [56] Ol jymšaq müžeš-

(11) li qatyn send́a da ol ašajyš ki čynyqmady tabany ajağy-

(12) nyn turma ol jer üstüne ašajyšlyqtan da jymšaq

(13) müžešlikten jaman bağar közü anyn qojundag்y eri

(14) üstüne da uvlu üstüne da qyzy üstü-

(15) \{ne\}. [5שליתה. [57] Da jaš ulany üstüne ol čyqqan

(16) bavursaqlaryndan da uvullary üstüne ki törese

(17) ki ašar alarny eksikliginde bar nersenin jašyr-

(18) tynlyqbyla qysyqlyqta da tarlyqta ki qysyqlyq

(19) eter saja dušmanyj šaharlaryjda. אם [58] [Eger

(20) $\{[\ldots]\}^{11}$ tynlamasaj qylma ošol bar sözlerin ol Toranyn

(21) ošpunun ol jazylġanlarny ošpu seferde qorqma

$329 \mathrm{r}^{\mathrm{o}} \quad$ (1) šeminden ol Tenrinin ol syjly da ol qorqunčlu

(2) ošpu Adonaj Tenrijden. והפלא. [59] Da tamaša

(3) eter Adonaj ošol karanjajny da ošol karanjalaryn

(4) urlugiujnun ullu karanjalar da tügengisizler da

(5) jaman ḥastalyqlar da tügengisizler. והשיב. [6o]

(6) Da qajtaryr saja ošol bar syzlavyn Micrinin ki

(7) qorqtuj alynlaryndan alarnyn da jabušurlar sende.

(8) גם [61] Dağyn barda ḥastalyqny da bar karanja-

(9) ny ki jazylmaġandy sefer ol Torada ošpu keltirir

(10) alarny Adonaj üstüje ta\{s\}polġanyjadejin. [62]

(11) Da qalyrsiz azġynaq elbyla anyn üčün ki edijiz

(12) jolduzlary kibik ol köklernin köplükke barysy bu

(13) bolur saja anyn üčün ki tynlamadyj ününe Adonaj

(14) Tenrijnin. [6יה [63] Da bolg̉aj ki nečik bijendi Adonaj

${ }^{1}$ There is a damaged and illegible marginal insertion by another hand. The Hebrew text suggests,

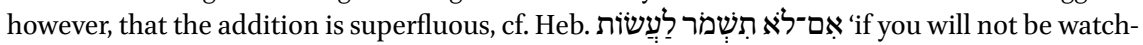
ful'. | TKow.o1: barysy bu bolur saja eger; unvocalized text. | H: barysy bu bolur sana eger. | C: egär. 
(5) intent at his brother and at his wife in his armpits,

(6) and at the rest of his children that he will have left-

(7) [55] From giving to one of them of the flesh of his children

(8) that he will eat, leaving nothing left to him

(9) in the oppression and in the distress with which your enemies will oppress you

(10) in all your cities. $[56]$ The $\left[{ }^{\dagger} \text { soft in touch }\right]^{302}$

(11) and the delightful woman among you who did not get used to set the sole of her foot

(12) on the ground to stand on it because of her delightfulness and $\left[{ }^{\dagger}\right.$ softness

(13) in touch $]^{303}$ : her eye will look |with| evil intent at the husband in her armpits,

(14) and at her son and at her daughter,

(15) [57] And at her infant child that comes out

(16) from her insides and at her children which she shall bear,

(17) because she will eat them secretly due the lack of everything

(18) in the oppression and distress with which

(19) your enemy will oppress you in your cities. [58] If

(20) you do not obey to do all the words of this Law

(21) that are written in this book, to fear

(1) the name of God, the honoured and awesome

(2) Lord your God: [59] Then

(3) the Lord will make your punishments and the punishments of your offspring astonishing,

(4) great and continuous punishments, and

(5) bad and continuous illnesses. [6o]

(6) And he will bring back on you all the diseases of Egypt which

(7) you were afraid of before them, and they will cling to you.

(8) [61] Also: every illness and every punishment

(9) which is not written in the book of this Law: the Lord will bring them

(10) on you until you are destroyed. [62]

(11) And you will be left few persons, because you were

(12) like the stars of the skies for multitude: all this

(13) will happen to you because you did not listen to the voice of the Lord

(14) your God. [63] And it shall be that as the Lord rejoiced

302 Uncertain interpretation; the meaning of the word müžešli is unclear.

303 Uncertain interpretation; the meaning of the word müžešlik is unclear. 
(15) siznin üčün jahšy etme sizge da arttyr-

(16) ma sizni alaj bijendi Adonaj siznin üčün tasetme

(17) da joq etme sizni da sibirilirsiz ol jer

(18) üstünden ki sen kelesen ary meresleme any.

(19) [64 Da tozdurur sizni Adonaj bar ol ulus-

(20) larda bašlap qyryjyndan ol jernin da qyryjynadejin ol

(21) jernin da qulluq etersiz anda qulluq etüvčüler-

$329 \mathrm{v}^{\mathrm{o}} \quad$ (1) ge özge tenrilerge ki bilmedij sen da atalaryj ${ }_{\text {L }}$ a gáacqa da tasqa $\}^{11}$.

(2) ובגוים Da ol hanlyqlarda tynč almassen da bol-

(3) masty tynčlyq tabanyna ajag̉yjnyn da berir Adonaj saja

(4) anda qaltravuqlu jürek da tunmaġyn közlernin da

(5) syzlavyn žannyn. והיו [66] Da bolurlar tirliklerij

(6) tağyladoġanlar saja qaršy[j] dan ${ }^{2}$ da qorqarsen kečebyla

(7) da kündüz da inanmassen tirliklerije.

(8) [67 [6rtenbylada ajtyrsen kim berip bol-

(9) sajedi ingir da ingirde ajtyrsen kim berip

(10) bolsajedi tan qorquvundan jüregijnin ki qorqarsen da

(11) körümünden közlerijnin ki körersin. והשיבך. [68]

(12) Da qajtaryr \{seni\} Adonaj Micrige gerepler byla jolbyla

(13) ki ajttym saja arttyrmasen artyq körme

(14) any da satylyrsiz anda dušmanlaryja qullarğa

(15) da qaravašlarg̉a da bolmasty satyn aluvču. אלה. [69]

(16) Bulardylar sözleri ol šertnin ki bujurdu Adonaj

(17) Mošege kesme ulanlary byla Jisra'elnin jerinde

(18) Mo’avnyn bašqa ol šertten ${ }^{3}$ ki kesti birgeleri-

(19) ne Horevde.

[Deuteronomy 29] $]^{4}$

(19) [1] Da čağyrdy Moše bar

(20) Jisra'elge da ajtty alarğa siz kördüjüz ošol

(21) barča neki qyldy Adonaj közlerijizče jerinde

$330 \mathrm{r}^{\mathrm{o}}$ (1) Micrinin par`og̀a da bar qullaryna da bar jerine

(2) anyn. המסות. [2] Ol ullu synavlarny ki kördüler

(3) közlerij ol belgilerni da ol nišanlarny ol ullu-

\footnotetext{
${ }^{1}$ Marginal insertion by another hand in South-Western Karaim. | TKow.o1: deest. | H: senin aǵacly da tasly. | C: ag்ač da taš. $\quad{ }^{2} \mathrm{~K}$ : qaršydan; a scribal error or a mistranslation. | TKow.o1: qaršydan.

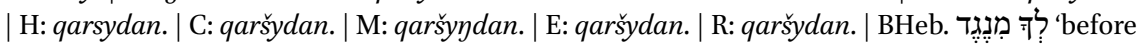
you'. $\quad{ }^{3} \mathrm{~K}$ : This word is not vocalised. $\quad{ }^{4} \mathrm{~K}$ : The chapter number is not indicated.
} 
(15) over you to do good to you and to multiply

(16) you, so the Lord will rejoice over you to destroy you

(17) and to bring you to nothing, and you will be swept from off the land

(18) where you are coming to inherit it. [64] And the Lord will scatter you among all

(19) people, from the one edge of the earth even to the other edge of the

(20) earth, and there you shall serve those who serve

(1) other gods which you have not known, you and your fathers, \{wood $329 \mathrm{v}^{\mathrm{o}}$ and stone\}.

(2) [65] And among these kingdoms you will take no rest, and

(3) there will be no rest for the sole of your foot, and the Lord will give you

(4) there a trembling heart and misty eyes and

(5) sorrow of mind. [66] And your life will be

(6) hanging in front [of you], and you will fear night

(7) and day and will not trust your life.

(8) [67] At dawn you will say, "If only it were

(9) evening," and at evening you will say, "If only it

(10) were morning," because of the fear of your heart by which you shall fear and

(11) because of the sight of your eyes which you will see. [68]

(12) And the Lord will bring you back into Egypt in ships, by the way

(13) of which I spoke to you, "You shall see it no more."

(14) And you will be sold there to your enemies as servants

(15) and maidservants, and there will be no buyer.' [69]

(16) These are the words of the covenant which the Lord commanded

(17) Moses to make with the children of Israel in the land

(18) of Moab, besides the covenant which he made with them

(19) at Horeb.

[Deuteronomy 29]

(19) [1] And Moses called to all

(20) Israel, and said to them, 'You have seen

(21) all that the Lord did before your eyes in the land

(1) of Egypt to Pharaoh and to all his servants and to all his land,

(2) [2] The great tests which your eyes have seen,

(3) the signs and those great tokens. 


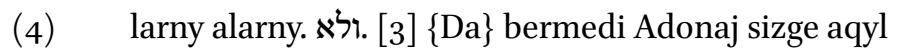

(5) bilme da közler körme da qulaqlar ešitme

(6) ošpu künge dejin. ואולך] [4] Da jürüttüm sizni

(7) qyrq jyl midbarda upranmadylar upraqlaryjyz üs-

(8) tüjüzden da etigij upranmady ajaġyj üstün-

(9) den. לחם [5] Ötmek ašamadyjyz da čag̉yr da esir[t]-

(10) ki ${ }^{1}$ ičmedijiz anyn üčün ki bilgejsiz ki men men Adonaj

(11) Tenrijiz. [תבואו. [6] Da keldijiz ol orung̉a oš-

(12) pu da čyqty Siḥon biji Ḥešbonnun da 'Og̉ biji ol

(13) Bašannyn uturumuzġa da qyrdyq alarny. [7]

(14) Da aldyq ošol jerlerin alarnyn da berdik ülüš-

(15) ke ševetine Ru'uvennin da ševetine Gadnyn da jarym

(16) ševetine $\{[0] 1\}^{2}$ Menašenin. ושמרתם. [8] Da saqlajyz ošol

(17) sözlerin ol šertnin ošpunun da qylyjyz alarny anyn \{üčün\}

(18) ki onarğajsiz ošol barča neki qylsajyz.

פרשת נצבים (19)

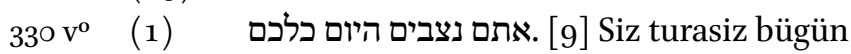

(2) ba $\{r\}$ laryjyz alnynda Adonajnyn Tenrijiznin ag̉araq-

(3) laryjyz agaraqlary ševetlerijiznin qartlaryjyz da tajaqčylaryjyz

(4) bar eli Jisra’elnin. טפבם. [10] Jašyjyz qatynlaryjyz da

(5) ġaripij ki ortasynda avulujnun bašlap kesüvčü-

(6) den otunlaryjny süzüvčügedejin suvlaryjny. לעברך. [11]

(7) Ašma sen kirme šertine Adonaj Tenrijnin da qar-

(8) ġyšyna anyn ki Adonaj Tenrij kesedi birgeje bügün.

(9) [12] Qajjam etmek üčün seni bügün özü-

(10) ne ulusqa da ol bolur saja Tenrige ki nečik

(11) sözledi saja da ki nečik antetti atalaryja Avraham-

(12) ga Jichaqqa da Ja'aqovğa. ולא [13] Da tüvül bir-

(13) gejizge jalġyzlar özüjüz men kesemen ošol ol šert-

(14) ni ošpunu da ošol ol qarg̉yšny ošpunu. כי [14]

(15) Ki ančaq anyn byla kim ki bardy bunda birgemizge

(16) turady bügün alnynda Adonajnyn Tenrimiznin da anyn

(17) bylada kim ki joḥtu bunda birgemizge bügün. כי [15]

(18) Ki siz bilesiz ošol neki kečiktik jerinde Micrinin

(19) da ošol ne ki aštyq ortasynda ol ḥanlyqlarnyn ki

(20) aštyjyz. ותראו. [16] Da kördüjüz ošol qusqunčuluq-

\footnotetext{
${ }^{1}$ K: esirki; a scribal error. Cf. Deu 14:26. | TKow.o1: esirtüvčü; unvocalized text. | H: esirtki. | C: boza.

${ }^{2}$ TKow.o1: deest. | H: ol. | C: ol.
} 
(4) [3] But the Lord has not given you a mind

(5) to know and eyes to see and ears to hear

(6) until this day. [4] And I have led you

(7) forty years in the wilderness, your clothes have not worn away

(8) on you, and your shoes have not worn away on your foot,

(9) [5] You have not eaten bread, and you have not drunk wine, and

(10) you have not drunk strong drink, that you may know that I am the Lord

(11) your God. [6] And you came to this place.

(12) And Sihon, king of Heshbon, and Og, king

(13) of Bashan, came out against us, and we smote them. [7]

(14) And we took their land and gave it as inheritance

(15) to the Reubenites and to the Gadites and to the half

(16) tribe of Manasseh. [8] And you shall keep the

(17) words of this covenant and do them, that you

(18) may prosper in all that you do.

(19) Parashat Nitzavim

(1) [9] You are standing today,

(2) all of you, before the Lord your God-your superiors,

(3) the superiors of your tribes, your elders and your overseers,

(4) all the men of Israel, [10] Your infants, your wives and

(5) your stranger who is in your camp, from one who cuts

(6) your wood to one who draws of your water-[11]

(7) For you to cross and enter into the covenant of the Lord your God and

(8) into his curse, which the Lord your God makes with you today,

(9) [12] In order to establish you today for him

(10) as a people, and he will be a God to you as

(11) he has said to you and as he has sworn to your fathers: to Abraham,

(12) to Isaac, and to Jacob. [13] It is not

(13) with you alone that I am making

(14) this covenant and this curse, [14]

(15) But with the one who is here with us,

(16) stands today before the Lord our God, and

(17) also with the one who is not here with us today. [15]

(18) Because you know that we stayed in the land of Egypt

(19) and that we passed among the kingdoms that

(20) you passed. [16] And you have seen their abominations 
(21) laryn alarnyn da ošol hečliklerin alarnyn ag̉ačtan da taš-

$331 \mathrm{r}^{\mathrm{o}} \quad$ (1) tan kümüšten da altyndan ki birgelerine alarnyn.

(2) פן [17] Mag̉at bardy sizde kiši jemese qatyn jeme-

(3) se uruv jemese ševet ki jüregi anyn qajyryldy

(4) bügün qullugiundan Adonajnyn Tenrimiznin barma qulluq

(5) etme abaqlaryna ol ḥanlyqlarnyn alarnyn magat

(6) bardy sizde koreń jajyladogan uv da zahürmer.

(7) והיה Da bolg̀aj ešitkeninde ošol sözle-

(8) rin ol qarg்yšnyn ošpunun da alġyšlar özü ö-

(9) zün kölnünde ajtadoġač bazlyq bolur maja ḥote

(10) tersligibyla jüregimnin jürüsemde eksitmek

(11) üčün ol cadiqni ol rašábyla. לא. [19] Klemes-

(12) ti Adonaj bošatma jazyġyn anyn ki ol vaḥtta qabunur

(13) ačuvu Adonajnyn da künülügü anyn ol kišide e-

(14) ger bir kiši bolsa ol da eger uruv bolsa

(15) ol da jatyr anda bar ol qarg்yš ol jazylġan oš-

(16) pu seferde da sürter Adonaj ošol atyn anyn

(17) töbünden ol köklernin. והבדילו [20] Da eger

(18) ševet bolsa ol da ajyryr any Adonaj jamanlyqqa bar

(19) ševetlerinden Jisra’elnin bar qarğyšlaryna köre ol

(20) šertnin ol jazylġan ošpu $\{$ ool T[ora $] d a o l\}^{11}$ seferde. ואמר. [21] Da

(21) ajtyr ol sondragy dor ulanlaryjyz ki tursalar

$331 \mathrm{v}^{\mathrm{o}} \quad$ (1) özüjüzden sortun da ol jat k[i $]^{2}$ kelse jyraq jerden da

(2) körerler ošol karanjalaryn ol jernin da ošol ḥastalyqla-

(3) ryn anyn ki ḥastalatty Adonaj anda. גפרית. [22] Kügürt

(4) da tuz küvgen bolur bar jeri anyn čačylmasty da bit-

(5) tirmesti da ösmesti anda heč kögöt aḥtaryl-

(6) maggykibik Sedomnun da Amoranyn Admanyn da Cevojim-

(7) nin ki aḥtardy Adonaj ačuvu byla da qahiribyla.

(8) ואמרו 23] Da ajtyrlar bar ol hananlyqlar ne üčün qyl-

(9) dy Adonaj bulaj ošpu jerge nedir qabunmağy ol ullu

(10) ačuvnun ošpunun. ואמרו. [24] Da ajtyrlar anyn

(11) üčün ki kemištiler ošol šertin Adonajnyn Tenrisinin

(12) atalarynyn ki kesti birgelerine čyġarg̉anynda alarny jerin-

(13) den Micrinin. וילכו [25] Da bardylar da qulluq ettiler

(14) özge tenrilerge da bašurdular alarg̉a tenrilerge

${ }^{1}$ Marginal insertion by another hand. | TKow.o1: ol Torada ošpu; different wording; unvocalized text. | H: ol Torada ol. | C: ušbu Toranyy. $\quad{ }^{2} \mathrm{~K}$ : ke; a scribal error. | TKow.o1: unvocalized text. | H: ki. $\mid \mathrm{C}: k i$. 
(21) and their vanities, of wood and stone,

(1) of silver and gold, which were with them.

(2) [17] Lest there be among you a man or woman or

(3) family or tribe whose heart turns away

(4) today from the service of the Lord our God to go and serve

(5) the gods of their kingdoms; lest

(6) there be among you a root spreading poison and wormwood:

(7) [18] And it shall be, when he hears the words

(8) of this curse, that he will bless himself

(9) in his heart, saying, "I will have peace, though

(10) I will walk in the obstinacy of my heart, so as to drive away

(11) the righteous and the wicked ${ }^{1304}$ : [19] The Lord will not be willing

(12) to forgive his sin, because then

(13) the anger of the Lord and his jealousy will burn against that man,

(14) be it one man, be it a family,

(15) and he will lie on him all the curses that are written

(16) in this book, and the Lord will wipe out his name

(17) from under heaven. [20] And if

(18) it is a tribe, the Lord will separate him, for bad,

(19) from of all the tribes of Israel, according to all the curses of the

(20) covenant that is written in this Law, in the book. [21] And

(21) the next generation will say-your children that will rise up

(1) after you and the foreigner that will come from a far land, and

(2) they will see the punishments of that land and its illnesses

(3) with which the Lord has made it ill, [22] Sulphur

(4) and salt, all the land will be a burnt, it will not be sown, and

(5) it will give no produce, and no plant will grow there,

(6) like the ruining of Sodom and Gomorrah, Admah and Zeboim

(7) which the Lord ruined with his anger and with his fury-

(8) [23] And all the kingdoms will say, "Why

(9) has the Lord done thus to this land? What is this burning of this great

(10) anger?" [24] And they will say,

(11) "It is because they have left the covenant of the Lord, God

(12) of their fathers, which he made with them when he brought them out from of the land

(13) of Egypt. [25] And they went and served

(14) other gods and worshiped them, gods

304 Interpretative translation. 
(15) ki bilmesediler alarny da ülüš bermedi Tenri alarny

(16) alarg̉a. ויחר [26] Da qabundu ačuvu Adonajnyn ol jer

(17) üstüne keltirme anyn üstüne ošol bar ol

(18) qarğyšny ol jazylġanny ošpu seferde. ויתשם [27 Da

(19) tašlady alarny Adonaj jerleri üstünden ačuvbyla da

(20) $\langle\text { ullu }\rangle^{1}$ qahir byla ${ }_{\llcorner}\{\text {da ullu }[\mathrm{a}] c ̌ c u v l a[\mathrm{n}] \text { maq byla }\}^{12}$ da saldy alarny galutqa özge jerge

(21) ošpu künkibik. הנסתרות. [28] Ol jašyryn nerseler

$332 \mathrm{r}^{\mathrm{o}} \quad$ (1) erkindedi Adonajnyn Tenrimiznin da ol aškarala $\{\mathrm{r}\}$ ny borč-

(2) tu qylma bizge da ulanlarymyzğa dunjaġadejin qylma

(3) ošol bar sözlerin ol Toranyn ošpunun.

$[\text { Deuteronomy 30 }]^{3}$

(4) bolgaj ki kelseler üstüje bar ol sözler ošpular

(5) ol alğyš da ol qarg்yš ki berdim alnyjda da qaj-

(6) tarğyn esije boladog̉ač bar ol ḥanlyqlarda ki azaštyr-

(7) sa seni Adonaj Tenrij ary. ושבת [2] Da tešuvabyla

(8) qajtqyn bar క̌anyjbyla ki jetkej alnyna Adonaj Tenrij-

(9) nin da tynlağyn ününe anyn barča nečik ki men bujura-

(10) men saja bügün sen da ulanlaryj bar jüregijbyla da

(11) bar žanyjbyla. ושב. [3] Da körse Adonaj tügel

(12) tešuva byla qajtqanyjny da tynč eter Adonaj Tenrij

(13) ošol qajtuvujnu da raḥmetler seni da qajtyr da

(14) jyštyryr seni bar ol uluslardan ki tozdur[du $]^{4}$ seni Adonaj

(15) Tenrij ary. [4 [4] Eger bolsa azašqanyn qyryjynda

(16) ol köklernin andanda jyštyryr seni Adonaj Tenrij da

(17) andanda alyr seni. [הביאך. Da keltirir seni Adonaj

(18) Tenrij ol jerge ki mereslediler atalaryj da meresler

(19) sen any jahšyraq eter saja da köprek eter seni ata-

\footnotetext{
${ }^{1}$ Correction by another hand. | TKow.o1: deest. | H: deest. | C: deest. $\quad{ }^{2}$ Marginal insertion by another hand. | TKow.o1: da ullu ačuv byla; unvocalized text. | H: da ullu acuv byla. | C: da ullu ačuv bilän. $\quad{ }^{3} \mathrm{~K}$ : The chapter number is not indicated. | TKow.or: Deu 3о. | H: Deu 3o. | C: Deu 3o. ${ }^{4} \mathrm{~K}:$ tozduru $\{r\}$; a scribal error. | TKow.o1: tozdurdu. | H: tozdurdu. | C: tozdurdu.
} 
(15) whom they had not known and whom God has not given to them as an inheritance.

(16) [26] And the anger of the Lord was kindled

(17) against this land to bring on it all the

(18) curses that are written in this book. [27] And

(19) the Lord cast them out from their land in anger and

(20) 〈great〉 fury \{and great enragement $\}$ and threw them into exile into another land,

(21) as it is this day." [28] The secret things

(1) belong to the Lord our God, and the revealed |things| are an obliga- $\quad 332 \mathrm{r}^{\mathrm{o}}$ tion to be done,

(2) for us and for our children forever, to do

(3) all the words of this law.

[Deuteronomy 30]

(4) it shall be, when all these things come on you,

(5) the blessing and the curse which I have set before you, and

(6) you shall bring them back to your mind, being among all the kingdoms where

(7) the Lord your God has caused you go astray, [2] And

(8) you shall return to the Lord your God with repentance with all your soul,

(9) and you shall listen to his voice according to all that I command

(10) you today, you and your children, with all your heart and

(11) with all your soul. [3] LAnd when the Lord sees

(12) your returning with a complete repentance, the Lord your God will quieten

(13) your return ${ }^{1305}$ and have mercy on you, and he will come back and

(14) gather you from all the nations where the Lord your God [has scattered] you.

(15) [4] If there be any of you gone astray to the edge

(16) of the skies, even from there the Lord your God will gather you, and

(17) he will take you even from there. [5] And the Lord your God will bring you

(18) to the land which your fathers inherited, and you will inherit

(19) it. And he will be better to you and multiply you more

305 Interpretative translation. 
(20) laryjdan. [6 [ [ [ Da ḥatna qylar Adonaj ošol jüregijni da

(21) ošol jüregin urlugiujnun ${ }_{L}$ ki ol remezdi eksilmegine

$332 \mathrm{v}^{\mathbf{0}} \quad$ (1) jecer hara'nyn anlyqbyla alajoq bolursen ${ }^{11}$ süvme $^{2}$ qullu-

(2) g̉un Adonaj Tenrijnin bar jüregijbyla da bar žanyjbyla tirlik-

(3) lerij üčün. [7] Da berir Adonaj Tenrij ošol

(4) bar ol qarg̉yšlarny ošpularny dušmanlaryj üstüne

(5) da bek tutuvčularyj üstüne ki quvdular seni.

(6) ואתה [8 [8 Da sen tešuva byla qajtqyn da tynlağyn ünü-

(7) ne Adonaj Tenrijnin da qylġyn ošol bar micvalaryn anyn

(8) ki men bujuramen saja bügün. והותירך. [9] Da qaldyryr

(9) seni Adonaj Tenrij bar išinde qullaryjnyn jemišinde qursaġyj-

(10) nyn da jemišinde tuvaryjnyn da jemišinde jerijnin jạ̣-

(11) šylyqqa ki qajtyr Adonaj bijenme senin üčün jahšygga

(12) ki nečik bijendi atalaryj üčün. כי [10] Ki tynlasaj ünü-

(13) ne Adonaj Tenrijnin saqlama micvalaryn anyn da resimlerin

(14) anyn ol jazylġanny sefer ol Torada ošpu ki qajtsaj

(15) tešuva byla Adonajğa Tenrije bar jüregijbyla da bar žanyj

(16) byla. כי בי Ki ol micva ošpu ki oldu micvasy tešuva-

(17) nyn ki men bujuramen saja bügün tamaša tüvüldü ol

(18) senden da tüvüldü jyraq ol. לא. [12] Tüvüldü kökler-

(19) de ol ki ajtqajsen kim minsejedi bi\{z\}nin üčün ol kök-

(20) lerge da alsajedi any bizge da ešittirsejedi bizge

(21) any da qylġajedik any. ולא [13] Da tüvüldü ekinči

$333 \mathrm{r}^{\circ} \quad$ (1) janynda tengiznin ol ki ajtqajsen kim ašsajedi biznin ü-

(2) čün ekinči janyna ol tengiznin da alsajedi any bizge

(3) da ešittirsejedi bizge any da qylġajedik any. כי [14]

(4) Ki juvuqtu saja iši ${ }_{L}$ ol tešuvanyn ${ }^{13}$ astry avzujbyla

(5) ${ }_{\llcorner}$mode bolma ${ }^{14}$ da jüregijbyla ${ }_{\perp}$ kajaccetme jazyqly išlerij

(6) üčün da ${ }^{15}$ qylma ${ }_{L}$ andij išler jazylg̈angia köre Tora-

\footnotetext{
${ }^{1}$ Interpretative addition to the standard text. $\quad{ }^{2} \mathrm{~K}$ : süvme Adonaj; a scribal error. | TKow.o1: süvme; unvocalized text. | H: sivme. | C: sevmä. $\quad{ }^{3}$ Interpretative addition to the standard text. ${ }^{4}$ Interpretative addition to the standard text. ${ }^{5}$ Interpretative addition to the standard text.
} 
(20) than your fathers. [6] And the Lord your God will circumcise your heart and

(21) the heart of your offspring, ${ }_{L}$ which is an allegory of the disappearance

(1) of evil inclination, ${ }^{1306}$ by which, by the same token, you will love the $33^{2} \mathrm{v}^{\mathrm{o}}$ service of the Lord

(2) your God with all your heart and with all your soul,

(3) for the sake of your life. [7] And the Lord your God will set

(4) all these curses on your enemies

(5) and on them who seized you strongly and persecuted you.

(6) [8] And you shall return with repentance and listen to the voice

(7) of the Lord and do all his commandments

(8) which I command you today. [9] And

(9) the Lord your God will recommend you in every work of your hand, in the fruit of your womb

(10) and in the fruit of your livestock and in the fruit of your land

(11) for good. Because the Lord will come back to rejoice over you for good

(12) as he rejoiced over your fathers, [10] When you will listen to the voice

(13) of the Lord your God to keep his commandments and his statutes

(14) which are written in this book of the Law, when you will turn

(15) with repentance to the Lord your God with all your heart and with all your soul.

(16) [11] Because this commandment which is a commandment of repentance

(17) that I command you today: it is not too wondrous

(18) for you, and it is not |too| far. [12] It is not in the skies,

(19) that you should say, "Who shall go up for us to the skies

(20) and take it for us and make us hear

(21) it, so that we may do it?" [13] And it is not on the other

(1) side of the sea that you should say, "Who shall go over the sea for us, $333 \mathrm{r}^{\circ}$

(2) to its other side, and take it for us

(3) and make us hear it, so that we may do it?" [14]

(4) But the matter of repentance is very near to you, in your mouth,

(5) ${ }_{L}$ to confess, ${ }^{1307}$ and in your heart, ${ }_{L}$ to repent of your sinful deeds

(6) and $^{1308}$ to do ${ }_{L}$ things like those written in the Law

306 An interpretative addition to Deu 30:6.

307 An interpretative addition to Deu 30:14.

308 An interpretative addition to Deu 30:14. 
(7) da ol jazyqly jaman išler ornuna ki tešuva byla qajtty

(8) alarğa ${ }^{11}$. ראה. [15] Baqqyn berdim alnyjda bügün ošol

(9) ol tirlikni da ošol ol jaḩšyny da ošol ol ölüm-

(10) nü da ošol ol jamanny. אשר. [16] Ki men bujuramen saja

(11) bügün süvme ošol qullugiun Adonaj Tenrijnin jürüme jol-

(12) larybyla anyn da saqlama micvalaryn da resimlerin da tö-

(13) relerin anyn da tiri bolursen da artarsen da alğyšlar

(14) seni Adonaj Tenrij jerde ki sen kelesen ary meresleme

(15) any. ואם [17] Da eger qajyrylsa jüregij da tynlamasaj

(16) da azašsaj da bašursaj özge tenrilerge da qulluq

(17) etsej alarg̉a. הגדתי. [18] Anlatamen si[zge] bügün ki

(18) taspolma taspolursiz uzartmassiz künler ol jer

(19) üstüne $\mathrm{ki}_{L}$ siz kelesiz $^{13}$ ary meresleme any.

(20) העידותי (19) Tanyq turg̉uzamen sizde bügün ošol ol

(21) köklerni da ošol ol jerni ol tirlikni da ol ölüm-

$333 \mathrm{v}^{\mathrm{o}} \quad$ (1) nü berdim alnyjda ol alġyšny da ol qarg்yšny da s[a]jla-

(2) ġyn ${ }^{4}$ tirlikni anyn üčün ki tiri bolġajsen sen da urlug̉uj.

(3) לאהבה [20 [20 bunluqbyla sajlarsen tirlikni eger klesej ${ }^{15}$

(4) süvme qulluggun Adonaj Tenrijnin da tynlama ününe

(5) anyn da jabušma Torasyna anyn ki oldu tirlikle-

(6) rij da uzunluğu künlerijnin olturma ol jer üstü-

(7) ne ki antetti Adonaj atalaryja Avrahamġa Jichaqqa

(8) da Ja'aqovga.

[Deuteronomy 31 $]^{6}$

פרשת וילך משה (9) (9) (10)

(10) [10 Da bardy Moše

(11) da sözledi ošol ol sözlerni ošpularny bar

(12) Jisra’elge. ויאמר Da ajtty alarg̉a jüz egir-

(13) mi jašarmen men bügün bolalmanmen artyq čyqma da kirme

(14) da Adonaj ajtty maja ašamassen ošol ol Jardenni

(15) ošpunu. יהוה. [3] Šehinasy Adonaj Tenrijnin ol aša-

\footnotetext{
${ }^{1}$ Interpretative addition to the standard text. $\quad{ }^{2}$ TKow.o1: sizge; unvocalized text. | H: sizge. | C: sizgä. $\quad{ }^{3}$ Probably a scribal error. | TKow.o1: sen ašasen ol Jarden ašyra kelme ary. | H: sen asasen osol ol Jardenni kelme ary. | C: ki sen kečäjdirsen šol Jardenni kelmä anda. $\quad{ }^{4} \mathrm{~K}$ : syjlaġyn; a scribal error. | TKow.o1: unvocalized text. | H: sajlagyn. | C: sajlagynn. $\quad{ }^{5}$ Interpretative addition to the standard text. $\quad{ }^{6} \mathrm{~K}$ : The chapter number is not indicated. | TKow.o1: Deu 31. | H: Deu 31. | C: Deu 31.
} 
(7) instead of the sinful evil deeds which returned to them by repentance. ${ }^{1309}$

(8) [15] See: I have set in front of you today

(9) life and good, and death

(10) and evil, [16] In that I command you

(11) today to love the service of the Lord your God, to walk

(12) in his ways and to keep his commandments and his statutes and

(13) his judgments, so that you may live and multiply. And

(14) the Lord your God will bless you in the land where you are coming to inherit

(15) it. [17] But if your heart turns away, and you will not listen,

(16) and you will go astray and worship other gods and

(17) serve them, [18] I declare to you today that

(18) you will surely perish, you will not prolong your days on the land

(19) to which ${ }_{L}$ you are coming ${ }^{310}$ to inherit it.

(20) [19] I call the skies and the earth as witness regarding you today:

(21) I have set life and death in front of you,

(1) blessing and cursing. And you shall choose

(2) life, that you may live, you and your offspring.

(3) $\quad[20]_{1}$ And with that: you will choose life, if you want ${ }^{1311}$

(4) to love the service of the Lord your God and to listen to his voice

(5) and to cling to his Law, because he is your life

(6) and the length of your days to dwell on the land

(7) which the Lord swore to your fathers: to Abraham, to Isaac,

(8) and to Jacob.'

[Deuteronomy 31]

(9) Parashat Vayelech

(10) [1] And Moses went

(11) and spoke these words to all

(12) Israel. [2] And he said to them, 'I am a hundred

(13) twenty years old today. I will not be able to go out and come in anymore.

(14) And the Lord has said to me, "You will not cross this Jordan."

(15) [3] The divine Presence of the Lord your God: he is crossing

309 An interpretative addition to Deu 30:14.

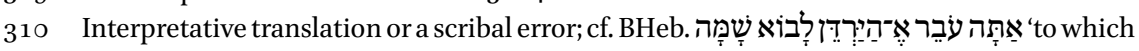
you are crossing the Jordan to come'.

311 An interpretative addition to Deu 30:20. 
(16) dy alnyjda ol tasetar ošol ol ḥanlyqlarny ošpularny

(17) alnyjdan da mereslersen alarny Johošua ol ašady alnyj-

(18) da ki nečik sözledi Adonaj. ועשה. [4] Da qylar Adonaj

(19) alarg̉a ki nečik qyldy Sihonġa da 'Oggga bijlerine

(20) ol Emorinin da jerlerine alarnyn ki tasetti alarny.

$334 \mathrm{r}^{\mathrm{o}}$ (1) ונתנם [5] Da berir alarny Adonaj alnyjyzda da qylyjyz alar-

(2) ga bar ol bujruqqa köre ki bujurdum sizge.

(3) חזקו [6] Kücjijiz da kiplenijiz qorqmajyz da synyqmajyz

(4) alynlaryndan alarnyn ki Adonaj Tenrijnin bolušluğu oldu

(5) ol baruvču birgeje salpratmasty seni da kemišmesti

(6) seni. ויקרא. [7] Da ündedi Moše Johošua'ny da ajtty

(7) anar közleriče bar Jisra’elnin küčejgin da kiplengin ki

(8) sen kelirsen ol ulusbyla ošpu ol jerge ki antet-

(9) ti Adonaj berme alarğa da sen üleširsen any alarg̉a.

(10) Da šehinasy Adonajnyn oldu ol baruvču alnyj-

(11) da anyn bolušluğu bolur birgeje salpratmasty seni da

(12) kemišmesti seni qorqmag̉yn da synyqmag̉yn. ויכתוב. [9]

(13) Da jazdy Moše ošol ol Torany ošpunu da berdi

(14) any ol kohenlerge uvullaryna Levinin ol eltüvčüler-

(15) ge ošol aron šertin Adonajnyn da bar qartlaryna Jis-

(16) ra'elnin. [יצו [10] Da bujurdu Moše alarg̉a ajtadoġač

(17) bašlyg்yndan jedi jyllarnyn vag̉dasynda jylynyn ol šmitanyn ḥy̌̌yn-

(18) da ol Sukotnun. בבוא. [11] Kelgende bar Jisra’el körün-

(19) me qyblalary alnyna Adonajnyn Tenrijnin ne orunda ki saj-

(20) lasa oḥuguun ošol ol Torany ošpunu qaršysyna bar

(21) Jisra’elnin qulaqlaryča alarnyn. הקהל. [12] Jyštyrg̉yn ošol ol

$334 \mathrm{~V}^{\mathrm{o}} \quad$ (1) ulusnu ol erenlerni da ol qatynlarny da ol jašny da

(2) garipijni ki šaharla\{r\}yjda anyn üčün ki ešitkejler da anyn

(3) üčün ki üvrengejler da qorqqajlar Adonaj Tenrijizden

(4) da saqlag̉ajlar qylma ošol bar sözlerin ol Toranyn oš-

(5) punun. ובניהם. [13] Da ulanlary alarnyn ki bilmejdiler

(6) ešitkejler da üvrengejler qorqma Adonaj Tenrijiz-

(7) den bar ol künlerde ki siz tirilirsiz ol jer üs-

(8) tüne ki siz ašasiz ošol ol Jardenni ary meresle- 
(16) before you. He will destroy these nations

(17) from before you, and you shall inherit them. Joshua: he is crossing

(18) before you, as the Lord has spoken. [4] And the Lord will do

(19) to them as he did to Sihon and to Og, kings

(20) of the Amorites, and to their land, that he destroyed them.

(1) [5] And the Lord will give them up before you, and you shall do to them

(2) according to all the commandments which I have commanded you.

(3) [6] Grow stronger and strengthen yourselves. Do not fear and do not be broken down

(4) before them, because the help of the Lord your God: he is

(5) the one who goes with you. He will not emaciate you and will not leave

(6) you.' [7] And Moses called Joshua and said

(7) to him in the sight of all Israel, 'Grow stronger and strengthen yourself, because

(8) you will go with this people to the land which the Lord has sworn

(9) to them to give them, and you will put them in possession of it.

(10) [8] And the divine Presence of the Lord: he is the one who goes before you.

(11) His help will be with you, he will not emaciate you and

(12) will not leave you. You shall not fear and be broken down.' [9]

(13) And Moses wrote this Law and gave

(14) it to the priests, sons of Levi, who were carrying

(15) the ark of the covenant of the Lord, and to all the elders of

(16) Israel. [10] And Moses commanded them, saying,

(17) 'At the beginning of every seven years, in the set time of the year of remission,

(18) at the feast of Sukkot, [11] When all Israel has come to appear

(19) before the directions of Lord your God in the place which

(20) he will choose, you shall read this Law in front of all

(21) Israel in their ears. [12] Gather the

(1) people together - the men and the women and the infants and

(2) your stranger who is in your cities - that they may hear and that

(3) they may learn and fear the Lord your God

(4) and be watchful to do all the words of this Law.

(5) [13] And their children who have not known

(6) may hear and learn to fear the Lord your God

(7) all the days you are living on the land

(8) to which you are crossing the Jordan to inherit 
(9) me any. ויאמר [14] Da ajtty Adonaj Mošege mu-

(10) na juvudular künlerij ölme ündegin ošol Johošua-

(11) ny da turujuz ohel mo'edde da zynharlajym any

(12) da bardy Moše da Johošua' da turdular ohel mo'edde.

(13) (15] Da aškara boldu šehinasy Adonajnyn čatyr-

(14) da baġanasy byla bulutnun da turdu bagaanasy ol bulut-

(15) nun ešigi üstüne ol čatyrnyn. ויאמר [16] Da

(16) ajtty Adonaj Mošege muna sen jatyrsen atalaryjbyla

(17) da turar ol ulus ošpu da azar qulluğu artyna

(18) jat tenrilerinin ol jernin ki ol keledi ary ortasyna

(19) anyn da kemišir qulluğumnu menim da buzar ošol šer-

(20) timni ki kestim birgesine. וחרה [17 Da qabu-

(21) nur ačuvum anda ol künde da kemiširmen alarny

$335 \mathrm{r}^{\mathrm{o}} \quad$ (1) raḥmetlemekten da jašyryrmen qyblalarymny alardan da

(2) bolur tavusmaqqa da učrarlar any köp jamanlyqlar

(3) da tarlyqlar da ajtyr ol künde muna anyn üčün

(4) ki joḥtu šehinasy Tenrimnin ortamda učradylar

(5) meni bar ol jamanlyqlar ošpular. ואנכי [18] Da men jašyr-

(6) ma jašyryrmen qyblalarymny ol künde bar ol jamanlyq

(7) üčün ki qyldy ki qajyryldy qulluğuna özge tenriler-

(8) nin. [19] Da haligine jazyjyz özüjüzge ošol ol

(9) širany ošpunu da üvretkin any ulanlaryna Jisra’el-

(10) nin qojġun any avuzlaryna alarnyn anyn üčün ki bolġaj

(11) maja ol šira ošpu tanyqqa ulanlaryna Jisra’elnin.

(12) כי [20] Ki keltirirmen any ol jerge ki antettim atala-

(13) ryna alarnyn jer ag̉adog̉an süt da bal da ašar da

(14) tojar da bögövrer da qajyrylyr qullugiuna özge

(15) tenrilernin da qulluq eterler alarğa da ačyrg̉andy-

(16) ryrlar meni da buzar ošol šertimni. והיה [21] Da

(17) bolġaj ki učrasalar any köp jamanlyqlar da tarlyqlar da

(18) tanyqlyq čyğar ol šira ošpu alnynda anyn tanyqqa ki

(19) unutulmasty avzundan urlugiunun ki bilemen ošol

(20) jecerin anyn neki ol qyl[a]dy ${ }^{1}$ bügün keltirmesimden burun

(21) any ol jerge ki antettim. יויכתוב [22] Da jazdy Moše

$335 \mathrm{v}^{\mathrm{o}} \quad$ (1) ošol ol širany ošpunu ol künde da üvretti any

(2) ulanlaryna Jisra'elnin. [יצו. [23] Da bujurdu Johošuaçga uvluna

\footnotetext{
${ }^{1} \mathrm{~K}$ : qyldy; a scribal error. | TKow.o1: unvocalized text. | H: qylady. | C: qylajdyr.
} 
(9) it.' [14] And the Lord said to Moses, 'Lo,

(10) your days to die have come close. Call Joshua

(11) and stand up in the tent of meeting, that I may command him.'

(12) And Moses and Joshua went and stood up in the tent of meeting.

(13) [15] And the divine Presence of the Lord appeared in the tent

(14) in a pillar of cloud, and the pillar of cloud stood

(15) over the door of the tent. [16] And

(16) the Lord said to Moses, 'Lo, you will lie down with your fathers,

(17) and this people will rise up and go astray after the service

(18) of foreign gods of the land into the midst of which it is coming,

(19) and it will leave my service and break my covenant

(20) which I have made with them. [17] And

(21) my anger will be kindled at it on that day, and I will resign

(1) from being gracious, and I will hide my directions from them, and

(2) they will be |left| for being devoured, and many evils and troubles shall befall it.

(3) And it will say on that day, "Lo, because

(4) the divine Presence of my God is not present among me,

(5) all these evils have befallen me." [18] And I

(6) will surely hide my directions in that day because of all the evils

(7) which it has done, because it turned to the service of other gods.

(8) [19] So now write this song for yourselves

(9) and teach it to the children of Israel.

(10) Put it in their mouths, that this song may be a witness

(11) for me against the children of Israel.

(12) [20] When I will bring it to the land which I swore

(13) to their fathers, a land flowing $\mid$ with $\mid$ milk and honey, and it will eat and

(14) be full and quench, and it will turn to the service of other

(15) gods, and they will serve them, and they will annoy

(16) me, and it will break my covenant, [21] Then

(17) it shall be, when many evils and troubles will befall it,

(18) this song shall testify before them as a witness, because

(19) it shall not be forgotten from the mouths of their offspring. Because I know

(20) its inclination that it [is doing] today, before I bring

(21) it to the land which I swore.' [22] And Moses wrote

(1) this song the same day and taught it

(2) to the children of Israel. [23] And he commanded Joshua, son 
(3) Nunnun da ajtty küčejgin da kiplengin ki sen keltiri[rs]en ${ }^{1}$

(4) ošol ulanlaryn Jisra’elnin ol jerge ki antettim alarg̉a

(5) da bolušluğum bolur birgeje. [24] Da edi tügelle-

(6) gečoq Moše jazma ošol sözlerin ol Toranyn ošpunun

(7) sefer üstüne tügellengenlerinedejin. ויצו [25] Da bujur-

(8) du Moše Levililerge eltüvčülerge aron šertin Adonajnyn

(9) ajtadoġač. לקוח . [26] Alma ošol sefer ol Torany oš-

(10) punu da qojujuz any janyndan aron šertinin Adonajnyn Ten-

(11) rijiznin da bolsun anda saja tanyqqa. כי. [27] Ki men bilemen

(12) ošol tanmaġyjny da ošol ensejni ol qaty muna hanuz ti-

(13) ri egenimde bügün tanuvčular edijiz alnynda Adonajnyn

(14) da jovšem ki ölgenimden sortun. הקהילו. [28] Jyštyryjyz

(15) maja ošol bar qartlaryn ševetlerijiznin da tajaqčylaryjyzny

(16) da sözlejim qulaqlaryča alarnyn ošol sözlerni ošpularny

(17) da tanyq turg̉uzajym alarda ošol köklerni da ošol ol

(18) jerni. [כ] [2] [29] Ki bilemen ki ölgenimden sortun čejpama čejpar-

(19) siz jollaryjyzny da ketersiz ol joldan ki bujurdum sizge

(20) da učrar sizni ol jamanlyq sonġusunda ol künlernin ki

(21) qylsajyz ošol ol jaman körüngenni 'enajatlarynda Adonajnyn

$336 \mathrm{r}^{\mathrm{o}}$ (1) ačyrg̉andyrma any iši byla qollaryjyznyn. וידבר. [30] Da

(2) sözledi Moše qulaqlaryča bar qahalynyn Jisra’elnin ošol sözlerin

(3) ol širanyn ošpunun tügellengenlerinedejin.

$[\text { Deuteronomy 32 }]^{3}$

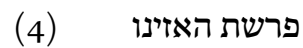

(1] Qulaq salyjyz e kök-

(6) ler da sözlejim da tynlasyn ol jer

(7) ajtmaqlaryn avuzumnun. יערף. [2] Javsun jamgiur kibik

(8) aqylym tamsyn čyqkibik ajtmaġym kiči jamġurlarkibik

(9) jaš ot üstüne da ullu jamġurlar kibik [kögöt] $]^{4}$ üs-

(10) tüne. [3] Ki atyn Adonajnyn čaġyrsam sizde qotaryjyz

(11) ullug̉un Tenrimiznin. הצור. [4] Ol jartuvčunun tügel-

(12) di iši anyn ki bar jollary anyn töre bylady qajjam Tenri

(13) da qylmajdy avanlyq rastty da tüzdü ol. שחת. [5]

(14) Čejpady Jisra’el özü özün anlyqbyla ki ündelmedi-

${ }^{1} \mathrm{~K}$ : keltiririsen; a scribal error. | TKow.o1: keltirirsen; unvocalized text. | H: keltirirsen. | C: keltirirsin.

${ }^{2}$ Heb. יִ. $\quad{ }^{3} \mathrm{~K}$ : The chapter number is not indicated. | TKow.o1: Deu 32. | H: Deu 32. | C: Deu 32.

${ }^{4} \mathrm{~K}$ : gököt; a scribal error. | TKow.o1: kögöt; unvocalized text. | H: köget. | C: kök ot. 
(3) of Nun, and said, 'Grow stronger and strengthen yourself, because you will bring

(4) the children of Israel to the land which I swore to them.

(5) And my hep will be with you.' [24] And it was

(6) when Moses had finished writing the words of this Law

(7) on a scroll until they were finished, [25] And

(8) Moses commanded the Levites, who carried the ark of the covenant of the Lord,

(9) saying, [26] to 'Take this book of the Law,

(10) and put it by the side of the ark of the covenant of the Lord

(11) your God, that it may be there for you as a witness. [27] Because I know

(12) your rebellion and your hard neck. Lo, while I am yet

(13) alive with you today, you have been rebellious before the Lord,

(14) and |you will be| all the more |so| after my death. [28] Gather

(15) to me all the elders of your tribes and your overseers,

(16) so I may speak these words in their ears

(17) and call the skies and earth as witness regarding them.

(18) [29] Because I know that after my death you will utterly destroy

(19) your ways and turn aside from the way which I have commanded you.

(20) And evil will befall you in the latter days, because

(21) you will do things that seem bad in the eyes of the Lord,

(1) to annoy him with the work of your hands.' [30] And

(2) Moses spoke in the ears of all the community of Israel the words

(3) of this song until they were ended.

[Deuteronomy 32]

\section{(4) Parashat Haazinu}

(5) [1] 'Give ear, oh you skies,

(6) so I may speak, and let the earth hear

(7) what my mouth says. [2] Let my mind drop like rain,

(8) let my speech drip like dew, like the small rain

(9) on grass and like great rains on herbs.

(10) [3] When I call the name of the Lord, praise, you too,

(11) the greatness of our God. [4] The work of the Creator

(12) is perfect, for all his ways are judgement. An eternal God,

(13) and he makes no wickedness, just and right is he. [5]

(14) ${ }_{\mathrm{L}}$ Israel has destroyed itself because they were not called 
(15) ler ulanlary Tenrinin bu boldu ajipleri alarnyn anyn üčün

(16) ki alar dor ters da tornaqšy. הליהוה. [6] Adonajġamo

(17) tölejsiz bundij tölev nekes ulus da tüvül uslu mu-

(18) na oldu ataj ki bar etti seni ol jaratty seni da

(19) tüzüdü seni. זכ] [7] Sag்yng்yn avalġy künlerni esijiz-

$336 \mathrm{v}^{\mathbf{0}}$ (1) ni qojujuz jollaryna har bir dornun sorg̉un atajdan da anlat-

(2) syn saja qa $\{r\}$ tlaryjdan da ajtsynlar saja. בהנחל. [8] Ü-

(3) leškende joġarğy Tenri ḥanlyqlarny ajyrg̉anynda ulanlaryn Adam-

(4) nyn turg̉uzdu čeklerin uluslarnyn sanyča ulanlarynyn Jisra’elnin.

(5) כי [9] Ki ülüšüdü Adonajnyn ulusu anyn Ja'aqov tijiš ü-

(6) ימצאהו. [10] Jüüü anyn Jetkiligin berdi anyn jerinde

(7) midbarnyn da veren pusta jerde quršady any ${ }_{L}$ bulutu byla ${ }^{11}$

(8) aqyllatty any LTorasy byla ${ }^{12}$ abrady any ${ }_{L}$ micvalarybyla abra-

(9) ganlaj ${ }^{3}$ kiši böbejin közünün. כנשר. [11] Nečik nešer ačady

(10) hujasyn balalary üstüne jelpijdi jajady qanatlaryn alady

(11) any eltedi any qanaty üstüne. יהוה. [12] Alaj Adonaj

(12) jalġyz özü könderdi Jisra’elni midbarda ${ }^{4}$ da jog̉edi birge-

(13) sine jat tenri. ירכבהו. [13] Atlangyzdyrdy any bijik o-

(14) runlary üstüne jernin da ašady bitišlerin tarlavnyn

(15) da ömüzdürdü anar bal skaladan da jav almas ${ }^{5}$ skala-

(16) dan. חמאת [14] Saryjavyn syg̈yrnyn da sütün qojnun

(17) javybyla qozularnyn da qočqarlarnyn Bašan balalarynyn da tege-

(18) lerni javybyla büvreklerinin budajnyn da qanyndan borlany[n] ${ }^{6}$

(19) ičersen qyzyl čağyr. וישמן. [15] Da semirdi Jisra’el

\footnotetext{
${ }^{1}$ Interpretative addition to the standard text. $\quad{ }^{2}$ Interpretative addition to the standard text.

${ }^{3}$ Interpretative addition to the standard text. ${ }^{4}$ Interpretative addition to the standard text. ${ }^{5}$ Erroneously corrected into aqmas by another hand. | TKow.o1: almas; unvocalized text. | H: aqmas. | C: almas. ${ }^{6}$ TKow.o1: borlanyn; unvocalized text. | H: borlalarnyn. | C: borlalarnyy.
} 
(15) the children of God, this has become their blemish because

(16) they are a defiant and cunning generation. ${ }^{1312}$ [6] Is it to the Lord

(17) that you repay such a payment? Wastrel people and unwise! Lo,

(18) he is your father who brought you into existence, he created you and

(19) built you. [7] Remember the days of old.

(1) Take heed of the years of every generation. Ask your father, and he will tell

(2) you, your elders, and they will say to you: [8]

(3) When the high God divided to the kingdoms their inheritance, when he separated the children of mankind ${ }^{313}$,

(4) he set the borders of the people according to the number of the children of Israel.

(5) [9] For the Lord's portion is his people. Jacob is his allotted

(6) portion. [10] He gave him affluence in a

(7) wilderness land and in a desolated desert. He encircled him ${ }_{L}$ with his cloud ${ }^{1314}$,

(8) he instructed him ${ }_{\perp}$ with his Law ${ }^{1315}$, he kept him ${ }_{\perp}$ with his commandments ${ }^{1316}$ like

(9) ${ }^{\text {the man keeps }}{ }^{1317}$ the apple ${ }^{318}$ of his eye. [11] Like an eagle uncovers

(10) its nest, flutters over its young, spreads out its wings, takes

(11) it, bears it on its wings, [12] So the Lord

(12) alone led Israel ${ }_{L}$ in the wilderness ${ }^{1319}$, and there was no

(13) strange god with him. [13] He made him ride over the high

(14) places of the earth, and he ate the produce of the fields,

(15) and he suckled him with honey out of the rock, and oil out of the diamond ${ }^{320}$ rock,

(16) [14] Butter of the cattle, and milk of the flock,

(17) with fat of lambs, and rams of the breed of Bashan, and he-goats

(18) with the fat of their kidneys, of the wheat, and from grape's blood

(19) you will drink red wine. [15] And Israel grew fat,

\footnotetext{
312 An interpretative translation of Deu 32:5.

313 Or: Adam.

314 An interpretative addition to Deu 32:10.

315 An interpretative addition to Deu 32:10.

316 An interpretative addition to Deu 32:10.

317 An interpretative addition to Deu 32:10.

318 Lit. 'pupil'.

319 An interpretative addition to Deu 32:12.

320 Corrected into waterproof by another hand.
} 
(20) da tersejdi semirdij bazyq bolduj japty javy aqylyjny

(21) da kemišti qu[llugun ] $]^{1}$ Tenrinin ki jaratty any da ḥor

$337 \mathrm{r}^{\mathrm{o}} \quad$ (1) etti sözün jarlyggašly jaratuvčusunun. יקניאוהו [16 ]

(2) Künülettiler any qulluq etmekleribyla jat tenriler-

(3) ge jerenči išlerbyla ačyrg̉andyrdylar any. יזבחו. [17]

(4) Debehạa ettiler šejtanlarg̉a tüvül Tenrige abaqlarg̉a

(5) ki bilmesediler alarny jangylar juvuq zamandan keldiler

(6) qorqmadylar alardan atalaryjyz. צור. [18] Qullugiun jaratuv-

(7) čunun ki jaratty seni kemištij da unuttuj bujrug̈un

(8) Tenrinin joqtan bar etüvčüjnün. [19] Da kördü

(9) Adonaj da ačyrg̉andy ačyrg̉andyrmaġyndan uvullarynyn

(10) da quzlarynyn. [יאמר Da ajtty jašyrajym qyblala-

(11) rymny alardan körejim ne bolur sonġulary alarnyn ki dor

(12) terstiler alar ulanlar joḥtu inam alarda. הם. [21]

(13) Alar künülettiler meni qulluq etmekleribyla tüvül

(14) Tenrige ačyrg̉andyrdylar meni [hečlik]l[e]ribyla ${ }^{2}$ özle-

(15) rinin da men $\mathrm{k}[\ddot{\mathrm{u}}]$ nületirmen ${ }^{3}$ alarny tüvül ulusbyla

(16) nekes ḥanlyqbyla ačyrg̉andyryrmen alarny. כי. [22] Ki

(17) ot čyqty ačuvu $\{\mathrm{m}\}$ da da jandy töbengi ${ }^{4}$ görgedejin

(18) da örtedi jerni da bitišin anyn da jalynlady bunjat-

(19) laryn tavlarnyn. אספה. [23] Ajttym tügellejim alar üs-

(20) tüne bar jamanlyqlarny oqlarymny tavusajym alarda.

(21) מזי [24] Qyranlaryn ačlyqnyn da ašalġanlaryn qušnun ${ }^{5}$

$337 \mathrm{v}^{0} \quad$ (1) da ačy kesmek da tišin jaman kijiklernin ijermen alarda

(2) uvubyla sürkelüvčülerinin topraqnyn. מחוץ. [25] Tyš-

(3) qartyn tuv eter qylyč da hư̌̌u $\{$ ra\}lardan qorquv daġyn jigitni

\footnotetext{
${ }^{1}$ TKow.o1: qullugiun; unvocalized text. | H: qullugiun. | C: micvalaryn. $\quad{ }^{2}$ TKow.o1: hečlikleribyla; unvocalized text. | H: heclikleri byla. | C: hečlikläri bilän. $\quad{ }^{3} \mathrm{~K}$ : könületirmen; a scribal error. | TKow.o1: unvocalized text.|H: kinilettirimen.|C: künlätäjim. $\quad{ }^{4}$ Possibly a scribal error (although noted in KarRPS), instead of tüptegi. | TKow.o1: töbengi; changed into tebengi. | H: tebendegi. | C: tiptägi.|R: tuptagi. $\quad{ }^{5}$ Possibly a mistranslation or a translation influenced by the Septuagintpossibly via (Old Church) Slavonic translations (see our detailed commentary in the translation). | TKow.o1: qušnun; unvocalized text. | H: qusnun. | C: učqunnyy. | M: učqunnyy. | E: učqunnyy. | R:

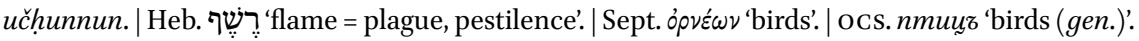


(20) and was defiant- you grew fat, you are grown thick, fat covered your mind-

(21) and it forsook the [service] of God who created him, and disdained

(1) the word of his gracious creator. [16]

(2) They made him jealous by serving foreign gods,

(3) with repulsive things they made him annoyed. [17]

(4) They sacrificed to devils, not to God, to gods

(5) whom they had not known, new ones |that| came in the close past,

(6) whom your fathers feared not. [18] You have left the service

(7) of the Creator who created you, and have forgotten the command

(8) of God who brought you into existence from nothing. [19] And the Lord saw

(9) and was annoyed, because of the annoyance of his sons

(10) and his daughters. [20] And he said, "Let me hide my directions

(11) from them. Let me see what their end will be. For

(12) they are a defiant generation, children in whom is no faith. [21]

(13) They made me jealous with serving not God,

(14) they have annoyed me with their own [vanities].

(15) And I: I will make them jealous with no-people,

(16) I will annoy them with a wastrel kingdom. [22] For

(17) a fire went out in my anger and burned to the lowest grave

(18) and consumed the earth with its produce and set on fire the foundations

(19) of the mountains. [23] I said, "Let me execute

(20) all the evils over them, I will exhaust my arrows on them,

(21) [24] Dead by famine, devoured by birds ${ }^{321}$,

(1) and bitter blows. And I will send the teeth of evil wild |animals| on them,

(2) with the poison of those who wallow in the dust. [25]

(3) Outside: the sword will bereave, and throughout the chambers: terror, both young man

321 K: qušnun; either a translation influenced by the Septuagint - possibly via (Old Church) Slavonic translations; or a mistranslation of BHeb. רֵنשֶף 'flame = plague, pestilence' (Koehler \& Baumgartner 1985: 911) influenced by Med.Heb. רִשֶׁף '1. glow, flame, spark; 2. bird (of prey)' (Jastrow 1903: 1502; Klein 1987: 631); or a mistranslation being the result of misinterpreting Kar. učqun 'spark' (used in this verse in other Karaim manuscripts) as a word meaning 'bird' caused by the fact that $u c ̌ q u n$ is a -qun derivative of $u \check{c}$ - 'to fly' (see A. Zajączkowski 1932: 81, Berta 1996: 402) and influenced by the medieval meaning of Heb. רֶֶֶּ. The latter would suggest that the translation was based on another Karaim manuscript. Repeated in H. Translated 'spark' in C, M, E, and R. | BHeb. רֶֶׁׁף 'flame =

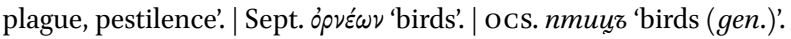


(4) daġyn boj qyzny ömedoġan ulanny pir kišibyla.

(5) .26] Ajttym tozdurajym alarny har tarafta

(6) eksitejim adamdan saġynčlaryn alarnyn. לולמרי [27] Eger

(7) ačyrgaandyrmag̉yndan dušmannyn qorqmasajedim mag̉at

(8) tanyġysyz eterler dušmanlary alarnyn mag̉at ajtyrlar

(9) qolumuz küčejedi da tüvül Adonaj qyldy bar bunu.

(10) כי [28] Ki ol dušmanlar ḥanlyq taspolġan kenešlidirler

(11) alar da joḥtur alarda aqyl. לו. [29] Eger uslu bol-

(12) sajediler eslerin qojsajediler bunar anlagajediler

(13) songularyn özlerinin de. [30] Nečik quvadyr

(14) bir kiši minni da ökövlen qačyradylar tümenni

(15) özge tüslü tüvül ki jaratuvčulary satty alarny

(16) da Adonaj čyġara berdi alarny. כי [31] Ki tüvüldü

(17) jaratuvčumuzkibik abaqlary alarnyn da dušmanlarymyz

(18) özleri törečilerdi bu ište. כי. [32] Ki borlalyġyn-

(19) \{dan\} Sedomnun borlalyqlary alarnyn da tarlavlaryndan 'Amora-

(20) nyn borlalary alarnyn uv borlalardy ačy solqunlar

(21) [alarġa]'. חמת . [33] Uvu aždahalarnyn čag̈yrlary alar[nyn] ${ }^{2}$

$338 \mathrm{r}^{\circ} \quad$ (1) da uvu šavagiatsyz aždahalarnyn. הלא. [34] Muna ol

(2) astralgandy qatymda mohorlanġandy hạaznalarym-

(3) da. 35] Menim erkimdedi öč almaq da

(4) tölemek tajğan vaḥtta ajaqlary alarnyn ki juvuqtu

(5) zaval künleri alarnyn da žahtlar kelesi nerselerni ${ }^{3}$

(6) alarg̉a. כי ידין d36] Ki jarg̉u jarar Adonaj ulu-

(7) sun da qullarybyla uvunur ki körse ki tügendi

(8) küčü qolnun da joḥtu ḥazna da tuvar. פשט שלי (9) (פשי)

(9) (אל כי ידין) (Ki jarg̉usu alyr Adonaj ulusunun duš-

(10) manlaryndan anyn da ol vaḥtta qullarybyla uvunur).

(11) [ואמר (37) Ki ajtyredi Lol dušman umasyna

(12) Jisra’elnin ${ }^{14}$ qajdady tenrileri alarnyn jaratuvču ki iša-

(13) nyrediler anar. אשר. [38] Ki javyn debeḥalarynyn aša-

(14) rediler ičerediler čag̉yryn nesehlerinin haligine tur-

\footnotetext{
${ }^{1}$ TKow.o1: alarga | H: alarg்a. | C: alarġa. $\quad{ }^{2}$ TKow.o1: alarnyn. | H: alarnyn. | C: deest. $\quad{ }^{3} \mathrm{~K}$ : probably a scribal error, instead of nerseler. | TKow.o1: nerselerni. | H: deest; different wording. | C: keläžäklär.| R: išlarni. $\quad{ }^{4}$ Interpretative addition to the standard text.
} 
(4) and the virgin, the nursing child with the man of grey hairs."

(5) [26] I said, "Let me scatter them into all directions,

(6) let me make the remembrance of them cease from among men." [27]

(7) If I did not fear the enemy's annoyance, lest

(8) their enemies should not acknowledge, lest they should say,

(9) "Our hand is growing stronger, and it was not the Lord who did all this."

(10) [28] For the enemies are a kingdom of a lost counsel,

(11) and there is no reason in them. [29] If they were wise,

(12) they would took note of this, that would even understand

(13) their own end! [30] How should one man chase

(14) a thousand, and two make ten thousand flee,

(15) if not that their creator had sold them,

(16) and that the Lord had given them up? [31] For

(17) their gods are not as our Creator, and our enemies

(18) themselves are judges in this matter. [32] For their vine

(19) is from the vine of Sodom and from the fields of Gomorrah.

(20) Their grapes are grapes of poison: bitter bunches

(21) for them. [33] Their wine is a poison of serpents,

(1) and merciless poison of serpents. [34] "Lo,

(2) he is buried by my side, and sealed up in my treasures.

(3) [35] To me belongs vengeance and

(4) recompense when their foot shall slide, for

(5) the day of their calamity is close and comes fast: future things |prepared| for them."

(6) [36] For the Lord will judge his people

(7) and have compassion on his servants when he sees that

(8) the strength of their hand is gone, and there is no treasure and livestock. $\mathrm{L}$ (A second translation

(9) [of the verse] 'For [the Lord] will judge ...') (For the Lord will judge his people

(10) and then he will have compassion on his servants because of their enemies.)

(11) [37 $]_{\mathrm{L}}$ Because the enemy of the people

(12) of Israel ${ }^{1322}$ would say, "Where are their gods, a creator

(13) in whom they trusted? [38] Who ate the fat of their sacrifices

(14) and drank the wine of their drink offerings? Let them rise up

322 An interpretative addition to Deu 32:37. 
(15) sunlar da bolušsunlar sizge bolsun üstüjüzge

(16) syjynč qutqarma sizni qolumuzdan. ראו [39] „Da

(17) ol vaḥtta ajtyrmen ${ }^{11}$ baġyjyz \{haligine\} ki men men ol da joḥtu

(18) tenri birgeme men öltürürmen da tirgizirmen

(19) kessem da men ongaltyrmen da joḥtu qudratym-

(20) dan qutqaruvču. כי [40] Ki kötüremen köklerge qud-

(21) ratymny da ajtamen qajjamdyr men dunjagadejin. אם [41]

$338 \mathrm{v}^{\mathrm{o}} \quad$ (1) Kertiden kelir vaḥt ki bilermen itisin qylyčymnyn da tutar

(2) töreni qudratym qajtaryrmen öč dušmanlaryma da bek

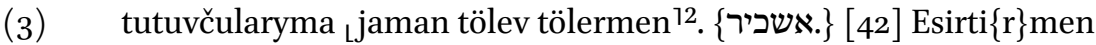
oqla-

(4) rymny qandan da qylyčym ašar et qanyndan qyrannyn da

(5) jesirnin ilk öčlerinden dušmannyn. הרנינו. [43] Sarnajyz

(6) ḥanlyqlar ševetleri Jisra’elnin ündeledog̉an ulusu anyn

(7) ki qany üčün qullarynyn öč alyr da öč qajtaryr

(8) dušmanlaryna Jisra’elnin da julur jerni da ulusunda.

(9) ויבוא [4] Da keldi Moše da sözledi ošol bar sözleri

(10) ol širanyn ošpunun qulaqlaryča ol ulusnun ol da

(11) Hošea uvlu Nunnun. ויכל. [45] Da tügelledi Moše söz-

(12) leme ošol bar ol sözlerni ošpularny bar Jisra’elge.

(13) ויאמר (46] Da ajtty alarğa qojujuz esijizni bar

(14) ol sözlerge ki men tanyq etemen sizde bügün ki

(15) $[\mathrm{bu}]\{\mathrm{ju}\}[\mathrm{r}] \mathrm{g} a j s i z^{3}$ alarny ulanlaryjyzğa saqlama qylma ošo $[1]^{4}$

(16) bar sözlerin ol Toranyn ošpunun. כי. [47] Ki tüv[ül]-

(17) dü ${ }^{5}$ boš söz ol sizden ki oldu tirligijiz da ošp $[u]^{6}$

(18) söz üčün uzartyrsiz künler ol jer üstüne ki s[iz $]^{7}$

(19) ašasiz ošol ol Jardenni ary meresleme any. וידבר [48]

(20) Da sözledi Adonaj Mošege kensisinde ošpu kün[nün] $]^{8}$

(21) ajtadoġač. עלה. [49] Mingin tavyna ol köčüvlerni[n]

\footnotetext{
${ }^{1}$ Interpretative addition to the standard text. $\quad{ }^{2}$ Interpretative addition to the standard text. ${ }^{3}$ TKow.o1: zynharlagajsiz; unvocalized text.| H: bujurgajsiz.| C: symarlagajsyz. ${ }^{4}$ TKow.o1: ošol; unvocalized text. | H: osol. | C: šol. ${ }^{5}$ TKow.o1: tüvüldü; unvocalized text. | H: tivildi.| C: dügüldir. ${ }^{6}$ TKow.o1: ošpu; unvocalized text. | H: ol ospu.|C: ušbu. $\quad{ }^{7}$ TKow.o1: siz; unvocalized text. | H: siz. | C: siz. $\quad{ }^{8}$ TKow.o1: künnün; unvocalized text. | H: künnün. | C: künniø. $\quad{ }^{9}$ TKow.o1: köčüvlernin; unvocalized text. | H: kecivlernin. | C: kečivlärniq.
} 
(15) and help you, may it be your

(16) shelter to save you from our hands." [39] A And

(17) then I will say: 1323 "Look now that I am he, and there is no

(18) god besides me. I will kill, and I will make alive.

(19) If I cut, I will heal. And there is no

(20) deliverer from my hand, [40] When I lift up my hand to the skies,

(21) and say, "I am eternal, forever. [41]

(1) Indeed, the time will come when I will know the edge of my sword, $338 \mathrm{v}^{\mathrm{o}}$ and

(2) my hand will take hold on judgment, I will give back vengeance to my enemies and

(3) to those who seized you strongly. ${ }_{\text {LI }}$ will pay back an evil payment. ${ }^{324}$ [42] I will give my arrows

(4) blood to drink, and my sword will eat flesh from the blood of the dead and

(5) of the captives, from the main |leaders| of the enemy." [43] Rejoice,

(6) kingdom, its people who are called tribes of Israel,

(7) for he will avenge the blood of his servants, and will give back vengeance

(8) to the enemies of Israel, and will redeem the land and his people.'

(9) [44] And Moses came and spoke all the words

(10) of this song in the ears of the people, he and

(11) Hoshea, son of Nun. [45] And Moses finished speaking

(12) all these words to all Israel.

(13) [46] And he said to them, 'Take heed of all the words

(14) which I testify regarding you today, that

(15) you shall command your children to be watchful to do,

(16) all the words of this Law. [47] Because

(17) it is not a vain word about you, because it is your life. And through this

(18) word you shall prolong your days on the land to which you

(19) you are crossing the Jordan to inherit it.' [48]

(20) And the Lord spoke to Moses that very same day,

(21) saying, [49] 'Go up to this [mountain of encampments ${ }^{1325}$,

323 An interpretative addition to Deu 32:39.

324 An interpretative addition to Deu 32:41.

325 A literal translation of Heb. הַר הָָָּׁברִים 'mountain of the Abarim'. | TKow.o1: mountain of encampments. | H:mountain of encampments. | C: mountain of encampments. | R: mountain of encampments. 
$339 \mathrm{r}^{\mathrm{o}} \quad$ (1) ošpu tavyna Nevonun ki jerinde Mo’avnyn ki alnynda

(2) Jeriḥonun da baqqyn ošol jerin Kena'annyn ki men beremen

(3) ulanlaryna Jisra’elnin tutuvluqqa. ומת [5\%] Da

(4) ölersen tavda ki sen minesen ary da jyštyrylġyn

(5) uluslaryja ki nečik öldü Aharon qaryndašyj Hor Hahar-

(6) da da jyštyryldy uluslaryna. על [51] Anyn üčün

(7) ki tandyjyz sözüme ortasynda ulanlarynyn Jisra’el-

(8) nin talaš suvla $\{r\} y n d a$ Qadešnin midbarynyn Cinnin anyn ü-

(9) čün ki azizligimni körgüzmedijiz menim ortasynda

(10) ulanlarynyn Jisra’elnin. כי [52] Ki qaršydan körersen ošol

(11) ol jerni da ary kelmessen ol jerge ki men beremen

(12) ulanlaryna Jisra’elnin.

\section{[Deuteronomy 33 $]^{1}$}

פרשת וזאת הברכה (13) (14)

(14] Da budu ol

(15) alġyš ki alġyšlady Moše navisi ol

(16) Tenrinin ošol $\left[\right.$ [uvullaryn] Jisra’elni $\{n\}^{12}$ ölmegi alnyna. [2]

(17) Da ajtty šehinasy Adonajnyn Sinaj sartyn keldi da balqydy

(18) balquvu šehinanyn Se ir sartyn alarğa balqytty tavyndan

(19) Parannyn da keldi tümenleribyla aziz malahlarynyn on

$339 \mathrm{v}^{\circ} \quad$ (1) qudratyndan ot ašyra Torany symarlady Jisra'elge.

(2) אך [3] Ham süvedi barda uluslarny ki alardy on eki

(3) ševetleri Jisra’elnin \{vale\} bar azizreklerin anyn ki alardy

(4) ševeti Levinin ajyrdyj bolma jumuš etüvčüler aziz

(5) orunda toḥtamag̉ynyn šehinajnyn da alar [jančyla-

(6) dylar] jürüjdoġač bujruqlaryjbyla eltedi syjly söz-

\footnotetext{
${ }^{1} \mathrm{~K}$ : The chapter number is not indicated. | TKow.o1: Deu 33. | H: Deu 33.|C: Deu 33. $\quad{ }^{2} \mathrm{~K}$ : Corrected into Jisra'elnin by another hand; yet, this amendment would also require the addition of the word uvullaryn; cf. TKow.o1, H, and C. | TKow.o1: uvullaryn Jisra'elnin; unvocalized text. | H: uvul-

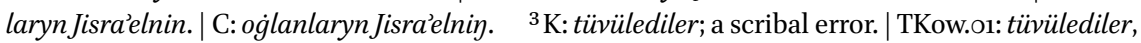
corrected into jančyladylar.| H: jancyladylar. | C: deest; different wording.
} 
(1) to the Mount Nebo, which is in the land of Moab, which is facing

(2) Jericho, and see the land of Canaan, which I am giving

(3) to the children of Israel for a possession. [50] And

(4) you will die in the mountain to which you are going up, and be gathered

(5) to your people, as Aaron, your brother, died in Mount Hor

(6) and was gathered to his people, [51] Because

(7) you rebelled against my word in the midst of the children of Israel

(8) at the waters of $q u a r r e l^{1326}$ of Kadesh of the wilderness of Zin, because

(9) you did not show my holiness in the midst

(10) of the children of Israel. [52] Because you will see the land from opposite,

(11) but you will not come there, to the land which I am giving

(12) to the children of Israel.'

[Deuteronomy 33]

(13) Parashat Vezot Haberachah

(14) $[1]$ And this is the

(15) blessing with which Moses, the prophet of

(16) God, blessed [the sons] $\{o f\}$ Israel before his death. [2]

(17) And he said: 'The divine Presence of the Lord came from Sinai, and

(18) the shine of the divine Presence shone from Seir for them. He shone from Mount

(19) Paran, and he came with ten thousands of holy angels.

(1) ${ }_{L}$ From his right hand, through fire, he commanded the Law for Israel ${ }^{1327}$.

(2) [3] AAlso, he loves all the people, that is, the twelve

(3) tribes of Israel. But the holiest ${ }^{328}$ of them, which is

(4) the tribe of Levi, you have separated for ministering in the holy

(5) place of dwelling of your divine Presence, and they were [hit].

(6) They bear your excellent words walking according to your commandments. ${ }^{1329}$

326 A literal translation of Heb. 1ִ מְרִיבָה Meribah; 2. strife, contention'. | TKow.o1: quarrel. | H: quarrel. | C: quarrel. | R: quarrel.

327 Interpretative translation.

328 Lit. 'holier'.

329 An interpretative translation of Deu 33:3. 
(7) תורה . [4] Torany symarlady bizge Moše

(8) mereslik qahalyna Ja'aqovnun. [5] Da boldu ol

(9) Tora Jisra’elde bij jyštyrylġanda ag̉araqlary ulusnun

(10) birge ševetleri Jisra’elnin. [יחי] [6] _Da bulaj alğyš-

(11) lady Ru'uvenni da ajtty ${ }^{11}$ tiri bolg̀aj Ru'uven da öl-

(12) megej da bolgaj eli anyn sanly sanlary arasyna ševet-

(13) lerinin Jisra’elnin. [7] Da bu alğyš Juhudag̉a

(14) da ajtty tynlagiyn e Adonaj avazyn Juhudanyn da ulu-

(15) suna keltirgin any öz küčü jeter anar ančaq boluš-

(16) luq dušmanlaryndan bolg̀un. וללוי. [8] Da Levi üčün ajt-

(17) ty tumimlerijni da urimlerijni symarladyj hasid

(18) kišije Aharonġa ki synadyj any Masada ügütledij

(19) any talaš suvlary qatyna. האומר. [9] Ol ajtuvču ata-

(20) sy üčün da anasy üčün körmedim any da ošol

(21) qaryndašlaryn tanymady da ošol uvullaryn bilmedi

34 r $^{\mathrm{o}} \quad$ (1) Löltürgende qulluq etüvčülerni buzovğa ki rast ${ }^{12}$

(2) saqladylar ajtmag்yjny da šertijni abradylar.

(3) יורו . [10] Anlyqsartyn zohe boldular ${ }^{13}$ ki üvretkejler

(4) törelerijni Jacaqovga da Torajny Jisra’elge da

(5) ki qojġajlar tütü ačuvlanġan vaḥtyjda da tügel

(6) qarban mizbeahyj üstüne. ברך. [11] Alġyšlağyn e

(7) Adonaj malyn anyn ki oldu ol tunġučlar da ončalar

(8) da bikurim da išin qollarynyn qabul etken ki ol-

(9) dur ol qarbanlar keskin bellerge uturu turuvču-

(10) laryn anyn da dušmanlaryn anyn qajartyn ki tursalar.

(11) לבנימן [12] Binjamin üčün ajtty süveri Adonajnyn

(12) toḥtar eminlik byla anyn qatyna quršar šehina

(13) anyn üstüne har kün da bijik orunlary üstü-

(14) ne ülüšünün toḥtar šeḩinasy Adonajnyn.

(15) וליוסף] Da Josef üčün ajtty alğyšlanġandy

(16) Adonajdan jeri anyn nametinden köklernin čyqtan da

\footnotetext{
${ }^{1}$ Interpretative addition to the standard text. $\quad{ }^{2}$ Interpretative addition to the standard text.

${ }^{3}$ Interpretative addition to the standard text.
} 
(7) [4] Moses commanded us a Law,

(8) an inheritance for the community of Jacob. [5] And the Law was

(9) king in Israel when the superiors of the people were gathered;

(10) all the tribes of Israel together.' [6] And he blessed thus

(11) Reuben, and said:1330 'Let Reuben live, and

(12) not die, and let his men be numerous among the numbers of the tribes

(13) of Israel.' [7] And this is the blessing for Judah-

(14) and he said: 'Hear, oh Lord, the voice of Judah and

(15) bring him to his people. Let his strength be sufficient for him, and

(16) be a help to him from his enemies.' [8] And of Levi he said:

(17) 'You commended your Thummim and your Urim to your pious

(18) man, Aaron, whom you tested at Massah. You reproved

(19) him at the waters of ${ }_{L}$ quarrel ${ }^{1331}$, [9] Who said to his father

(20) and to his mother, "I have not seen him," and

(21) he did not recognize his brother, and he did not know his children

(1) ${ }_{L}$ when those who served the calf were killed by those who have justly ${ }^{1332}$

(2) kept your word and kept your covenant.

(3) $[10]_{L}$ Because of that, worthy are those ${ }^{1333}$ who shall teach

(4) your judgments to Jacob, and your Law to Israel, and

(5) those who shall put incense and whole sacrifice when you are angry

(6) on your altar. [11] Bless, oh

(7) Lord, his wealth ${ }_{\mathrm{L}}$ which is the firstborn, the tithe,

(8) the firstfruits, and the work of his hands-accepted because it

(9) is the sacrifice. Cut the loins of his adversaries

(10) and of his enemies after they rise.' 1334

(11) [12] Of Benjamin he said: "The beloved of the Lord

(12) will dwell in safety by him, the divine Presence will surround

(13) him every day, and the divine Presence of the Lord will

(14) dwell ${ }_{L}$ on the high places of his share.' 1335

(15) [13] And of Joseph he said: 'Blessed

(16) by the Lord is his land, from the goods of heaven, from the dew, and

330 An interpretative addition to Deu 33:6.

331 A literal translation of Heb. מִרְרָיבה '1. Meribah; 2. strife, contention'. | TKow.o1: quarrel.| H: quarrel.| C: Meribah.| R: Meribah.

332 An interpretative addition to Deu 33:9.

333 An interpretative addition to Deu 33:10.

334 Interpretative translation.

335 Interpretative translation. 
(17) darjadan jatadoġan ašag̉a. וממגד. [14] Da nametinden

(18) bitišlerinin qujašnyn da nametinden sürüvünün aj-

(19) larnyn. ומראש] Da bašyndan avaldaġy tavlarnyn da

(20) nametinden qajalarynyn dunjanyn. וממגד [16] Da nametin-

(21) den jernin da tolusunun da kleginden toḥtavčunun

$340 \mathrm{v}^{\mathrm{o}} \quad$ (1) qurğaq orunda kelgejler bašyna Josefnin da töbesi-

(2) ne ajyrylġannyn qaryndašlaryndan. בכור. [17] Tung̉uču ö-

(3) güzünün hörmet bolur anar da müvüzleri $\{k i b i[k]\}^{1}$ karkedennin

(4) müvüzleri anyn alar byla uluslarny süzer birge

(5) boluvčularny qyryjlarynda jernin da alar tümenleri

(6) Efrajimnin da alar minleri Menašenin. ולזבולן [18]

(7) Da Zevulun üčün ajtty bijengin e Zevulun čyqqanyj-

(8) da joluja da Jissahar ohujdoğač ${ }^{2}$ olturg̉anyjda

(9) čatyrlaryjda. עמים [19] Bargaanlarynda üč qurlalar

(10) jylda körünme qyblalary alnyna Adonajnyn özgede

(11) uluslaryn ševetlerinin Jisra’elnin ünderler barma

(12) tavyna ol Morijanyn ki anda bolur qondarylġan

(13) bet hamiqdaš da anda debeḥa eterler rast

(14) debehalar ki nametin tengizlernin ömerler da jašyryn

(15) haznalarny kömülgenlerni qum ičine. ולגד. [20]

(16) Da Gad üčün ajtty maḥtavludu kenertüvčü čegin

(17) Gadnyn tiši arslan kibik toḥtar da jyrtar bilekni

(18) hem töbeni. [ירא. [21] Da kördü ilk orunnu ö-

(19) züne ki anda ülüšü tora jazuvčunun astral-

(20) gandy da keldi ag̉araqlaryna ulusnun qolma ol

(21) orunnu özüne rastlyğgn Adonajnyn qyldy da kečin-

$341 \mathrm{r}^{\circ} \quad$ (1) meklerin özünün Jisra’el byla ${ }_{\perp}$ nečik bujurdu Adonaj ki barg̉aj-

(2) lar jasanġanlar čerüvge alnynda qaryndašlarynyn orušma

(3) ašyp ol Jardenni olturuvčularybyla jerinin Kena'annyn ${ }^{13}$.

(4) ולדן [22] Da Dan üčün ajtty Dan arslan balasy kibik se-

\footnotetext{
${ }^{1}$ TKow.or: kibik; unvocalized text. | H: kibik. | C: deest. $\quad{ }^{2}$ Interpretative addition to the standard
} text. ${ }^{3}$ Interpretative addition to the standard text. 
(17) from deep lying beneath, [14] And from the goods

(18) of the produce of the sun, and from the yield of the moons,

(19) [15] And from the top of the ancient mountains, and

(20) from the goods of the hills of eternity, [16] And from the goods

(21) of the earth and its fullness, and the /good| will of him who dwells

(1) in a dry place. Let the blessing come on the head of Joseph and on the top

(2) of the head of him who was separated from his brothers. [17] His firstborn

(3) bull: it will be honoured, and his horns are like the horns of a rhinoceros-

(4) with them he shall butt the people together,

(5) those who are at the edges of the earth. And they are the ten thousands

(6) of Ephraim, and they are the thousands of Manasseh.' [18]

(7) And of Zebulun he said: 'Rejoice, oh Zebulun, in your going out

(8) to your way and, Issachar, ${ }_{L}$ in reading ${ }^{1336}$ while you are sitting

(9) in your tents. [19] LWhen they go three times

(10) a year to appear before the directions of the Lord,

(11) they shall call other peoples, too, of the tribes of Israel, to go

(12) to Mount Moriah, because there will be built a temple,

(13) and there they will sacrifice right sacrifices. ${ }^{1337}$

(14) For they will suck of the goods of the seas and the hidden

(15) treasures buried in the sand.' [20]

(16) And of Gad he said, 'Praised is one who widens the borders

(17) of Gad: he dwells like a lioness and tears the arm

(18) and the top of the head. [21] And he saw the first place

(19) for himself, for the portion of the law-writer was kept there.

(20) ${ }_{1}$ And he came to the elders of the people to ask

(21) for a place for himself ${ }^{1338}$. He did the justice of the Lord and his deeds

(1) toward Israel, ${ }_{L}$ as the Lord commanded that they shall go

(2) armed to war before his brothers to wage war,

(3) after crossing Jordan, with the inhabitants of the land of Canaan.'1339

(4) [22] And of Dan he said: 'Dan is like a lion's whelp:

336 An interpretative addition to Deu 33:18.

337 Interpretative translation.

338 Interpretative translation.

339 An interpretative addition to Deu 33:21. 
(5) kirir ol Bašandan. ולנפתלי [23] Da Naftali üčün ajt-

(6) ty Naftali tojğan [kl] ekten ${ }^{1}$ da tolu alġyšyndan Adonajnyn

(7) macaravny² da daromnu meresler. ולאשר. [24] Da Ašer

(8) üčün ajtty alġyšlanġan bolur ulanlardan Ašer bolur

(9) süveri qaryndašlarynyn anlyqbyla ${ }_{L}$ ki köplügünden semiz-

(10) ברזל (25]

(11) Temir da tuč bolur qazyl[a]doġan ${ }^{4}$ jerijde qajdady ba[s]ynčağy ${ }^{5}$

(12) etiklerinin ajaqlaryjnyn , da jigitlik künlerij kibik bo-

(13) lurlar qartlyq künlerij ki eksik bolmassen heč namet-

(14) ke ki bar zamanlaryjda bolur jerij aġadoġan süt da bal ${ }^{16}$.

(15) [26] Joḥtur Tenri Tenrisi ${ }^{7}$ kibik Jisra’elnin Ješurun

(16) byla ündeledoġan ${ }_{L}$ kečinmegi üčün micvalaryna köre

(17) tüz Toranyn ${ }^{18} \mathrm{ki}$ ol Tenri qyjasa atlandy kökler

(18) üstüne bolušluqqa saja da ulluluğu byla jaratty

(19) bijiktegi köklerni. מענה. [27] Syjynčty bütün dunja-

(20) ga Tenri avaldan da ašagiartyn bunjat etti kip-

(21) liklerin dunjanyn da sürdü alnyjdan dušmanny da

$341 \mathrm{v}^{\mathrm{o}}$ (1) ajtty tasetkin. וישכן. [28] Da toḥtady Jisra’el emin-

(2) likbyla jalg̀yz özü urlug̉u Ja'aqovnun jer üstü-

(3) ne bürtüklü da šarbetli ham kökleri any[n $]^{9}$ javdurdu-

(4) lar čyq. אשריך. 29] Sandyr saja e Jisra’el

(5) kim barmo senin kibik jarlyğašly ulus Adonajda ki

(6) hammeše jarlyğašlanasen jarlyğašy\{by\}la hašgahasynyn

(7) ki oldu qalqany bolušluğujnun \{da\} ki qylyčydy ulluluğujnun

(8) da anyn bolušlug̉ubyla synyġyrlar dušmanlaryj alnyjda

(9) da sen töbeleri ${ }^{10}$ üstüne alarnyn basarsen.

\footnotetext{
${ }^{1}$ TKow.or: klekten; vocalized by another hand. | H: klekten. | C: kiläkniך; different wording. ${ }^{2}$ From this line on, until the end of Deuteronomy 34, the vowel points have been added to the text most probably by another hand (in light brown ink with a different quill pen). ${ }^{3}$ Interpretative addition to the standard text. $\quad{ }^{4} \mathrm{~K}$ : qazyldogan; a scribal error (by the person who added the vowel points). | TKow.o1: tabuladogan; vocalized by another hand. | H: deest. | C: deest. ${ }^{5} \mathrm{~K}$ : bačynčaġy; a scribal error. | TKow.o1: basynčaġy; vocalized by another hand. | H: deest; different wording. | C: deest; different wording. $\quad{ }^{6}$ Interpretative addition to the standard text. $\quad{ }^{7} \mathrm{~K}:$ Tenrisij; a scribal error. | TKow.o1: Tenrisi; unvocalized text. | H: Tenrisi. $\quad{ }^{8}$ Interpretative addition to the standard text. ${ }^{9} \mathrm{~K}$ : any; a scribal error. | TKow.or: anyn; unvocalized text. | H: anyn. | C: deest. $\quad{ }^{10} \mathrm{~K}$ : Spelled טיוֹביִירִירי; a scribal error (by the person who added the vowel points).
} 
(5) he will leap from Bashan.' [23] And of Naphtali he said:

(6) Naphtali is satisfied with favour and full with the blessing of the Lord.

(7) He will inherit the west and the south.' [24] And of Asher

(8) he said: 'Asher will be blessed out of the children. He will be

(9) the beloved of his brothers \& because of the abundance of the fat

(10) of the land as if ${ }^{1340}$ he would dip his foot in oil. [25]

(11) IIron and bronze will be dug out in your land where

(12) the shoes of your feet tread, and like the days of your youth

(13) the days of your old age will be, because you will not lack any goods,

(14) because your land will be flowing $\mid$ with $\mid$ milk and honey in all your times.' 1341

(15) [26] 'There is no God like the God of Israel called Jeshurun,

(16) because he behaves according to the commandments

(17) of the right Law ${ }^{1342}$ — because God rides in a way through the heavens

(18) to your help, ${ }_{\text {L }}$ and with his greatness he created

(19) the skies above. ${ }^{1343}[27]$ The ancient God is a refuge

(20) ${ }_{L}$ for the world, and underneath he established the strength

(21) of the world. ${ }^{1344}$ And he drove out the enemy from before you, and

(1) he said, "Destroy!" [28] And Israel dwelt in safety

(2) alone, the offspring of Jacob, on a land

(3) of grain and must, and its skies dropped

(4) dew. [29] Praise to you, oh Israel!

(5) Who is like you, ${ }_{L}$ people gracious for the Lord, because

(6) you are always being saved by the grace of his Providence,

(7) because it is the shield of your help, and because it is the sword of your greatness!

(8) And with his help your enemies will be broken before you. ${ }^{1345}$

(9) And you: you will tread on the top their heads.'

340 An interpretative addition to Deu 33:24.

341 An interpretative translation of Deu 33:25.

342 An interpretative addition to Deu 33:26.

343 Interpretative translation.

344 Interpretative translation.

345 Interpretative translation. 
[Deuteronomy 34 $]^{1}$

(10) Da mindi Moše jylġalyqlaryndan Mo’avnyn tavyna Nevo-

(11) nun bašyna ol singirnin ki alnynda Jeriḥonun da

(12) körgüzdü anar Adonaj ol bar jerni bašlap ol Gil'ad-

(13) dan Danġadejin. [2] Da ošol bar jerin Naftalinin

(14) da ošol jerin Efrajimnin da Menašenin da ošol

(15) bar jerin Juhudanyn ol ma'arav sarġy tengizge dejin.

(16) [ואת [3] Da ošol ol tüšlüknü da ošol ol maj-

(17) danny enišin Jerihononun šaharyn ol temarimnin ki anda

(18) tabulurediler artyqsy hurma terekleri da Co'ar-

(19) gadejin ${ }^{12}$. ויאמר [4] Da ajtty Adonaj anar budur ol

(20) jer ki antettim Avrahamgia Jichaqqa da

(21) Ja'aqovg̉a ajtadog̉ač [ur]lug̉uja ${ }^{3}$ berirmen any kör-

$342 \mathrm{r}^{\mathrm{o}} \quad$ (1) güzemen saja baqqyn közlerijbyla da ary ašmassen.

(2) וימת [5] Da öldü anda Moše qulu Adonajnyn jerin-

(3) de Mo’avnyn bujrugiuna köre Adonajnyn. ויקבר. [6]

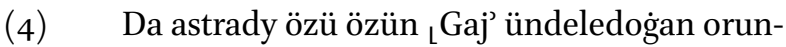

(5) da ${ }^{14}$ jerinde Mo'avnyn uturusuna Bet Po'ornun

(6) da bilmedi kišide ošol zeretin anyn ošpu künge-

(7) dejin. [ומשה [ Da Moše jüz egirmi jašar edi

(8) ölgeninde tunmady nuru közünün da sönmedi

(9) balquvu jüzünün. ויבכו. [8] Da jyladylar ulanlary Jisra’el-

(10) nin Moše üčün jylg̀alyqlarynda Mo’avnyn otuz kün

(11) da tüǵandiĺar jylamaq künĺari jasynyn Mošenin.

(12) ויהושע [9] Da Johošua uvlu Nunnun tolu edi alhe-

(13) minden usnun ki sundu Moše ošol qollaryn özü-

(14) nün alġyš byla anyn üstüne da tynladylar anar

(15) ulanlary Jisra’elnin da qyldylar ki nečik bujurdu Adonaj

(16) Mošege. ולא [10] Da turmady artyq navi Jisra’elde

(17) Moše kibik ki bildi any Adonaj aqyl aqylg̀a. לכל. [11]

(18) Bar ol belgilerge köre da ol nišanlarğa köre

(19) ki ijdi any Adonaj qylma jerind́a Micrinin paro-

(20) ga da bar qullaryna da bar jerine anyn. ולכל [12]

\footnotetext{
${ }^{1} \mathrm{~K}$ : The chapter number is not indicated. | TKow.o1: Deu 34. | H: Deu 34. | C: Deu $34 . \quad{ }^{2}$ This fragment is not vocalized. ${ }^{3}$ TKow.o1: urlugiuja; unvocalized text. | H: urlugiuna. | C: urlyg்yga. ${ }^{4}$ A mistranslation. | TKow.o1: Gaj' ündeledoġan orunda. | H: Gajda. | C: Gajda. | R: Gajda. | Heb. בֵַַּ 'in the valley'.
} 
[Deuteronomy 34]

(10) And Moses went up from the plains of Moab to Mount Nebo,

(11) to the top of the summit that is opposite Jericho. And

(12) the Lord showed him all the land, from Gilead,

(13) to Dan, [2] And all the land of Naphtali,

(14) and the land of Ephraim and Manasseh, and all the

(15) land of Judah, as far as the sea to the west,

(16) [3] And the south, and the valley

(17) of the plain of Jericho, the city of palm trees, because

(18) there were many palm trees, as far as Zoar.

(19) [4] And the Lord said to him, 'This is the

(20) land which I swore to Abraham, to Isaac, and

(21) to Jacob, saying, "I will give it to your offspring."

(1) I am showing it to you, see it with your eyes, but you will not cross there.'

(2) [5] And Moses, the Lord's servant, died there in the land

(3) of Moab, according to the command of the Lord, [6]

(4) And he buried him in a place called Gay ${ }^{1346}$,

(5) in the land of Moab, opposite Beth-Peor.

(6) And no man knew of his grave to this day.

(7) [7] And Moses was a hundred twenty years old

(8) when he died. The light of his eye was not dim, and

(9) the shine of his face did not fade. [8] And the children of Israel wept

(10) for Moses in the plains of Moab thirty days.

(11) And the days of weeping, the mourning of Moses, ended.

(12) [9] And Joshua, son of Nun, was full

(13) of the spirit of wisdom, because Moses had reached out his hands

(14) over him with a blessing. And the children of Israel listened to him,

(15) and did as the Lord commanded

(16) Moses. [10] And a prophet did not rise again in Israel

(17) like Moses, whom the Lord knew mind to mind: [11]

(18) According to all the signs and the tokens

(19) that the Lord sent him to do in the land of Egypt to Pharaoh

(20) and to all his servants and to all his land, [12]

346 A mistranslation based on interpreting Heb. בַבַּ 'in a valley' as a place name. 
(21) Da bar ol küčlü qudratqa köŕa da bar ol ullu

$342 \mathrm{v}^{\mathrm{o}} \quad$ (1) qorquvġa köre ki qyldy Moše közleriče bar Jisra’elnin.

\begin{tabular}{|c|c|}
\hline בריד רחמנא דסייען[1ו, & \\
\hline ישתבח שם האל הגדול הגבור והנורא ' אשר עמיה & \\
\hline שרא נהורא 'והוא בעל הכח והגבורה 'שסייעני & \\
\hline לכתוב פשטי ספר משנה התורה ' & \\
\hline ובכן נשלמו פשטי כל מצות א' ברה ' ולו יאותו הנצח & \\
\hline וההוד והתפארה 'אשר פארנו במחכימת פתי & \\
\hline ועינים מאירה 'הוא ברחמיו יפקח עין לבנו להבין & \\
\hline סוד כל מצוה מעקרה ' ויזכנו לשמור ולעשות & \\
\hline ככל הכתוב בה כפי כוונת גוזרה ' לבלתי נטות & \\
\hline ימין ושמאל שלא לצאת מפשוטו של מקרא ' וברוך & \\
\hline השם אשר לעמו ישראל הורה ' דרך תורתו הישרה ' & \\
\hline לטובלנו כל הימים בעולם הזה לשמרנו מכל צרה ' & \\
\hline ולחיותנו כהיום הזה בחיי העולם הבא שכלו אורה ' & \\
\hline בְלךך2 & \\
\hline
\end{tabular}

והיתה התחלת הכתיבה יום אל לסדר ולהורות את בני ישראל

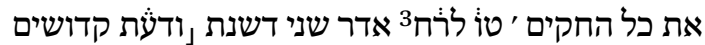

\footnotetext{
${ }^{1}$ A quotation from Mishneh Torah, Sefer Taharah (Tumat Ochalin 15:10). $\quad{ }^{2}$ Probably an abbrevi-

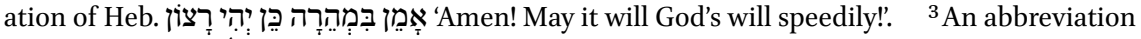

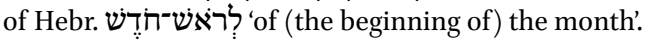


(21) And according to all the mighty hand and according to all the great

(1) fear which Moses did in the sight of all Israel.

(2) Blessed be the Merciful One who offers assistance!

(3) May the name of the great, mighty, and awesome Lord, with whom the light dwells, be praised.

(4) And He possesses the strength and the might to help me

(5) to write the peshatim of the ${ }_{1}$ book of the repetition of the Torah ${ }^{1347}$.

(6) The peshatim of all the pure commandments of the Lord were completed and the eternity,

(7) the majesty, the glory - which we praised in ${ }_{\mathrm{L}}$ Mahkimat Peti ${ }^{1348}$

(8) belongs to Him and enlightens the eyes ${ }^{1349}$. He, in his mercy, will open the eyes of our heart to make us understand

(9) the secret of the essence of all commandments, and we will be able to keep and do

(10) all that is written in it ${ }^{350}$, according to the intention of its author in order to prevent that we are turned aside,

(11) right or left, in order not to leave the literal meaning of the Scripture. And blessed

(12) be God who showed to the people of Israel the straight way of His Law

(13) to keep us for all the days |of our life| in this World, and to keep us away from all trouble

(14) so that to bring us to life on that day in the World to Come, which is all lightness.

(15) Amen! May it be God's will speedily!

(16) And the writing started on the first day of the ${ }_{\mathrm{L}}$ parashat Shemini ${ }^{1351}$,

(17) on the 15th of Adar Sheni of the year 801

347 It is not the Mishneh Torah of Maimonides what the copyist meant here, cf. משנה התורה in line 5, but rather the Book of Deuteronomy; cf. also Deu 17:18.

348 The work of Joseph ben Abraham ha-Kohen ha-Ro'eh, Karaite philosopher and theologian, written in Arabic in the first half of the 11th century; translated by Tobia ben Moses ha-Abel (11th/12th century) into Hebrew under the title מַחְכְּימַת פֶּת see Broydé (1904:

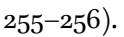

349 Uncertain translation.

350 I.e., in Mahkimat Peti.

$35^{1}$ This is expressed by quoting a passage read during this parashah, namely the initial frag-

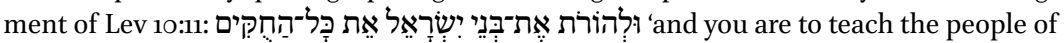
Israel all the statutes'. 


$$
\begin{aligned}
& \text { תמצא ז1 לפק2 ' ונשלמה יום ה'לס׳3 אלה החקים והמשפטים }
\end{aligned}
$$

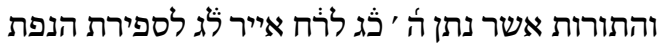

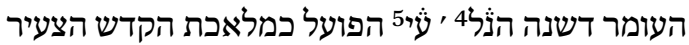

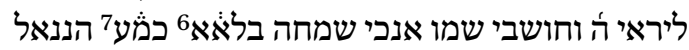

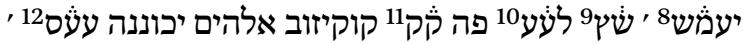

$$
\begin{aligned}
& \text { אמן }
\end{aligned}
$$$$
\text { ברוך נותן ליעף כח 'ולאין אונים עצמה ירבה ' }
$$

בירושה כספי ביושיה

מן אביו הידד19 הנל וכבר סלקתי לידו הדמים עד הפרוטה האחרונה עכ 20 אני חותם

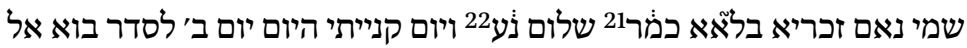

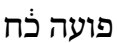
לخח טבת דשנתינו זו תקכח לפק '

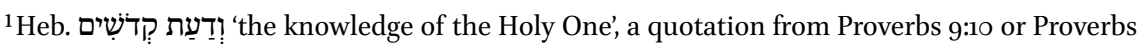

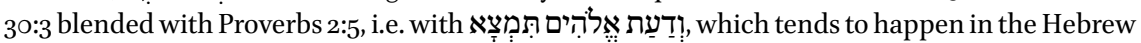
religious literature. The first word of the quotation, i.e. ודעת , encloses the date, i.e., waw + daleth + לִפרְרט

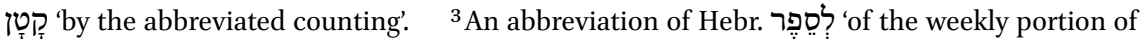

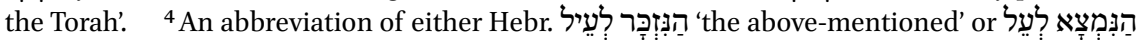

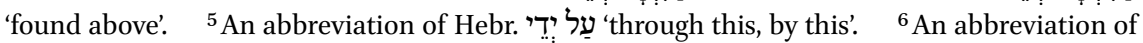

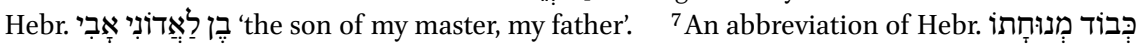

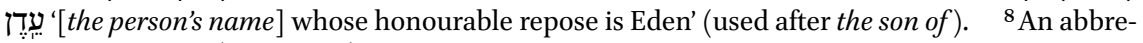

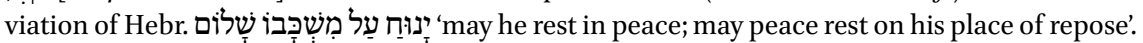

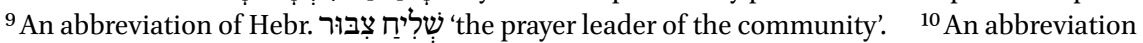

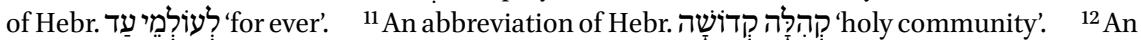

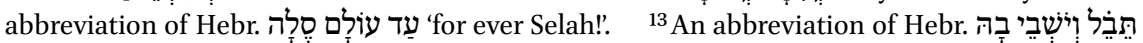
'the world and those who dwell therein', see Psalm 24:1. ${ }^{14}$ Pslam 24:1. ${ }^{15}$ Unclear form. ${ }^{16} \mathrm{An}$

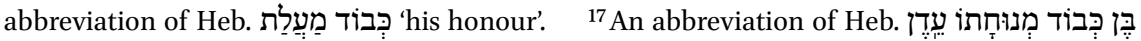
'the son of (the person's name), whose honourable repose is Eden'. ${ }^{18}$ An abbreviation of Heb. זִכְרוֹנוֹ לִבְרָכָה

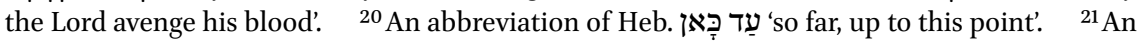

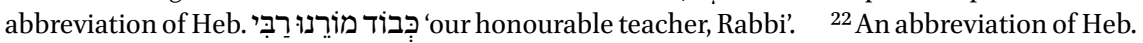

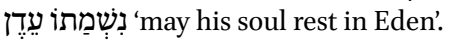


(1) by the abbreviated counting. And the writing was completed on the $5^{\text {th }} \quad 343 \mathrm{r}^{\mathrm{o}}$ day of the ${ }_{\text {L }}$ parashat

(2) Bechukotai ${ }^{1352}$, on the 23 rd of the month Iyar, on the 33 rd day of counting

(3) the Omer of the year mentioned above by the performer of the holy enterprise, the youngest

(4) among the God-fearing and those who respect His name - me, Simcha son of my lord and my father Chananel the honourable repose of which is Eden,

(5) may he rest in peace, the prayer leader of the community, forever. Here, in the holy community of Kukizów, may the Lord keep the community upright forever. Selah!

(6) Amen!

(7) Blessed be He who ${ }_{\mathrm{L}}$ gives power to the faint ${ }^{1353}$.

(8) The earth is the Lord's and the fullness thereof, the world and those who dwell therein. ${ }^{1354}$ I, the young, was endowed with this [ ${ }^{\dagger}$ peshat of $]$ Pentateuch, which I bought for my best

(9) money for a high and full price from the hands of the honourable Josef son of Juhuda the honourable repose of which is Eden, may his memory be a blessing, who inherited it

(10) from his above-mentioned father, may the Lord avenge his death; and up to this moment I had given the payment to his hands, up to the last coin. I sign myself

(11) with my name:Zecharia son of my master, my father Shalom, may his soul rest in Eden. And the day of this purchase of mine is today, the 2nd day of the parashat Bo, 28 th

(12) of the moth Tevet of our year 428 by the abbreviated counting. 